\title{
Annual Report for RCRA Groundwater Monitoring
Projects at Hanford Site Groundwater Monitoring Facilities for 1995 .
}

Revision 0

United States
Department of Energy
Fictland, Wastington

Approved for Public Release

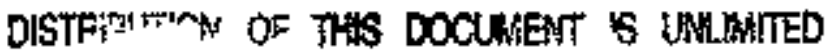




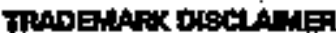

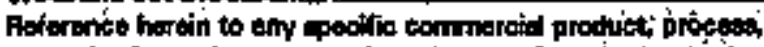

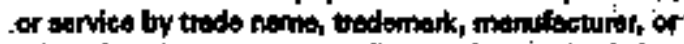

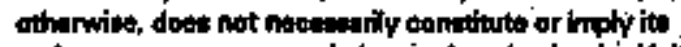

endorement, recommendetion, or favoning by the bling

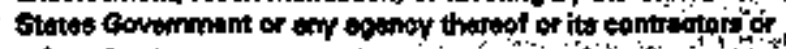

enconbratore.

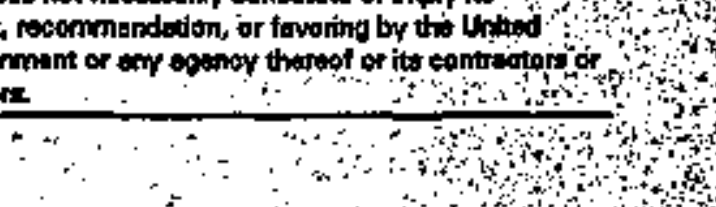

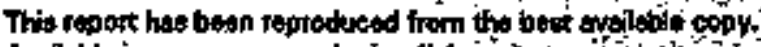
Avellebia in peper copy and microfichas.

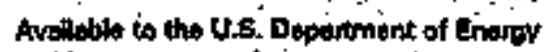

and lis cantrators from

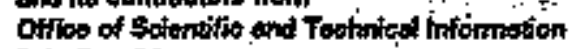

P.0. Box 62

Ook Fidgo, TN 37 G31

(616) 576-8401

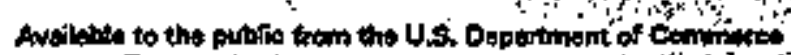
Nationat Taghniod Infommation Serwes

S2ass Pon Ropol Pood

Springitald, VA 22161

Co3) $497-4850$

Pinted h the Unted of inde.

DisceM5,CHP (9.91)

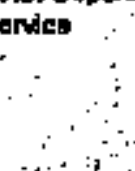

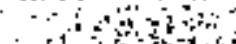

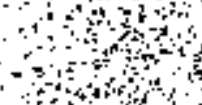

की

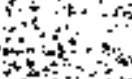

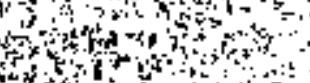

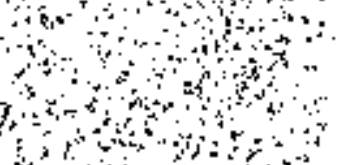

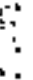

(x)

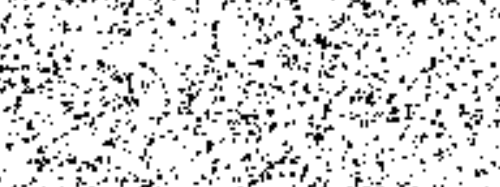

a

$\cdots$



DOE/FL-96-01

Revision 0

Uc-702

\section{Annual Report for RCRA Groundwater Monitoring Projects at Hanford Site Facilities for 1995}

Earth and Environmental

Technical Services

Westinghoxuse Hantord Compary

Date Fublistied

February 1996

United States
Department of Energy

Pigciland, Washingtan 99352

Approved for Public Release

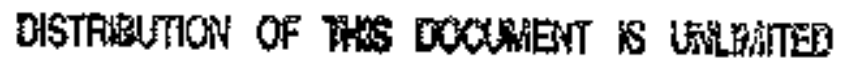





\section{EXECUTIVE SUITHARRY}

This report presents the annual hydrogeologic evaluation of 19 Resource Conservation and Recovery Act of 1976 facilities and 1 nonhazardous waste faciljty at the U.S. Department of Energy's Hanford Site. Although most of the facilittas no longer receive dangerous waste, a few facilities continue to receive dangerous waste constituents for treatment, storage, or disposal. The 19 Resource Conservation and Recovery Aet facilities comorise 29 waste managenent units. Nine of the unfts are monitored under groundwater quality assessment status because of elevated levels of contamination indicator parameters. The impact of those units on groundwater quality, if any, is being investigated. If dangerous waste or waste constituents have entered groundwater, their concentration profiles, rate, and extent of migration are eva]uated. Groundwater is monitored at the other 20 units to detect leakage, should it occur.

This report provides an interpretation of groundwater data collected at the waste management units between October 1994 and September 1995. Groundwater quality is described for the entire Hanford Site. Widespread contaminants include nitrate, chromitum, carbos tetrachloride, tritium, and other radionuc]ides.

\section{DISCTAIMER}

This report was prepared at an account of work sponsorod by an agenty of the Unitod Silates

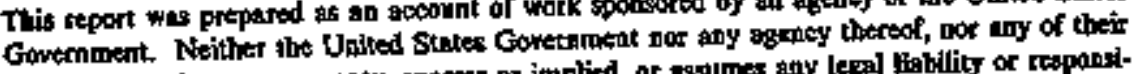
employees, makes ady warranty, express or implied, ar segumes any legal figbillity or reapansibilit for the accuracy, completeness, or userwiness of any information, apporatos, product, er process disclosed. of represents that its use mould aot tinfinge privately owoed rights. Refer-

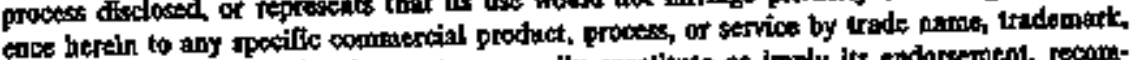
munufaturer, or otherwise does not necessarily constivate of imply its epdarsented, recoummendation, or faroring by the Jnifod states Government or any agency thereoi. The riews and opinions of enthors expressed bertin do ook nesessarily stuts or reflest thase of the Uniled States Goveroment or any agency thereof. 
DOE/RL-96-01, REV. 0

This page intentionally left blank. 


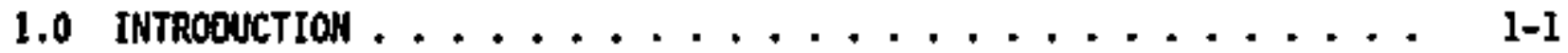

2.0 HANFORO SITE HYOROGEOLOGY ............... 2-1

3.0100 AREAS $\ldots . . . \ldots 3.1-1$

3.1 100 M AREA RESOURCE CONSERVATION AMD

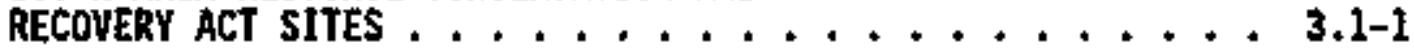

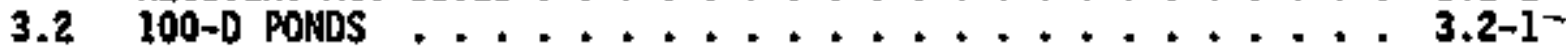

3.3 183-H SOLAR EVAPORATION BASINS . . . . . . . 3.3-I

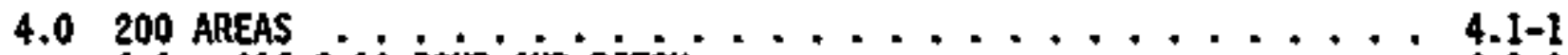

4.1 216-5-10 POND ANO OITCH ..................... 4.1

4.2 216-U-12 CRIB $\ldots \ldots \ldots \ldots \ldots \ldots \ldots . \ldots \ldots \ldots$

4.3 216-B-3 POND SYSTEM ............... 4.3-1

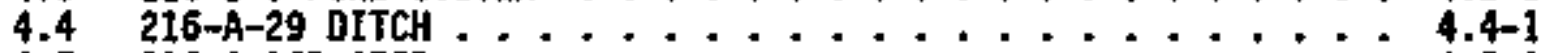

4.5 216-A-36B CRIB ...................... 4.5-1

4.6 2I6-A-10 CRIB .................... 4.6-1

4.7 216-B 63 TRENCH . . . . . . . . 4.7-1

4.8200 EAST AREA LIQUID EFFLUENT RETENTION FACILITY . . . . 4.8-1

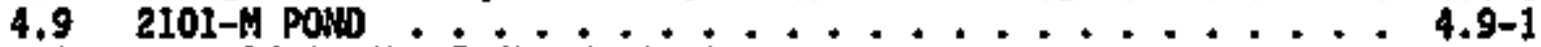

4.10200 AREAS LON-LEYEL BURIAL GROUNDS ..........4.10-1

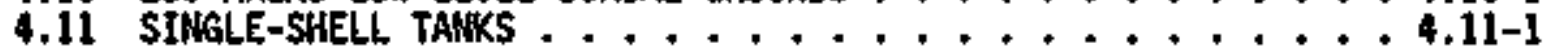

5.0600 AREA . . . . . . 5.1-1

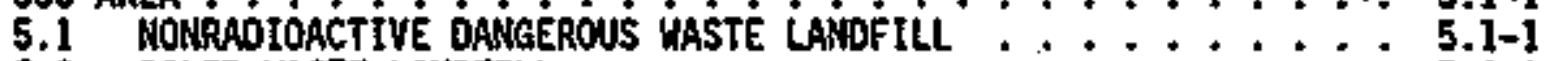

5.2 SOLID WASTE LANOFILL ........................

6.0300 AREA . . . . . . . . . . 6.1-1

6.1300 AREA PROCESS TREMCH $\ldots \ldots \ldots \ldots \ldots \ldots . \ldots \ldots$

APPENDICES:

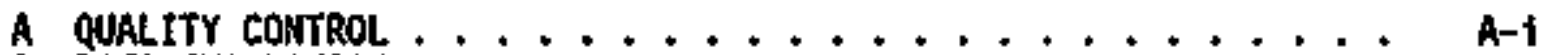

B DATA EVALUATION .......................... B-i

c STATISTICS ......................... c-1 
DOE/RL-96-01, REY, 0

\section{LIST OF JERMS}

11-DCA

111-TCA

183-H Basins

A-10 Crib

A-36B Crib

A-29 Ditch

B-63 Trench

B Pond

CERCLA

CFR

CIP

CH

CRQL

CY

DUS

Ecology

EPA

ERA

FY

LERF

LLBG

LLWWA

LOD

LOM

LivF

MDL

MEMO

MCR

NRONL

PCE

PUREX

QA

QC

RADE

RCRA

REDOX

RSU

S-I0 Facility

SST

Sill. 1,1-dichloroethane

$1,1,1-t$ richloroethane

183-H Solar Evaporation Bastins

216-A-10 Crib

216-A-36B Crib

216-A-29 0itch

216-B-63 Trench

216-8-3 Pond

Comprehensive Enviromoental Response, Compensation, and Liability Act of 1980

Cade of Federal Regulations

contamination indicator paranter

critical mean

contractually required quantitation limit

calendar year

drinking water standard

Washington State Department of Ecology

U.S. Environmental Protection Agency

expedfted response action

ftscal year

Liquid Effluent Retention Facility

Low-Leve] Burial Grounds

Low-Level Waste Management Area

1 intt of detection

1 imit of quantitation

Liquid Waste Disposal Facjltty

mathod detection limit

Monitoring Efficiency Model

nonconformance report

Nonradioactive Dangerous Waste Landfill

tetrachloroethene

Plutoniu:-Uranfum Extraction (PIant)

quality assurance

qual tty control

request for analytical data evaluation

Resource Conservation and Recovery Act of 1976

Reduction-0xidation (Plant)

retrievable storage unit

216-5-10 Pond and Ditch

single-shell tank

Solid Waste Landfill 
DOE/RL-96-0I, REV. 0

\section{LIST OF JERHS (cont.)}

TCE

TEDF

TOC

TOX

TSD

U-12 crib

U Pond

WAC

WHC

Wha

WP

WS trichloroethylene

Treated Effluent Disposal Faci门ity (200 Areas) total organic carbon total organic halogen treatwent, storage, and/or disposal

216-J-12 Crib

216-U-10 Pond

Washington Admintstrative Code

Westinghouse Hanford Company

Waste Management Area

Water Pollution

Water Supply 
DOE/RL-96-01, REV. O

METRIC CONVERSIOH CHART

\begin{tabular}{|c|c|c|}
\hline \multicolumn{3}{|c|}{ IMTO AETRIC } \\
\hline If you know & Multiply by & To get \\
\hline \multicolumn{3}{|c|}{ Length } \\
\hline inches & 2.54 & cent imeters \\
\hline feet & 30.48 & centimeters \\
\hline \multicolumn{3}{|c|}{ Volume } \\
\hline gallons & 3.786 & 7 iters \\
\hline cubic feet & 0.02832 & cubic meters \\
\hline \multicolumn{3}{|c|}{ Temperature } \\
\hline${ }^{9}$ Fabrenhe1t & $\begin{array}{l}\text { Subtract } 32^{\circ} \text {, then } \\
\text { multiply by } 5 / 9 \text { ths }\end{array}$ & ${ }^{\circ}$ Celsius \\
\hline \multicolumn{3}{|c|}{ Pressure } \\
\hline inches water & 1.87 & mाn $\mathrm{Hg}$ \\
\hline inches water & 249 & pascal $(\mathrm{Pa})$ \\
\hline \multicolumn{3}{|c|}{ OLI of METRIC } \\
\hline \multicolumn{3}{|c|}{ Length } \\
\hline centimeters & 0.3937 & inches \\
\hline meters & 3.28 & feet \\
\hline \multicolumn{3}{|c|}{ Volume } \\
\hline mi\}liliters & $1.247 \times 10^{-3}$ & cubic feet \\
\hline 11ters & 0.264 & gallons \\
\hline cubic meters & 35.31 & cubic feet \\
\hline \multicolumn{3}{|c|}{ Temperature } \\
\hline${ }^{\circ}$ Celsius & $\begin{array}{c}\text { Hultiply by } 9 / 5 \text { ths, } \\
\text { then add } 32^{\circ}\end{array}$ & ${ }^{\circ}$ Fahrenheit \\
\hline \multicolumn{3}{|c|}{ Pressure } \\
\hline $\operatorname{Hg}$ & 0.5353 & inches water \\
\hline pascal (Pa) & $4.02 \times 10^{-3}$ & inches water \\
\hline
\end{tabular}


DOE/RL-96-01, REV. 0

COHTENS

1.0 INTRODUCTIOA ....................... 1-1

1.1 REFEREMCES

1.1 .1 Chapter References $: \ldots \ldots \ldots \ldots \ldots \ldots$

1.1.2 RCRA Quarterly and Annual Reports ........ 1-5 
DOE/RL-96-01, REY. O

\section{LIST OF FIGURES}

1-1 Locations of the RCRA Groundwater Monitoring Projects and Landiarks on the Hanfurd Site............ 1-10

\section{LITT OF TABLES}

1-I Status of Hanford Stte RCRA Interim-Status Groundwater Monjtoring Projects as of September 30, 1995 .......... 1-11 
AMWUAL REPORT FOR RCRA GROTHNOWATER MONITORIHG PROJECTS

AT HARFORD SITE FACILITIES FOR 1995

\title{
1.0 IKTRODHCTION
}

\author{
H. J. Hartman \\ Westinghouse Hanford Company
}

Thts report presents the annual evaluation of 19 Resource Conservation and Recovery Act of 1976 (RCRA) groundwater monitoring projects and 1 nonhazardous waste facility at the U.S. Department of Energy's (OOE) Hanford 5tte. It presents interpretations of groundwater monitoring data for samples collected between October 1, 1994 and September 30, 1995. These data were presented in the quarterly reports from October 1994 through September 1995 (COE-RL 1995a, 1995b, 1995c, 1996). The reference 11st for this chapter includes a 1 ist of all quarterly and annual reports since RCRA groundwater monitoring began at the Hanford site (Section 1.1.2).

DataChem Laboratories performed hazardous chenical analyses and Quanterra Environemental Services (formerly International Technologies Corporation) performed radiochemical analyses. These contracts were administrated by Pacific Northwest National Laboratory. Total organic halogen analyses were performed by Roy $F$. Weston Laboratories during the first part of the year and Datachem Laboratories during the remainder of the year.

The groundwater monitoring programs described in thts document comply with the following Washington Adninistrative Code (WAC) regulations:

(1) "Oangerous Waste Regulations," WAC 173-303-400, for hazardous waste; and

(2) "Winimum Functional Standards for Sol ld Waste Handling," WAC 173-304-490, for nonhazardous waste. The projects meet the federal requirenents for "Interim Status Standards for Owners and Operators of Hazardous Waste Treatment, Storage, and D1sposa] Fac111ties," 40 Code of Federal Regulations (CFR) 265, Subpart F; and "Criteria for Classification of Sol id Waste Disposal Facjlities and Practices," 40 CFR 257, for nonhazardous waste.

The RCRA projects are monitored under one of three programs:

(1) a background monitoring program, (2) an indicator eva]uation program, or (3) a groundwater quajity assessment program. When a groundwater monitoring system has been installed, a background monitoring program begins. Samples and water levels fron upgradient monitoring weIl(s) must be obtained and analyzed quarterly for at least 1 year to establish background concentrations in the groundwater. All of the RCRA sites at the Hanford Site have completed their background monitoring programs.

After background is established, the indicator evaluation program commences. Samples are collected seniannually to detect groundwater contamination. Data obtained through the indicator evaluation program are compared to background data; if a statistically significant change has occurred in a downgradient well, a groundwater quality assessment plan must be implemented. The objective of assessment monitoring is to daternine if dangerous waste constituents have entered groundwater, and, if so, the 
concentration, rate, and extent of the constituents. Table 1-1 lists all of the RCRA facilities and waste management units and their monitoring program status. Figure $1-1$ is an index map for locating all of the RCRA facflities on the Hanford Site.

One unjt, 2101-14 Pond, was clean-closed in October 1995 and groundwater monitoring is no longer required. It is included in this doculient but will not be included in future quarterly or annual reports.

The 183-H Solar Evaporation Basins are included th the Hanford Facility RCRA Perwit and are now subject to final status regulation (Ecology 1994). However, the Basins were monitored under interin status regutations untii septewber 1995, when a new, final-status monitoring program was implenented.

One addtional facility, the 216-A-37-1 Crib, was originally excluded from the 1 ist of RCRA sites in the Hanford Federal Factifty Agreeipent and Consent order (Tri-Party Agree甲ent) (Ecology et a1. 1994). Later it was determined that regulated waste had been discharged to the $\mathrm{crib}$ and it is therefore subject to RCRA regulations. A groundwater monitoring plan is being prepared for the site and it wil] be monitored in the future.

The constituent lists for Taboratory analyses are established in accordance with the requirements of 40 CFR 265.92. The contanination indicator parameters are specified in 40 CFR $265.92(\mathrm{~b})(3)$. The paraneters establishing groundwater quality are specified in 40 CFR 265.92(b)(2). The drinking water standards are specified in 40 CFR 265.92(b)(1), Appendix III. Site-specific paraneters (including radionaclides) are determined from evaluation of the waste strear (or source) associated with the facility. Addttonal site-specific constituents may be included to aid in tracking groundwater movement and the influence of other facilities. In some cases, an Appendix IX list of constituents (40 CFR 264) is analyzed to estabish a baseline for future comparisons and analyses.

The Solid Waste Landfill (SWL) is a solid waste disposal facility. It is not a RCRA hazardous waste s1te and is not addressed under the Tri-Party Agreement. The current operations of the SWL fall under the regulations of WAC 173-304. The SWL is included in this report for completeness. A permit application was submitted to the Benton-Franki in District Health Department in 1991 (DOE 1991). Responsibility for the site was subsequently assumed by the Washington State Department of Ecology (Ecology) and a revtsed perrait application was submitted to Ecology in 1993 (DOE 1993).

40 CFR Part 265.94, "Recordkeeping and Reporting," requires that for indicator evajuation monttoring projects, concentrations and any changes in contamination indicator parameters for each groundwater monitoring well must. be reported annually, and the locations of the monitoring weils must be shown to continue to satisfy regulatory criteria (265.94[a][2]). It must be identified separately if indicator paraneter levels have changed significantly at an upgradient well sfnce the initial background levels were established (265.94[a][2]). For assessment-]evel monitoring, the results of the groundwater quality assessment progran must be submitted annually. The report must include the calculated (or measured) rate of migration of hazardous waste or hazardous waste constituents in the groundwater (40 CFR 265.94 [b] [2]). An annual report for solid waste landfilis is required under WAC 173-304. 
This report is organized by geographical area. Chapter 2.0 presents an overview of Hanford 51 te hydrogeology. Chapters 3.0, 4.0,5.0, and 6.0 discuss the $100,200,600$, and 300 Areas, respectively. Far a description of the hydrogeologic setting of each area, see DDE-RL (1994). Appendix A provide. a brief description of the quality control program and a sumary of the year's actfvities. Appendix $B$ describes the data evaluation process and activities during the year. Appendix C provides methods of statistica] evaluation and summary tables for background conditions.

Each subsection describing an individual RCRA site begins with an overview of the facllity, a sumary of 1995 RCRA activities, and a summary of other activities related to the hydrogeology of the stte. Next, the sampling and analysis program is described, including well locations, the constituent list, and sampling frequency. For sites in indicator evaiuation monitoring, a section on groundwater chemistry discusses elevated constituents, their changes with time, and results of statistical evaluations. For sites in assessment monitoring, the groundwater chemistry section descr tbes concentration histories of waste constituents and the rate and extent of contaminant migration. For all sites, the final subsections describe the direction of groundwater flow, the rate of flow, and provide an evaluation of the monitoring network.

Units of measurement are expressed in metric, with english equivalents following in parentheses. Water levels, drill depths, etc. were originally measured in feet and were converted to meters.

The drinking water standards referred to in this doctiment have been updated from interim standards (as listed in 40 CFR 265, Appendix III) to final standards ( 40 CFR 141). The most notable changes are for chromium (changed from 50 to $100 \mathrm{ppb}$ ) and fluoride (changed from 1,400 to 2,000 ppb).

The constituent lists for most of the RCRA sites at Hanford were trimed during the past year. Constituents were dropped if they are no longer required by regulations and are not constituents of interest at the RCRA site.

\subsection{REFERENCES}

\subsubsection{Chapter References}

40 CFR 141, "National Prłmary Drinking Water Regulations," Code of Federa? Regulations, as amended.

40 CFR 257, "Criteria for Classification of Solid Waste Disposal Facilities and Practices," Code of Federal Regulations, as amended.

40 CFR 264, "Standards for Owners and Operators of Hazardous Haste Treatment, Storage, and Disposal Facilities," Code of Federal Regulations, as amended.

40 CFR 265, "Interim Status Standards for Owners and Operators of Hazardous Waste Treatment, Storage, and Disposal Factlities," Code of Federal

- Regulations, as amended. 
DOE-RL, 1991, Hanford Site Solid Waste Landfill Perioit Application, DOE/RL-90-38, Rev. 0, U.S. Departwent of Energy, Richland Operations Office, Richiland, Washington.

DOE-RL, 1993, Hanford Site Solid Waste Landfill Permit Application, DDE/RL-90-38, Rev. 1, U.S. Department of Energy, Rich1and Operations Office, Richland, Washington.

DOE-RL, 1994, Annual Report for RCRA Groundwater Honitoring Projects at Hanford Site Facilities for 1993, DOE/RL-93-88, U.S. Departuent of Energy, Richland Operations Office, Richland, Washtngton.

DOE-RL, 1995a, Quarterly Report of RCRA Groundwater Nonitoring Data for Period Oetober 1, 1994 through December 31, 1994, DOE/RL-94-36-4, U.S. Department of Energy, Richland Operations Offtce, Richland, Washington.

DOE-RL, 1995b, Quarterly Report of RCRA Groundwater Nonftoring Data for Period January 1, 1995 through March 31, 1995, D0E/RL-95-69-1, U.S. Department of Energy, Richland Operations Office, Richland, Washington.

DOE-RL, 1995C, Quarter7y Report of RCRA Groundwater Nonitoring Dat» for Period Apri 1 1, 1995 through June 30, 1995, D0E/RL-95-69-2, J.S. Department of Energy, RichTand Operations Office, Richland, Washington.

DOE-RL, 1996, Quarterly Report of RCRA Groundwater Monitoring Data for Period July 1, 1995 through September 30, 1995, BOE/RL-95-69-3, U.S. Departinent of Energy, Richland Operations Office, Richland, Washington.

Ecalogy, 1994, Dangerous Waste Portion of the Resource Conservation and Recovery Act Permit for the Treatment, Storage, and Disposal of Dangerous Waste, Permit No. WA7890008967, effective September 28, 1994, Washington State Department of Ecology, 01ympia, Washington.

Ecology and EPA, 1985, Consent Agreenent and Conpliance Order, DE86-133, PCHB No. 86-44, Washington \$tate Department of Ecology, and the U.S. Envirnmental Protection Agency, Olympia, Washington.

Ecology, EPA, and DOE, 1994, Hanford Federa] Facility Agreenent and Consent Order, fourth Amendment, Washington State Department of Ecology, U.S. Environmental Protection Agency, and U.S. Bepartment of Energy, Olympta, Washington.

Resource Conservation and Recovery Act of 1976, 42 USC 6901 et seq.

WAC 173-303, "Dangerous Waste Regulations," Washington Administrative Code, as amended.

WAC 173-304, "Hiniatu Functional Standarts for Sol td Waste Handing," Washington Administrative Code, as anended. 
DOE/RL-96-01, REV. 0

\subsubsection{RCRA Quarterly and Annual Reports}

\subsubsection{Period 1986.}

PNL, 1986, Ground-Water Honitoring Conplitance Projects for Hanford Site Facilities: Progress Report for the Period Way 1 to September 30, 1986, PHL-6466, Pacific Northwest Laboratory, Richland, Washington.

Pill, 1987, Ground-Water Monitoring Cowpliance Projects for Hanford Site Facjitites: Progress Report for the Period Dctober 1 to Decenber 31, 1986, 3 vols., PhL-6465, Pacific Northwest Laboratory, Richiand, Washington.

\subsubsection{Period 1987.}

PNL, 1987a, Ground-Hater Monftoring Compliance Projects for Hanford Site Factitites: Progress Report for the Period January 1 to Narch 31, 1987, 3 vols., PHL-6476, Pacific Northwest Laboratary, Richland, Washington.

PNL, 1987b, Ground-Water Monitoring Compliance Projects for Hanford Site Facilities: Progress Report for the Period April I to June 30, 1987 , PNL-6468, Pacific Morthwest Laboratory, Rich1and, Washington.

Pll, 1987c, Ground-Water Monitoring Compliance Projects for Hanford Site Facilities: Progress Report for the Period JuTy 1 to September 30, 1987, PNL-6469, Pacific Northwest Laboratory, Richland, Washington.

PNL, 1988, Ground-Water Monitoring Compliance Prajects for Hanford Site Factitities: Progress Report for the Period October 1 to Decenber 31, 1987, PAL-6536, Pacific Northest Laboratory, Richland, Washington.

\subsubsection{Period 1988 .}

PNL, 1988a, Ground-Hater Nonitoring Compltance Projects for Hanford Site Facilities: Progress Report for the Period January I to Narch 31, 1988, PNL-6581, Paciftic Northwest Laboratory, Richland, Washington.

PNL, 1988b, Ground-Hater Honitoring Compliance Projects for Hanford Site Facilities: Progress Report for the Period April 1 to June 30, 1988 , PNL-6675, Pacific Morthwest Laboratory, Richtand, Washington.

Fruland, R. M., D. J. Bates, and R. E. Lundgren, 1989a, Resource Conservation and Recovery Act Ground-Water Monitoring Projects for Hanford Factlities: Progress Report for the Period July 1 to September 30, 1988, PNL-6789, Pacjfjc Northwest Laboratory, Richland, Washington.

Fruland, R. M., D. J. Bates, and R. E. Lundgren, 1989b, Resource Conservation and Recovery Act Ground-Water Monftoring Projects for Hanford Facflities: Progress Report for the Period October 1 to Deceaber 31, 1988, PNL-6944, Pacific Northwest Laboratory, Rjchland, Nashington. 
DOE/RL-96-01, REV. 0

FruT and, R. M., and R. E. Lundgren, eds., 1989, RCRA Ground-Hater Monitoring Projects for Hanford Facllities: Annual Progress Report for 1988, PNL-6852, Pacific Horthwest Laboratory, Rich1 and, Washington.

\subsubsection{Period 1989 .}

Snith, R. H., D. J. Bates, and R. E. Lundgren, 1989a, Resource Conservation and Recovery Act Ground-Water Mont toring Projects for Hanford Facilities: Progress Report for the Perfod January I to March 31, 1989, PNL-6957, Pacific Northwest Laboratory, Richland, Washington.

Snith, R. N., D. J. Bates, and R. E. Lundgren, 1989b, Resource Conservation and Recovery Act Ground-Water Monitoring Projects for Hanford Facilities: Progress Report for the Period April 1 to June 30, 1989, Pill-7134, Pacific Northwest Latioratory, Richland, Washington.

Smith, R. M., D. J. Bates, and R. E. Lundgren, 1989c, Resource Conservation and Recovery Act Ground-Water Monitoring Projects for Hanford Facilities: Progress Report for the Period July 1 to September 30, 1989, PNL-7222, Pacific Horthwest Laboratory, Richland, Washington.

Smith, R. M., D. J. Bates, and R. E. Lundgren, 1990, Resource Conservation and Recovery Act Ground-Water Monf toring Projects for Hanford Facilities: Progress Report for the Period October 1 to Decepaber 31, 1989, PNL-7306, Pacifíc Northwest Laboratory, Rtchl and, Washington.

Smith, R. H., and W. R. Gorst, eds., 1990, RCRA Ground-Water Monitoring Projects for Hanford Facilities: Annual Progress Report for 1989, PNL-6852, Pacific Northwest Laboratory, Richland, Washington.

\subsubsection{Period 1990.}

Lerch, R. E., 1990, Quarteriy Report of Resource Conservation and Recovery Act Groundwater Monitoring Data for Period January 1, 1990 Through Harch 31, 1990, (internal letter \#9053781 to R. D. Izatt, May 25), Westinghouse Hanford Company, Richland, Washington.

DOE-RL, 1990a, Quarteriy Repart of RCRA Groundwater Monitoring Oata for Period Aprit 1, 1990 through June 30, 1990, DOE/RL-90-36, U.S. Department of Energy, Rjchland Operations office, Richland, Mashington.

DOE-RL, 1990b, Quarterly Report of RCRA Groundwater Monitoring Oata for Period July 1, 1990 through September 30, 1990, DOE/RL-90-46, V.S. Department of Energy, Richland Operations Office, Richiand, Washington.

DOE-RL, 1991a, Quarteriy Report of RCRA Groundwater Monttoring Data for Period October 1, I990 through Decenber 31, 1990, DOE/RL-91-04, U.S. Department of Energy, Richland Field Office, Richland, Washington. 
OOE-RL, 1991b, Annual Report for RCRA Groundwater Nonitoring Projects at Hanford Site Facilitjes for 1990, DOE/RL-91-03, U.S. Department of Energy, Richland Field office, Richland, Washington.

\subsubsection{Period 1991.}

DOE-RL, 1991a, QuarterJy Report of RCRA Groundwater Nonitoring Data for Perfod January 1, 1991 through Narch 31, 1991, 00E/RL-91-26, U.\$. Department of Energy, Richland Fleid Office, Rjchland, Washington.

DOE-RL, 1991b, Quarterly Report of RCRA Groundwater Wonjtoring Data for Perfod April 1, 1991 through June 30, $1991,00 \mathrm{E} / \mathrm{RL}-91-47$, U.S. Department of Energy, Rich]and Field office, Richland, Washington.

DOE-RL, 199lc, Quarterly Report of RCRA Groundwater Monjtoring Data for Period July 1, 1991 through September 30, 1991, DOE/RL-91-57, U.S. Department of Energy, Rich] and Field Office, Richland, Washington.

DOE-RL, 1992a, Quarterly Report of RCRA Groundwater Nonitoring Data for Period October 1, 1991 through Doceaber 31, 1991, DOE/RL-92-26, U.\$. Department of Energy, Richland Field office, Richland, Washington.

DOE-RL, 1992b, Annual Report for RCRA Groundwater Monitoring Projects at Hanford Site facilfties for 199I, 00E/RL-92-03, U.S. Department of Energy, Richland Field office, Richt and, Washington.

\subsubsection{Pariod 1992.}

DOE-RL, 1992a, Quarterly Report of RCRA Groumdwater Nonitoring Data for Period January 1, 1992 through Warch 31, 1992, DOE/RL-92-26-1, U.S. Department of Energy, Richland Field Office, Richland, Washington.

OOE-RL, 1992b, Quarterly Report of RCRA Groundwater Monitoring Data for Period April 1, 1992 through June 30, 1992, DOE/RL-92-26-2, U.S. Department of Energy, Richl and Field Office, RichTand, Washington.

DOE-RL, 1992c, Quarterly Report of RCRA Groundwater Nonitoring Data for Perfod July 1, 1992 through Septenber 30, 1992, DOE/RL-92-26-3, U.S. Department of Energy, Richland Field Office, Richland, Washington.

BOE-RL, 1993a, Quarterly Report of RCRA Groundwater Monitoring Data for Period october 1, 1992 through Decenber 31, 1992, DOE/RL-92-26-4, U.S. Department of Energy, Richland Dperations Office, Richland, Washington.

DOE-RL, 1993b, Annual Report for RCRA Groundwater Monitoring Projects at Hanford Site Facilitfes for 1992, D0E/RL-93-09, U.S. Department of Energy, Richland operations Office, Richl and, Washington. 
DOE/RL-96-01, REY, 0

\subsubsection{Pertod 1999 .}

DDE-RL, 1993a, Quarterly Report of RCAA Groundwater Nonitoring Data for Period January 1, 1993 through Narch 31, 1993, DOE/RL-93-56-1, U.S. Department of Energy, Richland Operations Office, Richland, Washington.

DOE-RL, 1993b, Quarterly Report of RCRA Groundwater Nonjtoring Data for Period Apri] 1, 1993 through June 30, 1993, DOE/RL-93-56-2,

U.S. Department of Energy, Rich] and Operations office, Rfchland, Washington.

DOE-RL, 1994a, Quarterly Report of RCRA Groundwater Honitoring Oata for Perlod July 1, 1993 through September 30, 1993, DOE/RL-93-56-3, U.S. Department of Energy, Richland Operations Office, Richland, Washington.

DOE-RL, 1994b, Quartar7y Report of RCRA Groundwater Honitoring Data for Period October 1, 1993 through December 31, 1993, DOE/RL-92-56-4, U.S. Department of Energy, Richland Operations Office, Richland, Washington.

DOE-RL, 1994C, Anntal Report for RCRA Groundwater Honitoring Projects at Hanford Site Facilities for 1993, 00E/RL-93-88, U.\$. Department of Energy, Richland Operations Office, Richland, Washington.

\subsubsection{Period 1994 .}

DOE-RL, I994a, Quarterly Report of RCRA Groundwater Nonitorfing Data for Period January 1, 1994 through March 31, 1994, DOE/RL-94-36-1, U.S. Department of Energy, Richland Operations Office, RichT and, Washington.

DOE-RL, 1994b, Quarter7y Report of RCRA Groundwater Monttoring Data for Period April 1, 1994 through June 30, I994, DOE/RL-94-36-2,

U.S. Department of Energy, Richland Operations Office, Richland, Washtington.

OOE-RL, 1995a, Quarterly Report of RCRA Groundwater Monitoring Data for Period July 1, 1994 through September 30, 1994, DOE/RL-94-36-3, U.S. Department of Energy, Richtand Operations office, Richland, Washington.

DOE-RL, 1995b, Quarterly Report of RCRA Groundwater Nonitoring Data for Perfod October 1, 1994 through December 31, 1994, DOE/RL-94-36-4, U.S. Department of Energy, Richland Operations Office, Richland, Washington.

DOE-RL, 1995c, Annual Report for RCRA Groundwater Monjtoring Projects at Hanford Site Facilities for 1994, DOE/RL-94-136, U.S. Department of Energy, Richland Operations Office, Richland, Washington. 


\subsubsection{Period 1995.}

DOE-RL, 1995a, Quarterly Report of RCRA Groundwater Nonftoring Data for Period January 1, 1995 through March 31, 1995, DOE/RL-95-69-1, U.S. Department of Energy, Richland Operations office, Rich1 and, Washington.

DOE-RL, 1995b, Quarterly Report of RCRA Groundwater Honitoring Data for Period Apri7 1, 1995 through June 30, 1995, 00E/RL-95-69-2, U.S. Departiment of Energy, Richland Operations office, Richland, Washington.

DOE-RL, I996, Quarter7y Report of RCRA Groundwater Wonftoring Data for Period July 1, 1995 through September 30, 1995, DOE/RL-95-69-3, U.S. Department of Energy, Rlchland Operattons Office, Richl and, Washington. 

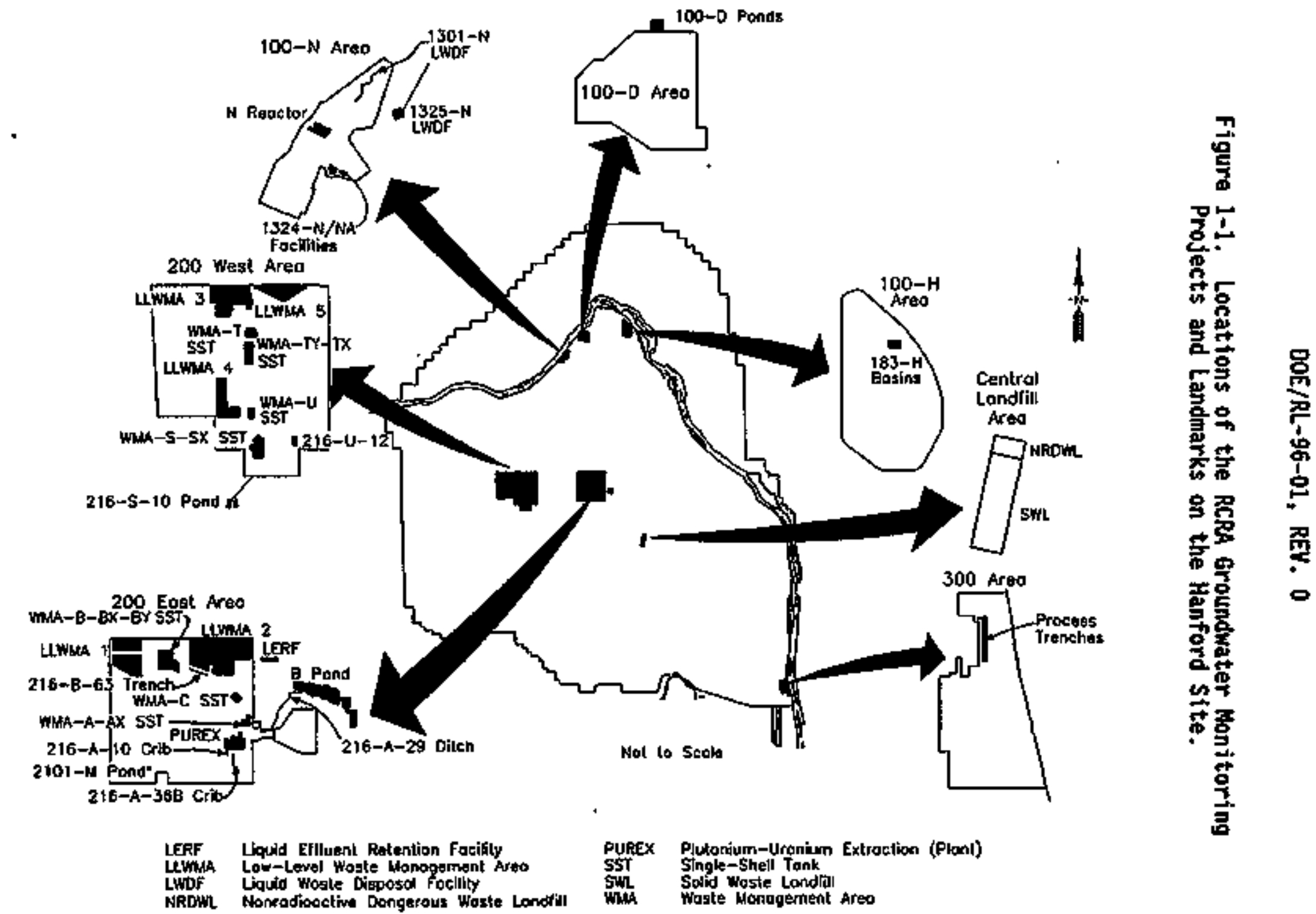
Table 1-1. Status of Hanford S1te RCRA Interim-Status Groundwater Honjtoring Projects as of September 30, 1995. (3 sheets)

\begin{tabular}{|c|c|c|c|}
\hline \multirow[b]{2}{*}{$\begin{array}{c}\text { Praject } \\
\text { (date initiated) }\end{array}$} & \multicolumn{2}{|l|}{ r } & \multirow[b]{2}{*}{$\begin{array}{l}\text { Regul atory } \\
\text { requi rements }\end{array}$} \\
\hline & $\begin{array}{l}\text { Indicator } \\
\text { paramater } \\
\text { evaluation }\end{array}$ & $\begin{array}{l}\text { Gi: quality } \\
\text { assessment }\end{array}$ & \\
\hline $\begin{array}{c}\text { 100-0 Ponds } \\
(4 / 92)\end{array}$ & $x^{n}$ & & $\begin{array}{l}40 \text { CFR } 265.93(b) \\
\text { WAC } 173-303-400\end{array}$ \\
\hline $\begin{array}{c}\text { 183-H Basin } \\
(6 / 85)\end{array}$ & & $x^{b}(9 / 95)$ & $\begin{array}{l}40 \text { CFR } 264.99 \\
\text { WAC } 173-303-645\end{array}$ \\
\hline $\begin{array}{c}1301-11 \text { LNDF } \\
(12 / 87)\end{array}$ & $x$ & & $\begin{array}{l}40 \text { CFR } 265.93(b) \\
\text { WAC } 173-303-400\end{array}$ \\
\hline $\begin{array}{c}\text { 1324-N/NA Pond } \\
(12 / 87)\end{array}$ & . & $\begin{array}{c}X(5 / 89) \\
\text { Spe cond, } \\
\text { ToX }\end{array}$ & $\begin{array}{l}40 \text { CFR } 265.93 \text { (d) } \\
\text { HAC } 173-303-400\end{array}$ \\
\hline $\begin{array}{c}1325-N \text { LWDF } \\
(12 / 87)\end{array}$ & $x$ & & $\begin{array}{l}40 \text { CFR } 265.93(b) \\
\text { WAC } 173-303-400\end{array}$ \\
\hline $\begin{array}{l}\text { 216-8-3 Pond } \\
\text { (11/88) }\end{array}$ & & $x \underset{\text { TOX }}{(5 / 90)}$ & $\begin{array}{l}40 \text { CFR } 265.93(d) \\
\text { WAC } 173-303-400\end{array}$ \\
\hline $\begin{array}{c}\text { 216-A-29 0itch } \\
\text { (11/88) }\end{array}$ & & $\begin{array}{l}x(6 / 90) \\
\text { Spe cond }\end{array}$ & $\begin{array}{l}40 \text { CFR } 265.93(d) \\
\text { WAC } 173-303-400\end{array}$ \\
\hline $\begin{array}{c}216-A-36 B \text { Crib } \\
(5 / 88)\end{array}$ & $X$ & & $\begin{array}{l}40 \text { CFR } 265.93(b) \\
\text { WAC 173-303-400 }\end{array}$ \\
\hline $\begin{array}{c}216-A-10 \text { Crib } \\
(11 / 88)\end{array}$ & $x$ & & $\begin{array}{l}40 \text { CFR 265.93(b) } \\
\text { WAC } 173-303-400\end{array}$ \\
\hline $\begin{array}{c}216-8-63 \text { Trench } \\
(8 / 91)\end{array}$ & $x$ & & $\begin{array}{l}40 \text { CFR } 265.93(b) \\
\text { WAC } 173-303-400\end{array}$ \\
\hline $\begin{array}{c}216-\$-10 \text { Pond } \\
(8 / 91)\end{array}$ & $x$ & & $\begin{array}{l}40 \text { CFR } 265.93(b) \\
\text { WAC } 173-303-400\end{array}$ \\
\hline $\begin{array}{c}216-11-12 \text { crib } \\
(9 / 91)\end{array}$ & & $\begin{array}{l}x(1 / 93) \\
\text { spe cond }\end{array}$ & $\begin{array}{l}40 \text { CFR 265.93(d) } \\
\text { WAC } 173-303-400\end{array}$ \\
\hline $\begin{array}{l}\text { LERF } \\
(7 / 91)\end{array}$ & $x$ & & $\begin{array}{l}40 \text { CFR } 265.93(b) \\
\text { WAC } 173-303-400\end{array}$ \\
\hline $\begin{array}{l}\text { 2101-M Pond } \\
(8 / 88)\end{array}$ & $X$ & & $\begin{array}{l}40 \text { CFR } 265.93 \text { (b) } \\
\text { WAC } 173-303-400\end{array}$ \\
\hline
\end{tabular}


DOE/RL-96-01, REV, 0

Table 1-1. Status of Hanford Site RCRA Interim-Status Groundwater

Monitoring Projects as of September 30, 1995. (3 sheets)

\begin{tabular}{|c|c|c|c|}
\hline $\begin{array}{c}\text { Project } \\
\text { (date initfated) }\end{array}$ & $\begin{array}{l}\text { Indicator } \\
\text { paraneter } \\
\text { evaluation }\end{array}$ & $\begin{array}{l}\text { GW quality } \\
\text { assessment }\end{array}$ & $\begin{array}{l}\text { Regulatory } \\
\text { requirements }\end{array}$ \\
\hline LLBG & & & \\
\hline $\begin{array}{l}\text { MAA } 1 \\
(9 / 88)\end{array}$ & $x$ & & $\begin{array}{l}40 \text { CFR } 265.93(\mathrm{~b}) \\
\text { WAC } 173-303-400\end{array}$ \\
\hline $\begin{array}{l}\text { MiNA } 2 \\
(9 / 88)\end{array}$ & $x$ & & $\begin{array}{l}40 \text { CFR 265.93(b) } \\
\text { WAC } 173-303-400\end{array}$ \\
\hline $\begin{array}{l}\text { MNA } 3 \\
(10 / 8 B)\end{array}$ & $\mathbf{x}$ & & $\begin{array}{l}40 \text { CFR } 265.93(b) \\
\text { WAC } 173-303-400\end{array}$ \\
\hline $\begin{array}{l}\text { WWA } 4 \\
(10 / 88)\end{array}$ & $x$ & & $\begin{array}{l}40 \text { CFR 265.93(b) } \\
\text { WAC } 173-303-400\end{array}$ \\
\hline $\begin{array}{l}\text { WWA } 5 \\
(3 / 92)\end{array}$ & $x$ & & $\begin{array}{l}40 \text { CFR } 265.93 \text { (b) } \\
\text { WAC } 173-303-400\end{array}$ \\
\hline SST & & & \\
\hline $\begin{array}{c}\text { WIA-A-AX } \\
(2 / 90)\end{array}$ & $x$ & & $\begin{array}{l}40 \text { CFR 265.93(b) } \\
\text { HAC } 173-303-400\end{array}$ \\
\hline $\begin{array}{c}\text { WHA-B-BX-BY } \\
(2 / 90)\end{array}$ & $x$ & & $\begin{array}{l}40 \text { CFR 265.93(b) } \\
\text { WAC } 173-303-400\end{array}$ \\
\hline $\begin{array}{l}\text { WWA-C } \\
(2 / 90)\end{array}$ & $x$ & & $\begin{array}{l}40 \text { CFR } 265.93(b) \\
\text { WAC } 173-303-400\end{array}$ \\
\hline $\begin{array}{c}\text { WHA-S-SX } \\
(10 / 91)\end{array}$ & $x$ & & $\begin{array}{l}40 \text { CFR } 265.93 \text { (b) } \\
\text { WAC } 173-303-400\end{array}$ \\
\hline $\begin{array}{l}\text { WMA-T } \\
(2 / 90)\end{array}$ & & $\begin{array}{l}X(7 / 93) \\
\text { Spe cond }\end{array}$ & $\begin{array}{l}40 \text { CFR } 265.93 \text { (d) } \\
\text { HAC } 173-303-400\end{array}$ \\
\hline $\begin{array}{l}\text { WA-TX-TY } \\
(9-10 / 91)\end{array}$ & & $\begin{array}{l}X(7 / 93) \\
\text { Spe cond }\end{array}$ & $\begin{array}{l}40 \text { CFR } 265.93 \text { (d) } \\
\text { WAC } 173-303-400\end{array}$ \\
\hline $\begin{array}{l}\text { WMA-U } \\
(10 / 9)\end{array}$ & $x$ & & $\begin{array}{l}40 \text { CFR } 265.93 \text { (b) } \\
\text { WAC } 173-303-400\end{array}$ \\
\hline
\end{tabular}


Table 1-1. Status of Hanford Site RCRA Interim-Status Groundwater Monitoring Projects as of September 30, 1995. (3 sheets)

\begin{tabular}{|c|c|c|c|}
\hline $\begin{array}{c}\text { Profect } \\
\text { (date inttiated) }\end{array}$ & $\begin{array}{l}\text { Indicator } \\
\text { parameter } \\
\text { evaluation }\end{array}$ & $\begin{array}{l}\text { GN quality } \\
\text { assessment }\end{array}$ & $\begin{array}{l}\text { Regulatory } \\
\text { requirements }\end{array}$ \\
\hline $\begin{array}{l}300 \text { Area Process } \\
\text { Trenches } \\
(6 / 85)\end{array}$ & & $X(6 / 85)$ & $\begin{array}{c}\text { Consent Agreement and } \\
\text { Comp } 7 \text { iance Ondert }\end{array}$ \\
\hline $\begin{array}{l}\text { MRDWL } \\
(10 / 86)\end{array}$ & $x$ & & $\begin{array}{l}40 \text { CFR } 265.93(\mathrm{~b}) \\
\text { WAC } 173-303-400\end{array}$ \\
\hline
\end{tabular}

Hote: An $X$ and date in the third column indicates the

following: (1) the date that the assessment was fnitiated and

(2) the indicator parameter that triggered assessment monitoring. Background conductivity ts being reestablished.

binal status compliance program implemented September 1995. EEcology and EPA (1986).

$C F R=$ Code of Federal Regulations.

GW = groundwater.

LERF = Liquid EffTuent Retention Facility.

LLBG = Low-Level Burial Grounds.

LVOF = Liquid Waste Disposal Facility.

MROWL = Nonradioactive Oangerous Waste Landfill.

spe cond = speciffic conductance.

SST = single-shell tanks.

TOX - total organic ha7ogen.

WAC = Washington Administrative Code.

WMA - Waste Management Area. 
BOE/RL-96-0I, REV. 0

This page intentionally left blank. 
2.0 HANFORD SITE HYDROGEOLOGY ............... 2-1

2.1 SITE GEOLOGY $\ldots \ldots \ldots$ 2-1

2.1.1 Stratigraphy of the Ringold Formation ....... 2-1

2.1.2 Post-Ringold, Pre-Hanford Deposits .......... 2-2

2.1.3 Stratigraphy of the Hanford Formation ....... 2-2

2.1.4 Holocene Surficial Deposits ........... 2-3

2.1.5 Structural Geology of the Hanford Site . . . . . , 2-3

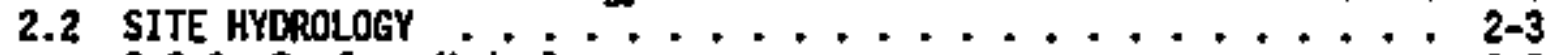

2.2.1 Surface Hydrology ................ 2-3

2.2 .2 Hydrogeologic Units ..................... 2-4

2.2 .3 Groundwater Flow .................. 2-5

2.2.4 Groundwater Chemistry ............... 2-5

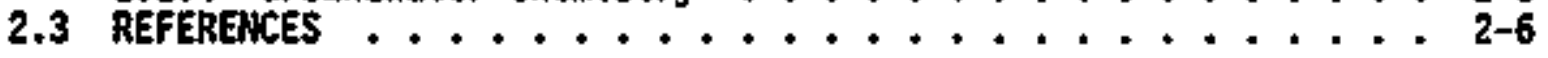


DOE/RL-96-01, REV. 0

\section{LIST OF FIGURES}

2-1 Generalized Stratigraphy of the Suprabasalt Sediments Beneath the Hanford site ................. 2-9

2-2 Geologic Structure of the Hanford Stte ........... 2-10

2-3 Neekly Average Coluwia River Stage at the Hanford Site. . . . - 2-11

2-4 Hanford Site Water Table Hap, June $1995 . \ldots . . . . . . .2-12$

2-5 Tritiun Distribution in the Upperinost Aquifer, Hanford \$1te, January 1991 through September Ig93 . . . . . . . 2-13

2-6 Gross Beta Distribution in the upperuost Aquifer, Hanford Site, January 1991 through September $1993 . \ldots$. . . . . 2-15

2-7 Technetium-99 Distribution in the upperwost Aquifer, Hapford Site, Jantary 1991 through September $1993 . . . . . . .2$ 2-17

2-8 Iodine-129 Distribution in the Uppermost Aquifer, Hanford Site, January 1991 through September $1993 \ldots$ 2-19

2-9 Mitrate Distribution in the Uppermost Aquifer, Hanford Site, January 1991 through September $1993 \ldots . . . . . . . . .2-21$

2-10 Carbon Tetrachloride Oistribution in the Uppermost Aquifer Beneath the 200 West Area . . . . . . . . 2-23

\section{LIST OF TABLES}

2-1 Range of Chemical Constituents in Columbia and

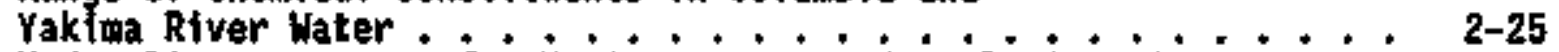

2-2 Hydraul te Parameters for Various Areas and Geologic Units at the Hanford Site . . . . . . . 2-26

2-3 Inorganic Constituents in Unconfined Groundwater Unaffected by

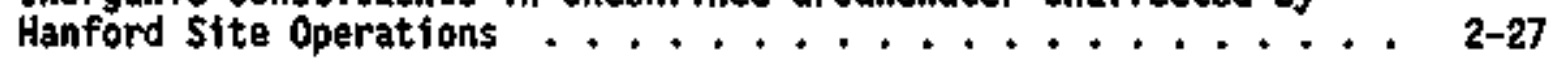


DOE/RL-96-01, REV. O

\subsection{HANFORD SITE HYOROGEOLOGY \\ H. J. Hartman \\ Westinghouse Hanford Conpany}

This chapter presents a sumpary of the geology and hydrology of the

Hanford Site. Additional detail is available from Delaney et al. (1991) and DOE (1988).

\subsection{SITE GEOLOGY}

The information in this section is summarized from Delaney et al. (1991) and other sources as noted. The Hanford $s t$ te is underTain by Mfocene-aged basalt of the Colurbia River Basalt Group, and late Miocene to Pleistocene sediments.

The Columbia River Basalt Group comprises an assemblage of tholeiit/c, continental flood basalts that cover an area of more than $160,000 \mathrm{~km}^{2}$ $\left(63,000 \mathrm{mi}^{2}\right)$. Sediments of the Ellensburg Formation forn interbeds between basalt flows. The Levey interbed is the uppermost untt of the Ellensburg Formation. It is tuffaceous sandstone to s 17 tstone and, at the Hanford sjte, it is found only beneath the 300 Area. The Rattlesnake Ridge interbed is the shatiowest interbed beneath the rest of the hanford \$ite. It is up to $33 \mathrm{~m}$ (108 ft) thick and includes clay, siltstone, and sandstone.

The suprabasalt sedimentary sequence beneath the Hanford Site is up to 230 m $(750 \mathrm{ft})$ thick. It pinches out against areas where the basatt has been up]ifted. The suprabasalt sediments are dominated by lateraliy extensive deposits assigned to the late Hiocene to Pliocene-aged Ringold Fomation and the Pleistocene-aged Hanford formation (informal name). The remtainder of the sequence comprises localized strata assigned to the Informally defined P1 to-Pleistocene unit, early "Palouse" soil, and pre-Missoula gravels.

\subsubsection{Stratigraphy of the Ringold Formation}

The Ringold Formation comprises atternating fine- and coarse-grained, semi-indurated sediments. Lindsey (1991) designates fluvial sand and graveldoninated sequences $A$ (oldest) through $E$ (youngest) (Figure 2-1). Not a11 of the fluvial sequences are continuous beneath the Hanford Site.

The lowest Ringold deposits consist of up to $46 \mathrm{~m}$ (150 ft) of fluvial gravel, designated untt $A$. Unit $A$ is not found in the vicinity of the 300 and 1100 Areas or near the $100-\mathrm{H}$ and $100-\mathrm{F}$ Areas.

The Tower mud untt, comprising overbank and lacustrine deposits, lies over unit $A$. The lower mud unit is up to $43 \mathrm{~m}(140 \mathrm{ft})$ thick.

Fluvial gravel unit B lies over the lower asd unit. Unit B is up to $25 \mathrm{~m}$ (82 ft) thick, but is not present beneath the 200 Areas. 
Deposits typical of the overbank facies association overlie unit B throughout the Hanford Stte. Where unit B is absent, these overbank deposits interfinger with the Tower mud sequence.

Another fluvial gravel-dominated sequence, unit $c$, is present in a relatively narrow linear tract trending northwest to southeast trending across the Pasco Basin. It is up to $35 \mathrm{~m}$ (115 ft) thick near the 100-B/C Area, but it is absent north of the 100-N and 100-F Areas. In the Cold Creek syncline, the unit stretches from east of the 200 East Area to near the city of Rich] and.

Another sequence of fthe-gratned overbank deposits overties unit $C$. Thin fluvial sands are present locally.

The uppermost fluvial gravel-dominated sequence in the Ringold Formation, unit $E$, is the most widespread of the gravel sequences. Init $E$ is up to 30 ir (100 ft) thick near the 100-8/C Area, and pinches out north of the 100-0 Area and east of Gable Gap. Laterally equivalent strata near the 100-F and 100-H Areas consist of overbank deposits with minor intercalated fluvial sand. Unit $E$ is found throughout the cold Creek syncline, forwing a west-thickening wedge that is 30 to $40 \mathrm{~m}$ ( 98 to $130 \mathrm{ft}$ ) thick south and east of the 200 East Area, and $91 \mathrm{~m}$ ( $300 \mathrm{ft}$ ) thick south and west of the 200 West Area. Near the 300 Area the overbank deposits beneath untt $E$ are absent and unit $E$ overiles or truncates underlying coarse-grained sequences (unit $C$ or B).

More interbedded fluvial sand and overbank deposits lie over unit $E$ in some areas of the Hanford Site. Erosional remants of these deposits are found south and east of the 200 East Area and near the 200 West Area. North of the 100-F and 100-N Areas, fluvial sands pinch out and overbank deposits dominate the sediments.

\subsubsection{Post-Ringold, Pre-Hanford Deposits}

Thin alluvial deposits between the Hanford and Ringold Formations are referred to inforwally as the: (1) Plio-Pleistocene unit, (2) pre-lissoula gravels, and (3) early "Palouse" sol1.

The Plo-Pleistocene unit is laterally discontinuous and is up to $25 \mathrm{~m}$ (a2 ft) thick. It is present in the vicinity of the 200 West Area. Pre-Hissoula gravels, up to $25 \mathrm{~m}$ (82 ft) thick, are present east and south of the 200 East Area. It is unclear whether the pre-Missoula gravels overlie or interfinger with the early "Palouse" soi] and Plio-Pleistocene unit. The early "Palouse" soil comprises up to $20 \mathrm{~m}(65 \mathrm{ft})$ of silt and fine-grained sand. It is present around the 200 West Area.

\subsubsection{Stratigraphy of the Haniord Formation}

The Hanford formation consists of gravel- and sand/silt-dominated deposits. It is up to $64 \mathrm{~m}(210 \mathrm{ft})$ thick near the 200 Areas.

The gravel-dominated deposits comprise coarse-grained sand and gravel

with boulders. Matrix commonly is lacking in these gravels. Gravels doninate 
the formation in the 100 Areas, the northern part of the 200 East Area, and the eastern Hanford Site, including the 300 Area. The gravels generaliy become finer to the south in the 200 Area5. The gravel-dominated facies of the Hanford formation were deposited by high-energy glacial flood waters in or immediately adjacent to the wain cataclyseic flood channels.

The sand/silt-dominated deposits corprise two facies: (1) laminated sand and (2) rhythmite. The laminated sand facies consists of fine- to coarsegrained sand that way contain sall pebbles or pebble-gravel interbeds less than $20 \mathrm{~cm}$ (8 in.) thick. This facies is common in the 200 Areas. It was deposited adjacent to main flood channels where it sptiled out of the channels. The rhythwite facjes consists of silt and fine- to coarse-grained sand that commonly display normally graded rhythmites a few centfaeters to tens of centimeters thick in outcrop. These sediments were deposited under stack water condtifons. The facies is found within and south of the 200 Areas.

\subsubsection{Holocene Surfictal Deposits}

Holocene surficial deposits form a thin $(<5-m[<16-f t])$ veneer across much of the Hanford site. The deposits comprise silt, sand, and gravel.

\subsubsection{Structural Geology of the Hanford Site}

The Hanford Site is located in the Pasco Basjn, one of the largest structural basins on the Columbia Plateau. The Pasco Basin is divided by the Gable Hountain anticline into the Wahluke and Cold Creek synclines (Figure 2-2).

The cold Creek syncline is an asymmetric and relatively flat-bottomed structure. The 200 Areas lie on the northern flank and the bedrock dips gently to the south into the cold Creek syncline. The 300 Area lies at the eastern end of the cold Creek syncline.

The Wahluke synctine contains the 100 Areas. It is an asymatric and relatively flat-bottomed structure similar to the Cold Creek syncline. The northern limb dips gently to the south; the steepest 1 imb is adjacent to the Gabie Mountain anticline.

The Umtanum Ridge-Gable Mountain structural trend is a segnanted anticlinal ridge extending in an east-west directfon between the 200 and 100 Areas. On the Hanford Site the Umtanum Ridge segment plunges eastward and joins the Gable Mountain-Gable Butte segment.

\subsection{SITE HYDROLOGY}

\subsubsection{Surface Hydrology}

Primary surface water features assoclated with the Hanford site are the Columbia River and its tributary, the Yakima Rtver. West Lake, about 4 ha 
(10 acres) in size and Tess than $1 \mathrm{~m}(3 \mathrm{ft}$ ) deep, is the only natural lake on the Hanford Site.

The Columbia River flows through the northern part and along the eastern border of the Hanford Site. Flow along this section of the river, which is called the Hanford Reach, is controlled by Priest Rapids Dan upstream of the Hanford Site. River stage recorders, consisting of pressure transducers and data loggers, are operating at the $100-8 / \mathrm{C}, 100-\mathrm{H}, 100-\mathrm{H}, 100-\mathrm{F}$, and 300 Areas. The river drops $14 \mathrm{~m}(46 \mathrm{ft})$ between the $100 \mathrm{~B} / \mathrm{C}$ and 300 Areas, in a distance of approximately $64 \mathrm{~km}(40 \mathrm{mi})$. The average gradient is 0.0002 . Figure 2-3 shows the average weekly river stage for the past year. The river stage graphs are paralle], with some damping of asplitude further downstream (e.9., 300 Area).

Riverbank springs have been observed and sampled along the Hanford Reach (HcCormack and Caribile 1984; Dirkes 1990; Peterson and Johnson 1992). Contaminants originating on the Hanford Site have been detected in spring water along the Hanford Reach. The type and concentrations of contaminants in the spring water are simtlar to those known to exist in the groundwater near the river.

Approximately one-third of the Hanford Site is drained by the Yakima River system. Cold Craek and its tributary, Ory Creek, are ephemeral streams within the Yakima River drainage system.

Table 2-1 lists the chemical composition of river water at the Hanford Site. Precipitation at the Hanford Site contains very few dissolved solids. Columbia River water is low in dissolved solids. Yakima River water contains higher concentratjons of some constituents, which may be influenced by anthropogenic activity (DOE-RL 1992).

\subsubsection{Hudrogeologic Units}

Hydrogeologic units beneath the Hanford Site include: (1) the vadose zone, (2) an aquifer system in the suprabasalt sediments, and (3) a series of confined aquifers in the basalts and interbeds. This document will focus on the units above the basalts. The source of the following information is Delaney et al. (1991) unless otherufse indicated. Hydraulic properties of various hydrologic units are 11sted tn Table 2-2.

The vadose zone at the Hanford Site includes Holocene surftcial deposits, the Hanford formation and, in scme areas, portions of the Ringold formation. In the 100 Areas, the water table is located near the Hanford-Ringold contact and the vadose zone consists of poorly sorted gravel, sand, and silt. In the 200 Areas, unsaturated sediments include Ringold unit $\varepsilon$ and the units above it (see Section 2.1). Onily the Hanford formation is continuous throughout the vadose zone in the 200 Areas. The vadose zone beneath the 300 and 1100 Areas is almost entirely in the Hanford formation. The vadose zone is less than $30 \mathrm{~m}(100 \mathrm{ft}$ ) thick near the Columbia River (i.e., the 100,300 , and 1100 Areas). The vadose zone beneath the 200 Areas is up to $104 \mathrm{~m}$ (340 ft) thick. 
The saturated sediments of the Hanford and Ringold Formations make up a series of aquifers and aquitards that has been referred to as the suprabasalt aquifer systef. The shallowest producing Tayer within the systen at a given location is called the uppersost aquifer. In general, the sand- and graveldoninated stratigraphic unjts (see Figure 2-1) forti aquifers and the overbank/1 acustrine deposits form aquitards.

The uppernost aquifer in the 100 Areas comprises unconfined sand and gravel of Ringold unit $E$ or the Hanford foration. In the 200 West Area the uppermost aquifer is contained in the Ringold Formation under unconfined to locatiy confined conditions. In the 200 East Area the uppermost aquifer occurs in the Hanford and Ringold formations under unconfined to locally confined conditions. The aquifer pinches out north of the 200 East Area where the basalt is above the water table. The uppermost aquifer at the 300 and 1100 Areas is dominated by the fluvial gravels of the Ringold Formation.

Water enters the uppermost aquifer from precipitation, deeper aquifers, influent streams, and artificial sources such as liquid effluent disposal and irrigation.

Coarse-grained units deeper in the Ringold formation are isolated beneath fine-grained units, forming a series of locally confined aquifers. Hydrologic data on these aquifers are limited. There is an upward gradient between these shallow, cenfined aquifers and the unconfined aquifer in the 100-H Area.

\subsubsection{Groundwater Flow}

Figure 2-4 is a water table map of the Hanford site for June 1995. Groundwater flow in the unconfined aquifer is inferred to be generally from west to east, discharging to the Columbia River. Artificial recharge from liquid effluent disposal has locally altered groundwater flow and raised the water table. The most notable examples of this are in the 200 West Area and east of the 200 East Area.

The volume of water discharged in the 200 Areas has decreased and the location of the disposal facilitites has changed in recent years. These changes have caused the water table to decline. During the past year this decline slowed, and water levels stabilized in many wells.

\subsubsection{Groundwater Chenistry}

Natural chemfistry of unconfined groundwater on the Hanford Site is subiarized in Table 2-3. The listed values were dertved from walls located upgradient (to the west) of Hanford site activitifes. These values are provided for general information only, and should not be used as a baseline to assess groundivater contamination.

Hanford Site operations have introduced chemical and radiological contaminants to the groundwater in the uppermost aquifer. Contaminant plumes originate in the operational areas. Contamtnation is also present from offsite sources, e.g., nitrate from agricultural practices. 
Figures 2-5 through 2-10 are contour maps showing the distribution of the most widespread contaminants in the uppermost aquifer of the Hanford Site. The maps were constructed from data collected from shallaw wells between January 1991 and September 1993. Anomalous data points were removed and values were averaged where more than one result existed. Groundwater chentstry data were retreived from the Hanford Environmental Information System, and include data froal Pacific Northmest Laboratory sitewide wonitoring as weli as from Westinghouse Hanford Company's wanitoring programs. Plume naps constructed from data collected in 1994 (Dresel et al. 1995) look very sinilar to the maps constructed of 1991-93 data.

Figure 2-5 shows the distribution of tritium in the uppermost aquifer. Sources of tritiuu contasination are, or have been, effluent storage or disposal sites in the reactor areas and the 200 Areas. Tritium contamination from the 200 Areas has moved in a widespread p] ume toward the east. It appears that tritfum contamination a] so has moved northward between Gable Mountain and Gable Butte. Once through this "gap," the tritium contamination migrates toward the northest.

Figure 2-6 illustrates gross beta activity in the uppermost aquifer. The highest observed activities are in the 200 Areas and in the 100-N Area. Like the tritium plume, the gross beta plume has moved from the 200 East Area through Gable Gap.

The gross beta plumes in the 200 Areas and the plume woving through Gable Gap coincide with the "Tc plume in those areas (see Figure 2-7).

Technetjum-99 is a beta emitter. A group of wells near the Columbia River due east of the 200 Areas al so shows elevated ${ }^{9} \mathrm{Tc}$. It is not known whether this plume is connected to contamination in the 200 Areas.

Figure 2-8 shows the distribution of ${ }^{129} 1$ in the uppermost aquifer. Contaminant plumes are moving east from the 200 Areas. 5maller areas of contamination are also observed near the 300 Area.

Figure 2-9 illustrates nitrate distribution in the uppermost aquifer. Hitrate contamination above the drinking water standard $(45,000 \mathrm{ppb})$ is observed at 7ocations throughout the Hanford Site.

Groundwater beneath most of the 200 West Area is contaminated with carbon tetrachloride ( $F$ igure $2-10$ ). Discussion of potential sources of the contamination are contained in DOE (1991).

The concentrations of certain metals have been elevated in many unfiltered groundwater samples collected at the Hanford Site. The elevated metals are believed not to be representative of groundwater quality. Only filtered samples are now analyzed for metals at wost of the RCRA sites, and filtered samples generally have much Tower concentrations of metals.

\subsection{REFEREICES}

Comprehensive Environmental Response, Compensation, and Liability Act of 1980, 42 USC 9601 et seq. 
Delaney, C. D., K. A. Lindsey, and S. P. Reide], 1991, GeoTogy and Hydrology of the Hanford Site: A Standandized Text for Use in Westinghouse Hanford Company Documents and Reports, WHC-SD-ER-TI-003, Rev. 0, Westinghouse Hanford Company, Richland, Washington.

Dirkes, R. L.. 1990, 1988 Hanford Riverbank Springs Characterization Report, PNL-7500, Pacific Horthwest Laboratory, Richiand, Washington.

DOE, 1998, Site Characterization Plan, DOE/RW-0164, VoTs. 1 and 2, U.S. Department of Energy, Washington, D.C.

DOE, 1991, Expedited Response Action Proposal for 200 West Area Carbon Tetrachloride Plusie, U.S. Department of Energy, Washington, D.C.

DOE-RL, 1990, Readial Investigation/feasibility Study Work Plan for the 300 FF-5 Operable Unit, Hanford Site, Richland, Washington, DOE/RL 89-14, U.S. Department of Energy, Richland Field Office, Richiand, Washington.

DOE.-RL, 1992, Hanford Site Groundwater Background, DDE/RL-92-23, U.S. Department of Energy, Richland Field Office, Richland, Washington.

Drese1, P. E., P. O. Thorne, S. P. Luttrell, B. H. Gillespie, H. D. Webber, J. K. Merz, J. T. Rieger, M. A. Chamness, S. K. Wurstner, B. E. Opitz, 1995. Hanford Site Ground-Water Monjtoring for 1994, PNL-10698, Pacific Horthwest Laboratory, Richland, Mashington.

Eariy, T. 0., M. D. Mtche11, and 6. 0. Spice, 1986, A Hydrochewical Data Base for the Hanford 5fte, Washington, SD-BNI-DP-061, Rev. 1, Rockwell Hanford Operations, Richland, Washington.

Gephart, R. E., R. C. Arnett, R. 6. Baca, L. S. Leonhart, and F. A. Spane, Jr., 1979, Hydrologic Studies within the Columbia Plateat, Washington: An Integration of Current Knowledge, RHO-BNI-\$T-5, RockweII Hanford Operations, Richland, Washington.

Grahan, H. J., H. D. Hall, S. R. Strajt, and W. R. Brown, 1981, Hydrology of the Separations Area, RHO-ST-42, Rockweil Hanford Operations, Rich7and, Washington.

Grahan, H. J., 6. V. Last, and K. R. Fecht, 1984, An Assessutent of Aguifer Intercomonication in the $B$ Pond-6able hountain Pond Area of the Hanford Site, RH0-RE-ST-12P, Rockwell Hanford Operations, Richland, Washington.

Hartman, H. J., 1994, "Hanford Site Hydrogeology," in Annual Report for RCRA Groundwater Monitoring Projects at Hanford site Facijfties for 1993, DOE/RL-93-88, Rev. 0, U.S. Department of Energy, Richland Operatjons Office, Richiand, Washington.

Last, G. V., B. H. BJornstad, H. P. Bergeron, D. H. Hatlace, D. R. Newcomer, J. A. Schramke, M. A. Chamness, C. S. Ci ine, S. P. Aỉrhart, and J. S. Wilber, 1989, Hydrogeotogy for the 200 Areas Low-Level Burial Grounds - An Interin Report, PlkL-6820, Pacific Northwest Laboratory, RichT and, Washington. 
Lijkala, T. L., R. L. Aaberg, N. J. Alen, D. J. Bates, T. J. Gilmore, E. J. Jensen, G. V. Last, P. L. Overlander, K. B. Olsen, F. R. Oster, L. R. Roome, J. C. Simpson, S. S. Teel, and E. J. Nestergard, 198B, Geohydrologic Characterization of the Area Surrounding the 183-H Solar Evaporation Basins, PNL-6728, Pacific Northwest Laboratory, Richland, Washington.

Lindberg, J. W., and F. W. Bond, 1979, Geohydrology and Ground-water Quality Beneath the 300 Area, Hanford Site, Washington, PNl-2949, Pacific Northwest Laboratory, Richtand, Washington.

Lindsey, K. A., 1991, Revised Stratigraphy for the Ringold Formation, Hanford Site, South-Central Washington, WHC-SD-EN-EE-004, Rev. O, Westinghouse Hanford Company, Richland, Washington.

McCormack, M. D., and J. M. V. Carlile, 1984, Invest gation of Groundwater Seepage from the Hanford Shoreline of the Columbia River, PNL-5289, Pacific Morthwest Laboratory, Richland, Washington.

Peterson, R. E., and Y. 6. Johnson, 1992, Riverbank Segpage of Groundwater Along the 100 Area Shoreline, Hanford Site, WHC-EP-0609, Nestinghouse Hanford Company, Richland, Washington.

Resource Conservation and Recovery Act of 1976, 42 USC 6901 et seq.

Serkowski, J. A., M. J. Hartman, and W. A. Jordan, 1994, Groundwater Maps of the Hanford Site, June 1994, WHC-EP-0394-9, West inghouse Hanford Company, Richl and, Washington.

Trent, S. J., 1994, "Hydrogeologic Setting of the 200 Areas," in Annual Report for RCRA Groundwater Monitoring Projects at Hanford Site Facilities for 1993, DDE/RL-93-88, Rev, 0, U.S. Department of Energy, Rjchland Operations office, Richland, Washington.

WHC, 1990, Liquid Effluent Study: Ground Water Characterization Data, WHC-EP-0366, Westinghouse Hanford Company, Richland, Washtngton. 
Figure 2-I. Generalized Stratigraphy of the Suprabasalt Sediments Beneath the Hanford Site (Delaney et a]. 1991).

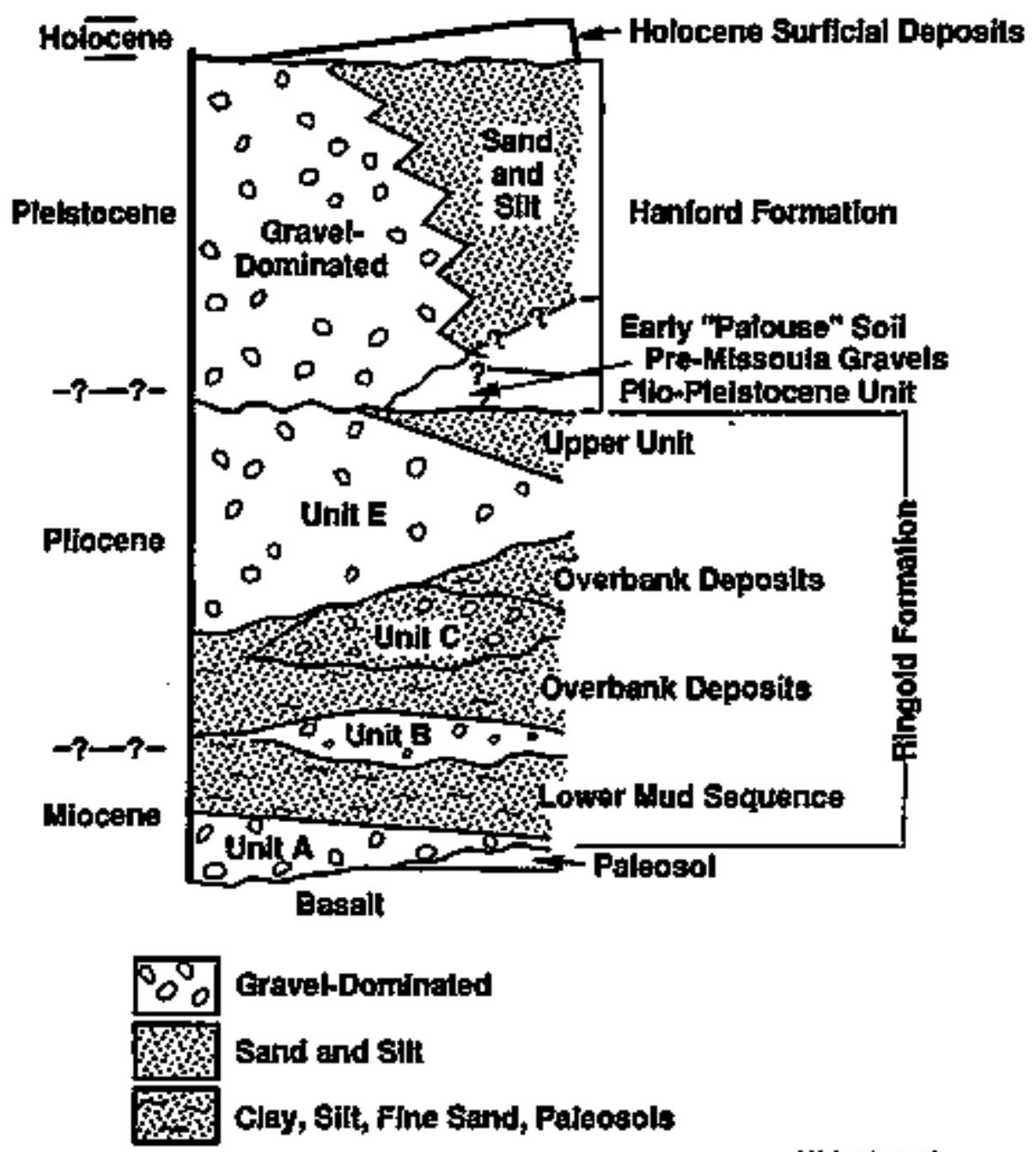

19411010.16 
Figure 2-2. Geologic Structure of the Hanford Site (Delaney et a1. 1991).

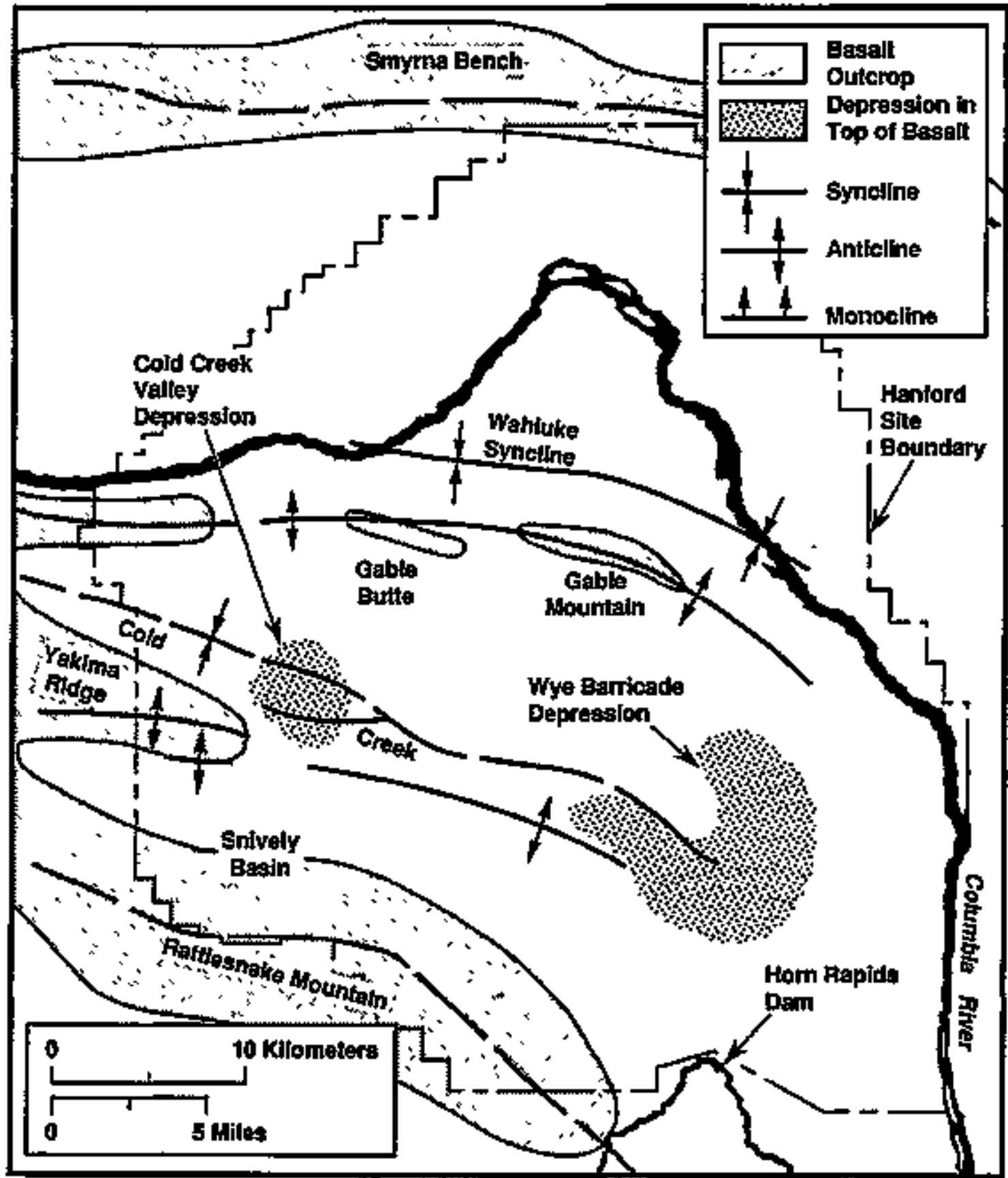

H\$312025.1 


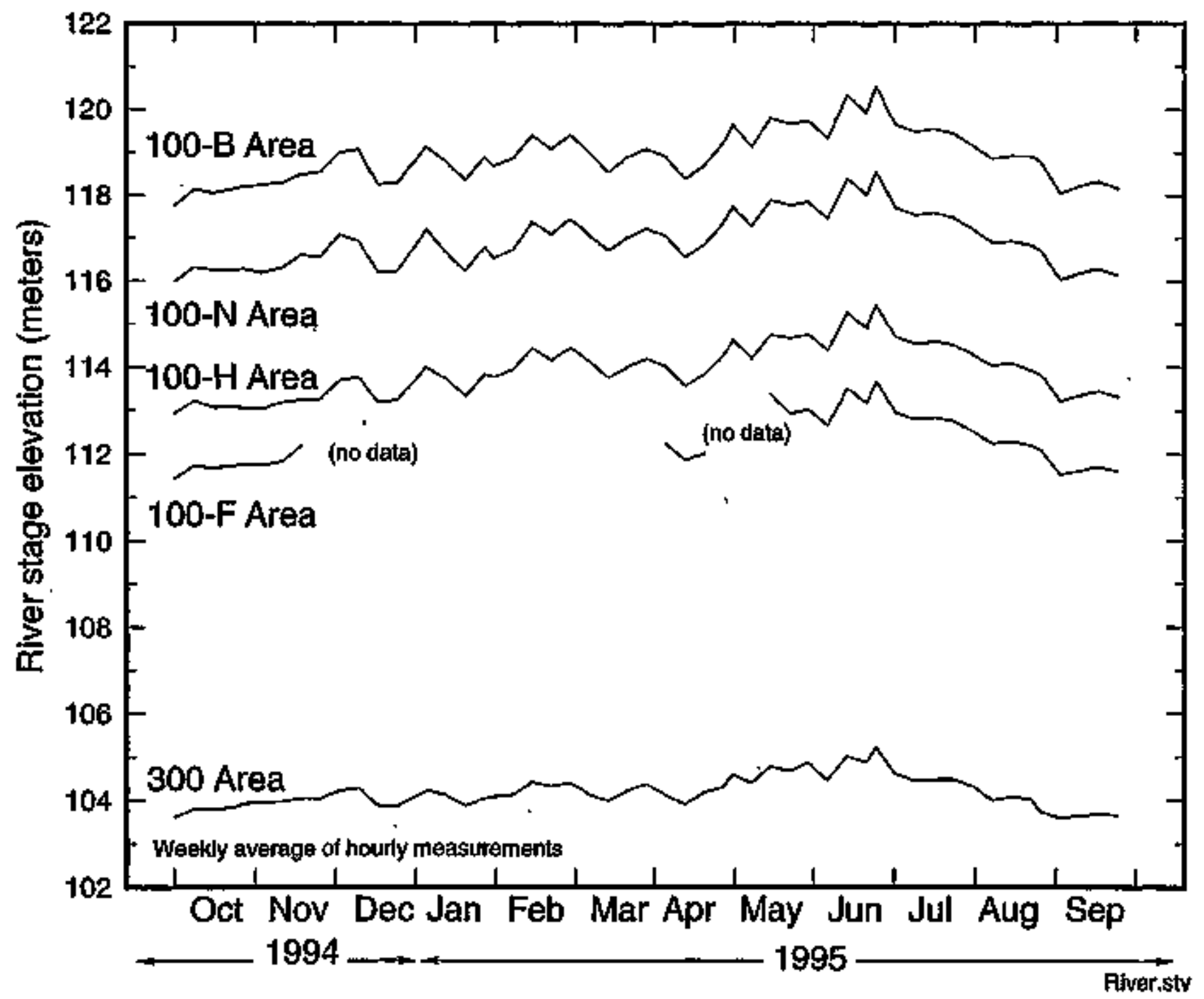


00E/RL-96-01, REV. 0

Ffgure 2-4, Hanford Site Water Table Map, June 1995.

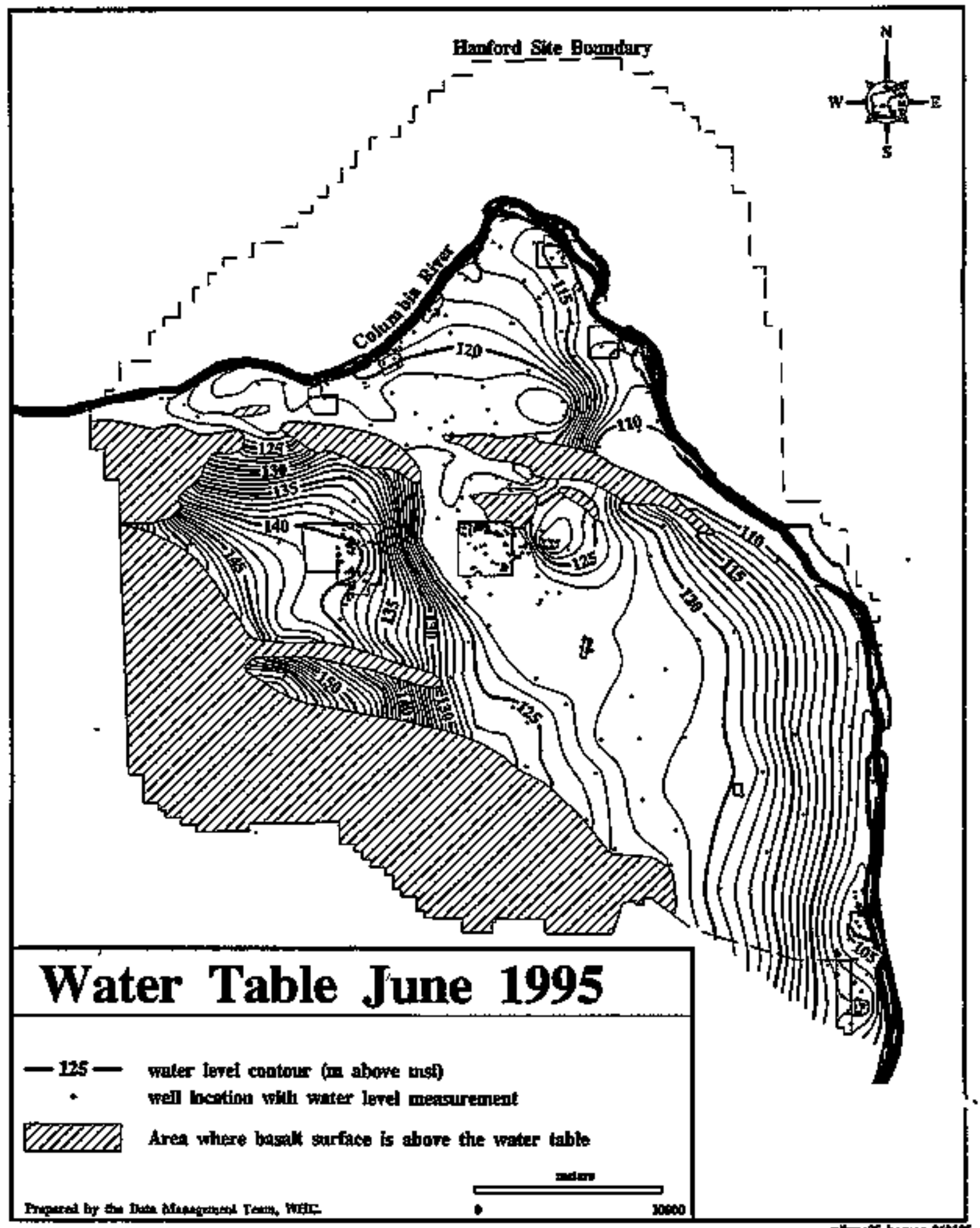

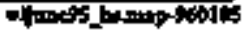




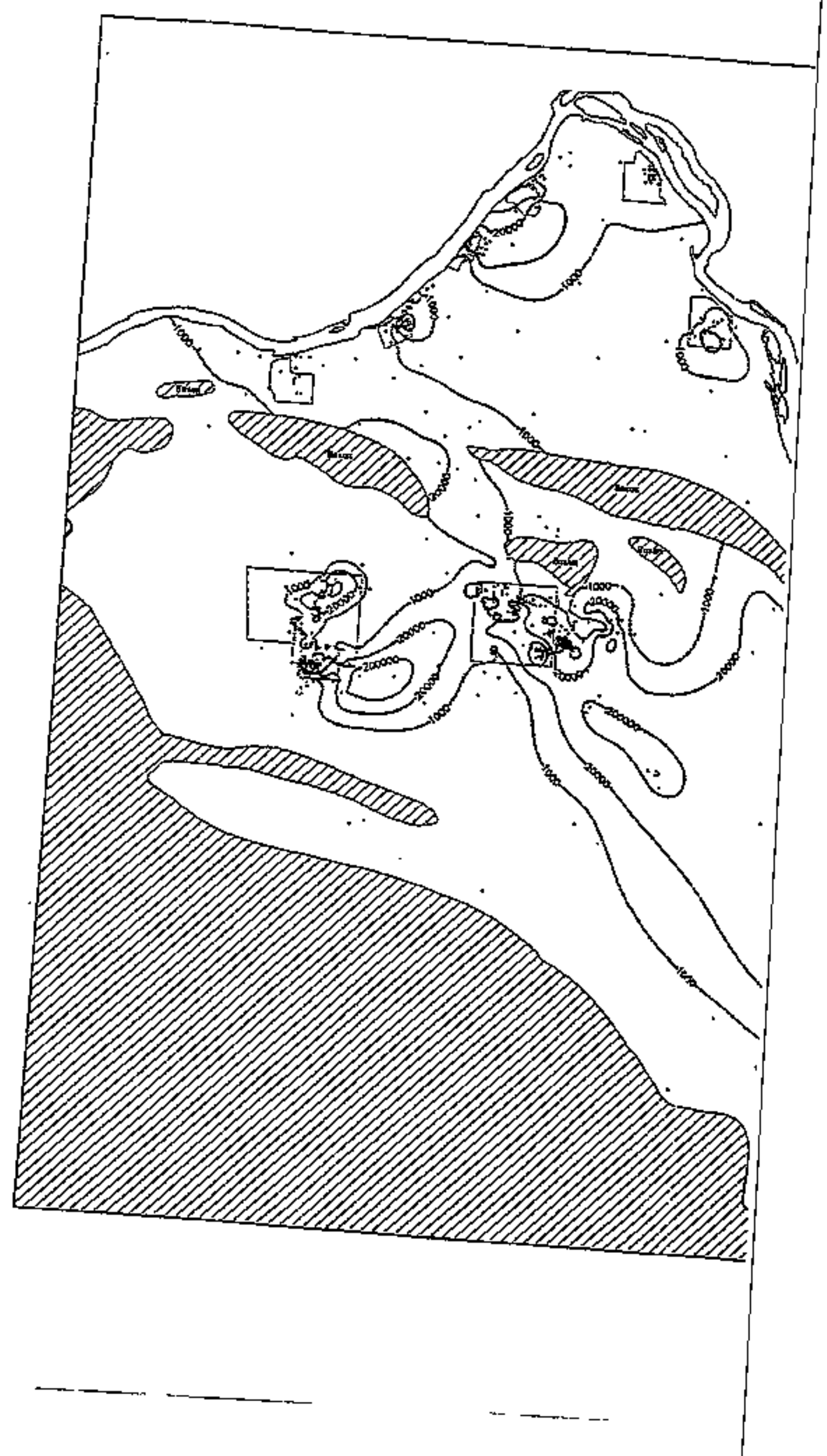


Figure 2-5. Tritfum Otstribution in the Uppermost Aquifer, Hanford Site, January 1991 through 11 1:- September 1993 (Hartman 1994). Honfora site Tritium Groundwater Plume Map
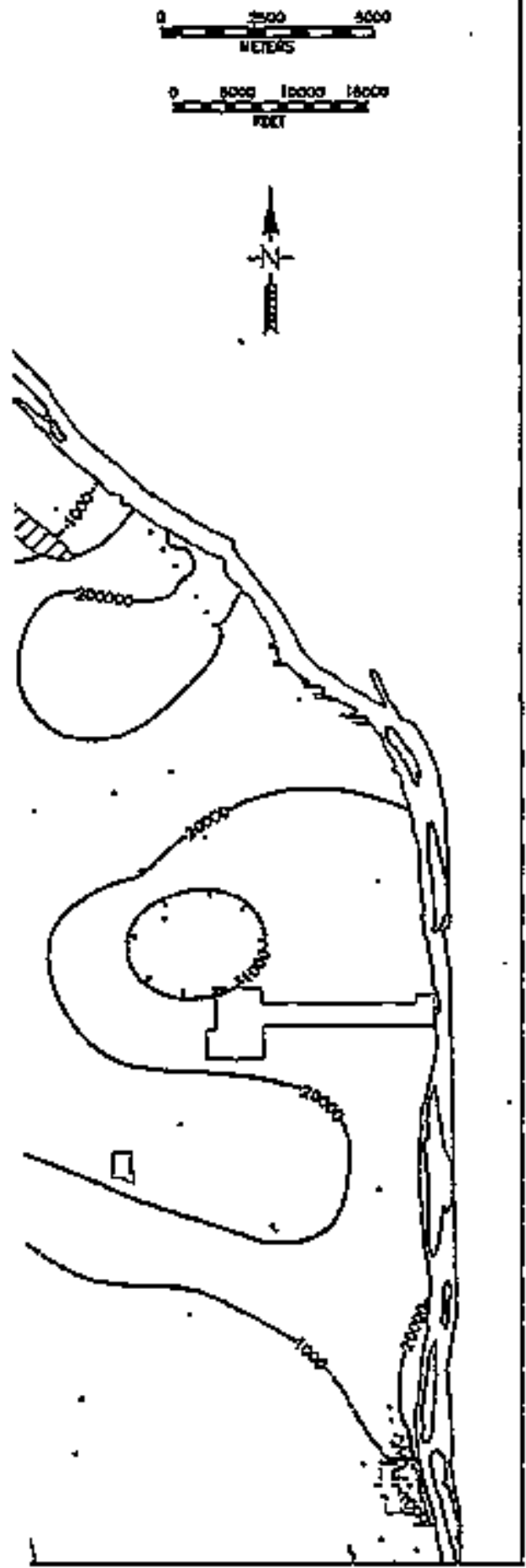

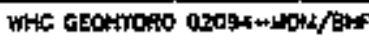

- Went Locotion

raon Concuntrolion isoplath

This mop rys constructed from averoge volues for the period 1/1/91 - 10/1/93, with onomalour dato points removed.

Delection Limit. . . . . . . . . . . . .500 pCi//L

Orinking Water Slondard. . . . . . 20,000 $\mathrm{pCi} / \mathrm{L}$

Woshinglon Woter Quality Slandard. . 20,000 pCi/h 1/25 Garived Coreentration Gtide. . . 90,000 pCl/L. Haxtmun Concanisation Lhrit. . . . . $20.000 \mathrm{pCi} / \mathrm{h}$ 


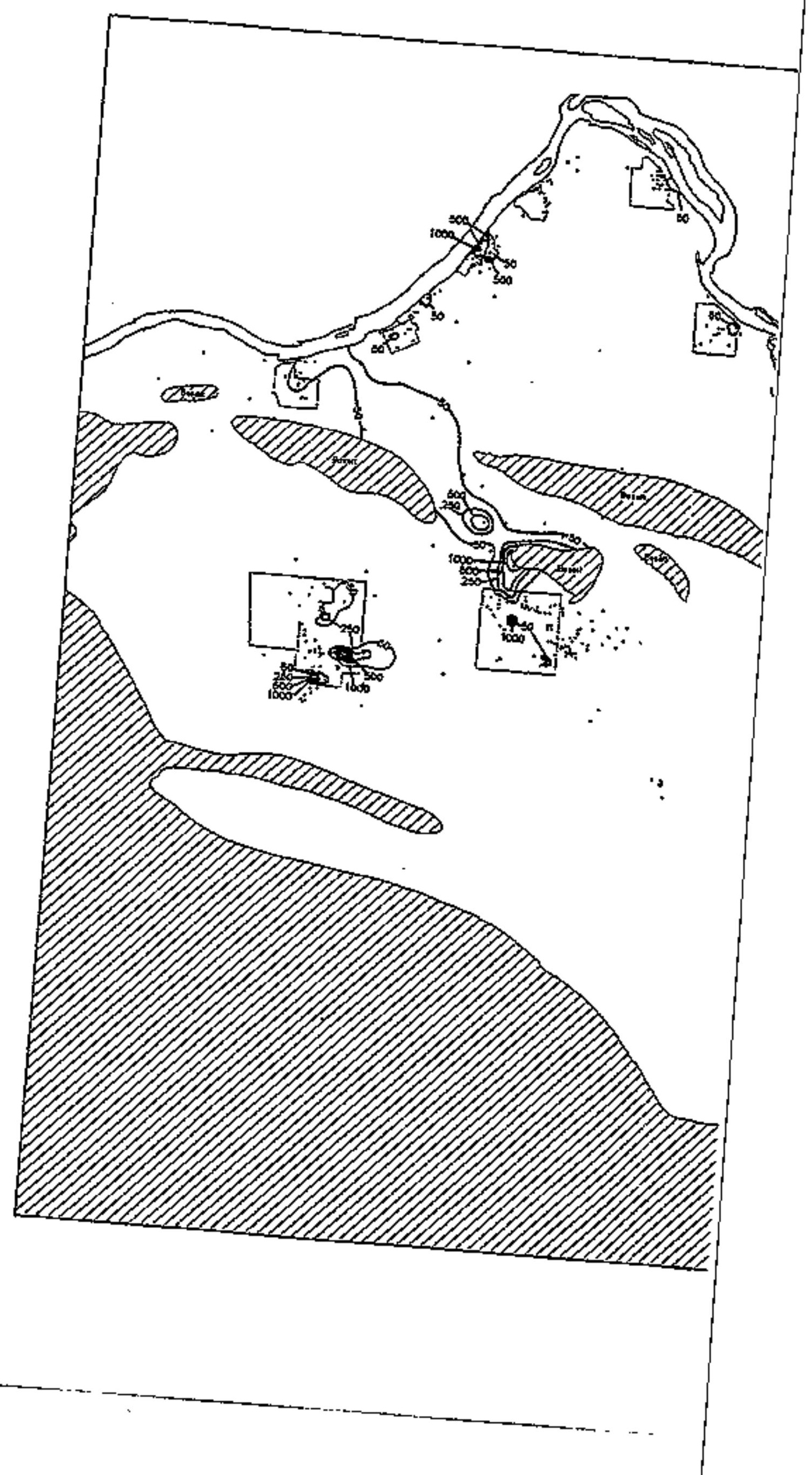


Figure 2-6. Gross Beta Distribution in the lippermost Aquifer, Hasford Site, January 1991 through September 1993 (Hartman 1994).

Hanford Site

Gross Beto

Groundwoter Plume Mop
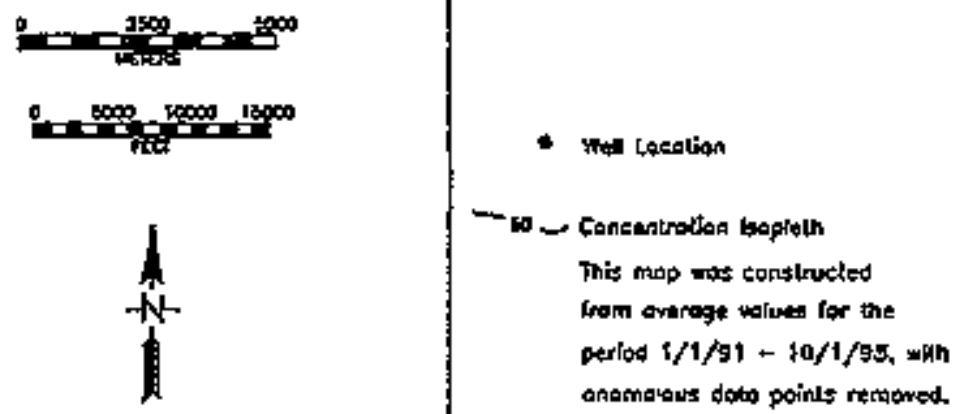

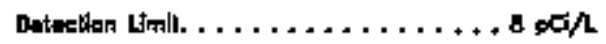

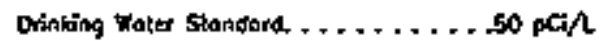

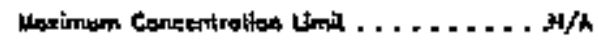

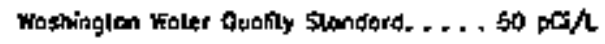

$1 / 25$ Derived Concesalralion Gutd. . . . . . N/h 


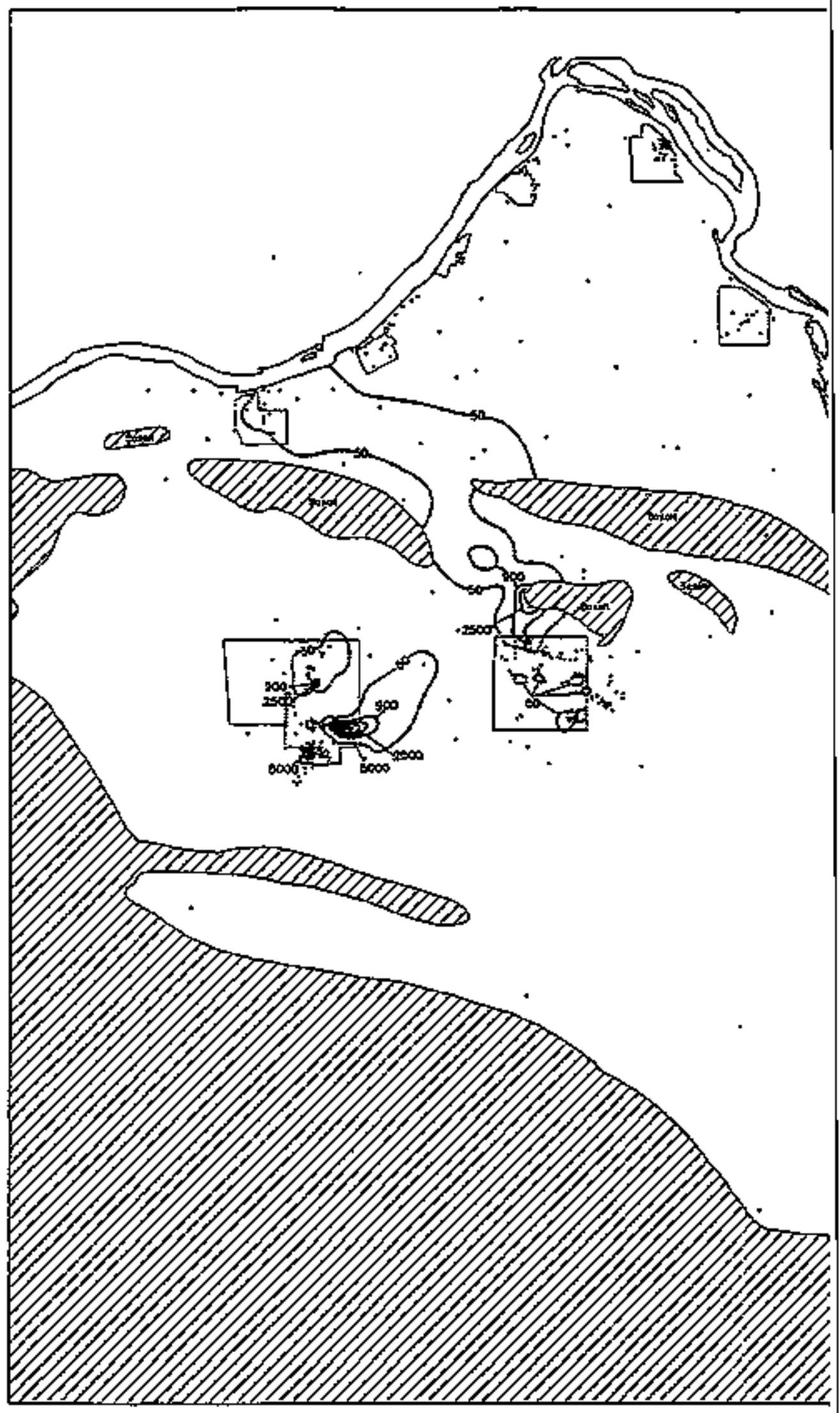


Figure 2-7. Technetium-99 Distribution in the Uppermost. Aquifer, Hanford Sjte, January 1991

- through September 1993 (tartman 1994).

Hanford Site

Technetium-99

Grounciwoter Plume Map
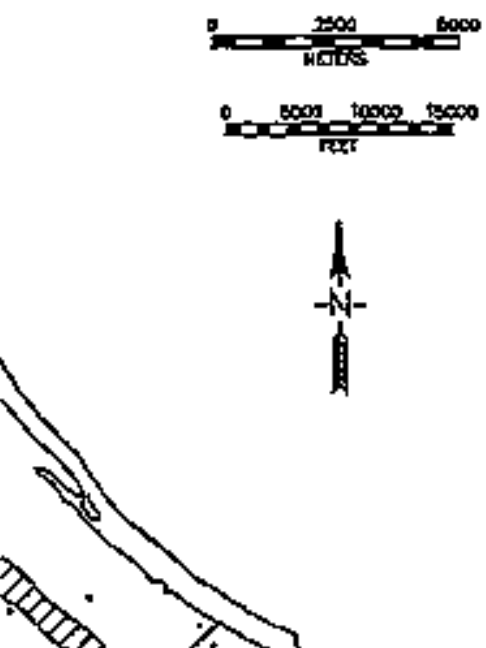

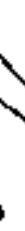

(1)

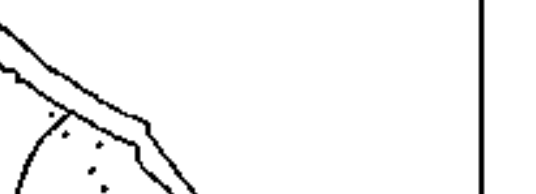

Detection Unit. . . . . . . . . . $15 \mathrm{pel} / \mathrm{h}$

Drinklng Walar stondard. . . . . . . . . . .900 pcl/h

Haximum Coacentratien tima . . . . . 9 900 pta/h

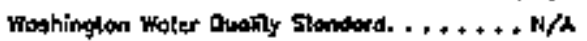

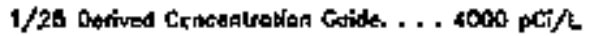




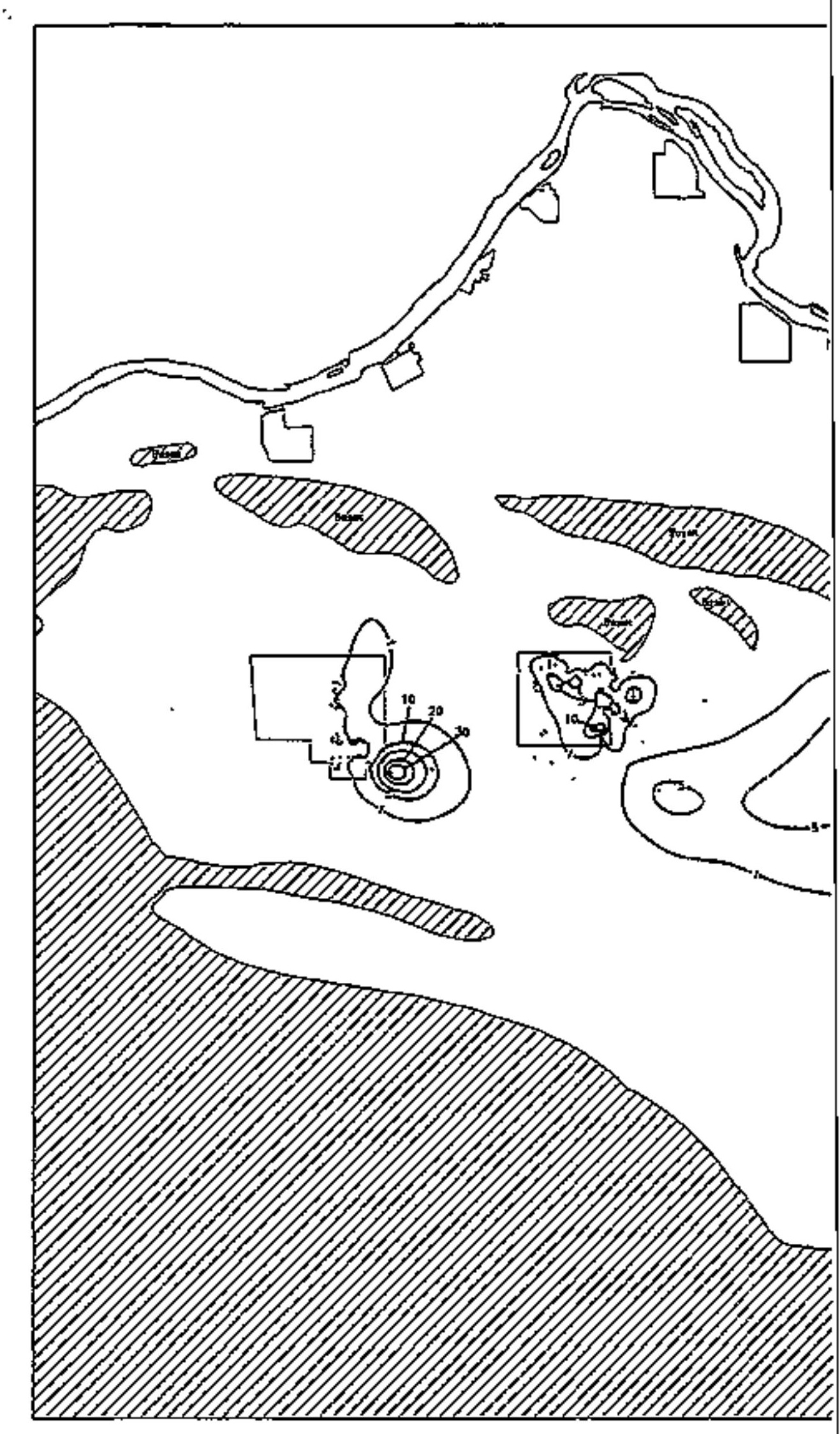


Figure 2-8. Iodine-129 Distribution in the Uppermost Aquifer, Hanford Site, January 1991 through September 1993 (Hartman 1994).

\section{Hanford Site}

lodine- 129

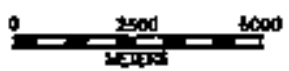

Grouridwoter Plume Map

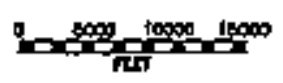

- Wet Lasalion

- I - Coocendralion ksoglęlh

Thls map was construeted

irom oretoge volues for the

parlod 1/1/91 - 10/1/93, wile

comalaus dolo points tersoverd.

Oetretion Lirrt. . . . . . . . . . . . . 1 pet/h

Drinding Woter Standord. . . . . . . . . . . 1 pel/

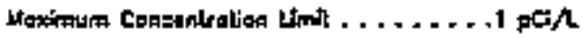

Washiaglon Whter Oudily Slandard, . . . + + N/A

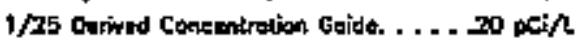

【
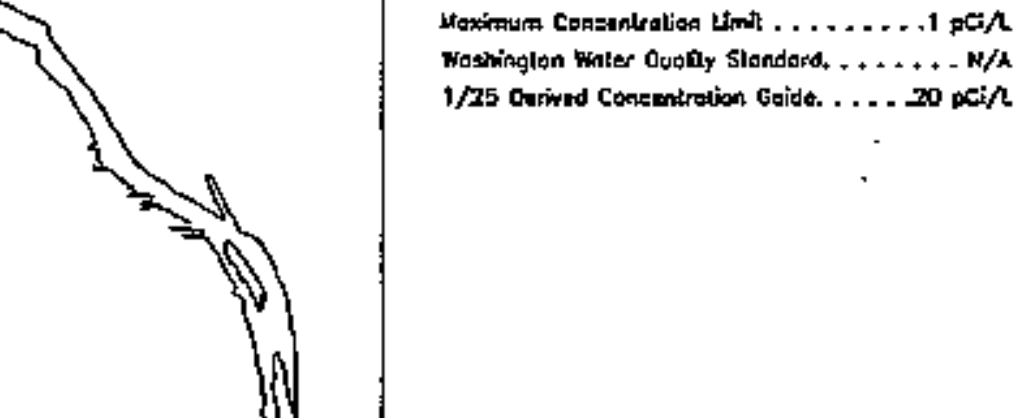


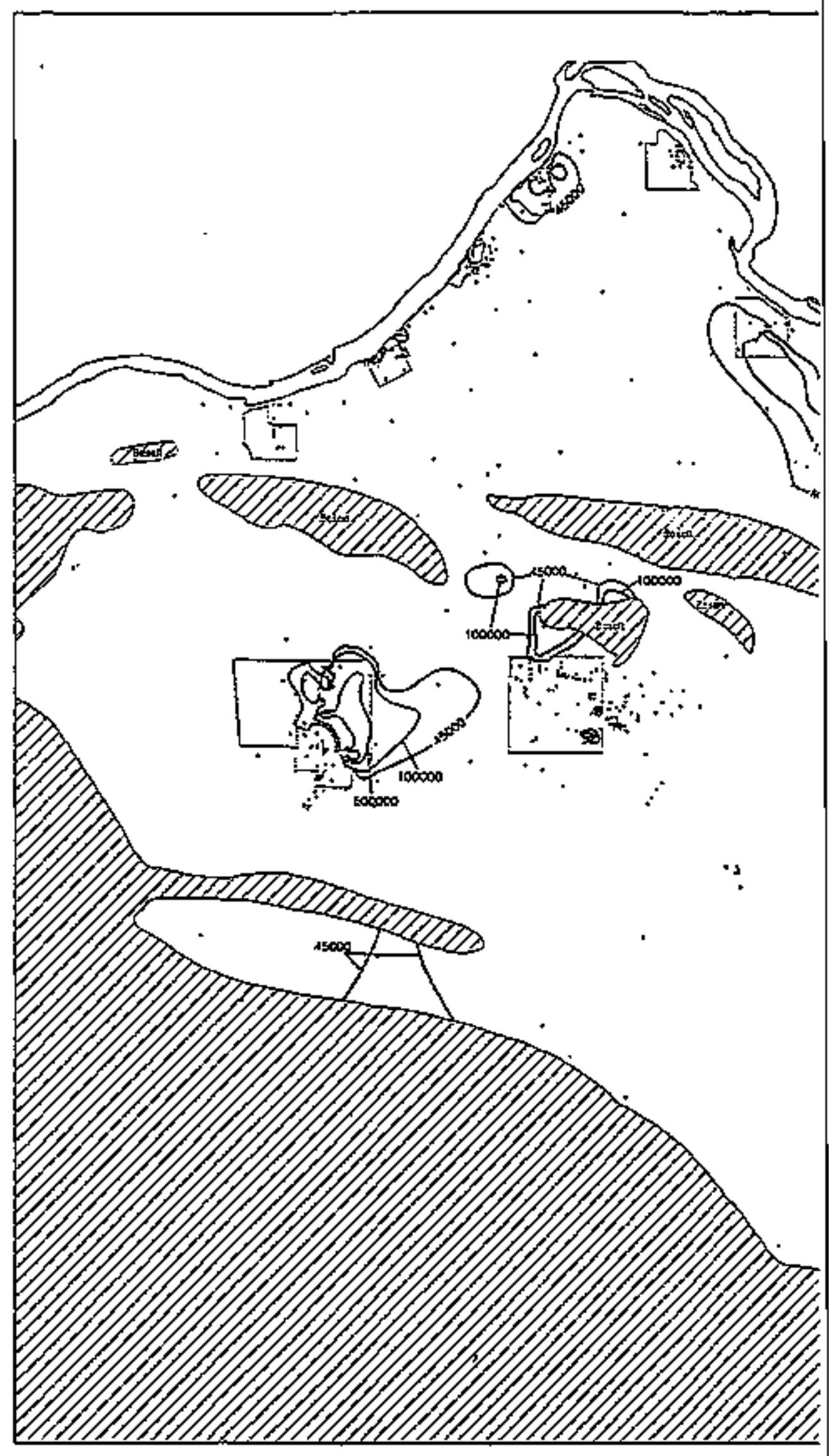



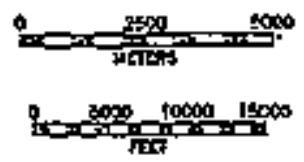

Figure 2-9. N1trate Distribution in the ipperalost Aquifer, Hanford Site, January 1991 through September 1993 (Hartman 1994).

Honford Site

Nitrote

Groundwoter Plume Map

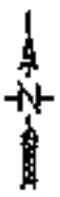

- Net Lacolion

\section{- dsoos.Concendrotion lsoplelh \\ Mit map wat constructed \\ indin averoge woltets for the \\ feriod $1 / 1 / 91$ - 10/1/93. with \\ onomoloes dolo goints romored.}

Datedton init. . . . . . . . . . . . . . . s00 ppb

Criming Walter Slondort. $+\ldots+\ldots+\ldots+45000 \mathrm{Fpb}$

Morimun Concenlrolion Limit . . . . . . . N/A

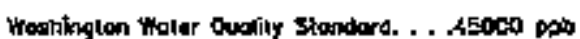

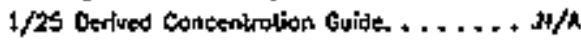




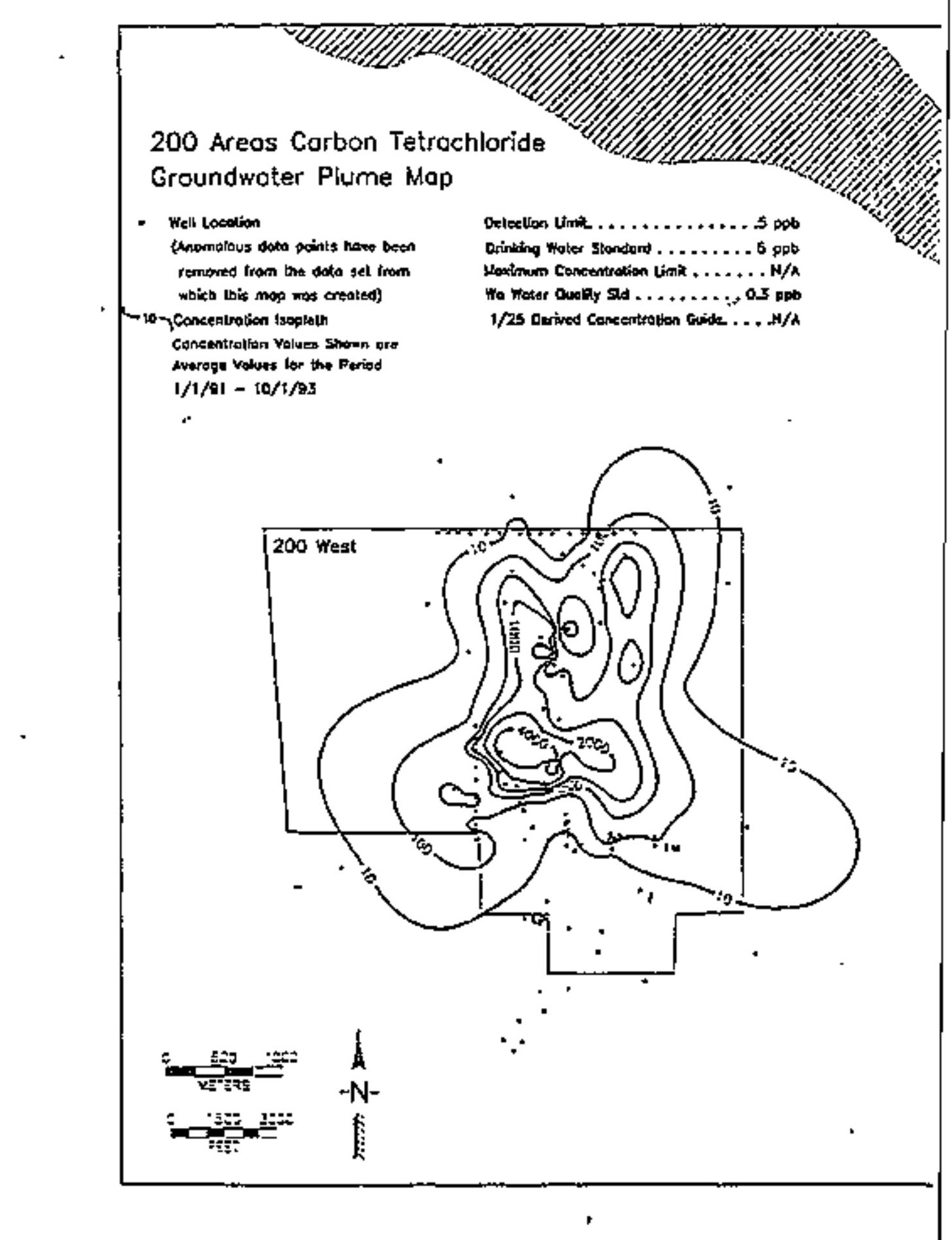


Table 2-1. Range of Chemical Constituents in Colubita and Yakima River Water (DOE 1988, pp. 3.4-3 and 3.4-4).

\begin{tabular}{|c|c|c|c|}
\hline \multirow[b]{2}{*}{ Paranteter } & \multirow[b]{2}{*}{ Units } & \multicolumn{2}{|c|}{ Range ${ }^{\circ}$} \\
\hline & & $\begin{array}{c}\text { Columbia River } \\
\text { at Vernita }\end{array}$ & $\begin{array}{l}\text { Yakima River at } \\
\text { Horn Rapids }\end{array}$ \\
\hline Calcium & 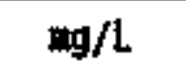 & $17.3-22.2$ & $12.7-30.3$ \\
\hline Chlorine & $\mathrm{mg} / \mathrm{L}$ & $0.9-1.1$ & $2.2-6.9$ \\
\hline Fluorine & $\mathrm{mg} / \mathrm{L}$ & $0.13-0.32$ & $0.18-0.22$ \\
\hline Potassium & $\mathrm{mg} / \mathrm{L}$ & $0.42-0.91$ & $1.3-3.0$ \\
\hline Magnesium & $\mathrm{mg} / \mathrm{L}$ & $4.0-5.2$ & $4.2-10.7$ \\
\hline Soditm & $\mathrm{mg} / \mathrm{L}$ & $2.2-2.4$ & $6.2-16.3$ \\
\hline Nitrate (as $\mathrm{NO}_{3}$ ) & $\mathrm{mg} / \mathrm{L}$ & $0.15^{b}$ & $0.4-4.0$ \\
\hline silican & $\mathrm{mg} / \mathrm{L}$ & $1.8-2.1$ & $8.0-10.7$ \\
\hline Sulfate & $\mathrm{mg} / \mathrm{L}$ & $9.13-13.4$ & $5.4-17.9$ \\
\hline Total carton & $\mathrm{mg} / \mathrm{L}$ & $13.9-16.3$ & $14.9-29.5$ \\
\hline Total organic carbon & $\mathrm{mg} / \mathrm{L}$ & $1.2-2.0$ & $1.7-3.3$ \\
\hline Tritiun & $\mathrm{pCi} / \mathrm{L}$ & $81.1-96.3$ & $40.4-45.2$ \\
\hline pH & -- & $7.94-8.71$ & $7.25-8.78$ \\
\hline Turbidtty & MTU & $1.1-3.5$ & $9.2-23.5$ \\
\hline Alkal inity & $\mathrm{mg} / \mathrm{L}$ & $53.0-62.0$ & $51-121$ \\
\hline Conductivity & $\mu \Pi_{h o} / \mathrm{cm}$ & $123-152$ & $122-291$ \\
\hline Iron & $\mathrm{mg} / \mathrm{L}$ & $<0.03$ & $<0.015-0.066$ \\
\hline Manganese & $\mathrm{mg} / \mathrm{L}$ & $<0.01$ & $0.012-0.028$ \\
\hline
\end{tabular}

"Samples were collected in April, July, and Noverber 1985 and January and May 1986.

Only one sample analyzed for nitrate.

NTU = nephelometric turbidity units. 
Table 2-2. Hydraultc Parameters for Various Areas and Geologic Units at the Hanford Site (Delaney et al. 1991).

\begin{tabular}{|c|c|c|c|c|}
\hline Location & Interval tested & $\begin{array}{l}\text { Hydraulic } \\
\text { conduct fvity } \\
\text { (m/d) } \\
\text { (ft/d) }\end{array}$ & $\begin{array}{c}\text { Transmissivity } \\
\left(m^{2} / \mathrm{d}\right) \\
\left(\mathrm{ft}^{2} / \mathrm{d}\right)\end{array}$ & Data source \\
\hline 100 Area & $\mid \begin{array}{l}\text { Rattlesnake Ridge } \\
\text { Interbed }\end{array}$ & $\begin{array}{l}0-30.5 \\
(0-100)\end{array}$ & - & $\begin{array}{l}\text { Gephart } \\
\text { et al. (1979) }\end{array}$ \\
\hline 100 Area & Ringold unit E & $\begin{array}{c}8.8-396 \\
(29-1,300)\end{array}$ & $\begin{array}{c}534-2,480 \\
(5,750-26,700)\end{array}$ & $\begin{array}{l}\text { Lifkala } \\
\text { et al. (1988) }\end{array}$ \\
\hline 200 Area & \begin{tabular}{|l|} 
Rattlesnake Ridge \\
interbed
\end{tabular} & -- & $\begin{array}{l}0.74-108 \\
(8-1,165)\end{array}$ & $\begin{array}{l}\text { Grahan et al. } \\
\text { (1981, 1984) }\end{array}$ \\
\hline $\begin{array}{l}200 \text { Hest } \\
\text { Area }\end{array}$ & Ringold unit $E$ & $\begin{array}{c}0.18-61 \\
(0.6-200)\end{array}$ & - & $\begin{array}{l}\text { Last et al. } \\
\text { (1989) }\end{array}$ \\
\hline II00 Area & $\mid \begin{array}{l}\text { Ringold units C } \\
\text { and } B\end{array}$ & $\begin{array}{l}0.09-1.5 \\
(0.3-5)\end{array}$ & -- & $\begin{array}{l}\text { Lindberg and } \\
\text { Bond (1979) }\end{array}$ \\
\hline 1100 Areal & $\begin{array}{l}\text { Ringold overbank } \\
\text { deposits }\end{array}$ & $\begin{array}{l}0.00024=0.03 \\
(0.0008=0.1)\end{array}$ & - & $\begin{array}{l}\text { Lindberg and } \\
\text { Bond (1979) }\end{array}$ \\
\hline 300 Area & Levey interbed & $\begin{array}{c}0.003-305 \\
(0.01-1,000)\end{array}$ & - & COE-RL (1990) \\
\hline 300 Area & Ringold Formation & $\begin{array}{c}0.58-3,050 \\
(1.9-10,000)\end{array}$ & -- & DOE-RL (1990) \\
\hline 300 Area & Hanford formation & $\begin{array}{c}3,350-15,200 \\
(1,, 000-50,000)\end{array}$ & - & COE-RL (1990) \\
\hline
\end{tabular}


Table 2-3. Inorgantc Constftuents in Unconfined Groundwater Unaffected by Hanford Stte Operations (DOE-RL 1992, TabTes 5-9 and 5-11). (2 sheets)

\begin{tabular}{|c|c|c|c|}
\hline Parameter & Units & $\begin{array}{c}\text { Mean } \pm 1 \text { standard } \\
\text { deviation (sample size) }\end{array}$ & $\begin{array}{l}\text { Provisional } \\
\text { threshold value }\end{array}$ \\
\hline Aluninum & ppb & $<200^{\circ}(50)$ & $<200$ \\
\hline Amrontum & $\mathrm{ppb}$ & $<50(18)$ & $<120$ \\
\hline Arsentc & $\mathrm{ppb}$ & $<5(14)$ & 10 \\
\hline Barium & $p p b$ & $41 \pm 20(53)$ & 68.5 \\
\hline Beryll iun & $\mathrm{ppb}$ & $<5(16)$ & $<5$ \\
\hline Bismuth & ppb & $<5(4)$ & $<5$ \\
\hline Boron & ppb & $<100(35)$ & $<100$ \\
\hline Cadmi unt & $\mathrm{ppb}$ & $<10(16)$ & $<10$ \\
\hline Calcium & $\mathrm{ppb}$ & $38,542 \pm 11,023(53)$ & 63,600 \\
\hline Chloride-Low & $\mathrm{ppb}$ & $5,032 \pm 1,774(53)$ & 8,690 \\
\hline Ch7ortde-Htgh & $\mathrm{ppb}$ & $23,296 \pm 2,463(14)$ & 28,500 \\
\hline Chlortde-Al1 & $\mathrm{ppb}$ & $8,848 \pm 7,723(67)$ & Not calculated \\
\hline Chromium & $\mathrm{ppb}$ & $<30(8)$ & $<30$ \\
\hline Copper & ppb & $<30(50)$ & $<30$ \\
\hline Fluoride & ppb & $437 \pm 131^{6}(47)$ & $775^{\mathrm{b}}$ \\
\hline Iron-Low & $\mathrm{ppb}$ & $<50(34)$ & 86 \\
\hline Iron-Hid & $\mathrm{ppb}$ & $115 \pm 52(7)$ & 291 \\
\hline Iron-HIgh & $\mathrm{ppb}$ & $494 \pm 118(12)$ & 818 \\
\hline Iron-A11 & $\mathrm{ppb}$ & $149 \pm 199(53)$ & Not calculated \\
\hline Lead & $\mathrm{ppb}$ & $<5(15)$ & $<5$ \\
\hline Magnesium & $\mathrm{ppb}$ & $11,190 \pm 2,578(53)$ & 16,480 \\
\hline Manganese-Low & $\mathrm{ppb}$ & $<20(33)$ & 24.5 \\
\hline Manganese-High & $p p b$ & $118 \pm 17(20)$ & 163.5 \\
\hline Nanganese-AII & ppb & $50 \pm 55(53)$ & Not calculated \\
\hline Hercury & $\mathrm{ppb}$ & $<0.1(14)$ & $<0.1$ \\
\hline Mickel & ppb & $<30(23)$ & $<30$ \\
\hline Hitrate & $\mathrm{ppb}$ & $5,170 \pm 3,576(78)$ & 12,400 \\
\hline Phosphate & $\mathrm{ppb}$ & $<1,000^{c}$ & $<1,000$ \\
\hline Potassiun & $p p b$ & $4,993 \pm 1,453(53)$ & 7,975 \\
\hline
\end{tabular}


Table 2-3. Inorganic Constituents in Unconfined Groundwater Unaffected by Hanford S1te Operations (DOE-RL 1992, Tabies 5-9 and 5-11). (2 sheets)

\begin{tabular}{|c|c|c|c|}
\hline Paraneter & Unjts & $\begin{array}{c}\text { Mean } \pm \text { l standard } \\
\text { deviatton (sample size) }\end{array}$ & $\begin{array}{c}\text { Provisional } \\
\text { threshoid value* }\end{array}$ \\
\hline Selenium & ppb & $<5(14)$ & $<5$ \\
\hline Sitver & ppb & $<10^{d}$ & $<10$ \\
\hline Stilicon & ppb & $18,152 \pm 4,974(35)$ & 26,500 \\
\hline Sodjun & $\rho \rho b$ & $15,774 \pm 6,784(53)$ & 33,500 \\
\hline Strontium & $\mathrm{ppb}$ & $164 \pm 47(43)$ & 264.1 \\
\hline Sulfate & $p p b$ & $30,605 \pm 22,611(67)$ & 90,500 \\
\hline Urantum & ppb & $1.7 \pm 1.2$ & 3.43 \\
\hline Vanadium & ppb & $9 \pm 4(18)$ & 15 \\
\hline Zinc-Low & ppb & $<50(36)$ & $<50$ \\
\hline Zine-High & ppb & $247 \pm 165(17)$ & 673 \\
\hline Zinc-All & ppb & $95 \pm 140(53)$ & Not calculated \\
\hline Fleld alkalinity & ppb & $137,758 \pm 33,656(31)$ & 215,000 \\
\hline Lab alkaljnity & ppb & $137,717 \pm 29,399 \cdot(52)$ & 210,000 \\
\hline Fteld pH & - & $7.57 \pm 0.29(57)$ & {$[6.90,8.24]$} \\
\hline Lab pH & $=$ & $7.75 \pm 0.21(52)$ & {$[7.25,8.25]$} \\
\hline Total organic carbon & $\mathrm{ppb}$ & $519 \pm 367^{b}(62)$ & $1,610^{6}$ \\
\hline Field conductivity & $\mu \mathrm{mho} / \mathrm{cm}$ & $344 \pm 83(22)$ & 539 \\
\hline Lab conductivity & wnho/cm & $332 \pm 93(36)$ & 530 \\
\hline Total organic halogen & ppb & $<20^{b}(14)$ & $37.6^{b}$ \\
\hline Total carbon & $\mathrm{ppb}$ & $31,772 \pm 7,022(48)$ & 50,100 \\
\hline Gross a]pha & $\mathrm{pC} j / \mathrm{L}$ & $2.5 \pm 1.5^{b}(36)$ & $5.79^{6}$ \\
\hline Gross beta & $\mathrm{pCi} / \mathrm{L}$ & $7.1 \pm 2.6^{b}(44)$ & $12.62^{b}$ \\
\hline Radju: & $\mathrm{pC} 1 / \mathrm{L}$ & Hot detected (10) & 0.23 \\
\hline
\end{tabular}

Threshold value described in DOE-RL (1992). Estimate of the upper

95\% confjdence limit on the 95th percentije of the natural background. Potential outlier observation(s) were removed.

from springs data (Early et ai. 1986).

¿Frai WHC (1990), based on inductively coupled plasma/mass spectrometer data. \& findicates constituent was not detected above detection limit $X$. 


\section{ConTEkTS}

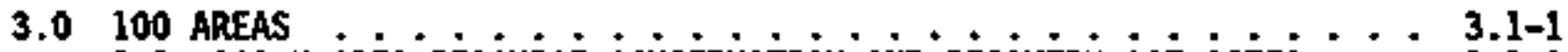

3.1100 N AREA RESOURCE CONSERVATION AND RECOVERY ACT SITES $\ldots$ 3.1-1

3.1.1 Factlity 0vervien . . . . . . . . . . . 3.1-1

3.1 .2 Summary of 1995 Acttvittes . . . . . . . . 3.1-2

3.1 .3 other Activities in $1995 \ldots . . . . . . . .3 .1-2$

3.1.4 Sampling and Analysis Program .......... 3.1-2

3.1.5 Groundwater Chemistry: 130I-N and 1325-N Liofs . . 3.1-3

3.1.6 Groundwater Chemistry: 1324-H/MA ......... 3.1-5

3.1 .7 Groundwater Flow . . . . . ........... 3.1-5

3.1 .8 References . . . . . . . . . . . 3.1-7 
BOE/RL,-96-01, REV. 0

\section{LIST OF FIGtRES}

3.1-1 Locations of $100 \mathrm{~N}$ Area RCRA Sites and Groundwater Monitaring Wells ............. 3.1-9

3.1-2 Nitrate Versus Time in I301-N and 1325-N Welis ....... 3.1-10

3.1-3 Stronti 4 m-90 in the Uppermost Aquifer

Beneath the $100 \mathrm{~N}$ Area, $1995 \ldots \ldots . . \ldots . . \ldots 11$

3.1-4 Gross beta Versus Tíme in 1301-N and 1325-N Weils ...... 3.1-12

3.1-5 Tritium in the Uppermost Aquifer

Beneath the $100 \mathrm{~W}$ Area, $1995 . \ldots \ldots . . . \ldots .1-13$

3.1-6 Tritium Versus Time in 1301-N and 1325-N Wells ...... 3.1-14

3.1-7 Specifíc Conductance Versus Tíme in 1301-N and 1325-N Wells . . 3.1-15

3.1-8 Specific Conductance and Total Organic

Halogen Versus Time in 1324-N/NA We11s .......... 3.1-16

3.1-9 Specific Conductance in the Uppermost Aquifer

Beneath the $100 \mathrm{~N}$ Area, 1995. . . . . . . . 3.1-17

3.1-10 Water Levels Versus Time in the 100 A Area ..........1-18

3.1-11 Water Table in the $100 \mathrm{~N}$ Area, March 1995 ............1-19

3.I-12 Water Table in the $100 \mathrm{~N}$ Area, June $1995 \ldots . . . . .3 .1-20$

\section{LIST OF TABLES}

3.1-1 Wells Used to Monitor Groundwater Chemistry for the 1301-N Liquid Waste Disposal Facility ........................ 31

3.1-2 Wells Used to Monitor Groundwater Chemistry for the 1325-N Liquid

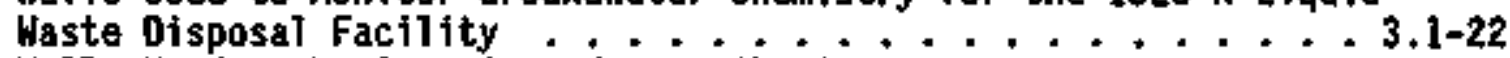

3.1-3 Wells Ised to Monitor Grotndwater Chemistry

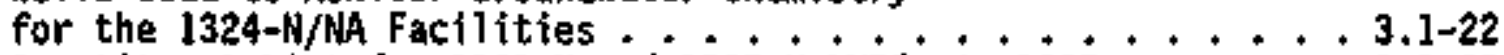

3.1-4 Constituent List for 1301-N and 1325-N LWDFs in 1995 . . . . 3.1-23

3.1-5 Constituent List for 1324-N/MA Assessment Moritaring . . . . . 3.1-23

3.1-6 Critical Heans Table for 32 Comparisons--Background Contamination Indicator Parameter Data for the 130I-N Liquid

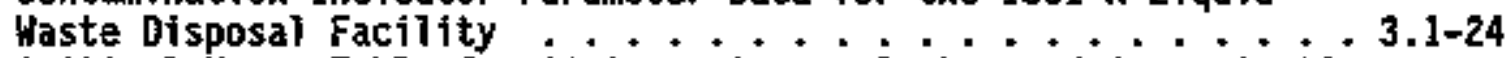

3.1-7 Critical Means Table for 24 Comparisons--Background Contamination Indicator Parameter Data for the 1325-N Liquid Waste Disposal Factlity $3.1-25$ 
DOE/RL-96-01, REY. 0

\title{
3.0 100 AREAS
}

\subsection{IOO A ARE RESOUACE COASERNATIOA AN RECOVERY ACT SITES}

\author{
H. 3. Hartran \\ Hestinghouse Hanford Company
}

Four Resource Conservation and Recovery Act of 1976 (RCRA) untts are located in the $100 \mathrm{H}$ Area: the 1301-N Liquid Waste Disposal Facility (LWDF), the 1324-15 Surface Impoundment, the 1324-sis Percolation Pond, and the 1325-N LHDF (Figure 3.1-1). The 1324-N and 1324-NA units are monjtored as a single site. Interim-status groundwater monitoring began at all of the sites in December 1987. The sites are located close together and have retated effects on the groundwater hydrotogy of the $100 \mathrm{H}$ Area. Therefore, they are discussed in a single section of this report.

The 1301-H and 1325-H LtWDs are monitored under jndicator evaluation programs, as described in the groundwater monjtoring plan (Hartman 1993a). The 1324-K/MA site is monitored under a groundwater quality assessment. program, as described in the assessuent plan (Hartman 1993b).

\subsubsection{Faciltty overvien}

The 1301-N LWof was the primary liquid waste disposai factilty for the N Reactor from 1963 unt 11 1985. Discharges to the 1301-N LWDF were primarily radioactive fission and activation products. Minor amounts of dangerous waste also were discharged, including the following: hydrazine, ammoniun hydroxide, diethylthtourea, sodium dichromate, morpholine, phosphoric acid, lead, and cadosium. The 1301-N LWDF consists of a concrete basin with an unlined, zig-zagging extension trench, covered with concrete paneis.

The 1325-N LWDF was constructed in I983, and $N$ Reactor effluent was discharged to it and to the 1301-N LWDF. In 1985, discharge to the 1301-N LWDF ceased, and all effluent was sent to the 1325-N LWDF. All discharge to the 1325-N LWDF ceased in Jate 1991. The 1325-N LWDF consists of a concrete basin with an unlined extension trench, covered with concrete panels.

The 1324-N Surface Impoundment was a treatment facility that was in service frow Kay 1986 to November 1988. This facility is a doubTe-lined pond that was used to neutralize high- and low-pH waste from a demineratization plant. The 1324-NA Percolation Pond is an unlined pond that was used to treat waste from August 1977 to May 1986, and to dispose of treated waste from Hay 1986 to August 1990. The effitrent to both facilities contained sulfurjc acid and sodium hydroxide, and its pH was occasionally high or low enough to be classified as a dangerous waste.

The RCRA sites in the $100 \mathrm{~N}$ Area are part of the 100-NR-1 source operable unit, under the Comprehensive Environoental Response, Compensation, and Lfabflity Act of 1980 (CERCLA) program. Eroundwater is addressed by the 100-AR-2 operable unit. Groundwater sampling and analysis are coordinated between the RCRA and CERCLA prograns. 
Hartman and Lindsey (1993) describe the hydrogeology of the $100 \mathrm{~A}$ Area. The uppermost aquifer beneath the 100 A Area is a sand and gravel unit in the Ringold Formation. The base of the aquifer is believed to be a clay-rich unit approximately $12 \mathrm{~m}(40 \mathrm{ft})$ beneath the water table.

Hydraulic conductivity estimates for the uppermost aquifer are highly variable. Gilmore et a1. (1992) used several methods to derive a representative range. Horizontal hydrailic conductivity is estimated to range from 6 to $37 \mathrm{~m} / \mathrm{d}(20$ to $120 \mathrm{ft} / \mathrm{d})$ beneath most of the area.

\subsubsection{Summary of 1995 Activities}

The 1301-H and 1325-N LWDF remined in indicator evaluation programs during the past year, and monitoring weils were sampled semiannualiy. The results of the first phase of the ToX assesstent program at 1324-N/WA were presented by Hartman (1995d). The 1324-H/MA network wells were sampled quarterly during the past year.

\subsection{3 other Activities in $\mathbf{1 9 9 5}$}

The ERC sampled wells in the 100-NR-2 nonftoring network twice in the past year, in conjunction with RCRA sampling.

An expedited response action was undertaken to reduce the amount of ${ }^{90} \mathrm{Sr}$ entering the Columbia River through riverbank springs in the $100 \mathrm{~N}$ Area (N Springs). The Environmental Restoration Contractor (ERC) atteingted to insta11 a grouted-hinge sheet pile barrier in the aquifer along the shoreline, but they were unsuccessful. A purp-and-treat system was installed to remove So from groundwater in the 1301-H contaminant plume and reinject the treated water into we11s near the 1325-N LWOF. The system began to operate in August 1995, but had no noticeable effects on groundwater quality or water levels in RCRA wells sampled in August and September. As the system continues to operate, groundwater flow direction will change, especjally around the 1301-H LWDF. The RCRA nonitoring networks will need to be reevaluated to account for the changes.

The ERC aaintains a network of pressure transducers and data loggers in 20 wells and in the Colubia River at $100 \mathrm{~N}$ Area.

\subsubsection{Sampling and Analysis Progran}

Salipling and analysis for the 1301-N, 1325-N, and 1324-N/NA sites are described by Hartman (1993a, 1993b). Wells in the sampling networks are listed in Tables $3.1 . .1,3.1-2$, and $3.1-3$; constituents analyzed are 1 fsted in Tables 3.1-4 and 3.1-5.

The 1301-N and 1325-N networks are sampled seniannually. The 1324-N/MA network is sampled quarterly under an assessment program. Well locations for the $100 \mathrm{~W}$ Area are shown in figure 3.1-1. 
Low water levels in some wells hamper sample collection. Wells $\mathrm{N}-57^{1}$ and $1-67$ of the 1301-N network, and we] $\mathrm{N}-59$ of the 1324-N/WA network have often pumped dry in the past. Low-flow bladder pumps are now used to sample these wel1s, but well N-59 can be sampled only when water levels are seasonally high.

Water levels and results of laboratory analyses of $100 \mathrm{~N}$ Area groundwater were reported in quarterly reports (Hartman 1995a, 1995b, 1995c, 1996).

\subsubsection{Eroundwator Chempistry:, 1301-N and 1325-N LWofs}

This section describes results of chemical analyses of groundwater samples and defines the constituents of concern for the 1301-N and 1325-N WNoF sites. The sites are discussed together because they are close together, their effluents were virtually identical, and their contaminant plumes overlap.

3.1.5.1 Constituents of Concern: 1301-A and 1325-A LwoF. The indicator parameters at the 1301-N and 1325-N LWDFs are spectfic conductance, pH, tota] organic carbon (TOC), and TOX (40 Code of Federa) Regutations

[CFR] 265.92(b][3]). Groundwater is also ana]yzed for other constituents that were discharged to the 1301-N and 1325-N LWDFs during their use (see

Section 3.1.1). These analytes include nitrate, chromium, phosphate, lead, and cadmium. Phosphate, chromium, lead, and cadmium have not been detected in filtered samples from 1301-N or 1325-N LWDF groundwater in signjfjcant concentrations. Nitrate has increased in some we11s near 130I-N and 1325-N during the past yoar, exceeding the drinking wator standard in wel1s $\mathrm{N}-2$ and N-3 (Figure 3.1-2). We1T $N-26$, southwest of 1301-N, also had nitrate above the standard. The source of nitrate is unknown.

While the 1301-N and 1325-N LWDFs were in use, they introduced radioactive constituents, primarily tritiun and ${ }^{90} \$ r$, to the groundwater. Figure $3.1-3111$ ustrates $90 \mathrm{Sr}$ in the uppermost aquifer. This map, constructed of an average of data from September 1994 through September 1995, includes data from new wells installed for the 1 Springs expedited response action. ${ }^{0} \mathrm{Sr}$ is elevated around the I30I-H and 1325-H LWDF, with the highest activities (over $5,000 \mathrm{pCi} / \mathrm{L}$ ) in new wells along the shoreline doungradient from the 1301-N LWDF.

Figure 3.1-4 illustrates recent trends in gross beta activity in selected 1301-N and 1325-N we17s. " $\mathrm{Sr}$ is the primary beta-emitter in the $100 \mathrm{H}$ Area. Gross beta in 1301-N downgradient we 11 $\$-75$ has reasined relatively stable since late 1992. Gross beta activity is reTatively low in some weils that had very high ${ }^{90} \mathrm{Sr}$ activity in the 1980 s (e.g., wells $N-2$ and $N-29$ ). As the water table dropped in the vicinity of these wells, the higher concentrations of ${ }^{\circ} \mathrm{Sr}$ may have sorbed onto the sediments and remalned in what is now the unsaturated zone.

Well numbers in this section are abbreviated by removing the 199-prefix (e.g., wel1 199-N-57 is written $N-57$ ). 
Figure 3.1-5 shows tritium in the uppermost aqujfer. Like ${ }^{90} \mathrm{Sr}$, tritjum is elevated around the $1301-N$ and $1325-N$ LWDF. Tritium-contaminated water from the $100 \mathrm{~N}$ Area appears to have migrated northward to the $100 \mathrm{D}$ Area (see Figure 2-5). It also migrated to the south, toward what is now the upgradient weil ( $N-74$ ) for the 1325- $N$ LLDF site. Tritium is declining in 1325-N wolls and is stable in I301-N wells (Figure 3.1-6).

Specffic conductance is relatively low and stable in most of the downgradient wells in the 1301-N network (Figure 3.1-7). It is higher in upgradient we1J N-57. The position of this well and the chemical composttion of the water tndicate that the source of the elevated speciffc conductance is the 1324-N/NA site (Hartman 1992).

When the 1325-N site was in use, spectfic conductance of groundwater was low because of artificial recharge with low-conductivity water. After discharge to the 1325-N LWDF ceased, specific conductance of groundwater gradualify tncreased. Specific conductance in the upgradient well, $\mathrm{N}-74$, was elevated (possibly because of the influence of 1324-N/NA), but has declined in the past 4 years (see Figure 3.1-7). Specific conductance in the downgradient wells may continue to increase gradually as the higher conductivity water moves northward.

The pH of groundwater beneath the 1301-N and 1325-N LwDFs ranged from 7.5 to 8.8 in the past year. There are no clear upward or downward trends. Replicate averages of Toc have been at or below the contractually required quantitation limit durting the past year in most wells, but was detected at. approximately 600 ppb in wells $\mathrm{N}-3$ and $\mathrm{N}-57$. ToX also is usually Tess than its contractually required quantitation 1 imit but has been detected at 10 to $15 \mathrm{ppb}$ in upgradient wel1 $\mathrm{M}-74$. There is no apparent pattern to TOC or TOX dotections in 1301-N or 1325-N LWDF we77s.

Tritium and ${ }^{90} \mathrm{Sr}$ have been consistently above their drinking water standards in many of the 1301-N and 1325-N LWDF wells during the past year. Nitrate concentrations were higher than the drinking water standard in August/September 1995 in wells $\mathrm{N}-2$ and $\mathrm{N}-3$.

3.1.5.2 Statistical Evaluations: 130I-N and 1325-N LiDFs. New critical mann values were established for the indicator parameters at 1301-N because of a change in upgradient wells. Comparisons between upgradient and downgradient wells were performed for the 1301-N and 1325-N sites. All values of specific conductance, $\mathrm{pH}, \mathrm{TOX}$, and TOC in the downgradient weIls in the past year were below the upgradient/downgradient comparison values except one set of pH measurements frow weil $\mathbf{N - 8 1}$. Verification sampling indicated the original values (around 5.9) were erroneous. Statistical analyses are discussed in more detail in the following paragraph.

Statistical analyses required by 40 CFR $265.93(\mathrm{~b})$ and Washington Adainistrative Code (WAC) 173-303-400 were performed on the samples collected from the upgradient wells. Results are presented in Tables 3.1-6 and 3.1-7: These tables jist the background average, standard deviation, critical mean (or critical range, in the case of $\mathrm{pH}$ ), and upgradtent/downgradient comparison values for the contamination indicator parameters. The conparison value is the value to whtch current and future averages of indicator parameters are compared. The comparison vatue is generajly the critical nean or critical 
range. The limit of quantitation is used as the comparison value for TOC at 1325-H instead of the critical mean because most of the upgradient concentrations were below the contractually required quantitation limit (see Appendix C).

\subsubsection{Broundwater Chenistry: 1324-H/MA}

3.1.6.1 Concentration Histories of Kaste Indicators. Groundwater beneath the 1324-H/MA site is characterized by high spectfic conductance, primarily because of elevated sulfate and sodium. Specific conductance increased in we]1s $\mathrm{H}-72, \mathrm{H}-73$, and $\mathrm{H}-77$ in the past few years, but leveled off in 1995 (Flgure 3.1-8). Sulfate and sodium concentrations follow the same pattern. The pH in 1324-M/HA wells generally is between 8 and 8.2 .

ToX was stightily elevated in some of the I324-N/NA downgradient wa7ls in 1992-93, but has decreased in the past 4 years and is nearly the same as in the upgradient we1] (see Figure 3.1-8). A revised assessment program is investigating the elevated Tox (Hartman 1993c). Results of the first phase of assessment indicate that chioroform is the cause of the Tox. A French drain, used to dispose of nondangerous chlorinated water, is located near the 1324-NA pond, and way be the cause of the chloroform (1.e., chlorine interacting with organic materla]). Results of the first phase of the ToX assessment are presented by Hartman (19g5d).

\subsubsection{Distribution of Waste Constituents: 1324-N/HA. The 1324-HA} Percolation Pond has introduced nondangerous constituents, primarily sulfate and sodium, to the groundwater. The distribution of speciffe conductance is t11ustrated in Figure 3.1-9.

As discussed in section 3.1.6.1, TOX and chloroform were elevated in we 11 s $\mathrm{N}-72$ and $\mathrm{N}-77$. Concentrations of these parameters have dec1 ined to near local background and there is no evidence of a widespread pluatie.

\subsubsection{Groundwater F10w}

This section describes the direction and rate of groundwater flow beneath the 1301-N, 1325- $\mathrm{A}$, and 1324-N/NA sites. The water tabie in the $100 \mathrm{H}$ Area is no longer elevated from artificial recharge, but it is affected by fluctuations in the Columbia River stage (Figure 3.1-10, see Figure 2-3). Data presented in this section were collected by an automated system using pressure transducers and data loggers. Nater levels are measured hourly; wonthly averages were calcutated from the hourly data.

\section{1:7.1 Groundwater Flow Direction. During onst of the year, groundwater} flowed toward the north and northwest beneath the $100 \mathrm{~W}$ site, under a gradient that is typified by the Harch 1995 water table map (Figure 3.1-11). Figure 3.1-12 shows the water table beneath the $100 \mathrm{~N}$ Area in June 1995, when the river level was high and there was a potantial for water to flow out of the river into the aquifer.

Groundwater is more strongly influenced by river stage near the 1301-K LWOF than near the other RCRA sites, because the 1301-N site is closest 
to the river. In June, groundwater near the river may have flowed towand the northeast. During the rest of the year, groundwater is inferred to flow toward the river (i.e., toward the northwest) beneath the 1301-N LWBF. The average horizontai gradient for Harch 1995 was calculated between we 11 s $\mathrm{N}-34$ and $N-76$ :

$$
\begin{aligned}
& \text { difference in head }=0.68 \mathrm{~m}(2.2 \mathrm{ft}) \\
& \text { horizontal distance }=460 \mathrm{~m}(1,500 \mathrm{ft}) \\
& \text { gradient }=1.5 \times 10^{-3} \text {. }
\end{aligned}
$$

Groundwater flows prinarily toward the north beneath the 1325-A LWDF, as inferred from the water table. River stage did not affect the direction of groundwater flow at the $1325-N$ site during the past year. The average

horizontal gradient for March 1995 was calculated between we 11 s $\mathbf{H}-28$ and $\mathrm{H}-50$ :

$$
\begin{aligned}
& \text { difference in head }=0.92 \mathrm{~m}(3.0 \mathrm{ft}) \\
& \text { horizontal distance }=820 \mathrm{~m}(2,690 \mathrm{ft}) \\
& \text { gradient }=1.1 \times 10^{-3} .
\end{aligned}
$$

The general direction of groundwater flow beneath the 1324-N/WA stte is toward the northwest. The average horizontal gradient for Harch 1995 was calculated between we11s $\mathrm{N}-72$ and $\mathrm{H}-25$ :

$$
\begin{aligned}
& \text { difference in head }=0.75 \mathrm{~m}(2.5 \mathrm{ft}) \\
& \text { horizontal distance }=344 \mathrm{~m}(1130 \mathrm{ft}) \\
& \text { gradtent }=2.2 \times 10^{-3} .
\end{aligned}
$$

Vertical gradients are not wetl known in the $100 \mathrm{~N}$ Area. Wells adjacent to the Columbia River show an upward gradient in the uppermost aquifer (Hartman and Lindsey 1993). Further inland there is no significant difference in head between wetis completed at the water table and wel1s completed at the base of the aquifer, which are approximately $6 \mathrm{~m}(20 \mathrm{ft})$ deeper. Limited data prevent a clear comparison of vertscal heads in the unconfined and shallowest confined Ringold aquifers.

3.1.7.2 Rate of Flow. The rate of groundwater flow can be estimated by using a form of the Darcy equation with a range of input parameters.

$$
v=\frac{K i}{n_{0}}
$$

where:

$$
\begin{aligned}
& v=\text { Average linear velocity of groundwater } \\
& k=\text { Horizontal hydraulic conduct ivity } \\
& i=\text { Hydraulic gradient } \\
& n_{-}=\text {Effective porosity of the aquifer. }
\end{aligned}
$$


The following input paraneters were used:

$K=6.1$ to $36.6 \mathrm{a} / \mathrm{d}$ (20 to $120 \mathrm{ft} / \mathrm{d}$ ) (617more et al. 1992)

$i=1.5 \times 10^{-3}(1301-\mathrm{H}) ; 1.1 \times 10^{-3}(1325-\mathrm{H}) ; 2.2 \times 10^{-3}$ (1324-N/MA)

$n_{e}=0.1$ to 0.3 .

Resulting estimates of groundwater velocity are as follows:

1301-H LWDF: 0.03 to $0.50 \mathrm{~m} / \mathrm{d}(0.1$ to $1.6 \mathrm{ft} / \mathrm{d})$

1325-N LWDF: 0.02 to $0.40 \mathrm{~m} / \mathrm{d}(0.07$ to $1.3 \mathrm{ft} / \mathrm{d})$

1324-H/MA: 0.04 to $0.80 \mathrm{~m} / \mathrm{d}(0.13$ to $2.6 \mathrm{ft} / \mathrm{d})$.

3.1.7.3 Evaluation of Monitoring Noll Hotworks. The monitoring networks for the 1301-H, 1325-H, and 1324-N/HA sites are considered adequate under current flow condtitions. However, pump-and-treat act trities will change groundwater flow and chenistry beneath the 1301- $\mathrm{H}$ and 1325-H LNOF and the RCRA networks may need to be modified at these sites. Nestinghouse Hanford Company, the ERC, and other contractors that conduct groundwater monitoring in the $100 \mathrm{~N}$ Area are working to coordinate and streamt ine sampling and analysis.

\subsubsection{References}

40 CFR 265, "Interim Status Standards for Owners and Operators of Hazardous Maste Treatment, Storage, and Bisposal Facilities," Code of Federal Regulations, as amended.

Comprehensive Environmental Response, Compensation, and Liability Act of 1980, 42 USC 9601 et seq.

Gilmore, T. J., F. A. Spane, Jr., D. R. Newconer, and C. R. Sherwood, 1992, Applications of Three Aguifer Test Methods for Estimating Hydraulic Properties Within the 100-II Area, PNL-8335, Pacific Morthwest Laboratory, Richiand, Washington.

Hartman, M. J., 1992, Results of Ground Water Quality Assessment Wonitoring at the 1301-N Liquid Waste Disposal Facllity and I324-K/HA Facilities, WHC-SD-EH-EV-003, Rev. 1, Westinghouse Hanford Company, Richl and, Washington.

Hartman, M. J., 1993a, Groundwater Monitoring Plan for the $1301-N$ and 1325-N Facilities, WHC-SD-EM-AP-038, Rev. 1, Mestinghouse Hanford. Company, Rich] and, 'Washington.

Hartman, M. J.. 1993b, Groundwater Qualfty Assessment P7an for the 1324-N/NA site, WHC-SD-EN-AP-005, Rev. 1, Westinghouse Hanford Company, Richland, Washington.

Hartuan, H. J., 1995a, "100-N Area RCRA Sites," in Quarterfy Report of RCRA Groundwater Nonftoring Data for Period October 1, 1994 through December 31, 1994, DOE/RL-94-36-4, U.S. Department of Energy, Richland Operations Office, Richland, Washington. 
Hartman, *. J., 1995b, "100- $N$ Area RCRA Sites," in Quarterly Report of RCRA Groundwater Monitoring Data for Period January 1, 1995 through March 31, 1995, DDE/Rl,-95-69-1, U.S. Department of Energy, Richland Operations Office, Richland, Washington.

Hartman, H.J., 1995c, "100-N Area RCRA Sites," in Quarterly Report of RCRA Groundwater Monitoring Data for Period Apri7 1, 1995 through June 30, 1995, D0E/RL-95-69-2, U.S. Department of Energy, Richland Operations Office, Richland, Washington.

Hartiman, M.J., I995d, RCRA Assessment Report: Total Organic Halogen at the 1324-N/NA Site, WHC-SD-EH-EV-031, Rev. O, West inghouse Hanford Caapany, Richi and, Washington-

Hartman, M. J., 1996, "100-A Area RCRA Sites," In Quarterly Report of RCRA Groundwater Monitoring Data for Period Ju7y 1, 1995 through Septenber 30, 1995, DOE/RL-95-69-3, U.5. Department of Energy, Rjchland operations office, Richland, Washington.

Hartman, M. J., and K. A. Lindsey, 1993, Hydrogeology of the 100-H Area, Hanford site, Washington, WHC-SO-EN-EV-027, Rev. 0, Westinghouse Hanford Company, Richiand, Washington.

Resource Conservation and Recovery Act of 1976, 42 USC 6901 et seq.

WAC 173-303, "Dangerous Waste Regulations," Washington Administrative Code, as amended. 


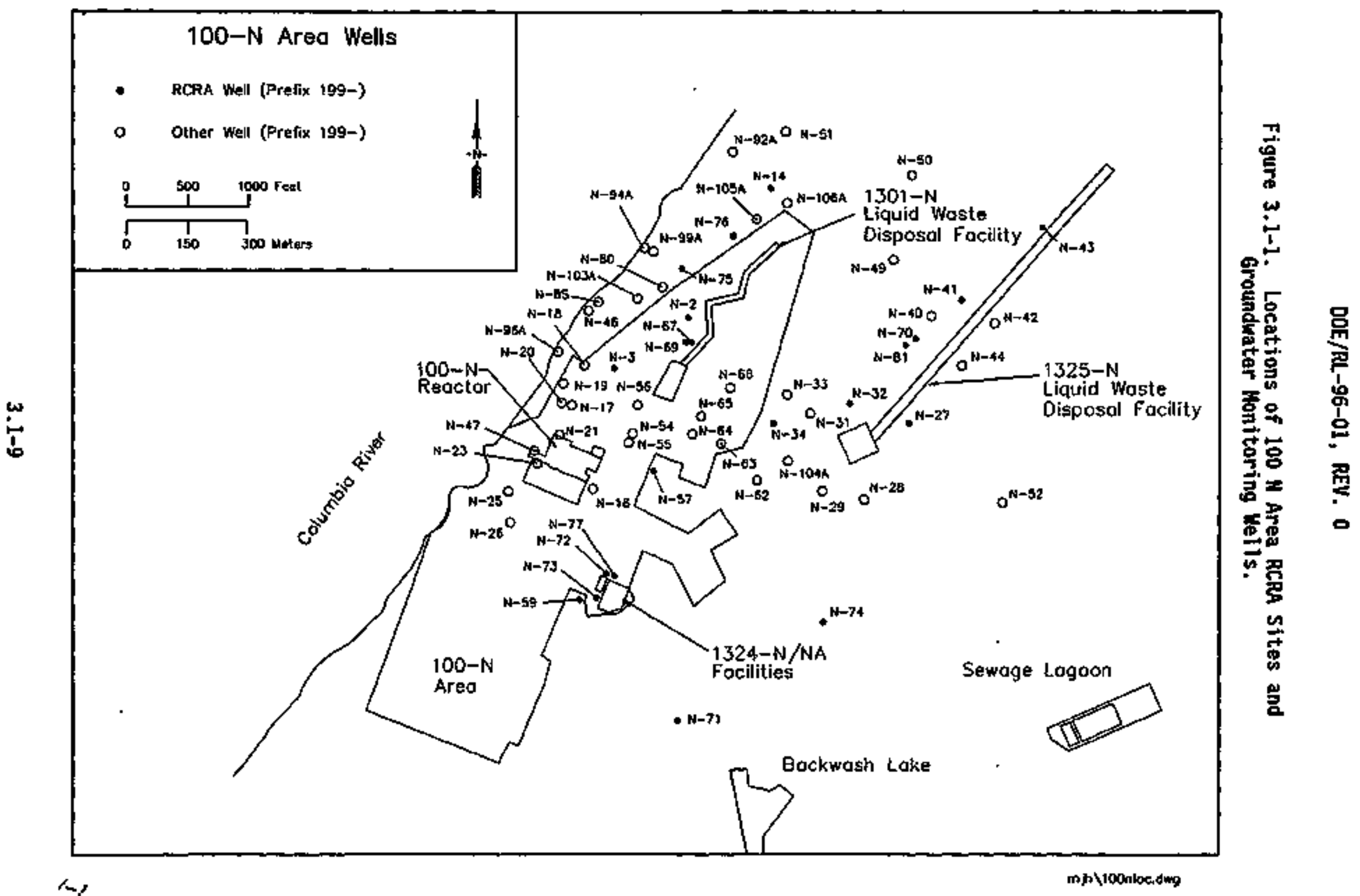


DOE/RL-96-01, REV. 0

Figure 3.1-2. Nitrate Versus $T$ íme in 1301-N and 1325-N MeIts.
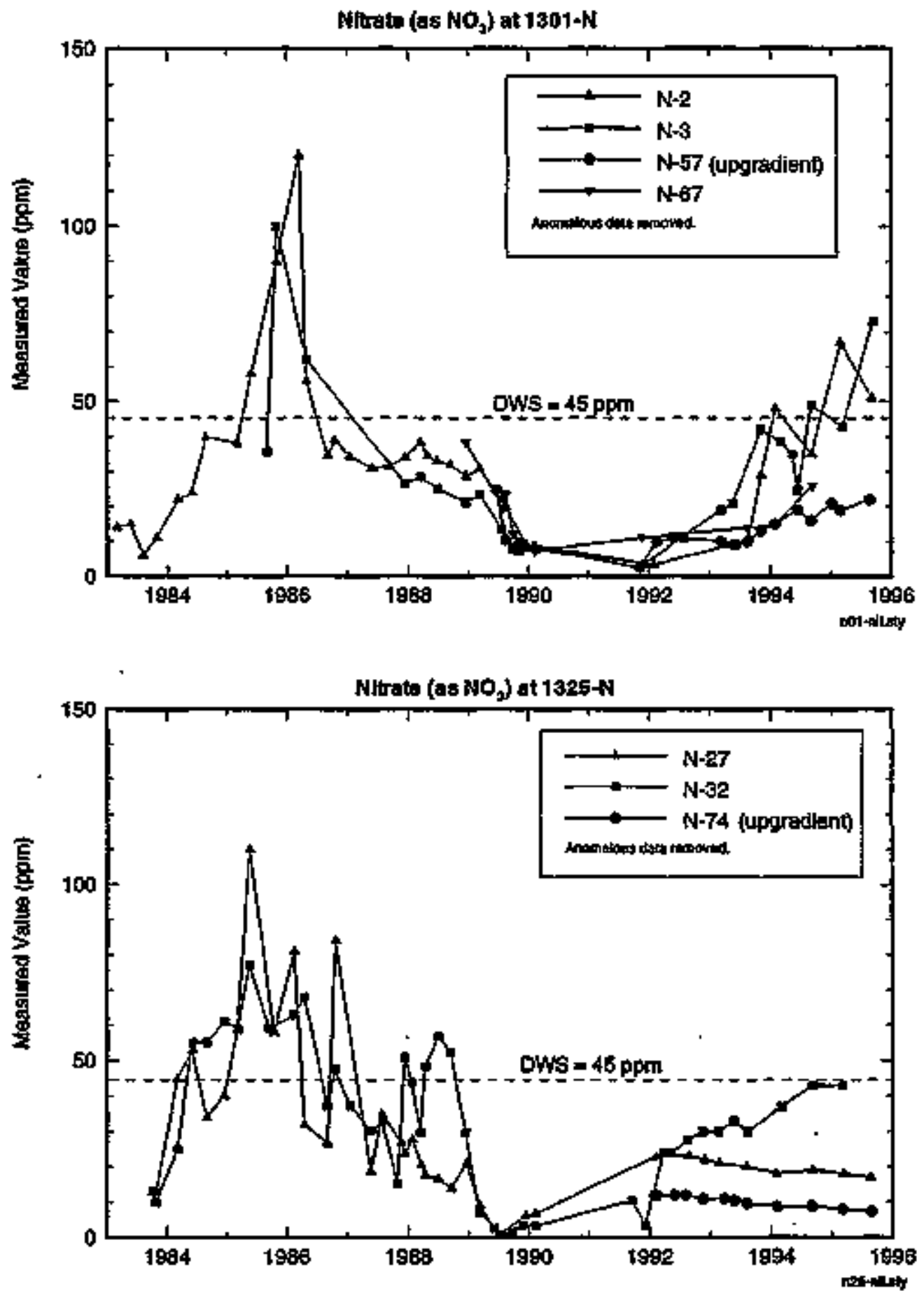


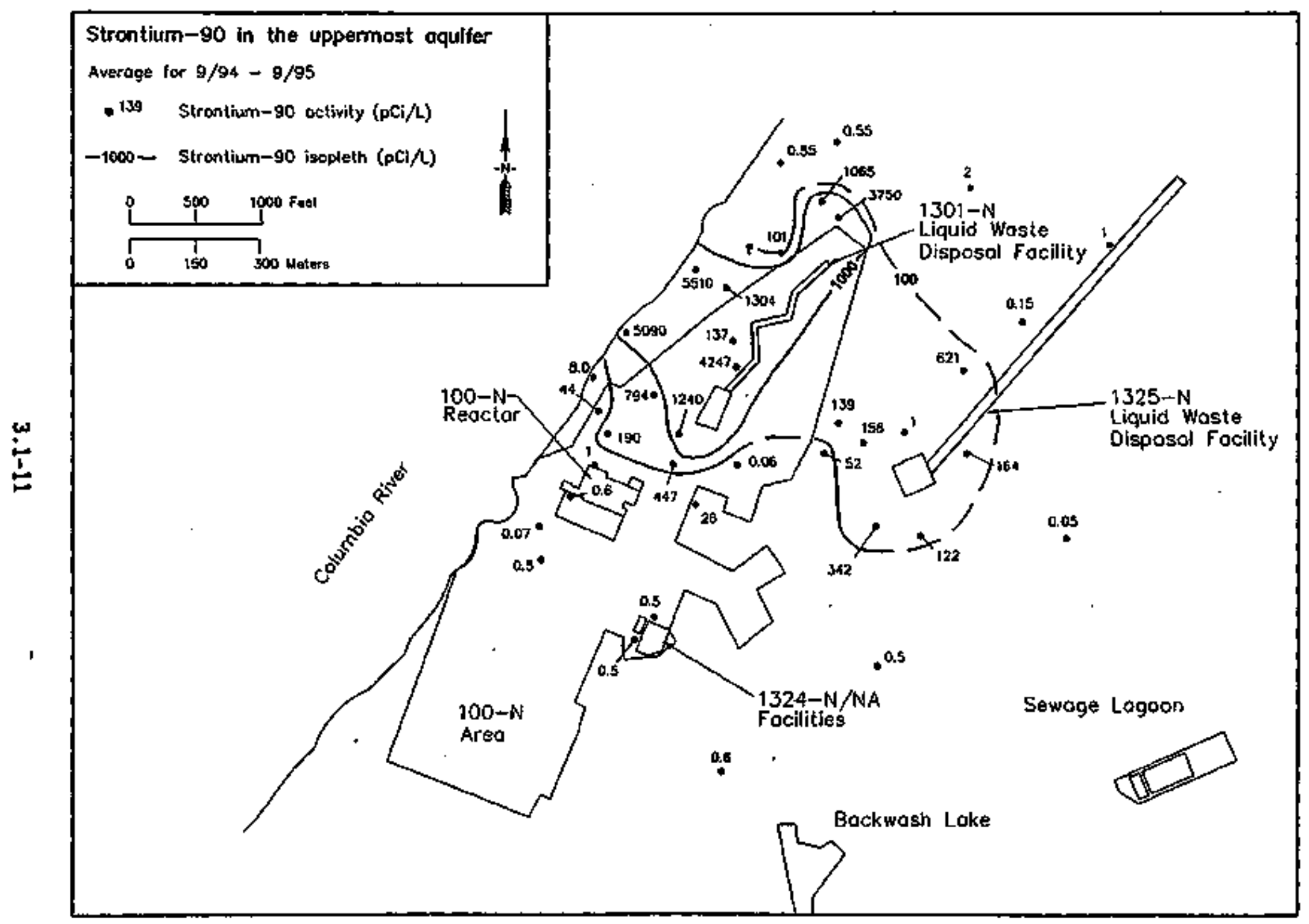

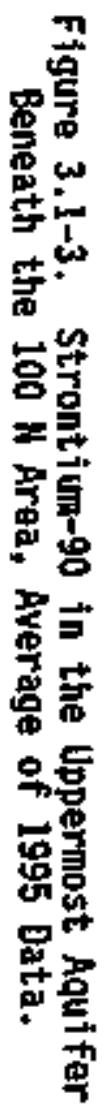

min 100 arsit, Awg 
DOE/RL-96-01, REV. 0

Figure 3.1-4, Gross Beta Versus Time in 1301- $\mathrm{H}$ and 1325-M Mells.
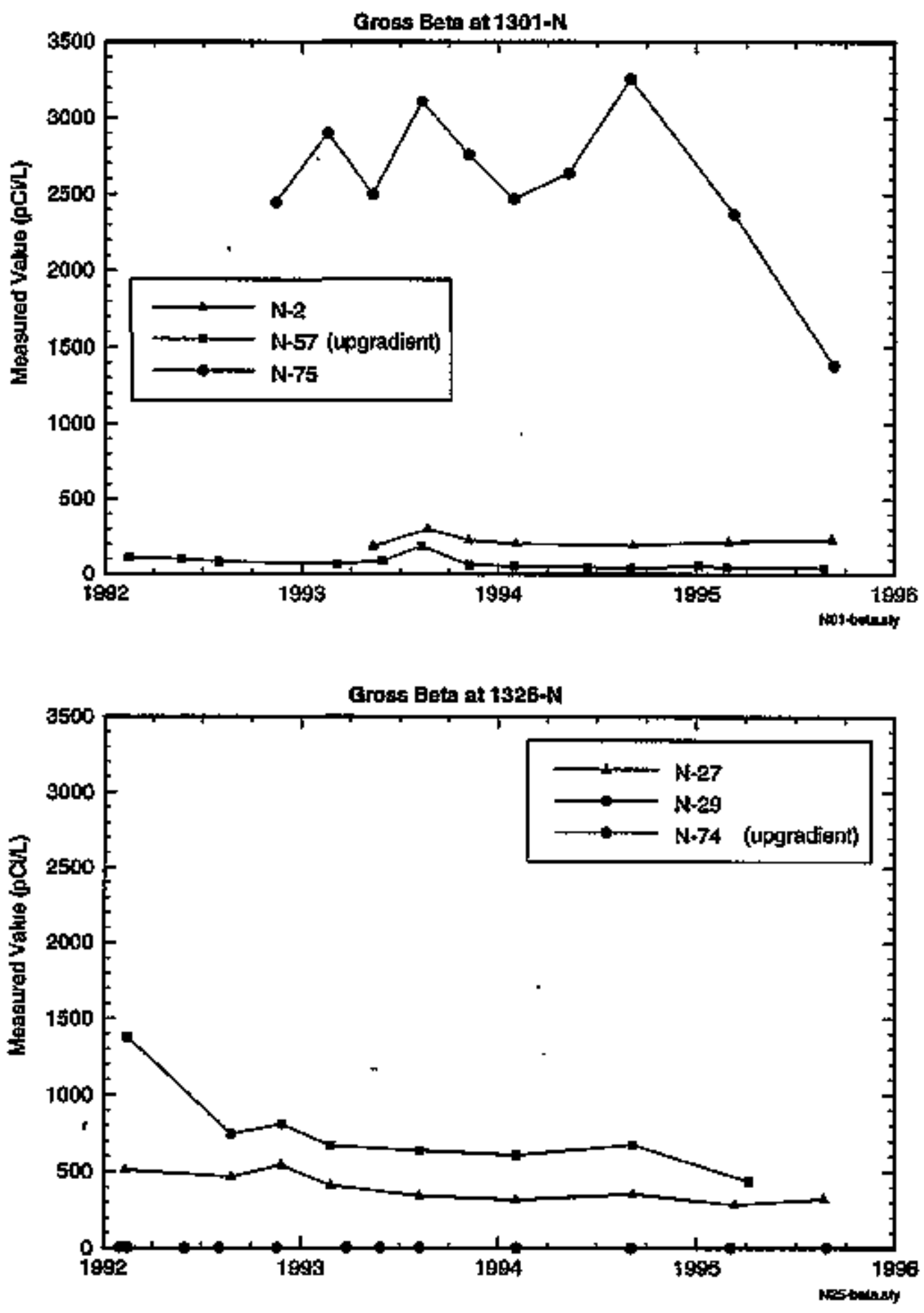


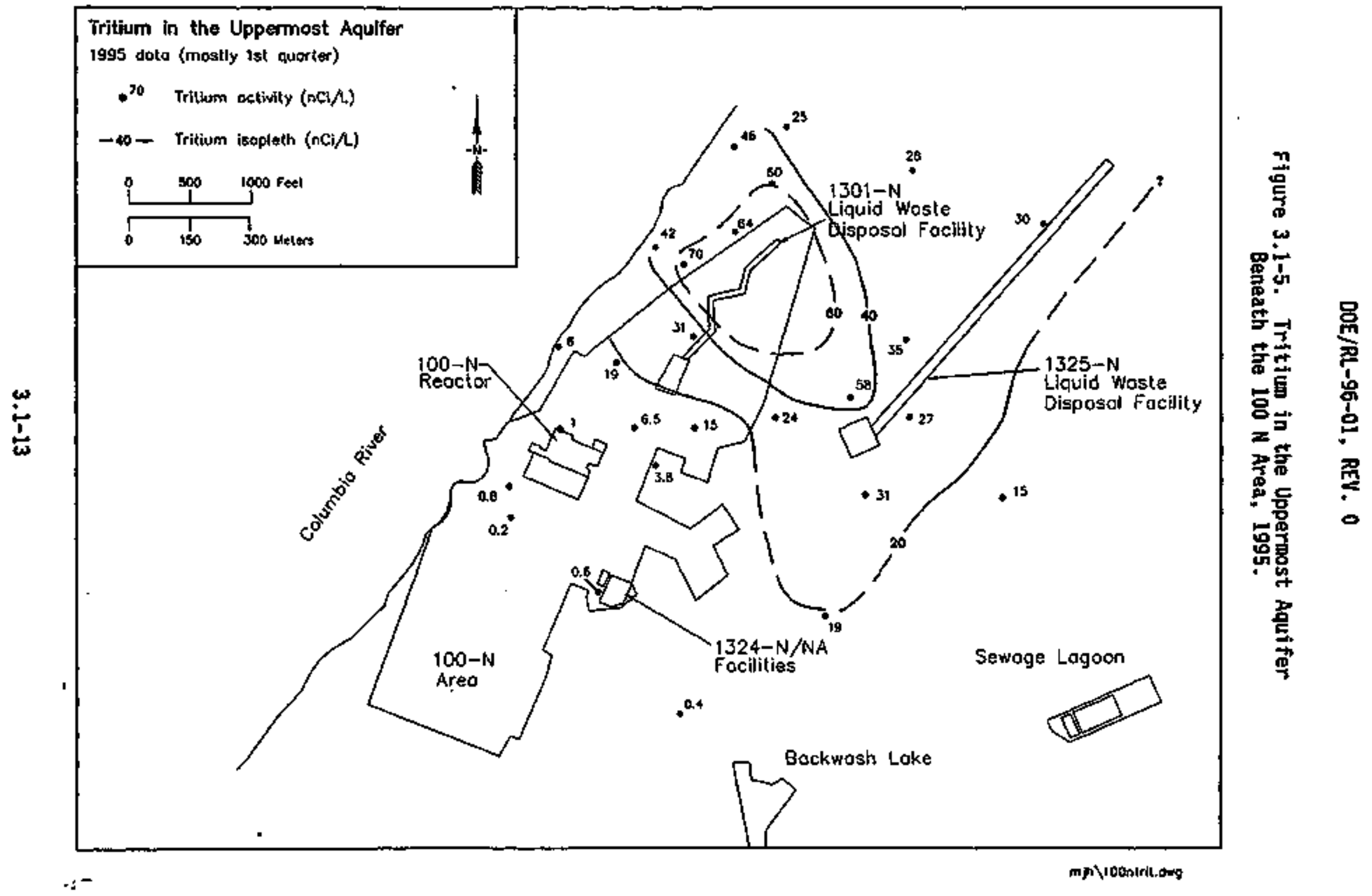


Figure 3.1-6. Tritiun Versus Time in 1301-N and 1325-N Mells.

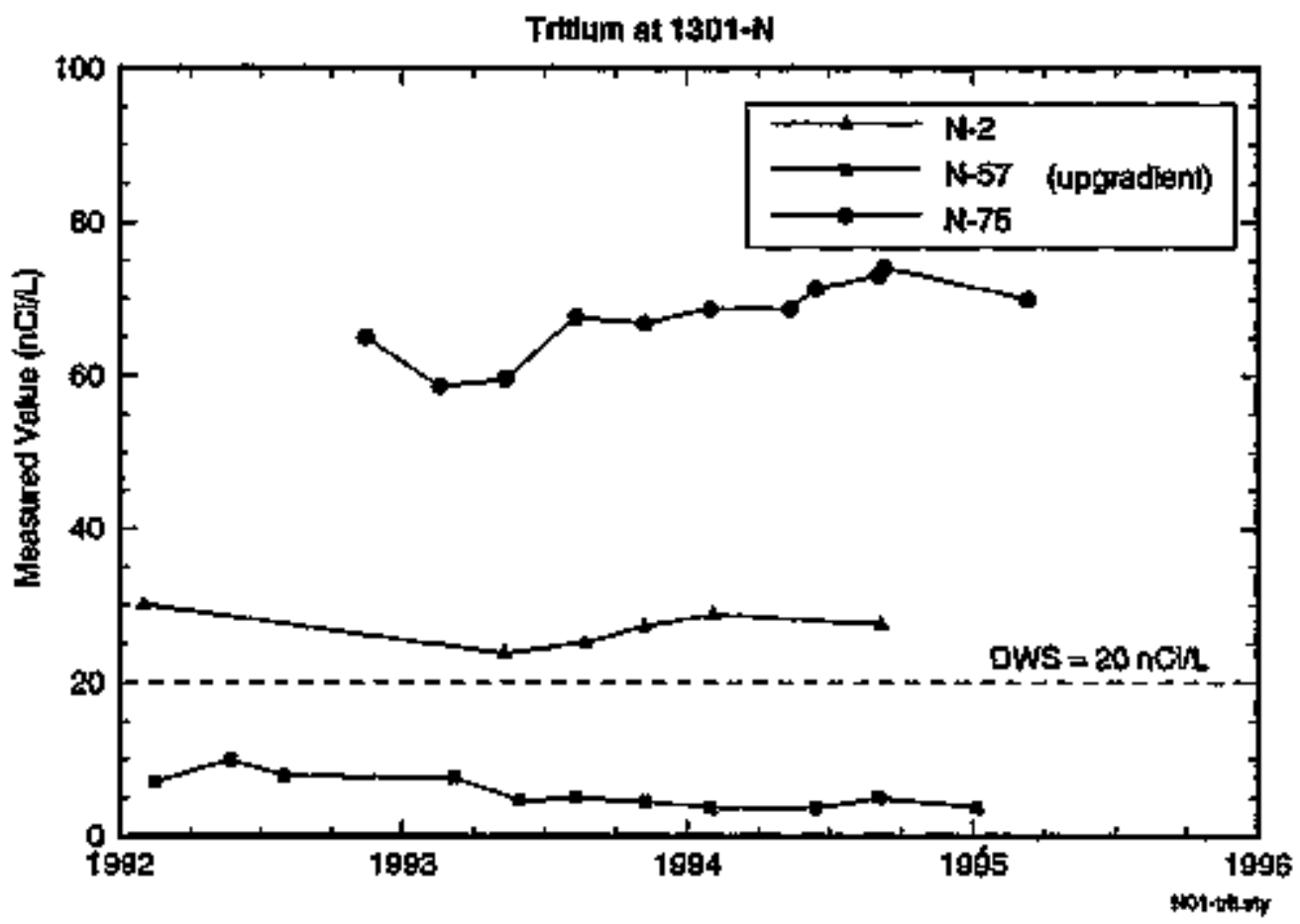

Trittum at 1328-N

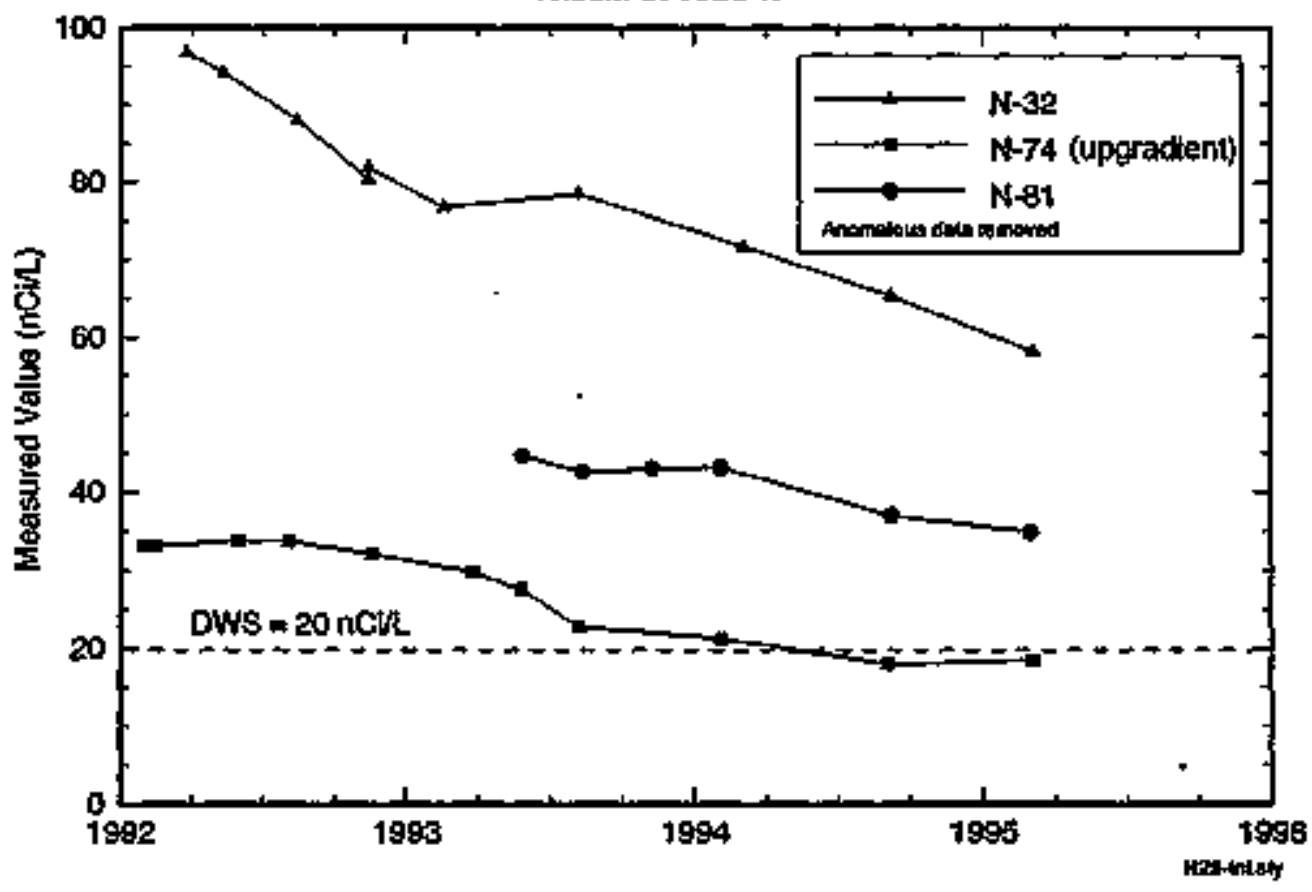


DOE/RL-96-01, REV. O

Figure 3.1-7. Specific Conductance Versus Time in 1301-N and 1325-N We11s.
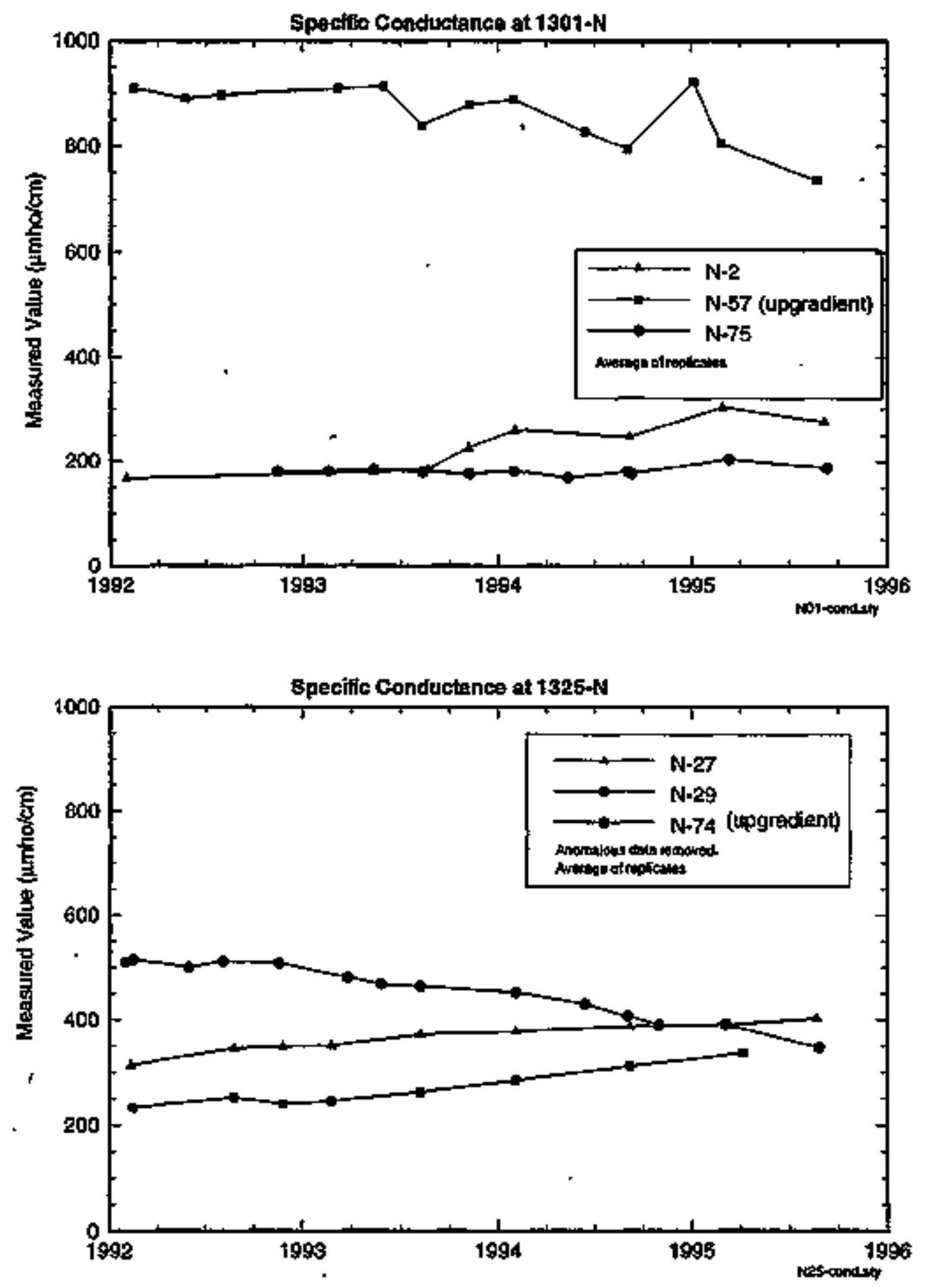
DOE/RL-96-01, REV. O

Figure 3.1-8. Specific Conductance and Total Organic Halogen Versus Tíme in 1324-N/WA Mells.
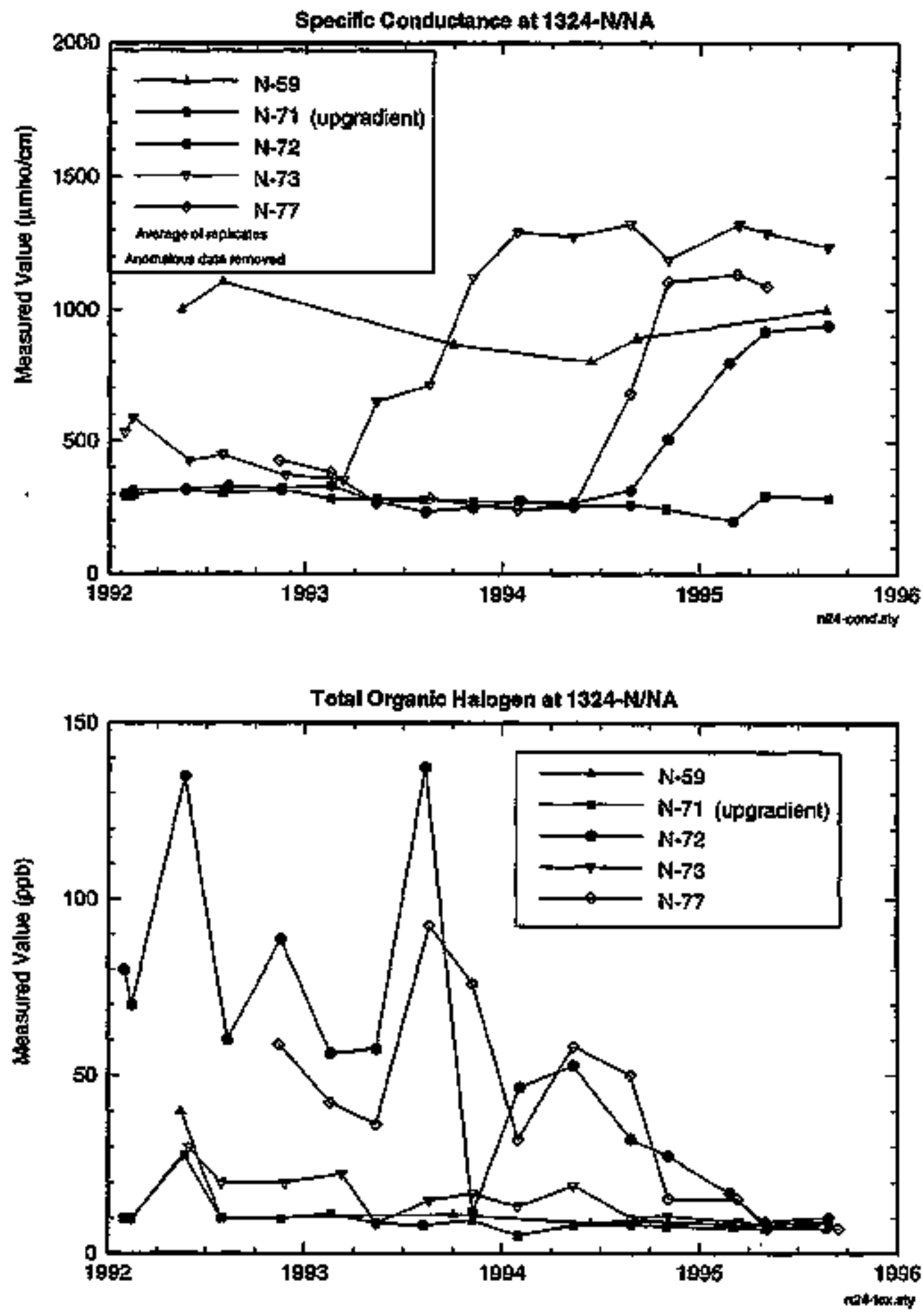


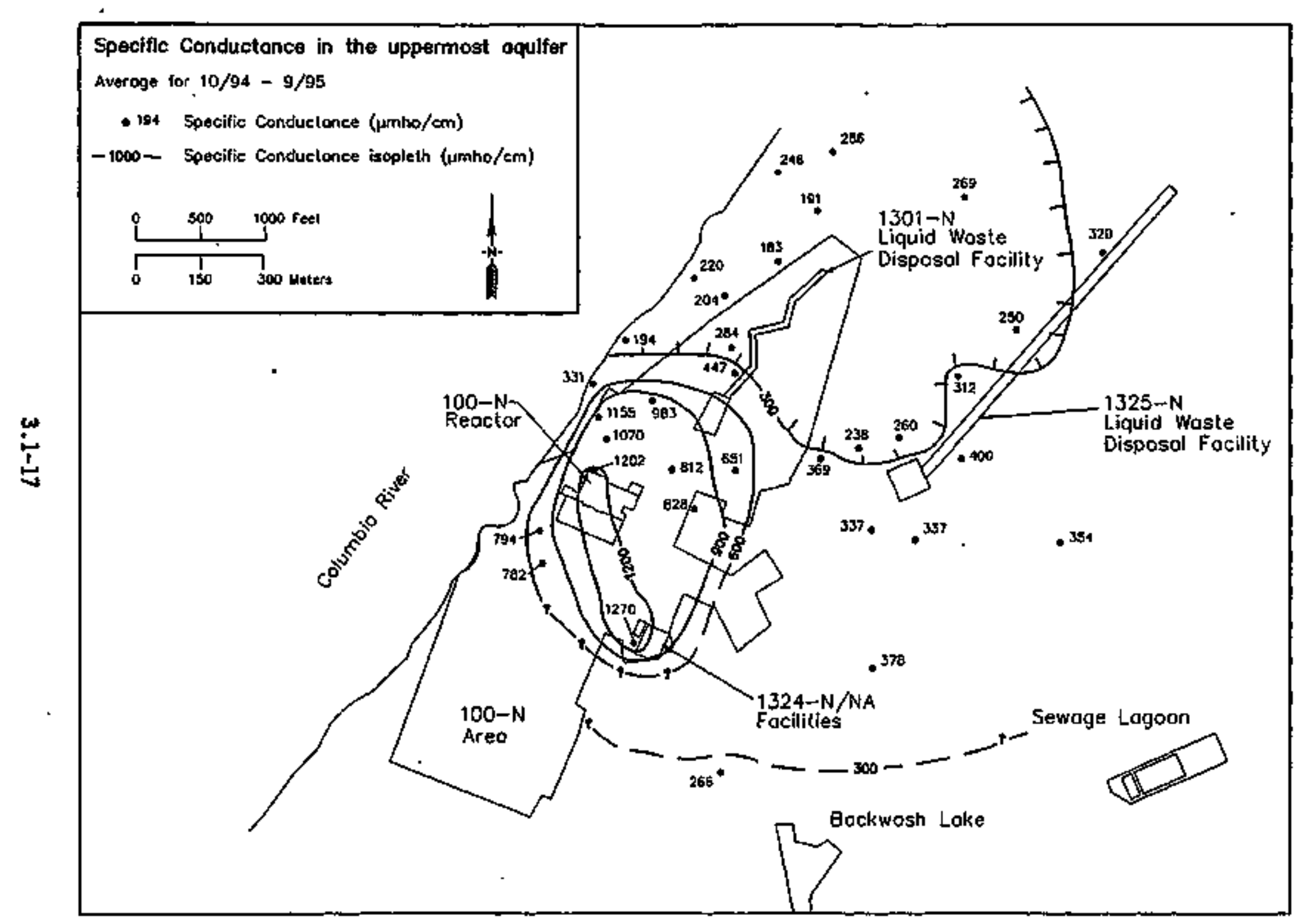

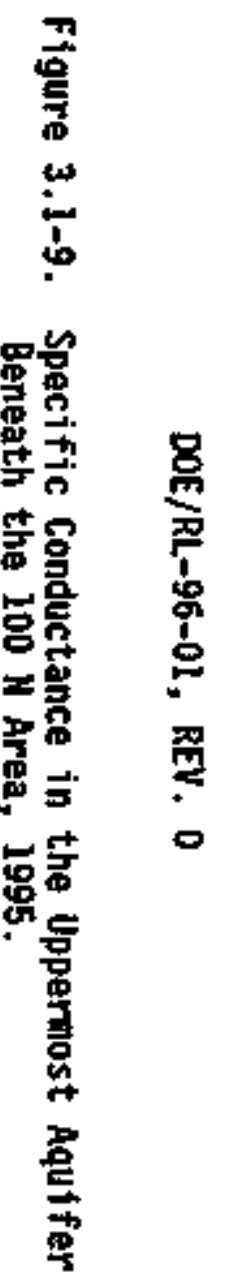

mhyo0nspen.dwy 
DOE/RL-96-01, REV. 0

Figure 3.1-10. Water Levels Versus Time in the $100 \mathrm{H}$ Area.

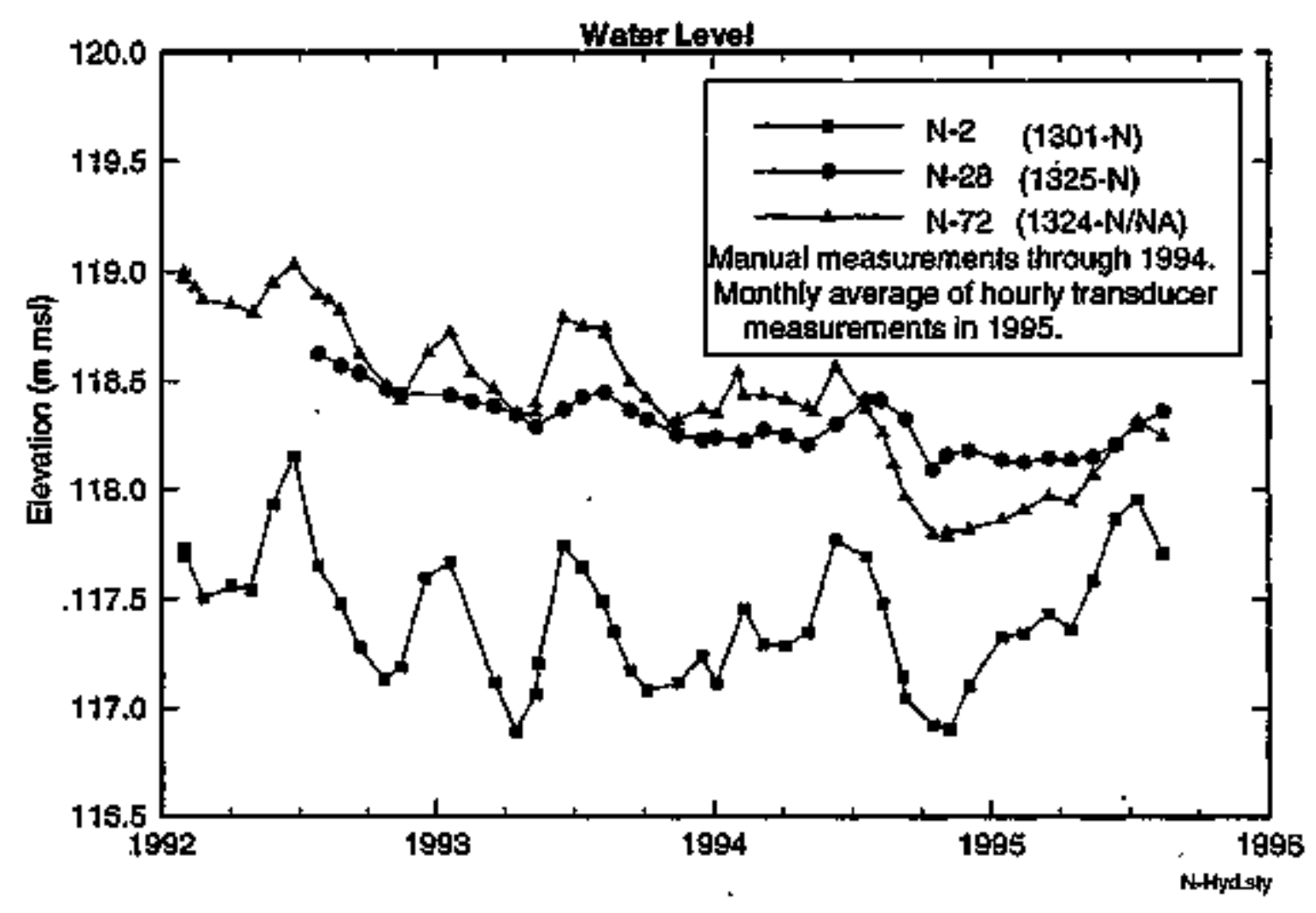




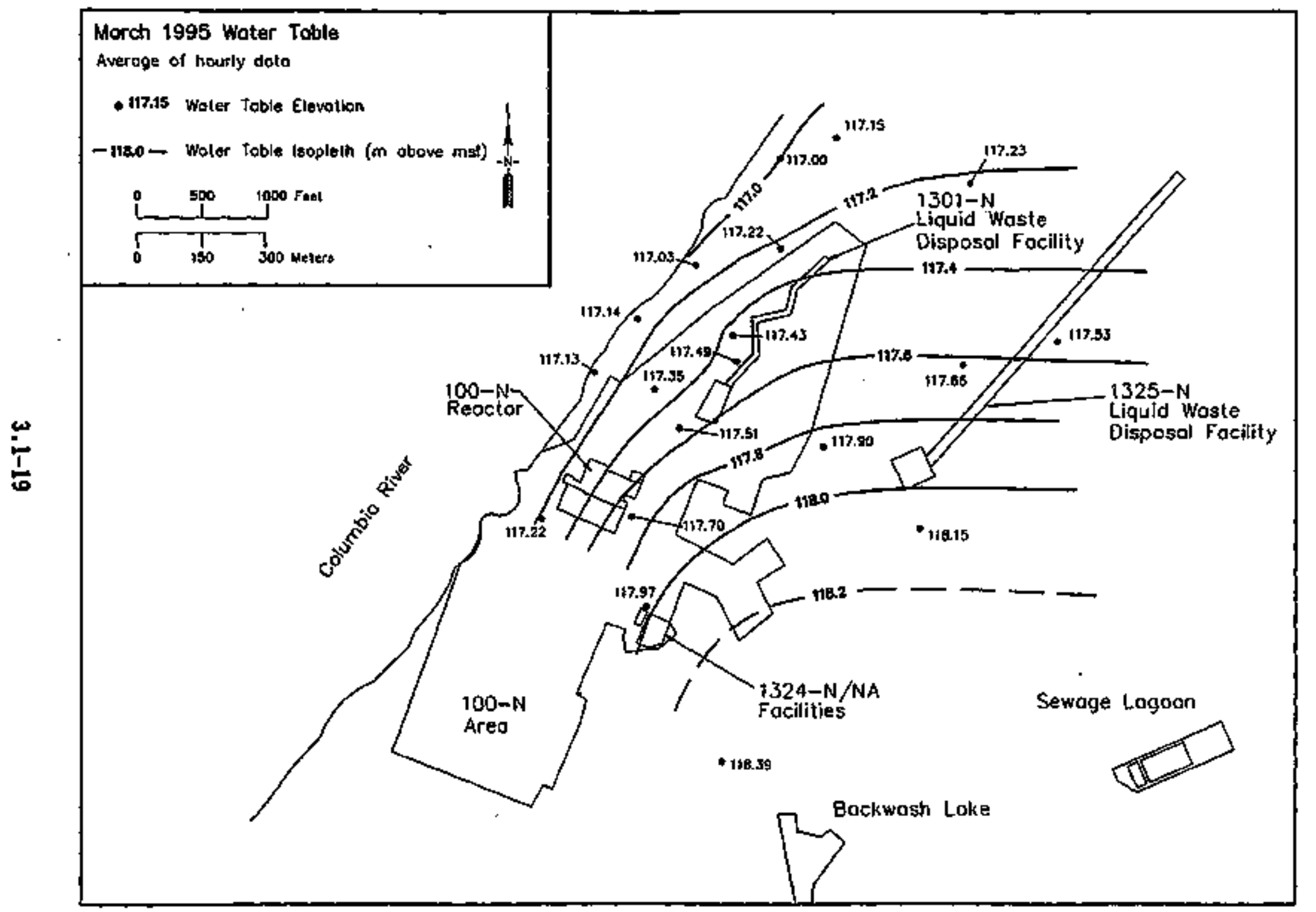

章 


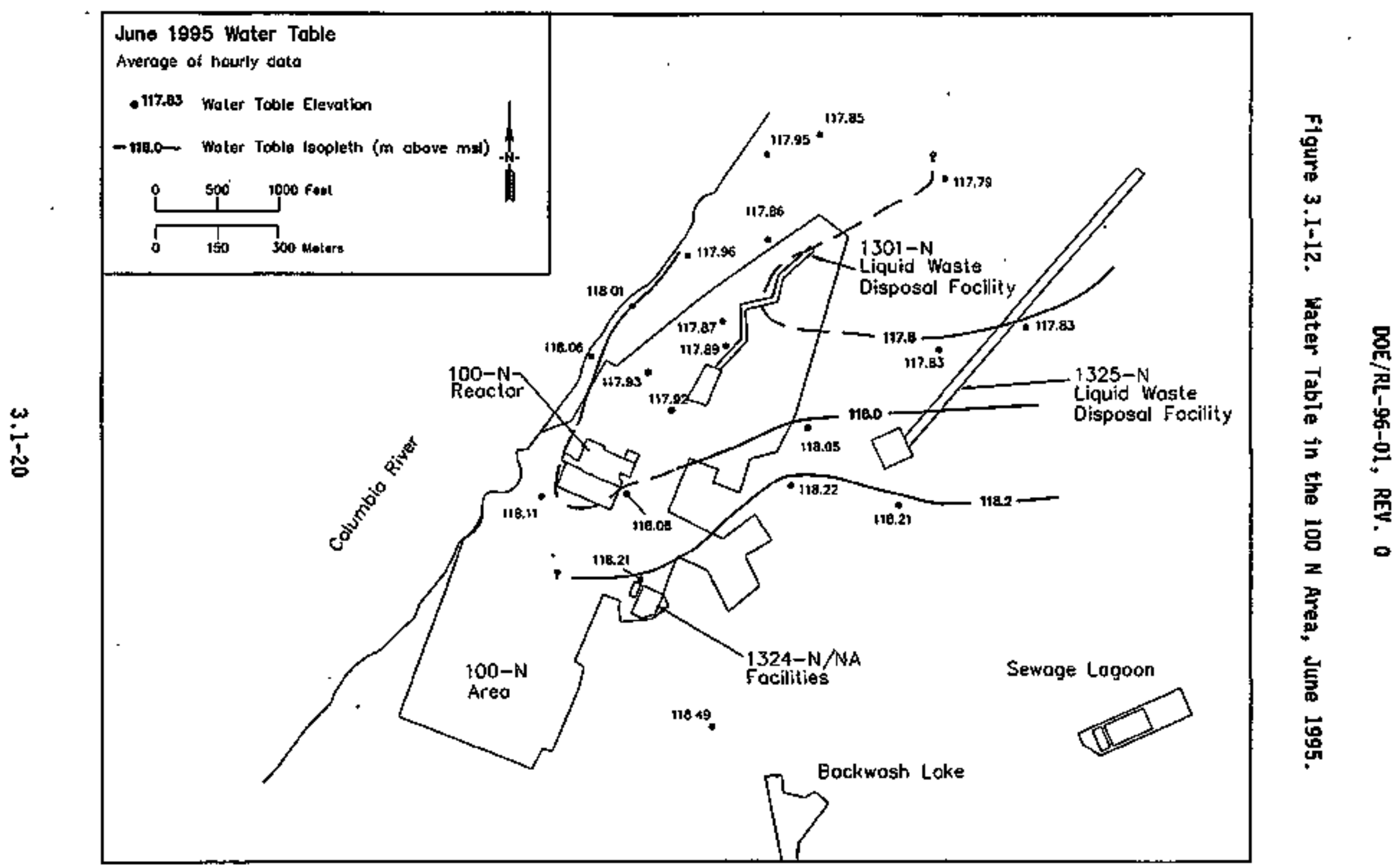

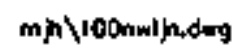


Table 3.1-1. Wells Used to Honitor Groundwater Chemistry for the 1301-N Liquid Waste Disposal Faciltty.

\begin{tabular}{|c|c|c|c|c|}
\hline Well & Aquifer & $\begin{array}{l}\text { Sampling } \\
\text { frequelicy }\end{array}$ & $\begin{array}{l}\text { We11 } \\
\text { standard }\end{array}$ & $\begin{array}{c}\text { other } \\
\text { networks }\end{array}$ \\
\hline $199-14-2^{64}$ & Top of unconfined & SA & PRE & -- \\
\hline $199-14-3^{64}$ & Top of unconfined & $\overline{S A}$ & PRE & $\begin{array}{c}\text { 100-NR-2, } \\
\text { Sftewide }\end{array}$ \\
\hline $199-N-14^{69}$ & Top of unconfined & SA & PRE & A Sortings \\
\hline $199-14-34^{83}$ & Top of unconfined & SA & PRE & - \\
\hline $199-14-57^{87}$ & Top of unconfined & SA & RCRA & - \\
\hline $199-H-67^{83}$ & Top of unconfined & SA & RCRA & $\begin{array}{l}\text { 100-NR-2, } \\
\text { Sitewide }\end{array}$ \\
\hline $199-H-69^{58}$ & Bottom unconfined & $\overline{S A}$ & RCRA & Sitewide \\
\hline $199-N-75^{92}$ & Top of unconfined & $\overline{S A}$ & RCRA & $\begin{array}{l}\text { 100-NR-2, } \\
\text { N Springs }\end{array}$ \\
\hline $199-N-76^{92}$ & Top of unconfined & SA & RCRA & $\begin{array}{l}\text { 100-NR-2, } \\
\text { N Springs }\end{array}$ \\
\hline
\end{tabular}

Hotes: Shading denotes upgradient wells. Superscript

following well number denotes the year of installation.

PRE = well is not constructed to RCRA standards.

SA = frequency on a serilannual basis.

RCRA = well is constructed to RCRA standards. 
Tabie 3.1-2. Wel1s Used to Monitor Groundwater Chemistry for the 1325-N Liquid Waste Disposal Facility.

\begin{tabular}{|c|c|c|c|c|}
\hline WeIl & Aquifer & $\begin{array}{l}\text { Sampling } \\
\text { frequency }\end{array}$ & $\begin{array}{l}\text { Mell } \\
\text { standard }\end{array}$ & $\begin{array}{c}\text { Other } \\
\text { networks }\end{array}$ \\
\hline $199-11-27^{930}$ & Top of unconfined & SA & PRE & Sitewride \\
\hline $199-\mathrm{N}-29^{230, b}$ & Top of unconfined & SA & PRE & A Springs \\
\hline $199-N-32^{83}$ & Top of unconfined & SA & PRE & $\begin{array}{l}\text { 100-N1R-2, } \\
\text { Sitewide }\end{array}$ \\
\hline $199-k-41^{54}$ & Top of unconfined & SA & PRE & - \\
\hline $199-N-43^{84}$ & Top of unconfined & SA & PRE & -- \\
\hline $199-11-70^{83}$ & Bottom unconfined & SA & RCRA & $100-N R-2$ \\
\hline $199-11-74^{91}$ & Top of unconfined & SA & RCRA & $100-N R-2$ \\
\hline $199-11-81^{93}$ & Top of unconfined & SA & RCRA & Sitewide \\
\hline
\end{tabular}

Hotes: Shading denotes upgradient weIl. Superscript following well number denotes the year of installation.

Although weils $\mathrm{N}-2 \mathrm{~J}$ and $\mathrm{H}-29$ are current1y upgradient of the 1325-H LWDF, they were downgradient when the facility was active. The groundwater chemistry at these wells is still affected by the factifty, so they are monitored as downgradtent wells.

We11 1 -29 was dropped from the 1325-N network before the September 1995 sampling because it is an injection well for the ERC's pump and treat progran.

PRE = well is not constructed to RCRA standards.

RCRA $=$ woll is constructed to RCRA standards.

$S A$ = frequency on a semiannual basts.

Tabie 3.1-3. Wells Used to Wonftor Groundwater Chemistry for the 1324-N/NA Facilities.

\begin{tabular}{|c|c|c|c|c|}
\hline Welt & Aquifer & $\begin{array}{l}\text { Sampling } \\
\text { frequency }\end{array}$ & $\begin{array}{c}\text { Ne11 } \\
\text { standard }\end{array}$ & $\begin{array}{c}\text { Other } \\
\text { networks }\end{array}$ \\
\hline $199-N-59^{87}$ & Tep of unconfined & $\overline{\mathbf{Q}}$ & RCRA & - \\
\hline $199-11+71^{91}$ & Top of unconfined & $Q$ & RCRA & $100-N R-2$ \\
\hline $199-k-72^{91}$ & Top of unconfined & $\mathbf{Q}$ & RCRA & - \\
\hline $199-4-73^{91}$ & Top of unconfined & $\mathbf{Q}$ & RCRA & $100-k R-2$ \\
\hline $199-\mathrm{N}-77^{92}$ & Botton of unconfined & $\mathbf{Q}$ & RCRA & $100-N R-2$ \\
\hline
\end{tabular}

Notes: Shading denotes upgradient well. Superscript following

well nuaber denotes the year of insta7lation.

$Q=$ frequency on a quarterly basis.

RCRA - wel1 is constructed to RCRA standards. 
Table 3.1-4. Constituent List for 1301-N and 1325-M LWDFs in 1995.

\begin{tabular}{|c|c|c|}
\hline \multicolumn{3}{|c|}{ Contamination indicator parameters } \\
\hline $\begin{array}{l}\text { pH (field) } \\
\text { Specifjc conductance } \\
\text { (field) }\end{array}$ & $\begin{array}{l}\text { Total organic carbon } \\
\text { Total organic halogen }\end{array}$ & \\
\hline \multicolumn{3}{|c|}{ Other parameters } \\
\hline $\begin{array}{l}\text { Turbidity } \\
\text { Alkalinity } \\
\text { Phenols }\end{array}$ & $\begin{array}{l}\text { ICP metals (filterod) } \\
\text { Lead (filtered) } \\
\text { Anions }\end{array}$ & $\begin{array}{l}\text { Gross alpha } \\
\text { Gross beta }\end{array}$ \\
\hline
\end{tabular}

Table 3.1-5. Constituent List for 1324-N/NA Assossment Monitoring.

\begin{tabular}{|ll|}
\hline \multicolumn{3}{|c|}{ Contamination indicator parareters } \\
\hline $\begin{array}{l}\text { ph (fteld) } \\
\text { Specific conductance } \\
\text { (fteld) }\end{array}$ & $\begin{array}{l}\text { Total organic carbon } \\
\text { Total organtc halogen }\end{array}$ \\
\hline \multicolumn{3}{|c|}{} \\
\hline $\begin{array}{l}\text { Turbidity } \\
\text { Alkalinity } \\
\text { TDS }\end{array}$ & Other paraneters \\
\hline
\end{tabular}

"Wells $\mathrm{N}-72$ and $\mathrm{H}-77$ only. 
Table 3.1-6. Critical Means Table for 32 Corparisons--Background Contamination Indicator Paraneter Data for the 1301-H Ltqutd Waste Disposal Facility ${ }^{a}$

\begin{tabular}{|l|r|r|r|r|r|r|r|}
\hline $\begin{array}{c}\text { Constituent } \\
\text { (Unit) }\end{array}$ & $n$ & df & tc & $\begin{array}{c}\text { Average } \\
\text { background }\end{array}$ & $\begin{array}{c}\text { Standard } \\
\text { deviation }\end{array}$ & Critical mean & $\begin{array}{c}\text { Upgradient/ } \\
\text { downgradient } \\
\text { comparison } \\
\text { valtle }\end{array}$ \\
\hline $\begin{array}{c}\text { Speciflc } \\
\text { Conductance } \\
\text { ( } \mu \text { mho/cm) }\end{array}$ & 10 & 9 & 5.1241 & 592.70 & 272.527 & $2,057.3$ & $2,057.3$ \\
\hline Field pHt & 9 & 8 & 6.0313 & 7.855 & 0.248 & {$[6.28,9.43]$} & {$[6.28,9.43]$} \\
\hline TOC (ppb) & 10 & 9 & 5.1241 & 377 & 205.037 & $1,478.9$ & $1,478.9$ \\
\hline TOX (ppb) & 10 & 9 & 5.1241 & 10.742 & 5.087 & 38.1 & 38.1 \\
\hline
\end{tabular}

- Oata collected from February 1994 to February 1995 for upgradient wells $1-57$ and $\mathrm{N-34.}$ Values calculated based on 32 comparisons.

The following notations are used in this table: df $=$ degrees of freedom $(n-1)$.

$n$ = number of background replicate averages.

$t_{c}=$ Bonferroni crłtical $t$-vajue for appropriate df and 32 comparisons.

Excluding suspect pH data collected on 9/6/94 from woll $\mathrm{N}-57$.

H. C. - not calculated. 
Table 3.1-7. Critical Means Table for 24 Comparisons--Background Contamination Indicator Parameter Data for the 1325-H Liquid Waste Oisposal Facil ity , b

\begin{tabular}{|c|c|c|c|c|c|c|c|}
\hline $\begin{array}{l}\text { Const ituent } \\
\text { (Unit) }\end{array}$ & $\mathbf{n}$ & $\mathbf{d f}$ & tc & $\begin{array}{c}\text { Average } \\
\text { background }\end{array}$ & $\begin{array}{l}\text { Standard } \\
\text { deviation }\end{array}$ & Critical mean & $\begin{array}{l}\text { Upgradient/ } \\
\text { downgradient } \\
\text { comparison } \\
\text { value }\end{array}$ \\
\hline $\begin{array}{l}\text { Specific } \\
\text { Conductance } \\
\text { ( } \mu \text { mho } / c \text { co) }\end{array}$ & 4 & 3 & 13.745 & 501.75 & 14,046 & 729.1 & 717.6 \\
\hline Field pH & 4 & 3 & 17.358 & 7.991 & 0.129 & {$[5.27,10.55]$} & {$[6.50,9.12]^{d}$} \\
\hline$T 0 C^{c}(p p b)$ & 4 & 3 & 13.745 & 500 & H.C. & H.C. & 976 \\
\hline$T 0 X(p p b)$ & $\overline{4}$ & 3 & 13.745 & 11.185 & 2.952 & 59.0 & 56.6 \\
\hline
\end{tabular}

Data collected from Hay 1992 to Warch 1993 for upgradient we? 1 N-74 except for ToX mich was collected frow June 1994 to March 1995. Values calculated based on 24 compartsons (well $\mathrm{H}-29$ was not sampled in 1995).

The following notations are used in this table; of $\approx$ degrees of freedom (n-1).

$n$ * number of background replicate averages.

$t_{c}=$ Bonferront critical t-value for appropriate df and 24 comparisons.

'Critical mean cannot be calculated due to lack of an estimate of background standard deviation. The upgradient/downgradient comparison value for toc is the 1 init of quantitation (see Appendix A).

Upgradient/downgradient comparison values for $\mathrm{pH}$ were calculated using data collected from Hay 1992 to Hovember 1994 (well $N-74$ ) because the critical range calculated using only four quarters of data is too large to be meaningful.

H. C. - not calculated. 
D0E/RL-96-01, REV. O

This page intentionally left blank.

$3.1-26$ 


\section{CoHreirs}

3.2100 D PONDS $\ldots \ldots \ldots \ldots \ldots \ldots \ldots \ldots \ldots . \ldots \ldots \ldots$

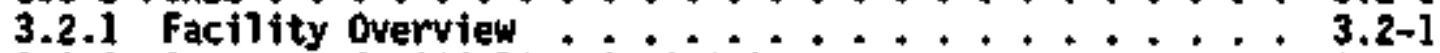

3.2.2 Summary of $1995 \mathrm{RCRA}$ Activities .............. 3.2-1

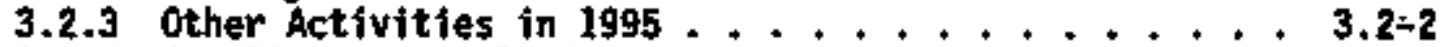

3.2.4 Sampling and Analysis Program .......... 3.2-2

3.2 .5 Groundwater Chemistry ........... 3.2-2

3.2.6 Groundwater Flow ................ 3.2-3

3.2.7 References.................. 3.2-4 


\section{LIST OF FIGURES}

3.2-1 Groundwater Monjtoring Welis Located Near the 100 0 Ponds . . 3.2-6

3.2-2 Geologic Cross Section Through the 100 D Ponds . . . . . . 3.2-7

3.2-3 Groundwater Monjtoring Wells In and Near the $100 \mathrm{D}$ Area ... 3.2-8

3.2-4 Specific Conductance and pH Versus Time in $100 \mathrm{D}$ Ponds Wells . 3.2-9

3.2-5 Nitrate and Sulfate Versus Tine in $100 \mathrm{D}$ Ponds Mells . . . 3.2-10

3.2-6 Witrate in the Uppermost Aquifer,

100 D Area, February-Harch, 1995. . . . . . . . . . . 3.2-11

3.2-7 Chromiun in the Uppermost Aquifer,

1000 Area, February-March, 1995.............. 3.2-12

3.2-8 Tritjum in the Upperiost Aquifer,

1000 Area, February-Harch, 1995. . . . . . . . . . . 3.2-13

3.2.9 Water Level Versus time in $100 \mathrm{D}$ Ponds We11s.........3.2-14

3.2-10 Water Table in the 1000 Area, February, $1995 \ldots \ldots$. . . . 3.2-15

3.2-11 Water Table in the 100 D Area, June, 1995. . . . . . . . 3.2-16

\section{LIST OF TABLES}

3.2-1 Wells Monitored for Chentstry or Water Levels

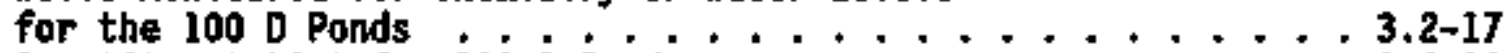

3.2-2 Constituent list for 100 o Ponds . . . . . . . . . . 3.2-19

3.2-3 Crittical Means Table for 16 Comparisons--Background

Contamination Indicator Parameter Data for the 100-D Ponds . . 3.2-20 
DOE/RL-96-01, REV. 0

\subsection{PONDS}

\section{H. d. Hartman \\ Westinghouse Hanford Company}

This chapter describes groundwater monitoring at the $100 \mathrm{D}$ Ponds, a Resource Conservation and Recovery Act of 1976 (RCRA) disposal unit located in the 100 D Area of the Hanford Site (see Figure 1-1, Chapter 1.0). The 100 D Ponds monjtoring progrin began in 1991 and the four wells in the network were sampled for the first time in 1992. The groundwater ronitoring progran is described by Hartman (1991). The site is monitored in an indicator evaluation progran.

\subsubsection{Facility overview}

The 100 o Ponds facility was constructed in 1977 for disposal of nonradloactive effluents derived from $100 \mathrm{D}$ Area operating facilities. The 100 D Ponds are located in the-former 188 D Ash Disposal Basin. The 100 D Ponds include a settling pond and a percolation pond, separated by a dtke (Figure 3.2-1).

Effluent to the $100 \mathrm{D}$ Ponds originated from two sources: the 183D F1]ter Plant and the 1890 Building engineering testing laboratorles. Some past discharges contained hydrochloric acid, sulfuric acjd, and sodium hydroxide. Before 1986, the effluent may have had a pH of greater than 12.5 or iess than 2.0 and, thus, may have been dangerous waste. Also, up to $2.3 \mathrm{~kg}$ (5 1b) of mercury may have been discharged to the $100 \mathrm{D}$ Ponds. Effluent discharge cessed in 1994 . Between 1986 and 1994 the effluent tncluded chlorine and flocculating agents such as aluminum sulfate.

In addition to being a RCRA facflity, the 100 Donds are regulated under the Cosprehensive Environmental Response, Coopensation, and Liabifity Act of 1980 (CERCLA) program. Groundwater beneath the $100 \mathrm{D}$ Area is considered part of the 100-HR-3 operable unit. The $100 \mathrm{D}$ Ponds themselves are located in the 100-DR-1 source operabie unit. Hydrogeologic data from CERCLA wells were jnterpreted in this section along with data from the 100 D Ponds RCRA wells to better understand the hydrogeology of the $100 \mathrm{D}$ Area.

The uppermost aquifer beneath the $100 \mathrm{D}$ Ponds is a sand-and-grave] unit. in the Ringold Formation (Figure 3.2-2), approximately 3 to $9 \mathrm{~m}$ (10 to $30 \mathrm{ft}$ ) thick. This unit corresponds to Ringold tinit E (see Section 2.1). The base of the aquifer is a fine-grajned overbank interval, which is approxinately $15 \mathrm{~m}$ (50 ft) thick elsewhere in the 100 D Area (DOE-RL, 1993).

\subsubsection{Summary of 1995 RCRA Activities}

The downgradient wells in the 100 D Ponds network were sampled twice during the past year. The upgradient we11 was sampled four times to reestablish background specific conductance, which is increasing. Water levels were measured nonthly. 
DOE/RL-96-01, REV. O

\subsubsection{Othar Activities in 1995}

Several activities were conducted for the 100-HR-3 groundwater operable unit during the past year. Nells in the $100 \mathrm{D}$ Area were sampled twice. A pump-and-treat svstea, wnich began operation in August 1994, continued to operate during the past year. The system is designed to remove chromitum from groundwater. Water is withdrawn from wells 05-14, 05-15, and 05-16; treated in an 1on exchange column; and infected into wells D5-18 and 05-19

(Ftgure 3.2-3).

\subsubsection{Sampling and Analys1s Program}

The wonitoring prograt for the $100 \mathrm{D}$ Ponds is described by Hartman (1991). Four wells are sampled for the $100 \mathrm{D}$ Ponds and additional wells are used to monitor water levels. Table 3.2-1 1ists the walls monitored for water levels and/or chemistry for the 100 O Ponds RCRA program. The locations of the wells are shown 1n Figure 3.2-1.

The RCRA sampling network consists of one upgradient wo1] (D5-13) and three downgradient wells. Two of the downgradtent wells (08-4 and DB-6) are located adjacent to the $100 \mathrm{D}$ Ponds. The remaining well (D8-5) is located farther from the factlity, outside of the ash mounds, and nearer to the river. The location of this weli was deternined in discussions with the Washington State Department of Ecology. The well's location was chosen to provide more information on river/aquifer relationships.

Samples are analyzed for the constituents listed in Table 3.2-2. Water levels are measured monthly in most of the wells in the $100 \mathrm{D}$ Area and its vicinity (see Table 3.2-1 and Figure 3.2-3). Water levels and results of cheoical analyses are presented in quarterly reports (Hartman 1995a, 1995b, 1995c, 1996).

\subsubsection{Groundwater Chemistry}

3.2.5.1 Constituents of Concern. The indicator parameters for the $100 \mathrm{D}$ Ponds are: pH, spectfic conductance, total organic carbon (TOC), and total organic halogen (TOX) ( 40 Code of Federal Regulations

[CFR] 265.92[b][3]). TOC was below the contractually required quant tation Ifit in all we11s except upgradient well 05-13 (approxisately 800 pph in August 1995). TOX was less than $15 \mathrm{ppb}$ in all wells. The $\mathrm{pH}$ tends to be higher in the wells immedfateiy adjacent to the ponds (D9-4 and DB-6) than in the upgradient well (D5-13) or the well further downgradient (DB-5)

(Figure 3.2-4). The change in $\mathrm{pH}$ ay be caused by reactions with lime and perfelase in the ash beneath the ponds (ATexander 1993). Specific conductance is lower in the wells nearest the pond's (see Figure 3.2-4). This is 7ikely because of difution by artificial recharge from the ponds.

'Well numbers in this section are abbreviated by removing the 199 prefix, e.g., well 199-05-14 is written 05-14. 
Specific conductance in the upgradient wel1, 05-13, which had increased in 1994, 5 tabtlized at approxtmately $500 \mu \mathrm{mho} / \mathrm{cm}$ during the past year (see Figure 3.2-4). The elevated spectfic conductance is believed to be caused by an Influx of higher conductivity groundwater fron upgradient sources. Hitrate and suifate also are elevated in well 05-13 (Figure 3.2-5). This well is sampled quarterly to establish a new background value for specific conductance.

Hercury is a dangerous waste constituent that was potentially dfscharged to the $100 \mathrm{D}$ Ponds (BOE-RL 1993). No mercury has been detected in the 100 Ponds downgradient wel1s.

Nitrate, chromium, and tritium are elevated in the $100 \mathrm{D}$ Area from sources other than the 100 o Ponds (Ftgures 3.2-6,3.2-7, and 3.2-8). Each of these constituents is lowest in the area surrounding the $100 \mathrm{0}$ Ponds. As with specific conductance, this is Iikely because pond efftuent has diluted local groundwater. This dilution effect is expected to disappear gradually now that effluent disposal has ceased.

3.2.5.2 Stattstical Evaluation. Indicator paraneter data from upgradient well D5-13 were statistically evaluated as required by 40 CFR 265.93 (b) and Washington Administrative Code (WAC) 173-303-400. Table 3.2-3 lists background averages, standard deviations, critical mean values, and upgradient/downgradient comparison values for the indicator paraneters. Statistical methods are descrfbed in Appendix $C$. The upgradient/downgradient comparison value is the value to which current and future averages of indicator parameters are compared. The conparison value is generally the critical aean or critical range. The ijait of quantitation is used as the comparison value for TOC instead of the critical mean because most of the upgradient concentrations were below the contractually required quantitation Ifatits (see Appendix C).

Specific conductance, pH, TOX, and TOC values for the downgradient weTls were compared to the upgradient/domgradient couparison values. Ho downgradient values exceeded the comparison values, except pH in well 08-6 in August 1995. Verification samples from the wall had pH within the critical range. The original values (around 9.3) were determined to be nonrepresentative.

Specific conductance has increased in upgradient well D5-13. A new critical mean will be established in the future.

\subsubsection{Groundwater Flow}

Water levels were measured in wells in and near the $100 \mathrm{D}$ Area each month during the past year. The water table currently 1 les approximately $24 \mathrm{~m}$ $(80 \mathrm{ft}$ ) beneath 1and surface at the $100 \mathrm{D}$ Ponds, within Ringold formation gravel. Interpretations of groundwater flow are based on water table maps constructed from the measured water levels.

3.2.6.1 Groundwater Flow Direction. Groundwater leve1s in the 100 Area fluctuate with the stage of the Columbia River (Figure 3.2-9; see Figure 2-3). Seasonal changes of up to $1 \mathrm{~m}(3 \mathrm{ft})$ were observed during the past year in the 
1000 Ponds wel]s. When river stage is high, water levels in downgradient wells 08-4 and 08-6 can be s]ightly higher than in upgradient well 05-13.

Figure 3.2-10 shows the water table in the 1000 Arsa in February 1995 when the river stage was relatively low. Groundwater is inferred to flow northwest toward the river beneath the 100 D Ponds. The river stage was htgh in June 1995, and the gradient between the river and 100 D Ponds was fiat or perhaps reversed (Figure $3.2-11$ ).

Hartman (1994) estinated an upward vertical gradient ranging fron $7 \times 10^{-5}$ to $2 \times 10^{-2}$ between we 115 o8-54A and 08-548. Well 08-54A is cotoleted across the water table. We]1 $08-548$ is completed $22.6 \mathrm{~m}$ (74 ft) deeper than well D8-54A in a thtn 7 ayer of silty sand that is confined beneath $15 \mathrm{~m}$ (50 ft) of clay.

3.2.6.2 Rate of Flow. The herizental hydraulic gradient was calculated between wells $05-13$ and $08-4$ using data from February 1995:

difference in head: $0.07 \mathrm{~m}(0.23 \mathrm{ft})$

horizonta] distance: $161 \mathrm{~m}$ ( $530 \mathrm{ft}$ )

gradient: $\quad 4.3 \times 10^{-4}$.

The rate of groundwater flow can be estimated by using a form of the Darcy equation with a range of input parameters.

$$
v=\frac{k i}{n_{\theta}}
$$

where:

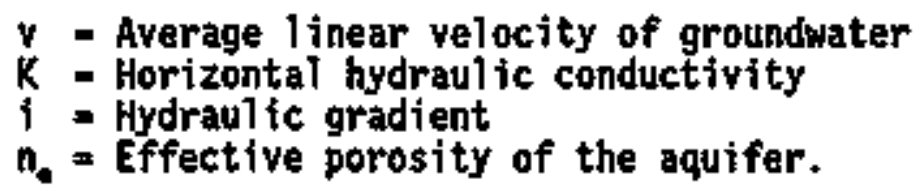

The following input parameters were used:

$\begin{aligned} K & =1.2 \text { to } 40 \mathrm{n} / \mathrm{d}(3.9 \text { to } 130 \mathrm{ft} / \mathrm{d} \text { ) (slug withdrawa); Hartman 1992) } \\ \mathrm{j} & =4.3 \times 10^{-4} \\ n_{\mathrm{e}} & =0.1 \text { to } 0.3 .\end{aligned}$

The resulting estimate of groundwater velocity ranges from $2 \times 10^{-3}$ to $0.2 \mathrm{~m} / \mathrm{d}\left(6 \times 10^{-3}\right.$ to $\left.0.6 \mathrm{ft} / \mathrm{d}\right)$.

3.2.6.3 Evaluation of Monitoring Hell Hetwork. When the 100 ponds were in use, recharge from the ponds diluted groundwater, apparently affecting even the upgradient well. With the cessation of effiuent discharge to the $100 \mathrm{D}$ Ponds, contaminated water from elsewhere in the 100 a Area can be expected to flow beneath the ponds. The pump-and-treat system current]y operating in the $100 \mathrm{D}$ Area and another planned system may atso have an effect on groundwater flow and chemistry in the $100 \mathrm{D}$ Ponds monitoring network. 
00E/RL-95-01, REV, 0

\subsubsection{References}

40 CFR 265, "Interim Status Standards for Owners and Operators of Hazardous Waste Treatment, Storage, and Disposal Faciltties," Code of Federal Regulations, as amended.

Alexander, D. J., 1993, Groundwater Inpact Assessment Report for the 100-0 Ponds, KHC-EP-0666, Nestinghouse Hanford Company, Richland, Washington.

Comprehensive Environmental Response, Cospensation, and lfabilfty Act of 1980, 42 USC 9601 et seq.

DOE-RL, 1993, 100-D Ponds Closure PTan, DOE/RL-92-71, Rev. 0, U.S. Department of Energy, Richland Operations Office, Richland, Washington.

Hartman, M. J., 1991, Groundwater Monitoring Plan for the 100-D Ponds, WHC-SD-EH-AP-048, Rev, 0, Hestinghouse Hanford Company, Richland, Washington.

Hartaan, M. J., I992, Borehole Completion Data Package for the 100-D Ponds: CY Ig92, WHC-SD-EN-DP-043, Rev. 0, Westinghouse Hanford Company, Richland, Washington.

Hartman, H. J., 1994, "100-D Ponds," in Annual Report for RCRA Groundwater Nonitoring Projects at Hanford Site Facilities for 1993, DOE/RL-93-8B, U.S. Department of Energy, Rtchl and Operations Office, Rich] and, Washington.

Hartman, H. J., 1995a, "100-D Ponds," in Quarterly Report of RCRA Groundwater Monitoring Data for Period October 1, 1994 through December 31, 1994, DOE/RL-94-36-4, U.\$. Department of Energy, Richiand Dperations offjce, Richland, Washington.

Hartman, M. J., 1995b, "100-D Ponds," in Quarterly Report of RCRA Groundwater Monitoring Data for Period January 1, 1995 through March 31, 1995, DOE/RL-95-69-1, U.S. Department of Energy, Richland Operations Office, Richland, Washington.

Hartman, N.J., 1995c, "100-D Ponds," in Quarterly Report of RCRA Groundwater Honftoring Data for Periad April 1, 1995 through June 30, 1995, DOE/RL-95-69-2, U.S. Department of Energy, Richland Operations Office, Richland, Washington.

Hartman, H. J., 1996, "100-D Ponds," in Quarterly Report of RCRA Groundwater Nonitoring Data for Period July 1 , 1995 through September 30, 1995, DOE $/ R L-95-69-3$, U.S. Department of Energy, Richland Operations office, Richland, Washington.

Resource Conservation and Recovery Act of 1976, 42 USC 6901 et seq.

WAC 173-303, "Dangerous Waste Regulations," Washington Administrative Code, as amended. 
DOE/RL-96-01, REY. 0

Figure 3.2-1. Groundwater Monjtoring Wells Located Mear the $100 \mathrm{D}$ Ponds.

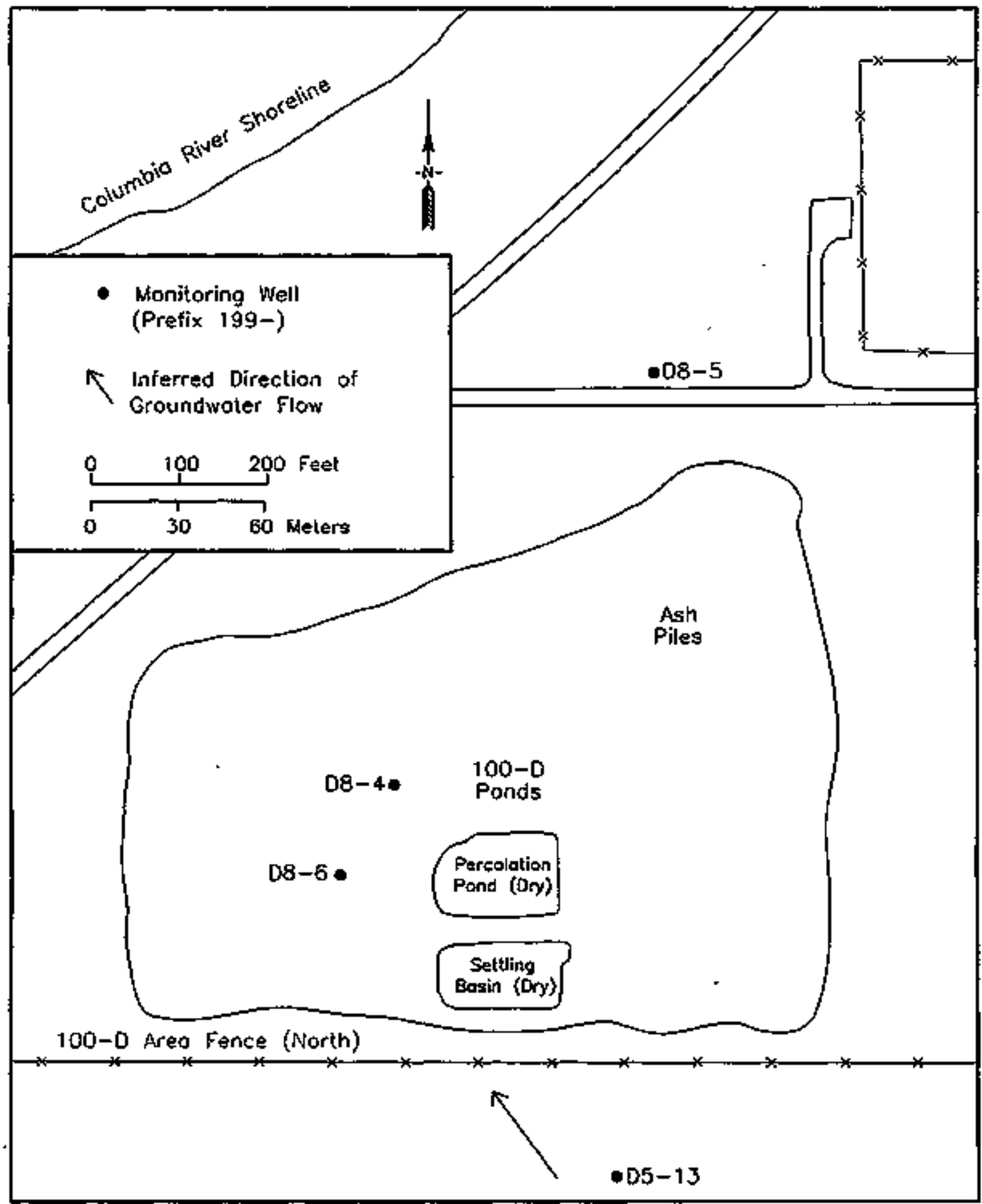

min $\backslash 100010 c . d w g$ 


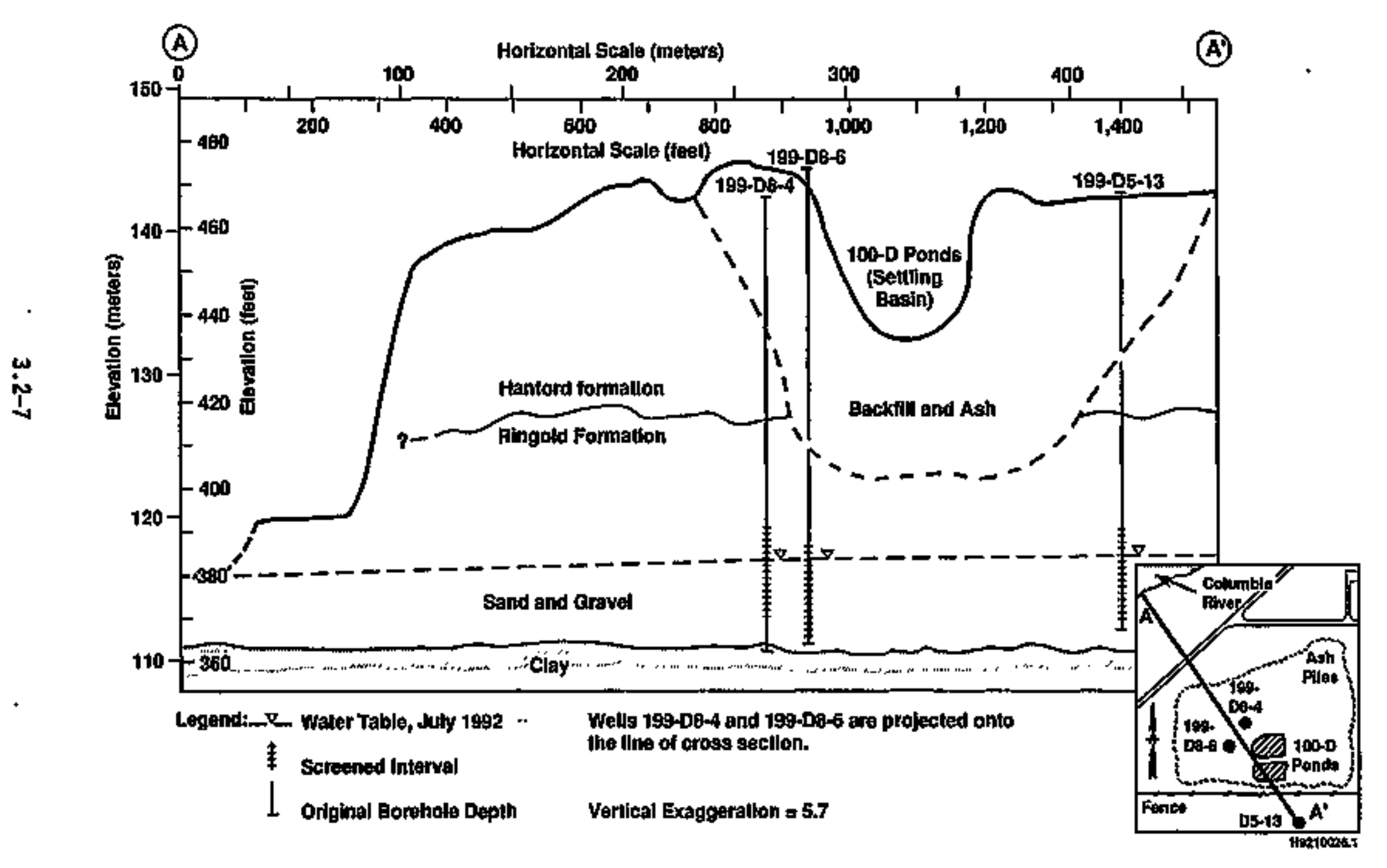


DOE/RL-96-01, REY. 0

Figure 3.2-3. Groundwater Monitoring We11s in and Mear the $100 \mathrm{D}$ Area.

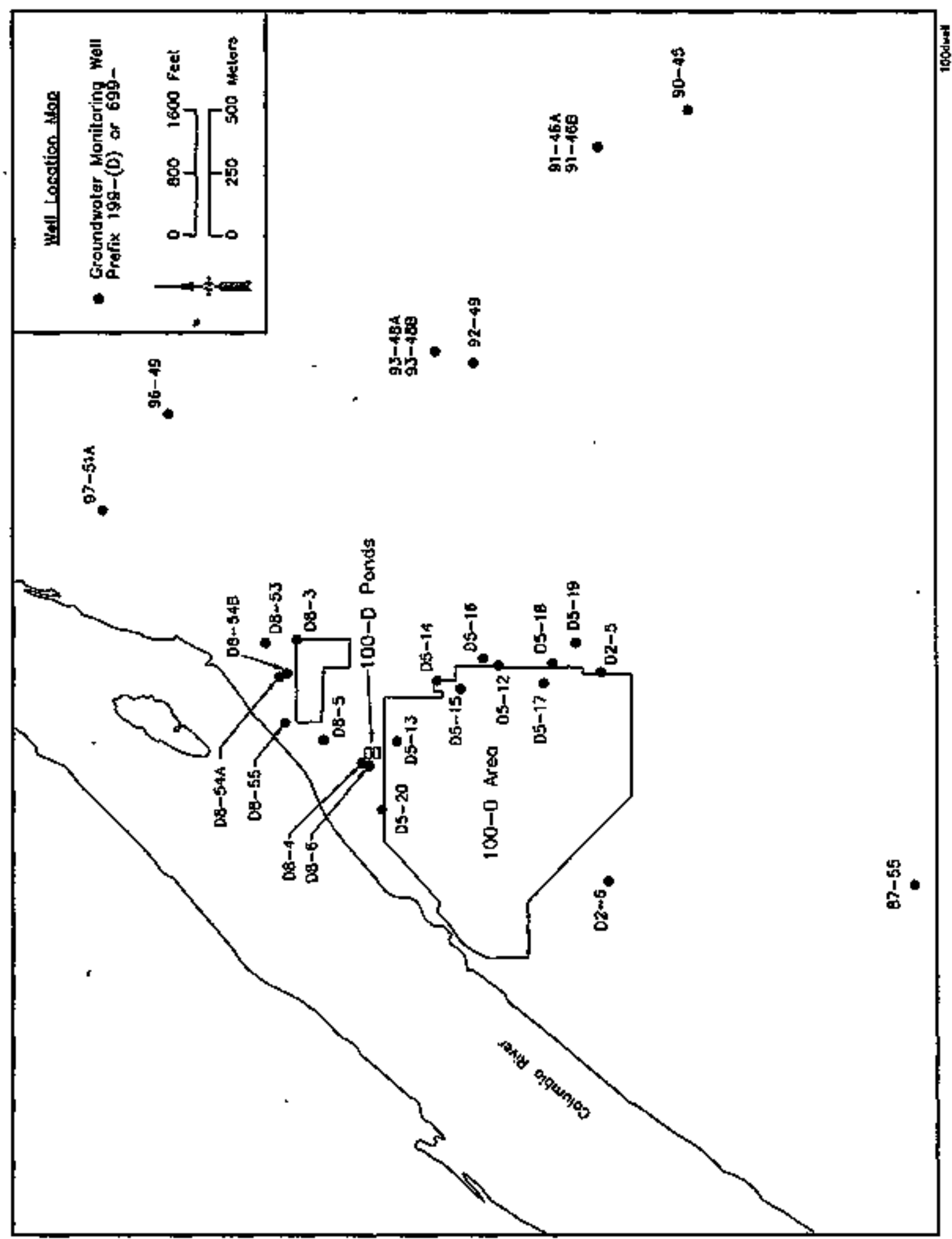


DOE/RL-96-01, REV. 0

Figure 3.2-4. Specific Conductance and pH Versus Time in 1000 Pónds Vells.
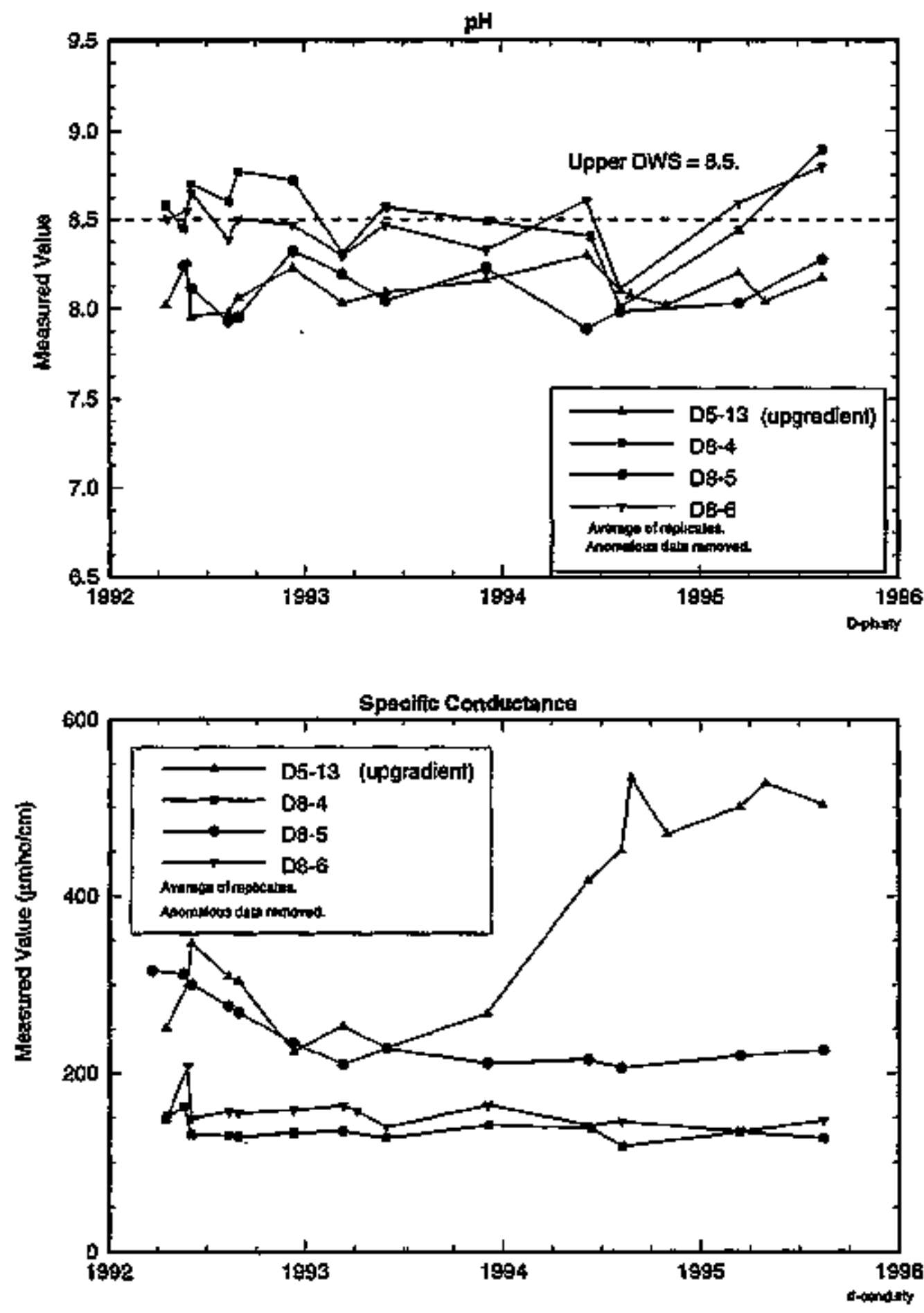
Figure 3.2-5. Hitrate and Sulfate. Versus Time in $100 \mathrm{D}$ Ponds Wells.

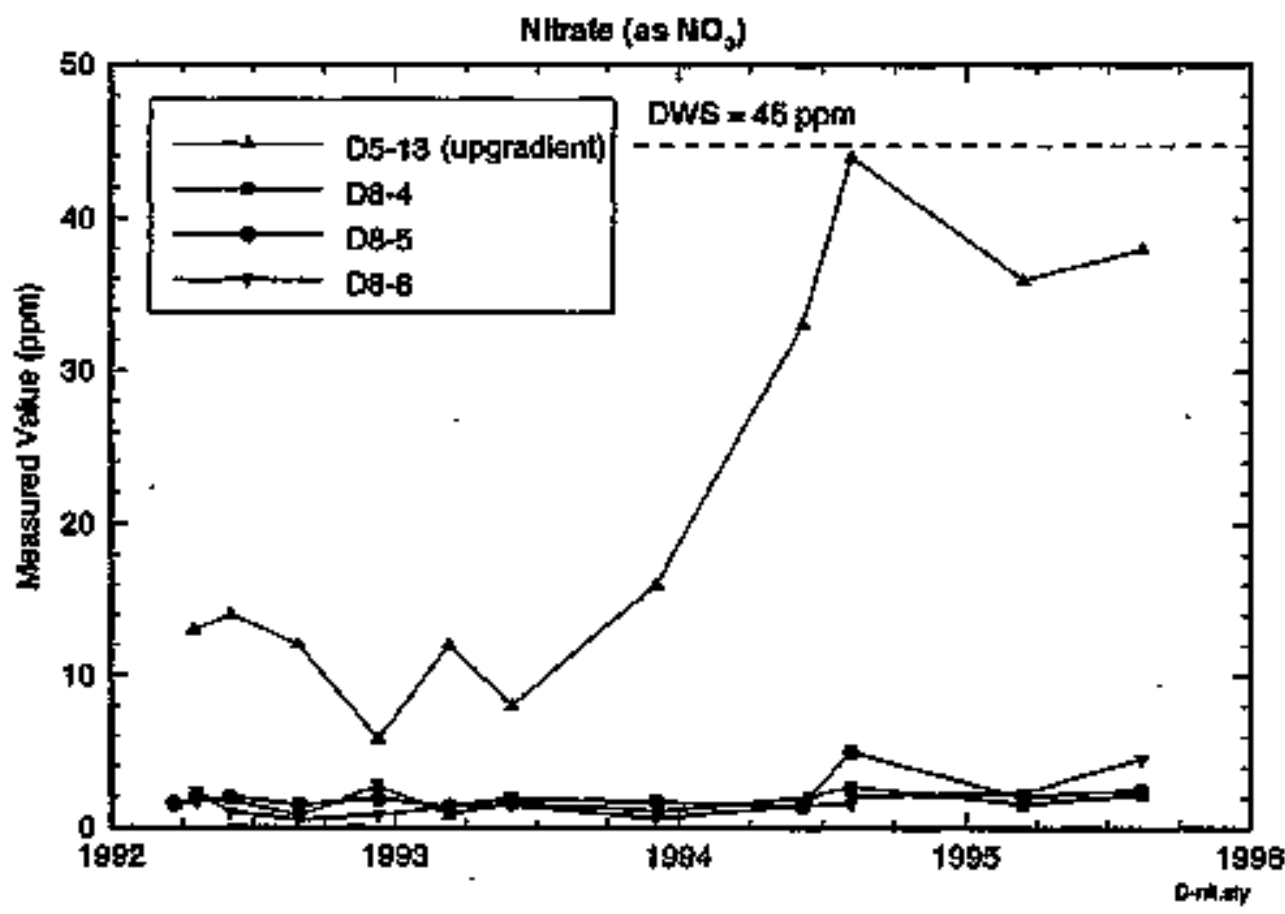

Sulfaw

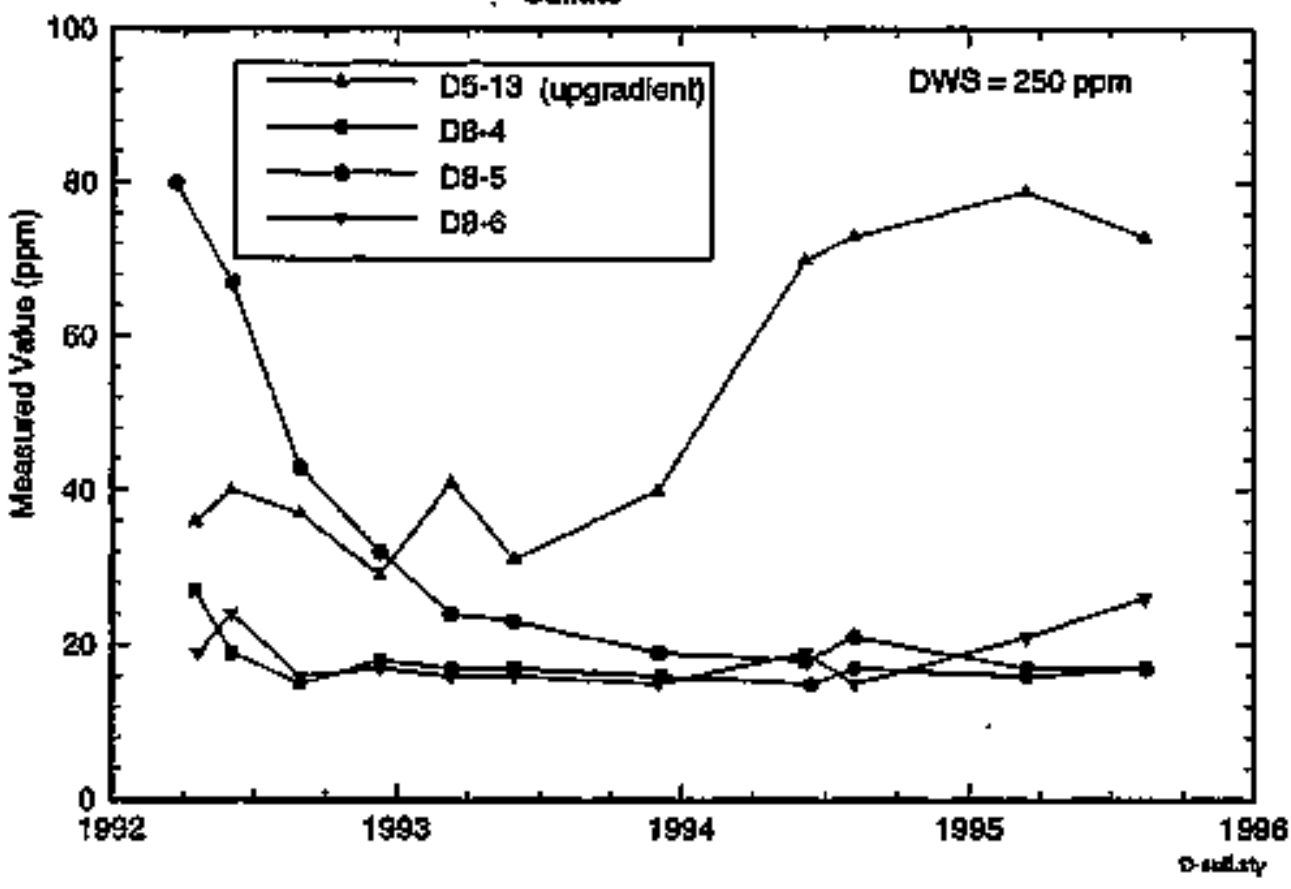




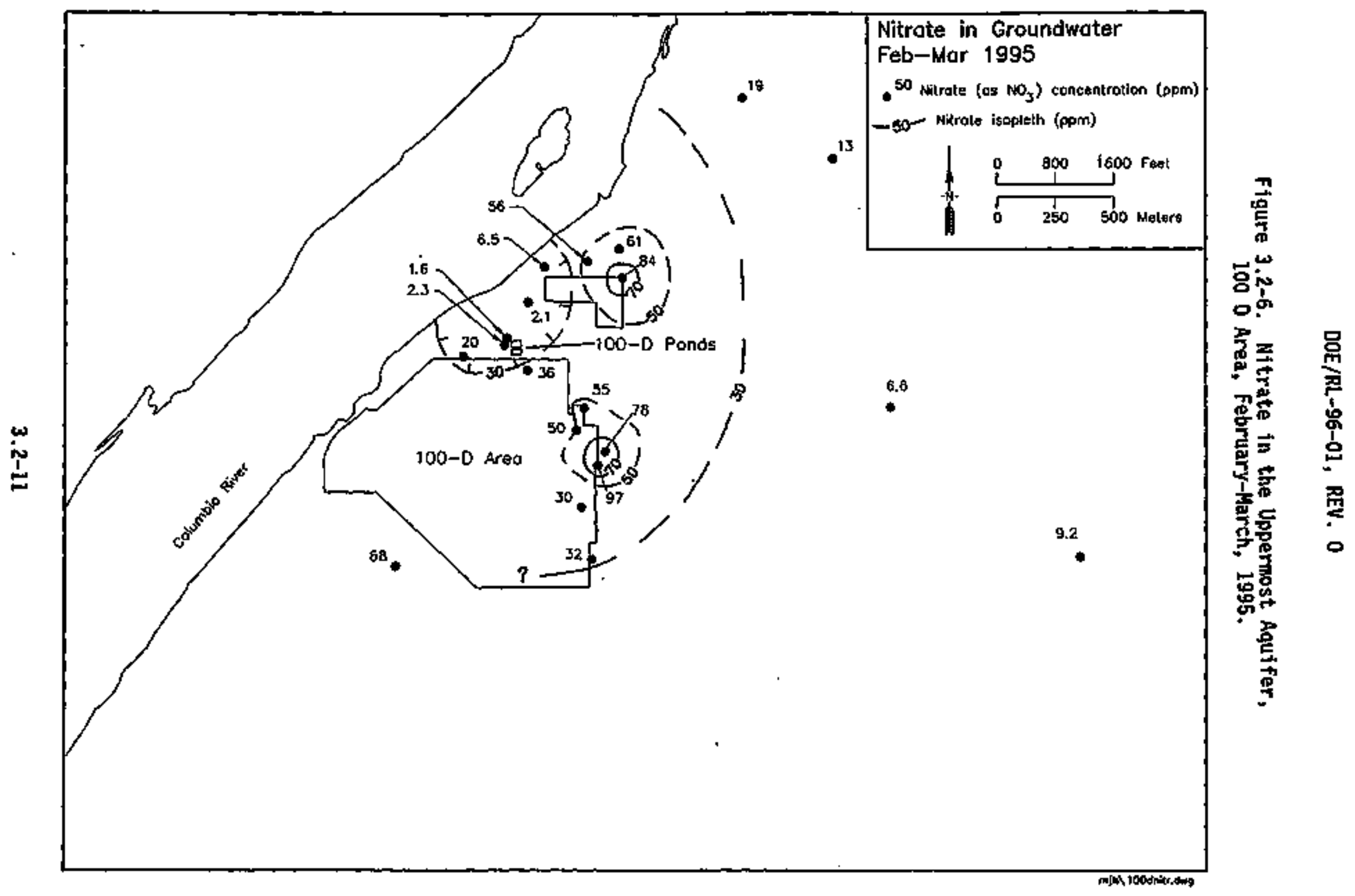


Figure 3.2-7. Chromium in the Uppernost Aquifer, 100 D Area, February-March, 1995.

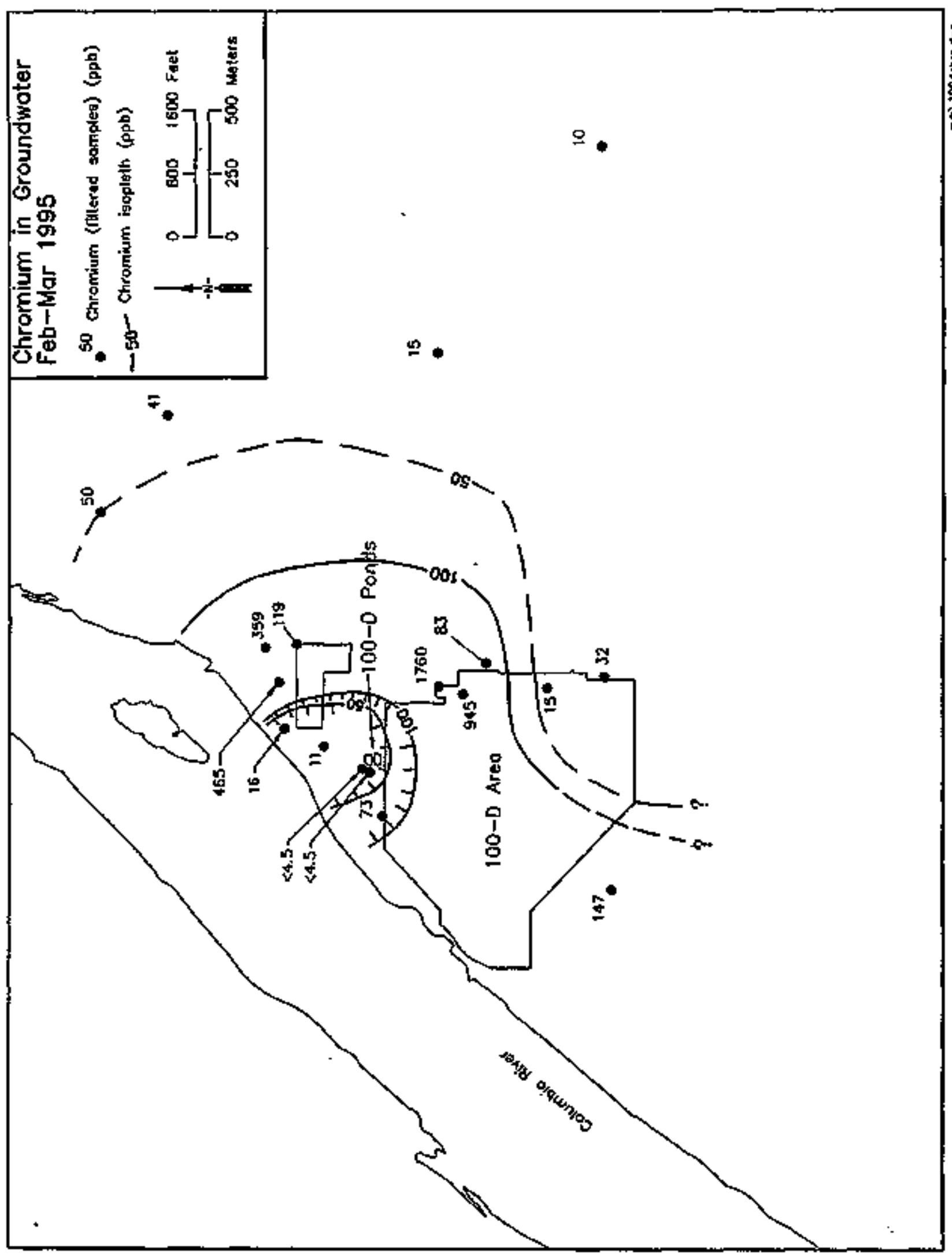




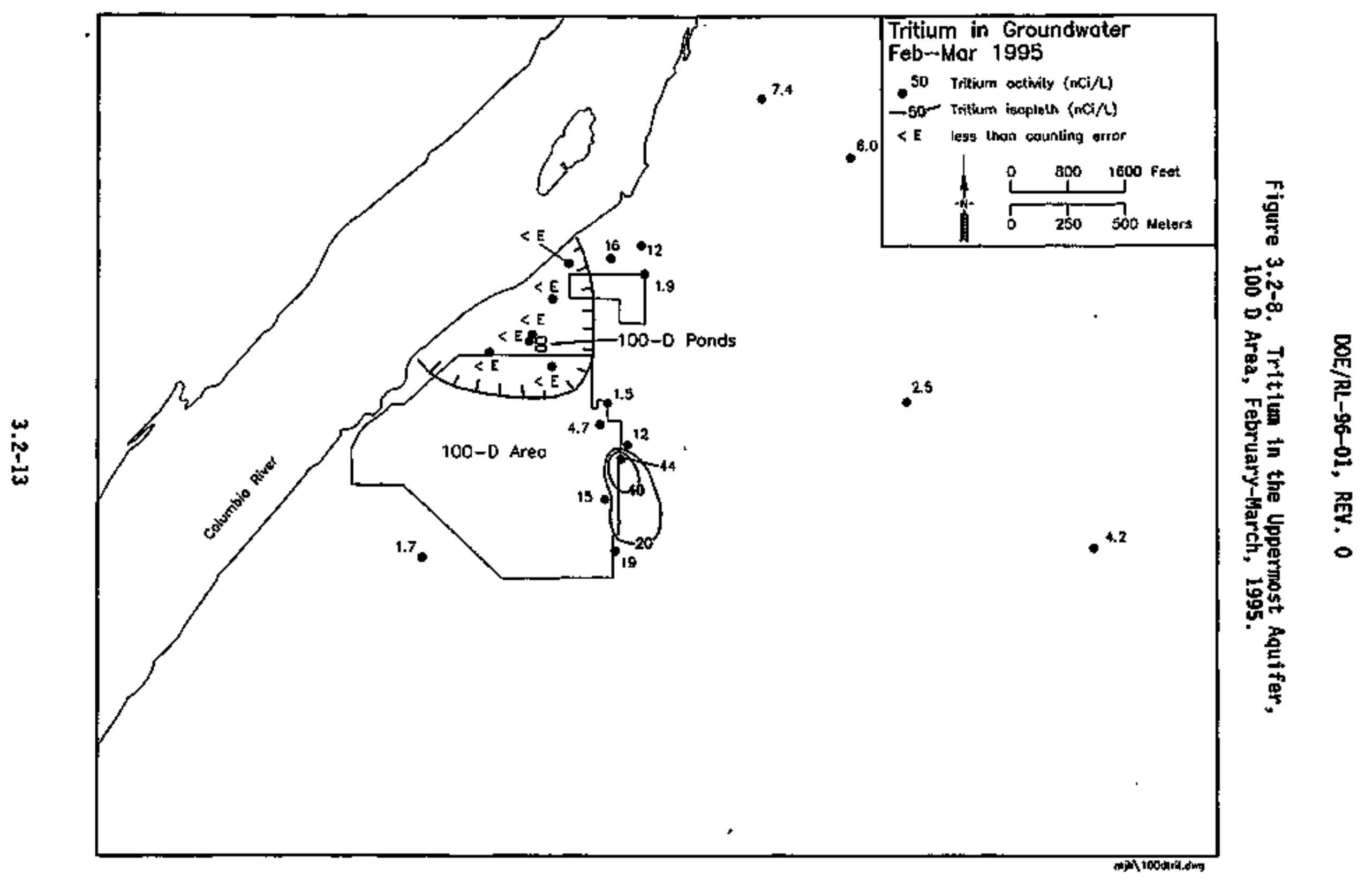


DOE/RL-96-01, REV. 0

Figure 3.2-9. Water Level Versus Time in $100 \mathrm{D}$ Ponds Wel1s.

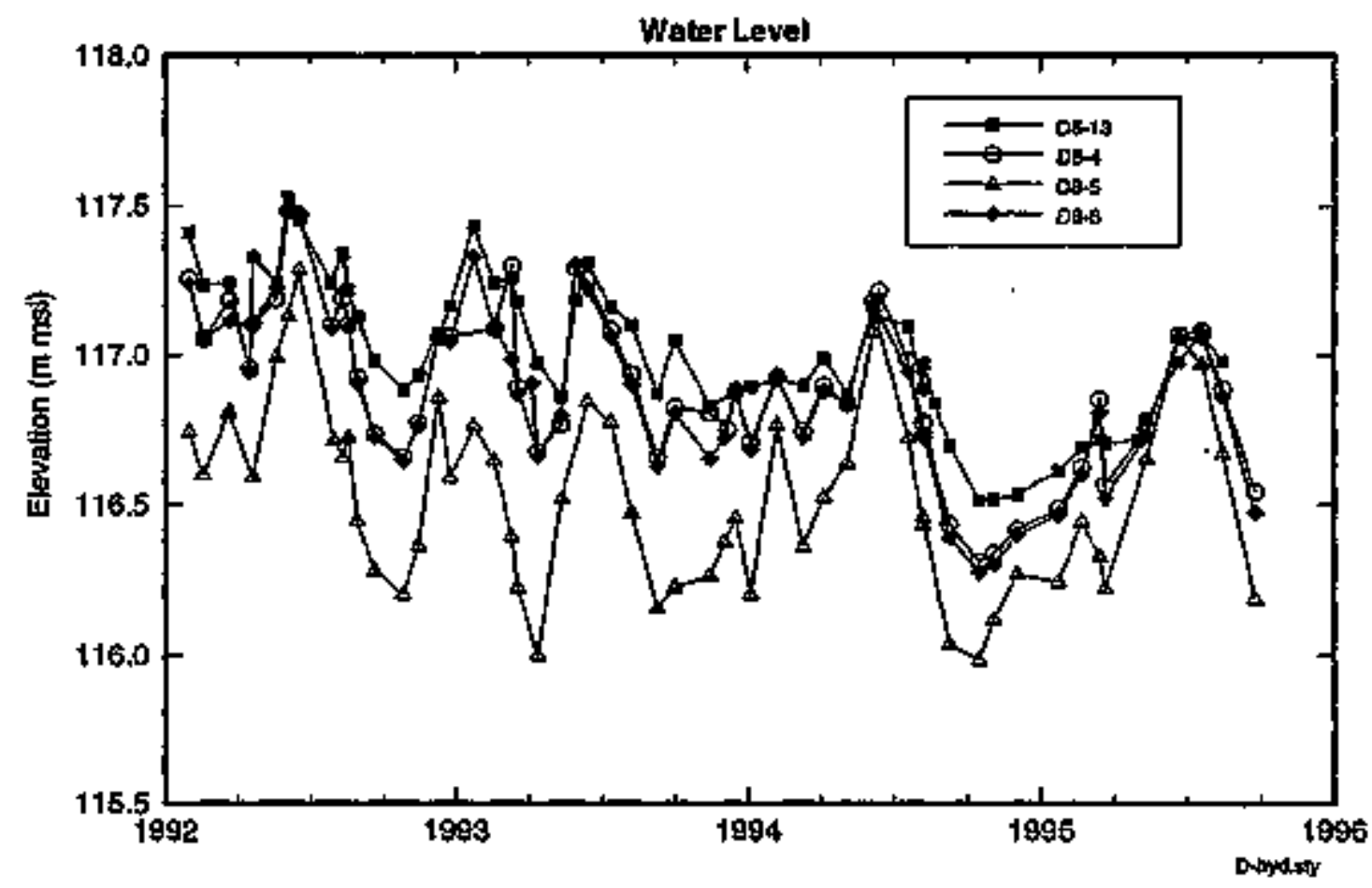




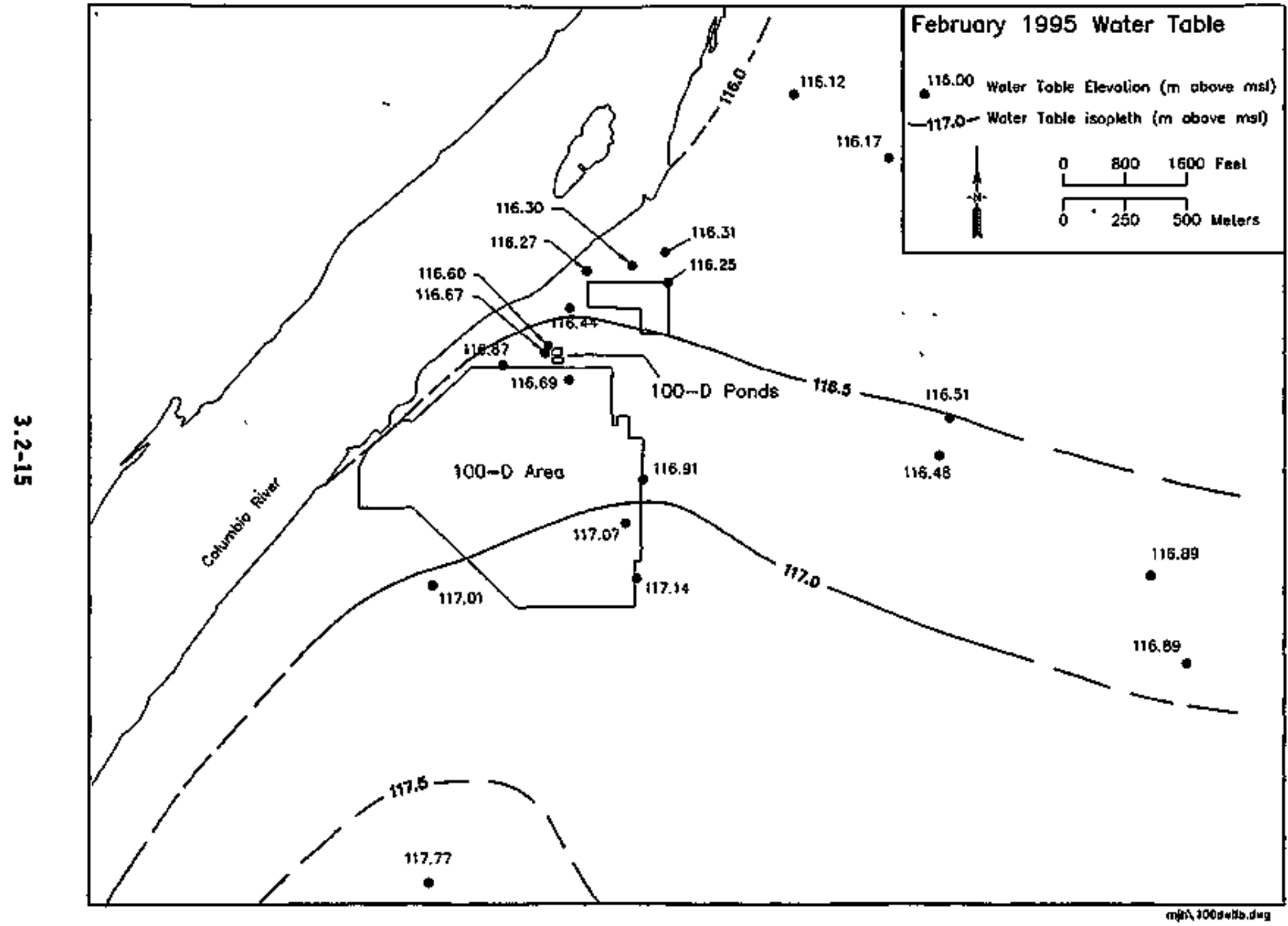

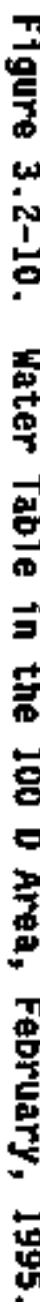

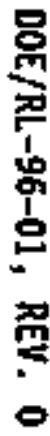




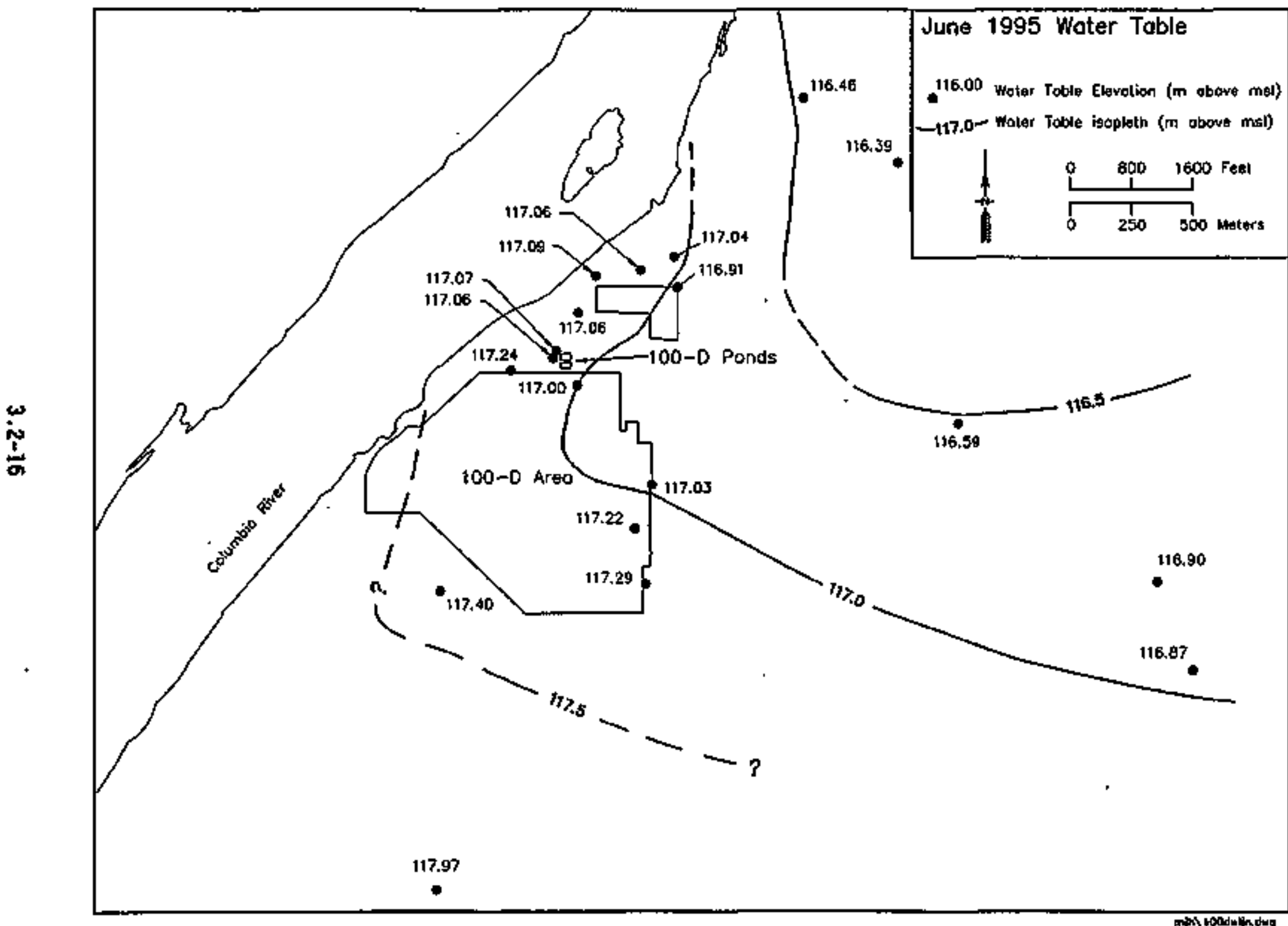

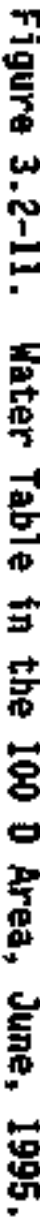


Table 3.2-1. Wells Monitored for Chemistry or Water Levels for the $100 \mathrm{D}$ Ponds. (2 sheats)

\begin{tabular}{|c|c|c|c|c|c|}
\hline Well & Aquifer & $\begin{array}{c}\text { RCRA } \\
\text { sampling } \\
\text { frequency }\end{array}$ & $\begin{array}{l}\text { Water } \\
\text { levels }\end{array}$ & $\begin{array}{c}\text { Well } \\
\text { standards }\end{array}$ & $\begin{array}{c}\text { other } \\
\text { networks }\end{array}$ \\
\hline $199-02-5^{60}$ & Top of unconflned & $=$ & M & PRE & $-m$ \\
\hline $199-02-6^{92}$ & Top of unconfined & $=$ & $\bar{H}$ & RCRA & $100-H R-3$ \\
\hline $199-05-12^{60}$ & Top of unconfined & $\rightarrow$ & $\mathbf{M}$ & PRE & 100-HR-3 \\
\hline $199-05-13^{91}$ & Top of unconftned & $\mathbf{Q}$ & $M$ & RCRA & $100-H R-3$ \\
\hline $199-05-14^{32}$ & Top of unconfined & -+ & $\mathbf{H}$ & RCRA & $\overline{100-H R-3}$ \\
\hline $199-05-15^{92}$ & Top of unconfined & $=$ & 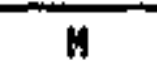 & RCRA & $100-\mathrm{KR}-3$ \\
\hline $199-05-16^{92}$ & Top of unconfined & - & M & RCRA & 100-HR-3 \\
\hline $199-05-17^{92}$ & Top of unconfjned & -- & H & RCRA & $100-H R-3$ \\
\hline $199-05-18^{92}$ & Top of unconfined & $=$ & $M$ & RCRA & $100-h R-3$ \\
\hline $199-05-19^{92}$ & Top of unconfined & $=$ & 4 & RCRA & $100-H R-3$ \\
\hline $199-05-20^{92}$ & Top of unconftined & $=$ & $M$ & RCRA & $100-H R-3$ \\
\hline $199-09-3^{52}$ & Top of unconfined & $=$ & $\bar{N}$ & PRE & $100-H R-3$ \\
\hline $199-08-4^{71}$ & Top of unconfined & \$A & N & RCRA & -- \\
\hline $199-08-5^{91}$ & Top of unconfined & SA & H & RCRA & - \\
\hline $199-08-6^{91}$ & Top of unconfined & SA & H & RCRA & -- \\
\hline $199-08-53^{92}$ & Top of unconfined & -- & H & RCRA & 100-HR-3 \\
\hline $199-09-54 A^{92}$ & Top of unconfined & $=$ & M & RCRA & 100-HR-3 \\
\hline $199-08-548^{92}$ & Top of unconfined & -- & H & RCRA & 100-HR-3 \\
\hline $199-08-55^{72}$ & Shallow confined & - & If & RCRA & $100-H R-3$ \\
\hline $699-87-55^{*}$ & Top of unconfined & -- & $M$ & PRE & -- \\
\hline $699-90-45^{\circ}$ & Top of unconfined & -- & In & PRE & -- \\
\hline $699-91-46 A^{92}$ & Top of unconfined & $\rightarrow$ & H & RCRA & -- \\
\hline $699-92-49^{\circ}$ & Top of unconfined & $m$ & H & PRE & $=$ \\
\hline
\end{tabular}


Table 3.2-1. Wells Monitored for Chemistry or Water Levels for the $100 \mathrm{D}$ Ponds. (2 sheets)

\begin{tabular}{|l|c|c|c|c|c|}
\hline Nel1 & Aquifer & $\begin{array}{c}\text { RCRA } \\
\text { sampling } \\
\text { frequency }\end{array}$ & $\begin{array}{c}\text { Water } \\
\text { levels }\end{array}$ & $\begin{array}{c}\text { Nell } \\
\text { standards }\end{array}$ & $\begin{array}{c}\text { Other } \\
\text { networks }\end{array}$ \\
\hline $699-93-48 A^{92}$ & Top of unconfined & -- & M & RCRA & $100-$ HR-3 \\
\hline $699-96-49^{62}$ & Top of unconfined & -- & M & PRE & -- \\
\hline $699-97-51 A^{4}$ & Top of unconfined & -- & M & PRE & $100-H R-3$ \\
\hline
\end{tabular}

Hotes: Shading denotes upgradient well in sampling network. Superscript following well number denotes the year of installation.

The year of well completion is unknown.

$M=$ frequency on a monthiy basis.

PRE = well was not constructed to RCRA standards.

$\mathbf{Q}=$ frequency on a quarterly basis.

RCRA = well is in compliance with RCRA standards.

$S A=$ frequency on a seqliannual basis.

Tab7e 3.2-2. Constituent L†st for $100 \mathrm{D}$ Ponds.

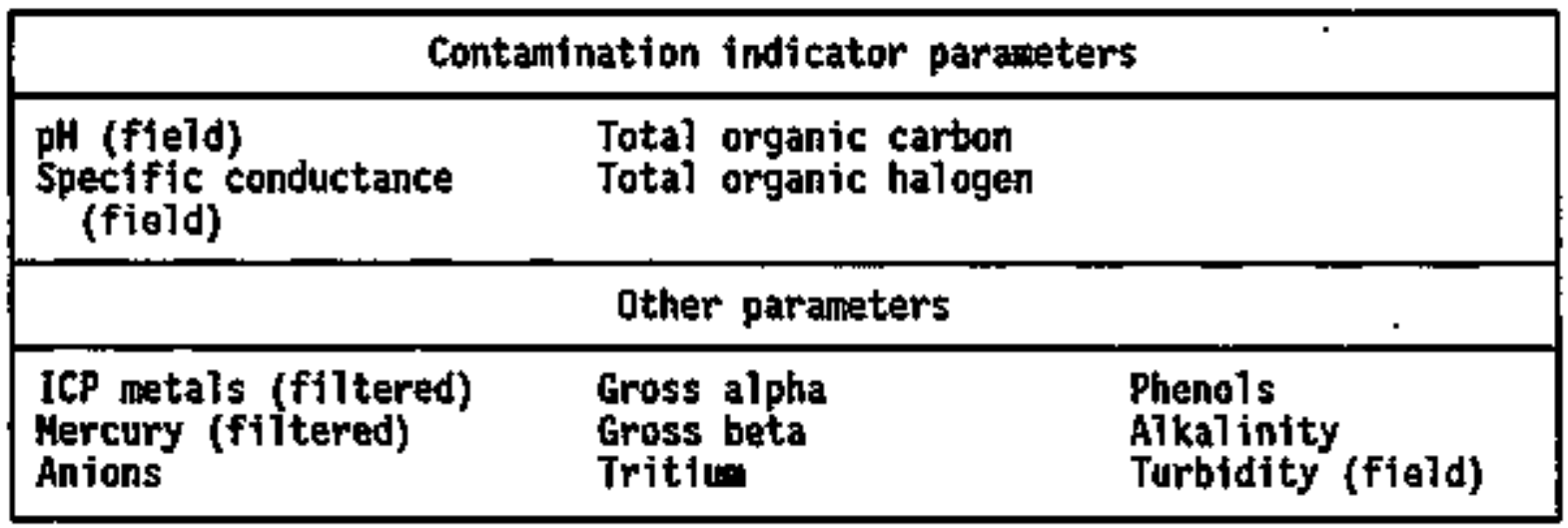


Table 3.2-3, Critical Means Table for 16 Comparisons--Background Contamination Indicator Parameter Data for the 100-0 Pond."

\begin{tabular}{|c|c|c|c|c|c|c|c|}
\hline $\begin{array}{c}\text { Constituent } \\
\text { (Unit) }\end{array}$ & $\pi$ & df & tc & $\begin{array}{c}\text { Average } \\
\text { background }\end{array}$ & $\begin{array}{c}\text { Standard } \\
\text { deviation }\end{array}$ & Critical mean & $\begin{array}{l}\text { Upgradient/ } \\
\text { downgradient } \\
\text { conparison } \\
\text { value }\end{array}$ \\
\hline $\begin{array}{l}\text { Specific } \\
\text { Conductance } \\
\text { ( } \mu \text { mho/cm) }\end{array}$ & 5 & 4 & 8.122 & 275.90 & 48.976 & 711.6 & 711.6 \\
\hline Field pH & 5 & 4 & 9.729 & 8.070 & 0.101 & {$[6.99,9.15]$} & {$[6.99,9.15]$} \\
\hline$T O C^{c}$ (ppb) & 5 & 4 & 8.122 & 500 & A.C. & R.C. & 976 \\
\hline TOX (ppb) & 4 & 3 & 11.984 & 11.7 & 2.697 & 47.8 & 47.8 \\
\hline
\end{tabular}

Data collected from Apri1 1992 to March 1993 for upgradient well 05-13 except for ToX which was collected from June 94 to Harch 95 . Values calculated based on 16 comparisons.

'The following notations are used in this table:

df $=$ degrees of freedom $(n-1)$.

n - number of background replicate averages.

$t_{*}=$ Bonferroni critical t-value for appropriate df and 16 comparisons.

critical mean cannot be calculated due to lack of an estimate of background standard deviation. The upgradient/downgradient comparison value for TOC is the 1ialt of quantitation (see Appendix A).

H. C. - not calculated. 
DOE/RL-96-01, REV. 0

This page intentionally left blank.

$3.2-20$ 


\section{CONTEMS}

3.31 183-H SOLAR EVAPORATION BASIMS $\ldots \ldots \ldots \ldots . \ldots \ldots$

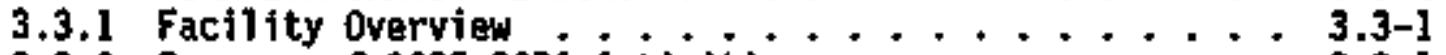

3.3.2 Summary of 1995 RCRA Activities . . . . . . 3.3-1

3.3.3 Other Activities in 1995 ............ 3.3-2

3.3.4 Sampling and Analysis Program ........... 3.3-2

3.3.5 Groundwater themistry ... . . . . . . 3.3-3

3.3.6 Groundwater Flow .......................... 3-4

3.3.7 References . . . . . . . . . . 3.3-6 


\section{LIST OF FIEURES}

3.3-1 Honitoring Nell Locations for the I00-H Area . . . . . . 3.3-9

3.3-2 Generalized Hydrogeology of the 100-h Area . . . . . . . 3.3-10

3.3-3 Gross Alpha and Witrate in Well H4-3 ............. 3.3-11

3.3-4 Gross Alpha and Gross Beta Versus Time

in 183-H Solar Evaporation Basins Plene Wells . . . . . . . 3.3-12

3.3-5 witrate and Sulfate Versus Time in

183-H Solar Evaporation Basins Plune Wells . . . . . . . 3.3-13

3.3-6 Chroniun Versus Time in 183-H Solar

Evaporation Basins Plume Wells ............. 3.3-14

3.3-7 Gross Alpha in the Uppermost Aquifer

Beneath the 100-H Area, June 1995. . . . . . . . . . 3.3-15

3.3-8 Gross Beta in the Uppernost Aquifer

Beneath the 100-H Area, June 1995 . . . . . . . . . . . 3.3-16

3.3-9 Hitrate in the Uppermost Aquifer Beneath

the 100-H Area, June 1995. ................ 3.3-17

3.3-10 Chromium in the Uppermost Aquifer Beneath

the 100-H Area, June 1995. . . . . . . . . . . . . . 3.3-18

3.3-11 Gross Alpha and Gross Beta Versus Time in

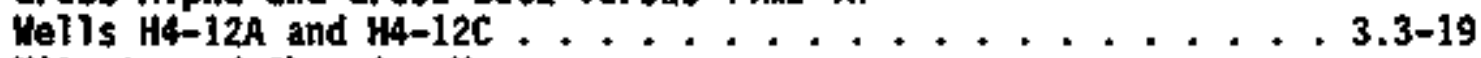

3.3-12 Nitrate and Chromitun Versus

Tine in We11s H4-12A and H4-12C ...............3-20

3.3-13 Uater Jable in the 100-H Area, September 1995. . . . . . . 3.3-21

3.3-14 Water Table in the 100-H Area, June 1995 ...........3-22

\section{LIST OF TABLES}

3.3-I Wonitortng Nelis in 183-H Solar Evaporation Basins Network . . 3.3-23

3.3-2 Constituent List for the 183-H So]ar Evaporation Basins . . . . 3.3-24 
DOE/RL-96-01, REV. 0

\title{
$3.3 \quad 183-H$ SOLAR EVAPORATIOH BASIIS
}

\author{
H. J. Hartman \\ Westinghouse Hanford Company
}

The 183-H Solar Evaporation Basins (183-H Basjns) have been monitored under an interim-status assessment program since 1986 (Ecology and EPA 1986). This report presents resuTts of interim-status groundwater monjtoring during the fourth quarter of 1994 and the first three quarters of 1995.

\subsubsection{Factitity overview}

The 183-H Basins are located beside the Columbia River in the northern portion of the Hanford Site (see Figure 1-1, Figure 3.3-1). The facility comprised four separate concrete basins surrounded by an earthen berm. Each basin measured approximately 16 by $39 \mathrm{~m} \mathrm{(52}$ by $128 \mathrm{ft}$ ). Originally, the concrete basins were part of a water treatrent faciltty that provided coolant water to the 105-H Reactor, which was shut down in 1965. Between 1973 and 1985, the 183-H Basins were used to store liquid waste that resulted primarily from nuclear fuel fabrication activities conducted in the 300 Area. Volute reduction occurred by solar evaporation. The waste was predominantly acidetch solutions that had been neutralized with sodium hydroxide before being discharged into the 183-H Basins (DOE-RL 1991a). The acid solutions included nitric, sulfuric, hydrofluoric, and chromic acids. The waste solutions, described as supersaturated, contained various metal1ic and radloactive constituents (e.g., chromium, uranjum, technetiur).

By the end of 1990, essentjally all of the waste had been removed from the 183-H Basins. The walls of all four bastns have been decontaminated, and the walls from Basins 3 and 4 have been demolished. Decontamination and demolition of the remajning walls and the basin floors are planned for 1996.

The 183-H Basins are located within two operable units regulated under the Comprehensive Environmental Response, Compensation, and Liability Act of 1980 (CERCLA). Operable unit 100-HR-1 adoresses surface sources of contamination and I0O-HR-3 addresses groundwater contamination.

A comprehensive description of 100-H Area stratigraphy is presented by Lindsey (1992, 1993). The uppermost portion of the unconfined aquifer in the 100-H Area resides in cataclysuic flood deposits. The saturated portion of these deposits ranges in thickness from 2 to $6 \mathrm{~m}$ (6 to $18 \mathrm{ft}$ ) (Peterson and Connel1y 1992). It consists of unconsolidated sands and gravels, referred to as the Hanford formation (Figure 3.3-2). An erosional unconformity separates this hydrogealogic unit from the more consolidated fluvial sands and overbank deposits of the underlying Ringold Formation.

\subsubsection{Summary of 1995 RCRA Activities}

Rout the monitoring of groundwater continued during 1995. Three wells directly in the 183-H conta:inant plume were sampled wonthly until Aprit 1995, when they were switched to a quarterly schedule. These wells were sampled monthly to provide mare inforation on groundwater closest to the basins. 
Four wells not directly affected by the plume were sampled once, in June. The remaining wells, includting upgradient wells and wells on the margins of the plume, were sampled quarterly. Water levels were measured quarterly in most of the wells in the 100-ti Area.

Over the past several years, the 183-H groundwater monitoring program was streanlined from what was described in the monitoring plan, which was included in the Closure Plan (DOE 1991). This resulted in the program being out of coapliance with the monitoring plan. The groundwater monitoring program was revised in the spring of 1995 to bring it back into compliance with the monitoring plan. Several wells that had been dropped were added back to the network, and three wells that had been sampled monthly were switched to quarterly. These changes were temporary, because a new, final-status monitoring progran was designed and initiated in September 1995 (Hartman and Chou 1995). The final-status progran includes eight wells sanpled twice per year.

Decontamination and dewolition of the 183-H Basins proceeded in 1995. The concrete walls of the basins were sampled and tested for dangerous and radioactive waste. The walls were decontaminated where waste was found; the walls of Basins 3 and 4 were demolished.

\subsubsection{Other Activities in 1995}

In addition to RCRA groundwater monitoring actlvities, severa] other groundwater investtgations were under way during 1995 in the 100-H Area: Semiannual sampling of selected wells continued under the CERCLA remedial investigation for the 100-HR-3 operable unit.

Pacific Northwest. National Laboratory completed characterization activities at a field test site in the 100-H Area. Sixteen wells were installed within the uppermost unconfined aquifer beneath the test site. Characterization activtties focused on sediment physical properties, geochemical properties, microbiologic population data, and aquifer hydraulic properties (Vermeul et al. 1995).

Approximately 40 gallons of oil leaked from a backhoe hydraulic system into a shallow pit ("claarweli") adjacent to the 183-H Basins in June 1995 . The ERC sampled wells near the spill in July; no hydrocarbons were detected. The wells were sampled again in December 1995; results were not available at the time of this writing.

\subsubsection{Sampling and halysis Program}

The initfal interim-status RCRA groundwater monitoring plan for the 183-H Basins was prepared by the Pacfiftc Horthwest Nattonal Laboratory (PHL 1986). A revised program was described in the Closure P1an (DOE 1991). That program had been revised in practice in recent years by dropping some wells that were not in the flow path beneath the bastns. However, in early 1995 those wells were added back to the network until the monitoring pian could be formally revised. 
The 183-H Basins are included in the Hanford Facility RCRA Permit and are now subject to final-status regulations (Ecology 1994). A new, final-status monitoring plan was released in 1995 (Hartman and Chou, 1995). Honftoring under the new plan began in September. This annual report wilt focus on the interim-status program that was in place for 11 months of the past year.

Twenty-three groundwater monjtoring weITs were monitored for RCRA in FY95 (Table 3.3-1). Many are fointly used by other programs, including the 100-h:-3 remediat investigation and the Sitewide Environmental Surveillance progran.

The sampling schedule for the past year included quarterly sampling of weils that are used to define the extent of contanination and upgradient conditions. Honthly sampling was conducted in selected wells located in wediately downgradjent of the 183-H Basins until Apri1 1995, when they were switched to a quarterly schedule. Quarterly sampling is sufficient to meet the objectives of the monitoring program. Annual sampling of wells in the vicinity of, but not directly in the flowpath under the 183-H Basins, was conducted to provide 100-H Area basetine data. The constituent 1 ist is sumbarized in Tabie 3.3-2.

Water levels were measured quarterly with a steel tape. Water levels also were recorded before each we? water levels in the river and in severa] wells monftored under the CERCLA progran. The data from these efforts are used to help explain the tempora] variability observed in 100-H Area groundwater quality, particulariy in wells near the river. They can aTso be usefu] in helping to deteratne the transport of contaminants in groundwater toward the river.

Water lever and chenistry data for the past year were presented in quarterly reports (Hartman 1995b, 1995c, 1995d, 1996).

\subsubsection{Groundwater Chenistry}

The primary constituents of concern in groundwater downgradient of the 183-H basins are nitrate, chroniun, uranitum, and ${ }^{90} \mathrm{Tc}$ (Hartman and Chou 1995). Sulfate and sodium are aj 50 elevated in groundwater, but are not dangerous or radloactfve contaninants. Gross alpha and gross beta activitfes are monitored as indicators of turanium and technetium, respectively.

3.3.5.1 Concentratton Historios of Waste Indicators. Concentrations of waste constituents in groundwater have generally declined in the past 10 years, with several exceptions. Figure 3.3-3 illustrates the trends for gross alpha and nitrate in well H4-3 ${ }^{1}$. During the last half of 1990 and first half of 1991 , the sampling and analysis progran was tnterrupted by analytical laboratory problens. When sampting resumed, concentratjons of waste indicators in wells within the contaminant piume were higher than the previously established trends. The cause for this may have been an atypically high water table during that period (Peterson 1993).

We11 numbers in this section are abbreviated by dripping the 199prefix, e.g., weit 199-H4-3 is uritten H4-3. 
Concentrations of 183-H waste constituents increased in sore wells in 1993 and remained elevated in 1994 . Figures 3.3-4 through 3.3-6 t]1ustrate the trend for gross alpha, gross beta, nitrate, sulfate, and chromium in wells H4-3, H4-4, and H4-12, which lie directly in the 183-H contaminant plune. The increases in concentration were most notjceable in well $\mathrm{H4-3}$, which is adjacent to the 183-H Basins on the downgradient side. Gross a]pha and chronium declined in 1995. Gross beta, nitrate, and sulfate remained elevated in 1995 and showed large seasonal fluctuations.

3.3.5.2 Distribution of laste constituents. The 183-H Basins have contaminated groundwater between the basins and the river. Maps showing the concentrations of gross alpha, gross beta, nitrate, and chromium for June 1995 are presented in Figures 3.3-7 through 3.3-10. The river stage was high in June, and contaminants were diluted jn wells near the river. When the river stage is lower, the contaminant plume from 183-H extends in a narrow band from the basins straight eastward to the river (Hartman I995a).

No conclusive evidence of dowmward migration of 183-H Bastins waste const ttuents has been found. Well H4-12A is screened at the water table. Adjacent weIl H4-12C is screened at mid-depti in the Ringold formation. Waste constituents in the two wells are plotted in Figures 3.3-11 and 3.3-12. Gross a]pha, gross beta, and nitrate are low in the deeper well. Chromiun is the only 183-H waste indicator elevated in well H4-12C. The source of the chromium is unknown.

\subsubsection{Groundwater Flow}

3.3.6.1 Groundwater Flow Birection. Groundwater in the 100-H Area flows toward the river, as inferred from plume configurations and the average water tabie. Figure 3.3-13 is a water table map of the 100-H Area constructed fros September 1995. The contours indicate that flow is toward the east-northeast beneath the 183-H Basins, approximately perpendicular to the river channe1. The shape of the gross alpha and gross beta plumes (Hartman 1995a) indicates that these constituents have migrated toward the east from the 183-H Basins.

Daily, week]y, and seasonal river level changes affect water levels and fTow patterns in the 100-H Area. Seasonally high river levels temporarity reverse the hydraulic gradient near the river. Figure 3.3-14 shows the water table in June 1995 when the river stage was high. Hater apparently flowed from the river fato the aquifer during that tite (see Section 3.3.5). When the river level falls, the river water stored in the bank flows back towards the river, and groundwater resumes its flow towards the river under a more typical gradient.

Hell pairs such as H4-12A and H4-12B indicate that the vertical gradient within the uppermost unconfined aguifer svstem is generally upward, aithough the direction can be reversed at the shaliowest levels in response to changes in river stage. At mid-depths in the Ringold Formation, the potential for flow is upward, as indicated by data from well H4-15CR. Vertical fiow frow the confined aquifers near the base of the Ringold Formation and upper Columbia River basalt units is upward. Evidence for this comes from flowing wel]s H4-2 and H4-15CP, both of which are completed in the uppermost basalt aquifer. 
3.3.6.2 Rate of Flow. The rate of migration of waste constituents has been estimated using the following wethods: numerical flow models, analyzing time delays in the downgradient migration of waste indicator "pulses, " directly measuring speed and direction using an instrument lowered into a weil, and calculations using the Darcy equation. A representative range of estinates is 0.3 to $3 \mathrm{~m} / \mathrm{d}$ (1 to $10 \mathrm{ft} / \mathrm{d}$ ).

Computer modeling based on an initial, Timited water level data set indicated an average velocity of $0.31 \mathrm{~m} / \mathrm{d}(1.0 \mathrm{ft} / \mathrm{d}$ ) (Liikala et al. 1988). An estimate based on the migration of a single nitrate pulse suggested a value of $0.6 \mathrm{v} / \mathrm{d}$ (2 ft/d) (Hall 1989). Analysis of the migration rate of nitrate pulses in two pairs of wells downgradient from 183-H Basins over a 3-year interval suggested rates of 2.56 to $4.82 \mathrm{~m} / \mathrm{d}(8.4$ to $15.8 \mathrm{ft} / \mathrm{d})$ (Peterson 1992). Nitrate travels at essentiatiy the sane rate as groundwater flow because that constituent is not sorbed onto sedinents or reduced appreciab]y by chemical reactions.

Three devices designed to measure groundwater flow velocjty directiy have been used in the 100-H Area: the In Situ Permeable Flow Sensor (a permanently installed device), the Colloidal Borescope, and the K-V Associates Geoflow Heter. The in sjtu flow sensor djd not produce meaningful results near the 183-H Basins. Results of the colloidal borescope and the $K-V$ flow meter are stumartzed in Table 3.3-3. Results indicate that local flow directions are quite varlable. Many measurements indicate a more northward flow than expected based on the water table map and plume configuration. Flow rates ranged from 0.65 to $4.92 \mathrm{~m} / \mathrm{d}(2.1$ to $16.1 \mathrm{ft} / \mathrm{d})$.

The horizontal hydraulic gradient was calculated between wells H3-2A and H4-12A using data from September 1995:

difference in head: $0.83 \mathrm{~m}(2.7 \mathrm{ft})$

hortzontal distance: $417 \mathrm{~m}(1370 \mathrm{ft})$

gradient: $2.0 \times 10^{-3}$.

The rate of groundwater flow can be estimated by using a form of the Darcy equation with a range of input parameters.

$$
v=\frac{K i}{n_{e}}
$$

where:

$$
\begin{aligned}
& v=\text { Average linear velocjty of groundwater } \\
& K=\text { Horizontal hydraulic conductivity } \\
& i=\text { Hydraulic gradient } \\
& n_{e}=\text { Effective porosity of the aquifer. }
\end{aligned}
$$

The following inpat parameters were used:

$$
\begin{aligned}
K & =15 \text { to } 130 \mathrm{~m} / \mathrm{d}(50 \text { to } 430 \mathrm{ft} / \mathrm{d}) \text { (PNL } 1987 \text { and Liikala et a1. 1988) } \\
i & =2 \times 10^{-3} \\
n_{-} & =0.1 \text { to } 0.3 .
\end{aligned}
$$


The resulting estimate of groundwater velocity ranges from 0.1 to $2.6 \mathrm{~m} / \mathrm{d}$ ( 0.3 to $9 \mathrm{ft} / \mathrm{d}$ ), which is in general agreement with the estimates discussed eariter.

3.3.6.3 Evaluation of lionftoring Hetwork. A final-status groundwater monitoring program was designed and implemented in September 1995 (Hartman and Chou, 1995). The network includes six downradient wells and two upgradient wells (see Table 3.3-1). These wells wilt be monjtored for ${ }^{\circ}$ Tc, urantum, chromium, and nitrate.

A pump-and-treat system for chromium is being planned for the 100-HR-3 Operable Unit. Pumping walls will be located in the most concentrated part of the chromium plume, which is doungradient of the 183-H Basins. The system will change groundwater flor and chesistry and the RCRA network will probably no longer be adequate. A new approach to monitoring will be deveToped in the future.

\subsubsection{References}

40 CFR 265, "Interim Status Standards for Owners and Operators of Hazardous Waste Treatment, Storage, and Disposal Fac1lities," Code of Federa] Regulations, as amended.

Comprehensive Environmental Response, Compensation, and liability Act of 1980 , 42 USC 9601 et seq.

DOE-RL, 1991, Ia3-H Solar Evaporation Basins Closure/Post-Closure Plan, DOE/RL 88-04, Rev. 3 (page changes only), U.S. Departwent of Energy, Richland Fleld office, Richland, Washington.

Ecology and EPA, 1986, Consent Agreement and Compliance Order, Ecology No. DE 86-133, Washington State Department of Ecology and the U.S. Environmental Protection Agency, Olympia, Washjington.

Ecology, 1994, Dangerous Waste Portion of the Resource Conservation and Recovery Act Peroit for the Treatment, Storage, and Disposal of Dangerous Waste, Permit Mo. WA7990008967, effective September 28, 1994, Washington State Department of Ecology, 0iympia, Washington.

Hal1, S. H., 1989, Evaluation of the Groundwater Contaminant plome Extending from the 123-H Solar Evaporation Basins, PNL-7130, Pacifjc Northwest Laboratory, Richl and, Washington.

Hartman, M. J., 1995a, "183-H Bastns," in Annual Report for RCRA Groundwater Nonitoring Projects at Hanford Site Facilities for 1994, DOE/RL-94-136, Rev. 0, U.5. Department of Energy, Richland, Washington.

Hartman, M. J., 1995b, "183-H Basins," in Quarterly Report of ACRA Groundwater Honitoring Data for Period October 1, 1994 through December 31, 1994, DOE/RL-94-36-4, U.S. Department of Energy, Richland Operations Office, Richland, Hashington. 
Hartman, M. J., 1995C, "183-H Basins," in Quarter7y Report of RCRA Groundwater Honitoring Data for Period January 1, 1995 through Warch 31, 1995 , DOE/RL-95-69-1, U.S. Department of Energy, Rjchl and Operations Office, Richiand, Wastington.

Hartman, M.J., 1995d, "183-H Basins," in Quarterly Report of RCRA Groundwater Nonitoring Data for Poriod Apri] I, 1995 through June 30, 1995, DOE/RL-95-69-2, U.S. Department of Energy, Richland Operations Office, Richland, Washington.

Hartman, M. J., 1996, "183-H Basins," in Guarterly Report of RCRA Groundwater Nonftoring Data for Period July 1, 1995 through Septemer 30, 1995 , DOE/RL-95-69-3, U.S. Department of Energy, Richland Operattons Office, Richland, Hashington.

Hartman, M. J., and C. J. Chou, 1995, Groundwater Nonitoring P7an for the 183-H Solar Evaporation Basins, WHC-SD-EN-AP-180, Rev. 0, Hestinghouse Hanford Company, Richland, Washington.

Li ikala, T. L., R. 1. Aaberg, N. J. Aimo, D. J. Bates, T. J. Gilmore, E. J. Jensen, G. V. Last, P. L. Oberlander, K. B. OIsen, K. R. Oster, L. R. Roome, J. C. Siapson, S. S. Teel, and E. J. Westergard, 1988, Geohydrologic Characterization of the Area Surrounding the I83-H Solar Evaporation Basins, PNL-6728, Pacific Northwest Laboratory, Rfehland, Washington.

Lindberg, J. W., D. B. 8arnett, and J. A. Coates, 1995, "Oirect Measurement of Groundwater Velocity and Direction at the Hanford Site," presented at The Ist Symosium on the Hydrogeology of Washington State, August 28-30, I9g5, olymia, Washington.

Lindsey, K. A., 1992, Geology of the Northern Part of the Hanford Site: An Outline of Data Sources and the Geologic Setting of the 100 Areas, WHC-SD-EN-TI-011, Rev. 0, Westinghouse Hanford Company, Richt and, Washington.

Lindsey, K. A., 1993, Geologic Setting of the 100-HR-3 Operable Unit, Hanford Sfte, South-Central Washington, WiC-SD-EN-TI-132, Rev. 0, Westinghouse Hanford Company, Richland, Washington.

Peterson, R. E., 1992, "183-H Solar Evaporation Basins," in Annual Report for RCRA Groundwater Monitoring Projects at Hanford Site Facflities for 1991, DOE/RL-92-03, U.S. Department of Energy, Richland Fteld Office, Richland, Washington, pp. 3-1 to 3-21.

Peterson, R. E., and H. P. Connelly, I992, Characterization of a Chromiun Pluive in Groundwater Along the Columbia River Shoreline, Hanford Site, Washington, WHC-SA-1674-VA, Westinghouse Hanford Company, Richland, Washington.

Peterson, R. E. , 1994, "183-H Solar Evaporation Basins," in Annual Report for RCRA Groundwater Honitoring Projects at Hanford Site Facilities for 1993, DOE/RL-93-88, Rev. 0, U.5. Department of Energy, Richland Operations

- Office, Richiand, Washington. 
PUL, 1986, Revised Groundwater Monftoring Conpliance PJan for the 183-H Solar Evaporation Basins, PHL-6470, Pacific Northwest Laboratory, Richland, Washington.

PNL, 1987, Interfin Characterization Report for the Area Surrounding the 183-H Basins, PNL-6471, Pactfic Morthwest Laboratory, Richland, Washington.

Resource Conservation and Recovery Act of 1976, 42 USC 6901 et seq.

Vermeue I, V. R., S. S. Teel, J. E. Anonette, C. R. Cole, J. S. Fruchter, Y. A. Gorby, F. A. Spane, J. E. Szecsody, H. O. Willjans, and S. B. Yabusaki, 1995, Geologic, Geochemical, Hicrobiologic, and Hydrologic Characterization at the In Situ Redox Hanipulation Test Site, PNL-10633, Pacific Morthwest Laboratory, Richland, Washington. 
Figure 3.3-1. Monitoring Well Locations for the 100-H Area.

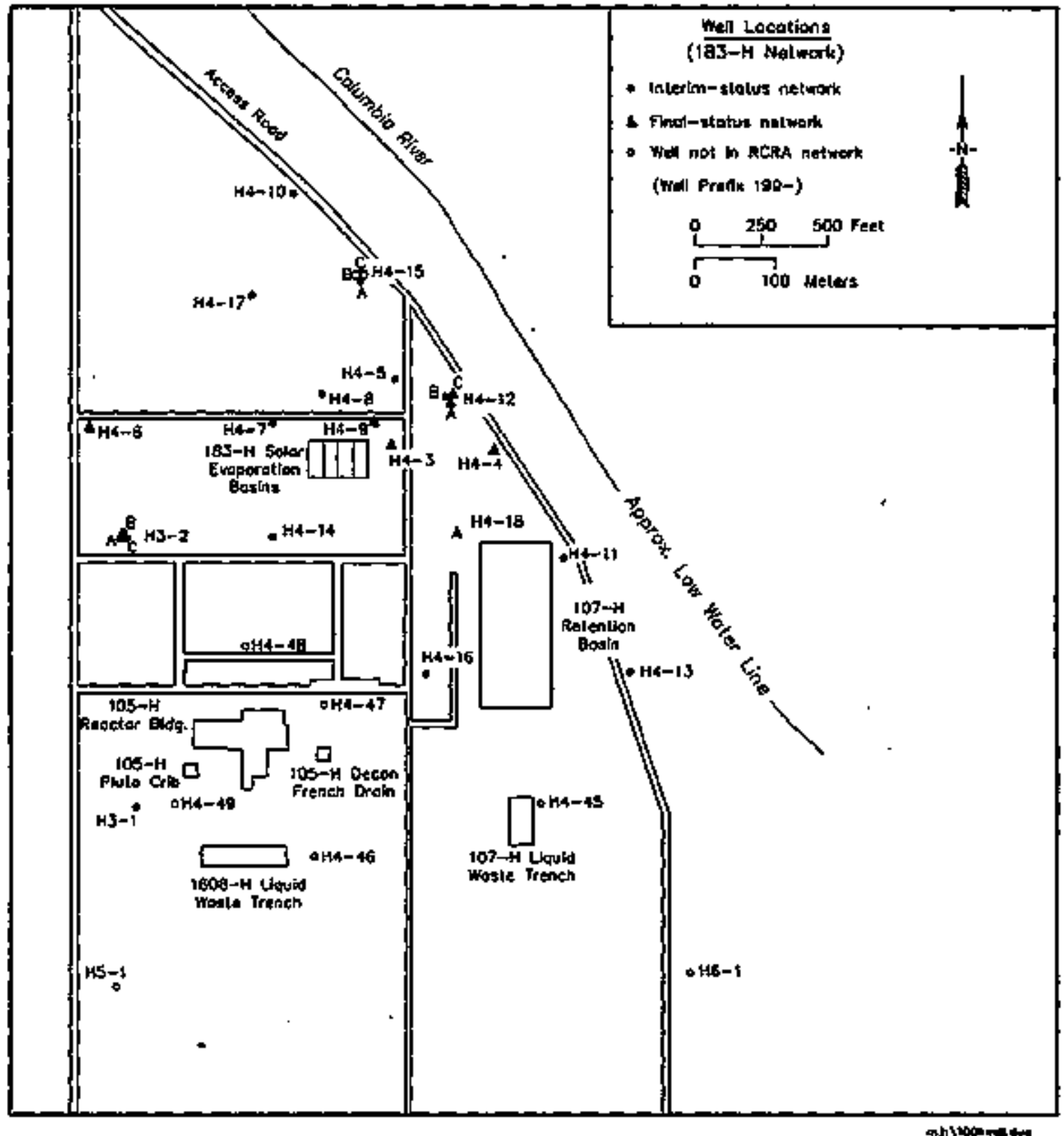


Figure 3.3-2. Generalized Hydrogeology of the 100-H Area (Lindsey 1993).

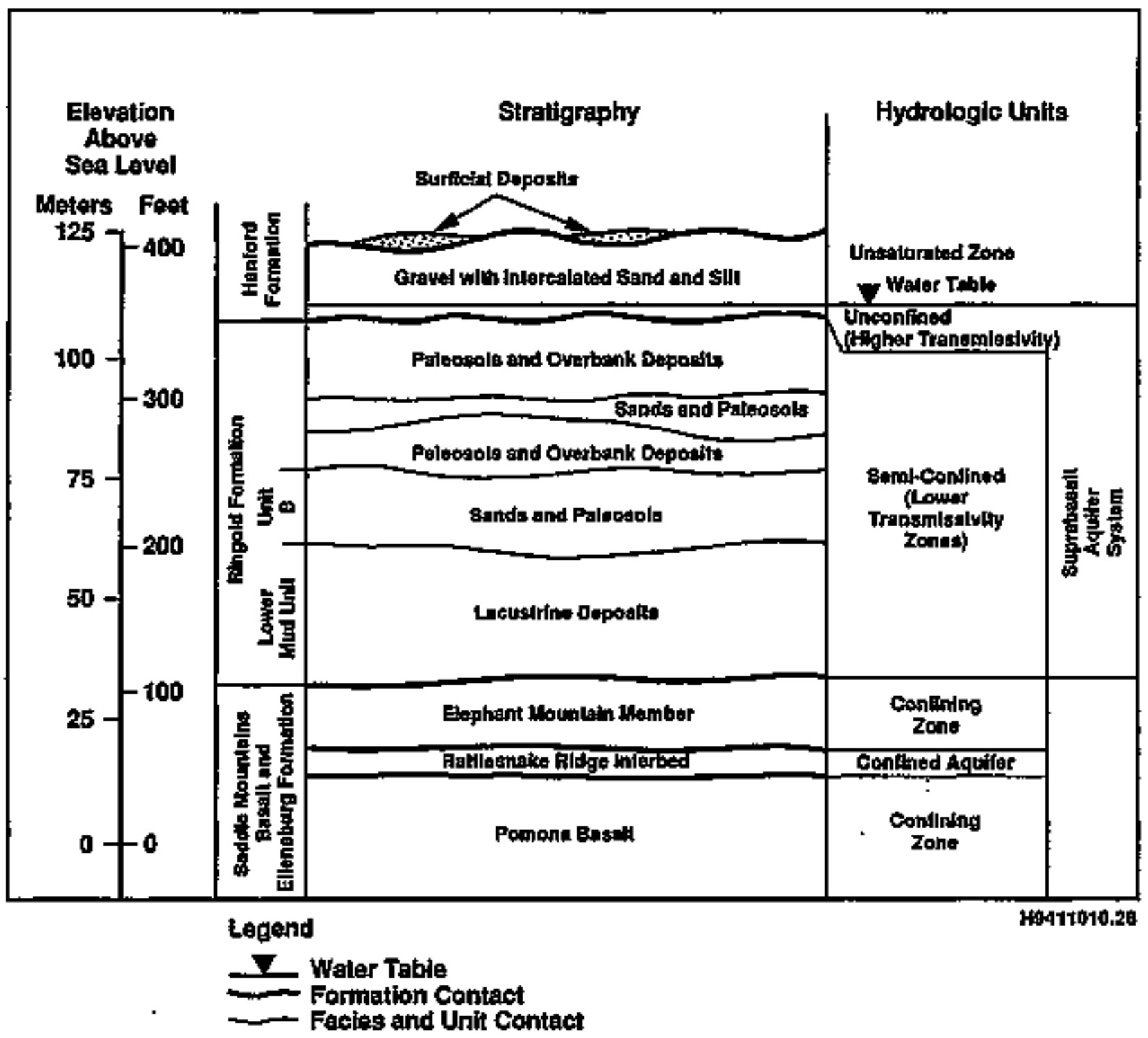


DOE/RL-96-01, REY. 0

Figure 3.3-3. Gross Alpha and Hitrate in Mell H4-3.
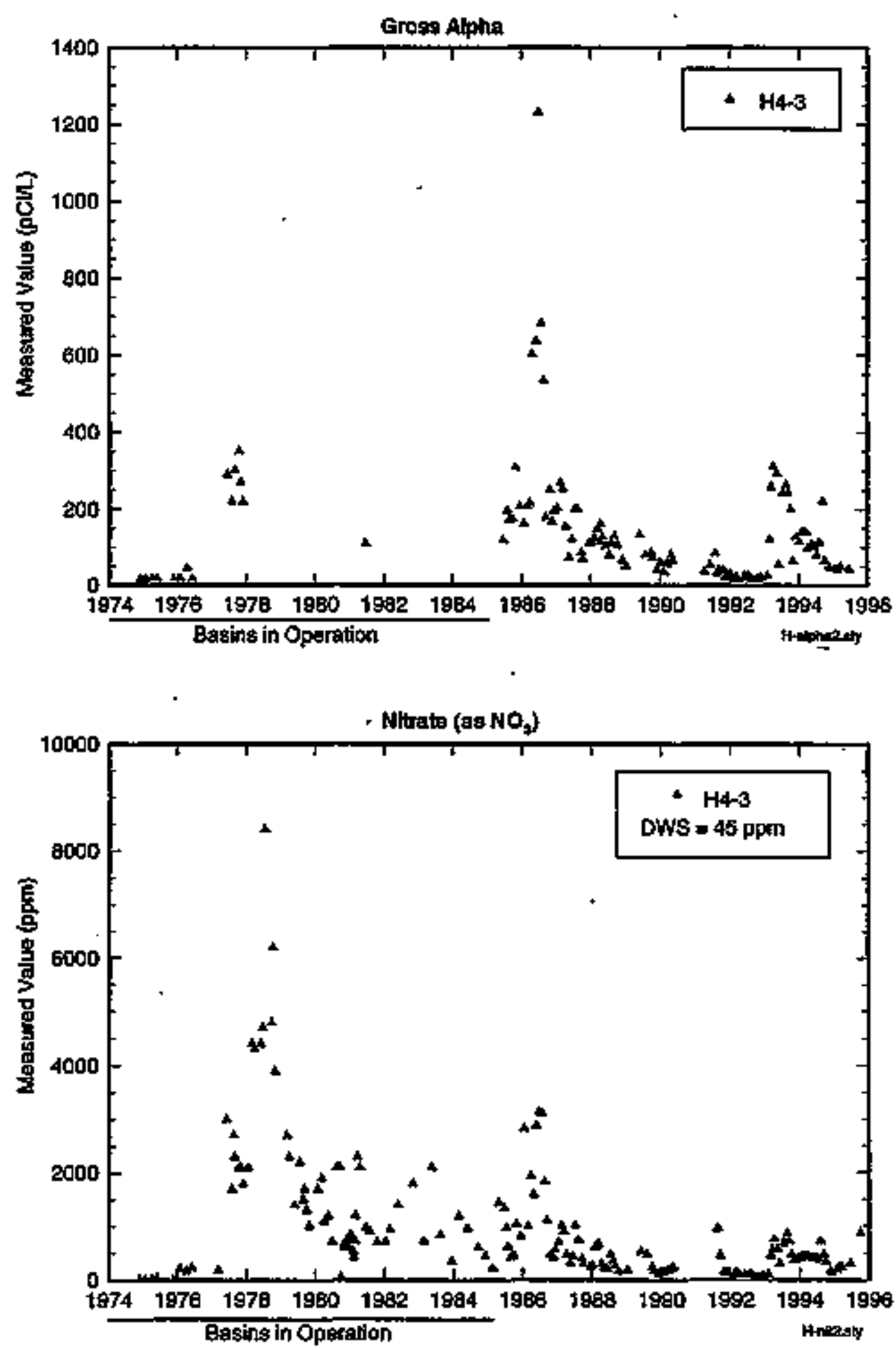
DOE/RL-96-0l, REY. O

F1gure 3.3-4. Gross Alpha and Gross Beta Versus Time in 183-H Solar Evaporation Basins Plume Welis.
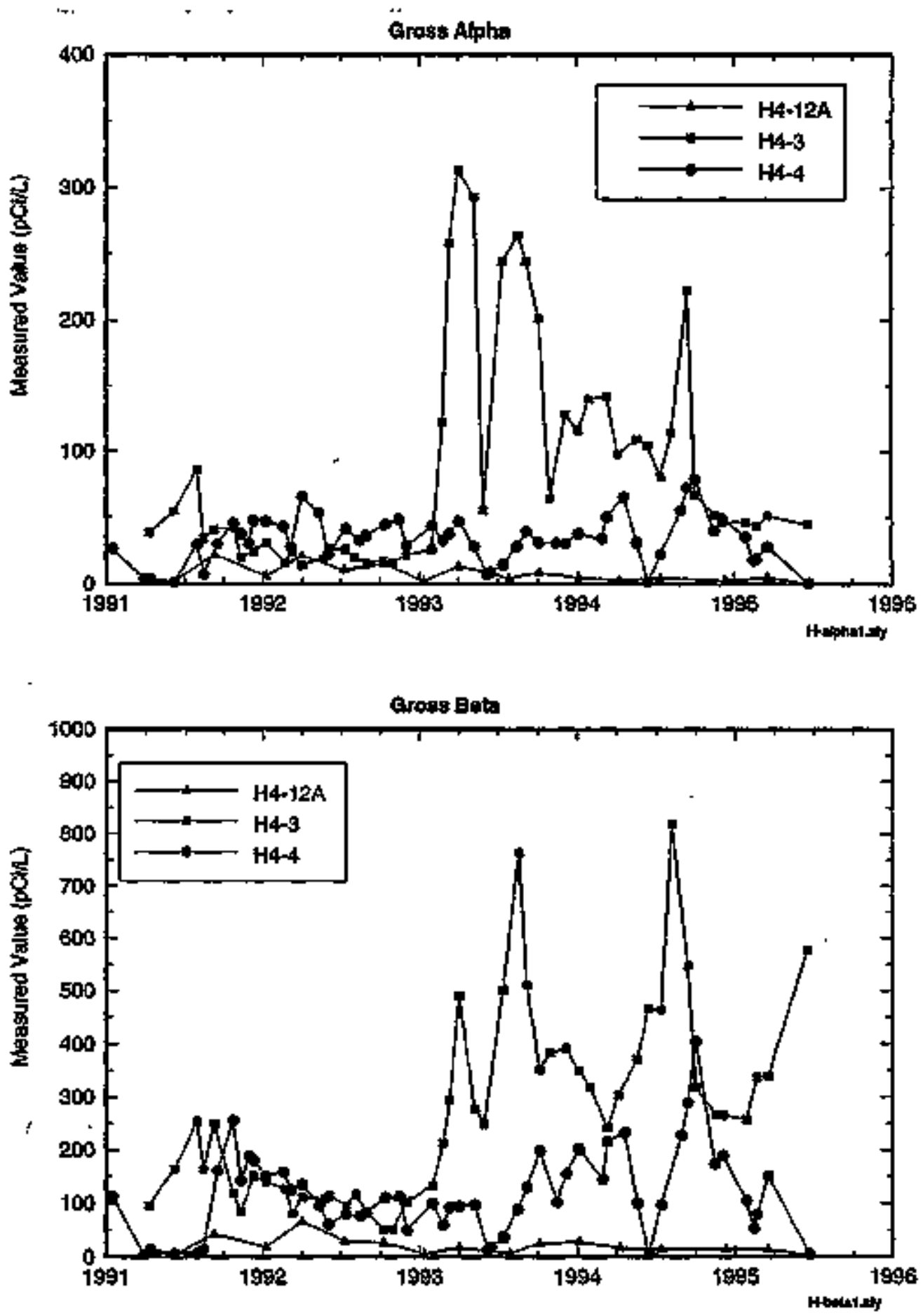

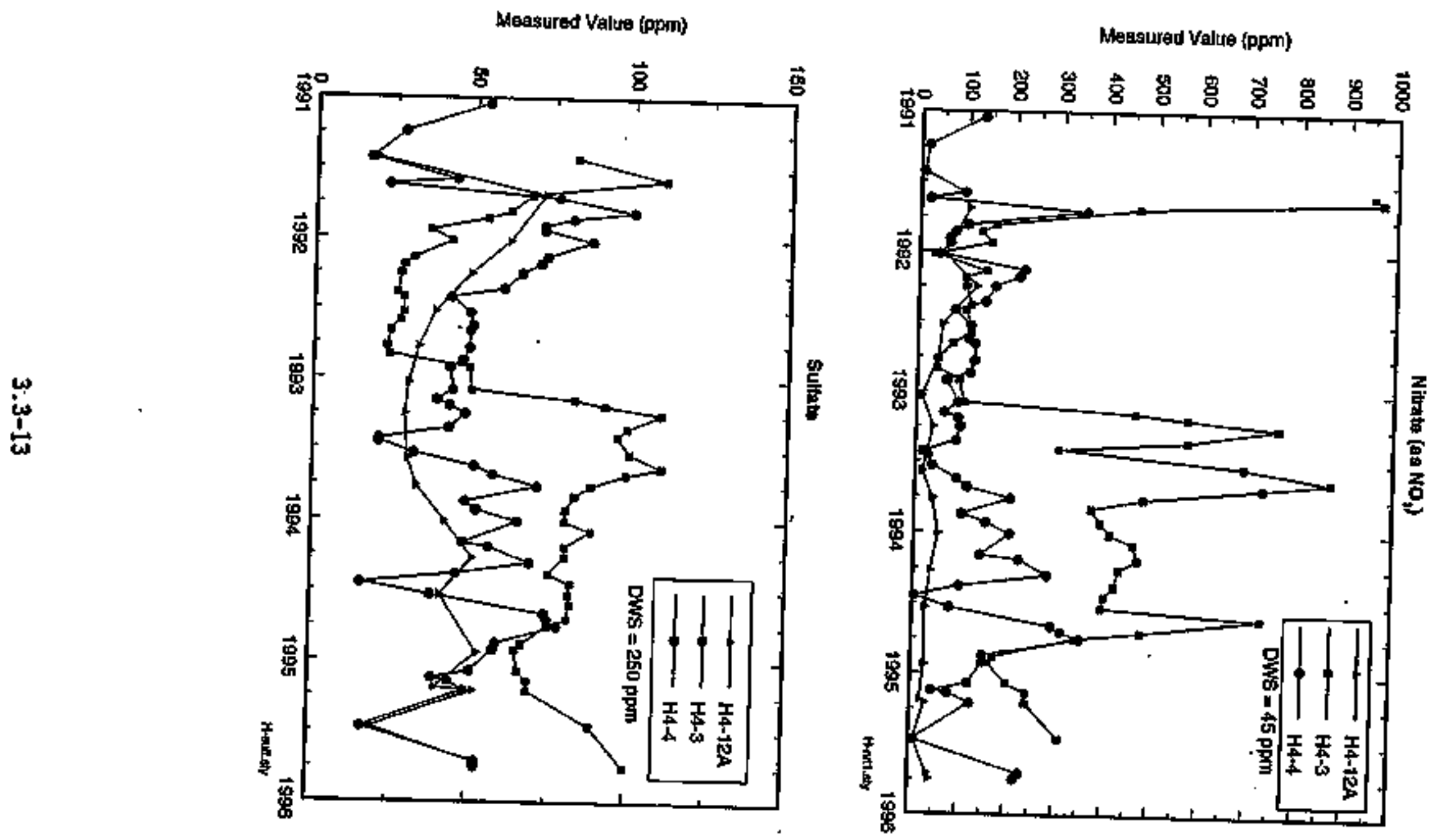

若

览

‥

$m=$

. 号

용

20

ت.

을

四

焉蛋

0

寻点

点

焉焉

ᄏ 
DOE/RL-96-01, REV. O

Figure 3.3-6. Chromium Yersus Time in 183-H Solar Evaporation Basins Plune Wells.

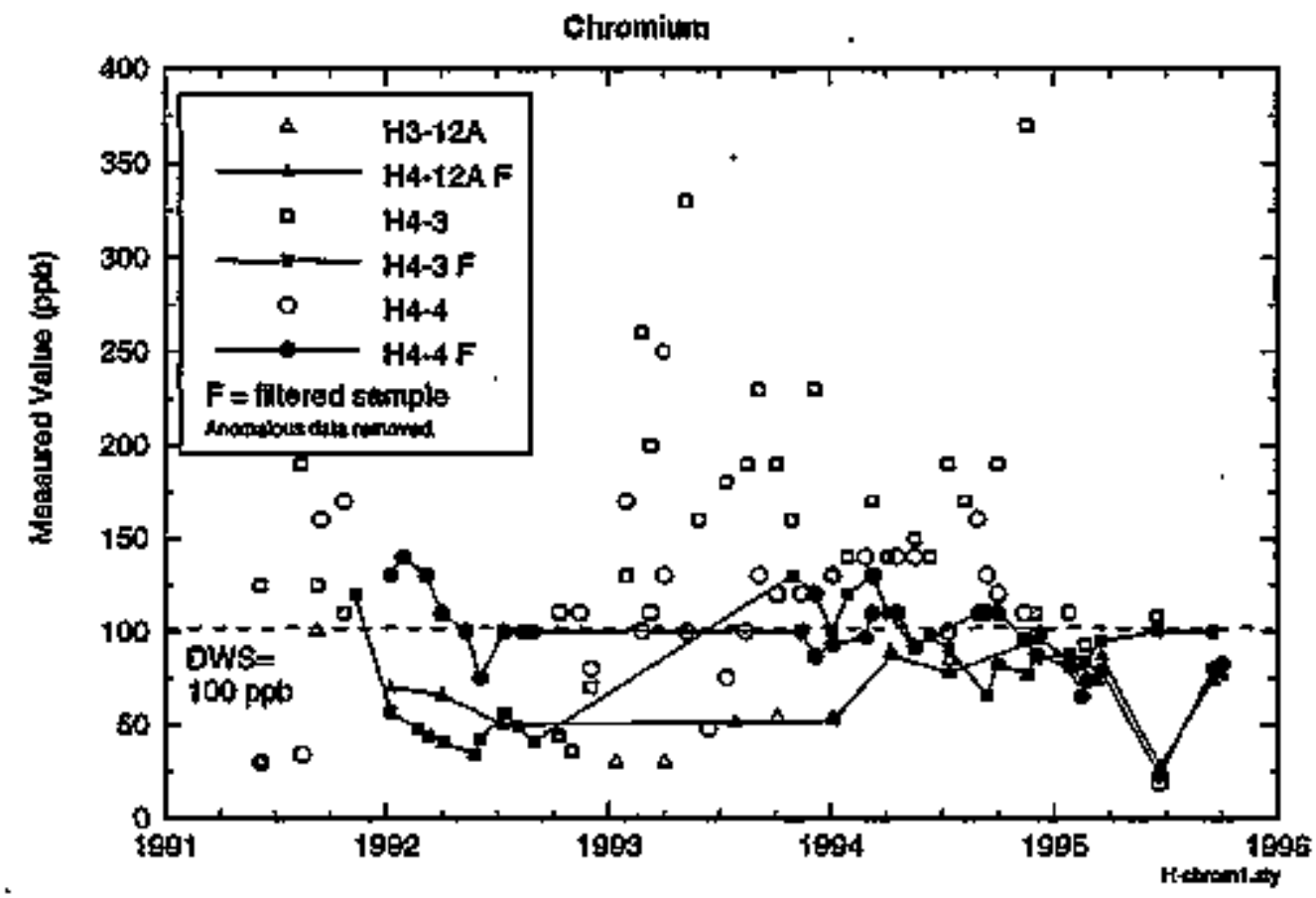


Figure 3.3-7. Gross Alpha in the Uppernost Aquifer Beneath the 100-H Area, June 1995.

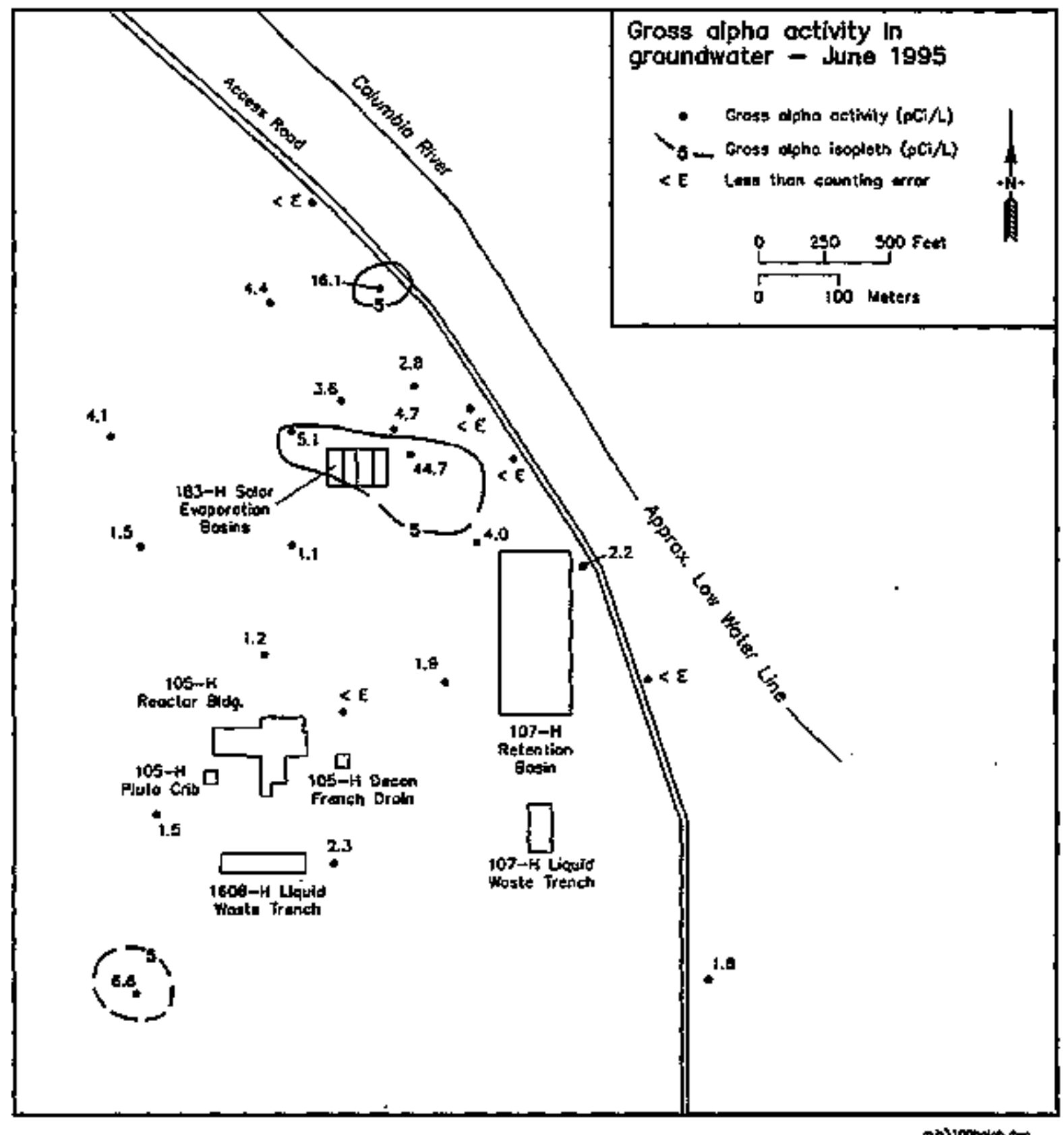


Figure 3.3-8. Gross Beta in the Uppermost Aquifer Beneath the 100-H Arsa, June 1995.

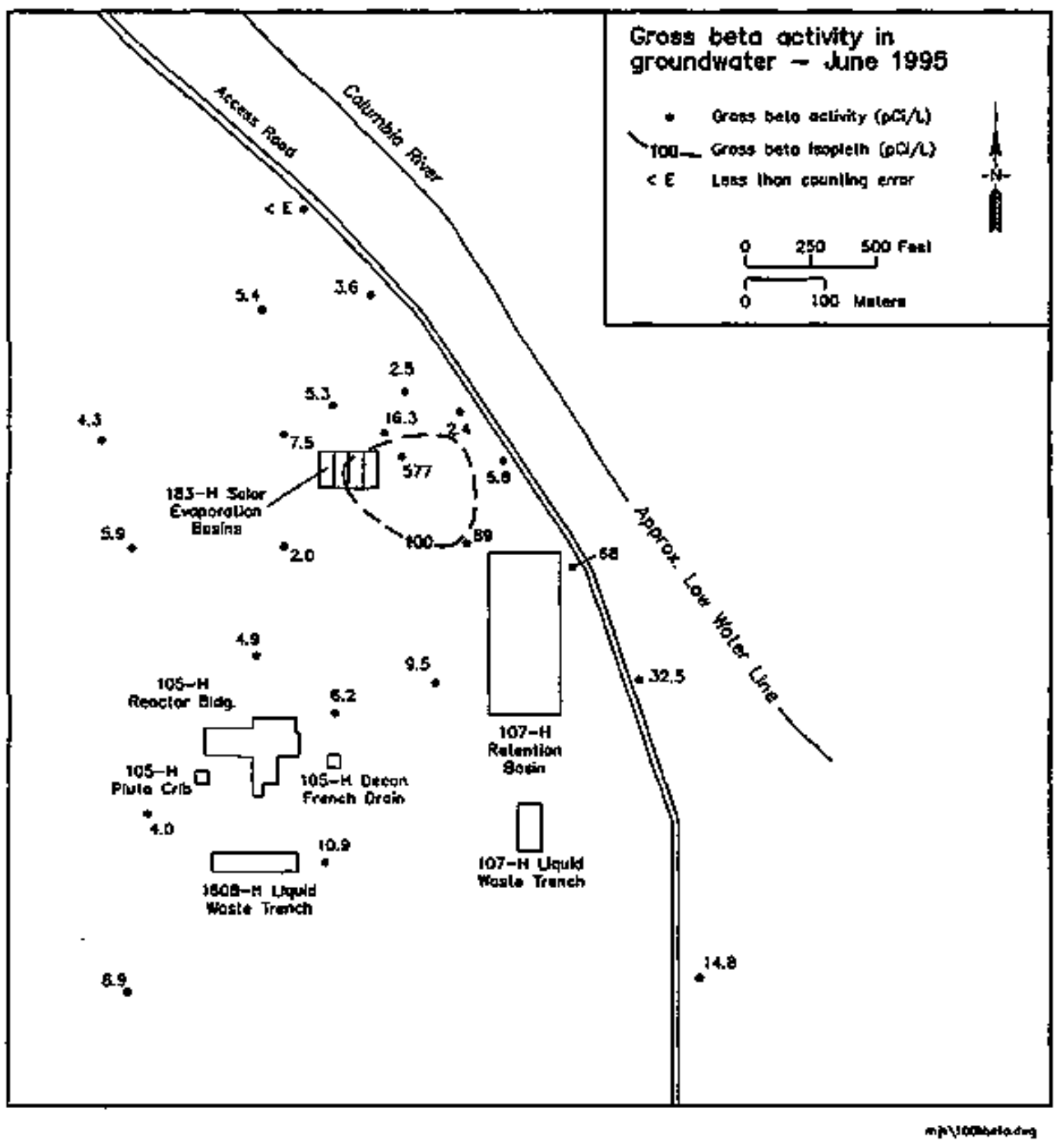


Figure 3.3-9. Nitrate in the Uppermost Aquifer Beneath the 100-H Area, June 1995.

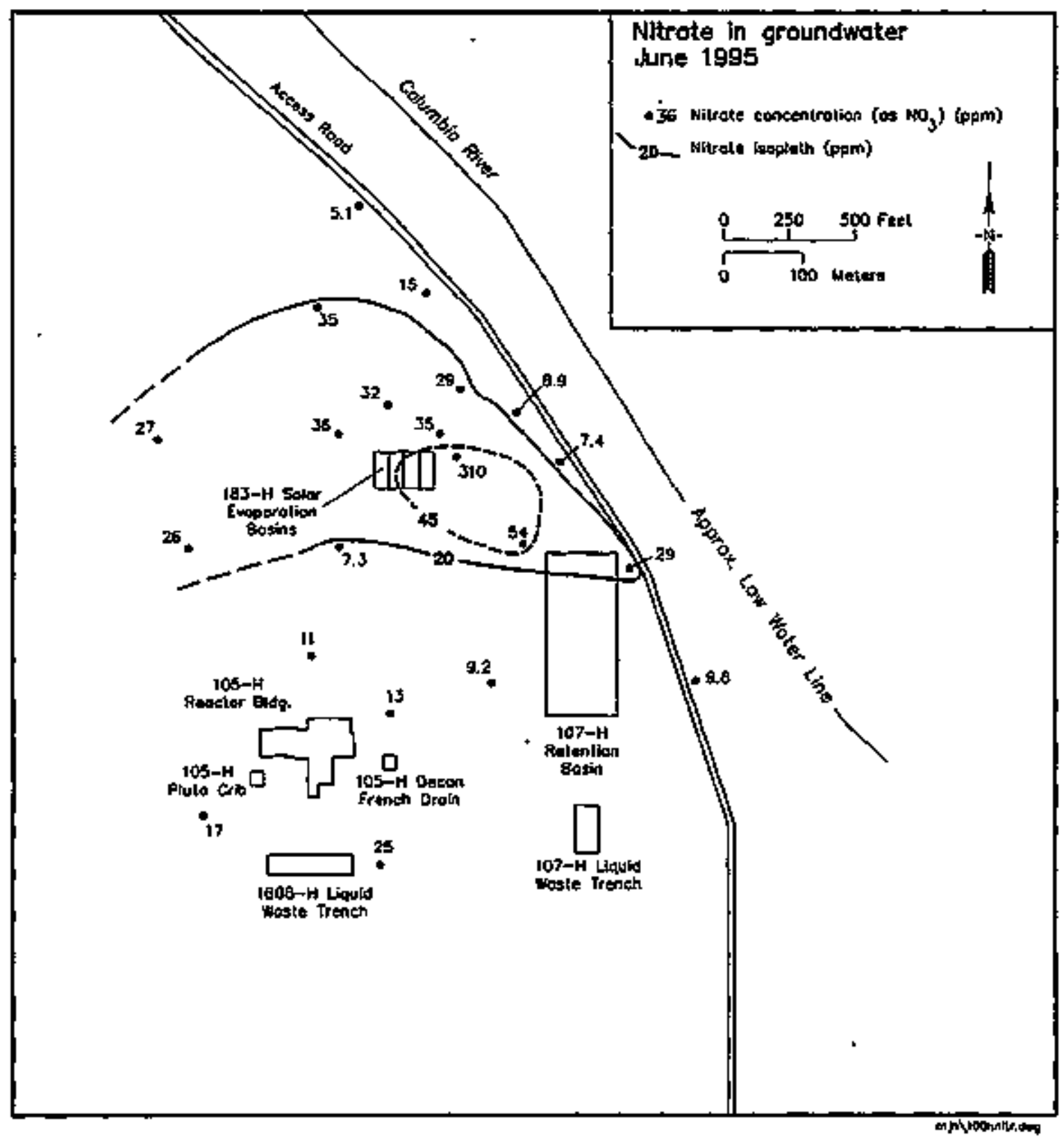


Figure 3.3-10. Chromiun in the Uppermost Aquifer Beneath the 100-H Area, June 1995.

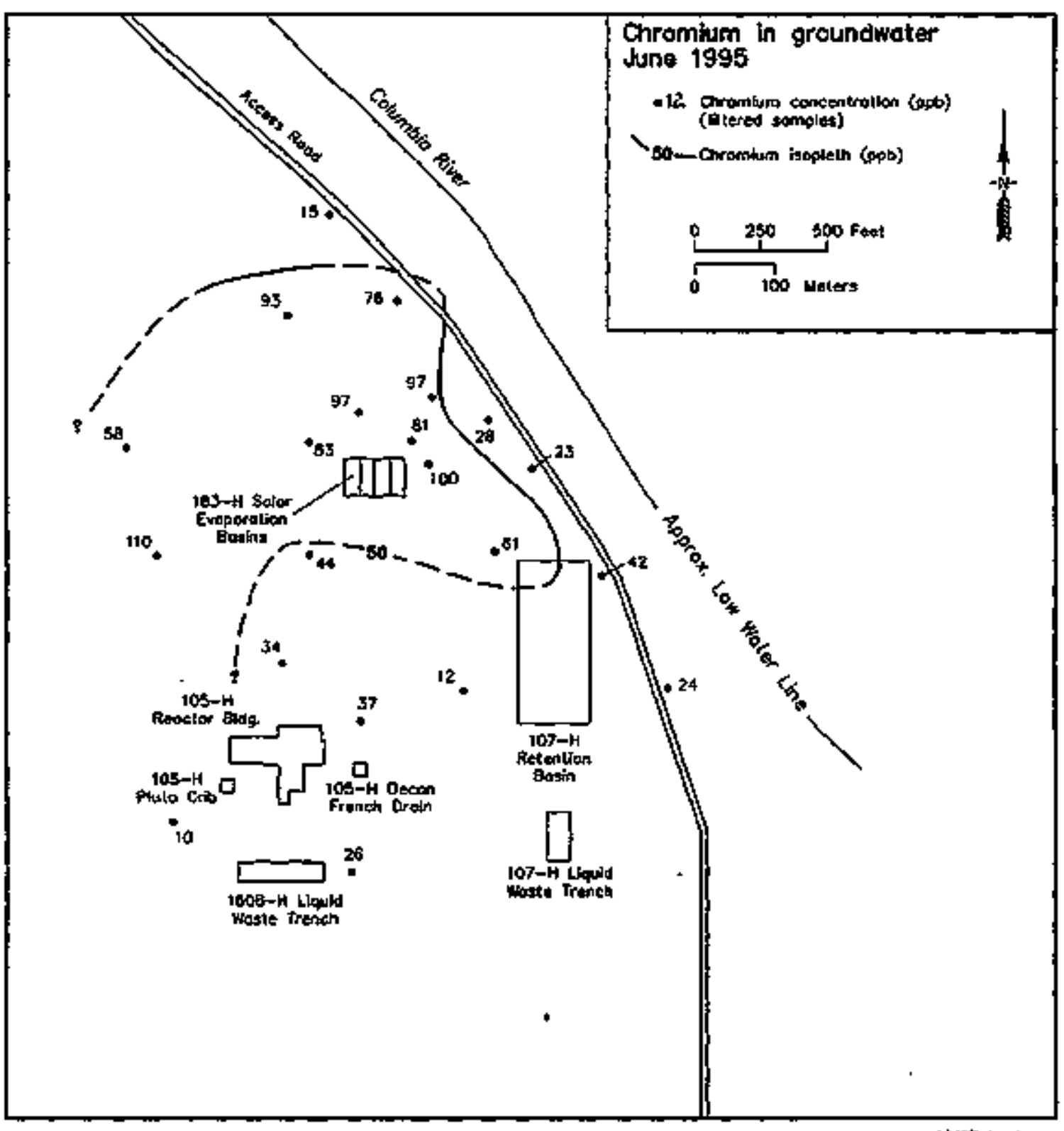


DOE/RL-96-01, PEV. O

Figure 3.3-11. Gross A7pha and Gross Bata Versus Tima in We11s $\mathrm{H} 4-12 \mathrm{~A}$ and H4-12C.
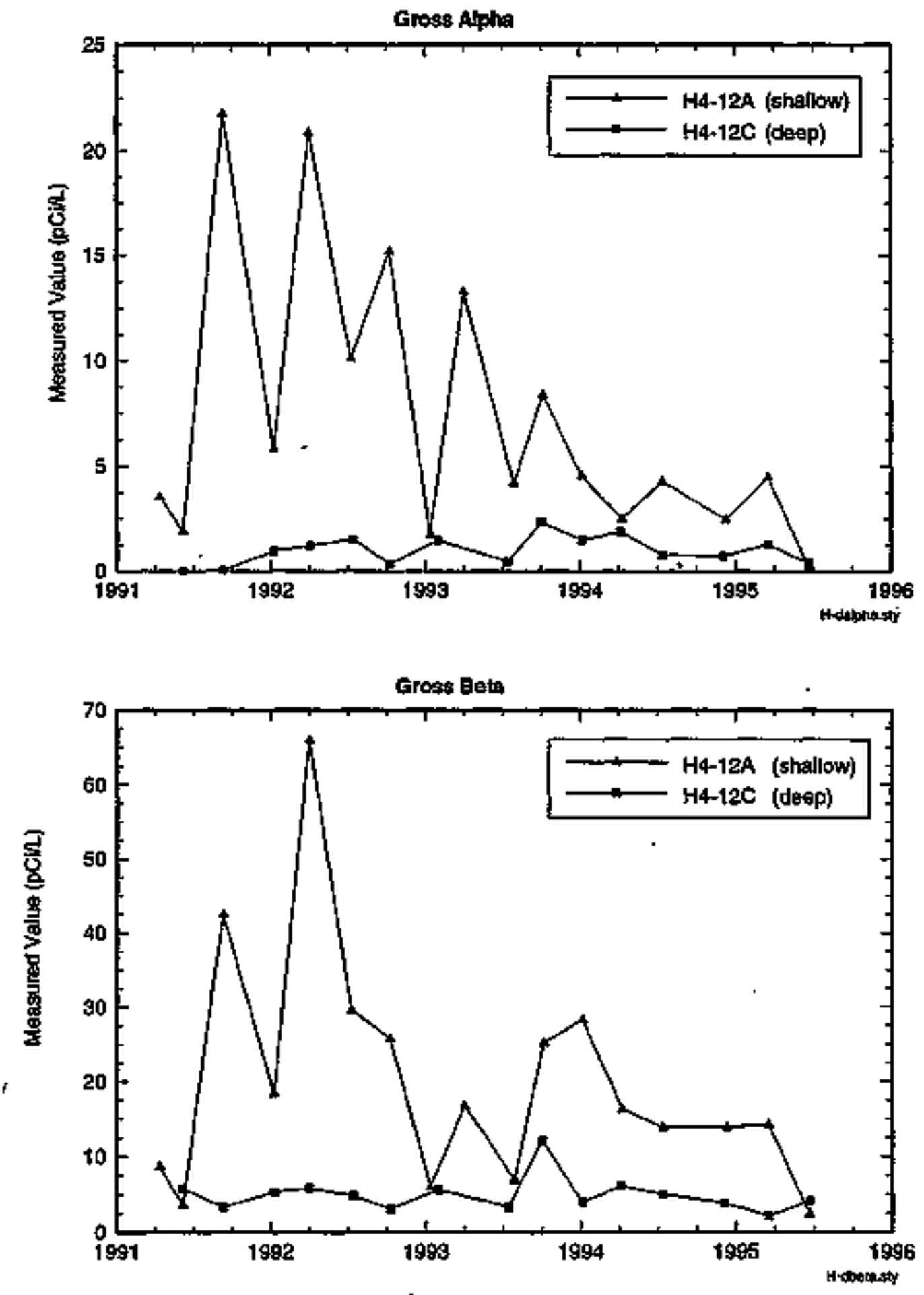
Figure 3.3-12. Nitrate and Chromium Versus Time in Wells H4-12A and H4-12C.
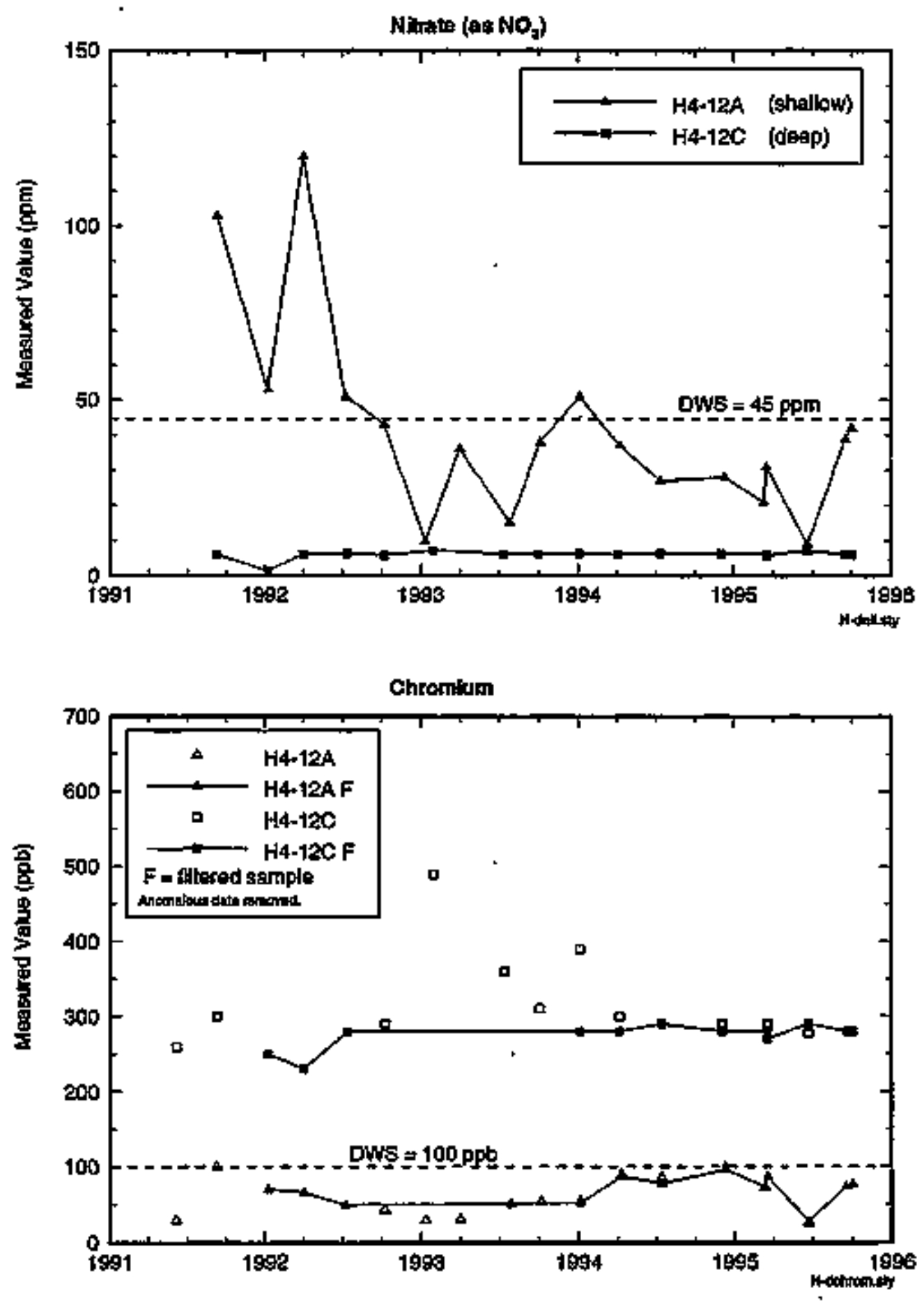
DOE/RL-96-01, REV. O

Figure 3.3-13. Water Table in the 100-H Area, September 1995.

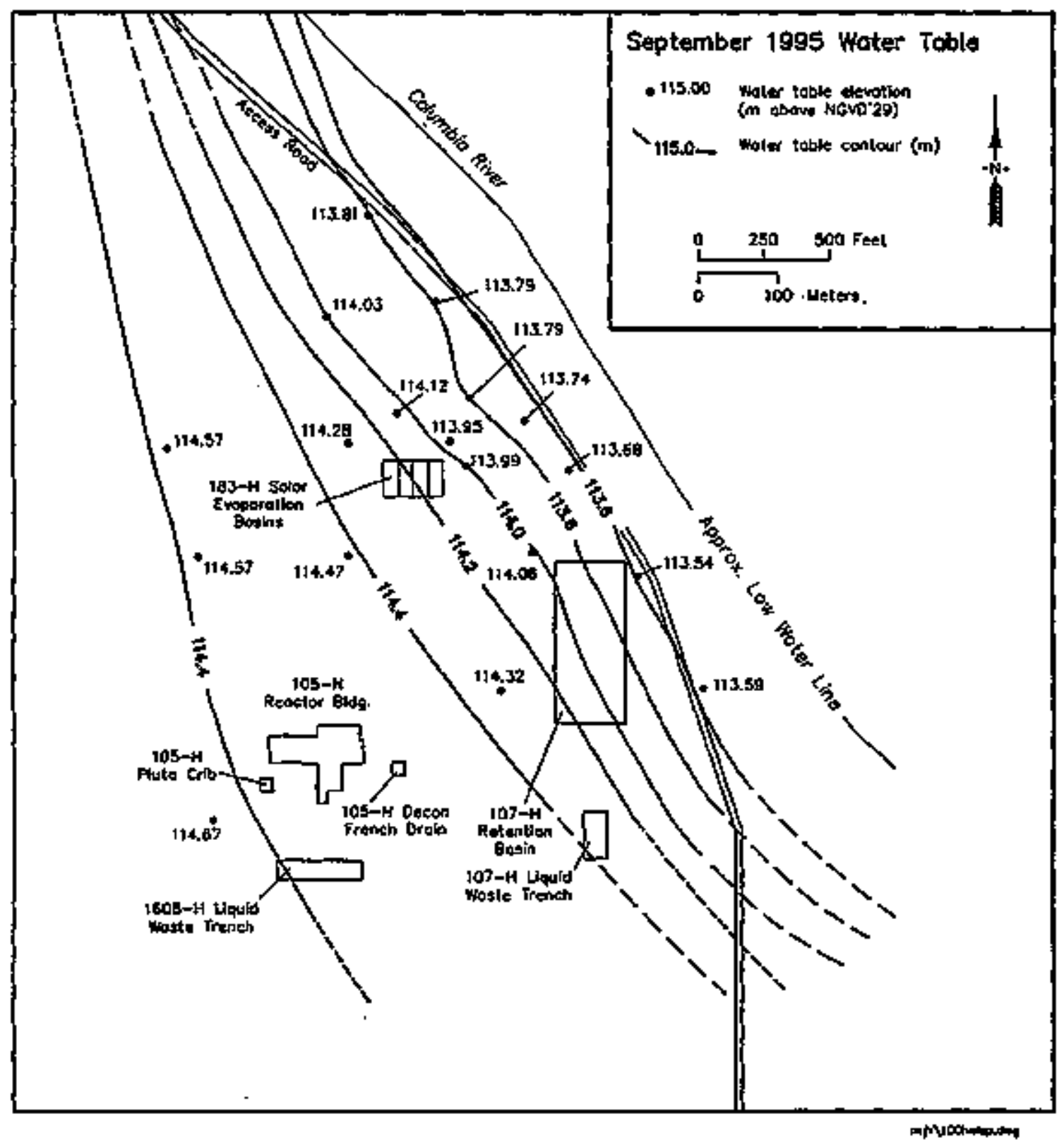


Figure 3.3-14. Water Table in the 100-H Area, June 1995.

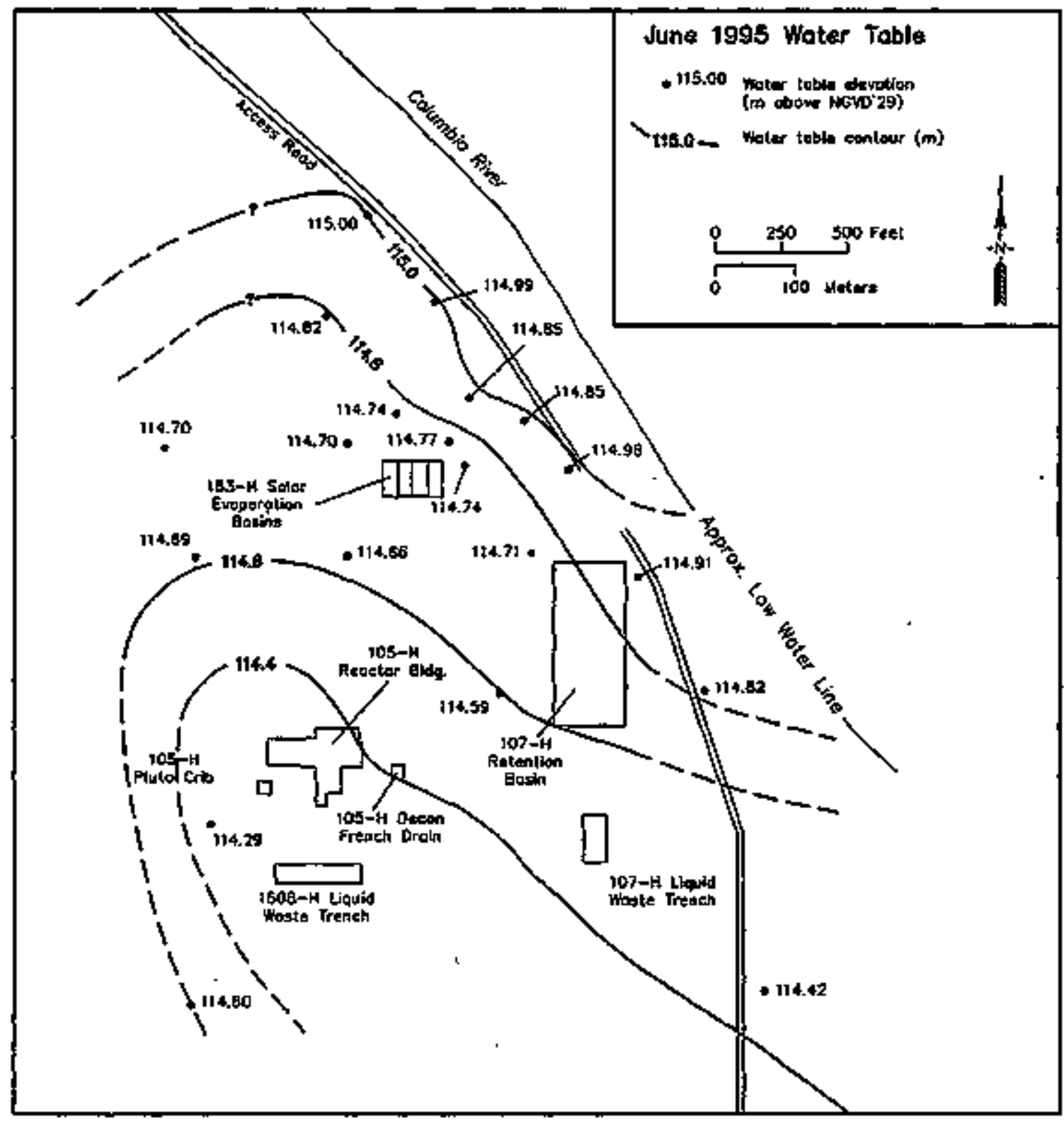

mhylothedhan 
Table 3.3-1. Monttoring Wells in 183-H Solar Evaporation Basins Metwork.

\begin{tabular}{|c|c|c|c|c|}
\hline $\begin{array}{c}\text { Well no. } \\
\text { (199-) }\end{array}$ & $\begin{array}{l}\text { Hydrologic unit } \\
\text { monitored }\end{array}$ & $\begin{array}{l}\text { Sampling } \\
\text { frequency }\end{array}$ & $\begin{array}{c}\text { Well } \\
\text { standards }\end{array}$ & $\begin{array}{c}\text { Other } \\
\text { networks }\end{array}$ \\
\hline $43-1^{1960}$ & Top of unconftned & Annual1y & PRE & $\begin{array}{l}\text { HR3, } \\
\text { Sitewide }\end{array}$ \\
\hline$H 3-2 A^{19 B S}$ & Top of unconfined & Quarterly & $\overline{R C R A}$ & Sitewide \\
\hline $113-2 B^{138}$ & Top of unconfined & Annually & RCRA & sitewide \\
\hline H3-2C & Wid-depth unconfined & Quarterly & RCRA & $=$ \\
\hline $14-10^{1963}$ & Top of unconfined & NS & RCRA & $\overrightarrow{\text { HR3 }}$ \\
\hline H4-11 1986 & Top of unconfined & Quarteriy & RCRA & + \\
\hline$H 4-12 A^{1986}$ & Top of unconfined & Quarterly & $\overline{R C R A}$ & Siteride \\
\hline $\mathrm{H} 4-12 \mathrm{~B}^{1986}$ & Top of unconfined & Annually & RCRA & Sitewide \\
\hline H4-12C & Mid-depth unconfined & Quarterly & RCRA & Sitewide \\
\hline$H 4-13^{1966}$ & Top of unconfined & MS & RCRA & HR3 \\
\hline $\mathrm{H} 4-14^{1966}$ & Top of unconfined & Quarterly & RCRA & $\cdots$ \\
\hline $14-15 A^{1986}$ & Top of unconfined & Quarterly & RCRA & $\overline{\text { HR3 }}$ \\
\hline H4-15日 ${ }^{1586}$ & Top of unconfined & MS & RCRA & Sitewide \\
\hline H4-15Cq ${ }^{5986}$ & Bottom of unconfined & NS & RCRA & $=$ \\
\hline $\mathrm{H} 4-15 \mathrm{Cr} \mathrm{r}^{1986}$ & Mid-depth unconfined & MS & RCRA & $=$ \\
\hline $\mathrm{H4}-15 \mathrm{Cs} \mathrm{s}^{\mathrm{5} 86}$ & Mid-depth unconfined & NS & RCRA & - \\
\hline $\mathrm{H4}-16^{\mathrm{tg}}$ & Top of unconfined & Annual1y & RCRA & $\begin{array}{c}\text { HR3, } \\
\text { sitewide } \\
\end{array}$ \\
\hline$H 4-17^{1987}$ & Top of unconfined & Annualty & RCRA & $\begin{array}{c}\text { HR3, } \\
\text { Sitewide }\end{array}$ \\
\hline $\mathrm{H}$ & Top of unconfined & Quarterly & RCRA & Sitewide \\
\hline $\mathrm{H}_{4-3^{197 / 4}}$ & Top of unconfined & Honthi & PRE & - \\
\hline H4. & Top of unconfined & Nonthly & PRE & $\begin{array}{c}\text { Siteinfide, } \\
\text { DOH }\end{array}$ \\
\hline$H 4-5^{1985}$ & Top of unconfined & Quarterly & PRE & $=$ \\
\hline $44-6^{19, k}$ & Top of unconfined & Quarterly & PRE & - \\
\hline $44-7^{1986}$ & Top of unconfined & QuarterTy & RCRA & Sitewide \\
\hline $144-8^{15 B E}$ & Top of unconfined & Quarterly & RCRA & Sitewide \\
\hline H4-9 & Top of unconfined & Monthly & $\overline{R C R A}$ & sttewide \\
\hline
\end{tabular}


Notes: This table represents interim-status network, which was in place prior to September 1995. Thick outilines denote welis in the finalstatus network, which will be sampled semiannual]y. Superscript

following well number denotes year installed. Shading denotes upgradient well.

Water Jevels are measured quarterly in all wells.

Wonthly until April 1995; quarterly remainder of year.

DOH = Washington State Department of Health.

HR3 = 100-HR-3 groundwater operable unit.

HS = not sampled (piezometer).

PRE = constructed before RCRA standards.

RCRA = in compliance with RCRA construction standards.

Sitewide = Sitewfde Environmental Surveitlance Program.

Table 3.3-2. Constituent List for the 183-H Solar Evaporation Basins (intarim status, before Septenber 1995).

Specific conductance (field)

pH (field)

Turbidity
Total organic carbon

Total organic

halogen Alkalinity

ICP metals (filtered)

Antons
Gross alpha

Gross beta

Uran fum

Fc 
00E/RL-96-01, REV. O

Table 3.3-3. Groundwater Flow Estinates from Direct Methods.

\begin{tabular}{|c|c|c|c|}
\hline Device & $\begin{array}{l}\text { Depth } \\
\text { below top } \\
\text { of casing }\end{array}$ & $\begin{array}{l}\text { Average } \\
\text { direction }\end{array}$ & $\begin{array}{l}\text { Average } \\
\text { flow rate }\end{array}$ \\
\hline \multicolumn{4}{|c|}{ Wel1 H4-7 } \\
\hline$k-V$ flow meter & $14 \mathrm{~m}$ & $\mathrm{~N} 10^{\circ} \mathrm{E}$ & $0.65 \mathrm{~m} / \mathrm{d}$ \\
\hline Colloida1 borescape & $14 \mathrm{~m}$ & H $8^{\circ} \mathrm{W}$ & $4.32 \mathrm{~m} / \mathrm{d}$ \\
\hline \multicolumn{4}{|c|}{ Well H3-2A } \\
\hline \multirow{2}{*}{ K-Y flow meter } & $12.8 \mathrm{~m}$ & $S 62^{\circ} \mathrm{E}$ & $1.38 \mathrm{~m} / \mathrm{d}$ \\
\hline & $14.9 \mathrm{~m}$ & $\mathrm{~N} 23^{\circ} \mathrm{N}$ & $4.92 \mathrm{~m} / \mathrm{d}$ \\
\hline \multirow[b]{2}{*}{ Colloidal borescope } & $12.8 \mathrm{~m}$ & $\mathrm{~N} 9^{\circ} \mathrm{W}$ & $2.42 \mathrm{~m} / \mathrm{d}$ \\
\hline & $14.9 \div$ & $\begin{array}{l}\text { swirling } \\
\text { flow }\end{array}$ & $\begin{array}{c}\text { swirling } \\
\text { flow }\end{array}$ \\
\hline \multicolumn{4}{|c|}{$\mathrm{He}] \mathrm{T} \mathrm{H4-48}$} \\
\hline \multicolumn{2}{|c|}{$K-V$ flow meter } & $\begin{array}{c}\text { RE (not } \\
\text { quantified) }\end{array}$ & $1 \mathrm{~m} / \mathrm{d}$ \\
\hline
\end{tabular}


DOE/RL-96-01, REV. 0

This page intentionally left blank. 
DOE/RL-96-01, REV, 0

COKTEHTS

4.1 216-5-10 POND AND DITCH . . . . . . . . . . 4.1-1

4.1.1 Fac17ity overview ............ 4.1-1

4.1 .2 Sumary of 1995 Activities ............ 4.1-2

4.1.3 Sampling and Analysis Progran .......... 4.1-2

4.1.4 Groundwater Chernistry ............4 4.1-3

4.1.5 Groundwater Flow . . . . . . . . . . . . . 4.1-4

4.1 .6 References . . . . . . . . . . . . 4.1-6 
ODE/RL-96-01, REY. 0

\section{LIST OF FIGURES}

4.1-1 Monitoring Well Locations for the 216-5-10 Facility ... . 4.1-8 4.1-2 Gross Alpha Concentration Plot for the 216-5-10 Facility Monitoring Wells ..................... 4.9

4.1-3 Uranium Concentration Piot for the $216-\dot{s}-10$ Facility

Monitoring Wells ....................... 4-10

4.1-4 216-5-10 Facility Water Table Map, June $1995 \ldots$. . . . .11

4.1-5 Hydrograph of the 216-\$-10 Facility Uncenfined Aquifer

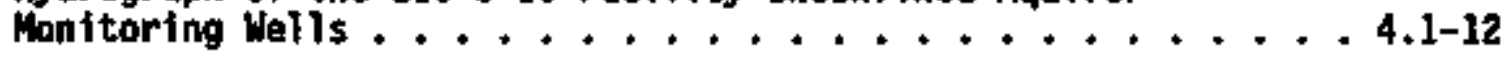

\section{LIST OF TABLES}

4.1-1 216-S-10 Facility Groundwater Monitoring Metwork . . . . . 4.1-13

4.1-2 Constituents Analyzed at the 216-5-10 Facility . . . . . 4.1-14

4.1-3 Critical Means Table for 20 Comparisons--Background Contanination

Indicator Parameter Data for the 216-S-10 Faci1ity . . . . 4.1-15 
DOE/RL-96-01, REV. 0

\subsection{6-S-10 POHD AMD DITCH}

J. W. Lindberg

Iestinghouse hanford Company

\subsubsection{Facility Overview}

A Resource Conservation and Recovery Act of 1976 (RCRA) groundwater monitoring network has been established according to the RCRA Interia-Status Groundwater Honitoring P1 an (WHC 1990) for the 216-S-10 Pond and Ditch (referred to as the S-10 Facility). This facility operates under RCRA interim-status regulations ( 40 code of Federal Regulations [CFR] 265). The site is currently in the indicator parameter evaluation program. The site is a] so within the 200-UP-1 operable unit of the Conprehensive Environiental Response, Cospensation, and lfability Act of 1980.

The \$-10 facility is located south-southwest of the 200 West Area, directly outside the perjneter fence (see figure 4.1-1). Inttially the S-10 Facjity consisted of an open, uni ined ditch that was $1.82 \mathrm{p}(6 \mathrm{ft})$ deep, $1.21 \mathrm{~m}(4 \mathrm{ft})$ wide at the bottom, and $685.8 \mathrm{n}(2,250 \mathrm{ft})$ long. An open, uni ined percolation pond, constructed at the southust end of the 216-S-10 Ditch and approximate]y 2.0 ha (5 acres) in size, also was active during part of the time that the ditch was receiving waste ( $\$-10$ Pond).

The 216-S-10 Dttch began recetving wastewater from the ReductionOxidation (REDOX) P] ant in August 1951. The 216-5-10 Pond was excavated and placed in service in February 1954. In October 1985, the 216-5-10 Pond and portions of the 216-5-10 01tch were decommissioned, backfilled, and interim stabjlized. The remaining portion of the 216-5-10 0itch recelved nondangerous, nonregulated wastes fron the 202-5 Buflding chenical sewer. The waste strean comprised cooling water, steam condensate, water tower overflow, and drain effluent. Fron 1985 to October 1991, physical controls and operating procedures were nodified to avoid inadvertent discharge of hazardous chemicals to the wastewater strean. The effiuent stream to the \$-10 Facility was permanentiy deactivated in October 1991. The S-10 Facility will not receive additional dangerous substances but will be closed in final status pursuant to the authorized State Dangerous Waste Program in accordance with Washington Admintstrative Code (WAC) 173-303-610 (Ecology et al. 1994).

Releases of dangerous materials and constituents to the S-10 Facility are poorly documented. Radioactive waste was reportedly disposed to the S-10 Facility as a result of contaminated floor and sewer drains at the REOOX Plant. Hazardous chemtcal releases were doctunented in 1954 and 1983 and Included $\mathrm{A}]\left(\mathrm{MO}_{3}\right)_{3}, \mathrm{NaHO}_{3}, \mathrm{HaOH}, \mathrm{Na}_{3} \mathrm{PO}_{4}, \mathrm{HaF}$, $\mathrm{NaCl}$, and $\mathrm{K}_{2} \mathrm{Cr}_{2} \mathrm{O}_{7}$. 1ower):

Stratigraphy at the S-10 facility includes the following (from upper to

- About $52 \mathrm{~m}$ (17) ft) of Hanford formation consisting of silt and sand

* $1.8 \mathrm{~m}$ ( $6 \mathrm{ft})$ of Plio-Pleistocene unit composed of si7ty sandy gravel capped with a $0.3-m$ (I-ft) layer of callehe 
DOE/RL-96-01, REY. 0

- $14 \mathrm{~m}(45 \mathrm{ft})$ of upper Ringord unit sand

- 61 пr (199 ft) of Ringold Formation unit E composed of sandy gravel

- Approximately $15 \mathrm{~m}(50 \mathrm{ft})$ of the lower med unit of the Ringold Formation.

The top of the lower mud unit is the base of the uppermost aquifer system at the S-10 Facility. Most of the uppermost aquifer is within gravel unit $E$ of the Ringold Formation. However, the water table is approximately $2 \mathrm{~m}(7 \mathrm{ft}$ ) above unit $E$ in the upper Ringold unit. Depth to water varies from $55 \mathrm{~m}$ (t80 ft) toward the southwestern end of the S-10 Facility to about $67 \mathrm{~m}$ $(220 \mathrm{ft})$ toward the northeastern end because of topography (drainage).

In 1991 approximately $1.89 \times 10^{8} \mathrm{~L}\left(5.0 \times 10^{7} \mathrm{gal}\right)$ of effluent were discharged to the 216-5-10 Ditch. This and previous discharges created a local recharge mound and an associated perched water table directly below the receiving end of the 216-5-10 Ditch. In 1990 well 299-1426-11 was installed to monitor the perched aquifer. Perching occurred on the silt and fine sand within the lower portion of the Hanford formation or possibly the caliche Tayer at the top of the PIjo-Pleistocene unit. Depth to water in the perched zone was about $38 \mathrm{~m}$ ( $125 \mathrm{ft}$ ). However, when surface water discharges ceased in 1991, the perched water began receding. The water Tevel within the well instaried in this perched zone (299-426-11) dropped below the level of the well screen shortly after the surface water discharges ceased at the \$-10 Facility.

\subsubsection{Sumnary of 1995 Activities}

Sampling and analysis were performed for the wells in the monitoring network according to the RCRA Interim-Status Groundwater Monitoring P7 an (WHC 1990). The facility now has two upgradient and four downgradient monitoring welis (Figure 4.1-1). This monitaring network will be used to monitor groundwater Tevels and water quality before and after closure of the facility. During FY 1995 the wells of the monitoring network were sampled semiannually and water levels were measured quarterly (except for we11 299-427-2, which was measured semiannually) under the indicator parameter evaluation program. The sampling dates were December 7, 1994, and June 13-15, 1995. In addition, well 299-H27-2 was not sampled with the others on Oecember 7, 1994, but was sampled January $20,1995$.

\subsubsection{Sampling and Analys is Program}

The groundwater monitoring $\mathrm{plan}$ for the \$-10 Facility (WHC 1990) estabiishes the justification and requirements for the monitoring network. The current monitoring well netwark consists of six wells as shown in Figure 4.1-1 and listed in Table 4.1-1. Five monitor the upper portion of the unconfined aquifer, and one (299-w27-2) monitors the base of the unconfined aquifer. The wells in the monitoring network were sampled for contamination indicator parameters, some drinking water standards (ONS) (40 CFR 265, Appendix III), groundwater quality parameters, and site-spectfic parameters, 
as identified in Table 4.1-2. Site-specific parameters were selected based on a history of waste disposed of at this site and in surrounding cribs.

\subsubsection{Groundwater Chenistry}

A brief discussion of the analytical data available for 1995 is provided in Sections 4.1.4.1 and 4.1.4.2. Tables sumarizing the available analytical data for the year can be found in the RCRA quarterly reports (Lindberg 1994, 1995a, 1995b, and 1996).

\subsubsection{Constituents of Concern}

Groundwater quality parameters, drinking water parameters, and sitespecific parameters did not exceed ows during 1995 except for chromium, jron, manganese, and carbon tetrachloride (tetrachloromethane). The exceedances for chromium, iron, and manganese were in wells 299-W26-7, $-8,-10$, and -12 and were for unfiltered samples except for one sample from 299-\$26-7. The highest chromium result was $340 \mathrm{ppb}$ (DWS $100 \mathrm{ppb}$ ) in well 299-W26-a. The highest 1ron result was 5,000 ppb (DWS 300) in we11-299-W26-10, as was the highest manganese result (100 ppb) (DWS $50 \mathrm{ppb}$ ). Wells 299-W26-7 and -8 are upgradfent weTls suggesting that the elevated concentrations of these metals may not be caused by wastewater fron the 216-S-10 Facility. High 1evels of these metals also have been reported in the past in Hanford site wells and are assumed to be artifacts of well construction or the use of stainiess steel screens. A concentration of $5.3 \mathrm{ppb}$ of cartion tetrachloride (Dis $5.0 \mathrm{ppb}$ ) was discovered in well 299-W27-2 for one sample taken January 20, 1995. The occurance of carbon tetrachloride above the DWS correlates weil with the elevated TOX in that well at the same time (TOX 11.7-17.5 ppb). The elevated carbon tetrachloride and TOX are probably caused by upgradient sources

(Figure 2-I0). Well 299-W27-2 is screened at the bottom of the unconfined aquifer, and there are no upgradient wells corresponding to the same depth at the 216-S-10 Facility.

Well 299-W26-8 continues to show slightly elevated levels of gross alpha (Figure 4.1-2). The cause of the elevated gross alpha is probably uranium, which also is in higher concentrations $f_{n}$ well 299-N26-8 (Figure 4.1-3). Because this well is upgradient of the 216-S-10 Facility, the source of the urantum concentrations may be from the area of the 216-j-10 Pond, which is known to have received radioactive wastewater (DOE-RL 1992).

There were a few anomalous exceedances of indicator parameters. In the December 1994 sampling, oH exceeded the criticat range (6.74-9.04) with field results of 4.51 and 4.11 in wells $299-1 \% 26-8$ and -10 , respectively. These results do not fit the historical trend for these wells, and Taboratory results do not corroborate these results. A RADE was submitted. ResuTts of subsequent verification sampling confirmed that these pH exceedances were caused by errors in the field measurements. Results for pH exceeded the Dus (8.5) in wgll 299-W26-8 for the June 1995 sampling, but did not exceed the critical range for $\mathrm{pH}$. These high pit results are typical of this upgradient we?l. 
We11 299-V27-2, which monitors the base of the unconfined aquifer, continues to have high specific conductance and, in the sample collected in January 1995, showed elevated ToX levels (11.7 to $17.5 \mathrm{ppb})$. Specific conductance is typjcally in the range of 330 to $360 \mu m h o s / c m$ for this wel1. Because we11 299-W27-2 monitors a different portion of the aquifer than the other wells of the network, it is jnappropriate to compare the anaTytical results with the critical mean. Results from well 299-w27-2 are used as supplemental information only.

4.1.4.2 Statistical Evaluation. Statistica] eva]uations of data for the past year at the \$-10 Facility consisted of the required comparisons of indicator parameters between upgradient and downgradient wells for any indication of contamination in the groundwater underjying the facility. Statistical methods are described in Appendjx $\mathrm{C}$. The contamination indicator parameters for the S-10 Facility include field specific conductance, fjeld pH, total organic carbon (TOC), and total organic halogen (TOX). Statistical analyses required by $40 \mathrm{CFR} 265.93$ (b) and WAC 173-303-400 were performed on the samples collected from August 1991 to June 1992 for upgradient we1]s 299-W26-7 and 299-426-8. Results are presented in Table 4.1-3. This table lists the background average, background standard deviation, and crittcal mean (or eritical range, in the case of $\mathrm{pH}$ ) for the four contamination indicator parameters. The critical mean (or critfical range) is the value to which future averages of quadruplicate measurements are compared. The upgradient/downgradient comparison value is generaljy the critical mean or critical range. The 7 imit of quantitation is used instesd of the critical mean as the comparison value for TOC because wost of the upgradient concentrations were below the contractually required quantitation limits (see Appendix () .

If the average from a downgradient well for a parameter exceeds the upgradient/downgradient comparison values listed in Table 4.1-3, that parameter is considered statistically different from background. If this is confirmed by subsequent verjfication sampling and analysis, the regulatory program is triggered into assessment. Except for the error (false positive) in measuring $\mathrm{pH}$ at wells 299-\$26-8 and -10 , none of the sampies collected during the 1ast year for the upper portion of the unconfined aquifer had indicator parameters that exceeded the critical means (or in the case of pH, critical range). However, field speciflc conductance for well 299-W27-2 ranged from 339 to $354 \mu \mathrm{mho} / \mathrm{cm}$. The critical mean for field-specific conductance is $301.1 \mu m h o / c m$. Although groundwater samples collected from well 299-H27-2 exceed the critical mean for field-specific conductance, it is inapproprtate to compare these analytical results with the critical mean because wei] 299-W27-2 samples the bottom of the unconfined aquifer. [Furthermore, the average specific conductance background value for the Hanford Site is $332 \pm 93$ (Johnson 1993).] The critical means were calculated from sasples and analytical results corresponding to the upgradient wells (299-W26-7 and 299-W26-8) that sample groundwater in the upper portion of the unconfined aquifer.

\subsubsection{Eroundwater Flow}

4.1.5.1 Groundwater Flow Direction. Tables sumarizing available water Ievel data are reported in the RCRA quarterly reports (L1ndberg 1994, I995a, 1995b, 
and 19g6). Figure 4.1-4 depicts the contoured water table elevations for the unconfined aquifer for June 1995. This figure indicates that the flow direction is toward the east to southeast beneath the S-10 Facility. This general flow direction coincides with the reglonal groundwater map (see Figure 2-4). Vertical groundwater flow (June 1995) in the vicinity of wells 299-w27-2 and 299-W26-12 is slightly upuard [ $\$ . \theta .$, head in well $\$ 27-2$ (138.54 m) is slightly higher than in well $/ 26-12(138.42 \mathrm{~m})]$. Well hydrographs (figure 4.1-5) show the continued declines in water table elevations with time at the S-10 Facility.

4.1.5.2 Rate of Flow. The rate of horizontal groundwater flow can be estimated by using a form of the Darcy equation with a range of input parameters.

$$
v=\frac{\mathbf{K}_{i}}{\bar{n}_{0}}
$$

where:

$$
\begin{aligned}
v & =\text { Average } 1 \text { inear velocity of groundwater } \\
k & =\text { Horizontal hydrauljc-conductivity } \\
i & =\text { Hydraulic gradient } \\
n_{e} & =\text { Effective porosity of the aquifer. }
\end{aligned}
$$

The following input parameters were used:

$$
\begin{aligned}
& K=10 \mathrm{~m} / \mathrm{d} \text { (34 ft/d) (Wjllians and Barnett 1993); } 12 \text { to } 152 \mathrm{~m} / \mathrm{d} \\
& \text { (40 to } 500 \mathrm{Ft} / \mathrm{d} \text { ) (Kjpp and Hudd 1973) } \\
& \dagger=0.0014 \text { to } 0.0022 \text { (fron June } 1995 \text { water table map) } \\
& n_{8}=0.1 \text { to } 0.3 \text {. }
\end{aligned}
$$

Resulting estimates of groundwater velocity range from 0.05 to $3.34 \mathrm{~m} / \mathrm{d}$ $(0.16$ to $10.96 \mathrm{ft} / \mathrm{d}$ ).

The most recent aquifer testing in network wells was done in November 1992 when a constant discharge test was performed (at the water tabie in we11 299-w27-2) with an observation wel1 (299-W25-12) (Williams and Barnett 1993). The interpreted hydraulic conductivity is $10 \mathrm{~m} / \mathrm{d}$ (34 ft/d). 5 lug tests in the same well provided similar rest]ts (6 to $10 \mathrm{w} / \mathrm{d}$ [21 to $34 \mathrm{ft} / \mathrm{d}$ ] hydraulic conductivity). These results have a much smaller range than the results reported by Kipp and Hudd (1973) (12 to $152 \mathrm{w} / \mathrm{d}$ [40 to $500 \mathrm{ft} / \mathrm{d}]$ ). If the more recent estinates of hydraulic conductivity are used, the resulting estimates of groundwater velocity would fall more closely to the lower end of the originaliy estinated range (0.028 to $0.22 \mathrm{~m} / \mathrm{d}[0.092$ to $0.72 \mathrm{ft} / \mathrm{d}]$ ).

4.1.5.3 Evaluation of Monitoring We11 Hetwork. Based on the MEHO mode] (Jackson et al. 1991) and the hydrogeology of the site, the existing network should provide a monjtoring efficiency of approximately $85 \%$ for the S-10 Facility. Presentiy, the network is judged to be adequate for the indicator parameter evaluation program. There are no plans to drill additional wells or to modify the existing ones in the near future unless 
DOE/RL-96-01, REV. 0

groundwater sampling results indicate a significant change in groundwater chemistry or there is a significant change in groundwater flow conditions.

The water table in the vicinity of the 216-S-10 Facility is dropping at an average rate of $0.43 \mathrm{~m}$ per year. Assuwing the rate continues, wells 29-426-8, -9 , and -10 will be completely dry in 4 to 6 years (2000 to 2001) and well 299-126-12 in about 7 years (2002). In approxisately 3.4 years, weil 299-W26-8 will not have enough water to sample with the instal]ed Hydrostar pump. [The minimum amount of water needed in a well with a Hydrostar pump is approximately $0.61 \mathrm{~m}(2.0 \mathrm{ft})$, assuming there is no draw-down.] With increasingly greater anounts of draw-down, a jarger column of water is needed, which means that the well will need to be replaced sooner.

\subsubsection{References}

40 CFR 265, 1989, "Interim Status Standards for Owners and 0perators of Hazardous Waste Treatment, Storage, and Disposal Facilities," Code of Federa] Regulations, as amended.

Comprehensive Environmental Response, Compensation, and Liability Act of 1980, 42 USC 9601 et seq.

Ecology, EPA, and DOE, 1994, Hanford Federal Facility Agreement and Consent Order, Fourth Amendment, Washington State Department of Ecology, U.S. Environmental Protection Agency, and U.S. Department of Energy, 0lympia, Washington.

Ecology, 1994, Dangerous Waste Portion of the Resource Conservation and Recovery Act Treatsient for the Storage and Disposal of Dangerous Waste, Permit Mo. Wa7890008967, Effective September 28, 1994, Washington State Department of Ecology, 07ymia, Washington.

DOE-RL, 1992, 200 West Area Groundwater Aggregate Area Management Study Report, DOE/RL-92-16, U.S. Department of Energy, Richland Operations office, Richland, Washington.

Jackson, R. L., C. M. Einbereger, R. B. Mercer, and C. R. Hilson, 1991, Efficiency-Based Groundwater Monitoring Network Design for Hazardous Waste Sftes, WHC-SA-1157-FP, West1nghouse Hanford Company, Richland, Washington.

Johnson, V. G., 1993, Westinghouse Hanford Company Operational Monitoring Groundwater Status Report, 1990-1992, WiHC-EP-0595, Westinghouse Hanford Company, Richl and, Washington.

Kipp, K. L., and R. D. Mudd, 1973, Colfection and Analysis of Pump Test Data for Transmissivity Values, BNWL-1709, prepared for the U.S. Atomic Energy Comission under Contract AT(45-1):1830 by Battelle, Pacific Northwest Laboratory, Richiand, Washington.

'Hydrostar is a trademark of Instrumentation Northwest, Inc. 
- Lindberg, J. H., 1996, "216-5-10 Pond and Ditch," in Quarterly Report of RCRA Groundwater Mont toring Data for Perfod July 1, 1995 through September 30, 1995, DOE/RL-95-69-3, U.S. Department of Energy, Richland Operations office, Richland, Washington.

Resource Conservation and Recovery Act of 1976, 42 USC 6901 at seq.

Lindberg, J. N., 1994, "216-S-10 Pond and Ditch," in Quarterly Report of RCRA Groundwater Honftoring Data for Period Dctober 1, 1994 through Deceaber 31, 1994, DOE/RL-94-36-4, U.S. Department of Energy, RichTand Operations Office, Richland, Washington.

Lindberg, J. W., 1995a, "216-S-10 Pond and Ditch," in Quarterly Report of RCRA Groundwater Honitoring Oata for Perfod January 1 , 1995 through Harch 31, 1995, DOE/RL-95-69-1, U.S. Department of Energy, Richland operations Office, Richland, Washington.

Lfndberg, J. W., I995b, "216-\$-10 Pond and Ditch," in Quarter7y Report of RCRA Groundwater Honitoring Data for Period Apri? 1, 1995 through June 30, 1995, DOE/RL-95-69-2, U.S. Departwent of Energy, Richland Operations office, Richl and, Washington.

WAC 173-303, "Dangerous Waste Regulatjons," Washington Adwinistrative Code, as amended.

WHC, 1990, Interin-Status Ground-Water Honitoring P7an for the 216-5-10 Pond and Ditch, WHC-SD-EN-AP-018, Rev. O, ECNs 618168 and 618188, Westinghouse Hanford Cowpany, Richland, Washington.

Williams, B. A., and D. B. Baraett, 1993, Borehole Completion Data Package for the 216-\$-10 facility, CY 1992, WHC-SD-EN-DP-052, Hestinghouse Hanford Company, Richland, Washington. 


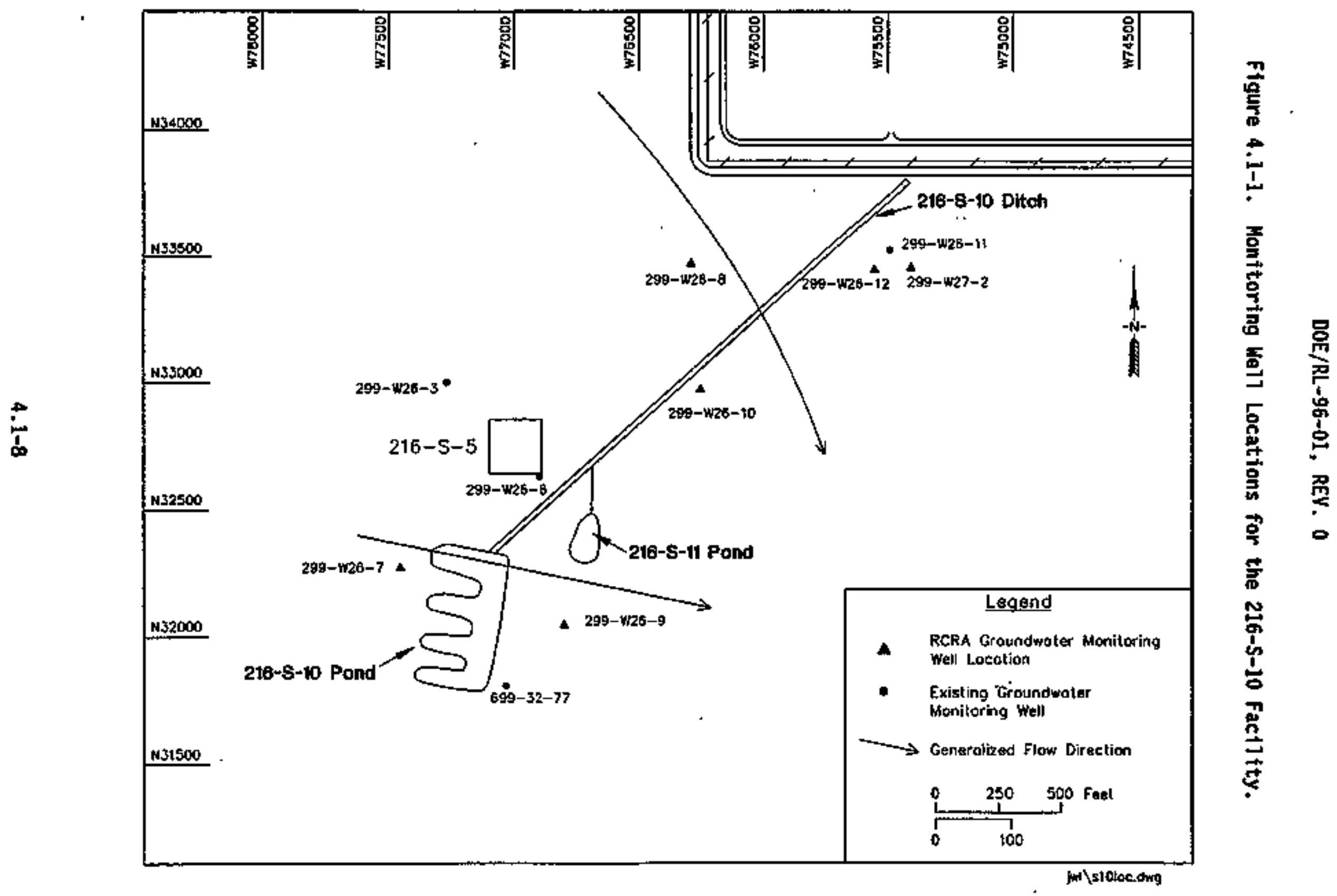


DOE/RL-96-01, REV. 0

Figure 4.1-2. Gross A7pha Concentration PTot for the 216-5-10 Facility Monitoring Wells.

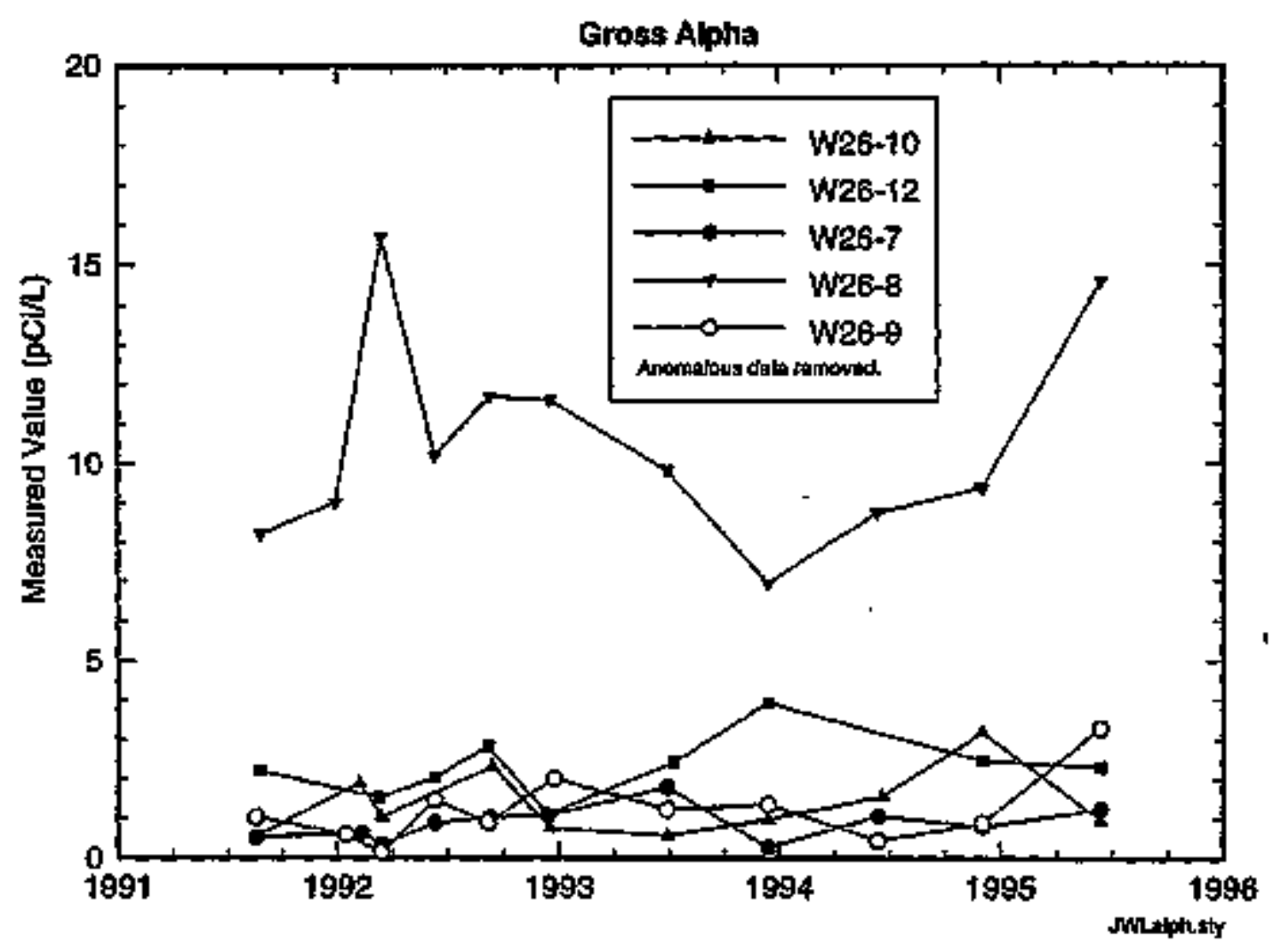


DOE/RL-96-01, REV. 0

Figure 4.1-3. Uranium Concentration Plot for the 216-5-10 Faci3ity Monitoring Wells.

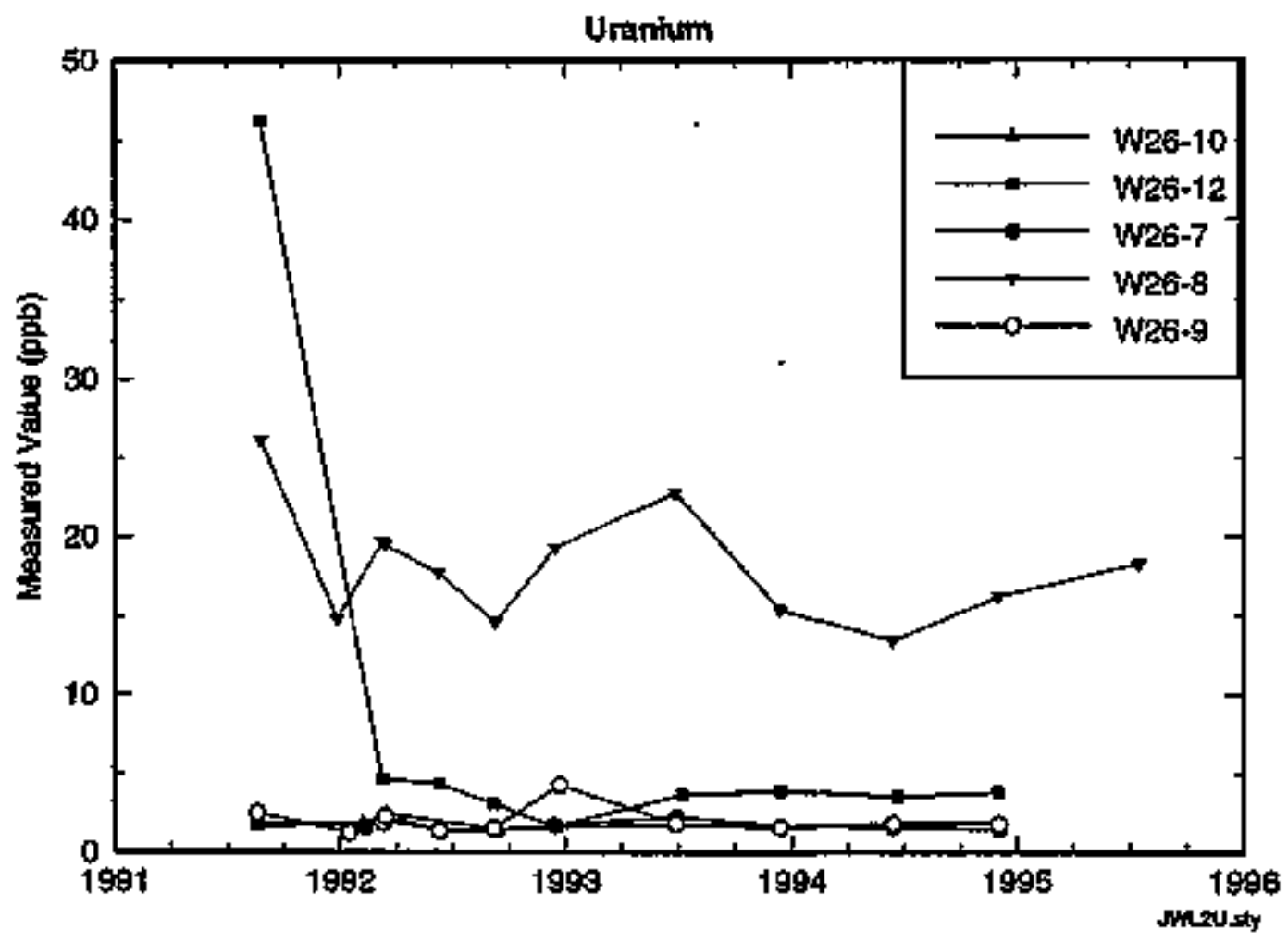

4.1-10 


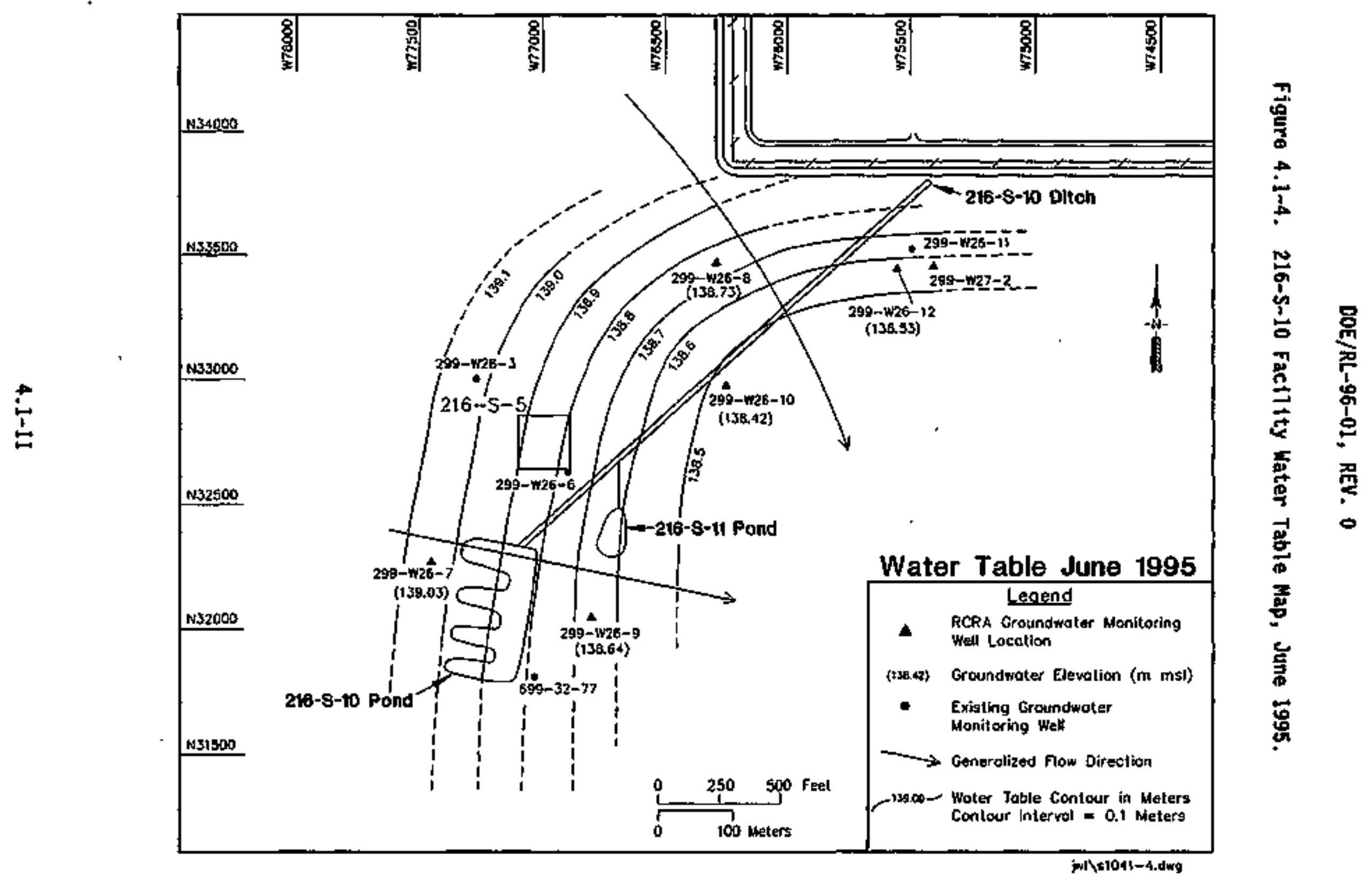


Figure 4.1-5. Hydrograph of the 216-S-10 Facility Unconfined Aquifer Honitoring Wells.

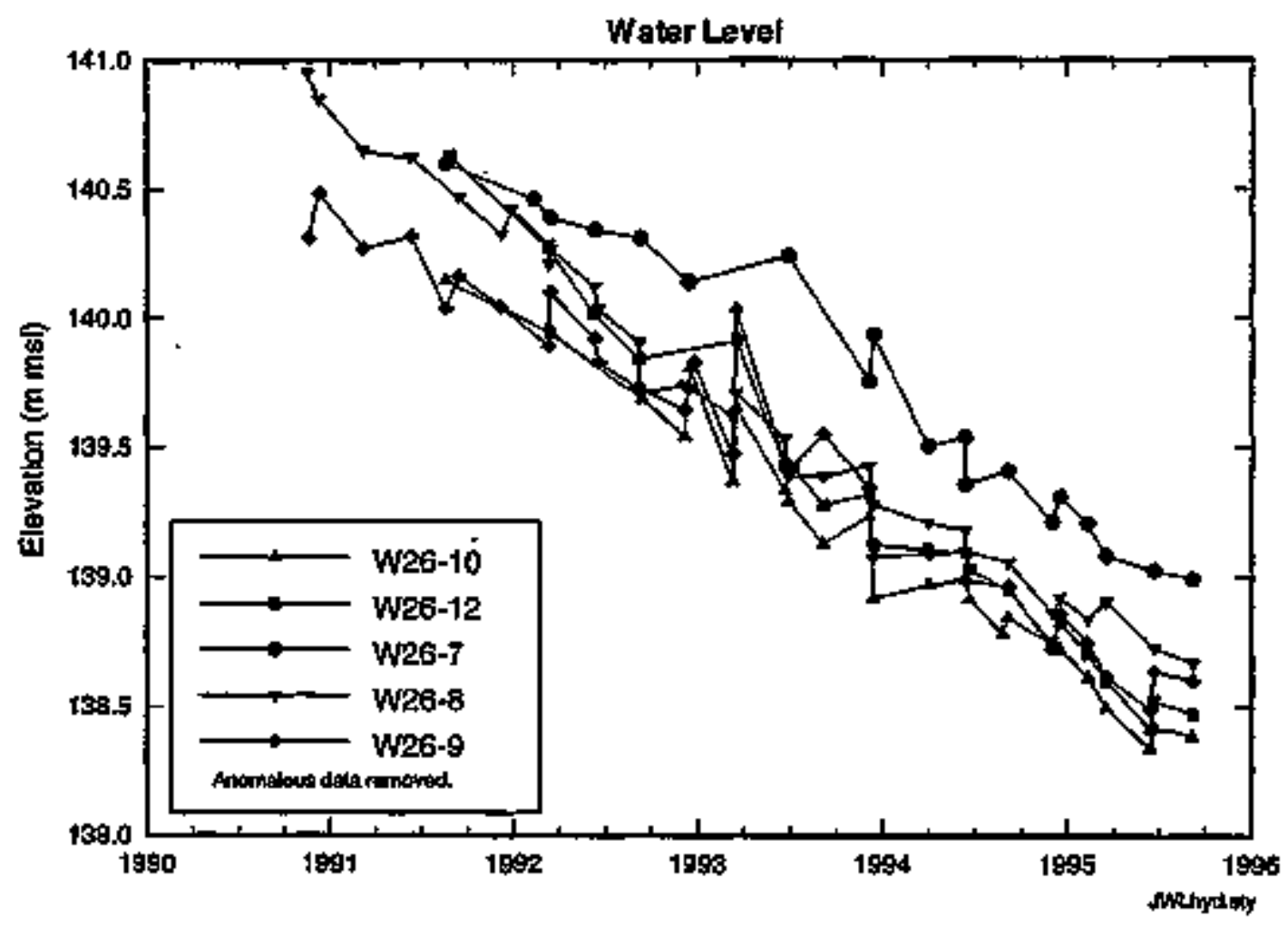


DDE/RL-96-01, REV. 0

Table 4.1-1. 216-5-10 Facility Groundwater Monitoring Metwork.

\begin{tabular}{|c|c|c|c|c|}
\hline $\mathrm{Nell}$ & Aquifer & $\begin{array}{l}\text { Sampling } \\
\text { frequency }\end{array}$ & $\begin{array}{l}\text { Nater } \\
\text { levels }\end{array}$ & $\begin{array}{c}\text { Yell } \\
\text { standards }\end{array}$ \\
\hline $299-126-7^{91}$ & Top of unconfined & $\bar{s}$ & $\bar{Q}$ & RCRA \\
\hline $299+126-8^{90}$ & Top of unconfined & $\$$ & 0 & RCRA \\
\hline $299-426-9^{90}$ & Top of unconfined & 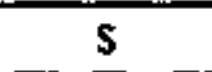 & $Q$ & RCRA \\
\hline $299-126-10^{91}$ & Top of unconfined & 5 & Q & RCRA \\
\hline $299-N 26-12^{97}$ & Top of unconfined & 5 & Q & RCRA \\
\hline $299-127-2^{92}$ & Base of unconfined & 5 & $\mathbf{S}$ & RCRA \\
\hline
\end{tabular}

Notes: Shading denotes upgradient wells. Superscript following well number denotes the year of installation.

$Q=$ frequency on a quarterly basts.

RCRA = wel1 is constructed to RCRA-specified standards.

$\$=$ frequency on a semtannual basis. 
DOE/RL-96-01, REV. 0

Table 4.1-2. Constituents Analyzed at the 216-5-10 Facility.

\begin{tabular}{|c|c|c|}
\hline \multicolumn{3}{|c|}{ Groundwater Contamination Indicator Parameters } \\
\hline $\begin{array}{l}\text { pH SA } \\
\text { Specific conductance } \$ A\end{array}$ & $\begin{array}{l}\text { Tota] organic ca } \\
\text { Tota] org. halog }\end{array}$ & \\
\hline \multicolumn{3}{|c|}{ Groundwater quality parameters } \\
\hline $\begin{array}{l}\text { Chloride A } \\
\text { Iroin } A\end{array}$ & $\begin{array}{l}\text { Hanganese A } \\
\text { Phenots A }\end{array}$ & $\begin{array}{l}\text { Sodiun A } \\
\text { Sulfate A }\end{array}$ \\
\hline \multicolumn{3}{|c|}{ Drinking water parameters } \\
\hline $\begin{array}{l}2,4-0 * \\
2,4,5-T P \text { silvex * } \\
\text { Arsenic * } \\
\text { Barium A } \\
\text { Cadiun A } \\
\text { Chromiun A } \\
\text { Coliform bacteria * }\end{array}$ & $\begin{array}{l}\text { Endrin } \\
\text { Fluoride A } \\
\text { Gross a]pha SA } \\
\text { Gross beta SA } \\
\text { Lead * } \\
\text { Lindane * } \\
\text { Hercury * }\end{array}$ & $\begin{array}{l}\text { Mathoxychlor } \\
\text { Nitrate A } \\
\text { Radiun * } \\
\text { Selenium * } \\
\text { Silver A } \\
\text { Toxaphene * } \\
\text { Turbidity SA }\end{array}$ \\
\hline \multicolumn{3}{|c|}{ Stte-specific parameters } \\
\hline $\begin{array}{l}\text { Technetium-99* } \\
\text { Tritiun * }\end{array}$ & $\begin{array}{l}\text { Uraniun * } \\
\text { Votatile organic } \\
\text { analysis }\end{array}$ & Alkalinity ** SA \\
\hline
\end{tabular}

- Discontinted after ath quarter of 1994.

* - Added 2nd quarter of 1995.

SA - Sampled semi-annualty after the 4th quarter of 1994.

A - Sampled annually after the 4th quarter of 1994. 
Table 4.1-3. Critical Means Table for 20 Comparisons-Background Contamination Indicator Parameter Data for the 216-S-10 Facti ity. ${ }^{*, b}$

\begin{tabular}{|c|c|c|c|c|c|c|c|}
\hline $\begin{array}{c}\text { Constituent } \\
\text { (unit) }\end{array}$ & $\boldsymbol{n}$ & df & $t_{c}$ & $\begin{array}{l}\text { Average } \\
\text { background }\end{array}$ & $\begin{array}{l}\text { Standard } \\
\text { deviation }\end{array}$ & Critical mean & $\begin{array}{c}\text { Upgradient// } \\
\text { downgradient } \\
\text { comparison } \\
\text { vaJue }\end{array}$ \\
\hline $\begin{array}{l}\text { Spectfic } \\
\text { conductance } \\
\text { ( } \mu \text { who/cm) }\end{array}$ & 8 & 7 & 5.4079 & 248.375 & 9.186 & 301.1 & 301.1 \\
\hline Field pH & 8 & 7 & 6.0818 & 7.888 & 0.178 & {$[6.74,9.04]$} & {$[6.74,9.04]$} \\
\hline $\begin{array}{l}\text { Total } \\
\text { organic } \\
\text { carbon } \\
\text { (ppb) }\end{array}$ & $7^{\circ}$ & 6 & 5.9588 & 500 & $\mathrm{MC}$ & $\overrightarrow{M C}$ & 976 \\
\hline $\begin{array}{l}\text { Total } \\
\text { organic } \\
\text { halogent } \\
\text { (ppb) }\end{array}$ & $M$ & $M C$ & $M$ & NC & NC & $M C$ & 13.6 \\
\hline
\end{tabular}

Oata collected from August 1991 to June 1992 for upgradient wells 2-W26-7 and 2-W26-a. Values calculated based on 20 comparịsons.

The following notations are used in this table: df $=$ degrees of freedon $(n-1)$

$n=$ number of background repl icate averages

$t_{c}=$ Bonferroni critical $t$-value for approprlate df and 20 tamparisons.

"Crittcal mean cannot be calculated because of lack of an estimate of background standard deviation. The upgradient/downgradient comparison value for TOC is the limit of quantitation (see Appendix A).

Critical mean cannot be calculated because of problems associated with data quality for samples analyzed aby $\mathrm{OCL}$. The upgradient/downgradient comparison value for TOX ts the limit of quantitation (see Appendix A). Excluding total organic carbon values collected on 2/11/92 from we11 2-W26-7 because of Honconformance Report.

NC * not calculated. 
DOE/RL-96-01, REV. 0

This page intentionally left blank.

4.1-16 
DOE/RL-96-01, REV. 0

\section{CONTENTS}

4.2 216-U-12 CRIB . . . . . . . . . . . . . 4.2-1

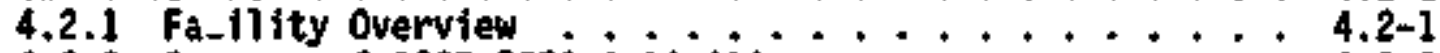

4.2.2 Sunmary of 1995 RCRA Activities $\ldots \ldots \ldots, \ldots .2-2$

4.2.3 Sampling and Analysis Program ........... 4:2-2

4.2.4 Groundwater Chemistry .............. 4.2-3

4.2.5 Groundwater flow . . . . . . . . . . . 4.2-5

4.2 .6 References ................ 4.2-7 


\section{LIST OF FIQURES}

4.2-1 Well Location Hap for the 216-U-12 Crib . . . . . . . . 4.2-9

4.2-2 jpecific Conductivity at the 216-U-12 Crib ......... 4.2-10

4.2-3 Nitrate Concentrations at the 216-U-12 Crib . . . . . . 4.2-10

4.2-4 Gross Beta Activity at the 216-U-12 Crib . . . . . . . . 4.2-11

4.2-5 Technetium-99 Activity at the 216-U-12 Crjb . . . . . . . 4.2-11

4 2-6 Trtttum Activtty at the 216-U-12 Crib . . . . . . . . 4.2-12

4.2-7 Iodine-129 Concentrations at the 216-J-12 Crib . . . . . . 4.2-12

4.2-8 Composite Hydrograph of Quarterly Water Level Measurements

4.2-9 Contour Map sea level) at the 216-U-12 Facility . . . . . . 4.2-13

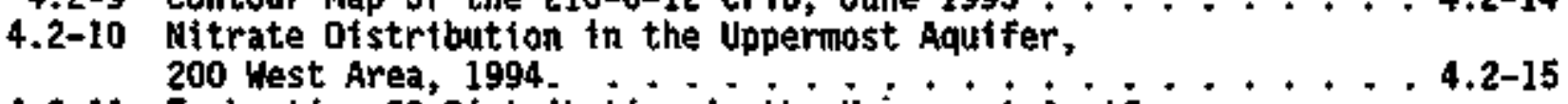

4.2-11 Technetium-99 of stribution in the Uppemost Aquifer,
200 West Area . . . . . . 4.2-16

4.2-12 Trit 1um Distribution in the Uppermost Aquifer,
200 West Area, $1994 \ldots . . . . . .4 .2-17$

4.2-13 Iodine-129 Distribution in the Upermost Aquifer,
200 West Area, $1994 \ldots \ldots .+\ldots .2-18$

\section{LIST OF TABLES}

4.2-1 Groundwater Monftoring Metwork ................ 4.2-19

4.2-2 Constituents Analyzed at the 216-U-12 Crib . . . . . . . 4.2-20 
DOE/RL-96-01, REV. 0

\subsection{6-V-12 CRIB}

B. A. Nilliams

Westinghouse Hanford Company

\subsubsection{Facility Overvien}

This section summarizes data collected and analyzed in fiscal year (FY) 1995 to define the distribution and concentration profiles of waste constijtuents in groundwater at the 216-v-12 Crib (referred to as the U-12 Crib). Groundwater monitoring was elevated from a Resource Conservation and Recovery Act of 1976 (RCRA) detection-level to an assessment-level groundwatar monitoring program in 1993 because of elevated concentrations of specific conductance in two of the downgradient wells. An Interin-status Ground-Water Qua7ity Assessment Plan for the 216-U-12 Crib (WHC 1993) was submitted to the Washington State Department of Ecology. This plan was developed to present a program to determine whether the $U-12$ crib is the source of contamination and if so, the concentration, flow rate, and extent of the contaminant plumes. Elevated concentrations of nitrate, technetium-99, tritium, and fodine-129 are being investigated under the assessment monitoring program. The $\mathrm{U}-12 \mathrm{Crib}$ is also part of the Comprehensive Envirompental Response, Compensation, and Liability Act of 1980 (CERCLA) 200-UP-1 groundwater operable unit. The closure of this facility will be coordinated with the CERCLA past-practice cleanup process.

The U-12 Crib is located approximately 610 m $(2,000 \mathrm{ft})$ south of the $\checkmark$ Plant in the 200 Hest Area (see Figure 4.2-1). The U-12 Crib is an un] ined, gravel-bottomed, percolation crib that has bottom dimensions of $3.05 \mathrm{~m}(10 \mathrm{ft}$ ) wide, $30.5 \mathrm{~m}$ (100 ft) long, and $4.3 \mathrm{~m}$ (14 ft) deep. The J-12 $\mathrm{Cr}$ ib has a plastic barrier cover and is backfilled with the original excavated soil. A vitriffed clay distributor pipe buried in gravel dispersed the effluent across the bottom of the $\mathrm{J}-12 \mathrm{Crib}$.

The U-12 Crib received wastewater from the U Plant in the 200 Hest Area from Aprif 1960 until February 1989, when the crib was permanentTy retired and replaced by the 216-U-17 Crib. The wastewater disposed of to the $\mathrm{U}-12 \mathrm{Crib}$ contained dangerous waste and radioactive raterials. Specifically, the waste was composed of effluent from the U Plant and included dratinage froe the 291-U-1 Stack and process condensate from the 224-U Bufiding. The U-12 Crib received this waste strean from April 1960 unt:17 1972, when It was deactivated. The $\mathrm{U}-12$ Crib was react tvated in lovember 1981 , and received U Plant waste untj 1 it was permanent1y retired in February 1988 . An average of over $1.33 \times 10^{8} \mathrm{~L} / \mathrm{yr}\left(3.5 \times 10^{7} \mathrm{gal} / \mathrm{yr}\right)$ of effluent was discharged to the U-12 crib during its act fve 7 ife. The $U-12$ Crib has received Jow-level radioactive waste that is known to have included chemicals such as nitric acid, in addition to plutonium, strantium, ruthenitum, and uranium. In 1985 , physical controls and operating procedures were modified to avoid inadvertent. discharge of hazardous chemicals to the wastewater strean.

Vadose zone investigations beion the $\mathrm{U}-12$ Crib reveal radioactive contamination at various depths. An investigation in 1983 indicated radjoactive contagination to a depth of at least $42.7 \mathrm{~m}(140 \mathrm{ft}$ );

investigations in 1993 detected radioactive contamination to a depth of $19.5 \mathrm{~m}$ 
(64.5 ft) (DOE-RL 1993f). A CERCLA vadose zone 1 jajted field investigation (BHI 1993) supporting the 200-UP-2 operabie unit reported ${ }^{2} \mathrm{U}$ at a depth of about $6.1 \mathrm{~m}(20 \mathrm{ft}$ ). The unsaturated interval (vadose) is approximately $64 \mathrm{~m}$ (210 ft) thick and is composed of unconsolidated sandy gravel and sand of the Hanford formation, and sandy silt and gravelly sand of the Plio-Pleistocene unit. The unconfined aquifer lies belou and within the silty, sandy gravels of the middle Ringold unit.

\subsubsection{Sumary of 1995 RCRA Activities}

The U-12 Crib continued in a groundwater quality assessment nonitoring program during 1995. Wells in the network (Figure 4.2-1 and Table 4.2-1) were sampled quarterTy during December 1994 and January, March, June, and September of 1995 .

To neet Hanford Federal Facitity Agreenent and Consent Order MiTestone M-24-33 (Ecology et a]. 1994), one assessment wel] was constructed during late FY 1994-early FY 1995 and was sampled quarterly starting in January 1995. This well, 699-36-70A, was constructed to provide hydrogeologic characterization data for the entire upper unconfined aquifer, to de] ineate groundwater contaminants in the unconfined aquifer, and to monitor the upperwost portion of the aquifer. Results of the driliting, construction, and hydrogeologic characterization are reported in a borehole conpletion data package (Williams 1995). It al so supports the Environmental Restoration Disposal Facility as an upgradient monitoring well. sampling.

Nater levet measurements were recorded at least once a month and during

The summary and interpretation of quarterly monitoring resuits (groundwater chemistry) are presented in Section 4.2.4. The $\mathrm{y}-12 \mathrm{Cr}$ ib groundwater analyte itst and assessment monitoring schedule were revised and modifjed in 1995 to reflect more accurately the intent of the assessment groundwater monitoring program at the U-12 crib. These changes are defined in a supplementa] change notice (No. 618170) to the groundwater assessment plan (WHC 1993). The U-12 Crib assessment sampling and analysts progran w111 stj11 meet the analytical requirements found in 40 CFR 265 .

\subsubsection{Sampling and Analysis Program}

Sampling and analysis activities are conducted based on requirements set forth in the U-12 Crib groundwater monitoring plan (WHC 1990) and as modified in the assessment plan (WH 1993). Currentily the monitoring network consists of five shallow monitoring wells (one upgradient and four downgradient) completed at the top of the unconfined aquifer (Ffgure 4.2-1 and Table 4.2-1). Wel1s installed for the U-12 Crib RCRA network in 1990 were first sampled in September 1991. The ffrst ful year of quarteriy sampling was completed by CY 1993. The site was ininediately shifted into assessment evaluation monitoring status (DOE-RL 1994a) and network wells are sampled quarterly for constituents listed in Tab7e 4.2-2 (40 CFR 265). S1te-specific parameters were selected based on evaluations of the history of waste disposed of to the site and surrounding cribs, and groundwater monitoring results. Additional 
DOE/RL-96-01, REV. O

analyses associated with a particular analytical method are also included in the data tables.

As a result of contamination detected in wells 299-W22-41 and 299-k22-42, two wells were added to the network in $C Y 1993$ to provide more detailed information for plume evaluation and source determination. These two wells, 299-W22-22 and 299-W22-23, were sampled for onTy one year. Deteriorating casing conditions and substandard construction materjals in these wells caused questionabie results, so both wells were dropped from the 1995 sampling schedule.

Based on data associated with the Phase I assessment program at the U-12 Crib, well 699-36-70A was added to the network to determine the extent of contaninant migration. We11 699-36-70A was installed approxtmately $914 \mathrm{~m}$ (3,000 ft) downgradient of the $\mathrm{V}-12$ Crib just beyond the 200 West Area fence bottndary. WeTT construction information, including as-built diagrans, geologic and geophystcal data, and aquifer test results, is documented in willians (1995).

A]l RCRA-compliant wells in the network have been sampled at loast once for the complete 40 CFR 264, Appendix IX list of constituents. Al] availabie data results are presented in the guarterly reports for RCRA groundwater monitoring data (OOE-RL I995a, 1995b, 1995c, and 1995d).

\subsubsection{Groundwater Chemistry}

The groundwater below the $\mathrm{U}-12 \mathrm{Crib}$ has been monitored and analyzed as part of the RCRA program since Septenber 1991. " The site-specific waste parameters selected for the U-12 Crjb are listed in Table 4.2-2 and include tritium, ${ }^{9} \mathrm{Tc}$, and ${ }^{129} \mathrm{I}$. Nttrate, ${ }^{9} \mathrm{Tc},{ }^{129} \mathrm{I}$, and tritium have been detected repeated $1 y$ and are being investigated to deterwine $1 f$ the $U-12$ Crib is the source.

Summary and interpretation of the cheajcal and radiological results are being completed for all past data results and are evaluated with timeconcentration plots found in Section 4.2.4.1. Only those constituents that ray have a significant impact on the quality of the groundwater are discussed. A fina] assessment report originally scheduted for September 1995 has been deferred unti1 CY 1996.

4.2.4.1 Concentration Histories of Waste Indjcators: Specific conductance has exceeded the critical mean ( $457.8 \mu$ liho/cn) in downgradient wells 299-W22-4I, 299-W22-42, and later in 699-036-70A since groundwater monitoring began (Figure 4.2-2). Nitrate is the only constituent with signifjcantly consistent and elevated concentrations in the downgradient wells (Figure 4.2-3) and is probably the source of the elevated specific conductance. Initial data evaluation suggests that the $\mathrm{U}-12$ Crib nay be a source of this contamination. Documented releases of nitric acid waste to the J-12 Crib during its operation substantiate this interpretation.

Nitrate concentrations have continued to exceed the $45,000-\mathrm{ppb}$ DWS and are more than 10 times above the average background value. The elevated concentration trends (see Figures $4.2-2$ and $4.2-3$ ) in the four downgradfent 
wells have been changing since monitoring began. Vadose zone modeling and studjes have shown that liquid travel times to the aquifer could take many years. Therefore, it is possible that effluent disposed of during the last years of active crib life (effluent disposal ceased in 1983) is still seeping into the aquifer, but at a slower rate than when a driving head was available. These slugs and seeps of effluent are believed to still be anving downward and way be contaminating the aquifer. The fluctuations in concentration are a result of this noncontinuous effluent migration and of heterogeneities within the aquffer. Concentration trends are expected to remain the same in the short term and eventually decl ine as the vadose zone drains.

Gross beta contamination has also been detected in downgradient weils 299-422-41, 299-422-42, and new assessuent we11, 699-36-70A since monitoring began (Figure 4.2-4). Technetiun-99 is the only specific betaemitting radionuclide with concentrations above background (Figure 4.2-5). Gross beta is a weak indicator of Tc (a $1: 5$ activity retationship). Compartson of the concentration trends reveals this relationship and substantiates ${ }^{9}$ Tc as the primary source of the elevated beta values. Concentration trends of both beta and ${ }^{5} \mathrm{Tc}$ throughout the monitoring Tife have fluctuated somewhat but appear to be relatively stable. As with the nitrate plume, the concentrations are expected to decrease over tine.

Concentrations of tritiun in we11 299-W22-42 indicate that jt could be a contamfnant released from the $\mathrm{U}-12 \mathrm{Crib}$. However, data collected last year in renediated weIT 299-W22-23 (upgradient) suggest that there may also be an upgradient source for this constituent (Figure 4.2-6). Tritium wij] also be evaluated as part of the $\mathrm{U}-12$ Crib assessment. Tritiun is a documented (WHC 1990) component of the effluent disposed of at the facility. The new assessment we17, 699-36-70A, has tritium values that are over $300,000 \mathrm{pCi} / \mathrm{L}$, we]] over background and DWS. These new data will be useful in updating the tritium plume map and will provide another point of control.

The concentration trends for ${ }^{129}$ I in wet 15 299-W22-23 and 699-36-70A relative to the trends for the other wells indjcate that these wells are probably detecting ${ }^{12}$ I released from an upgradient source southwest of the U-12 Crib (Figures $4.2-7$ and $4.2-13$ ). This constituent is al so evaluated as part of the $\mathrm{j}-12 \mathrm{Crib}$ assessment. Iodine- 129 is not a documented component of the effluent disposed of at the facility.

Carbon tetrachloride concentrations have predoninantiy exceeded the DWS (5 ppb) in all network wells since RCRA monitoring began. Because this constituent is not a contaminant emanating from the $U-12 \mathrm{Crib}$ and is being sampled in support of other CERCLA programs, it was dropped from the 1995 RCRA sagpling schedule.

4.2.4.2 Distribution of Maste Constituents. It is pessible that signiffcantiy higher undetected levels of nitrate contanination 1 ife downgradient of the current U-12 Crib monitoring network, given the history and timing of effluent volumes that have been disposed of at the facility (see Section 4.2.1). Preliwinary contaminant transport medeling indicates that a signtficant portion of the nitrate plume nay be located beyond the three downgradient polnt-of-compltance weils. Current downgradient well spacing is very limfted and the spatial coverage available for accurate plume mapping in the area may be inadequate. It is possible that the U-12 Crib contributed a 
significant portion of nitrate to the groundwater and the concentrations are mixed with and indistinguishable from the regionally extensive nitrate plume (see figure 4.2-10). Data from well 699-36-70A support this interpretation and wili be used to identify future groundwater monitoring well locations as necessary. All groundwater and contaminant modeling results will be presented in the $\mathrm{v}-12 \mathrm{crib}$ assessment report.

Monftoring at downgradient well 299-W22-40 has not detected any nitrate contamination; the well is alost likely outsjde the flow path of the U-12 Crib nitrate plume. This is supported by mapping flow lines on the water table map. The spatjal relationship of the monitoring network, with respect to the detected contamination, indicates that the current source is restricted and of relatively low volume and high concentration.

One full year's worth of data (four quarters) has now been collected from assessment well 699-36-70A. This well was installed to determine the extent of contaminants migrating downgradient frow the U-12 Crib. Spectfic conductance has been above the critical mean, averaging over $540 \mathrm{mmhos} / \mathrm{cm}$ during 1995. Nitrate was consistently elevated above the DWS, averaging $150,000 \mathrm{ppb}$. These data substantiate prelioinary travel time estimates for a plume emanating from the U-12 Crib. These estimates will be prosented in detait in the assessont report. This new well provides data that change the earlfer interpretation of the nitrate pluate. The arsas within the $100 \rightarrow \mathrm{pCi} / \mathrm{L}$ contour are much greater than prevlously mapped (Figure 4.2-10). The "Tc plume map, presented in Figure 4.2-11, w113 be modffied in the future to incorporate the new data provided by woll 699-36-70A. The area of the plume, like that for the nitrate plume, will likely be enlarged. These constituents will be monitored and evaluated as part of the assessment investigation.

Technetiun-99 exhibits a distribution similar to nitrate. Time/ concentration plots (figure 4.2-5) raflect a consistent, low-volume source emanating from below the U-12 Crib. A review of the regional technetjum plume (see Figure 4.2-11) reveals an asymetrical plume shaped similarly to the nitrate plume. The skewed portion tn the plume is toward the U-12 Crib, which may hint at a larger plune downgradient of the current monitoring system.

Review of the tritiua plume map, Ffgure 4.2-12, reveals that a regionally extensive plume exists southeast and adjacent to the groundwater flow paths from the $\mathrm{U}-12 \mathrm{Cr} 1 \mathrm{~b}$. The skewed nature of this plume, which encompasses the U-12 Crib, the elevated tritiun activity to weIt 299-w22-42 (Figure 4.2-6), and documented trition disposal (hic 1990) to the crib indicate that the U-12 Crib may also be contributing tritium to the groundwater that is mixing with the larger plume.

\subsubsection{Groundwater FTow}

4.2.5.1 Groundwater Flow Direction. Figure 4.2-8, the hydrograph of the U-12 Crib groundwater monitoring network, depicts the drop in the water table beneath the crib since the start of RCRA monitoring. The groundwater below the U-12 Crib has declined over $0.45 \mathrm{~m}(1.5 \mathrm{ft}$ ) since the last annual report. This indicates a slight increase in the rate of decline over last year (DOE-RL 1994a). Water levels are reported in previous quarterly reports. Figure 4.2-9 depiets the contoured water table elevations for June 1995 . The 
groundwater gradient indicates a flow direction to the east-southeast that cojncides with the regional groundwater map presented in Figure 2-4. This flow direction remains unchanged from 1994 to 1995. Based on this information, the wells are appropriately located to detect continuing contaminant $\mathrm{d} f$ scharges from the $\mathrm{J}-12 \mathrm{crjb}$. The expected high values of nitrate and $"$ Tc detected in the new assessment wo $11,699-36-70 \mathrm{~A}$, are indicative of plumes that have migrated from the site. This supports the conclusion that groundwater fTow at the $\mathrm{U}-12 \mathrm{Cr}$ ib has not changed significantly. This welt wit support the location of additional assessment wolls, as needed, in the future.

4.2.5.2 Groundwater Flow Rate. The rate of groundwater fiow beneath the $\mathrm{U}-12$ crib is about the same as last year. The upper aquifer is composed of silty, sandy gravel that exhibits variable or heterogeneous flow conditions. Evaluation of the hydraul ic gradient over the past several years reveals a sight decrease in the decline rate. The average gradient messured across the $\mathrm{J}-12 \mathrm{Cr}$ b in 1995 was 0.0021 .

Based on Trent (1992), the upper unconflned aquffer in the area surrounding the $\mathrm{U}-12 \mathrm{Crib}$ is characterized by relatively low hydraulic conductivities (K) ranging from to 1 to $12 \mathrm{n} / \mathrm{d}(5$ to $40 \mathrm{ft} / \mathrm{d}$ ). The range of $K$ for the U-12 Crib wells (Goodutn 1990) is from 2 to $13 \mathrm{~m} / \mathrm{d}$ (8 to $44 \mathrm{ft} / \mathrm{d}$ ).

Groundwater velocity can be calculated based on the Darcy average linear groundwater flow equation

$$
V=\{K(1)\} / n_{e}
$$

where:

$$
\begin{aligned}
V & =\text { average linear velocity } \\
K & =\text { geonetric mean value of hydraulife conductivity } \\
i & =\text { hydraulic gradient } \\
n_{e} & =\text { effective porosity. }
\end{aligned}
$$

The geowetric'mean value of conductivity (K) calculated for the network $156.2 \mathrm{~m} / \mathrm{d}(20.2 \mathrm{ft} / \mathrm{d})$. Effective porasity is estiniated at 0.2 and the hydraulic gradient is calculated to be 0.0021 from June 1995 water table results. The calculated average veiocity for the $\mathrm{U}-12 \mathrm{Crib} 1 \mathrm{\$} 0.07 \mathrm{n} / \mathrm{d}(0.21$ ft/day). This is a $\$ 1$ ight decrease in the groundwater veloctly compared to 1ast year.

Average groundwater velocitios have a] so been estinlated based on pitume transport velocities. The ${ }^{99}$ Tc plume has a calculated average velocity of $0.1 \mathrm{~m} / \mathrm{d}(0.32 \mathrm{ft} / \mathrm{d})$. Th\$s velocity is within the reported range and supports the groundwater velocity determination at the $\mathrm{U}-12 \mathrm{Crib}$, whtch is corroborated by the new assessment well (699-36-70A) results and by calculated contaminant arrival tines.

4.2.5.3 Evaluation of Nonftoring Ne]1 Network. Because the groundwater flow direction is unchanged, the wells are appropriately located to monitor 
releases and assess contaminant discharges from the $\mathbb{V}-12$ Crib. The original detection monitoring network at the $\mathrm{U}-12 \mathrm{Crib}$ was designed based on the Honitoring Efficiency Model (Jackson et a1. 1991) to provide leak detection sonitoring efficiency of 90 percent.

Water levels are measured regularly and the adeguacy of the existing monitoring network is evaluated according to the ability of the downgradient wells to detect contanination at the point of compliance. Declining water Tevels at the U-12 Crib are not expected to jeopardize the ability to sample the network

Continued assessmant at the $\mathrm{U}-12 \mathrm{Cr}$-1b wil require the use of the groundwater flow meter to confirm flow directions before completing the assessment report. Addittonal wel] installations or network uodifications may be required as a result of the flow meter testing. These will be planned and integrated wt the CERCLA remediation activfties in the area.

\subsubsection{References}

40 CFR 264, "Standards for Owmers and Operators of Hazardous Waste Treatment, Storage, and Disposal Facilities," Code of Federal Regulations, as antended.

40 CFR 265, "Interfm Status Standards for Oumers and Operators of Hazardous Waste Traatment, Storage, and Disposal Facilities," Code of Federal Regutations, as amended:

8hI, 1993, Borehole Sumbary Report for the 200-Up-2 Operable Unit, 200 West Area, BHI-00034, Rev. 0, Bechtel Hanford, Inc., Rjehland, Washington.

Coaprehensive Enviromental Response, Compensation, and liability Act of 19g0, 42 USC 9601 et seq.

DOE-RL, 1995a, Quarterly Report for RCRA Groundwater Monitoring Data for Period October 1, 1994 through December 30, 1994, DOE/RL-94-36-4, U.S. Department of Energy, Richland Operations Office, Richland, Washington.

DOE-RL, I995b, Quarter7y Report for RCRA Groundwater Nonitoring Oata for Perfod January 1, 1995 through March 31, 1995, D0E/RL-95-69-1, U.S. Department of Energy, Richland Operations Office, Richland, Washington.

DOE-RL, 1995c, Quarterly Report for RCRA Groundwater Nonitoring Data for Period Aprif 1, 1995 through Jwe 31, 1995, 00E/RL-95-69-2, U.S. Department of Energy, Richland Operations Office, Richland, Washington.

DOE-RL, 1995d, Quarterly Report for RCRA Groundwater Nonitoring Data for Period July 1, 1995 through September 30, 1995, DOE/RL-95-69-3, U.5. Departiment of Energy, Rtchland Operations Office, Richland, Hashington. 
Ecology, EPA, and DOE, 1994, Hanford Federal Facility Agreement and Consent Order, Fourth Aoendaent, Washington State Department of EcoTogy, U.S. Environmental Protection Agency, and the U.S. Department of Energy, Digmia, Nashington.

Jackson, R. L., C. M. Ejnbereger, R. B. Mercer, and C. R. Wilson, 1991, Efficiency-Based Groundwater Monitoring Metwork Design for Hazarfous Waste Sites, WHC-SA-1157-FP, Westinghouse Hanford Coupany, Richland, Washington.

Drese1, P. E., P. D. Thorne, S. P. Luttre11, B. A. Gillespie, W. D. Webber, J. K. Mertz, J. T. Rieger, K. A. Channess, 5. K. Wurstner, B. E. Opitz, 1995, Hanford Site Groundwater Nonitoring for 1994, PNL-10698, Pacific Horthest National Laboratory, Richland, Nashington.

Resource Conservation and Recovery Act of 1976, 42 USC 6901, at seq.

Trent, S. J., 1992, Hydrologic Hodel for the 200 Nest Groundwater Aggregate Area, WHC-SD-EH-TI-014, Rev. 0, Nestinghouse Hanford Company, Richi and, Washington.

MHC, 1990, Interin-Status Ground-Water Honitoring Plan for the 2I6-U-12 Crib, WHC-SD-EN-AP-019, Rev. 0, Hestinghouse Hanford Corpany, RichTand, Washington.

WHC, 1993, Interio-Status Ground-Water Quality Assessment plan for the 216-U-12 Crib, WHC-SD-EK-AP-103, Rev, 0, Westinghouse Hanford Company, Richiand, Hashington.

Wil1ians, B. A., 1995, Borehole Data Package for the 216-ل-12 Crib Welf 699-36-70A, Calendar Year 1994, WHC-SD-EN-0P-091, Rev. 0, Uestinghouse Hanford Company, Rjchland, Washingtor. 
DOE/RL-96-01, REV. 0

Figure 4.2-1. We11 Location Map for the 216-U-12 Crib.

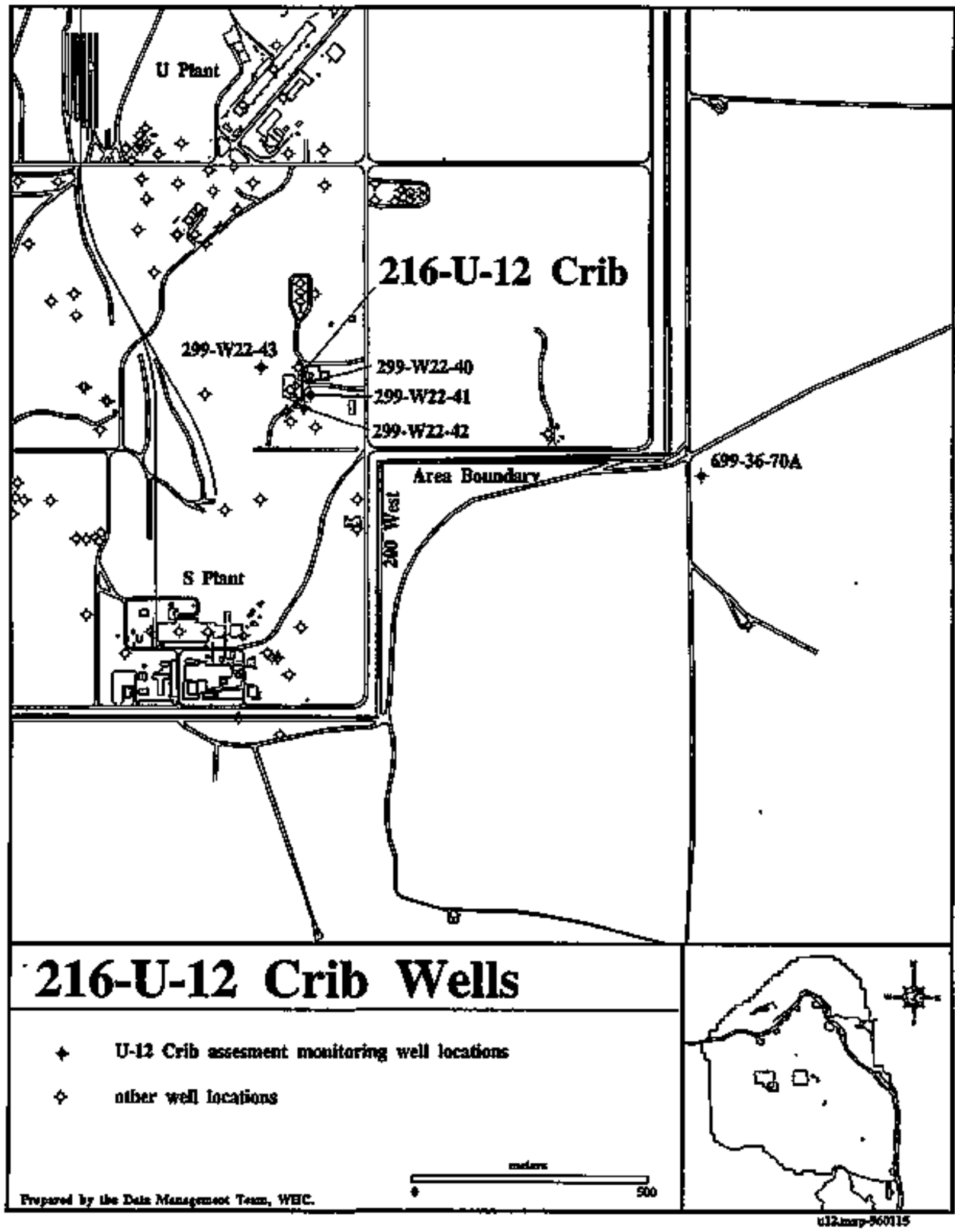


DOE/RL-96-01, REV. 0

Figure 4.2-2. Specific Conductivity at the 216-J-12 $\mathrm{Crib}$.

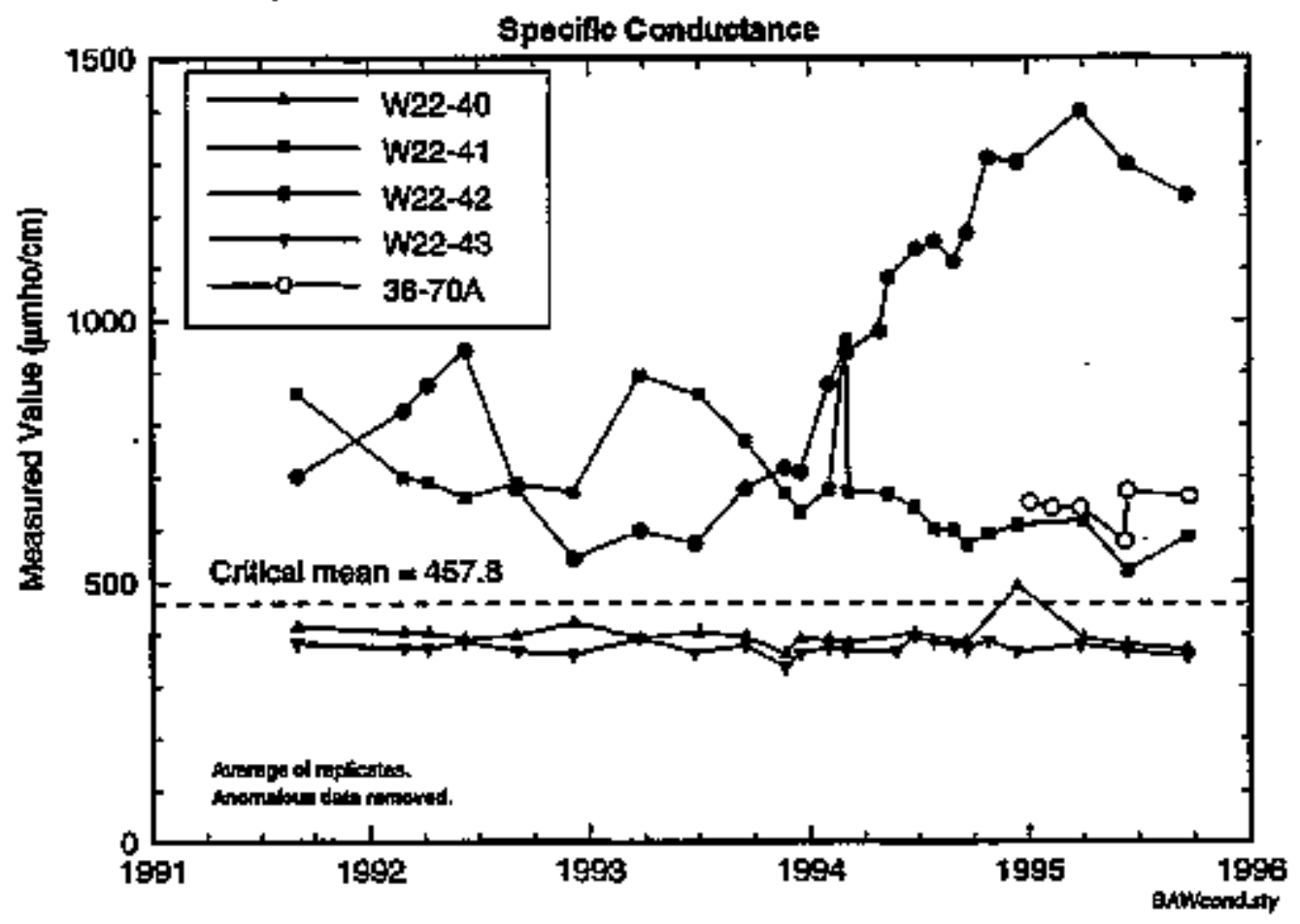

Figure 4.2-3. Nitrate concentrations at the 216-0 $-12 \mathrm{Cr}-\mathrm{b}$.

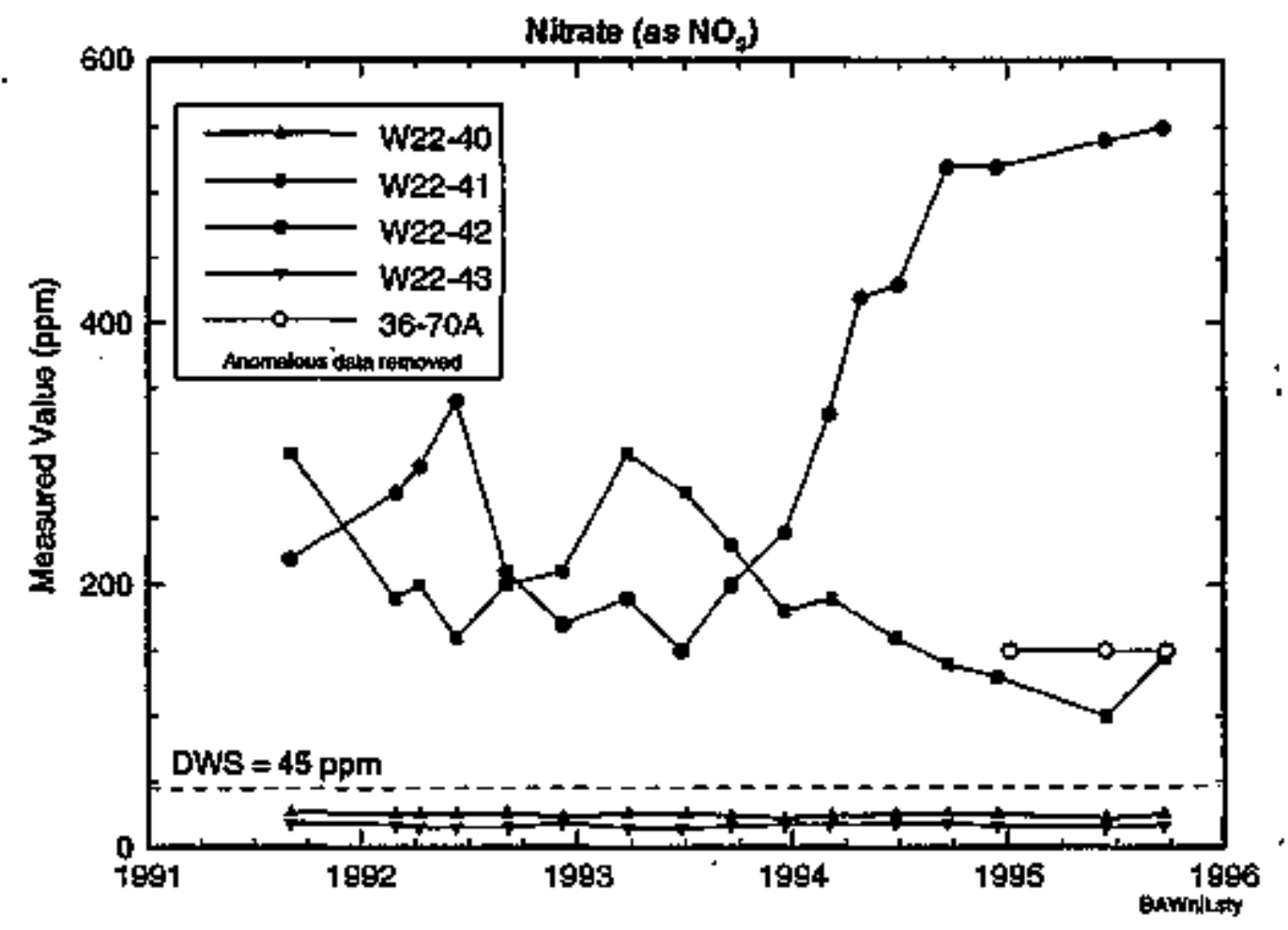


Figure 4.2-4. Gross Beta Activity at the 216-U-12 Crib.

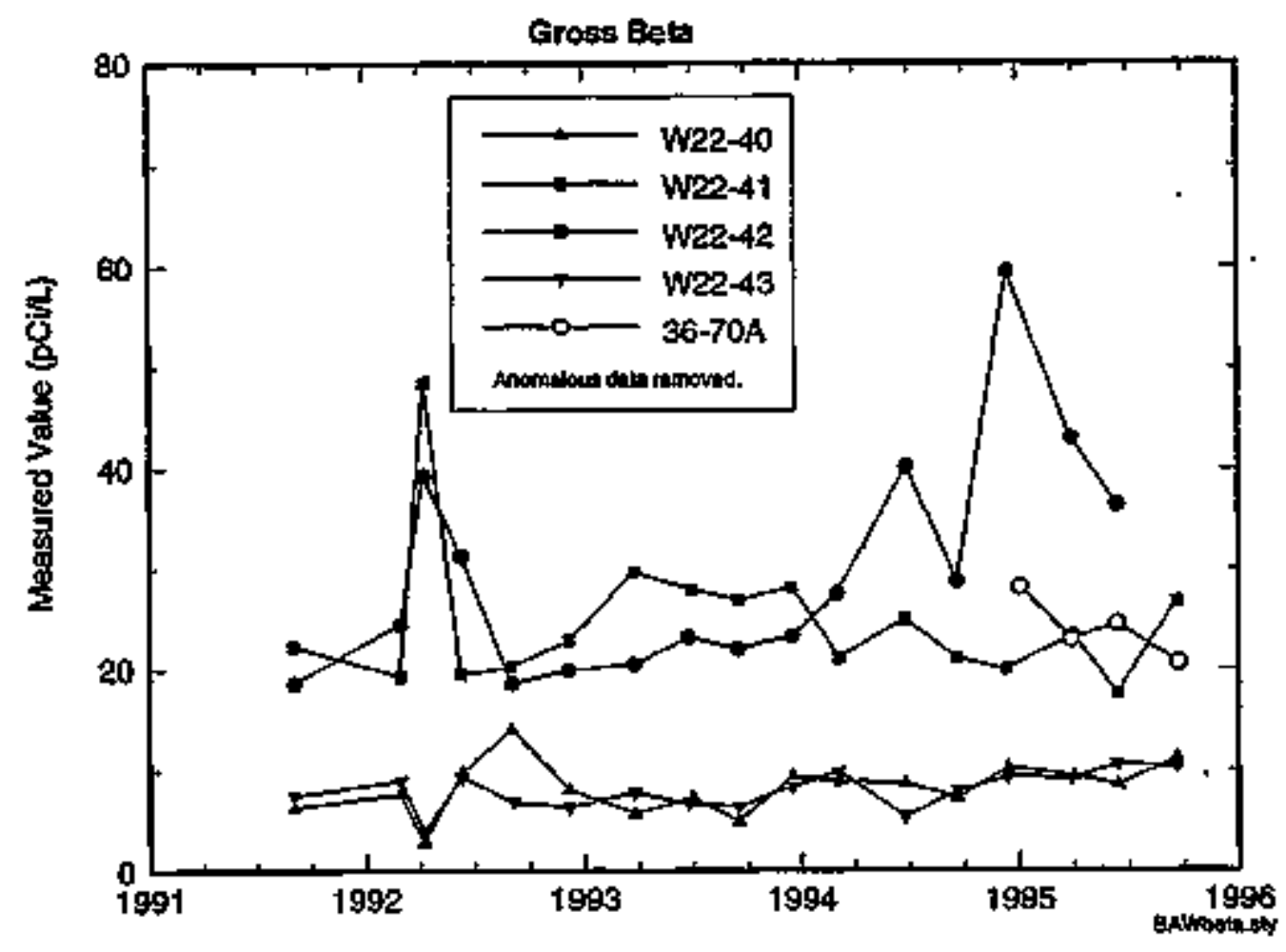

Figure 4.2-5. Technetium-99 Activity at the 216-y-12 Crib.

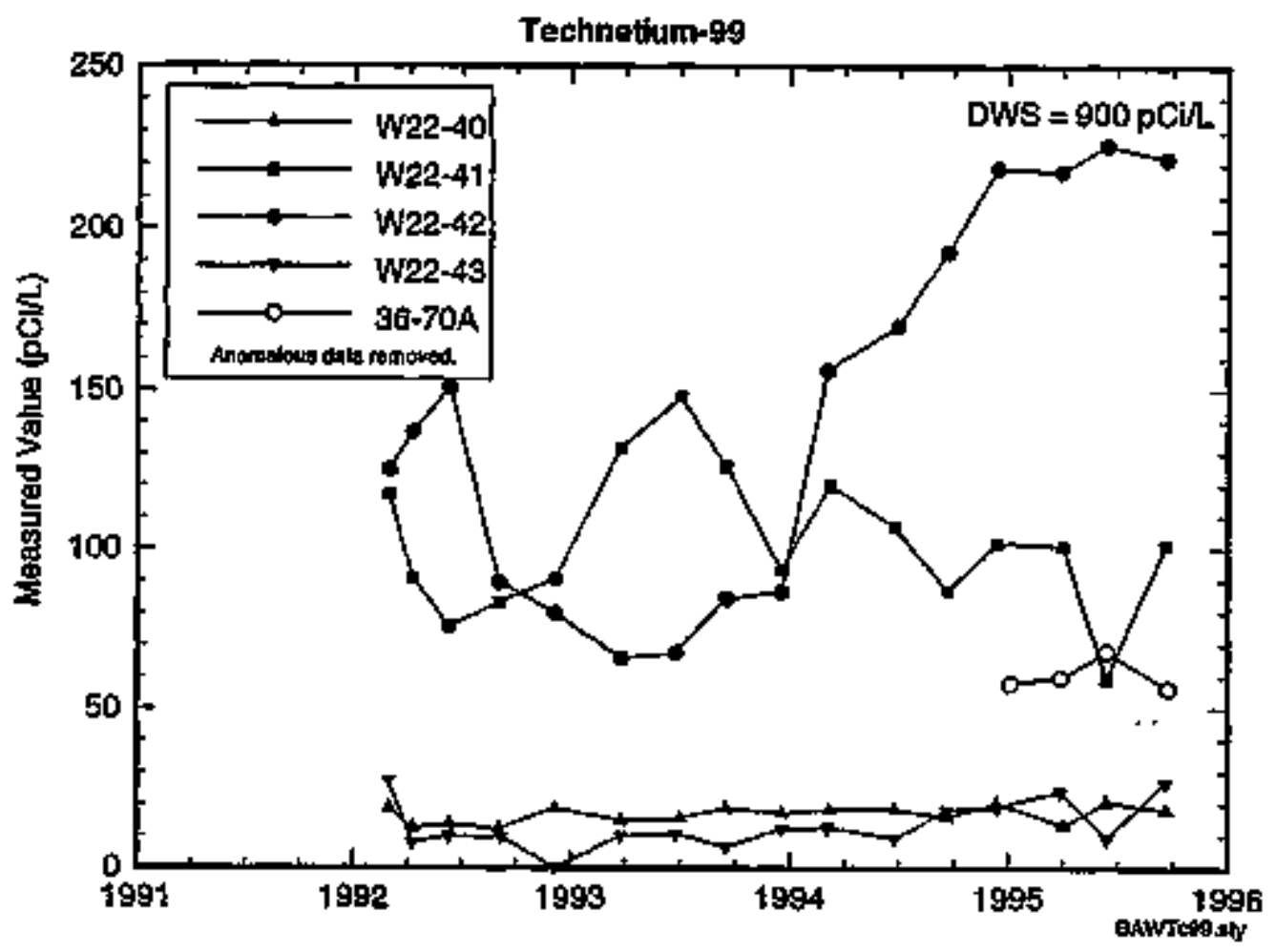


Figure 4.2-6. Tritiun Activity at the 216-U-12 Crib.

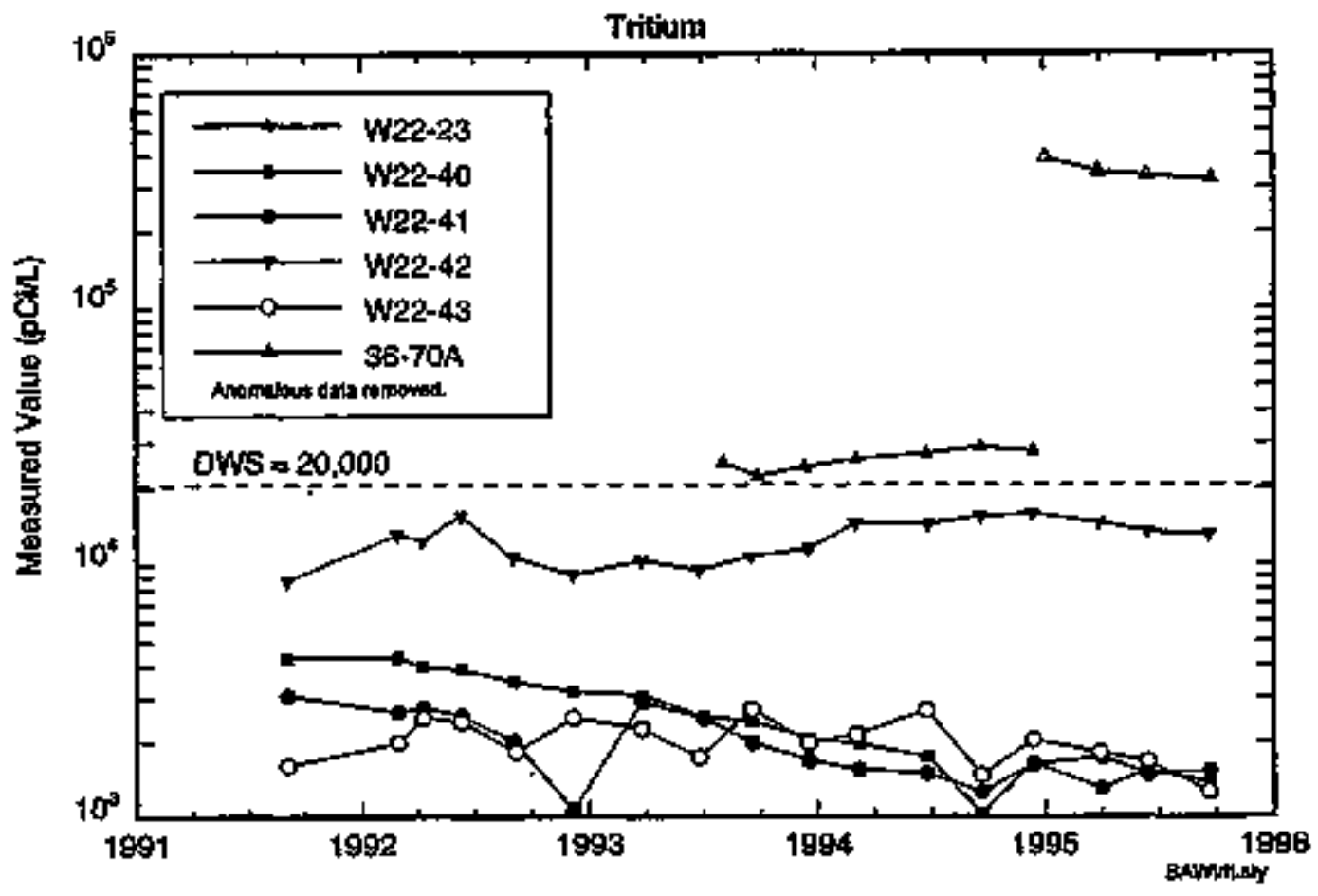

Figure 4.2-7. Iodine-129 Concentrations at the 216-U-12 Crib.

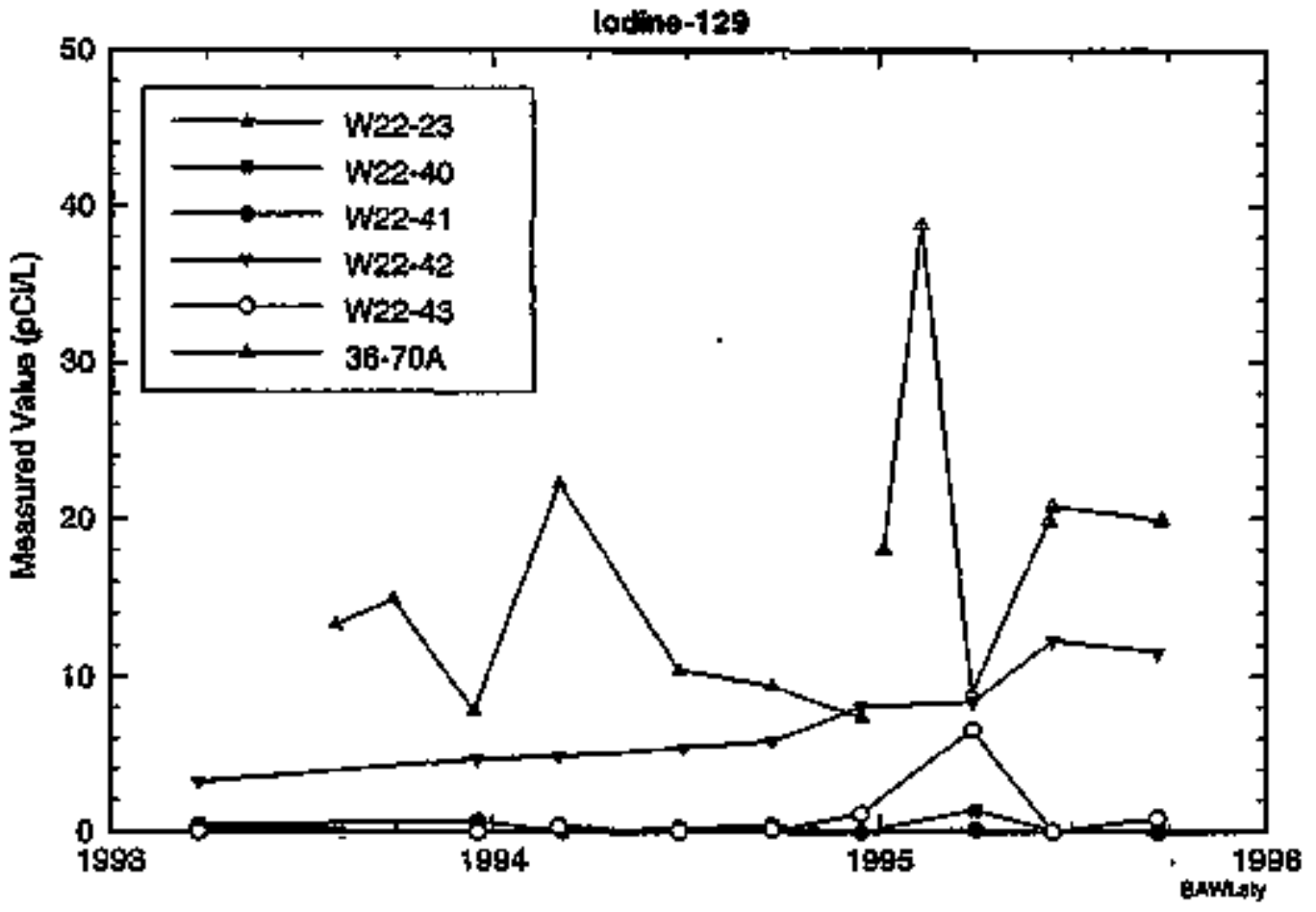


Figure 4.2-a. Composite Hydrograph of Quarterly Water Level Measurements (feet above sea level) at the 216-U-12 Facility.

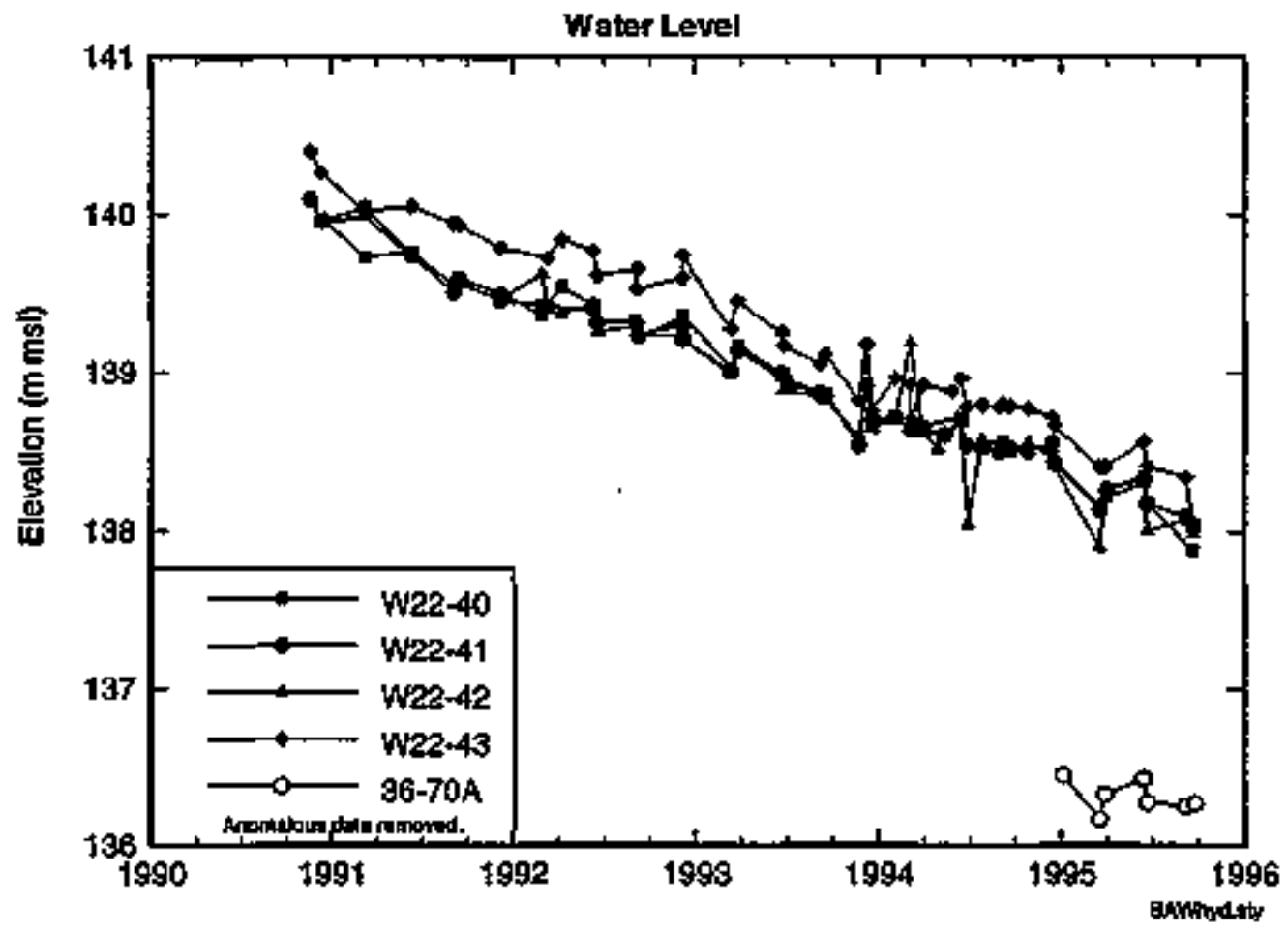


Figure 4.2-9. Contour Map of the 216-U-12 Crib, June 1995.

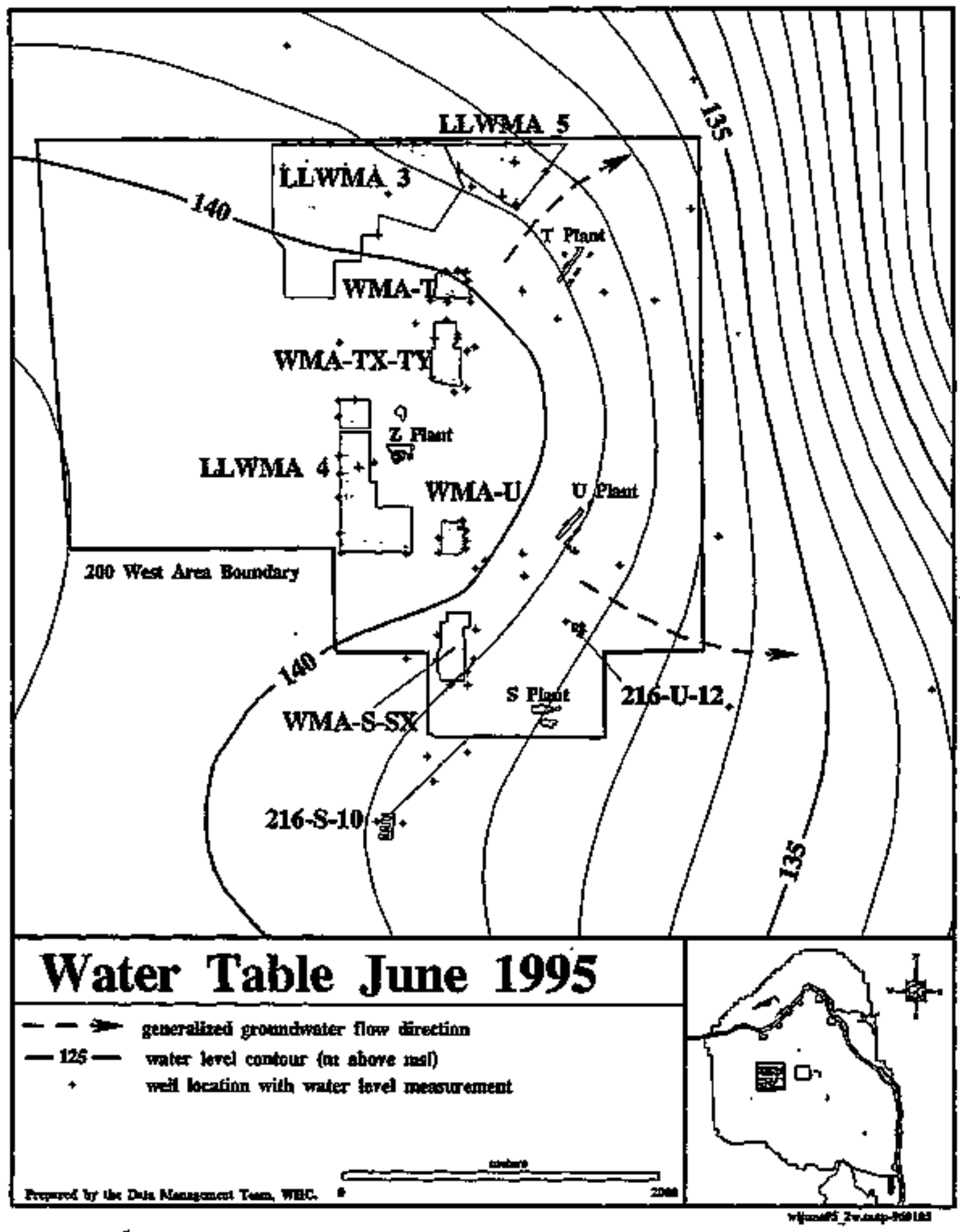


Figure 4.2-10. Nitrace Distribution in the Uppermost Aquifer, 200 West Area, 1994.

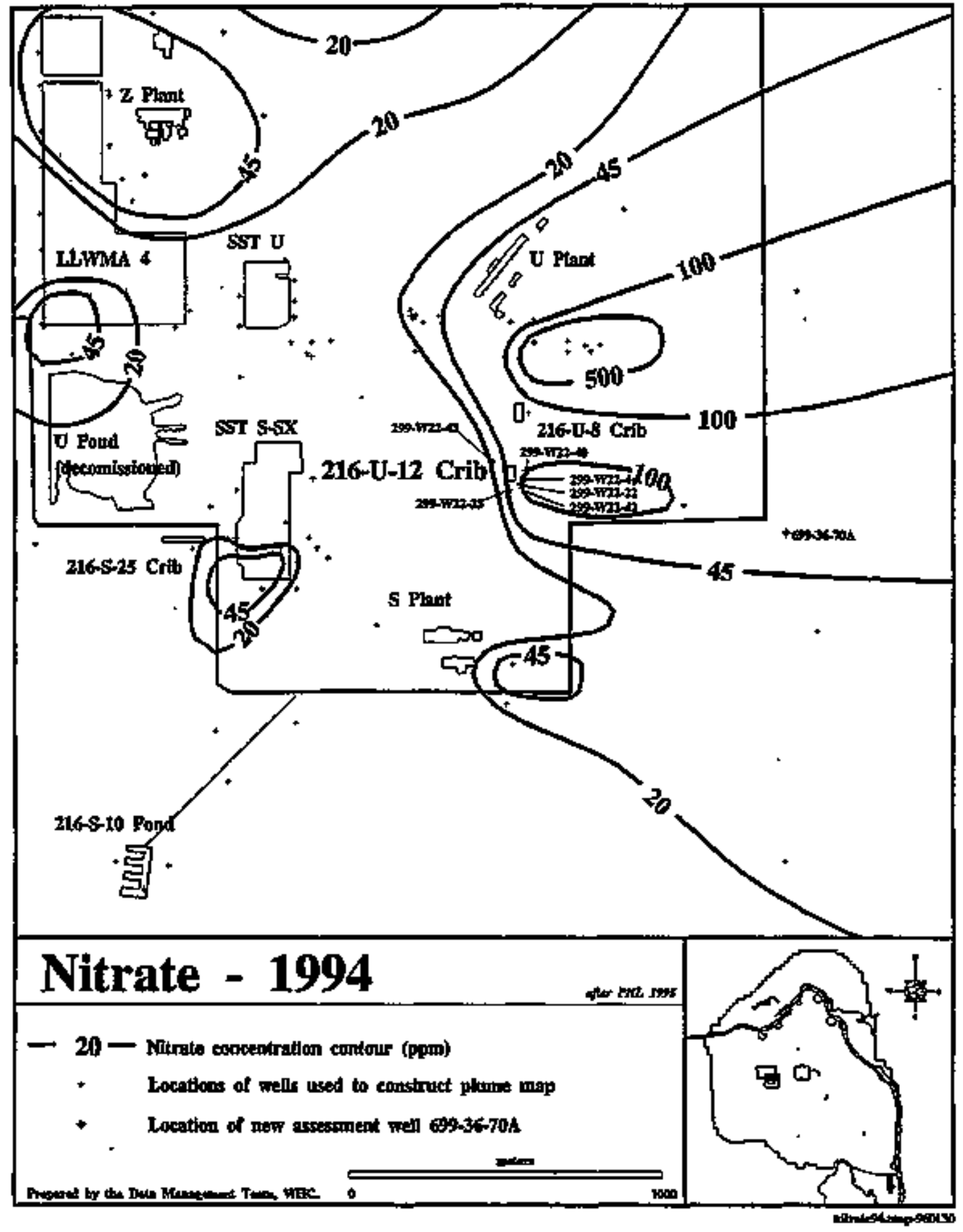


Figure 4.2-1. Technetium-99 Distribution in the Uppernost Aquifer, 200 West Area, 1994.

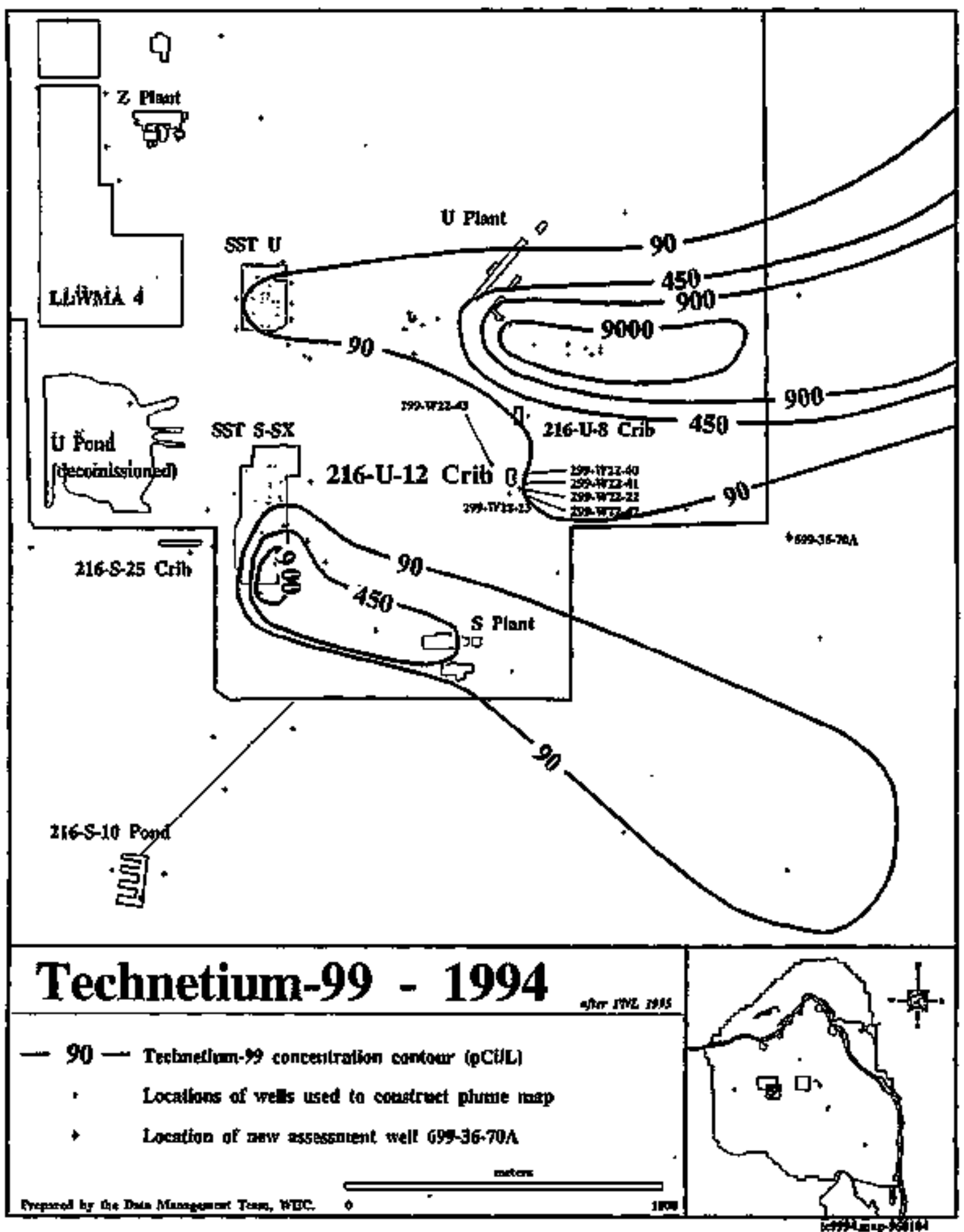


Figure 4.2-12. Trittum Distrtbution in the Uppermost Aquifer, 200 West Area, 1994.

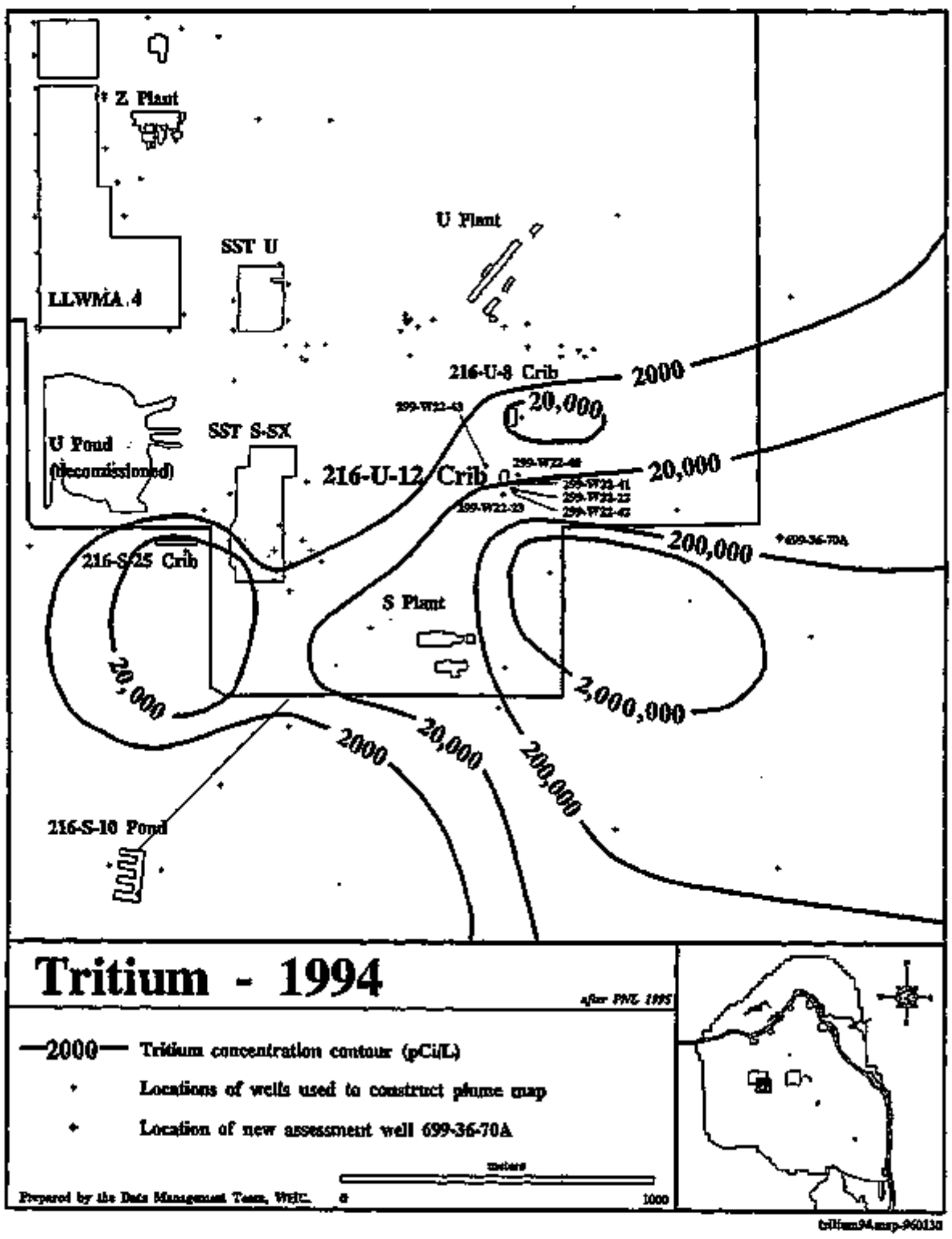


DOE/RL-96-01, REV. 0

Figure 4.2-13. Iodine-129 Distribution in the Uppermost Aquifer, 200 West Area, 1994.

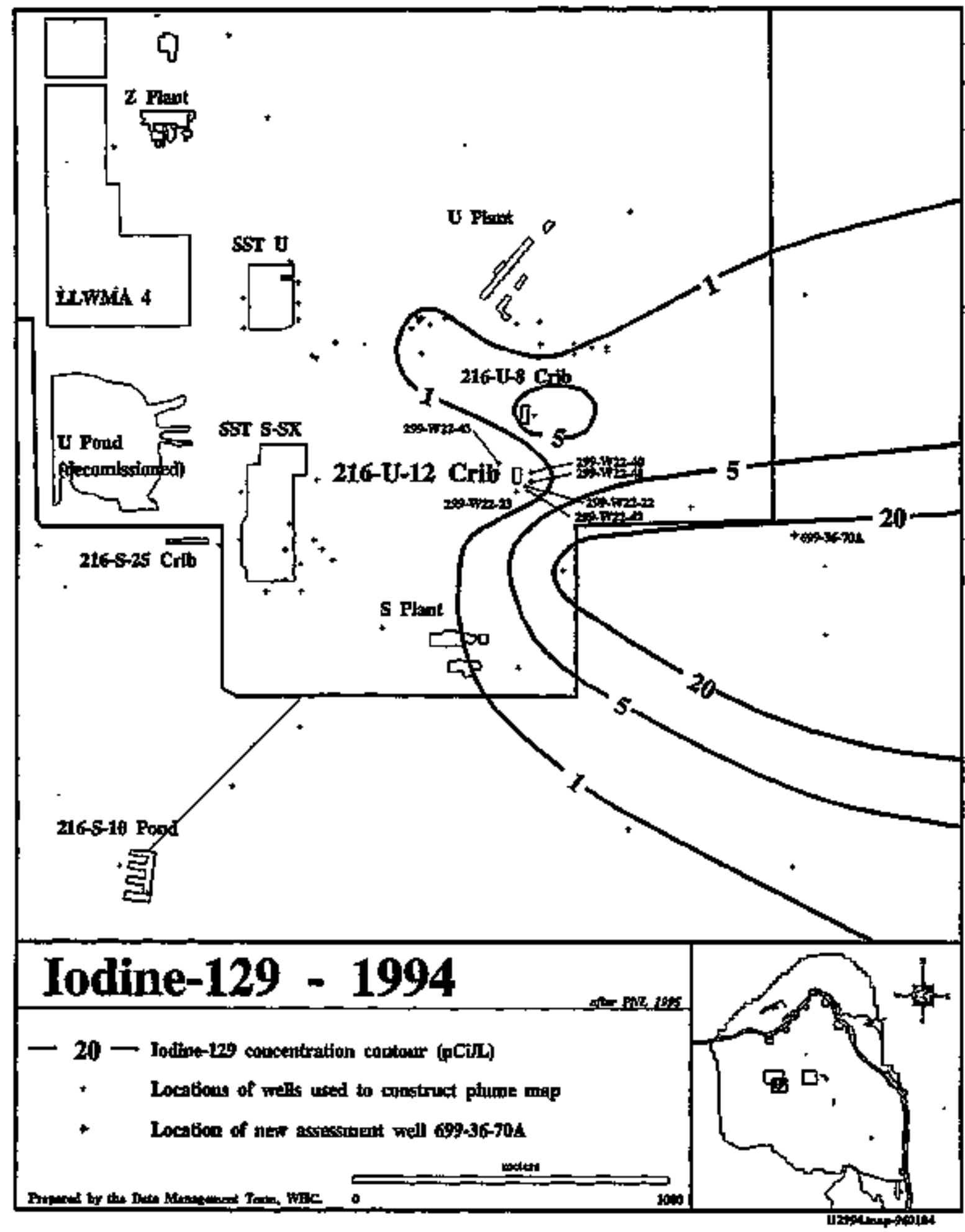


Table 4.2-1. Groundwater Monitoring Network.

\begin{tabular}{|c|c|c|c|c|c|}
\hline Well & Aquifer & $\begin{array}{l}\text { Sampling } \\
\text { frequency }\end{array}$ & $\begin{array}{l}\text { Vater } \\
\text { levels }\end{array}$ & $\begin{array}{c}\text { Well } \\
\text { standards }\end{array}$ & $\begin{array}{c}\text { other } \\
\text { networks }\end{array}$ \\
\hline $299-122-43^{50}$ & Top of unconfined & 9 & $H$ & RCRA & $\begin{array}{l}\text { Operational } \\
\text { and } \\
\text { Sitewide }\end{array}$ \\
\hline $299-w 22-40^{96}$ & Top of unconfined & 9 & $H$ & RCRA & $\begin{array}{l}\text { Operational } \\
\text { and } \\
\text { Sitewide }\end{array}$ \\
\hline $299-w 22-41^{90}$ & Top of uneonfined & 9 & $M$ & RCRA & $\begin{array}{l}\text { Operational } \\
\text { and } \\
\text { Sitewide }\end{array}$ \\
\hline $299-422-42^{90}$ & Top of unconfined & $\mathbf{Q}$ & 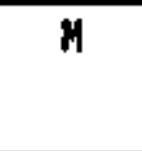 & RCRA & $\begin{array}{l}\text { Operational } 1 \\
\text { and } \\
\text { Sitewide }\end{array}$ \\
\hline $699-36-70 A^{94}$ & Top of unconfined & $Q$ & H & RCRA & $\begin{array}{l}\text { Operational } \\
\text { and } \\
\text { sitewide }\end{array}$ \\
\hline
\end{tabular}

Motes: Shading denotes upgradient wells. Suparscript following well number denotes the year of installation.

$H=$ frequency on a monthly basis.

$Q=$ frequency on a quarterly basis.

RCRA = well is constructed to RCRA-specified standards. 
DOE/RL-96-01, REV, 0

Table 4.2-2. Constituents Analyzed at the 216-U-12 Crib.

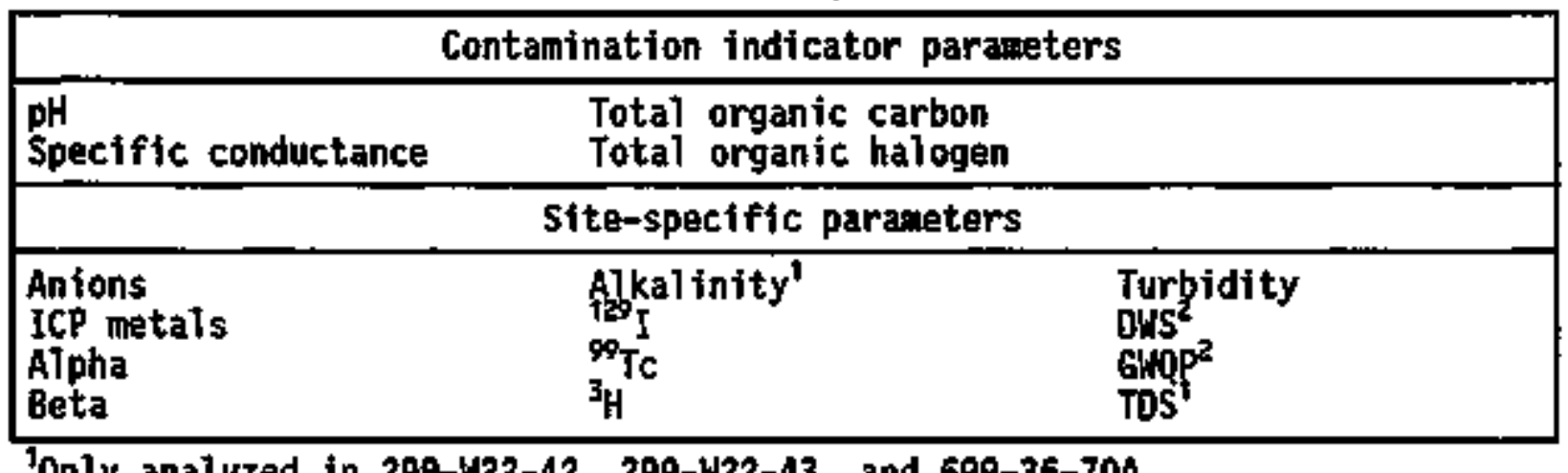

${ }^{9}$ Only analyzed in 299-W22-42, 299-W22-43, and 699-36-70A.

only analyzed for in 699-36-70A.

DWS = drinking water standards.

GWQP = groundwater quai ty parameters.

TDS - total dissolved solids.

$4.2-20-$ 


\section{CONTENTS}

4.3 216-8-3 PONO SYSTEM . . . . . . . . . . . . 4.3-1

4.3.1 Facility overview ............. 4.3-1

4.3.2 Summary of 1995 RCRA Activities . . . . . 4.3-2

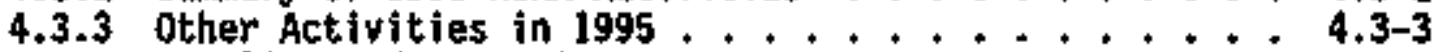

4.3.4 Sampling and Analysis Program .......... 4..... 4-3

4.3.5 Groundwater Cheni stry ............. 4.3-4

4.3.6 Groundwater Flow . . . . . . . . . . 4.3-7

4.3.7 References ................. 4.3-10 
DOE/RL-96-01, REV. 0

\section{LIST OF FIGURES}

4.3-1 Monitoring Mell Locations for the 216-B-3 Pond . . . . . . 4.3-13 4.3-2 Potentiometric Surface Map of the 216-B-3 Pond and Vicinity, June $1994 \ldots . . . . . . . . . .3-15$

4.3-3 Composite Hydrograph for Representative Welis, 216-6-3 Pond : . 4.3-16

\section{LIST OF TABLES}

4.3-1 Monitoring Wells Used for the 216-6-3 Pond Systen . . . . 4.3-17

4.3-2 216-B-3 Pond, 1995 Chemical Constituent List . . . . . . . 4.3-18 
DOE/RL-96-01, REV. 0

\title{
4.3 216-8-3 POHD SYSTEM
}

\author{
D. B. Barnatt \\ Nestinghouse Hanford Company
}

\subsubsection{Faciltty Overvien}

This section summarizes information collected and analyzed in fiscal

year 1995 to describe distribution and concentration of waste constituents in groundwater beneath the 216-B-3 Pond (B Pond) system. The B Pond system is a reguiated wastewater disposal facility for past operations in the 200 East Area of the Hanford Site. Groundwater monitoring under the Resource Conservation and Recovery Act of 1976 (RCRA) was changed from a detectionlevel program to an assessment program in 1990 because of elevated levels of total organic halogen (TOX) in two dorngradient wells. The Ground Water Quality Assessment P7 an for the 216-8-3 Pond Systen was submitted to Ecology as part of the original groundwater monitoring plan (Harris 1990). The assessment plan was Jater supplemented by the Interin-Status Groundwater Monitoring Plan for the 216-8-3 Pond (Sweeney 1995) and the closure/postclosure plan (DOE-RL 1994). The B Pond system is also part of the 200-BP-11 operable unit and the BP-5 and PO-1 groundwater operable units, which are regulated under the Comprehensive Environmental Response, Compensation, and Lfability Act of 1980 (CERCLA) program.

The B Pond system is located east of the 200 East Area and conststs of a main pond and three expansion ponds constructed for wastewater disposal. The main pond, which began receiving effluent in 1945, was located in a natural topographic depression, diked on the eastern margin, covered approximately 14.2 ha (35 acres), and had a maximum depth of about $6.1 \mathrm{~m}(20 \mathrm{ft})$. The 216-B-3A (3A), 216-B-36 (3B), and 216-B-3C (3C) Expansion Ponds were placed into service in 1983, 1984, and 1985, respectively. The 3A and 3B Expansion Ponds are about 4.5 ha (11 acres) in size, and the 3C Expansion Pond is approximately 16.6 ha (41 acres). Water discharged to these ponds infiltrated into the ground and artificially recharged the underlying aquifer. Details of the operation of these ponds are presented in DOE-RL, (1994).

During 1994, the main pond and 216-B-3-3 Ditch were filled with clean sol1, and all vegetation was removed from the periweter as part of interim stabifization activities. Three ditches (no longer in use) leading to the ponds are included in the systent for groundwater monitoring purposes (F1gure 4.3-1). Beginning in April 1994, discharges to the matn pond ceased, and ail effluents were rerouted to the $3 C$ Expansion Pond via the Project $X-009$ bypass pipeline. Only the $3 \mathrm{C}$ Expansfon Pond now receives wastewater.

Currently, the $3 C$ Expansion Pond receives wastewater primarily from the Plutanium-Uraniutr Extraction (PUREX) Plant and B Plant. Specifically, these streams consist of B Plant cooling water, the 242-A Evaporator (cooling water and steam condensate), 24I-A-702 vessel ventilation system (cooling water), 283-E Water Treatment Facility (filter backwash), and the 284-E Powerhouse (1 fquid effluent). These streams will continue to discharge to the 3C Expansion Pond until october 1997. At that time, they will be rerouted to the 200 Areas TEDF (see Section 4.3.3). 
In the past, the $\mathrm{B}$ Plant steam condensate and chemical sewer and the PUREX plant chemical sawer were al so discharged to the B Pond systent (primarjly the main pond). Potential contaminants that were contained in past waste streaws, which may have entered the groundwater, are discussed in DDE-RL (1994). During 1994, the volume of effluent discharged to the B Pond system averaged approximately $11,000 \mathrm{~L} / \mathrm{min}(3,000 \mathrm{gal} / \mathrm{min})$ or $16,000,000 \mathrm{~L} /$ day $(4,000,000 \mathrm{gal} /$ day). From January 31995 through october 41995 , discharges to the $3 \mathrm{C}$ pond averaged $11,836 \mathrm{~L} / \mathrm{min}(3,127 \mathrm{gal} / \mathrm{min})$ or $17,043,400 \mathrm{~L} / \mathrm{day}$ $(4,502,890 \mathrm{gal} / \mathrm{day})$. The greatest volumes of the 1995 discharges occurred during campaigns of the 242-A Evaporator, and were not evenly spread over the Jantary-0ctober time period.

RCRA groundwater monitoring for the B Pond system began in 1988 with an indicator-ovaluation program and was elevated from a detection-level to an assessment-level program following review of the analytical chemistry results from the first and second quarters of 1990. Concentrations of Tox were above the allowable background concentrations in two of the B Pond wells (see Section 4.3.5). The Ground Water Quality Assessment Plan for the 216-8-3 Pond Syster (Harris 1990) was prepared and submitted to Ecology in May 1990.

The uppermost aquifer beneath the B Pond systen occurs primarjly within sediments of the Ringold Formation, with the Hanford formation comprising the vadose zone under most of the factility. Ringold Formation sediments here consist of the unit $A$ gravel and Tower mud sequence (see Chapter 2.0). The Hanford formation consists of coarse sand and gravel of the lower gravel unit as described by Lindsey et al. (1992).

The Ringold intt A grave] ranges in thickness from about $12 \mathrm{~m}$ (40 ft), in the northwest part of the facilfty, to approximately $30 \mathrm{~m}$ (100 ft) in the southern portion. The Ringold lower mud sequence is not present in the northwest part of the facility, but is approximately $24 \mathrm{~m}$ ( $80 \mathrm{ft}$ ) thick near the southern end of the $3 C$ Expansion Poind. The Hanford formation ranges in thickness from 40 an (120 ft) beneath the $3 C$ Expansion Pond to approximately 50 (160 ft) at the northwest corner of the wain pond (Davis et a1. 1993).

\subsubsection{Summary of FY 1995 RCRA Activities}

The B Pond system continued in a groundwater quality assessment monitoring progran during FY 1995. Mells in the network ware sampled during October, January, and Aprit for the first three quarters of FY 1995, and during August and July for the final quarter. Water levels in all wells were measured four times each quarter, once a month and once during each quarterly sampling event for the first three quarters of FY 1995. Thereafter, water levels were measured once a quarter and during sampling. Beginning with the July-through-September sampling event, the monitoring well network was reduced by 11 downgradient wells. This action was taken to reduce redundancy in the $B$ Pond network and to reassign administration of the three welis near the TEDF to that facility (Also see Section 4.3.4).

In late CY 1994, the RCRA Part A permtt application was modified to distinguish the three expansion ponds ( $3 \mathrm{~A}, 3 \mathrm{~B}$, and $3 \mathrm{C}$ ) from the main pond and the 216-B-3-3 Ditch. This change allowed clean clostre of the expanston ponds to meet Tri-Party Agreement Milestone H-17-10 (Ecology et al. 1994). The 
clean closure did not include radjoactive contaninants included in the 200-BP-11 Operabie Unit. Therefore, the expansion ponds may be included in an upcoming RCRA facility investigation/corrective measures study for the 200-BP-11 operable unit (DOE-RL 1994). The decision on whether to proceed with this characterization will be rendered during FY 1996.

Closure of the main pond and the 216-B-3-3 Ditch is also being coordinated with the closure of the 200-BP-11 operable unit, but as a separate effort from closure of the expansion ponds. Interim stabilization activities for the main pond concluded in September 1994. The main pond was backfilled with cJean soil and vegetation was removed from the perimoter. Stabilization and backfilling of the 216-B-3-3 Ditch also was conpleted in August 1994.

\subsubsection{Other Activities in 1995-Project $t=049 H$}

As mandated by Tri-Party Agreement Milestone M-17-08, the Project W-049H TEDF was built to provide an infiltration site for treated 1 iquid eff]uent from the generating facilities in the 200 Areas. The TEDF allows infiltration of treated (cleaned) water to the soil column. Operation of the facility began in June 1995. Some of the streams formerly discharged to the 3C Expansion Pond were rerouted to the TEDF. Because of its proxinity to the B Pond system, jnformation from the TEDF sjte also enhances knowledge of B Pond hydrogeology and groundwater chemistry. The TEBF and its three monitoring wells are within the area of influence of the groundwater mound from the B Pond systen (Figure 4.3-2). A groundwater monitoring $p$ lan for the TEDF was submitted to Ecology in May 1995 (Barnett et al. 1995) as a condition of the State Waste Discharge Permit (WAC 173-216) required to operate the TEDF.

\subsubsection{Sampling and Analysis Program}

The monitoring well network for the B Pond systen consists of 2 upgradient and I2 downgradient monitoring wells, as show in Figure 4.3-1 and ilsted in Table 4.3-1. Although the three monitoring wells for the nearby TEDF have been reassigned administratively to that progran, results of groundwater chemistry analyses will still be evaluated as pertinent information for the B Pond network. The groundwater monitoring progran for the B Pond System is descrtbed in the groundwater monitoring pian (Sweeney 1995).

The upgradient we11s, in the western portjon of the 200 East Area, were constructed in 1987 and 1988. These two wells and most of the downgradient wells were constructed to monitor the top $4.6 \mathrm{~m}(15 \mathrm{ft})$ of the uppermost aquifer. Four of the downgradient wells (699-40-40A, 699-42-39B, 699-42-42B, and 699-43-416) are screened to monitor a lower horizon within the uppermost aquifer, approximately 7.6 to 15.2 (25 to $50 \mathrm{ft}$ ) below the top of the saturated zone.

The three wells around the W-049H Treated Effluent Disposal Basin are wonitored to extend coverage of the B Pond network to the east. These wells wonitor the upper portion of the uppermost aquffer, which is confined at these 
locations. Al1 three wells are screened within the Ringold Formation anit A, just below the Ringold lower mud sequence confining layer (see Section 4.3.1).

All 12 of the downgradient monttoring wells for the B Pond System and the three wells at the TEDF neet the regulatory criteria for Jocation downgradient from the facility because of a radia] groundwater flow pattem directed away from the pond syster. This pattern is induced by groundwater mounding from past operations (see Section 4.3.6). Because of this condition, no upgradient wel1, in the strict sense, could be placed within the immediate vicinity of the B Pond facjlity. Ljpgradient weils 299-E18-1 and 299-E32-4 were selected to represent groundwater chenistry unaffected by B Pond. The wells are located as near to $B$ Pond as possible, but renain outside the influence of the $B$ Pond growndwater mound, as indicated by regional contaminant plume maps (e.g., Law et a1. 1987, Johnson 1993).

As a result of the past several years of groundwater monitoring at the B Pond System, several wells in the network were deternined to be redundant or no longer critical to adequate monjtoring. Thus, the number of doungradient wells sampled was reduced from 23 to 12 . Also, several constituents that were regularly sought in analyses were deleted from the constituent list. The constituents that were elininated were determined to occur in insignificant quantities, were not a result of contanination, or were recognized as occurring in a predictabie trend (e.g., tritiun) that can be reevaluated on a less frequent schedule. The constituent 1 ist also was anended to include some constituents that may provide insight on the occurrence of elevated toX in some wel1s (Sweeney 1995 ).

Four quarters of samping were completed at the B Pond during 1995. Because of the elevated ToX and tota] organic carbon (TOC) detected in several wel1s fror 1990 to 1993 (699-43-41E, 699-43-41F, 699-42-40A, and 699-43-42J), seaivolatile organic compounds were sarpled in all the downgradient wells. These analyses were chosen to identify the particular chenica] species that may be causing the elevated Tox results and to evaluate the overall groundwater chemistry of the site. Analytical results of the groundwater sampling for B Pond are presented in quarterly reports (Barnett 1995a, 1995b, $1995 \mathrm{c}$, and 1996).

A11 wells in the network were sampled quarterly during 1995, and have been sampled at least once for the Appendix $I X$ constituents. The current list of constituents sought in groundwater analyses at $B$ pond ts given in Table 4.3-2.

\subsubsection{Groundwater Chentstry}

4.3.5.1 Concentration Histories of laste Indicators. Chenistry data for the groundwater contamination indjcator parameters (TOX, TOC, $\mathrm{pH}$, and specific conductance) from the two upgradient wells for B Pond have been used to establish background concentration linits not to be exceeded in the doungradient we]1s. The B Pond system was elevated to assessment-1evel monttoring in 1990 because of elevated concentrations of tox in downgradient we11 699-43-41E. During 1990, well 699-43-41F also exhibited high concentrations of TOX and TOC. 
4.3.5.1.1 ToX. Following the change in monitoring status to assessment in 1990, TOX in wel1s 699-43-41E and 699-43-41F continued to be above established background limits during 1991. Ouring the past year, well 699-40-408 has exhibited elevated Tox results. Although this well was removed from the network as a regularly schedui ad sampling point, it is still sampled for ToX and semivolatile organit compounds.

Attempts to isolate a specific constituent(s) that may account for elevated ToX results remain inconclusive. Analyses for semivolatile organic constituents have revealed 11 low-level detections of the compound tris-2-chloroethyl phosphate in 5 wells since April 1993. The highest result was $44 \mathrm{ppb}$ in well 699-40-40A. Comparing results for this compound and TOX results (from corresponding sampling events and wel1s) does not reveal a defensibie correlation between the two constituents. Further data accumulation and comparison is needed to confirm or disprove this connection. Thus far, however, levels of this contaminant have been so low that it is difficult to justify further research.

4.3.5.1.2 TOC. The highest reported averaged results for TOC were from well 699-42-41 (1,000 ppb in July 1995). Thts value was silghtly above the jimit of quantitation (976 ppb). No definitive trends were evident in any of the network wells for this parameter.

4.3.5.1.3 Specific Conductance, Ho trends in speciftc conductance were observed during FY 1995. Specific conductance (field measurements) ranged from a high average of $507 \mu m h o / \mathrm{cm}$ in upgradient we7] 299-E18-1, in June 1995, to a low average of $148 \mu \mathrm{mho} / \mathrm{cm}$ in well $699-42-41$ in October 1994.

4.3.5.1.4 pH. The average of replicates for we17 699-43-41G in Aprit was the highest averaged field pH resutts for the year (8.82). However, the laboratory result for the same sample ( 8.1 ) does not agree with the fleld results. The lowest replicate average for the year (6.23) in well 699-44-42 also disagrees with the comparison laboratory result of 8.1 . This average is the only result that fell below the lower drinking water standard (ONS) for pH. Four wells exceeded the upper limit of DWS for pH during 1994.

4.3.5.1.5 Site-Specific Constituents. Untij mid 1995, tritium was monitored quarterly in each well in the network. The trends in these wells over several years indicated a generai decline for tritium Teveis in groundwater at the B Pond System.

Although nfne we1ls produced tritjum results above drinking water standards during 1994, a consistentiy downard trend for this constituent has been established for all these wells. Results of tritium analyses from the first half of CY 1995 indicate no change in this trend. Tritium levels wil] be monitored and reported annually at this site through the Groundwater Survelliance Project groundwater monitoring program (e.g., Dresel et al. 1995).

4.3.5.1.6 other Constituents. Additional drinking water and groundwater quality paraneters are measured at all downgradient wells for comparison with established DWSs, and other components, such as turbidity, that are indicators of groundwater or sample. quality. 
The number of neta] analyses performed for the B Pond System in 1995 was significantly reduced from the number in 1994. Chromion in unfiltered samples, iron in unfiltered samples, and manganese in filtered and unfiltered samples, as in years past, remain the most common constituents exceeding DWSs in the B Pond systen wells (see discusston in Section 2.2.4).

Although the turbldity DWS applies onTy to surface water analyses (40 CFR 265), this property is monitored in groundwater at B Pond to provide insight into occurrences of other constituents. High turbidity levels are most obviously correlated to concentrations of certain metals. During 1995, purging and sampling rates were reduced in six wells to decrease turbidity. These we17s are 699-40-39, 699-40-40B, 699-41-40, 699-42-40A, 699-43-40, and 699-43-41E. As predlcted, reduced pumping rates during purging and sampling in these wells significantly lowered turbidity levels and resulited th lower levels of metals, particularly iron and manganese, in unfiltered samples. Turbidity a]so is monitored at the time of sampling to prevent excessive turbidity interference with analyses.

4.3.5.2 Bistribution of Naste Constituents. Grounduater beneath the B Pond system contains elevated levels of tritiun fron past wastewater dtsposal to the facility. Monitoring wells that have been in place around the $\mathrm{B}$ Pond system for several years show a consistent decline in trition activities since the late 1980 's. The observed dectine is likely a result of the dilution of older, more contaminated water by recent tritium-free effltient, and decay of the tritium radionuclide (half-iffe $=12.3$ years). The most recent depictions of tritiun distribution in groundwater at the B Pond System are presented by Barnett (1995a) and Dresel et aI. (1995).

\subsubsection{Groundwater Flow}

The sediments of the Ringold Formation comprise the bulk of the uppermost aquifer beneath the B Pond system. Specifically, groundwater flows mostly within the Ringold unit A gravel sequence and somewhat within the Ringold lower aud sequence. Section 4.3.1 discusses stratigraphy and hydrogeology in the vicintty of the B Pond system. Hydrogeology of the B Pond system and vicinjty is discussed in more detail by Davis et al. (1993), DOE-RL (1994), and Johnson et aI. (1995).

During 1995, water table elevations were measured at least quarterly in ail wells in the monitoring network, and monthiy for most wells as part of the grouncwater assessiment progran.

4.3.6.1 Groundwater Fiow Direction. Groundwater flow in the B Pond area is dominated by the groundwater mound created by large volumes of wastewater recharging the uppernost aquifer (see Figure 4.3-2). This hydraulic feature has altered the original groundwater flow pattern of the area. In the past, the mound was even more extensive because larger voitumes of effluent were discharged to the system than at present (see Section 4.3.1). As the rate of effluent discharge has decreased, water levels in wells within the influence of the mound are atso generally decreasing.

The horizontal component of groundwater flow at the $B$ Pond system is ratially outward from the center of the groundwater mound. Horizontal head 
gradient, as deternined by water leve] measurements taken in June 1995, is estimated at roughly 0.003 just east of the 3C Expansion Pond, to 0.005 immediately west of the former location of the main pond.

4.3.6.2 Rate of Groundwater Flow. Estimates of groundwater flow rates near the B Pond system are mostly based on numerical modeling, and by tracking tritium gigration from the 200 East Area operations to the Columbia River (Freshley and 6raham 1988, Freshley and Thorne 1992). Average horizontal groundwater flow rate determined by these methods is estimated at 0.2 to $2.7 \mathrm{a} / \mathrm{d}(0.6$ to $9.0 \mathrm{ft} / \mathrm{d})$.

The horizontal component of groundwater flow rate may also be estimated by the relationshfp:

$$
y=\frac{k i}{7}
$$

where:

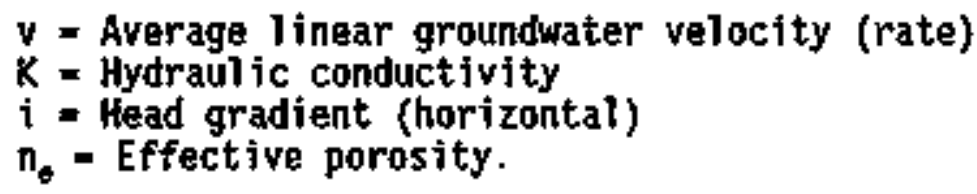

For the B Pond system, $K$ has been approximated at $640 \mathrm{~m} / \mathrm{d}(2,100 \mathrm{ft} / \mathrm{d})$ for the Hanford formation, and $1.5 \mathrm{a} / \mathrm{d}(5 \mathrm{ft} / \mathrm{day})$ for the Ringold Formation; est Imated effective porosity ranges were from 0.1 to 0.3 for both the Hanford and the Ringold Formations (WHC 1990). However, Thorme ot al. (1993, 1994) est 1mated horizontal hydraulic conductivity of the Hanford formation in some areas around $B$ Pond at no more than $1 \mathrm{~m} / \mathrm{d}(3 \mathrm{ft} / \mathrm{d})$. This is because of the rud content of the Hanford formation sediments at this location.

Estimates of average linear flow velocfty based on head gradients observed in May 1989 and aquifer properties ( $K$ and $n$ ) yjelded rates from 0.009 to $0.03 \mathrm{a} / \mathrm{d}(0.03$ to $0.1 \mathrm{ft} / \mathrm{d})$ for the Ringold Formation, and 15 to $46 \mathrm{~m} / \mathrm{d}$ (50 to $150 \mathrm{ft} / \mathrm{d}$ ) for the Hanford formation (whC 1990). Performing this calculation with head gradients observed for June 1995 and using the extreme values known for hydraul ic conductivity, gradient, and effective porostty, groundwater flow velocjties are estimated to range between 0.02 and $0.09 \mathrm{~m} / \mathrm{d}$ $(0.07$ to $0.3 \mathrm{ft} / \mathrm{d})$ for the Ringold Formation, and 0.01 to $38.4 \mathrm{~m} / \mathrm{d}(0.03$ to $126.0 \mathrm{ft} / \mathrm{d}$ ) for the Hanford formation.

Groundwater fiow velocities estimated at the W-049H Treated Effluent Disposal Basin site have ranged from 0.002 to $0.02 \mathrm{~m} / \mathrm{d}(0.005$ to $0.08 \mathrm{ft} / \mathrm{d})$ within the Ringold Formation unit $A$. Hydraulic conductivities used to ca]culate these estimates were derived from constant-discharge pumping tests conducted tn early 1993 (Davis et a1. 1993). Effective porosities are laboratory estimates fron borehole samples.

In February 1994, groundwater flow velocitjes (direction and rate) were measured directiy within the three wells at the W-049H site using a heat-pulse 
flowmeter. The detaijs of this investigation are presented in Bamett et a7. (1994) and Barnett et a1. (1995). Groundwater velocities determined by this method ranged from an estimated average of $0.07 \mathrm{~m} / \mathrm{d}$ $(0.23 \mathrm{ft} / \mathrm{d})( \pm 17 \%)$ at $181^{\circ}\left( \pm 12^{\circ}\right)$ aztmuth in well 699-40-36, to $0.57 \mathrm{~m} / \mathrm{d}$ $(1.88 \mathrm{ft} / \mathrm{d})( \pm 17 \%)$ at $92^{\circ}\left( \pm 11^{\circ}\right)$ azimuth in well 699-42-37. All three of these wells are screened within the Ringold unit $A$ gravel.

4.3.6.3 Evaluation of the Honftoring Iell Hetwork. Currently, the monitoring well network is adequate to detect contanination originating from the $B$ Pond site. As discussed in Section 4.3.4, eight wel1s were dropped from the regular sampling 1tst during 1995 to eliminated duplication of effort. Because of the radial flow fron the apex of the groundwater mound, a const ftuent introduced at this apex should theoretically be detectable at any selected point within the mound, barring heterogeneities in the geologic structure of the aquifer. As known from drilling, heterogenelties do exist at this stte, but they are not predictable to a level of detaj] that would justify siting weils at specific locations. Hydraulic head measurements do indicate, however, that groundwater nost likely flows with the greatest ease in an east-to-southeasteriy direction. In the future, particular attention wil1 be focused in that area to ensure adequate coverage and well integrity.

Figure 4.3-3 is a conposite hydrograph of wells at the B Pond system network showing typical patterns of water level decline. Beginning in late 1993 and early 1994, water levels in some wells in the network actually began to rise. This rise was probably in response to a series of temporary increases in discharges to the facility during that period (Davis et al. 1995; Johnson et al. 1995), and may also have been enhanced by the rerouting of dtscharges in earjy 1994. The trend was reversed again in late $\mathrm{Cr} 1994$. In 1995 these wells have apparent7y resumed their declining-water-level trend. Distal portions of the groundwater wound are relatively unaffected by these changes, as noted in well 699-40-36 at the TEDF.

During 1993 the network was evaluated to determine whether any wells wore on the verge of going dry and becoming incapable of producing a groundwater sample. The evaluation determined that wells 699-42-41, 699-43-45, 599-44-42, and 699-44-43B may be going dry. Comparing the 1993 water levels in these wells with levels measured in November 1995 showed that water levels had fallen by as much as 0.6 m (2 ft). However, only well 699-44-42 was in iumlediate danger of going dry, with the water level approaching the puinp intake leve]. This well was recently eliminated fron the samping schedule because it is not essential to the network.

Redirection of discharges fron the matn pond to the $3 C$ Expansion. Pond that began in early 1994 is possibly tntroducing wastewater into the parts of the Hanford formation (i.e., above the Ringold lower mud sequence) that were formerly dry. Concomitantly, the original mound beneath the B Pond system will diuintsh. Wurstner and Freshley (1994) predict that as many as seven wells in the network (mostly around the mafn pond) witl be dry by the year 2000. The monitoring network will be pertodically assessed for adequacy of coverage. 


\subsubsection{References}

40 CFR 265, "Interim Status Standards for Owners and Operators of Permitted Hazardous Waste Facilities," Code of Federal Regulations, as amended.

Barnett, D. B., 1995a, "216-8-3 Pond System," Annual Report for RCRA Groundwater Monitoring Projects at Hanford site Facilities for 1994: DOE/RL-94-136, U.S. Department of Energy, Richland Operations office, Richland, Washington.

Barnett, D. B., 1995b, "216-B-3 Pond System," Quarterly Report of RCRA Groundwater Honitoring Data for Period October 1, 1994 through Decamber 30, I994, DOE/RL-93-56-4, U.S. Department of Energy, RIch] and Operations office, Richland, Washington.

Barnett, D. B., 1995c, "216-B-3 Pond System," Quarterly Report of RCRA Groundwater Nonitoring Data for Period January I, 1995 through Harch 3I, 1995, DOE/RL-94-36-1, U.S. Oepartment of Energy, Rjchland Operations office, Richland, Washington.

Barnett, D. B., 1995d, "216-B-3 Pond System," Quarterly Report of RCRA Groundwater Nonitoring Oata for Period April 1, 1995 through Jume 30 , 1995, 00E/RL-94-36-2, U.S. Departwent of Energy, Rich1 and Operations Dffice, Richland, Washington.

Barnatt, 0. B.; 1995e, "216-B-3 Pond System," Quarterly Report of RCRA Groundwater Honitoring Data for Period July I, 1995 through September 30 , 1995, DOE/RL-94-36-3, U.\$. Department of Energy, Richland Operations Office, Richland, Washington.

Barnett, D. B., J. A. Coates, and B. F. Strode, 1994, Application of the $K-V$ Assocjates Flowweter at the Site of Project W-049H Treated Effluent DisposaT Basin, MHC-SD-EH-ER-006, Rev. 0, Westinghouse Hanford Corpany, Richland, Washington.

Barnett, D. B., J. D. Davts, C. J. Chou, L. C. Collard, and P. B. Freeman, 1995, Groundwater Screening Evaluation/Homitoring Plan -- 200 Area Treated Effluent Disposal Facility (Project H-049H), WHC-\$D-EN-WP-012, Rev. 0 , Westinghouse Hanford Company, Richland, Washington.

Comprehensive Environmental Response, Compensation, and Liability Act of 1980, 42 USC 9601 et seq.

Davis, J. D., D. B. Bamett, L. C. Swanson, W. J. Mchahon, and C. D. Palomares, 1993, Site Characterization Report: Results of Detailed Evaluation of the Suitability of the Site Proposed for Disposal of 200 Areas Treated EffTuent, WHC-SD-EN-ES-004, Rev. 0, Westinghouse Hanford Company, Rjchiand, Washington.

DOE-RL, 1994, 216-8-3 Expanstion Ponds Closure Plan, DOE/RL-89-28, Rev. 2, U.S. Department of Energy, Richland Operations Office, Richland, Washington. 
Dresel, P. E., P. D. Thorne, S. P. Luttrell, B. M. Gillespie, W. D. Webber, J. K. Merz, J. T. Rieger, M. A. Chamness, S. K. Wurstner, B. E. Opitz, 1995 Hanford Site Ground-Water Honitoring for 1994, PHL-10699, Pacifjc Northwest Laboratory, Richland, Washington.

Ecology, EPA, and DOE, 1994, Hanford Foderel Facility Agrecient and Consent Order, Fourth Amendment, Washington State Department of Ecology, U.S. Environmenta] Protection Agency, and U.S. Department of Energy, 0lyopia, Hashington.

Freshley, H. 0., and H. J. Graham, 19g8, Estiaation of Ground-Water TraveI Time at the Hamford Site: Description, Past Nork, and Future Needs, PNL-6328, Pacific Horthwest Laboratory, Richland, Washington.

Freshley, H. 0., and P. D. Thorne, 1992, Ground-Water Contribution to Dose from Past hanford Operations, PHNO-1974 HEDR, Paciffic Northwest Laboratory, Richland, Washington.

Harris, S. F., 1990, Ground Water Quality Assessment Plan for the 216-B-3 Pond System, WHC-EN-AP-030, Rev. 0, Westinghouse Hanford Company, Richland, Washington.

Johnson, V. 6., 1993, Westinghouse Hanford Company Operational Groundwater Status Report, 1990-1992, WHC-EP-0595, Westinghouse Hanford Company, Richi and, Vashington.

Johnson, V. G., A. G. Law, S. P. Reidel, S. D. Evelo, D. B. Barnett, H. D. Sweeney, 1995, Ground Water Impact Assessment Report for the 216-8-3 Pond Syster, WHC-EP-0813, Westinghouse Hanford Company, Richland, Washington.

Law, A. G., J. A. Serkowski, and A. L. Schatz, 1987, Results of the Separations Area Ground-Water Monitoring Network for 1986, RHD-RE-SR-87-24 P, Rockwe11 Hanford Operations, Richland, Washington.

Lindsey, K. A., B. N. Bjornstad, J. H. Lindberg, K. M. Hoffunan, 1992, Hydrogeologic Setting of the 200 East Arsa: An Update, WHC-SD-EH-TI-012, Rev. 0, Westinghouse Hanford Company, Richland, Washington.

Resource Conservation and Recovery Act of 1976, 42 USC 6901 et seq.

Sweeney, H. 0., 1995, Interim-Status Groundwater Nonitoring Plan for the 216-B-3 Pond System, WHC-\$D-EN-AP-013, Rev. 1, Westinghouse Hanford Company, Richland, Washington.

Thorne, P. D., H. A. Chamness, F. A. Spane, V. R. Yermeut, and W. D. Webber, 1993, Three-Dinensional Conceptual Hodel for the Hanford Site Unconfined Aquifer System, FY 1993 Status Report, PNL-897I, Pacific Northwest Laboratory, Richi and, Washington.

Thorne, P. D., M. A. Chamness, V. R. Vermeul, Q. C. MacDonald, S. E. Schubert, I994, Three-Dimensional Conceptual hodel for the Hanford Site Unconf ined Aquifer System: FY 1994 Status Report, PNL-10195, Pacific Horthwest. Laboratory, Richt and, Washington. 
WHC, 1990, Interin Hydrogeologic Characterization Report for the 216-8-3 Pond, WHC-SO-EV-002, Rev. 0, Westinghouse Hanford Company, Richland, Washington.

Wurstner, S. K., and M. D. Freshley, 1994, Predicted Ispacts of Future Water Level Decline on Monitoring Wells Using a Ground-Water Hodel of the Hanford Site, PHL-10196, Pacific Northwest Laboratory, Richland, Washington. 
DOE/RL-96-01, REV. 0

This page intentionally left blank.

4. 3-12 


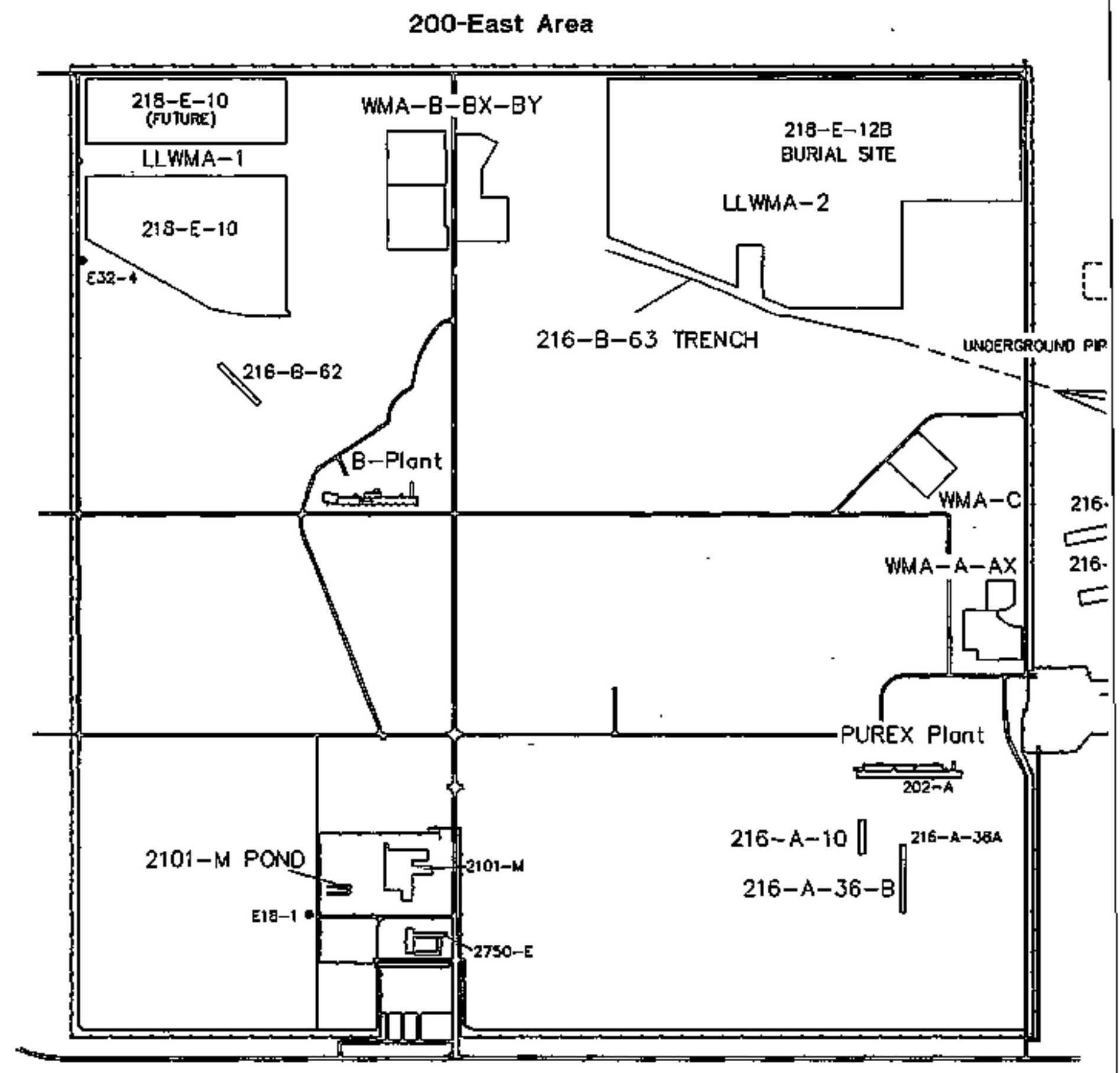


D0E/RL-96-01, REV. 0

Figure 4.3-1. Monitoring We11 Locations for the 216-8-3 Pond.

Groundwoter Monitoring Weil - B Pond

- Groundwoter Monitoring Well - TEDF

5-44-438 Well identification Number

W049H Boundory

Decommissioned Focility

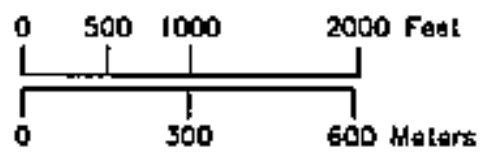

216-B-3 POND SYSTEM

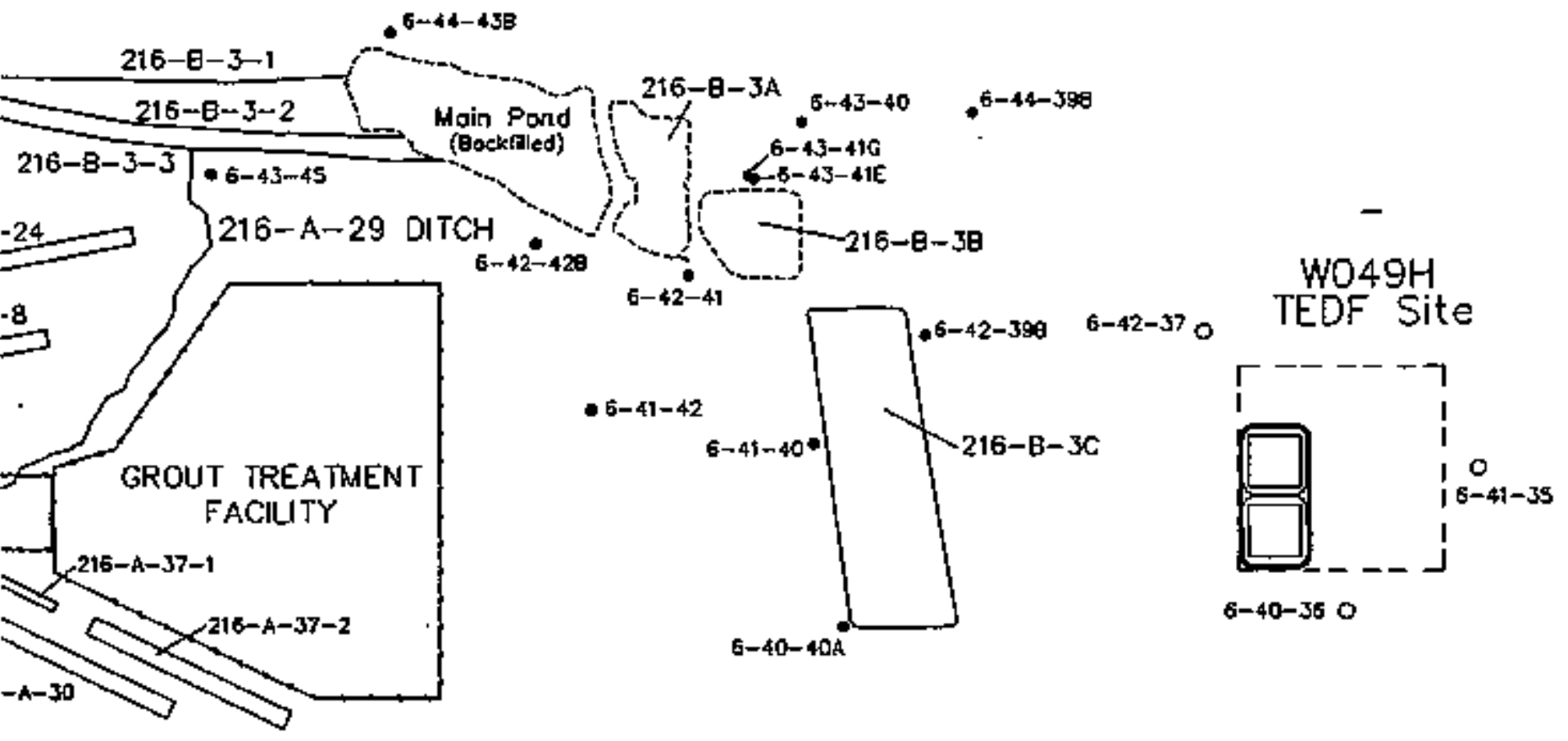


Figure 4.3-2. Potentiometric Surface Map of the 216-B-3 Pond and Vicinity, June 1995.

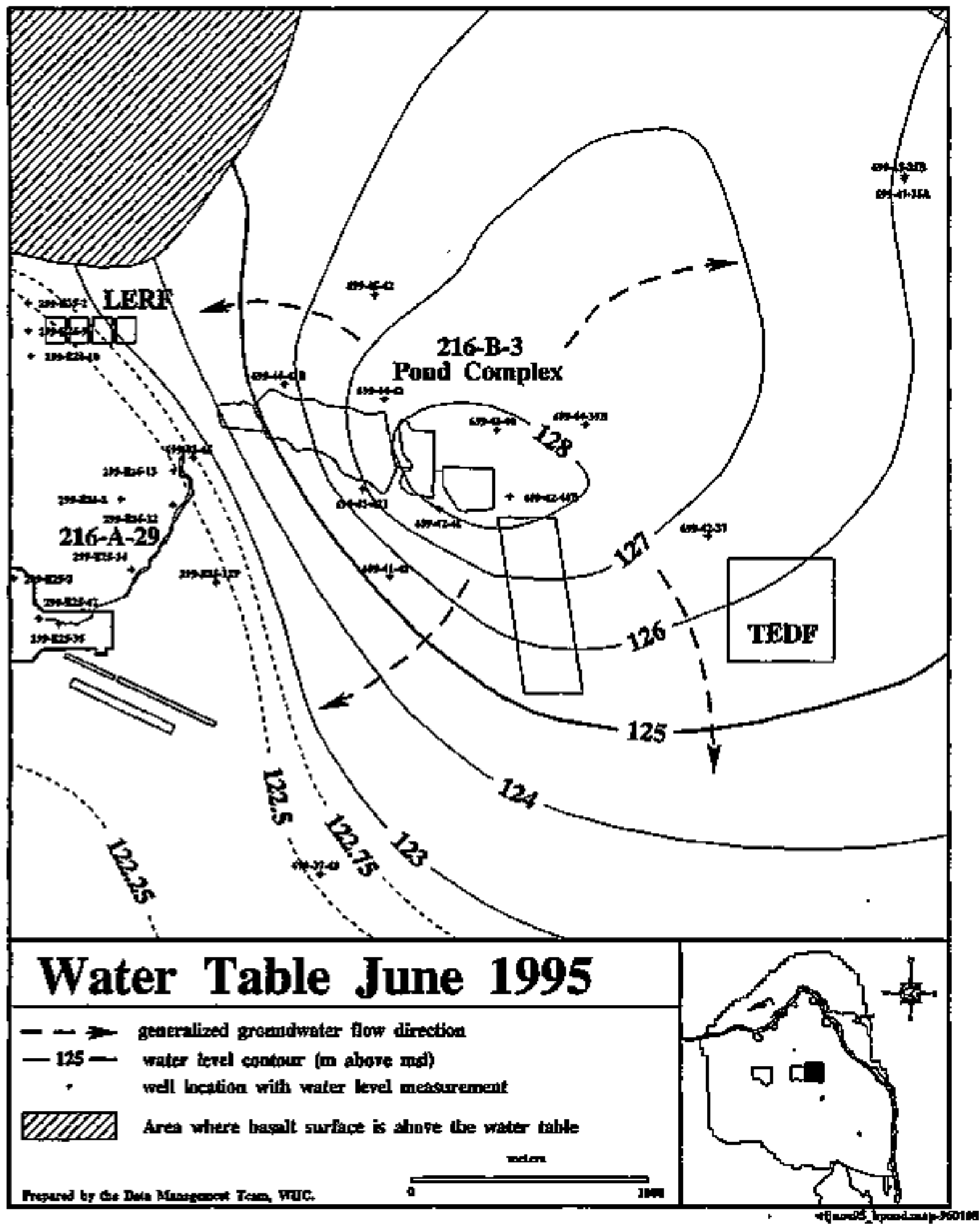


D0E/RL-96-01, REV. O

Figure 4.3-3. Composite Hydrograph for Representative We11s, 216-B-3 Pond.

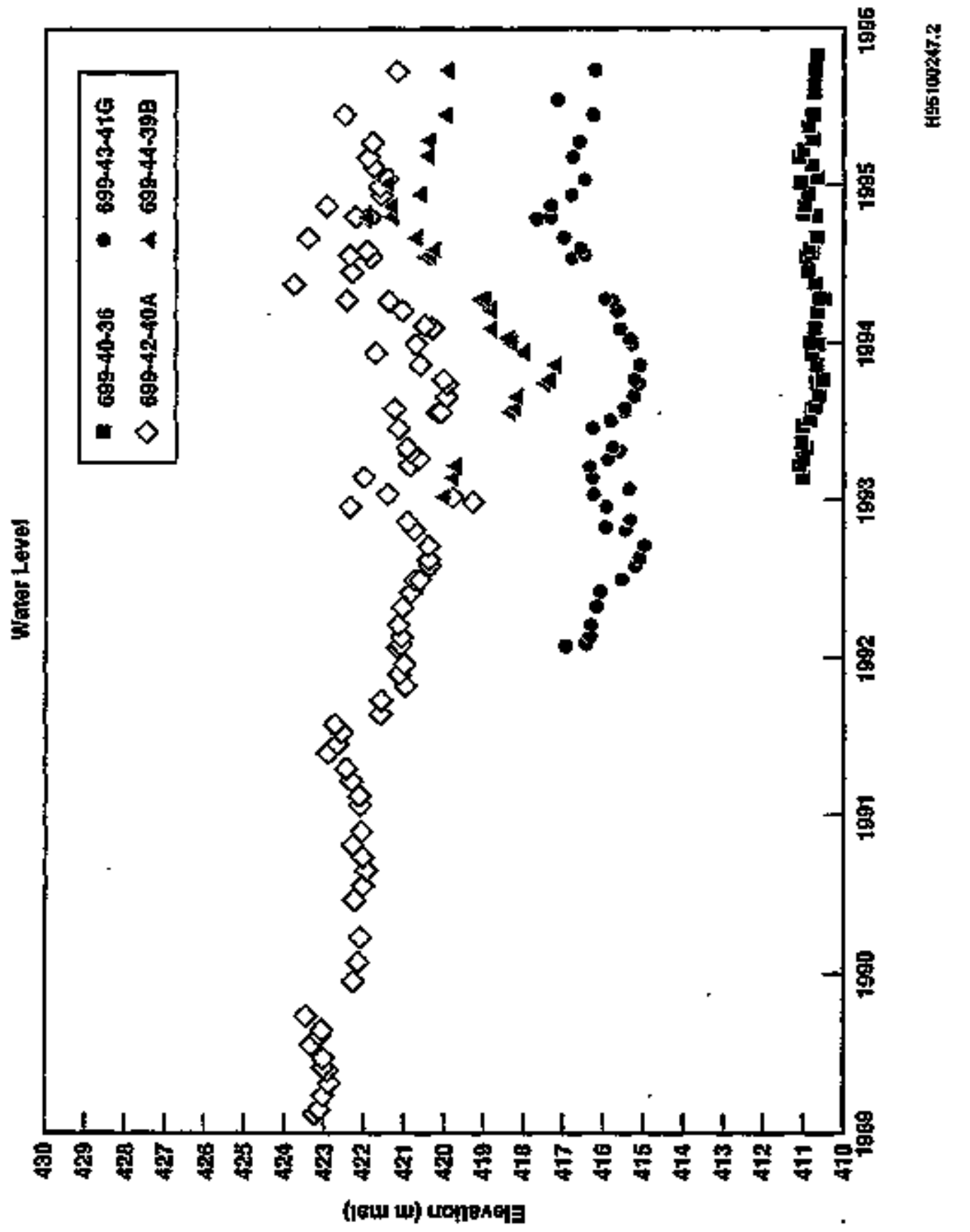


Table 4.3-1. Nonitoring Wells Used for the 216-B-3 Pond System.

\begin{tabular}{|c|c|c|c|c|c|}
\hline WeIt & Aquifer & $\begin{array}{l}\text { Sampling } \\
\text { frequency }\end{array}$ & $\begin{array}{l}\text { Water } \\
\text { levels }\end{array}$ & $\begin{array}{c}\text { Well } \\
\text { standards }\end{array}$ & $\begin{array}{c}\text { other } \\
\text { networks }\end{array}$ \\
\hline $299-618-1^{80}$ & Top of unconfined & $\mathbf{Q}$ & M & RCRA & 2101-M \\
\hline $299-532-4^{6 / 7}$ & Top of unconfined & 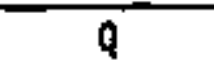 & 音 & RCRA & LLEMMA-2 \\
\hline $699-40-40 A^{51}$ & Lower confined & Q & M & RCRA & $=$ \\
\hline $699-41-40^{89}$ & Top of confined & $Q$ & H & RCRA & $\overline{-}$ \\
\hline $699-41-42^{\% 2}$ & Top of unconfined & Q & $\mathbf{M}$ & RCRA & -- \\
\hline $699-42-39 B^{91}$ & Lower confined & $Q$ & M & RCRA & - \\
\hline $699-42-41^{97}$ & Top of unconfined & $Q$ & M & RCRA & - \\
\hline $699-42-42 B^{68}$ & Top of unconfined & Q & H & RCRA & 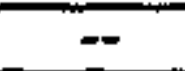 \\
\hline $699-43-40^{91}$ & Top of unconfined & 9 & H & RCRA & 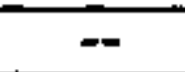 \\
\hline $699-43-41 E^{89}$ & Top of confined & Q & $\bar{H}$ & RCRA & - \\
\hline $699-43-416^{97}$ & Top of confined & Q & 북 & RCRA & $-\infty$ \\
\hline $699-43-45^{8 y}$ & Top of unconfined & $\mathbf{q}$ & $\mathbf{N}$ & RCRA & $A-29$ \\
\hline $699-44-39 B^{92}$ & Top of confined & $\overline{\mathbf{Q}}$ & H & RCRA & + \\
\hline $699-44-43 B^{89}$ & Top of unconfined & $\overline{\mathbf{Q}}$ & $\bar{H}$ & $\overline{R C R A}$ & $m$ \\
\hline
\end{tabular}

Notes: Shading denotes upgradient wells. Superscript following well number denotes the year of instajiation.

H - frequency on a nonthly basis.

PRE $=$ weli was constructed before RCRA-specified standards.

$Q=$ frequency on a quarterly basis.

RCRA = well is constructed to RCRA-specified standards. 
DOE/RL-96-01, REV. 0

Table 4.3-2. 216-8-3 Pond, 1995 Chenical Constituent List.

\begin{tabular}{|c|c|c|}
\hline \multicolumn{3}{|c|}{ Contamination indicator parameters } \\
\hline $\begin{array}{l}\text { pH } \\
\text { Specific } \\
\text { conductance }\end{array}$ & $\begin{array}{l}\text { Total organ } \\
\text { carbon } \\
\text { Total organ } \\
\text { hajogens }\end{array}$ & \\
\hline \multicolumn{3}{|c|}{ Stte Specific Parameters } \\
\hline $\begin{array}{l}\text { Semivolatil } \\
\text { ICP metals } \\
\text { Gross alpha } \\
\text { Gross beta }\end{array}$ & $\begin{array}{l}\text { ic compounds } \\
\text { ed) }\end{array}$ & $\begin{array}{l}\text { Alkal inity } \\
\text { Anions } \\
\text { Turbidity }\end{array}$ \\
\hline
\end{tabular}


DOE/RL-96-01, REV. 0

\section{CoHrans}

$4.4216-\mathrm{A}-29$ DITCH $\ldots \ldots \ldots \ldots \ldots \ldots \ldots \ldots \ldots$. . . . . . . .

4.4.1 Facility Overview .............. 4.4-1

4.4.2 Summary of 1995 Activities . . . . . . . 4.4-2

4.4.3 Sampiting and Analysis Progran .......... 4.4-2

4.4.4 Groundwater Chemistry ............ 4.4-2

4.4.5 Groundwater Flor . ............... 4.4-4

4.4 .6 References .................... 4.4-5 


\section{LIST OF FIGURES}

4.4-1 Cross Section Parallel to the 216-A-29 Ditch . . . . . 4.4-7 4.4-2 Monitoring Well Locations at the 216-A-29 Ditch ...... 4.4-8 4.4-3 Specific Conductance and Sulfate, Sodium, and Calcium Concentrations Over Time at Well 299-E25-35 ...... 4.4-9

4.4-4 Specific Conductance Concentrations over Time at Weil 299-E25-35

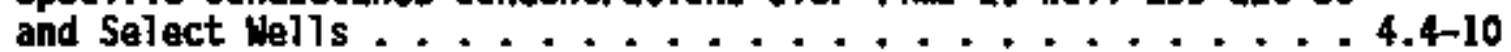

4.4-5 Sulfate Concentrations Over Tiue at Weli $29 \dot{9}^{\circ}$-É25-35 and Select Wells....................4-10

4.4-6 Specific Conductance of Groundwater . . . . . . . . 4.4-11 4.4-7 June 1995. Water Table . . . . . . . . . . . 4.4-8 Hydrograph of 216-A-29 Ditch Monitoring Network Helis $\ldots .4$ 4.13

\section{LIST OF TABLES}

4.4-1 Monitoring Wells Used for the 216-A-29 Ditch . . . . . 4.4-14 4.4-2 Constituents Analyzed in the Groundwater Beneath the 216-A-29 Ditch ................4-15 
COE/RL-96-01, REV. 0

\subsection{6-A-29 DITCH}

J. H. Votava

Nest inghouse Hanford Company

\subsubsection{Facility overview}

The 216-A-29 0itch (A-29 Ditch) was first used in 1955 when the Plutonfum-Uraniug Extraction (PUREX) Plant began operation. The A-29 Ditch is located east of the 200 East Area in the central portion of the Hanford Site. It was an excavated unlined percolation trench that was approximately 2 n (6 ft) wide at the botton and 2,000 (3,600 ft) long. It received effiuent from the PUREX Plant chenical sewer line (CSL) and conducted it to the 216-8-3 Pond systen' (B Pond).

Effluents disposed of in the A-29 0itch inftltrated into approxiately $76 \mathrm{~m}(250 \mathrm{ft})$ of unsaturated Hanford formation sediments above the water table. The water table beneath the A-29 Ditch occurs within the indistinct contact between the Hanford formation lower gravel sequence and the underlying Ringold gravel unit $A$. The uppermost portion of the saturated zone beneath the ditch consists of Ringold Formation sediments (Figure 4.4-1) (WHC 1992).

The A-29 Ditch received sequential discharges of sodfum hydroxide and sulfurtc acid fron the water treatment denineralizer almost dajiy durting the early years of operation. The A-29 Ditch also received inadvertent spilis of potentially hazardous chemicals and discharges of characteristicaliy corrosive waste and waste containing the hazardous constituent hydrazine. In 1984, adrinistrative and physical controls were implemented to avoid inadvertent discharges of hazardous chemicals.

A RCRA-compliant groundwater monitoring network was completed and the groundwater beneath the A-29 Ditch has been monitored since Novenber 1988 (Kasza and Goodwin 1992). In January 1990, statistical evaluation indicated that speciffic conductance in downgradient we7] 299-E25-35 had exceeded the critical mean. Impediate resamping of the we]l vertfied that the specific conductance in we71 299-E25-35 was statistically greater than the critical mean. As required by the RCRA, a groundwater quality assessment plan was prepared and 1ssued (Chou et a1. 1990). As a result, monthiy water level measurements and quarterly groundwater samples were collected from the assessment network as part of the assessment jnvestigation. Groundwater sampling and analysis were not conducted between June 1990 and July 1991 because the groundwater analytical contract was suspended.

On July 15, 1991, effluent from the PUREX CSL was rerouted to the PUREX cooling water fine and discharges to the A-29 Ditch were eliminated. The A-29 Ditch was backfilled and the location was graded and revegetated as an interin stabifization measure during autumn of 1991 (Smith 1992). This activity marked the completion of Hamford Federal Facility Agreement and Consent onder Hilestone H-17-10 (Ecology et al. 1994).

A report describing the results of the groundwater quality assessment program at the 216-A-29 Ditch RCRA facility was prepared and released in october 1995 (Votava 1995). The results of the investigation indicated that. 
the 216-A-29 Ditch is the source that caused elavated specific conductance in we]] 299-E25-35, and that the source (sulfate, sodium, atc.) is nonhazardous. The report describes the current monitoring status of the 216-A-29 Ditch, groundwater chenical data interpretation, and recommends the reinstatement of an indicator-evaluation monitoring program in accordance with 40. CFR 265.93 (d) (6). This program began at the start of FY 1996.

The A-29 Ditch is located in the 200-P0-5 Comprehensive Environmenta? Response, Cowpensation, and Liability Act of 1980 (CERCLA) operable unit. The RCRA closure plan is due to the Washington State Departinent of Ecology and the U.S. Environmental Protection Agency in March 2000.

\subsubsection{Sumary of 1995 Activities}

During 1995, the menitoring activities required by the assessment plan and the groundwater monitoring pTan were conducted. The depth to the water table was measured month1y in the wells that constitute the A-29 groundwater monitoring network and quarterly in the wells used to gather suppiementary data for the groundwater quality assessutent program. Groundwater samples were collected for chemical analysis from the designated monttoring wells during each quarter. Site water Tevels and groundwater chemistry data were reported in the sertes of quarterly RCRA groundwater monttoring data reports (Freeman 1995; Votava 1995a, 1995b, and 1996).

\subsubsection{Sampling and Analys is Program}

The A-29 groundwater monitoring network currently consists of 2 upgradient and 11 downgradient wells, all of which were constructed to RCRA standards. Thirteen additional wells were used to gather supplementary groundwater data for the groundwater quality assessment investigation. Detajis about the groundwater monitoring network and assessment wells are Tisted in Table 4.4-I. Fjgure 4.4-2 shows the Tocations of the wells. Five welts were cosampled to satisfy the monitoring requirements of other RCRA facilities.

As part of the groundwater quality assessment investigation, the groundwater of the unconfined aquifer beneath the A-29 Ditch was saspied during each calendar quarter at the monitoring network wells and at selected assessment investigation wells (see Table 4.4-1 and Figure 4.4-2) (Chou et a1. 1990). These groundwater samples were then analyzed for the constituents listed in Table 4.4-2. Analytical results were reported in the previously listed quarterly reports (see Section 4.4.1.2).

The groundwater quality assessment investigation was designed to deternine whether the A-29 Ditch or one of the adjacent disposal sites was the actual source of the groundwater contamination. The determination of the groundwater flow direction and the analyses for the various chemical constituents $l$ isted in Table 4.4-2 were intended to identify both the contaminant and the source of the contamination found at well 299-E25-35. 
DOE/RL-96-01, REV. 0

\subsubsection{Groundwater Chemistry}

The facility was evaluated for changes in the water quality in the 2 upgradient and 11 downgradtent. RCRA-compliant wells (Section 4.4.5.1). The 13 wells in the assessment program were evaluated to provide a compartison to downgradient wel] 299-E25-35 (Sect ton 4.4.5.2).

4.4.4.1 Concentratfon itstorfes of Haste Indfcators. The groundwater quality assessment monitoring program was injtiated at A-29 in 1990 because fie]dmeasured specific conductance at wel1 299-E25-35 was 784 whos (January 29, 1990). This was above the original critical mean of 455.31 umhos. The mean was estabitshed using weIT 299-E25-32P, which was then upgradient.

Specific conductance reftects the guantity of jons in the groundwater. The assessment investigation method included evaluating concentrations of major anions and cations that have been anonitored and comparing them to average concentrations of waste constituents disposed of to the A-29 Ditch and surrounding cribs. Time concentration patterns of specific conductance in weIl 299-E25-35 correspond to similar trends of sulfate, sodium, and calcium. Figure 4.4-3 depicts the sfmilar historical concentration plots of these constituents and speciffic conductance over time. Catcjum and sodiun, however, are not ideal indicators of contamination because they occur naturaliy in the uppermost aquifer and thay are reported at considerably lower values than sulfate. Therefore, the primary contaminant was determined to be suifate (Figure 4.4-4).

The specific conductance in wol] 299-E25-35 fell dramatically in 1993 to approximately one-half of the historic range of values for this constituent. As shown in Figure 4.4-4, the specific conductance vaTues measured at this well during 1995 have remained conststent with 1994 values. The specific conductance values measured at we11 299-E25-35 during I995 rewain approximately 1.5 times higher than upgradient wells to the northeast (699-43-43 and 299-E25-43) and slightiy higher than upgradient wells to the west (299-E25-42) and southeast (299-E25-IB). The specifjc conductance measured for weil 299-E25-35 during a]1 1995 sample collections was below the critjcal mean value $(455.3 \mu$ mho/ $\mathrm{Cm}$ ) established when the A-29 Ditch went into groundwater quality assessment monitoring in 1990.

4.4.4.2 Distribution of Waste Constituents. Sulfate ts elevated in the groundwater at well 299-E25-35 (Figure 4.4-5). Sulfuric acid from the CSL effluent disassociates into sulfate in water watrices by the resin columns (regeneration cycle) and/or by the soil carbonate in the ditch. Weil 299-E25-35 is located at the head of the ditch; therefore, if any infiltration occurred, it would be noticed first at this wel1. Specific conductance and sulfate also are elevated slightly, but are not above the critical mean, in well 299-E25-42, which is downgradient of wel1 299-E25-35. Figure 4.4-6 presents 1995 average specific conductance concentrations in the groundwater. Sulfate concentrations in ${ }^{2}$ the groundwater never exceeded the secondary drinking water standard $(250,000 \mathrm{ppb})$ and it is not a hazardous waste constituent. A report on the findings of the groundwater quality assessment investigation was released in October 1995 (Votava 1995). This document recommended to reinstate detection monjtoring and schedule it to begin during fiscal year 1996. 


$$
\text { DOE/RL-96-01, REV. } 0
$$

\subsection{5 . Groundwater Fjow}

4.4.5.1 Eroundwater Flow Direction. The A-29 Bitch ts Tocated approxinately 600 to $1,200 \mathrm{~m}(2,000$ to $4,000 \mathrm{ft}$ ) west of the B Pond system. The regional groundrater flow pattern in the unconfined aquifer is radially outward fron the B Pond groundwater mound. Fjgure 4.4-7 presents the June 1995 water level data from surrounding groundwater monttoring wells. The figure defines the local water table and groundwater flow direction in the unconfined aquifer beneath the A-29 Ditch. As shown, the local groundwater flow direction near the A-29 Ditch ranges from a westward flow at the north end of the ditch to a southwestward flow at the south end of the ditch.

Hydrographs from local we1]s with nested piezometers (299-E25-29P and 299-E25-29Q, and 299-E25-32P and 299-E25-32Q) and a pair of adjacent A-29 network welis wtth shallow and deep completjons (299-E25-34 and 299-E25-28) were examfned for calculation of vertical gradients. Review of the avallable data indicates that the vertical head difference is very snall and is difficult to distinguish from measurement errors.

The hydrograph of the A-29 Ditch groundwater monttoring network, Figure 4.4-8, depicts the change in the water table beneath the A-29 Ditch since the start of RCRA monitoring. The hydrograph indicates that water levels across the network have gradually declined. The water table and hydrograph ffgures indicate that nonitoring we77s 699-43-43 and 699-43-45 continue to be upgradient of the facility and are appropriate upgradient monitoring wells for the ditch.

Figure 4.4-2 shows the location of the A-29 bitch in relation to other RCRA or operational factiittes. In the past, the disposal of liquid effluent. at some of these facilities may have produced local changes to the groundwater flow pattern and may have caused local contaninant flow counter to the regional flow direction. Considering the proxinity of the 216-A-30 and 216-A-37-1 Cribs to well 299-E25-35 and the ongoing decrease in the regjona] water table, the potential for contaminant migration from any of these cribs toward we11 299-E25-35 is possible. Water levels and groundwater movenent in the area surrounding the A-29 Ditch are also discussed in Section 4.3, 216-B-3 Pond Systero; Section 4.5, 216-A-36B Crib; and Section 4.6, 216-A-10 Crib of this report.

4.4.5.2 Rate of Flow. Groundwater movement beneath the A-29 Ditch is Influenced by the water table mound beneath the B Pond. In June 1995, there was a $5 \mathrm{~m}(17 \mathrm{ft}$ ) difference in the water tabie between the highest part of the $B$ Pond mound and the monitoring wells imediately adjacent to the A-29 Ditch. The hydraulic gradient and groundwater flow veloctty beneath different segments of the A-29 Ditch depend on the proximity of the segutent to the $B$ Pond round. Using the June 1995 water table, the hydraulic gradient at the north end of the ditch is approximately $8.0 \times 10^{-3}$ and the hydraulic gradient at the south end $1 \mathrm{~s} 1.6 \times 10^{-3}$.

An estimate of the groundwater velocities in these two areas can be caiculated from the measured gradients and aquifer test data from the A-29 monitoring network we11 299-E25-42 using Darcy's 1aw: 


$$
v=\frac{k i}{n_{e}}
$$

where:

$V=$ Average linear velocity (m/d)

$K=$ Hydraut ic conductivity (in/d), $18.29 \mathrm{~m} / \mathrm{d}$ (Kasza 1992)

, $\mathbf{i}=$ Hydraulic gradient $(\mathrm{m} / \mathrm{m}), 8.0 \times 10^{-5}$ to $1.6 \times 10^{-3}$

n. - Effect ive porosity, 0.25 (WHC 1990).

Eroundwater flow veloctties beneath the A-29 Ditch during June 1995 ranged from $1.7 \times 10^{-3} \mathrm{~m} / \mathrm{d}\left(5.9 \times 10^{-3} \mathrm{ft} / \mathrm{d}\right)$ in the southern portion to $3.6 \times 10^{-2} \mathrm{~m} / \mathrm{d}$ $(0.12 \mathrm{ft} / \mathrm{c})$ in the northern portion.

4.4.5.3 Evaluation of Monitoring Nell Network. Water levels in each well of the A-29 groundwater monftoring network were compared to the depth of the screen interval and the pump intake elevation to ensure that sufficient. voluaes of water exist for sampling purposes. There is no short-term need to replace any of the existing groundwater monjtoring wells. Wells with high turbidity are slated for cleaning and redevelopment. Once each well is redeveloped, the purge rate determined at developiment will be the highest rate used for subsequent sampling events. This will reduce the potential for producing turbidity during sampling.

An evaluation of monitoring well locations confirmed that any effect the A-29 Ditch had on groundwater quality could be determined by the nonitoring wells located upgradient and downgradient of the facility.

\subsubsection{References}

Chou, C. J., 6. L. Kasza, and R. B. Mercer, 1990, Interin Status Groundwater Quality Assessment Plan for the A-29 Oitch, WHC-SD-EN-AP-031, Rev, 0, Westinghouse Hanford Company, Rich]and, Washington.

DOE, 1997, 216-A-29 Ditch Preliwinary Closure/Post Closure Plan, TRAC-0098, U.S. Department of Energy, Rich] and Operations Office, Richland, Hashington.

DOE-RL, 1992, 200 East Area Groundwater Aggregate Area Nanagenent Study Report, DOE/RL-92-19, U.S. Department of Energy, Richiand Field Office, Rich] and, Washington.

Ecology, EPA, and DOE, 1994, Hanford Federal Facflity Agreement and Consent Order, Fourth Amendment, Washington State Department of Ecology, U.S. Environmental Protection Agency, and U.S. Department of Energy, 0)ympta, Washington.

Freeman, P. J., 1995, "216-A-29 Ditch" in Quarterly Report of RCRA Groundwater Honitoring Data for Period Dctober, 1, 1994 through Deceniber 31, I994, DOE/RL-94-36-4, U.S. Departwent of Energy, Richland Operations office, Richiand, Washington. 
Kasza, G. L., 1992, Borehole Completion Data Package for the 216-A-29 RCRA Facility Nonitoring Wells: Calendar Year 1991, NHC-SD-EN-DP-047, Rev. 0, Westinghouse Hanford Company, Richland, Washtngton.

Kasza, G. L., and S. M. Goodwin, 1992, Groundwater Monitoring Plan for the 216-A-29 Ditch, WHC-SB-EN-AP-045, Rev. 0-A, Westinghouse Hanford Company, Richland, Washington.

Resource Conservation and Recovery Act of 1976, 42 USC 6901 et seq.

Smith, D. L., 1992, 216-A-29 Oitch Interim Stabilization Final Report, WHC-SD-DD-TI-060, Rev 0-A, Westinghouse Hanford Company, Richland, Washington.

Votava, J. M., 1995a, Results of the Groundwater Quality Assessount Progran at the 216-A-29 Ditch RCRA Facility, WHC-5D-EN-EY-032, Westinghouse Hanford Company, Richiand, Washington.

Votava, J. M., 1995b, "216-A-29 Ditch," Quarterly Report of RCRA Groundwater Nonitaring Data for Period Jantary 1, 1995 through Narch 30, 1995 , DOE/RL-94-69-1, U.S. Department of Energy, Richland Operations Office, Richland, Nashington.

Votava, J. H., 1995c, "216-A-29 Bitch," Quarterly Report of RCRA Groundwater Monttoring Data for Period April 1, 1995 through June 30, 1995 , DOE/RL-94-69-2, U.S. Department of Energy, Richland Operations office, Richl and, Washington.

Votava, J. M., 1996, "216-A-29 Ditch," Quarterly Report of RCRA Groundwater Nonitoring Data for Period July 1, 1995 through Septeaber 30, 1995, DOE/RL-94-69-3, U.S. Department of Energy, Richland Operations office, Richiland, Mashington.

WHC, 1990, Interin Hydrogeologic Characterization Report for the 216-8-3 Pond, WHC-SO-EA-EV-002, Rev. 0, Westinghouse Hanford Conapany,

Richland, Washington.

WHC, 1992, Hydrogeologic Nodel for the 200 East 6roundwater Aggregate Area, WHC-SD-EN-TI-019, Rev. 0, prepared by H. P. Connelly, B. H. Ford, J. W. Lindberg, S. J. Trent, and C. D. Delaney, Nestinghouse Hanford Company, Richland, Washington, and J. V. Borghese, Paclfic Morthwest Laboratory, for Westinghouse Hanford Company, Richland, Washington. 
A

- $\mathbf{A}^{\prime}$
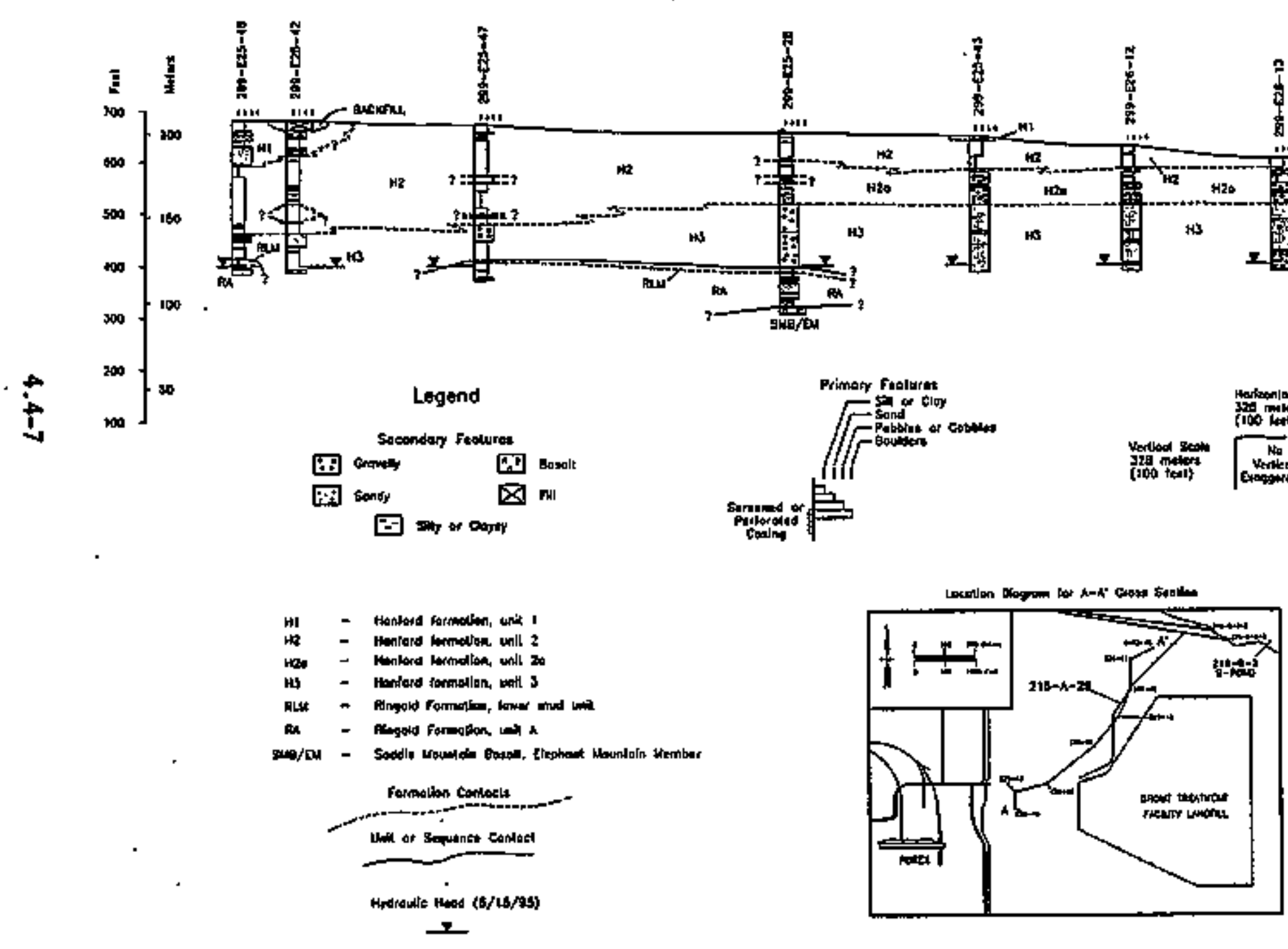

Primaty follurst
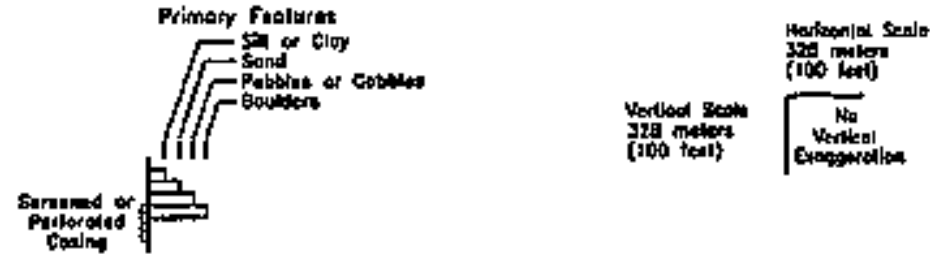

' 
DOE/RL-96-01, REV. 0

Figure 4.4-2. Monitoring Well Locations at the 216-A-29 Ditch.

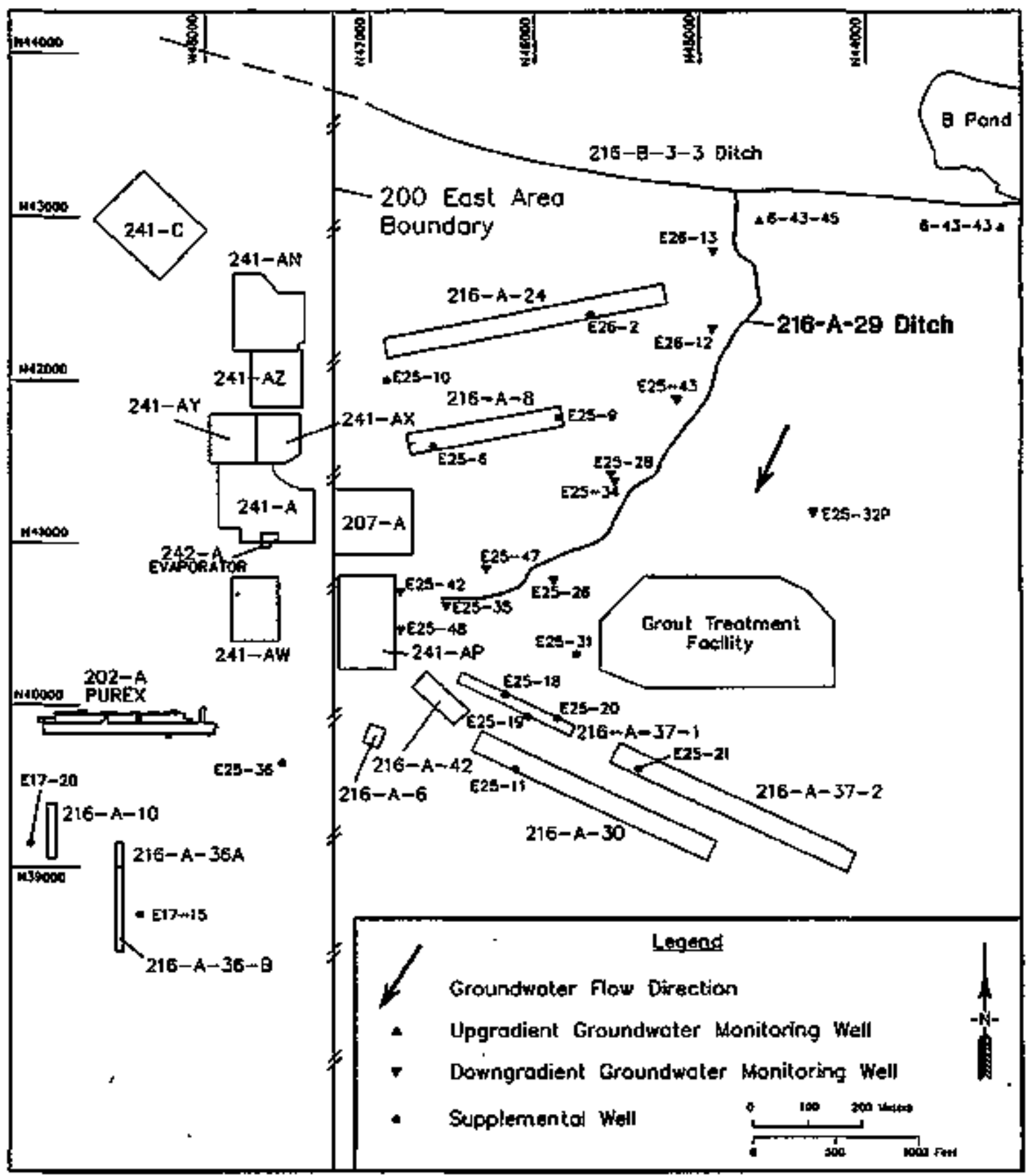

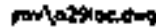


Figure 4.4-3. Specific Conductance and Sulfate, Sodium, and Calcjum Concentrations Over Tí at Well 299-E25-35.
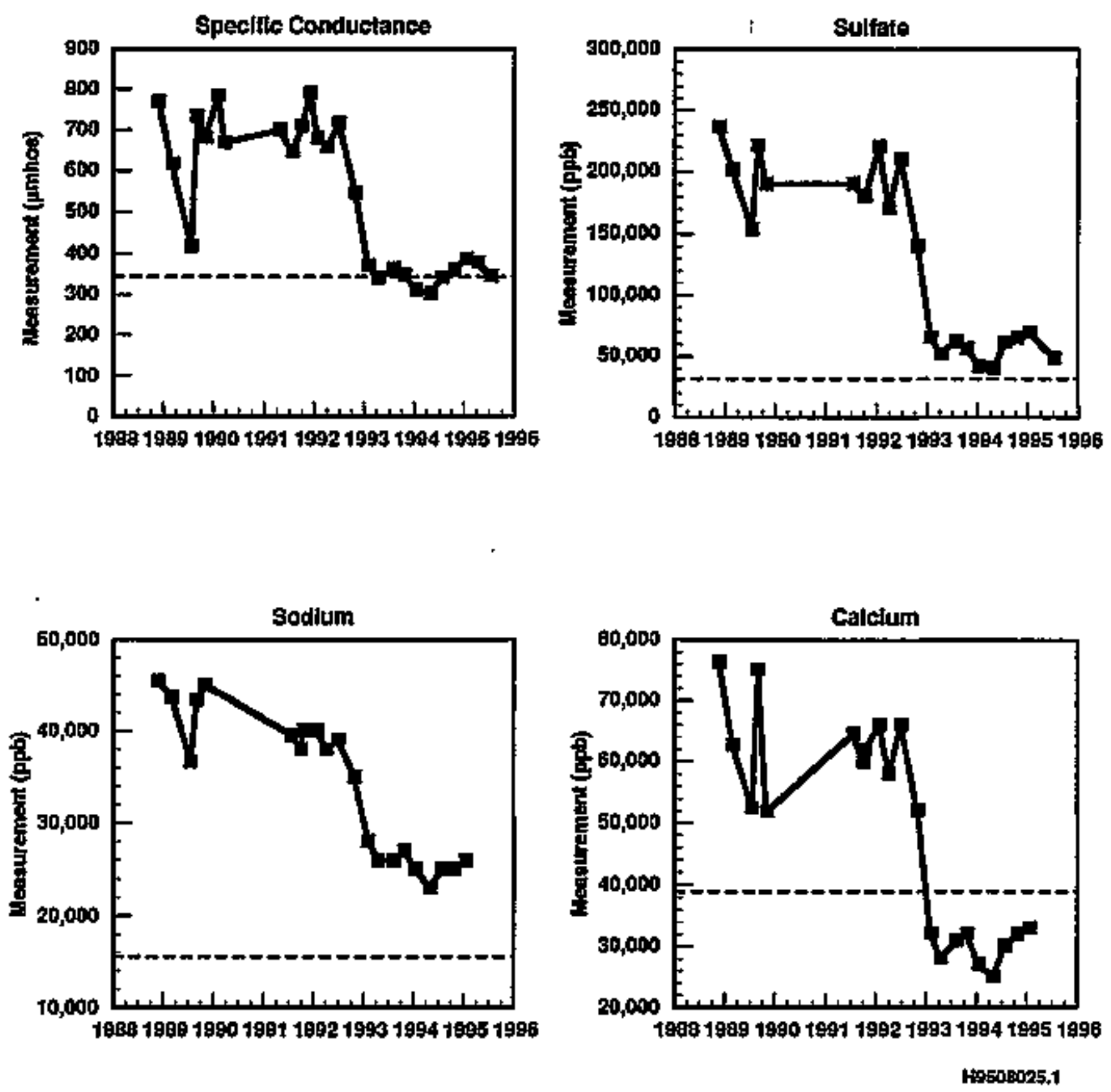

----. Hanford Site Mean Eackground Level (Johnson, 1999) 
Figure 4.4-4. Specific Conductance Concentrations Over Time at Mell 299-E25-35 and Select Wel15.

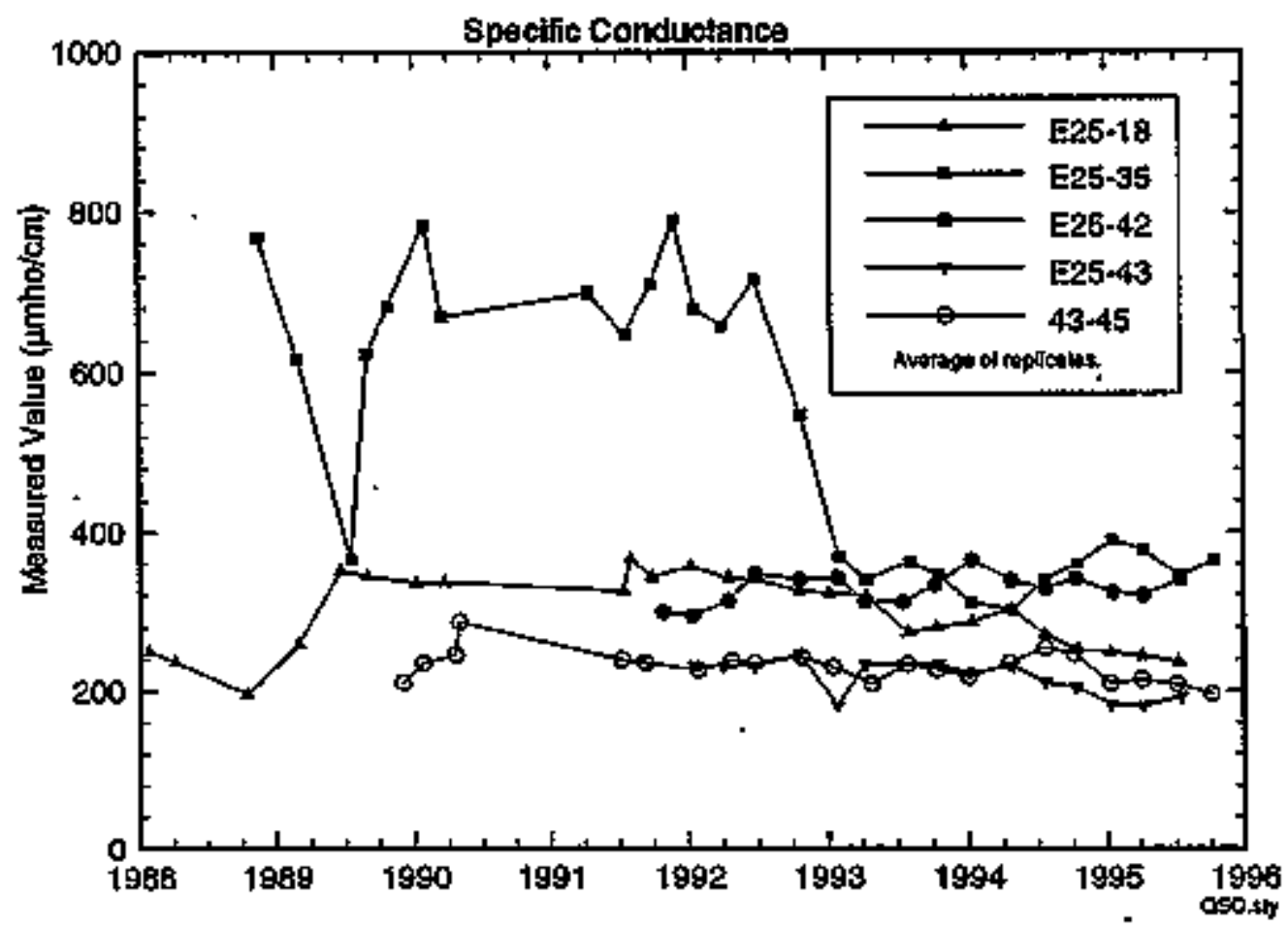

Figure 4.4-5. Sulfate Concentrations Over Time at Well 299-E25-35 and Select Wells.

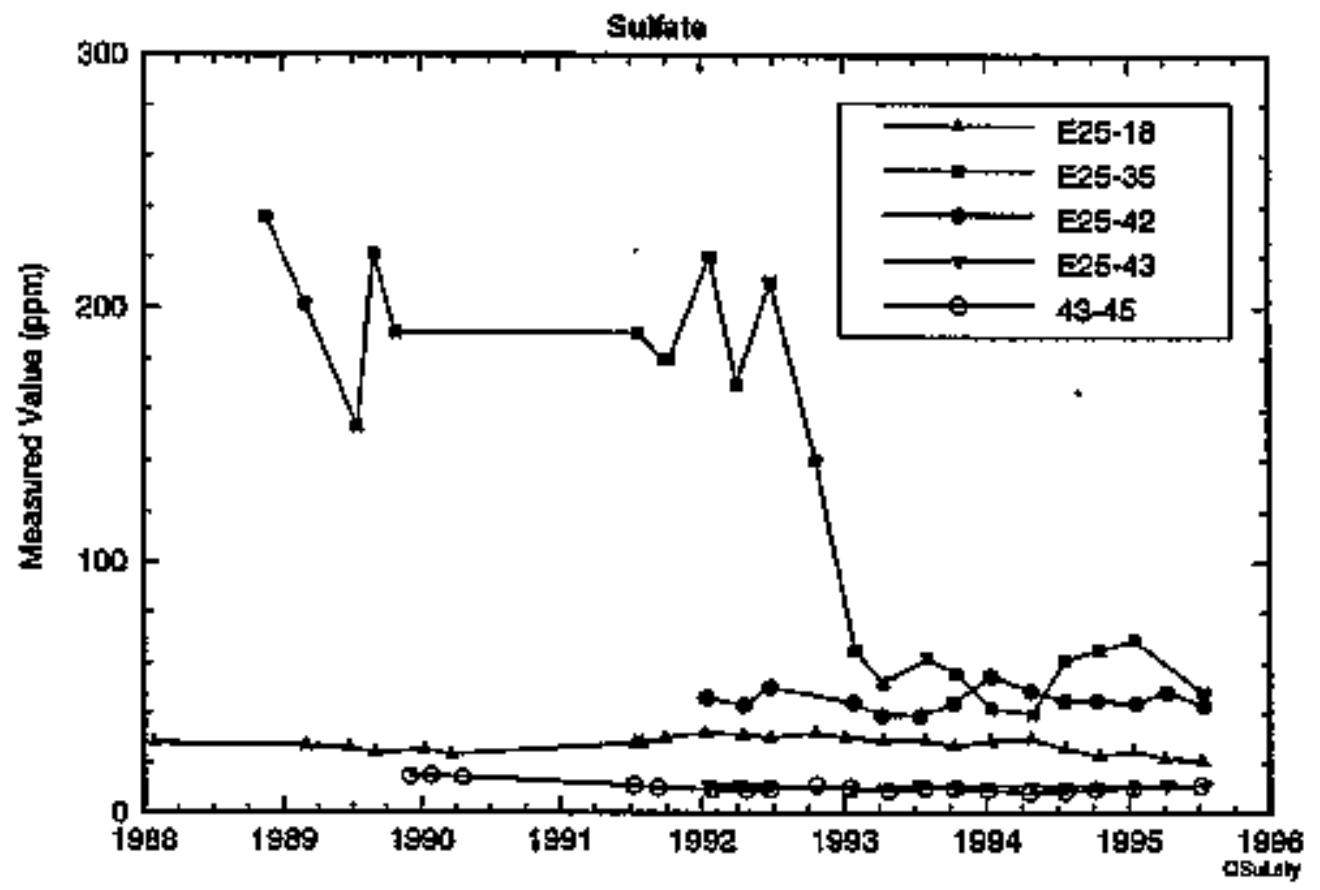


D0E/RL-96-01, REV. 0

Figure 4.4-6. Specific Conductance of Groundwater (Average 1/95 - 8/95).

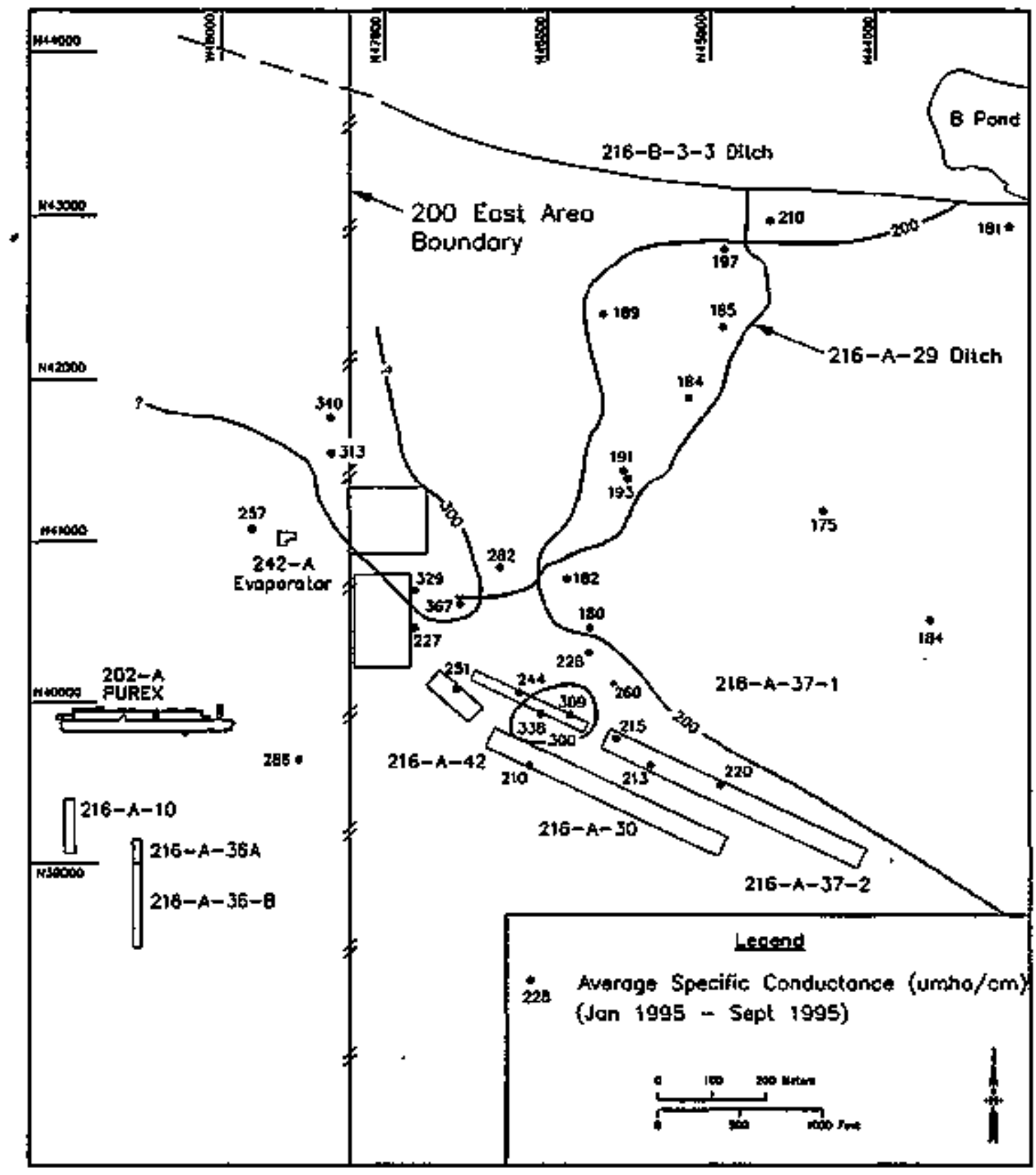

morpatipention 
Figure 4.4-7. June 1995 Nater Table.

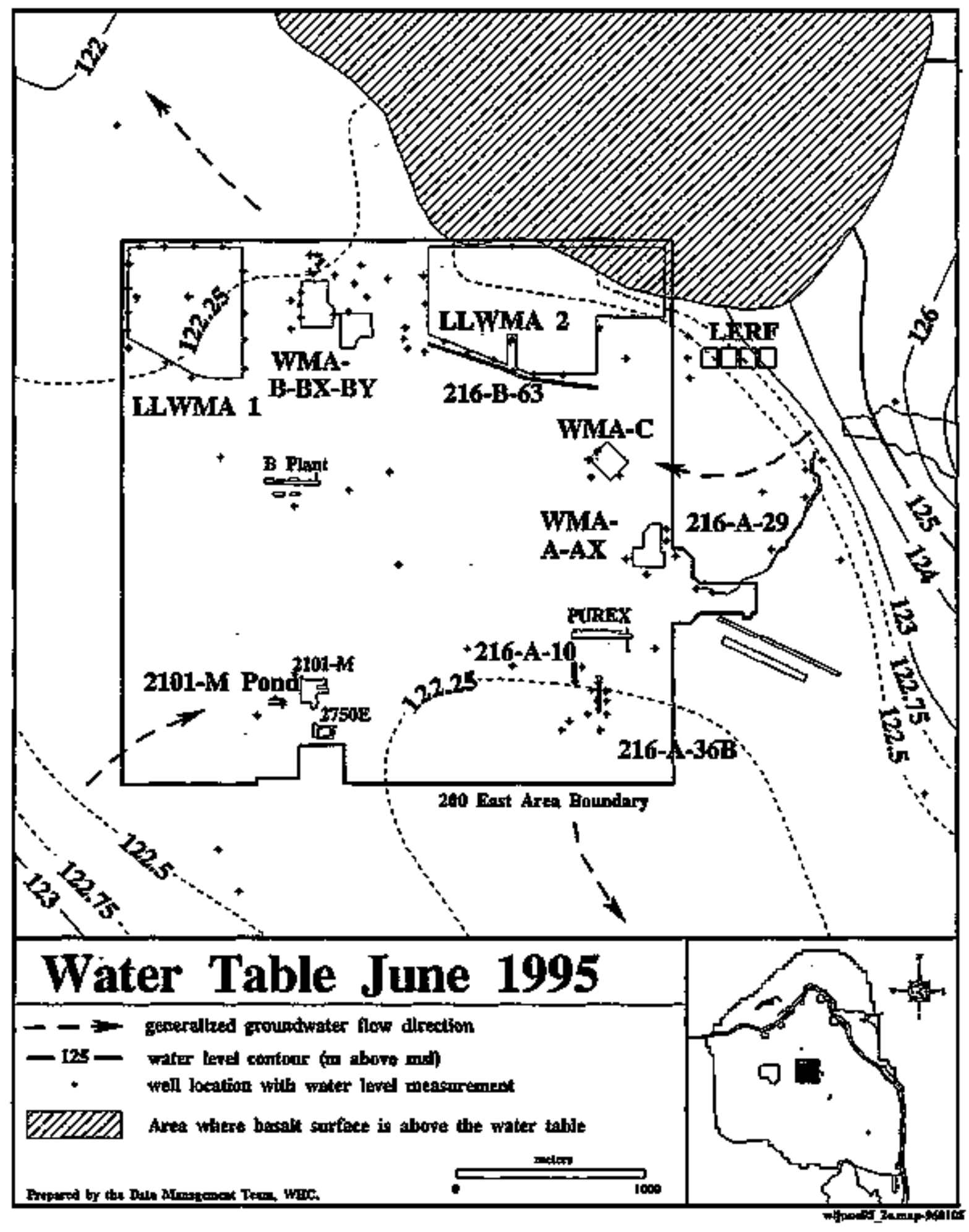


DOE/RL-96-01, REY. O

Figure 4.4-8. Hydrograph of 216-A-29 Ditch Monftoring Network Metls.

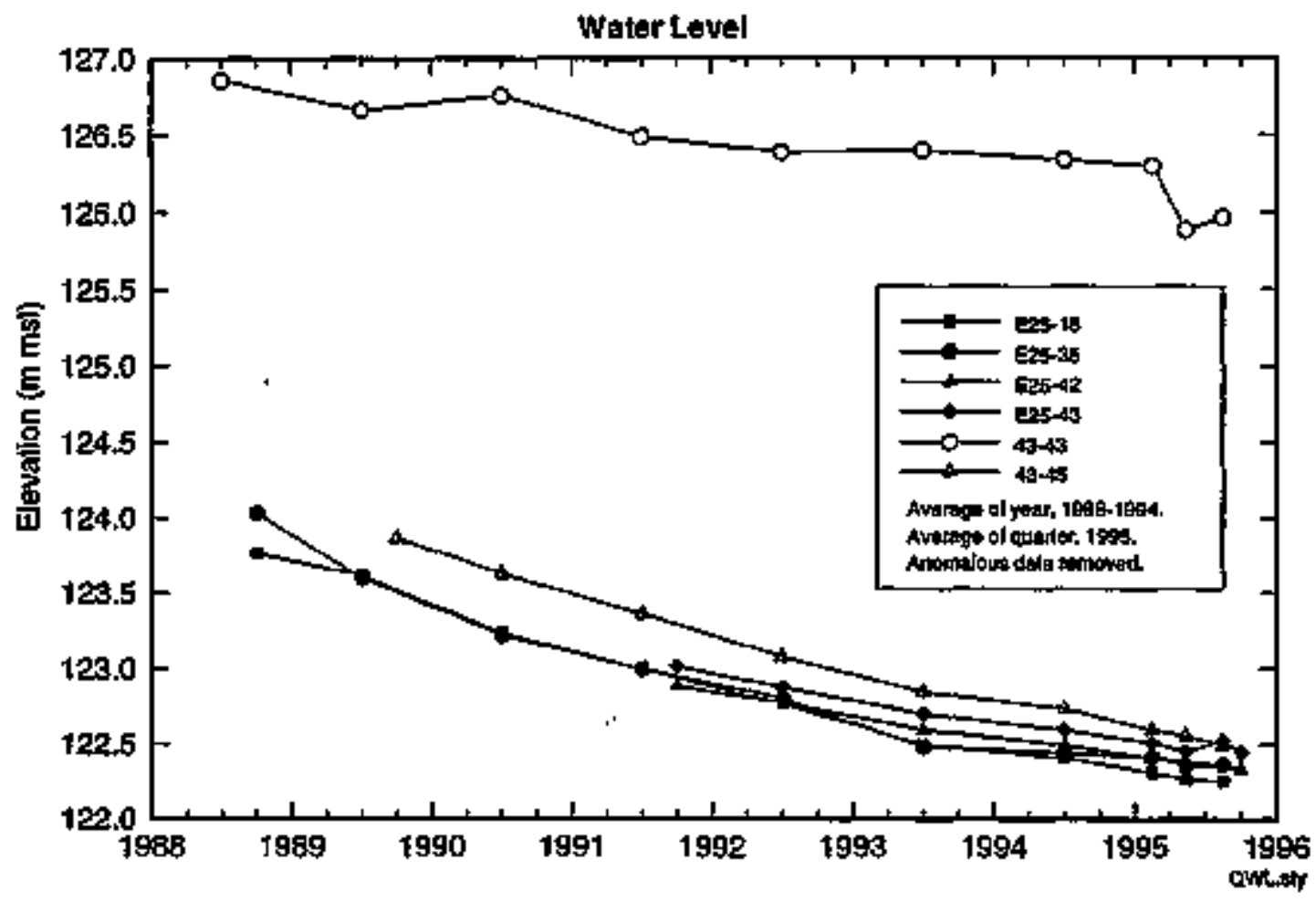


Table 4.4-1. Monitoring Wells Used for the 216-A-29 Ditch.

\begin{tabular}{|c|c|c|c|c|c|}
\hline We11 & Aquifer & $\begin{array}{l}\text { Sampling } \\
\text { frequency }\end{array}$ & $\begin{array}{l}\text { Hater } \\
\text { levels }\end{array}$ & $\begin{array}{c}\text { Well } \\
\text { standard }\end{array}$ & $\begin{array}{c}\text { other } \\
\text { networks }\end{array}$ \\
\hline $299-E 25-26^{85}$ & Upper unconfined & $\mathbf{q}$ & H & RCRA & $\overline{--}$ \\
\hline $299-E 25-28^{85}$ & Deep unconfined & q & H & RCRA & - \\
\hline $299-625-34^{88}$ & Top of unconfined & 9 & H & RCRA & - \\
\hline $299-E 25-35^{85}$ & Top of unconfined & 4 & M & RCRA & - \\
\hline $299-E 25-42^{9 t}$ & Top of unconfined & $\mathbf{Q}$ & $\mathbf{H}$ & RCRA & - \\
\hline $299-E 25-43^{91}$ & Top of unconfined & 4 & H & RCRA & -- \\
\hline $299-\mathrm{E} 25-47^{92}$ & Top of unconfined & $\mathbf{Q}$ & H & RCRA & -- \\
\hline $299-E 25-48^{92}$ & Top of unconfined & $\mathbf{Q}$ & $\mathbf{H}$ & RCRA & - \\
\hline $299-E 26-12^{\text {gh }}$ & Top of unconfined & Q & $M$ & RCPA & $=$ \\
\hline $299-E 26-13^{95}$ & Top of unconfined & Q & H & RCRA & 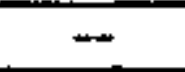 \\
\hline $299-E 25-32 p^{85}$ & Top of unconfined & Q & M & RCRA & - \\
\hline $699-43-43^{39}$ & Top of unconfined & Q & H & RCRA & B Pond \\
\hline $699-43-45^{69}$ & Top of unconfined & 9 & M & RCRA & B Pond \\
\hline $299-E 17-15^{80} \mathrm{~A}$ & Top of unconfined & 4 & 9 & RCRA & $A-36 B$ \\
\hline $299-E 17-20^{88} A$ & Top of unconfined & 9 & $\mathbf{Q}$ & RCRA & $A=10$ \\
\hline $299-E 25-06^{36} A$ & Top of unconfined & -- & 0 & PRE & - \\
\hline $299-E 25-09^{56} A$ & Top of unconfined & - & Q & PRE & -- \\
\hline $299-E 25-10^{58} A$ & Deep unconfined & $\rightarrow$ & Q & PRE & -- \\
\hline $299-E 25-11^{60} A$ & Deep unconfined & $\mathbf{Q}$ & Q & PRE & - \\
\hline $299-E 25-18^{76} A$ & Top of unconfined & $\mathbf{Q}$ & $\mathbf{Q}$ & PRE & 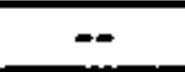 \\
\hline $299-E, 25-19^{76} \mathrm{~A}$ & Top of unconfined & 4 & 4 & PRE & -- \\
\hline $299-E 25-20^{76} \mathrm{~A}$ & Top of unconfined & $\mathbf{q}$ & Q & PRE & -- \\
\hline $299-E 25-21^{83} \mathrm{~A}$ & Top of Unconfined & $Q$ & 4 & PRE & $=$ \\
\hline $299-E 25-31^{87} A$ & Top of unconfined & $\mathbf{Q}$ & Q & RCRA & $=$ \\
\hline $299-E 25-36^{88} A$ & Top of unconfined & $\mathbf{Q}$ & $\mathbf{Q}$ & $\overline{R C R A}$ & $A-10$ \\
\hline $299-E 26-02^{58} A$ & Top of unconfined & - & Q & PRE & $\rightarrow$ \\
\hline
\end{tabular}

Hotes: Shading denetes upgradient wells. Superseript following wall number denotes the year of installation.

A - assessnent program well that is sampled for supplementary data.

$H=$ frequency on a monthly basis.

PRE - well was constructed before RCRA-specified standards.

$Q$ - frequency on a quarterly basis.

RCRA = well is constructed to RCRA-specified standards. 
DOE/RL-96-01, REY. 0

Table 4.4-2. Constituents Analyzed in the Groundwater Beneath the 216-A-29 Ditch.

\begin{tabular}{|l|l|}
\hline \multicolumn{1}{|c|}{ Semiannually } & \multicolumn{1}{|c|}{ Annual1y } \\
\hline TOX & alkalinity \\
\hline TOC & anions \\
\hline PH & ICP metals \\
\hline specific conductance & tritium \\
\hline turbidity & phenols \\
\hline
\end{tabular}


D0E/RL-96-01, REY. 0

This page intentionally left blank.

$\begin{array}{ll}. & 4.4-16\end{array}$ 
$D O E / R L-96-01, R E Y .0$

\section{CONTENTS}

4.5 216-A-36B CRIB .................. 4.5-1

4.5.1 facility overview . . . . . . . . . . . . 4.5-1

4.5.2 Summary of 1995 RCRA Activities ......... 4.5-2

4.5.3 Sampling and Analysis Progran . . . . . . . . . . 4.5-2

4.5.4 Groundwater Chentstry ............... 4.5-2

4.5.5 Groundwater Flow ................. 4.5-4

4.5.6 References .................. 4.5-5 
DOE/RL-96-01, REV. 0

\section{LIST OF FIGURES}

4.5-1 Monitoring Nell Locations for the 216-A-36B Crib . . . . . 4.5-7

4.5-2 Nitrate Distribution in the Uppermost Aquifer

Beneath the 200 East Area ................... 4-8

4.5-3 Tritium Distribution in the Uppermost Aquifer

Beneath the 200 East Area ........... 4.5-9

4.5-4 Nitrate Concentrations in the 216-A-368 Metwork We17s . . . 4.5-10

4.5-5 Trititim Concentrations in the 216-A-36B Hetwork Wells ... 4.5-11

4.5-6 Composite Hydrograph for the 216-A-36B Network Wells . . . 4.5-12

4.5-7 200 East Area and 216-A-36B Crib Vicinity

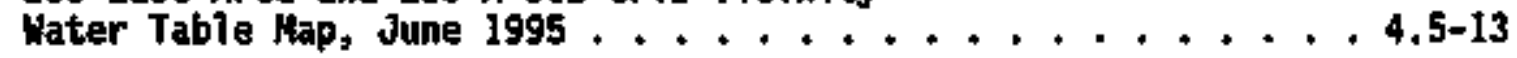

\section{LIST OF TABLES}

4.5-1 Manitoring Wel1s in the 216-A-36B Crtb Network . . . . . . 4.5-14

4.5-2 Const tuents Analyzed in the 216-A-36b Crib Groundwater

Monitoring Network ................. 4.5-14

4.5-3 Critica] Means TabTe for 28 Comparisons--Background

Contamination Indicator Parameter Data for the 216-A-36B Crib , 4,5-15 
DOE/RL-96-0l, REV. O

\subsection{6-A-36B CRIB}

J. H. Yotava

Westinghouse Hanford Company

\subsubsection{Facility Overview}

The 216-A-36B Crib (A-36B Crjb), now retired from use, was a liquid waste disposal facility for the Plutonium-Uranium Extraction (PUREX) Plant. The A-368 Crib is located in the 200 East Area approximately $360 \mathrm{~m}(1,200 \mathrm{ft})$ south of the PUREX Plant. It is approximately $110 \mathrm{~m}$ (360 ft) east of the 216-A-10 Crib. The A-36B Crib is the south end. [150 m (500 ft)] of the crib, originally known as the 216-A-36 Crib (Figures 1-1 and 4.5-1).

The original crib dimenstons rere $180 \mathrm{~m}$ (600 ft) Tong, $4 \mathrm{~m}$ (12 ft) wide, and $4 \mathrm{~m}$ (12 ft) deep. A $0.15-\mathrm{m}-(0.5-\mathrm{ft}-$ ) diameter perforated distributor pipe was placed at the botton of the crib on a $0.3-\mathrm{m}(1-\mathrm{ft})$ bed of gravel, covered with another $0.3 \mathrm{~m}$ (1 ft) of gravel, and backfilied to grade. Ammonia scrubber distillate waste from the PUREX Plant was discharged through the distribution pipe to the crfb and allowed to percolate through the soil column.

The original crib (216-A-36) received liquid effluent from September 1965 to March 1966. A substantial inventory of radionuctides was disposed of and was assumed to have infi]trated sediments near the inlet to the crib. To prevent radionuclides from reaching the water table, Operations personnel decided to treat the head end of the crib as a specific retention facitity. This limits the amount of water discharged to the crib (Smith and Kasper 1983). To continue eff]uent discharge to the crib, the crib was divided into two sections: 216-A-36A and 216-A-36B. Grout was injected into the gravel layer to form a curtain separating the two sections. The liquid effTuent discharge point was woved to the 216-A-36B Crib section and the 216-A-36A Crib section was no longer used. Discharge to the 216-A-368 Crib resumed in March 1966 and continued until 1972, when the crib was temporarily removed from service. The 216-A-36B Crib was placed back in service in Navember 1982 and operated until it was taken out of service again in October 1987.

Ammonia scrubber distillate discharged to the A-36B Crjb consisted of condensate from nuclear fuel decladding operations in which zirconium cladding was removed from irradiated fuel by boiling in a solution of ammonium fluoride and anowiun nitrate. other waste strean constituents included

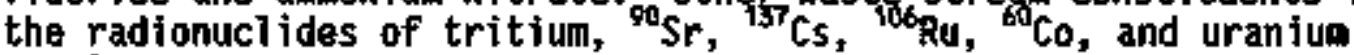
(Buelt et al. 1988).

Waste disposed of in the A-36B Crib encountered approximately $97 \mathrm{~m}$ (318 ft) of unsaturated Hanford formation sediments above the water table. The water table beneath the A-36B Crib occurs very near the hard-todfstinguish contact between the unsaturated Hanford formation upper gravel and sandy sequences of the underlying Ringold gravel unit $E$ (see Chapter 2.0). ApproximateTy $40 \mathrm{~m}(130 \mathrm{ft})$ of Ringold Formation sedtments make up the saturated zone of the uppermost aquifer system beneath the A-36B Crib (WHC 1992). 
An interim-status Resource Conservation and Recovery Act of 1976 (RCRA) groundwater monitoring program has been in operation at the A-36B Crib since May 1988. The groundwater monitoring program at the A-36B Crib is currentiy in indicator-parameter evaluation status. The RCRA closure/post-closure plan for the A-36B Crib is scheduled to be submitted to the Washington State Department of Ecology and the U.S. Environmental Protection Agency in June 1998. This action wilT satisfy the Hanford Federal Facility Agreesent and Consent Order Milestone M-20-34 (Ecology et a]. 1994). The A-36B Crib is part of the CERCLA 200-PO-2 operable unit.

\subsubsection{Sumary of 1995 RCRA Activities}

Groundwater samples were collected and analyzed semiannualty for ToX, TOC, pH, specific conductance, turbidjty, gross a]pha, gross beta and tritium and annualty for alkalinity, anions, ICP metals, $I$, and phenols during 1995 for the wells in the A-36B Crib groundwater monitoring network. Samples were collected during Dctober 1994 and April 1995. The depth to the groundwater beneath the A-36B Crib was measured in the monitoring network wells during sapple collection and for each quarterly reporting period. The groundwater chemistry data and water leve] measurements were reported quarterly (Edrington 1995, 1995a; Votava 1995, 1996).

\subsubsection{Sampling and Analysis Program}

The A-36B Crib groundwater monitoring network (Figure 4.5-1) consists of three upgradient and six downgradient wells. All wells are shallow groundwater monjtoring we17s. Monitoring well information is presented in Table 4.5-1. All wells in the network, except 299-E17-5 (used for water leve] measurements only) and 299-E17-9, meet RCRA construction standards. These two wells are older remedjated wel]s with perforated carbon steel casing. Samples from these wells are not used in statistical evaluation of the groundwater monitoring network.

Groundwater samples from the A-36B monitoring network are collected and analyzed semiannually and annua]ly, depending on the constituent, to detect any groundwater contamination originating from the facility. Groundwater sampies are analyzed for a series of constituents including: groundwater quality parameters, groundwater contamination indjcator parameters, and sitespecific constituents. The site-specific constituents were selected based on knowledge of the waste streans formerly discharged to the A-36B Crib. Table 4.6-2 lists these constituents. This sample and anaiysis progran meets RCRA requirements (40 CFR 265).

We11 299-E25-36 is shared with the grouniwater monitoring network for the 216-A-29 Ditch (see Section 4.4). Th is we1] is sampled quarterly to provide supp:ententary local groundwater quality data for the 216-A-29 Factlity groundwater quality assessment program. We7l 299-E24-18 is shared with the 216-A-10 groundwater monitoring network. It is sampled semiannually. 


$$
\text { DOE/RL-96-01, REV. } 0
$$

\subsubsection{Groundwater Chemistry}

The A-368 Crib is located directly over several plumes that define areas where specific constituents exceed the drinking water standards (ONS). The prianary constituents of concern are nitrate and tritium (Figures $4.5-2$ and 4.5-3). Similarities in the effiuent constituents discharged to the A-10 and 216-A-45 Cribs and their proximity to the A-36B Crib make it difficult to determine how much the A-36B Crib affects the groundwater quality.

4.5.4.1 Elevated constituents. The critical means ware not excaeded for the four contamination indicator parameters (specific conductance, $\mathrm{pH}, \mathrm{TOC}$, and TOX) in the A-36B Crib monttoring network during 1995 . DWS for the following const ituents were exceeded in the A-36B network during 1995: nitrate, tritjum, ${ }^{29} I$, unfiltered chromiuin, and unfiltered iron (Edrington 1995; Edrington and Yotava 1995; Votava 1995, 1996). Requests for analytical data evaluatton were submitted for all unusual oecurrences of constituents.

Nitrate concentrations (Figure 4.5-4) exceeded the OWS (45,000 ppb) at least once in wells 299-E17-9, 299-E17-14, 299-E17-15, and 299-EI7-16 during 1995. The trend of the nitrate concentration in the groundwater beneath the A-36B facitity has generally been steady to slightly declining since 1987 .

The tritium DNS $(20,000 \mathrm{pCi} / \mathrm{L})$ was exceeded in all wells, except 299-E25-36, in the A-36B groundwater monftoring network during 1995 (Figure 4.5-5). The measured concentrations of tritium are unchanged to slightly lower than 1994 results. The ${ }^{129} \mathrm{I}$ OHS $(1 \mathrm{pCi} / \mathrm{L})$ a] 50 was exceeded in all of the network wells.

During 1995, the chromium DUS (100 ppb) was exceeded in unfiltered samples from welts 299-E24-18 and 299-E25-36. Iron in unfiltered samples also exceeded the OHS (300 ppb) for wells 299-E17-15, 299-E17-16, 299-E17-17, and 299-E25-36. Unfiltered metals are belfeved to represent effects caused by well construction and not groundwater.

4.5.4.2 Statistical Evaluation. During 1995, groundwater quality beneath the A-36B Crib was subject to the RCRA-required continuing evaluation for sttes under indicator parameter evaluation status. Appendix $C$ explains the statistical method used to evaluate the groundwater analytical results. The statistical evaluations of the indicator parameter data consisted of reestablishing background conditions and comparing sample results from upgradient and downgradient wells for any indication of contamination in the groundwater underlying the facility. Statistical analyses required by 40 CFR 265.93(b), and Washington Administrative Cade (WAC) 173-303-400 were perforwed on the samples collected from September 1988 to June 1989 for upgradient (at that time) well 299-E17-17 (DOE-RL 1991). Results are presented in Table 4.5-3. This table lists the background average, background standard deviation, and critical mean (or critical range, in the case of pH) and upgradient/downgradient comparison values for the four contamination indicator parameters. The comparison value is the value to which current and future averages of quadruplicate measurements are compared. The comparison value is generally the critical mean or critical range. Alt values of specific conductance, $\mathrm{pH}$, TOC, and TOX in the downgradtent wells in the past year were below the upgradient/downgradient comparison value. 


$$
\text { DOE/RL-96-01, REY. } 0
$$

\subsubsection{Groundwater Flow}

4.5.5.1 Water Level. Water levels in the A-36B network were measured quarterly and during sentiannual sampling events in 1995 (Edrington 1995, Edrington and Votava 1995; Votava 1995, 1996). Mater leve1 data through September 1995 are presented for all wells in figure 4.5-6. The average water level decl ine in these wells was approximately 0.15 of $(0.5 \mathrm{ft}$ ) between June 1994 and June 1995. This trend contintes the long-term decline in water levels that began during 1988 after the PUREX Plant operations shut down and discharges to the A-36B Crib and other nearby liquid effluent disposal factlitites ceased.

4.5.5.2 Groundwater Flow Direction. Groundwater flow directlons in the vicinity of the A-36B Crib are poorly defined because the local hydratulic gradient is extronely low (Figures 4.5-7). Regional-scale, water table elevation changes indicate that local groundwater flow is toward the southsoutheast (see Figure 2-4).

4.5.5.3 Rate of Flow. Water table gradient is estimated to be in the range of 0.0001 to 0.0002 (HHC 1992). Based on these estimates and estinates of hydraulic conductivity (150 to $300 \mathrm{~m} / \mathrm{d}[500$ to $1,000 \mathrm{ft} / \mathrm{d}]$ ) and porosity (0.25) for the unconfined aquifer near the A-36B Crib (WHC 1992), groundwater flow velocities may range from 0.06 to $0.24 \mathrm{~m} / \mathrm{d}(0.2$ to $0.8 \mathrm{ft} / \mathrm{d}$ ) (see Section 4.4). Determining the vertical groundwater gradient is not possible because paired (deep) well completions are lacking in the surrounding area.

4.5.5.4 Evaluation of Monitoring Mell Metwork. Water levels are measured regulariy and the adequacy of the existing monitoring network is evaluated accordingly. Because of the steadily decreasing water levels since the newest wells in the network were drilled in 1988, the water level in each well was compared to the depth of the screened interval and pump intake elevation to ensure that sufficient volumes of water exist for sampling. As stated in Section 4.5.2, there is no near-term need to replace any of the existing groundwater monitoring wells. Because the A-36B Crib is surrounded on all sides by seven groundwater monitaring wells, the downgradient monitoring well network is currently adequate to monitor the quality of the groundwater bentath the A-36B Crib.

Because of the low local hydraulic gradient and the continuing decline of the regional water table, the evaluation of the upgradient wells is difficult. Very small relative changes in wator levels between wells way constitute a reversal in gradient. Figure 4.5-6 shows that al though well 299-E17-17 is an upgradient monttoring polnt for the A-36B Crib, two other wells in the network have had water levels as high or higher during certain periods. On several occas lons during the current report period, downgradient welTs 299-E17-14 and 299-E17-18 have had higher water levels than upgradient well 299-E17-17. The use of well 299-E17-17 as the upgradient groundwater monitoring well may not be appropriate in view of the current water table configuration. This issue was addressed in the revision of the Interio-Status Groundwater Monttoring PI an for the 216-A-10 and 216-A-36B Cribs (WHC 1994). In the last sampling year, the two upgradient wells from the A-10 monitoring network (299-E25-36 and 299-E24-18) were added as upgradient wells to the A-36B monitoring notwork for a tota] of three upgradient wells. See Figure 4.6-6 for the location of these'wel7s; see Section 4.6 for-more information about these wells. 


\subsubsection{References}

40 CFR 265, "Interin Status Standards for Owners and Operators of Permitted Hazardous Waste Facilities," Cade of Federal ReguTations, as amended.

Buelt, J. L., W. Coubere, M. D. FreshTey, R. J. Hicks, W. L. Kuhn, D. A. Lamar, R. J. Serne, and J. L. Smoot, 1988, The Predfeted Inpacts to the Ground Water and Columbia River from Anoniated Water Discharged to the 216-A-368 Crib, PNL-6463, Pacific Northwest Laboratory, Richiand, Washington.

Comprehensive Environmental Response, Cowpensation, and Liability Act of 1980, 42 USC 9601 et seq.

DOE-RL, 1991, Annual Report for RCRA Groundwater Nonitoring Profects at Hanford Site Facilities for 1990, DOE/RL-91-03, U.S. Department of Energy, Richland Fjeld office, Richland, Washington.

DOE-RL, 1994, Annual Report for RCRA Groundwater Honitoring Profects at Hanford site facilitifes for 1993, DOE/RL-93-88, Rev. 0, U.S. Departinent of Energy, Richland Operations Office, Richiand, Washington.

Ecology, EPA, and DOE, 1994, Hanford Federal Facility Agreement and Consent Order, Fourth Amendment, Washington State Department of Ecology, U.S. Environmental Protection Agency, and U.S. Department of Energy, olympia, Washington.

Edrtngton, H. H., 1995, "216-A-10 Cr1b," Quarterly Report of RCRA Groundwater Honftoring Data for Period October 1, 1994 through Decenber 31, 1994, OOE/RL-94-36-4, U.S. Departwent of Energy, Rfchland Operattons Office, Richland, Washington.

Edrington, H. H. and J. M. Votava, 1995, "216-A-10 Crib, " Quarterty Report of RCRA Groundwater Honitoring Data for Period January 1, 1995 through Narch 31. 1995, DOE/RL-95-69-1, U.S. Department of Energy, Richland Operations office, Richland, Washington.

Resource Conservation and Recovery Act of 1976, 42 USC 6901 et seq.

Smith, R. H. and R. B. Kasper, 1983, Serviceability of Cribs Affected by PUREX Startup, RHO-HS-EV-18, Rockwe11 Hanford Operations, Richland, Washington.

Votava, J. H., 1995, "216-A-10 Crib," Quarterly Report of RCRA Groundwater Monitoring Data for Period April 1, 1995 through June 30 , 1995, OOE/RL-94-69-2, U.\$. Department of Energy, Richland Operations office, Richland, Washington.

Votava, J. M., 1996, "216-A-10 Crib, "Quarterly Report of RCRA Groundrater Nonitoring Data for Pertod July I, 1995 through September 30, 1995, DOE/RL-94-69-3, U.S. Department of Energy, Richland Operations Office, Richl and, Washington. 
DOE/RL-96-01, REV. 0

WAC 173-303, "Dangerous Waste Regulations," Washington Administrative Code, as amended.

WHC, 1992, Hydrologic Hodel for the 200 East Groundwater Aggregate Area, WHC-SD-EN-TI-019, Rev. 0, Nestinghouse Hanford Company, Richland, Hashington.

WHC, 1994, Interino-Status Groundwater Nonitoring Plan for the 216-A-10 and 216-A-36B Cribs, WHC-SD-EN-AP-170, Rev. O-A, Westinghouse Hanford Company, Rich] and, Washington. 
DOE/RL-96-0l, REV. O

Figure 4,5-1. Monitoring Nell Locations for the 216-A-36B Crib.

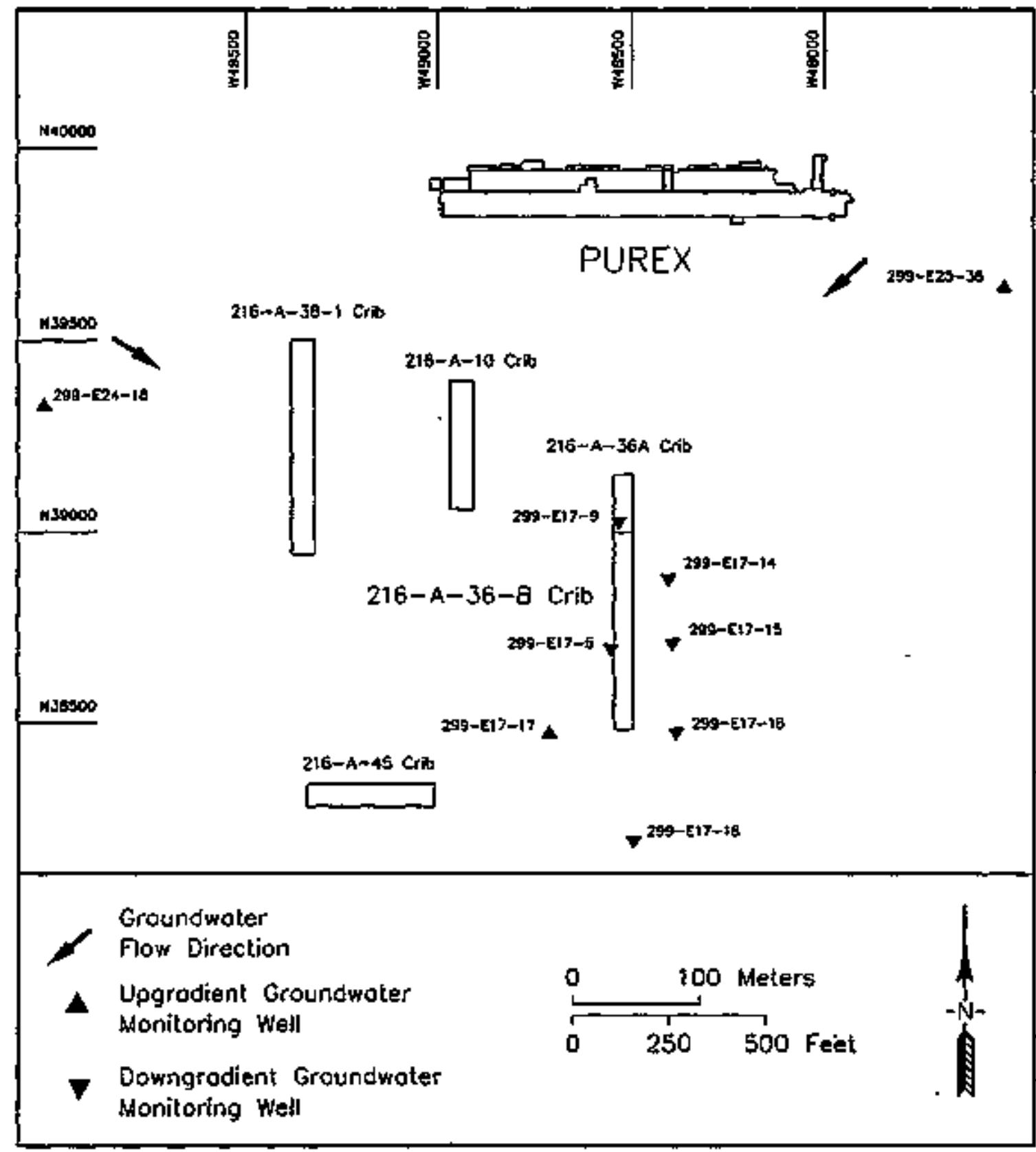

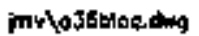


Figure 4.5-2. Nitrate Oidribution in the Uppermost Aquifer Beneath the 200 East Area.

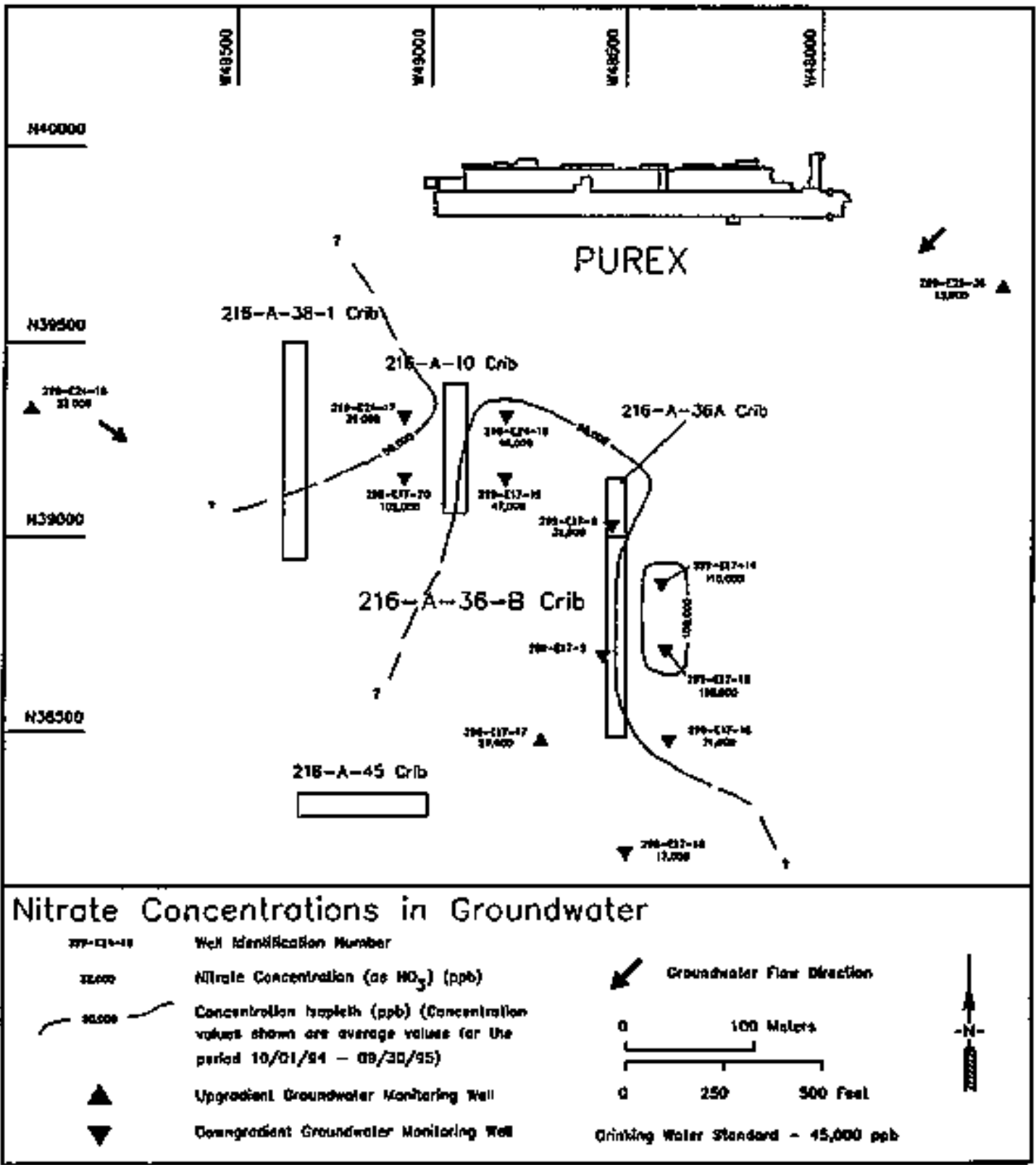

hertojebolinded 
Figure 4.5-3. Tritium Distribution in the Uppermost Aquifer Beneath the 200 East Area.

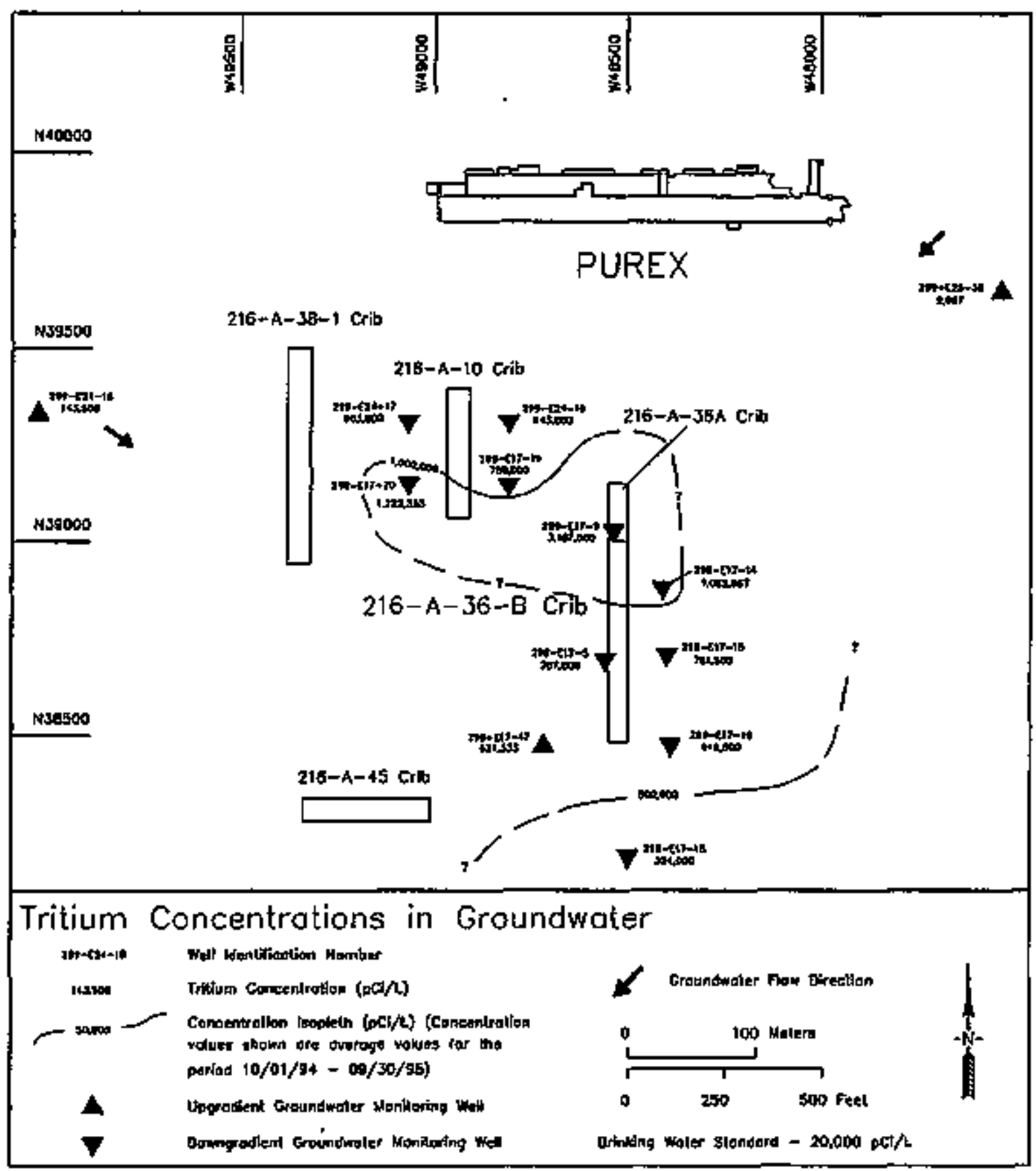

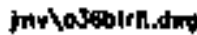


DDE/RL-96-01, REV. O

Figure 4.5-4. Nitrate Concentrations in the 216-A-36B Network Wel1s.
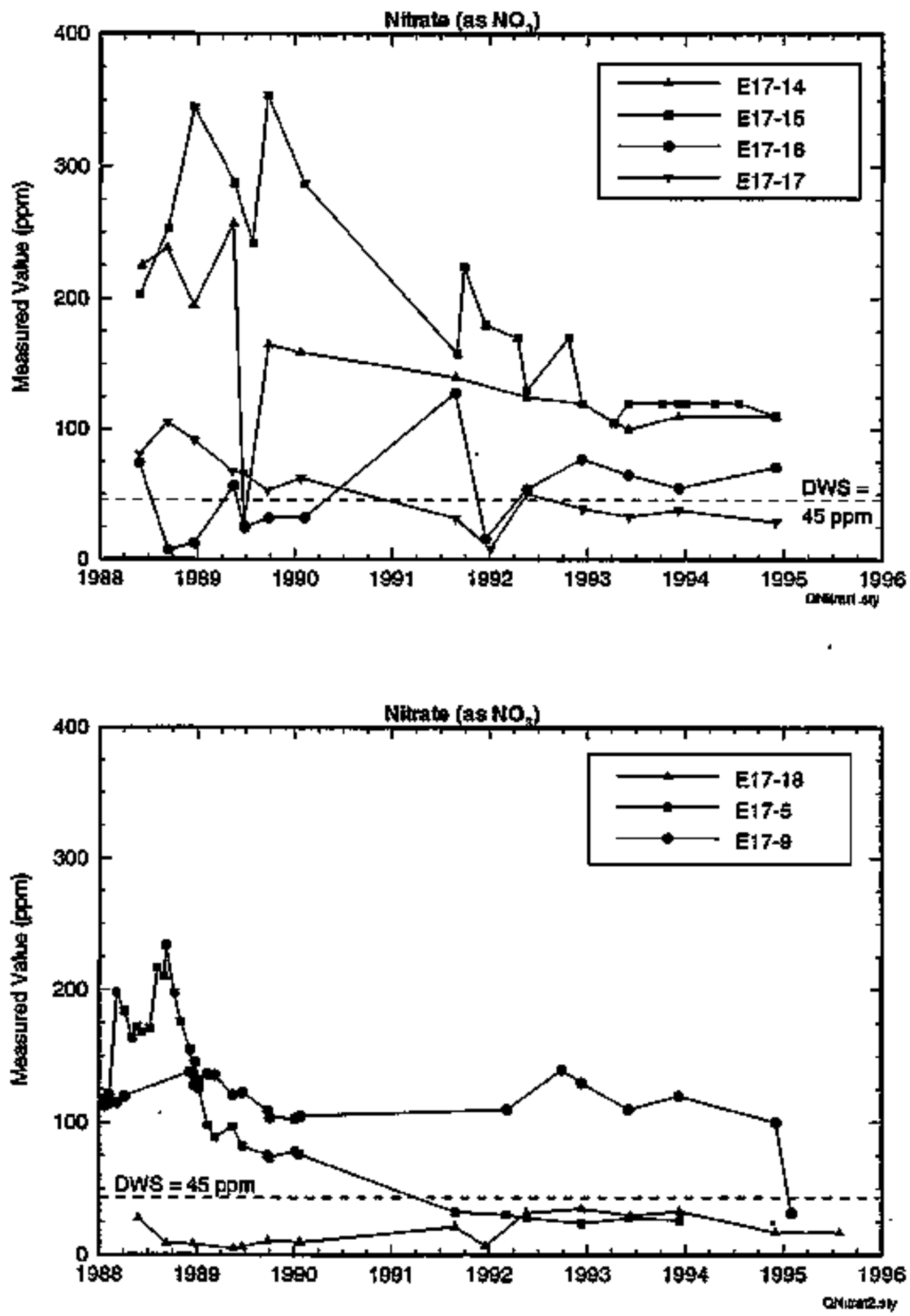
DOE/RL-96-01, REV. 0

Figure 4.5-5. Tritium Concentrations in the 216-A-368 Network Wells.

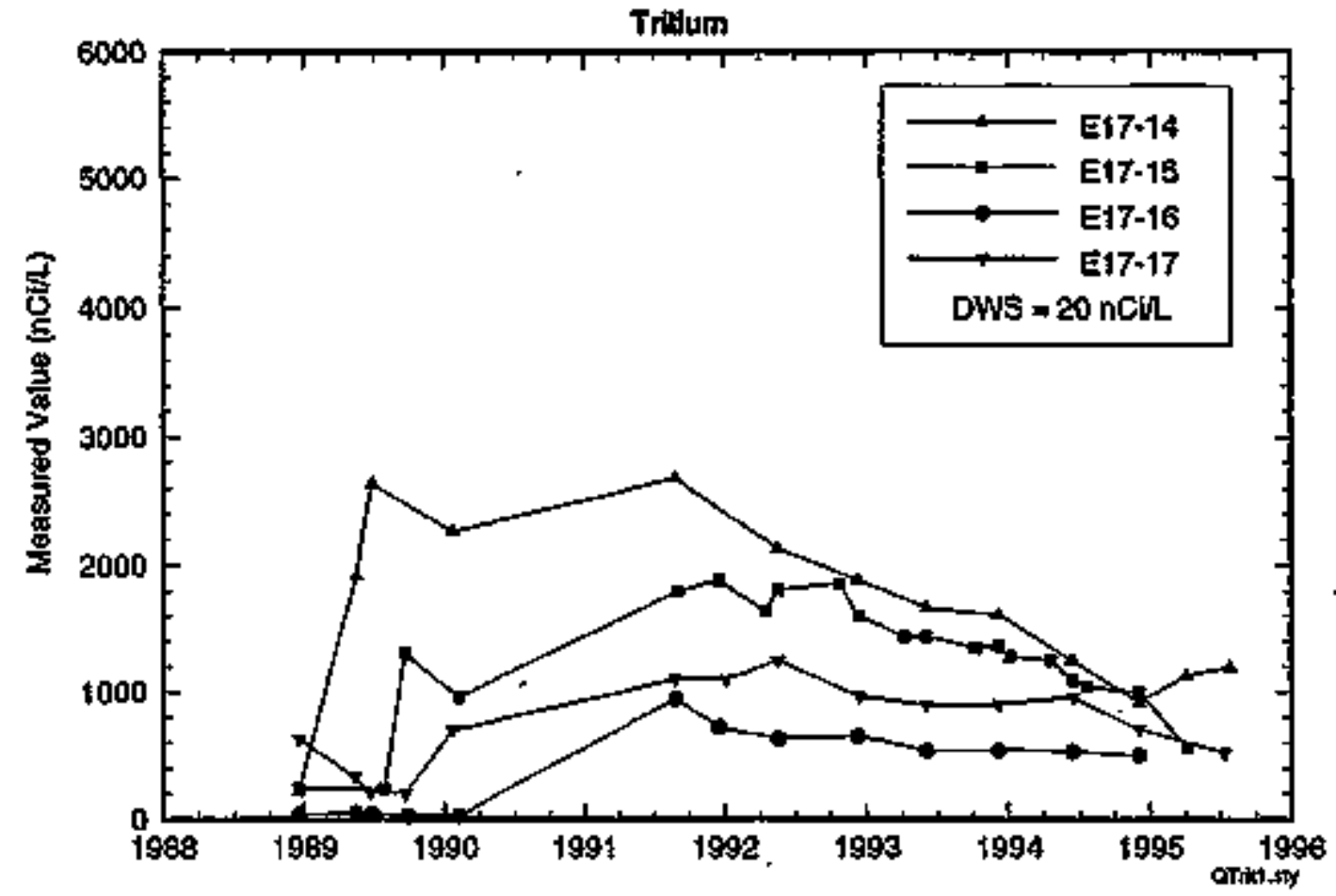

Tritum

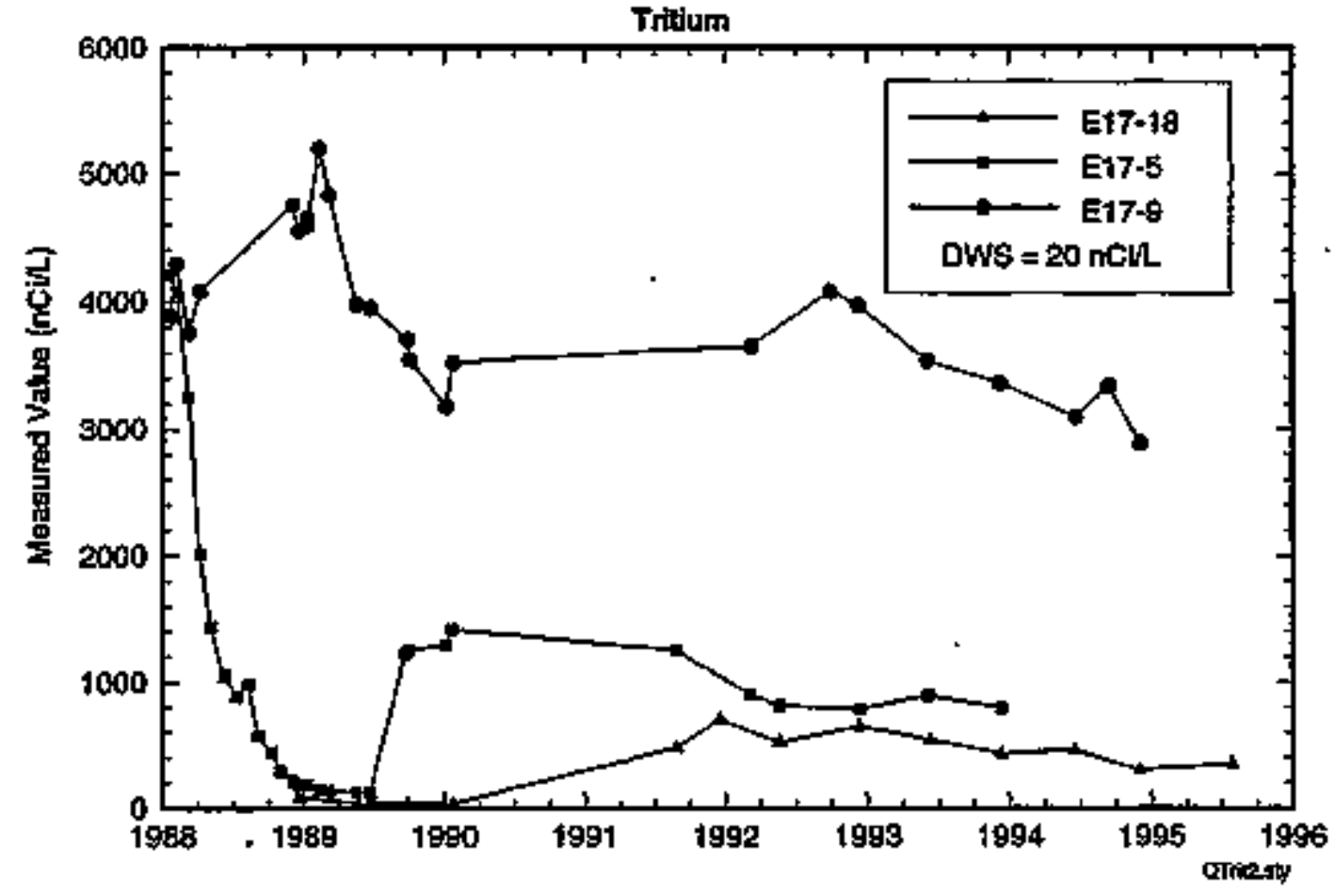


DOE/RL-96-01, REY. 0

Figure 4.5-6. Composite hydrograph for the 216-A-36B Network Ne11s.
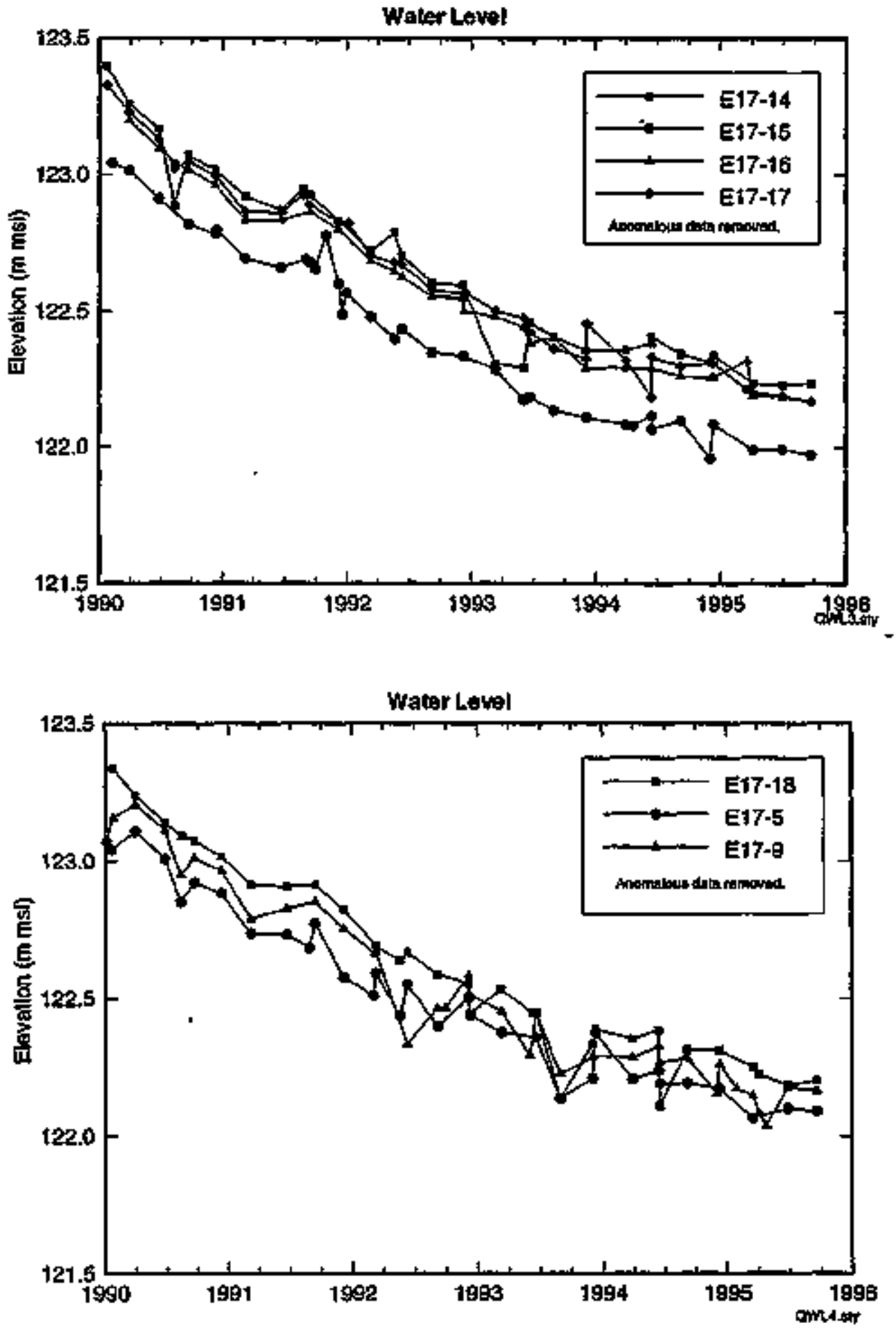
Figure 4.5-7. 200 East Area and 216-A-36B Crib Vicinity Water Table Kap, June 1995.

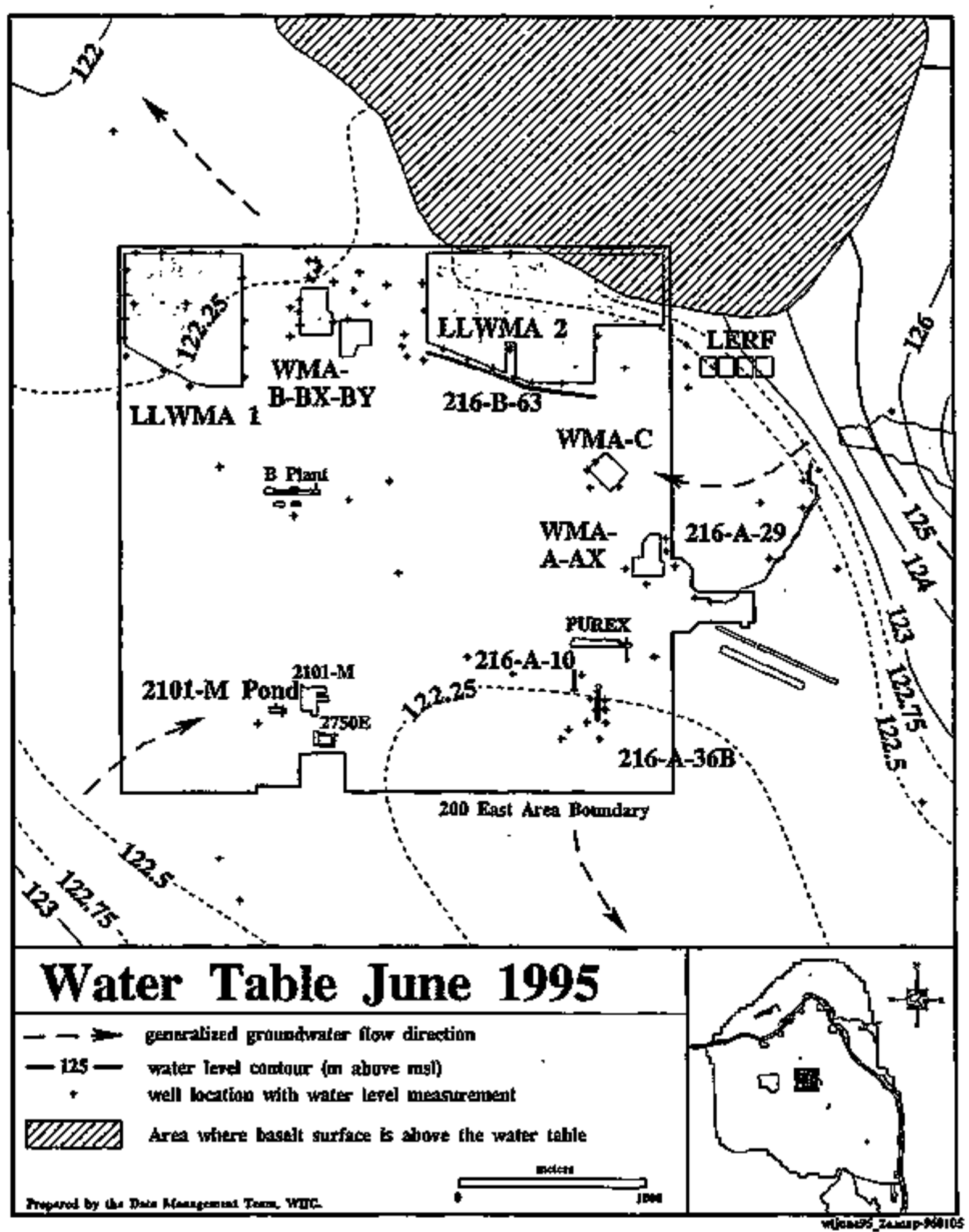


Table 4.5-1. Monjtoring Wells in the 216-A-36B Crtb Network.

\begin{tabular}{|c|c|c|c|c|c|}
\hline WeIl & Aquifer & $\begin{array}{l}\text { Sampling } \\
\text { frequency }\end{array}$ & $\begin{array}{l}\text { Water } \\
\text { Jevels }\end{array}$ & $\begin{array}{c}\text { Well } \\
\text { standard }\end{array}$ & $\begin{array}{c}\text { Other } \\
\text { networks }\end{array}$ \\
\hline 299-E17-14 & Top of unconfined & $S$ & $\mathbf{Q}$ & RCRA & \\
\hline $299-E 17-15$ & Top of unconfired & $\mathbf{S}$ & $Q$ & RCRA & \\
\hline $299-E 17-16$ & Top of unconfined & $\mathbf{S}$ & Q & RCRA & - \\
\hline 299-EI7-17 & Top of unconfined & 5 & $\mathbf{Q}$ & RCRA & - \\
\hline $299-E 17-18$ & Top of unconfined & $S$ & 0 & RCRA & - \\
\hline $299-E 24-18$ & Top of unconfined & $s$ & 4 & RCRA & $216-A-10$ \\
\hline 299-E25-36 & Top of unconfjined & $\mathbf{s}$ & Q & RCRA & $216-A-29$ \\
\hline 299-E17-9 & Top of unconfined & $\$$ & Q & PRE & $=$ \\
\hline 299-E17-5 & Top of unconfined & $-\infty$ & $\mathbf{Q}$ & PRE & - \\
\hline
\end{tabular}

Note: Shading denotes upgradient wells.

PRE - well was constructed before RCRA-specified standards and is not used for statistical evaluation.

0 - frequency on a quarterly basis.

RCRA $=$ well is constructed to RCRA-specified standards.

$S=$ frequency on a semiannual basis.

Table 4.5-2. Constftuent's Analyzed in the 216-A-36b Crib Groundwater Monitoring Network.

\begin{tabular}{|l|l|}
\hline \multicolumn{1}{|c|}{ Semiannuaily } & \multicolumn{1}{c|}{ Annually } \\
\hline ToX & alkalinity \\
\hline TOC & anions \\
\hline pH & ICP metals \\
\hline specific conductance & iodine-129 \\
\hline turbidity & phenols \\
\hline gross a]pha/gross beta & \\
\hline tritjun & \\
\hline
\end{tabular}


Table 4.5-3. Critical Means Table for 28 Comparisons--Background

Contamination Indicator Paraneter Data for the 216-A-36B Crib-*,

\begin{tabular}{|c|c|c|c|c|c|c|c|}
\hline $\begin{array}{l}\text { Constituent } \\
\text { (Unit) }\end{array}$ & n & df & tc & $\begin{array}{c}\text { Average } \\
\text { background }\end{array}$ & $\begin{array}{l}\text { Standard } \\
\text { deviation }\end{array}$ & $\begin{array}{c}\text { Critical } \\
\text { mean }\end{array}$ & $\begin{array}{l}\text { Upgradient/ } \\
\text { downgradient } \\
\text { comparison } \\
\text { value }\end{array}$ \\
\hline $\begin{array}{l}\text { Specific } \\
\text { Conductance } \\
(\mu \mathrm{mho} / \mathrm{cm})\end{array}$ & 12 & 11 & 4.6425 & 281.646 & 68.595 & 613.1 & 613.1 \\
\hline Field pH & 12 & 11 & 5.0765 & 7.953 & 0.290 & $\begin{array}{r}{[6.42} \\
9.48]\end{array}$ & $\begin{array}{r}{[6.42} \\
9.48]\end{array}$ \\
\hline$T O C^{\infty d}(p p b)$ & 12 & 11 & 4.6425 & 598.708 & 125.606 & $1,205.6$ & $1,205,6$ \\
\hline TOX (ppb) & 12 & 11 & 4.6425 & 4.075 & 2.176 & 14.6 & 14.6 \\
\hline
\end{tabular}

Oata collected fraw September 1988 to June 1989 for upgradient

wells 299-E17-17, 299-E24-18, and 299-E25-36. Values calculated based on

28 comparisons.

The following notations are used in this table:

df = degrees of freedom $(n-1)$.

$n=$ ntmber of background replicate averages.

$t_{c}=$ Bonferront critical t-value for appropriate df and 28 comparisons.

critical means were calculated from values reported below the CRDL (DOE-RL 1991).

critical mans were calculated using data analyzed by U.S. Testing. Inc. of Rtchl and.

N. C. = not calculated. 
DOE/RL-96-01, Rev. 0

This page intentionally left blank.

4.5-16 
DOE/RL-96-01, REV. O

\section{CONTENTS}

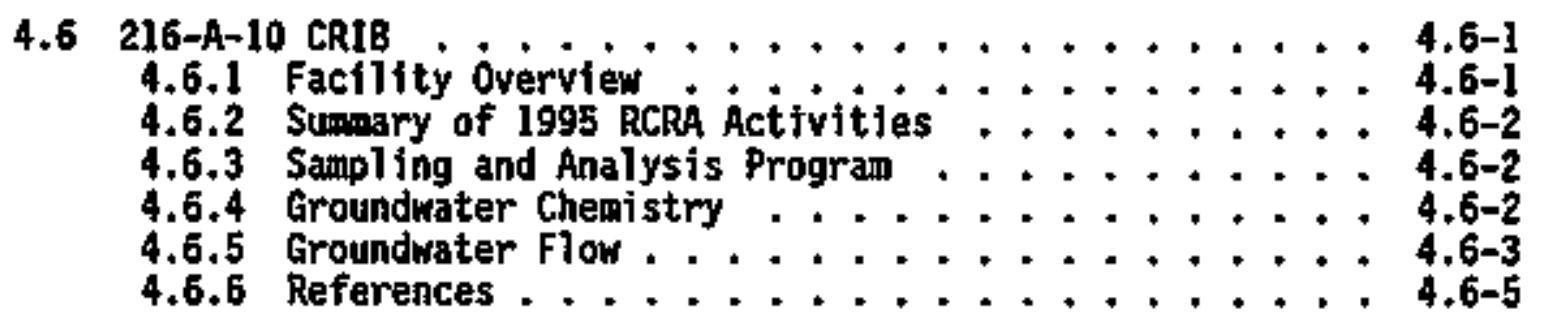




\section{LIST OF FIGURES}

4.6-1 Monitoring Well Locations for the 216-A-10 Crib ...... 4.6-6

4.6-2 Hitrate Distribution in the Uppermpst Aquifer

Beneath the 200 East Area .......... 4.6-7

4.6-3 Tritiun of stribution in the Uppermost Aquifer

Beneath the 200 East Area .............. 4-8

4.6-4 Mitrate Concentrations in the 216-A-10 Hetwork Wells..... 4.6-9

4.6-5 Tritiun Concentrations in the 216-A-10 Metwork Wells . . . 4.6-10

4.6-6 Composite Hydrograph for the 216-A-10 Network Wolls . . . . 4.6-11

4.6-7 200 East Area and 216-A-10 Crib Vicfufty

Nater Table Map, June 1995 ........... . 4.6-12

\section{LIST OF TABLES}

4.6-1 Monitoring Wells in the 216-A-10 Crib Network ...... 4.6-13

4.6-2 Constituents Analyzed in the 216-A-10 Crib Groundwater

Monttoring Hetwork .............. 4.6-13

4.6-3 Crittical Means Table for 24 Comparisons--Background

Contanination Indicator Parameter Data for the 216-A-10 Crib . 4.6-14 
DOE/RL-96-01, REV. 0

\subsection{6-A-10 CRIB}

\section{J. H. Votava}

Westinghouse Hanford Company

\subsubsection{Factlity Overview}

The 216-A-10 Crib (A-10 Crib), now retired from use, was a liquid waste disposal facility for the Plutonium-Uranjum Extraction (PUREX) Plant. The A-10 Crib is located in the 200 East Area approxinately 122 m (400 ft) south of the PUREX Plant. It is approximately $110 \mathrm{~m}(360 \mathrm{ft})$ west of the 216-A-36B Crib (Figures 1-1 and 4.6-1).

The A-10 Crib is $84 \mathrm{~m}$ (275 ft) long, has a V-shaped cross section, and is $14 \mathrm{~m}$ (45 ft) deep. Several waste streams, collectively described as process distillate discharge, were disposed of to the $\mathrm{A}-10 \mathrm{Crib}$ and were ajlowed to percolate through the soil column. The A-10 Crjb first received fiquid waste over a 4-month perjod during the PUREX startup in 1956. In 1961, the A-10 Crib replaced the 2I6-A-5 Crib and received PUREX effiluent continuousiy unti1 1973. Periodic discharges were received in 1977, 1978, and 1981. From 1982 to 1987 , effluent discharges resumed on a cont jnuous basis. Discharge between 1981 and 1986 averaged $1 \times 10^{8} \mathrm{~L}\left(2.6 \times 10^{7}\right.$ gal $)$ per year. In 1987 . the $A-10$ Crib was taken out of service and replaced by the 216-A-45 Crib.

The process distillate discharge waste stream to the A-10 Crib was characteristicatly acidic and contained concentrated sa7t.s. other waste stream constituents included al iphatic hydrocarbon compounds; organjc complexants; and the radionucl ides plutonium, uranion, ${ }^{90} \mathrm{Sr},{ }^{80}{ }_{\mathrm{Co}},{ }^{\circ}{ }^{\mathrm{C}} \mathrm{Cs},{ }^{137} \mathrm{Cs}$, ${ }^{103 u}$, ${ }^{t c o s u}$, and tritiun (A1dricis 1987).

Waste disposed of in the A-10 Crib encountered approximately 97 in (318 ft) of unsaturated Hanford formation sedinents above the water table. The water table beneath the A-10 crib occurs very near the contact between the unsaturated Hanford formation upper gravel and sandy sequences and the underlying Ringold gravel unit E (see Chapter 2.0). Approximately $40 \mathrm{~m}$ (130 ft) of Ringold Formation sediments make up the saturated zone beneath the A-10 Crib (Wht 1992).

An tnterim-status Resource Conservation and Recovery Act of 1976 (RCRA) groundwater monitoring network has been in place for the A-10 Crjb since November 1988. The groundwater monjtoring progran is currently in indicatorparameter evaluation status. The RCRA closure/post-closure pTan for the A-10 Crib is scheduled to be submitted to the Washington State Department of Ecology and the U.S. Environmental Protection Agency in June 1998. This document will satisfy the Hanford Federal Facility Agreement and Consent Order Htlestone M-20-33 (Ecology et a1. 1994). The A-10 Crib is part of the CERCLA 200-PO-2 operable unit. 


\subsubsection{Sumary of 1995 RCR Activities}

Grounchater samples were collected and analyzed semiannually for Tox, TOC, pH, specific conductance, turbidity, gross alpha, gross beta, and tritium and annualiy for alkalinity, antons, ICP metals, ${ }^{129} I$, and phenols during 1995 for the wel1s in the A-10 Crib groundwater monftoring network. Samples were collected in October 1994 and April 1995. The depth to the groundwater beneath the A-10 Crib was measured in the monjtoring network wells during sample collection and for each quarterly report period. The groundwater chemistry data and water level measurenents were reported quarterly (Edrington 1995, Edrington and Votava 1995, Votava 1995).

\subsubsection{Sampling and Analysis Program}

The A-10 Crib monitoring network (Figure 4.6-1 and Table 4.6-1) includes two upgradient and stx downgradient wells. All wells are shallow groundwater monjtoring wells. All RCRA monitoring network wells, except 299-Ei7-1 and 299-E24-2, meet RCRA construction standards. These two wells are older, renediated wells with perforated carbon steel casing. Samples from these wells are not used in statistical evaluation of the groundwater wonttoring network.

Groundwater samples from the A-10 monitoring network are collected and analyzed semiannually or annually, depending on the constttuent, to detect any groundwater contamination originating from the faci]ity. Groundwater samples are anaiyzed for a series of constituents including: groundwater quality parameters, groundwater contamination indicator paraneters, and site-specific constjtuents. The site-specific constituents were selected based on knowledge of the waste streans formerly of scharged to the A-10 Crib. Table 4.6-2 1ists these constituents. This sample and analys is program meets RCRA requirements (40 CFR 265).

NelTs 299-E17-20 and 299-E25-36 are also used for the 216-A-29 groundwater nonitoring network. These wells were sampled quarterly to satisfy the groundwater quality assessment monitorting requirements for the 216-A-29 Facility (see Section 4.4).

\subsubsection{Eroundwater Chentstry}

The A-10 Crib is located in a region where several groundwater plumes contain constituents that exceed the drinking water standards (DNS). Examples of some of these constituents include njtrate and tritium (Figures 4.6-2 and $4,6-3)$. The similarities in effluent constituents disposed of at cribs 216-A-36B and 216-A-45 (monitored under the Operational Program) make determining the effect of the A-10 Crib on groundwater quality difficult.

4.6.4.1 Elevated Constituents. The critical weans were not exceeded for the four contamination indicator parameters in the A-10 crib monjtoring network during 1995. DNS for the following constituents are regularly exceeded in the A-10 network during 1995: nitrate, trititu, ${ }^{129}{ }_{I}$, unfittered chromium, unfiltered iron, unfiltered manganese, and gross a]pha (Edrtugton 1995, Edrington and Votava 1995; Votava 1995, 1995). A (dos concentration of 
$70.5 \mathrm{pCi} / \mathrm{L}$ was reported for we11 299-E24-16 during the October 1994 sampling. However, because its short half-life $(-1$ year $)$, detectable amounts of this radionuclide are unlikely and the subject result is thus regarded as a false positive. This conclusion is also consistent with a previous LOD

determination of $130-150 \mathrm{pC} i / \mathrm{L}$ for ${ }^{\mathrm{R} U}$ (DOE-RL 1994). RADEs werc subnitted for all unusual concentrations of constituents.

Nitrate concentrations (Figure 4.6-4) exceeded the WS $(45,000 \mathrm{ppb}$ ) at Teast once in all weTls except 299-E24-17, 299-E24-18 and 299-E25-36 during 1995. The trend of nitrate concentration in the groundwater beneath the A-10 Facility has generally been steady to silight]y declining since 1987 .

Trittum concentrations (Figure 4.6-5) exceeded the OWS $(20,000 \mathrm{Pci} / \mathrm{L}$ ) at least once in all wells in the network except upgradient well z99-E25-36. All we11s show a decreasing trend in tritium concentrations since 1987 when discharges to the $A-10$ Crib ended. The ${ }^{129} \mathrm{I}$ Gis $(\mathrm{I} \mathrm{pCi} / \mathrm{L}$ ) was exceeded in all of the network wells also.

During 1995, the DWS for chromium (100 ppb) and iron (300 ppb) were exceeded in unfiltered samples from wells 299-E17-19, 299-E17-20, 299-E24-16, 299-E,24-17, 299-E24-18, and 299-E25-36. Unfiltered metals are believed to represent effects caused by we11 construction and not groundwater.

4.6.4.2 Statistical Evaluation. During 1995, the quality of the groundwater beneath the A-10 Crib was subjected to the required evaluation process for sites in indicator parameter evaluation status. Appendix $\mathrm{C}$ explains the statistical method used to evaluate the facility's impact, if any, on the quality of groundwater results. The statistical evaluations of data compared sample results between upgradient and downgradient wells for indications of contamination in the uppermost aquifer. Statistical analyses required by 40 CFR 265.93(b) and Washington Adointstratsve Code (WAC) 173-303-400 were performed on the samples collected from November 1988 to August 1989 for upgradjent wells 299-E24-18 and 299-E,25-36 (DOE-RL 1991). Results are presented in Table 4.6-3. This table lists the background average, background standard deviation, critical mean (or critical range, in the case of pH), and upgradjent/doungradient comparison values for the four contamination indicator parameters. The comparison value is the value to which current and future averages of quadruplicate measurements are compared. The comparison value is generaiby the critical mean or critical range. Mone of the doingradient wells exceeded the contanination indicator parameter critical means.

\subsubsection{Groundwater FJow}

4.6.5.1 Water Levels. Hater levels in the A-10 network were measured quarterty and during semiannual sampl ing events in 1995 (Edrington 1995; Edrington and Votava 1995; Votava 1995, 1996). A composite hydrograph for data through Septenber 1995 for all wells in the A-10 network is presented in Figure 4.6-6. Water levels declined in all wells during the report period. The average water level decline in the A-10 monitoring well network was approximately $0.13 \mathrm{~m}(0.44 \mathrm{ft})$ between October 1994 and October 1995 . This trend in declining water levels sustains a longer term decline that became evident during 1988 and 1989, after PUREX PJant operations ended and 
DOE/RL-96-01, REV. 0

discharges to the A-10 Crib and other nearby liquid effluent disposal fac111ties ceased.

4.6.5.2 Groundwater Flow Birection. Groundwater flow in the vicinity of the A-10 Crib is poorly defined because the local hydraulic gradtent is extremely low (Figures $4.6-7$ ) and the quality of measurement data is occasionally suspect. Reglonal-scale, water table elevation measurements suggest that local groundwater flow is generally toward the south-southeast (see Figure 2-4).

4.6.5.3 Rate of Flow. Regional hydraul tc head gradient is estimated to be in the range of 0.0001 to 0.0002 (MHC 1992). Based on these estinates and estimates of hydraulic conductivity (150 to $300 \mathrm{~m} / \mathrm{d}[500$ to $1,000 \mathrm{ft} / \mathrm{d}])$ and porosity (0.25) for the unconfined aquifer near the A-10 Crlb (NHC 1992), groundwater flow velocities may range from 0.06 to $0.2 \mathrm{~m} / \mathrm{d}(0.2$ to $0.8 \mathrm{ft} / \mathrm{d})$ (see Section 4.4). Determining vertical groundwater gradients is not possible because paired (shallow and deep) well completions are not located in the immediate vicinity.

4.6.5.4 Evaluation of Monitoring Hell Hetwork. Water levels are measured regulariy and the adequacy of the existing monitoring network is evaluated accordingly. The water level in each weli is compared to the depth of the screened interval and pump intake to ensure that sufficient volumes of water exist for sampling. There is no near-tern need to replace any of the existing grounctwater monitoring we 31s. Because the A-10 Crib is surrounded by six groundwater monitoring wells, the doungradient monitoring network is currently adequate to monitor the groundwater quality beneath the crib.

Because of the low hydraulic gradient and continuing dectine of the regional water table, the evaluation of the suitability of the upgradtent wells is difficult. We11s 299-E24-18 and 299-E25-36 were selected when the monitoring well network was established (1988) to determine the groundwater quality in the most probable upgradient directions from the facility. As Figure 4,6-6 i 17ustrates, assigning relative positions (upgradient or downgradient) for some wells currently is difficult because very sall] changes in water leveis may constitute a reversal in gradient. The adequacy of upgradient wellis wil] be assessed periodically in the future and new upgradient lis will be drilled if necessary. 
COE/RL-96-01, REV. 0

\subsubsection{References}

40 CFR 265, "Interim Status Standards for Omers and Operators of Perwited Hazardous Waste Facilities," Code of Federal Regulations, as amended.

Aldrich, R. C., 1987, Radfoactive Lfquid Wastes Oischarged to Ground in the 200 Areas During 1986, RHO-HS-SR-B6-003, 4QLIQP, Rockwel1 Hanford Company, Richland, Washington.

Comprehensive Environsental Response, Compensation, and Lfabjitity Act of 1980, 42 USC 9601 et seq.

DOE-RL, 1991, Annual Report for RCRA Groundwater Nonitoring Projects at Hanford Site Facfifties for 1990, DOE/RL-91-03, U.S. Department of Energy, Richland Field office, Richland, Washington.

Ecology, EPA, and DOE, 1994, Hamford Federal Facility Agreenent and Consont order, Fourth Amendinent, Washington State Department of Ecology, U.S. Environmental Protection Agency, and U.S. Department of Energy, 01 ympia, Washington.

Edrington, H. H., 1995, "216-A-10 Crib," Quarterly Report of RCRA Groundiater Monitoring Data for Perfod October 1, 1994 through December 31, 1994, DOE/RL-94-36-4, U.S. Department of Energy, Richl and Operations Office, Richland, Washington.

Edrington, H. H. and J. M. Votava, 1995, "216-A-10 Crib," Quarterly Report of RCRA Groundwater Nonftorfing Data for Perfod January $I$, 1995 through Narch $3 I, 1995$, DOE/RL-95-69-1, U.S. Department of Energy, Rjch] and Operations Office, Richland, Washington.

Resource Conservation and Recovery Act of 1976, 42 USC 6901 tt seq.

Votava, J. H., 1995, "216-A-10 Crib," in Quarterly Report of RCRA Groundwater Monitoring Data for Period Aprit 1, 1995 through June 30, 1995, DOE/RL-94-69-2, U.S. Department of Energy, Richland Operations Office, Richland, Washington.

Votava, J. M., 1995, "216-A-10 Crib," in Quarterly Report of RCRA Groundwater Monitoring Data for Perfod JuIy 1, 1995 through Septeaber 30, 1995. DOE/RL-95-69-3, U.S. Department of Energy, Richland Operations Office, Richland, Washington.

MAC 173-303, "Dangerous Waste Regulations," Washington Administrative Code, as amended.

WHC, 1992, Hydrologic Nodel for the 200 East Groundwater Aggregate Area, VHC-SD-EH-TI-019, Rev. 0, Westinghouse Hanford Company, Richland, Washington.

WHC, 1994, Interim-Status Groundwater Nonitoring P7an for the 216-A-10 and 216-A-36B Cribs, WHC-SD-EN-AP-170, Rev. 0-A, Westinghouse hanford Company, Richland, Washington. 
DOE/RL-96-01, REV. 0

Figure 4.6-1. Monitoring Well Locations for the 216-A-10 Crib.

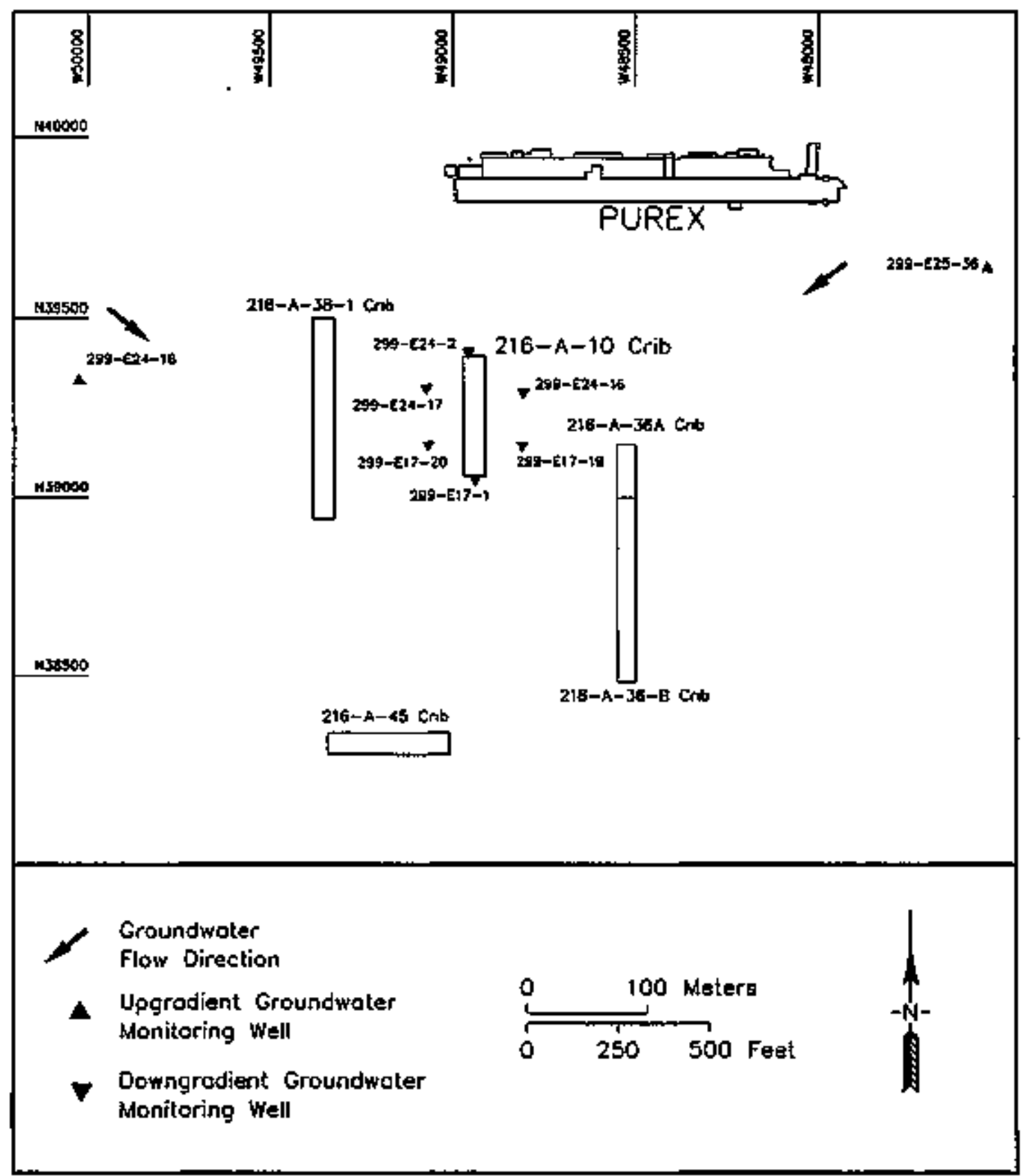

$\operatorname{mr} \backslash 210 \times 10$ 
Figure 4.6-2. Nitrate Distribution in the Uppermost Aquifer 8eneath the 200 East Area.

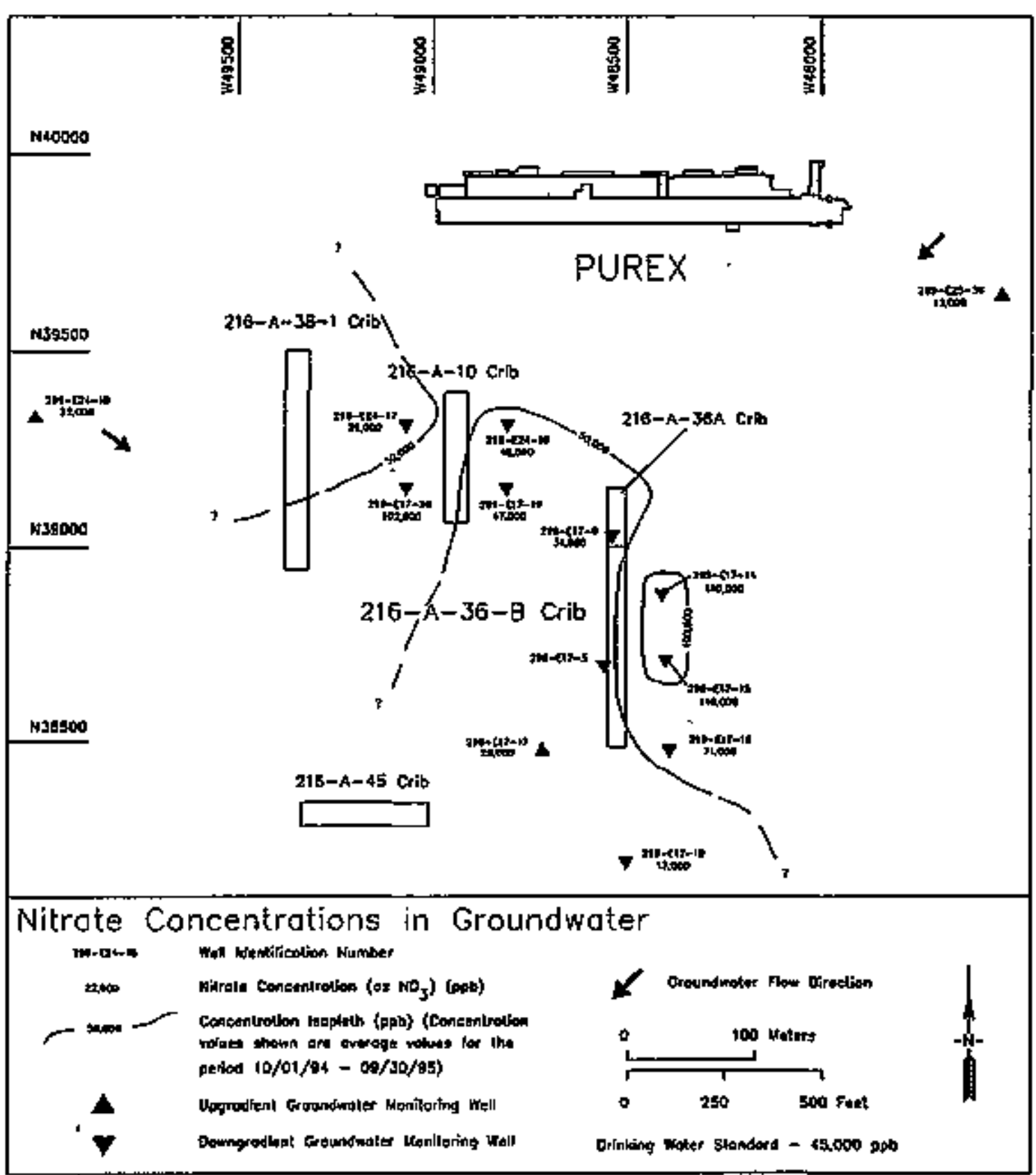

imrlo3stankr,ong 
Figure 4.6-3. Tritium Distribution in the Uppermost Aquifer Beneath the 200 East Area.

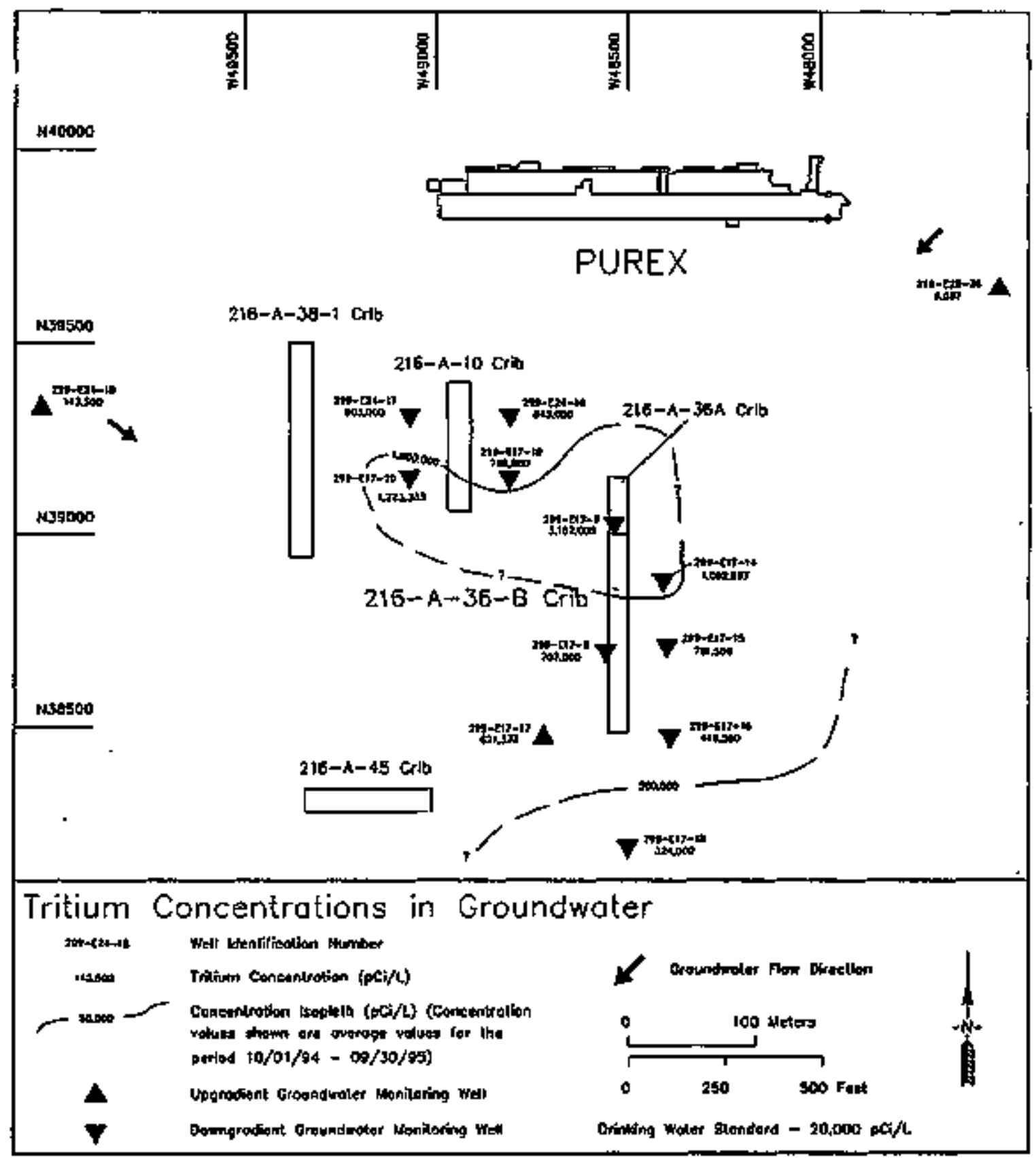

imrlaseblolldarg 
Figure 4.6-4. Nitrate Concentrations in the 216-A-10 Network Wells.
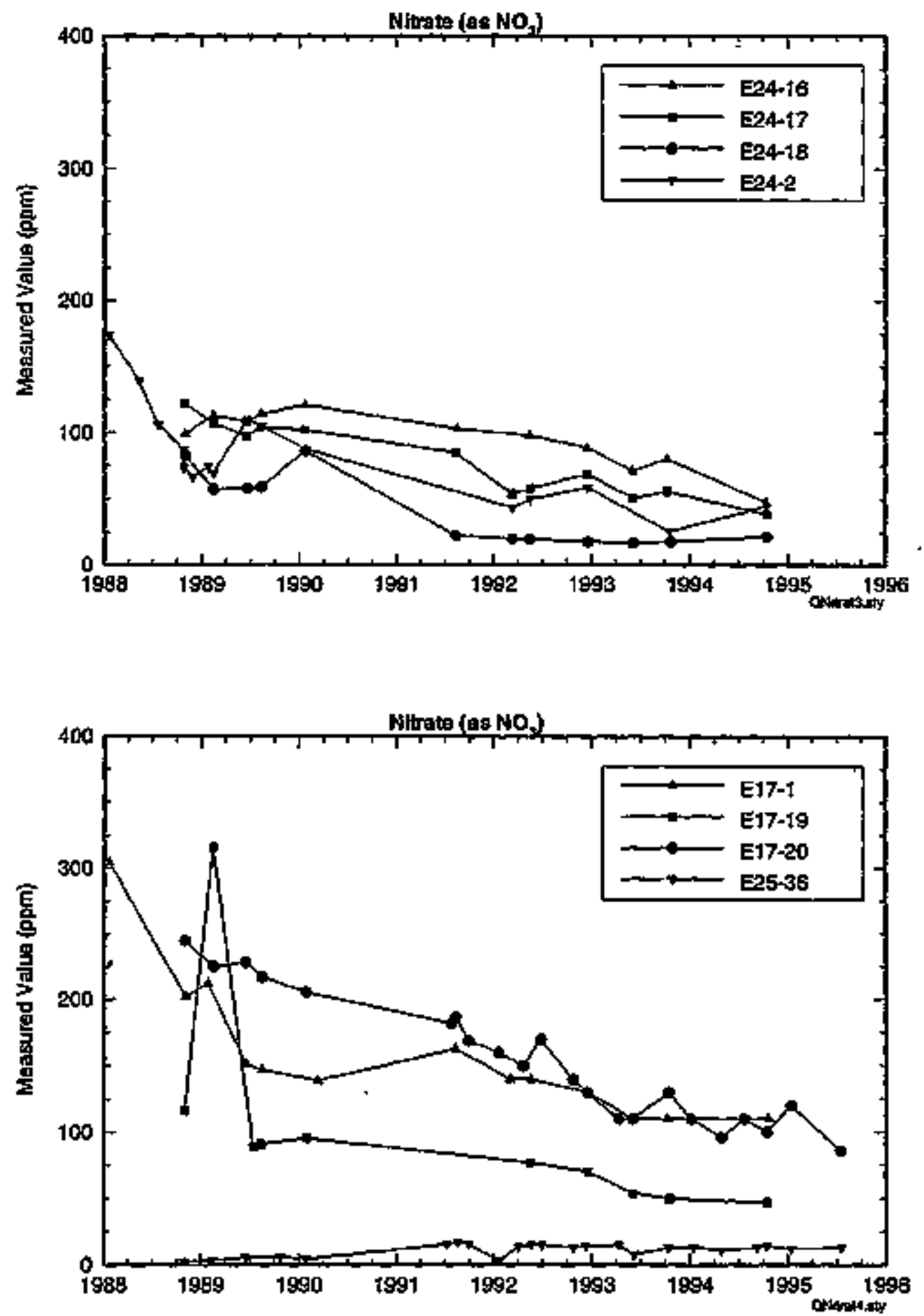
DOE/RL-96-01, REV. O

Figure 4.6-5. Tritiun Concentrations in the 216-A-10 Hatwork We11s.
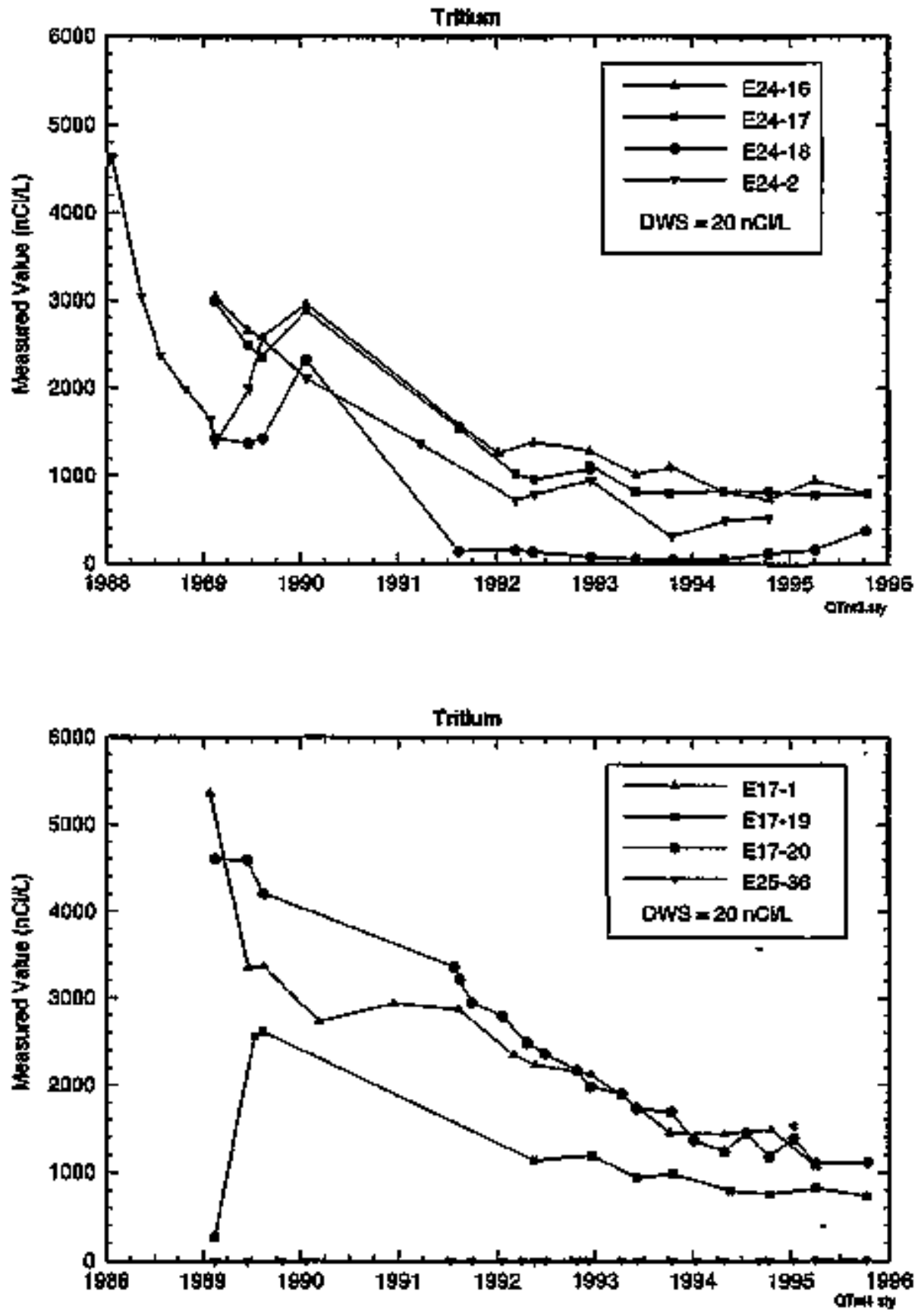
DOE/RL-96-01, REV . 0

Figure 4.6-6. Composite Hydrograph for the 216-A-10 Network We11s.
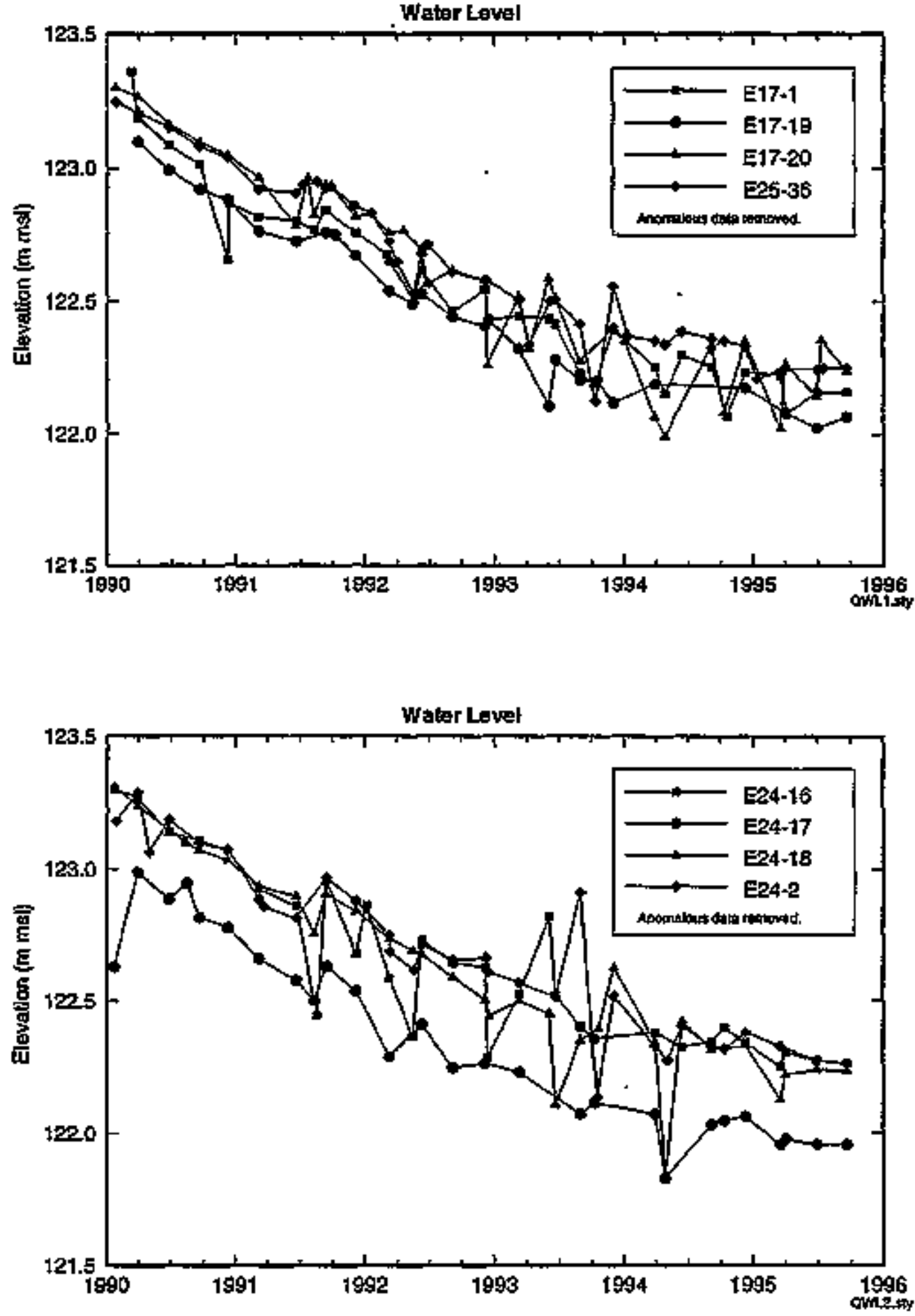
Figure 4.6-7. 200 East Area and 216-A-10 Crib Vicinity Water Table Map, June 1995.

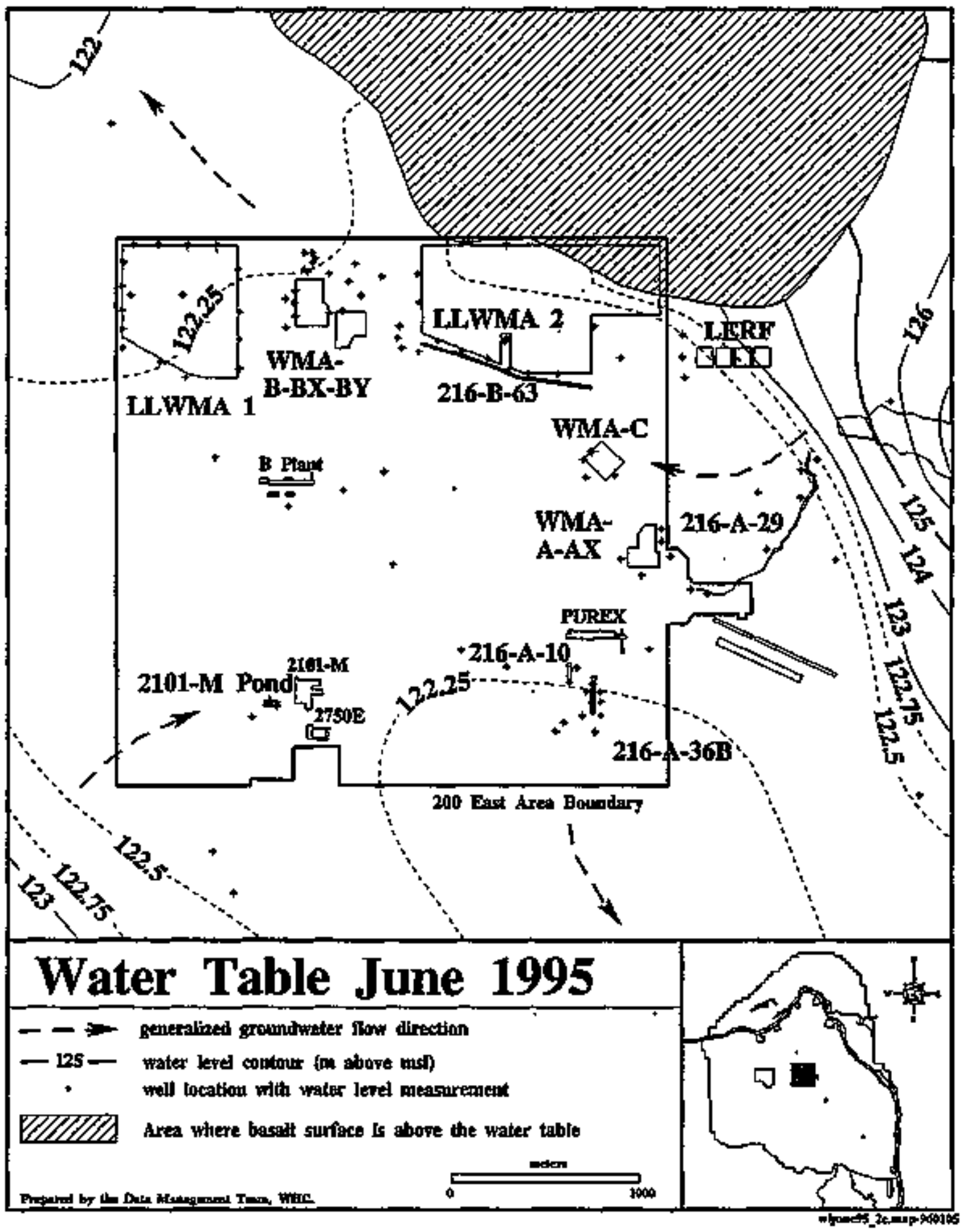


Table 4.6-1. Monttorfing Nel1s in the 216-A-10 Crib Network.

\begin{tabular}{|c|c|c|c|c|c|}
\hline We11 & Aquifer & $\begin{array}{l}\text { Samp] ting } \\
\text { frequency }\end{array}$ & $\begin{array}{l}\text { Water } \\
\text { levels }\end{array}$ & $\begin{array}{c}\text { Well } \\
\text { standards }\end{array}$ & $\begin{array}{c}\text { other } \\
\text { networks }\end{array}$ \\
\hline $299-E 24-18^{80}$ & Top of unconfined & $\mathbf{S}$ & Q & RCRA & - \\
\hline $299-E 25-36^{86}$ & Top of unconfined & $\bar{Q}$ & $\bar{Q}$ & RCRA & $\overline{216-A-29}$ \\
\hline $299-E 17-19^{98}$ & Top of unconfined & $\mathbf{S}$ & $\mathbf{Q}$ & RCRA & $=$ \\
\hline $299-E 17-20^{88}$ & Top of unconfined & $\bar{q}$ & $\bar{Q}$ & RCRA & $216-A-29$ \\
\hline $299-E 24-16^{82}$ & Top of unconfined & $\bar{s}$ & $\bar{Q}$ & RCRA & - \\
\hline $299-E 24-17^{89}$ & Top of unconfined & $\mathbf{s}$ & 9 & RCRA & 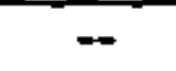 \\
\hline $299-E 17-1^{55}$ & Top of unconfined & $\vec{s}$ & $\bar{Q}$ & PRE & - \\
\hline $299-\mathrm{E} 24-2^{56}$ & Top of unconfined & $\bar{s}$ & $\bar{Q}$ & $\overline{\text { PRE }}$ & - \\
\hline
\end{tabular}

Notes: Shading denotes upgradient wells. Superscript following well number denotes the year of installation.

PRE * well was constructed before RCRA-specified standards.

Q = frequency on a quarterly basis.

RCRA = well is constructed to RCRA-specified standards.

$S$ - frequency on a senjannual basis.

Table 4,6-2. Constituents Analyzed in the 216-A-10 crib Groundwater Monitoring Network.

\begin{tabular}{|l|l|}
\hline \multicolumn{1}{|c|}{ Seniannually } & \multicolumn{1}{|c|}{ Annua]ly } \\
\hline IOX & alkal inity \\
\hline TOC & anions \\
\hline pH & ICP metals \\
\hline specific conductance & iodine-129 \\
\hline turbidity & phenols \\
\hline gross alpha/gross beta & \\
\hline tritium & \\
\hline
\end{tabular}


Table 4.6-3. Critical Means Table for 24 Comparisons--Background Contamination Indicator Parameter Data for the 216-A-10 Crib. ${ }^{5, b}$

\begin{tabular}{|l|c|c|c|c|c|c|c|}
\hline $\begin{array}{c}\text { Constituent } \\
\text { (Unit) }\end{array}$ & $\mathrm{n}$ & $\mathrm{df}$ & $\mathrm{tc}$ & $\begin{array}{c}\text { Average } \\
\text { background }\end{array}$ & $\begin{array}{c}\text { Standard } \\
\text { deviation }\end{array}$ & Critical mean & $\begin{array}{c}\text { Upgradient/ } \\
\text { dowmgradient } \\
\text { compar1 son } \\
\text { valule }\end{array}$ \\
\hline $\begin{array}{c}\text { Specific } \\
\text { Conductance } \\
\text { (pmho/cm) }\end{array}$ & 8 & 7 & 5.5799 & 273.31 & 77.643 & 732.8 & 732.8 \\
\hline Field pH & 8 & 7 & 6.2684 & 8.0241 & 0.319 & {$[5.90,10.14]$} & {$[5.90,10.14]$} \\
\hline TOC $^{\text {cd }}(\mathrm{ppb})$ & 8 & 7 & 5.5799 & 618.75 & 117.83 & $1,316.1$ & $1,316.1$ \\
\hline TOX $^{\text {cd }}$ (ppb) & 8 & 7 & 5.5799 & 4.47 & 1.544 & 13.6 & 13.6 \\
\hline
\end{tabular}

Oata collected from November 1988 to August 1989 for upgradient wells 299-E24-18 and 299-E25-36. Values calculated based on 24 comparisons.

The following notations are used in this table:

df $=$ degrees of freedom $(n-1)$.

$n=$ number of background replicate averages.

- Bonferroni critical t-value for appropriate df and 24 comparisons.

"Critical mean were calculated from values reported below the CFDL (DOE-RL 1991).

dCritical mean were calculated using data analyzed by U.S. Testing, Inc. of Richland.

H. C. = not calculated. 
DOE/RL-96-01, REY. 0

CONTERTS

4.7 216-B-63 TRENCH ................. 4.7-1

4.7.1 Facîlfty overview ........... 4.7-1

4.7.2 Summary of 1995 RCRA Activities . . . . . 4.7-2

4.7.3 Sampling and Analysis Program ......... 4.7-2

4.7.4 Groundwater Chemistry ............. 4.7-2

4.7.5 Groundwater Flow ................ 4.7-3

4.7 .6 References . . . . . . . . . . . 4.7-4 
DOE/RL-96-01, REV. 0

\section{LIST OF FIGIRES}

4.7-1 Monitoring WeII Locations for the 216-B-63 Trench . . . 4.7-6

4.7-2 Hydrographs of Mater Level Heasurenents for 216-B-63 Weils $: \ldots 4.7-7$

4.7-3 200 East Water Table Hap . . . . . . . . . . 4.7-8

\section{LIST OF TABLES}

4.7-1 216-8-63 Groundwater Monitoring Hetwork . . . . . . . 4.7-9

4.7-2 Constituent List for the 216-B-63 Trench Honitoring Hetwork $\because 4.7-10$ 


$$
\text { DOE/RL-96-0I, REV. O }
$$

\title{
4.7 216-8-63 TRENCH
}

\author{
A. D. Syeeney \\ Nestinghouse Hanford Company
}

\subsubsection{Facility Overview}

The 216-8-63 Trench (B-63 Trench), in service frow March 1970 to February 1992, received liquid effluent $\left[3.8 \times 10^{5}\right.$ to $1.5 \times 10^{6} \mathrm{~L} / \mathrm{d}(1.0 \times$ $10^{5}$ to $4 \times 10^{5} \mathrm{ga7} / \mathrm{d}$ ) ] from the $B$ Plant chemical sewer. The i iquid effiuent was a $70 / 30$ mixture of steam condensate and raw water, which was disposed to the west end of the open, unTined earthen trench. Past rejeases to the trench included radioactive and dangerous waste. Documented hazardous discharges occurred from 1970 to october 1985, and consisted of aqueous sulfuric acid and sodium hydroxtde solutions that had pH values of $<2.0$ and $>12.5$, respectively. Radioactive solls were dredged from the trench in August 1970, but no records exist of radioactive waste disposal to the trench. Starting in 1985, physical controls, radiation monitors, and operating procedures were modified to avoid Inadvertent discharge of chemicals or radioactive substances to the wastewater strean. Liquid effiurent discharge to the B-63 Irench ceased peranently in February 1992.

A Resource Conservation and Recovery Act of 1976 (RCRA) Indfcator evaJuation groundwater monftoring network has been established under guidel ines estabi ished in the RCRA interim-status groundwater monitoring plan for the B-63 Trench (PNLL 1989) and in accordance with the Hanford Federal Facility Agreement and Consent Order, Milestone M-20-38 (EcoTogy et a]. 1994). This network operates under RCRA interim-status regulations ( 40 code of Federal Regulations [CFR] 265). During its operat lon, the B-63 Trench received wastemater from the B Plant located in the 200 East Area (see figure 1-1). This wastewater contafned dangerous waste and materials. A RCRA closure/postclosure plan for the B-63 Trench, which is part of the 200-UP-11 operable unit, is due to be submitted in May 1996.

The B-63 Trench lies at an elevation of about 195 m $(640 \mathrm{ft})$ along the northern flank of cold Creek bar. Cold Creek bar was formed along the margin of a Pleistocene cataclysmic flood channel located in the northeastern portion of the 200 East Area.

Only a single stratigraphic unit, the Hanford formation, overlies basalt beneath the site. The sediments directly beneath the 8-63 Trench appear to be mostly mixtures of sand and gravel associated with high-energy deposition by cataclysmic floods. Lateral facies changes occur in the flood deposits to the south and west. Along the southern wargin of the flood channe], deposits become finer grained and include fine sand, silt, and occasionajty clay, which could act locally as aquitards leading to perched water conditions.

The sediments overlying the basalt become progressively thinner to the northeast. The sediments are 75 to $82 \mathrm{~m}(245 \mathrm{to} 269 \mathrm{ft})$ thick beneath the trench. The thickness of the saturated zone varies from 1.3 to $7.0 \mathrm{~m}$ (4 to $23 \mathrm{ft}$ ). The water table varies from 70 to $77 \mathrm{~m}(228$ to $252 \mathrm{ft})$ below ground surface. 
DOE/RL-96-01, REV. 0

\subsubsection{Sumary of 1995 RCRA Activities}

The 12 wells in the monitoring network were sampled in December 1994 and June 1995 for contamination indicator, groundwater quality, and site-specific parameters. Other analyses, such as for uraniun, gamma scan, and volatile organic compounds, were performed during the fourth quarter of 1994 but were subsequently rentoved fron the list of constituents. Results of these analyses are discussed in Section 4.7.4. Data were included in each of the four quarter7y reports (Sweeney 1995a, 1995b, 1995c, and 1996).

Periodtc water level measurements of the 12-wel1 monftoring network were made from October 1994 through September 1995. Routine water level

measurements wore made at the time of sampling.

\subsubsection{Sampting and Analysis Progran}

The current groundwater monitoring network consists of 12 wells (Table 4.7-1). The well locations are shown in Figure 4.7-1. The monitoring network conforms to the groundwater monitoring plan for the B-63 Trench (WHC 1995).

Groundwater chenistry data are avajlable for nost of the B-63 groundwater monitoring wells for 1995. The wel]s have been sampled for contamination indicator parameters, groundwater qua]1ty paraneters, and site-5pecific parameters as identified in Tabie 4.7-2. Site-specific paraneters were selected based on history of waste disposed at this site and in surrounding waste managentent areas. Uraniun, gamma scan, and volat jle organic compounds were removed from the sampling schedule in the second quarter. These constituents were consistently reported below regulatory thresholds, or were not detected, and were not considered to have affected groundwater beneath the facility. Data were published in quarterly reports (Sweeney 1995a, 1995b, 1995c, and 1996).

\subsubsection{Groundwater Chenistry}

Groundwater chenistry sanples were collected from wells within the B-63 groundwater monitoring network during 1995 on a semiannual schedule.

\subsubsection{Constituents of Concern. Groundwater monitoring at the 216-B-63} Trench provides no evidence that dangerous, nonradioactive constituents from the site have entered the groundwater. The indicator paranaters are specific conductance, $\mathrm{pH}$, total organic carbon (TOC), and total organic halogen (TOX) (40 Code of Federal Regulations [CFR] 265.92[b][3]). These analyses are considered screening techniques since the concentrations reported are not for specific contaminants. Other analytes are monitored in groundwater to look for the dangerous waste constituents that were discharged to B-63 Trench during their use (see Table 4.7-2). Included in the B-63 analysis list are garma scan, alkalinity, gross beta and tubidtty. There were no significant. detections for these analyses that could be attributed to the B-63 Trench. 
4.7.4.2 Statistical Evajuation. Statjstical analyses required by 40 CFR 265.93(b) and Washington Adwinistrative Code (WAC) 173-303-400 were performed on the samples collected fron upgradjent we17s 299-E27-8, 299-E27-9, 299-E27-11, 299-E27-17, and 299-E34-10. Results are presented in Table 4.7-3. This table lists the background average, standard deviation, critical mean (or critical range, in the case of $\mathrm{phi}^{\mathrm{i}}$, and upgradient/downgradient comparison values for the contamination indicator parameters. The upgradient/downgradient comparison value is the value to which current and future averages of indicator parameters are compared. The comparison value is generaily the critical mean or critjcal range. The 1 imit of quantitation is used as the comparison value for total organic carbon and total organic halogen instead of the critjcal mean because most of the upgradient concentrations were below the contractually required quantitation Timit (see Appendix C).

There were no exceedances in specific conductance, TOC or TOX. One incident of $\mathrm{pH}$ exceedance occurred at a downgradient wel] 299-E33-36 during the November 11, 1994 sampling event. The replicate average of 6.46 was beTow the lower critical limit of 7.08 . Subsequent verification sampling results confirmed that the initial exceedance was caused by an error in the field measuremant.

\subsubsection{Eroundwater FTow}

4.7.5.1 Groundwater Flow Direction. In general, groundwater levels continued to decline in 1995 (Figure 4.7-2). Water levels are recorded sentannualty during sample collection. These data are reported in quarterly reports of RCRA groundwater monitoring data (Sweeney 1995a, 1995b, 1995c, and 1996). A water tabie map of the 200 East Area for June 199515 presented in Figure 4.7-3. Water table elevations reveal a westward flow direction that roughly parallels the trend of the B-63 Trench (Sweeney 1995d). A significant7y steeper gradient than that observed for the region is stitl apparent based on anomalously low water level readings measured at the west. end of the trench in well 299-E33-36 (Sweeney 1995d). The well was surveyed during 1993 but the results do not indicate a survey elevation problem. Other possibile explanations for the discrepancy are being explored.

4.7.5.2 Rate of Flow. The horizonta] groundwater gradient in the unconfined aquifer under the $\mathrm{B}-63$ Trench is approximately $2.6 \times 10^{-4}$ between

we]ls 299-E27-17 and 299-E33-37 tn 1995. The rate of groundwater flow can be est imated by using a form of the Darcy equation with a range of input parameters

$$
v=\frac{K i}{n_{6}}
$$

where:

$v=$ Average linear velocjty in $\mathrm{m} / \mathrm{d}(\mathrm{ft} / \mathrm{d}$ )

$K=$ Hydraulic conduct fvity in a/d (ft/d)

. i - Hydraulic gradient (dimensionless) 
$n_{e}$ - Effective porosity (dimensionless).

The calculations of groundwater velocity assune horizontal flow and a homogeneous aquifer. The following toputs from slug test data were used to determine the velocity near w-11 299-E33-36:

$K=174 \mathrm{n} / \mathrm{d}(570 \mathrm{ft} / \mathrm{d})$

$i=2.6 \times 10^{-6}$

$n_{e}=0.20$ (Graham et al. 1981).

The given value of $K$ ts representative of the Hanford formation, based on punp tests in the 200 Areas (Grahan et al. 1981). The calculated velocity is $0.23 \mathrm{~m} / \mathrm{d}(0.7 \mathrm{ft} / \mathrm{d}\}$.

4.7.5.3 Evaluation of the Monitoring Mell Motwerk. Based on the Monitoring Efficiency Hode] (Jackson et a1. 1991), the existing network should provide a monjtoring efficiency of 66 to $85 \%$ for the 8-63 Trench. The $66 \%$ monitoring officiancy results from a flow azimuth of $270^{\circ}$ (toward the west from 299-E27-17), while an $85 \%$ monitoring officiency is associated with a $225^{\circ}$ azjouth flow direction (toward the southwest from 299-E34-10).

The current network is composed of six weils drllled specifjcally to monitor the $\mathrm{B}-63$ Trench. The network a7so inciudes five wells drilled to monitor the Low-Level Burial Grounds located Just north of the B-63 Trench (upgradient), and one well drilled to monitor the single-shell tanks (upgradient). Currently the network is considered adequate but will be continuously evaluated as water levels and groundwater gradtents change over time.

\subsubsection{Refarences}

40 CFR 265, "Interim Status Standards for Owners and Operators of Hazardous Waste Treatrent, Storage, and Disposal Facilities, "Code of Federal Regutations, as antended.

Ecology, EPA, and DOE, 1994, Hanford Federal Facility Agreedent and Consent Order, Fourth Anenduent, Washington State Department of Ecology, U.S. Environmental Protection Agency, and U.S. Department of Energy, 0lympia, Washington.

Graham, H. J., H. D. Hal1, 5. R. Strait, and W. R. Brown, 1981, Hydrology of the Separations Area, RHO-ST-42, Rockwell Hanford Operations, Richland, Washington.

Jackson, R. L., C. H. Einberger, R. B. Mercer, and C. R. Wiison, 1991. Efficiency Based Groundwater Monftoring Network Design for Hazardous Waste Sites, WHC-SA-1157-FP, Westinghouse Hanford Company, Richland, Washington.

WHC, 1995, Interim Status Groundwater Monitoring Plan for the 216-8-63 Trench, WHC-SD-EN-AP-165, Rev. 1, Westinghouse Hanford Company, Richland, Washington. 
Resource Conservation and Recovery Act of 1976, 42 USC 6901 et seq.

Sweeney, H. D., 1995a, "216-B-63 Trench," Quarterly Report of RCRA Groundwater Monitoring Data for Period October 1, 1994 through Decentar 30, 1993, DOE/RL-94-36-4, U.S. Departinent of Energy, Richl and Operations Office, Richl and, Washington.

Sweeney, M. D., 1995b, "216-B-63 Trench," Quarterly Report of RCRA Groundwater Monitoring Data for Period January 1, 1995 through March 31, 1995, DOE/RL-94-69-1, U.S. Department of Energy, Richland Operations Office, Richland, Nashington.

Sweeney, M. D., 1995c, "216-B-63 Trench," Quarterly Report of RCRA Groundwater Nonttoring Data for Period Aprin 1, 1995 through June 30, 1995, DOE/RL-94-69-2, U.S. Departalent of Energy, Richl and Operations Office, Rjeh] and, Nashington.

Sweeney, M. 0., 1995d, "216-B-63 Trench," in Annual Report for RCRA Groundwater Wonitoring Prajects at Hanford Site Facilities for 1994, DOE/RL-94-136, Westinghouse Hanford Company, Richland, Washington.

Sweeney, M. D., 1996, "216-B-63 Trench," Quarterly Report of RCRA Groundwater Honitoring Data for Period July 1, 1995 through Septenber 30, 1995, DOE/RL-94-69-3, U.S. Department of Energy, Richland Operations Office, Richl and, Washington. 


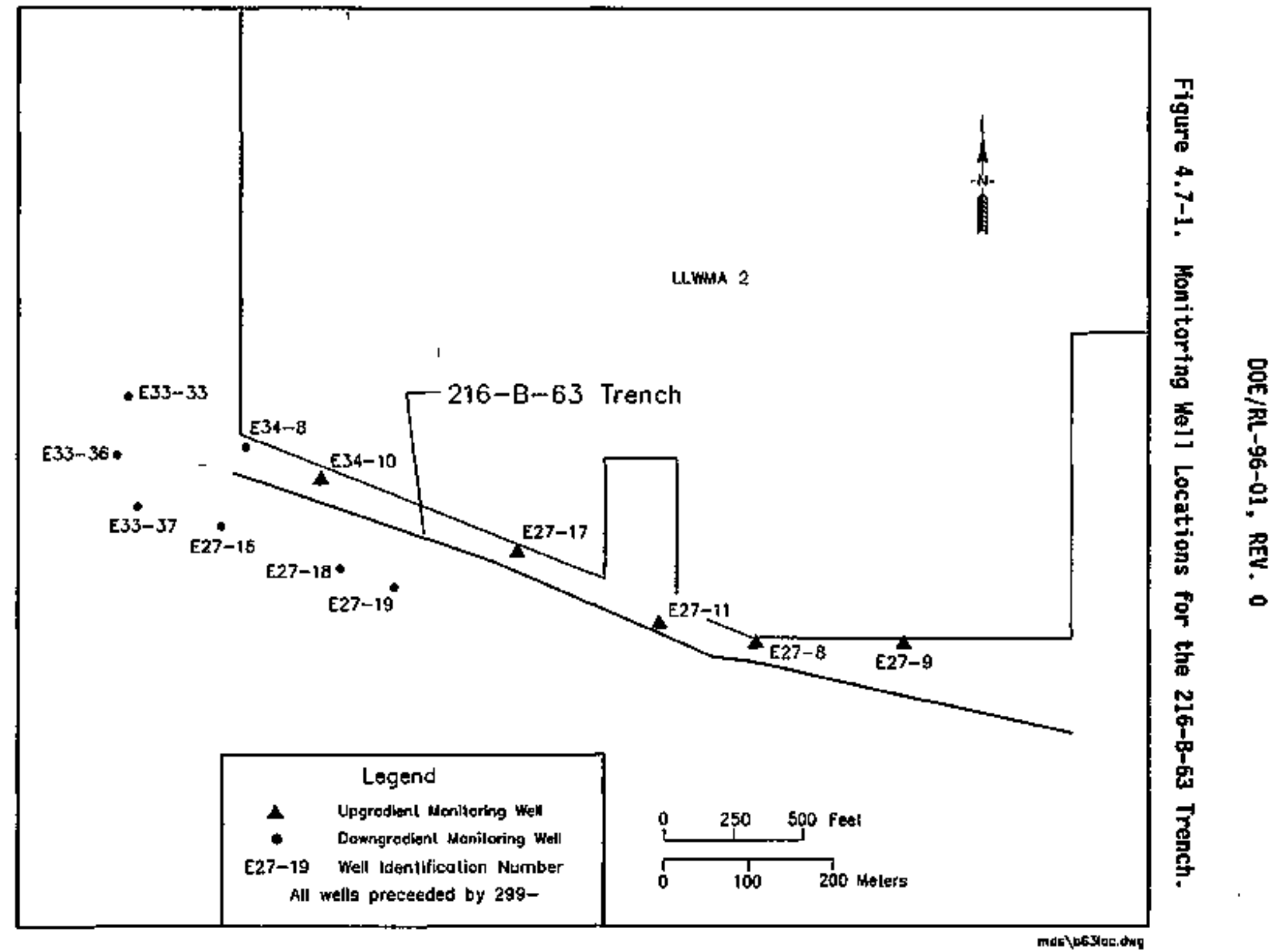


DDE/RL-96-01, REV. 0

Figure 4.7-2. Hydregraphs of Water Leve] Measurements for 216-8-63. Wells.

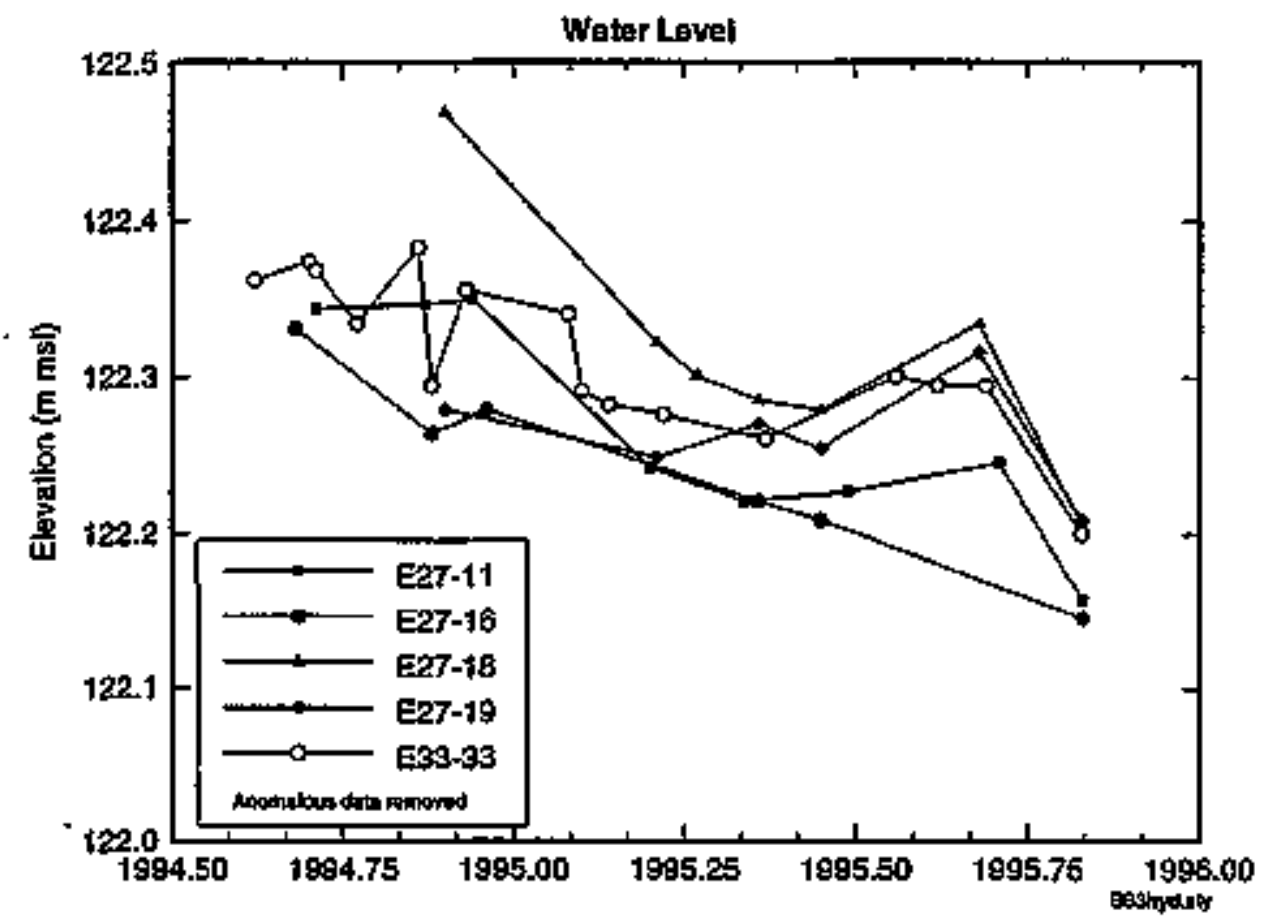


DOE/RL-96-01, REV. O

Figure 4.7-3. 200 East Water Table Map.

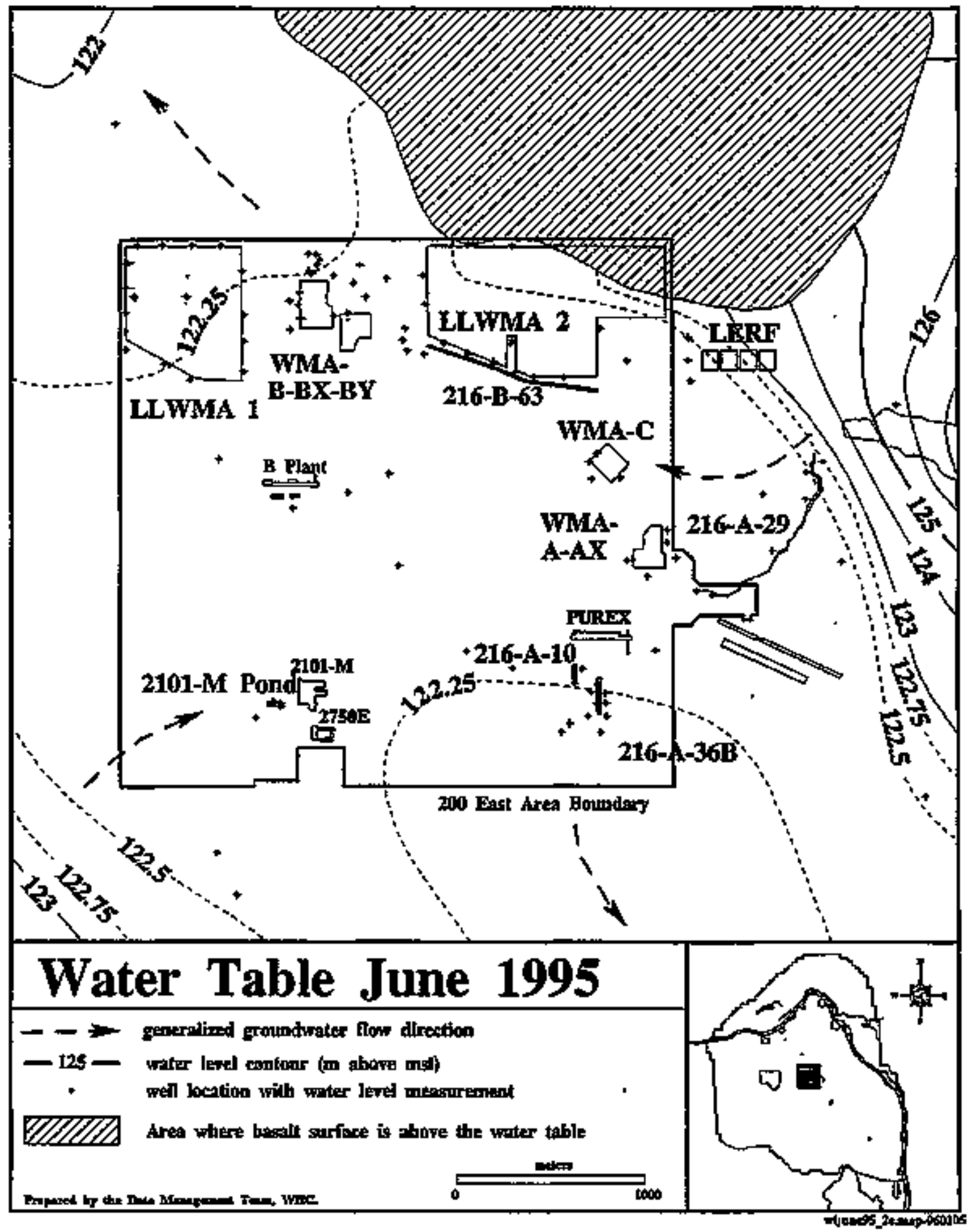


Table 4.7-1 . 216-B-63 Groundwater Honttoring Network.

\begin{tabular}{|c|c|c|c|c|c|}
\hline Well & Aquifer & $\begin{array}{l}\text { Sampling } \\
\text { frequency }\end{array}$ & $\begin{array}{l}\text { Water } \\
\text { levels }\end{array}$ & $\begin{array}{c}\text { Well } \\
\text { standard }\end{array}$ & $\begin{array}{c}\text { Other } \\
\text { networks }\end{array}$ \\
\hline $299-\left[27-11^{69}\right.$ & Top of unconfined & $\$$ & 4 & RERA & LEtinta-2 \\
\hline $299-E 27-16^{90}$ & Top of unconfined & $\$$ & Q & RCRA & $=$ \\
\hline $299-E 27-8^{67}$ & Top of unconfined & $\mathbf{s}$ & 0 & $\mathrm{RCRA}$ & 11,WHA-2 \\
\hline $299-\mathrm{E} 27-9^{87}$ & Tap of unconfined & 5 & 9 & RCRA & LCHMA-Z \\
\hline $299-E 33-33^{90}$ & Top of unconfined & 5 & 9 & RCRA & SST B-BX-BY \\
\hline $299-E 33-36^{90}$ & Top of unconfined & 5 & $\vec{Q}$ & RCRA & $m$ \\
\hline $299-E 33-37^{90}$ & Top of unconfined & $\bar{s}$ & $\bar{Q}$ & RCRA & $=$ \\
\hline $299-E 34-8^{20}$ & Top of unconfined & $S$ & $\mathbf{Q}$ & RCRA & LLWHA-2 \\
\hline $299-E 34-10^{91}$ & Top of unconfined & $s$ & 9 & RCRA & LLWHA-2 \\
\hline $299-\varepsilon 27-17^{91}$ & Top of unconfined & 5 & $\bar{Q}$ & RCRA & LLWHA-2 \\
\hline 299-E27-1892 & Top of unconftined & $s$ & $\bar{Q}$ & RCRA & 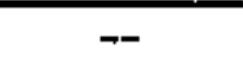 \\
\hline $299-E 27-19^{92}$ & Top of unconflned & $\$$ & $\overline{\mathbf{Q}}$ & RCRA & - \\
\hline
\end{tabular}

Hotes: Shading denotes upgradient wells. Superseript follouing well number denotes the year of installation.

LLMMA = Low-Level Haste Management Area.

Q - frequency on a quarterly basis.

RCRA * well is constructed to RCRA-speciffed standards.

$\$$ - frequency on a semiannual basis.

SST * single-she?] tank. 
DOE/RL-96-01, REV, O

Table 4.7-2. Constituent List for the

216-8-63 Trench Monttoring Hetwork.

\begin{tabular}{|c|c|c|}
\hline \multicolumn{3}{|c|}{ Contanination indicator parameters } \\
\hline $\begin{array}{l}\text { pH } \\
\text { Specific conductance }\end{array}$ & $\begin{array}{l}\text { Total orga: } \\
\text { Total orga: }\end{array}$ & \\
\hline \multicolumn{3}{|c|}{ Groundwater quality parameters } \\
\hline $\begin{array}{l}\text { Chloride } \\
\text { Iron }\end{array}$ & $\begin{array}{l}\text { Manganese } \\
\text { Phenols }\end{array}$ & $\begin{array}{l}\text { Sodiun } \\
\text { Sulfate }\end{array}$ \\
\hline \multicolumn{3}{|c|}{ Site-spectfic parameters } \\
\hline $\begin{array}{l}\text { Alkalinjty } \\
\text { Gross alpha }\end{array}$ & $\begin{array}{l}\text { Gross beta } \\
\text { Turbidtty }\end{array}$ & \\
\hline
\end{tabular}

4.7-10 
Table 4.7-3. Critical Means Table for 48 Comparisons-Background Contamination Indjcator Parameter Data for the 216-8-63 Trench

\begin{tabular}{|l|c|c|c|c|c|c|c|}
\hline $\begin{array}{c}\text { Constjtuent } \\
\text { (Unjt) }\end{array}$ & $n$ & df & tc & $\begin{array}{c}\text { Average } \\
\text { background }\end{array}$ & $\begin{array}{c}\text { Standard } \\
\text { deviation }\end{array}$ & Critical mean & $\begin{array}{c}\text { Upgradient/ } \\
\text { downgradient } \\
\text { comparison } \\
\text { value }\end{array}$ \\
\hline $\begin{array}{c}\text { Specific } \\
\text { Conductance } \\
\text { ( } \mu \text { mho/cas) }\end{array}$ & 21 & 20 & 4.224 & 369.393 & 60.192 & 629.6 & 629.6 \\
\hline Field pH & 20 & 19 & 4.572 & 7.975 & 0.190 & {$[7.08,8.87]$} & {$[7.09,8.87]$} \\
\hline TOC $^{\circ}$ (ppb) & 20 & 19 & 4.267 & 500 & N.C. & N.C. & 976 \\
\hline TOX $^{d}$ (ppb) & H.C. & N.C. & N.C. & N.C. & H.C. & N.C. & 13.6 \\
\hline
\end{tabular}

"Data collected from July 1992 to April 1993 for upgradient wells 2-E27-8, 2-E27-9, 2-E34-10, and 2-E27-17. Data collected from July 1992 to July 1993 for upgradient we11 2-E27-11. Values calculated based on 48 comparisons.

The following notations are used in this table:

df $=$ degrees of freedom $(n-1)$.

$\mathrm{n}$ = nuaber of background replicate averages.

$t_{c}=$ Bonferroni critical t-value for appropriate of and 48 conparisons.

critical mean cannot be calculated due to lack of an estimate of background standard deviation. The upgradient/downgradient comparison value is the limit of quantitation (see Appendix A).

"Critical maan cannot be calculated due to problems associated with data quality for samples analyzed by OCL. The upgradient/downgradient comparison value for TOX is the limit of quantitation (see Appendix $A$ ).

N. C. = not calculated. 
DOE/RL-96-01, Rev. 0

This page intentionally left blank.

$4.7-12$ 
DOE/RL-96-01, REV. 0

CONTENTS

4.8200 EAST AREA LIQUID EFFLUENT RETENTIOH FACILITY $\ldots \ldots$. $4.8-1$

4.8 .1 Overview of the Facility . . ........ 4.8-1

4.8.2 SUrmary of 1995 RCRA Activities ........ 4.8-2

4.8.3 Sampling and Analysts Progran ......... 4.8-2

4.8.4 Groundwater Chemistry . . . . . . . . . 4.8-2

4.8 .5 Groundwater Flow . . . . . . . . .... 4.8-3

4.8 .6 References . . . . . . . . . . . 4.8-4 
DOE/RL-96-01, REV. 0 .

\section{LIST OF FICURES}

4.8-1 Monitoring We?1 Locations for the Liquid Effluent Retention Facility ............. 4.8-6

4.8-2 Hydrograph of Water Level Measurements (Feet Above Sea Level) for Liquid Effluent Retention Facjlity Wells . . . 4.8-7

4.8-3 200 East Area Water Table Hap ............... 4.8-8

\section{LIST OF TABLES}

4.8-1 Liquid Effluent Retention Factilty Groundwater Monitoring Network.............. 4.8-9

4.8-2 Constituont List for the Liquid Effiuent Retention Facjicty Nonitoring Hetwork ......................... 4-9 
D0E/RL-96-01, REY, O

\title{
4.8 200 EAST AREA LIQUID EFFLUENT RETENTIOH FACILITY
}

\author{
H. D. Sweeney \\ Westinghouse Hanford Company
}

\subsubsection{Overview of the Factlity}

The ' iquid Effluent Retention Facjlity (LERF) consists of three $24.6 \times 10^{\circ}-L$ (6.5-ligal) surface impoundments (basíns), located on a 15.8-ha (39-acre) site northeast of the 200 East Area on the Hanford Site (Figure 4.8-1). The three basins were constructed of two composite tiners, a leachate collection system between the liners, and a floating cover. The fourth basin has been excayated but has not been completed and will not be used for 242-A Evaporator effluent.

The LERF serves as a temporary storage facility for evaporator process condensate until the Effluent Treatment Facility for the 242-A Evaporator is operational. The 242-A Evaporator is used to substantially reduce the quantity of waste stored in double-shell tanks. Effluent from the 242-A Evaporator was discharged to cribs in the 200 East Area. The evaporator was shut down when listed waste was found in the effiuent stream. The 242-A Evaporator was restarted on April 14, 1994.

Primary constituents detected in the effluent stream from the 242-A Evaporator have been ammonium, acetone, aluminum, 1-butano1, 2-butanone, tritium, ${ }^{0} \mathrm{Sr},{ }^{106} \mathrm{Ru}$, and ${ }^{3} \mathrm{Cs}$. Further inforastion of the effect on groundwater from release of this waste streat is documented in the Liquid Effivent Study Final Report (WHC 1990).

A groundwater monitoring network has been estabilished for the LERF (WHC 1991). The 242-A Evaporator process condensate effluent is regulated as a dangerous waste under Washington Administrative Code (UAC) 173-303 because of the toxicity of the ammonitum and the presence of 1 isted waste constituents. An interim-status groundwater monitoring system is in p]ace to determine the impact of this facility on the groundwater quality until a final permit has been approved (40 code of Federal Regulations [CFR] 265). It is monitored under an interia-status detection-level program.

Four wells have been constructed and are used to monitor groundwater levels and water quality. Bata from these wells were used to establish initial background groundwater qual fty.

A dangerous waste permit apptication (DOE-RL 1991) was submitted to the Washington State Department of Ecology (Ecology) for review in June' 1991. Ecology's response to the application was received in February 1994.

Only a single stratigraphic unit, the Hanford formation, overifes basalt beneath the site. The sediments directly beneath the LERF appear to be mostiy mixtures of sand and gravel associated with high-energy deposition by cataclysufic floods. Lateral facies changes occur tn the flood deposits to the south and west. Along the southern margin of the flood channel, deposits become finer grained and include fine sand, silt, and occasionally clay, which could act locally as aquitards leading to perched water conditions. 
The sediments overlying the basalt becowe progressively thinner to the northeast of the LERF. The sediments are 62 to $63 \mathrm{~m}(202$ to $206 \mathrm{ft}$ ) thick beneath the facility. The thickness of the saturated zone ranges from 0.5 to $3.8 \mathrm{~m}$ (2 to $12 \mathrm{ft}$ ). The vater table varies from 60.7 to $61 \mathrm{in}$ (199 to $200 \mathrm{ft}$ ) belc.t ground surface.

\section{B.2 Summary of 1995 RCRA Activities}

We]ls in the monitoring network were sanpled in December 1994 and June 1995 for contamination indicator, groundwater qualtty, and site specific parameters. The water level in the LERF monitoring network continues to decline, thereby requiring the use of specially adapted equipinent to obtain representative samples. Results of these sampling event analyses are discussed in Section 4.8.4. Data were included in each of the four quarterly reports (Sweeney 1995a, 1995b, 1995c, and 1996).

Periodic water level moasurements of the four-we]1 monitoring network were made from October 1994 through Septomber 1995, in addition to routine water level measurements made at the timo of sampling.

\subsubsection{Sampling and Analysis Progran}

The current groundwater monitoring network consists of four wells (Table 4.8-1). The well locations are shown in Figure 4.8-1.

Groundwater chemtstry data are avallable for most of the LERF groundwater monitoring wells for fiscal year 1995. The wells have been sampled for contanination indjcator paraneters, groundwater quality paraneters, and sitespecific paramoters as idantified in Table 4.8-2. Constituents such as uranium, tritium, ganma scan, and volatile organic compounds were deleted from the list of constituents. These constituents were consistently bel ow regulatory 1 imit and termination of these analyses was considered to have no impact on groundwater monitoring beneath the facility. Site-spectfic parameters were selected based on a history of waste discharged in surrounding waste management areas and on proposed waste characteristics for the effluents targeted for LERF. Data were published in quarterly reports (Sweeney 1995a, $1995 \mathrm{~b}, 1995 \mathrm{c}$, and 1996).

\subsubsection{Eroundwater Chomistry}

During 1995, groundwater samples were collected for most welis within the LERF groundwater monitoring network. We11 299-E26-9 had been renoved from the sanpling schadule in 1993 because of the Tow water level in the well casing (0.15 $\mathrm{m}[0.5 \mathrm{ft}])$. The we]1 has subsequently been placed back on the schedule now that sampling equipment capable of obtaining samples in low-static water level wells is available.

4.8.4.1 Constituents of Concem. Groundwater manitoring at the LERF provides no evidence that dangerous, nonradioactive constituents from the site have entered the groundwater. The indicator parameters are specific conductance, pH, total organic carbon (TOC), and total organic halogen (TOK) (40 Code of 
Federal Regulations [CFR] 265.92[b][3]). These ana]yses are considered screening techniques since the concentrations reported are not for specific contaminants. Other analytes are monjtored in groundwater to jook for the dangerous waste constituents that have been stored in the LERF since it began recelveling waste (see Table 4.7-2). Included in the LERF analys is list are gross alpha, alkalinity, gross beta and tubidity. There were no significant detections for these analyses that could be attributed to the LERF.

\subsubsection{Statistica] Evaluation. Statistical analyses required by} 40 CFR 265.93(b) and WAC 173-303-400 were performed on the samples collected from upgradient well 299-E26-11. Results are presented in Table 4.8-3. This table lists the background average, standard deviation, critjca] mean (or critical range, in the case of $\mathrm{BH}$ ), and upgradient/downgradient comparison values for the contanination indicator parameters. An alternative range for upgradient/downgradient comparisons was calculated using data collected from June 1991 to October 1993 because the critical range calculated using four quarters of data is too large to be meaningful (see Appendix $C$ ). The upgradient/downgradient comparison value is the value to which current and future averages of indicator parameters are compared. The compartson va]ue is generally the critical mean or critical range. The limit of quantitation is used as the comparison value for total organic halogen instead of the crittcal mean because most of the upgradient concentrations were below the contractualky required quantitation 1 imit (see Appendix $C$ ).

There were no exceedances in specific conductance, Toc or ToX. One incldent of pH exceedance occurred at a downgradient we 11 299-E35-2 during the January 31,1995 sampling event. The replicate average of 5.54 was below the lower critical iluat of 6.25 . Subsequent verification sampling results conflrmed that the inftial exceedance was caused by an error in the fieid measurement.

\subsubsection{Groundwater Flow}

4,8.5.1 Groundwater Flow Direction. In general, the LERF hydrograph flattened in 1995, which indicates that the water table continues to decline (F/gure 4.8-2). These data are reported in previous quarterly reports of RCRA groundwater monitoring data (Sweeney 1995a, 1995b, 1995c, and 1996). A water table map for June 1995 is presented in Figure 4.8-3. The general trend of groundwater flow is from east to west.

4.8.5.2 Rate of Flow. The horizonta 1 groundwater gradient in the unconfined aquifer under the LERF is approximately $6.3 \times 10^{-3}$ between weils 299-E26-11 and 299-E26-9. An estimation of the average 1 inear groundwater velocity can be calculated fron the following equation based on Darcy's law: 
DOE/RL-96-01, REV. D

$$
v=\frac{\mathrm{Ri}_{i}}{\mathrm{n}_{*}}
$$

where:

$$
\begin{aligned}
& y=\text { Yelocity in } \mathrm{m} / \mathrm{d} \text { (ft/d) } \\
& K=\text { Hydraufic conductivity in } \mathrm{m} / \mathrm{d} \text { ( } \mathrm{ft} / \mathrm{d} \text { ) } \\
& 1 \text { - Hydraul ic gradient (dimensionless) } \\
& n_{0} \text { - Effective porosity (dimensionless). }
\end{aligned}
$$

The calculations of groundwater velocity assume horizontal flow and a homogeneous aquifer. The following inputs from 57 ug test data were used to determine the veloctty near we]7-299-E26-9:

$K=122 \mathrm{n} / \mathrm{d}(400 \mathrm{ft} / \mathrm{d})$

$i=6.3 \times 10^{-3}$

$n_{6}=0.20$ (Grahan et a1. 1981).

The given value of $K$ is representative of the Hanford formation based on puatp tests in the 200 Areas (Grahan et al. 1981). The calculated velocity is $3.8 \mathrm{~m} / \mathrm{d}(12 \mathrm{ft} / \mathrm{d})$.

4.8.5.3 Evaluation of the Monitoring Hetwork. The current network comprises four we1ls, one of which is upgradient. The network is currently constdered adequate but will be continually evaluated as water levels and groundwater gradients change over time. The initial MEMD efficiency wodel was calculated at 95.5\%. Ho additional wells are under consideration at this time.

\subsubsection{References}

40 CFR 265, "Interin Status Standards for Omners and Operators of Hazardous Waste Treatment, Storage, and Disposal Facilities," Code of Federal Regul at fons, as anended.

DOE-RL, 1991, Liquid Effluent Retention Facility Dangerous Waste Permit Application, DOE/RL-90-43, U.S. Department of Energy, Richland Field office, Richland, Washington.

Graham, M. J., H. D. Hal1, 5. R. Strait, and W. R. Brown, 1981, Hydrology of the Separatfons Ares, RHO-ST-42, Rockwell Hanford Operations, Richland, Washington.

Sweeney, H. D., 1995a, "Liquid Effluent Retention Facility," Quarterly Report of RCRA Groundwater Monf toring Data for Period October 1, 1994 through Deceraber 31, 1994, DOE/RL-93-36-4, U.S. Department of Energy, Richland Operations office, Richland, Washington.

Sweeney, H. D., 1995b, "Liquid Effluent Retention Facility," QuarterIy Report of RCRA Groundwater Monitoring Data for Period January 1, 1995 through March 31, 1995, 00E/RL-94-69-1, U.S. Department of Energy, Richland

- Operations office, Richland, Washington. 
Sweeney, M. D., 1995c, "Liquid Effluent Retention Facility," Quarterly Report of RCRA Groundwater Monitoring Data for Period April 1, 1995 through June 30, 1995, 00E/RL-94-69-2, U.S. Department of Energy, Richland Operations Office, Richland, Washington.

Sweeney, H. D., 1996, "Liquid Effl uent Retention Facil1ty," Quarterly Report of RCRA Groundwater Honitoring Data for Period JuIy 1, 1995 through September 30, 1995, DOE/RL-94-69-3, U.S. Department of Energy, Richland Operations Office, Richland, Washington.

WAC 173-303, "Dangerous Waste Regulations," Washington Administrative Code, as amended.

WHC, 1990, Liquid Effluent Study Final Report, WHC-EP-0367, Westinghouse Hanford Company, Richland, Washington.

WHC, 1991, Interin Status 6roundwater Monitoring Plan for the 200 Esst Ared Liquid Effluent Retention Facifity, WHC-SD-EK-AP-024, Rev, 1, Westinghouse Hanford Company, Richl and, Washington. 


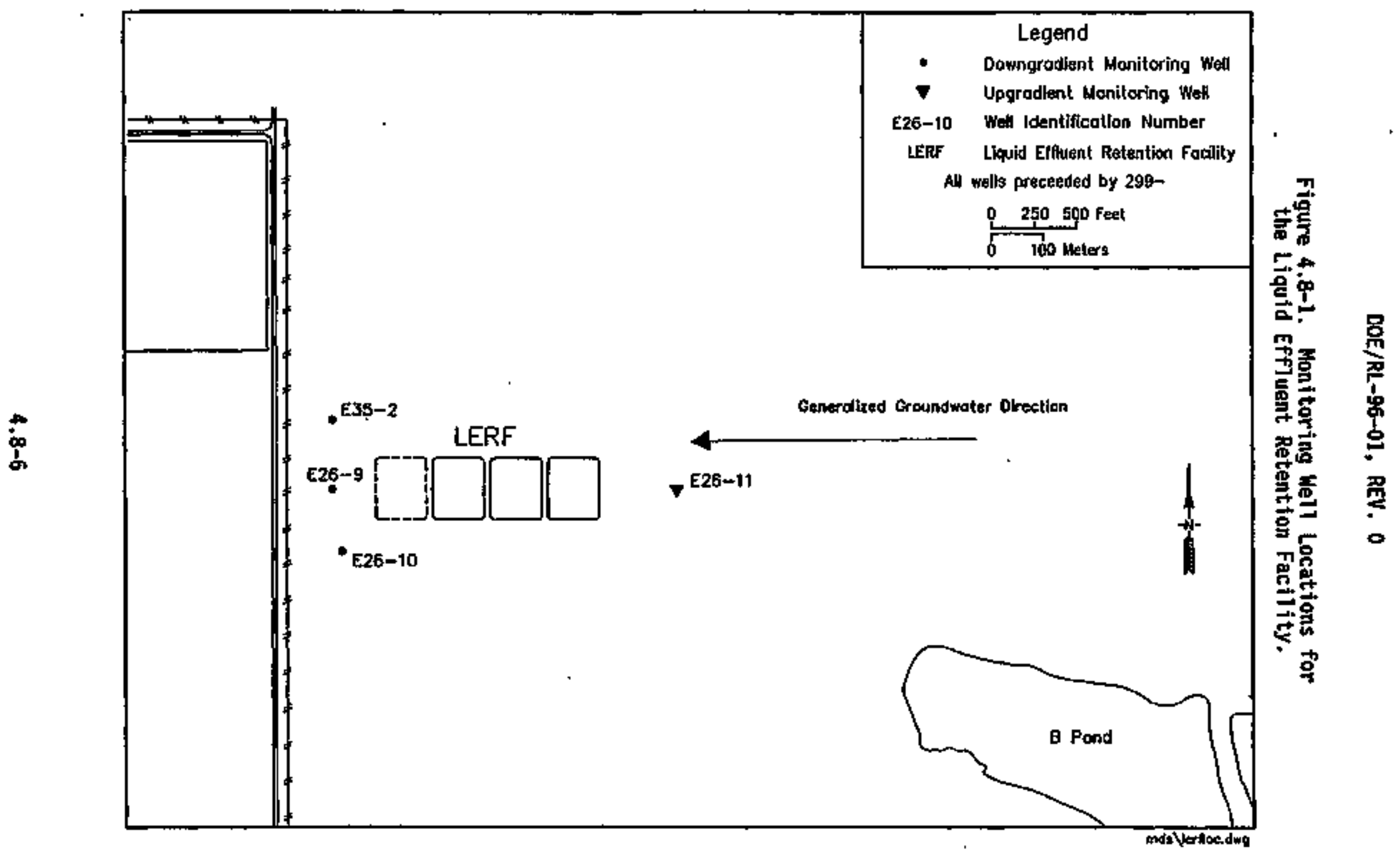


DOE/RL-96-01, REV. 0

Figure 4.8-2. Hydrograph of Hater Level Measurements (Feet Above Sea Leval) for Liquid Effiluent Retention Facility Wells.

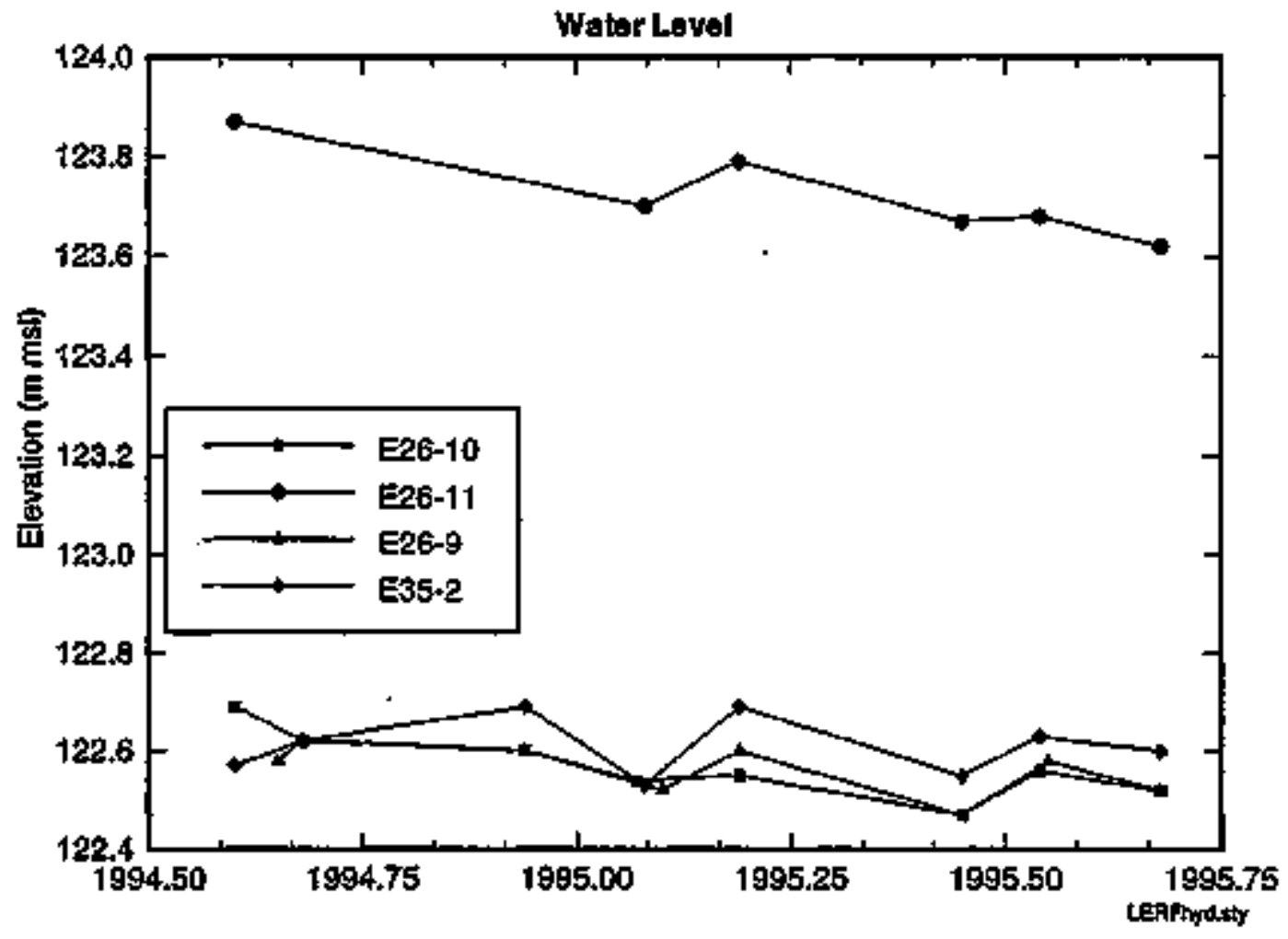


DOE/RL-96-01, REY, O

Figure 4.8-3. 200 East Area Water Table Map.

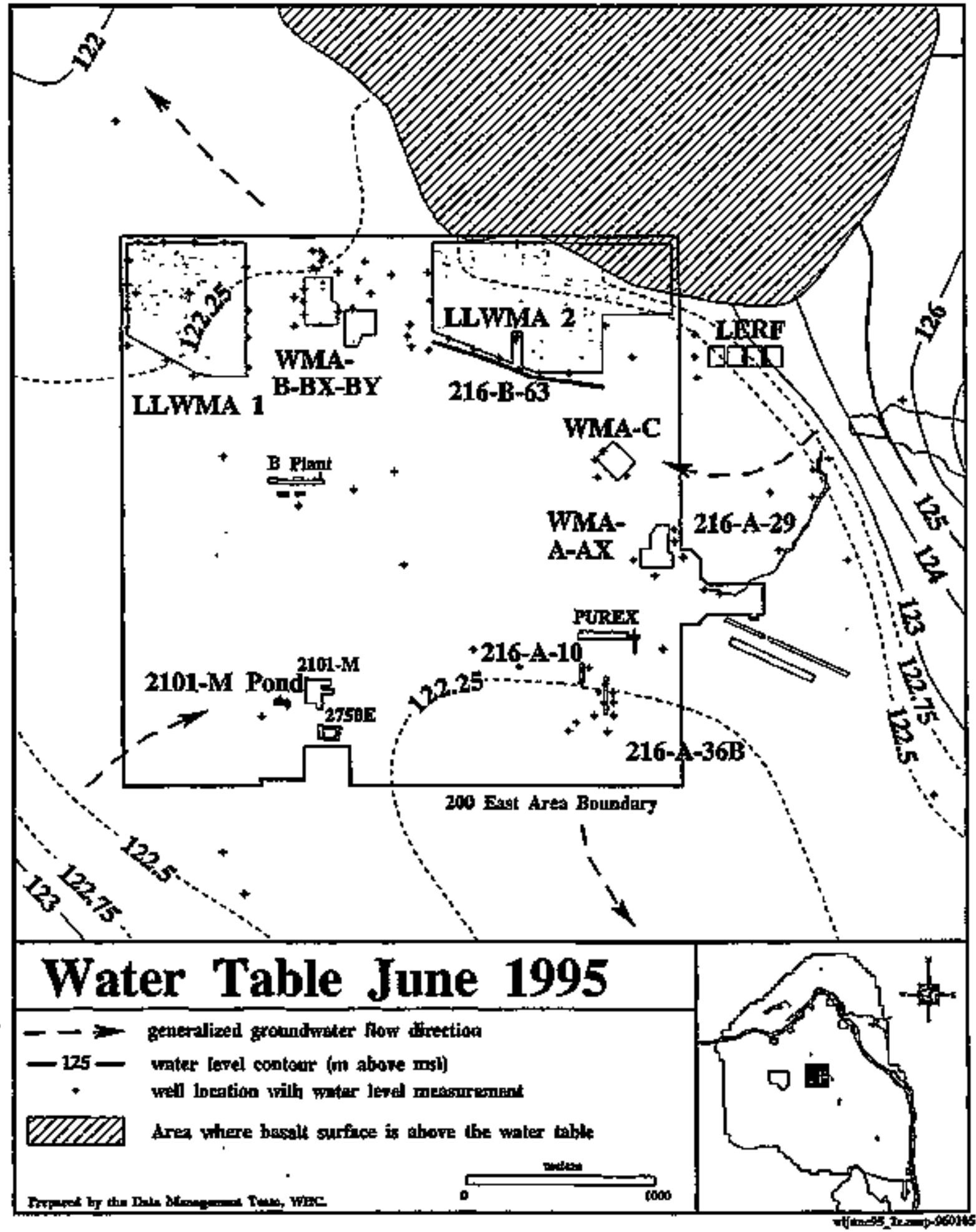


Table 4.8-1. Liquid Effluent Retention Facility Groundwater Monitoring Metwork.

\begin{tabular}{|l|l|c|c|c|c|}
\hline \multicolumn{1}{|c|}{ Well } & Aquifer & $\begin{array}{c}\text { Sampling } \\
\text { frequency }\end{array}$ & $\begin{array}{c}\text { Nater } \\
\text { levels }\end{array}$ & $\begin{array}{c}\text { Mell } \\
\text { standard }\end{array}$ & $\begin{array}{c}\text { Other } \\
\text { networks }\end{array}$ \\
\hline $299-E 26-11^{89}$ & Top of unconftiad & S & $Q$ & RCRA & -- \\
\hline $299-E 26-10^{90}$ & Top of unconfined & S & QQ & RCRA & -- \\
\hline $299-E 26-9^{87}$ & Top of unconfined & S & $Q$ & RCRA & -- \\
\hline $299-E 35-2^{87}$ & Top of unconfjned & S & $Q$ & RCRA & -- \\
\hline
\end{tabular}

Notas: Shading denotes upgradient wells. Superscrtpt following well number denotes the year of installation.

$Q$ - frequency on a quarterly basis.

RCRA = well is constructed to RCRA-specified standards.

$S$ - frequency on a semiannual basis.

Table 4.8-2. Constjtuent List for the Liquid Effluent Retention Fácility Monitoring Network.

\begin{tabular}{|c|c|c|}
\hline \multicolumn{3}{|c|}{ Contamination indicator parameters } \\
\hline $\begin{array}{l}\text { pH } \\
\text { Specific } \\
\text { conductance }\end{array}$ & $\begin{array}{l}\text { Total orga } \\
\text { Total orga }\end{array}$ & \\
\hline \multicolumn{3}{|c|}{ Groundwater quality parameters } \\
\hline $\begin{array}{l}\text { Chloride } \\
\text { Iron }\end{array}$ & $\begin{array}{l}\text { Hanganese } \\
\text { Phenols }\end{array}$ & $\begin{array}{l}\text { Sodium } \\
\text { Suifate }\end{array}$ \\
\hline \multicolumn{3}{|c|}{ Site-specific parameters } \\
\hline $\begin{array}{l}\text { Alkatinity } \\
\text { Gross alpha }\end{array}$ & & $\begin{array}{l}\text { Gross beta } \\
\text { Turbidity }\end{array}$ \\
\hline
\end{tabular}


Table 4.8-3. Crttical Heans Table for 16 Comparisons--Background Contanination Indicator Paraneter Data for the Liquid Effluent Retention Factlity ${ }^{\text {, }}$

\begin{tabular}{|c|c|c|c|c|c|c|c|}
\hline $\begin{array}{c}\text { Constituent } \\
\text { (Unit) }\end{array}$ & $n$ & df & tc & $\begin{array}{c}\text { Average } \\
\text { background }\end{array}$ & $\begin{array}{c}\text { Standard } \\
\text { deviation }\end{array}$ & Critical mean & $\begin{array}{c}\text { Upgradient/ } \\
\text { downgradient } \\
\text { comparison value }\end{array}$ \\
\hline $\begin{array}{l}\text { Speciflc } \\
\text { Conductance } \\
\text { ( } \mu \text { nho/col) }\end{array}$ & 4 & 3 & 11.984 & 332.125 & 11.736 & 489.4 & 489.4 \\
\hline Field pH & 4 & 3 & 15.145 & 7.742 & 0.311 & {$[2.48,13.01]$} & {$[6.25,9.42]^{\circ}$} \\
\hline$T O C^{c}$ (ppb) & 4 & 3 & 11.984 & 718.75 & 295.364 & 4,676 & 4,676 \\
\hline$T O X^{d}(p \rho b)$ & H.C. & H.C. & N.C. & H.C. & H.C. & H.C. & 13.6 \\
\hline
\end{tabular}

Data collected from June 1991 to April 1992 for upgradient well 2-E26-11. Values calculated based on 12 compartsons.

The following notations are used in this table: df $=$ degrees of freedon (n-1).

$n$ - number of background replicate averages.

$t_{0}=$ Bonferroni critical $t-v a l u e$ for appropriate df and 16 compartsons.

CCritical mean was calculated from values reported below the CRQL.

Critical mean cannot be calculated due to problems associated with data quality for samples analyzed by DCL. The upgradient/downgradient comparison value for TOX is the limit of quantitation (see Appendix A).

-Upgradtent/downgradient comparison values for pH were calculated using data from June 1991 to October 1993 (we11 2-E26-11) because the critical range calculated using 4 quarters of data is too large to be meantingful.

N. C. = not calculated. 
DOE/RL-96-01, REY. 0

CONTERS

4.9 2101-H POND . . . . . . . . . . . . 4.9-1

4.9.1 Facitity overview $\ldots \ldots \ldots \ldots$ 4.9-1

4.9.2 Sunmary of 1995 RCRA Activities $\ldots \ldots$ 4.9-1

4.9 .3 Sampiing and Analysis Program ......... 4.9-2

4.9.4 Groundwater Chemtistry ............. 4.9-2

4.9.5 Groundwater Flow ................ 4.9-3

4.9 .6 References ................. 4.9-5 
DOE/RL-96-0I, RET. 0

\section{LIST OF FIEURES}

4.9-1 Monitoring Well Locations for the 2101-H Pond and Location of Cross Section A-A' ............4.9-6

4.9-2 Geologíc Cross Section A-A $\ldots \ldots \ldots$ 4.9. . . . . . .

4.9-3 Specific Conductance Versus Time in Upgradient Yel1 299-E18-1 and Downgradient Wel1s 299-E18-2, 299-E18-3, and 299-E18-4 .................. . . . .

4.9-4 Filtered Barfum Yersus Time in Upgradient We11 299-E18-1 and Downgradient Weils 299-E18-2, 299-E18-3, and 299-E18-4 .............. 4.9-8

4.9-5 200 East Area and 2101-H Pond Water Table Wap, June $1995 \ldots \ldots$. . . . . . . . 4.9-9

4.9-6 Hydrograph of Monthly Water Leve] Measurements

(Weters Above Hean Sea Level) at the 2101-M Pond . . . . . 4.9-10

\section{LIST OF TABLES}

4.9-1 Monitoring Mell Hetwork for the 2101-H Pond . . . . . . 4.9-11

4.9-2 Constituents Analyzed at the 2101-M Pond ......... 4.9-12

4.9-3 Critical Means Table for 16 Comparisons--Background

Contanination Indicator Paraneter Data for the 2101-N Pond . . 4.9-13 
DOE/RL-96-01, REV. 0

\subsection{1-K POHD}

E. C. Thornton

Westinghouse Hanford Company

\subsubsection{Facitity Overview}

A revision of the closure plan has been fssued for 2101-M Pond (OOE-RL 1993). Acceptance of a clean closure certification of the 2101-H Pond was indicated by the Washington State Department of Ecology on October 26, 1995. The last groundwater sampling event for this facility occurred in June 1995. We]1 299-E18-1 wi11 continue to be sampled, however, in support of the 216-8-3 Pond System.

The 2101-H Pond is a U-shaped, unlined trench located west-southwest of the 2101-N Butlding in the southwest portion of the 200 East Area (Figure 4.9-1). It has received nondangerous wastewater from the 2101-M Building heating and air conditioning system since 1953. In 1981, Basalt Waste Isolation Project laboratories were plumbed into the discharge line frow the 2101-M butiding to the 2101-M Pond. Fron 1981 until mid-1985, these laboratories may have discharged dangerous waste into the 2101-H Pond. The most important chemicals used in the 2101-14 Laboratory were barium chloride and hydrochloric and nitric acids. They are assumed to have been disposed of in 1aboratory drains connected to the 2101-H Pond. Selentum and chromiun were also potential contaminants assocfated with 1aboratory operations. Adminfstrative controls were established in July 1985 to prohibit disposal of dangerous waste via the laboratory drajns.

Since November 1989, the 2101-M Pond has been fonitored under Resource Conservation and Recovery Act of 1976 (RCRA) interim-status regulations (40 code of Federal Regulations [CFR] 265) in an indicator-parameter evalution program using a four-welt network (Chamness et al. 1989). The monjtoring wells are installed in the uppermost portion of the unconfined aquifer and completed across the interpreted contact between the base of the Hanford formation and the top of the Rjngold Formation (Ford and Trent Ig94, Lindsey et a1. 1994). The stratigraphy consists of a muddy, sandy gravel to a slightly muddy gravelly sand over the screened interval, which ranges fron approximately 92 to $101 \mathrm{~m}$ (302 to $331 \mathrm{ft}$ ) belor the top of the casing (Figure 4.9-2). The 2101-H Pond is located within the 200-S5-1 operable unit.

\subsubsection{Summary of 1995 RCRA Activities}

All four wells in the monitoring network were sampled in December 1994 and June 1995 for contamination indicator, groundwater quality, and orinking water quality parameters. In addition, we]1 299-E18-1 was sampled in March and September of 1995 because this weli is also an upgradient monitoring well for the 216-8-3 Pand System and is currently being sampled quarterty as part of the assessment monitoring program for that unit. Restits of groundwater analyses for 2101-N Pand are discussed-in Section 4.9.4.

Month]y water level measurements of the four-wetl monitoring network were made frow October 1994 through December 1994. Since then water level 
DOE/RL-96-01, REV, 0

measurements have been performed quarterly (Narch and June 1995). In addition, water level measurements have been performed at the time of sampling. A discussion of the water level measuraments is included in Section 4.9.5.

\subsubsection{Sampling and Analysis Progran}

The indicator-parameter evaluation groundwater monitoring prograw for the 2101- $M$ Pond is described in Chammess et al. (1989). The monitoring network consists of one upgradient (299-E18-1) and three downgradient (299-E18-2, 299-E18-3, and 299-E18-4) groundwater monitoring wells installed in the uppermost portion of the unconfined aculfer. A well location map is shown in Figure 4.9-1. Sanpling began in August 1988 and was conducted quarterly unti1 August 1989 to estabilish background values. Semiannua] indicator parameter evaluation monitoring was initiated in Movember 1989. Additional information regarding the monitoring network is provided in Table 4.9-1.

Samples were collected frop all four wells in December 1994 and June 1995. All four wells were analyzed for the constituents jisted in Table 4.9-2 and the resulting gata presented in quarterly reports (Thornton 1995a, 1995b, and 1995c). Verification sampling for total organic halogen (TOX) was also performed in October of 1994 for wetT 299-E18-4 because of a ToX exceedance associated with sampling conducted in December 1993.

\subsubsection{Groundwater Chemistry}

4.9.4.1 Constituents of Concern. All of the analytical values obtained in the past year for 2101-H Pond were below the drinking water standards (Dis). The four contarination indicator parameters, pH (field), conductance (field), total organic carbon (TOC), and TOX, were monitored for the continuing evaluation of the 2101- $H$ Pond Facility's impact on groundwater. An exceedance of the critical mean for ToX was observed for the December 1993 samping of well 299-E18-4. The wel1 was resampled for verification and sample splits were sent to two laboratories for analysjs. However, results obtained fron the two laboratories were considered inconclusive owing to high variability. Another round of verification sampling was undertaken on October 19, 1994. Laboratory results for TOX assocjated with this sampling were below the critical mean, indicating the earlier exceedance does not reflect an finpact of 2101-M Pond on groundwater quality. Specific conductance, pH, and Toc values have not exceeded the statistical background values (see Sectjon 4.9.4.2). Data discussed here have been presented in the quarterly reports (Thornton $1995 \mathrm{a}, 1995 \mathrm{~b}$, and 1995c).

Regulatory standards for turbidity do not apply to groundwater, which is measured at this site oniy as an indicator of solids content. Only filtered metals are used in measuring the impact of the site on the groundwater; however, unfiltered metals have also been analyzed at 2101comparison with the filtered metals and to evaluate we11 construction or other - effects on groundwater sample data. Elevated unfiltered chronium, iron, manganese, zinc, and nickel concentrations are thought to have been introduced during or after well construction (e.g., netal corrosion products or clays). Unfiltered chromium concentrations for we11 299-Elg-4 and unfiltered iron for 
wells 299-E18-1 and 299-E18-4 were elevated relative to the corresponding unfiltered meta] concentrations for groundwater samples collected on December 1, 1994. Turbidity values s] ight7y htgher than 3 NTUs were also reported for these samples. These data support the proposal that higher metal concentrations associated with unfi]tered samples are often related to the presence of so] id debris.

Comparing the water chenistry of upgradient well 299-E18-1 with downgradient we11s 299-E18-2, 299-E18-3, and 299-E18-4 indicates that a significant volume of water has entered the unconfined aquifer from the 2101-W Pond. Thus, a decrease of specific conductance (Figure 4.9-3) in downgradient wel1s versus the upgradient well is interpreted to be a dilutional effect of water draining from the pond into the aquifer. Conversely, barium concentrations of about $55 \mathrm{ppb}$ occur in downgradient wells versus 25 to $30 \mathrm{ppb}$ in the upgradient well (Ftgure 4.9-4). The differences in barium concentrations, however, appear to be inversely related to differences in sulfate concentrations between the upgradient and downgradient wells. Therefore, barfun concentrations likely reflect dissolution and precipitation equilibria in the natural system associated with dilutional effects and not from a bariun source introduced via the pond (Channess et al. 1990).

\subsubsection{Statistical Evaluation. Statistical evaluations at 2101-14 Pond} during the past year consisted of comparisons between upgradient and downgradient wells for indication of contanination in the groundwater beneath the site. All values of specific conductance, $\mathrm{pH}$, TOC, and TOX in the downgradient wells in the past year were below the upgradient/domgradient comparison values. Statistical methods are described in Appendix $C$.

Statfstical analyses required by 40 CFR 265.93 (b) and Washington Adefinistrative Code (MAC) 173-303-400 were perforaed on the samples col]ected from upgradtent well 299-E18-1. Results are presented in Table 4.9-3. This table lists the background average, standard deviatjon, critical itean (or critical range, in the case of $\mathrm{PH}$ ), and upgradient/donngradient comparison values for the contamination indicator parameters. The upgradient/ downgradient comparison value is the value to which current and future averages of indicator parameters are compared. The comparison value is generally the critical mean or crjtical range. An alternative pH range for upgradient/downgradient comparisons was calculated using upgradient data colTected from August 1988 to June 1989 (see Appendix C) because the critical range calculated using four quarters of data is outside the possibie range for pH $(0,14)$.

\subsubsection{Groundrater Flon}

4.9.5.1 Grounduater Flow Direction. Nater level measurements have been performed quarterly and before collecting groundwater samples during the past year. These data are used to eva] uate the groundwater gradient and fiow direction (Figure 4.9-5). The groundwater gradient across the 2101-M Pond wonitaring network is difficult to determine precisely bacause it is very snall (approximately $5 \times 10^{-4}$ ). The hydrograph for the four-we17 monitoring network (figure 4.9-6) reflects not only the dffficulty of acquiring accurate measurements but also the very slight difference in water leve] elevations between the four wells. The hydrograph also indicates a gradual drop in the 
water table, reflecting declining water levels throughout the 200 East Area because of decreased wastewater discharges to the ground in the 200 Areas. The Tocal water table map (see Figure 4.9-5) indicates, however, that the genera] groundwater flow direction is stjil east to northeast. No data are available at present regarding vertical gradients and flow.

In sumuary, analysis of water level weasurements indicates the following:

- The continued deciline in water levels of approximately $0.1 \mathrm{a}$ $(0.3 \mathrm{ft})$ in the past year

- A low hydraulic gradient in the vicinity of the 2101-M Pond

- A general groundwater flow direction to the northeast or east.

4.9.5.2 Rate of Flow. An estiuate of horizontal flow rates can be obtained by using Darcy's law (Freeze and Cherry 1979)

$$
\bar{v}=-\frac{k}{n} \frac{\partial h}{\partial j}
$$

where:

$$
\begin{aligned}
& \bar{V}=\text { Flow rate or average linear velocity } \\
& K=\text { Hydraulic conductivity } \\
& \mathbf{n}_{0}=\text { Effective porosity } \\
& \text { gh }^{\circ}=\text { Hydraulic gradient. }
\end{aligned}
$$

The monjtoring wells at 2101-M Pond are completed in the lower part of the Hanford formation and upper part of the Ringold Formation in a sfity graveldominated sequence. An estimated value for hydraulic conductivity of $45 \mathrm{~m} / \mathrm{d}$ (150 ft/d) is appropriate for the screened zone as indicated by pumping test data (Chamness et al. 1990, Connelly et a]. 1992). If the hydraultic gradient. is assumed to be $5 \times 10^{-4}$ and effective porosity is assumed to be 0.15 , a rate of flow of $0.15 \mathrm{~g} / \mathrm{d}(0.5 \mathrm{ft} / \mathrm{d})$ is obtained. This should be regarded as an approximation only because the hydraulic gradient is difficult to estinate at this location. At present the hydraulic gradient is very low because the water table is nearly flat.

4.9.5.3 Evaluation of Honitoring Nejl Hetarork. Honitoring well Jocations satisfied regulatory requtrements during the past year based on the regional and Jocal trend of groundwater flow near the 2101-H Pond. This network will no longer be used for 2101-H Pond RCRA monitoring activities because the unit has been clean-closed. Network wells will be evaluated for use in support of other programs, however. 
DOE/RL-96-01, REY. 0

\subsubsection{References}

40 CFR 265, "Interin Status Standards for Owners and Operators of Hazardous Haste Treatment, Storage, and Disposal Facjlities," Code of Federal Regulations, as andended.

Chamness, M. A., S. P. Luttrel1, and \$. Dudztak, 1989, 40 CFR 265 Interin Status Ground-Water Hontoring PIan for the 2101-H Pond, PNL-6851, Pactific Morthwest Laboratory, Richland, Nashington.

Chamness, H. A., S. P. Luttrell, D. J. Bates, and U. J. Martin, 1990, 2101-N Pond Hydrogeologic Characterization Report, PHL-7468, Paciftc Horthwest Laboratory, Richland, Washington.

Connelly, H. P., J. V. Borghese, C. D. Delaney, B. H. Ford, J. W. Lindberg, and S. J. Trent, 1992, Hydrogeologic Hodel for the 200 East Groundwater Aggregate Area, WHC-SD-EH-TI-019, Rev. 0, Westinghouse Hanford Company, Richl and, Washington.

DOE-RL, 1993, 210I-H Pond Closure Plan, DOE/RL 88-41, Rev, 2, U.S. Department of Energy, Richt and Oparatjons Office, Richt and, Washington.

Ford, B. H., and S. J. Trent, 1994, "200 Areas," in Annual Report for RCRA Groundwater Nonitoring Projects at Hanford Site Facilitios for 1993, DOE/RL-93-88, U.S. Department of Energy, Richland Operations Office, Rtch1and, Washington, pp. 4.1-1 to 4.1-66.

Freeze, R. A., and J. A. Cherry, 1979, Groundwater, Prentice-Ha11, Inc., Englawood Cliffs, Hew Jarsey.

Lindsey, K. A., J. L. STate, G. K. Jaeger, K. J. Swett, and R. B. Mercer, 1994, Geologic Setting of the Low-Level Burial Grounds, WHC-SD-EH-TI-290, Rev. 0, Westinghouse Hanford Company, Richland, Nashington.

Resource Conservation and Recovery Act of 1976, 42 USC 6901 et seq.

Thornton, E. C., 1995a, "2101-H Pond," in Quarterly Report of RCRA Groundwater Nonitoring Data for Period October 1 through December 31, 1994, DOE/RL-94-36-4, U.S. Department of Energy, Richland Operations Office, Richland, Washington, pp. 13-1 to 13-12.

Thornton, E. C., 1995b, "2101-H Pond," in Quarteriy Report of RCRA Groundwater Honitoring Data for Period January I through Harch 31, 1995, DOE/RL-95-69-1, U.S. Department of Energy, Richland Operations office, Richland, Washington, pp. 13-1 to 13-10.

Thornton, E. C., 1995c, "2101-H Pond," In Quarteriy Report of RCRA Groundwater Honitoring Data for Period April 1 through June 30, 1995, D0E/RL-95-69-2, U.S. Departient of Energy, Richland Operations Office, Rich] and, Washington, pp. 13-1 to 13-10. 
Figure 4.9-1. Monitoring Well Locations for the 2101-H Pond and Location of Cross Section A-A'.

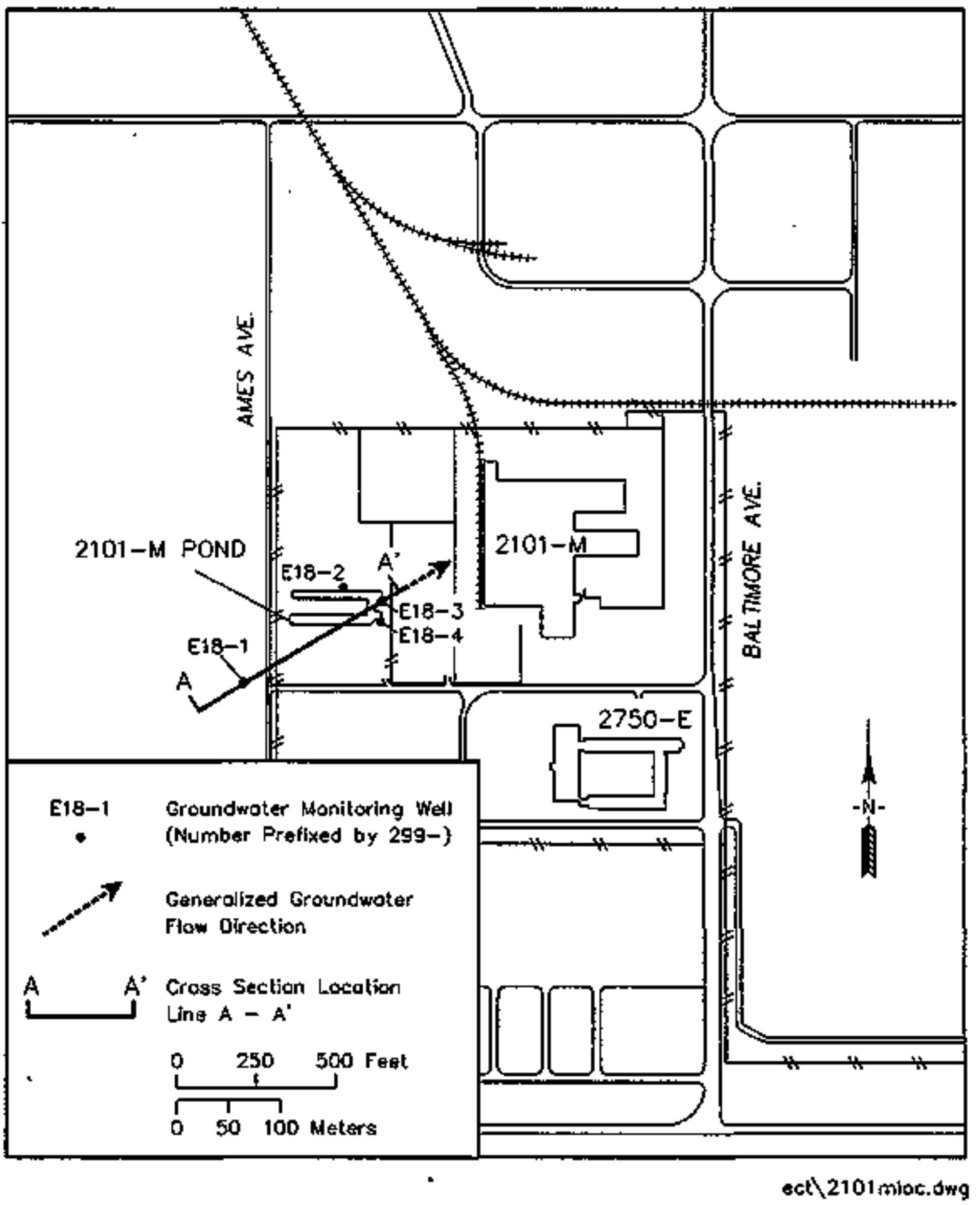


A

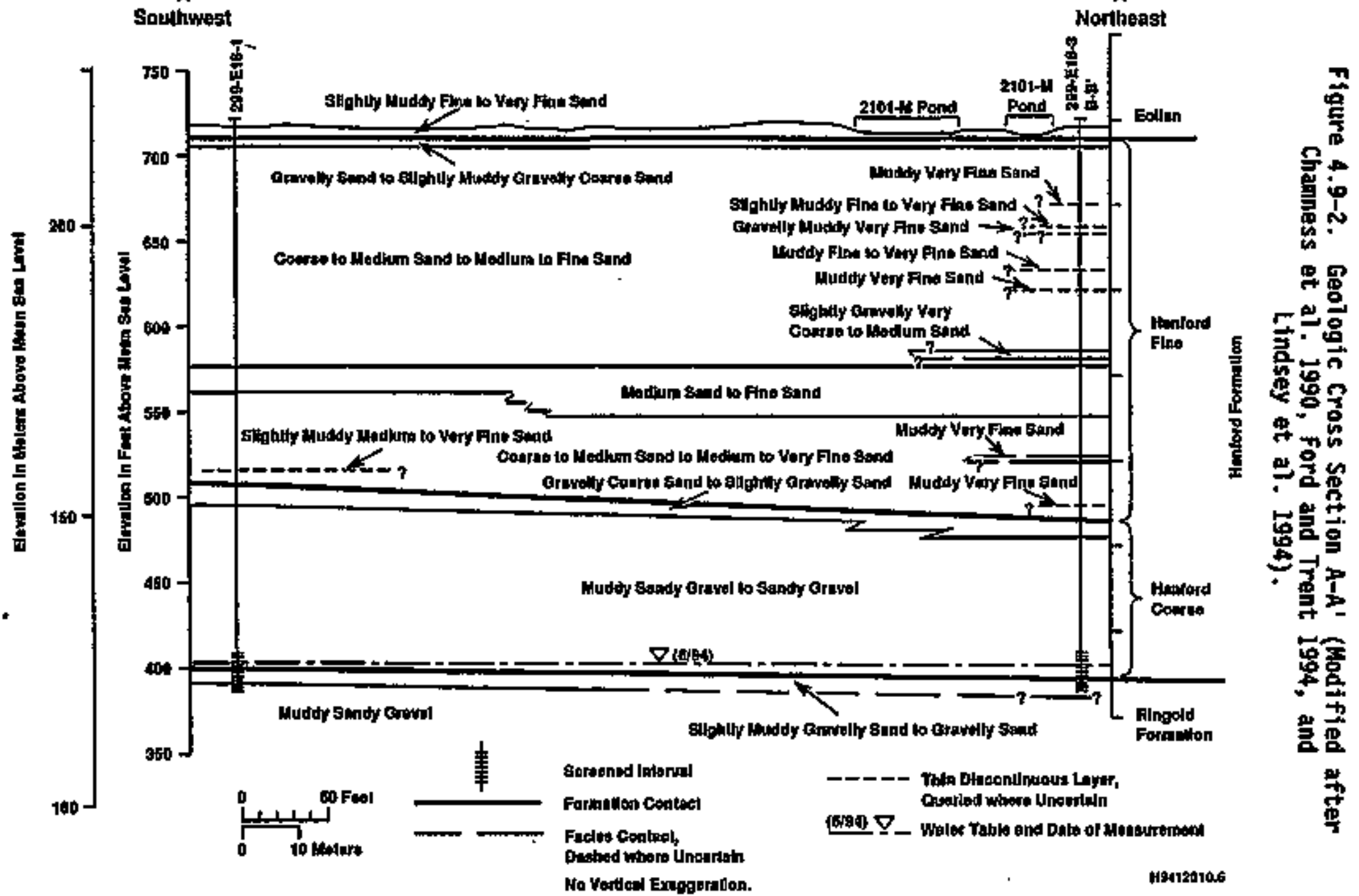


Figure 4.9-3, Specific Conductance Versus Time in Upgradient We11 299-E18-1 and Downgradient Wells 299-E18-2, 299-E18-3, and 299-E18-4.

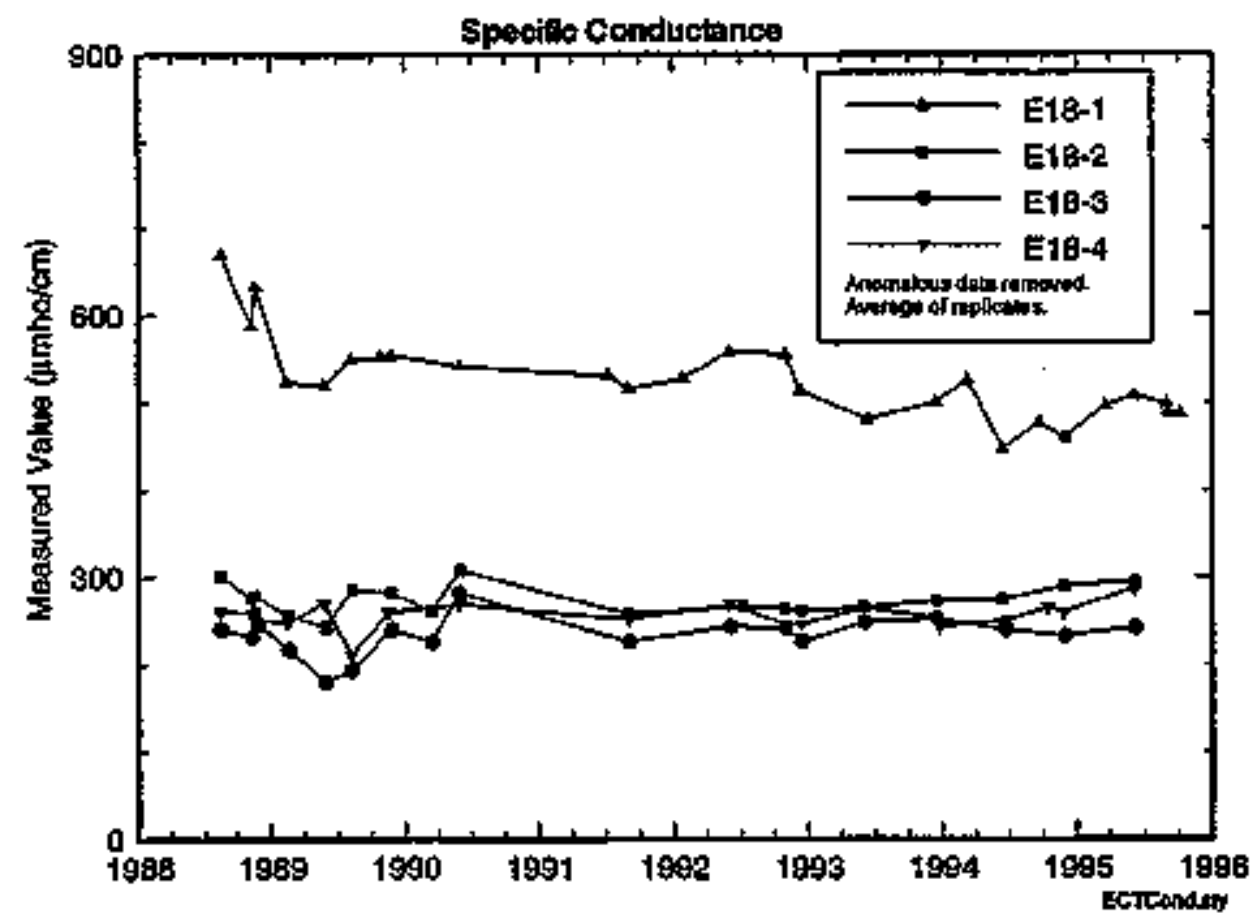

Figure 4,9-4. Fi7tered Barium Yersus T1me in Upgradient Well 299-E18-1 and Downgradient We11s 299-E18-2, 299-E18-3, and 299-E18-4.

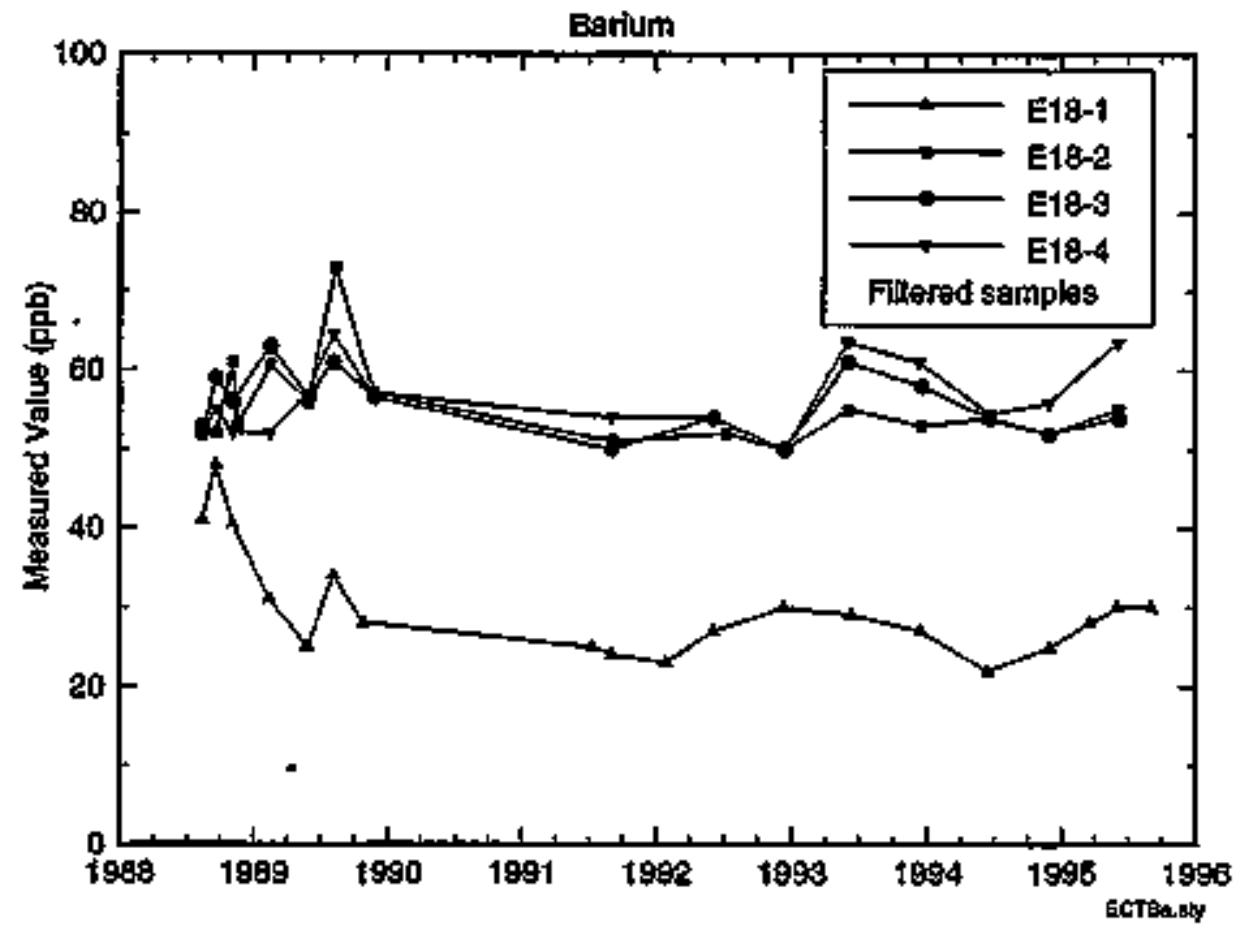


DOE/RL-96-01, REV. 0

Figure 4.9-5. 200 East Area and 2101-N Pond Water Tabie Map, June 1995.

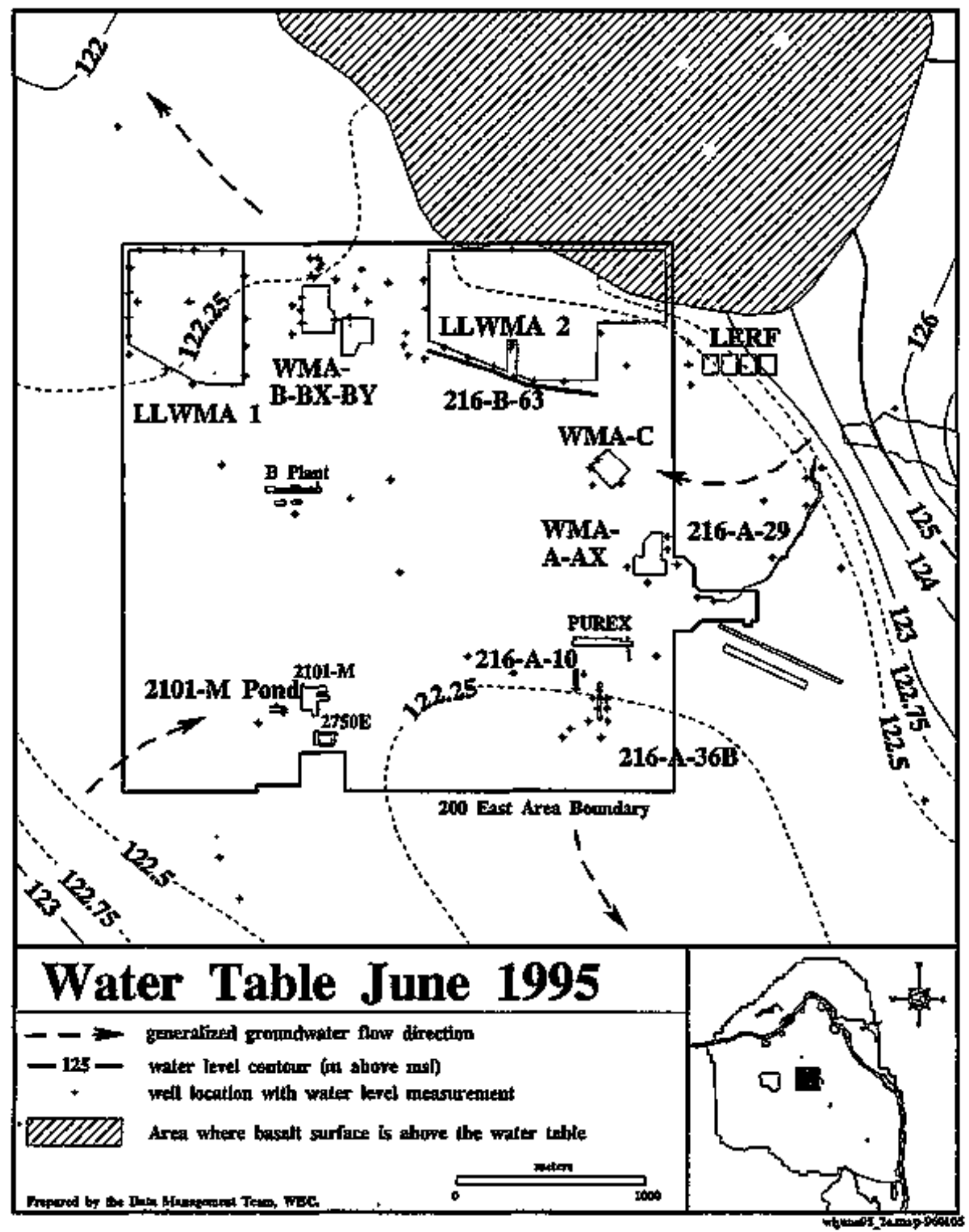


Figure 4.9-6. Hydrograph of Honthly Water Level Measurements (Meters Above Mean Sea Leve]) at the 2101-H Pond.

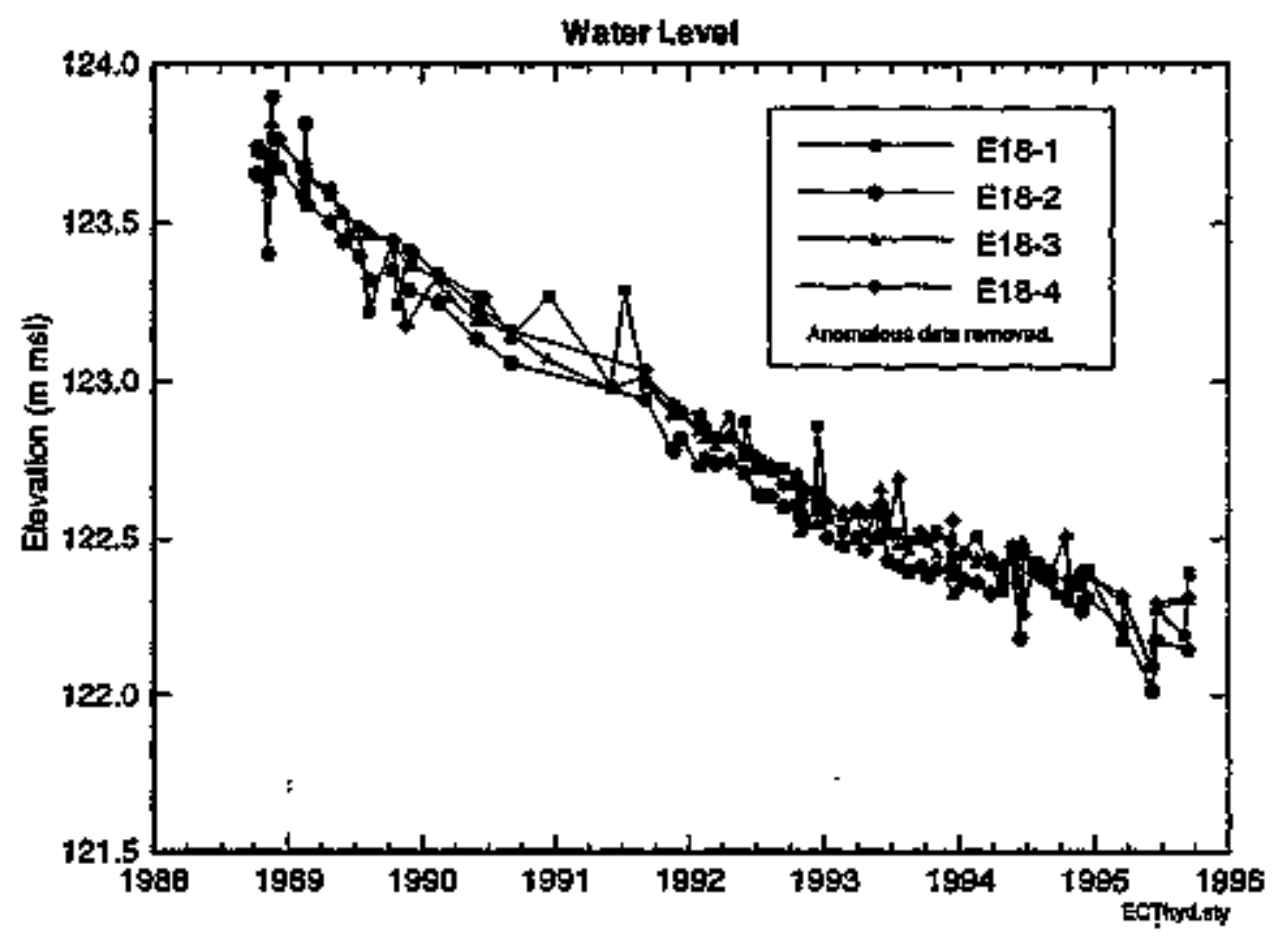


Table 4.9-1. Monitoring Hell Network for the 2101-M Pond.

\begin{tabular}{|c|c|c|c|c|c|}
\hline $\mathrm{Hell}$ & Aquifer & $\begin{array}{l}\text { Samoling } \\
\text { frequency }\end{array}$ & $\begin{array}{l}\text { Water } \\
\text { levels }\end{array}$ & $\begin{array}{c}\text { We1] } \\
\text { standards }\end{array}$ & $\begin{array}{c}\text { other } \\
\text { networks }\end{array}$ \\
\hline $299-E 18-1^{89}$ & Top of unconfined & $\bar{Q}$ & $\overline{\mathbf{Q}}$ & $\mathrm{RCRA}$ & A Pond \\
\hline $299-E 18-2^{88}$ & Top of unconftned & $\mathbf{S}$ & $\bar{Q}$ & RCRA & $m$ \\
\hline $299-E 18-3^{83}$ & Top of unconfined & $\vec{s}$ & $\bar{Q}$ & RCRA & 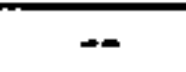 \\
\hline $299-E 18-4^{88}$ & Top of tuconfined & $\bar{s}$ & $\bar{Q}$ & RCRA & - \\
\hline
\end{tabular}

Notes: Shading denotes upgradjent well. Superscript following well number denotes the year of installation.

$M=$ monthty sampling frequency.

RCRA = well is constructed to RCRA-specified standards.

$S$ - semi annual sampling frequency.

Q - quarterly sampling frequency. We11 299-E18-1 is sampled on a quarterly basis because it is al so designated as an upgradient well for the 216-8-3 Pond systen. 
OOE/RL-96-01, REV. 0

Table 4.9-2. Constituents Analyzed at the 2101-M Pond.

\begin{tabular}{|c|c|c|}
\hline \multicolumn{3}{|c|}{ Contamination Indicator parameters } \\
\hline $\begin{array}{l}\text { pH } \\
\text { Specific conductance }\end{array}$ & $\begin{array}{l}\text { Total organ } \\
\text { Total organ }\end{array}$ & \\
\hline \multicolumn{3}{|c|}{ Groundwater quality parameters } \\
\hline $\begin{array}{l}\text { Chloride } \\
\text { Iron }\end{array}$ & $\begin{array}{l}\text { Manganese } \\
\text { Phenols }\end{array}$ & $\begin{array}{l}\text { Sodium } \\
\text { Sulfate }\end{array}$ \\
\hline \multicolumn{3}{|c|}{ Drinking water parameters } \\
\hline $\begin{array}{l}\text { Arsenic } \\
\text { Bartum } \\
\text { Cadmium } \\
\text { Chromf u作 }\end{array}$ & $\begin{array}{l}\text { Fluoride } \\
\text { Gross a]pha } \\
\text { Gross beta }\end{array}$ & $\begin{array}{l}\text { Nitrate } \\
\text { Seleniumb } \\
\text { Silver }\end{array}$ \\
\hline \multicolumn{3}{|c|}{ Site-specific parameters } \\
\hline Turbidity & Alkalintty & \\
\hline
\end{tabular}

Analyzed once a year.

Arsenic and seleniur were dropped from the 2101-M Pond constituent 14st in mid-Fy 1995 and col1form and uranfum were not analyzed for after FY 1994 because they were not present at significant concentration levels in samples previously anajyzed.

"Measured in field.

Note: No additional groundwater sampling is planned at 2101-H Pond since clean closure certification has been approved. 
Table 4.9-3. Critical Means Table for 16 Compartsons--Background Contamination Indicator Parameter Data for the 2101-4 Pond. ${ }^{45}$

\begin{tabular}{|c|c|c|c|c|c|c|c|}
\hline $\begin{array}{c}\text { Consti tuent } \\
\text { (unjt; }\end{array}$ & n & df & $t_{e}$ & $\begin{array}{c}\text { Average } \\
\text { background }\end{array}$ & $\begin{array}{l}\text { Standard } \\
\text { deviation }\end{array}$ & $\underset{\text { mean }}{\text { Critical }}$ & $\begin{array}{l}\text { Upgradient/ } \\
\text { downgradient } \\
\text { comparison } \\
\text { value }\end{array}$ \\
\hline $\begin{array}{l}\text { Specific } \\
\text { conductance } \\
(\mu \mathrm{mho} / \mathrm{cm})\end{array}$ & 4 & 3 & 11.984 & 621.94 & 128.621 & $2,345.2$ & $2,345.2$ \\
\hline Field pH & 4 & 3 & 15.145 & 7.804 & 0.656 & {$[-3.3,18.9]$} & {$[6.18,9.79]^{\circ}$} \\
\hline $\begin{array}{l}\text { Total } \\
\text { organic } \\
\text { carbone } \\
\text { (ppb) }\end{array}$ & 4 & 3 & 11.984 & 387.56 & 156.214 & $2,480.5$ & $2,480.5$ \\
\hline $\begin{array}{l}\text { Total } \\
\text { organic } \\
\text { haiogend } \\
\text { (ppb) }\end{array}$ & 4 & 3 & 11.984 & 3.587 & 0.99 & 16.8 & 16.8 \\
\hline
\end{tabular}

Data collected from August 1988 to June 1989 for upgradient

we11 299-E18-1. Yalues calculated based on 16 comparisons.

The following notations are used in this table:

df $=$ degrees of freedom $(n-1)$.

$n=$ number of background replicate averages.

$t_{c}$ - Bonferront crittcal t-value for appropriate df and 16 comparisons.

"Critica] mean was calculated from values reported below the contractually required detection 1 imits.

Critical mean was calculated using data analyzed by U.S. Testing Inc. of Richland.

*ipgradient/downgradient compartson values for pH were calculated using data from August 1988 to June 1992 (wel1 299-E18-1) because the critical range calculated using four quarters of data is outside the possible range for $\mathrm{pH},[0,14]$.

HC - not calculated. 
DOE/RL-96-01, REY. O

This page intentionaliy left blank.

4.9-14 
BOE/RL-96-01, REV. 0

\section{CONTENTS}

4.10200 AREAS LOH-LEVEL BURIAL GROUMOS ........ 4.10-1

4.10.1 Low-Leve1 Waste Management Area 1 ........ 4.10-1

4.10.2 Low-Level Waste Management Area $2 \ldots . . . .4 .10-4$

4.10.3 Low-Level Waste Managenent Area $3 \ldots . . . . .44 .10-6$

4.10.4 Low-Level Waste Management Area $4 \ldots . . . . .44 .10-3$

4.10.5 Low-Level Waste Management Area 5 ...... 4.10-10

4.10 .6 References ............... 4.10-12 
DOE/RL-96-01, REV. 0

\section{LIST OF FIEURES}

4.10-1 Low-Leve1 Waste Management Area $1 \ldots \ldots$ 4.10-14

4.10-2 Nitrate at Low-Leve], Waste Managenent Area I . . . . . . . 4.10-15

4.10-3 Tritjug at Low-Leve? Waste Hanagement Area I . . . . . . . 4.10-16

4.10-4 Water Table Contour Map for the 200 East Area, June 1995 . . 4.10-17

4.10-5 Low-Leve1 Waste Management Area $2 \ldots . . . . . . . . . .4 .10-18$

4.10-6 Low-Level Waste Management Area $3 \ldots \ldots$. . . . . . . . . 40-19

4.10-7 Carbon Tetrachloride at Low-Level Haste Managenent Area 3 . 4.10-20

4.10-8 Nitrate at Low-Level Waste Management Area 3. . . . . . . . 4.10-21

4.10-9 Water Table Contour Map for the 200 West Area, June 1995 . 4 4.10-22

4.10-10 Low-Level Waste Management Area 4..... 4.10-23

4.10-11 Nitrate and Carbon Tetrachloride at 299-W18-21 . . . . . 4.10-24

4.10-12 Low-Level Waste Management Area $5 \ldots . . . . . . .40-25$

4.10-13 Carbon Tetrachloride at Low-Level Waste Management Area 5 . 4.10-26

4.10-14 Nitrate at Low-Level Waste Managenent Area 5 . . . . . . . . 4.10-27

4.10-15 Tritium at Low-Level Haste Management Area $5 . . . . . .4 .10-28$

\section{LIST OF TABLES}

4:10-1 Low-Level Waste Managenent Area 1 Monitoring Hetwork . . . 4.10-29

4.10-2 Constjtuents Analyzed at the Low-Level Burial Ground . . . . 4.10-30

4.10-3 Critical Means Tabie for 68 Comparison--Background

Contamination Indicator Parameter Data for Low-leve1

Waste Management Area 1 ................ 4.10-31

4.10-4 Low-Leve] Waste Management Area 2 Monjtoring Network . . . 4.10-32

4.10-5 Critical Means Table for 52 Comparisons--Background

Contanination Indicator Parameter Data for Low-Level

Waste Managenent Area 2 .............. 4.10-33

4.10-6 Low-level Waste Management Area 3 Monitoring Network. . . 4.10-34

4.10-7 Critical Means Table for 32 Comparisons--Background

Contarination Indicator Parameter Data for

Low-Leve 1 Waste Management Area $3 \ldots . . . . . . .4$. . 10-35

4.10-8 Critica] Heans Table for 40 Comparisons--Background

Contamination Indicator Parameter Data for

Low-Level Waste Management Area $3 \ldots . . \ldots . . . .10-36$

4.10-9 Low-Level Haste Management Area 4 Monitoring Hetwork . . . . 4.10-37

4.10-10 Critical Means Table for 56 Comparisons--Background

Contanination Indicator Parameter Data for Low-Level Waste

Nanagement Area $4 \ldots \ldots$ 4.10-38

4.10-II Low-Level Haste Hanagement Area 5 Honitoring Hetwork . . . 4.10-39

4.10-12 Critical Means Table for 44 Comparisons--Background

Contamination Indicator Parameter Data for Low-Leve1

Waste Management Area $5 \ldots . . . . . . . . . .4 .10-40$ 
D0E/RL-96-01, REV. O

\title{
4.10200 AREAS LON-LEYEL BURIAL GROUNDS
}

\author{
R. B. Hercer \\ Westinghouse Hanford Company
}

The 200 Areas Low-Level Burial Grounds (LLBG) consfst of five Low-Level Waste Management Areas (LLS Conservation and Recovery Act of 1976 (RCRA) groundwater monitoring program for the LLBG began in 1988 (WHC 1989b) and is continuling under interim status. A RCRA Part B pernit application has been submitted to the Washington State Department of Ecology for these facilities (DOE-RL 1989).

A diverse range of both radioactive nixed and dangerous waste has been placed in the LLBG from Hanford Site and offsite sources. The waste includes, but is not limited to, miscellaneous dry waste, failed equipment, vehicles, contaminated soil, submarine reactor cores and reactor compartments, and cleanup waste. An inventory of the waste can be found in the Low-Level Burial Ground's Database (WHC 1989a). Waste has been placed in the LLBG since 1960. and is contained in unlined trenches and pits, which range from 3.7 to $18.3 \mathrm{~m}$ (12 to $60 \mathrm{ft}$ ) deep. The LLMMAs al so contain some concrete cafssons and retrievable storage units (RSU) that receive drummed waste. The RSUs consist of plywood- or asphalt-bottomed trenches or asphalt pads. Both trenches and pads are covered with plywood and, in some cases, an additional layer of heavy plastic and $1.2 \mathrm{~m}$ (4 ft) of soil. Each LLMAA wilt be discussed separately in this section.

The avaitable chemical and water level data collected at the LLBG in this reporting period are published in the 1995 quarterly reports (Mercer 1995a, $1995 b, 1995 c$, and 1996).

The most recent interpretation of the geology and hydrology of the LLBGs is discussed in Lindsey et aT. (1994). The 200 Areas are situated on the generally southward-dipping north 1 imb of the Cold Creek syncline. The Elephant Mountain Member of the Saddle Mountains Basalt ts the uppermost basalt beneath the LLBGs. The suprabasalt sediments in the 200 East Area (L.LMA-1 and LLMMA-2) are made up of the sands and gravels of the Hanford formation. The 200 West Area burial grounds are underlatn by the Ringoid Formation and Hanford formation. The uppermost aquifer beneath the 200 West Area is entirely within the Ringold Formation. There are indications that the aquifer is locally semiconfined beneath the northern portions of LIWMA-3 and LLMA4A-5.

\subsubsection{Low-Level Waste Management Area 1}

4.10.1.1 LLWMA-1 Facility overview. This LLWHA is located in the northwest corner of the 200 East Area (see Figure 1-1, Chapter 1.0). As recomended in the assessment report (Mercer 1994a), critical means for contamination indicator parameters (CIPs) were reestablished in 1994. This waste management area is currently following interim-status detection-level monitoring regulations. It includes all of the 218-E-10 Burial Ground (Figure 4.10-1) . This LLIMA is divided by an east-west access road. The southern portion of 
the burial ground is currently active, while the portion north of the road is reserved for future expansion. The active area measures 22.9 ha (56.7 acres) and the expansion area measures 15.3 ha (37.7 acres), for a total area of 38.2 ha (94.4 acres).

Oisposal activities at this LLMA began in 1960 and continue to the present. Haterials placed in this facility are prfmarity dragoff waste, failed equipment, and wixed industrial waste from the Plutonium-Uranium Extraction Plant, B Plant, and $N$ Reactor. LLWWA-1 is located within the 200-BP-10 source operabie unit and the 200-BP-5 groundwater operable unit.

4.10.1.2 LLWHA-1 Sumary of 1995 RCRA Activities. This LLWMA continued in CIP detection monttoring in 1995. Groundwater sampling was on a semiannual schedule and water levels were measured quarterly in 1995.

4.10.1.3 LLWhA-1 Sagpling and Analysis Program. The existing RCRA groundwater monitoring network consists of 16 wel1s (see Figure $4,10-1$ ). TabTe 4.10-1 1ists the wel1s in the LLWFA-1 monftoring network. The sampling and analysis program at LLWMA-1 was initiated in 1988. A 7 ist of anajytical constituents for LLWMA-1 is presented in Table 4.10-2.

\subsubsection{LLWMA-1 Groundwater Cheaistry.}

4.10.1.4.1 Constituents of Concern. Critfcal means for the CIPs established for LLWMA-1 were not exceeded at any LLWM-I groundwater monitoring we11 in this reporting year.

Chertica] analyses indicated that unfiltered iron and chromiun were above regulatory standards in 1995 in several wells at LLiniA-1. In the majority of cases, elevated levels are found only in the unfiltered samples and are not reflected in the correspondfing filtered samples. These constituents are not indicative of waste disposed of at the burial grounds and the eitevated levels are assumed to be related to well construction or some other common factor. The elevated values for unfiltered metals have been roughly correlated to high turbidity. As a result of the lack of a related source and continued spatially random and widely fluctuating values, analysis of unfiltered metals was discontinued in calendar year (CY) 1995 .

Although no evidence indicates any contribution from LLWA-1, contaninant plumes are affecting the groundwater quatity beneath LLWIAA-I (Johnson 1993, WHC 1992a). Nitrate and trftium plumes are evident and appear to be the major contaminants in the area of LLHWA-I (Figures $4.10-2$ and 4.10-3). Tritium values indicate the presence of a pTume beneath LLWhA-1 with a source to the southeast. The data suggest that the maximutin concentrations have al ready passed beneath LLinHA-1 and the vaitues continue to decline.

Values for gross alpha from we13 299-E32-5 exceeded the DWs in the 1 ast quarter of 1994. This resutt ( $15.6 \mathrm{pC} / \mathrm{L}$ ), while above the established standard (15 pCi/L), did not exceed the historical maximufin for upgradient well 299-E28-26 (24 pCi/L, Decenber 27, 1988). Values for gross alpha are generally declining in wells south of the east-west road that crosses LLiniA-1 (Figure 4.10-1) and generally increasing in the monitoring wells north of the road. These trends are expected to continue as the plune passes beneath the 
burial ground. This plume appears to originate at the 216-8-62 Crib (Johnson 1993).

We11s 299-E33-34 and 299-E33-35 continue to have elevated love's of gross beta contamination and the trends appear to be slightly dowmard.

An upgradtent source is apparent in the gross beta plume for the 200 East Area in Johnson (1993).

4.10.1.4.2 Statistical Evaluation. Statistical evaluations of data for the past year at the LLMA-I consisted of comparing upgradient and downgradient wells for any indication of contamination in the groundrater underlying the facjlity. Background data and background sumary statfstics are presented in Hercer (1994a). Statjstical analyses required by 40 Code of Federa) Regujations (CFR) 265.93(b) and Washington Adsinistrative Code (WAC) 173-303-400 were performed on the samples collected from upgradient wells. Results are presented in table 4.10-3. This table 1ists the background average, background standard deviation, critical mean (or critica] range, in the case of $\mathrm{pH}$ ) and upgradient/downgradient comparison value for the four CIPs. The comparison value (or range) is the value to which current and future averages of quadruplicate measurenents are compared. Statistical methods are described in Appendix $C$.

If the average concentration for a paraneter from a downgradient wel] exceeds the upgradient/downgradient conparison value listed in Table $4.10-3$, that parameter is considered statistically different from background. If this is confirmed by subsequent verification sampling and analysis, the regulatory program is triggered into assessment. There were no exceedances in 1995.

\subsubsection{LLWMA-1 Groundwater FTow.}

4.10.1.5.1 Groundwater Flow Direction. The groundwater flow direction in the area of LLWWA 1 is difficult to determine using only water level data from the monitoring wel]s around the burial ground. The groundwater gradient in this area is extremely low and several uncertainties contribute to the difficulties in producing a water table map. These uncertainties include barometric effects, inaccuracies in the borehole surveys, silight deviations from the vertical in the boreholes, and errors as\$ocjated with the water level measurements themselves. To demonstrate the groundwater flow directions under LLWMA-1, a general map of the entire 200 East Area is presented in

Figure 4.10-4. This map represents the best est imate of the water table elevation beneath LLWMA-1 in June 1995 and was generated using data frota wells in the 200 East Area and surroundings.

An interpretation of the groundwater flow direction from the groundwater map is inconclusive. A better estimate of the groundwater flow direction can be inferred from various contaminant plume maps presented in MHC (1992a) and Johnson (1993). The contanination distribution suggests that the general direction of fiow is to the northwest beneath LLink-1.

4.10.1.5.2 Rate of Flow. Using the Darcy equation (Equation 1) and some conservative values for hydrologic properties, an estimate of the groundwater flow velocity was determined. The hydraulic conductivity of the aquifer beneath LLMMA-1 has been estimated to be between 73 and $762 \mathrm{~m} / \mathrm{d}$ ( 240 and $2,500 \mathrm{ft} / \mathrm{d}$ ) (Last et a1. 1989, page 6.8) and the effective porosity is assumed 
to be on the order of 0.1. Using water levels from June 1995, an approximation of the hydraulic gradient can be estfmated to be 0.00008 . calculations using these values result in estimates of groundwater velocity between 0.06 and $0.60 \mathrm{~m} / \mathrm{d}(0.2$ and $2.0 \mathrm{ft} / \mathrm{d})$. These values are $h$ tghty subjective; however, they represent the best est tmate of the actual condftions beneath LLWHA-I.

$$
v=\frac{k 1}{n_{e}}
$$

where:

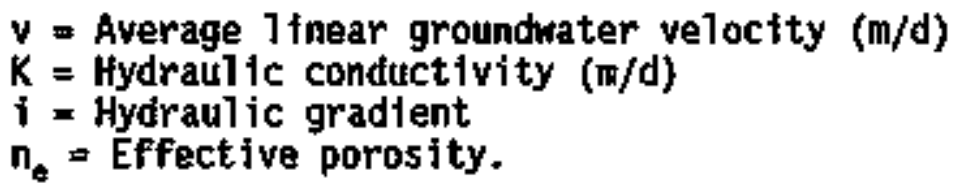

4.10.1.5.3 Evalustion of Monitoring Network. The groundwater monitoring network continues to meet requirements. There are no plans for additional groundwater monitoring wells at this time.

\subsubsection{Low-Leve1 Naste Management Area 2}

4.10.2.1 LLWhA-2 Facility overview. Currently in indicator parameter evaluation status, LLWMA-2 is Tocated in the northeast corner of the 200 East Area and includes all of burial ground 218-E-12B (Figures $1-1$ and 4.10-5). This burial ground has a total area of 70.1 ha (173.1 acres) and has been in use since 1968. The majority of the waste deposited in this area is located in the eastern half of the burial ground. This waste consists primarify of miscellaneous dry waste and submarine reactor compartments. Parts of two trenches contafn transuranic waste. LLWMA-2 is located in the 200-BP-11 source operable unit and the 200-BP-5 groundwater operable unit.

4.10.2.2 LLWMA-2 Summary of 1995 Activities. The indicator parameter evaluation monitoring program for LLWHA-2 continued in 1995. Grotsdwater samples were collected semiannually and water levels were neasured quarterly.

4.10.2.3 LLWWA-2 Sampling and Analys1s Program. The current monitoring network conststs of 16 wellis. Monjtoring we11s for LLinA-2 are listed in Table 4.10-4 and are shown in Figure 4.10-5. The sampling and analysis program for LLWMA-2 was initiated in 1988 (WHC 1989b), with quarterly sampling untif the last quarter of 1989. At that time the required background values were calculated. Sampling was placed on a semiannual schedule. The constituent 1ist for LLMMA-2 is the same as Table 4.10-2 with the addition of polychlorinated biphenyls (PCBs). No analyses of CIPs from downgradient wells exceeded the critical means. 


\subsubsection{LLWMA-2 Groundwater Chamistry Evaluatjon.}

4.10.2.4.1 Constituents of Concern. As at LLWMA-1, analyses indicated that unfittered iron and chromium were above regulatory standards in 1995 in several wells at LLWMA-2. This has been an ongoing concern at several RCRA sites (see section 4.10.1.4.1) and since these constituents are not indicative of wastes disposed in the LLBG analysis of unfiltered metals was discontinued in CY 1995. Values of Iodine-129 were slightly above the DWS in severa] of the wells a] ong the southern boundary of LLWMA-2. These are related tr the widespread ${ }^{129} I$ piume beneath the 200 East Area. There is no evidence of contamination from LLiMAM-2.

4.10.2.4.2 Statisticat Evaluation. Statistical evaluations at the LLWMA-2 compared CIP data from upgradient and downgradient wells for indications of contamination in the uppermost aquifer beneath the site. Values of specific conductance, ph, total organic halogen (TOX), and total organic carbon (TOC) in the downgradient wells in the past year were below the upgradient/downgradient comparison values. Statistical methods are described in Appendix $\mathrm{C}$.

Statistical analyses required by 40 CFR 265.93 (b) and WAC 173-303-400 were performed on the samples collected from tupgradient wells. Results are presented in Table 4.10-5. This table lists the background average, standard deviation, critical mean (or critical range, in the case of $\mathrm{pH}$ ), and upgradient/downgradient comparison values for the CIPs. The comparison value is the value to which current and future averages of fndicator parameters are compared. The comparison value is generally the critical mean or critical range. Statistical methods are described in Appendix C. Statistical analysis of indicator parameters indicated that the estabi ished critical means were not exceeded in any well in 1995.

\subsubsection{LlwA-2 Groundwater Flow.}

4.10.2.5.1 Groundwater Flow Direction. Water level data from LLMiNA-2 monitoring wells do not present a clear picture of groundwater fiow. To obtain a better overall jdea of the groundwater flow pattern, a water table map of the 200 East Area and surroundings for June 1995 was generated (see Figure 4.10-4). The grotndwater flow direction in this area is primarily from east to west. Groundwater flow is affected by the basalt high located north and east of LLWMA-2 and the presence of a groundwater mound associated with 8 Pond.

4.10.2.5.2 Rate of Flow. The groundwater gradient beneath LLillA-2 is very slight, f.e., on the order of 0.00001 . Using this gradient, an effective porosity of 0.1 , and hydraulic conductivity values in the range of 427 to $2,042 \mathrm{~m} / \mathrm{d}(1,400$ to $6,700 \mathrm{ft} / \mathrm{d})$ (Last et a1. 1989) and applying Equation 1 , groundwater velocities were estimated to be between 0.4 and $2.0 \mathrm{~m} / \mathrm{d}(1.4$ and $6.7 \mathrm{ft} / \mathrm{d}$ ).

4.10.2.5.3 Evaluation of Monftoring Hell Network. The monitoring network continues to satisfy the requirement for at least one upgradient and three downgradient wells and is adequate to monitor the burial ground. No addittonal manjtoring wells are planned for the LLWA-2 mon1toring network. 
The declining water level in this area is forcing a reevaluation of the groundwater monitoring network. Monitoring wel1s 299-E34-4, 299-E34-6, and 299-E35-1 rentain dry.

\subsubsection{Low-Lovel Waste Managesent Area 3}

4.10.3.1 LLWA-3 Facility Overview. LLWMA-3 continued in detection-level groundwater monitoring in this reporting year. Background 13]ues were reestablished for the CIPs following the March 1995 sampling event. This was necessary because of the recent installation of three additional upgradient monitoring we11s. Burial grounds 218-W-3A, 218-W-3AE, and 218-W-5 make up LLinds-3, which is located in the north-central portion of the 200 West Area (Figures 1-1 and 4.10-6). These facilities cover 74.3 ha (183.7 acres). Burial ground 218-1A-3A began accepting waste in 1970 and has received primarily ion-exchange resins and failed equipment (e.g., tanks, pups, ovens, agitators, heaters, hoods, jumpers, vehicles, and accessories). This burja7 ground also contains remote-handled transuranic waste in RSUs. Burjal ground 218-W-3AE was put in operation in 1981 and contains low-level and wixed waste. This tncludes rags, paper, rubber gloves, broken tools, and industrial waste. Burial ground 218-W-5 first received waste in 1986 . This buriat ground contatns low-level and low-level mixed waste, including lead bricks and shielding. LLinA-3 is in the 200-ZP-3 source operable unit and the 200-2p-1 groundwater operabTe unit.

4.10.3.2 LLAMA-3 SLmmary of 1995 Activities. Groundwater at LLWMA-3 samples were collected semiannualiy. Additional samples (CIPs only) were taken quarterly through the first quarter of 1995 at the five shallow upgradient monitoring wells to restablish background conditions. Water Tevels were measured quarterty.

4.10.3.3 LLima-3 Sampling and Analysis Program. Six upgradient and 14 downgradient groundwater wells monitor LLWMA-3. One upgradient and one downgradient well monitor the botton of the uppermost aquifer. A complete list of groundwater inonitoring wells for LLWMA-3 is presented in Table 4.10-6; the wells are shown in Figure 4.10-6. Groundwater sampling at LLMMA-3 began in 1988. A constituent Tist is presented in Table 4.10-2. Samples collected in the 1ast quarter of 1989 indicated that TOX vaTues jn downgradient well 299-47-4 exceeded the crjtical mean (95.5 ppb) calculated for LLhMA-3. An interim-status groundwater quality assessment plan (Chamness et a). 1990b) was prepared in response to the elevated TOX values. A groundwater quality assessment report (Mercer 1994b) determined that the cause of the elevated TOX was the extensively documented $\mathrm{CCl}_{4}$ plune beneath the 200 West Area. As recommended in the assessment report, quarterly sampling was continued at the shallow upgradient wells through the first quarter of 1995 to reestablish background levels for the CIPs.

\subsubsection{LLing-3 Groundwater Chemistry.}

4.10.3.4.1 Constituents of Concern. Carbon tetrachloride and nitrate have been consistent7y above OWSS at LLWMA-3. These constituents are trending apward in the LLWMA-3 wonitoring we11s, especially in upgradient wel1s and the wells near burial ground $216-4-3 A E$ (Figures $4 \cdot 10-7$ and $4 \cdot 10-8$ ). The elevated values can be attributed to contaminant plumes originating to the south of 
LLWMA-3 (see Ffgure 2-10). Additiona] plumes have been documented in

Jahnson (1993) and WHC (1992b). Trichloroethene has exceoded the OWS of 5 ppb in upgradient wells 299-W10-19, 299-\$10-20, and 299-410-21. There does not appear to be any groundwater contamination directly attributable to I,LWMA-3.

\subsection{Statistical Evaluation. Following the recomendations} presented in the groundwater quality assessment report (Nercer 1994b), the tupgradient/downgradient comparison values for the CIPs were reestabi ished for LinMA-3. On review of the data, it was decided to calculate two sets of critical means for LLWKA-3 (Tables 4.10-7 and 4.10-8). One set was calculated using 299-w9-1 and 299-w10-13 as the upgradient wells (Table 4.10-7). These critical means are used for comparison with the downgradjent wells north of burlal grounds $218-W-3 A$ and $218-W-5$. The second set of critica] means were calculated using 299-W10-19, 299-W10-20, and 299-W10-21 as the upgradient wel1s (Table 4.10-8). These values are used for comparing downgradient wells north and east of burial ground $218-W-3 A E$. This was done because of the obvious difference in ToX values between wells affected by the $\mathrm{CCl}_{4}$ plame and those so far unaffected by this plume (see Figure 4,10-7). There were no exceedances of CIPs in this reporting perjod. Statistical methods are discussed in Appendix $C$.

\subsubsection{LLWH-3 Groundwater Flow.}

4.10.3.5.1 Groundwator Flow Birection. A water table map of the entire 200 West Area (Figure 4.10-9) has been constructed in an attempt to present an overall concept of the groundwater flow pattern beneath LLWMA-3. This map used water leve] data from June 1995 . Figure $4.10-9$ generally confirms the flow directions presented previous $7 y$ in the groundwater monitoring plan (Last et al. 1989, page 6.20). The flow direction generally is northward with a slight eastward component, which increases to the east. The eastward copponent is increasing as expected, resulting from the decreased disposal of liquid in this area.

Water level data from the two groundwater wells that monitor the base of the unconfined aquifer indicate that the vertical groundwater gradient in the unconfined aquifer in this area is dowmard. The water levels in downgradjent shallor well 299-W7-2 are consistently greater than those in nearby deep well $299-17-3$ by approxintely $0.3 \mathrm{~m}$ (1 ft). Water levels in the upgradient shallow we7t 299-W10-13 are general1y $0.12 \mathrm{~m}(0.4 \mathrm{ft})$ greater than in deep wel1 299-\$10-14.

4.10.3.5.2 Rate of Groundwater Flow. The rate of groundwater flow beneath LLWHA-3 can be estimated using the Darcy equation (Equation 1). Values of hydraulic conduct1vity $(0.02$ to $9.8 \mathrm{~m} / \mathrm{d}[0.06$ to $32 \mathrm{ft} / \mathrm{d}])$ from Last et a7. (1989, page 6.18), a conservat tve effective porosity of 0.1 , and a hydraulic gradient of 0.00127 result in a groundwater velocity from 0.0002 to $0.12 \mathrm{~m} / \mathrm{d}(0.0008$ to $0.41 \mathrm{ft} / \mathrm{d})$. An average hydraulic conductivity value of $1.5 \mathrm{~m} / \mathrm{d}(\mathrm{s} \mathrm{ft} / \mathrm{d}$ ) gives a groundwater velocity of $0.02 \mathrm{~m} / \mathrm{d}(0.06 \mathrm{ft} / \mathrm{d}$ ).

4.10.3.5.3 Evaluation of Honitoring Nell Hetwork. The monitoring well network for LIWHA-3 is complete and adequateTy monitors the burial ground. Ho additional wells are planned at this time. 
DOE/RL-96-01, REV. O

\subsubsection{Low-Leve] Waste Management Area 4}

4.10.4.1 LLWMA-4 Fact] ity Overview. Waste Manageanent Area 4 covers 24.4 ha (60.3 acres) in the south-central portion of the 200 West Area (see Figure (-1) and is currentiy in detection-level indicator paraneter evaluation status. Burial grounds $218-\mathrm{W}-4 \mathrm{~B}$ and $218-\mathrm{W}-4 \mathrm{C}$ wake up LLMMA-4

(Figure 4,10-10). Burial ground 218- $k-4 B$ first recelved waste in 1968 and contains mixed and retríevable transuranic waste in trenches and 12 caissons. One caisson is believed to contain mixed waste. Waste was first deposited in burial ground 218-W-4C in 1978. Transuranic, nixed, and low-level waste has been placed in burial ground 218-W-4C. The waste includes contaminated soil, decommissioned equipment, and renote-handled transuranic waste. Several trenches in LLWMA-4 have been designed as RSUs. LLWMA-4 is within the 200-2P-3 source operable unit and the 200-2P-1 and 200-UP-1 groundwater operable units.

The monitoring network at LLWMA-4 has 17 wells: 6 tapgradient and 11 downgradient. Tabie 4.10-7 1ists a11 RCRA monttoring we11s for LLWHA-4 and figure 4.10-10 shows the we17 locations.

4.10.4.2 LLWMA-4 Sumaary of 1995 Activities. Indicator parameter evaluation monitoring continued at LLWMA-4 in 1995. Groundwater chemistry samples were collected semiannally and water levels were measured quarterly.

$\mathrm{A} \mathrm{CCl}_{4}$ pump-and-treat demonstration project uses several wells near LLWMA-4. Groundwater is being extracted from weII 299-W18-1 and injected into well 299-W18-4 after treatment. Groundwater levels are being monitored with transducers in the extraction and injection wells and in wells 299-W18-2, 299-W18-5, and 299-W18-24. Mell 299-w18-24 is an upgradient monitoring well for LLMMA-4. This project is part of the overall Hanford Site environienta] remediation program. A full-scale pump-and-treat program to contain the 1000-ppb $\mathrm{CCl}_{4}$ isopleth is being installed with extraction wells located to the east and injection wells to the west of LLMMA-4. Considerabie changes in the local hydrologic flow and hydrochemical regines are expected when this program begins operation in March of 1996.

4.10.4.3 LLWMA-4 Sampling and Analysis Progran. Groundwater sampling at LLWMA-4 began in 1988 (WHC 1989b) and continued quarterly until the last quarter of 1989. The requfred statistical comparisons were performed and downgradient wells did not exceed the critical means estabi ished for the indicator parameters in 1995. Indicator evaluation sampling is conducted semiannualy for constituents listed in Table 4.10-2.

\subsubsection{LWWA-4 Groundwater Chemistry.}

4.10.4.4.I Canstituents of Concern. LLWHA-4 does not appear to have contributed to groundwater contamination. The samples fron the downgradient welis have not exceeded the critical means established for the contamination indjcator parameters. Concentrations of $\mathrm{CCl}_{4}$ above DWSs were found in most wells in 1995; the elevated values are related to the plumes discussed in Johnson (1993) and $\mathrm{HHC}$ (1992b). The most 1ikely source for the $\mathrm{CC}_{4}$ is the 216-Z-18 Crib and other facilities associated with Z Plant located east of LLWMA-4 (see Figure 2-10). 
The ToX levels in the groundwater historically have been high beneath LLWWA-4. The high levels are related to the $\mathrm{CCl}_{4}$ plume. The upgradient wells are generally higher than the downgradient wells. The pH values were below the DiNS.

Nitrate also exceeded the DWSs in wells 299-W15-15, 299-W15-16, 299-W15-18, 299-W15-19, 299-W15-24, 299-W18-21, and 299-W18-24 this year. Thts is most likely related to the nitrate plume described in Johnson (1993) and WHC (1992b) (see Figure 2-9). Well 299-W18-21 has shown a continuing increase in nitrate and the values are consfderably above the adjacent wells. This discrepancy is also evident in the $\mathrm{CC}_{4}$ results (see Figure $4.10-11$ ). This leads to the supposition that there may be a highly localtzed preferential pathway to the southwest in this vicinity.

4.10.4.4.2 5tatistical Evaluatlon. Statistical evaluations at the LLWHA-4 compared upgradtent and downgradient wetls for indication of contamination in the uppermost aquifer beneath the site. All values of specific conductance, $\mathrm{pH}, \mathrm{TOX}$, and $\mathrm{TOC}$ in the downgradient wells were below the upgradient/downgradient comparison values. Statistical methods are described in Appendix $C$.

Statistical analyses required by 40 CFR 265.93 (b) and WAC 173-303-400 were performed on the samples collected from upgradjent wells. Results are presented in Table 4.10-8. This table lists the background average, standard deviation, critical mean (or critical range, in the case of ph), and upgradient/downgradient comparison values for the CIPs. In genera], the upgradient/downgradient comparison value is the value to which current and future averages of indicator parameters are compared. The comparison value is generaliy the critfeal mean or critical range. There were no exceedances in downgradient wells tn 1995. Upgradient well 299-W15-16 was below the critical range for pH during the November 18, 1994, sampling event. Laboratory pH confirmed that the exceedance was caused by an error in the field measurements.

\subsubsection{LLMMA-4 Eroundwater Flow.}

4.10.4.5.1 Groundwater Flow Birection. The water table map for the 200 West Area, presented in Fjgure 4.10-9, indfeates that the origina] interpretation of groundwater flow direction beneath. LLWMA-4 (Last et a1. 1989, page 6.20) is still valid. The flow direction is primarily to the west, trending to northwest in the northern portions of LLMAA-4, and possibiy slightly to the southwest in the extreme southern portions of LLWMA-4 (see Figure 4.10-9). Flow directions are expected to change radically when the $\mathrm{CCl}_{4}$ pump-and-treat program becomes operationa].

The vertical groundwater gradient in the unconfined aquifer in this area is downward based on water levels from the wells that monitor the base of the unconfined aquifer (wells 299-W15-17 and 299-W18-22). The water leve7s in these wells are consistently lower than the nearby wells monitoring the top of the unconftined aquifer. The differences are approximately $0.07 \mathrm{~m}(0.24 \mathrm{ft})$ between we $11 \mathrm{~s} 299-\mathrm{HIS}-16$ and $299-W 15-17$ and $0.13 \mathrm{~m}(0.43 \mathrm{ft})$ between wells 299-W18-21 and 299-W18-22. 
4.10.4.5.2 Rate of Flow. The groundwater flow velocity calculated for LLliwA-4 is in the range of 0.002 to $0.21 \mathrm{~m} / \mathrm{d}(0.006$ to $0.69 \mathrm{ft} / \mathrm{d})$. These values were determined using an approximate hydraulic gradient of 0.00034 , effective porosity of 0.1 , and values of hydraulic conductivity from 0.52 to $61 \mathrm{~m} / \mathrm{d}(1.7$ to $200 \mathrm{ft} / \mathrm{d}$ ) (Last et al. 1999, pages 6.18 and 6.19). The lower velocity value uses a hydraulic conductivity from well 299-N18-22, which monitors the bottom of the uppermost aquifer. Using the average sydraulic conductivity for shallow we $11 \mathrm{~s}(23.8 \mathrm{~m} / \mathrm{d}[78 \mathrm{ft} / \mathrm{d}])$ gives a groundwater velocity of $0.08 \mathrm{~m} / \mathrm{d}(0.27 \mathrm{ft} / \mathrm{d})$.

4.10.4.5.3 Evaluation of Nonitoring Nell Motwork. The groundwater monitoring network at LLIAHA-4 continues to satisfy the requirement for at least one upgradient and three downgradient wells. No additional monitoring wells are planned for this network. Considerable changes in the groundwater flow direction caused by the pump-and-treat activities will necessitate the review of the upgradient/downgradient status of wany wells in this monitorting network.

\subsubsection{Low-Level Waste Hanagement Area 5}

4.10.5.1 LLMA-5 Facility Overview. This waste management area contains future burial ground $218-4-6$ and is located in the north-central portion of the 200 West Area (Figures 1-1 and 4.10-12). LLWMA-5 has not yet recetved any waste. This facility will consist of 35 trenches and cover approximately 18.0 ha (44.5 acres). At this time the trenches are planned to be used for mixed waste. LLWHA-5 is within the 200-ZP-3 source operable unit and the 200-ZP-1 groundwater operable unit.

4.10.5.2 LLWA-5 Sumary of 1995 Actjvities. The indicator parameter evaluation monitoring program for LLHAA-5 continued in 1995. Groundwater samples were collected seniannually and water level measurements were made quarterly.

4.10.5.3 LLMAR-5 Sampling and Analysis Program. Groundwater sampling for LLWMA-5 began in 1992. Table 4.10-9 lists wells in the RCRA monjtoring network for LLM⿻川 -5 . Indicator parameter evaluation samples are collected semiannually for constituents 1fsted in Table 4.10-2.

\subsubsection{LLWMA-5 Groundwater Chemistry.}

4.10.5.4.1 Constituents of concern. No wastes have been disposed of at LLWHA-5 and there is no indication that the groundwater has been affected by this facility. The required background levels were calcutated and the critical means for the indicator parameters were not exceeded by any monitoring well in the LLWHA-5 network. Carbon tetrachloride (Figure 4.10-13) and nitrate (Figure 4.10-14) exceeded the DWSs in several wel1s. Both constftuents are assaciated with documented piumes in the 200 West Area (Johnson 1993 and WHC 1992b). Trichloroethylene has been reported above the 5 ppb ous in wells 299-W5-5, 299-W6-10, and 299-W11-31.

Tritium is also present in concentrations above the DWS at monitoring we]1s on the eastern side of LLinA-5 (Fjgure 4.10-15). 
Filtered samples for chromium (299-W6-5) and manganese (299-W6-6) were above the $100 \mathrm{ppb}$ and $50 \mathrm{ppb}$ DWS respectively. There is no obvious source of either of these contaminants.

4.10.5.4.2 5tatistical Evaluation. Statistical evaluations at the LLMAS-5 compared upgradient and domgradient wells for indications of contanination in the uppermost aquifor beneath the site. All values of specific conductance, $\mathrm{pH}$, and TOC in the downgradient wells in the past year were below the upgradtent/downgradient comparisot. values. Statistical methods are described in Appendix $C$.

Statistical analyses required by 40 CFR 265.93(b) and WAC 173-303-400 were performed on the samples collected from upgradient wells (see Table 4,10-9). Results are presented in Table 4.10-10. This table 7 ists the background average, standard deviation, critical mean (or critical range, in the case of $\mathrm{pH}$ ), and upgradient/downgradient comparison values for the contamination indjcator parameters. The upgradient/downgadient comparison value is the value to which current and future averages of indicator parameters are compared. The comparison value is generally the critical mean or critical range. The limit of quantitation, rather than the critical mean, is used as the comparison value for TOC because nost of the upgradient concentrations were below the contractually required quantitation 1 init (see Appendix C). Tox values from upgradient wells are detected above the detection imit. Therefore, four quarters of monitoring data will be needed to establish the upgradient/downgradient comparison value (see Appendix C). There were no confirmed exceedances in downgradient wells in 1995.

\subsubsection{LLITHA-5 Groundwater Flow.}

4.10.5.5.1 Groundwater Flow Direction. The water table map for the 200 West Area presented in Figure 4.10-9 gives the best representation of the conditions beneath $L L W M A-5$. The groundwater flow direction beneath LLWMA-5 is to the northeast.

The vertical groundwater gradient in the unconfined aquifer in this area is downward. Water levels in we11 299-W6-3, which monitors the base of the unconfined aquifer, are generally $0.2 \mathrm{~m}(0.64 \mathrm{ft})$ less than water levels in welt 299-w6-4. The difference in water level measurements from shat low/deep paired wells $299-\$ 5-6$ and $299-\$ 5-7$ is smaller: $0.01 \mathrm{~m}(0.04 \mathrm{ft})$.

4.10.5.5.2 Rate of Flow. The average hydraulic conductivity for shallow wells completed in 1991 and 1992 was $11.9 \mathrm{~m} / \mathrm{d}$ (39 ft/d) (Hercer 1993a, 1993b). Using this estimate, the Darcy equation (Equation 1), an effective porosity of 0.1 , and a hydraulic gradient of 0.0024 , a grounduater flow velocity of $0.29 \mathrm{~m} / \mathrm{d}(0.95 \mathrm{ft} / \mathrm{d})$ was calculated.

4.10.5.5.3 Evaluation of Monitoring Well Metwork. The groundwater monitoring network for LL.WMA-5 compTies with regulatory requirements for upgradient and downgradient wells. No additional groundwater monitoring wells are planned. 
DOE/RL-96-01, REV. 0

\subsubsection{References}

40 CFR 265, "Interin Status Standards for Owners and Operators of Hazardous Waste Treatment, Storage, and Disposal Facilities," Code of Federal Regulations, as amended.

DOE-RL, 1989, Low-Level Burial Grounds Dangerous Waste Pernit Application, DOE/RL 88-20, U.S. Department of Energy, Richland Operations Office, Richt and, Washington.

Johnson, V. G., 1993, Westinghouse Hanford Company Operational Groundiater Status Report, 1990-1992, WHC-EP-0595, Westinghouse Hanford Company, Richland, Washington.

Last, G. Y., B. N. Bjornstad, H. P. Bergeron, D. W. Wallace, D. R. Newcomer, J. A. Schranke, M. A. Channess, C. S. citne, S. P. Airhart, and ฟ. 5. W1ber, 1989, Hydrogeology for the 200 Areas Low-Level Burtat Grounds - An Interios Report, PNL-6820, Pacific Northwest Laboratory, Rich\}and, Washington.

EIndsey, K. A., J. L. S1ate, G. K. Jaeger, K. J. Swett, R. B. Mercer, 1994, Geologic Setting of the Low-Level Burial Grounds, WHC-SD-EN-TI-290, ReV. 0 , Westinghouse Hanford Company, Richl and, Washington.

Hercer, R. 8., 1994a, Resu'ts of Groundwater Qualfty Assessment Program at Low-Level Waste Managenent Area 1 of the Low-Level Burfal Grounds, HWC-SD-EN-EV-025, Rev. 0, Westinghouse Hanford Company, Richland, Washington.

Hercer, R. B., 1994b, Resujts of Groundwater Quality Assessuent Program at Low-Leve? Waste Managenent Area 3 of the Low-Level Burial Grounds, WHC-SO-EN-EV-026, Rev. 0, Westinghouse Hanford Company, Richland, Hashington.

Mercer, R. B., 1995b, "Low-Level Burial Grounds," in Quarterily Report of RCRA Groundwater Monftorfing Data for Period October 1, 1994 through December 31, 1994, DOE/RL-94-36-4, U.S: Department of Energy, Richland Operations Office, Richland, Washington.

Mercer, R. B., 1995c, "Low-Level Burlal Grounds," in Quarterly Report of RCRA Groundwater Monitoring Data for Period January 1, 1995 through Harch 31, 1995, DE/RL-94-69-1, U.S. Department of Energy, Richland Operations office, Richland, Washington.

Hercer, R. B., 1995d, "Low-Level Burjal Grounds," in Quarterly Report of RCRA Groundwater Monftoring Data for Period April 1, 1995 through June 30, 1995, DOE/RL-94-69-2, U.5. Department of Energy, Richland Operations office, Richland, Washtngton.

Mercer, R. B., 1996, "Low-Level Burial Grounds," in Ouarterly Report of RCRA Groundwater Nonitoring Data for Period JuTy I, 1995 through September 30, 1995, DOE/RL-94-69-3, U.S. Department of Energy, Richland Operations Office, Richland, Washington. 
Resource Conservation and Recovery Act of 1976, 42 USC 6901 et seq.

WAC 173-303, "Dangerous Waste Regulations," Washington Administrative Code, as amended.

WHC, 1989a, Low-Lavel Burisl Grounds Database, WHC-MR-0008, Westinghouse Hanford Company, Richland, Washington.

WHC, 1989b, Revised Ground-Water Monttoring Plan for the 200 Areas Low-Level Burial Grounds, WHC-SO-EK-AP-015, Rev. 0, prepared by G. V. Last and B. N. Bjornstad, Pacific Morthwest Laboratory for Westinghouse Hanford Company, Richland, Washington.

WHC, 1992a, Hydrogeologic Model for the 200 East Groundwater Aggregate Area, WHC-SD-EN-TI-019, Rev. 0, prepared by M. P. Connelly, B. H. Ford, J. W. Lindberg, S. J. Trent, and C. D. DeTaney, Westinghouse Hanford Company, Richl and, Nashington, and J. V. Borghese, Pacific Morthwest Laboratory for Westinghouse Hanford Company, Ríchiand, Mashington.

WHC, 1992b, Hydrogeologic Model for the 200 Mest Groundwater Aggregate Area, WHC-50-EM-TI-014, Rev. 0, prepared by M. P. Connelly and B. H. Ford, Westinghouse Hanford Company, Richland, Washington, and J. V. Borghese, Pacific Northwest Laboratory for Westinghouse Hanford Company, Rich1and, Nashington. 
DOE/RL-96-01, REV. 0

Figure 4.10-1. Low-Level Waste Management Area 1.

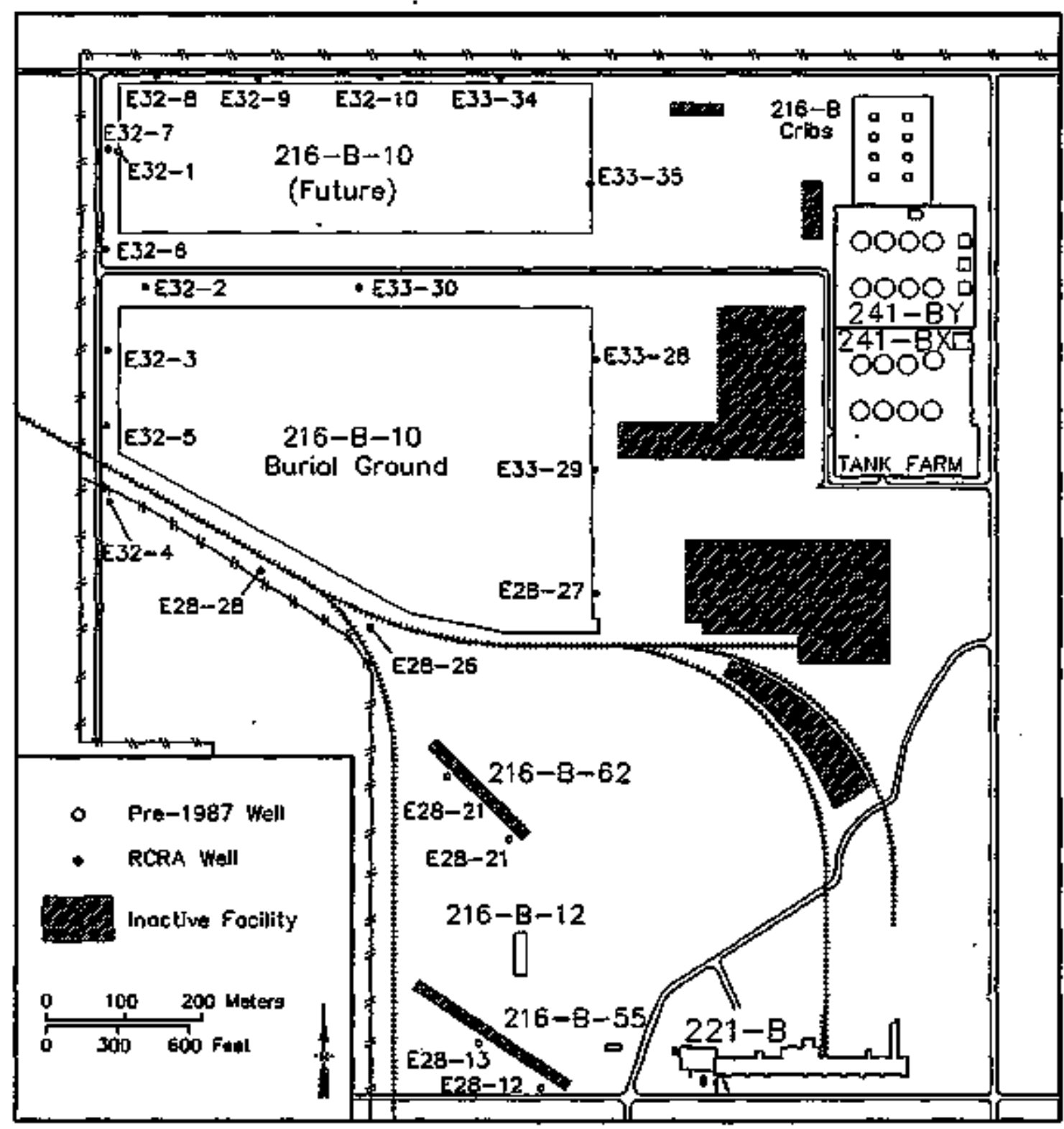

rbm لllwmol dwg 
D0E/RL-96-01, REV. 0

Figure 4.10-2. Nitrate at Low-Level Waste Management Area 1.
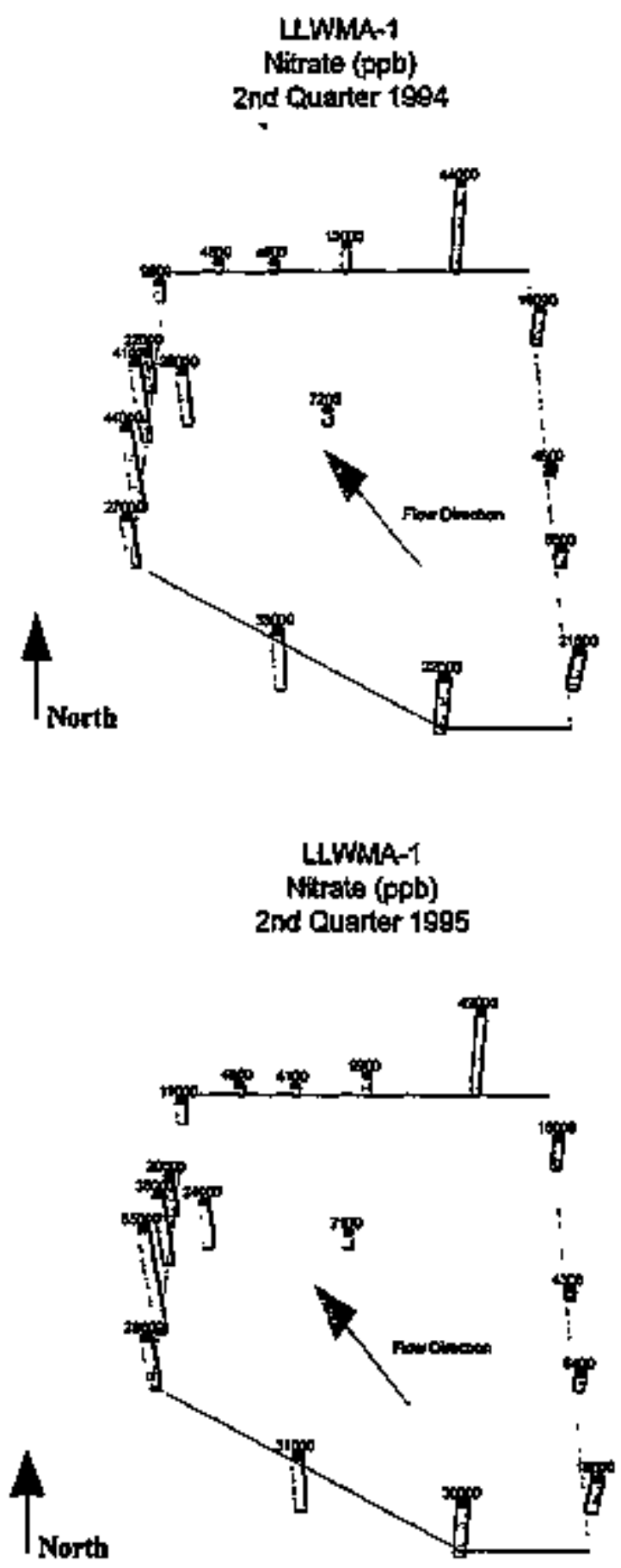

$4.10-15$ 
DOE/RL-96-01, REV. 0

Figure 4.10-3. Tritium at Low-Level Waste Managenent Area 1.
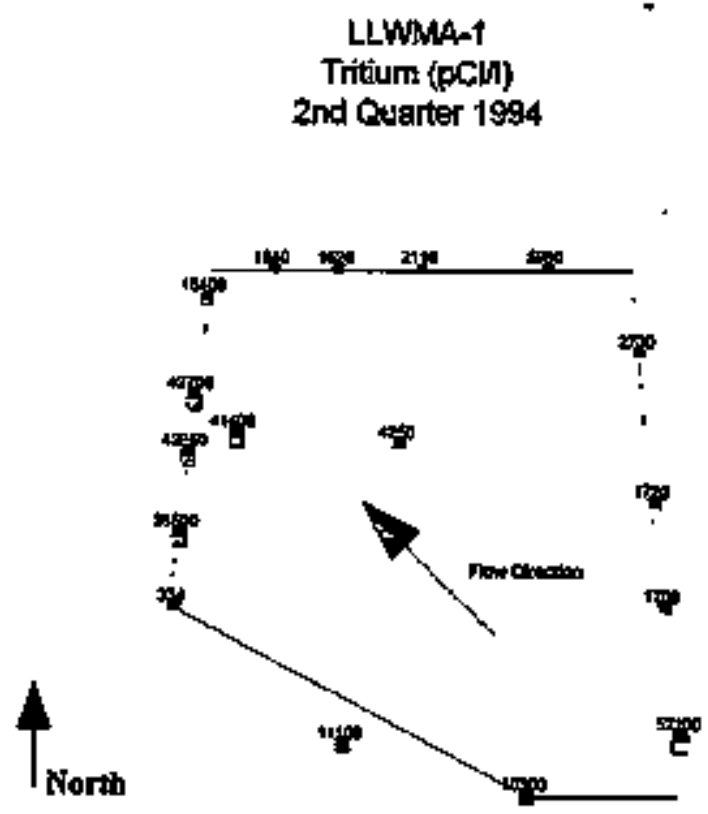

LLWMA-1

Tritium (PCis)

and Quarter

1995
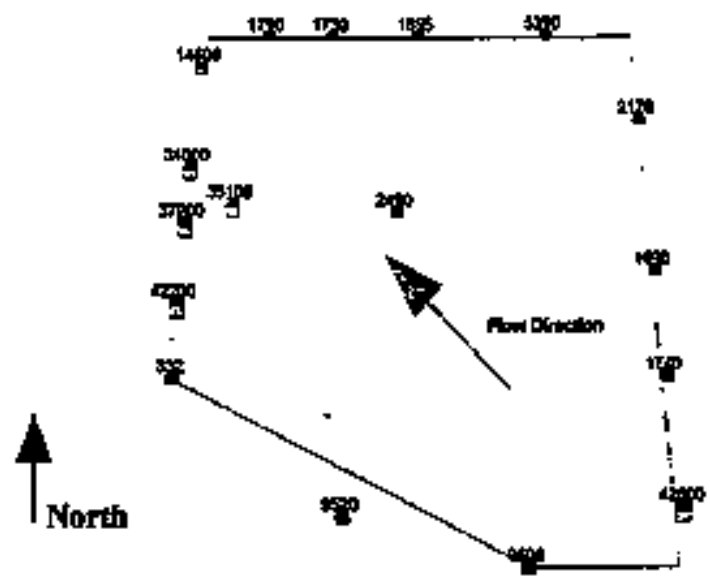

$4.10-16$ 
Figure 4.10-4. Water Table Contour Map for the 200 East Area, June 1995.

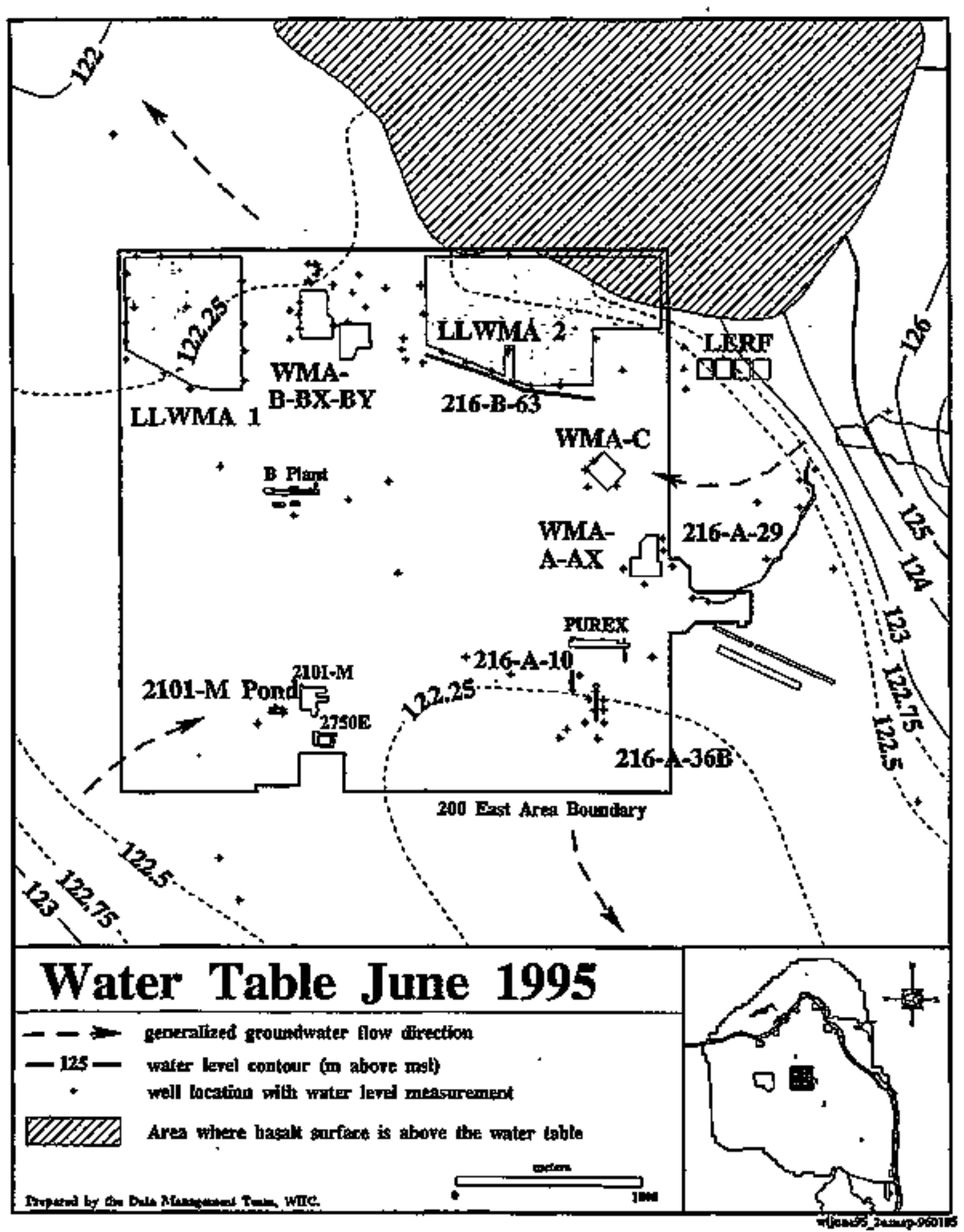




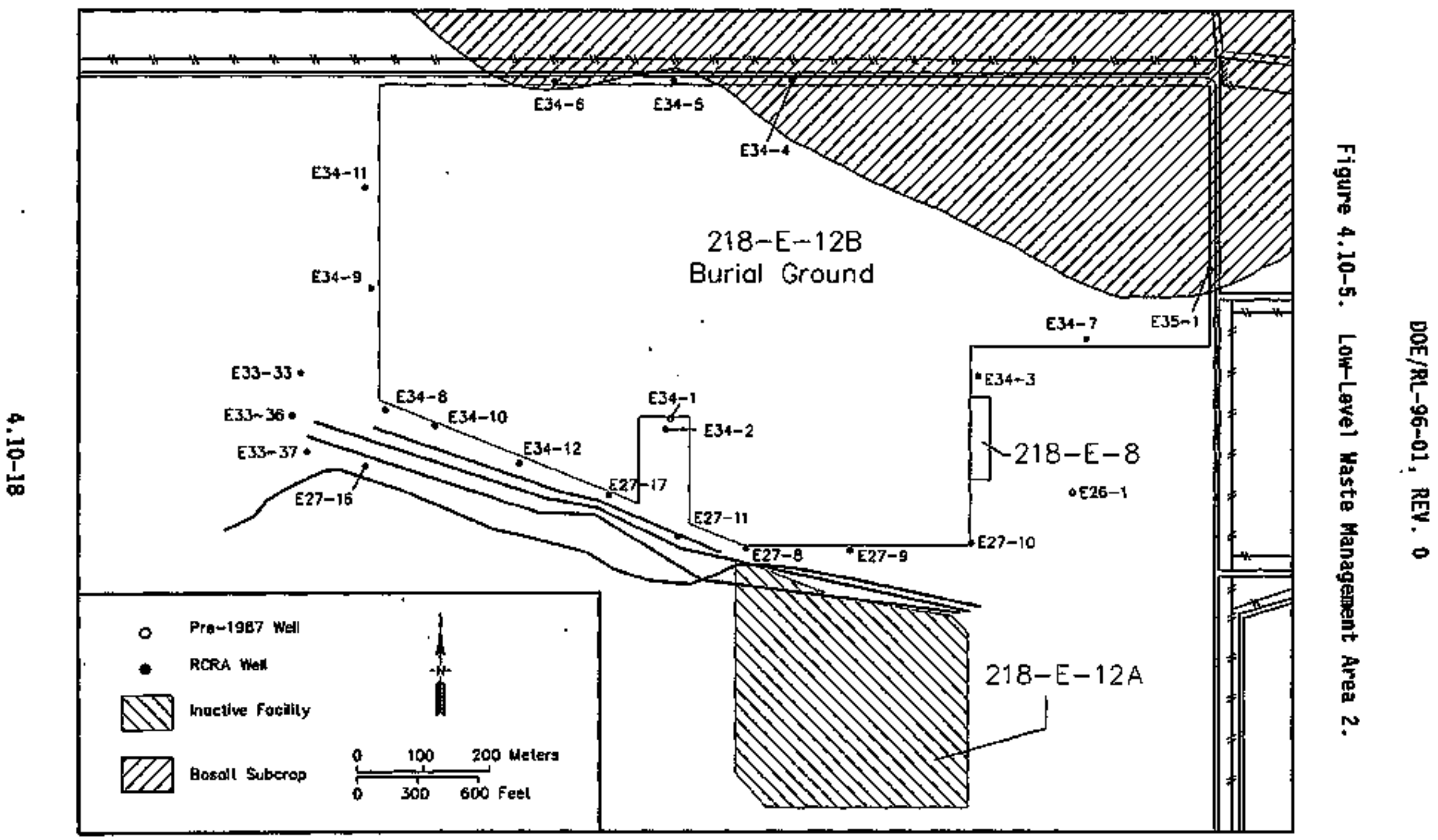

rbm \liwma2.durg 
DOE/RL-96-01, REV. 0

F1gure 4.10-6. Low-Leve1 Waste Management Area 3.

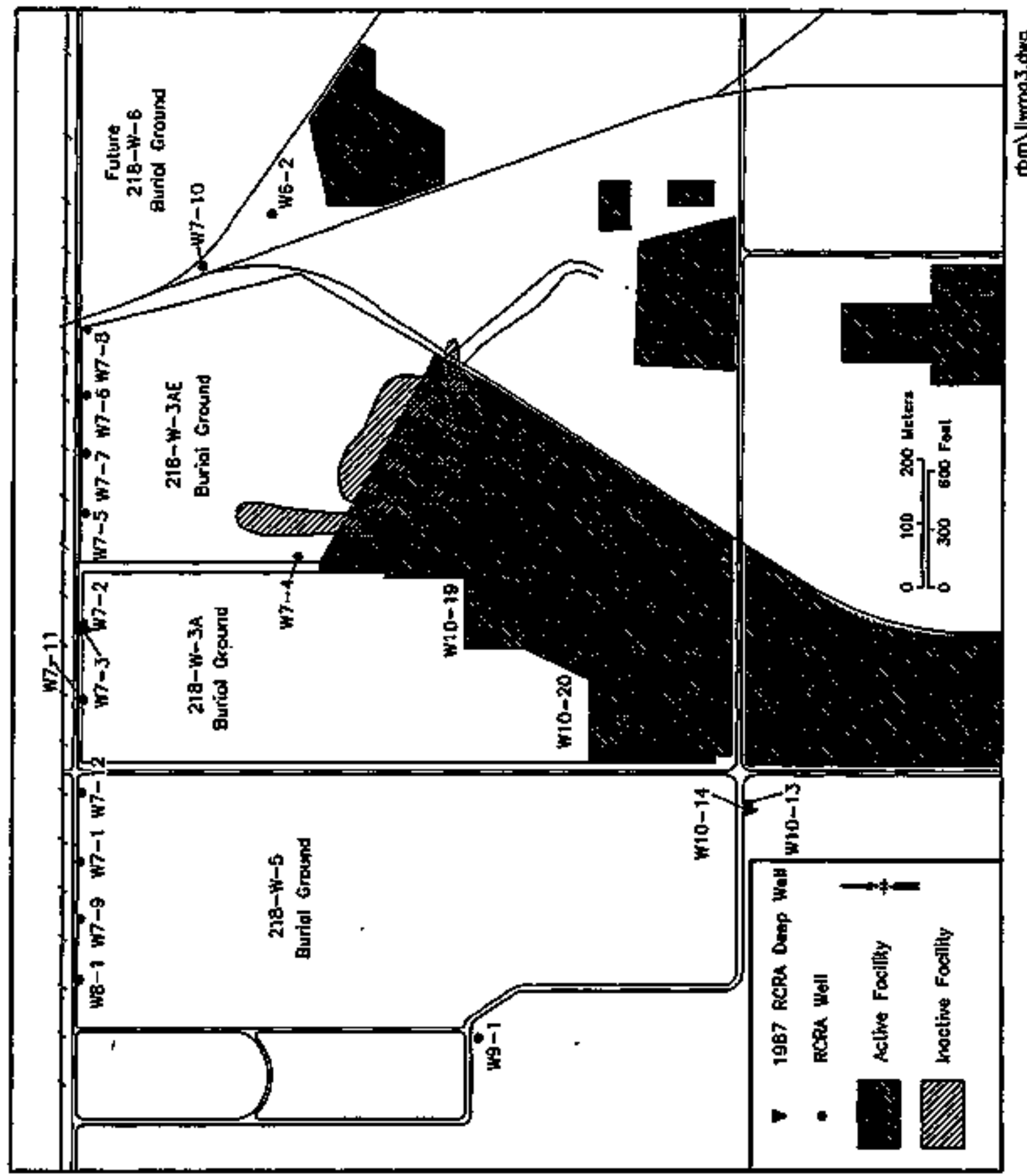


BOE/RL-96-01, REV. 0

Figure 4.10-7. Carbon Tetrachloride at Low-Level Waste Management Area 3.

LLWMMA-3

Carbon Tetrachloride (ppb)

3rd Quarter 1994

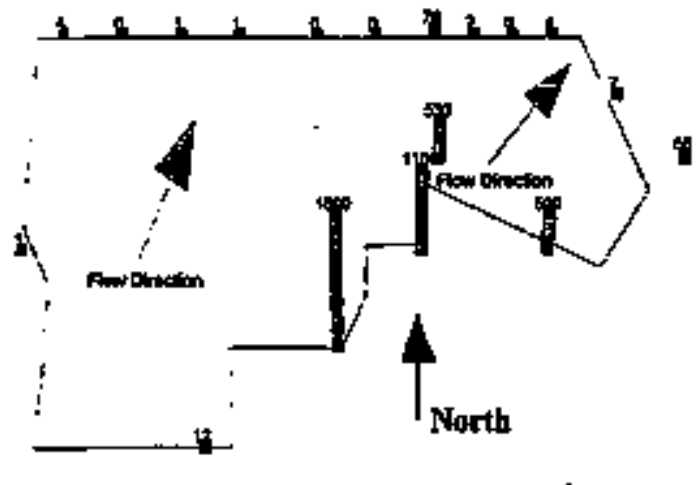

LLWWA-3

Carton Tefracilorids (ppt)

3d Quarter 1995

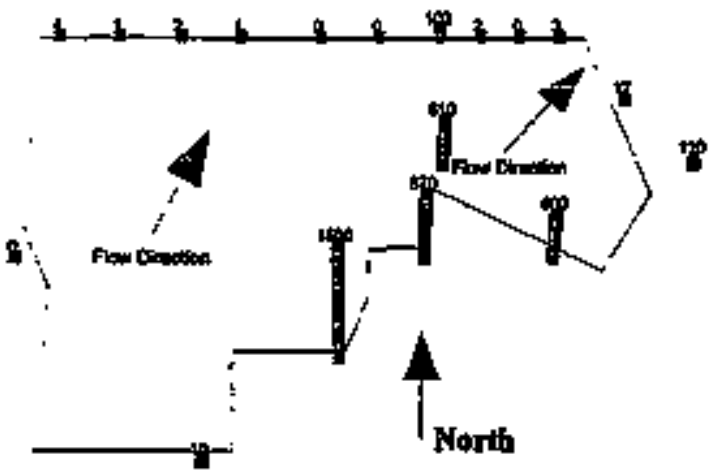


Figure 4.10-8. Nitrate at Low-Level Waste Managenent Area 3. LLWHA-3

Nitrate (ppo)

3d Quarter 1994

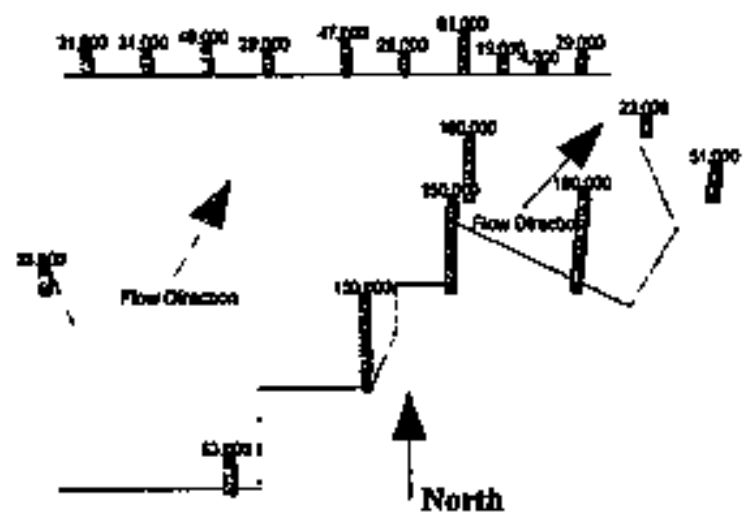

LNMHA-3

Nitrate (ppb)

3rd Quarter 1995

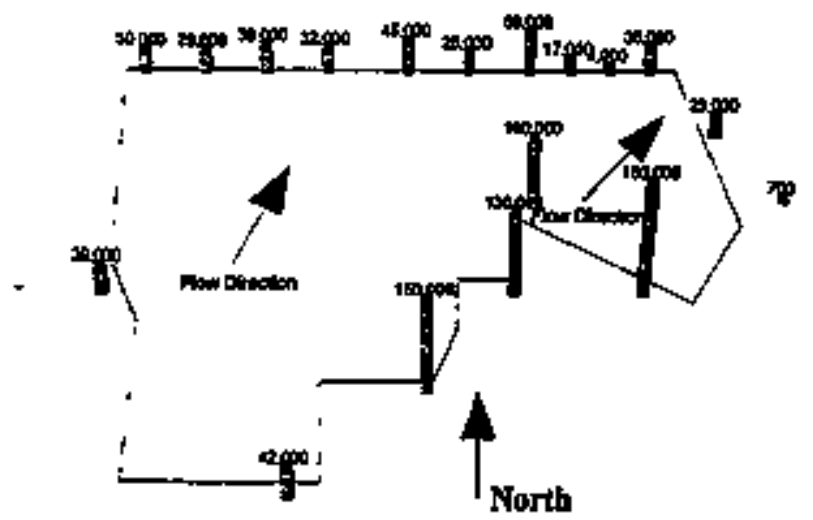

4.10-21 
BOE/RL-96-01, REV. 0

Figure 4.10-9. Water Table Contour Map for the 200 West Area, June 1995.

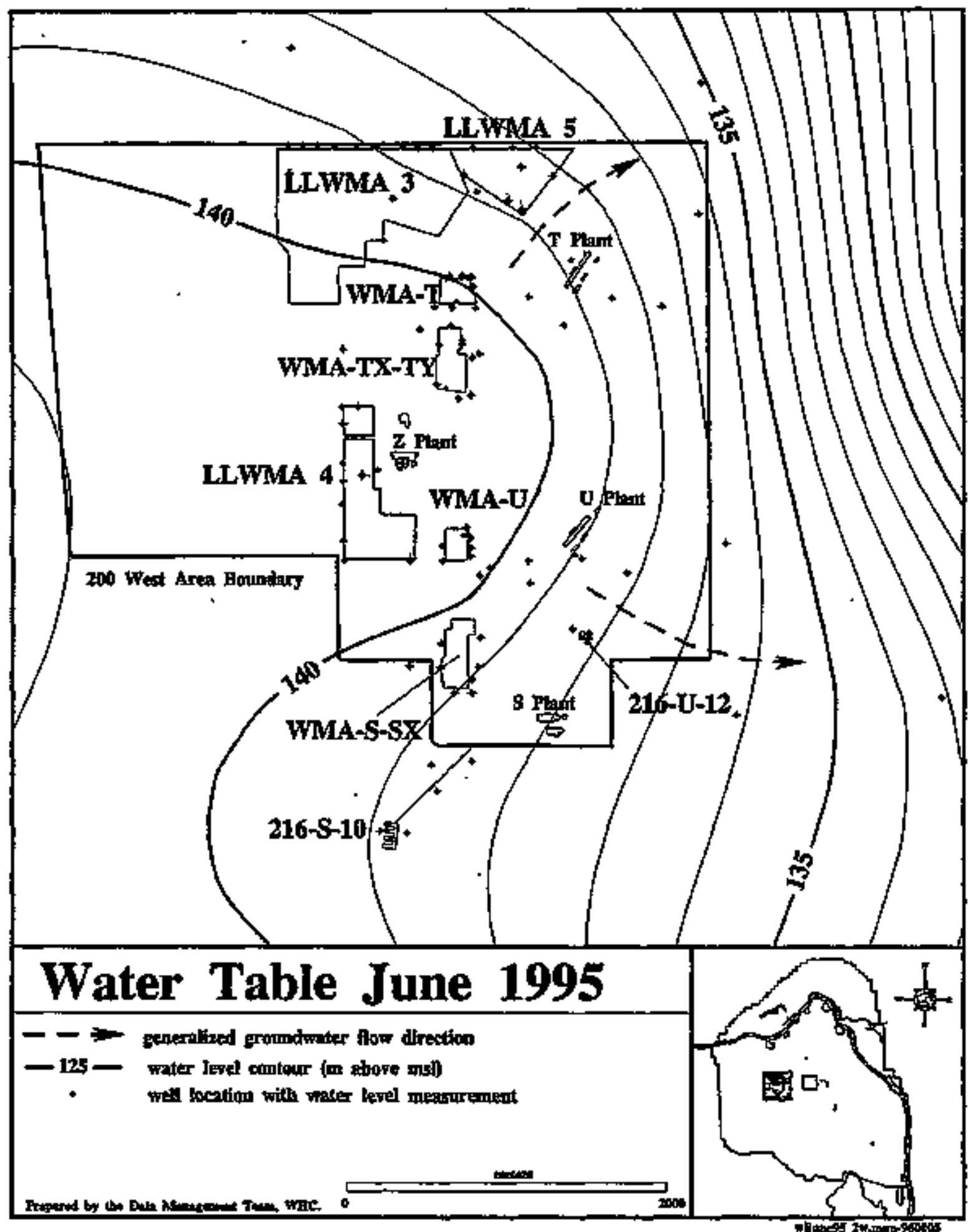


DOE/RL-96-01, REV. 0

Figure 4.10-10. Low-Level Waste Management Area 4.

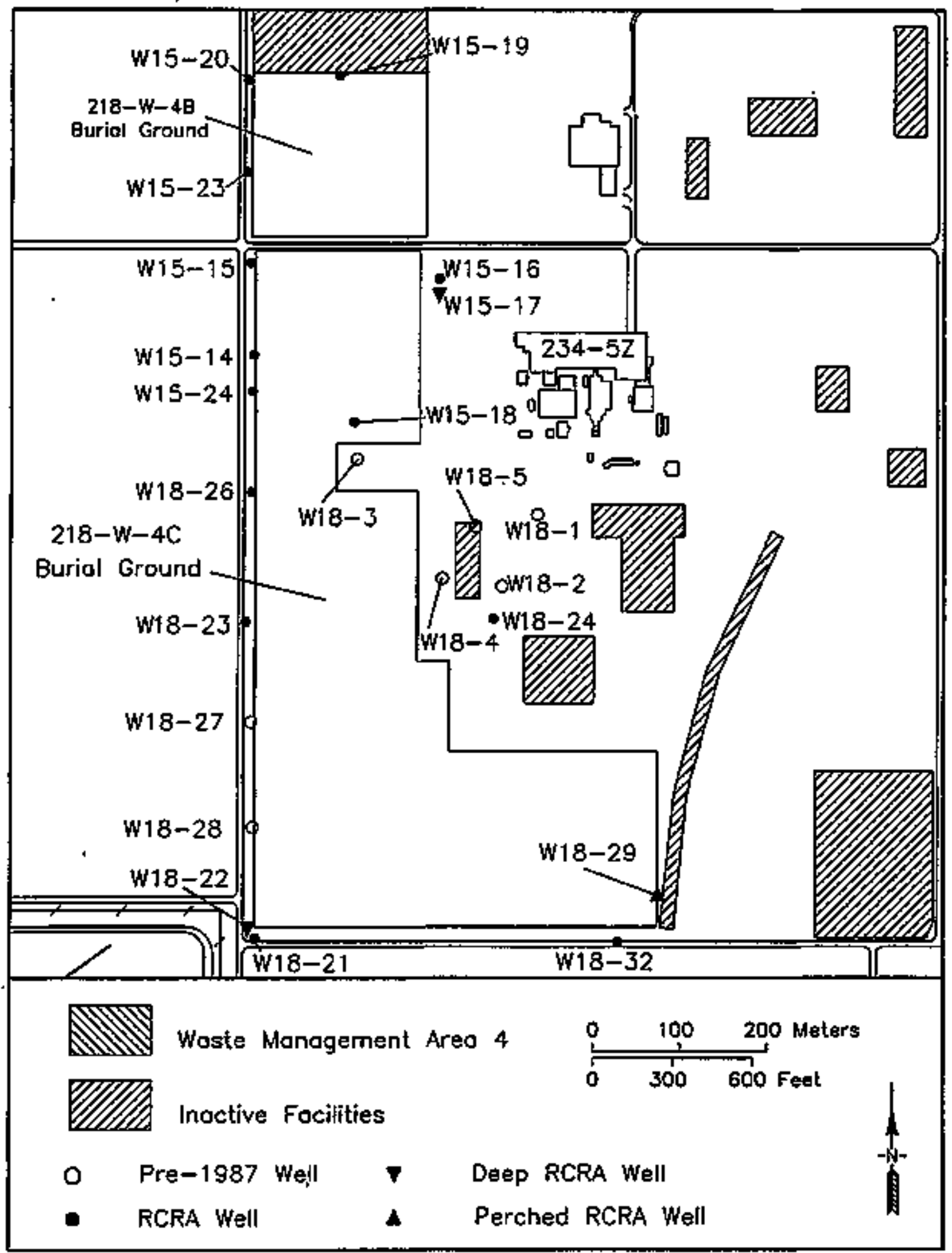

$\mathrm{rbm} \backslash \mathrm{llwm}$ 04.dwg 
$\rightarrow Z-O L^{*} \boldsymbol{t}$

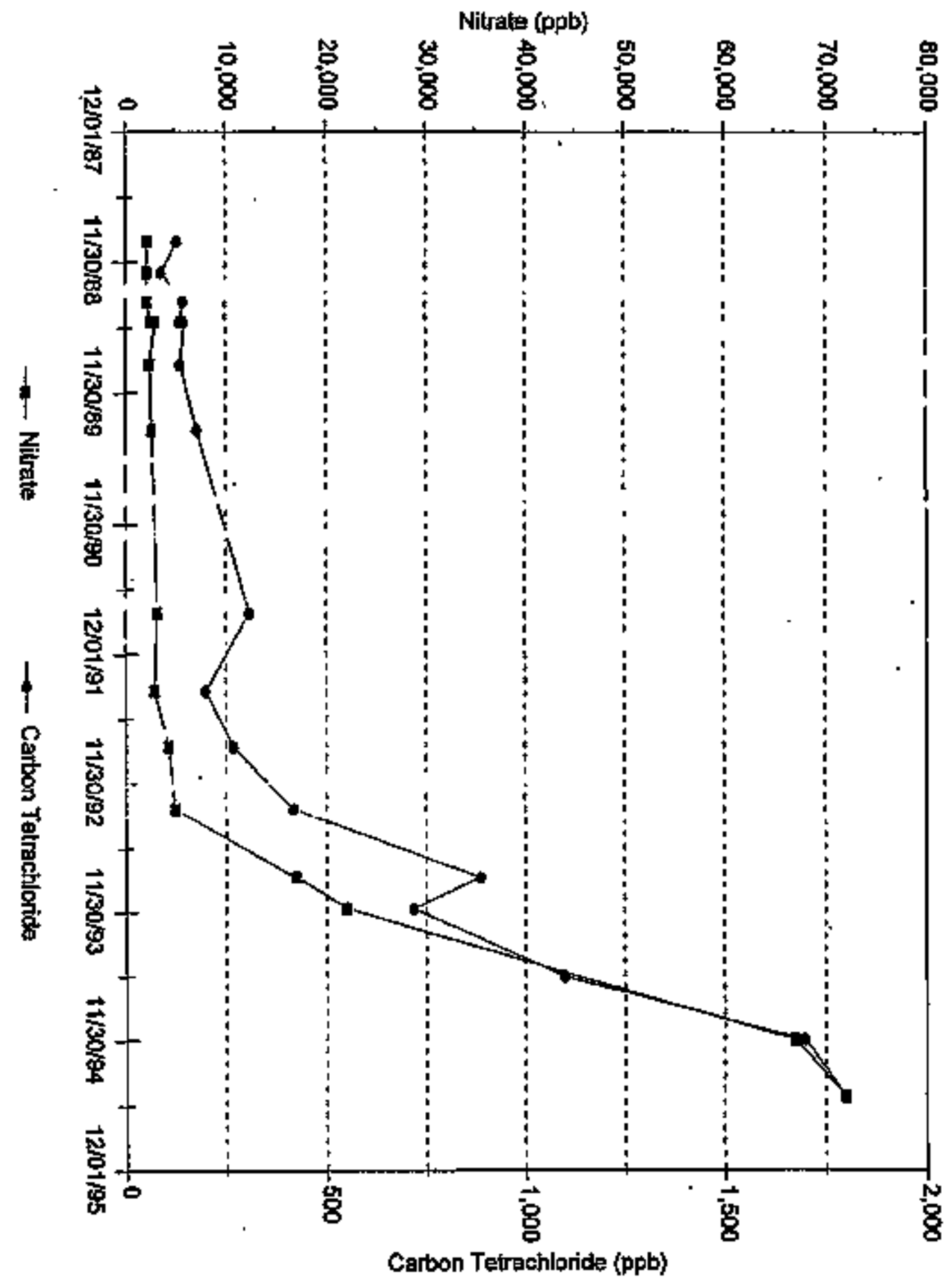

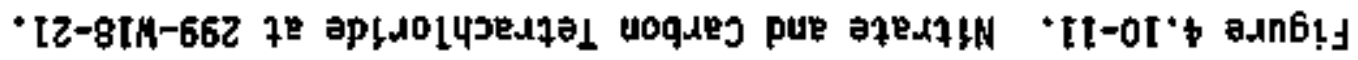


DOE/RL-96-01, REV. O

Figure 4.10-12. Low-Leve1 Waste Management Area 5.

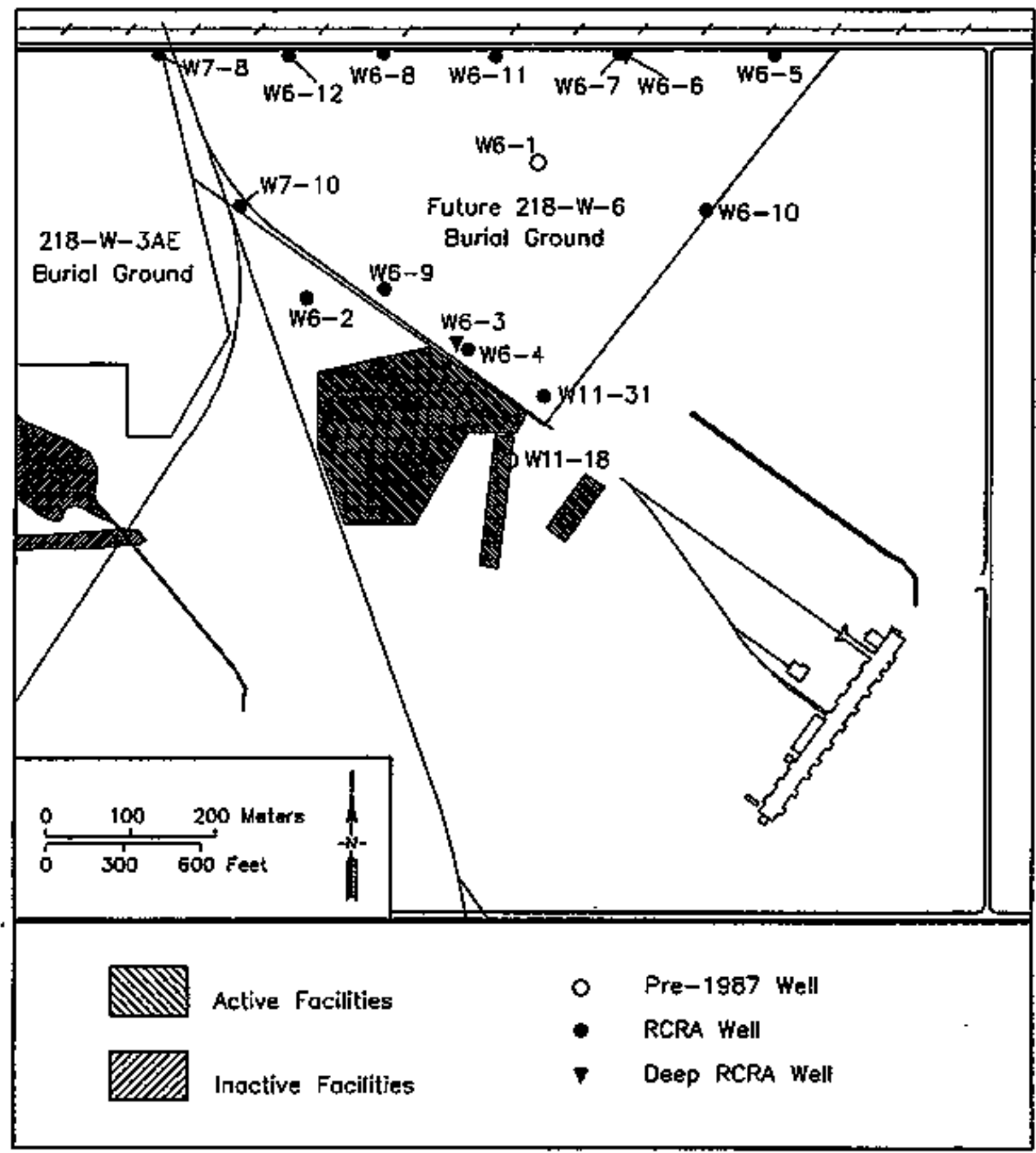

rbm\llwma5.dwg 
DOE/RL-96-01, REV, 0

Figure 4.10-13. Carbon Tetrachloride at Low-Lavel Waste Management Area 5. LIWMA-5

Carbon Tetrachloride (ppb)

3rd Qungrtar 1994

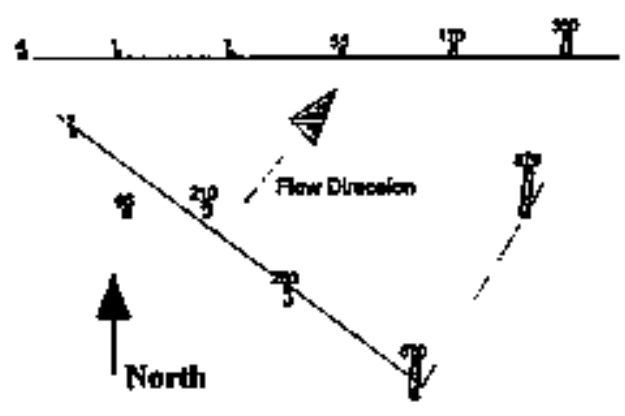

LLWMA-5

Certon Telrachloride (ppb)

3rd Quarter 1995

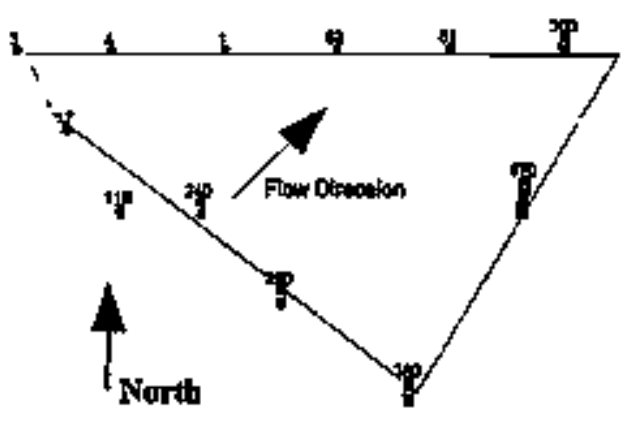


DOE/RL-96-01, REY. 0

Figure 4.10-14. Nitrate at Low-Leve1 Waste Management Area 5.

\author{
LLWMA-5 \\ Nitrate (ppb) \\ 3rd Quarter 1904
}

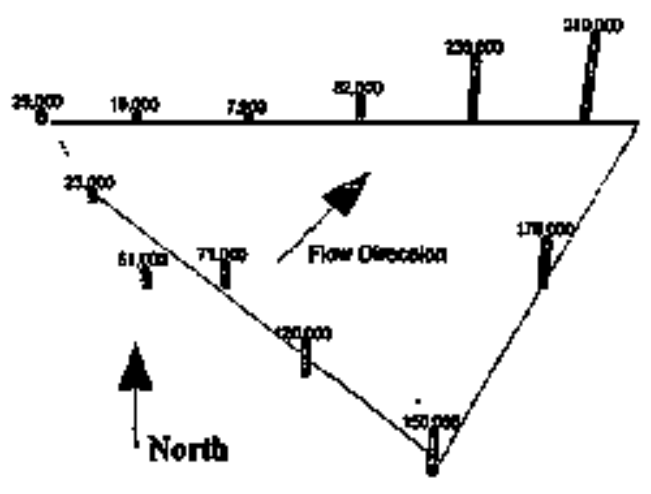

LLWMAN 5

Nitrate (ppb)

अd Quarter 1993

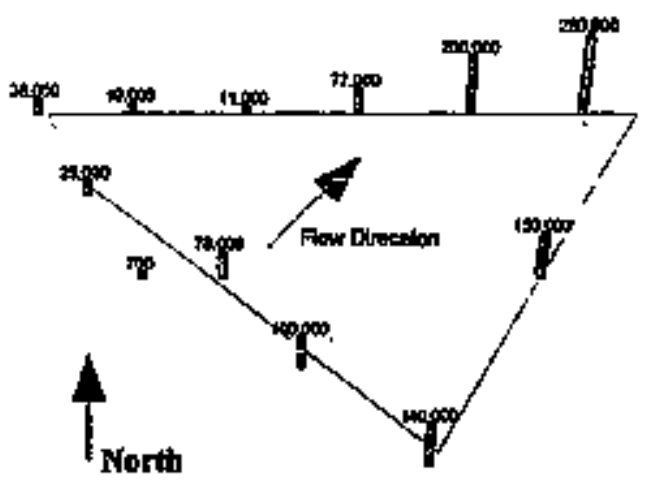


DOE/RL-96-01, REV. O

Figure 4.10-15. Trittum at Low-Level Waste Management Area 5.

LLWAA-5

Tratitum (pCotl)

3rd Quarter 1994

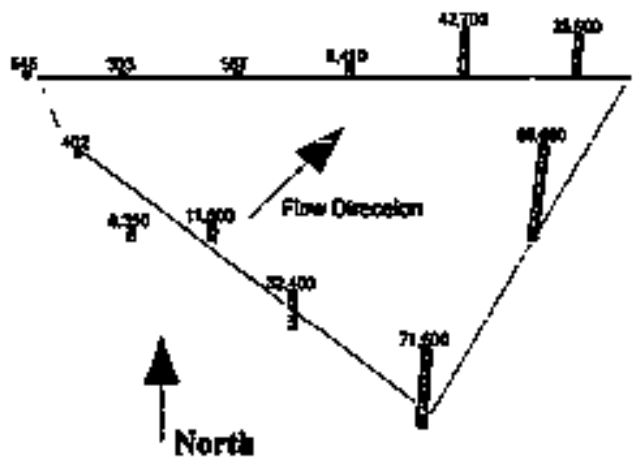

LLWMA-5

Trithum (pCM)

3rd Guarter togs

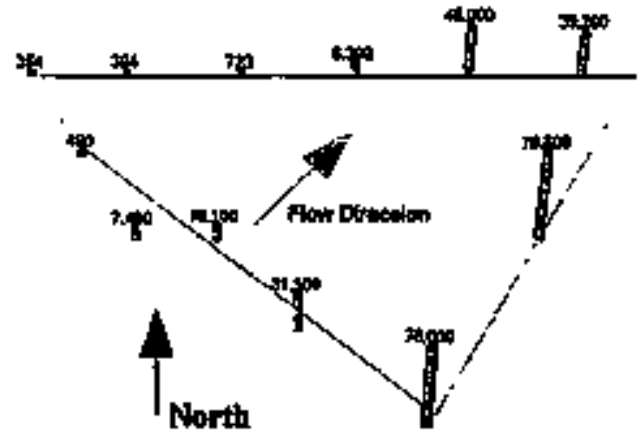

$4 \cdot 10-28$ 
Tab1e 4.10-1. Low-Level Naste Management Area 1 Monitoring Network.

\begin{tabular}{|c|c|c|c|c|c|}
\hline We11 & Aquifer & $\begin{array}{l}\text { Sampl ing } \\
\text { frequency }\end{array}$ & $\begin{array}{l}\text { Water } \\
\text { leveis }\end{array}$ & $\begin{array}{c}\text { Nell } \\
\text { standards }\end{array}$ & $\begin{array}{c}\text { Other } \\
\text { networks }\end{array}$ \\
\hline $299-E 28-26^{87}$ & Top of unconfined & $S A$ & $\mathbf{q}$ & RCRA & -- \\
\hline $299-E 28-27^{87}$ & Top of unconfined & SA & 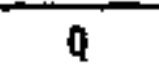 & RCRA & $\rightarrow$ \\
\hline $299-\mathrm{E} 28-28^{90}$ & Top of unconffined & $\overline{S A}$ & $\overline{\mathbf{Q}}$ & RCRA & - \\
\hline $299-E 32-2^{87}$ & Top of unconfined & $\overline{S A}$ & $\bar{Q}$ & RCRA & $200-B P-1$ \\
\hline $299-E 32-3^{87}$ & Top of unconfined & SA & $\bar{Q}$ & RCRA & - \\
\hline $299-E 32-4^{87}$ & Top of unconfined & SA & Q & RCRA & B Pond \\
\hline $299-E 32-5^{59}$ & Tap of unconfined & SA & $\bar{Q}$ & RCRA & - \\
\hline $299-E 32-6^{59}$ & Top of unconfined & $5 A$ & $\bar{Q}$ & RCRA & 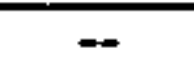 \\
\hline $299-E 32-7^{91}$ & Top of unconfined & SA & $\mathbf{Q}$ & RCRA & $m$ \\
\hline $299-532-8^{9 t}$ & Top of unconfined & SA & $Q$ & RCRA & $m$ \\
\hline $299-E 32-9^{91}$ & Top of unconfined & SA & $Q$ & RCRA & - \\
\hline $299-\mathrm{E} 32-10^{92}$ & Top of unconfined & SA & $Q$ & RCRA & -- \\
\hline $299-\mathrm{E} 33-28^{87}$ & Top of unconfined & $S A$ & $Q$ & RCRA & 200-BP-1 \\
\hline $299-533-29^{67}$ & Top of unconfined & SA & $Q$ & RCRA & $200-8 \mathrm{P}-1$ \\
\hline $299-E 33-30^{67}$ & Top of unconfined & $5 A$ & $Q$ & RCRA & 200-BP-1 \\
\hline $299-E 33-34^{90}$ & Top of unconfined & SA & $Q$ & RCRA & 200-BP-1 \\
\hline $299-E 33-35^{90}$ & Top of unconfined & $S A$ & $Q$ & RCRA & $200-B P-1$ \\
\hline
\end{tabular}

Motes: Shading denates upgradient wells. Superscript following well number denotes the year of installation.

$Q=$ frequency on a quarterly basis.

$S A=$ frequeacy on a semiannual basis.

$R C R A=$ well is in complfance with RCRA standards. 
DOE/RL-96-01, REV. 0

Table 4.10-2. Constituents Analyzed at the Low-Leve1 Burial Ground.

\begin{tabular}{|c|c|c|}
\hline \multicolumn{3}{|c|}{ Contamination indicator parameters } \\
\hline $\begin{array}{l}\text { gH } \\
\text { Spectefic conductance }\end{array}$ & $\begin{array}{l}\text { Total organic carbon } \\
\text { Total organic hajogen }\end{array}$ & \\
\hline \multicolumn{3}{|c|}{ Groundwater quality parameters } \\
\hline $\begin{array}{l}\text { Chloride } \\
\text { Iron }\end{array}$ & $\begin{array}{l}\text { Manganese } \\
\text { Phenols }\end{array}$ & $\begin{array}{l}\text { Sodfum } \\
\text { Sulfate }\end{array}$ \\
\hline \multicolumn{3}{|c|}{ Drinking water parameters } \\
\hline $\begin{array}{l}\text { 2,4-D } \\
2,4,5-T P \text { silvex } \\
\text { Arsenic } \\
\text { Barium } \\
\text { Cadmium } \\
\text { Chromium } \\
\text { Coliform bacteria }\end{array}$ & $\begin{array}{l}\text { Endrin } \\
\text { Fluoride } \\
\text { Gross alpha } \\
\text { Gross beta } \\
\text { Lead } \\
\text { Lindane } \\
\text { Mercury }\end{array}$ & $\begin{array}{l}\text { Hethoxychlor } \\
\text { Nitrate } \\
\text { Radium } \\
\text { Selen1um } \\
\text { Silver } \\
\text { Toxaphene }\end{array}$ \\
\hline \multicolumn{3}{|c|}{ Site-specific parameters for the Low-Level Burial Grounds } \\
\hline $\begin{array}{l}1,1,2,2 \text {-tetrachToroethane } \\
1,2 \text { dichloroethane } \\
1,2 \text { dichloropropane } \\
\text { Acetonitrile } \\
\text { Benzene } \\
\text { Beryl lium } \\
\text { Bromoforid }\end{array}$ & $\begin{array}{l}\text { Carbon tetrachloride } \\
\text { Chlorobenzene } \\
\text { cis-1,l djchloroethylene } \\
\text { Copper } \\
\text { Cyanide } \\
\text { Ethylbenzene } \\
\text { Maphthalene }\end{array}$ & $\begin{array}{l}\text { Tetrachloroethylene } \\
\text { Toluene } \\
\text { trans-1, I dichloroethylene } \\
\text { Trichloroethylene } \\
\text { Uranfum } \\
\text { Vinyl chloride } \\
\text { Xylene }\end{array}$ \\
\hline
\end{tabular}


Table 4.10-3. Critical Means Table for 68 Comparison--Background Contapination Indicator Parameter Data for Low-Level Wast $\theta$ Management Area 1.,6

\begin{tabular}{|c|c|c|c|c|c|c|c|}
\hline $\begin{array}{l}\text { Constituent } \\
\text { (Unit) }\end{array}$ & n & $d f$ & tc & $\begin{array}{c}\text { Average } \\
\text { background }\end{array}$ & $\begin{array}{l}\text { Standard } \\
\text { devtatton }\end{array}$ & Critical mean & $\begin{array}{c}\text { Upgradient/ } \\
\text { downgradient } \\
\text { comparison value }\end{array}$ \\
\hline $\begin{array}{l}\text { Specific } \\
\text { Conductance } \\
\text { ( } \mu \text { mho/cm) }\end{array}$ & $26^{*}$ & 25 & 4.2027 & 373.721 & 74.637 & 693.4 & 693.4 \\
\hline Field pH & 27 & 26 & 4.4409 & 7.896 & 0.330 & {$[6.40,9.39]$} & {$[6.40,9.39]$} \\
\hline$T O C^{c}(p p b)$ & 26 & 25 & 4.2027 & 500 & N.C. & N.C. & 976 \\
\hline$T 0 x^{d}(p p b)$ & A.C. & N.C. & N.C. & N.C. & N.C. & H.C. & 13.6 \\
\hline
\end{tabular}

Data collected from July 1992 to April 1993 for upgradient wells 299-E28-26, 299-E28-27, 299-E28-28, 299-E33-28, 299-E33-29, and from July 1992 to January 1993 for 299-E33-35, and from September 1991 to July 1992 for 299-E32-4. Critical means calculated based on 68 comparisons.

The following notations are used in this table: dfi degrees of freedon $(n-1)$.

$n-$ number of background replicate averages.

$t_{c}$ - Bonferroni critical t-value for appropriate df and 68 comparisons.

cCritfcal mean cannot be calculated because an estimate of background standard deviation is lacking. The upgradient/downgradient comparison value for TOC is the 1 init of quantitation (see Appendix $A$ ).

'Critical mean cannot be calculated because of problems associated with data quality for samples analyzed by $D C L$. The upgradient/downgradient comparison value for ToX is the Iimit of quantitation (see Appendix A).

Excluding outlifer (collected on 7/2/92 from well 299-E33-28).

H. $\mathrm{C}$. = not calculated. 
Table 4.30-4. Low-Leve1 Waste Management Area 2 Monttoring Network.

\begin{tabular}{|c|c|c|c|c|c|}
\hline Hell & Aquifer & $\begin{array}{l}\text { Sampling } \\
\text { frequency }\end{array}$ & $\begin{array}{l}\text { Water } \\
\text { Tevels }\end{array}$ & $\begin{array}{c}\text { We11 } \\
\text { standiards }\end{array}$ & $\begin{array}{c}\text { Other } \\
\text { networks }\end{array}$ \\
\hline $299-E 27-8^{37}$ & Top of unconfined & SA & Q & RCRA & B-63 Trench \\
\hline $299-E 27-9^{87}$ & Top of unconfined & SA & $Q$ & RCRA & B-63 Trench \\
\hline $299-E 27-10^{90}$ & Top of unconfined & SA & $Q$ & RCRA & $\because$ \\
\hline $299-E 27-11^{89}$ & Top of unconfined & SA & $Q$ & RCRA & B-63 Trench \\
\hline $299-\mathrm{E} 27-17^{9 i}$ & Top of unconftned & 5A & Q & RCRA & B-63 Trench \\
\hline $299-E 34-2^{87}$ & Top of unconfined & SA & $\mathbf{Q}$ & RCRA & 200-BP-I \\
\hline $299-E 34-3^{87}$ & Top of unconfined & SA & 4 & RCRA & -- \\
\hline $299-E 34-4^{97}$ & Top of unconfined & $-\cdots$ & Dry & RCRA & $\therefore$ \\
\hline $299-E 34-5^{87}$ & Top of unconfined & SA & Q & RCRA & $200-B P-1$ \\
\hline $299-E 34-6^{87}$ & Top of unconfined & -- & Dry & RCRA & - \\
\hline $299-E 34-7^{B 9}$ & Top of unconfined & SA & 0 & RCRA & - \\
\hline $299-E 34-9^{91}$ & Top of unconfined & SA & Q & RCRA & - \\
\hline 299-E34-10 & Top of unconfined & $5 \mathrm{~A}$ & $\mathbf{Q}$ & RCRA & B-63 Trench \\
\hline 299-E34-11\% & Top of unconfined & SA & Q & RCRA & $\rightarrow$ \\
\hline $299-E 34-12^{92}$ & Top of unconfined & SA & Q & RCRA & -- \\
\hline $299-E 35-1^{18}$ & Top of unconfined & - & Dry & RCRA & 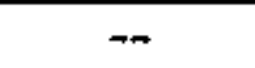 \\
\hline
\end{tabular}

Motes: Shading denotes upgradient wells. Superscript following well number denotes the year of installation.

$\mathrm{Q}=$ frequency on a quarterly basis.

$S A=$ frequency on a semiannual basis.

RCRA = wel] is in compliance with RCRA standards. 
Table 4.10-5. Critical Means Table for 52 Compartsons--Background Contamination Indicator Parameter Data for Low-Level Waste Management Area 2. ${ }^{\circ}$

\begin{tabular}{|c|c|c|c|c|c|c|c|}
\hline $\begin{array}{c}\text { Constituent } \\
\text { (Unit) }\end{array}$ & $n$ & df & t.c. & $\begin{array}{c}\text { Average } \\
\text { background }\end{array}$ & $\begin{array}{l}\text { Standard } \\
\text { deviation }\end{array}$ & $\begin{array}{c}\text { Critical } \\
\text { mean }\end{array}$ & $\begin{array}{l}\text { Upgradient/ } \\
\text { downgradient } \\
\text { comparison } \\
\text { value }\end{array}$ \\
\hline $\begin{array}{l}\text { Speciftc } \\
\text { Conductance } \\
\text { ( } \mu \mathrm{m} h \mathrm{ho} / \mathrm{cm})\end{array}$ & 12 & 11 & 5.0293 & 385.875 & 116.987 & 998.3 & 998.3 \\
\hline Field ph & 12 & 11 & 5.4790 & 8.077 & 0.174 & {$[7.08,9.07]$} & {$[7.08,9.07]$} \\
\hline$T 0 C^{c}(p p b)$ & 12 & 11 & 5.0293 & 445.833 & 94.648 & 941.3 & 976 \\
\hline$T 0 X^{4}(\rho p b)$ & 12 & 11 & 5.0293 & 4.833 & 2.861 & 19.8 & 19.8 \\
\hline
\end{tabular}

Data collected from September 1986 to July 1989 for upgradient wolls 299-E27-10 and 299-E34-5. Crittcal means calculated based on 52 conparisons.

The following notations are used in this table:

df $*$ = degrees of freedon $(n-1)$.

$n=$ number of background replicate averages.

$t_{c}=$ Bonferroni critical t-value for appropriate df and 52 comparisons.

cCritical mean was calculated from values reported below CRDL. The upgradient/downgradient comparison value for $T O C$ is the liait of quantitation (see Appendix A).

Critical mean was calculated using data analyzed by U.S. Testing, Inc of Richl and.

A. $\mathrm{C}$. = not calculated. 
DOE/RL-96-01, REV. 0

Tabie 4.10-6. Low-Levet Waste Management Area 3 Monitoring Metwork.

\begin{tabular}{|c|c|c|c|c|c|}
\hline Weit & Aquifer & $\begin{array}{l}\text { Sampling } \\
\text { frequency }\end{array}$ & $\begin{array}{l}\text { Hater } \\
\text { levels }\end{array}$ & $\begin{array}{c}\text { Well } \\
\text { standards }\end{array}$ & $\begin{array}{c}\text { Other } \\
\text { networks }\end{array}$ \\
\hline $299-16-2^{87}$ & Top of unconfined & SA & 4 & RCRA & LKNANA-5 \\
\hline $299-147-1^{87}$ & Top of tuconfined & $S A$ & q & RCRA & -- \\
\hline $299-47-2^{87}$ & Top of unconfined & SA & $\mathbf{Q}$ & RCRA & -- \\
\hline $299-47-3^{87}$ & Deep unconfined & SA & $\mathbf{Q}$ & RCRA & - \\
\hline $299-47-4^{87}$ & Top of unconfined & SA & Q & RCRA & - \\
\hline $299-117-5^{87}$ & Top of unconflined & SA & $\bar{Q}$ & RCRA & -- \\
\hline $299-17-6^{87}$ & Top of unconfined & $\mathbf{S A}$ & Q & RCRA & - \\
\hline $299-147-7^{89}$ & Top of unconftned & $\overline{5 A}$ & Q & RCRA & $=$ \\
\hline $299-147-8^{89}$ & Top of unconfined & SA & Q & RCRA & - \\
\hline $299-147-9^{90}$ & Top of unconfined & SA & Q & RCRA & -- \\
\hline $299-147-10^{90}$ & Top of unconfined & SA & Q & RCRA & LLWMA-5 \\
\hline $299-w 7-11^{99}$ & Top of unconfined & $\mathrm{SA}$ & $\bar{Q}$ & $\overline{\text { RCRA }}$ & -- \\
\hline $299-N 7-12^{91}$ & Top of unconfined & SA & Q & RCRA & -- \\
\hline $299-4 B-1^{87}$ & Top of unconfined & SA & $\bar{Q}$ & RCRA & - \\
\hline $299-49-1^{87}$ & Top of unconfined & Q & Q & RCRA & -- \\
\hline $299-W 10-13^{87}$ & Top of unconfined & Q & Q & RCRA & - \\
\hline $299-\mathrm{NIO}-14^{87}$ & Deep unconfined & SA & $\mathbf{Q}$ & RCRA & -- \\
\hline $299-110-19^{52}$ & Top of unconfined & Q & Q & RCRA & -- \\
\hline $299-110-20^{93}$ & Top of unconfined & Q & $\vec{q}$ & $\overrightarrow{\text { RCRA }}$ & -- \\
\hline $299-W 10-21^{95}$ & Top of unconfined & Q & $\bar{Q}$ & RCRA & $\rightarrow$ \\
\hline
\end{tabular}

Motes: Shading denotes upgradient wells. Superscript following well number denotes the year of installation.

LLMMA = Low-Leve] Waste Management Area.

$\mathrm{Q}$ - frequency on a quarterly basis through the lst quarter of 1995 then semtanntally.

$S A=$ frequency on a semiannital basis.

RCRA = wel1 is in complfance with RCRA standards . 
Table 4.10-7. Critical Heans Table for 32 Comparisons--Background Contamination Indicator Parameter Data for Low-Leve] Naste Management Area $3 .^{*}, b$

\begin{tabular}{|c|c|c|c|c|c|c|c|}
\hline $\begin{array}{l}\text { Constituent } \\
\text { (Unit) }\end{array}$ & $\mathbf{n}$ & df & tc & $\begin{array}{c}\text { Average } \\
\text { background }\end{array}$ & $\begin{array}{l}\text { Standard } \\
\text { deviation }\end{array}$ & $\begin{array}{c}\text { Critical } \\
\text { mean }\end{array}$ & $\begin{array}{l}\text { Upgradient/ } \\
\text { downgradient } \\
\text { conparison } \\
\text { value }\end{array}$ \\
\hline $\begin{array}{l}\text { Speciflc } \\
\text { Conductance } \\
\text { ( } \mu \text { mho/cin) }\end{array}$ & 12 & 11 & 4.7248 & 439.812 & 26.865 & 579.1 & 579.1 \\
\hline Fjeld pH & 12 & 11 & 5.1621 & 8.120 & 0.294 & {$[6.54,9.70]$} & {$[6.54,9.70]$} \\
\hline$T O C^{c}(p p b)$ & 10 & 9 & 5.1241 & 195.75 & 42.296 & 423.1 & 976 \\
\hline TOX (ppb) & 9 & 8 & 5.4284 & 8.731 & 7.183 & 49.8 & 49.8 \\
\hline
\end{tabular}

"Oata collected from February 1994 to March 1995 for upgradient wel1s 299-W10-13 and 299-49-1. Critical means calculated based on 32 comparisons for area of the LLbih-3 not impacted by upgradient source of contamination.

bThe following notations are used in this table:

df $=$ degrees of freedom $(n-1)$.

$n$ - number of background replicate averages.

$t_{c}=$ Bonferroni critical t-value for appropriate df and 32 comparisons.

"Crittcal mean was calculated from values reported below CRDL. The - upgradient/downgradient comparison value for TOC is the 11 mit of quantitation (see Append $1 \times$ A).

N. C. = not calculated. 
Table 4.10-8. Critical Heans Table for 40 Comparisons--Background Contagination Indicator Parameter Data for

Low-Level Waste Management Area 3."b

\begin{tabular}{|c|c|c|c|c|c|c|c|}
\hline $\begin{array}{c}\text { Constituent } \\
\text { (Unit) }\end{array}$ & $\mathbf{n}$ & df & tc & $\begin{array}{c}\text { Average } \\
\text { background }\end{array}$ & $\begin{array}{c}\text { Standard } \\
\text { deviation }\end{array}$ & $\underset{\text { mean }}{\text { Critical }}$ & $\begin{array}{c}\text { Upgradient/ } \\
\text { downgradient } \\
\text { comparison } \\
\text { value }\end{array}$ \\
\hline $\begin{array}{l}\text { Specific } \\
\text { Conductance } \\
\text { (unho/co) }\end{array}$ & 17 & 16 & 4.3467 & 580.941 & 32.230 & 725.1 & 725.1 \\
\hline Field pH & 17 & 16 & 4,6820 & 7.838 & 0.3867 & {$[5.97,9.70]$} & {$[5.97,9.70]$} \\
\hline$T 0 c^{c}(p p b)$ & 15 & 14 & 4.4995 & 367.833 & 107.483 & 867.3 & 976 \\
\hline$T O X(p p b)$ & 14 & 13 & 4.5978 & 797.923 & 319.605 & $2,319.0$ & 2.319 .0 \\
\hline
\end{tabular}

Data collected from February 1994 to March 1995 for upgradient wells 299-410-19, 299-W10-20, and 299-W10-21. Critical means calculated based on 40 comparisons for area of the LLWhA-3 inpacted by upgradient source of contanination.

'The following notations are used in this table: of a degrees of freedon $(n-1)$.

$n=$ number of background replicate averages.

$t_{c}=$ Bonferroni critical t-value for appropriate df and 40 comparisons.

Critical mean was calculated from values reported below CROL. The upgradient/downgradient comparison value for TOC is the linit of quantitation (see Appendix A).

N. C. = not calculated. 
DDE/RL-96-0l, REV. O

Table 4.10-9. Low-Leve) Waste Management Area 4 Monitoring Metwork.

\begin{tabular}{|c|c|c|c|c|c|}
\hline Hell & Aquifer & $\begin{array}{l}\text { Sampling } \\
\text { frequency }\end{array}$ & $\begin{array}{l}\text { Nater } \\
\text { levels }\end{array}$ & $\begin{array}{c}\text { Wel] } \\
\text { standards }\end{array}$ & $\begin{array}{c}\text { other } \\
\text { networks }\end{array}$ \\
\hline $299-415-15^{87}$ & Top of unconfined & SA & Q & $\overline{\text { RCRA }}$ & -- \\
\hline $299-W 15-16^{97}$ & Top of uiconfined & SA & Q & RCRA & -- \\
\hline $299-W 15-17^{67}$ & Deep unconfined & SA & Q & RCRA & -- \\
\hline $299-W 15-18^{67}$ & Top of unconfined & SA & $Q$ & RCRA & - \\
\hline $299-W 15-19^{69}$ & Top of unconfined & SA & $Q$ & RCRA & -- \\
\hline $299-W 15-20^{89}$ & Top of unconfined & SA & Q & RCRA & -- \\
\hline $299-W 15-23^{90}$ & Top of unconfined & SA & Q & RCRA & $=-$ \\
\hline $299-W 15-24^{89}$ & Top of unconfined & SA & $Q$ & RCRA & $=$ \\
\hline $299-W 18-21^{97}$ & Top of unconfined & SA & Q & RCRA & 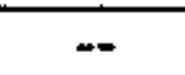 \\
\hline $299-W 18-22^{87}$ & Deep unconfined & SA & $Q$ & RCRA & $-\infty$ \\
\hline $299-418-23^{87}$ & Top of unconfined & SA & Q & RCRA & $\because$ \\
\hline $299-W 18-24^{97}$ & Top of unconfined & SA & Q & RCRA & $=$ \\
\hline $299-W 18-26^{89}$ & Top of unconfined & SA & $Q$ & RCRA & $=-$ \\
\hline $299-W 18-27^{91}$ & Top of unconfined & SA & $\mathbf{Q}$ & RCRA & $=-$ \\
\hline $299-W 18-28^{91}$ & Top of unconfined & $S A$ & $\mathbf{Q}$ & RCRA & -- \\
\hline $299-W 18-29^{91}$ & Perched zone & SA & Q & RCRA & -- \\
\hline $299-418-32^{94}$ & Top of unconfined & SA & $\bar{Q}$ & RCRA & -- \\
\hline
\end{tabular}

Notes: Shading denotes upgradient wells. Superscript following well number denotes the year of Installation.

$Q=$ frequency on a quarterly basis.

$S A=$ frequency on a semiannual basis.

RCRA = well is in compliance with RCRA standards. 
Table 4.10-10. Critical Means Table for 56 Comparisons--Background Contamination Indicator Parameter Data for Low-Level Waste Management Area 4 . $^{\mathrm{a}} \mathrm{b}$

\begin{tabular}{|c|c|c|c|c|c|c|c|}
\hline $\begin{array}{l}\text { Constituent } \\
\text { (Unit) }\end{array}$ & $\mathbf{n}$ & df & tc & $\begin{array}{c}\text { Average } \\
\text { background }\end{array}$ & $\begin{array}{c}\text { Standard } \\
\text { deviation }\end{array}$ & $\begin{array}{c}\text { Critical } \\
\text { mean }\end{array}$ & $\begin{array}{l}\text { Upgradient/ } \\
\text { downgradtent } \\
\text { comparison } \\
\text { value }\end{array}$ \\
\hline $\begin{array}{l}\text { Specific } \\
\text { Conduct ance } \\
(\mu \text { mho/cn) }\end{array}$ & 16 & 15 & 4.586 & 328.594 & 133.345 & 958.9 & 958.9 \\
\hline Field pH & 16 & 15 & 4.938 & 7.779 & 0.261 & {$[6.45,9.11]$} & {$[6.45,9.11]$} \\
\hline$T C^{c}$ (ppb) & 15 & 14 & 4.676 & 470.0 & 142.428 & $1,157.8$ & $1,157.8$ \\
\hline$T 0 X^{c}(p p b)$ & 11 & 10 & 5.2814 & $2,029.796$ & $2,002.864$ & 13,078 & 13,078 \\
\hline
\end{tabular}

Data collected from October 1988 to July 1989 for upgradient wells 299-W15-16, 299-W15-18, and 299-W18-24 and fron October 1992 to August 1993 for the newly installed upgradient we11 299-W18-32. Critical means calculated based on 56 compartisons.

'The following notations are used in this table:

$d f=$ degrees of freedont $(n-1)$.

$n=$ nuiber of background repl jcate averages.

$t_{c}=$ Bonferroni critical t-value for appropriate of and 56 comparisons.

${ }^{c} \mathrm{Cr}$ itfcal mean was calculated using data analyzed by U.S. Testing, Inc. of Richland. (see

Upgradient/downgradient comparison value for Joc is the 7iait of quantitation Appendix A).

H. $C_{\text {, }}=$ not calculated. 
Table 4.10-I1. Low-Level Waste Managenent Area 5 Honjtoring Hetwork.

\begin{tabular}{|l|l|c|c|c|c|}
\hline \multicolumn{1}{|c|}{ He11 } & Aquifer & $\begin{array}{c}\text { Sampling } \\
\text { frequency }\end{array}$ & $\begin{array}{c}\text { Water } \\
\text { levels }\end{array}$ & $\begin{array}{c}\text { Wei1 } \\
\text { standards }\end{array}$ & $\begin{array}{c}\text { Other } \\
\text { networks }\end{array}$ \\
\hline $299-W 6-2^{87}$ & Top of unconfined & SA & $Q$ & RCRA & LLWMA-3 \\
\hline $299-W 6-3^{91}$ & Deep unconfined & SA & $Q$ & RCRA & -- \\
\hline $299-W 6-4^{91}$ & Top of unconfined & SA & $Q$ & RCRA & -- \\
\hline $299-W 6-5^{91}$ & Top of unconfined & SA & $Q$ & RCRA & -- \\
\hline $299-W 6-6^{91}$ & Deep unconfined & SA & $Q$ & RCRA & -- \\
\hline $299-W 6-7^{91}$ & Top of unconfined & SA & $Q$ & RCRA & -- \\
\hline $299-W 6-8^{91}$ & Top of unconfined & SA & $Q$ & RCRA & -- \\
\hline $299-W 6-9^{92}$ & Top of unconfined & SA & $Q$ & RCRA & -- \\
\hline $299-W 6-10^{92}$ & Top of unconfined & SA & $Q$ & RCRA & -- \\
\hline $299-W 6-11^{92}$ & Top of unconfined & SA & $Q$ & RCRA & -- \\
\hline $299-W 6-12^{92}$ & Top of unconfined & SA & $Q$ & RCRA & -- \\
\hline $299-W 7-10^{90}$ & Top of unconfined & SA & $Q$ & RCRA & LLLWA-3 \\
\hline $299-W 11-31^{92}$ & Top of unconfined & SA & $Q$ & RCRA & -- \\
\hline
\end{tabular}

Hotes: Shading denotes upgradient wells. Superscript following well number denotes the year of installation.

LLWMA = Low-Level Waste Management Area.

0 = frequency on a quarterly basts,

RCRA = well is in compliance with RCRA standards.

SA = frequency on a semiannual basis. 
Table 4.10-12. Critical Heans Table for 44 Comparisons--Background Contanination Indicator Parameter Data for Low-Level Waste Managenent Area $5 .{ }^{4, b}$

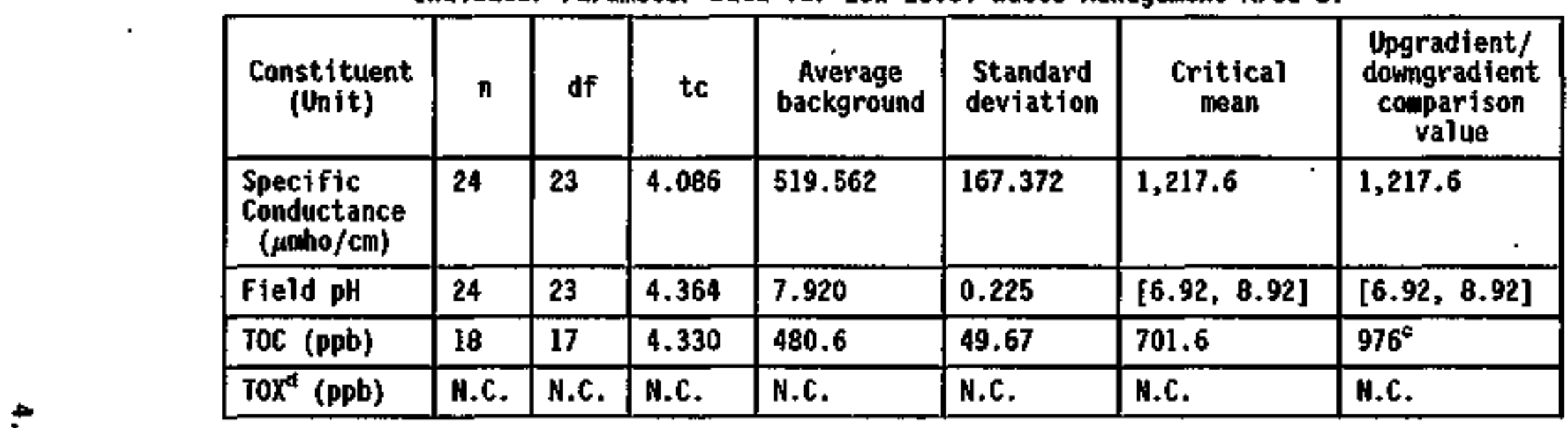

Data collected from December 1992 to September 1993 for upgradient wells 299-W6-9, 299-W6-10, and 299-M11-31 and from May 1992 to Hay 1993 for well 299-W6-2 and from September 1992 to June 1993 for well $299-\$ 6-4$ and fron August 1992 to Nay 1993 for well 299-47-10. Critical means calculated based on 44 comparisons.

The following notations are used in this table: df $=$ degrees of freedom $(n-1)$.

$n=$ number of background replicate averages.

$t_{c}=$ Bonferroni critical t-value for appropriate df and 44 comparisons.

"Upgradient/downgradient comparison value for TOC is the limit of quantitation (see Appendix A).

dCritical mean cannot be calculated becausè of problems assoclated with data quality for samples analyzed by DCL. TOX values fron upgradient wells have been detected above the method detection linit (see Appendix C).

H. c. = not cajculated. 
DOE/RL-96-01, REY. 0

CONTENTS

4.11 SIMGLE-SHELL TANKS . . . . . . . . . . 4.11-1

4.11 .1 Introduct ton ..................... . . . .

4.11 .2 5ampling and Analysts Program ......... 4.11-6

4.11.3 Groundwater Chemistry Evaluation . . . . . . 4.11-7

4.11.4 Evaluatton of Water Levels . . . . ...... 4.11-13

4.11 .5 References ................ 4.11-18 


\section{LIST OF FIGURES}

4.11-1 Single-She11 Tank Waste Managenent Areas

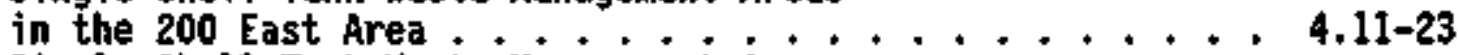

4,11-2 Single-Shell Tank Waste Hanagement Areas in the 200 Mest Area ................... 41-24

4.11-3 200 West Area Hydrographs for Single-She11 Tank Naste Management Areas TX-TY and $U \ldots . . \ldots$ 4.11-25

4.11-4 200 West Area Water Table Map, June $1995 \ldots . . . . . .4$ 4.11-26

4.11-5 Monitoring Mell Locations for the Single-Sheli Tank Maste Management Areas in the 200 East Area . . . . 4.11-27.

4.11-6 Monitoring Hel1 Locations for the Single-She11

Tank Maste Hanagement Areas in the 200 Hest Area . . . . 4.11-28

4.I1-7 Filtered Chromium and Micke? Versus Time for Well 299-E24-19 . . . . . . . . 4.11-29

4.11-8 Trends in Historic Groundwater Monitoring Data in Weits 299-W15-4 and 299-E25-2 . . . . . . . 4.11-30

4.11-9 200 East Area Water Table Map, June 1995 ......... 4.11-31

4.11-10 200 East Area Hydrographs for Single-Shel1

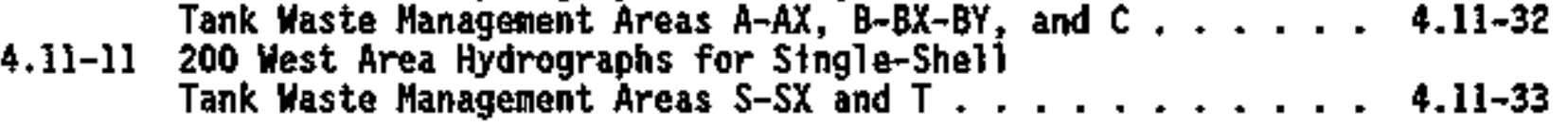




\section{LIST OF TABLES}

4.11-1 Groundwater Monitoring Wel1s for the

Single-Shell Tanks .................11-34

4.11-2 In-Situ Flow Meter Resuits Single-She11 Tanks Maste

Managenent Area $\mathrm{U}$, May 4-12, $1995 \ldots \ldots . . . .4 .11-36$

4.11-3 Const1 tuent 11st for the S1ngle-She11 Tanks . . . . . 4.11-36

4.11-4 Constituents Exceeding Regulatory Linits ........ 4.11-37

4.11-5 Critical Means Table for 20 Comparisons--Background

Contanination Indicator Parameter Data for the Single-Shell

Tanks Waste Management Area A-AX ...............11-42

4.11-6 Crittcal Means Table for 28 Comparfsons--Background

Contanination Indicator Parameter Oata for the Sing]e-Shell

Tanks Waste Panagement Area B-BX-BY ......... 4.11-43

4.I1-7 Critical Means Table for 16 Comparisons--Background

Contamination Indicator Parameter Data for the Single-Shell

Tanks Waste Management. Area C .......... 4.11-44

4.11-8 Critical Means Table for 28 Comparisons--Background

Contamination Indicator Parameter Data for the Single-She]l

Tanks Yaste Management Area S-SX .......... 4.11-45

4.11-9 Critical Means Table for 20 Comparisons--Background

Contanination Indicator Parameter Data for the Single-Shell

Tanks Waste Management Area $\mathrm{U} \ldots \ldots . . . . . .4 .11-46$

4.11-10 Water Level Declines in RCRA Mells: ......... 4.11-47

4.11-11 Water Leve1 Measurements 1991-1995........... 4.11-49

4.I1-12 Hydraulic Gradients at Single-She11 Tank

4.11-13 Groundwater Flow Velocities Unconfined Aquifer

Beneath Single-Shell Tank Waste Wanagesient Areas . . . . 4.11-52 
DOE/RL,-96-01, REY. O

This page intentionally left blank.

4.11-iv 
DOE/RL-96-01, REV. O

\section{II SIMGLE-SHELL TANKS}

\section{J. A. Caggiano \\ Hestinghouse Hanford Company}

\subsubsection{Introduction}

Although decomisstoned th 1980, the single-shell tanks (SST) are storing hazardous and radioactive waste and have been designated as Resource Conservation and Recovery Act of 1976 (RCRA) facilities. The groundwater beneath the SSTS is monitored by an interim-status RCRA groundwater monitoring network that was inftiated in 1989 (Jensen et a1. 1989). The SST monitoring network contains 35 RCRA-standard groundwater monitoring we11s. No wells were constructed this year. Three other wells monitor the top of the unconfined aguifer and comply with construction standards in Hashington Adrofnistrative Code (WAC) 173-160. These wel1s are Tocated around Waste Management Area (MWA) B-BX-BY and can be used for collecting groundwater samples for analys is of hazardous and radfoactive constituents. AIT SST waste management areas now comply with the RCRA requirement to have at least one upgradient and three downgradient wells. An additional 30 wells are used to measure water levels. Mast of these wells are older carbon steel wells, but some are RCRA-standard wells constructed for other projects. Table 4.11-1 lists the wells in the SST monitoring network.

Final disposition of SSTs and their contained waste is discussed in a closure/corrective action work plan submitted to the Washington State Department of Ecology (Ecology) in 1989 (COE-RL 1989). Revision 1 of this closure plan was submitted to Ecology in June 1995. Chapter 5.0 of the original closure $\mathrm{plan}$ on groundwater and groundwater wonttoring (DOE-RL I989) has been revised and is Appendix 2A of Revision A DOE-RL (1995). Appendix 2A also covers vadose zone characteristics and processes. The SST's are included in the following six source operable units.

\begin{tabular}{ccc}
$\begin{array}{c}\text { Waste } \\
\text { Management Area }\end{array}$ & $\begin{array}{c}\text { Source Operable } \\
\text { Unit }\end{array}$ & $\begin{array}{c}\text { Goundwater Operable Un1t } \\
\text { Ground }\end{array}$ \\
\hline$A-A X$ & $200-P 0-3^{\circ}$ & $200-P O-1$ \\
$C$ & $200-P O-3^{\circ}$ & $200-B P-5$ \\
$B-B X-B Y$ & $200-B P-7$ & $200-B P-5$ \\
$S-S X$ & $200-R 0-4^{\circ}$ & $200-U P-1$ \\
$T$ & $200-T P-3$ & $200-2 P-1$ \\
$T X-T Y$ & $200-T P-5$ & $200-Z P-1$ \\
U & $200-U P-3$ & $200-U P-1$ \\
\hline
\end{tabular}

'Includes one or more adjoining double-she11 tank farms.

Aitthough each SST farm (or groups of adjoining farms) is in a CERCLA aperable thit, the SSTs will be closed as RCRA TSD units. The radioactive component of the waste is regutated under the Atomic Energy Act of 1954. DOE is responsible for administration and compltance. The hazardous component is 


$$
\text { DOE/RL-96-01, REV. ? }
$$

regulated under the Washinyton Hazardous Waste Managenent Act of 1976. Ecology regulates the SST5 as RCRA treatment, storage, and disposal (TSO) units under WAC 173-303. RCRA/CERCLA conflicts are addressed as they are dtscovered. Groundwater beneath the SST farms is part of groundwater operable units (previously listed) that are being remediated under CERCLA. Further discussion of the regulatory process related to final disposition of the SSTs can be found in Chapter 3 of DOE-RL (1995).

4.11.1.1 Facility 0verview. The 149 SSTs are located in 7 WAs containing one or more tank farns. Three wAs are located in the 200 East Area (A-AX, $\mathrm{B}-\mathrm{BX}-\mathrm{BY}$, and C). Four are located in the 200 West Area (S-SX, T, TX-TY, and $U$ ) (Figures $1-1,4.11-1$, and 4.11-2). Each tank farm contains from 4 (AX Tank Farm) to 18 (TX Tank Farm) underground reinforced concrete tanks. Each tank has a single liner of carbon steei. The larger tanks have diameters of $22.86 \mathrm{~m}$ (75 ft), have varying heights, and are buried at least $1.8 \mathrm{~m}$ (6 ft) below the ground surface. Depending on their dimensions, these tanks hoid between $1,892,500$ and $3,785,000 \mathrm{~L}(530,000$ and $1,000,000 \mathrm{gal})$. They were constructed between 1943 and 1964. Tank farms $B, C, T$, and $U$ contain four 200-series tanks each. These tanks hold 208,175 L (55,000 gal).

The SSTs activeity store metal and first- and second-cycle radioactive and hazardous (i.e., mixed) waste received from chemical processing facilities in the 200 Areas of the Hanford Site. Types of waste added to the 55Ts and their general composition are discussed in Anderson (1990). The waste in the SSTs was generated by chemical processing of spent fuel rods from several reactors located in the 100 Areas of the Hanford Site, using the tributyl phosphate, bismuth phosphate, Reduction-0xidation, or Plutonium-Uranium Extraction (PUREX) process. Isotopes for various weapons systems were recovered in these processes and subsequentily refined to weapons-grade materials.

The S\$Ts received mixtures of organic and inorganic liquids containing radionuclides, solvents, and metals that were originally discharged to the tanks as alkaline siurries. Waste management operations have mixed waste streams from numerous processes and batches that were generated while processing spent fuel rods. This mixing and subsequent chemical reactjons and radionuclide degradation and decay make the specific contents of each tank difficuTt to determine. The radionuclide and chemical inventory of the SSTs was summarized in a Westinghouse Hanford Company (WHC) report (WHC 1993). H'storical operations at the tank farms are summarized in Anderson (1990).

The last SST was removed from active service in 1980 . Because discharges to the SSTs stopped in 1980 , some of the tanks have been interim stabilized by removing the supernate and interstitial liquids to minimize the potential for leaks. As of July 1995, 111 5STs have been interin stabilized. Some tanks were interio isolated by removing piping to prevent the inadvertent addition of 1tquids to the tanks. (See Hanion [1995] for detaijs.)

Presently, the SSTs cumulatively store about 140,045,000 L (37 kgal) of waste that consists mostly of salt cake and 5 ludge (the residue from pumping free liquids to the double-shell tanks). The waste al so contajns small quantities of supernate and interstitial jlquids that could not be removed by puraping. The waste is largely inorganic and consists primarily of sodium hydroxide and sodium salts of nitrate, nitrite, carbonate, aluminate, and phosphate. Some hydrous oxides of iron and manganese also are present. 
Fission-product radionuclides (such as ${ }^{137} \mathrm{Cs},{ }^{90} \mathrm{Sr},{ }^{99} \mathrm{Tc}$ ) and actinide elements (such as uranium, thorium, plutonium, and neptuniug) are the principal radioactive components of the waste. Some of the SSTs are "watch List Tanks" because they contain ferrocyanide or organic salts, they could possibty release hydrogen, or they generate high heat from the radioactive decay of thefr contents. (See Hanlon [1995] for detalls.)

The SST Tiners are made of carbon steel that was not treated during fabrication to reileve stress. Consequently, heat-induced stress-corrosion cracks have developed along with other stress-caused changes from fluctuating Iiquid Tevels and temperatures in the tanks. These changes have caused sone of the steel liners to fail and liquids to escape from some of the tanks. Of the 149 SSTs, 67 are assured to be Jeaking (Hanion 1995). The Jargest known Teaks occurred at Tank 241-T-106 in 1973 (estimated at 435,275 L [115,000 gai]) and Tank 241-BX-102 in 1971 (estimated at 264,950 L $[70,000 \mathrm{gall})$. Most leaks are estimated to be considerably smaller.

Water was added to some tanks (e.g., Tank 241-A-105) to control temperatures, which prevents degradation of the reinforced concrete. Some of this water also may have leaked from the tanks. The earljest leaks at the SSTs were detected in the late 1950's. The most recent change to the 11st of assumed Teakers was made in February 1994 when Tank 241-T-111 was declared an assumed releaker because measurements showed a trend of in-tank 1tquid 7evels decreasing. The 241-T-111 Tank was initiaily dec]ared to be of questionable integrity in 1974. No changes were made to the list of assumed leakers in 1995 .

Whether any contaminants in the groundwater in the Separations Areas were derived from the waste leaked from the SSTs or whether they were from nearby unlined waste disposal facilities such as crfbs, trenches, or ponds that recetved Tiquid wastes containing similar constituents is uncertain. Analyses of gross gamma logs from dry wel1s adjacent to Tank 241-T-106 indicate that the leaked waste appeared to stabilize in the vadose zone weil above the groundwater (Routson et a]. 1979). The maximum detected depth of the 1-pCi/L concentration of ${ }^{106}$ Ru (following the $T-106$ leak) was $28.8 \mathrm{~m}$ (95 $\mathrm{ft}^{\mathrm{t}}$ ) above the regional water table, while the depth to groundwater beneath the tanks exceeds $30.3 \mathrm{~m}$ (100 ft). Hodeling studfes usting ${ }_{\mathrm{Ru}}$ (Smoot et a1. 1989) suggest that some of the leaked waste from Tank $241-T-106$ may have reached groundwater. In 1993, a borehole (299-W10-196) was drilled through the waste plume leaked from this tank and, at least in this borehole, the waste is still

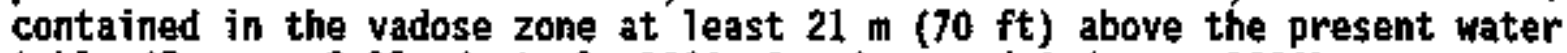
table (Freeman-Pollard et al. 1994, Caggiano and Anderson 1994).

Liquid observations wells (LOW) and liquid-monjtoring devices are used in the tanks to detect changing i iqutd levels. A series of vertical welis tn the unsaturated zone (đry we77s) around the periphery of each tank augnent this monttoring system. Two of the tank farms ( $A$ and $S X$ ) each have a series of three lateral lines beneath each tank extending from a $3.6-m-$ (12-ft-) diameter caison. The lines have been periodically monitored by gross gama probes to detect radioactive decay counts elevated above baseline and to observe any changes in the detected peaks.

Spectral gama logging in the dry wells and laterals around SSTs using high-purtty germanium lodide sources is now being performed by RUST Geotech 
under contract to the U.S. Department of Energy, Richland Operations Office (RL). Spectral gamna logging replaced gross gamma surveillance logging in 1995. The plan is to $l o g$ each dry well around each tank in each tank farm. Logging has been completed tn the 241-5X Tank Farm and is under way in the 241-y Tank Farm. These first logging runs witl ford a baseline against which future logs will be compared to detect changes from decay and/or transport. Characterizing the waste in the vadose zone and determining its mobility are significant because this uncontained waste could infiltrate to groundwater. A partial list of documents released to date about spectral gama logging of 5ST farms is included in the reference list.

In late 1993, new methods for detecting leaks at the SSTs were implemented in accordance with a new leak-detection strategy that was issued in July 1994 (WHC 1994). Gross ganua logging in external dry wells is no longer used to detect leaks at SSTs, al though logging wiTl cont inue temporarily until Lows have been installed in all 149 SSTs. Currentiy 61 tanks have LONs; additional wells are being installed each year in tanks containing pumpable liquids. Logging in the LOWs and measuring liquid levels in the tanks using Food Instrument Corporation equipment or manual tapes will be the primary methods of leak detection. It should be noted that technology is not available to detect the minjmum leak from an SST under RCRA regulations (currently $2 \mathrm{~kg}$ or $7.5 \mathrm{~L}$ [2 gals]) and that WHC is implementing best available technology in an effort to comply with the RCRA requirement.

Stratigraphy beneath tank faras in the 200 Areas is generaliy summarized in Chapter 2.0. More detajl about the stratigraphy beneath the 200 Areas are included in Section 4.1 of the 1993 annual report (Ford and Trent in DOE-RL 1994), which also contains figures showing numerous cross sections through the 200 Areas. Detaj1s of stratigraphy beneath each WMA are tncluded in the groundwater monitoring plan for the SSTs (Jensen et a1. 1989, Caggiano and Goodwin 1991). In genera], network groundwater monitoring wel]s in the 200 East Area are screened in the Hanford formation (WWA B-BX-BY) or the Ringold Formation (WiAs $A-A X$ and $C$ ). Wells in all whis in the 200 West Area are screened in the Ringold Formation (mostly in the Ringold unit $E$ gravels, most of which previously were deslgnated as the Middle Ringold).

4.11.1.2 Summary of 1995 Activitfes. A11 of the existing RCRA we11s were sampled quarterly or semiannually in 1995. Wells in WMAs T and TX-TY were sampled quarterly because they are in assessment monitoring status. AT other WAs were sampled in March and September. The data from all wel] sampling are reported in quarterly reports (Caggiano 1995b, 1995c, 1995d, 1996). Water levels were measured monthly in alt the RCRA-standard wells and tn 19 older non-RCRA wells. Hater level measurements are also included in the quarterly reports.

Wells near WMAs $T$ and TX-TY were evaluated for incorporation into an expanded network for groundwater quality assessment monjtoring. Several RCRAstandard groundwater monitoring wells for low-level burjal ground (LLBG) WhAs 3 and 5 were incorporated into the expanded network. Site-specific radionuclides were added to the constituent list for these wells in an effort. to determine the potential source of elevated field specific conductance, which triggered these two MAs into assessment monitoring. WHC is currently greparing an assessment report on WMAs $T$ and TX-TY. 
Measurements of water level in an expanded network of wells at WA $U$ confirmed that the direction of groundwater flow beneath this facility has changed (see WWA $U$ hydrograph on Figure 4.11-3). The origina] groundwater monitoring network was planned and installed beginning in 1989 when groundwater flow was to the northeast. The northeast direction of groundwater flow was in response to the 200 West Area water table mound that originated beneath the 216-J-10 Pond in the southwestern part of the 200 West Area. Since decommissioning of that facility in 1984, the apex of the water table mound has declined and moved eastward in response to the addition of 1 lquid effluent to other facilities (e.g., the 216-j-14 Ditch). Even though the highest point in the 200 West Area water table is north of WMA $U$ (Figure 4.11-4), the apex of a local water table mound is now located southeast of Win $v$ resulting in groundwater flow shifting to a northwestern direction. The configuration of the water table is expected to change because liquid discharges to the soil column ceased in June 1995.

A north-northwest direction of groundwater flow beneath WHA $U$ was confirmed in Hay 1995 when the borehole velocity flowmeter was run in wel1s 299-W19-31 and 299-W19-32. The flowmeter was set at three different levels within the screen of each well and measurements of flow direction and groundwater flow velocity were made. Each of these wells is screened in untt $\mathrm{E}$ of the Ringold Formation. Data obtained during the flowmeter testing are presented in Table 4.11-2. Note that a different direction of groundwater flow was measured in well 299-W18-25. The effjcjency of the grounchater monitoring network at WHA $\mathrm{U}$ (determined by MENO [Jackson et aI. 1991]) ts now 24.8\% for a north-northwestern direction of flow. The borehole velocity flownteter will be run in WMA $U$ wells periodically for the next year. This monitoring will ascertain whether this groundwater flow direction is permanent and help determine whether and where to construct a new well.

4.11.1.3 Other Activities in 1995. A RCRA-standard we11 (299-w10-22) was constructed north of WMA $T$ in 1994 as part of a groundwater impact assessment for the 216-T-4-2 ditch. A groundwater impact assessment report (Alexander et a1. 1995) on this facility was released in February 1995 and includes data on groundwater guality from this well located a few hundred feet north of WNA $\mathrm{T}$.

Spectral gamwa logging of vadose zone borings (dry wells) around the SSTs is now being performed by RUST Geotech under direct contract with BOE. Logging is proceeding by tank farm (RUST 1995). A report for the 241-5X tank farm is in preparation. Individual tank data reports have been prepared.

During 1995, the Environaental Restoration Contractor (ERC) conducted pump-and-treat operations in a nuaber of wells for operable units 200-BP-5 (northern 200 East area), 200-UP-1 (southern 200 West area) and 200-2P-1 (northern 200 Hest area). Groundwater was extracted from sone wells, passed through an ahove-ground treatment system, and then returned to the aquifer via injection wells. The feasibility of pump-and-treat systems was tested for both the 216-B-5 reverse well and the $216-\mathrm{BY}$ cribs in operable unit 200-BP-5 (DDE 1995e). These faciljties are located south and north of WHA B-BX-BY. To date no effects of these withdrawal and reinjection systems were observed on water Tevels or hydrochemistry in weils in WMA B-BX-BY. 


\subsubsection{Sampling and Anatys is Progran}

Groundwater beneath the \$STs is being monitored by a RCRA interim-status groundwater monitoring well network as specifled in the original groundwater jonitoring plan (Jensen et a1. 1989) and its revision (Caggiano and Goodwin 1991). Background values for indicator parameters have been established at each WMA. However, because groundwater flow has changed direction beneath WMA $U$, background values were recalculated for this site. Wells 299-119-31 and 299-W19-32, which were installed as downgradient wells, are now upgradient of this facility. Indicator parameter evaluatjon monitoring is occurring at all WhAs except MAS $T$ and $T X-T Y$, which are in assessment monitoring.

4.11.2.1 Monitoring Nel1 Metwork. Thirty-eight RCRA-standard welis monitor the SSTs; 3 of these we11s are part of other monitoring networks surrounding WMA B-BX-BY (see Table 4.11-1). An addftional 19 older carbon steel wells have been used to measure water levels. Older carbon steel wells within the perimeter fences of the tank farms have been removed from the water level monitoring network. Groundwater monitoring weIIs are shown in Figures 4.11-5 and 4.11-6 and are listed in Table 4.11-1. A71 RCRA-standard we 11s are Tocated outside the perimeter fences of the tank farms and at least 30.3 i (100 ft) from the nearest tank (in accordance with an agreement with Ecology). This agreement was reached to avoid drilling through contaminants in the unsaturated zone and driving then to groundwater during well construction. As a further precaution, cable tool driling is initiated with 30.5-cm- (12-in.-) or larger-diameter casing so that any string of casing can be terminated in a zone of contamination (or perched water) and the well drilling can be continued wth smaller diameter casing inside (if dritiling is continued after. an evaluation of field data). The first 12 RCRA groundwater nonitoring wells were installed in 1989 at WhAs $A-A X, B-B X-B Y, C$, and $T$. Eleven more were installed in 1990 at wAs $A-A X, B-B X-B Y, S-S X$, TX-TY, and U. Ten additiona] wel7s were constructed at the SST's in 1991 at WMAs B-BX-BY, S-SX, T, TX-TY, and $U$. Two were constructed in 1992 at whAs $A-A X$ and $S-\$ X$.

Fifty-one welis constructed of carbon steel casing before 1986 penetrate the uppermost unconfined aquifer withtn $300 \mathrm{~m}(1,000 \mathrm{ft}$ ) of the SSTs. The casing in these wells is perforated at various lengths and intervals to communicate with the unconfined aquifer. Hhen constructed, these we11s generally lacked annthar or surface seals and do not have nonreactive screens and filter packs surrounding the screens as required by WAC 173-160 for newly constructed monitoring (resource protection) wells. Partial annular seals were installed in some of these wells in the 1970's. Some of these wells have been used to measure water levels around the SSTs (see Table 4.11-1).

4.11.2.2 Sampling and Analysis. Groundwater sabpling began in February 1990 in we17s that were completed in 1989 and in sowe existing wells, but this activity was terainated in May 1990 because a contract was not in place for a supporting analytical Jaboratory. Quarterly sawoling of wells in hMA A-AX, $B-B X-B Y, C$, and $T$ was resumed in July 1991 . Wells in WAs $S-S X$, TX-TY, and $V$ were first sampled in October 1991. Analytical data have been reported in quarterly reports 1 isted in Section 1.1. Four quarters of background data have been obtajned at all Whas; however, background for tox for hils $U$ is being recalculated because of the change in groundwater flow direction. Groundwater is now sampled seraiannually at WHAS $A-A X, B-B X-B Y, C, S-\$ X$, and $U$ and analyzed 
for indicator parameters. Annual sampling for analysis of groundwater quality and site-speciftc parameters has occurred at these five MAs also. Quarterly sampling is conducted at WMAs $T$ and $T X-T Y$ because these sites are in groundwater quality assessment monttoring under interia status.

Groundwater samples from SST monitoring wells were analyzed for dri.sking water standards (CW5), indicator parameters, and water qual ity parameters (Table 4.11-3) during the period of background monitoring. Samples also were analyzed for ${ }^{137} \mathrm{Cs},{ }^{90} \mathrm{Sr},{ }^{99} \mathrm{Tc},{ }^{60} \mathrm{Co}$, and tritium because these were among tro key radionuclides discharged to the \$STs. SampTes are analyzed for 1 semiannual1y as a part of another program and the data are included for the SSTs. Total uranjum and piutonfum al so were monitored. Gamma scans were run on samples from SST wells. All SST twas except T and TX-TY are now in indicator-parameter evaluation status and are sampled semiannualty for Indicator paraieters and annually for selected groundwater-quality parameters and site-specific parameters (as shown on TabTe 4.11-3). Only filtered samples are now analyzed for metals. Site-specific constituents are analyzed only in samples from MMA $T$ and TX-TY.

\subsubsection{Groundwater Chemistry Evaluation}

4.11.3.1 Possible Sources. In addition to indicator parameters, certain other constituents identified in Tabie 4.11-3 were monitored during indicatorparameter evaluation in 1995. Because these constituents were also discharged to nearby cribs, tunlined specific-retention trenches, unlined ditches, French drains, and ponds (sone of which are upgradient of SST tank faras), distinguishing the source of these contaninants in groundwater is not possible. Ho unique indicator analytes are known that would allow tracing of contaminants directly to the SSTs as a source. If a leak from any SST had reached groundwater (jnvestigations of tank leaks indicate leaks are confined to the vadose zone well above groundwater), the analytes discharged to nearby cribs would overwheTmingly mask any contribution from the leaking tank. During operations, supernatant from the last tank in a cascade 1 ine was dtscharged to nearby cribs at times to make space for additional discharges to the SSTS. Some of this discharged supernatant may have infiltrated to groundwater.

4.11.3.2 ETevated Constituents. A number of constftuents have exceeded regulatory limits in RCRA groundwater monitoring weITs at SST WMAs. These exceedances are stinmarized in Table 4.11-4. Beginning in 1995, only filtered samples were analyzed for ICP metals and only exceedances of filtered oetals appear in Table 4.11-4.

Turbidity in samples often exceeds the WAC standard of 1 nephelometric turbidity unjt (NTU) for surface water, but is not included in this table. However, in previous analyses, turbidity appears to affect results for metals at about 30 NTU. Therefore, sample collection targets a turbidity of 5 NTU and no sample is collected if turbidity of the groundwater exceeds 20 NTU. A17 SST WMAs in the 200 East Area are located above a plume of ${ }^{2} 1$ that has been mapped in groundwater (Connelly et al. 1992a, DoE 1995). Host values for ${ }^{139}$ I in groundwater from 200 East Area $\$ S T$ wells are between 1 and $10 \mathrm{pCj} / \mathrm{L}$ (see Table 4.11-4 and Figure 2.8). 
Chroaiun in filtered analyses of groundwater in well 299-E24-19 at Mis A-AX has been erratic (Figure 4.11-7). This constituent exhibited a steady rise to 1,800 ppb in Movenber 1992, decilined to $280 \mathrm{ppb}$ in March 1993, and then rose again to $960 \mathrm{ppb}$ in June 1993. Results for filtered chromium in 1994 dectined to 1ess than the 100-ppb ows before rising again to 410 ppb in 1995. Results for filtered analyses of nickel and manganese have shown similar trends, but the concentrations have been lower. No other constituents appear to exhibit this trend and there has been no significant change in pH or specific conductance to accompany thts change. This is the only downgradient well at WHA-AX exhibiting this trend. Ho new leaks or spills of dangerous waste have been reported in elther the 241-A or 241-AX tank farm that might account for this phenomanon.

Groundwater contaminant plumes beneath the 200 Areas have been mapped (Ford 1993, Johnson 1993). Contaminants in groundwater include constituents dfscharged to SSTs. These constituents were al so discharged to unT ined cribs, ditches, French drains, and ponds at lower activity levels. Ho unique indicator contaminants are known that trace soleily to the SSTs as a source. Therefore, it is not possible to state unequivocally that the SSTs have not contaminated groundwater. A similar point was wade by Caggiano (1991b) regarding the fate of cooling water added to Jank 241-A-105 between 1971 and 1978. Routson et al. (1979) demonstrated that the contaminants that leaked from Tank 241-T-106, the Targest known tank leak at the Hanford Site, did not reach the water table and had stabilized in the vadose zone. A single borehole drtiled in 1993 through the platie of waste leaked from Tank 241-T-106 indicated that the waste that leaked in 1973 still appears to be confined to the vadose zone (Freeman-Pollard et a). 1994). Whether contaminants leaked from any of the SSTs have penetrated the entire vadose zone to reach groundwater is unknown, supernatant was pumped from the last tank in a cascade line of SSTS to cribs during earlier operations at the Hanford Site. Whether the SSTs have contributed to contamination of groundwater at the Hanford Site regajns equivocal.

As stated in Section 4.11.1, field specific conductance in downgradient well 299-W10-15 at WMA $T$ and wel's 299-W10-17 and 299-W14-12 at WMA TX-TY exceeded the critical mean for this parameter and triggered these sites into groundwater quality assessment monttoring under 40 CFR 265 . Field specific conductance in these wells has historically been high during RCRA sampling and continues to be elevated. Quarterly sampling during assessment monitoring was used along with historical groundwater monitoring and waste management data to identify nitrate and chloride as the causative constttuents. Large volumes of these constituents were discharged to nearby cribs, trenches, and ponds, with significantly elevated nitrate in several older wolls surrounding these facilities in the nid-1950's. Wtth crib-derived nitrate (and probably also chloride) tn groundwater before any SSTs were reported leaking, deterwtning whether leaking \$STs may bave contributed to degradation of groundwater quality is not possibie. Elevated specific conductance is areally widespread in groundwater in the northern part of the 200 hest Area. (See Johnson 1993, Figure 5-37.)

4.11.3.3 Analyte Trends. For most constituents in most we11s, analyte concentration and activity during RCRA sampling/analyses have shown no apparent trend. Some exceptions are discussed in the following: 
- Mim $\boldsymbol{N}_{\mathrm{AX}}$. Tritium activity has been decilining since 1991 in well 299-E25-40 at WMA A-AX. This upgradient well is downgradient of the 216-A-8 and 216-A-24 cribs, which received substantial quantities of PUREX liquid effluent. A similar decline in tritium over a longer time is seen in upgradient we17 299-E25-2

(Figure 4.11-8).

- Wh B-BX-BY. Nitrate and chioride have been steadily increasing in downgradient we73 299-E33-32 at HilA B-BX-BY and may have been causing a corresponding increase in specific conductance, which is approaching (but not exceeding) the critica] nean. These anions have more than dotrbied in concentration since the onset of monitoring in this well in 1992. However, the concentration of chloride aiso has been increasing in upgradient well 299-E33-33. This appears to have caused a rise of specific conductance by about $60 \mu$ mios/cn since 1992. Wel1 299-E33-33 was used to calculate the background criticai mat for indicator parametars for this site. The quality of groundwater in both the upgradient and one downgradient we]] is changing with time, reflecting dj]ution by a westward-extending lobe of "fresh" water from B Pond.

- NHA C. Gross beta and ${ }^{\%}$ Tc activities have declined steadily since 1991 in upgradient wel1 299-E27-14 at WMA C. Conversely, these two constituents have risen steadily since 1991 in downgradient we 7$]$ 299-E27-13. While the changes have been enough to make these trends apparent, the DWS has not been exceeded or even approached.

- WH S-sX. Gross beta, ${ }^{99} \mathrm{TC}$, and nitrate have declined significantly since 1993 in downgradient we11 299-W23-15 at Wilh 5-SX. Technitiun-99 and gross beta have been slowly increasing since 1992 in wel1 2-W22-39. Tritium in wells 299-W23-14 and 299-W23-15 has been declining steadily since 1992, but 1s still above the Dis of $20,000 \mathrm{pCi} / \mathrm{L}$. Tritium has been increasing in well 299-422-46 since 1993, but is still below the OWS. Trittum began a slow increase in late 1994, which has continued into 1995, moving from less than $1,000 \mathrm{pCi} / \mathrm{L}$ to about $1,600 \mathrm{pCi} / \mathrm{L}$.

- WHA TX-TY. Fie7d specific conductance has been slowly declining in downgradient we11 299-W10-17 (WHA TX-TY) since 1991 and is approaching the critical mean calculated in 1992. Along with elevated specific conductance in well 299-N14-12, specific conductance in this wel1 triggered WHA TX-TY into groundwater quality assessment monitoring in 1993. Field specific conductance in upgradient well 299-W15-22 has been slowly jncreasing since 1992 and now averages about 600 pansos/cm. Filtered sodium began increasing in downgradient we11 299-H14-12 in late 1994 and continues into 1995. Sodiun values have increased from about 25,000 ppo in 1994 to 31,000 in 1995. Technitiun-99 and gross beta increased in downgradient well 299-W10-18 in 1994 and 1995. Tritium is increasing in upgradient well 299-W15-22, but decreasing in downgradient we11 299-W10-18.

- Win $v$. The change in groundwater flow direction beneath WHA $U$ has caused some changes in the concentration/activity of some analytes. 
Gross alpha and uranium have increased noticeably in well 299-W19-32. Chloride, which rose steadity from 12,000 ppb in 1991 to 30,000 ppb in 1994, appears to have stabilized at about 28,000 ppb in 1995. Nitrate in well 299-w19-32 decifned steadily in 1994 from about $18,000 \mathrm{ppb}$ to about 2,000 ppb and appears to have stabtlized at Tower concentrations. Hitrate has steadily increased in wells 299-W18-25 and 299-W18-31 since 1993 and began increasing In wel1 299-W18-30 in 1994 (Figure 4.11-6). In 1995, gross beta and "Tc have also declined 10 we 11 299-419-32 from peaks in 1993 (60 $\mathrm{pCi} / \mathrm{L}$ and $300 \mathrm{pCi} / L{ }^{9} \mathrm{Tc}$, respectively) to values of less than $50 \mathrm{pCi} / \mathrm{L}$ in 1994 and stabilized at these Tevels in 1995. These trends appear to be continuing. These changes are an expected consequence of groundwater contamination emanating from cribs upgradient of Wik $U$ where wastes generated from urantum recovery oporations in the 221-U PIant (Uranium Oxide Plant) were discharged to ground.

Pre-RCRA Historical Data. A general decrease in the concentration and activity of analytes can be seen in data when comparing results from analyses performed in the 1950's, 1960 's, and 1970's with those performed during RCRA sampling/analyses. However, the analysis methods and detection limits have changed as have the wells that were sampled. The construction of the older carbon steel wells and the section of the unconfined aquifer sampled differ significantly from RCRA wells. Older wells have perforated carbon steel casing ranging in length from 6 to $30+\mathrm{m}$ (20 to 100+ ft), have no annular seal or filter pack, have experienced varying degrees of development, and may have been sampled by varying types of pumps or bailers during thetr history. The data are not directly comparable.

Contaminants 1 isted as elevated in Table 4.11-4 generally have been elevated to varying degrees in nearby older carbon steel wells at varying times during the well's sampling history. Few wells have been consistently sampled throughout their lifetimes; many were sampled while the facility that the well was monitoring operated, but long intervals with no sample data avajiable are common. One that was regularly sampled is well 299-W15-4, which is located adjacent to the $216-T-19 \mathrm{crib}$ and tile field and recejved $455,000,000 \mathrm{~L}(120,211,000 \mathrm{gal})$ of process condensate, second-cycle SST supernatant and stear: condensate from processing plants and an evaporator. The 216-T-19 crib and tile field is located adjacent to the south perimeter fence of the 241-TX Tank Farm in 200 West area (operable unft 200-TP-2) and was intermfttently active frow 1951 to 1980 . Figure 4.11-8 1llustrates variations in nitrate and tritium (two commonly and nearly continuously monitored constituents) in this we 1 over time. WIDS indicates that this crib received $150,000 \mathrm{~kg}$ nitrate, $18,000 \mathrm{~kg}$ ammonium nitrate, and many curies of tritium, wich had decayed to $4.25 \mathrm{cl}$ by 1989 . Tritium, with a haif Iife of 12.3 years, has declined significantly in this well from its peak of $5,600,000 \mathrm{pCi} / \mathrm{L}$ in 1973 , but is st111 we11 above the 20,000-pCi/L oHs for this constituent. The decrease in activity is likely caused by difution, decay, and transport. Nitrate concentration is declining at a much slower rate because it is chemicaliy stable. Ntrate is stilf above the $45,000 \mathrm{ppb}$ ows. The high nitrate concentration (in this well and this area) accounts for a significant part of the elevated specific conductance that has triggered WA TX-TY into grouncwater quality assessment monitoring under interim-status regulations. 
Another regularly sampled welt is 299-E25-2, a carbon steel well located adjacent to the 216-A-1 crib and downgradient of the 216-A-8 $\mathrm{crib}$. The 216-A-1 crib operated briefly in late 1955, but the 216-A-8 crib operated intermittentiy from 1955 to 1995 receiving waste from PUREX operations. The total volume of liquid effluent disc.,arged to the 216-A-8 $\mathrm{crib}$ was $1,150,000,000 \mathrm{~L}(303,831,000 \mathrm{yal})$. As of December 1989, $0.35 \mathrm{C} 1$ of tritiua remained from the large quantity discharged over time. A single value for trititum in 1967 showed nearly $900,000 \mathrm{pCi} / \mathrm{L}$ of tritju in this well.

Figure 4.11-8 illustrates the caciline in tritiur activity with time in this we11 from 1977 through 1989 reflecting decay, dilution, and transport.

To evaluate contamination in groundwater beneath the SSTs relative to total contasination of groundwater in the 200 Areas, the reader is referred to contaminant plune maps elsewhere in this report or those contained in Johnson (1993), Ford (1993), or the 1993 RCRA annual report (DOE-RL 1994).

4.11.3.4 Statjstical Evaluatjon. Background sampling and analyses have been completed at a11 WAAs. Tables 4.11-5 through 4.11-9 present the critical means for a]1 WHAs. Prevlous RCRA groundwater monttoring at the SSTs is summarized in other annua] reports (Cagglano 1991a, 1992a, 1993, 1994).

For a11 WHAs, the critical mean for TOC cannot be calculated because all of the background values taken from the upgradtent well (or wells) for Joc are below the contractualiy required quantitation $1 \mathrm{imit}$, and an estimate for the background standard deviation is not avallable. For these sites, a linit of quantitation (LOQ) is calculated from the 1995 field blanks data. Following I. S. Environmenta1 Protection Agency (EPA) guidance (EPA 1986), the LOQ wi11 be used as the TOC upgradient/downgradient comparison valte. This approach uses quality-control data to target the 1imit of quantifiable data and provide a realistic approach for upgradient/downgradient comparisons. The LOQ for TOC (analyzed by DataChem Laboratories) is $976 \mathrm{ppb}$ (see Appendix A for calculations).

For all WMAs, the critical mean for total organic halogen (TOX) is not calculated because audit findings of unsatisfactory were asstgned to the laboratory's quality control of analytical procedures for performing these analyses (see Section I.5-4). However, TOX data from downgradient wells were evaluated using methods described in Appendix C (see Section C.1.1).

4.11.3.4.1 Waste Management Area $A-A X$. The critical mean was not exceeded for field specific conductance, field $\mathrm{pH}, \mathrm{TOC}$, or TOX at WHA A-AX. Constituents that exceeded regulatory limits are jisted in Table 4.11-4.

4.11.3.4.2 Waste Wanagement Area B-BX-BY. The crftical mean was not exceeded for field specific conductance, fjeld $\mathrm{pH}, \mathrm{TOC}$, or TOX at WHA B-BX-BY. Constituents that exceeded regtrlatory linits are ifsted in Table 4.11-4.

4.11,3.4.3 Waste Management Area $c$. The critical mean was not exceeded for field specific conductance, field $\mathrm{pH}, \mathrm{TOC}$, or TOX at UMA $\mathrm{C}$. Constituents that exceeded regulatory 1 injts are 1 isted in Table 4.11-4.

4.11.3.4.4 Waste Managiant Area S-SX. The critjcal mean was not exceeded for field specific conductance, fleld $\mathrm{pH}$, TOC, or TOX at WHA $5-\mathbf{5 X}$. Constituents that exceeded regulatory limits are listed in Table 4.11-4. 
4.11.3.4.5 Waste Management Area T. The critica] mean (or critfca] range) was not exceeded for indicator parameters other than specific conductance at WNA T. Exceedance of the critical mean for field specific conductance triggered WhA $T$ into groundwater quality assessment monitoring status under 40 CFR 265. Jetails are in Section 4.11.1.2 and Caggiano and Chou (1993).

Field specific conductance values in woll 299-w10-15 have been both above and below the critic'l mean of $1,174 \mathrm{mmhos} / \mathrm{cm}$ during 1994 , but no consistent trend toward values below the critical mean has been observed. However, the variability of values for field specific conductance increased significantly this year. High conductivity of groundwater appears to be related to chloride, fluoride, and nitrate in well 299-N10-15, the woll that triggered this site into assessment monitoring under interin-status regulations. It is somewhat enigmatic that the high values for anions that were likely part of ifquid effluents discharged in this area are not accompanied by similariy high values for the radionuclides that were discharged in these solutions to nearby cribs, ponds, and trenches. Only tritium is significantly elevated, and it is elevated above the 20,000 $\mathrm{pCi} / \mathrm{L}$ I imit in upgradient well 299-410-16 as well as in downgradient weII 299-H10-15. Gross beta and ${ }^{9}$ Te were elevated in well 299-W10-15 in July, but these values depart significantly frow historical trends and are likely in error.

4.11.3.4.6 Waste Hanagement Area TX-TY. The critical mean (or critical range) has not been exceeded for indicator paraneters other than specific conductance at INA TX-TY. Exceedance of the critical mean for field specific conductance trfggered MMA TX-TY into groundwater quality assessment monitoring status under 40 CFR 265. Detaits can be found in Section 4.11.1.2 and Caggiano and Chou (1993). Constituents that exceeded regulatory Timits are Tisted in Table 4.1I-4.

4.11.3.4.7 Naste Management Area $U$. Statistical analyses required by 40 CFR 265.93 (b) and WAC 173-303-400 were performed on the salliples collected from July 1991 to May 1992 for upgradient wel]s 299-W19-31 and 299-W19-32. Resutts are presented in Table 4.I1-10, which lists the background average, background standard deviation, critjcal mean (or critical range, in the case of $\mathrm{pH}$ ), and the upgradient/downgradient comparison value for the contanination tndicator parameters. The comparison value is the value to which future averages of quadruplicate measurenents will be compared. In general, the upgradient/downgradient comparison value is the critical mean. As indicated in Section 4.11.3.2, critical mean for TOX was not calculated because the upgradient ToX values are above the MDL. Therefore, the quantitation 1 imit cannot be used as a surrogate for the critical mean. Statistical methods are described in Appendix $C$. Beginning in 1996, four quarters of TOX data will be obtained from upgradient wells.

The critical mean was not exceeded for fleld specific canductance, field $\mathrm{pH}$, or TOC at WHA $U$. Constituents that exceeded regulatory $11 \mathrm{mtt}$ s are listed in Table $4,11-4$. 


\subsubsection{Evaluation of Hator Levels}

4.11.4.1 Water Level Data. Water Tevels have been measured monthiy in at RCRA groundwater monitoring wells constructed in all WMA, as well as tn some older pre-RCRA wells. Hater level measurements for 1995 can be found in quarterly reports of RCRA groundwater monitoring (Caggfano 1995b, 1995c, 1995d, 1996). Data from these and other wells for june 1995 are plotted in Figures 4.11-4 and 4.11-9 to depict the general direction of groundwater flow. Across areas as small as most MAs, the difference in water level elevation is less than $0.3 \mathrm{~m}$ (1 ft), and in many cases less than $0.15 \mathrm{~m}(0.5 \mathrm{ft})$ (Table 4.11-11, hydrographs on Figure 4.11-10). To show direction of flow, data from 5ST welis and wells from other RCRA facilities have been combined into smalTer scale maps of larger areas to 111 ustrate the groundwater flow direction and gradient.

Hater level declines between June 1994 and June 1995 around SST MMAs are tabulated in Table 4.11-11. Water levels are measured monthly in 62 wells. Water level data are presented in quarterly reports (Caggiano 1995b, 1995c, 1995d, 1996). Water level trends can be seen on the hydrographs of 200 Area wells shown in Figures 4.11-3, 4.11-10, and 4.11-11.

From 1994 through 1995, the elevation of the water table has continued to decline beneath the 200 East and 200 West Areas because discharges to cribs, unitned trenches, and B Pond have decreased. A11 liquid effluent discharges to the ground ceased in June 1995 except for facilities that were granted operating permits by Ecology. As seen in Table 4.11-11, the declitie is not the same in all wells in a WaA. Differences in hydraulic conductivity may account for the different rates of decline between the 200 West and 200 East Areas shown on Figures 4.11-3, 4.11-10, and 4.11-11. Between June 1994 and June 1995 water levels beneath WMAs in the 200 East Area restmed a steady decline compared with 1994 when the rate of decline slowed noticeably (Table 4.11-11, flgure 4.11-10). From July to September the rate of water table decline again appeared to be slowing. The maximum declina in water level in SST wells in the 200 East Area from June 1994 to June 1995 was $40 \mathrm{~cm}$ $(1.32 \mathrm{ft}$ ) in we1] 299-W33-36.

Water Tevels in the southern part of the 200 West Area (WMAs S-SX and $U$ ) have declined between 50 and $120 \mathrm{~cm}$ ( 1.63 and $3.93 \mathrm{ft}$ ), with the declines in most wells being $49 \mathrm{~cm}$ (1.6 ft) or more (Figures $4.11-4,4.11-11$ ). The decline of the water table in 1995 accelerated rapidly beneath WA $U$ compared to the decline in 1994, with an average decline of $94 \mathrm{~cm}$ among 9 weils. The water level decline in the northern part of the 200 West Area resumed 1ts rate of decline from severa] years ago when the water table dropped at 7east. $45 \mathrm{~cm} / \mathrm{yr}(1.5 \mathrm{ft} / \mathrm{yr})$. The average water table drop for 11 wells beneath wA $T$ was $56 \mathrm{~cm}(1.85 \mathrm{ft}$.$) ; the average drop for 6$ wells beneath WMA TX-TY was 57 cot (1.88 ft.).

4.11.4.1.1 200 East Area Groundwater Flow Direction. For WHAs A-AX, $\mathrm{B}-\mathrm{BX}-\mathrm{BY}$, and $\mathrm{C}$, the controtiting influence of groundwater fTow is the water table mound beneath B Pond. Discharges to $B$ Pond have created this mound that has reversed the direction of flow from a west-to-east flow, which existed before Hanford Stte operations, to an east-to-west flow across the northern part of the 200 East Area. Along with the high transmissivity of the Hanford 
formation, the $B$ Pond mound creates a water table in the 200 East Area that slopes very gent1y.

Figure 4.11-9 11 ustrates that a low saddie in the water table exists beneath the 200 East Area. The saddle was created by both the regional eastward groundwater flow and the westward flow from the 8 Pand aound. Although difficult to demonstrate from water table elevations, past jong-term groundwater flow paths can be demonstrated by the digration of contaminant plumes from the area of the PUREX PIant as well as frow the 216-BY cribs in the northern part of the 200 East Area. Broundwater flow in the unconfined aquifer from the northern part of the 200 East Area is to the north toward Gable Mountain, while groundwater flow in the unconfined aquifer from the southeastern part of the 200 East Area is to the southeast. The top of the basalt (i.e., the botton of the unconfined aquifer in the 200 East. Area) slopes to the south along the north flank of the Cold Creek syncline, the axis of which p] unges southeast. The borehole velocity flownoter was run in several wells in operable unit 200-BP-1 this sumber, including a few SST water level monitoring wells (Kasza 1995, Lindberg 1995). The results tndicate that the groundwater divide in the 200 East Area is moving slowly to the north. The water table in the northern 200 East Area and the area immediately north is nearly fTat. The varjations in flow directions measured within and between wells with the borehole velocjty flow meter are consistent with this interpretation.

Groundwater flow across WHA A-AX is generally from the east to the westsouthwest. The hydraulic gradient calculated from June 1995 data is about 0.0005 . Groundwater flow across WHA $\mathrm{C}$ is generally toward the west. The hydraulic gradient calculated frow June 1995 water level data is about 0.0003 . Groundwater flow across WMA B-BX-BY is generally toward the west. The true direction of groundwater flow in this area of very low gradient in the northern part of the 200 East Area is difficult to determine accurately. The hydraulic gradient calculated from July 1995 water level data (April, May, and June 1995 data depart from the historical trend by $0.5 \mathrm{ft}$ because of an unknown error) is about 0.00008 .

4.11.4.1.2 200 West Area Groundwater Flow Direction. For Wils in the 200 West Area, the controliting influence on the direction of groundwater flow is the regional west-to-east gradient, as well as a water table mound that developed beneath the former 216-U-10 Pond (the U Pond mound) (see Figure 4.11-4). The U Pond received liquid effluents from 1944 to 1984. Since 1984, the $U$ Pond wound has been declining and the crest of the groundwater mound has been shifting eastward because the mound is decaying and loci of wastewater discharge are shifting (Serkowski and Jordan 1989, Kasza 1990, Newconer 1990, Kasza at al. 1992). Because the transmissivity of unit $E$ in the Ringold Formation (the principal stratigraphic unit of the unconfined aquifer in the 200 West Area) is lower, the $U$ Pond mound was higher and resulted in a steeper radtally outward gradient than the B Pond mound in the 200 East Area. (From June 1984 to June 1995, the water level in we11 299-N18-15 near U Pond had declined $7.6 \mathrm{~m}$ [25 ft].) Smaller groundwater mounds may have developed beneath some crjbs that recefved high volumes of liquid effluent in the early days of Hanford site aperations, but the data are not adequate to decipher any such small features. The water level around WMA U (in older carbon steel-constructed wel1 299-W19-1) is known to have fluctuated by about $2.4 \mathrm{~m} \mathrm{(B} \mathrm{ft)}$ from the 1ate $1950^{\prime} \mathrm{s}$ to 1984 when $\mathrm{U}$ Pond was 
DOE/RL-96-01, REV, 0

decontssioned. The water level in this well has declined more than $7.6 \mathrm{~m}$ (25 ft) since 1984 .

In the southern part of the 200 West Area, the direction of groundwater flow beneath MMA $S-S X$ is to the south-southeast. With the decline and eastward shift of the $U$ Pond mound, groundwater flow will assume a more southerly direction before eventuajy returning to the pre-Hanford \$ite westto-east flow. The hydraulic gradient calculated from June 1995 water level date is about 0.002 .

The direction of groundwater flow beneath WhA $T$ in the northern part of the 200 West Area is to the north-northeast. The gradient calculated from June 1995 water level data is 0.0006 . With the projected dec] ine in the U Pond mound in the next several years, groundwater flow is anticipated to return to the original pre-Hanford site west-to-east direction beneath this WHA.

The direction of groundwater flow beneath WisA TX-TY is to the north-northeast, similar to WMA $T$ imulediately to the north. The hydraulic gradient calculated fron June 1995 water level data is 0.0009 . With the anticipated further decline of the $U$ Pond mound, the direction of growndwater flow is expected to gradually shift to the reglonal west-to-east direction.

The direction of groundwater flow beneath WHA $\mathbf{U}$ in the southern part of the 200 West Area has been to the east-northeast. However, the water level in wel1 299-W19-32 has been trigher than in well 299-H18-25 by up to $9 \mathrm{~cm}(0.3 \mathrm{ft}$ ) beginning in late spring 1993. Water level data from an expanded water level monitoring network confirms that the apex of a water tabie round is now southeast of MMA U. The high point in the 200 West Area water table is still to the north of WMA U. A local water table mound southeast of MAA $U$ has resulted in a northwestern groundwater flow beneath WA $U$, which was measured with the borehole velocity flow meter in wells 299-WI9-31 and 299-W19-32 in early Hay (see Table 4.11-11). Water level data for June through Septeriber I995 indjcate a very gentle slope to the water table to the south-southwest (TabTe 4.11-11). The hydraulic gradient calculated from June 1995 water level data is about 0.0007 . Differences in hydraulic head between upgradient and downgradient we7]s are genera]ly less than $0.1 \mathrm{~m}(0.3 \mathrm{ft})$, within the probable range of combined error of geodettc survey measurements, depth to water measurements, and verticality of wells. The decline of water levels in an area of variable hydraulic conductivity through which a water table mound is migrating makes accurate determination of hydrautic head and gradient very difficult.

As seen from Table 4.11-11, groundwater levels beneath the 200 Areas are on a slow steady decline. The amount of decline of water level varies from well to welt within a network and with the location of the well. With the closure of chemical processing facilities at the Hanford Site, the volume of 1iquid effluents will continue to decrease; thus, artificial recharge also wi7l decrease. A7so, the discharges will be to locations where waste has not been prevfousty discharged to the soll. Reduction of 7iquid discharges is expected to result in a contilnued decline of water levels in SST groundwater monitoring wells. The discharge of liquids to the ground ceased in June 1995 except for discharges to facilities for which Ecology has granted a permit. 
4.11.4.1.3 Rate of Groundwater FTow. The groundwater gradient beneath the 200 West Area is steeper and better deffined than that beneath the 200 East Area where there is little more than a 30-cn (1-ft) difference in water table elevation between the eastern and western parts of the area (compare Figure 4.11-9 with Figure 4.11-4). Water table gradients are given in Table 4.11-12. The water table beneath the 200 East Area represents a broad hydraulic low area between westward-flowing water from the B Pond mound and the regiona1 eastward gradient (i.e., eastward flow from the 200 West Area, see figure $2-4$ ).

Groundwater flow velocities were calculated using equation (1) and are given in Table 4.11-13. Hydraulic conductivities were calculated fron analys is of single-well slug test data which Connelly et at. (1992b) found to be generally an order of magnitude lower than hydraulte conductivities calculated from constant discharge tests. Data from aquifer tests using constant discharge wethods are not available for any SST we71s; therefore, slug test data were used. Calculations used effective porosities of 10 and 20\%. Compare Tables 4.11-2 and 4.11-13 to compare calculated velocities to measured velocities in wells $299-W 18-25,299-W 19-31$, and 299-W19-32.

$$
v=\frac{R i}{n_{e}}
$$

where:

$$
\begin{aligned}
& y=\text { Groundwater velocity } \\
& k=\text { Hydraulic conduct } 1 \text { ifty } \\
& i=\text { Hydraul ic gradient } \\
& n_{*}=\text { Effective porosity. }
\end{aligned}
$$

4.11.4.2 Evaluation of Monitoring Mell Hetwork. Based on water levels measured in 1994 and 1995 and on tinterpreted direction of groundwater flow, the monitoring well networks for MA $A-A X, B-B X-B Y, C, S-S X, T$, and $T X-T Y$ appear to cowply with the requirement for piacentent of groundwater monitoring wel1s. The wells constructed as upgradient appear to be upgradient; wells constructed as downgradtent appear to be downgradtent. Groundwater flow direction beneath WHA $U$ has changed fron the northeast direction used to plan the original monitoring network. The present monitoring well network is inadequate and an additional RCRA-standard well may be constructed near the northwest corner of WMA $U$ to bring the network's efficiency to approximately $90 \%$ (as deternined by MEMO [Jackson et a]. 1991]). The direction of groundwater flow will be measured periodical1y in wells in Hith $U$ using the borehole velocity flowmeter to confirm that the north-northwest flon direction measured in May 1995 perststs.

Older carbon steel wells are present in all MAs and serve as screening wells for measuring water levels. Thus, nonitoring of the groundwater flow direction is more accurate than would be afforded by the minimat fourRCRA-standard-we11 network. 
The Honitoring Efficiency Hode1 (MEMO) was run for alt WHAs to maximize efficiency of the monitoring network and to expedite new well locations. The goal in locating wells is to achieve 90\% efficlency of the network using MEFo (Wilson et ai. 1992). Efficiencies were calculated for all WHAs; they are close to or exceed the target efficiency. Detalled results of the MEHO calculations can be found in the revised groundwater monitoring plan for the SSTs (Caggiano and Goodwin 1991).

4.11.4.3 Monitoring Network Modffications. Hydraul ic gradients are very low In the 200 East Area. Continued observation will be required as discharges to $B$ Pond diainish and the B Pond mound dissipates to ensure that wells are properly placed so as to be upgradient or downgradient from Whas. With a change in flow direction anticipated as long term, additional wells will be needed in the 200 East Area. As water levels continue to decline, groundwater monitoring wells may have to be replaced or remediated when the wells no longer penetrate the saturated zone of the uppermost unconfined aquifer. Pump intakes were lowered in several wells in 1995 to accombodate declining water levels. This activity is 1 ikely to be needed in other sst monitoring wells. Ho changes to any network because the groundwater flow direction is changing are anticipated in the 200 East Area at this time.

With dissipation of the $U$ Pond mound, groundwater flow in the 200 west Area will shift eastward. As this long-term change occurs, additional wells may be required to ensure that wells for the various WMAs in the 200 West Area are located appropriately upgradient and downgradient and that the wells penetrate the saturated section of the uppersost unconfined aguifer. The only anticlpated change to the SST facitity-specific monitoring networks in the 200 West Area is at MMA U where a new RCRA-standard we\}] may be instatied in 1996 because groundwater flow changed direction. Measurements made in May 1995 indicate that groundwater flows north-northwest in wells 299-W19-31 and 299-419-32. The borehole velocity floweter will be run in these and other wells to confirm the permanence of this direction before resources are committed to construct a new well near the northwest corner of the 241- $U$ Tank Farm.

The inability to deternine whether the SSTs or various nearby cribs are the source of contaminants in groundwater at WMAS $T$ and TX-TY way lead to an expansion and integration of cribs, trenches, etc., regulated under CERCLA into these two SST MANAS. The two WHAs wuld be expanded to one unit that would include the nearby cribs, trenches, and ponds that received essential]y the same wastes and that likely contributed the groundwater contaminants. The intent would be to deternine the magnitude, extent, and mobiltty of contaminants causing elevated spect fic conductance (njtrate and chloride) that triggered these two WMAs into groundwater quality assessment monitoring under interim-status regulations. Factlity-specific monitoring would be replaced or supplemental to plune tracking of selected constituents at regular intervals. For these two WMAs, using an expanded network using mostiy RCRA-standard wells from other nearby RCRA TSO facilities to monitor anjons and selected radionuclides seens appropriate.

Other SST WMAs may become candidates for RCRA/CERCLA integration as the need is changed from facility-specific monitoring to a regional approach. As integration occurs, the current networks will be compared to the data quality 
DOE/RL-96-0I, REV. O

objectives for the integrated networks to determine the adequacy of existing wells to accomplish the objectives.

\subsubsection{References}

40 CFR 265, "Interin Status Standards for Owners and Operators of hazardous Waste Treatment, Storage, and Disposal Facilities," Code of Federal Regulations, as anended.

Alexander, D.J., S.D. Evelo, V.G. Johnson, and H.D. Sweeney, 1995, Groundwater Inpact Assessment Report for the 216-T-4-2 Dftch, WHC-EP-0815, Westinghouse Hanford Corpany, Richland, Hashington.

Anderson, J. D., 1990, A History of the 200 Area Tank Farws, WHC-MR-0132, Westinghouse Hanford Company, Richland, Nashington.

Caggiano, J. A., 1991a, "Single-Shell Tanks," in Annual Report for RCRA Groundiater Nonitoring Projects at Hanford Site Facilities for 1990, D0E/RL-9I-03, U.S. Departiment of Energy, Rjehland Field Office, Richtand, Washtngton, pp. 16-1 to 16-I2.

Caggiano, J. A., 1991b, Fate and Transport of Constituents Leaked frod Tank 241-A-105, WHC-EP-0412, Nestinghouse Hanford Company, Rtchl and, Washington.

Caggiano, J. A., and S. H. Goodwin, 199lc, Interiotstatus Groundwater Nonitoring Plan for the Single-Shell Tanks, WHC-SD-EN-AP-012, Rev. 1, Westinghouse Hanford Company, Richland, Washington.

Caggiano, J. A., 1992a, "Single-Shell Tanks," in Annual Report for RCRA Groundwater Monitoring Projects at Hanford Site Facjifties for 1991, DOE/RL-92-03, U.S. Department of Energy, Richland Field office, Richland, Washington, pp. 16-1 to 16-23.

Caggiano, J. A., 1993a, "Single-Shel] Tanks," in Annual Report for RCRA Groundwater Honitoring Projects at Hanford Site Facilities for 1992, DOE/RL-93-09, U.S. Department of Energy, Richland Operations offtce, Richiand, Washington, Pp. 16-1 to 16-40.

Caggiano, J. A., 1993b, Borehole Completion Data Package for CY 1991 and CY 1992 RCRA Nells at Single-Shell Tanks, WHC-SD-EN-DP-042, West inghouse Hanford Company, Richtand, Washington.

Caggiano, J. A., and C. J. Chou, 1993, Interin-Status Groundwater Quality Assessment Plan for the Single Shell Tank Waste Nanagedent Areas $T$ and $T X-T Y$, $\mathrm{HHC}-\mathrm{SO}-\mathrm{EH}-\mathrm{AP}-132$, Rev. 0 , Westinghouse Hanford Company, Richt and, Wasthington.

Caggiano, J. A., 1994, "Single-Shell Tanks," in Annual Report for RCRA Groundwater Monitoring at Hanford Sfte Facflities for 1993, 00E/RL-93-88, U.S. Department of Energy, Richland Operations Office,

Richtand, Washington, $\mathrm{pp}$. 4.11-1 = 4.11-47. 
Caggiano, J. A., 1994, "Single-Shell Tanks," in Quarteriy Report of RCRA Groundwater Monitoring Data for Period Septenber 1, 1993 through Decenober 31, 1993, DOE/RL-93-56-4, U.5. Department of Energy, Rich7and Operations office, Richland, Washington, pp. 16-I to 16-75.

Caggiano, J. A., 1994, "Single-Shell Tanks," in Quarterly Report of RCRA Groundwater Monitoring Data for Period October 1, 1994, through Decenter 31, 1994, DOE/RL-94-36-4, U.S. Department of Energy, Richland Operations office, Richland, Washington, pp. 16-1 to 16-75.

Caggiano, J.A. and D.J. Anderson, 1994, Suswary of Construction Data for Borehole 299-W10-196 and 1993 Investigation into the 241-T-106 Leak, WHC-SD-EN-TI-272, Westinghouse Hanford Company, Richland, Washington.

Caggiano, J.A., 1995a, "Single-Shell Tanks," in Annual Report for RCRA Groundwater honitoring at Hanford Site Facilities for 1994, DOE/RL-94-136, U.S. Department of Energy, Rich] and Operations office, Richland, Washington.

Caggiano, J. A., 1995b, "Single-Shell Tanks," in Quarterly Report of RCRA Groundwater Monitoring Data for Pariod January 1, 1995 through March 31, 1995, DOE/RL-95-69-1, U.S. Department of Energy, Richland Operations Office, Rich]and, Washington.

Caggiano, J. A., 1995c, "Single-She11 Tanks," In Quarterly Report of RCRA Groundwater Monitoring Data for Period Aprit 1, I9g5 through June 30, 1995, DOE/RL-95-69-2, U.S. Department of Energy, Richland Operations office, Richland, Washington, pp. 15-1 to 15-31.

Caggiano, J.A., 1995d, "Single-She]] Tanks," in QuarterIy Report of RCRA Groundwater Nonitoring Data for Period July 1 through September 30, 1995, DOE/RL-95-69-3, U.S. Department of Energy, Richl and Operations Office, Richland, Washington, $\mathrm{pP}$. 15-1 to 15-53.

Comprehensive Environgental Response, Compensation, and Liability Act of 1980, 42 USC 9601 et seq.

Connelly, H. P., 3. V. Borghese, C. D. Belaney, B. H. Ford, J. W. Lindberg, and S. J. Trent, 1992a, Hydrogeologic Model for the 200 East Groundwater Aggregate Area, WHC-SO-EN-TI-019, Rev. O, Westinghouse Hanford Company, Richland, Washington.

Connelly, M. P., B. H. Ford, and J. V. Borghese, 1992b, Hydrogeologic Model for the 200 West Groundwater Aggregate Area, WHC-SO-EN-TI-014, Westinghouse Hanford Company, Richland, Washington.

DOE-RL, 1989, SingTe-Shell Tanks Systen Closure/Corrective Action Work PTan, DoE/RL-89-16, U.S. Department of Energy, Rjehiand Operations Office, Richland, Hashington.

DOE-RL, 1995, Singie-Shell Tank Closure Hork Plan, DOE/RL-89-16, Rey. A, U.S. Department of Energy, Richland Operations Office, Richland, Washington. 
DOE/RL, 1995d, Iodine-129 Contamination: Nature, Extent and Management Options: U.S. Dept. Energy, DOE/RL-95-89, Oraft A, U.S. Department of Energy, Richland Operations Office, Richi and, Washington.

DOE/RL, 1995e, Pump and Treat Investigations at Operable Unft 200-6P-5: U.S. Dept. Energy, DOE/RL-95-59, Draft A, U.S. Department of Energy, Richland Operations office, Rtchland, Washington.

Ecology, EPA, and DOE, 1992, Hanford Federal Facility Agreement and Consent Orfer, 2 vols., as amended, Hashington State Department of Ecology, U.S. Environmenta] Protection Agency, and U.S. Bepartment of Energy, alyoipla, Washington.

EPA, I985, RCRA Ground Water Monttoring Technical Enforcement Gutdance Document (TEGO), OSWER-9950.1, U.S. Environmental Protection Agency, Washington, D.C.

Ford, B. N., 1993, Groundwter Field Characterization Report for the 200 Aggregate Area Managerent Study, WHC-SD-EN-TI-020, Hestinghouse Hanford Company, Richland, Washington.

Freeman-Pollard, J. R., J. A. Caggiano, S. J. Trent, and EBASCO/Hart Crowser, 1994, Engineering Evaluation of the GAO/RCED-89-157, Tank 241-T-106 Vadose Zone Investigation, BHI-00061, Bechte1 Hanford Company, Inc., Richland, Washington.

Hanlon, B. M., 1995, Waste Tank Sumary for Month Ending July 31, 1995, WHC-EP-0182-88, Westinghouse Hanford Company, Richland, Washington.

Jackson, R. L., R. B. Hercer, C. R. Wilson, and C. M. Einberger, 1991, Effictency-Based 6roundwater Nonitoring Network Destgn for Hazardous Waste Sites, HHC-SA-1157-FP, Westinghouse Hanford Company, Richland, Washington.

Jensen, E. J., S. P. Ajrhart, H. A. Chamness, T. J. Gilmore, D. R. Newcomer, and K. R. Oster, 19B9, 40 CFR 265 Interim-Status Ground-Water Monitoring Plan for the Single-Shell Tanks, WAC-SD-EN-AP-012, Westinghouse Hanford Company, Richland, Washington.

Johnson, V. G., 1993, Westinghouse Hanford Company Operational Groundwater Status Report, 1990-1992, WHC-EP-0595, Westinghouse Hanford Company, Rtchland, Washington.

Kasza, 6. L., 1995, In-Situ Flowieter Results and Analysis for the 216-BY Cribs Vicinity, BHI-00442, Bechtel Hanford Company, Inc., Rich? and, Washington.

Kasza, G. L., 1990, Ground Water Naps of Hanford Site Separations Areas Deceriber 1989, WHC-EP-0142-4, Westinghouse Hanford Company, Richland, Washington.

Kasza, G. L., H. J. Hartman, F. N. Hodges, and D. C. Weekes, 1992, Ground Water Maps of the Hanford Site, June 1992, NHC-EP-0394-3, Westinghouse Hanford Company, Richland, Washington. 
Newcomer, D. R., 1990, Evaluation of Hanford Site Nater-7ab7e Changes 1980-1990, PNL-7498, Pacific Northwest Laboratory, Richland, Washington.

Newcomer, D. R., J. V. Borghese, and W. E. Cronin, 1990, Hydrologic Testing at the Single-Shell Tanks, 1989, MHC-SD-EN-TI-147, Rev. 0, Westinghouse Hanford Company, Richland, Washington.

Resource Conservation and Recovery Act of 1976, 42 USC 6901 et seq.

Routson, R. C., W. H. Price, D. J. Brown, and K. R. Fecht, 1979, High-Level Waste Leakage from the 241-T-106 Tank at Hanford, RHO-ST-14, RockweTI Hanford Operations, Rich1 and, Kashington.

RUST, 1995, Vadose Zone Monitoring Project at the Hanford Tank Farms, Spectra? Gansoa-Ray Borehole Geophysical Logging Characterization and Baseline Monitoring Plan for the Hanford Single-Shell Tanks, p-G.JPO-1780, RUST Geotech, Grand Junction, Colorado.

Serkowski, J. A., and W. A. Jordan, 1989, Operational Groundwater Monitoring at the Hanford Site--19a8, MHC-EP-0260, Kestinghouse Hanford Company, Richland, Washington.

Smoot, J. L., J. E. Szecsody, B. Sagar, G. W. Gee, and C. T. Kincaid, 1989, Simulations of Infiltration of Meteoric Water and Contaminant Plume Movement in the Vadose Zone at Single-She71 Tank 241-7-106 at the Hanford Site, WHC-EP-0332, Westinghouse Hanford Company, Richt and, Washington.

WAC 173-160, "Mininum Standards for Construction and Maintenance of We11s," Washington Adfinistrative coofe, as amended.

WAC 173-303, "Dangerous Waste Regulations," Washington Admintstrative Code, as amended.

MAC 248-54, "Public Water Supplies," Washington Administrative Code, as amended.

WHC, 1993, Radionuclide and Chemical Inventories for the Single-Shell Tanks, WHF-5D-WH-TI-565, Rev. 1, Westinghouse Hanford Company, Richland, Washington.

Wilson, C. R., C. M. Efnbereger, R. L. Jackson, and R. B. Mercer, 1992, "Design of Ground-Water Monitoring Networks Using the Monitoring Efficiency Model (MEH(0)," Ground Hater, V. 30, No. 6, pp. 965-970. 
RUST Geotoch Reports. In 1995, RUST Geotech, Grand Junction, Colorado, prepared the following reports on spectra] gamma logging in SST dry weils for the U.S. Department of Energy, Richland Operations office.

- Tank Sumary Data Report for Tank SX-101, GJ-HAN-5

- Tank Sumwary Data Report for Tank 5X-102, GJ-HAN-6

- Tank Summary Data Report for Tank SX-103, GJ-HAN-4

- Tank Sumwary Data Report for Tank SX-104, GJ-HAN-3

- Tank Sumpary Data Report for Tank SX-105, GJ-HAN-7

- Tank Sumwary Data Report for Tank SX-106, GJ-HAN-8

- Tank Sumpary Data Report for Jank T-107, G.-HAN-2

- Tank Sumwary Data Report for Tank T-110, GJ-HAN-1. 
Figure 4.11-1. Single-She11 Tank Naste Managenent Areas in the 200 East Area.

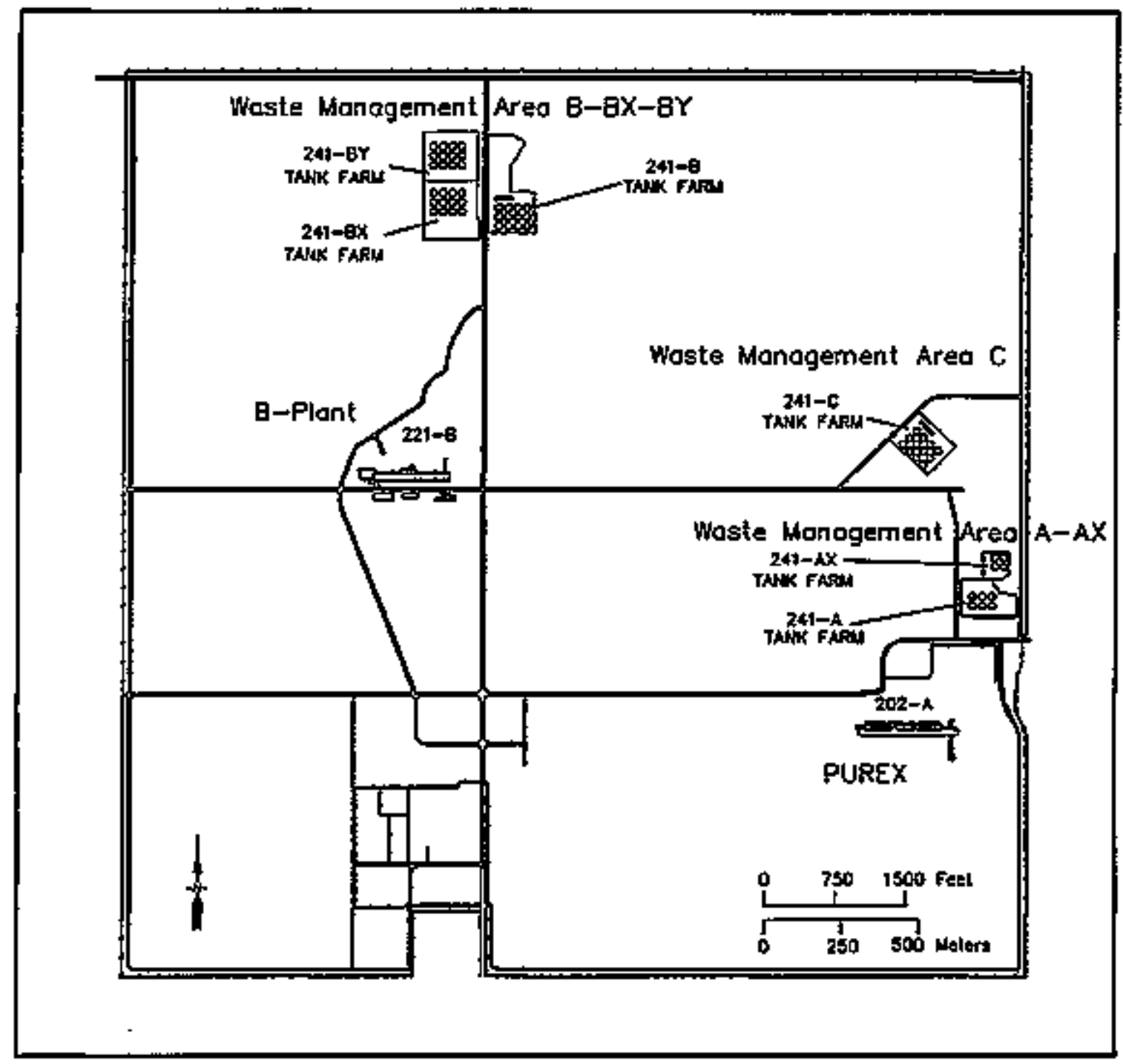

Joch nateqnidwg 
DOE/RL-96-01, REV, O

Figure 4.11-2. Single-Shell Tank Waste Management Areas in the 200 West Area.

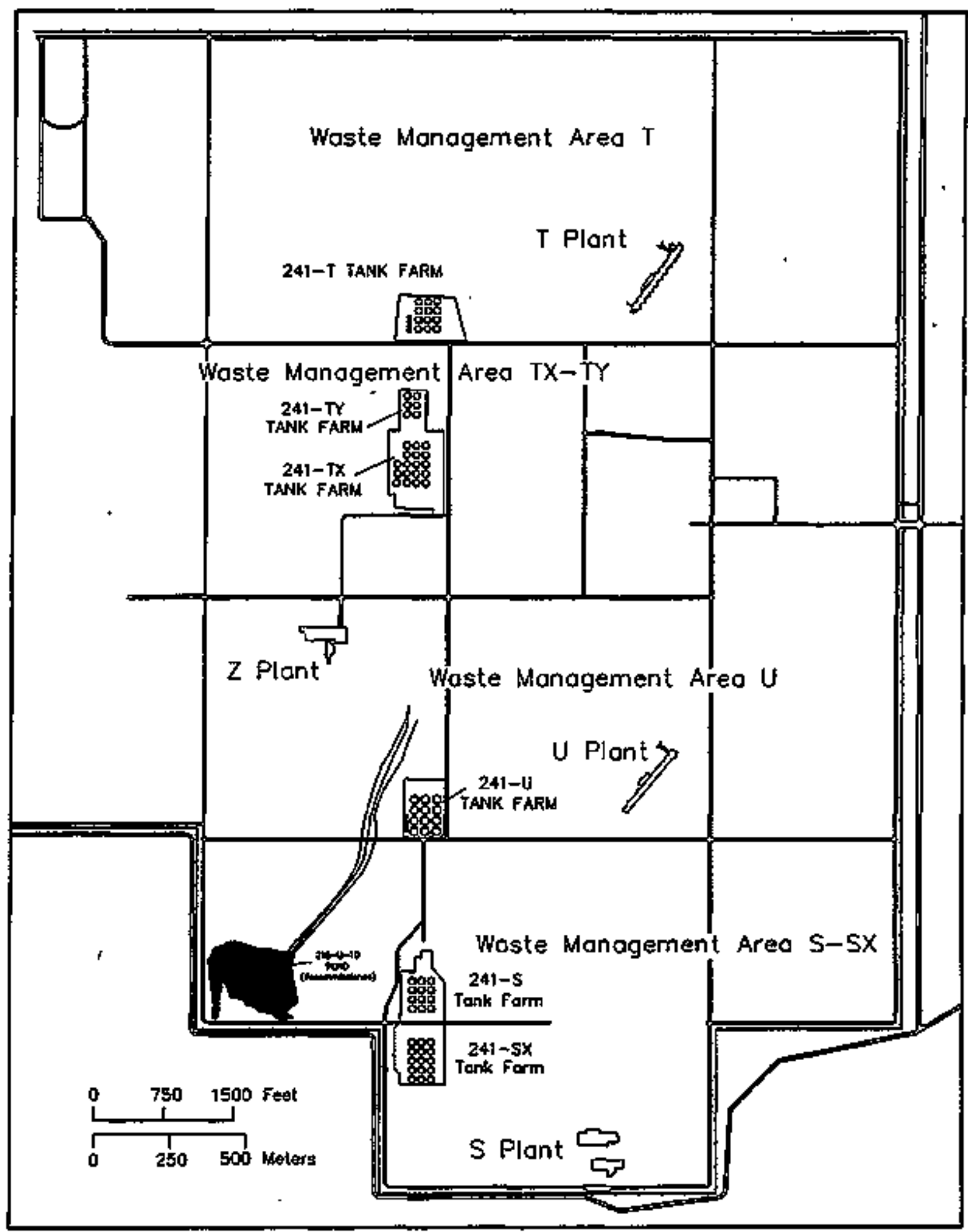

joch ostwest.dimg 
Figure 4,11-3. 200 West Area Hydrographs for \$ingle-Shel] Tank Waste Management Areas TX-TY and V.
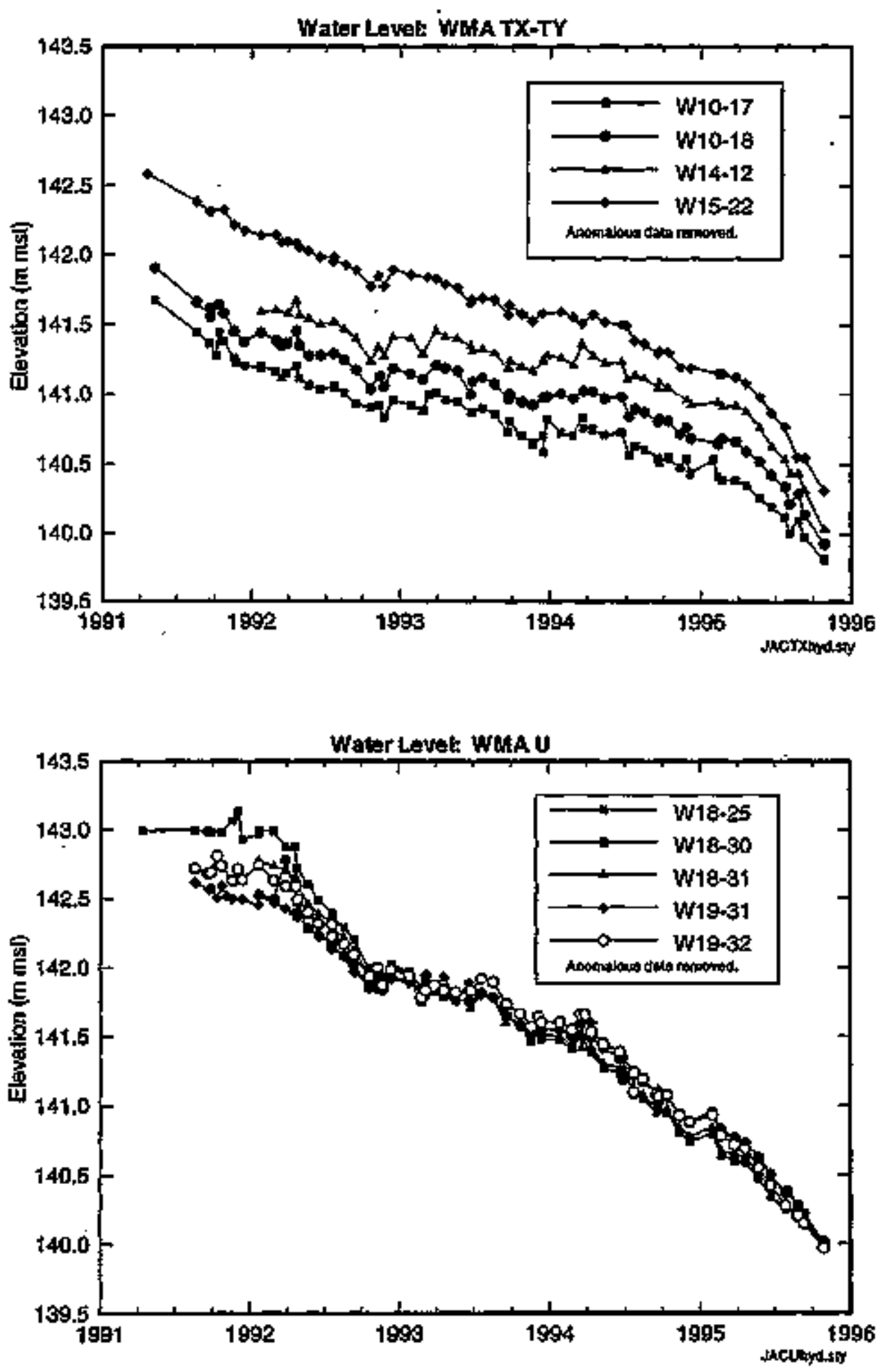
Figure 4.11-4. 200 West Area Water Table Map, June 1995.

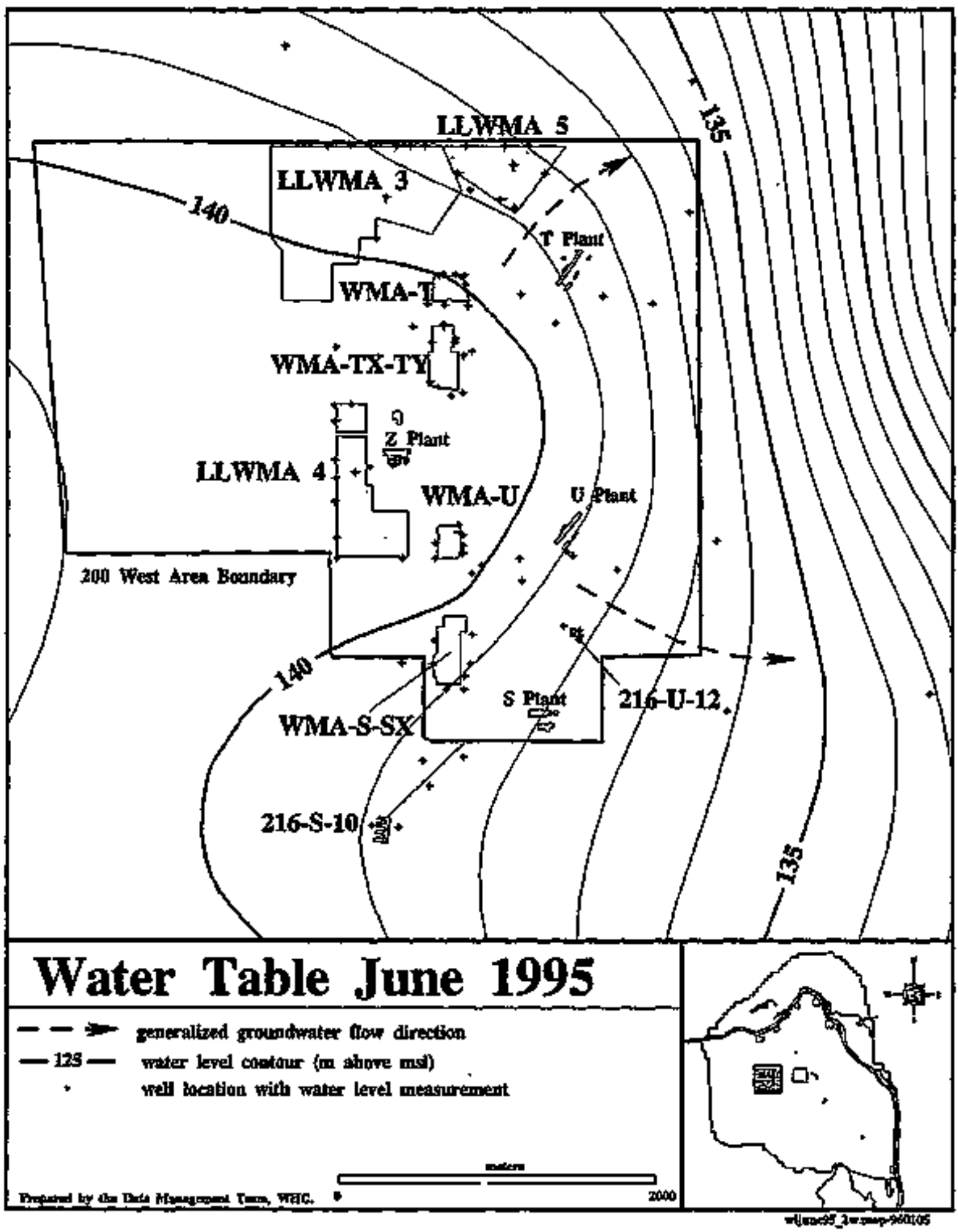


Woste dionogement Areo A-AX

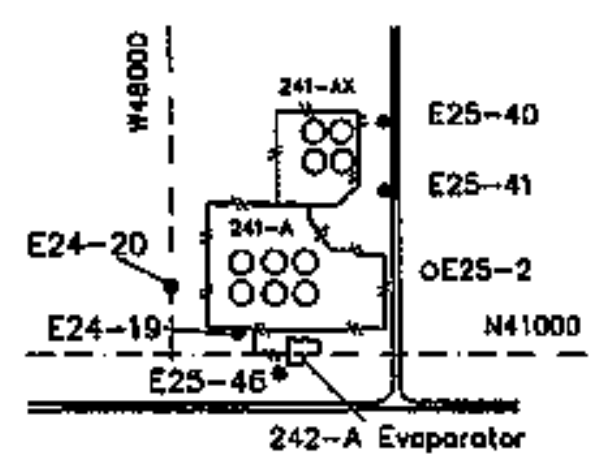

Wogle Management Areo C

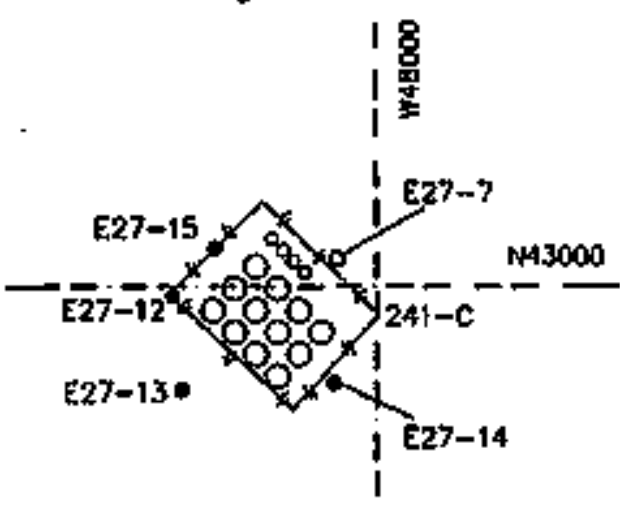

Monitorting Well Locations for the Single-Shel Tonk Waste Monotement Areos Within the 200 Easl Areo
Waste Management Areo B-BX-BY

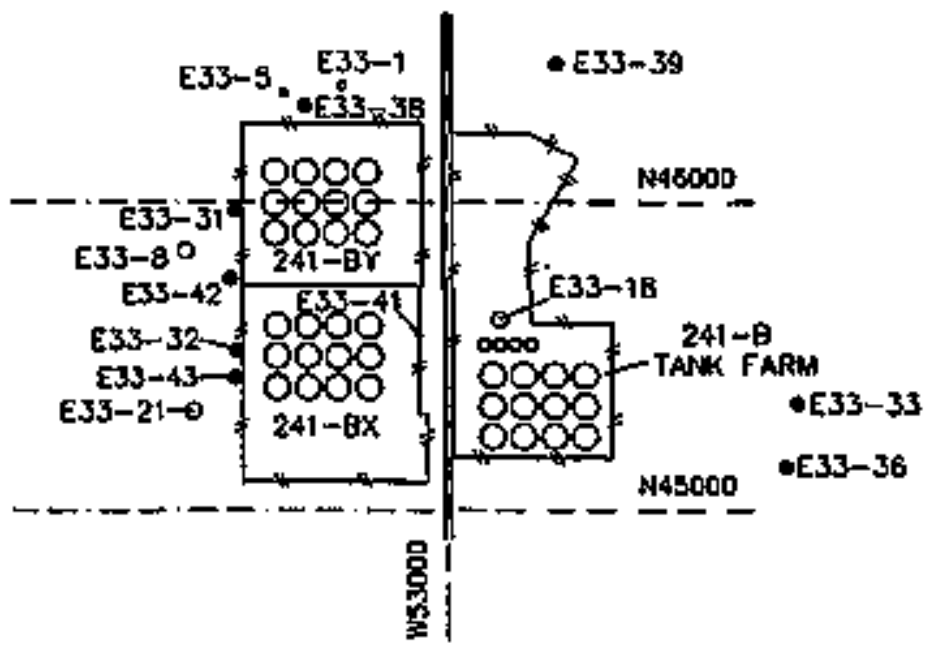

- Gorbon steel Ground Water Monitoring We

O 200 Strits Single-

RCRA Ground Water

Wonitoring well

() Single-Sholl Tonk

Decommlssioned Ground Woter Monitorlng Weil

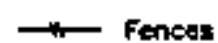

(20)

E25-1 Nurnbering System for Ground Whater Monltoring Veills. All Weillo Pratlxed by 291-

$$
\text { moods }
$$

Na1000 Haniord Sile cosrdinates

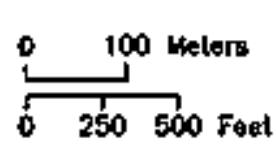


Wasta Management Areo TX-TY

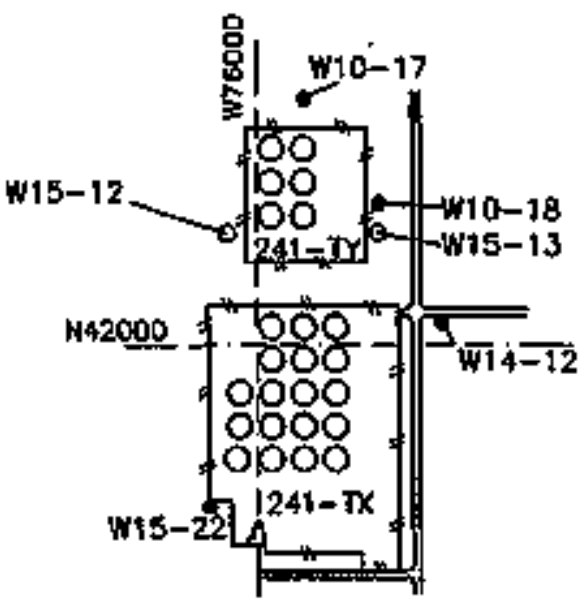

Woste Honagement Area U

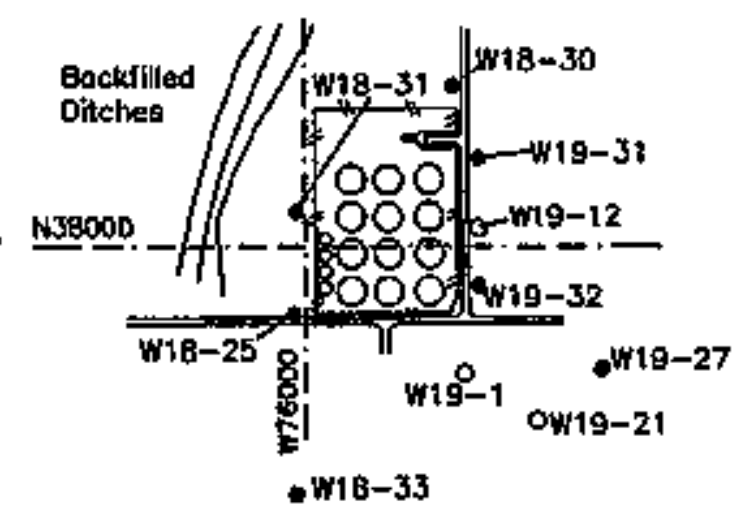

oพ19-8

Wonltorlng Well Lotations Ior the Single-Shell Tonk Waste Tank Waste Montagement Areas Whthin the 200 West Areo
Waste Management Area T
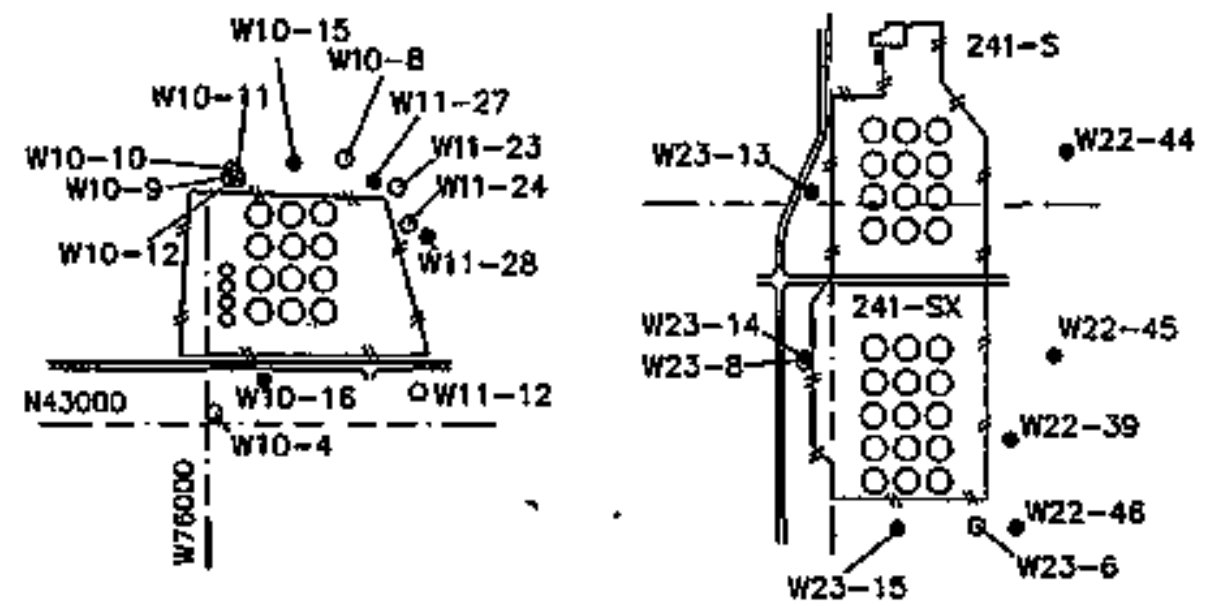

- RCRA Ground Water Monitoring Well

- Decommissioned Ground Woler Montloring Well.

V19-1 Numbering System for Ground Water Monitoring Wells. A Wols Prefike by 299-

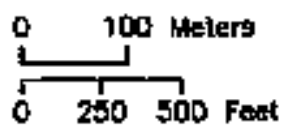

O 200 Series SingleShell Tank

Single-Shelt Tonk

$\rightarrow$ - fenses

= Rouds

N43000 Hardord sile Coordinoteg

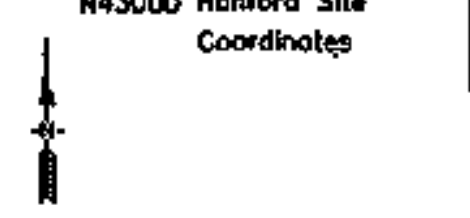




\section{DOE/RL-96-01, REV, 0}

Figure 4.11-7. Fittered Chromium and Nickel Versus Time for Well 299-E24-19.

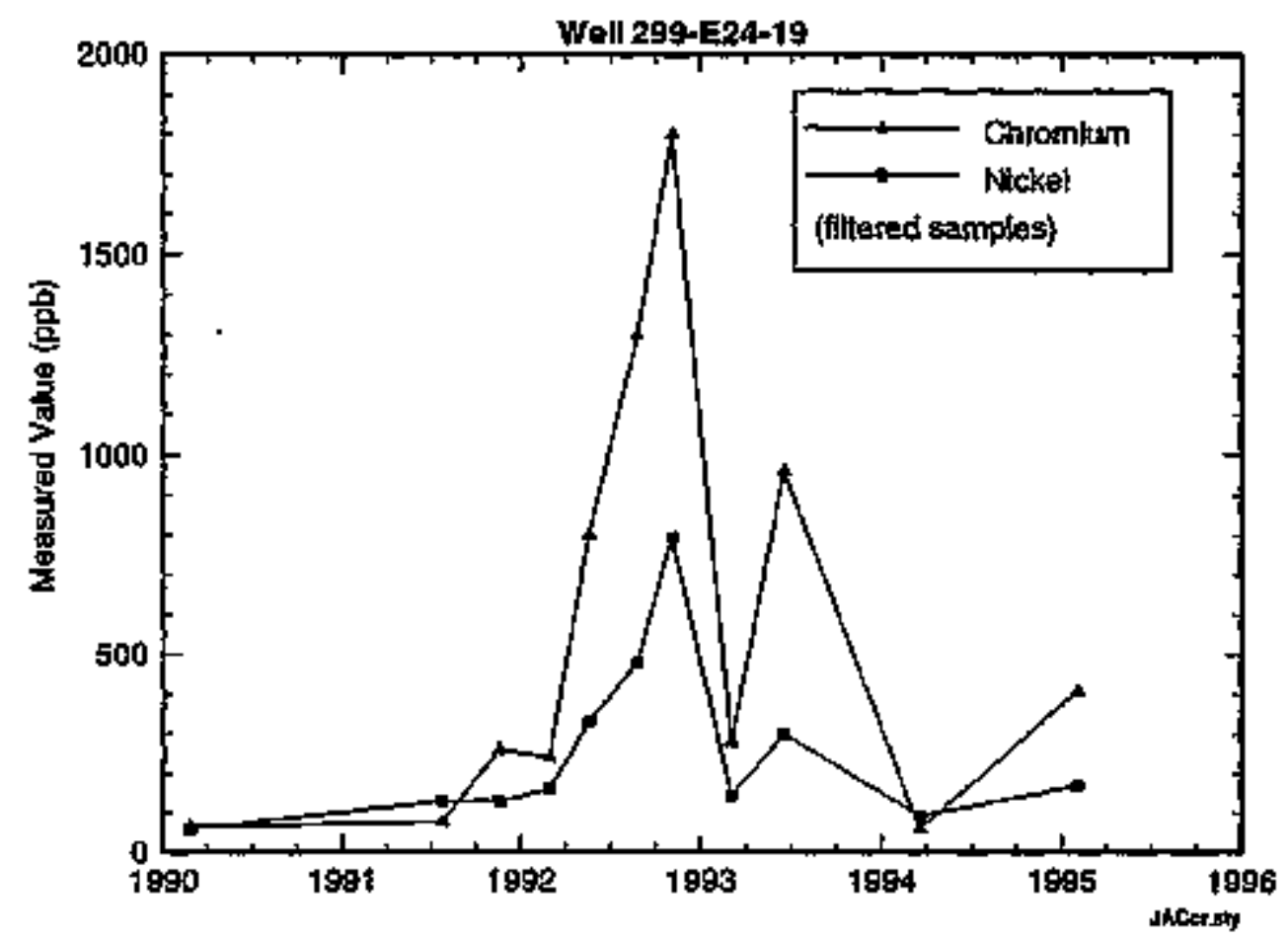




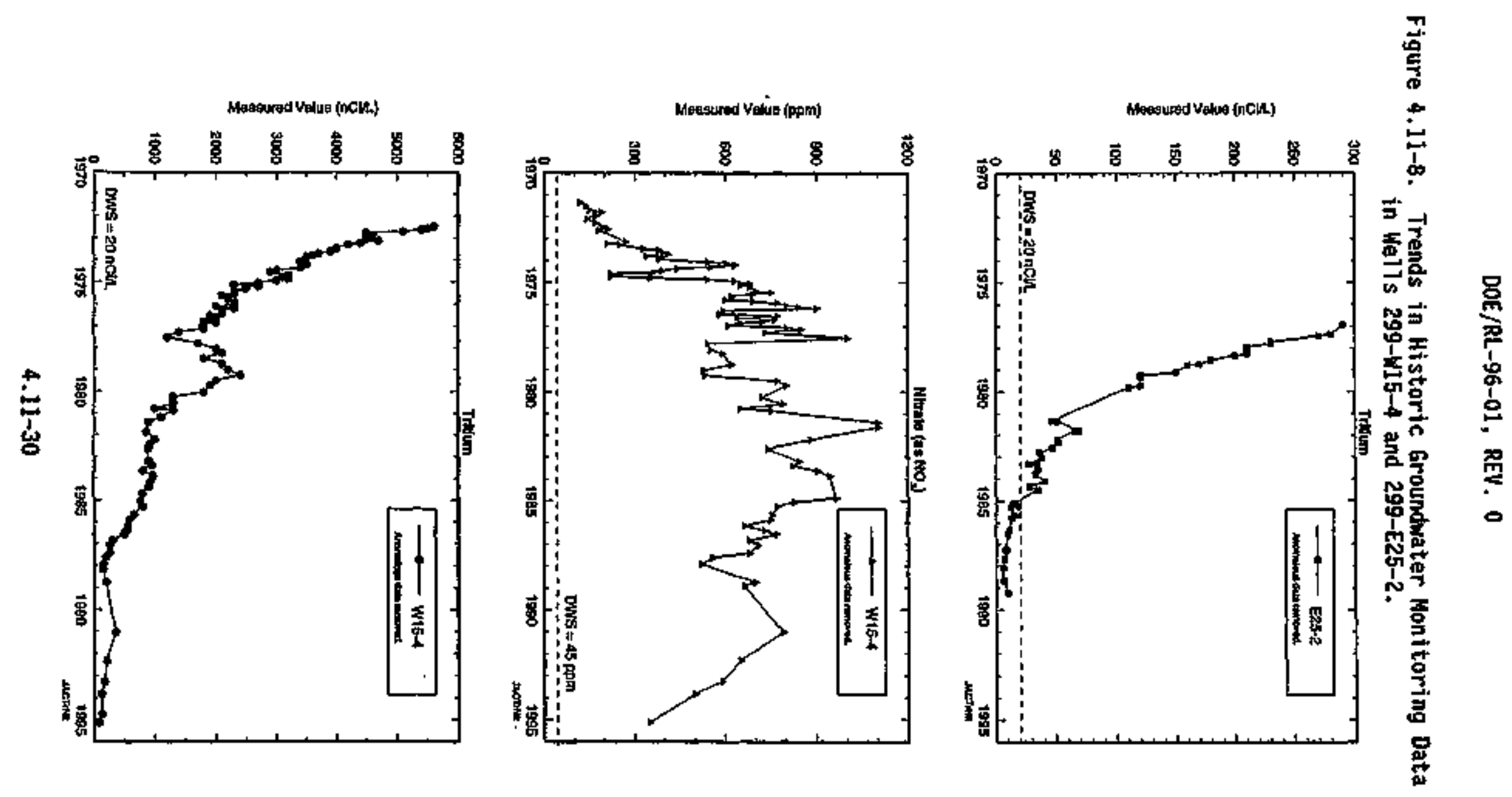


DOE/RL-96-01, REY. 0

Figure 4.11-9. 200 East Area Water Table Map, June 1995.

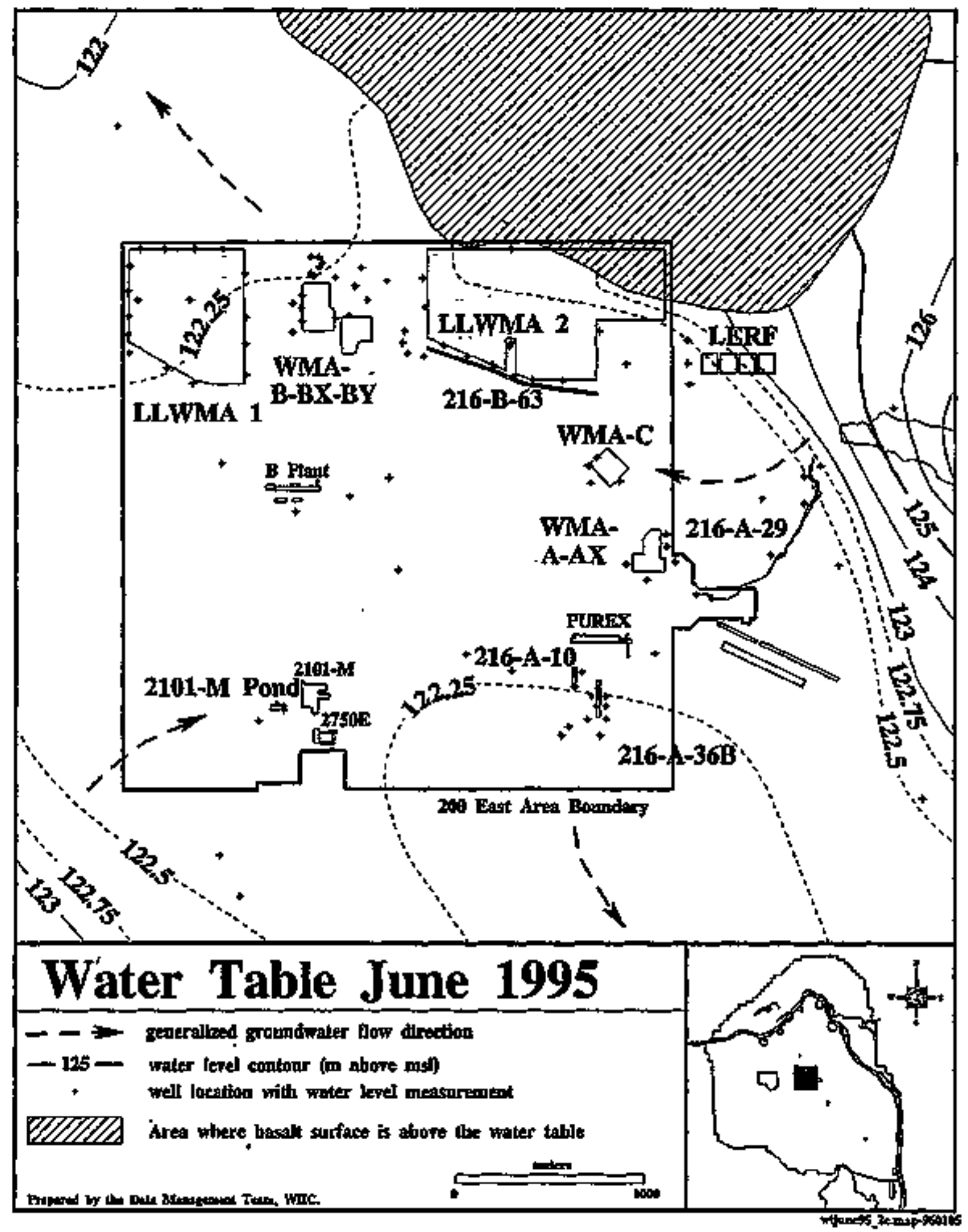


Figure 4.11-10. 200 East Area Hydrographs for Single-Shel1 Tank Waste Management Areas A-AX, B-BX-8Y, and C.
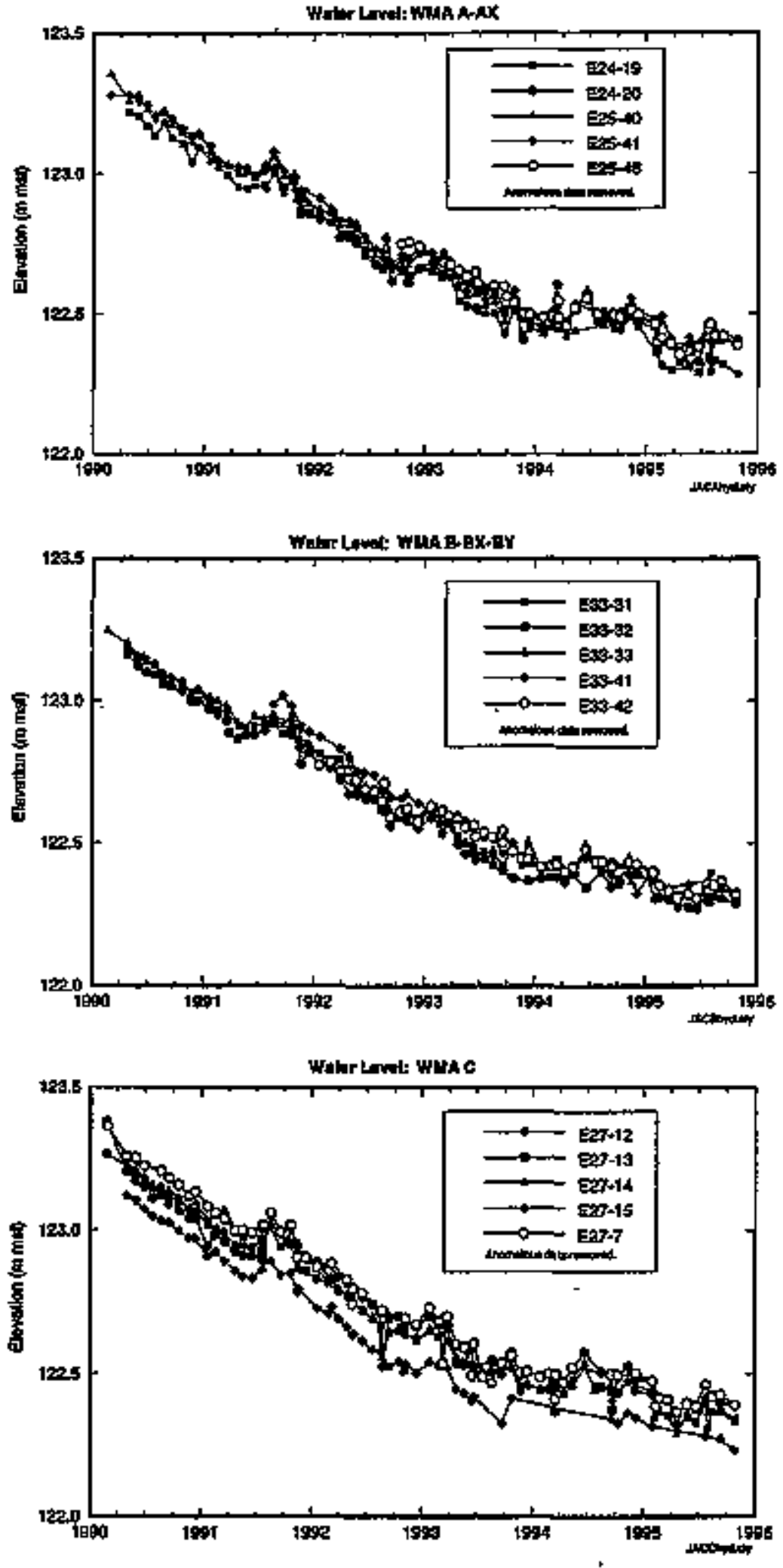
DOE/RL-96-01, REV. 0

Figure 4.11-Il. 200 West Area Hydrographs for Single-She11 Tank Waste Management Areas S-SX and $T$.
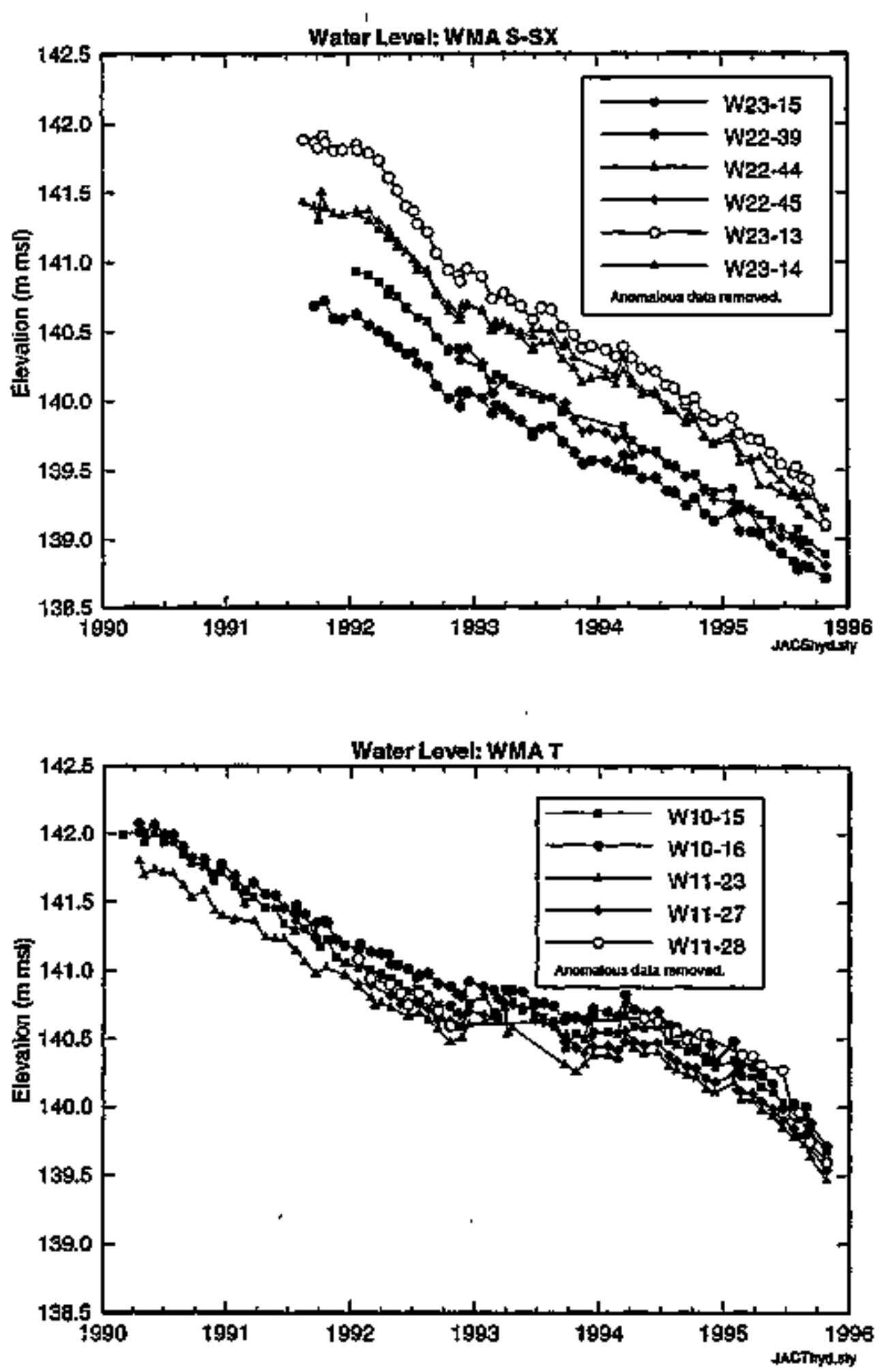
Table 4.11-1. Groundwater Honitoring Wells for the Single-Shell Tanks. (2 sheets)

\begin{tabular}{|c|c|c|c|c|c|}
\hline thedl & mopites & somplins & $\begin{array}{l}\text { Noter } \\
\text { levele }\end{array}$ & $\begin{array}{c}\text { Well } \\
\text { stenderw }\end{array}$ & $\begin{array}{c}\text { other } \\
\text { natuorks }\end{array}$ \\
\hline \multicolumn{6}{|c|}{ Waste Manogement Ares $A-\Delta X$} \\
\hline $299 \cdot E 24-19 *$ & Top of uneonfined & $\mathbf{s}$ & $\mathbf{n}$ & RCRA & $\cdots$ \\
\hline $299-E 26-20^{4}$ & Top of ureonf Ined & $\mathbf{s}$ & $\mathbf{H}$ & Rexk & -- \\
\hline $290-425-40 x$ & Top of unconfined & $\mathbf{s}$ & $\mathbf{N}$ & REFh & - \\
\hline $249-E 25-2^{4}$ & Top of urcenfined & $\cdots$ & $\mathbf{n}$ & PaE & $*$ \\
\hline $299-\mathrm{E} 25 \cdot 6 t^{4}$ & Top of untenfined & 8 & $\mathbf{H}$ & RERA & $\cdots$ \\
\hline $209-8>5-66^{4}$ & Top of uncont ined & $\$$ & $\boldsymbol{H}$ & RCPRA & 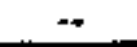 \\
\hline \multicolumn{6}{|c|}{ Waste Henagenent area $B-\mathrm{Ex}+\mathrm{BY}$} \\
\hline $299-\mathrm{E33}-31^{\circ}$ & Top of unemf ined & $\$$ & $\mathbf{M}$ & RCRA & $\cdots$ \\
\hline $299-E 33-30$ & Top of ureont inged & $\$$ & $\mathbf{H}$ & Reth & $\cdots$ \\
\hline $299-633+33^{* *}$ & Top of unemf inted & s & $\mathbf{M}$ & RCRA & -- \\
\hline $269-533-36$ & Top of uxcont ined & 5 & $\mathbf{H}$ & REFh & $216-8-63$ \\
\hline $299-033-47^{0}$ & Jop of uxcenfined & 5 & 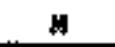 & RCRA & $\cdots$ \\
\hline 299-E33-38* & Top of uneonf ined & 8 & 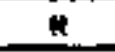 & RCRA & 200-ap-1 \\
\hline 299--33-39" & Iop of unconf ined & 5 & n & RCRA & $200-B F-1$ \\
\hline $299 \cdot E 33-42^{*}$ & Top of uncentined & 5 & N & RCRA & -- \\
\hline $299-633-43^{*}$ & Jop of uncont ined & $s$ & $\mathbf{H}$ & Rend & -- \\
\hline 297-633-1" & Top of uncontinad & $\omega$ & H & PRE & $\cdots$ \\
\hline $299-633-5^{4}$ & Top of uneonfined & -- & M & PRE & -- \\
\hline 249-133-8 & Top of uncarfined & $=$ & $\mathbf{M}$ & PAE & -- \\
\hline $299-e_{3}^{3}-18^{60}$ & Jop of uncont ined & 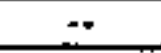 & H & PRE & $\cdots$ \\
\hline $299-E 33+21^{n}$ & Jop of manfined & $\cdots$ & $\mathbf{H}$ & PRE & $=-$ \\
\hline \multicolumn{6}{|c|}{ Waste Nendgement hea c } \\
\hline $299-E 7-12^{\circ}$ & Top of unemifined & $\mathbf{s}$ & $\mathbf{H}$ & RCRA & - \\
\hline $299 \cdot E 27 \cdot 13^{n}$ & Top of uncenf ined & 5 & M & Ac9k & -- \\
\hline $2 \%-E 7-16$ & Top of unoonfined & $\mathbf{s}$ & M & Both & 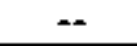 \\
\hline $299 \cdot E 27 \cdot 15$ & Top of unconfined & $\mathbf{s}$ & $\mathbf{N}$ & RERK & - \\
\hline $299-627+74$ & Jop of unemfined & $\mathbf{s}^{2}$ & $\mathbf{H}$ & PRE & - \\
\hline \multicolumn{6}{|c|}{ Wost Manogotent Mrea $\mathbf{s + 5 X}$} \\
\hline $299-1122-39^{\circ}$ & Top of unantined & $\mathbf{s}$ & $\mathbf{H}$ & $\operatorname{RERA}$ & $\cdots$ \\
\hline $299-472-44^{2}$ & Top of unconftined & $\$$ & $\mathbf{H}$ & RCARA & $=$ \\
\hline $299-422-45^{*}$ & Top of unconfined & $\mathbf{s}$ & $\mathbf{n}$ & RCRA & $\cdots$ \\
\hline $2 \%-122-46$ & Tep of unconfined & $\mathbf{s}$ & $\mathbf{H}$ & RERA & 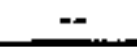 \\
\hline $299-143-13 *$ & Top of meonfined & 5 & $\boldsymbol{n}$ & RCRA & $\cdots$ \\
\hline $2 \%-103-14^{*}$ & Top of uncenfirad & $s$ & 보 & REChA & $\cdots$ \\
\hline $299-1 \times 3-15^{n}$ & Top of theonfined & 5 & $\boldsymbol{H}$ & RCRA & $\cdots$ \\
\hline $299-423-6^{n}$ & Top of unconfined & -- & $M$ & PRE & $\cdots$ \\
\hline $299-123-79$ & Top of uneonfined & $\cdots$ & $\boldsymbol{n}$ & PRE: & $\cdots$ \\
\hline $299-1273-g^{12}$ & Top of unconfinad & -- & $\mathbf{H}$ & PRE & -- \\
\hline
\end{tabular}


Table 4.11-1. Groundwater Monitoring Wel1s for the Single-Shell Tanks. (2 sheets)

\begin{tabular}{|c|c|c|c|c|c|}
\hline Well & Aadifer & $\begin{array}{l}\text { Sempting } \\
\text { frequency }\end{array}$ & $\begin{array}{l}\text { Neter } \\
\text { lavels }\end{array}$ & $\begin{array}{c}\text { Woll } \\
\text { stenderds }\end{array}$ & $\begin{array}{c}\text { other } \\
\text { netwerks }\end{array}$ \\
\hline \multicolumn{6}{|c|}{ Wagte Morugenent AFed $T^{*}$} \\
\hline $299-410-15=$ & Top of umanfined & $\mathbf{a}$ & $\mathbf{H}$ & RERh & $=$ \\
\hline $299-140-160$ & Top of unconfined & a & $\mathbf{n}$ & RCRA & $\cdots$ \\
\hline $299-1 \times 11-27^{n}$ & Top of unconf inted & 0 & H & RCeh & - \\
\hline $299+111-28^{2}$ & Top of uncenflined & a & 4 & RCRA & $-*$ \\
\hline $299-10-8$ & Top of uncont ined & $\cdots$ & H & PRE & $m$ \\
\hline $299-1010-9^{3}$ & Top of unconfined & -- & $\mathbf{n}$ & PRE & -- \\
\hline $27 \%-1010-1 f^{*}$ & Top of triconfinat & $=$ & $\mathbf{n}$ & PRE & $\cdots$ \\
\hline $299+110-12^{74}$ & Top of uncenfind & -- & $\mathbf{H}$ & PRE & - \\
\hline $299-111-23^{3}$ & Top of unconfined & -- & A & PRE & 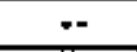 \\
\hline $299 \cdot 111-26^{n}$ & Top of encentined & 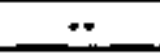 & $\mathbf{H}$ & PREE & $\cdots$ \\
\hline \multicolumn{6}{|c|}{ Wogte Manogolnent Ared TX-TY } \\
\hline $299-410-\$ 77^{\prime \prime}$ & Top of uncont tred & 9 & H & RCRA & $\boldsymbol{m}$ \\
\hline $2 \% 9-110-18^{*}$ & Top of uncenfined & 9 & H & RCR & $=$ \\
\hline $299+414-12^{\prime \prime}$ & Top of uncontined & Q & $\mu$ & RCRA & 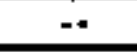 \\
\hline $2 \% 9-1+3-22^{11}$ & Top of unconfined & a & H & RCPA & $m$ \\
\hline $299-415-12^{2}$ & Top of unconfines & 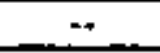 & $n$ & PRE & $\because$ \\
\hline $249-115 \cdot 13^{73}$ & Top of unconfined & $\cdots$ & $\mathbf{n}$ & FRE & $-\approx$ \\
\hline \multicolumn{6}{|c|}{ Uante Manugepent Ares Ut } \\
\hline $299-118-25^{* 10}$ & Top of unconfined & 5 & H & RCRA & 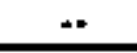 \\
\hline 299-W1日-30" & Top of uncorfined & $\mathbf{s}$ & $\mathbf{H}$ & ACRh & $=$ \\
\hline $279-418-31=$ & Top of unconfined & $s$ & $\mathbf{n}$ & Retere & $*$ \\
\hline $294-118-31^{\circ}$ & top of theonfined & $\mathbf{s}$ & M & ACRA & 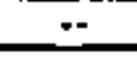 \\
\hline $299+119 \cdot 3 e^{n}$ & Top of uneonfinod & $s$ & n & RCRA & 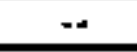 \\
\hline $299-1+19-124$ & Top of enconfined & $\$$ & M & Pat & $\ldots$ \\
\hline $299-418-33$ & Top of tueonfined & $=$ & $\mathbf{n}$ & $\operatorname{scRh}$ & \\
\hline $299-119-6$ & Hiddle unconfined & $*$ & n & PRE & \\
\hline 299-u+9-21 & Top of uconfined & $\cdots$ & H & PRE & \\
\hline $29 \cdot-119 \cdot 27$ & Top of unconflnest & \pm & H & FCRh & \\
\hline
\end{tabular}

Wotes Shading denotal upratient wel ls. Suparseript following well muber denotes the yeur of econgletion.

1 a frowarcy on a northly beris.

PRE I well wes corstructed bofore RCRA specified sterdands.

D. frogtuency on to quarterly basis.

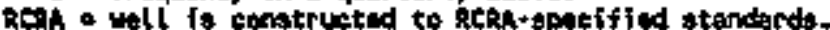

5 a frequency on a stontemust besis.

- MIt is anted for elpporting data.

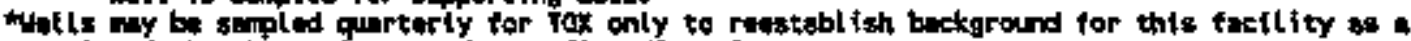
reault of the exande in sroundwater flow direction.

Helle 299-14-2, 299-44-4, 299-46-6, 299-46-9, 299-410-19, 299-410-29, 279-410-2t and 299-4t1-31 have

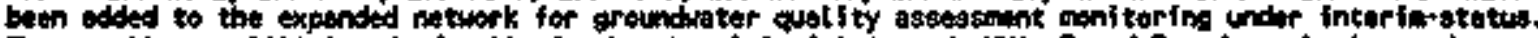

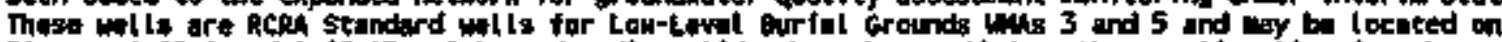

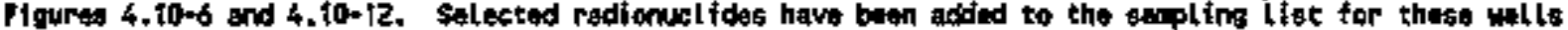

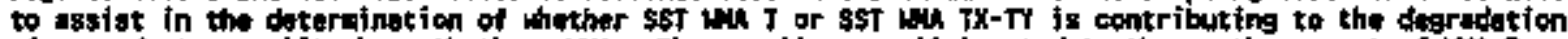

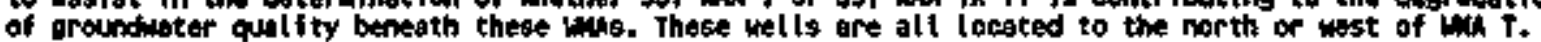


Table 4.11-2. In-Situ Flow Meter Results Single-Shell Tanks Waste Management Area U, May 4-12, 1995.

\begin{tabular}{|c|c|c|c|}
\hline Well No. & Probe Depth (ft) & Direction & $\begin{array}{c}\text { Velocity m/d } \\
\text { (ft/d) }\end{array}$ \\
\hline \multirow[t]{4}{*}{ 299-418-25 } & 208 & H. $72^{\circ} \mathrm{E}$. & $0.25(0.82)$ \\
\hline & 208 & N. $78^{\circ} \mathrm{E}$. & $0.20(0.65)$ \\
\hline & 212 & N. $86^{\circ} \mathrm{E}$. & $0.71(2.32)$ \\
\hline & 216 & N. $77^{\circ} \mathrm{E}$. & $0.45(1.46)$ \\
\hline \multirow[t]{4}{*}{$299-419-31$} & 214.5 & $?$ & $<0.01(<0.04)$ \\
\hline & 217.5 & N. $4^{\mathrm{C}} \mathrm{E}$. & $0.01(0.04)$ \\
\hline & 220.5 & N.14\%. & $0.22(0.71)$ \\
\hline & 223.5 & N. $35^{\circ} W$. & $0.23(0.74)$ \\
\hline \multirow[t]{3}{*}{ 299-419-32 } & 214.5 & N. $30^{\circ} \mathrm{W}$. & $0.12(0.40)$ \\
\hline & 217.5 & N.15\%. & $0.12(0.39)$ \\
\hline & 220.5 & N. $21^{\circ} \mathrm{H}$. & $0.07(0.23)$ \\
\hline
\end{tabular}

? - Direction indeterminate when velocity is below $0.01 \mathrm{~m} / \mathrm{d}(0.04 \mathrm{ft} / \mathrm{d})$.

Table 4.11-3. Constituent List for the Single-Shell Tanks.

\begin{tabular}{|c|c|c|}
\hline \multicolumn{3}{|c|}{ Contamination indicator parameters } \\
\hline $\begin{array}{l}\text { pH } \\
\text { Specific conductance }\end{array}$ & $\begin{array}{l}\text { Total organi } \\
\text { Total organi }\end{array}$ & \\
\hline \multicolumn{3}{|c|}{ Groundwater quality parameters } \\
\hline $\begin{array}{l}\text { Chlortde } \\
\text { Iron }\end{array}$ & $\begin{array}{l}\text { Manganese } \\
\text { Phenols }\end{array}$ & $\begin{array}{l}\text { Sodium } \\
\text { Sulf fate }\end{array}$ \\
\hline \multicolumn{3}{|c|}{ Drinking water parameters } \\
\hline $\begin{array}{l}\text { Barium } \\
\text { Cadnfum } \\
\text { Chromium }\end{array}$ & $\begin{array}{l}\text { Fluoride } \\
\text { Gross a]pha } \\
\text { Gross beta }\end{array}$ & $\begin{array}{l}\text { Nitrate } \\
\text { Silver } \\
\text { Turbidity }\end{array}$ \\
\hline \multicolumn{3}{|c|}{ Site-specific parameters } \\
\hline $\begin{array}{l}\text { Ammontum } \\
\text { Techn'fcfum-99+ }\end{array}$ & $\begin{array}{l}\text { Cesium-137+ } \\
\text { Coba1t-60+ } \\
\text { Gatrima scant }\end{array}$ & $\begin{array}{l}\text { lodine-129 } \\
\text { Trittum }\end{array}$ \\
\hline
\end{tabular}

+WMAs $T$ and TX-TY on $7 y$ 
Table 4.11-4. Constituents Exceeding Regulatory Limits. (5 sheets)

\begin{tabular}{|c|c|c|c|c|c|c|}
\hline 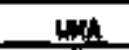 & Hell Mo. & Itpollow & constituent: & Valug & Linit & Data(s) \\
\hline$h=-\infty x$ & $2-E 24-19$ & Doen & Fittored chromiun & $410 \mathrm{mob}$ & 1000 & $2 / 2 / \% 5$ \\
\hline & & & $=1$ & $7.78 \mathrm{pCl} / \mathrm{t}$ & $1 \mathrm{ps} / \mathrm{L}$ & $2 / 2 / 5$ \\
\hline & & & & $5.36 \mathrm{pCi} / \mathrm{L}$ & $1 \mathrm{pci} / \mathrm{s}$ & $8 / 3 / 45$ \\
\hline & $2-824-20$ & Dom & int & $4.37 \times \mathrm{xt} / \mathrm{t}$ & $1 \mathrm{pcs} / \mathrm{h}$ & $2 / 2 / 95$ \\
\hline & & & & $6.73 \mathrm{pC}: / \mathrm{t}$ & $1 \mathrm{pCs} / \mathrm{L}$ & 8/2/\%5 \\
\hline & $2-E 25-40$ & up & w"I & $7.03 \mathrm{pCi} / \mathrm{t}$ & $1 \mathrm{pCi} / \mathrm{L}$ & $2 / 6 / 95$ \\
\hline & & & & $7.45 \mathrm{pCt} / \mathrm{L}$ & $1 \mathrm{pel} / \mathrm{h}$ & $8 / 1 / F$ \\
\hline & $2-t 25-41$ & $U_{p}$ & =ेI & $4,57 \mathrm{pCi} / \mathrm{A}$ & $1 \mathrm{pCl} / \mathrm{h}$ & $2 / 6 / 95$ \\
\hline & & & & 4.97 pCist & $1 \mathrm{pC1/L}$ & 6/2/95 \\
\hline & $2-t 25-46$ & Dom & $\Rightarrow t$ & $5.87 \mathrm{pCl} / \mathrm{t}$ & $1 D C i / L$ & $2 / 6 / 95$ \\
\hline & & & & $3.26 \mathrm{pC} 3 / \mathrm{s}$ & $1 \mathrm{pCi} / \mathrm{L}$ & $8 / 1 / 95$ \\
\hline$\theta=B X-B Y$ & 2-E33-31 & Dolm & $10 t$ & $5.99 \times 5 i / L$ & $1 \propto \mathrm{Ci} / \mathrm{L}$ & $2 / 8 / 85$ \\
\hline & & & & $7.59 \mathrm{pci} / \mathrm{L}$ & $1 \mathrm{peill}$ & 8/4/95 \\
\hline & $2-e 33-32$ & Dom & ${ }^{10} I$ & $5.65 \mathrm{pCi} / \mathrm{L}$ & 1 exis & $2 / 7 / 95$ \\
\hline & & & & 3.86 pC1/L & $1 \mathrm{DC1} / \mathrm{L}$ & $8 / 2 / 95$ \\
\hline & $2-E 33 \cdot 33$ & ip & ning & $3.62 \mathrm{pCi} / \mathrm{L}$ & $1 \mathrm{pCi} / \mathrm{L}$ & $2 / 7 /$ s \\
\hline & & & & $5.85 \mathrm{pCi} / \mathrm{L}$ & $1 \times \mathrm{PC} / \mathrm{L}$ & $8 / 1 / 95$ \\
\hline & 24E33-36 & up & $120 t$ & $5.3 \mathrm{pCi} / \mathrm{L}$ & $1 \mathrm{PCI} / \mathrm{L}$ & $2 / 7 / 45$ \\
\hline & & & & $5.65 \mathrm{pCi} / \mathrm{L}$ & pcit/ & 2/1/9s \\
\hline & $2-633-38^{6}$ & Dom & $m i$ & $6.1 \mathrm{DC} / \mathrm{L}$ & $1 \not C 1 / L$ & $4 / 5 / 95$ \\
\hline & $2-\operatorname{ext}-39^{\circ}$ & Down & $\ln t$ & $1.49 \propto \times i / L$ & $1 \mid \boldsymbol{X i} / \mathrm{L}$ & $4 / 5 / 95$ \\
\hline & 2-E33-41 & $\ldots$ & sint $^{\prime}$ & $5.07 \mathrm{pCi} / \mathrm{L}$ & $1 \mathrm{pCi} / \mathrm{L}$ & $2 / 13 / \%$ \\
\hline & & & & 5.95 pi/L & 1 pcill & $8 / 4 / 95$ \\
\hline & & & "Te & $948 \mathrm{pCI} / \mathrm{L}$ & $900 \mathrm{pCi} / \mathrm{L}$ & $2 / 13 / 45$ \\
\hline & & & & $1,630^{\circ} \mathrm{pC} \$ / \mathrm{l}$ & 9od pCi/L & $8 / 4 / 95$ \\
\hline & $2- \pm 33-42$ & Down & itat! & $5.65 \mathrm{pCi} / \mathrm{L}$ & $1 \mathrm{pCi/h}$ & $2 / 8 / 9$ \\
\hline & & & & 8.68 pCi/L & $1 \mathrm{pCt} / \mathrm{L}$ & $8 / 3 / 45$ \\
\hline & $2-E 53-43$ & Down & $x_{I}$ & $4.18 \mathrm{pCi/L}$ & 1 pCi/L & $2 / 8 / 8$ \\
\hline & & & & $3.62 \times 61 / \mathrm{L}$ & $1 \mathrm{PC}: / \mathrm{h}$ & $8 / 3 / 9$ \\
\hline E & $2-E 27 \div 7$ & sp & $180 \mathrm{tg}$ & $3.19 \times 1 / 2$ & $1 \mathrm{xt} / \mathrm{h}$ & $2 / 9 / \% 5$ \\
\hline & & & & $3.8 \mathrm{pCi} / \mathrm{C}$ & $1 \mathrm{pC} 3 / \mathrm{h}$ & $8 / 2 / 8 s$ \\
\hline & $2=[+27+12$ & Down & $13 \mathbf{4}$ & $2.62 \mathrm{pCI} / \mathrm{L}$ & $1 \times C 3 / L$ & $2 \pi / 95$ \\
\hline & & & & 3.92 ріл & $1 \mathrm{pci} / \mathrm{L}$ & $5 / 2 / 95$ \\
\hline & $2+E 27-13$ & Dom & int & 4.73 pCi/l & $1 \mathrm{pCs} / \mathrm{L}$ & $2 / 13 / \% 5$ \\
\hline & & & & 4.37 pCt/ & $1 \mathrm{pCi} / \mathrm{L}$ & $8 / s / s /$ \\
\hline & 2-Ezt-14 & up & $x_{1}$ & 4. $17 \mathrm{pCi} / \mathrm{t}$ & $1 \mathrm{gci} / \mathrm{h}$ & $2 / 13 / \% 5$ \\
\hline & & & & $4.07 \mathrm{pCi} / \mathrm{L}$ & 1 ecsill & 8/2/95 \\
\hline & $2+t 27-15$ & Down & $\boldsymbol{x I}_{I}$ & $3.71 \mathrm{pc}: 九$ & $1 \mathrm{pci} / \mathrm{h}$ & $2 / 8 / 9 \$$ \\
\hline
\end{tabular}


Table 4.11-4. Constituents Exceeding Regulatory Limits. (5 sheets)

\begin{tabular}{|c|c|c|c|c|c|c|}
\hline was & Hell Ha, & Upoom & Eorstituent & Yolun & Linit & pate(s) \\
\hline & & & & $7.09 \mathrm{pCi} / \mathrm{L}$ & $t \mathrm{pCi} / \mathrm{t}$ & $8 / 2 / 25$ \\
\hline \multirow[t]{4}{*}{$8-8 x$} & $2-\operatorname{ta}^{2} 3-14$ & W & Iritiur & 127,000 pci/le & 20,000 pcin & $2 / 14 / 95$ \\
\hline & & & & 137,000 рCi/ & $20,000 \mathrm{pCl} / \mathrm{h}$ & $8 / 9 / 95$ \\
\hline & $2+423-15$ & Dem & Tritium & $4,200055 / 1$ & $20,000 \mathrm{pci} / \mathrm{h}$ & $2 / 14 / 95$ \\
\hline & & & & $27, \pi 00 \times 1 / 1$ & 20,000 p01/L & $8 / 9 / 95$ \\
\hline \multirow[t]{32}{*}{$t^{n}$} & $2 \cdot-1+2$ & Dowin & Mitrete & $52,090 \mathrm{nab}$ & $45,000 \mathrm{ppb}$ & $17 / 14 / 94$ \\
\hline & & & & $53,000 \mathrm{ppb}$ & $45,000 \mathrm{ppb}$ & $3 / 13 / 95$ \\
\hline & & & & 59,000 & $45,000 \mathrm{ppb}$ & $6 / 14 / 95$ \\
\hline & $2-116-6$ & Down & Tritites & $37,900 \mathrm{pCi} / \mathrm{L}$ & $20,000 \mathrm{pCi} / \mathrm{L}$ & $12 / 14 / 94$ \\
\hline & & & & 31,600 pcit/ & $20,000 \mathrm{pCi} / \mathrm{L}$ & $3 / 3 / \%$ \\
\hline & & & & $31,600 \mathrm{pEi}$ & $20,000 \mathrm{pCi} / \mathrm{L}$ & $6 / 12 / 85$ \\
\hline & & & & 31,300 pcist & 20,009 DCifl & $8 / 74 / 95$ \\
\hline & & & Mitrate & $97,000 \mathrm{ppt}$ & $45,000 \mathrm{ppb}$ & $12 / 14 / 94$ \\
\hline & & & & $97,000 \mathrm{pps}$ & $45,000 \mathrm{ppb}$ & $3 / 3 / 95$ \\
\hline & & & & 100,000 ppb & 45,000 gpb & $6 / 12 / 55$ \\
\hline & & & & $100,000 \mathrm{ph}$ & $45,000 \mathrm{ph}$ & $9 / 14 / \%$ \\
\hline & $2-116-9$ & Doin & Mitrate & $69,000 \mathrm{ppb}$ & $45,000 \mathrm{ppb}$ & $12 / 13 / \%$ \\
\hline & & & & $70,000 \mathrm{ppt}$ & $45,000 \mathrm{ppb}$ & $3 / 2 / 95$ \\
\hline & & & & $7,000 \mathrm{ppb}$ & $45,000 \mathrm{ppb}$ & $6 / 13 / 55$ \\
\hline & & & & $79,000 \mathrm{pob}$ & $45,000 \mathrm{ppb}$ & $9 / 14 / 95$ \\
\hline & $2-146-10$ & bom & irjtiup & $85,700 \mathrm{pC5} / \mathrm{L}$ & 20,000 рCi/L & $\mathrm{t} / 2 / 14 / 96$ \\
\hline & & & & $80,400 \mathrm{pCi} / \mathrm{L}$ & $20,000 \propto \mathrm{Ci} / \mathrm{L}$ & $3 / 3 / 95$ \\
\hline & & & & $79,600 \mathrm{pCj} / L$ & $20,000 \mathrm{pCi} / \mathrm{L}$ & $6 / 13 / 95$ \\
\hline & & & & $79,800 \mathrm{pCi} / \mathrm{L}$ & $20,000 \mathrm{pCA} / \mathrm{L}$ & $9 / 13 / 95$ \\
\hline & & & Mitrate & $130,000 \mathrm{ppb}$ & $45,000 \mathrm{ppb}$ & $12 / 14 / 94$ \\
\hline & & & & $130,000 \mathrm{ppb}$ & $45,000 \mathrm{ppt}$ & $3 / 3 / 95$ \\
\hline & & & & $140,000 \mathrm{ppb}$ & $45,000 \mathrm{ppb}$ & $6 / 13 / 98$ \\
\hline & & & & $150,000 \mathrm{ppb}$ & $45,000 \mathrm{ppb}$ & $9 / 13 / 95$ \\
\hline & $2-470-15$ & Down & cerbon Tetrachloride & $930 \mathrm{pDb}$ & $5 \mathrm{ppb}$ & $\$ / 5 / 6$ \\
\hline & & & Viltwred Iron & $3,100 \mathrm{pob}$ & $300 \mathrm{pob}$ & $8 / 8 / \% 5$ \\
\hline & & & filtered chropiun & t10 pob & $100 \mathrm{pos}$ & $11 / 30 / 44$ \\
\hline & $\cdot$ & & & $310 \mathrm{mb}$ & $109 \mathrm{ppb}$ & $2 / 10 / 95$ \\
\hline & & & & $110 p 0$ & $100 \mathrm{ppb}$ & 5/18/9s \\
\hline & & & & $9 \mathrm{gtc}^{*} \mathrm{ppt}$ & $100 \mathrm{ppb}$ & s/a/ss \\
\hline & & & Filtared Hiakel & $500^{5} \mathrm{ppb}$ & $700 \mathrm{ppb}$ & a/8/9s \\
\hline & & & Fluop fid? & 5,4000 & 4,000 $\mathrm{Fpb}^{4}$ & $9 / 24 / 94$ \\
\hline & & & & $4,700 \mathrm{ppb}$ & 4,000 pp" & $2 / 10 / 55$ \\
\hline
\end{tabular}


Table 4.11-4. Constituents Exceeding Regulatory limits. (5 sheets)

\begin{tabular}{|c|c|c|c|c|c|c|}
\hline $\ln$ & Sell Ko, & yparain & constitumats & Volus & timit & Doter(s) \\
\hline & & & & $5,000 \mathrm{pp}$ & $4,000 \mathrm{pab}$ & $5 / 18 / 55$ \\
\hline & & & & $4,8000 \mathrm{ppos}$ & $4,0000,0$ & $0 / 8 / 55$ \\
\hline & & & Mitrate & $320,000 \mathrm{fpb}$ & $45,000 \mathrm{pph}$ & $9 / 21 / 94$ \\
\hline & & & & 230,000 pp & 45,000 ppt & $2 / 10 / 55$ \\
\hline & & & & $260,000 \mathrm{ppob}$ & $45,000 \mathrm{ppos}$ & $5 / 18 / 95$ \\
\hline & & & & $200,000 \mathrm{mb}$ & $45,000 \mathrm{mb}$ & $8 / 5 / 95$ \\
\hline & & & TOS' & 700 & $590 \mathrm{ppa}$ & $11 / 50 / 94$ \\
\hline & & & & $760 \mathrm{pm}$ & $500 \mathrm{ppm}$ & $2 / 10 / \% 5$ \\
\hline & & & & 760 par & $500 \mathrm{FPm}$ & $5 / 18 / 5 s$ \\
\hline & & & & 760 & $500 \mathrm{ppm}$ & $8 / 8 / 95$ \\
\hline & & & Trition & $32.800 \mathrm{pC} / \mathrm{L}$ & $20,000 \mathrm{pCt} / \mathrm{L}$ & $11 / 30 / 94$ \\
\hline & & & & $35,200 \mathrm{pci} / \mathrm{c}$ & $20,000 \mathrm{pGi} / \mathrm{L}$ & $2 / 10 / 55$ \\
\hline & & & & $35,300 \mathrm{pcj} / \mathrm{h}$ & $20,000 \mathrm{pcF} / \mathrm{L}$ & $5 / 18 / 95$ \\
\hline & & & & $33,100 \mathrm{pCin}$ & $20,000 \mathrm{pci} / \mathrm{L}$ & $8 / 8 / 95$ \\
\hline & & & at & $0.4,8.74$ & $8.4 \cdot 8.5$ & $11 / 30 / 96$ \\
\hline & 2-410-16 & $U_{p}$ & Corbon Tetratht aride & $1,200^{\circ} \mathrm{ppb}$ & $5 \mathrm{ppb}$ & $11 / 39 / 96$ \\
\hline & & & Nitrate & $140,000 \mathrm{ppb}$ & $45,000 \mathrm{ppob}$ & $9 / 21 / 94$ \\
\hline & & & & $120,000 \mathrm{ppb}$ & $45,0000 \mathrm{ppb}$ & $2 / 9 / 95$ \\
\hline & & & & $120,000 \mathrm{ppb}$ & $45,000 \mathrm{ppb}$ & $5 / 17 / 95$ \\
\hline & & & & $130,000 \mathrm{ppb}$ & $45,0000 \mathrm{ppb}$ & $8 / 7 / 65$ \\
\hline & & & TDS' & $510 \mathrm{ppri}$ & 500 pal & $2 / \% / \%$ \\
\hline & & & & $520 \mathrm{ppth}$ & $500 \mathrm{ppos}$ & $5 / 17 / 65$ \\
\hline & & & & $510 \mathrm{ppon}$ & $500 \mathrm{DP}=$ & $8 / 7 / 95$ \\
\hline & & & Tritics & $45,000, \times C 1 / L$ & $20,000 \mathrm{pCj} / \mathrm{L}$ & $11 / 29 / 96$ \\
\hline & & & & $43,800 \mathrm{pci} / \mathrm{h}$ & $20,000 \mathrm{p} \div \mathrm{i} / \mathrm{L}$ & $2 / \% / 95$ \\
\hline & & & & $45,600 \times \times i / L$ & $20,000 \times 1 / 1$ & $8 / 7 / 95$ \\
\hline & $2-411-28$ & Dom & Wftrate & $200,000 \mathrm{ppb}$ & $45,000 \mathrm{ppb}$ & $9 / 21 / 94$ \\
\hline & & & & $130,000 \mathrm{ppb}$ & $45,000 \mathrm{ppb}$ & $2 / 2 / 94$ \\
\hline & & & & $130,000 \mathrm{cpb}$ & $45,000 \mathrm{ppb}$ & $5 / 17 / 95$ \\
\hline & & & & $\$ 40,000 \mathrm{ppb}$ & $45,000 \ldots$ & stors \\
\hline & & & TOS & $640 \mathrm{ppm}$ & $500 \mathrm{pom}$ & $10 / 26 / 96$ \\
\hline & & & & $620,500 \mathrm{pPm}$ & $500 \mathrm{pm}$ & $2 / 2 / 95$ \\
\hline & & & & $610 \mathrm{pmin}$ & 500 ppr & $5 / 17 / 5 s$ \\
\hline & & & - & 650 ppp & $500 \mathrm{ppn}$ & $8 / 10 / 95$ \\
\hline & & & trition & $57,500 \mathrm{pCi} / \mathrm{L}$ & $20,000 \mathrm{DI} / \mathrm{L}$ & $10 / 26 / 94$ \\
\hline & & & & $57,600 \mathrm{pCl} / \mathrm{t}$ & $20,000 \mathrm{pCft}$ & $2 / 23 / 95$ \\
\hline & & & & $60,300 \mathrm{pCi} / \mathrm{L}$ & 20,000 pCi/L & $5 / 17 / 98$ \\
\hline
\end{tabular}


Table 4.11-4. Constituents Exceeding Regulatory Linits. (5 sheets)

\begin{tabular}{|c|c|c|c|c|c|c|}
\hline m & Hell Mo. & $15 /$ tom & Constitument" & Volve & tinit & Dake(s) \\
\hline & & & & $57,900 \times 11 / 6$ & $20,000,061 / 6$ & $8 / 10 / 95$ \\
\hline & & & Corben Tetrachlor ide & $1,068 \mathrm{ppb}$ & $5 p$ & $12 / 13 / 44$ \\
\hline & & & & $1,000 \mathrm{ppb}$ & $5 \mathrm{pto}$ & $7 / 26 / 95$ \\
\hline & 2-411-31 & Don & Eritimn & $74,000 \mathrm{pC} \neq 1 / 2$ & $20,000 \mathrm{pCi} / \mathrm{t}$ & $12 / 14 / 94$ \\
\hline & & & & $76,200 \mathrm{pCi} / \mathrm{L}$ & 20,000 pCiL & $3 / \Delta / 4 s$ \\
\hline & & & & $73,100 \mathrm{pcin}$ & $20,000 \mathrm{pCi} / 2$ & $6 / 12 / \%$ \\
\hline & & & & $76,000 \mathrm{pC}: / \mathrm{L}$ & $20,000 \mathrm{pci} / \mathrm{c}$ & $9 / 13 / 95$ \\
\hline & & & Hitrate & $12 B, 000$ & $45,000 \mathrm{ppb}$ & $12 / 14 / 94$ \\
\hline & & & & 110,000 pop & $45,000 p p b$ & $3 / 8 / 85$ \\
\hline & & & & $130,000 \mathrm{ppt}$ & $45,000 \mathrm{ppt}$ & $6 / 12 / 55$ \\
\hline & & & & $140,000 \mathrm{ppb}$ & $45,000 \mathrm{ppb}$ & $9 / 13 / \%$ \\
\hline$T X=T Y$ & $2-410 \cdot 17$ & Dom & Hifrate & 100,000 & $45,000 \mathrm{pot}$ & $9 / 22 / 94$ \\
\hline & & & & $9,000 \mathrm{ppb}$ & $45,000 \mathrm{ppb}$ & $2 / 10 / 95$ \\
\hline & & & & $86,600 \mathrm{ppb}$ & $45,000 \mathrm{pob}$ & $5 / 17 / 95$ \\
\hline & & & & $97,060 p p$ & 45,000 pab & $8 / 7 / 95$ \\
\hline & & & Irjtiun & $33,800 \mathrm{pCi} / \mathrm{L}$ & $20,000 \mathrm{PCS} / \mathrm{L}$ & $11 / 30 / 94$ \\
\hline & & & & $35,6100 \mathrm{PC} 1 / \mathrm{L}$ & $20,000 \mathrm{pCi} / \mathrm{L}$ & $2 / 10 / 95$ \\
\hline & & & & $34,200 \mathrm{pCi} / \mathrm{L}$ & $20,000 \mathrm{pCi} / \mathrm{L}$ & $5 / 17 / 95$ \\
\hline & & & & $29,900 \mathrm{pCi} / \mathrm{L}$ & $20,000 \times 01 / 2$ & $8 / 7 / 45$ \\
\hline & & & Carion Tetrachleride & $1,000 \ldots$ & $5 \mathrm{ppb}$ & $5 / 11 / 95$ \\
\hline & $2-410-18$ & Down & Mitrate & $78,000 \mathrm{ppb}$ & $45,000 \mathrm{ppb}$ & $11 / 30 / 94$ \\
\hline & & & . & $23,000, p$ & 45,000906 & $2 / 10 / 95$ \\
\hline & & & & $\begin{array}{l}95,000 p^{6} \\
94,100\end{array}$ & 45, 0000 ppo & $5 / 17 / 6$ \\
\hline & & & & 95,000 pot & $45,000 \mathrm{ppb}$ & S/7NS \\
\hline & $2-414-12$ & Down & Mitrate & 320,000 pab & 45,000 paph & $11 / 30 / 94$ \\
\hline & & & & 450,000000 & 45,000000 & $2 / 10 / 95$ \\
\hline & & & & $360,000 \ldots+1$ & $45,0000, p+b$ & $5 / 47 / 95$ \\
\hline & & & & 350,000 p & $45,000 \mathrm{ppb}$ & $6 / 6 / 95$ \\
\hline & & & ${ }^{m} \mathrm{Tc}$ & $6,200 \mathrm{pci} / \mathrm{L}$ & $500 \mathrm{pci} / \mathrm{L}$ & $11 / 30 / 24$ \\
\hline & & & & $9,950 \mathrm{pCs} / \mathrm{L}$ & $900 \mathrm{pC1} / \mathrm{L}$ & $2 / 10 / 95$ \\
\hline & & & & $9,000 \mathrm{DCi} / \mathrm{C}$ & $900 \mathrm{pCi} / \mathrm{L}$ & $5 / 17 / 25$ \\
\hline & & & & $6,060 \mathrm{pCj} / \mathrm{L}$ & $900901 / 6$ & $8 / 8 / 95$ \\
\hline & & & Trititur & $233,000 \mathrm{pCI} / \mathrm{L}$ & 20,000 DCt/ & $11 / 30 / \%$ \\
\hline & & & & $585,000 \mathrm{pci} / \mathrm{t}$ & $20,000 \mathrm{pCi} / \mathrm{L}$ & $2 / 10 / \% 5$ \\
\hline & & & & $319,000 \mathrm{pCl} / \mathrm{L}$ & $20,000 \mathrm{pCt} / \mathrm{L}$ & $5 / 17 / 95$ \\
\hline & & & & $184,000 \mathrm{pC} 1 / \mathrm{L}$ & $20,600 \mathrm{pCl} / \mathrm{L}$ & $9 / 3 / \%$ \\
\hline & & & ba्at & 29 pclith & 1 pCi/l & $11 / 30 / 94$ \\
\hline
\end{tabular}


Table 4.11-4. Const ituents Exceeding Regulatory Limits. (5 sheets)

\begin{tabular}{|c|c|c|c|c|c|c|}
\hline uㅐㅅㅐ & Hell Ha, & Yy/Dow & comst ituent* & Volue & lfnit & Dote(s) \\
\hline & & & & $47 . \mathrm{BPC} / \mathrm{L}$ & 1 pCi/ & $2 / 10 / 95$ \\
\hline & & & & 39.3 pat/l & $t \mathrm{pCt} / \mathrm{L}$ & $s / 17 / 96$ \\
\hline & & & & $30.4 \times 1 / 2$ & $1 \mathrm{PCi} / \mathrm{L}$ & 6/6/95 \\
\hline & & & Filtered chrowites & $190 \mathrm{mob}$ & $100 \mathrm{ppb}$ & $11 / 50 / 94$ \\
\hline & & & & $290 \mathrm{mb}$ & 10,0 pob & $2 / 10 / 95$ \\
\hline & & & & 360 pab & 100 & $5 / 17 / \% 5$ \\
\hline & & & & $250 \mathrm{ppb}$ & 100 क力 & $8 / 2 / 55$ \\
\hline & & & Fittured Manganoss & $120 \mathrm{pm}$ & $50 p 0$ & $11 / 30 / 94$ \\
\hline & & & & 100 & 50 pot & $2 / 10 / \%$ \\
\hline & & & $\mathrm{TDS}^{\prime}$ & Tro pp & $500 \ldots$ & $17 / 30 / 94$ \\
\hline & & & & 970 ppr & $500 \mathrm{pmon}$ & $2 / 10 / 95$ \\
\hline & & & & B99 ppn & 500 & $5 / 17 / 95$ \\
\hline & & & & $810 \mathrm{ppm}$ & 500 & $8 / 2 / 95$ \\
\hline & $2-415-22$ & $4 p$ & NItrate & $110,000 \mathrm{ppb}$ & $45,000 \mathrm{ppb}$ & $11 / 30 / 94$ \\
\hline & & & & 96,000 pb & $45,000 \mathrm{ppb}$ & $2 / 10 / 55$ \\
\hline & & & & $93,000 \mathrm{ppb}$ & $45,0: 00 \mathrm{ppb}$ & $5 / 17 / \% 5$ \\
\hline & & & & $100,0000 \mathrm{ppb}$ & $45,000 \mathrm{ppb}$ & $8 / 24 / 45$ \\
\hline & & & Trititu & $22,600 \mathrm{pei} / \mathrm{L}$ & $20,000 \mathrm{PC1} / \mathrm{L}$ & $11 / 30 / 94$ \\
\hline & & & & $27,800 \times 1 / 6$ & $20,000 \mathrm{pC1} / \mathrm{L}$ & $2 / 10 / 95$ \\
\hline & & & & $30,600 \mathrm{DCi} / \mathrm{L}$ & $20,000 \neq 5 i / L$ & $5 / 17 / 95$ \\
\hline & & & & $43,200 \mathrm{pCi/L}$ & $20,000 \mathrm{pCi} / \mathrm{L}$ & $8 / 24 / 55$ \\
\hline & & & Corbon Jetruchlor id & $600 \mathrm{ppb}$ & $5 \mathrm{ppb}$ & $11 / 30 / 64$ \\
\hline$\underline{u}$ & $2-418-23$ & an & Carbon Tetrachloride & $100 \mathrm{mpb}$ & $5 \mathrm{mph}$ & $2 / 13 / 95$ \\
\hline & $2-419-31$ & Up & Carbon Tatrachlorido & 71 לק & $5 \mathrm{ppb}$ & $2 / 1 t / 05$ \\
\hline & $2-449-32$ & p & Carbon Tetrachlorife & 30 ppob & 5 ppb & $2 / 13 / 95$ \\
\hline
\end{tabular}

nores

+Elevated specific conductence in this well has triggered the site into oroudwater qublity obsessenent mont tor ing under inter in-stetus regulstions (40 CFR 265)

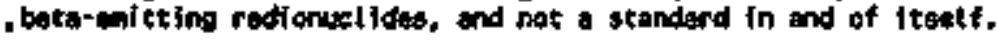

The ous for ehronium changed to $100 \mathrm{ppb}$ in July $19 \% \mathrm{z}$, but the interin Dus in 40 efr 265 is $35 i(150 \mathrm{ph}$.

- Well sorpled for $200-8 p+1$ imvertigations.

Suspet value under imvestigation.

Dus troin to CFR 264: bus from 40 GFR 265 is 1,400 * 2,400 ppb.

Tos a Totol piesolved salfe.

Value figged by taboratory because result wo gbove high standard, but uithin instrument range.

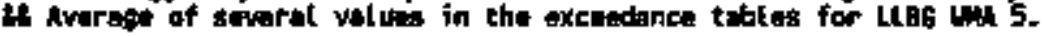


Table 4.11-5. Critical Means Table for 20 Comparisons--Background

Contamination Indicator Parameter Data for the Single-Shell Tanks Waste Managenent Area A-AX.

\begin{tabular}{|c|c|c|c|c|c|c|c|}
\hline $\begin{array}{c}\text { Const ituent } \\
\text { (Unit) }\end{array}$ & $\mathbf{n}$ & $d f$ & tc & $\begin{array}{c}\text { Average } \\
\text { background }\end{array}$ & $\begin{array}{l}\text { Standard } \\
\text { deviation }\end{array}$ & $\begin{array}{c}\text { Critical } \\
\text { mean }\end{array}$ & $\begin{array}{l}\text { Jpgradient/ } \\
\text { downgradient } \\
\text { comparison } \\
\text { value }\end{array}$ \\
\hline $\begin{array}{l}\text { Specific } \\
\text { Conductance } \\
(\mu \text { who } / \mathrm{cm})\end{array}$ & 8 & $\overline{7}$ & 5.4079 & 396.563 & 59.671 & 738.8 & 738.8 \\
\hline Field pH & 8 & 7 & 6.0818 & 7.798 & 0.194 & {$[6.55 / 9.05]$} & {$[6.55 / 9.05]$} \\
\hline$T^{2} C^{E}$ (ppb) & 6 & 5 & 5.4079 & 500 & H.C. & N.C. & 976 \\
\hline FOX $\mathrm{X}^{\mathrm{d}}(\mathrm{ppb})$ & H.C. & H.C. & A.C. & N.C. & N.C. & N.C. & 13.6 \\
\hline
\end{tabular}

Data collected from July 1991 to Hay 1992 for upgradient weils 299-E25-40 and 299-E25-41. Critical weans calculated based on 20 comparisons.

The following notations are used in this table:

df a degrees of freedom $(n-1)$.

$n=$ nuber of background replicate averages.

$t_{c}=$ Bonferroni critical $t$-value for appropriate of and 20 comparisons. N.C. = not calculated.

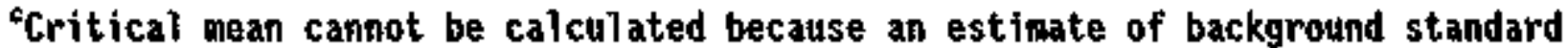
deviation is lacking. ToX values from upgradient wells have been detected above the nethod-detection limit (see Appendix A).

dCritical mean cannot not be calculated because of probiens associated with data quality for samples analyzed by OCL. The upgradient/downgradient comparison value for toX is the 1 imit of quantitation (see Appendix $A$ ).

"Excluding TOC values collected on 2/28/92 from wells 299-E25-40 and 299-E25-41 because of Honconformance Report. 
Tab]e 4.11-6. Critical Heans Table for 28 Conparisons--Background Contanination Indicator Parameter Data for the Single-She11 Tanks Waste Hanagement Area B-BX-BY., 6

\begin{tabular}{|c|c|c|c|c|c|c|c|}
\hline $\begin{array}{l}\text { Constituent } \\
\text { (Unit) }\end{array}$ & $\mathbf{n}$ & df & tc & $\begin{array}{l}\text { Average } \\
\text { background }\end{array}$ & $\begin{array}{l}\text { Standard } \\
\text { deviation }\end{array}$ & $\underset{\text { mean }}{\text { Critical }}$ & $\begin{array}{l}\text { Upgradient/ } \\
\text { downgradtent } \\
\text { comparison value }\end{array}$ \\
\hline $\begin{array}{l}\text { Specific } \\
\text { Conductance } \\
(\mu \text { mho } / \mathrm{cm})\end{array}$ & 8 & 7 & 5.7282 & 262.656 & 16.958 & 365.7 & 365.7 \\
\hline Fleld pH & $\frac{8}{7}$ & $\begin{array}{l}7 \\
6\end{array}$ & $\begin{array}{l}6.4295 \\
7.2227\end{array}$ & $\begin{array}{l}7.902 \\
8.126\end{array}$ & $\begin{array}{l}0,709 \\
0,344\end{array}$ & $\begin{array}{l}{[3.07 / 12.74]} \\
{[5.47 / 10.78]}\end{array}$ & {$[6.91 / 9.28]^{7}$} \\
\hline$T C^{c}(p p b)$ & 8 & 7 & 5.7282 & 500 & H.C. & N.C. & 976 \\
\hline$T \phi X^{d}(p p b)$ & N.C. & H.C. & M. C. & H.C. & H.C. & A.C. & 13.6 \\
\hline
\end{tabular}

Data collected from July 1991 to June 1992 for upgradient wells 299-E33-33 and 299-E33-36. Critical means calculated based on 28 comparisons.

bre following notations are used in this table: df $=$ degrees of freedom $(n-1)$.

$n=$ number of background replicate averages.

$t_{c}=$ Bonferronj critical t-value for appropriate df and 20 comparisons.

$H . C .=$ not calculated.

CCritical mean cannot be calculated because an estinate of background standard deviat ion is lacking. The upgradient/downgradient comparison value for Toc is the 1 imit of quantitation (see Appendix A).

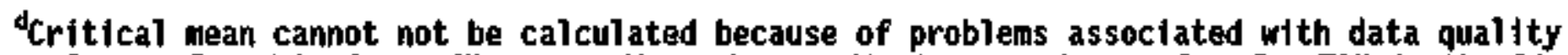
for samples analyzed by OCL. The upgradient/doungradient comparison value for Tox is the Itmit of quantitation (see Appendix A).

"Upgradient/downgradient comparison value for $\mathrm{pH}$ is the critical mean calculated excluding the inconsistent pH replicate average 6.335 of samples collected on 1/3/92 from we11 299-E33-36. 
Tabile 4.11-7. Critical Heans Table for 16 Comparisons-Background Contamination Indicator Parameter Data for the Single-She11 Tanks Waste Nanagement Area $C, 0, b$

\begin{tabular}{|c|c|c|c|c|c|c|c|}
\hline $\begin{array}{l}\text { Constituent } \\
\text { (Unit) }\end{array}$ & $n$ & $d f$ & tc & $\begin{array}{c}\text { Average } \\
\text { background }\end{array}$ & $\begin{array}{l}\text { Standard } \\
\text { deviation }\end{array}$ & $\begin{array}{c}\text { Critical } \\
\text { mean }\end{array}$ & $\begin{array}{c}\text { Upgradient/ } \\
\text { Dowingradient } \\
\text { Comparison } \\
\text { Value }\end{array}$ \\
\hline $\begin{array}{l}\text { Specific } \\
\text { Conductance } \\
\text { ( } \mu \text { mho/cm) }\end{array}$ & 4 & 3 & $\begin{array}{r}11.9838 \\
. \\
\end{array}$ & 353.063 & 14.244 & 543.9 & $\overline{543.9}$ \\
\hline Fletd pH & 4 & 3 & 15.1451 & 8.038 & 0.109 & {$[6,19 / 9,88]$} & [6.19/9.8B] \\
\hline$T O C^{\circ}(p p b)$ & 4 & 3 & 11.9838 & 500 & N.C. & H.C. & 976 \\
\hline Tox (ppb) & N.C. & N.C. & H.C. & M.C. & N.C. & N.C. & 13.6 \\
\hline
\end{tabular}

Data collected froin July 1991 to August 1992 for upgradtent well 299-E27-14. Critical means calculated based on 16 comparisons.

The following notations are used in this table: df = degrees of freedor $(n-1)$.

$n=$ number of background replicate averages.

$t_{c}=$ Bonferroni critical t-value for appropriate df and 20 comparisons. N.C. $\ldots$ not calculated.

'Critical mean cannot be calculated because an estimate of background standard deviation is lacking. The upgradient/downgradient comparison value for ToC is the $i$ imit of quantitation (see Appendix A).

tritical mean cannot not be calculated because of problems associated with data quality for samples analyzed by DCL. The upgradient/downgradient comparison value. for TOX is the limit of quantitation (see Appendix A). 
Table 4.11-8. Critical Means Table for 28 Comparlsons--Background Contamination Indicator Parameter Data for the $\$$ ingle-\$hell Tanks Uaste Management Area $\mathbf{S - \$ X}, \ldots$

\begin{tabular}{|c|c|c|c|c|c|c|c|}
\hline $\begin{array}{c}\text { Constituent } \\
\text { (Unit) }\end{array}$ & $n$ & $\cdot d f$ & t.c & $\begin{array}{c}\text { Average } \\
\text { background }\end{array}$ & $\begin{array}{l}\text { Standard } \\
\text { deviation }\end{array}$ & Critical mean & $\begin{array}{c}\text { Upgradient/ } \\
\text { downgradient } \\
\text { comparison value }\end{array}$ \\
\hline $\begin{array}{l}\text { Specific } \\
\text { Conductance } \\
\text { (umho/con) }\end{array}$ & 8 & 7 & 5.3168 & 246.3125 & 42.666 & 486.9 & 486.9 \\
\hline Field pH & 7 & $6^{6}$ & 6.4295 & 7.918 & 0.307 & {$[5.81,10.03]$} & {$[6.68 / 9.18]^{\circ}$} \\
\hline$T O C^{0}(\rho p b)$ & 8 & 7 & 5.3168 & 500 & N.C. & N.C. & 976 \\
\hline $\mathrm{Tox^{d }}$ (ppb) & H.C. & N.C. & N.C. & N.C. & N.C. & H.C. & 13.6 \\
\hline
\end{tabular}

aData collected from October 1991 to July 1992 for upgradient wells 299-W23-13 and 299-W23-14.

critical means calculated based on 28 comparisons.

'The following natations are used in this table:

df = degrees of freedon $(n-1)$.

$n=$ number of background repl jcate averages.

$t_{c}=$ Bonferroni crttical t-value for appropriate of and 20 comparisons.

H.C. = not calculated.

cCr1tical mean cannot be calculated because an estimate of background standard deviation is lacking. The upgradient/downgradient comparison value for Toc is the limit of quantitation (see Appendix A).

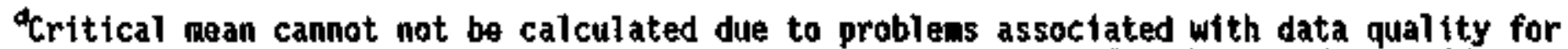
samples analyzed by DCL. The upgradient/downgradient comparison value for TOX is the limit of quantitation (see Appendix A).

Epgradient/downgradient comparison value for pH were calculated using data collected from October 1991 to June 1993 (weIls 299-W23-13 and 299-W23-14) because the critical range calculated using four quarters of data is too large to be meaningful.

Excluding inconsistent pH replicate average 5.868 of samples collected on 10/9/91 from well 299-W23-14. 
Table 4.11-9. Critical Means Table for 20 Comparisons--Background Contamination Indicator Paraweter Data for the Stngle-Shell Tanks Waste Management Area $U .4, b$

\begin{tabular}{|c|c|c|c|c|c|c|c|}
\hline $\begin{array}{c}\text { Constituent } \\
\text { (Unit) }\end{array}$ & $\mathbf{n}$ & df & tc & $\begin{array}{c}\text { Average } \\
\text { background }\end{array}$ & $\begin{array}{l}\text { Standard } \\
\text { deviation }\end{array}$ & $\underset{\text { mean }}{\text { Critical }}$ & $\begin{array}{c}\text { Upgradient/ } \\
\text { Downgradient } \\
\text { Comparison Valus }\end{array}$ \\
\hline $\begin{array}{l}\text { Specific } \\
\text { Conductance } \\
\text { (pmho/cm) }\end{array}$ & B & 7 & 5.4079 & 335.906 & 27.700 & 494.8 & 494.8 \\
\hline Field pH & 8 & 7 & 6.0818 & 8.040 & 0.202 & {$[6.74,9.34]$} & {$[6.74 / 9.34]$} \\
\hline $\operatorname{Toc}^{\mathrm{C}}(\mathrm{ppb})$ & $7^{e}$ & 6 & 5.9588 & 500 & N.C. & A.C. & 976 \\
\hline Tox (ppb) & H.C. & H.C. & N.C. & H.C. & N.C. & N.C. & A.C. \\
\hline
\end{tabular}

Data collected from April 1992 to March 1993 for upgradient wells 2-W19-31 and

299-\$19-32. Critical means calculated based on 20 comparisons.

'The follawing notations are used in this table:

$d f=$ degrees of freedom $(n-1)$.

$n=$ number of background replicate averages.

$t_{c}$ - Bonferroni critica] $t$-value for appropriate of and 20 comparisons.

N.C. = not calculated.

"Critical mean cannot be calculated because an estimate of backgreund standard deviation is lacking. ToX values from upgradient wells have been detected above the method detection limit (see Appendix C).

dCritical mean cannot not bo calculated because of problems associated with data quality for samples analyzed by DCL. The upgradient/downgradient comparison value for ToX is the limit of quantitation (see Appendix A).

"Excluding TOC values collected on 4/21/92 from wells 299-W19-31 because of a nonconformance report. 
DOE/RL-96-01, Rev, O

Table 4.11-10. Water Level Declines in RCRA Wells. (2 shoets)

\begin{tabular}{|c|c|c|c|c|c|}
\hline PMAA & Wello. & $B / 91-6 / 2$ & 6 & $693-6 / 94$ & 94.6795 \\
\hline$A-\dot{A} \bar{X}$ & $\overline{E 24} \cdot \overline{19}$ & 0.62 & 6.64 & $\overline{0} . \overline{2}$ & 0.49 \\
\hline & $524-20$ & $=$ & $\approx$ & 0.08 & 0.80 \\
\hline & EZs5-2 & 0.52 & 0.57 & 0,0 & 0.67 \\
\hline & $E 25 \div 40$ & 0.74 & 0.60 & +0.03 & 0.60 \\
\hline & E25.4t & 0.71 & 0.57 & 0.06 & 0.70 \\
\hline & $525-46$ & $=$ & - & 0.22 & 0.57 \\
\hline & Avg. & 0.70 & 0.00 & 0.12 & 0.64 \\
\hline $\bar{\theta} \cdot \mathrm{EX} \cdot \overline{\mathrm{B}} \bar{Y}$ & $\overline{E x 3} \cdot 3$ & 0.70 & 0.63 & +0.02 & 0.57 \\
\hline & E\$3-18 & $=$ & - & 0.23 & 0.70 \\
\hline & $E 30-21$ & 0.73 & 0.70 & $+0,09$ & 0.55 \\
\hline & $E 33-31$ & 0.73 & 0.7 & \pm 0.009 & 0.61 \\
\hline & $E 33-32$ & 0.75 & 0.70 & 0.32 & 0.24 \\
\hline & E33.33 & 0,80 & 0,7 & +0.08 & 1.02 \\
\hline & E33-36 & 0.81 & 0,59 & 0.25 & 1.32 \\
\hline & $533-45$ & - & 0.75 & 0.24 & 0.46 \\
\hline & $E 33-42$ & $=$ & 0.54 & 0.15 & 0.58 \\
\hline & $E 33-43$ & $=$ & 0.57 & 0.18 & 0.56 \\
\hline & Avg. & 0.75 & 0.67 & 0.12 & 0.68 \\
\hline & & & & & \\
\hline $\bar{c}$ & 527.7 & $0 . \overline{\theta^{\prime}}$ & $0 . \overline{56}$ & 0.23 & $0.43^{*}$ \\
\hline & $E 27-12$ & 0.71 & 0.68 & +0.03 & 0.64 \\
\hline & E27-13 & 0,46 & 0,81 & 0,04 & 0.65 \\
\hline & E27-14 & 0.89 & 0.62 & +0.03 & 0.70 \\
\hline & E27-15 & 0.72 & 0.64 & $\mathbf{0 , 6 4}$ & 0.02 \\
\hline & Avo. & 0.59 & 0,87 & 0.05 & 0.67 \\
\hline & & & & & \\
\hline s-sx & W22 39 & 1.57 & 193 & 1.00 & 1.80 \\
\hline & $\overline{w 22}+4$ & $=$ & 2.01 & 1.31 & 2.41 \\
\hline & w22,45 & $\overline{-}$ & $=$ & 120 & 2.01 \\
\hline & WZ2-46 & $=$ & 1,85 & 1.01 & 1.63 \\
\hline & $\overline{W Z 3-0}$ & 1.37 & 2.12 & 0.67 & 1.81 \\
\hline & w23-8 & 158 & 2,47 & 1.07 & $1+\underline{x}$ \\
\hline & Whos 13 & 1.93 & 2.67 & 1.23 & $\underline{2.2}$ \\
\hline & whs-14 & $t .5 B$ & 2.33 & $1.0 \mathrm{~B}$ & 200 \\
\hline & W/23-15 & 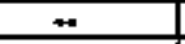 & 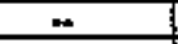 & 1.09 & 1.84 \\
\hline & AVA, & t.81 & 2.20 & 1.07 & 1.97 \\
\hline & & & & & \\
\hline$T$ & WID-B & 1.87 & 0.52 & 0.32 & 1.88 \\
\hline & Wto- & $\bar{z}$ & 0.71 & 0.27 & 1.8 \\
\hline & Wo.10 & 1.59 & 0.80 & 0.23 & 1.87 \\
\hline & WTo-11 & 1.59 & 0.59 & $0.2 B$ & 1,8 \\
\hline & \begin{tabular}{|l|l|}
$10-12$ \\
\end{tabular} & 1.58 & 0.61 & 0.25 & 1.85 \\
\hline & W10-15 & 1.82 & 0.57 & 0.26 & 1.85 \\
\hline & W10-1s & 1,47 & 0.81 & 0.20 & $\underline{2.3}$ \\
\hline & W11-23 & 1.89 & 0.04 & $=$ & $1, \bar{B}$ \\
\hline & $W 11-24$ & 1.82 & 0.69 & $\overline{-}$ & 1.84 \\
\hline & W1t-27 & 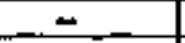 & 0,69 & 0.54 & $1, \frac{B}{2}$ \\
\hline & $W 11-28$ & - & $=$ & $=$ & 1.20 \\
\hline & Avg. & 1.83 & 0.63 & Q2. & 1. BS \\
\hline$\overline{I X-T Y}$ & W:0-17 & 1.46 & 0.54 & 0.47 & $\overline{t .76}$ \\
\hline & W10-18 & 1.37 & 0.62 & $\frac{2}{0.35}$ & $\frac{1.82}{1.82}$ \\
\hline & $W 14-12$ & $=$ & 0.62 & 0.25 & 1.97 \\
\hline
\end{tabular}


Table 4,1l-10. Water Level Declines tn RCRA Wells. (2 sheets)

\begin{tabular}{|c|c|c|c|c|c|}
\hline & WSt -12 & 1.48 & 0.98 & 0.47 & 1.84 \\
\hline & Wt5-13 & 1.40 & D.85 & 0.37 & $1 . \bar{\delta}$ \\
\hline & Wif-22 & 1.51 & 10 & 0.5 & 2.08 \\
\hline & Avg. & $1 . \overline{44}$ & 0.77 & 0.42 & $1 . \overline{\mathrm{B}}$ \\
\hline & & & & & \\
\hline U & Wra-2s & 2.08 & 256 & 1.56 & 2.92 \\
\hline & $1418-30$ & - & 1.55 & 0.39 & 2.73 \\
\hline & W1a-31 & $=$ & 2.25 & 1.40 & 2.85 \\
\hline & $W_{18-33}$ & $=$ & $=$ & $\approx$ & 2.85 \\
\hline & W19-12 & 1.65 & 1.80 & 1.32 & 294 \\
\hline & W/19-21 & 0.79 & $2.4 B$ & 1.38 & 3.83 \\
\hline & W1927 & 0.86 & 1.29 & 1.91 & 3.72 \\
\hline & W10-31 & $t, 66$ & 1.56 & 1.73 & 2.80 \\
\hline & W19-32 & 1.03 & 1.59 & 1.46 & 3.17 \\
\hline & Avg. & 145 & 1.89 & 140 & 3.10 \\
\hline & & & & & \\
\hline NOTES & & & & & \\
\hline
\end{tabular}


DOE/RL-96-01, Rev. 0

Table 4.11-11. Water Level Heasurements 1991-1995. (2 sheets)

\begin{tabular}{|c|c|c|c|c|c|}
\hline then & wetl 30. & $6 / 93+6 / 92$ & $6 / 92-6 / 93$ & $6 / 93-6 / 94$ & $6 / 96-6 / 96$ \\
\hline \multirow[t]{7}{*}{$A-h x$} & $624-19$ & 0.82 & 0.64 & 0.29 & 0.43 \\
\hline & $524-20$ & $*$ & $=$ & 0.06 & 0.80 \\
\hline & $E+6-2$ & 0.52 & 0.57 & 0.0 & 0.67 \\
\hline & E25-41) & 0.74 & 0.60 & $+0,05$ & 0.68 \\
\hline & $625-41$ & 0.71 & 0.57 & 0.06 & 0.70 \\
\hline & $825-46$ & -2 & -- & 0.22 & 0.57 \\
\hline & Avg & 0.70 & 0.60 & 0.12 & 0.4 \\
\hline \multirow[t]{11}{*}{ B-BX-EY } & $633-8$ & 0.70 & 0.63 & +0.02 & 0.57 \\
\hline & $E 33-18$ & $=$ & -- & 0.23 & 0.70 \\
\hline & E33-2t & 0.73 & 0.70 & +0.09 & 0.55 \\
\hline & $E 33-31$ & 0.73 & 0.77 & $\rightarrow 0.08$ & 0.61 \\
\hline & E33-32 & $0 . \pi 5$ & 0.70 & 0.32 & 0.24 \\
\hline & $633-33$ & 0.80 & 0.77 & $\bullet 0.08$ & 1.02 \\
\hline & E33-36 & 0.87 & 0.59 & 0.25 & 1.37 \\
\hline & $635-47$ & $\cdots$ & 0.75 & 0.26 & 0.46 \\
\hline & $E 53-42$ & -- & 0.54 & 0.15 & 0.56 \\
\hline & $233-43$ & $\cdots$ & 0.57 & 0.16 & 0.56 \\
\hline & Awg & 0.5 & 0.67 & 0.12 & 0.66 \\
\hline \multirow[t]{6}{*}{$\epsilon$} & $627-7$ & 0.69 & 0.58 & 0.23 & $0.43^{*}$ \\
\hline & E27- 12 & 0.71 & 0.68 & +0.03 & 0.64 \\
\hline & E27-13 & 0.66 & 0.81 & 0.06 & 0.65 \\
\hline & $E 27+14$ & 0.89 & 0.62 & $\$ 0.03$ & 0.70 \\
\hline & $E 27-15$ & 0.72 & 0.64 & 0.84 & 0.72 \\
\hline & avg & 0.69 & 0,67 & 0.05 & 0.67 \\
\hline \multirow[t]{10}{*}{$5-5 x$} & $122-39$ & 1.57 & 1.95 & 1.00 & 1.80 \\
\hline & $122-44$ & $\cdots$ & 2.01 & 1.31 & 2.61 \\
\hline & $w 22-45$ & -- & $*$ & 1.20 & 2.01 \\
\hline & W22-46 & $*$ & 1.65 & 1.a1 & 1.63 \\
\hline & waz-6 & 1.37 & 2.12 & 0.67 & 1.81 \\
\hline & $1023-8$ & 1.58 & 2.47 & 1. 197 & 1.99 \\
\hline & $123-13$ & 1.93 & 2.67 & 1.23 & 2.20 \\
\hline & W23-14 & 1.58 & 2.35 & 1.08 & 2.00 \\
\hline & $123-15$ & 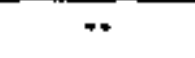 & -- & 1.09 & 1.84 \\
\hline & nve & 1.61 & 2.20 & 2.07 & 1.97 \\
\hline $\mathbf{T}$ & w10-g & 1.87 & 0.52 & 0,32 & 1,88 \\
\hline
\end{tabular}


Table 4.11-11. Water Level Measurements 1991-1995. (2 sheets)

\begin{tabular}{|c|c|c|c|c|c|}
\hline $\sin$ & Wall No. & $6 / 91-6 / 92$ & $6 / 92-6 / \%$ & $6 / 93-6 / 94$ & $6 / 94=6 / \% 5$ \\
\hline & w10-9 & -- & 0.71 & 0.27 & 1.92 \\
\hline & w10-to & 1.59 & 0.60 & 0.23 & 1.67 \\
\hline & W10-I1 & 1,59 & 0.59 & 0.26 & 1.83 \\
\hline & $410-12$ & 1.58 & 0.61 & 0.25 & 1.85 \\
\hline & W10-15 & 1.62 & 0.57 & 0.26 & 1.85 \\
\hline & 110-\$6 & 1.47 & จ.81 & 0.20 & 2.34 \\
\hline & 1411-23 & 1.86 & 0.64 & + & 1.82 \\
\hline & W11-26 & 1.82 & 0.69 & -- & 1.86 \\
\hline & 411-27 & $\because$ & $0.6 P$ & 0.54 & 1.87 \\
\hline & $111-28$ & 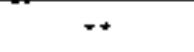 & 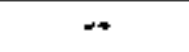 & $\therefore$ & 1.29 \\
\hline & Ang & 1.8 & 0.83 & 0.29 & 1.85 \\
\hline$T X-\pi Y$ & $410-17$ & 1.46 & 0.54 & 0.47 & 1.74 \\
\hline & $410=18$ & 1.37 & 0.67 & 0.35 & $1,8 ?$ \\
\hline & $414=12$ & 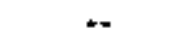 & 0.62 & 0.25 & 1.97 \\
\hline & บ15-12 & 1.48 & 0.98 & 0,47 & 1,84 \\
\hline & 415-13 & 1.40 & 0.85 & 0.37 & 1.80 \\
\hline & $415-22$ & 1.51 & 1.0 & 0.59 & 2.08 \\
\hline & Avg & 2.44 & 0.77 & 0.42 & 1.88 \\
\hline tt & 1478-25 & 2.08 & 2.56 & $t .56$ & 2.92 \\
\hline & WT8-30 & -- & 1,53 & 0.36 & 2.73 \\
\hline & $418-39$ & $*$ & 2.26 & 1.40 & 2.85 \\
\hline & $418-35$ & $*$ & $\omega$ & $*$ & 2.85 \\
\hline & W19-12 & 1.65 & 1.60 & 1.32 & 2.94 \\
\hline & N19.21 & 0.79 & 2.48 & 1.38 & 3.93 \\
\hline & W19-27 & $0 . \$ 6$ & 1.25 & 1.91 & 3.72 \\
\hline & 419-3t & 1,66 & 1.55 & 1,73 & 2. 80 \\
\hline & tw19-32 & 1.63 & 1.59 & 1.46 & 3.17 \\
\hline & livg & 1.45 & 1.87 & 1.40 & 3.10 \\
\hline
\end{tabular}

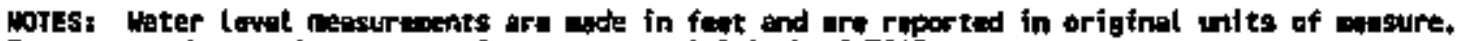
To comvert these values to motrfic neasure, nutleiply by 0.3048 .

- Amual data for perfod May to following hey (sather than June) are reported. 
Table 4.11-12. Hydrautic Gradients at Single-Shell Tank Waste Management Areas.

\begin{tabular}{|l|c|c|c|c|}
\hline \multicolumn{1}{|c|}{ WMA } & We11 no. & $\begin{array}{c}\text { Date water } \\
\text { levels } \\
\text { measured }\end{array}$ & $\begin{array}{c}\text { Difference } \\
\text { in head } \\
\text { (ft) }\end{array}$ & Gradient \\
\hline A-AX & E25-2, E24-19 & $6 / 23 / 95$ & 0.38 & 0.0005 \\
\hline B-BX-BY & E33-33, E33-32 & $7 / 25 / 95^{\mathrm{c}}$ & 0.15 & 0.00008 \\
\hline $\mathrm{C}$ & E27-7, E27-12 & $6 / 23 / 95$ & 0.19 & 0.0003 \\
\hline S-SX & W23-14, W22-46 & $6 / 21 / 95$ & 1.85 & 0.002 \\
\hline T & W10-16, W11-27 & $6 / 20 / 95$ & 0.47 & 0.0006 \\
\hline TX-TY & W15-22, W10-17 & $6 / 20 / 95$ & 2.21 & 0.0009 \\
\hline$U^{b}$ & W18-25, W18-30 & $6 / 21 / 95$ & 0.52 & 0.0007 \\
\hline
\end{tabular}

Measurements are made in feet and fractions thereof and are therefore reported in those units. To convert feet to meters, divide by 3.28 .

'The direction of groundwater flow beneath wha $u$ has changed. Water level data for the perfod June through September 1995 indicate that groundwater is flowing approximately south-southwest. Borehole velocity flowineter measurements in wells 299-w19-31 and 299-W19-32 in May 1995 measured a north-northwest direction of flow. The calculation of gradient. here assumes a south-southwest flow, with well 299-w18-30 as the upgradient wel1. Water level data for September 1995 indicate a head difference of $0.22 \mathrm{ft}$ between these two wells.

'Gradient was calculated from JuTy Iggs water level measurements because of an error of unknown ortgin in June 1995 data. 
Table 4.11-13. Groundwater Flow Velocities"b,f Unconfined Aquifer Beneath Single-She11 Tank Waste Managenent Areas.

\begin{tabular}{|c|c|c|c|c|c|}
\hline WA & $\begin{array}{l}\text { Hel1 } \\
\text { no. }\end{array}$ & $\begin{array}{l}\text { Hydrau]ic } \\
\text { conductivity } \\
\text { (m/d [ft/d]) }\end{array}$ & $\begin{array}{l}\text { Hydraulic } \\
\text { gradient }\end{array}$ & $\begin{array}{c}\text { Effective } \\
\text { porosity }\end{array}$ & $\begin{array}{c}\text { F]ow } \\
\text { velocity } \\
\text { (idd [ft/d]) }\end{array}$ \\
\hline \multirow[t]{3}{*}{$A-A X$} & E24-19 & $\begin{array}{l}33.5(110) \\
33.5(110)\end{array}$ & $\begin{array}{r}0.0005 \\
0.0005\end{array}$ & $\begin{array}{l}0.20 \\
0.10\end{array}$ & $\begin{array}{l}0.08(0.28) \\
0.17(0.55)\end{array}$ \\
\hline & E25-40 & $\begin{array}{l}21.3(70) \\
21.3(70)\end{array}$ & $\begin{array}{l}0.0005 \\
0.0005\end{array}$ & $\begin{array}{l}0.20 \\
0.10\end{array}$ & $\begin{array}{l}0.05(0.18) \\
0.11(0.35)\end{array}$ \\
\hline & E25-41 & $\begin{array}{l}7.3(24) \\
7.3(24)\end{array}$ & $\begin{array}{l}0.0005 \\
0.0005\end{array}$ & $\begin{array}{l}0.20 \\
0.10\end{array}$ & $\begin{array}{l}0.02 \\
0.04\end{array}(0.06)$ \\
\hline$B-B X-B Y$ & $833-33$ & $\begin{array}{l}97.5(320) \\
97.5(320)\end{array}$ & $\begin{array}{l}0.00008 \\
0.00008\end{array}$ & $\begin{array}{l}0.20 \\
0.10\end{array}$ & $\begin{array}{l}0.04(0.13) \\
0.08(0.26)\end{array}$ \\
\hline \multirow[t]{3}{*}{ C } & $E 27-13$ & $\begin{array}{l}54.8(180) \\
54.8(180)\end{array}$ & $\begin{array}{l}0.0003 \\
0.0003\end{array}$ & $\begin{array}{l}0.20 \\
0.10\end{array}$ & $\begin{array}{l}0.08(0.27) \\
0.16(0.54)\end{array}$ \\
\hline & E27-14 & $\begin{array}{l}48.7(160) \\
48.7(160)\end{array}$ & $\begin{array}{l}0.0003 \\
0.0003\end{array}$ & $\begin{array}{l}0.20 \\
0.10\end{array}$ & $\begin{array}{l}0.07 \quad(0.24) \\
0.15(0.48)\end{array}$ \\
\hline & E27-15 & $\begin{array}{l}119(390) \\
119(390)\end{array}$ & $\begin{array}{l}0.0003 \\
0.0003\end{array}$ & $\begin{array}{l}0.20 \\
0.10\end{array}$ & $\begin{array}{l}0.18(0.56) \\
0.36(1.17)\end{array}$ \\
\hline \multirow[t]{2}{*}{$5-5 X$} & W23-13 & $\begin{array}{l}27.4(90) \\
27.4(90)\end{array}$ & $\begin{array}{l}0.002 \\
0.002\end{array}$ & $\begin{array}{l}0.20 \\
0.10\end{array}$ & $\begin{array}{l}0.27(0.9) \\
0.55(1.8)\end{array}$ \\
\hline & W23-14 & $\begin{array}{l}0.43(1.4) \\
0.43(1.4)\end{array}$ & $\begin{array}{l}0.002 \\
0.002\end{array}$ & $\begin{array}{l}0.20 \\
0.10\end{array}$ & $\begin{array}{l}0.004(0.01) \\
0.009(0.03)\end{array}$ \\
\hline \multirow[t]{2}{*}{$T$} & W10-15 & $\begin{array}{l}10.1(33) \\
10.1(33)\end{array}$ & $\begin{array}{l}0.0006 \\
0.0006\end{array}$ & $\begin{array}{l}0.20 \\
0.10\end{array}$ & $\begin{array}{l}0.03(0.1) \\
0.05(0.2)\end{array}$ \\
\hline & W10-16 & $\begin{array}{l}10.1(33) \\
10.1 \quad(33)\end{array}$ & $\begin{array}{l}0.0006 \\
0.0006\end{array}$ & $\begin{array}{l}0.20 \\
0.10\end{array}$ & $\begin{array}{l}0.03(0.1) \\
0.06(0.2)\end{array}$ \\
\hline \multirow[t]{2}{*}{$\overline{T X-T Y}$} & W15-22 & $\begin{array}{l}15.2(50) \\
15.2(50)\end{array}$ & $\begin{array}{l}0.0009 \\
0.0009\end{array}$ & $\begin{array}{l}0.20 \\
0.10\end{array}$ & $\begin{array}{l}0.07(0.23) \\
0.14(0.45)\end{array}$ \\
\hline & W10-18 & $\begin{array}{l}54.8(180) \\
54.8(180)\end{array}$ & $\begin{array}{l}0.0009 \\
0.0009\end{array}$ & $\begin{array}{l}0.20 \\
0.10\end{array}$ & $\begin{array}{c}0.25(0.81) \\
0.49(1.8)\end{array}$ \\
\hline \multirow[t]{2}{*}{$\mathbf{U}$} & W18-25 & $\begin{array}{r}6.1(20) \\
6.1(20)\end{array}$ & $\begin{array}{l}0.0007 \\
0.0007\end{array}$ & $\begin{array}{l}0.20 \\
0.10\end{array}$ & $\begin{array}{ll}0.02 & (0.07) \\
0.04 & (0.14)\end{array}$ \\
\hline & W19-31 & $\begin{array}{l}36.6(120) \\
36.6(120)\end{array}$ & $\begin{array}{l}0.0007 \\
0.0007\end{array}$ & $\begin{array}{l}0.20 \\
0.10\end{array}$ & $\begin{array}{l}0.13(0.42) \\
0.26(0.84)\end{array}$ \\
\hline
\end{tabular}

"Calcutated using: $v=K i / n$, where $K=$ hydraulic conductivity, $i=$ gradient, $a$ - effective porosity, and Equation 1.

bydraulic conductivities were calculated from results of slug tests performed in wel1s indicated (Hewcomer et a). 1990). Connelly et al. (1992b) found that hydraulic conductivities determined from slug tests may be an order of magnitude too low compared with hydraulic conductivities calculated from constant discharge tests.

aAl of these wells are completed as 4-in. Wells with stainless steel screens $(0.10$ or 0.20 slot) in the uppermost part of the unconfined aquifer beneath each site. Most 200 East Area wells are completed in the Hanford formation; most 200 West Area weils are completed in the Ringold Formation. 
DOE/RL-96-01, REY. 0

Contarts

5.0600 AREA $\ldots \ldots \ldots \ldots . \ldots \ldots \ldots$

5.1 NOARADIOACTIVE DANGEROUS NASTE LAHDFILL . . . . . 5.1-1

5.1 .1 Facility Overview . . . . ....... 5.1-1

5.1 .2 Summary of 1995 RCRA Activities . . . . . . 5.1-2

5.1.3 Sampling and Analysis Program .......... 5.1-2

$\mathbf{5 . 1 . 4}$ Groundwater Chemistry .............. 5.1-2

5.1.5 Groundwater Flow ................. 5.1-4

5.1 .6 References . . . . . . . . . . . . 5.1-6 
DOE/RL-96-01, REV. 0

\section{LIST OF FIGURES}

5.1-1 Map of the Nonradioactive Dangerous Waste Landfill and Solid Waste Landfill Showing the Locations of Groundwater Monitoring Nells ....................... . .

5. I-2 Generalized Stratigraphic Column for the Honradioactive

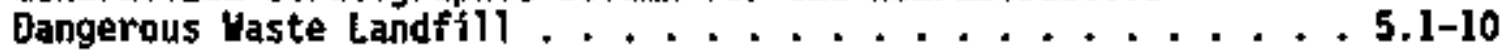

5.1-3 Tine Series Plot of Hitrate concentrations in Shallow Monitoring Hells at the NROA ............. 5.1-11

5.1-4 Time Series Plot of Tritiua Concentrations in Shallow

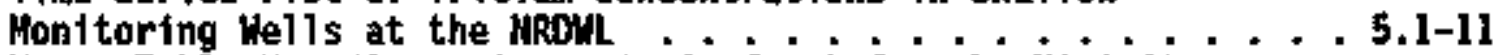

5.1-5 Water Table Map (Potentionetric Surface) for the Vicinity of the Monradioactive Dangerous Waste Landf111 Based on June 1994 Nater Level Measurements . . . . . . . . . . 5.1-12

5.1-6 Hydrographs of Monthiy Water Level Measurements at the Honradioact ive Dangerous Waste Landfij] ......... 5.1-13

\section{LIST OF TABLES}

5.1-1 Monttoring Wells Used for the Monradioactive Dangerous Waste Landfil1. . . . . . . . . . . . . . . . . . .

5.1-2 Constituent 1 ist for the Honradioactive Oangerous Waste Landfiil . . . . . . . . . . 5:1-14

5.1-3 Critfcal Means Table for 28 Compari sons--Background Contamination Indicator Parameter Data for the Monradioactive

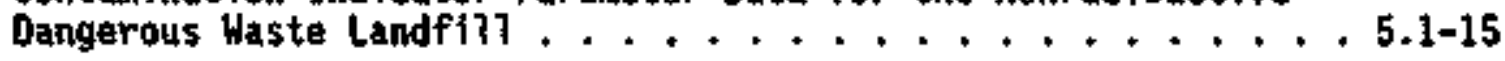


DOE/RL-96-01, REV. O

\subsection{AREA}

\subsection{NOKRADTOACTIVE DANSEROUS MASTE LANDFILL}

\section{F. H. Hodges}

Westinghouse Hanford Company

The Monradioactive Dangerous Waste Landfitl (NRDNL) is a 4-ha (10-acre) inactive dangerous waste landfi11 located approximately $5.5 \mathrm{~km}$ (3.5 $\mathrm{mi})$ southeast of the 200 East Area (See Figure I-I, Chapter 1.0).

\subsubsection{Facility 0verview}

The NRDWL, part of the Central Landfill Complex, which also includes the adfacent Sol id Waste Landfill (SWL), received dangerous nonradioactive waste from 1975 to 1985 . The NRDNL cont inued to receive asbestos waste unt 111988 (DOE-RL 1990). It was agreed in 1989, as part of the Hanford federal Facility Agreement and Consent onder (Ecology et al. 1994), to close the NRDNL under the appropriate Washington State dangerous waste regulations (Washington Adginistrative Code [WAC] 173-303). The NRDWL is part of the 200-IS-3 operable unit, which also inclufes the adjacent SWL. A closure/ postclosure plan was submitted to the Washington State Department of Ecology (Ecology) in 1990 (DOE-RL 1990). Groundwater monitoring at the MRDWL is controlied by the MRDWL groundwater monitoring plan (WHC 1993b).

An indicator parameter evaluation groundwater monitoring program was initiated at the MRDWL in late 1986 and early 1987 under interim-status regulations (40 CFR 265, Subpart F) as a result of an Ecology coupliance order (Ecology and EPA 1986). Site characterization and establishment of the groundwater monitoring program are described in Weekes et al. (1987). quarterly sampling at the NRDWL was concluded in the fourth quarter of 1989 and the initial monitoring network is currently on a semiannual sempling schedule. Quarterly sampling for the two monitoring wells completed in October 1992 (WHC 1993a) was completed in November 1993. The groundwater monitoring network for the NRDWL is shown in Figure 5.1-1.

The NRDWL 1 ies above approximately $180 \mathrm{~m}(600 \mathrm{ft})$ of suprabasa $\mathrm{t}$ sediments consisting of the Hanford and Ringold Formations. The Hanford formation beneath the site consists of sands and gravels, with sands predominant near the surface and gravels dominating the deeper portions of the formation (figure 5.1-2). Thin, discontinuous silt layers as well as clastic dikes are cominon in the upper part of the formatton (Weekes et a]. 1987). The water table occurs at a depth of approximately $38 \mathrm{~m}(125 \mathrm{ft})$ and approximately $18 \mathrm{~m}(60 \mathrm{ft})$ of Hanford formation is saturated. The deepest well at the NRDWL, penetrated to a depth of $78-(255 \mathrm{ft})$, bottoming in the top of Ringold Formation unit E (see Chapter 2.0). The upper Ringold Formation contains a thin, clay, silt-rich layer that may be locally confining (Weekes et al. 1987) and the two deep wells are screened impediately above that interval. The general stratigraphy of the sediments beneath the landfill is presented in figure 5.1-2, and a more complete presentation of 600 Area geology and hydrology is presented in DOE-RL (1994a). 
DOE/RL-96-01, REV. 0

\subsubsection{Summary of 1995 RCRA Activities}

Scheduled semiannual sampling of the monftoring network was carrled out in March and August of 1995.

Water levels were determined in a11 of the monjtoring wells as part of the routine samplings in March and August of 1995 . Water level determinations were carried out monthly throughout 1995 for all monitoring wells in the network.

The 1995 analytical results and water table elevation measurenents for the NRDWL groundwater monitoring network are reportod in RCRA quarterly reports (00E-RL 1995b,1995c, 1995d, 1996).

\subsubsection{Sampifing and Anajysts Program}

The monttoring network at the ARDNL consists of nine wells, seven completed in late 1986 and early 1987, and two completed in 1992 (see Figure 5.1-1, wic 1993a). There are three upgradtent wells. Two of the upgradient wells (699-26-35A and 699-26-34A) are completed in the top of the

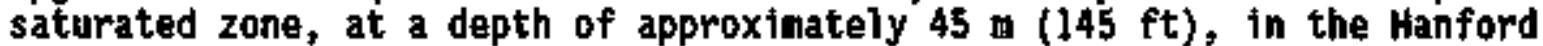
formation. One upgradient well (699-26-35C) is consleted inmediately above a low permeability unit in the upper part of the Ringold formation, approximate1y $21 \mathrm{~m}$ (70 ft) beneath the water table. There are six downgradient wells. Five of the downgradjent we71s (699-26-33, 699-26-34B, 699-25-34A, 699-25-34B, and 699-25-34D) are completed in the top of the saturated zone, at a depth of approximately $45 \mathrm{~m}$ (145 ft), in the Hanford formation. One downgradient well (699-25-33A) is completed inmediately above a low-permeability unit in the upper part of the Ringold Formation, approximately 21 m $(70 \mathrm{ft})$ beneath the water table. Honitoring well descriptions are provided in Table 5.1-1.

The NROWL monitoring network is on a semiannual sampling schedule as required by 40 CFR 265 . The constituent 1 ist (Table 5. I-2) for analys is consists of the contanination indicator parameters, the interim primary drinking water paraneters, and the groundwater quality paraneters. In addition, the list of analyses includes volatile halogenated hydrocarbons and tritium. Halogenated hydrocarbons were added to the constituent 1 ist both because of their presence at the adjacent SWL (Section 5.1.5) and because of their potential as contantinants fron waste in the HRONL. Tritiun was added to the constftuent Tist in 1989 to hejp deternine groundwater flow directions and flow rates at the site. Tritiug and elevated nitrate concentrations in groundwater at the NRONL have sources in the 200 Areas.

\subsubsection{Groundwater Chemistry}

The following discussion concentrates on the contanination indicator parameters, tritiun, nitrate, and chlorinated hydrocarbons. The indicator parameters are monitored because they are required by Resource Conservation and Recovery Act of 1976 (RCRA) regulations; nitrate and tritiun, which have an upgradient source, because of their potential role as groundwater tracers; 


$$
\text { DOE/RL-96-01, REV. } 0
$$

and chlorinated hydrocarbons because they may represent, to some extent, groundwater contamination originating from the ARDWL.

5.1.4.1 Constituents of Concern. Field pH values in shallow downgradient wells ranged from 7.5 to 8.0 , while values in the shallow upgradient wells ranged from 7.4 to 8.2 . pH values in the two deeper wells tended to be slightly higher, ranging from 8.0 to 8.3 .

Field conductance values for the shallow downgradient wells ranged from 431 to $541 \mu^{n}$ io/ca. Values for the upgradient wells ranged fron 444 to $453 \mu$ mho/cm. Values for the deep upgradient well ranged from 370 to 417 emho/cm and for the deep downgradient well from 330 to $332 \mu \pi m o / c m$.

Concentrations for total organic carbon reported for the March 1995 sampling ranged fron less than 110 to $225 \mathrm{ppb}$. Reported concentrations for the August 1995 sampling ranged from 155 to $250 \mathrm{ppb}$.

Reported values for total organfe halogen (TOX) for the February 1995 sampling ranged from 6.9 to $11.4 \mathrm{ppb}$ in the shallow downgradient woits and from 6.3 to 9.8 in the shallow upgradient wells. The value $358.2 \mathrm{ppb}$ for the deep upgradient well and $5.2 \mathrm{ppb}$ for the deep downgradient we1]s. Reported values for the August 1995 sampling were all less than $6.9 \mathrm{ppb}$. The lower TOX values for August 1995 may be a result of laboratory bias. The two sets of analyses were done in different laboratories and the laboratory responsible for the August set has been consistently low on its TOX performance evaluation (PE) samples (see Appendix A, Section A-2).

Nitrate and tritium in the groundwater beneath the NRDWL are elevated as a result of plumes originating in the 200 East Area and woving to the southeast beneath the NROHL. Nitrate values in the shallow monitoring wells, from February 1995 to August 1995, ranged from 23,000 to $26,000 \mathrm{ppb}$. Nitrate values in deep upgradtent well 699-26-35C ranged from 23,000 to 24,000 ppj; nitrate values in deep downgradient well 699-25-33A ranged were 3,700 ppb for both analyses. Groundwater nitrate concentrations since 1987 are 11$\}$ ustrated in Figure 5.1-3.

Fron February 1995 to August 1995, tritium values in shallow monitoring wells ranged from 118,000 to $179,000 \mathrm{pCi} / \mathrm{L}$. Tritiun concentrations in deep upgradient well 699-26-35C ranged from 39,200 to 45,300 pCi/L; deep downgradient well 699-25-33A concentrations ranged from 362 to $366 \mathrm{pCi} / \mathrm{L}$. These tritium concentrations, with the exception of values from deep downgradient well 699-25-33A, exceed the primary groundwater standard of $20,000 \mathrm{pC} 1 / \mathrm{L}$. The peak of a tritium pulse apparentiy has passed beneath the site (see Section 5.2.6) and tritiun concentrations are currently declining (Figure 5.1-4).

Five chlortinated hydrocarbons have been detected in groundwater at the NROWL during the period from February 1995 through August 1995; however, none exceeded U.S. Environmental Protection Agency driaking water standards. ChTorinated hydrocarbons with concentrations above detection liats are $1,1,1$-trichloroethane $(0.24$ to $2.35 \mathrm{ppb})$, trichloroethylene ( $<0.08$ to $0.57 \mathrm{ppb}$ ), tetrachloroethene $(0.04$ to $1.75 \mathrm{pph}$ ), carbon tetrachloride $(<0.04$ to $2.0 \mathrm{ppb})$, and chloroform $(<0.03$ to $0.09 \mathrm{ppb})$. 
1,1,l-trichloroethane and trichloroethylene are believed to be present in groundwater at the MRDNL principally as a result of vadose zone vapor

transport from the adjacent SHL; however, a contribution from the NRDWL cannot be ruted out. Tetrachloroethene is present in vadose gas beneath the SilL and is the principal vadose gas contaminant around the cheicical disposal tronches at the NROWL; thus, there may be contributions from both sources. Carbon tetrachloride and chloroform may be a result of vadose zone contamination at the NRDWL. Distributions of chlortnated hydrocarbon concentrations along the compliance point boundaries of the HRONL and SUL are presented in

Section 5.2.5.2.

5.1.4.2 Statistical Evaluation. Statistical evaluations of data for this year at the NRONL consisted of the required comparisons between upgradient and downgradient wells for any indication of contamination in the groundwater underlying the facility. Statistical methods are described in Appendix C. Statistical analyses required by 40 CFR 265.93(b) and WAC 173-303-400 wore perforded on background samples collected from November 1987 to July 1988; the results are presented in Table 5.1-3. This table 11sts the background average, background standard deviation, critical mean (or critical range, in the case of $\mathrm{pH}$ ), and the upgradient/downgradient comparison values for the four contamination indicator parameters frow the upgradient wells. The upgradient/downgradient comparison value is the value to which current and future averages of quadruplicate measurements are compared and is, in most cases, the critical mean or critical range. For the NRONL, the calculated critical range for $\mathrm{pH}$ is so large that it is meaningless. An alternative range for upgradient/downgradient comparisons was calculated by using upgradtent data collected fron Novewber 1987 to June 1992.

If the average constituent concentration for a downgradient well exceeds the upgradient/downgradjent comparison value 1 isted in Table 5.1-3, that parameter is considered statisticaliy different from background. If the value is confirmed by subsequent verification sampling and analys is, the regulatory program is triggered into assessment.

Va]ues for field $\mathrm{pH}$, specific conductance, total organic carbon, and total organic halogen were all below their upgradient/downgradient comparison values for the sampling perjod.

\subsubsection{Groundwater Flow}

In addftion to water table elevations determined at the time of groundwater sampling, regular measurements were made for all wells on a monthly schedule during 1995. The discussions of water table elevations, groundwater flow directions, and groundwater flow velocities are based on the regular monthly measurements. The 1995 water level measurements for the NROWL monitoring network were reported in RCRA quarterly reports.

The MRDWL ljes in a zone of very high transmissivity (Jacobson and Freshley 1990) and as a result thero is a very low hydraul ic gradient across the site. A map of the water table in the vicinity of the site, based on June 1995 data, is presented in Figure 5.1-5. This map illustrates the Jow hydratic gradients in the vicinity of the NRDHL. 
The water tabie in the vicinity of the NRDNL has apparentiy dropped approximately $1.5 \mathrm{~m}(5 \mathrm{ft})$ since December 1988; however, the exact decrease is difficult to estimate because of the scatter in the water level data. Data from the adjacent SWL, which shows much less scatter, fndicates a consjderable slowing in water table decrease and a drop of approximately $1.4 \mathrm{~m}$ (4 ft) over the salne ttme interval (Section 5.2). This decrease in water table elevation, apparently a result of decreased water input to the 216-8-3 Pond, is

illustrated in Figure 5.1-6, which shows hydrographs of the MRDWL weTls based on wonthly water level measurements.

The reason for the degree of scatter in the RRDLll water level data is uncertain. Water levels at the NROWL and SWL are measured by the same people, using the same equipment and techniques; therefore measurement error does not seem 1 ikely. The case against measurement error is reinforced by the much lower variability in the two deep wellis at the HRONL, which were measured at the same time. It seems that the effect is real; however, the cause, whether aquifer tnhomogenetty or some other effect, is unknown.

5.1.5.1 Groundwater Flow Directions. Hydrautic gradients across the WRDL are on the order of 0.0001 , yielding water level differences across the site that are well within the envelope of surveying and measurentent error. In past years average groundwater flow directions could be estimated on the bas is of water level measurements; however, the large scatter in groundwater elevation data have made this impossible for 1994 and 1995.

Groundwater flow directions, previously calculated from regular water Tevel messurements for wells 699-26-35A, 699-26-33, and 699-25-34B have provided relatively consistent average flow direction, $62 \pm 10^{\circ}$ east of north (OOE-RL 1994a), $65 \pm 20^{\circ}$ east of north (DOE-RL 1991), and 67 to $90^{\circ}$ east of north (Weekes et al. 1987). These values are in poor agreement with the groundwater flow direction of approximately 125 east of north, indicated by the nttrate and tritium plumes that pass through the area (DOE-RL 1991) and regional water table maps. The difference in flow directions indjcated by the two technigues may indicate well survey problens; however, a resurvey by Katser Engineers Hanford in 1991 resulted in no significant change in well elevations.

Two well pajus (699-25-34A/699-25-33A and 699-26-35A/699-26-35C) sample the top of the unconfined aquifer and the top of the Rtngold Foration. The lack of a detectable head difference in these well pairs indicates that any vertical gradient within the upper portion of the aquifer is quite small.

5.1.5.2 Rate of Flow. The rate of groundwater flow beneath the NRDil is highly uncertain. The aquifer beneath the HRDLL is characterized by high hydraulic transmissivity and very low gradients. On the bas is of sitespecific aquifer testing and the observed hydraultc gradients, the expected groundwater velocities, based on Darcy law calculations, should be on the order of 1.2 to $1.8 \mathrm{~m} / \mathrm{d}$ ( 4 to $6 \mathrm{ft} / \mathrm{d}$ ) (Weekes et al. 1987). However, more direct velocity indicators, as discussed in the following paragraphs, indicate a range of much higher values.

Transport velocities in the 200 East Area, identffied by contaninant transport within the Hanford formation, indicate groundwater flow velocities from 3 to $4.3 \mathrm{~m} / \mathrm{d}$ (10 to $14 \mathrm{ft} / \mathrm{d}$ ) (Wilber et $\mathrm{a} 1$. 1983). Tracer tests in the 


$$
\text { DOE/RL-96-01, REY. } 0
$$

area southeast of the 200 East Area indicated groundwater velocities in excess of $30 \mathrm{~m} / \mathrm{d}(100 \mathrm{ft} / \mathrm{d})$; however, they occurred at higher hydraulic gradfents than exist today (Bierschenk 1959).

Tracking of the present tritium and nitrate plumes from wells several kilometers upgradient from w11 699-24-33, which is located approximately $150 \mathrm{~m}(500 \mathrm{ft})$ east of the SNL, indicates contaminant transport rates of approximately $6 \mathrm{~m} / \mathrm{d}(20 \mathrm{ft} / \mathrm{d})$. Additional information on flow rate is provided by the recent decrease in nitrate and tritium concentrations across the site. Nitrate and tritium, which have upgradient sources, exhibit nearly identical time-concentration variation in upgradient and downgradient well pairs with quarterly sampling (see Section 5.2.6.2). This indicates that the time required for the contaminants to traverse the site is on the order of 3 months. This traverse time indicates groundwater transport rates of approximately $5.5 \mathrm{~m} / \mathrm{d}(18 \mathrm{ft} / \mathrm{d})$. The actual transport rate is probably controlled by zones of very high groundwater velocjty within the Hanford formation that are missed or averaged out in normal aquifer testing.

5.1.5.3 Evaluation of Nonitoring Nell Metwork. The uncertainty in groundwater flow directions beneath the MRDWL makes the evaluation of the monitoring network difficult. If the groundwater flows toward the southeast, as indicated by the nitrate and tritium p]umes, the boundary between the MRDWL and SWL should be part of the compliance point. If the groundwater flows in a east-northeast direction, as indicated by the water level data, the northern boundary of the site should be part of the compliance point. The two monitoring wells along the north and south boundaries of the MROWL, completed in 1992, solve this problem and provide Monitoring Efficiency Model (Jackson et al. 1991) efficiencies between 96 and $99 \%$, depending on groundwater flow directions. The current shallow monitoring network is adequate; however, deep characterization and monitoring, as called for in the NROWL groundwater monjtoring plan (WHC 1993b), is stiti needed to fully characterize the aquifer beneath the site.

\subsubsection{References}

40 CFR 265, "Interim Status Standards for Owners and Operators of Hazardous Waste Treatment, Storage, and Disposal Facilities," Code of Federa? Regulations, as amended.

Bierschenk, H. H., 1959, Aquifer Characteristjes and Groundwater Movement at Hanford, HW-60601, Hanford Atomte Products Operations, Richl and, Washington.

DOE-RL, 1990, Nonradioactive Dangerous Naste Landfill Closure/Postclosure Plan, DOE/RL-90-17, U.S. Department of Energy, Richland Operations Office, Richland, Washington.

DOE-RL, 1991, Annual Report for RCRA Groundwater Nonitoring Projects at Hanford Site Facilities for 1990, DOE/RL-91-03, U.5. Department of Energy, Richland Field Office, Richland, Washington. 
DOE-RL, 1994, Annual Report for RCRA Groundwater Monitoring Projects at Hanford Site Facilities for 1993, D0E/RL-93-88, Rev, 0, U.S. Department of Energy, Richl and Operations Office, Richland, Washington.

DOE-RL, 1995a, Annual Report for RCRA Groundwater Monitoring Projects at Hanford Site Facilities for 1994, D0E/RL-94-136, Rev. 0, U.\$. Department of Energy, Richland Operations Office, Richland, Mashington.

DOE-RL, 1995b, Quarteriy Report of RCRA Groundwator Monitoring Data for Periof October 1 , 1994 through December 31, 1994, DDE/RL-94-36-4, U.S. Department of Energy, Richland Operations Office, Richland, Washington.

DOE-RL, 1995C, Quarteriy Report of RCRA Groundwater Monitoring Data for Period January 1, 1995 through March 31, 1995, DOE/RL-95-69-1, U.S. Department of Energy, Richland Operations Dffice, Richland, Washington.

DOE-RL, 1995d, Quarterly Report of RCRA Groundwater Monitoring Data for Period Apri1 1, 1995 through June 30, 1995, DOE/RL-95-69-2, U.S. Department of Energy, Richland Operations Office, Ríchland, Washington.

DOE-RL, 1996, Quarter7y Report of RCRA Groundwater Monitoring Data for Period July 1, 1995 through Septenber 30, 1995, D0E/RL-95-69-3, U.S. Department of Energy, Richl and Operations Office, Richland, Washington.

Ecology and EPA, 1986, Consent Agreement and Compliance Order, Ecology No. DE 86-133, PCHB No. 86-44, Washington State Department of Ecology, U.S. Environmentaî Protection Agency, Olymoia, Washington.

Ecology, EPA, and DOE, 1994, Hanford Federal Facility Agresment and Consent order, as amended, Washington State Department of Ecology, U.S. Environmenta1 Protection Agency, and U.S. Department of Energy, 01 map 1 a, Washington.

Jackson, R. 1., C. M. Einberger, R. B. Mercer, and C. R. Wilson, 1991, Efficiency-8ased Groundwater Monitoring Network Design for Hazardous Waste Sites, WHC-SA-1157-FP, Westinghouse Hanford Company, Richland, Washington.

Jacobson, E. A., and M. D. Freshley, 1990, An Initial Inverse Calibration of the Ground-Water Flow Hodel for the Hamford Unconfined Aquifer, PNL-7144, Pacific Northwest Laboratory, Rtchland, Washington.

Resource Conservation and Recovery Act of 1976, 42 USC 6901 et seq.

WAC 173-303, "Bangerous Waste Regulations," Washington Administrative Code, as amended. 
Weekes, D. G., S. P. Luttrell, and M. R. Fuchs, 1987, Interim Hydrogeologic Characterization Report and Groundwater Monitoring Systers for the Nonradioactive Dangerous Waste Landfill, Hanford Site, Washington, WHC-EP-0021, Westinghouse Hanford Company, Richl and, Washington.

WHC, 1993a, Borehole Completion Oata Package for MROWL Facility Monitoring Wells 699-25-340 and 699-26-34B, WHC-SO-EN-OP-055, Rev. O, West inghouse Hanford Company, Richiand, Washington.

WHC, 1993b, Interim Status Groundwater Nonitoring Plan for the Nonradioactive Dangerous Waste Landfill, Hanford, Washington, WHC-SD-EN-AP-026, Rev. 0, Westinghouse Hanford Company, Richland, Washington.

Wilber, J. S., M. J. Graham, and A. H. Lu, 1983, Results of the Separations Area Ground-Water Nonitoring Network for 1982 , RA10-RE-SR-23-24 P, Rockwell Hanford Operations, Richland, Washington. 
Figure 5.1-1. Map of the Monradioactive Dangerous Waste Landfil1 and Solid Waste Landfill Showing the Locations

of Groundwater Monitoring We11s.

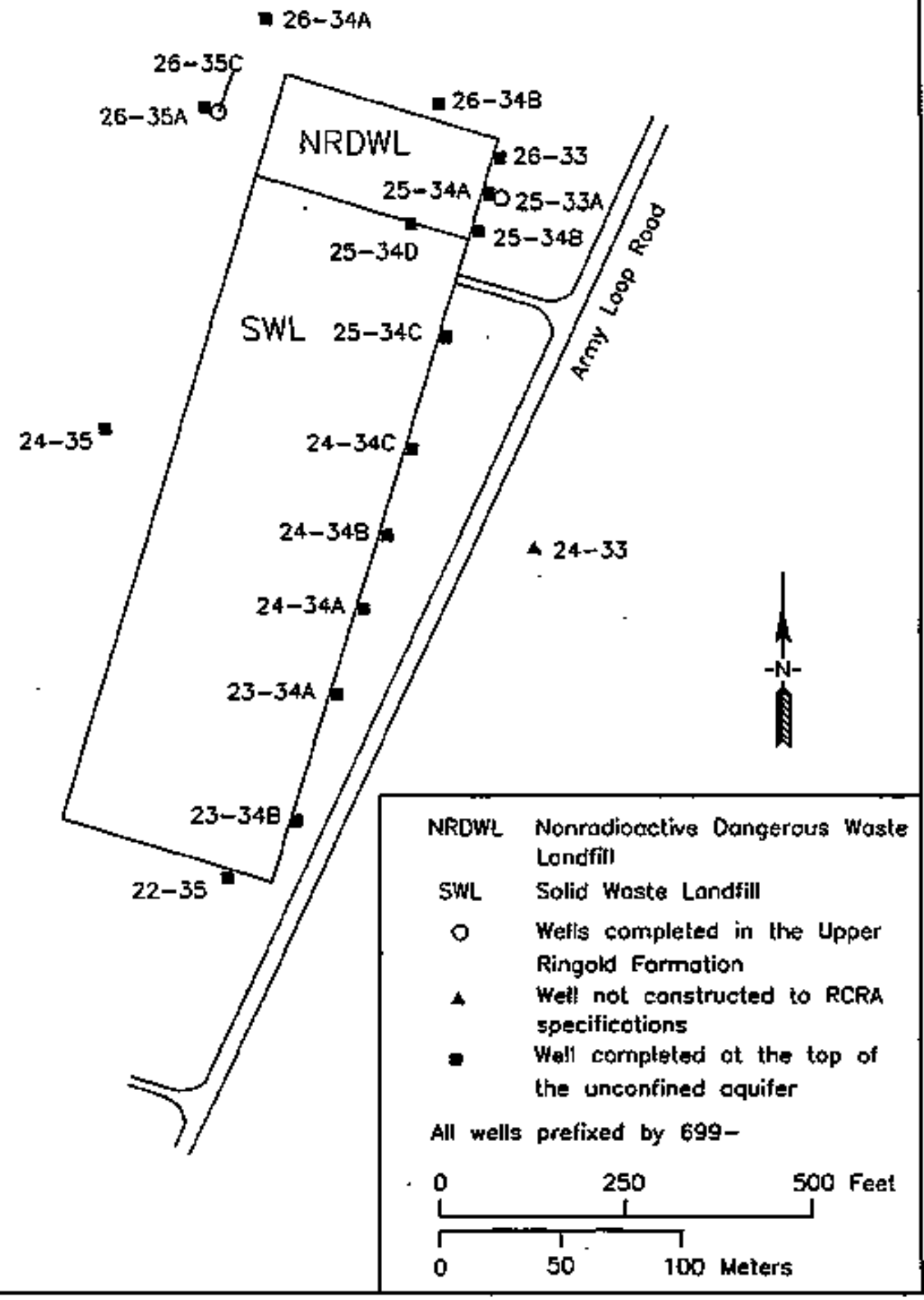

fah swinrdwl.dwg 
Figure 5.1-2. Generalized Stratigraphic Colunn for the Monradioactive Dangerous Waste Landfiti

(modified from Weekes et a1. 1987).

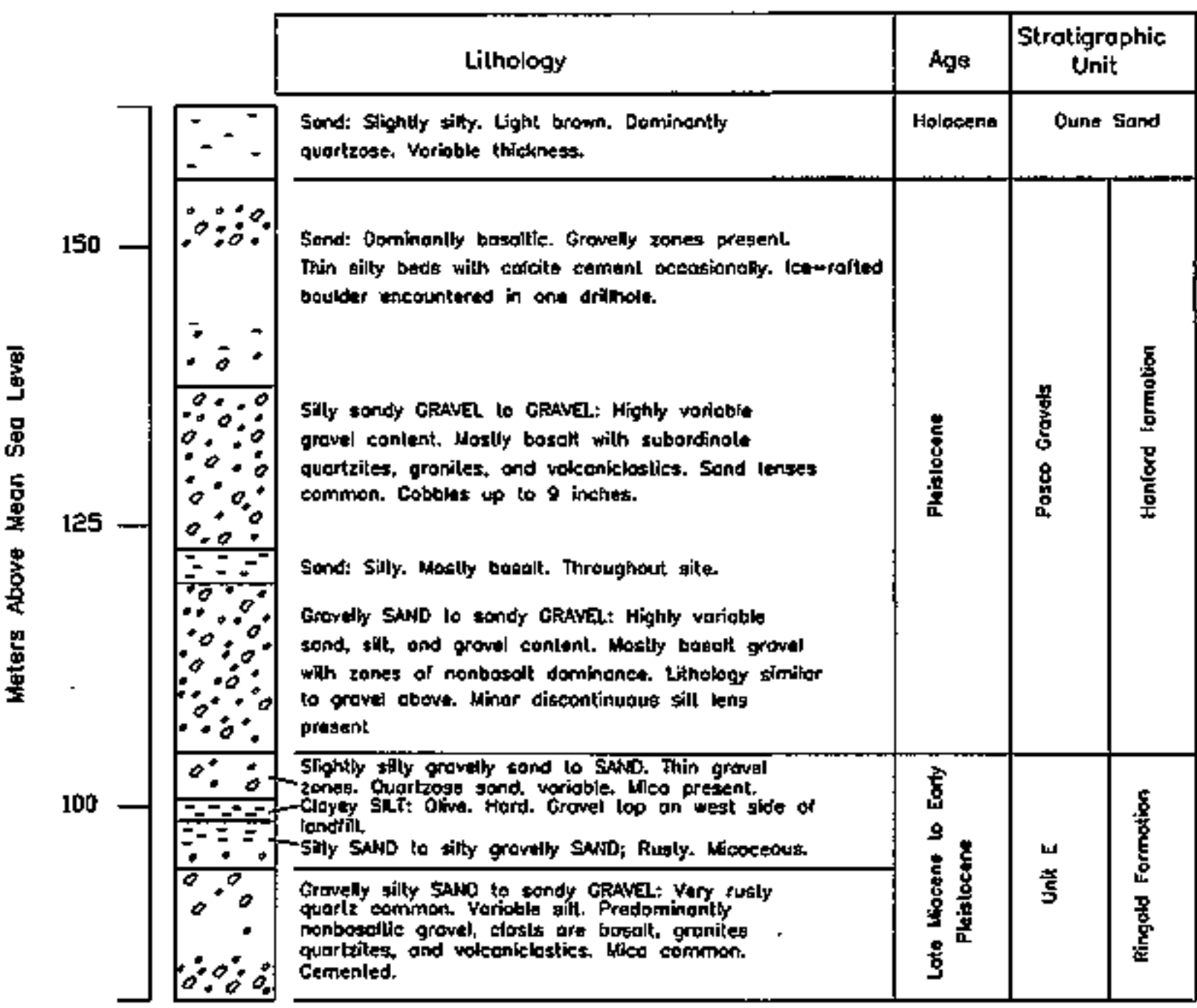

fnh \swlith,dwg 
Figure 5.1-3. Time Series Plot of Nftrate Concentrations (ppb) in Sha11ow Monitoring We11s at the NROWL.

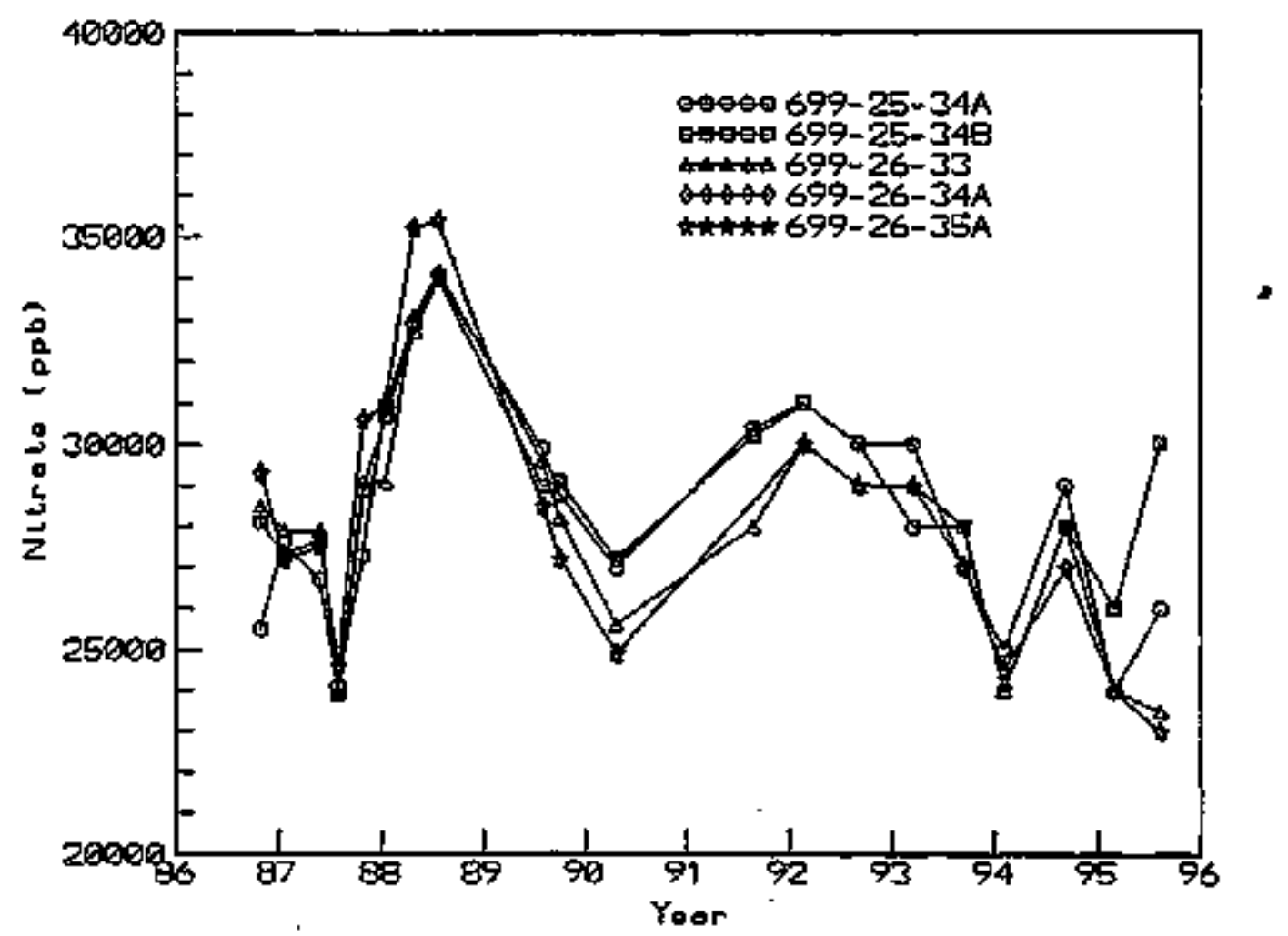

Figure 5.1-4. Tfme Series PTot of Tritiun Concentrations (pCi/L) in Shallow Monitoring Welis at the RROHL.

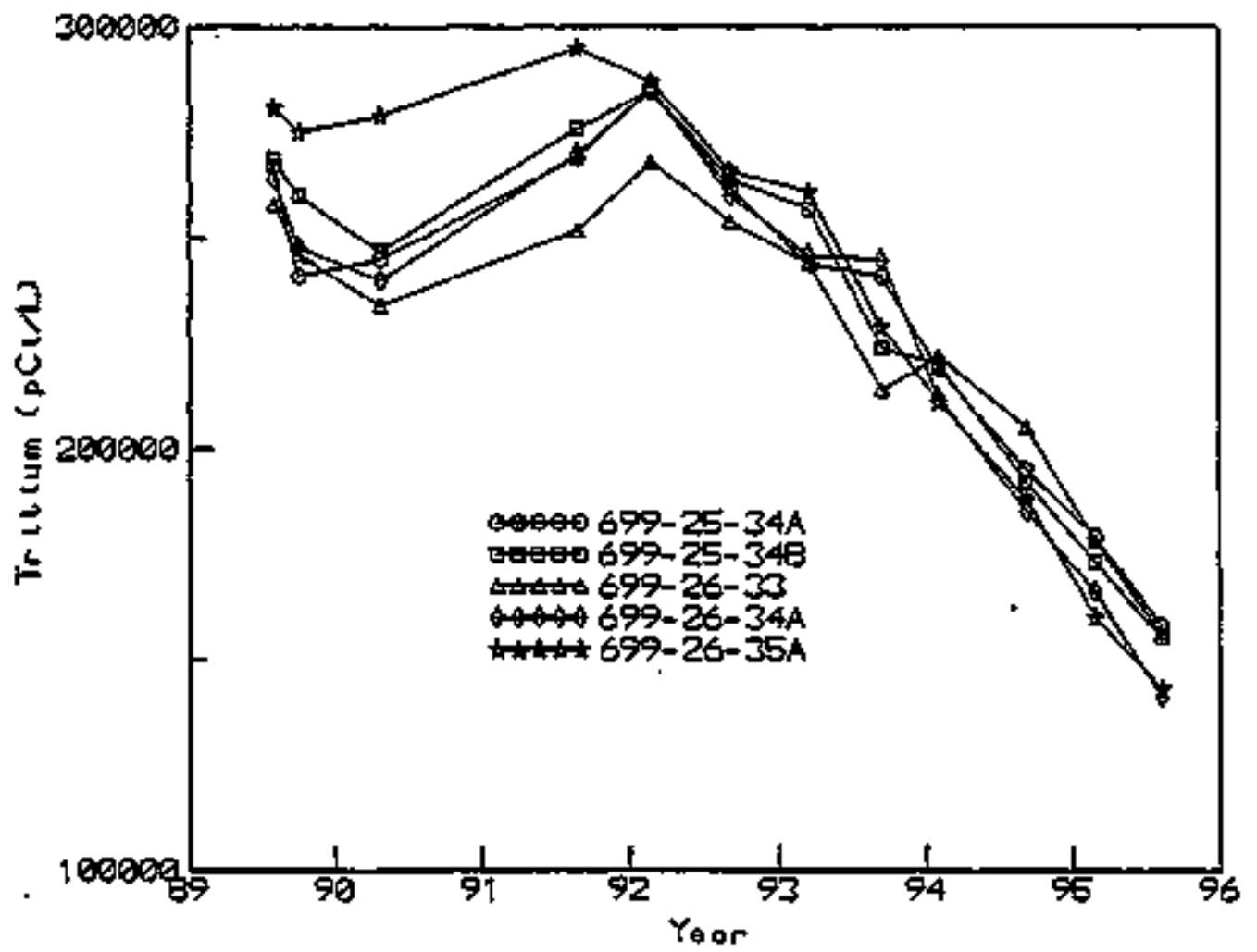


Figure 5.1-5. Water Table Map (Potentiowetrte Surface) for the Vicinity of the Nonradioactive Dangerous Naste Landfiti

Based on June 1995 Water Level Measurements

(Oatum is Mean Sez Level).

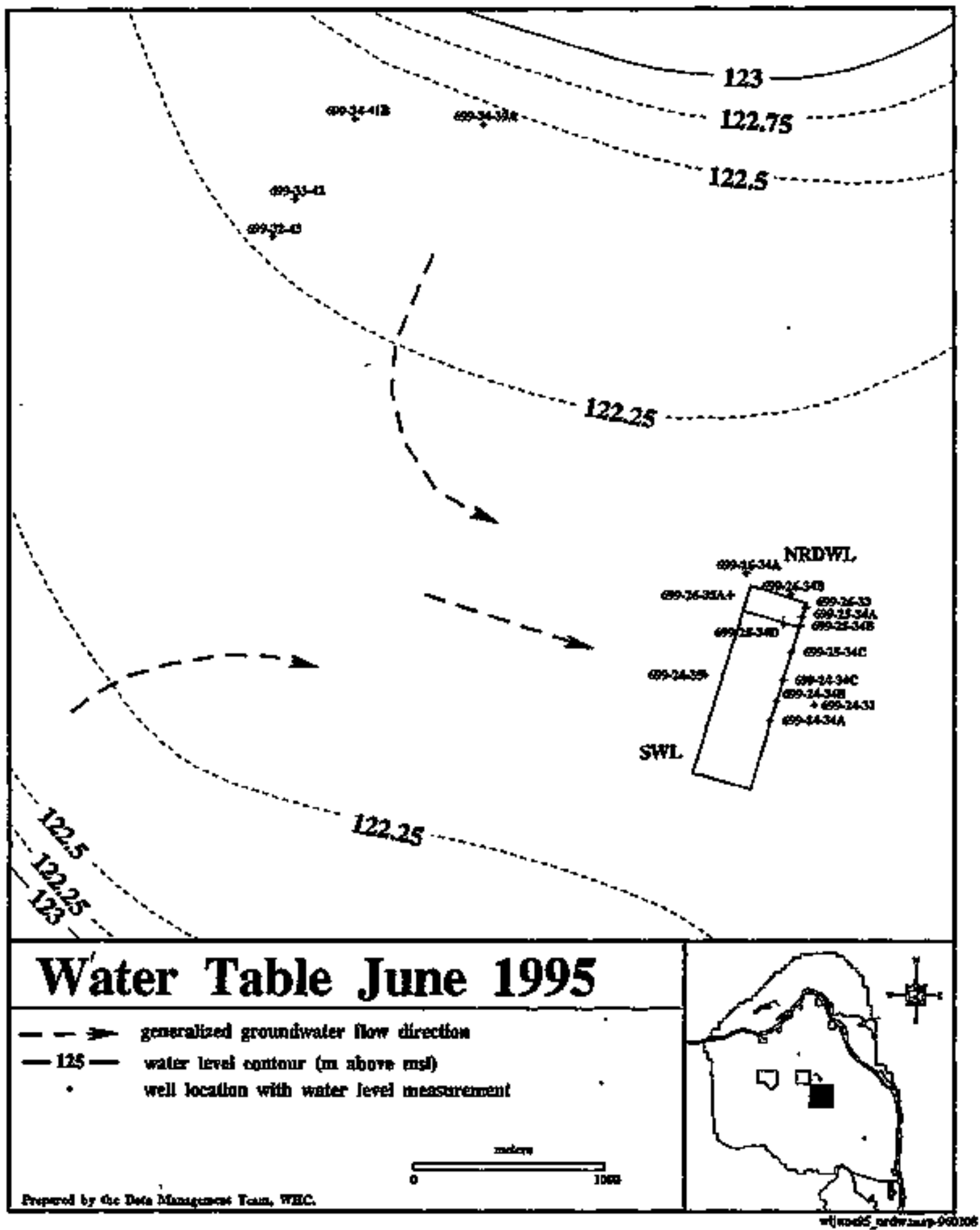


DOE/RL-96-01, REY. 0

Figure 5.1-6. Hydrographs of Monthiy Water Level Heasurements (Meters Above Mean Sea Level) at the Nonradioactive Dangerous Waste Landfill.

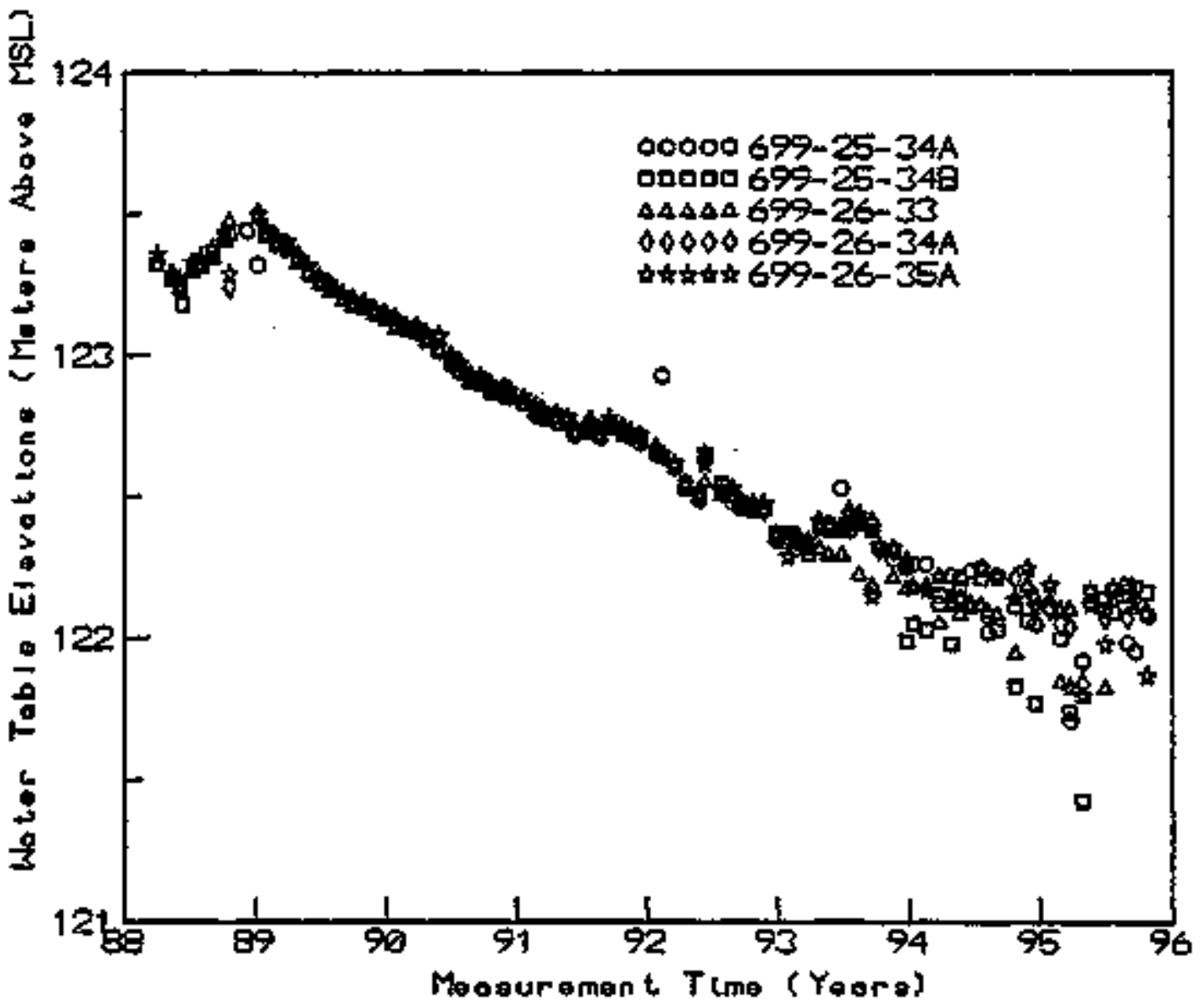


Table 5.1-1. Hon'toring Wells Used for the Monradioactive Dangerous Naste Landfil1.

\begin{tabular}{|c|c|c|c|c|c|}
\hline Weit & Aquifer & $\begin{array}{l}\text { Sampling } \\
\text { frequency }\end{array}$ & $\begin{array}{l}\text { Nater } \\
\text { levels }\end{array}$ & $\begin{array}{c}\text { Well } \\
\text { standard }\end{array}$ & $\begin{array}{c}\text { Other } \\
\text { networks }\end{array}$ \\
\hline $699-26-33^{86}$ & Top of unconfined & $\widehat{S A}$ & M & RCRA & \pm \\
\hline $699-26-34 A$ & Top of unconfined & SA & $M$ & RCRA & $=$ \\
\hline $699-26-34 B^{\$ 2}$ & Top of unconfined & $\mathbf{Q}$ & $\bar{M}$ & RCRA & -- \\
\hline $699-26-35 A^{26}$ & Top of unconfined & SA & $M$ & RCRA & SWL \\
\hline $699-26-35 C^{87}$ & Top of LPS" & SA & M & RCRA & - \\
\hline $699-25-33 A^{87}$ & Top of LPJ & $\overline{S A}$ & $\bar{M}$ & RCRA & -- \\
\hline $699-25-34 A^{86}$ & Top of unconfined & $\overline{S A}$ & $\bar{M}$ & RCRA & - \\
\hline $699-25-348^{36}$ & Top of unconfined & SA & M & RCRA & $=$ \\
\hline $699-25-340^{52}$ & Top of unconfined & $\bar{Q}$ & $M$ & RCRA & -- \\
\hline
\end{tabular}

Notes: Shading denotes upgradient wells. Superscript number

following well number denotes the year of installation.

Low permeability unit in the upper Ringold Formation.

LPU $=$ low permeability unit.

$H=$ sampled or measured on a monthly basis.

$Q=$ sampled or measured on a quarterly basis.

RCRA = well is constructed to RCRA-specified standards.

$S A=$ sampled or measured on a seniannual basis.

SHL = Soljd Naste Landfill.

Table 5.1-2. Constituent L1st for the Honradioactive Dangerous Waste Landfill.

\begin{tabular}{|c|c|}
\hline \multicolumn{2}{|c|}{ Contamination tndfcator parameters } \\
\hline $\begin{array}{l}\text { pH } \\
\text { Spectfic conductance }\end{array}$ & $\begin{array}{l}\text { Total organic carbon } \\
\text { Total organic halogen }\end{array}$ \\
\hline \multicolumn{2}{|c|}{ Groundwater quality parameters } \\
\hline Chiortde & Hanganese. \\
\hline
\end{tabular}

DOE/RL-96-01, REY, 0

This page intentionally left biank. 


\section{CONTENTS}

5.2 SOLID MASTE LANDFILL $\ldots \ldots \ldots \ldots \ldots \ldots \ldots . \ldots \ldots$

5.2.1 Facil ity 0verview . . . . . 5.2-1

5.2.2 Sumbary of 1995 Groundwater Honitoring Activities . 5.2-1

5.2 .3 other Activities in $1995 \ldots \ldots \ldots . \ldots \ldots$. . . . . . .

5.2 .4 Sampling and Analysis Program ......... 5.2-2

$\mathbf{5 . 2 . 5}$ Groundwater Chemistry . . . . . . . . . 5.2-2

5.2.6 Groundwater Glow . . . . . . . . . . 5.2-8

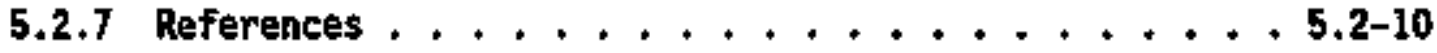

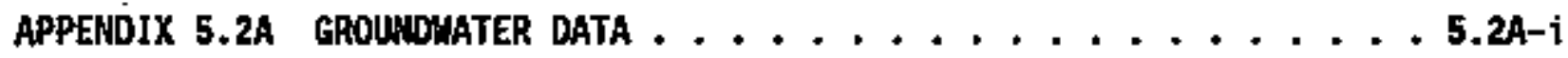

appendix 5.2B water level measurements $\ldots \ldots \ldots \ldots \ldots . \ldots \ldots$ 


\section{LIST OF FIGIRES}

5.2-1 Map of the Solid Waste Landfill Showing the Locat Ions of Groundwater Monftoring Wells . . . . . . 5.2-13

5.2-2 PTot of 1,1,1-Trichloroethane Concentrations in

5.2-3 Downgradient Wells at the SWL and MROWL ........ 5.2-14

Downgradient Wells at the SWL and MROWL ...... . . 2-14

5.2-4 Plot of Trichloroethene (TCE) Concentrations in

5.2-5 Plot of 1,1-0ichloroethane (11-DCA) Concentrations in Downgradient Wells at the SWL and NROWL

for Selected 1994 and 1995 Data .............. 5.25

5.2-6 Time Series Plot of Tritfum and Nitrate Concentrations

5.2-7 Plot of Tritium Concentrations in Downgradtent Monitoring We11s for the SWL and NRONL .... 5.2-17

5.2-8 Water Table Map (Potentiometric Surface) for the Vicinity of the Solid Waste Landfill Based on June 1995 Water Table Measurements .................... 5-18

5.2-9 Hydrograph Showing Monthiy Water Level Measurements (Meters Above Mean Sea Leve1) for the Solid Waste Landf111 . 5.2-19

5.2-10 Time Series Plots of Tritium Concentrations in UpgradientDowngradient Kel1 Pairs: (a) Ne11s 699-26-35A and 699-25-34C;

(b) We11s 699-24-35 and 699-23-34A ................ 5-20 
DOE/RL-96-01, REV. 0

\section{LIST OF TABLES}

5.2-1 Monitoring We11s Used for the Solid Waste Landfill . . . . 5.2-21

5.2-2 Constituents Analyzed at the Solid Waste Landfill . . . . 5.2-21

5.2-3 Sarpling Results for Required Constituents (MAC 173-304) at the Hanford Solid Waste Landfi]l . . . . . . . . . . 5.2-22

5.2-4 Ranges of Concentrations (ppb) of chlorinated Hydrocarbons in Groundwater at the Solid Waste Landfill from Movenber 1994 to August 1995 . . . . . . . . . 5.2-25

5.2-5 Surptary Statistics for the Background Monttoring Constituent. Parameter Data for the So7 id Waste Landfill . . . 5.2-26

5.2-6 Results of Lililefors Test for Hormality and Background Threshold Values for the Solid Maste Landfill . . . 5.2-27 
DOE/RL-96-01, REV. O

This page intentionally left blank. 
DOE/RL-96-01, REV. 0

\title{
5.2 SOLID MASTE LANBFILL
}

\author{
F. H. Hodges \\ Westinghouse Hanford Company
}

The Solid Wast.e Landfill (Sill) is a disposal facility whose current activities are regulated under Washington Administrative Code (WAC) 173-304, "N1nfmum Functional Standards for Solid Waste Handling." The SWL is not a Resource Conservatior and Recovery Act of 1976 (RCRA) site and is included here for completeness. A perwit application for operation of the site under WAC 173-304 was submitted to the Benton-Frankjin District Health Department in I991 (COE-RL 1991a). Responsibility for the site was subsequent1y assured by the Washington State Department of Ecology (Ecology) and a revtsed permit application was submitted to Ecology in 1993 (DOE-RL Ig93b). As part of the permit review, Ecology requested that a corrective action progran be established for the site. A corrective action plan (Hodges 1994) was submitted to Ecology in Novenber 1994.

\subsubsection{Facility overview}

The SWL is a 27-ha (66-acre) landfill facllity located approximately $5.6 \mathrm{~km}(3.5 \mathrm{mi})$ southeast of the 200 East Area (see Figure I-1, Chapter 1.0). The SWL, along with the adjacent Nonradioactive Dangerous Waste Landfil (NRGLL), are parts of the old Central Landfill Complex; however, the two facilitios are now considered separately under different regulations. The SWL has been in operation since 1972 and has received principaliy solid waste including paper waste, construction debris, asbestos waste, and lunchroom waste. In addition to the solid waste, an est fmated $3,800,000$ to $5,700,000 \mathrm{~L}$ (1 to 1.5 Mgal) of sewage waste were discharged to trenches along the east and west sides of the SHL between 1975 and 1987 , and approximately $380,000 \mathrm{~L}$ $(100,000 \mathrm{gal})$ of Hanford Site bus-garage washwater was discharged to three short trenches along the west side of the site between 1985 and 1987 . The present groundwater monitoring program was initiated in 1987 (Fruland et al. 1989). Current groundwater monjtoring of the landfil1 is regulated under WAC 173-304 and is controlled by the SUL groundwater monitoring plan (WHC 1993). The stratigraphy of the Central Landft11 Complex, including the SWL, is indicated in Figure 5.1-2. The geology and hydrology of the 600 area are descrtbed in more detail in DOE-RL (1994).

\subsubsection{Sturaary of 1995 Groundwater Monitoring Activities}

Quarterly sampling of the groundwater monitoring network was carried out in Hovember 1994 and March, Hay, and August 1995. Water level measuraments were made in conjunction with the scheduTed sampling. In addition, water level measurements were carried out monthly throughout the year.

\subsubsection{Other Activities in 1995}

A corrective action plan for the SWL (Hodges 1994) was approved by Ecology. At the same time, because of evidence that the SWL is contaninating groundwater, Ecology directed the U.S. Department of Energy, Richland 
Operations office (RL) to either line all future trenches or close the landfill. RL opted to close the landfill by March 1996. RL has since told Ecology that funding is not avajlable for closure activities or corrective action at the SiN. Hegotiation between Ecology and DOE/RL will determine the future course $0^{*}$ action at the site.

\subsubsection{Samplting and Anabysis Progran}

The monitoring network at the Sill consists of two upgradient and seven downgradient, compliance-point wells (figure 5.2-1). The monitoring walls are RCRA compliant with stainless steel casings and screens. The wells were comploted at depths of approximately 44 in (145 ft) with screened intervals of $4.6 \mathrm{~m}(15 \mathrm{ft})$. The bottoms of the screens were set at $3 \mathrm{~m}$ (10 ft) below the water table (Fruiand et al. 1989). Two woll's completed in late 1993 ware set with 10.7-1 (35-ft) screens to al Tow for the expected decling in the water table. The wells are all equipped with HydroStar' pumps.

In addition, HRONL upgradient wall 699-26-35A is bejng monitored as an upgradient well for the SiHL and an older non-RCRA well (699-24-33), located approxiately $150 \mathrm{~m}$ (500 ft) east of the SWl, is sampled for indication of trends in groundwater chemistry and historical continuity. A description of the Sill wonitoring wells is provided in Table 5.2-1.

The Sill is on a quarterly sampling program as required by MAC 173-304. The constituent 1ist for analysis (Tabie 5.2-2) consjsts of the constituents and parameters required by WAC 173-304-490, volatile chlorinated hydrocarbons, trititur, and other constituents to atd in interpretation of groundwater chentstry.

\section{\$.2.5 Groundwater Chendstry}

This section discusses the constituents required by WAC 173-304: chlorinated hydrocarbons, which are site-specific constituents, and tritium, which is monitored to provide information on grounduater flow direction and flow rate.

5.2.5.1 Constituents of Concern. Avatlable analytical results for groundwater sampling events from November 1994 through August 1995 are presented in Appendix 5.2A. A summary of results for all required monitoring parameters is provided in Table 5.2-3. Results for chlorinated hydrocarbons are presented in Table 5.2-4. This section discusses the concentration ranges of constituents in downgradient wel]s and compares then to the tolerance interval values calculated in Section 5.2.5.3, where appropriate. Interpretations are provided in Section 5.2.5.2.

'Hydrostar is a regtstered trademark of Instruments Northwest, Inc. 
5.2.5.1.1 Temperature. Average values for replicate temperature determinations weasured during santipling range from 17.4 to $19.8{ }^{\circ} \mathrm{C}$ (63) to $67{ }^{\circ} \mathrm{F}$ ). AlT measurements for the year are below the tolerance interval of $21{ }^{\circ} \mathrm{C}\left(70^{\circ} \mathrm{F}\right)$. There is a tendency for the higher temperatures to occur at the north end of the site, near the axis of the tritium and nitrate plumes.

5.2.5.1.2 Conductivity. Average values for replicate conductivity measurenents carried out during sampling range from 550 to 797 amho/cw. Repl icate averages for monitoring wel1s 699-22-35 and 699-23-348 exceed the Ecology Secondary Standard for "Public Water Supplies" (WAC 248-54) of $700 \mu m h o / c n$ for all samplings. The tolerance interval value of $550 \mu$ mo/cm was exceeded for al1 samples from downgradient wells, with the exception of the March 1995 sampling of well 699-25-34C, which equalled the tolerance interval value.

5.2.5.1.3 pH. Average values for replicate pH measurements in downgradient wells, made at the time of sampling, range from 6.4 to 7.4 . None of the pH measurements exceed the tolerance interval range of 6.2 to 8.5 . As in the past, the lower values tend to occur in the southernmost downgradient monitoring wells.

5.2.5.1.4 Chlortde. Chloride concentrations in downgradient wells range fron 6,100 to 7,400 $\mathrm{ppb}$ during the reporting period. The tolerance interval value of 9,045 ppb was not exceeded during this period. There is a tendency for the higher values to occur in the northernnost wells.

5.2.5.1.5 Hitrate. Hitrate concentrations in the downgradient monitoring wells at the Sil range from 11,000 to $25,000 \mathrm{ppb}$ for the reporting perlod. During this period the reported nitrate concentrations exceeded neither the tolerance interval concentration of 33,800 ppb nor the Ecology groundwater protection standard (WAC 173-200) of 45,000 ppb. The highest nitrate concentrations occur in the northernostost we11s.

5.2.5.1.6 Mitrite. All nitrite analytica1 results are nondetects, reported as etther $<18$ or $<140 \mathrm{ppb}$ for the reporting period.

5.2.5.1.7 Ammonium. Most resuits are nondetects, reported as <27 or $<37 \mathrm{ppb}$. However, isolated vaiues, ranging from 30 to $70 \mathrm{ppb}$ were reported for both upgradient and downgradient weits.

5.2.5.1.8 sulfate. Reported sulfate concentrations in downgradient wells range fram 32,000 to $55,000 \mathrm{ppb}$ for this reporting period. One sample, fron the Hay sampling of welt 699-22-35, exceeded the tolerance interval value of $51,500 \mathrm{ppb}$. None of the samples exceeded the Ecology groundwater protection standard of $250,000 \mathrm{ppb}$ (WAC 173-200). There is a strong tendency for the highest sulfate concentrations to occur to the southernmost wells.

5.2.5.1.9 Dissolved Iron. Reported values for fittered iron in downgradiant wells range from <15 to $65 \mathrm{ppb}$ during the reporting period. Reported filtered fron concentrations did not exceed the tolerance Interval concentration of $78 \mathrm{ppb}$ during the reporting pertod.

5.2.5.1.10 Dissolved Nanganese. Filtered manganese results range from $<0.55$ to $4.7 \mathrm{ppb}$ for the reporting period. Hone of the reported manganese 


$$
\text { DOE/RL-96-01, REV. O }
$$

concentrations exceeded the tolerance interval concentration of $11 \mathrm{ppb}$ or the Ecology groundwater protection standard of $50 \mathrm{ppb}$.

5.2.5.1.11 Dissolved Zinc. Reported values for filtered zine range from $<3.7$ to $28 \mathrm{ppb}$ for the reporting period. Reported concentrations for fijtered zinc did not exceed the tolerance interval concentration of $\mathbf{3 4} \mathrm{ppb}$ or the Ecology groundwater protection standard of $5,000 \mathrm{ppb}$ during the reporting period.

B.2.5.1.12 Chewical oxygen Dewand. Reported values for chemical oxygen demand are all below the method detection 1 imit of $2.9 \mathrm{ppb}$ and the tolerance interval concentration of 3 ppw for the reporting period.

5.2.5.1.13 Total Organic Carbon. Average (of replicates) total organic cartoon (TOC) concentrations range from $<110$ to $300 \mathrm{ppb}$. The reported values do not exceed the tolerance interval concentration of $976 \mathrm{ppb}$.

5.2.5.1.14 Total coliform. All reported values for total coliform are nondetects for this reporting period, reported as either $<1$ or $<3.7$ colony/100 mL.

5.2.5.1.15 Total Organic Halogen. TOX values range from $<7$ to $40 \mathrm{ppb}$ (see Table 5.2-4). The analyses for the Noverber 1994 and March 1995 are consistent with provious analyses; howaver, those for May and August 1995 are conststently lower. The low values reported for May and August may be a result of laboratory bias. The two sets of analyses were carried out at different laboratories and the laboratory responsibie for the hay and August results has returned low results for TOC performance assessment (PE) samples on previous occasions.

5.2.5.1.16 ChJorinated Hydrocarbons. Chlorinated hydrocarbons have been detected at the SHL in low concentrations (see Table 5.2-4). These include 1,1,1-trichloroethane (111-TCA), trichloroethene (TCE), tetrachloroethene (PCE), and 1,1-dichloroethane (11-DCA). Several of these constituents occur in low concentrations in the upgradient wells; however, the highest concentrations consistently occur in the doungradient wells, particularly toward the south end of the landfill. The trend of southward-increasing concentrations apparent in historical data is continued by concentration data for 111-TCA, TCE, and 11-OCA in the two new downgradient wel1s at the south end of the landfiti. However, concentrations of PCE are lower in the two new wells.

Low concentrations of chioroform (0.04 - $0.35 \mathrm{ppb})$ have been detected in all downgradient wolls during this reporting period. Carbon tetrachloride has been detected in two downgradient and both upgradient wells; cis-1,2-dichloroethene has been detected in four doungradient we11s.

Concentrations have declined since the first detect on of chlorinated hydrocarbon at the site; however, several of the constituents remain above the groundwater quality criteria (GWQC) set forth in WAC 173-200. The ranges of reported concentrations of chlorfnated hydrocarbons at the SWL during this reporting period are given in Table 5.2-4. Reported concentrations for groundwater samples exceed the GKQC for PCE (0.8 ppb), 11-DCA (1 ppb), and carbon tetrachloride $(0.3 \mathrm{ppb})$. 
5.2.5.1.17 Tritium. Tritium was added to the $S H L$ const.tuent 7 ist in 1989 as an aid in determining groundwater flow directions and flow rates at the SWL. Tritium concentrations in groundwater monitoring wel1s at the SWL. have ranged from $<56$ to $218,000 \mathrm{pCi} / \mathrm{L}$ during the reporting period and are currently decreasing. The tritium concentrations in five sill monitoring we11s have been above the Washington State and U.S. Environmenta] Protectlon Agency primary drinking water standard (40 Code of Federal Regulations [CFR] 141) of $20,000 \mathrm{pCl} / L$ during the current reporting period.

\subsubsection{Interpretation of Groundwater Chemistry. Downgradient wells at the} SWL have h'gher specific conductance, alkal inity, total carbon, and cation concentrations than upgradient wells. As indicated in DOE-RL $(1991 \mathrm{a}, 1991 \mathrm{~b}$, 1992, 1993a, and 1994), this is belfeved to be a result of high vadose concentrations of carbon dioxide, resulting from the degradation of sewage material beneath the SHL. High vadose zone concentrations of carbon dioxide are indicated by the vadose zone gas surveys of Evans et a1. (1989) and Jacques and Kerkow (1993). Solution of carbon dioxide in groundwater produces carbontc acid $\left(\mathrm{H}_{2} \mathrm{CO}_{3}\right)$. Carbonic acid lowers groundwater ph, raking it wore reactive with aquifer materials. Reaction with aquifer materials, principaijy hydrolysis of silicates, results in the dissolution of cations with a resultant increase in groundwater $\mathrm{pH}$. The aquifer matertals in effect act as a $\mathrm{pH}$ buffer. The dissolution of carbon dioxide is indicated by concentrations of inorganic carbon (total carbon minus TOC) that are 30 to $40 \%$ higher in downgradient wells than in upgradient wells. At the ambient groundwater pH almost all of this inorganic carbon witi exist in the form of the bicarbonate jon $\left(\mathrm{HCO}_{3}{ }^{\circ}\right)$.

A number of chTorinated hydrocarbons have been detected in groundwater at the SWL, the most important being 111-TCA, PCE, TCE, and 11-DCA (see Tabie 5.2-4). 111-TCA occurs at the highest concentrations (Figure 5.2-2); however, it is far below the GWQC of WAC 173-200 (200 ppb). PCE occurs in the 1- to 4-ppb range (Figure 5.2-3), above the GWQC of $0.8 \mathrm{ppb}$ in a11 downgradient wel1s. TCE occurs in the 1- to 3-ppb range (Figure 5.2-4) and is below the GiQC (3 ppb) for all wells in the downgradient network. 11-DCA occurs in the 0.5- to 5-ppb range (Figure 5.2-5) and has exceeded the GWQC (1 ppb) in alt downgradient weljs.

The southernmost monitoring wells at the SWL have had the highest concentrations of chlorinated hyorocarbons since the initiation of samping in 1988. The concentratjons generally increase from north to south along the Iine of downgradient wells, indicating that the highest source concentration is south of the area sampled by the southernmost downgradient we11. This southward-increasing trend is extended by the two new downgradient wells for 111-TCA, TCE, and 11-DCA, but not for PCE. This demonstrates that the principal source for 11-TCA, TCE, and 11-DCA has probabTy migrated south of the SWL boundary. However, the principal source of PCE is probably still within the boundaries of the SWL.

The most likely cause of the widespread contamination with chlorinated hydrocarbons at the SWL, including upgradient wells and the adjacent ARDNL, is the dissolution of vadose zone vapors into groundwater. However, the source of the vadose zone vapors is sowewhat uncertatn. The source coutd be chlorinated hydrocarbons trapped within the vadose zone or dense nonaqueous phase liquids within the aquifer. Total inorganic carbon (total carbon minus 
TOC) Increases southward along with the chlorinated hydrocarbons. This correspondence suggests a link between the chlorinated hydrocarbon contaminants and the sewage waste, which is the most probabie source of the elevated inorganic carbon in groundwater. Thus, the chlorinated hydrocarbons source(s) way be chlorinated hydrocarbons dissolved in sewage 7 iquids that are migrating southward (down dip) along silt layers in the vadose zone.

In recent years the major concentration axes of the 200 East Area nitrate and tritium plumes have passed. directly beneath the SWL (see figures 2-5 and 2-9). Tritiun and $n^{3}$ trate concentrations in well 699-24-33, located approximateTy $150 \mathrm{n}(500 \mathrm{ft}$ ) east (downgradient) of the SWL, are decreasing (Figure 5.2-6), indicating that a maxinum in the plumes has passed beneath the SWL. This decrease in tritiun concentrations is confirmed by reported concentrations in SWL monitoring we11s. However, it also appears that the concentration axis of the tritiun plune is shifting northward as it decreases (Figure 5.2-7), consistent with the plune interpretation presented by Orese] et al. (1994). This shift in plume axes is probably a result of decreasing effluent input to the 216-B-3 Pond (B Pond). Nitrate concentrations beneath the SWL exhibit a pattern similar to that of tritiun and are currently decreasing.

5.2.5.3 Statistical Evaluation. Statistical evaluation of data consisted of the required comparisons between upgradient and downgradient wells for deterwining whether a significant change over background has occurred for constituents specified in WAC 173-304-490. WAC 173-304 does not require replicate analyses. Thus, the tolerance interva] mathod, suitable for individual sample comparisons, was chosen because replicated analyses were not done for most of the constituents of concern. Statistical evaluattons are described as follow.

Calculation of background summary statistfes--Sunmary statistics were calculated using background sampies for the site (DOE-Ri. 1993a, Appendix D, Table 010.1). The results are presented in Table 5.2-5. Some of the background data are below the contractual detection liafts required of the U.S. Testing Company or below the contractually required quantitation limit. In cases where measured values are available (e.g., nost of the TOC values), these values were used in calculating the surmary statistics. In cases where the proportion of nondetects is between 15 and $50 \%$, less-than values were replaced by half of their contractual detection 1 imits and/or contractually reguired quantitation 1 inits, and the usual calculations were performed (e.g., filtered iron). In cases where the proportion of nondetects is greater than 50x, surwary statistics are not calculated (e.g., nitrite, amonium, filtered zinc, filtered manganese, coliform, and chemical oxygen denand).

5.2.5.3.1 Testing the Assumption of Hormality of Data. The tolerance interval defines a concentration range (fron background well data) that contains at least a speciffed proportion (coverage) of the population with a spectfied probability (conftence level). There are two types of tolerance intervals: parametric and nonparametric. Parametric tolerance interval techntques are sensitive to the assumption that the data are drawn from a norma] population. The stattstical tests used for evaluating whether or not the data follow a specified distribution are called goodness-of-fit tests. The L111iefors test is used to evaluate the fit of a hypothesized normal or lognorna 1 dfstribution. Test procedures are described by Conover (1980). 
STATGRAPHICS ${ }^{1}$ (Yersion 4.2) was used to calculate the Lilliefors test statistics. If the data are not normal, the Lilliefors test was applied to the logarithm (natural logarithm) of the data to see if the transformed data are approximately normal. This is equivalent to testing the hypothesis that the concentration measurenents follow a lognomal distribution. If the proportion of nondetects is more than 15\%, a goodnes5-of-fit test is not performed and a nomparanetric tolerance interval w111 be calculated to the extent possible.

Results of the Lilliefors test are presented in Tabie 5.2-6. Tenperature, field pH, and chloride concentration measurements from background weils are approxinately normatiy distributed. Specifjc conductance, TOC. nitrate, and sulfate concentrattons are netther normal nor lognormal.

B.2.5.3.2 Establishing Background Levels. Tolerance thtervals are constructed from the data on background.we11s. Both the upper and lower bounds of the interval (two sided) were calculated for field pH. For other constjtuents of concern only the upper bounds of the intervais (one sided) were ca7culated.

If a normal (or a lognormal) distribution is a reasonable approximation of the background concentrations, a parametric tolerance interval of the following form is calculated:

$$
\text { T.I. }=\bar{X}_{b} \pm K_{b} \text { (two sided) or T.I }=\bar{X}_{b}+K S_{b} \text { (one sided) }
$$

where:

$\bar{X}_{b}$ - Background mean

$K=A$ normal tolerance factor, whtch depends on the number of background samples ( $n$ ), coverage ( $P \%$, and confidence level ( $Y$ ). A coverage of 95\% and confidence level of $95 \%$ are recommended (EPA 1989). With $n-16, P-95 \%$, and $Y=95 \%, K$ is 2.523 ( $K$ is 2.566 , if $n-15$ ) for a one-sided normal tolerance interval (Natrella 1956)

$\mathrm{S}_{\mathrm{b}}=$ Background standard deviation.

If background concentrations do not follow a normal or a lognormal distribution, a nonparametric tolerance interval can be constructed (Conover 1980). A two-sided nomparanetric tolerance interval is just the range of the observed data. An upper one-sided nonparametric tolerance limit is the largest observation. The number of background saaples determines the coverage (P\%) and the probability level (Y) associated with that proportion. For a one-sided $95 \%(P=95 \%$ ) nonparanetric tolerance interval with $95 \%$ ( $Y=95 \%)$ probability, the number of background samples requfred is $\mathbf{5 9}$ (Conover 1980). With only 15 background samples (nitrate, filtered jron, and filtered zinc), the coverage is $\mathbf{8 5}$ and the confidence level is $90 \%$. That is, the upper one-sided tolerance 1 imit defined by the largest background concentration contatins at least $85 \%$ of the background population with $90 \%$

'STATGRAPHICS is a trademark of Statistical Graphics Corporation. 
probabitity. Hore background samples are needed if a 7arger coverage and/or a larger probability levei are desired.

In cases where all of the background values are below the contractually established detection linits or where the proportion of nondetects is more than 15\%, a 11mit of quantitation (LOQ) was also calculated using 1994 field bTanks data or based on method detect ion 1 imits (see Appendtx A). Following the guidance in the RCRA Ground Water Monitoring Technical Emforcenent Guidance Document (TEGD) (EPA 1986), it was decided that for cases where the calctlated upper tolerance timit is below the LOQ, the LOQ witl be used as the background threshold value (1.e,, comparison value) between background and downgradient weits. This approach uses quality control data to target the 1 inits of quant jfiable data and provides a realistic approach for upgradient/downgradient well cowparisons when a facility upgradient we1\} ylelds values that are below the detection 1tmit. In cases where LoQ is not available (e.g., col iform and chemical oxygen demand), the CRQLs were used as the background threshold va]ues. Hote that a narrower range for $\mathrm{pH}$, after removing inconsistent $\mathrm{pH}$ values, is used as the comparison value. The resulting tolerance 1 laits, LOQs, and background threshold values are also presented in Table 5.2-6.

5.2.5.3.3 Comparisons with Background Levels. Once the background threshold values are established, data from compliance-point walls were compared individtally with these background concentration levels. If the bacikground Tevels are exceeded, it is tnterpreted as providing avidence of statistically significant containination.

The sampling results from 1995 were compared to the background levels estabilished earlifer. The results are presented in Table 5.2-4 and are d1scussed in Section 5.2.5.2. Values for specific conductance exceed the background tevel in downgradient wells 699-22-34, 699-23-34A, 699-23-34B, 699-24-34A, 699-24-34B, and 699-24-34C for all samplings during this reporting period and in downgradient we 11 699-25-34C in three sarplings. This pattern of exceedances is sintlar to those observed from 1990 through 1994. In addition, the background threshold was exceeded for sulfate in doingradient. well 699-22-35, and for filtered iron in upgradient woll 699-24-35.

\subsubsection{Groundwater Flow}

Water table elevations were determined at the tine of groundwater sampling;'during 1995, monthly water level measurenents were made for all sul welis except the two new wells.: The discussions of water table elevations, groundwater flou directions, and groundwater flou velocjtles are based on the monthly measurements. The 1995 water level measurements for the SWL monitoring network are listed in Appendix 5.26 .

5.2.6.1 Groundwater Flow Direction. The SWL lies in a zone of very high transmissivities (Jacobson and Freshiey 1990) and, as a result, there is a very Tow hydraulf gradient across the site. A map of the water table in the vicinity of the site, based on June 1995 data, is presented in Figure 5.2-8. This map 117 ustrates the low hydraulic gradtents in the vicinity of the \$UL. The zone of high transmissivities, which includes the ShL, extends to the northwest beneath the southeast corner of the 200 East Area. Groundwater 
flows into this zone from the B Pond mound to the north, and fron the $U$ Pond mound to the west. The principal source is apparently the input to B Pond, which strongly affects the water tabie elevations over a wide area, including the vicinity of the SWL.

The water table in the vicinity of the SWL has dropped more than $1.3 \mathrm{~m}$ (>4 ft) stnce December 1988, apparentily as a result of decreased water input to 8 Pond, a trend that has slowed but has not stopped. This variation in the water tabile is illustrated in Figure 5.2-9, which depicts hydrographs of monthly water leve] measurements in sall weils. These hydrographs indicate the low hydraulic gradient across the SHL.

Groundwater flow directions beneath the SHL are indicated by both the water leve] measurements and the paths of nitrate and tritium plumes that originate in the 200 East Area and pass beneath the SWL. The nitrate and trititu plumes in 1990 indicated that the principal direction of groundwater flow beneath the \$HL was approximately $125^{\circ}$ east of north (DOE-RL 1991b), a value confirmed by current groundwater chemistry data. The difference in water table elevation across the site is comonily on the order of $1 \mathrm{~cm}$ $(0.03 \mathrm{ft})$, well within the error expected from well surveyting and water table elevation measurements. However, fiow directions based on water table eJevations agree to some extent with the flow direction indicated by the plumes. Previous determinations using water level measurenents yield fiow directions ranging fron $96 \pm 28^{\circ}$ east of north to $139 \pm 15^{\circ}$ east of north (COE-RL 1991b, 1992, 1993a, 1994). Flow direction estinated from 1995 water level data, using weils 699-24-35, 699-25-34C, and 699-23-34A, and weeding out apparent fijers, is $115 \pm 25^{\circ}$ east of north $(n=8)$. The flow direction indicated by the contaninant plumes is probably the most accurate and the trute groundwater flow direction is approxinately $125^{\circ}$ east of north.

5.2.6.2 Rate of Flow. The rate of groundwater flow beneath the SHL is highly uncertain. The aquifer beneath the SWL is charactertzed by high transatssivities and very low gradients. On the basis of site-specific aquifer testing and the observed hydraulic gradients, the expected groundwater velocities, calculated using the Darcy equation, should be on the order of 1.2 to $1.8 \mathrm{~m} / \mathrm{d}$ ( 4 to $6 \mathrm{ft} / \mathrm{d}$ ) (Weekes et al. 1987). However, more direct velocity indicators indicate a range of auch higher values. Transport velocities in the 200 East Area, indicated by contaminant transport within the Hanford formation, display groundwater flow velocities between 3 and $4.3 \mathrm{~m} / \mathrm{d}$ (10 to $14 \mathrm{ft} / \mathrm{d}$ ) (Wilber et a1. 1983). Tracer tests in the area southeast of the 200 East Area indjcated groundwater velocities in excess of $30 \mathrm{~m} / \mathrm{d}$ (100 ft/d); however, they occurred at higher hydraulic gradients than exist today (Bterschenk 1959). Tracking of the present tritiug and nitrate plumes from wells severa? kilometers upgradient from well 699-24-33, east of the $5 \mathrm{wL}$, indicates contaminant transport rates of approxinately $6 \mathrm{~m} / \mathrm{d}(20 \mathrm{ft} / \mathrm{d}$ ). Additional information on flow rate is provided by the recent decrease in nitrate and tritium concentrations across the site. Nitrate and trittum, which have upgradient sources, exhibit nearly identica] time-concentration variation in upgradient and downgradient weII pairs with quarterly sampling (Figure 5.2-10). The time required for the contaminants to traverse the site is on the order of 3 months. Thts traverse time indicates groundwater transport rates of approximately $5.5 \mathrm{~m} / \mathrm{d}(18 \mathrm{ft} / \mathrm{d})$. The actual transport rate is probabiy near $6 \mathrm{~m} / \mathrm{d}(20 \mathrm{ft} / \mathrm{d})$ and is controlled by zones of very $\mathrm{high}$ 
DOE/RL,-96-01, REV. D

groundwater velocity within the Hanford formation that are missed or averaged out in normal aquifer testing.

5.2.6.3 Evaluation of Monftoring Mell Metwork. Two downgradient wells were completed in Decamber 1993, completing the shallow compliance-point monitoring network for the site. The presence of the two downgradient wells raises the Monitoring Efficiency Model (Jackson et al. 1991) monitoring efficiency for the site from 68 to $94 \%$. Additional wells will be needed only if significant quantitjes of contaminants are shown to have migrated south of the site boundary (Hodges 1994).

\subsubsection{References}

40 CFR 141, "National Primary Drinking Water Regulations," Code of Federal Regulations, as amended.

Bjerschenk, W. H., 1959, Aquifer Characteristics and Groundwater Movement at Hanford, Mi-60601, Hanford Atomic Products Operations, Richland, Washington.

Conover, W. J., 1980, Practical Nonparametric Statistics, 2nd ed., John Wiley and Sons, Inc., New York, New York.

DOE-RL, 1991a, Hanford Site Solid Waste Landfill Perwit Application, DOE/RL 90-38, Rev. 0, U.S. Department of Energy, Richland Field office, Richl and, Washington.

DOE-RL. 1991b, Annual Report for RCRA Groundwater Honftoring Projects at Hanford Site Facilities for 1990, DOE/RL-91-03, U.S. Department of Energy, Richland Fjeld Office, Richland, Washington.

DOE-RL, 1992, Annual Report for RCRA Groumdwater Monitoring Projects at Hanford site Faci7ities for 1991, DOE/RL-92-03, U.S. department of Energy, Richland Field office, Richland, Washington.

DOE-RL, 1993a, Annual Report for RCRA Groundwater Monitoring Projects at Hanford Site Facilities for 1992, BOE/RL-93-09, U.S. Department of Energy, Richland Operations Office, Richland, Washington.

DOE-RL, 1993b, Hanford Site Solid Waste Landfill Pernit Appification, DOE/RL-90-38, Rev. 1, U.5. Department of Energy, RfchTand Operations office, Richland, washington.

DOE-RL, 1994, Annual Report for RCRA Groundwater Honitoring Projects at Hanford Sfte Facijities for 1993, DOE/RL-93-88, U.S. Department of Energy, Richland Operations Office, Richland, Washington.

DOE-RL, 1995, Annual Report for RCRA Groundwater Monitoring Projects at Hanford Sfte Facilities for 1994, 00E/RL-94-136, U.S. Department of Energy, Richland Operations Office, Richland, Washington. 
Drese 1, P. E., S. P. Luttre11, J. C. Evans, W. D. Webber, P. D. Thorne, M. A. Chamness, B. K. Gillespie, B. E. Opitz, J. T. Rieger, and J. K. Merz, 1994, Hanford Sfte Ground-Water Nonitoring for 1993, PHL-10082, Pacific Northwest Laboratory, Rich]and, Washington.

EPA, 1986, RCRA Ground Water Monitoring Technical Enforcenent Guidance Document (TEGD), U.S. Environmental Protection Agency, Hashington, D.C.

EPA, 1989, Statistical Analysis of Ground-Water Nonitoring Data at RCRA Facilities, Interim Final Guidance, Office of Solid Waste Hanagement Division, U.S. EnvironmentaT Protection Agency, Washington, D.C.

Evans, J. C., R. H. Fruland, D. W. Glover, and C. Veverka, 1989, Final Report So 11-Gas Survey at the Sol fo Waste Landfi11, PNL-7147, Paciftc Horthwest Laboratory, Richland, Washington.

Frutand, R. M., D. J. Bates, C. S. CTine, J. C. Evans, R. A. Hagen, and R. L. Aaberg, 1989, Interio Site Characterization Report and Ground-Water Monitoring Progras for the Hanford Solid Waste Landfil], PHL-6823, Pacific Northwest. Laboratory, Richland, Washington.

Hodges, F. N., 1994, Corrective Action Plan for the Hanford Site Solfd Waste Landfi17, DOE/RL-94-143, U.S. Department of Energy, Rich] and Operations Office, Richland, Washington.

Jackson, R. L., C. M. Einbereger, R. B. Mercer, and C. R. Hilson, 1991, Efficiency-Based Groundwater Honitoring Network Desfign for Hazardous Waste Sites, NHC-SA-1157-FP, Westinghouse Hanford Company, Richiand, Washington.

Jacobson, E. A., and M. D. Fresh1ey, 1990, An Initfal Inverse Calibration of the Ground-Water Flow Hodel for the Hanford Unconfined Aquifer, PNL-7144, Pacific Northwest Laboratory, Richiand, Wash1ngton.

Jacques, 1. D., and R. B. Kerkow, 1993, Nonradioactive Dangerous Waste Landfill Soil Gas Survey: Final Report, WHC-SD-EN-TI-199, ReV. 0, West1nghouse Hanford Company, Rich]and, Washington.

Natre17a, H. 6., 1966, Experimental Statistics, National Bureau of Standards, John Wiley and Sons, Inc., New York, New York.

Resource Conservation and Recovery Act of 1976, 42 USC 6901 et seq.

HAC 173-200, "Water Quality Standards of the State of Washington," Washington Adsinfstrative Code, as amended.

WAC 173-304, "Minimum Functional Standards for Solid Waste Handling," Washington Administrative Code, as amended.

WAC 248-54, "Public Water Supplies," Weshington Adnifistrative Code, as amended. 
Weekes, D. G., S. P. Luttre11, and M. R. Fuchs, 1987, Interin Hydrogeologic Characterization Report and Groundwater Monitoring Systen for the Nonradioactive Dangerous Waste Landfill, Hanford Site, Washington, WHC-EP-0021, Westinghouse Hanford Company, Richland, Washington.

WHC, 1993, Groumdwater Honitoring Plan for the Hanford Solfd Waste Landfill, WHC-SO-EN-AP-043, Rev. 0, Westinghouse Hanford Company, Richland, Nashington.

Wilber, J. S., M. J. Grahan, and A. H. Lu, 1983, Results of the Separations Area Ground-Water Monitoring Network for 1982, RHO-RE-SR-83-24 P, Rockwe11 Hanford Operations, R1ch1 and, Washington. 
Figure 5.2-1. Map of the Solid Maste Landfill Showing the Locations of Groundwater Honitoring Wells.

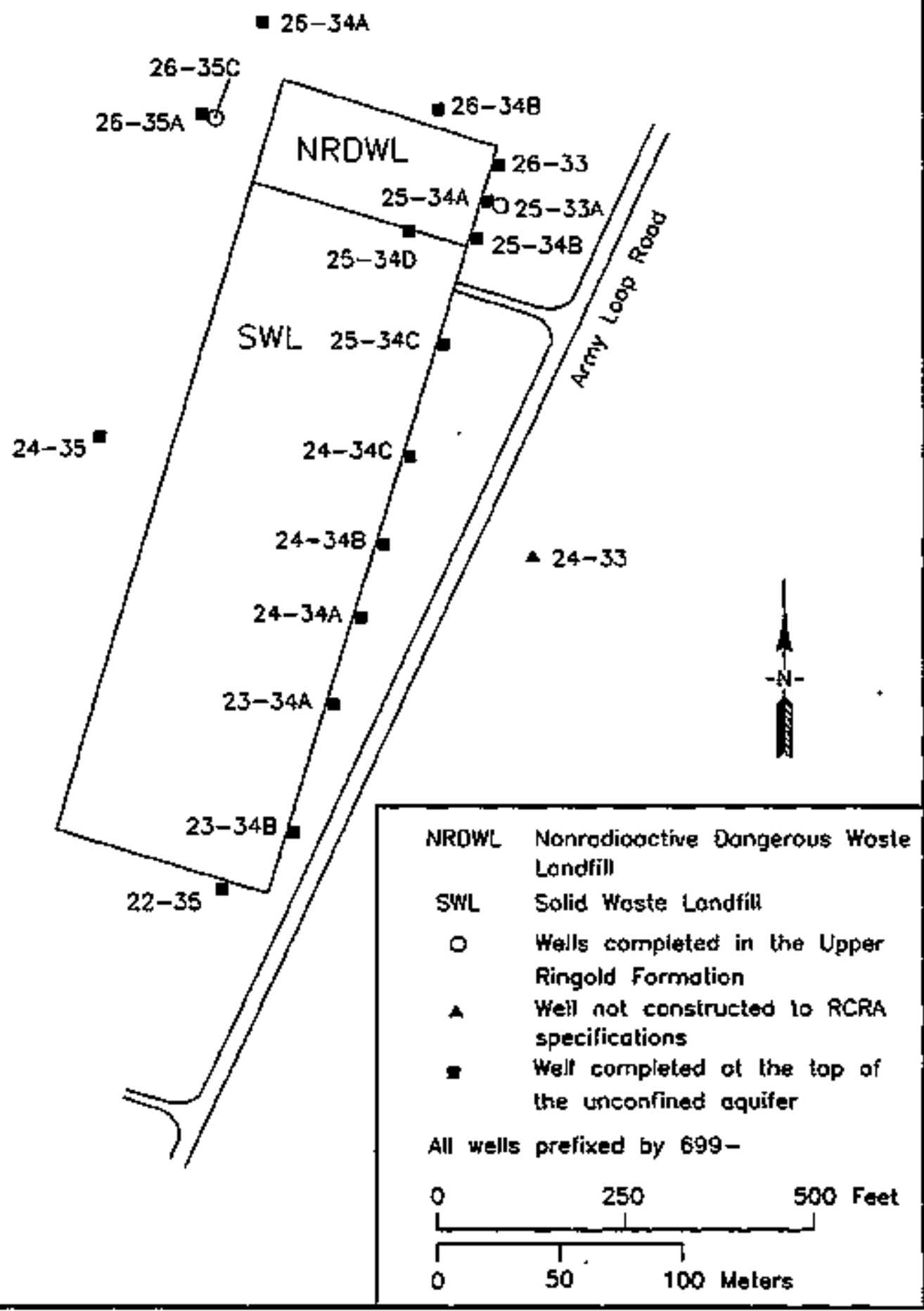

fnh \swinrdwl.dwg 
Figure 5.2-2. Plot of 1,1,1-Trichloroethane Concentrations (ppb) in Downgradient Weils at the SWL and NRDWL for Selected 1994 and 1995 Data.

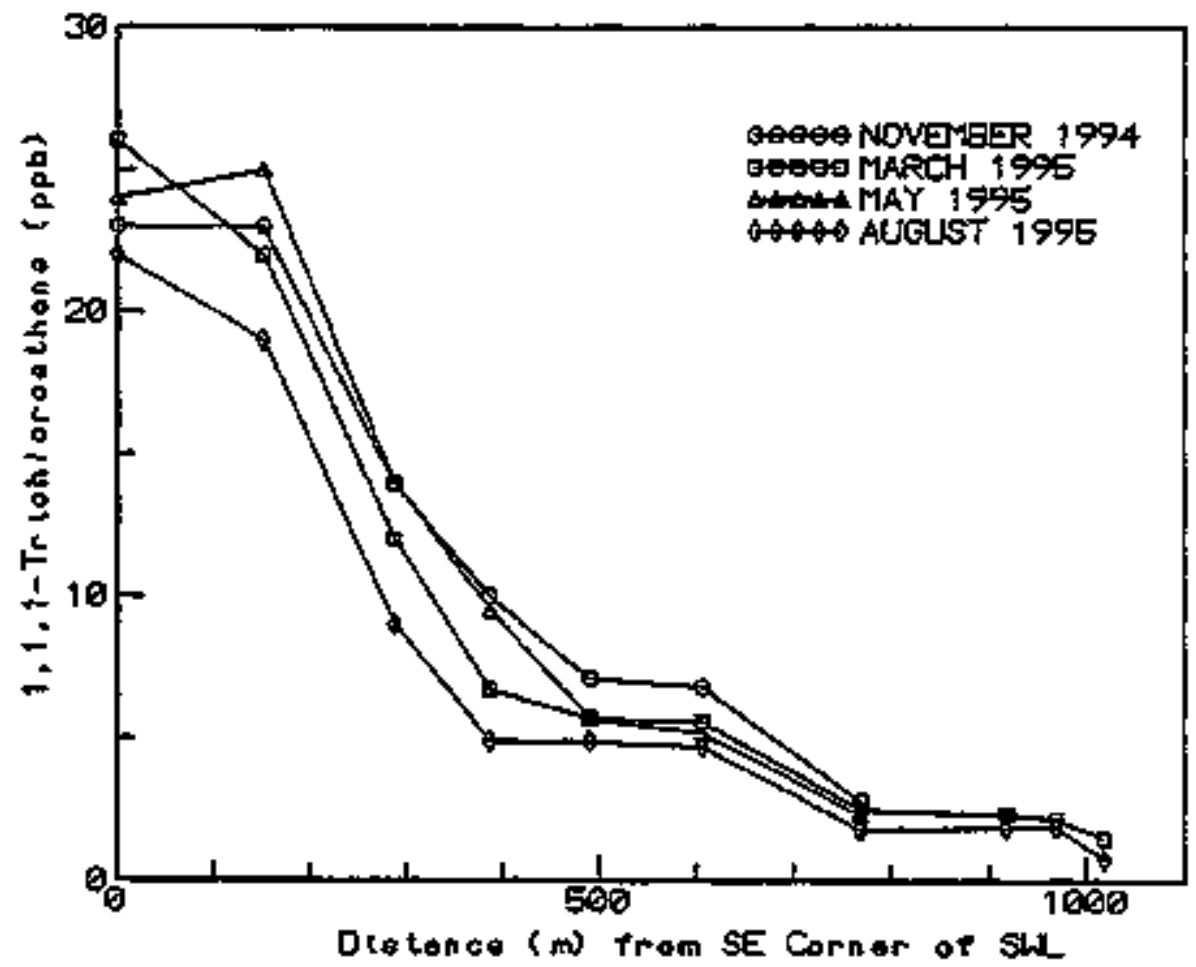

Figure 5.2-3. PJot of Tetrachloroethene (PCE) Concentrations (ppb) in Downgradient Nolls at the SWL and NRDUL for Selected 1994 and 1995 Data.

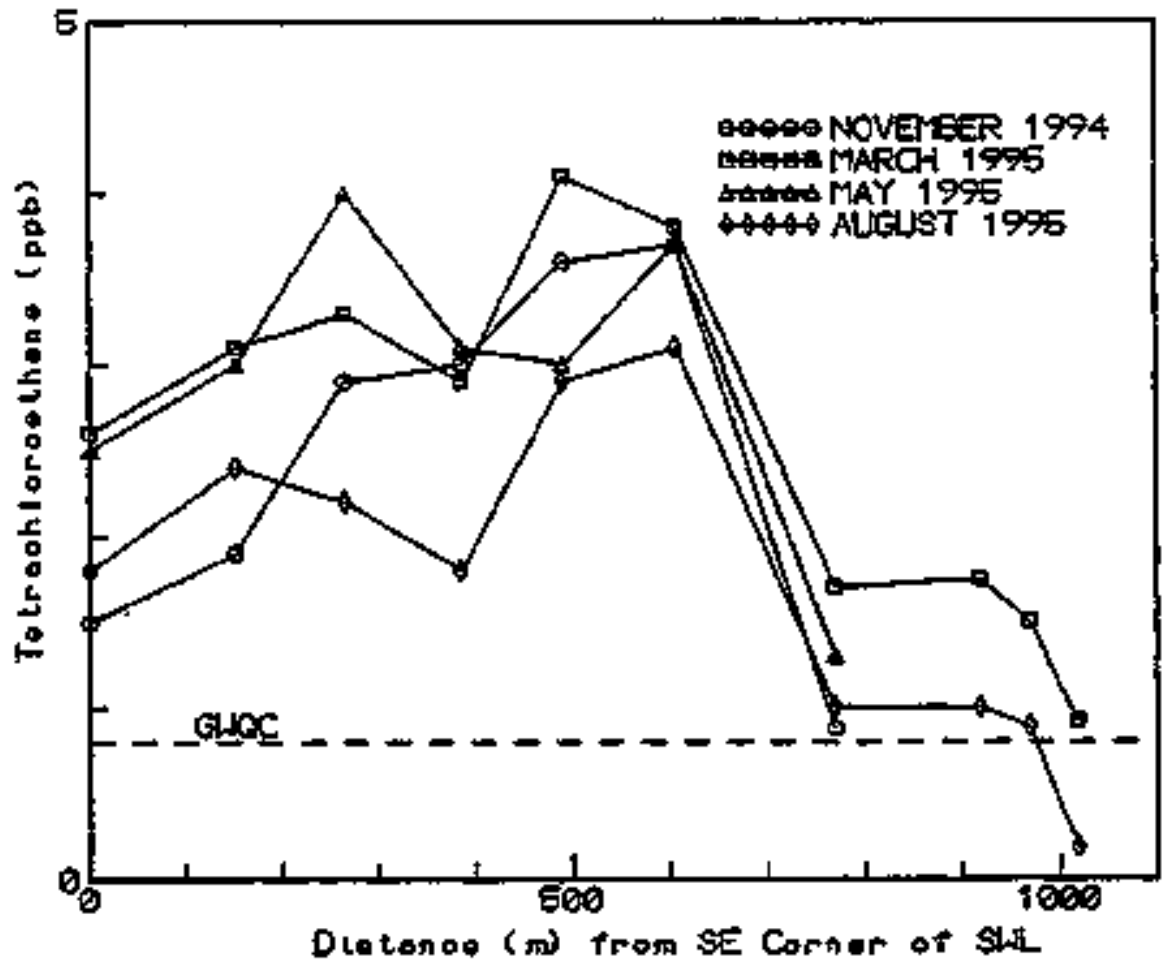


Figure 5.2-4, P1ot of Trichloroethene (TCE) Concentrations (ppb) in Downgradient Wel7s at the SWL and NRDHL for Selected 1994 and 1995 Data.

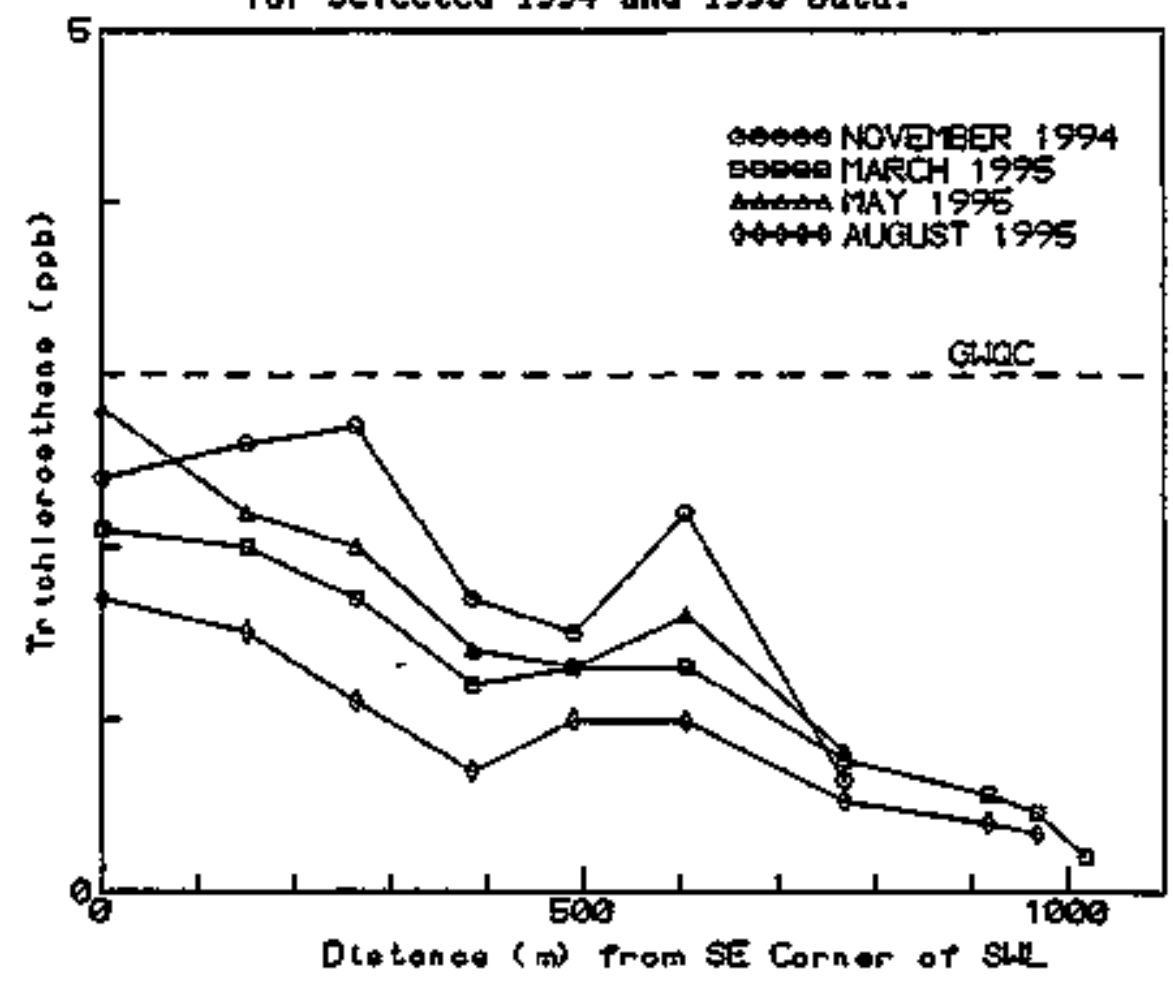

Figure 5.2-5. Plot of 1,1-D1chloroethane (11-DCA) Concentrations (ppb) in Downgradient We11s at the SWL and NRDWL for Selected 1994 and 1995 Data.

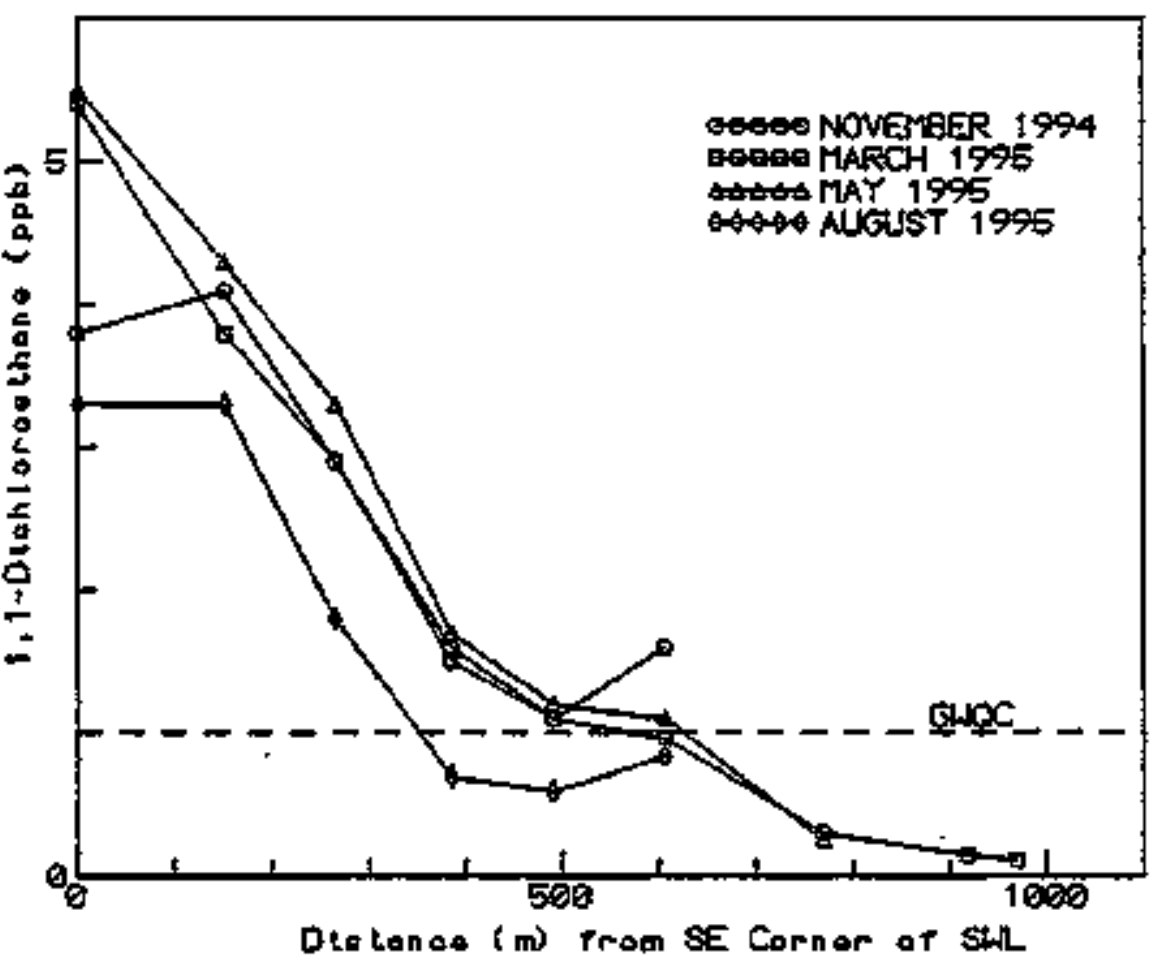


Figure 5.2-6. Time Series Plot of Trttium (pCi/L) and Nitrate (ppb) Concentrations in Doungradfent Well 699-24-33.
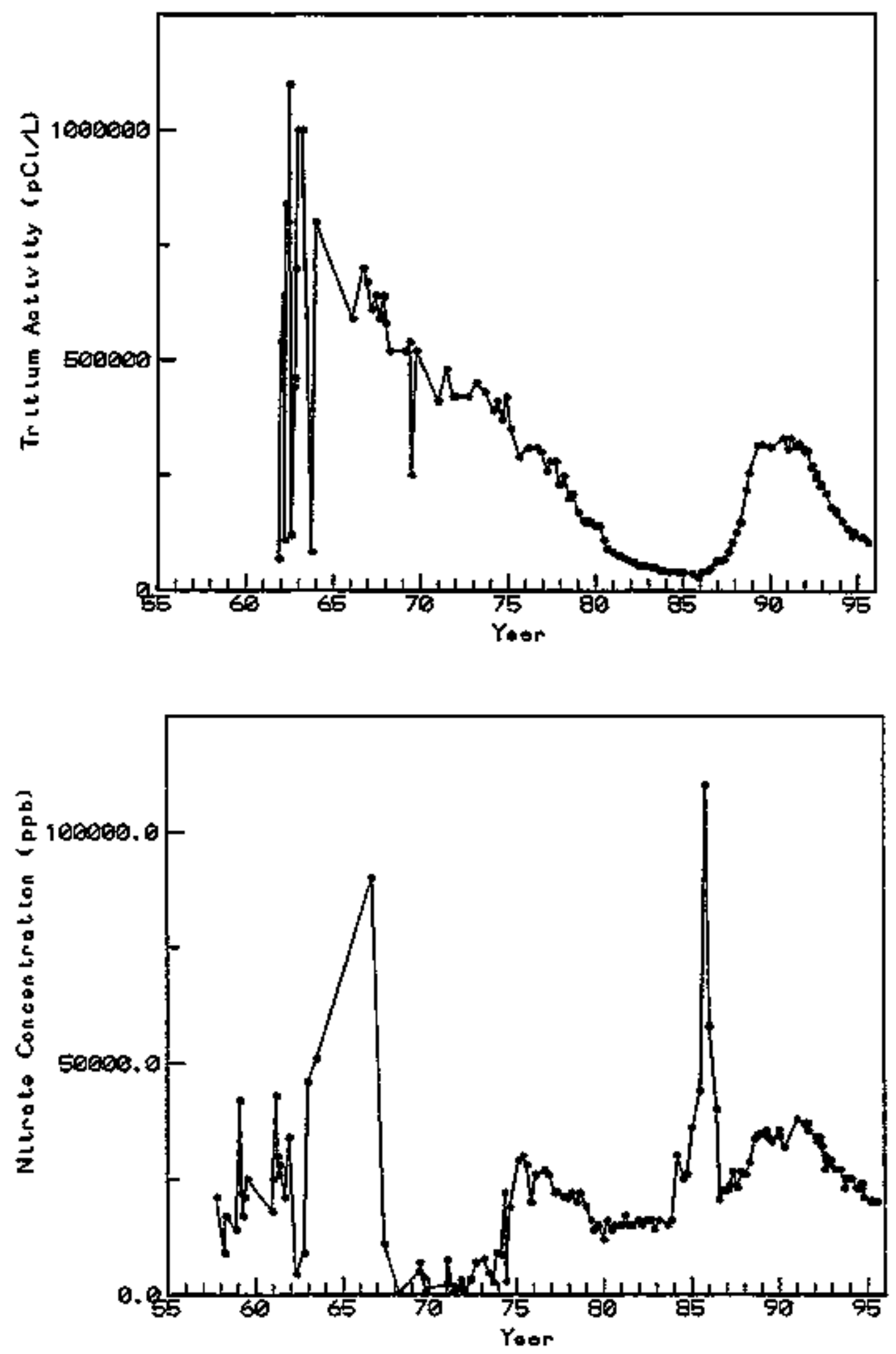
DOE/RL-96-0I, REV, O

Figure 5.2-7. Plot of Trjtium Concentrations (PCi/L) in Downgradient Monitoring Mells for the SWL and RRDWL.

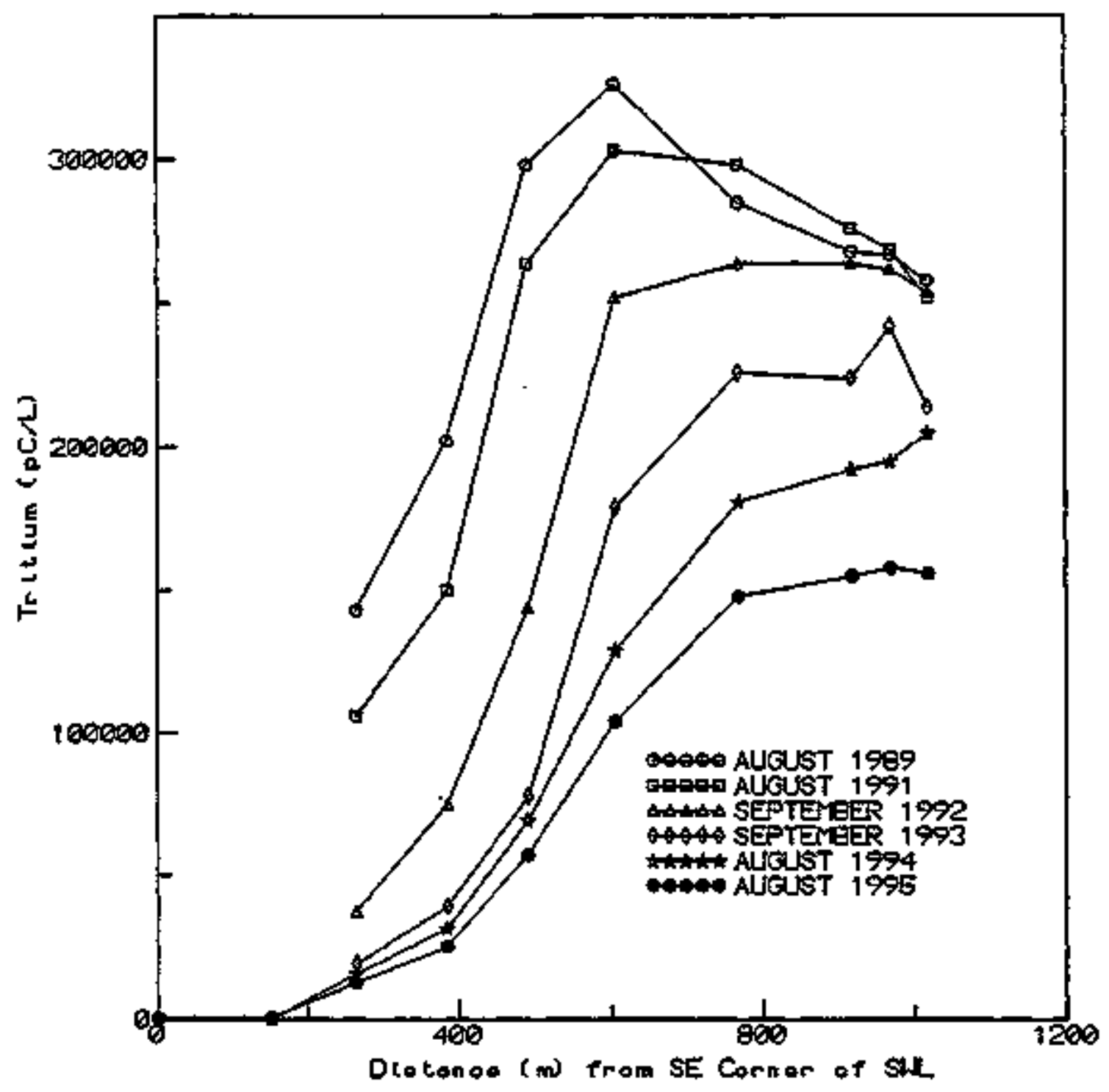


Figure 5.2-8. Wa.er Tabie Map (Potent1ometric Surface) for the Vicinity of the Solid Waste Landf171 Based on June 1995

Water Table Measurements. (Datum is Mean Sea Leve1)

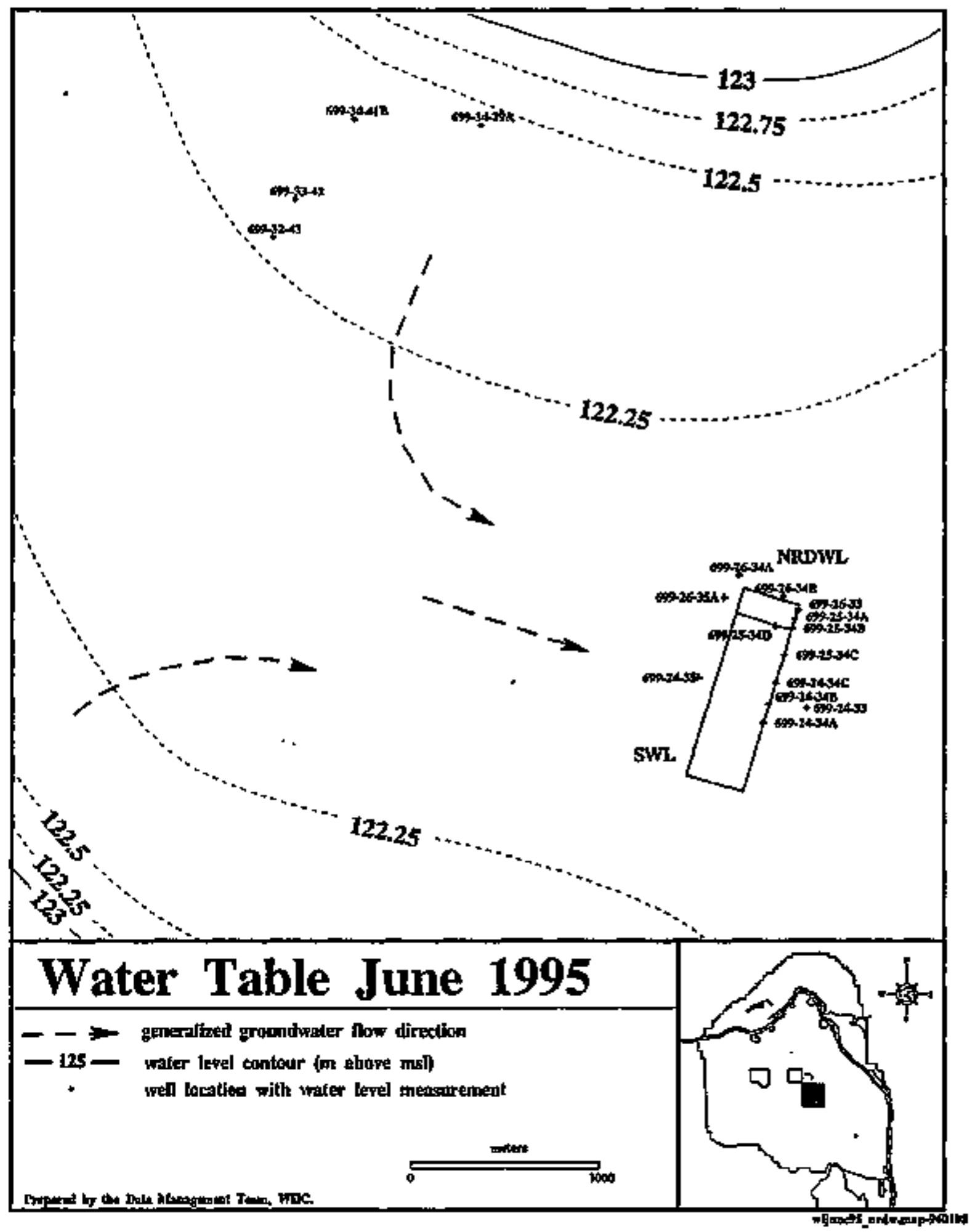


DOE/RL-96-01, REV. 0

Figure 5.2-9. Hydrograph Showing Monthly Water Level Measurements (Meters Above Mean Sea Level) for the Solid Waste Landfill.
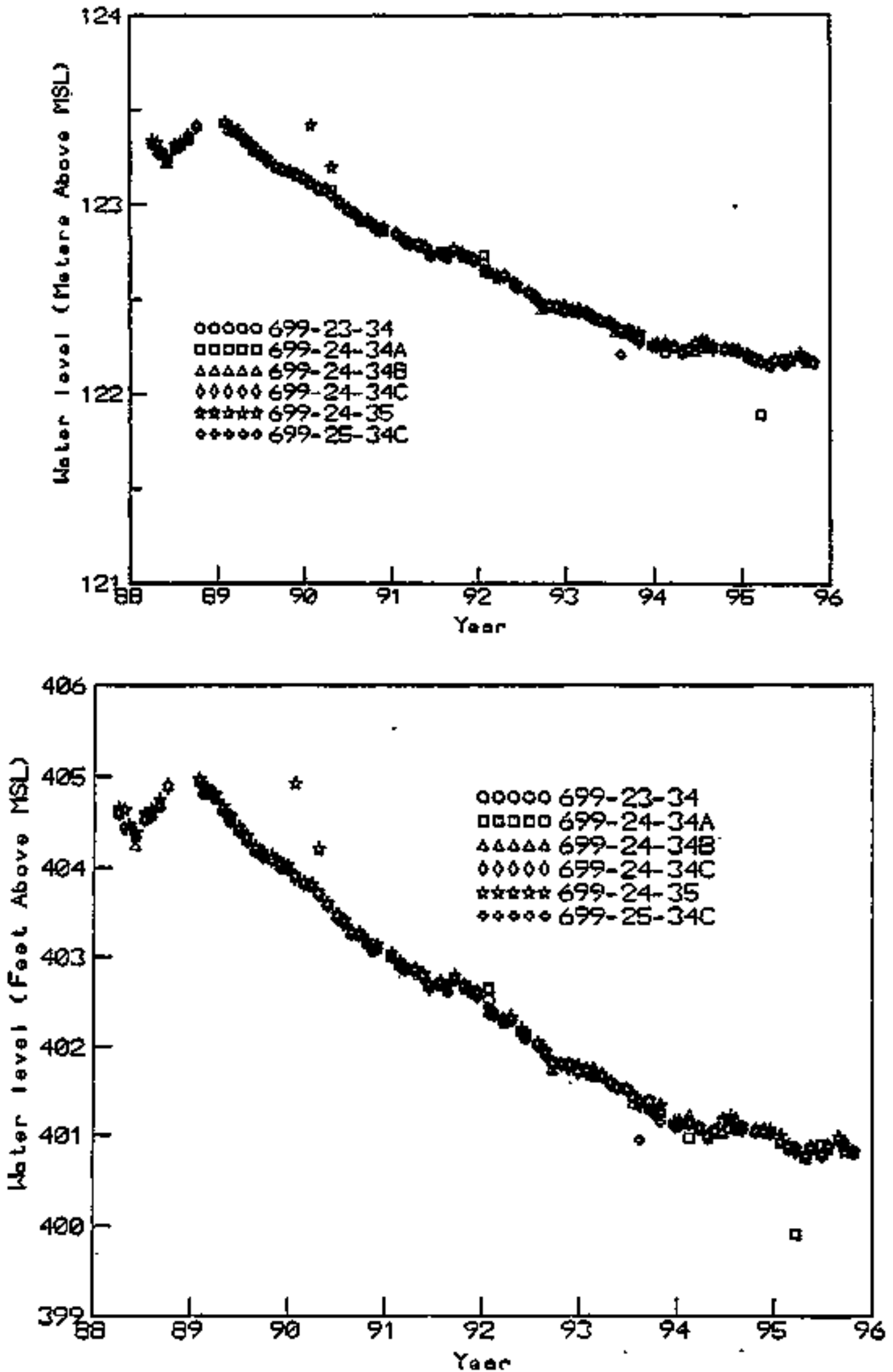
Figure 5.2-10. Time Serles Plots of Tritium Concentrations ( $\mathrm{pCi} / \mathrm{L}$ ) in Upgradient-Downgradient Mell Pairs: (a) Wel1s 699-26-35A and 699-25-34C; (b) Wells 699-24-35 and 699-23-34A.
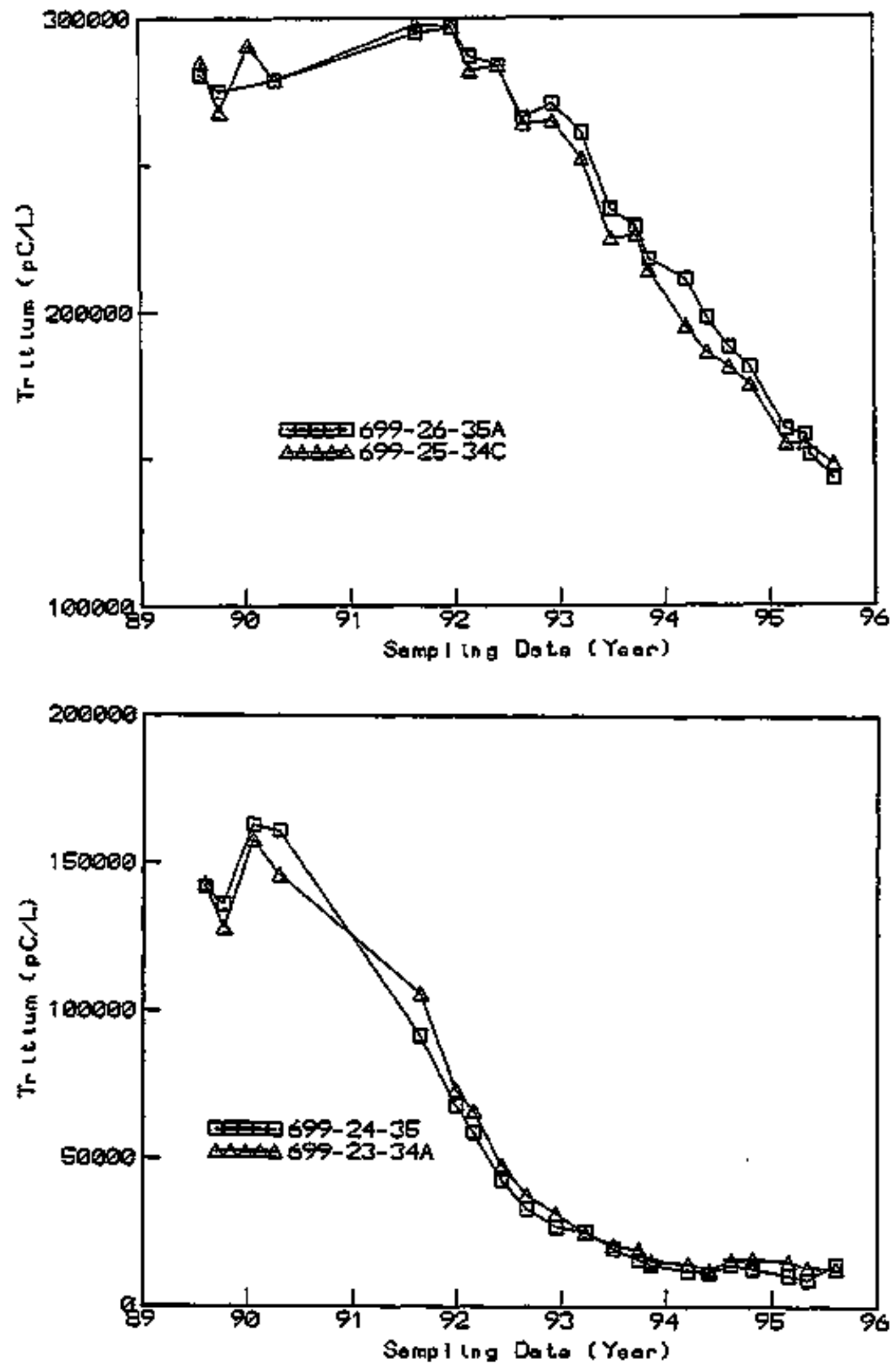
Table 5.2-1. Monitoring Wells Used for the Solid Waste Landfill.

\begin{tabular}{|l|l|c|c|c|c|}
\hline \multicolumn{1}{|c|}{ Well } & \multicolumn{1}{|c|}{ Aquifer } & $\begin{array}{c}\text { Samol ing } \\
\text { frequency }\end{array}$ & $\begin{array}{c}\text { Water } \\
\text { levels }\end{array}$ & $\begin{array}{c}\text { Wel] } \\
\text { standard }\end{array}$ & $\begin{array}{c}\text { Other } \\
\text { networks }\end{array}$ \\
\hline $699-22-35^{93}$ & Top of unconfined & $Q$ & - & RCRA & -- \\
\hline $699-23-34 A^{87}$ & Top of unconfined & $Q$ & M & RCRA & -- \\
\hline $699-23-34 B^{95}$ & Top of unconfined & $Q$ & - & RCRA & -- \\
\hline $699-24-33^{48}$ & Top of unconfined & $Q^{2}$ & M & PRE & PAHL \\
\hline $699-24-35^{87}$ & Top of unconfined & $Q$ & H & RCRA & -- \\
\hline $699-24-34 A^{87}$ & Top of unconfined & $Q$ & M & RCRA & -- \\
\hline $699-24-34 B^{87}$ & Top of unconfined & $Q$ & M & RCRA & -- \\
\hline $699-24-34 C^{87}$ & Top of unconfined & $Q$ & M & RCRA & -- \\
\hline $699-25-34 C^{87}$ & Top of unconfined & $Q$ & M & RCRA & -- \\
\hline $699-26-35 A^{86}$ & Top of unconfined & $Q$ & H & RCRA & NRONL \\
\hline
\end{tabular}

Notes: Shading denotes upgradient weils. Superscript following wall number denotes the year of installation.

Well is sampled for supporting data.

$M=$ frequency on a monthly basis.

NRDNL = Monradioact Ive Dangerous Waste Landfi11.

PNAL = well is sampled by Pacific Northwest National Laboratory site-wide monitoring progran.

PRE * well was constructed before RCRA-specified standards.

Q = frequency on a quarterly basis.

RCRA $=$ well is constructed to RCPA-specified standards .

Table 5.2-2. Constituents Analyzed at the Solid Waste Landfill.

\begin{tabular}{|c|c|c|}
\hline \multicolumn{3}{|c|}{ Parameters and constituents required by WAC $173-304-490$} \\
\hline $\begin{array}{l}\text { Ammonia as nitrogen } \\
\text { Chemical oxygen demand } \\
\text { Chiloride } \\
\text { Conductivity } \\
\text { Dissolved iron }\end{array}$ & $\begin{array}{l}\text { Dissolved zinc } \\
\text { Dissolved manganese } \\
\text { Nitrate } \\
\text { Nitrite } \\
\text { pH }\end{array}$ & $\begin{array}{l}\text { Sulfate } \\
\text { Temperature } \\
\text { Tota] coliform } \\
\text { Total organic } \\
\text { carbon }\end{array}$ \\
\hline \multicolumn{3}{|c|}{ Site-specific constituents } \\
\hline 1,1,1-Trichloroethane & Total organic halogen & Trichloroethylene \\
\hline \multicolumn{3}{|c|}{ others } \\
\hline Tritium & & \\
\hline
\end{tabular}


'Table 5.2-3. Sampling Results for Required Constituents (WAC 173-304) at the Hanford Solid Waste Landfill November 1994 through August 1995. (3 sheets)

\begin{tabular}{|c|c|c|c|c|c|c|c|c|c|c|c|}
\hline Const 1tuent & $\mathrm{TI}^{*}$ & Date & $22-35$ & $23-34 A$ & $23-34 B$ & 24-34A & $\begin{array}{l}24- \\
348\end{array}$ & $24-34 C$ & $24-35^{b}$ & $25-34 c$ & $26-$ \\
\hline $\begin{array}{l}\text { Temperature } \\
\left({ }^{\circ} \mathrm{C}\right)\end{array}$ & 21.0 & $\begin{array}{l}\text { Hov } / 94 \\
\text { Mar } / 95 \\
\text { Hay/95 } \\
\text { Aug/95 }\end{array}$ & $\begin{array}{l}17.4 \\
16.6 \\
18.0 \\
18.3\end{array}$ & $\begin{array}{l}19.5 \\
16.9 \\
18.7 \\
18.6\end{array}$ & $\begin{array}{l}17.6 \\
17.8 \\
18.4 \\
18.2\end{array}$ & $\begin{array}{l}18.6 \\
18.4 \\
17.8 \\
19.3\end{array}$ & $\begin{array}{l}19.3 \\
16.8 \\
18.9 \\
19.1\end{array}$ & $\begin{array}{l}18.1 \\
18.1 \\
18.8 \\
19.8\end{array}$ & $\begin{array}{c}25 \\
16 \\
18.1 \\
18.4\end{array}$ & $\begin{array}{l}18.6 \\
19.4 \\
18.7 \\
19.4\end{array}$ & $\begin{array}{l}19.7 \\
19.2 \\
19.9 \\
20.4\end{array}$ \\
\hline $\begin{array}{l}\text { Specifjc } \\
\text { conductance } \\
\text { ( } \mu \text { mho/cm) }\end{array}$ & 550 & $\begin{array}{l}\text { Hov/94 } \\
\text { Mar/95 } \\
\text { Hay/95 } \\
\text { Aug/95 }\end{array}$ & $\begin{array}{l}797^{\mathrm{E}} \\
758^{\mathrm{E}} \\
747^{\mathrm{E}} \\
766^{\mathrm{E}}\end{array}$ & $\begin{array}{l}693^{E} \\
644^{\mathrm{E}} \\
640^{\mathrm{e}} \\
659^{\mathrm{E}}\end{array}$ & $\begin{array}{l}776^{E} \\
755^{E} \\
714^{E} \\
739^{E}\end{array}$ & $\begin{array}{l}450^{E} \\
631^{E} \\
605^{E} \\
611^{E}\end{array}$ & $\begin{array}{l}523^{E} \\
617^{\mathrm{E}} \\
616^{\mathrm{E}} \\
624^{\mathrm{E}}\end{array}$ & $\begin{array}{l}666^{E} \\
661^{E} \\
675^{E} \\
710^{E}\end{array}$ & $\begin{array}{l}497 \\
506 \\
509 \\
504\end{array}$ & $\begin{array}{c}579^{E} \\
550 \\
551^{E} \\
568^{E}\end{array}$ & $\begin{array}{l}455 \\
445 \\
453 \\
450\end{array}$ \\
\hline Field pH & $\begin{array}{l}{[6.2,} \\
B .46]\end{array}$ & $\begin{array}{l}\operatorname{Mov} / 94 \\
\operatorname{Mar} / 95 \\
\operatorname{May} / 95 \\
\text { Aug/95 }\end{array}$ & $\begin{array}{l}6.9 \\
7.0 \\
6.6 \\
7.1\end{array}$ & $\begin{array}{l}6.8 \\
6.7 \\
6.7 \\
6.7\end{array}$ & $\begin{array}{l}6.8 \\
6.9 \\
6.9 \\
6.9\end{array}$ & $\begin{array}{l}6.8 \\
6.7 \\
6.8 \\
6.7\end{array}$ & $\begin{array}{l}6.8 \\
6.8 \\
6.8 \\
6.9\end{array}$ & $\begin{array}{l}6.4 \\
7.1 \\
7.0 \\
6.9\end{array}$ & $\begin{array}{l}7.3 \\
7.1 \\
7.1 \\
7.2\end{array}$ & $\begin{array}{l}7.4 \\
7.2 \\
7.3 \\
7.2\end{array}$ & $\begin{array}{l}6.7 \\
7.6 \\
7.4 \\
7.4\end{array}$ \\
\hline $\begin{array}{l}\text { Total } \\
\text { organtc } \\
\text { carbon } \\
\text { (ppb) }\end{array}$ & 976 & $\begin{array}{l}\text { Nov } / 94 \\
\text { Nar } / 95 \\
\text { May } / 95 \\
\text { Aug/95 }\end{array}$ & $\begin{array}{l}175 \\
275 \\
300 \\
250 \\
\end{array}$ & $\begin{array}{l}135 \\
250 \\
<140 \\
250 \\
\end{array}$ & $\begin{array}{c}182 \\
250 \\
<140 \\
250 \\
\end{array}$ & $\begin{array}{r}148 \\
213 \\
<140 \\
240 \\
\end{array}$ & $\begin{array}{l}125 \\
200 \\
<140 \\
200 \\
\end{array}$ & $\begin{array}{l}168 \\
178 \\
<140 \\
300 \\
\end{array}$ & $\begin{array}{l}162 \\
225 \\
250 \\
150 \\
\end{array}$ & $\begin{array}{l}168 \\
<110 \\
<140 \\
150 \\
\end{array}$ & $\begin{array}{l}125 \\
<110 \\
<140 \\
200 \\
\end{array}$ \\
\hline $\begin{array}{l}\text { Chloride } \\
\text { (ppb) }\end{array}$ & 9,045 & $\begin{array}{l}\text { Nov/94 } \\
\text { Nar/95 } \\
\text { Nay/95 } \\
\text { Aug/95 }\end{array}$ & $\begin{array}{l}6,200 \\
6,500 \\
6,400 \\
6,250 \\
\end{array}$ & $\begin{array}{l}6,200 \\
6,400 \\
6,100 \\
6,100\end{array}$ & $\begin{array}{l}6,100 \\
6,300 \\
6,200 \\
6,200 \\
\end{array}$ & $\begin{array}{l}6,400 \\
6,800 \\
6,400 \\
6,200 \\
\end{array}$ & $\begin{array}{l}6,800 \\
7,000 \\
6,800 \\
6,900 \\
\end{array}$ & $\begin{array}{l}7,200 \\
7,400 \\
7,300 \\
7,200\end{array}$ & $\begin{array}{l}6,000 \\
6,200 \\
5,900 \\
5,800\end{array}$ & $\begin{array}{l}7,000 \\
7,300 \\
7,300 \\
7,100 \\
\end{array}$ & $\begin{array}{l}6,900 \\
7,100 \\
7,100 \\
6,900\end{array}$ \\
\hline $\begin{array}{l}\text { Aftrate } \\
\text { (ppb) }\end{array}$ & 33,800 & $\begin{array}{l}\text { Hov } / 94 \\
\text { Mar/95 } \\
\text { May/95 } \\
\text { Aug/95 }\end{array}$ & $\begin{array}{l}13,000 \\
12,000 \\
13,000 \\
13,000\end{array}$ & $\begin{array}{l}11,000 \\
11,000 \\
12,000 \\
12,000\end{array}$ & $\begin{array}{l}12,000 \\
12,000 \\
12,000 \\
12,000\end{array}$ & $\begin{array}{l}13,000 \\
13,000 \\
12,000 \\
13,000 \\
\end{array}$ & $\begin{array}{l}16,000 \\
15,000 \\
15,000 \\
16,000 \\
\end{array}$ & $\begin{array}{l}21,000 \\
21,000 \\
21,000 \\
20,000\end{array}$ & $\begin{array}{l}11,000 \\
11,000 \\
11,000 \\
11,000\end{array}$ & $\begin{array}{l}25,000 \\
24,000 \\
24,000 \\
23,000\end{array}$ & $\begin{array}{l}25,000 \\
23,000 \\
23,000 \\
23,000 \\
\end{array}$ \\
\hline $\begin{array}{l}\text { iftrite } \\
\text { (ppb) }\end{array}$ & 631 & $\begin{array}{l}\text { Hov } / 94 \\
\text { Mar/95 } \\
\text { Hay/95 } \\
\text { Aug/95 }\end{array}$ & $\begin{array}{l}<18 \\
<140 \\
<140 \\
<140\end{array}$ & $\begin{array}{l}<18 \\
<140 \\
<140 \\
<140\end{array}$ & $\begin{array}{l}<18 \\
<140 \\
<140 \\
<140\end{array}$ & $\begin{array}{l}<18 \\
<140 \\
<140 \\
<140\end{array}$ & $\begin{array}{l}<18 \\
<140 \\
<140 \\
<140\end{array}$ & $\begin{array}{l}<18 \\
<140 \\
<140 \\
<140\end{array}$ & $\begin{array}{l}<18 \\
<140 \\
<140 \\
<140\end{array}$ & $\begin{array}{l}<18 \\
<140 \\
<140 \\
<140\end{array}$ & $\begin{array}{l}<18 \\
<140 \\
<140 \\
<140\end{array}$ \\
\hline
\end{tabular}


Table 5.2-3. Sampling Results for Required Constituents (WAC 173-304) at the Hanford Solid Waste Landfill Hovember 1994 through August 1995. (3 sheets)

\begin{tabular}{|c|c|c|c|c|c|c|c|c|c|c|c|}
\hline Constituent & $\mathrm{TI}^{\mathrm{n}}$ & Date & $22-35$ & $23-34 A$ & $23-34 \mathrm{~B}$ & $24-34 A$ & $\begin{array}{l}24- \\
348^{b}\end{array}$ & $24-34 C$ & $24-35$ & $25-34 C$ & $\begin{array}{l}26- \\
35 A^{b}\end{array}$ \\
\hline $\begin{array}{l}\text { Amioni um } \\
(\mathrm{ppb})\end{array}$ & 122 & $\begin{array}{l}\text { Nov/94 } \\
\text { Mar } / 95 \\
\text { Nay/95 } \\
\text { Aug/95 }\end{array}$ & $\begin{array}{c}<37 \\
<27 \\
30 \\
<27-30\end{array}$ & $\begin{array}{l}60 \\
70 \\
<27 \\
30\end{array}$ & $\begin{array}{l}<37 \\
60 \\
<27 \\
30\end{array}$ & $\begin{array}{l}37 \\
<27 \\
<27 \\
30\end{array}$ & $\begin{array}{l}<37 \\
60 \\
<27 \\
<27\end{array}$ & $\begin{array}{l}80 \\
<27 \\
<27 \\
30\end{array}$ & $\begin{array}{l}<37 \\
60 \\
<27 \\
<27\end{array}$ & $\begin{array}{l}<37 \\
60 \\
<27 \\
40\end{array}$ & $\begin{array}{l}<37 \\
<27 \\
<27 \\
40\end{array}$ \\
\hline $\begin{array}{l}\text { Sulfate } \\
(p p b)\end{array}$ & 51,500 & $\begin{array}{l}\text { Hov } / 94 \\
\text { Mar } / 95 \\
\text { May } / 95 \\
\text { Aug } / 95\end{array}$ & $\begin{array}{c}51,000 \\
49,000 \\
55,000^{E} \\
50,000\end{array}$ & $\begin{array}{l}43,000 \\
42,000 \\
44,000 \\
42,000\end{array}$ & $\begin{array}{l}49,000 \\
50,000 \\
51,000 \\
48,000\end{array}$ & $\begin{array}{l}43,000 \\
43,000 \\
44,000 \\
41,000\end{array}$ & $\begin{array}{l}42,000 \\
42,000 \\
43,000 \\
41,000\end{array}$ & $\begin{array}{l}32,000 \\
40,000 \\
42,000 \\
40,000\end{array}$ & $\begin{array}{l}42,000 \\
41,000 \\
43,000 \\
40,000\end{array}$ & $\begin{array}{l}39,000 \\
39,000 \\
44,000 \\
38,000\end{array}$ & $\begin{array}{l}38,000 \\
38,000 \\
38,000 \\
37,000\end{array}$ \\
\hline $\begin{array}{l}\text { Iron, } \\
\text { filtered } \\
\text { (ppb) }\end{array}$ & 78 & $\begin{array}{l}\text { Mov } / 95 \\
\text { Mar } / 95 \\
\text { May } / 95 \\
\text { Aug/95 }\end{array}$ & $\begin{array}{l}34 \\
33 \\
30 \\
15 \\
\end{array}$ & $\begin{array}{l}37 \\
23 \\
47 \\
19 \\
\end{array}$ & $\begin{array}{l}49 \\
28 \\
32 \\
23 \\
\end{array}$ & $\begin{array}{l}65 \\
29 \\
23 \\
58 \\
\end{array}$ & $\begin{array}{l}45 \\
29 \\
28 \\
24 \\
\end{array}$ & $\begin{array}{l}31 \\
28 \\
26 \\
18 \\
\end{array}$ & $\begin{array}{r}19 \\
25 \\
29 \\
540^{R} \\
\end{array}$ & $\begin{array}{l}23 \\
35 \\
17 \\
15 \\
\end{array}$ & $\begin{array}{c}<5.3 \\
12 \\
<8.9 \\
15 \\
\end{array}$ \\
\hline $\begin{array}{l}\text { Zinc, } \\
\text { filtered } \\
\text { (ppb) }\end{array}$ & 34 & $\begin{array}{l}\text { Hov } / 94 \\
\text { Har } / 95 \\
\text { May } / 95 \\
\text { Aug/95 }\end{array}$ & $\begin{array}{r}11 \\
<3.7 \\
8.6 \\
<3.7 \\
\end{array}$ & $\begin{array}{r}<6.3 \\
13 \\
7.6 \\
<3.7 \\
\end{array}$ & $\begin{array}{r}7.2 \\
<3.7 \\
<3.7 \\
<3.7 \\
\end{array}$ & $\begin{array}{r}12 \\
<3.7 \\
<3.7 \\
<3.7 \\
\end{array}$ & $\begin{array}{c}9.3 \\
<3.7 \\
28 \\
<3.7 \\
\end{array}$ & $\begin{array}{r}14 \\
12 \\
22 \\
<6.4 \\
\end{array}$ & $\begin{array}{r}12 \\
<3.7 \\
<3.7 \\
<3.7 \\
\end{array}$ & $\begin{array}{l}6.7 \\
<3.7 \\
<3.7 \\
<3.7 \\
\end{array}$ & $\begin{array}{r}8.3 \\
<3.7 \\
53 \\
<3.7 \\
\end{array}$ \\
\hline $\begin{array}{l}\text { Hanganese, } \\
\text { filtered } \\
\text { (ppb) }\end{array}$ & 11 & $\begin{array}{l}\text { Hov } / 94 \\
\text { Mar } / 95 \\
\text { may } / 95 \\
\text { Allog/95 }\end{array}$ & $\begin{array}{l}3.0 \\
1.4 \\
0.67\end{array}$ & $\begin{array}{c}4.7 \\
1.0 \\
<0.55\end{array}$ & $\begin{array}{l}3.2 \\
0.89 \\
0.75 \\
0.81\end{array}$ & $\begin{array}{c}3.3 \\
0.83 \\
<0.55 \\
1.3\end{array}$ & $\begin{array}{c}1.5 \\
<0.55 \\
<0.55 \\
1.4\end{array}$ & $\begin{array}{c}3.7 \\
1.0 \\
0.62 \\
<0.55 \\
\end{array}$ & $\begin{array}{c}1.5 \\
<0.55 \\
<0.55 \\
6.3\end{array}$ & $\begin{array}{c}2.2 \\
<0.55 \\
<0.55 \\
<0.55\end{array}$ & $\begin{array}{l}<0.72 \\
<0.55 \\
<0.55\end{array}$ \\
\hline $\begin{array}{l}\text { Chemica1 } \\
\text { oxygen } \\
\text { demand } \\
\text { (ppb) }\end{array}$ & 3 & $\begin{array}{l}\text { Nov } / 94 \\
\text { Har } / 95 \\
\text { Hay } / 95 \\
\text { Aug } / 95\end{array}$ & $\begin{array}{l}<2.6 \\
<2.9 \\
<2.9 \\
<2.9\end{array}$ & $\begin{array}{l}<2.6 \\
2.8 \\
<2.9 \\
<2.9\end{array}$ & $\begin{array}{l}<2.6 \\
<2.9 \\
<2.9 \\
<2.9\end{array}$ & $\begin{array}{l}<2.6 \\
<2.9 \\
<2.9 \\
<2.9\end{array}$ & $\begin{array}{l}<2.6 \\
<2.9 \\
<2.9 \\
<2.9\end{array}$ & $\begin{array}{l}<2.6 \\
<2.9 \\
<2.9 \\
<2.9\end{array}$ & $\begin{array}{l}<2.6 \\
<2.9 \\
<2.9 \\
<2.9\end{array}$ & $\begin{array}{l}<2.6 \\
<2.9 \\
<2.9 \\
<2.9\end{array}$ & $\begin{array}{l}<2.6 \\
<2.9 \\
<2.9 \\
<2.9\end{array}$ \\
\hline
\end{tabular}


'Table 5.2-3. Sampling Results for Required Constituents (WAC 173-304) at the Hanford Solid Waste Landfjl] November 1994 through August 1995. (3 sheets)

\begin{tabular}{|c|c|c|c|c|c|c|c|c|c|c|c|}
\hline Constituent. & $\mathrm{TI}^{\mathrm{s}}$ & Date & $22-35$ & $23-34 A$ & 23-34B & $24-34 A$ & $\begin{array}{l}24- \\
348^{b}\end{array}$ & 24-34C & $24-35$ & $25-34 C$ & $\begin{array}{c}26- \\
35 A^{b}\end{array}$ \\
\hline $\begin{array}{l}\text { Colfform } \\
\text { bacterta } \\
\text { (mpn) }\end{array}$ & 16 & $\begin{array}{l}\text { Nov } / 94 \\
\text { Mar } / 95 \\
\text { May/95 } \\
\text { Aug/94 }\end{array}$ & $\begin{array}{c}<1 \\
<1 \\
<3.7 \\
<1\end{array}$ & $\begin{array}{c}<1 \\
<1 \\
<3.7 \\
<1\end{array}$ & $\begin{array}{c}<1 \\
<1 \\
<3.7 \\
<1\end{array}$ & $\begin{array}{c}<1 \\
<1 \\
<3.7 \\
<1\end{array}$ & $\begin{array}{l}<1 \\
<1 \\
<3.7 \\
<1\end{array}$ & $\begin{array}{c}<1 \\
<1 \\
<3.7 \\
<1\end{array}$ & $\begin{array}{c}<1 \\
<1 \\
<3.7 \\
<1\end{array}$ & $\begin{array}{l}<1 \\
<1 \\
<1 \\
<1\end{array}$ & $\begin{array}{l}<1 \\
<1 \\
<1 \\
<1\end{array}$ \\
\hline
\end{tabular}

Tumbers are obtained from Table 5.2-6 (Background threshold value colunn).

Uipgradient wells.

Exceeding background threshold values (downgradient well only).

$R_{A}$ request for anaiytical data evaluation has been filed.

$<$ - data values are less than the contractualiy required quantitation 1 imit (CRQL). The number given

is the respective CRQL.

$N A=$ not avaflable.

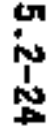

$T I=$ tolerance interval (see Section 5.2.5.3). 
Table 5.2-4. Ranges of Concentrations (ppb) of Chlorinated Hydrocarbons in Groundwater at the Sol fd Waste Landfi]l from Novenber 1994 to August 1995.

\begin{tabular}{|c|c|c|c|c|c|c|c|c|c|}
\hline & $2 k-35$ & $23-34 \mathbf{A}$ & $23-348$ & $24-344$ & $24-348$ & $24-34 C$ & $25-34 c$ & 24-35 & $26-35 A$ \\
\hline $1,1,1$ if ichtofoethane & $21-26$ & 9.16 & $19-25$ & $4.9-10$ & $4.9-7.1$ & $4.7-6.6$ & $1.8-2.6$ & $1.9 \cdot 6.4$ & $0.50-1.3$ \\
\hline Triahlorouthenn & $1.7-2.4$ & $1.1-2.7$ & $1.5-2.6$ & $0.7 \cdot 1.7$ & $1.0+1.5$ & $0.99-2.2$ & $0.53-0.42$ & $+0,00-0.22$ & $0.12-0.17$ \\
\hline Tetrochlaroethene & $1.0+2.6$ & $2.2-3.3$ & $1.9-3.1$ & $1,8-3.1$ & $2.9-4.1$ & $3.1-3.2$ & $0.60 \times 1.3$ & $0.30-1.2$ & $0.39-1.1$ \\
\hline 1,1-pichloreethenm & $3.2-5.4$ & $1.8+3.3$ & $3.3-4.3$ & $0.60 \cdot 1.7$ & $0.59 \cdot 1.2$ & $0,8<-1,6$ & $0.05-0.30$ & $\infty, 05-0.04$ & $\infty 0.05-00,06$ \\
\hline Chloratorn & $<0.03-0.35$ & $\$ 0.03-0.1$ & $0.03-0.24$ & $\infty 0.03-0.05$ & $0.04-0.04$ & $=0,05-0,06$ & $\infty .03-0.11$ & $\infty .03-<0.04$ & $=0.03-<0.04$ \\
\hline certoon tetracilatorido & $00.04-0.08$ & $\infty, 04-\infty, 00$ & $40.04-1.2$ & $<0.04=0.41$ & $<0.04=-0.08$ & $\times 0.04 \times 0.019 \mid$ & $40,04-0,45$ & $+0.04 \cdot 00.09$ & $0.31 \cdot 2.0$ \\
\hline $1,1,2-7$ richlorosthen & $\infty 0.07 \div 0.00$ & $<0.07-<0.08$ & $<0.07-\times 0.00$ & $<0.07-40.00$ & $<0.07-40.08$ & $\infty, 07=00,00$ & $<0.07-<0.08$ & $<0,07 \div<0,08$ & $40.07-40,08$ \\
\hline 1,2-0 Jchloroethano & $\infty 0.03 \cdot \infty .05$ & $<0.05-\infty 0.05$ & $40.03 \times 40.05$ & $<0.03-<0.05$ & $<0.03-80.05$ & $\infty .03-\infty .05$ & $40,03-40,05$ & $<0.03 \div 40.05$ & $40.03 \times 4.05$ \\
\hline cis-t, 2 - bichlorcotimene & $\infty .05-<0.11$ & $<0.05-<0.11$ & $<0,05 \cdot-\infty 0,11$ & $<0.05 \cdot 0.1$ & $<0.05 \cdot 40.11$ & $40.05-0.05$ & $<0.05-0,23$ & $<0,05-<0.11$ & $0.05-40.11$ \\
\hline Irans-Dlethloroethene & $\infty .05=0.07$ & $40.05-40.07$ & $<0.05-40.07$ & $<0.05-40.07$ & $<0.05-\infty 0.07$ & $\$ .05-4.07$ & $<0,05-<0,07$ & $<0.05-<0.07$ & $\$ 0.05-40.07$ \\
\hline Total organic hulooen & $20 \cdot 40$ & $15-27$ & $23-36$ & $9=20$ & $47-16$ & $7 \cdot 19$ & $4-11$ & $<7 \cdot 12$ & $<7 \cdot 10$ \\
\hline
\end{tabular}

thll will numbera profixed by 609 . 
Tab]e 5.2-5. Summary Statistics for the Background Monitoring Constituent Paraneter Data for the Soltd Waste Landft]T.

\begin{tabular}{|c|c|c|c|c|c|c|c|c|c|}
\hline Const Iturent: & $\mathbf{n}$ & Gr & $\mathbf{t T}$ & Niman & Nedtan & $\begin{array}{l}\text { stal. } \\
\text { per. }\end{array}$ & $G(k)$ & Min. & Max. \\
\hline feperaturt" & 20 & $\ddot{2}$ & 0 & 18.7 & 19.8 & 1.00 & 5.6 & 16 & 20.4 \\
\hline 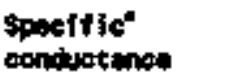 & 38 & $\mathbf{3 8}$ & $\mathbf{0}$ & 385.3 & 397 & 68.9 & 17.9 & 206 & 550 \\
\hline $\begin{array}{l}\text { Fold put } \\
\text { Fiteld pit }\end{array}$ & 36 & 38 & $\stackrel{0}{0}$ & $\begin{array}{l}7.23 \\
7.35\end{array}$ & $\begin{array}{l}7.29 \\
7.31\end{array}$ & 0.62 & $\begin{array}{l}0.5 \\
6.5\end{array}$ & $\begin{array}{l}5.4 \\
6.08\end{array}$ & $\begin{array}{l}8.45 \\
8.45\end{array}$ \\
\hline Total orginife & 38 & 0 & 30 & 421.6 & 468 & 142.9 & 3.9 & $\mathbf{3}$ & 750 \\
\hline Chloride & 36 & 36 & 0 & $7,3 \mathbf{4 1}$ & 7,280 & 704,4 & 30.9 & 6,000 & 5,600 \\
\hline Ditrate & 36 & 36 & 0 & 25,969 & $27, \sqrt{14}$ & 5.139 .2 & 19.8 & 16,000 & 33,800 \\
\hline Witrite & 24 & 0 & 24 & att & at. & uc & Me & ept & Bat \\
\hline Nmoritu & 24 & 4 & 20 & EDL & BDA & WF & WF & gOL & 100 \\
\hline sulfot: & 36 & $\mathbf{3 6}$ & $\mathbf{0}$ & 44,169 & 46,060 & $4,675.0$ & 10.6 & 34,000 & 51,500 \\
\hline Iron", filtered & 29 & 16 & 13 & 35.3 & 28 & 19.3 & SE.0 & ant & ra \\
\hline Zinc. filteerud & 29 & 16 & 15 & Bat & Dist & Me & int & ant & 4 \\
\hline $\begin{array}{l}\text { langenese, } \\
\text { filtered }\end{array}$ & 29 & 1 & 28 & Ex, & BDL & ne & ate & pint & 11 \\
\hline $\begin{array}{l}\text { Coliford" } \\
\text { becterís }\end{array}$ & 29 & $z$ & 27 & Bat & gat & ine & w & Bat & 16 \\
\hline $\begin{array}{l}\text { Whemiest oxyeen } \\
\text { derind }\end{array}$ & 8 & 0 & 8 & $\mathrm{BOL}$ & mant & WC & WC & ADL & Bon \\
\hline
\end{tabular}

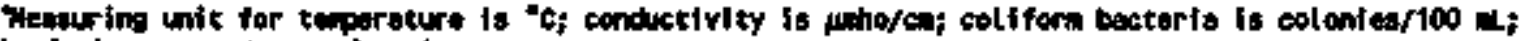
all themfict conporeate are in por.

"Inoonsistent py values of 5.4 and 5.5 were excluded.

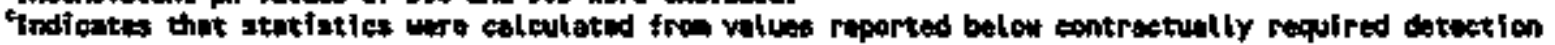
Ifinit (BOOL).

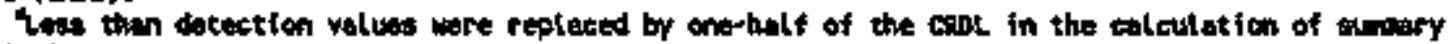
stutistice.

BOL = below CapL.

Cr a toeffielent of variation.

GT $x$ nubor of sagtes thot are greater then the ceol.

LT $=$ nutber of semplest that are lass then the chot.

n = total nubur of inpiles.

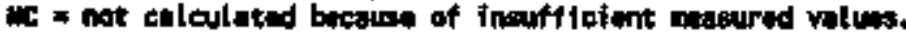


Table 5.2-6. Results of Lilliefors Test for Normaljty and Background Threshold Values for the Sol id Waste Landfill.

\begin{tabular}{|c|c|c|c|c|}
\hline $\begin{array}{l}\text { Constituent } \\
\text { (untt) }\end{array}$ & $\begin{array}{c}\text { Test } \\
\text { statistic } \\
\text { (raw dita) }\end{array}$ & $\begin{array}{c}\text { Test } \\
\text { statistic } \\
\text { (iog value) }\end{array}$ & $\begin{array}{c}\text { Upper } \\
\text { tolerance } \\
\text { ligit }\end{array}$ & $\begin{array}{c}\text { Background } \\
\text { threshold } \\
\text { value }\end{array}$ \\
\hline Temperature $\left({ }^{\circ} \mathrm{C}\right)$ & 0.115 n.s. & $M A$ & $21.0^{6}$ & 21.0 \\
\hline $\begin{array}{l}\text { Specific } \\
\text { conductance } \\
\text { (amho/cn) }\end{array}$ & $0.162 \mathrm{~s}$ & $0.207 \mathrm{~s}$ & $550^{c}$ & 550 \\
\hline $\begin{array}{l}\text { Field pH } \\
\text { Field ph* } \\
\end{array}$ & $\begin{array}{l}0.140 \mathrm{n.s} . \\
0.089 \mathrm{n.s} .\end{array}$ & MA & $\begin{array}{l}{[5.7,8.75]^{b}} \\
{[6.2,8.46]^{b}}\end{array}$ & {$[6.2,8.46]$} \\
\hline $\begin{array}{l}\text { Total organic } \\
\text { carbon (ppb) }\end{array}$ & $0.191 \mathrm{~s}$ & $0.181 \mathrm{~s}$. & $\begin{array}{l}750^{c} \\
976^{d} \\
\end{array}$ & 976 \\
\hline Chloride (ppb) & 0.104 n.s. & NA & $9,045^{6}$ & 9,045 \\
\hline Nitrate (ppb) & $0.168 \mathrm{~s}$. & $0.195 \mathrm{~s}$. & $33,800^{\circ}$ & 33,800 \\
\hline Hitrite (ppo) & $\mathrm{NC}$ & $\mathrm{NC}$ & $631^{d}$ & 631 \\
\hline Ammonjum (ppb) & $\mathrm{NC}$ & $\mathrm{NC}$ & $\begin{array}{l}122^{\mathrm{t}} \\
122^{\mathrm{d}}\end{array}$ & 122 \\
\hline Sulfate (ppb) & $0.179 \mathrm{~s}$. & $0.190 \mathrm{~s}$. & $51,500^{\circ}$ & 51,500 \\
\hline $\begin{array}{l}\text { Iron, filtared } \\
\text { (ppb) }\end{array}$ & NC & NC & $\begin{array}{l}78^{\mathrm{x}} \\
40^{\mathrm{d}}\end{array}$ & $78^{c, d}$ \\
\hline $\begin{array}{l}\text { Zinc, filtered } \\
\text { (ppb) }\end{array}$ & $\mathrm{NC}$ & $\mathrm{NC}$ & $\begin{array}{c}34^{c} \\
16.7^{d}\end{array}$ & 34 \\
\hline $\begin{array}{l}\text { Manganese, } \\
\text { fj1tered (ppb) }\end{array}$ & NC & $\mathrm{NC}$ & $\begin{array}{c}11^{\mathrm{E}} \\
2.5^{\mathrm{d}}\end{array}$ & 11 \\
\hline Coll form (mpn) & $\mathrm{NC}$ & $\mathrm{NC}$ & $\begin{array}{c}16^{c} \\
1\end{array}$ & 16 \\
\hline $\begin{array}{l}\text { Chemical oxygen } \\
\text { denand }\end{array}$ & NC & MC & $3^{*}$ & 3 \\
\hline
\end{tabular}

"Background threshold value for each constjtuent is the larger of the upper tolerance limit or the applicable liajt of quantitation (LOQ).

Based on normal distribution.

Maximun value reported.

Based on LOQ (see Appendix A).

"Based on contractually required detection 7 imit (see Table 5.2-5 and its footnotes). HA $=$ not applicable.

HC = not calculated because of insufficient measured values.

n.s. = not significant at 0.05 level of significance.

$s$. = significant at 0.05 level of significance. 
DOE/RL-96-01, REV. 0

This page intentianal1y left blank.

$5.2-28$ 
DOE/RL-96-01, REV. 0

APPEMDIX 5.2A

GROLMDUATER DATA

\subsection{A-1}


DOE/RL-96-01, REV. O

This page intentionally left blank. 


\subsection{A.0 GROUDDATER OATA}

\subsection{A.1 DATA TABLES}

Four diffarent formats are used to display water Tevel measurements and groundwater sample analytical results (Tables 5.2A-1 through 5.2A-3). This section describes the meaning of each table colum heading, defines the abbreviations used, explains the data qualifiers and flags, and 1ists analysis method codes and relevant regulatory standards.

In the table, results below the contractualiy required quantstation 1 imits (CRQL), but above the method detection limit (MDL), are reported with the measured value followed by an L qualifier. Results below the HOL are reported with the MoL value followed by a $U$ qualifier. MOLs are determined semiannually. In the sumary tables only the most recent NDL values are referenced; however, in the data tables the analytical values are referenced to the $\mathrm{MLL}$ appropriate for the time of analysis.

\subsection{A.1.1 Water Level Feasurement Report}

The Water Level Measurement Report has four columns as follows:

- Nell--Well in which : :

- Daté--Date of measturement.

- Denth_to water--Depth, in feet, from well casting reference point to top of water in wej].

- Water.leve]--Elevation, in feet above mean sea level, of water level computed by subtracting depth to water from casing reference elevation.

Weils are grouped according to the zone that they monitor beginning with the top of the unconfined aguifer and continuing downward to the confined aquifer.

Only measurements made during the reporting period are included in the tables. In addition to measurements made during sampling, which are narked with an asterisk (*), measurements are routinejy performed at other times to permit collection of data for an entire network within a 1- or 2-day tine perjod.

Data that are judged to be suspect are flagged with ' + ' in the table. Before data are designated as suspect, checks are conducted to determine if a transcription error occurred between the fjeld sheet and the electronic database. 


\subsection{A.1.2 Constituent List and Surpary of Results}

The Constituent List and Sumary of Results table (Summary table) is the first of three tabies that present the results of groundwater saiple analyses. The Summary table dfsplays statistics based on the complete data set for the reporting period.

The fields in the Sunmary table are as follows:

- Constituent name--Name of the analyzed constituent being summarized; the Short name is an abbreviation used in the Constituents with at Least One Value Above the CRQL tab7e (Section 5.2A.1.3); the (llethod), when present, is a code (Section 5.2A.1.5) used to distinguish between different analytical methods for the same const 1 tuent.

- Units--Units in wich the MOL and drinking water standards (DWS) are reported in this tabTe.

- Laboratory MDL--MDL imposed on the laboratory. This field is blank for radionuclides where the CRQL is defined as the value of the total error reported by the laboratory for each result.

- Orinking water standard_limit/agency--The ous used for comparison to the reported resuits; see Section 5.2A.1.5 for enency definitions and a complete l1sting of standards used.

- Number of samples--Total is the number of sample results from all wells in the project contained in the complete data set for that constituent; $\$ k_{0} \mathrm{~L}$ is the number of results that exceed the W.OL; $\geq$ DWS is the number of results that exceed the listed DWS.

Sumarized constituents are grouped as contamination indicator parameters (CIP). drinkína_water nakamitanc

$$
\text { DOE/RL-96-01, REV. } 0
$$

\subsection{A.1.5 Codes and Abbreviations}

Abbreviations--The abbreviations used in the data tables are as follows:

\begin{tabular}{|c|c|}
\hline $\begin{array}{l}\text { COL } \\
\text { CRQL } \\
\text { DUS } \\
\text { ft } \\
\text { MDL } \\
\text { ns1 } \\
\text { NTU } \\
\text { pCi } 1 / L \\
\text { ppb }\end{array}$ & $\begin{array}{l}\text { coliform colonies per } 100 \text { millijitters } \\
\text { contractually required quantitation linit } \\
\text { drinking water standard } \\
\text { feet } \\
\text { method detection limit } \\
\text { mean sea level } \\
\text { nephelometric turbidity unit } \\
\text { picocuries per liter } \\
\text { parts per bijlion } \\
\text { parts per mijion } \\
\text { micrombos per centimeter. }\end{array}$ \\
\hline
\end{tabular}

Anencies and suffixes--Agency codes and Ous suffixes identify the regulatory origin of the standard of the DHS. Agency codes are used in the Sumpary table, and DWS suffixes are used in the Above MOL and CIP tables. The codes are defined as follows: 
Quality control flags:

H - Laboratory holding time exceeded

P - Potential problem; see text associated with table

Q - Result associated with suspect quality control data

F - Suspect data currently under review

$R$ - Reviewed data that have been rejected

$Y$ - Reviewed data that continue to be suspect.

$G$ - Raviewed data that are considered to be valid

+ - Suspect water level data currently under review

- MDL is greater than DWS, so exceedance of DWS is undeterained.

Analysis method codes--Analysis method codes are used as an abbreviation for the laboratory method used to perform an analysis. A complete listing of the analysis whod codes used in the Sumary and Above WDL tables is shown in Table 5.2A-4.

DWSs--DWSs are used in all of the chemistry tabTes to provide a standard with which to compare sample results.

\subsection{A.2 REFERENCES}

40 CFR 141, "Nationa] Primary Drinking Water Regulations," Code of Federal Regulations, as amended.

40 CFR 143, "National Secondary Orinking Water Regulations," Code of federal Regulations, as amended.

APHA, 1989, Standard Methods for Evaluation of Water and Wastewater, 17th ed., American Public Health Association, Washington, D.C.

ASTM, 1991, Annual Book of ASTM Standards, Vo7. 11.01, Water and Environmental Technology, Philadelphia, Pennsylvania.

EPA, 1979, Methods for Chewical Anglysis of Water and Waste, EPA-600/4-79-020, U.S. Environmental Protection Agency, Cincinnati, Oh1o.

EPA, 1986, Test Methods for Evaluating Solid Waste, SW-846, Third Edition, U.S. Environmental Protection Agency, Washington, D.C. 


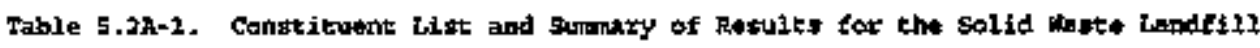
Daten for Reporting Period Wowamer 1. 2994 throbgh soptenther 30, 2995.

lahoot 1 of 3 \}

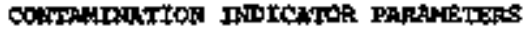

\begin{tabular}{|c|c|c|c|c|c|c|c|c|c|c|c|}
\hline \multirow[b]{2}{*}{ Sharet } & \multicolumn{2}{|r|}{ Conacitunets Fam: } & \multirow[b]{2}{*}{ Units } & \multirow{2}{*}{\multicolumn{2}{|c|}{$\begin{array}{l}\text { bat } \\
\text { 10ا }\end{array}$}} & \multicolumn{2}{|c|}{ Enst } & \multicolumn{4}{|c|}{ lumber of somples } \\
\hline & (Hepthod) & Furd1 & & & & Limitt & Axpoty & & Total & SYOLt & + Dis \\
\hline 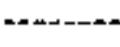 & -- & 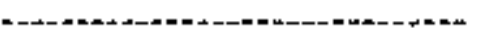 & nentest & & - +- & 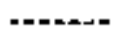 & - - & & 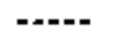 & $---\infty$ & $-\infty-$ \\
\hline 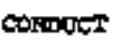 & 94 & conductivity, field & unings & 1 & & & & $l$ & 164 & 164 & \\
\hline कीजिएत्र & 73 & conduot zulter, lab & whos & 1 & & & & 1 & $\mathbf{3 1}$ & 32 & \\
\hline Toc & & Total organic caxton & ppt & I & 140 & & & | & 169 & 111 & \\
\hline $\operatorname{Tox}$ & & Tetent oxganic halogen & pob & 1 & $6+7$ & & & i & 169 & 132 & \\
\hline EH & 93 & DE, tiold & pA & l & & $6+5-3+5$ & BPAS & I & 164 & 164 & 5 \\
\hline EH & 125 & pH, lab & HA & 1 & & $6+5-6.5$ & EPAS & I & 42 & 42 & 0 \\
\hline
\end{tabular}

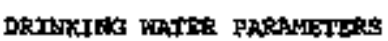

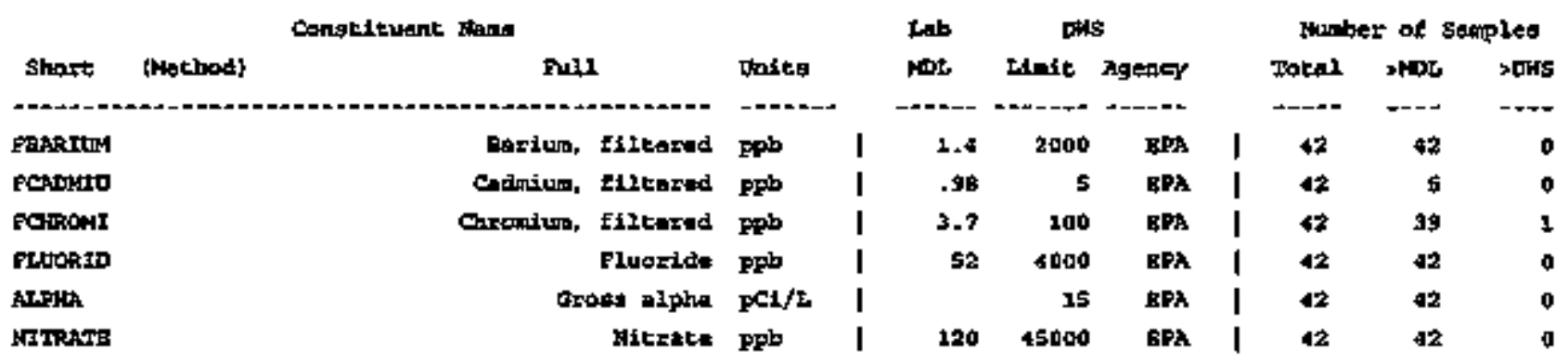

\section{GROTROAAYER OWTITY PARAMETERS}

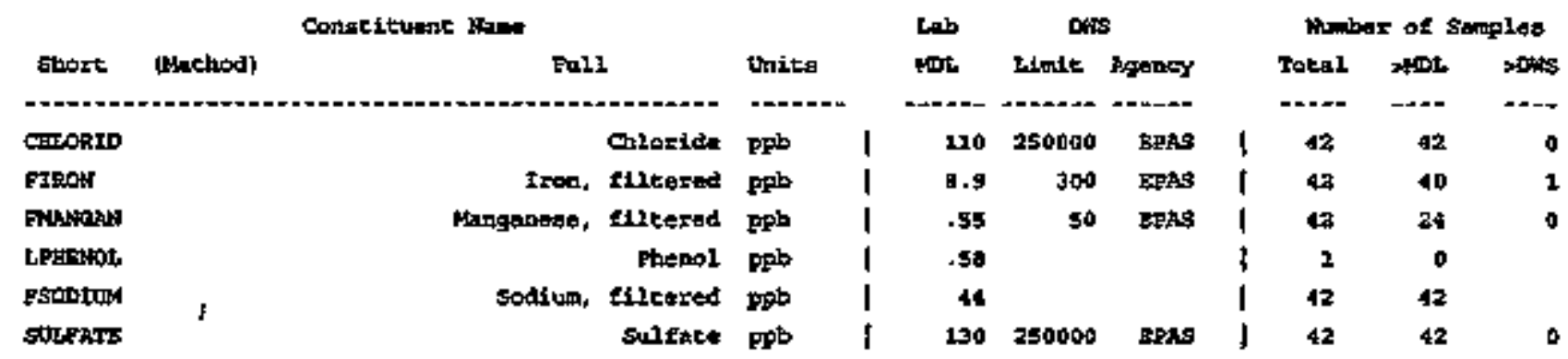

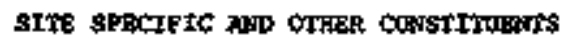

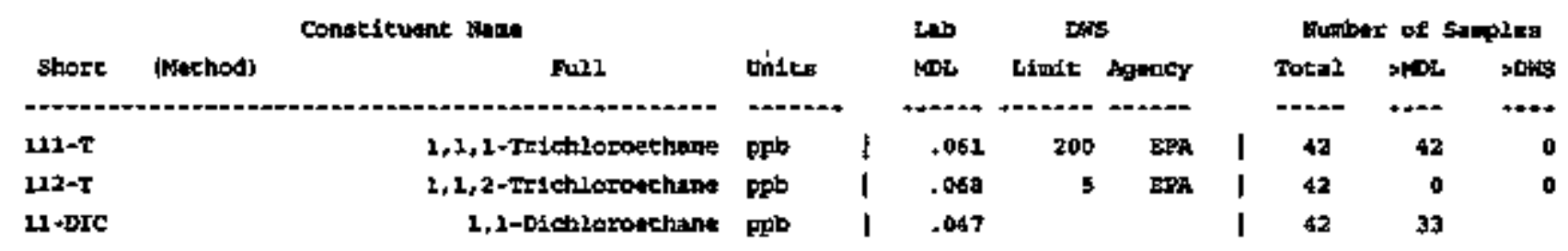




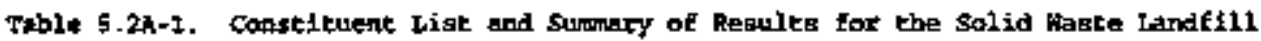

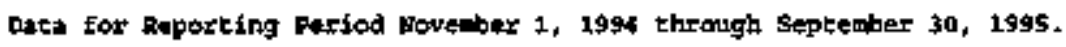

(ahwer 2 of 3 )

\begin{tabular}{|c|c|c|c|c|c|c|c|c|c|}
\hline \multirow[b]{2}{*}{ shert } & \multirow[t]{2}{*}{ Constituent Ramb } & \multirow[b]{2}{*}{ Dnites } & \multirow{2}{*}{$\begin{array}{l}\text { thab } \\
\text { tot }\end{array}$} & \multicolumn{2}{|c|}{ puss } & \multicolumn{4}{|c|}{ Rumber of sanples } \\
\hline & & & & Gimie & Agenoy & & Tocal 1 & s: & ,OHS \\
\hline-+ & $---\infty+\infty$ & 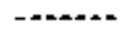 & 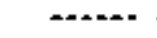 & 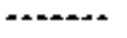 & 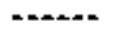 & & -nes & 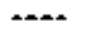 & $m+$ \\
\hline 12-Drc & 1,2-Dichloroethens & ppo & .049 & 5 & EPh & | & 42 & 0 & 0 \\
\hline 14-dren & 1. 4-Dlghlarobanzerze & ppb & .056 & 75 & EPa & l & 42 & 16 & 0 \\
\hline 246 - בRRP & $2,4,6$-Irichloroghenol & pops & .8 & & & 1 & 1 & 0 & \\
\hline 24-dchp & 2,4-Dichlorogbenol & igh & .43 & & & 1 & 1 & 0 & \\
\hline DIMPHEN & 2,4-Dimathyl-phenol & $\mathbf{p g b}$ & .62 & & & 1 & 1 & 0 & \\
\hline DAMPнEя & 2,4-Dinitrepherol & $\mathbf{F p b}$ & 6.8 & & & $\downarrow$ & $\mathbf{1}$ & $\mathbf{0}$ & \\
\hline 26-D대P & 7, 5-Dichloroghenol & gpb & +52 & & & 1 & 1 & 0 & \\
\hline CFPFIEN & 2-Ch1oxophenol & polp & .6 & & & [ & 1 & 0 & \\
\hline 2त्ATrPH & 2-Mitrophenol & ppb & .6 & & & I & $\mathbf{1}$ & $\mathbf{0}$ & \\
\hline exrtotsip & z-sec-Buty 2-4, 6-dinitroghetol ice & pop & .42 & 7 & $\mathbf{E R}$ & 1 & 1 & 0 & 0 \\
\hline Cutchass & A-Muloro-3-tittbylpha:pl & Pob & -52 & & & $i$ & $\mathbf{1}$ & $\mathbf{0}$ & \\
\hline KITPAER & A-Wit:ropherol & ppb & +49 & & & 1 & 1 & 0 & \\
\hline MKNIN & Alkadxalty & ppt & 3500 & & & I & 43 & 42 & \\
\hline FALDMIX & Aluminnm; c\$lkered & ppt & 31 & 200 & EpMS & 1 & 42 & 4 & 0 \\
\hline MADARU & naramivan for & ppb & 37 & & & I & 42 & 18 & \\
\hline FXNTIM & Ant1nocy, Filterad & ppb & $\mathbf{z} \$$ & 6 & EqA & I & 42 & 0 & 42* \\
\hline BEHZZNE & temzene & ppb & .059 & $\mathbf{6}$ & ERA & 1 & 42 & 2 & 0 \\
\hline FEERTL & Anry2liva, Elltared & pps & .63 & 4 & BPA & 1 & 42 & 0 & 0 \\
\hline gROMUIDE & Promide & pqb & 72 & & & I & 42 & 6 & \\
\hline FCALCID & aleive, filtered & $\mathbf{p a b}$ & 41 & & & I & $\mathbf{4 2}$ & $\mathbf{a I}$ & \\
\hline TETPAT: & Corbon tetrachlor-1de & $P p$ & .042 & $s$ & EPA & I & 42 & 11 & 0 \\
\hline $\operatorname{cop}$ & berical oxygem demant & Ppb & 2900 & & & I & 42 & 2 & \\
\hline CHAFOFN & chlocofore & Fpb & . 029 & & & 1 & 42 & 17 & \\
\hline COUIFCRH & Col1tants & $\cot$ & 1 & & & 1 & 10 & 0 & \\
\hline FCOPPER & Copper, 11tered & Bpb & 2.2 & 1000 & Epas & 1 & 42 & 7 & 0 \\
\hline CresoLs & Crecold imethytphenoloy & gph & 1.7 & & & I & 1 & 0 & \\
\hline ETFEEה⿰冫上口 & Ethytbegens & קpo & .034 & 700 & $\mathbf{E P \mathbf { R }}$ & I & 42 & 0 & $\mathbf{0}$ \\
\hline DITA & Grost bete & $\mathrm{ICL} / \mathrm{L}$ & I & & & $d$ & 42 & 42 & \\
\hline I-129 & Fodint-129 & $\operatorname{tct} / \mathrm{L}^{\prime}$ & i & 1 & EPS & I & 4 & 4 & 1 \\
\hline Puntrises & Magonaive, filcered & bקر & 26 & & & I & 42 & 12 & \\
\hline NËrryes & 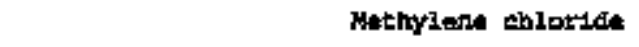 & Fab & .094 & $\mathbf{s}$ & Erph & $\downarrow$ & 42 & 0 & 0 \\
\hline Exrckat & bidkel, filturtad & Ppb & 1 & 100 & EgA & 1 & 47 & $\mathbf{T}$ & 0 \\
\hline BITRITE & Fittrathe & Fpb & 140 & 4000 & EPA & I & 48 & 0 & 0 \\
\hline PENTC & Penterehtorophenol & Fpl & .48 & 1 & $\mathbf{E D}$ & $\downarrow$ & 1 & 0 & 0 \\
\hline mosph & Phorphece & Dpp & 340 & & & 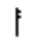 & 42 & 0 & \\
\hline FPATREs & goteneitu, filtered & batp & 350 & & & I & 42 & 42 & \\
\hline PGIIVER & slver, filtared & $P p^{b}$ & E.5 & 100 & EPas & l & 42 & $\mathbf{0}$ & 0 \\
\hline Pstratidy & Strontiual, Filtered & $\mathbf{p p b}$ & .31 & & & 1 & 9 & 9 & \\
\hline$T C=99$ & Teobnetsur-99 & $\nabla+1 / L$ & \rfloor & 900 & EFh & 1 & 2 & $\mathbf{2}$ & 0 \\
\hline This & Tappezacure & Deg̣c & 1 & & & 1 & 252 & 152 & \\
\hline PERCIVIE & Thersachloromthtes & bק & .035 & $\mathbf{5}$ & $\mathbf{z e n}$ & 1 & 42 & 43 & a \\
\hline TATPEAT & Tetrachlonophenols & Ppb & $\$ 2$ & & & I & 1 & 0 & \\
\hline BTIN & TIn, elltered & קpo & 30 & & & 1 & 42 & 0 & \\
\hline
\end{tabular}




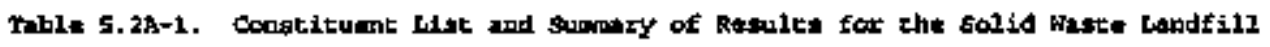
Data car Reporting Ferkad toverbar 1, 1994 tbrough Septenbur 30. 1995.

tohet 3 of 31

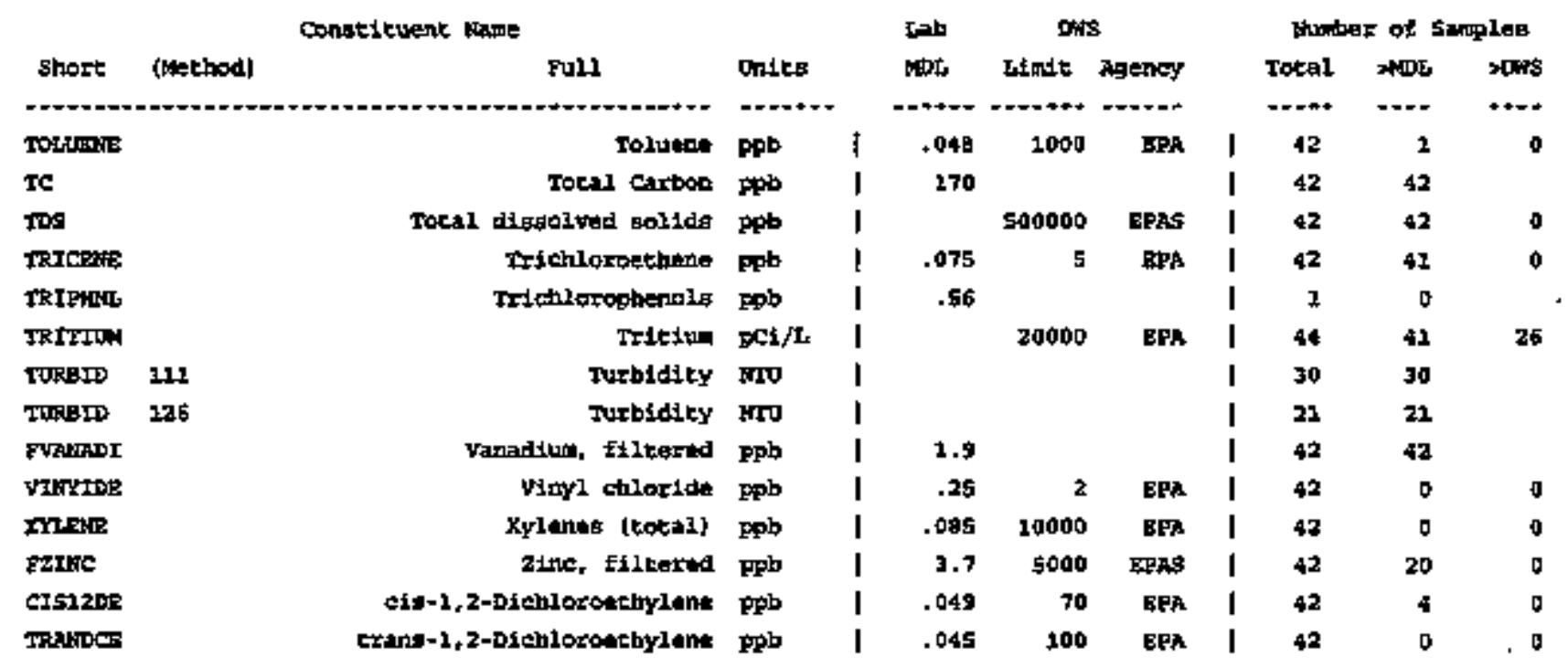




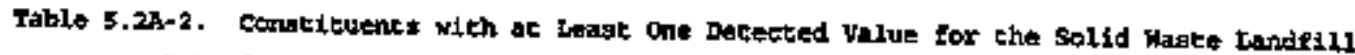
Data for Roparting Perriad flovinbur 1, 1994 through septeabex 30, 1995.

(Shtet 1 of 23)

\begin{tabular}{|c|c|c|c|c|c|c|}
\hline $\begin{array}{l}\text { Welt } \\
\text { Raphe }\end{array}$ & $\begin{array}{l}\text { collection } \\
\text { Date }\end{array}$ & $\begin{array}{l}\text { Sampla } \\
\text { sumber }\end{array}$ & $\begin{array}{c}211-\mathrm{T} \\
2 \mathrm{D} / \mathrm{PQb} \\
.061 / 200\end{array}$ & $\begin{array}{l}11-D I C \\
25 / \mathrm{ppb} \\
.047 /\end{array}$ & $\begin{array}{l}\text { 14-dbeh } \\
25 / \mathrm{ppb} \\
.056 / 7 \$\end{array}$ & $\begin{array}{c}\text { At_tats } \\
\text { 357/ppo } \\
\text { 3500/ }\end{array}$ \\
\hline - & $*+\infty-+-\infty$ & 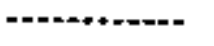 & - & $-\cdots$ & -- & $=-\infty+\infty$ \\
\hline $699-22-35$ & $11 / 02 / 94$ & 900638 & 23.00 & $3+80$ & +060 & $330000+00$ \\
\hline $699-22 \cdot 35$ & $3 / 01 / 95$ & Bobops & 26.00 & 5.40 & $.06 \mathrm{t}$ & 350000.00 \\
\hline $699 \cdot 22-35$ & $5 / 10 / 95$ & Bofasw1 & 24.00 & 5.10 & $.06 \$$ & $340000.00 \mathrm{D}$ \\
\hline $699-22-36$ & $6 / 14 / 95$ & Bogsx4 & 22.90 & 3.20 & .060 & 330000.000 \\
\hline $699-22-35$ & $0 / 14 / 95$ & 800926 & 21.00 & $3+30$ & +060 & $340000.00 \mathrm{D}$ \\
\hline $699-23 \cdot 34 \lambda$ & $11 / 02 / 94$ & B0D693 & 14.00 & 2.90 & $.26 \mathrm{I}$ & 270000.00 \\
\hline $699-23-34 \lambda$ & $3 / 01 / 96$ & $\cot 403$ & 12.00 & 2.90 & $.38 \mathrm{~L}$ & 290000.00 \\
\hline $699 \cdot 23-34 \mathrm{~A}$ & $5 / 19 / 95$ & BORTHE & 24.00 & $3 . \mathbf{3 0}$ & $-16 \mathrm{~J}$ & 280000.000 \\
\hline $699-23-34 \mathrm{~A}$ & $0 / 24 / 95$ & BoGer: & 9.00 & 2.00 & .8 .3 & $290000.00 \mathrm{D}$ \\
\hline $699-23-340$ & $11 / 02 / 94$ & BODG49 & 23.00 & 4.10 & .060 & 320000.00 \\
\hline $699-23-3 A B$ & $3 / 02 / 95$ & Bopooses & $23+00$ & 3.90 & $+16 \mathrm{~L}$ & $33000-0+00$ \\
\hline $699-23-348$ & $5 / 16 / 95$ & $\operatorname{Dog} \times 1$ & 25.00 & 4.30 & $.09 \mathrm{I}$ & $330000.00 \mathrm{D}$ \\
\hline $699-23-348$ & $9 / 14 / 95$ & Bogean & 29.00 & 3.30 & $.07 \mathrm{I}$ & 330000.000 \\
\hline $699-24+33$ & $1 \pm / 00 / 94$ & Boptis3 & 4.80 & $.45 \mathrm{t}$ & $.06 \mathrm{y}$ & 270000.00 \\
\hline $699-24+33$ & $3 / a_{2} / 95$ & $\operatorname{DoDon} 3$ & 4.40 & $.73 \mathrm{t}$ & .050 & 270000,00 \\
\hline $699-24-33$ & $3 / 01 / 93$ & BODORA & 6.70 & $+72 \mathrm{E}$ &, $05 \mathrm{z}$ & 270000,00 \\
\hline $699-24-33$ & $5 / 19 / 95$ & BOpOXi & 4.60 & $.79 \mathrm{ty}$ & $.06 \mathrm{~T}$ & +290000.000 \\
\hline $695-24-33$ & $0 / 14 / 95$ & Docret4 & 3.60 & .28 & $.06 \mathrm{~J}$ & $270000.00 \mathrm{D}$ \\
\hline $699-24-34 h$ & $11 / a_{1} / 94$ & P0D662 & 10.00 & 1.60 & $-35 \mathrm{I}$ & 200000.00 \\
\hline $699-24-34 A$ & $3 / 02 / s s$ & EoDogs & 6.70 & 1.50 & $.24 \mathrm{~L}$ & 260000.00 \\
\hline $699-24-34 h$ & $5 / 29 / 95$ & BofJr & 9.50 & 1.70 & $.19 \mathrm{~L}$ & 260000.000 \\
\hline $699-24-36 A$ & $6 / 14 / 95$ & 800676 & 4.90 & .69 & $.07 \mathrm{t}$ & $230000.00 \mathrm{D}$ \\
\hline $699-24-348$ & $31 / 01 / 94$ & EODEti & 7.10 & 1.10 & $-43 \mathrm{~L}$ & 260000.00 \\
\hline $699-24-348$ & $3 / 01 / 95$ & Bosuss & 5.30 & 2.10 & $.22 \mathrm{~L}$ & 260000.00 \\
\hline $699-24-349$ & $5 / 15 / 95$ & BOFJY' & 5.70 & $1.20 \mathrm{Y}$ & $.23 \mathrm{t}$ & 230000.000 \\
\hline $699-24=348$ & $8 / 15 / 96$ & DOGAB1 & 1.90 & .59 & $-00 \mathrm{D}$ & $290000.00 \mathrm{~b}$ \\
\hline $699-24+34 C$, & $11 / 02 / 94$ & BoDs 72 & 6.80 & 2.60 & $.05 \mathrm{t}$ & 300000.00 \\
\hline $699-24-34 c$ & $3 / 01 / 96$ & BDDOrs & $5+50$ & $.96 \mathrm{~L}$ & $.06 \mathrm{~J}$ & 280000.00 \\
\hline $699-24=34 \mathrm{C}$ & $5 / 28 / 95$ & Borost & 5.20 & 1.10 & .060 & 300000.000 \\
\hline $699 \cdot 24-34 c$ & $a / 14 / 95$ & BOGSE & 4.70 & +84 & +060 & 320000.00 \\
\hline $699-24-35$ & $11 / 01 / 94$ & 000673 & 4.40 & $.06 \mathrm{D}$ & $.06 \mathrm{~T}$ & 190000.00 \\
\hline $699-24-35$ & $3 / 01 / 95$ & godort & 2.90 & $.08 \mathrm{t}$ & .060 & $210000+00$ \\
\hline $699-24-35$ & $5 / 18 / 95$ & E0FJ26 & 2.10 & .050 & .050 & $210000.00 \mathrm{D}$ \\
\hline $699-24+35$ & $8 / 11 / 95$ & Bogsis & 1.90 & - 05 & $.06 廿$ & 200000.00 \\
\hline $699-25=34 c$ & $11 / 02 / 94$ & 000682 & $2+80$ & .060 & $.06 \mathrm{Jt}$ & 220000.00 \\
\hline $699-25-34 C$ & $3 / 02 / 95$ & $8000 \%$ & a.so & $.30 \mathrm{~L}$ & .060 & 220000.90 \\
\hline $699-25-312$ & $5 / 19 / 95$ & DOPKO2 & 2.30 & $.25 \mathrm{~L}$ & $.08 \mathrm{~T}$ & $220000.00 \mathrm{D}$ \\
\hline $699-25-34 C$ & $0 / 14 / 95$ & boangk & 2.60 & .05 廿 & $.06 \mathrm{tJ}$ & 220000.000 \\
\hline $699-26+35 \lambda$ & $11 / 01 / 94$ & E0D6: & 1.10 & .060 & .060 & 260000.00 \\
\hline $699-26-35 A$ & $2 / 20 / 65$ & Bocogra & 1.30 & .050 & $.06 \mathrm{~V}$ & 160000.00 \\
\hline $699-26-35 \mathrm{~A}$ & $5 / 22 / 55$ & Dompos & 1.10 & $.05 \pi$ & $.06 \mathrm{~V}$ & $160000+00$ \\
\hline $695-26-35 \lambda$ & $8 / 11 / 95$ & $\operatorname{soc} 5 y$ & 99 & $.05 \mathrm{tt}$ & $.06 \mathrm{u}$ & 260000.00 \\
\hline
\end{tabular}




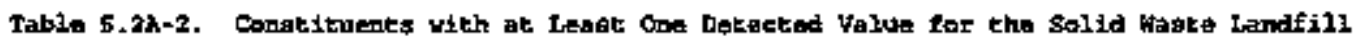
Date for Reporeing period rovember 1, 1994 kbcough soptember 30, 1995.

lohter 2 of 23)

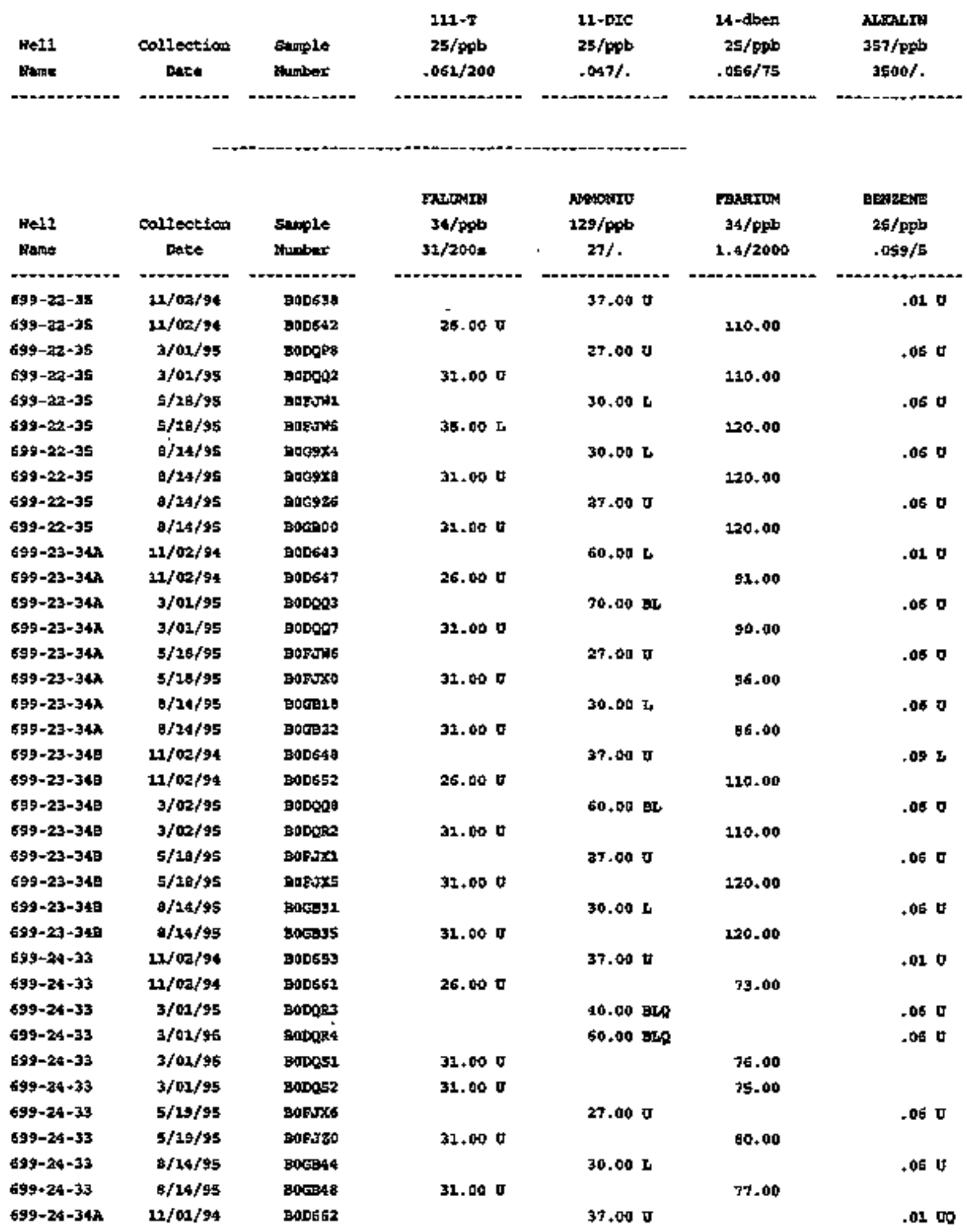


Table 5.2A-2. Congticuentes rich ac Least one Detacted Value tor the solld ragte tandfill Daca For Rtporckng Pariod Novanber 2, 1994 chrough Sepetinbar 30, 1995.

(Bheet 3 or 23)

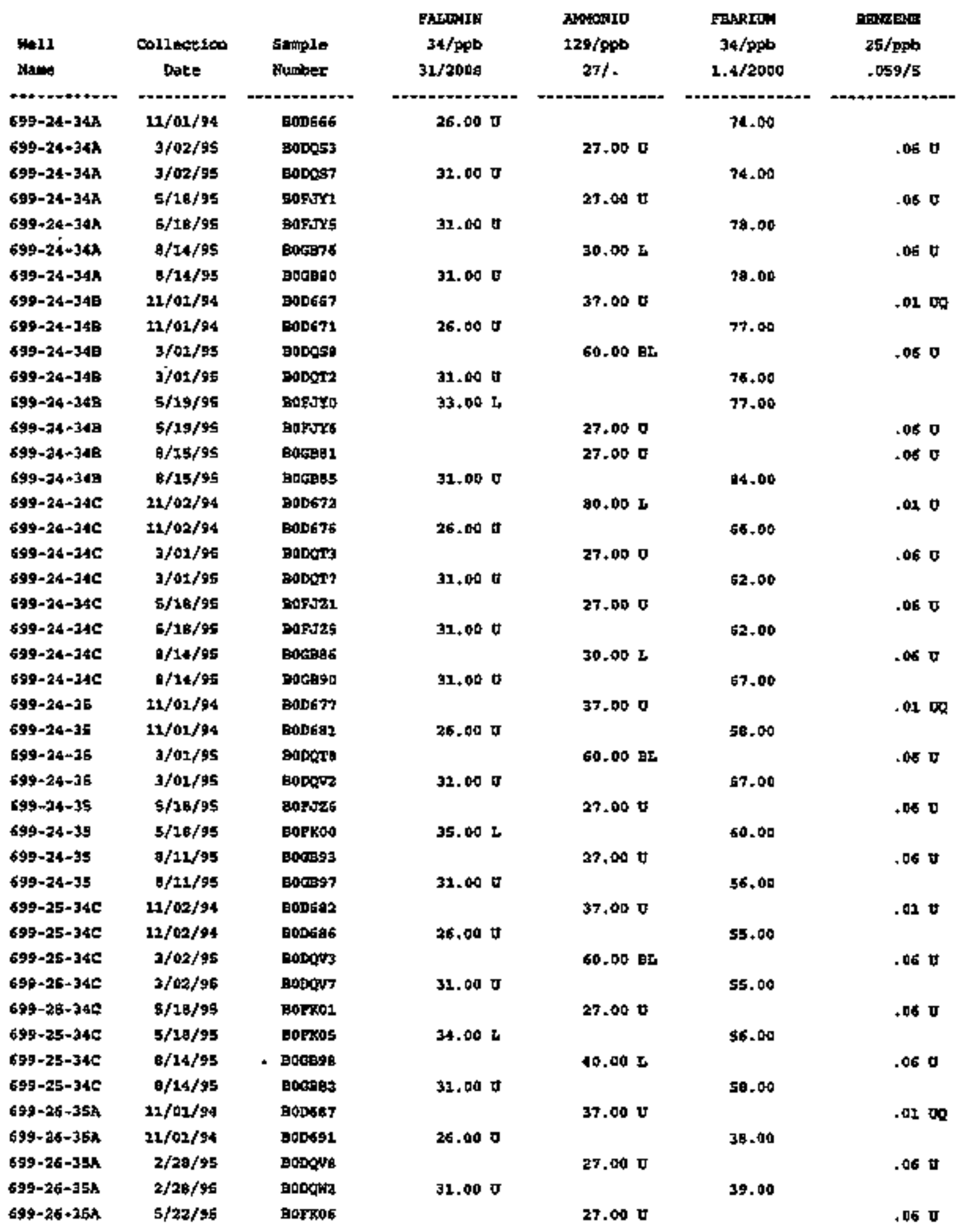




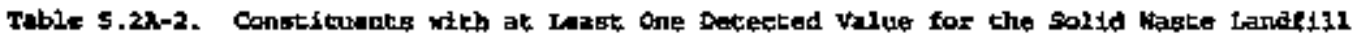
tace tax keporting Period Boveaber 2, 1994 through septenber 30, 1995.

(shete 4 of 23)

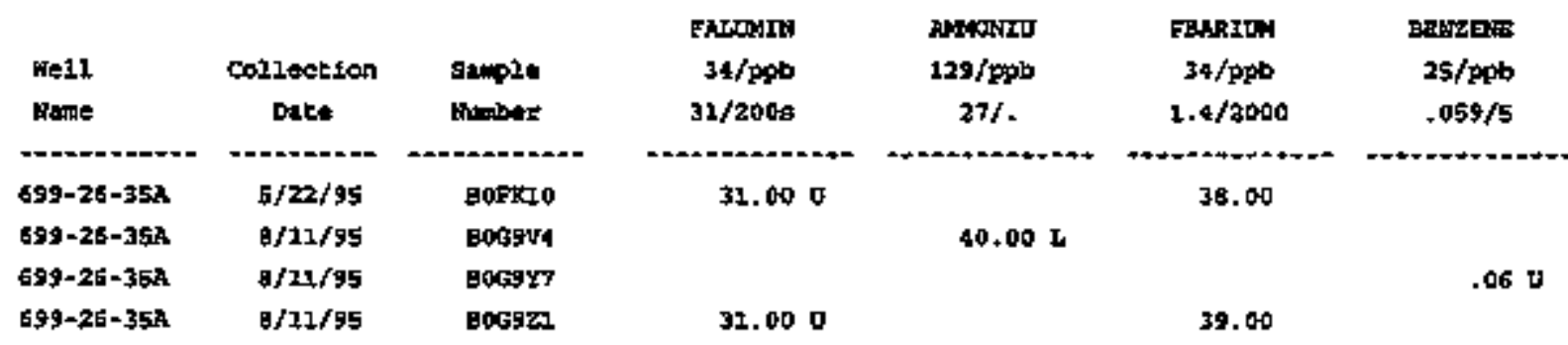

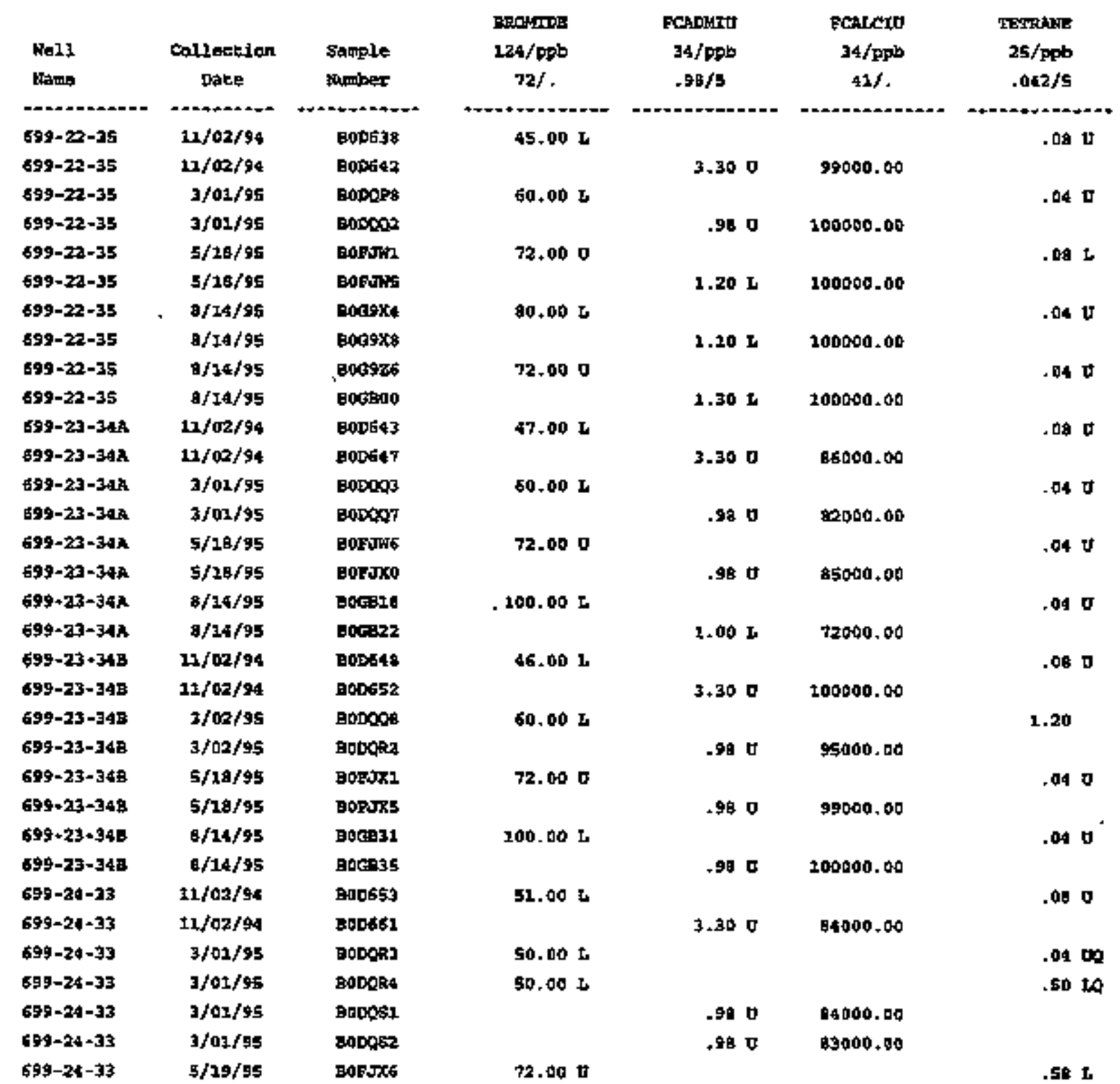




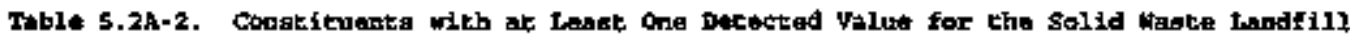
Datn for Reparting Reriod Nowember 1, 1994 chrough september 30, 1995.

(abeec $\$$ of 23)

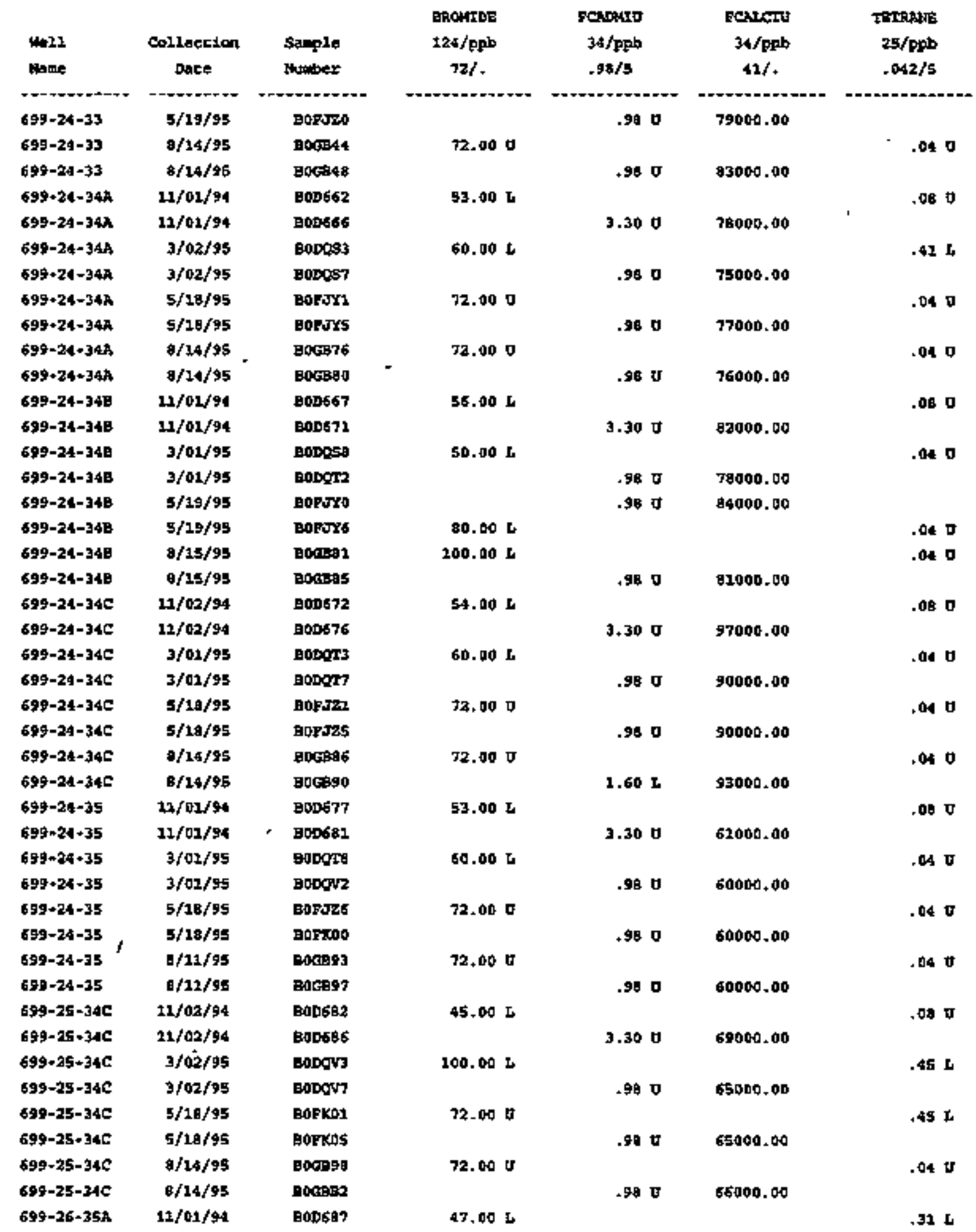




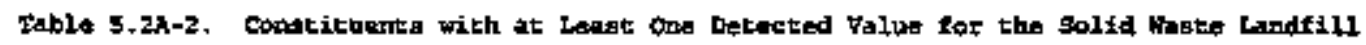
Date lor teporting period Novenber 1, 1994 chrough septenber $90,1999$.

(sho:tet 5 of a3)

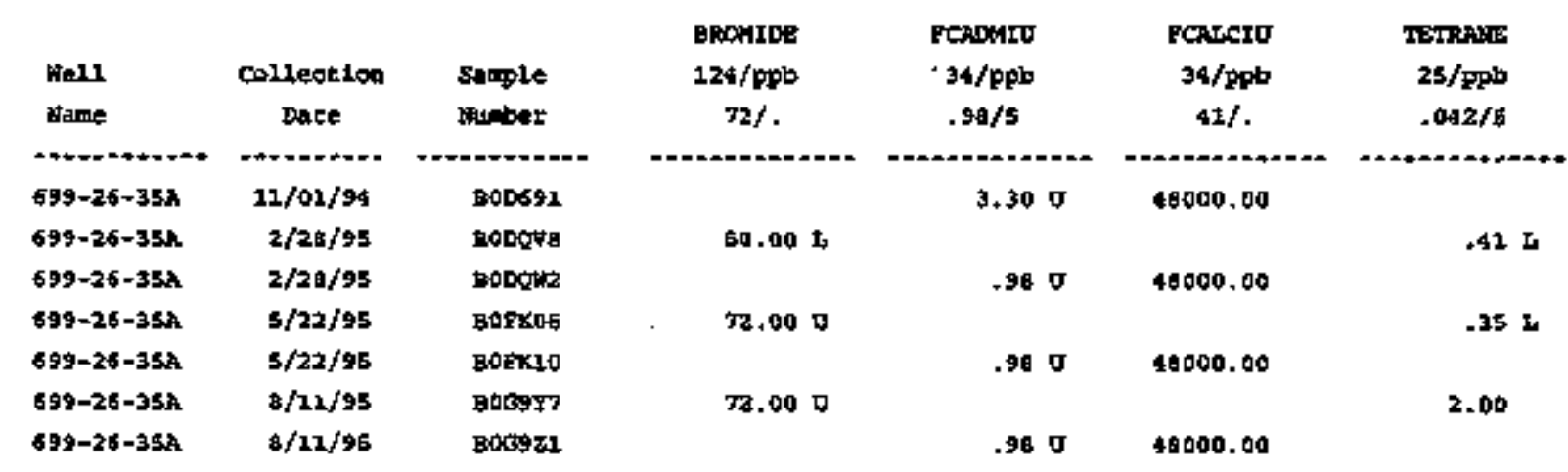

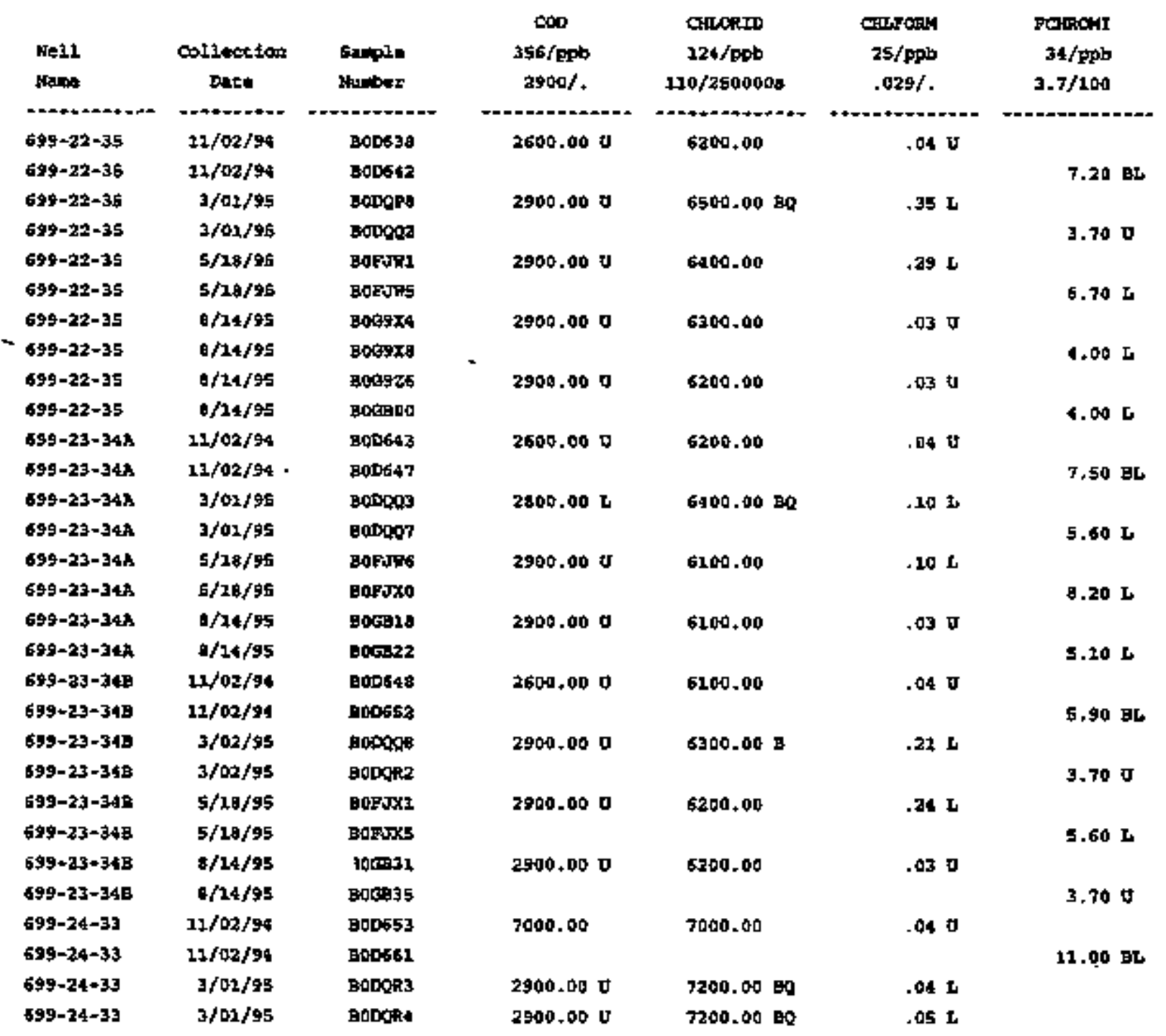


Table 5.2A-2. Constituancs trich at Lact one Decected Falue for the solid waste Landrili

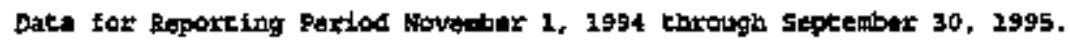

\author{
(aheet 7 of 23)
}

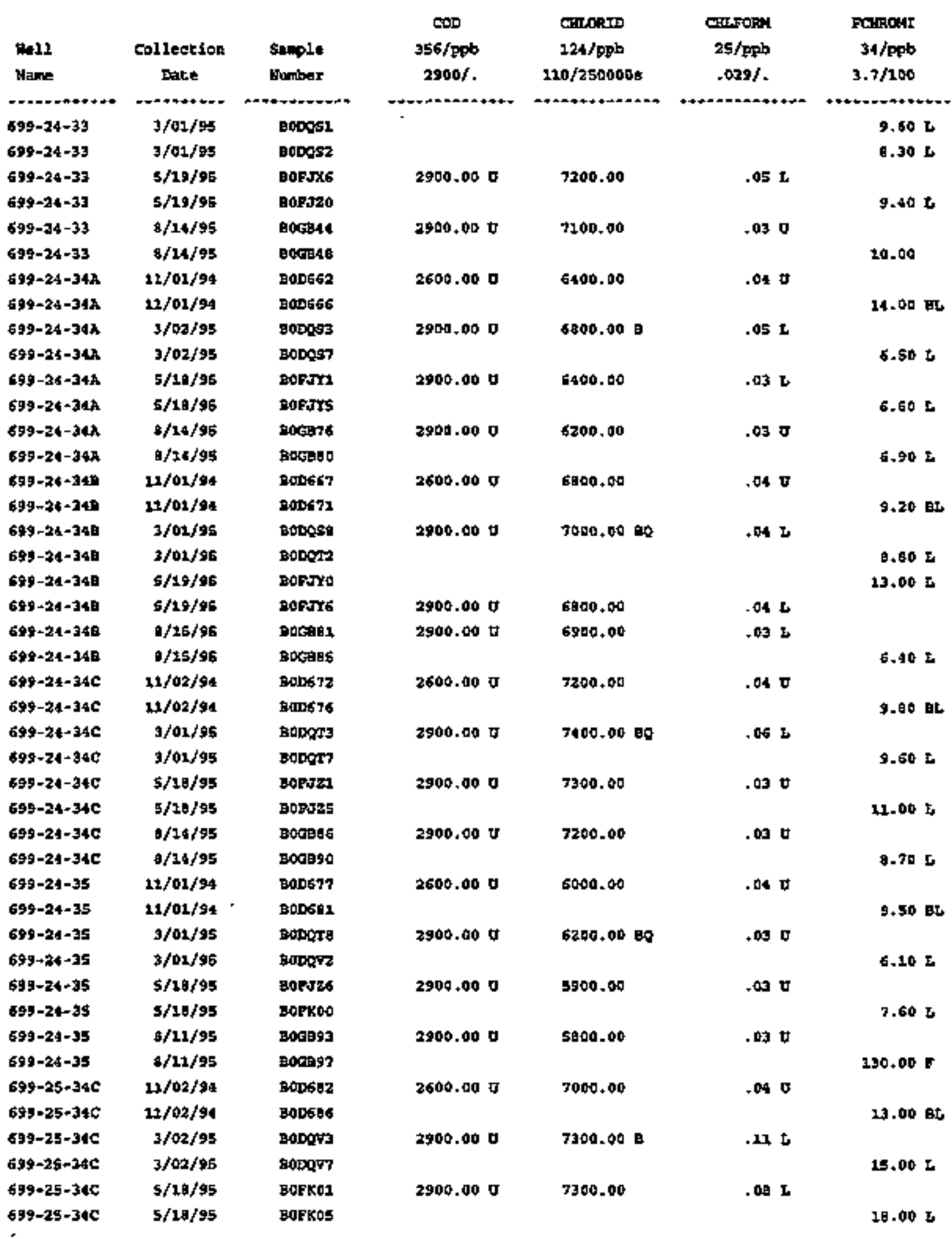




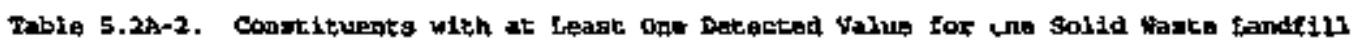
pata for Reporking Period forvember 1, 1994 through septeriber 30, 1995.

(sheec of 23)

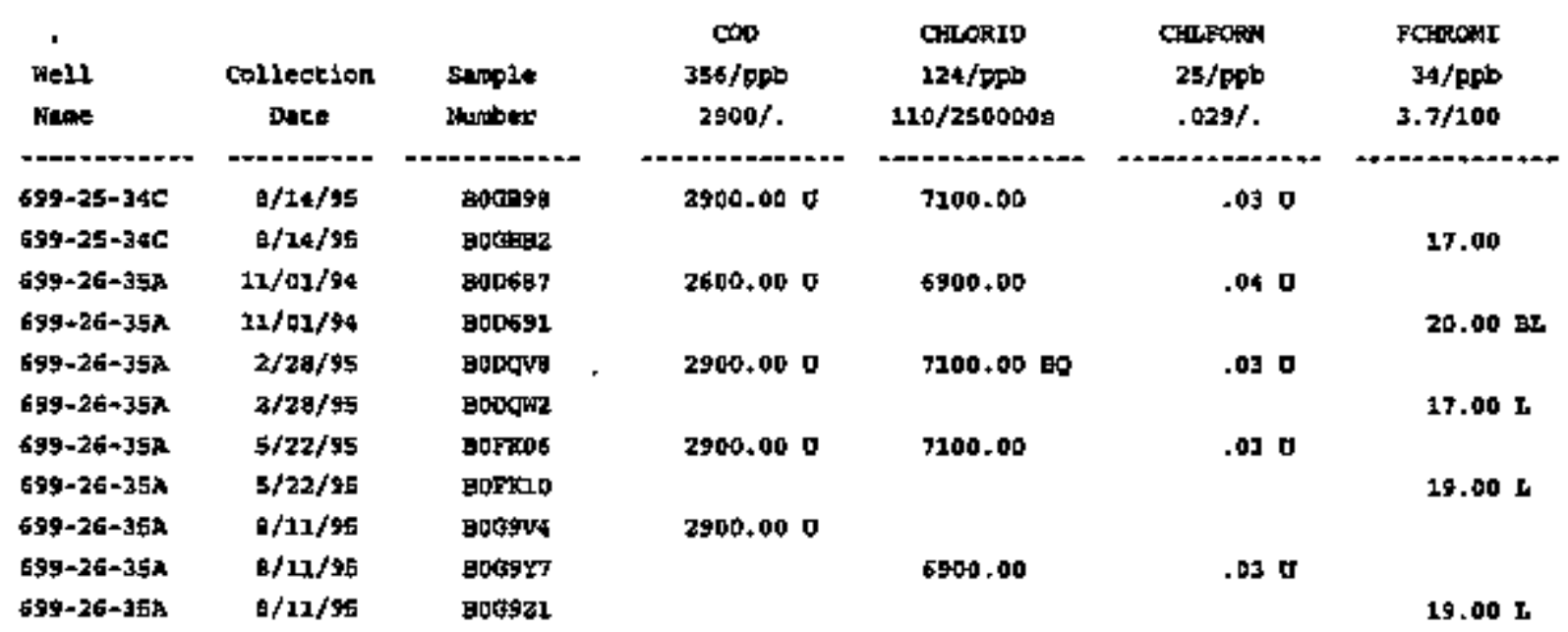

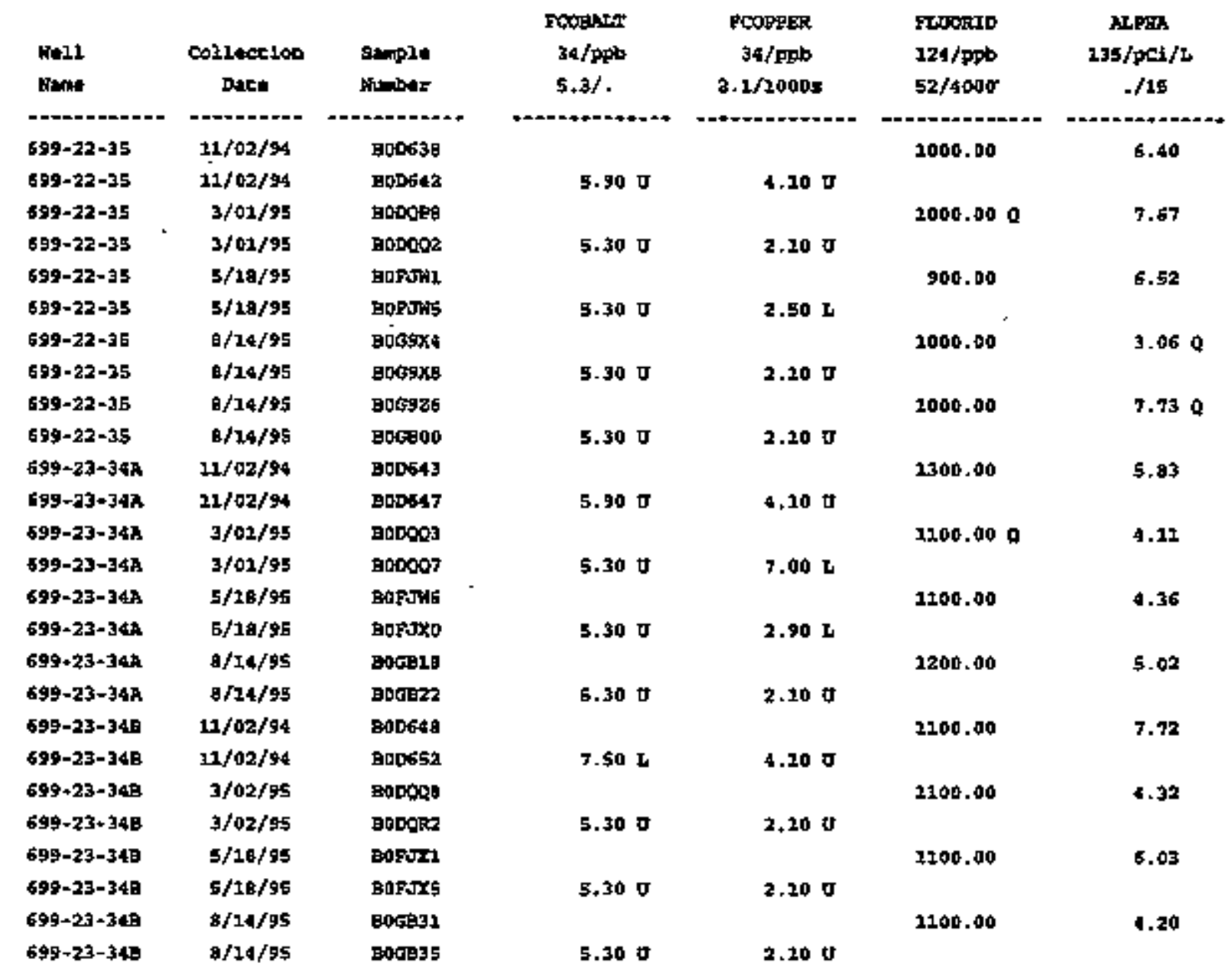




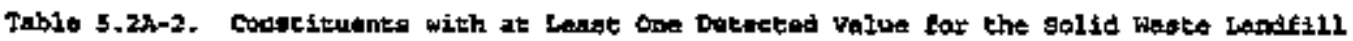
Dota tor Raporting Pariod Noventher 2, 1994 through sopecmbur 30, 1995.

(shitet 9 of 23)

\begin{tabular}{|c|c|c|c|c|c|c|}
\hline Well & $\begin{array}{l}\text { Colleocion } \\
\text { Dace }\end{array}$ & $\begin{array}{l}\text { Eamplos } \\
\text { itunlbex }\end{array}$ & $\begin{array}{l}\text { Focosint } \\
34 / \mathrm{gpt} \\
5.3 /\end{array}$ & $\begin{array}{c}\text { FCOPSER } \\
\text { 34/Fpt } \\
\text { 3+1/3009g }\end{array}$ & $\begin{array}{l}\text { ELAORTD } \\
324 / \mathrm{pPb} \\
52 / 4000\end{array}$ & $\begin{array}{c}\text { ALPAR } \\
235 / \mathrm{pCi} / \mathrm{L} \\
. / 15\end{array}$ \\
\hline 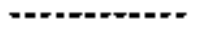 & - - & 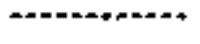 & 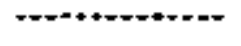 & - & --n-n-n & $=$ \\
\hline $699-24-33$ & $11 / 02 / 94$ & $\operatorname{800653}$ & & & 2000.00 & 5.72 \\
\hline $699-24-33$ & $21 / 02 / 94$ & 5000661 & 5.900 & $1.10 \mathrm{~J}$ & & \\
\hline $699-24-33$ & $3 / 01 / 95$ & $\mathrm{BODQR} 3$ & & & 900.008 & 3.390 \\
\hline $699+24=33$ & $3 / 03 / 95$ & $8000 R A$ & & & $900.00 \mathrm{Q}$ & 2.000 \\
\hline $699=24+33$ & $3 / 01 / 95$ & 200052 & $5.30 \ddagger$ & $2.10 \mathrm{~J}$ & & \\
\hline $699-24-33$ & $3 / 02 / 95$ & 500002 & $5+300$ & $2.10 \mathrm{~J}$ & & \\
\hline $699-24-33$ & $5 / 19 / 95$ & B0FTX6 & & & 100.00 & 7.45 \\
\hline $899-24-33$ & $5 / 29 / 95$ & Bofutzo & 5.300 & $2.10 \mathrm{O}$ & & \\
\hline $599-24-33$ & $6 / 14 / 95$ & восқР4 & & & 900.00 & 4.27 \\
\hline $699-24-33$ & $0 / 14 / 95$ & BOGB & 5.300 & $2.10 \mathrm{t}$ & & \\
\hline $699-24-34 A$ & $12 / 01 / 94$ & 800662 & & & 2300.00 & 5.22 \\
\hline $699+24-344$ & $31 / 01 / 94$ & 805665 & 5.900 & 4.10 ఫ & & \\
\hline $699-34 \cdot 34 x$ & $3 / 02 / 95$ & 200053 & & & 2100.00 & 2.46 \\
\hline $699+74-34 A$ & $3 / 02 / 95$ & Bopos7 & 5.300 & 2.100 & & \\
\hline $699-24-34 \lambda$ & $5 / 18 / 95$ & EOEJY1 & & & 2100.00 & 6.86 \\
\hline $699-24-34 A$ & $5 / 18 / 96$ & BOFJYS & 5.300 & $2.10 \mathrm{t}$ & & \\
\hline $695-24-30 k$ & $0 / 14 / 95$ & Bog-76 & & & 1000.00 & 3.99 \\
\hline $699-24-34 A$ & $0 / 14 / 95$ & BOGB80 & 5.100 & $2.10 \mathrm{t}$ & & \\
\hline $699-24-348$ & $11 / 01 / 94$ & 800667 & & & 1200.00 & 3.23 \\
\hline $699-24-34 D$ & $11 / 01 / 94$ & 800571 & $5.90 \mathrm{0}$ & $-4.10 \mathrm{U}$ & & \\
\hline $699-24-34 B$ & $3 / 01 / 96$ & Bopose & & & 1000.000 & 2,60 \\
\hline $699-24-34 D$ & $3 / 01 / 95$ & BoDort2 & 5.300 & 2.100 & - & \\
\hline $699-29-34 B$ & $5 / 19 / 95$ & BOFAY & $5.30 \mathrm{U}$ & $2,10 \mathrm{0}$ & & \\
\hline $699-24-34 B$ & $5 / 19 / 96$ & BOFAY6 & & & 1200.00 & 2.07 \\
\hline $699-29-349$ & $8 / 15 / 95$ & BOGE:1 & & & 1100.00 & 5.35 \\
\hline $699-24-348$ & $\$ / 15 / 95$ & Doged5 & $5.30 \mathrm{t}$ & 2.100 & & \\
\hline $699-29-346$ & $11 / 02 / 94$ & 300672 & - & & 1100.00 & 4.41 \\
\hline $699 \cdot 21 \cdot 34 c$ & $12 / 02 / 94$ & 800676 & $5.90 \mathrm{t}$ & 4.100 & & \\
\hline $699+24+314 c$ & $3 / 02 / 95$ & Eopors & & & 900.000 & 3.70 \\
\hline $699-2 s+34 c$ & $3 / 01 / 95$ & BODGT? & $5.30 \mathrm{U}$ & 2.100 & & \\
\hline $699-24-34 c$ & $5 / 16 / 95$ & BOFJ21 & & & 1000.00 & 2.62 \\
\hline $699-24-34 C$ & $5 / 18 / 95$ & BOFTRS & $5.30 \mathrm{~J}$ & $2.50 \mathrm{C}$ & & \\
\hline $699-24-34 C$ & $0 / 20 / 95$ & BoGt86 & & & 2000.00 & $2+98$ \\
\hline $699-24-34 C$ & $6 / 14 / 95$ & G0G:50 & $5.30 \mathrm{~J}$ & 2.100 & & \\
\hline $698-24-36$ & $11 / 01 / 94$ & 000677 & & & 1000.00 & 5.05 \\
\hline $699-24-35$ & $11 / 01 / 94$ & BOD682 & 5.900 & 4.100 & & \\
\hline $695 \cdot 24 \cdot 35$ & $3 / 01 / 95$ & Bopors & & & $\cos 000$ & 4.49 \\
\hline $699-24-35$ & $3 / 01 / 95$ & Boogura & $\$ .300$ & $2.10 \mathrm{tJ}$ & & \\
\hline $695-25-35$ & $5 / 18 / 95$ & BDPJZG & & & 800.00 & 3.23 \\
\hline $699-24-35$ & $5 / 10 / 95$ & GOEXON & 5.300 & $2.90 \mathrm{I}$ & & \\
\hline $699-24+35$ & $0 / 12 / 95$ & 800093 & & & 000.00 & 2.94 \\
\hline $699-24-35$ & $9 / 11 / 96$ & Bocag? & $5.30 \mathrm{~V}$ & $20.00 \mathrm{~F}$ & & \\
\hline $699-25-3-4 c$ & $11 / 02 / 91$ & B000602 & & & 1000.00 & $3+28$ \\
\hline $699-25-346$ & $11 / 02 / 94$ & 900806 & 5.900 & 4.200 & & \\
\hline
\end{tabular}




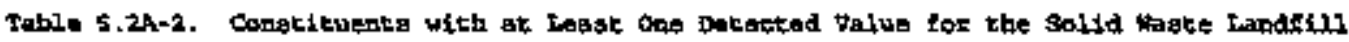

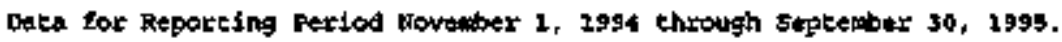

\{abuet 20 of 23)

\begin{tabular}{|c|c|c|c|c|c|c|}
\hline Well & $\begin{array}{c}\text { Collodion } \\
\text { Dace }\end{array}$ & $\begin{array}{l}\text { Sanple } \\
\text { mumber }\end{array}$ & $\begin{array}{l}\text { RCOBALT } \\
\text { 34/Pab } \\
5.3 / .\end{array}$ & $\begin{array}{c}\text { FCOPPER } \\
34 / \mathrm{ppb} \\
2.1 / 1000 \mathrm{~s}\end{array}$ & $\begin{array}{l}\text { FLOORD } \\
224 / \mathrm{ppb} \\
52 / 4000\end{array}$ & $\begin{array}{c}\text { ANFHR } \\
135 / \mathrm{pct} / \mathrm{L} \\
. / 15\end{array}$ \\
\hline (t)- & $=-0-1=-0=0$ & 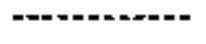 & - & - & - & $m+\infty+\infty$ \\
\hline $699-25-34 C$ & $3 / 02 / 95$ & Bobuts & & & $800+00$ & $3+08$ \\
\hline $699-25-340$ & $3 / 02 / 95$ & Bobxy? & $5+300$ & $2.10 \mathrm{D}$ & & \\
\hline $699-25-345$ & $5 / 19 / 95$ & Bofkol & & & 800.00 & 3.03 \\
\hline $699-25-34 c$ & $5 / 3$ 的 $/ 95$ & BDFADS & 5.300 & 2.200 & & \\
\hline $699-25-340$ & $8 / 14 / 95$ & BaKGP9日 & & & 900.00 & 4.32 \\
\hline $695-25-34 C$ & af $14 / 95$ & BDFEA & 5.300 & $2.10 \mathrm{~J}$ & & \\
\hline $699-26-35 A$ & $11 / 61 / 94$ & $B 00687$ & & & 500.00 & 4.97 \\
\hline $699-26-358$ & $12 / 02 / 94$ & 900691 & $5+900$ & $=1,20$ घ & & \\
\hline $699-25-35 x$ & $2 / 20 / 95$ & Bobeva & & & $600.00 \mathrm{Q}$ & 3.74 \\
\hline $699-26-39 \mathrm{~A}$ & $2 / 29 / 95$ & Batónis2 & $5+300$ & 2.100 & & \\
\hline $699-26-398$ & $5 / 22 / 95$ & Bafkos & & & 700.00 & 2.40 \\
\hline $699-26-35 A$ & $s / 22 / 9 t$ & $\operatorname{Bap} \times 0$ & $5+30 \mathrm{U}$ & $2,10 \mathrm{~b}$ & & \\
\hline $699-26-35 x$ & $0 / 11 / 95$ & Pods? & & & 700.00 & 4.58 \\
\hline $699-26-35 \mathrm{~A}$ & $8 / 31 / 9 t$ & $\operatorname{Bogsz1}$ & 5.300 & $2,40 \mathrm{~L}$ & & \\
\hline
\end{tabular}

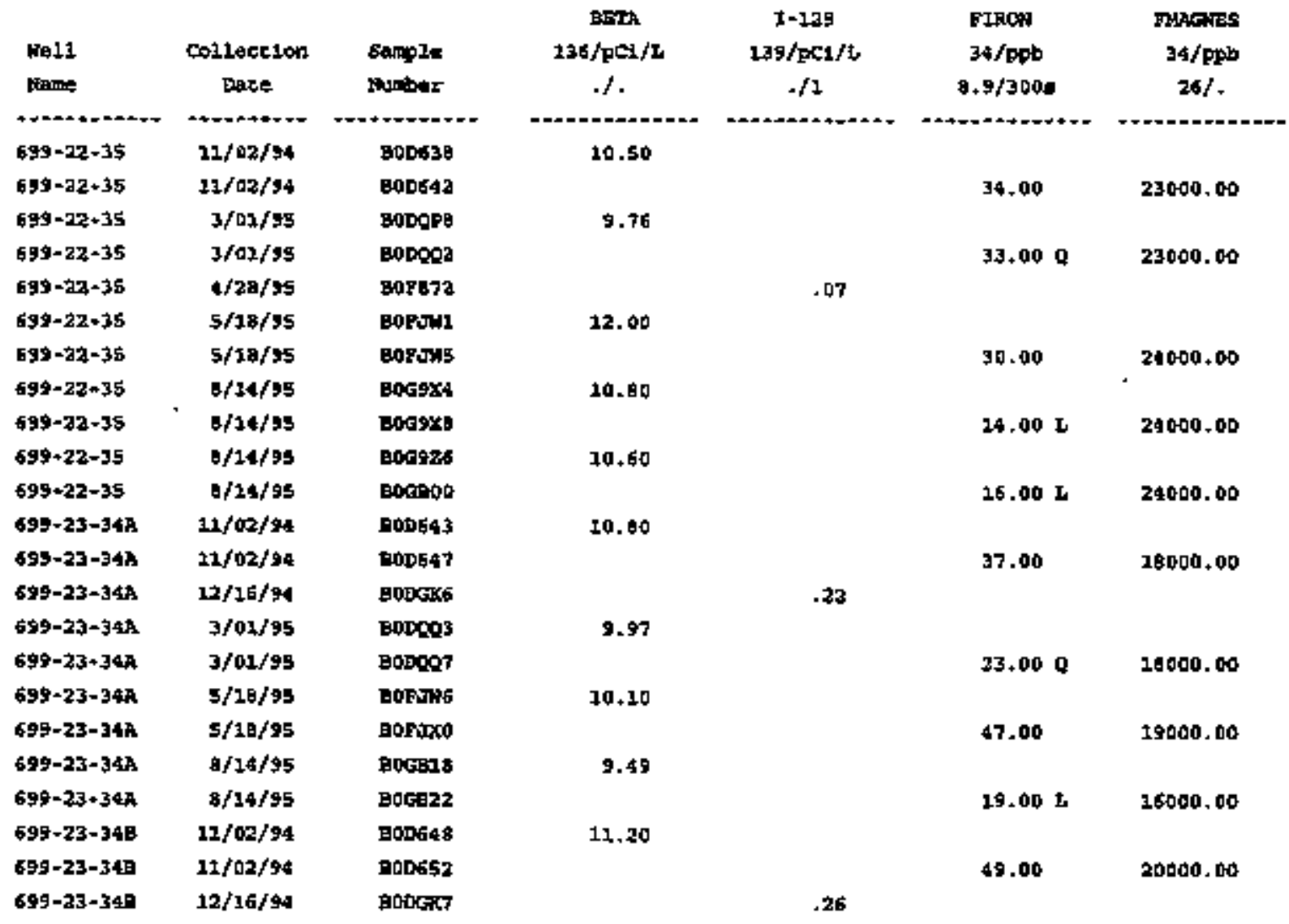




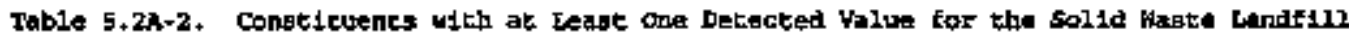

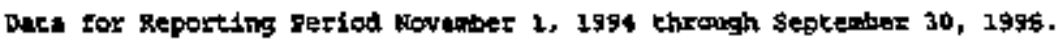

(sheter 11 of 23]

\begin{tabular}{|c|c|c|c|c|c|c|}
\hline $\begin{array}{l}\text { Well } \\
\text { Name }\end{array}$ & $\begin{array}{l}\text { Collection } \\
\text { Date }\end{array}$ & $\begin{array}{l}\text { Sample } \\
\text { sumbex }\end{array}$ & $\begin{array}{c}\text { BETh } \\
236 / \mathrm{pCl} / \mathrm{L} \\
. /\end{array}$ & $\begin{array}{c}\mathrm{I}-129 \\
1.39 / \mathrm{PC1} / \mathrm{L} \\
+/ 1\end{array}$ & $\begin{array}{c}\text { FIROA } \\
34 / \mathrm{ppl} \\
8+9 / 30 \mathrm{tg}\end{array}$ & $\begin{array}{c}\text { FHARgBs } \\
\text { 34/pgh } \\
26 /\end{array}$ \\
\hline 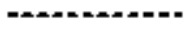 & -...en- & 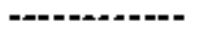 & 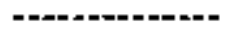 & -- & & \\
\hline $699-23-348$ & $3 / 02 / 95$ & Botopos & 12.60 & & & \\
\hline $659-23-349$ & $3 / 02 / 85$ & Bopgea & & & 28.000 & 20000.00 \\
\hline $699-23-3.48$ & $5 / 20 / 95$ & BofJX1 & 9.75 & & & \\
\hline $699-39-349$ & $5 / 19 / 95$ & BUFJYG & & & 32.00 & $22,000.00$ \\
\hline $699-23-348$ & /14/96 & Ratge31 & 8. 76 & & & \\
\hline $699-23-349$ & $6 / 14 / 95$ & =05035 & & & $73,00 \mathrm{~L}$ & 21000.00 \\
\hline $699-24-33$ & $11 / 02 / 94$ & 800653 & 13.40 & & & \\
\hline $699-24-33$ & $11 / 02 / 94$ & BOD661 & & & $9.60 \mathrm{C}$ & 22000.00 \\
\hline $699-24-33$ & $3 / 01 / 95$ & DoDoR & $15+\$ 0$ & & & \\
\hline $699-24-33$ & $3 / 01 / 95$ & BODORA & 14.10 & & & \\
\hline $699-24-33$ & $3 / 01 / 95$ & Bopos1 & & & 16,0000 & 19000.00 \\
\hline $699-24-33$ & $3 / 01 / 95$ & Botos 2 & & & $21+000$ & 19008.00 \\
\hline $699-24-33$ & $6 / 19 / 95$ & DopJx6 & 11.50 & & & \\
\hline $699-24-33$ & $5 / 10 / 95$ & Borj20 & & & $23+00$ & 18000.00 \\
\hline $699-24-31$ & $1 / 24 / 95$ & BoGe4s & 11.20 & & & \\
\hline $699-21-23$ & $0 / 21 / 95$ & $\operatorname{coc} 048$ & & & $13.00 \mathrm{t}$ & 19000.04 \\
\hline $649-24-24 A$ & $11 / 0 \pm / 94$ & 800562 & 11.40 & & & \\
\hline $699-24-14 A$ & $11 / 01 / 94$ & B00665 & & & 55.60 & 17008.00 \\
\hline $699-24-24 A$ & $3 / 02 / 95$ & $\operatorname{Bog} 093$ & 10.60 & & & \\
\hline $698-24-344$ & $3 / 02 / 95$ & CoDes7 & & & $29+000$ & 17000,00 \\
\hline $698-24-24 A$ & $5 / 28 / 95$ & BOFJY & 20.70 & & & \\
\hline $649-24-24 A$ & $6 / 26 / 95$ & BopJys & & & $23+00$ & 10000.00 \\
\hline $699-24-34 A$ & $0 / 24 / 95$ & Bocer76 & 9.03 & & & \\
\hline $609-24-34 \lambda$ & $1 / 24 / 95$ & BOGB:O0 & & & $59+00$ & 17000,00 \\
\hline $5 \$ 9+24-346$ & $11 / 01 / 94$ & 00bб6? & 12.10 & & & \\
\hline $699-24-34 B$ & $11 / 07 / 94$ & 600571 & & & 45.00 & 18000.00 \\
\hline $699-24-348$ & $3 / 01 / 95$ & $\operatorname{copose}$ & $13+00$ & & & \\
\hline $699-24-34 B$ & $3 / 01 / 95$ & opoot3 & & & 29.000 & 17000.00 \\
\hline $699-24-34 B$ & $5 / 19 / 95$ & BOFJY0 & & & 28.00 & 19000.00 \\
\hline $499-24-34 B$ & $5 / 29 / 9 \mathrm{~S}$ & EOFJYS & $11+10$ & & & \\
\hline $699-24-34 B$ & $8 / 25 / 95$ & B0GE:91 & 22.30 & & & \\
\hline $695-24-34 B$ & $8 / 15 / 95$ & Bocke95 & & & $24.00 \mathrm{BC}$ & 18000.00 \\
\hline $699-24-34 c$ & $11 / 02 / 94$ & 000672 & 21.90 & & & \\
\hline $699-24-34 C$ & $11 / 02 / 94$ & 000676 & & & 31.00 & 20000,00 \\
\hline $699-24-34 c$ & $3 / 0 \pm / 45$ & $\cos Q 13$ & 15.30 & & & \\
\hline $699-21-34 C$ & $3 / 01 / 95$ & Bopgrt? & & & $23+000$ & 19000.00 \\
\hline $699-24-34 c$ & $5 / 18 / 95$ & EDFath & $28+80$ & & & \\
\hline $693-24-34 C$ & $5 / 10 / 95$ & BorJus & & & 26.00 & 19000.00 \\
\hline $699-24-34 c$ & $a / 14 / 95$ & BocBas & 11.70 & & & \\
\hline $699-24-34 c$ & $0 / 14 / 95$ & BDorgo & & & $19+00 \mathrm{E}$ & 19000.00 \\
\hline $699-24 \cdot 35$ & $13 / 01 / 94$ & E0067? & 12.30 & & & \\
\hline $659-24-35$ & $11 / 01 / 94$ & E0Dsd2 & & & $19.00 \mathrm{~L}$ & 29000.00 \\
\hline $699-24-35$ & $3 / 01 / 95$ & Botogrs & 9.70 & & & \\
\hline $699-24-36$ & 3/01/9s & Dotogra & & . & $25+000$ & $16000+00$ \\
\hline
\end{tabular}




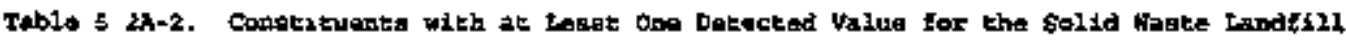
Data for Reporting Pextod boverber i, 1994 through \$epctber 30, 1995.

[alhete 12 of 23)

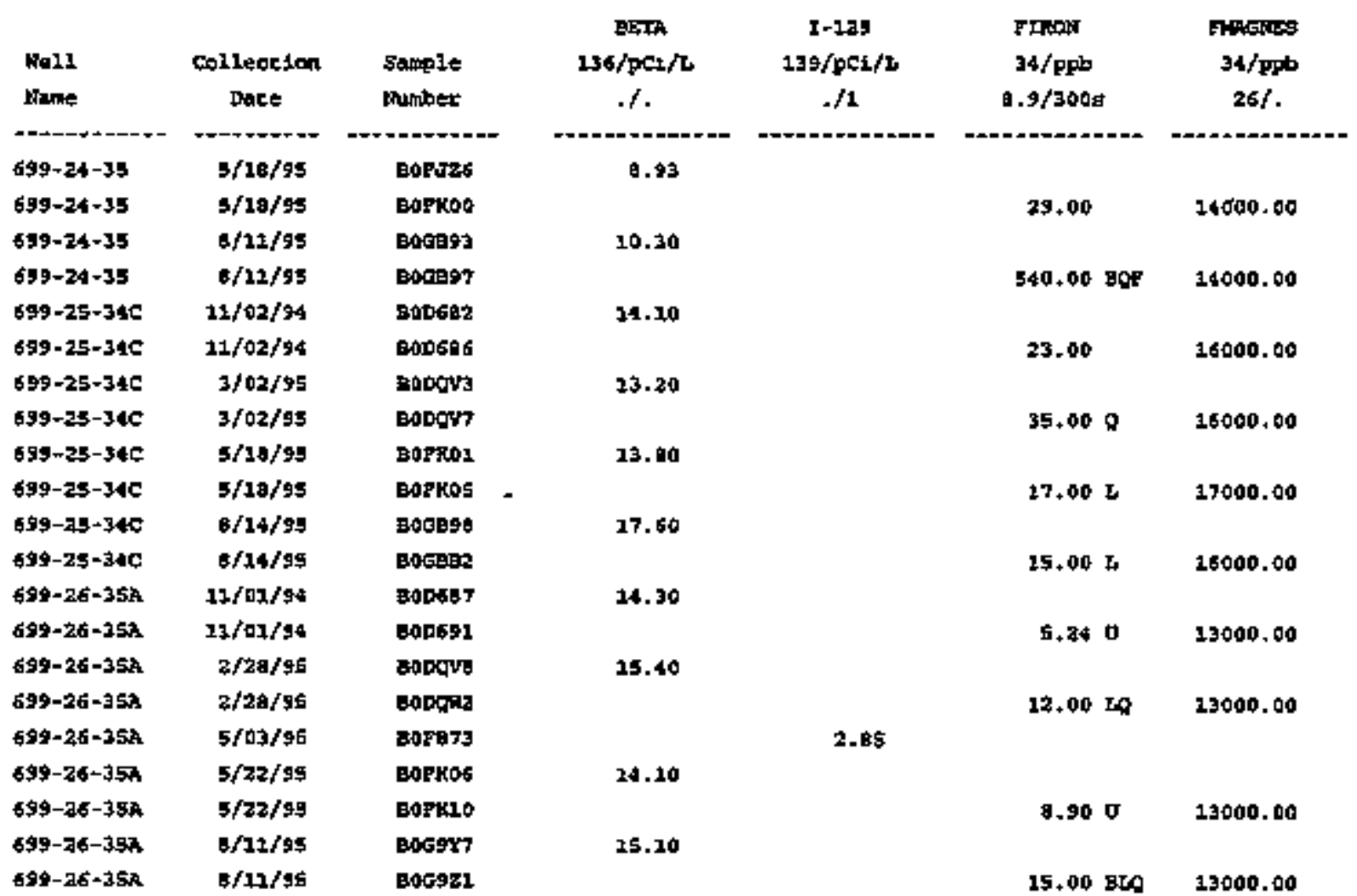

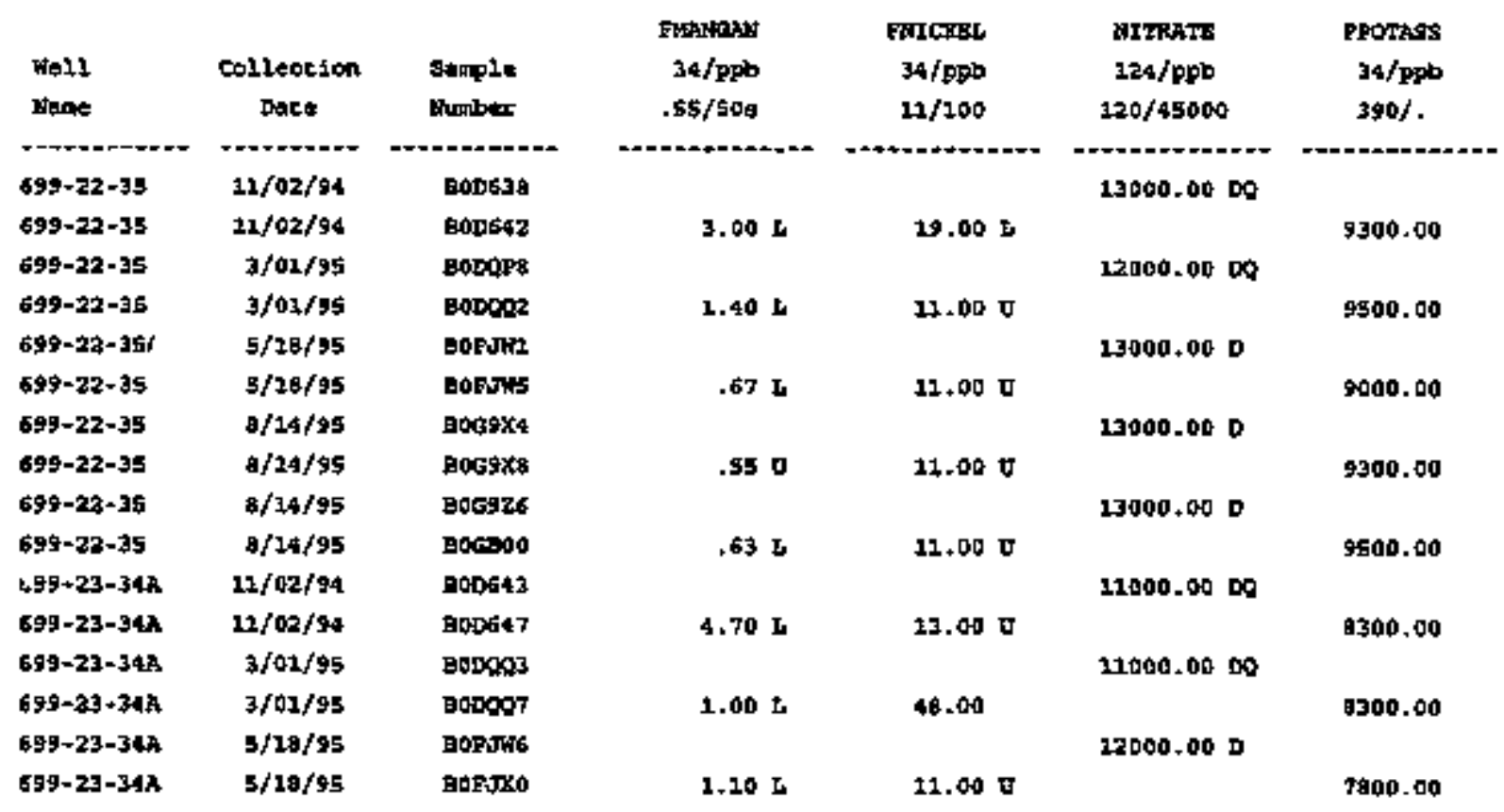




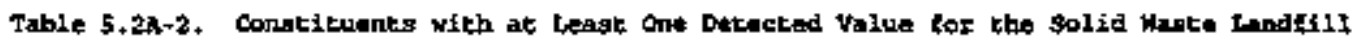
Duce Cor Reporting Period Rovember 1, 1994 through sepcenber 90, 1995.

(sheat 23 of 23 )

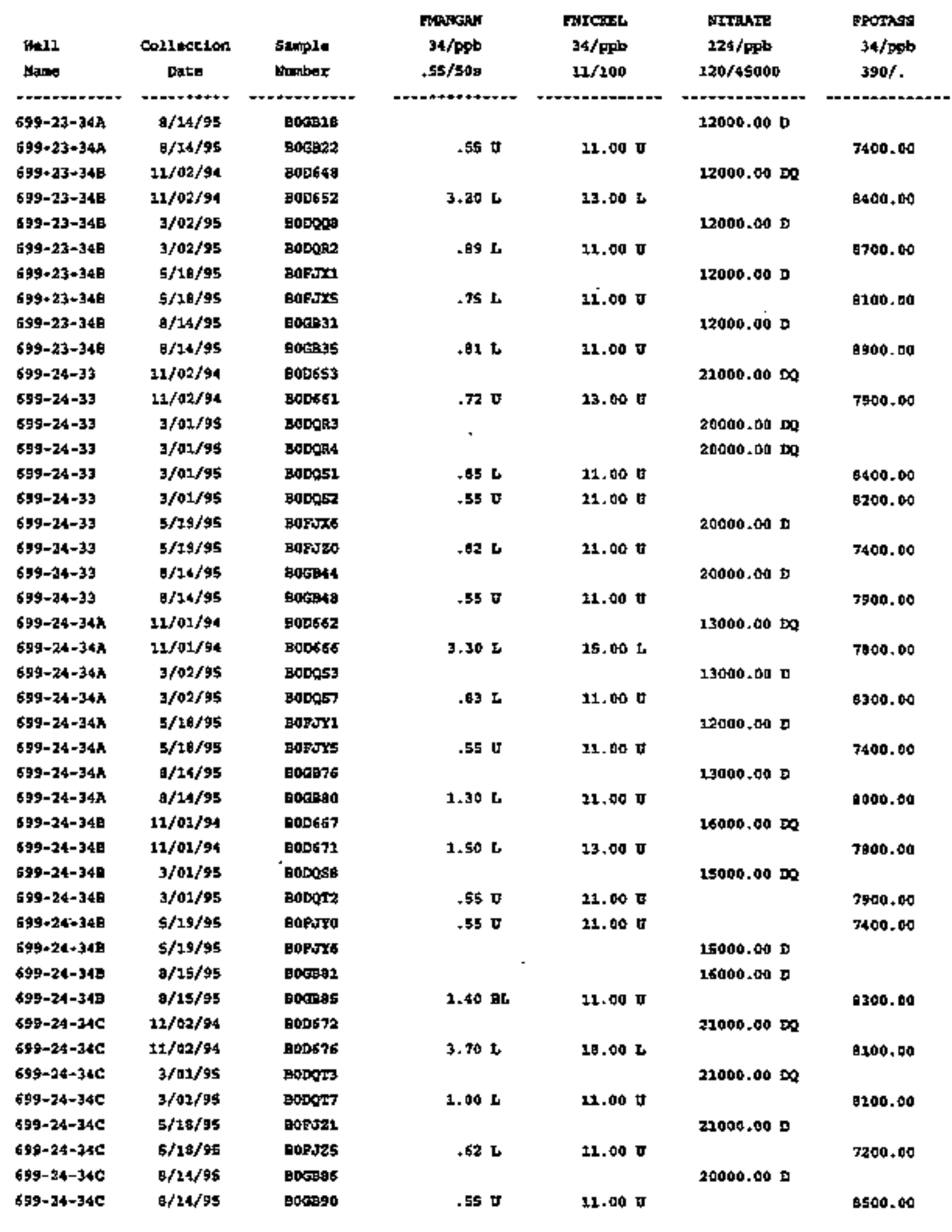




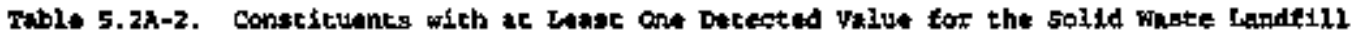
Data for Reporting Pariod roverber 2, 1994 through Sepcunber 30, 199g.

(Bheet 14 of 33)

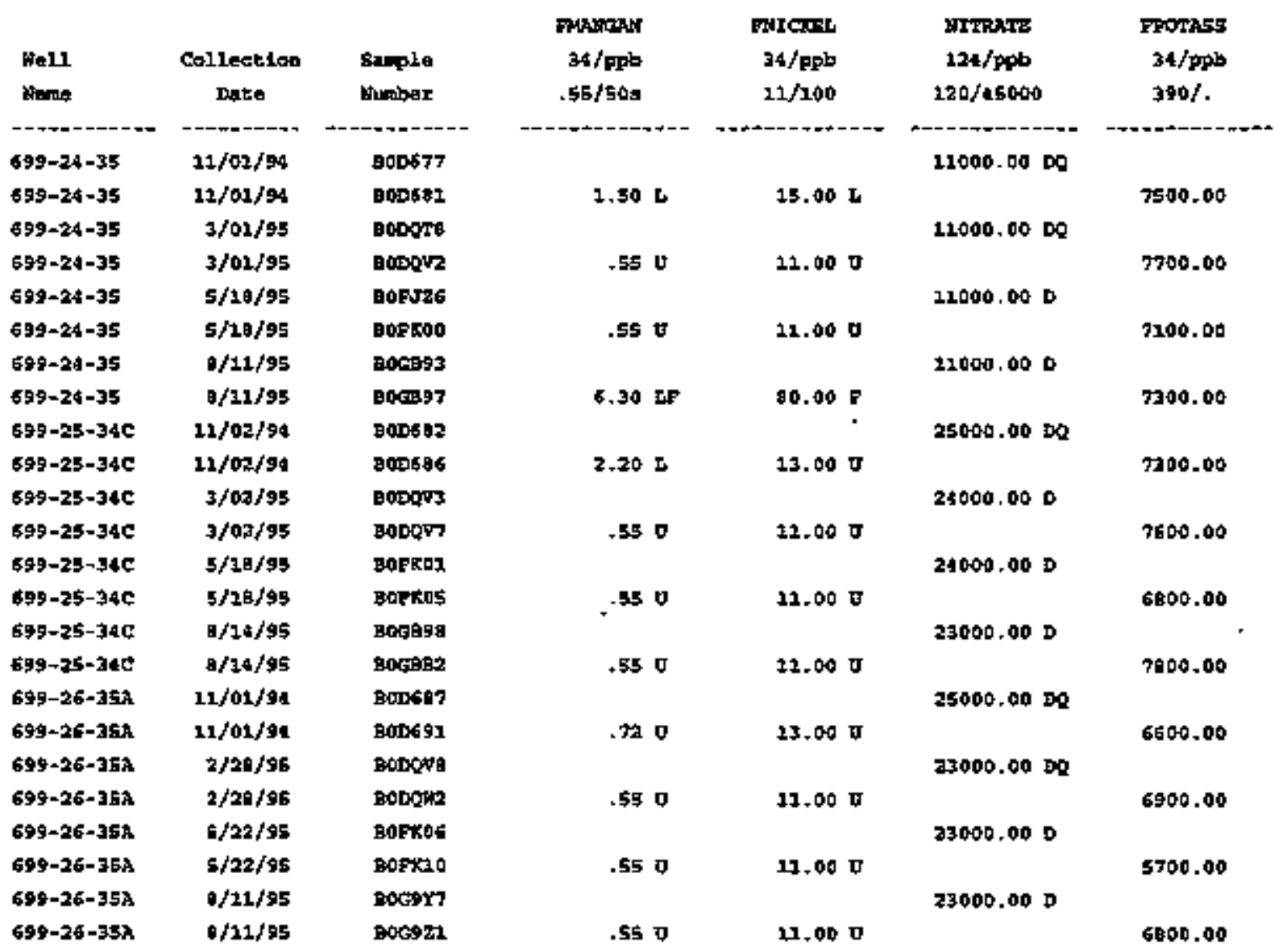

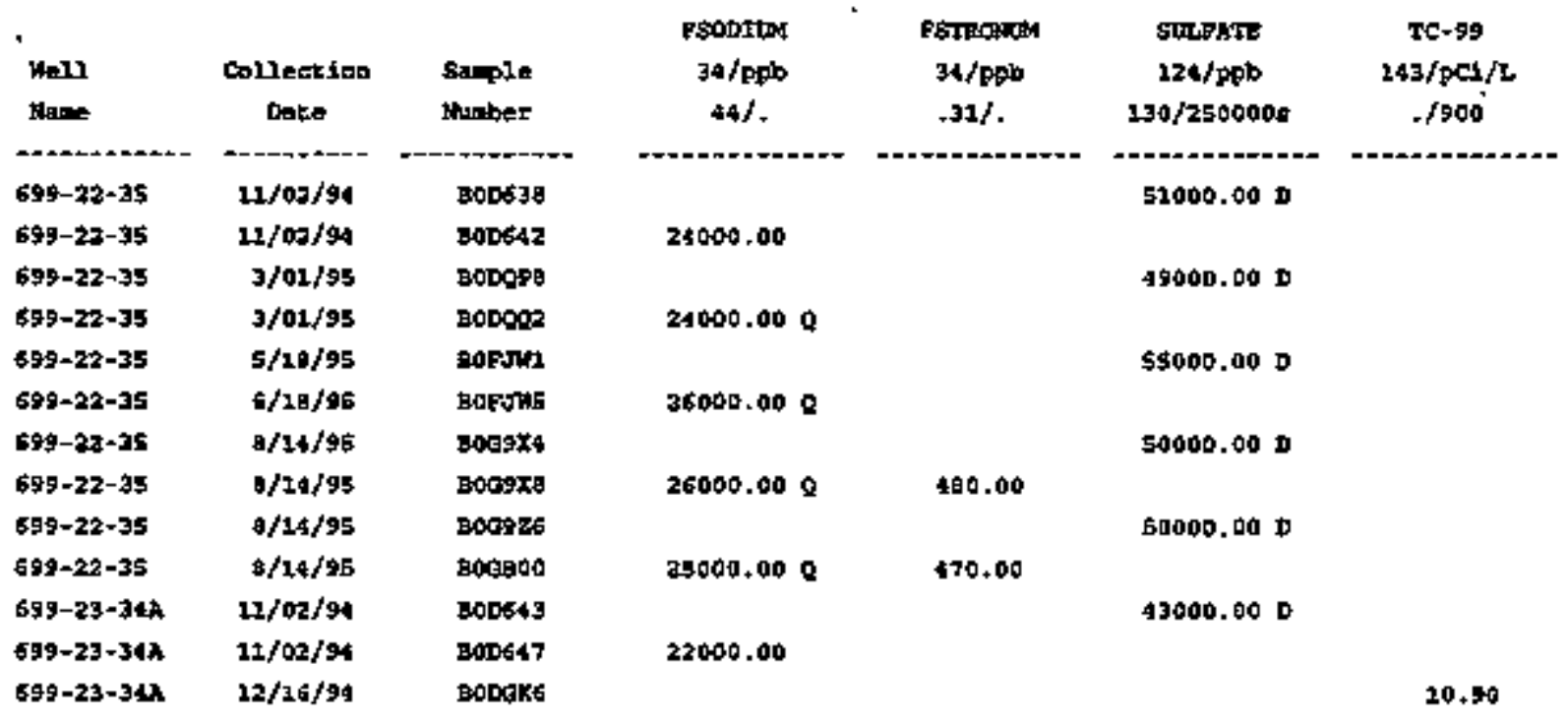


DOE/RL-96-01, REV. O

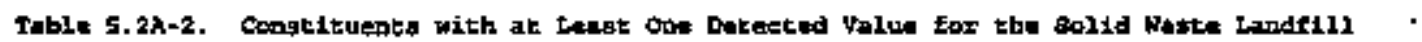
Data for Reporting Period Noverber 1, 1994 through seppember $30,1945$.

tahepetr 25 of 33\}

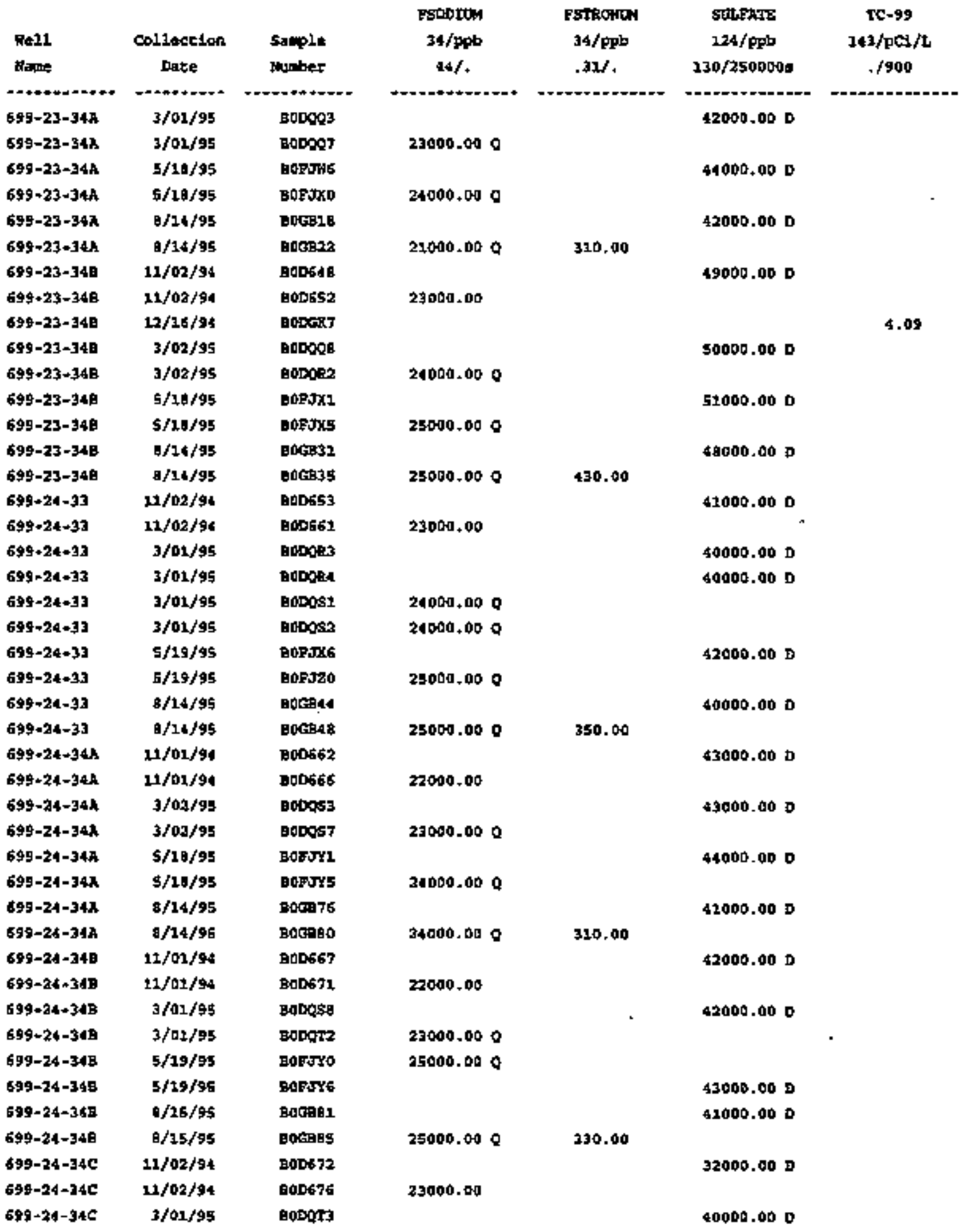


Table 6.2A-2. Congtitugnts with at Labet One Dateoted value for the selid waste indAftil

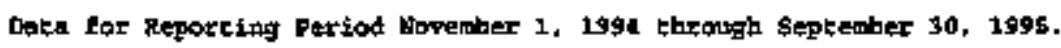

[ohete 16 of 23 !

\begin{tabular}{|c|c|c|c|c|c|c|}
\hline $\begin{array}{l}\text { Hall } \\
\text { Kanes }\end{array}$ & $\begin{array}{l}\text { Colleation } \\
\text { Dace }\end{array}$ & $\begin{array}{l}\text { satpl: } \\
\text { surbar }\end{array}$ & $\begin{array}{c}\text { Fsoptits } \\
34 / 096 \\
44 /\end{array}$ & $\begin{array}{l}\text { FSTREOATS } \\
34 / \text { pot } \\
.31 /\end{array}$ & $\begin{array}{c}\text { stnFATE } \\
124 / \mathrm{ppt} \\
230 / 3500009\end{array}$ & $\begin{array}{c}T C-99 \\
143 / 051 / 5 \\
. / 900\end{array}$ \\
\hline 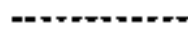 & - & 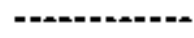 & 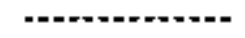 & - - & - & 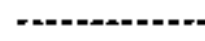 \\
\hline $699-24-34 C$ & $3 / 01 / 95$ & Bopest? & $24000.00 Q$ & & & \\
\hline $699-24-34 c$ & $5 / 10 / 9 s$ & DarJa1 & & & 42000.000 & \\
\hline $699-24-34 C$ & $5 / 10 / 95$ & BAFJZS & 25000.000 & & & \\
\hline $699-24-34 c$ & $8 / 14 / 95$ & BDEFT:46 & & & 40000.00 D & \\
\hline $695-24-346$ & $9 / 14 / 95$ & Dofest & 25000.000 & $370+00$ & & \\
\hline $699-24-35$ & $11 / 01 / 94$ & B00677 & & & $47000,00 \mathrm{D}$ & \\
\hline $599-24-35$ & $11 / 01 / 94$ & -00661 & 22000.00 & & & \\
\hline $699-24-35$ & $3 / 01 / 95$ & Eocors: & & & $42000.00 \mathrm{D}$ & \\
\hline $699-24-35$ & $3 / 01 / 95$ & 000042 & $22000.00 \%$ & & & \\
\hline $699-24-35$ & $5 / 18 / 95$ & BopJ26 & & & $43000.00 \mathrm{D}$ & \\
\hline $699-24-35$ & $5 / 26 / 95$ & BOFKO0 & 24000.000 & & & \\
\hline $699-24-35$ & $0 / 11 / 95$ & Docases & & & $40000.00 \mathrm{D}$ & \\
\hline $699-24-35$ & $0 / 11 / 95$ & Bocos97 & 22000.000 & & & \\
\hline $699-35-34 C$ & $11 / 02 / 94$ & 000682 & & & $39000.00 \mathrm{D}$ & \\
\hline $699-25-34 C$ & $11 / 02 / 94$ & 005686 & 23000.00 & & & \\
\hline $699-25-346$ & $3 / 02 / 95$ & Bopors & & & 39000.000 & \\
\hline $699-25-34 c$ & $3 / 03 / 95$ & Bopow & 25000,000 & - & & \\
\hline $699-26-340$ & $5 / 28 / 95$ & Bopro1 & $\cdot$ & & $\$ 4000.00 \mathrm{D}$ & \\
\hline $699-25-240$ & $5 / 19 / 95$ & BOFKos & $26000+000$ & & & \\
\hline $699-35-34 C$ & $8 / 14 / 95$ & E001898 & & & 30000.000 & \\
\hline $699-36-34 C$ & $8 / 14 / 99$ & Borsab2 & 25000.000 & 290.00 & & \\
\hline $699-25-25 s$ & $11 / 02 / 94$ & 000507 & & & 38000.000 & \\
\hline $699-26-35 A$ & $12 / 02 / 94$ & c00591 & $230-00+00$ & & & \\
\hline $699-26-35 A$ & $2 / 28 / 96$ & BoDQves & & & $38000.00 \mathrm{D}$ & \\
\hline $699-26-35 A$ & $2 / 20 / 56$ & BOpQHz & $34000+000$ & & & \\
\hline $699-26-35 A$ & $5 / 23 / 95$ & BOFKO6 & & & $38000.00 \mathrm{D}$ & \\
\hline $699-26-35 A$ & $6 / 23 / 95$ & Bork10 & $24000+000$ & & & \\
\hline $699-26-35 A$ & $8 / 11 / 95$ & B00957 & & & 37000.000 & \\
\hline $699-26-35 \lambda$ & $0 / 21 / 95$ & B00921 & 23000.000 & & & \\
\hline
\end{tabular}

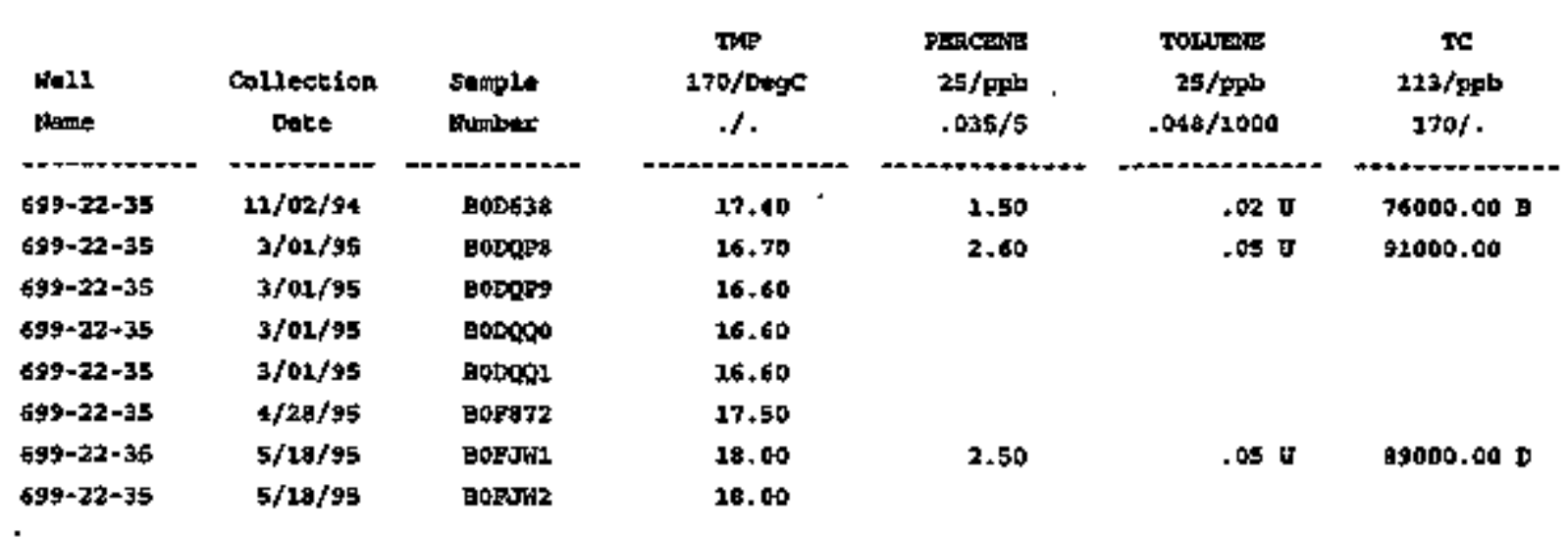


Table 5.2A-3. Corstituntes with at teast One Detacted value for the salid waste Iandfs11

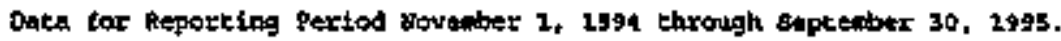

(abanc 17 of 23 \}

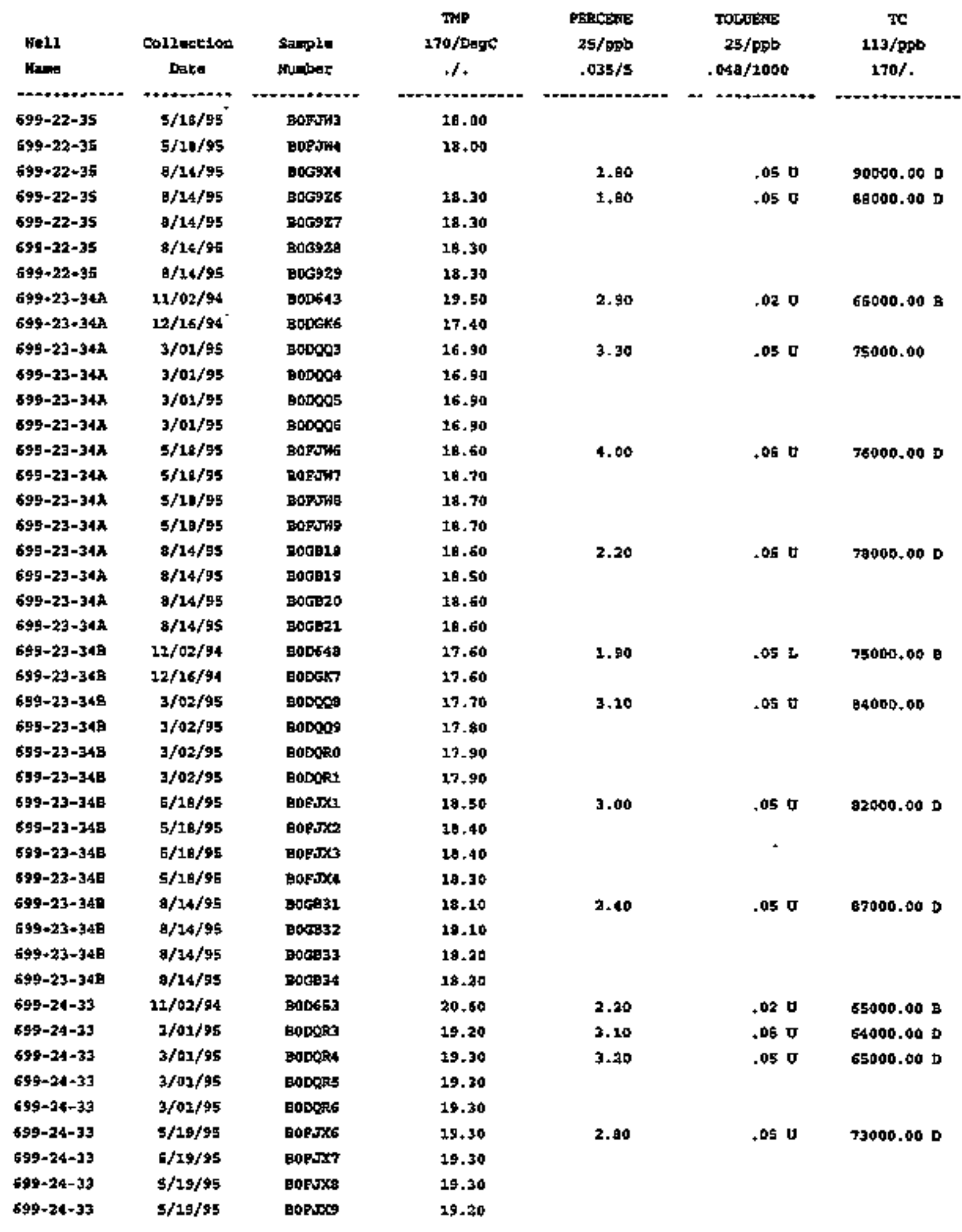


Table 5.2A-2. Conecituanta wich at Langc one Detecked Value for tha Solid Nasta Landfill Date Per Reporting Reriod Novembur 1, 2994 through september 30, 1995.

\{alhete 19 of 23!

\begin{tabular}{|c|c|c|c|c|c|c|}
\hline $\begin{array}{l}\text { Well } \\
\text { Neape }\end{array}$ & $\begin{array}{l}\text { collectiten } \\
\text { pate }\end{array}$ & $\begin{array}{l}\text { Senpla } \\
\text { Atmber }\end{array}$ & $\begin{array}{c}\text { THP } \\
270 / \text { ougc } \\
-1\end{array}$ & $\begin{array}{l}\text { FEACERTE } \\
25 / \mathrm{ppb} \\
.035 / 5\end{array}$ & $\begin{array}{c}\text { TULEER } \\
25 / \mathrm{pph} \\
.048 / 1000\end{array}$ & $\begin{array}{c}\mathrm{TC} \\
123 / \mathrm{pgb} \\
170 /\end{array}$ \\
\hline 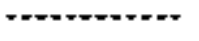 & 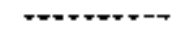 & 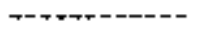 & 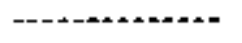 & 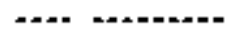 & - & $=$ \\
\hline $699-24-33$ & 8/24/95 & Bogs44 & 29.80 & 2.40 & .050 & 72000.000 \\
\hline $699-24-33$ & $0 / 24 / 95$ & B0GBA5 & 29.90 & & & \\
\hline $699-24-33$ & $0 / 24 / 55$ & B0GEA6 & 19.80 & & & \\
\hline $694-24-33$ & $6 / 14 / 95$ & BOCIBA7 & 19.00 & & & \\
\hline $699-24-34 A$ & $11 / 01 / 94$ & B0D662 & 18,60 & $3+00$ & . वर पर प & 55000.000 \\
\hline $699-26-34 A$ & $11 / 01 / 94$ & 300663 & 19.60 & & & \\
\hline $699-26-31 A$ & $12 / 01 / 94$ & 300664 & $19+60$ & & & \\
\hline $699-24-34 \lambda$ & $21 / 01 / 94$ & 900655 & $19+60$ & & & \\
\hline $699-24-34 \lambda$ & $3 / 02 / 95$ & Bodogs & $19+30$ & 2.90 & $.06 \mathrm{t}$ & 66000.00 \\
\hline $699-24-34 A$ & $3 / 02 / 95$ & $\operatorname{mog} 044$ & 18.30 & & & \\
\hline $699-24-34 \lambda$ & $3 / 02 / 95$ & Budoss & 18.40 & & & \\
\hline $699-24-34 \lambda$ & $3 / 02 / 95$ & popass & 18.40 & & & \\
\hline $699-24-34 A$ & $5 / 18 / 95$ & Eorayl & 18.80 & 3.10 & $.06 \mathrm{U}$ & $60000.00 \mathrm{D}$ \\
\hline $699-24-34 \lambda$ & $\$ / 18 / 95$ & BDFJa & 18.90 & & & \\
\hline $699-24-34 \lambda$ & $5 / 18 / 95$ & HorJła & 28.90 & & & \\
\hline $699-24-34 h$ & $5 / 18 / 95$ & DorJy & 19.00 & & & \\
\hline $699-24-344$ & $8 / 14 / 95$ & nocen & 18.30 & 1.00 & $.05 \mathrm{U}$ & $71000.00 \mathrm{D}$ \\
\hline $695-24-34 A$ & $8 / 24 / 95$ & Bocat? & 29.30 & & & \\
\hline $699-24-34 A$ & $1 / 24 / 95$ & 000978 & 19.30 & & & \\
\hline $699-24-34 A$ & $0 / 24 / 95$ & Bocte79 & 19.30 & & & \\
\hline $699-24-340$ & $11 / 01 / 94$ & 000667 & 19.30 & 3.60 & $.02 \mathrm{~J}$ & $62000.00 \mathrm{~B}$ \\
\hline $699-24-340$ & $11 / 01 / 94$ & อ00668 & 19.30 & & & \\
\hline $699-24-368$ & $12 / 01 / 94$ & B0D669 & 19.30 & & & \\
\hline $699-26-348$ & $11 / 01 / 94$ & 200670 & 19.20 & & & \\
\hline $699-24-360$ & $3 / 01 / 96$ & Bobces & 16.30 & 4.10 & $.05 \mathrm{E}$ & 68000.00 \\
\hline $699-24-258$ & $3 / 01 / 95$ & Eobogs & 16.80 & & & \\
\hline $699-24-210$ & $3 / 01 / 95$ & BoDero & 17.10 & & & \\
\hline $699-24-349$ & $3 / 01 / 95$ & BODCT2 & 17.20 & & & \\
\hline $699-26-360$ & $5 / 19 / 9 s$ & BofJ'G & 17.70 & 3.00 & .050 & $72000.00 \mathrm{D}$ \\
\hline $699-24-368$ & $5 / 19 / 91$ & DOFJY? & 17.80 & & & \\
\hline $699-34-348$ & $5 / 19 / 96$ & BapJYa & 17.90 & & & \\
\hline $699-34-349$ & $5 / 15 / 95$ & BAFSY9 & 17.90 & & & \\
\hline $699-24-369$ & $6 / 15 / 95$ & B0GBA1 & 19.00 & 2.90 & .050 & Ta000.00 D \\
\hline $699-24-349$ & $8 / 15 / 95$ & Bodges & 19.00 & & & \\
\hline $699-24-34 B$ & $8 / 15 / 95$ & Boges3 & 19.00 & & & \\
\hline $699-24-349$ & $0 / 15 / 95$ & BQGated & 19.10 & & & \\
\hline $699-2 s-34 c$ & $12 / 02 / 96$ & 900672 & 18.20 & 3.70 & .020 & $75000.00 \mathrm{~B}$ \\
\hline $699-a 4-340$ & $13 / 02 / 94$ & 900673 & 18.10 & & & \\
\hline $699-24-34 C$ & $21 / 02 / 94$ & Do0674 & 16.20 & 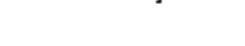 & & \\
\hline $699-24-34 C$ & $12 / 02 / 91$ & 900675 & 16.10 & & & \\
\hline $699-2 d-34 c$ & $3 / 01 / 95$ & 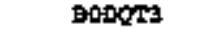 & 18.10 & 3.00 & $.05 \mathrm{U}$ & $69000.00 \mathrm{D}$ \\
\hline $6 \sin 20-31 c$ & $3 / 01 / 95$ & 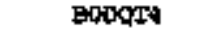 & $16+10$ & & & \\
\hline $699-24-34 C$ & $3 / 01 / 95$ & Boodis & 28.10 & & & \\
\hline $699-24-3-1 C$ & $3 / 01 / 95$ & DODOT6 & 28.10 & & & \\
\hline
\end{tabular}


DOE/RL-96-01, REV. 0

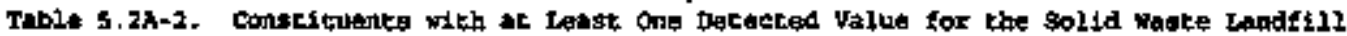

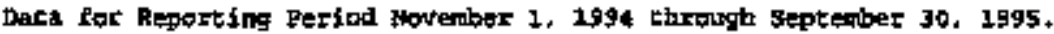

tsheet 29 of 23 !

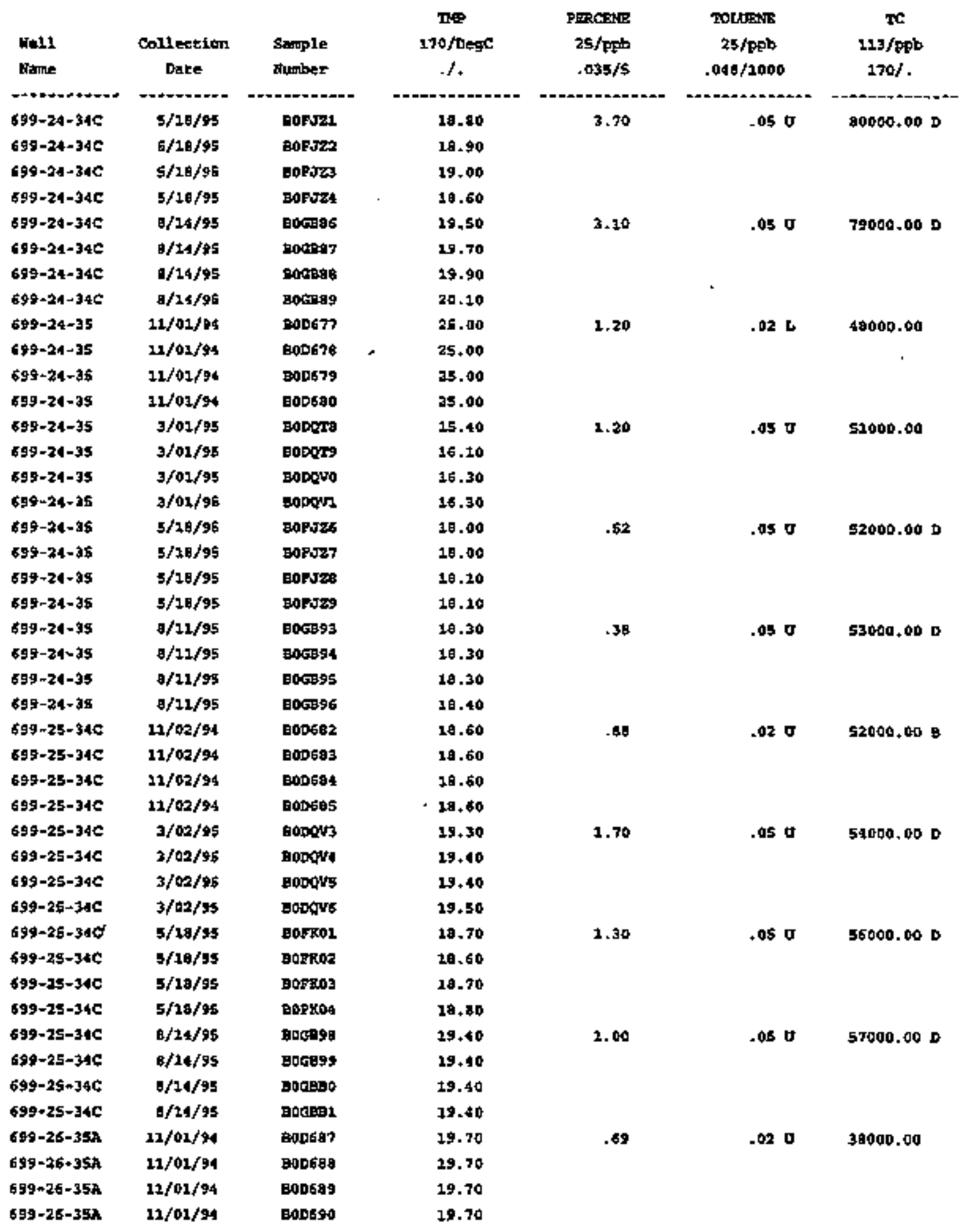




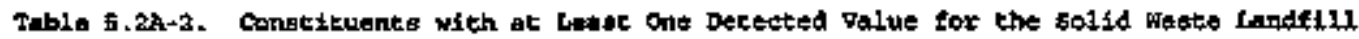
Dake tor Repoxting period lowember 1, 2994 chrough aepcember 30, 1995.

(sheet 2a of 23)

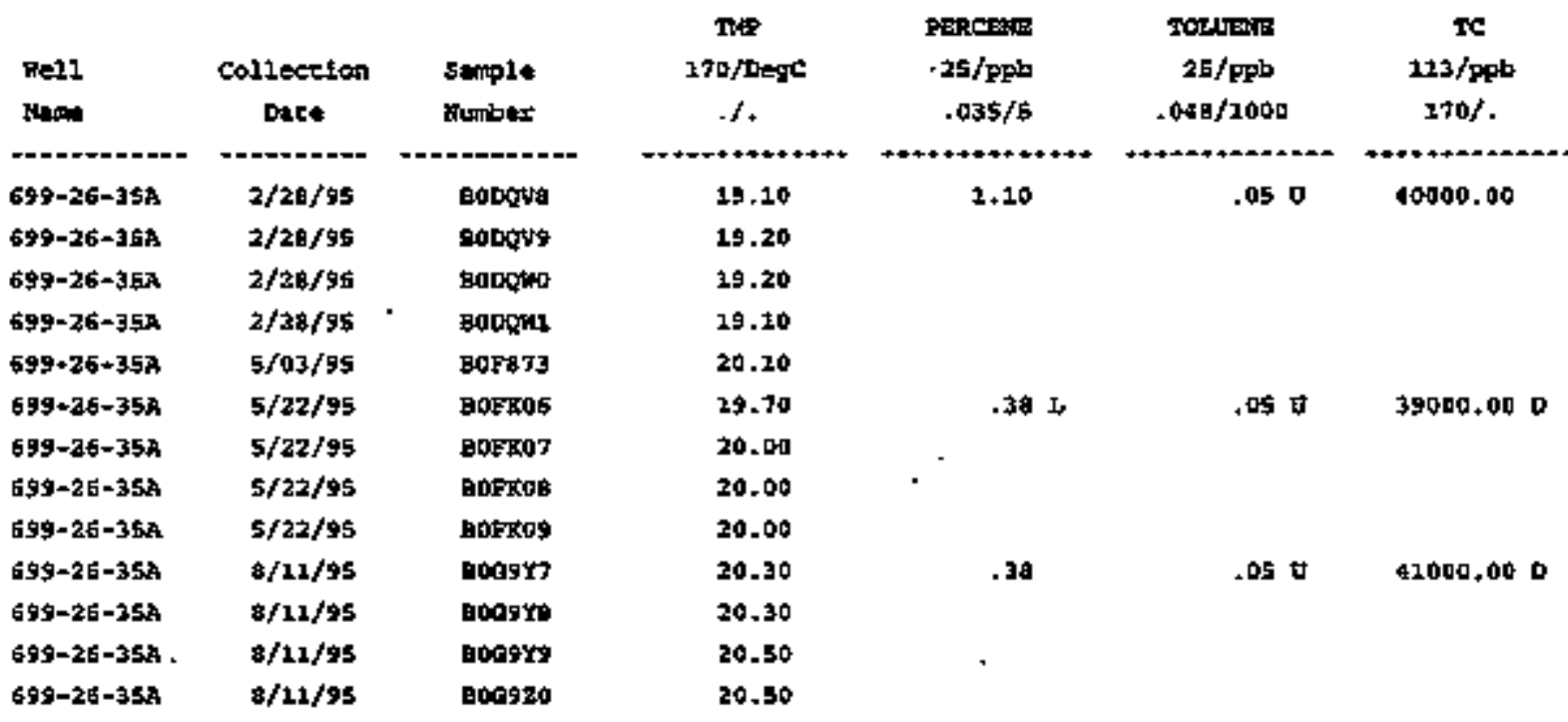

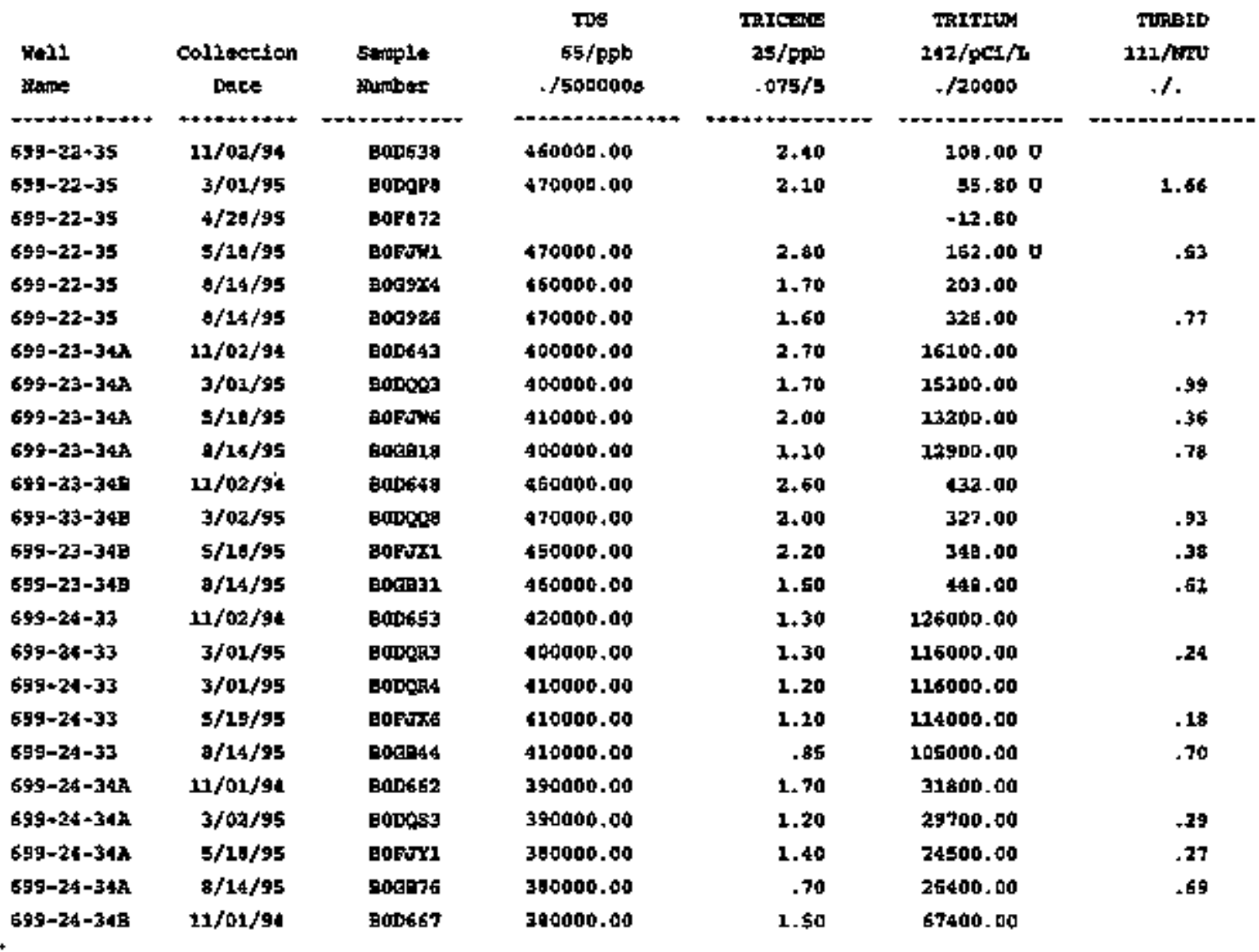




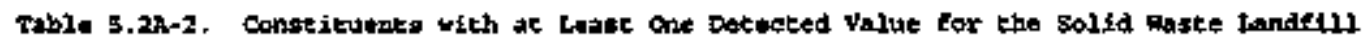

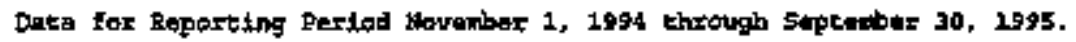

(eheer 21 of 23)

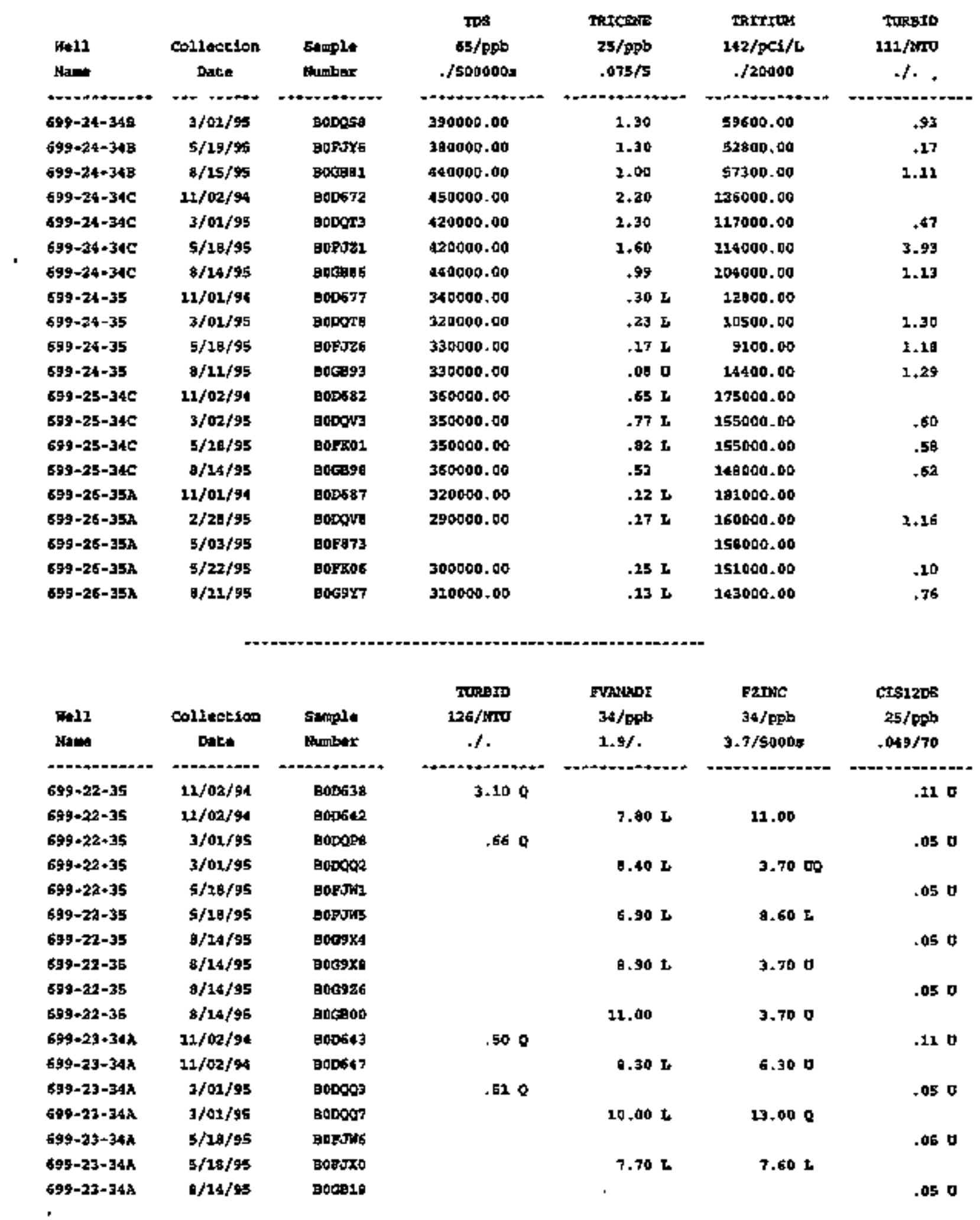




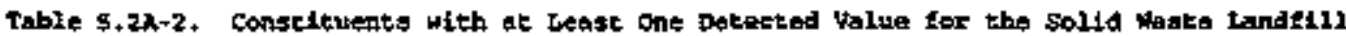
Dace for Reporting period rovenhar 1, 1994 ehrough september 30, 1995 .

\{abeat 22 of 23 \}

\begin{tabular}{|c|c|c|c|c|c|c|}
\hline Wantil & $\begin{array}{l}\text { Collection } \\
\text { pate }\end{array}$ & $\begin{array}{l}\text { Smluple } \\
\text { turneser }\end{array}$ & $\begin{array}{c}\text { TUReTD } \\
\text { 126/RTU } \\
/ /\end{array}$ & 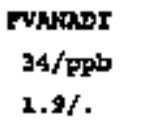 & $\begin{array}{c}\text { FZnts } \\
34 / \mathrm{ppb} \\
3.7 / 5000 \mathrm{~s}\end{array}$ & $\begin{array}{r}\text { Crs120E } \\
25 / \mathrm{ppb} \\
049 / 30\end{array}$ \\
\hline $699-23-14 A$ & a/14/95 & в0G823 & 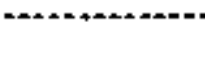 & $9.00 \mathrm{~L}$ & 3.7日 प & \\
\hline $699-23-34 B$ & $11 / 02 / 94$ & BDP648 & 2.600 & & & $.21 \mathrm{~J}$ \\
\hline $699-23-348$ & $11 / 02 / 94$ & B00652 & & $0.00 \mathrm{~L}$ & $7,20 \mathrm{Z}$ & \\
\hline $699 \cdot 23=348$ & $3 / 02 / 95$ & Bopoos & .650 & & & $.05 \mathrm{t}$ \\
\hline $699-23-348$ & $3 / 02 / 95$ & BODOR2 & & $0.30 \mathrm{t}$ & 3.7000 & \\
\hline $699-23-34 B$ & $5 / 10 / 9 s$ & Dof $x 1$ & & & & $.05 \mathrm{t}$ \\
\hline $699-23-34 B$ & $5 / 10 / 9 s$ & DOFJXS & & $5.40 \mathrm{~b}$ & $3.70 \mathrm{v}$ & \\
\hline $699-23-34 B$ & $8 / 14 / 95$ & ADGE31 & & & & $.05 \mathrm{t}$ \\
\hline $6 \$ 9-23-34 B$ & $8 / 14 / 95$ & BDG 355 & & $0.70 \mathrm{~L}$ & 3.700 & \\
\hline $699-34-33$ & $11 / 02 / 94$ & $\operatorname{BaD} 653$ & 2.100 & & & $.11 \mathrm{~J}$ \\
\hline $694-24-33$ & $11 / 02 / 94$ & MODEEI & & $12.00 \mathrm{I}$ & 16.00 & \\
\hline $698-24-33$ & $3 / 01 / 95$ & DODQR & .200 & & & $.05 \mathrm{U}$ \\
\hline $699-24-33$ & $3 / 01 / 95$ & MOtoRA & .230 & & & $.05 \mathrm{t}$ \\
\hline $698-24-33$ & $3 / 01 / 95$ & $\cot 0 \sec 1$ & & $13.00 \mathrm{I}$ & 12.000 & \\
\hline $699-24-33$ & $3 / 01 / 95$ & 0000092 & & $13.00 \mathrm{~L}$ & 13.000 & \\
\hline $699-24-33$ & $5 / 19 / 95$ & BofJX6 & & & & $-05 \mathrm{t}$ \\
\hline $699-24-33$ & $5 / 25 / 95$ & BOFuzG & & $8+30 \mathrm{~L}$ & $3+700$ & \\
\hline $699-24-33$ & $0 / 24 / 95$ & BOFBA4 & & & & $.05 \mathrm{v}$ \\
\hline $699-24-33$ & $\theta / 14 / 95$ & BoriaAa & & 13.09 & $6+75 \mathrm{~L}$ & \\
\hline $699-24-34 h$ & $11 / 01 / 94$ & BoDs62 & 1.800 & & & $.12 \mathrm{U}$ \\
\hline $699-24-34 x$ & $11 / 01 / 94$ & B0D666 & & $12.00 \mathrm{I}$ & 12.00 & \\
\hline $699-24-34 x$ & $3 / 02 / 95$ & Bopess & 510 & & & $+05 \mathrm{U}$ \\
\hline $699-24-34 x$ & $3 / 02 / 95$ & B00057 & & $12.00 \mathrm{t}$ & $3.70 \mathrm{D0}$ & \\
\hline $699-24-34 x$ & $5 / 24 / 95$ & BOFJY & & & & $+10 \mathrm{~J}$ \\
\hline $599-34-34 \lambda$ & $5 / 28 / 95$ & Boroys & & 10.00 t & 3.70 女 & \\
\hline $699-34-34 \lambda$ & $0 / 14 / 9 s$ & B0cis76 & & & & $+\infty \mathrm{U}$ \\
\hline $699-24-34 \lambda$ & $\theta / 14 / 95$ & Bogseo & & 13.00 & $3.70 \mathrm{~d}$ & \\
\hline $599-24-345$ & $11 / 01 / 94$ & 000667 & 1.200 & & & $+11 \mathrm{U}$ \\
\hline $599-24-348$ & $11 / 01 / 94$ & B00572 & & $10,00 \mathrm{~J}$ & $9.30 \mathrm{t}$ & \\
\hline $699-24-34 B$ & $3 / 01 / 95$ & BoDoss & 7.100 & & & $.05 \mathrm{U}$ \\
\hline $699-24-348$ & $3 / 01 / 05$ & modort2 & & $10.00 \mathrm{~J}$ & 3.7000 & \\
\hline $699-24-34 B$ & $5 / 29 / 96$ & Boptyo & & $10,00 \mathrm{~L}$ & 38.00 & \\
\hline $699-24-3 A B$ & $5 / 29 / 95$ & DOFJYG & & & & $.10 \mathrm{E}$ \\
\hline $698-24-348$ & 1/25/95 & E0G8B1 & & & & .050 \\
\hline $699-24-34 B$ & 0/15/95 & BoGBes & & 12.00 & $3.70 \mathrm{v}$ & \\
\hline 699-24-3AC & $11 / 02 / 94$ & 000672 & $2 . \$ 00$ & & & $+11 \mathrm{C}$ \\
\hline $699+24-34 C$ & $11 / 02 / 94$ & 000676 & & $11.00 \mathrm{E}$ & 14.00 & \\
\hline $699-24-34 c$ & $3 / 01 / 45$ & eodors & .498 & & & .050 \\
\hline $699-24-34 C$ & $3 / 01 / 95$ & DODQT & & $11.00 \mathrm{I}$ & $12.00 \mathrm{~g}$ & \\
\hline $699-24-34 C$ & $5 / 18 / 95$ & BOEJZ1 & & & & $+05 \mathrm{I}$ \\
\hline $699-24-34 C$ & $5 / 28 / 95$ & E0ruzs & & $\$+\$ 0 \mathrm{~L}$ & 24.00 & \\
\hline $699-24-34 c$ & $0 / 21 / 96$ & Dage日6 & & & & .050 \\
\hline $699-24-34 C$ & $8 / 14 / 95$ & Bogego & & 12.00 & $5.40 \mathrm{E}$ & \\
\hline $699-24=35$ & $11 / 01 / 94$ & B00677 & .750 & & & .110 \\
\hline
\end{tabular}




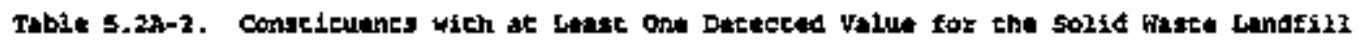
Daca for Rtporting Perlod Hovember 1, 1994 through \$trptomber 30, 2995.

$$
\text { (sheet } 23 \text { at } 231
$$

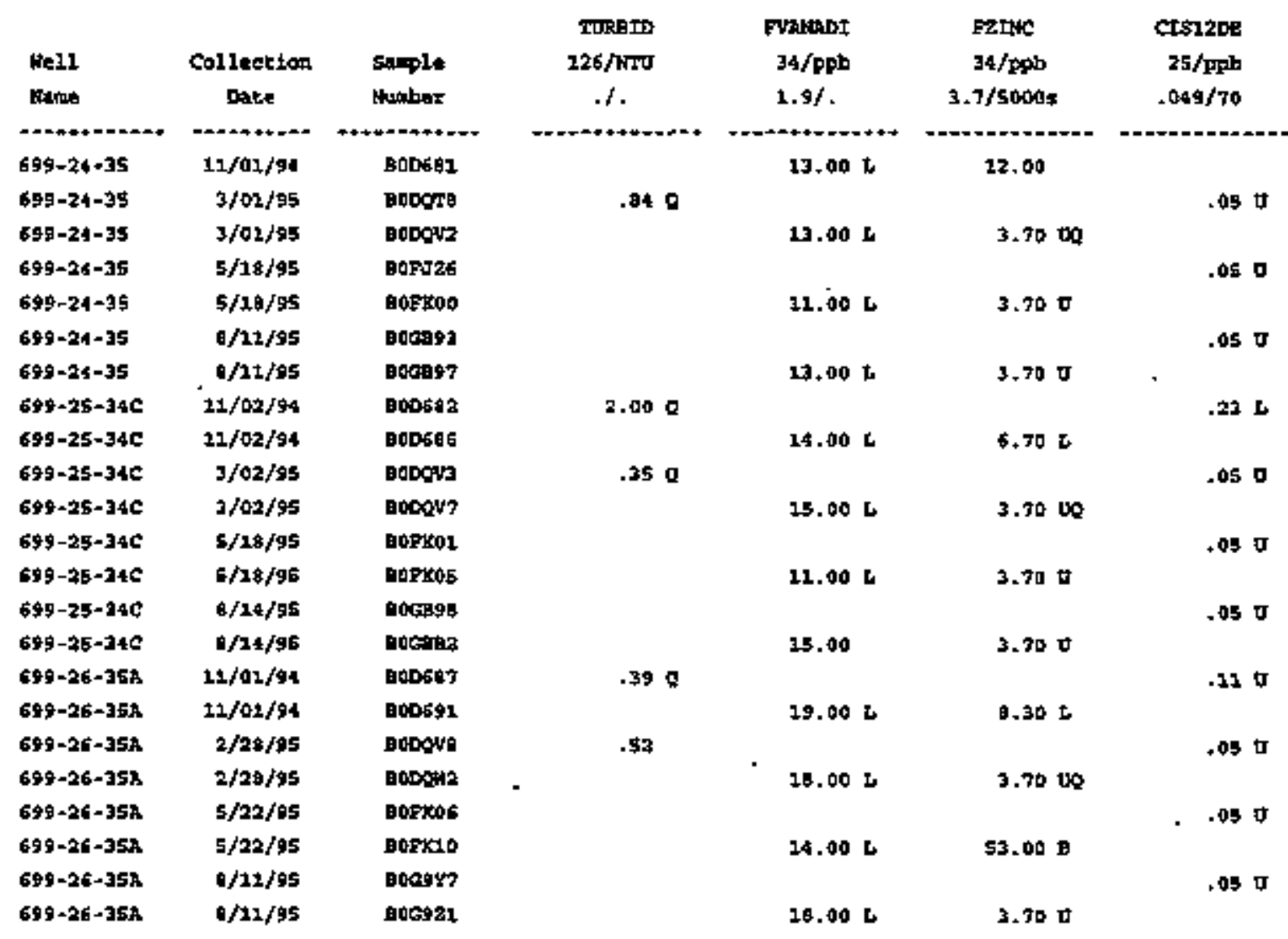




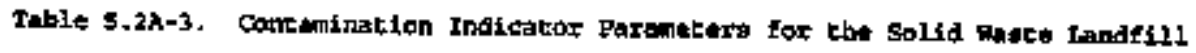
Duta Kar Ruporting Pertod Nowember 1, 1994 through Septamber 20, 1995.

(sheat 1 of 5 )

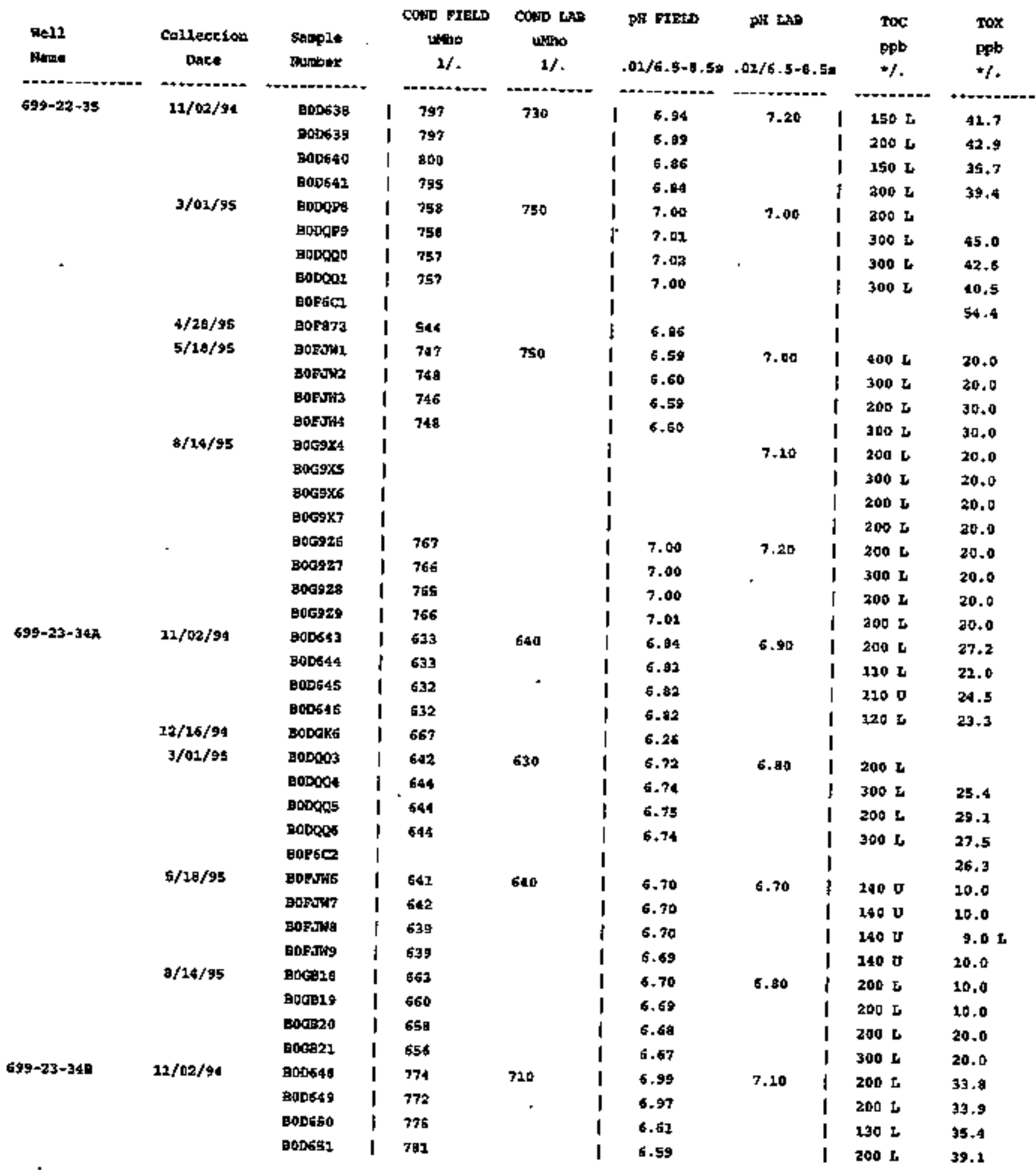




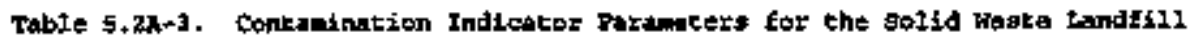
Data tor Reporcing Period kovaber 2, 1994 chrough saptenber 30, 1996.

(sheet 2 of 5 )

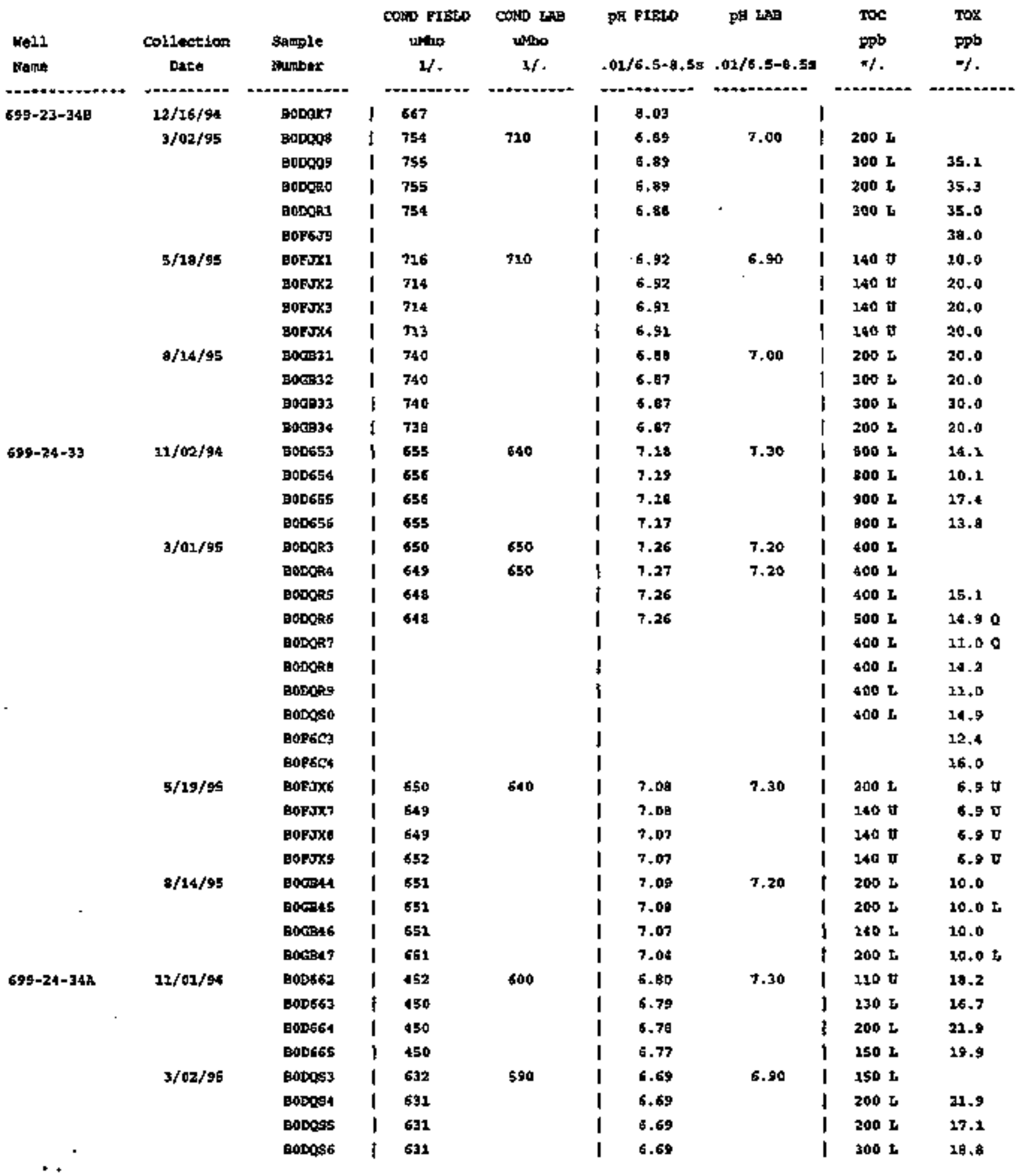


Table 5+2A-3. Concaninatien tpdicakor Paramatera tor the solid Waste Landeilt Date for Reporting Period November 1. L9h throwgh Septomber 30, 1985.

$$
\text { lobute } 3 \text { of } 5 \text { ) }
$$

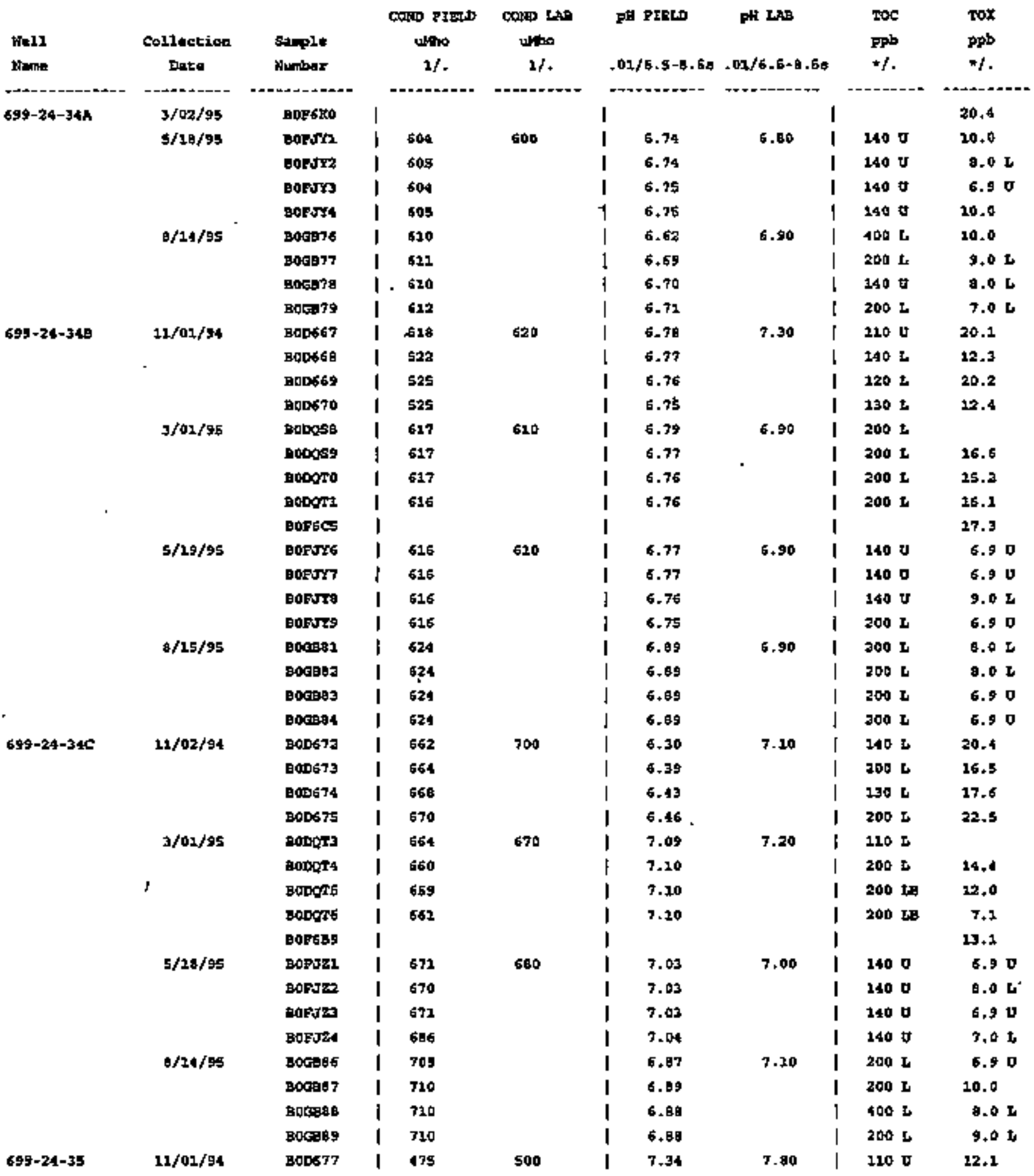




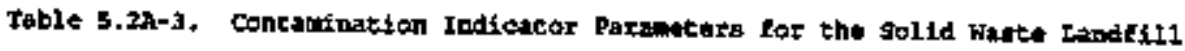
Data for Reparting pariod November 2. 1994 through sopcenbur 30, 1995.

(shuer at 5 \}

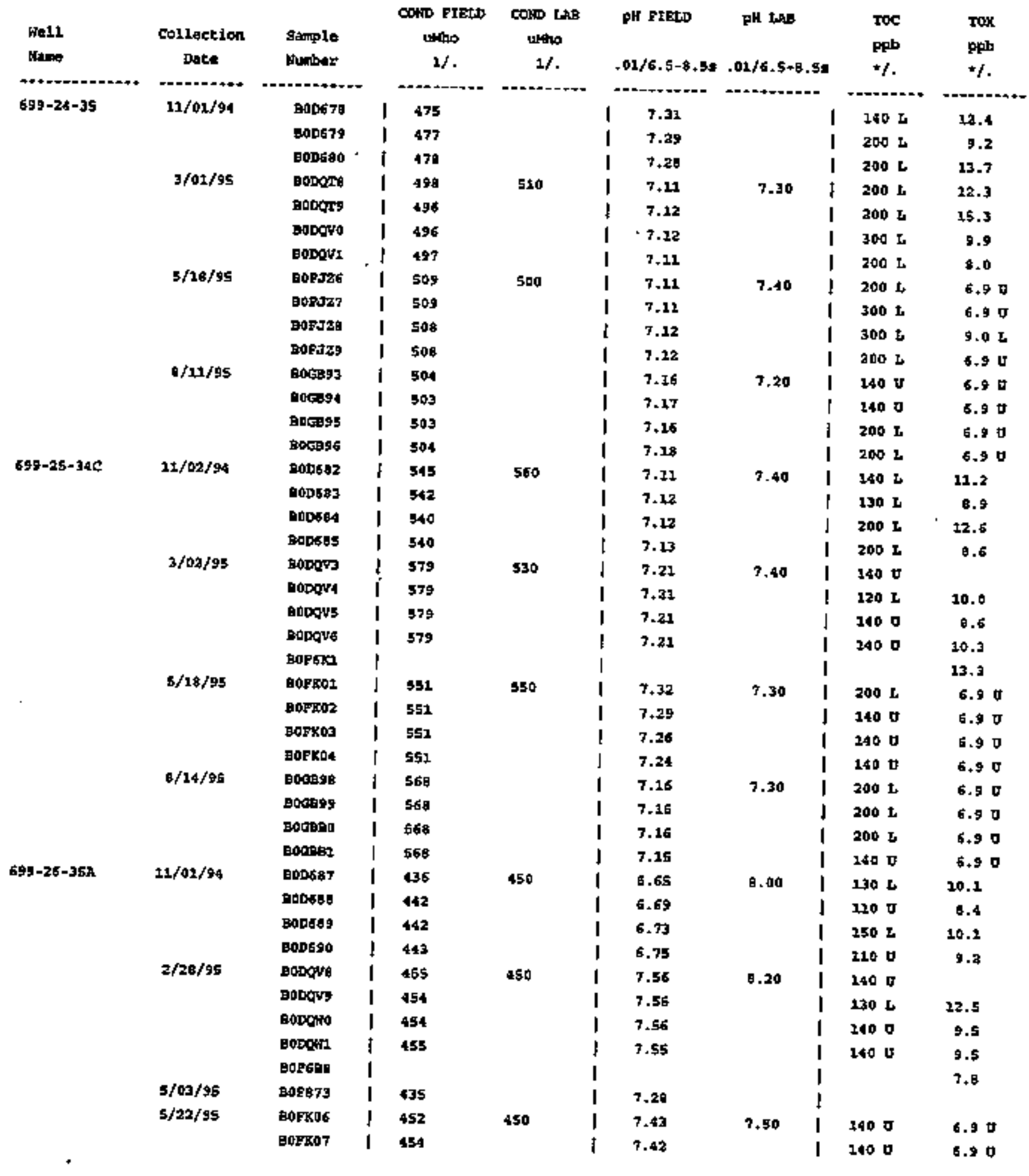


DOE/RL-96-01, REV. O

Table S.2A-3. Contandracten Indicator Paraneters for the Solfd waste fandill Daten tor Reporting pariod November 1, 1994 through septenter 30, 1995.

$$
\text { (sheac } 5 \text { of } 5 \text { ) }
$$

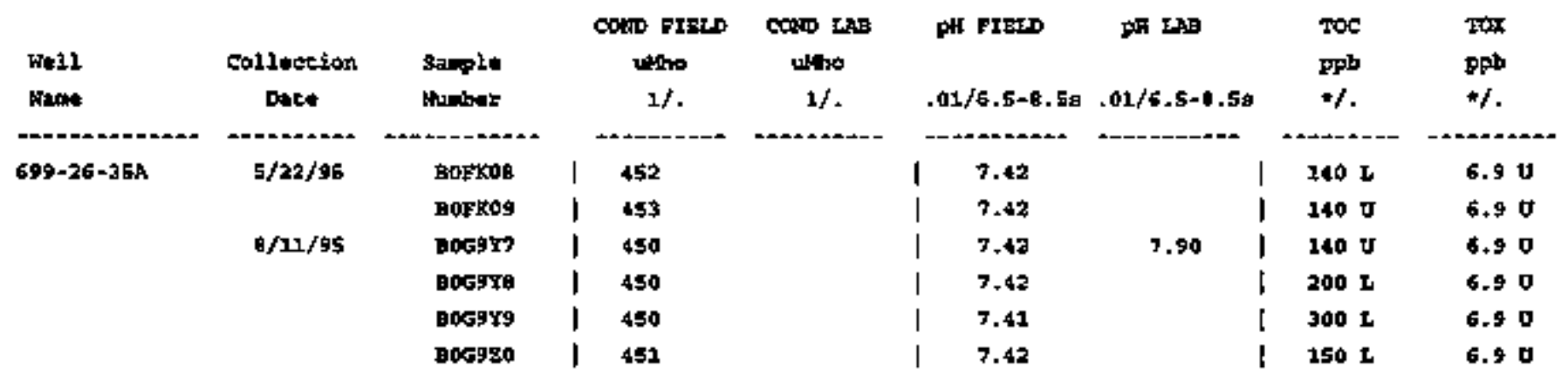

- Deteetion indes fer Toc and rox vary depending on the pextorming laboxabory. 
DOE/RL-96-01, REV. 0

APPENDIX 5.28

WATER LEVEL MEASUREMENTS

$5.2 B-i$ 
00E/RL-96-01, REV. 0

This page intentionally left blank.

\subsection{B-11}


Table 5.2B-1. Water Level Measurement Report Solid Waste Landfill Monitoring Mells.

(sheet 1 of 5 )

\begin{tabular}{|c|c|c|c|c|}
\hline We11 & Date & $\begin{array}{l}\text { Depth to } \\
\text { water (ft) }\end{array}$ & $\begin{array}{l}\text { Watel } \\
\text { elevatior } \\
\text { (ft) }\end{array}$ & $\begin{array}{l}\text { level } \\
\text { above msl } \\
\text { (m) }\end{array}$ \\
\hline $699-22-35$ & $\begin{array}{r}11 / 02 / 94 \\
3 / 01 / 95 \\
3 / 20 / 95 \\
4 / 25 / 95 \\
5 / 17 / 95 \\
6 / 29 / 95 \\
7 / 21 / 95 \\
8 / 14 / 95 \\
8 / 30 / 95 \\
9 / 22 / 95\end{array}$ & $\begin{array}{l}132.97^{\star} \\
133.12^{\star} \\
133.05 \\
133.28 \\
133.16 \\
133.23 \\
133.15 \\
133.20^{*} \\
133.06 \\
133.15\end{array}$ & $\begin{array}{l}401.00 \\
400.85 \\
400.94 \\
400.69 \\
400.81 \\
400.74 \\
400.82 \\
400.77 \\
400.91 \\
400.82\end{array}$ & $\begin{array}{l}122.22 \\
122.18 \\
122.21 \\
122.13 \\
122.17 \\
122.15 \\
122.17 \\
122.15 \\
122.20 \\
122.17\end{array}$ \\
\hline $699-23-34 A$ & $\begin{array}{r}11 / 02 / 94 \\
11 / 28 / 94 \\
12 / 15 / 94 \\
1 / 24 / 95 \\
2 / 24 / 95 \\
3 / 01 / 95 \\
3 / 20 / 95 \\
4 / 25 / 95 \\
5 / 17 / 95 \\
6 / 29 / 95 \\
7 / 21 / 95 \\
8 / 14 / 95 \\
8 / 30 / 95 \\
9 / 22 / 95\end{array}$ & $\begin{array}{l}131.80^{*} \\
131.83 \\
131.84 \\
131.94 \\
131.99 \\
131.97^{*} \\
132.00 \\
132.09 \\
132.01 \\
132.08 \\
131.99 \\
132.04^{*} \\
131.90 \\
131.95\end{array}$ & $\begin{array}{l}401.06 \\
401.03 \\
401.02 \\
400.92 \\
400.87 \\
400.89 \\
400.86 \\
400.77 \\
400.85 \\
400.78 \\
400.87 \\
400.82 \\
400.96 \\
400.91\end{array}$ & $\begin{array}{l}122.24 \\
122.23 \\
122.23 \\
122.20 \\
122.19 \\
122.19 \\
122.18 \\
122.15 \\
122.18 \\
122.16 \\
122.19 \\
122.17 \\
122.21 \\
122.20\end{array}$ \\
\hline $699-23-34 \mathrm{~B}$ & $\begin{array}{r}11 / 02 / 94 \\
3 / 02 / 95 \\
3 / 20 / 95 \\
4 / 25 / 95 \\
5 / 17 / 95 \\
6 / 29 / 95 \\
7 / 21 / 95 \\
8 / 14 / 95 \\
8 / 30 / 95\end{array}$ & $\begin{array}{l}132.48^{\star} \\
132.66^{\star} \\
132.71 \\
132.77 \\
132.68 \\
132.74 \\
132.66 \\
132.53^{*} \\
132.57\end{array}$ & $\begin{array}{l}401.02 \\
400.84 \\
400.79 \\
400.73 \\
400.82 \\
400.76 \\
400.84 \\
400.97 \\
400.93\end{array}$ & $\begin{array}{l}122.23 \\
122.18 \\
122.16 \\
122.14 \\
122.17 \\
122.15 \\
122.18 \\
122.22 \\
122.20\end{array}$ \\
\hline
\end{tabular}


Table 5.2B-1. Water Level Measurement Repart Sol id Waste Landfill Monitoring Wells. (sheet 2 of 5 )

\begin{tabular}{|c|c|c|c|c|}
\hline Well & Dater & $\begin{array}{l}\text { Depth to } \\
\text { water (ft) }\end{array}$ & $\begin{array}{l}\text { Water } \\
\text { elevation } \\
\text { (ft) }\end{array}$ & $\begin{array}{l}\text { Tevel } \\
\text { above ms1 } \\
\text { (m) }\end{array}$ \\
\hline $699-24-33$ & $\begin{array}{r}11 / 02 / 94 \\
11 / 28 / 94 \\
12 / 15 / 94 \\
1 / 24 / 95 \\
2 / 24 / 95 \\
3 / 01 / 95 \\
3 / 20 / 95 \\
4 / 25 / 95 \\
5 / 17 / 95 \\
6 / 29 / 95 \\
7 / 21 / 95 \\
8 / 14 / 95 \\
8 / 30 / 95 \\
9 / 22 / 95\end{array}$ & $\begin{array}{l}123.40^{*} \\
123.22 \\
123.24 \\
123.32 \\
123.40 \\
123.43^{*} \\
123.42 \\
123.47 \\
123.43 \\
123.37 \\
123.39 \\
123.33^{*} \\
123.30 \\
123.37\end{array}$ & $\begin{array}{l}400.87 \\
401.05 \\
401.03 \\
400.95 \\
400.87 \\
400.84 \\
400.85 \\
400.80 \\
400.84 \\
400.90 \\
400.88 \\
400.94 \\
400.97 \\
400.90\end{array}$ & $\begin{array}{l}122.19 \\
122.24 \\
122.23 \\
122.21 \\
122.19 \\
122.18 \\
122.18 \\
122.16 \\
122.18 \\
122.19 \\
122.19 \\
122.21 \\
122.22 \\
122.19\end{array}$ \\
\hline 699-24-34A & $\begin{array}{r}11 / 01 / 94 \\
11 / 28 / 94 \\
12 / 15 / 94 \\
1 / 24 / 95 \\
2 / 24 / 95 \\
3 / 02 / 95 \\
3 / 20 / 95 \\
4 / 25 / 95 \\
5 / 17 / 95 \\
6 / 29 / 95 \\
7 / 21 / 95 \\
8 / 14 / 95 \\
8 / 30 / 95 \\
9 / 22 / 95\end{array}$ & $\begin{array}{l}132.76^{\star} \\
132.84 \\
132.86 \\
132.97 \\
133.03 \\
132.02^{\star} \\
133.97 \\
133.13 \\
133.03 \\
132.99 \\
133.02 \\
132.89 \star \\
132.93 \\
132.99\end{array}$ & $\begin{array}{l}401.12 \\
401.04 \\
401.02 \\
400.91 \\
400.85 \\
401.86 \\
399.91 \\
400.75 \\
400.85 \\
400.89 \\
400.86 \\
400.99 \\
400.95 \\
400.89\end{array}$ & $\begin{array}{l}122.26 \\
122.24 \\
122.23 \\
122.20 \\
122.18 \\
122.49 \\
121.89 \\
122.15 \\
122.18 \\
122.19 \\
122.18 \\
122.22 \\
122.21 \\
122.19\end{array}$ \\
\hline
\end{tabular}


Table 5.2B-1. Water Level Measurement Report Solid Maste Landfinl Monitoring Wells.

(sheet 3 of 5)

\begin{tabular}{|c|c|c|c|c|}
\hline We]1 & Date & $\begin{array}{l}\text { Depth to } \\
\text { water (ft) }\end{array}$ & $\begin{array}{l}\text { Water } \\
\text { elevation } \\
\text { (ft) }\end{array}$ & $\begin{array}{l}\text { level } \\
\text { above ms I } \\
\text { (it) }\end{array}$ \\
\hline $699-24-34 B$ & $\begin{array}{r}11 / 01 / 94 \\
11 / 28 / 94 \\
12 / 15 / 94 \\
1 / 24 / 95 \\
2 / 24 / 95 \\
3 / 01 / 95 \\
3 / 20 / 95 \\
4 / 25 / 95 \\
5 / 17 / 95 \\
6 / 29 / 95 \\
7 / 21 / 95 \\
8 / 15 / 95 \\
8 / 30 / 95 \\
9 / 22 / 95\end{array}$ & $\begin{array}{l}132.39 * \\
132.43 \\
132.45 \\
132.55 \\
132.61 \\
132.60^{*} \\
132.65 \\
132.71 \\
132.62 \\
132.69 \\
132.61 \\
132.66 * \\
132.52 \\
132.57\end{array}$ & $\begin{array}{l}401.11 \\
401.07 \\
401.05 \\
400.95 \\
400.89 \\
400.90 \\
400.85 \\
400.79 \\
400.88 \\
400.81 \\
400.89 \\
400.84 \\
400.98 \\
400.93\end{array}$ & $\begin{array}{l}122.26 \\
122.25 \\
122.24 \\
122.21 \\
122.19 \\
122.19 \\
122.18 \\
122.16 \\
122.19 \\
122.17 \\
122.19 \\
122.18 \\
122.22 \\
122.20\end{array}$ \\
\hline $699-24-34 C$ & $\begin{array}{r}11 / 02 / 94 \\
11 / 28 / 94 \\
12 / 15 / 94 \\
1 / 24 / 95 \\
2 / 24 / 95 \\
3 / 01 / 95 \\
3 / 20 / 95 \\
4 / 25 / 95 \\
5 / 17 / 95 \\
6 / 29 / 95 \\
7 / 21 / 95 \\
8 / 14 / 95 \\
8 / 30 / 95 \\
9 / 22 / 95\end{array}$ & $\begin{array}{l}131.50^{*} \\
131.54 \\
131.57 \\
131.66 \\
131.73 \\
131.71 * \\
131.77 \\
131.82 \\
131.73 \\
131.81 \\
131.71 \\
131.59 * \\
131.63 \\
131.69\end{array}$ & $\begin{array}{l}401.09 \\
401.05 \\
401.02 \\
400.93 \\
400.86 \\
400.88 \\
400.82 \\
400.77 \\
400.86 \\
400.78 \\
400.88 \\
401.00 \\
400.96 \\
400.90\end{array}$ & $\begin{array}{l}122.25 \\
122.24 \\
122.23 \\
122.20 \\
122.18 \\
122.19 \\
122.17 \\
122.15 \\
122.18 \\
122.16 \\
122.19 \\
122.22 \\
122.21 \\
122.19\end{array}$ \\
\hline
\end{tabular}


Table 5.2B-1. Water Level Heasurement Report Solid Waste Landfill Nonitoring Wells.

(sheet 4 of 5 )

\begin{tabular}{|c|c|c|c|c|}
\hline We11 & Date & $\begin{array}{l}\text { Depth to } \\
\text { water (ft) }\end{array}$ & $\begin{array}{l}\text { Mater } \\
\text { elavation } \\
\text { (tt) }\end{array}$ & $\begin{array}{l}\text { leve] } \\
\text { above ms } 1 \\
\text { (m) }\end{array}$ \\
\hline $699-24-35$ & $\begin{array}{r}11 / 01 / 94 \\
11 / 28 / 94 \\
12 / 15 / 94 \\
1 / 24 / 95 \\
2 / 24 / 95 \\
3 / 01 / 95 \\
3 / 20 / 95 \\
4 / 25 / 95 \\
5 / 17 / 95 \\
6 / 29 / 95 \\
7 / 21 / 95 \\
8 / 11 / 95 \\
8 / 30 / 95 \\
9 / 22 / 95\end{array}$ & $\begin{array}{l}137.71^{*} \\
137.75 \\
137.75 \\
137.81 \\
137.92 \\
137.96^{*} \\
137.96 \\
138.03 \\
137.94 \\
138.01 \\
137.92 \\
137.99^{*} \\
137.82 \\
137.99\end{array}$ & $\begin{array}{l}401.10 \\
401.06 \\
401.06 \\
401.00 \\
400.89 \\
400.85 \\
400.85 \\
400.78 \\
400.87 \\
400.80 \\
400.89 \\
400.82 \\
400.99 \\
400.82\end{array}$ & $\begin{array}{l}122.26 \\
122.24 \\
122.24 \\
122.22 \\
122.19 \\
122.18 \\
122.18 \\
122.16 \\
122.19 \\
122.16 \\
122.19 \\
122.17 \\
122.22 \\
122.17\end{array}$ \\
\hline $699-25-34 C$ & $\begin{array}{r}11 / 02 / 94 \\
11 / 28 / 94 \\
12 / 15 / 94 \\
1 / 24 / 95 \\
2 / 24 / 95 \\
3 / 02 / 95 \\
3 / 20 / 95 \\
4 / 25 / 95 \\
5 / 17 / 95 \\
6 / 29 / 95 \\
7 / 21 / 95 \\
8 / 14 / 95 \\
8 / 30 / 95 \\
9 / 22 / 95\end{array}$ & $\begin{array}{l}134.38^{*} \\
134.42 \\
134.44 \\
134.54 \\
134.59 \\
134.58 * \\
134.65 \\
134.68 \\
134.60 \\
134.67 \\
134.58 \\
134.65 * \\
134.50 \\
134.58\end{array}$ & $\begin{array}{l}401.08 \\
401.04 \\
401.02 \\
400.92 \\
400.87 \\
400.88 \\
400.81 \\
400.78 \\
400.86 \\
400.79 \\
400.88 \\
400.81 \\
400.96 \\
400.88\end{array}$ & $\begin{array}{r}122.25 \\
122.24 \\
122.23 \\
122.20 \\
122.19 \\
122.19 \\
122.17 \\
122.16 \\
122.18 \\
122.16 \\
122.19 \\
122.17 \\
122.21 \\
122.19\end{array}$ \\
\hline
\end{tabular}


Table 5.2-B-1. Water Level Measurement Report Sol id Waste Landfill Monitoring Mells. (sheet 5 of 5 )

\begin{tabular}{|c|c|c|c|c|}
\hline We11 & Date & $\begin{array}{l}\text { Depth to } \\
\text { water (ft) }\end{array}$ & $\begin{array}{l}\text { Hater } \\
\text { elevation } \\
\text { (ft) }\end{array}$ & $\begin{array}{l}\text { level } \\
\text { above ms] } \\
\text { (n) }\end{array}$ \\
\hline $699-26-35 \mathrm{~A}$ & $\begin{array}{r}11 / 01 / 94 \\
11 / 28 / 94 \\
12 / 15 / 94 \\
1 / 24 / 95 \\
2 / 24 / 95 \\
2 / 28 / 95 \\
3 / 20 / 95 \\
4 / 25 / 95 \\
5 / 17 / 95 \\
6 / 29 / 95 \\
7 / 21 / 95 \\
8 / 11 / 95 \\
8 / 30 / 95 \\
9 / 22 / 95\end{array}$ & $\begin{array}{l}131.68^{\star} \\
131.59 \\
132.03 \\
131.79 \\
132.06 \\
131.45 \star \\
132.95 \\
133.05 \\
132.00 \\
132.45 \\
131.80 \\
131.30^{\star} \\
131.81 \\
131.98\end{array}$ & $\begin{array}{l}400.98 \\
401.07 \\
400.63 \\
400.87 \\
400.60 \\
401.21 \\
399.71 \\
399.61 \\
400.66 \\
400.21 \\
400.86 \\
401.36 \\
400.85 \\
400.68\end{array}$ & $\begin{array}{l}122.22 \\
122.25 \\
122.11 \\
122.19 \\
122.10 \\
122.29 \\
121.83 \\
121.80 \\
122.12 \\
121.98 \\
122.18 \\
122.33 \\
122.18 \\
122.13\end{array}$ \\
\hline
\end{tabular}

MOTES: 1. Water Teve] elevations are calciltated by subtracting the measured depth-to-water from the surveyed elevation for the well.

2. Depth-to-water values are transeribed from field records.

3. Measurements marked with an '*' were taken at the time of salipiling.

4. Measurements marked with a ' + ' are outside of the expected range, and are suspected of error. 
DOE/RL-96-01, REY. 0

This page intentionally left blank.

5.2B-6 
D0E/RL-96-01, REV. 0

\section{CONTENTS}

6.1300 AREA PROCESS TREMCH ................ $6.1-1$

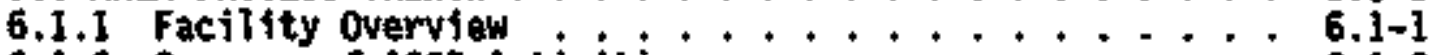

6.1 .2 Summary of 1995 Activities $\ldots \ldots \ldots \ldots . \ldots \ldots$

6.1 .3 Sampiting and AnaTysis Progran .......... 6.1-2

6.1 .4 Groundwater Chemtstry .............. 6.1-3

6.1 .5 Groundwater Flow ................. 6.1-4

6.1 .6 References . ................ 6.1-5 
DOE/RL-96-01, REV. 0

\section{LIST OF FIGLRES}

$6.1-1$ Facility and Well Location Map ............. 6.1-7

6.I-2 TCE in Well 399-1-168, 300 Area Process Trenches $\ldots \ldots \ldots$

6.1-3 CIS-DCE in Me11 399-1-168, 300 Area Process Trenches . . . . 6.1-8

6.1-4 Uranium in We11 399-1-17A, 300 Area Process Tronches ...... 6.1-9

6.1-5 Uranium Plume, 300 ATP, June 1995

6.1-6 Water Table Elevation Map, June 26,1995

6.1-7 Water Table Elevation Map, September 5, $1995 \ldots . . . .$.

$6.1-10$

6.1-11

$6.1-12$

6.1-13

\section{LIST OF TABLES}

6.1-1 Monttoring Wells Used for the 300 Area Process Trenches . . $6.1-14$

6. 1-2 Constituents Analyzed in the 300 Area Process Trenches.... $6.1-15$ 
DOE/RL-96-01, REV. 0

\subsection{AREA PROCESS TRENCH}

J. H. Lindberg

Westinghouse Hanford Company

The groundwater near the 300 Area Process Trenches (APT) has been monitored by a Resource Conservation and Recovery Act of 1976 (RCRA) interimstatus groundwater quality assessment well network since June 1985. The site continues to be regulated by the interim-status regulations Under the Hanford Fac171ty RCRA Permit (September 28, 1995, Ecology 1994). Konftoring wells were constructed in response to a consent Agreenent and cospljance order issued jofntly by the Washington State Department of Ecology and the U.S. Environmental Protection Agency (Ecology and EPA 1986). The 300 Area Process Trenches are located with in the Conprehensive Environmental Response, Compensation and Liability Act of 1980 (CERCLA) operable units 300-FF-1 and 300-FF-5. Currently the 300 Area Process Trenches are in the groundwater quality assessment stage of monitoring as discussed in the groundwater monttoring compliance plan (Schalla 1988). A revised groundwater monitoring plan has been written in anticipation of the site going into final status early next year. The existing closure/post-closure plan for the 300 Area Process Trenches is described in Dof (1985).

\subsection{Facitity overview}

The 300 Area Process Trenches are located in the northern portion of the 300 Area (Figure 6.1-1 and 1-1), the nuclear fuels fabrication area at the Hanford Stte. The two unl ined trenches were constructed in 1975. From 1975 unt 11 the shutdown of fuel fabrication in 1987 and other 300 Area operations in 1988, the trenches were used for the disposal of nost liquid wastes generated in the 300 Area. The tiquid waste was known or suspected of including the following (Schalla et a). 1988):

$\begin{array}{lll}\text { Uranium, or other alpha enitters } & \text { Sodium } & \text { Potassium } \\ \text { At least one beta emitter } & \text { Iron } & \text { Chioroform } \\ \text { Chlorfde } & \text { Sulfate } & \text { Mythy] chloride } \\ \text { Mitrate } & \text { Copper } & \text { JCE } \\ \text { Perchloroethylene (PCE) } & \text { Amatoniun } & \text { CIS-DCE } \\ \text { Barium } & \text { Vanadiun } & \end{array}$

The discharge rate reached a maximun of about $7,600 \mathrm{~L} / \mathrm{min}$ (2,000 gal/min). Since 1988, the wastewater has consisted of cooling water with small quantities of nonhazardous maintenance and process waste. In Juily 1991, the trenches were modjfied as part of an expedited response action (ERA). The modifications of the trenches involved removing bottom sedinent. from the inflow end of the trench and placing it at the opposite end of the trench behind a berm. The trenches were used on an alternating, as-needed basis. The west trench was rendered inoperable on Hovember 20, 1992. Subsequent1y, the east trench received al] discharges. Average discharge to the east trench was about $850 \mathrm{l} / \mathrm{min}(225 \mathrm{ga} 1 / \mathrm{min}$ ) in the iater years of operation. In December I994, the trenches were administratively isolated and all discharges were terminated. Complete physical isolation occurred one month Tater (January 1995). 
From the surface dowmard, the geologic units include the Hanford formation, the Ringold Formation, and the Columbia River Basalts. The Hanford formation is 9 to $12 \mathrm{~m}$ thick and is composed of gravelly sand and sandy gravel. The Ringold Formation is approximately $\mathbf{4 0}$ m thick and comprises of two major units. The upper half is interbedded sandy gravels, graveliy sands, and sjity sand. The lower haif is sandy and clayey sjit, and is called the lower mud unit. Flows of Columbia River Basalt and intercalated beds of the ETlensburg Formation underife the Ringold Formation lower mad unit.

The water table fs close to the position of the Hanford-Ringold formations contact, but near the river it rises and falls in response to river level. During average to low river stages, groundwater in the unconfined aquifer enters the 300 Area from the northwest and southwest, flows through the $\mathbf{3 0 0}$ Area in a west-to-east or northwest-to-southeast direction, and eventually flows into the river. Buring high water stages the water table can be quickly raised above the Hanford-Ringold formations contact near the river, and groundwater may temporarity flow in a reversed direction. Channeling in the top of the Ringold Fomation further complicates the direction and fiow rate of groundwater in the unconfined aquifer. Confined aquifers at depth (below the confining lower mud unit) have an overall greater amount of pressure than the overlying unconfined aqujfer, causing any interaquifer flow to be in an upward direction.

\subsubsection{Summary of 1995 Activities}

Mells in the monitorting network are sampled semiannually. They were sampled during the period of October 5-10, 1994, and June 1-5, 1995. In addition to regular sanpling events, one wel] (399-1-17A) is sampled four timas per year for a liwited 11st of analytes. Besides the october and June sampling, it was sampled December 15, 1994, and April 5, 1995. Water leve] maasurements were collected monthly for network and additional wells, but starting in September 1995 the frequency was changed to quarterjy. The frequency was reduced to quarterly because an adequate amount of data already have been collected to fully characterize the effect on the 300 Area groundwater systes caused by a fluctuating river level. In addition, water jevels are measured during sanpling for monitoring network wells.

\subsubsection{Sampling and Analysis Program}

The general groundwater monitoring program is described in the groundwater monitoring compliance plan (Schalla 1988). Sampling of 300 Area wells is coordinated with the 300-Ff-5 CERCLA program so that well trips can be reduced and data are shared.

Current7y, the monitoring network for the process trenches has 11 wells. The locations of these wells are shown in Figure 6.1-1. A list of these 11 wells, other wells, and their uses are presented in Table 6.1-1. Groundwater samples are collected sewjannualyy at all wells in the network except well 399-1-17A. Wel1 399-1-17A is sampled four time per year to monitor changes in groundwater quality near the process trench. 
Avallable analytical results have been reported in the quarteriy reports (Lindberg 1994, 1995a, I995b, and 1996). Analytica] constituents are Iisted in Table 6.1-2.

\subsubsection{Groundwater Chemistry}

The process trenches are located near other liquid dfsposal factlities in the 300 Area. Because of the proxiatity to the North Process Ponds (no longer in service) and sanjtary sewer lines, as well as other facilities downgradjent from the process trenches, it is diffjcult to deteraine constituents in the groundwater that can be directly attributed to the process trencies.

6.1.4.I Concentration Histories of Naste Indicators. The drinking water parameter gross alpha (DWS $15 \mathrm{\rho Ci} / \mathrm{L}$ ) is consistent]y elevated in seven wells, 399-1-10, 1-11, 1-12, 1-16A, 1-17A, 2-1, and 3-10. Concentrations range from $16.5 \mathrm{pCj} / \mathrm{L}$ in well 399-3-10 to $137 \mathrm{pCi} / \mathrm{L}$ in well 399-1-17A. Gross alpha is elevated in the same wells in which uraniun concentration is elevated.

The groundwater quality parameters filtered iron (WS $300 \mathrm{ppb}$ ) and filtered manganese (DWS $50 \mathrm{ppb}$ ) are above drinking water standards in wells $399-1-16 \mathrm{~B}$ and 1-178. Exceedances of iron range fror 340 to $420 \mathrm{ppb}$. Exceedances of nanganese range frost 62 to $82 \mathrm{ppb}$. These wells are screened at the botton of the unconfined aquifer downgradient of the process trenches. Higher concentrations of iron and manganese in these wells does not necessarily indicate that the process trenches are the source. The elevated fron and wanganese concentrations observed in the deep unconfined aquifer are probably infiuenced by chemical reducing conditions (i.e., the absence of oxygen and negative oxidation-reduction potentials). A similar relationship between sampling depth and concentration profiles for redox-sensitive species has been documented in Johnson et al. (1994).

Concentrations of site-specific parameters trichloroethylene (TCE) and cis-1,2-djchloroethylene (DCE) rema in elevated in we11 399-1-16B. Elevated concentrations of these contaminants in well 399-1-16B could indicate a contamfnant source because well $399-1-16 \mathrm{~B}$ is screened in the lower portion of the unconfined aquifer and the insoluble phase of these contaminants is more dense than water. The concentrations of TCE (DWS $5 \mathrm{ppb}$ ) is on a downward trend (Figures 6.1-2), and concentration of DCE (BWS $70 \mathrm{ppb}$ ), a degradation product of TCE, is on an upward trend (Figure 6.1-3). The concentration of TCE is down to $I .5 \mathrm{ppb}$, whereas DCE concentration rose to $100 \mathrm{ppb}$.

Like gross alpha, uranium concentration remalns high in seven network wells. The wells are 399-1-10A, 1-11, 1-12, 1-16A, 1-17A, 2-1, and 3-10. Results from these welTs ranged from a jow of $9.17 \mathrm{ppb}$ (0ct. 1994) to $179 \mathrm{ppb}$ (June 1995), both in the same well, 399-1-17A. PresumabTy, the uranium is responsible for the high gross ajpha in the same wells. Figure $6.1-4$ shows the historical trend for uranjunt concentration in wel1 399-1-17A. Uranium concentration dropped dranatically in 1991 as a result of the ERA. The rise since early 1995 is probably caused by the lack of dilution oy process trench discharge water. 
Concentrations of JOX (a contamination indlcator parameter) are elevated in three network wells, probably in response to degradation products of TCE and DCE. Weils 399-1-168, 399-1-17A, and 399-1-14A have TOX results that range from 11.7 to $107.0 \mathrm{ppo}$. Since the 300 APT is in RCRA assessment monitoring, contamination ind1cator parameters are not statjstically compared to background well results. However, samples are still analyzed for Tox to help in the manitaring for TCE and DCE.

6.1.4.2 B1stribution of Waste Constituents. Gross aTpha and uranium are elevated in seven network wells. Presumably, it is the uranium that causes the increase in gross alpha concentration. Figure 6-1.5 shows the uraniua pTume in the vicinity of the 300 APT during June 1995. The plume extended to the south during June, rather than strictly southeast, because the groundwater flows southwest at that time of the year (see Section 6.1 .5 .1 on groundwater flow).

The remainder of the elevated constituents related to the 300 APT during 1995 are confined to three or fewer wells each. Filtered iron and manganese are elevated in the two wells of the monitoring network that are screened in the lower portion of the unconfined aquifer (wells 399-1-163 and 17B). The elevated iros and manganese concentrations in these deeper wells are probably influenced by chenical-reducing conditions such as the absence of oxygen and negative oxidation-reduction potential (Lindberg et al. 1995). A similar relationship between sampling depth and concentration profiles for redoxsensitive species has been documented in Johnson and chou 1994 .

Trichloroethylene (TCE) and cis-1,2-dichloroethylene (DCE) remain elevated in only one well (399-1-168). Three wells near and upgradient of the 300 APT have higher concentrations of ToX. The three wells are 399-1-16B and 1-17A (downgradient) and 399-1-14A (upgradient throughout ost of the year except when the river level is elevated during Hay and June).

\subsubsection{Groundwater Flow}

6.1.5.1 Groundwater Flow Direction. The groundwater flow direction in the unconfined aquifer near the 300 Area Process Trenches is predowinantly to the southeast with changes caused by fluctuations in the Columbia River stage. Figure 6.1-6 shows the elevation of the water table June 26, 1995, when the river stage was very near the high for the year. Typically, durting these high water stages, a localized flow reversal occurs when the river stage is higher than the water level in the unconfined aquifer. The area involved in these flow reversals depends on the elevation of the high river stage and its duration. In June 1995 the river stage was high enough for a long enough period of time that the reversed gradient on the water table extended beyond we7] 399-6-1 to the southeast. Thts produced a reversed flow direction in the vicinity of the process trenches. Flgure 6.1-7 shows the elevation of the water table September 5, 1995, during the low stage for the Columbia River. Flow direction in the vicinity of the process trenches had returned to its direction before the high water stage.

Because wastewater is no longer discharged to the process trenches, the groundwater mound clearly observable on earlier water table maps of the 300 Area is no long present. As long as no sudden and projonged rises in river 
stage occur, the water table gradient in the vicinity of the process trenches slopes downard to the southeast in a relatively uniform manner

(F1gure 6.1-7).

There is a vertical head difference, with the gradient in an upward direction, between the unconfined aquifer above the Ringold lower mud unit and the gravels beneath the mud. At wells $399-1-17 \mathrm{~A}(103.88 \mathrm{~m})$ and $-17 \mathrm{C}$ (113.78 $\mathrm{m}$ ) the head difference is about $10 \mathrm{~m}(33 \mathrm{ft})$.

6.1.5.2 Rate of Flow. The flow rate in the top of the unconfined aquifer has been reported as about $10.6 \mathrm{~m} / \mathrm{d}(35 \mathrm{ft} / \mathrm{d}$ ) near the process trenches (Schalla et. a1. I988) based on data from a perchioroethene spi11. The rate of flow can also be estimated roughly by using the Darcy equation.

$$
v=\frac{x_{i}}{n_{\theta}}
$$

where:

$$
\begin{aligned}
& V=\text { Average } 1 \text { inear groundwater velocity } \\
& K=\text { Hydraulic conductivity } \\
& 1=\text { Hydraulic gradient } \\
& n_{e}=\text { Effective porosity. }
\end{aligned}
$$

Schaila et a]. (1988) reported values of hydraulic conductivity for the unconfined aquifer rangling from 150 to $15,240 \mathrm{~m} / \mathrm{d}(500$ to $50,000 \mathrm{ft} / \mathrm{d})$. These values were determined from punping tests. The hydraulic gradient near the process trenches, estimated from the September 1995 water table map (Figure 6.1-6), averages approximately 0.0007. This gradient is about average for the year. Estinates of effective porosity for the unconfined aquifer range from 0.10 to 0.30 . Using these values as input paraneters to the Darcy equation, the range of groundwater flow velocity is approximately 0.35 to $106.7 \mathrm{~m} / \mathrm{d}(1.15$ to $350 \mathrm{ft} / \mathrm{d})$. The large range in flow velocity vatues is a result of the large range in values of hydraulic conductivity reported for the aquifer. The range in hydraulic conductivity may be attributed to facies variations within and between the Hanford and Ringold formations.

6.1.5.3 Evaluation of Honitoring Hotwork. Groundwater flow has not changed significantly since the 300 Area Process Trenches nonitoring network was designed. The network is still adequate to assess contanination frow the trenches. 
DOE/RL-96-01, REV. 0

\subsubsection{Referonces}

Comprehensive Environmental Response, Compensation, and Liability Act of 1980,42 USC 9601 et seq.

DOE, 1985, CTosure/Post closure PJan for 300 Area Process Trenches, TRAC-0098, U.S. Department of Energy, Richland Operations Office, Rtchl and, Nashington.

Ecology and EPA, 1986, Consent Agreement and Compliance Order, DE 86-133, Washington State Department of Ecology and the U.S. Environmental Protection Agency.

Evans, J. C., R. W. Bryce, and D. J. Bates, 1992, Hanford Site Ground-Water Nonitoring for 1990, PNL-8073, Pacific Northwest Laboratory, Richland, Washington.

Johnson, V. G., C. J. Chou, and F. N. Hodges, 1994, Some Statistical Aspects of Background Based Groundwater Standards at Arid Hazardous Waste Sites, WHC-SA-2358-FP, Westinghouse Hanford Company, Richland, Washington.

Lindberg, J. W., 1994, "300 Area Process Trenches," Quarterly Report of RCRA Groundwater Nonitoring Data for Period October 1, 1994 through Decenber 31, 1994, DOE/RL-94-36-4, U.S. Department of Energy, Richland Operations Office, Richland, Washington.

Lindberg, J. W., 1995a, "300 Area Process Trenches," Quarteriy Report of RCRA Groundwater Monttoring Data for Perfod January 1, 1995 through March 31, 1995, DOE/RL-95-69-1, U.S. Department of Energy, Rich] and Operations Office, Rich] and, Washington.

Lindberg, J. W., 1995b, "300 Area Process Trenches," Quarteriy Report of RCRA Grouncivater Monitoring Data for Period April 1, 1995 through June 30, 1995, DOE/RL-95-69-2, U.S. Department of Energy, Richland Operations Office, Richland, Washington.

Lindberg, J. W., 1996, "300 Area Process Trenches," Quarterly Report of RCRA Groundwater Nonftoring Data for Period July 1, 1995 through September 30, 1995, DOE/RL-95-69-3, U.S. Departwent of Energy, Richland Operatjons Office, Richland, Washington.

Lindberg, J.W., C.J. Chou, and V.G. Johnson, 1995, Groundwater Nonitoring Plan for the 300 APT, WHC-SD-EN-AP-185, Westinghouse Hanford Company, Richland, Washington.

Resource Conservation and Recovery Act of 1976, 42 USC 6901 et seq.

Schalla, R., 1988, Revised Ground-Water Monitoring Conpliance Plan for the 300 Area Process Trenches, PNL-6671, Pacific Northwest Laboratory, Richi and, Washington. 
Schatla, R., R. L. Aaberg, S. P. Airhart, D. J. Bates, J. V. M. Carlile, C. S. Cline, D. I. Oennison, M. D. Freshley, P. R. Heller, E. J. Jensen, K. B. 01 sen, R. G. Parkhurst, J. T. Rieger, R. W. Wallace, and E. J. Westergard, 1988, Interf no Characterization Report for the 300 Area Process Trenches, PHL-6716, Pacific Horthwest Laboratory, Richiand, Mashington. 
Figure 6.1-1. Facility and Mell Location Map.

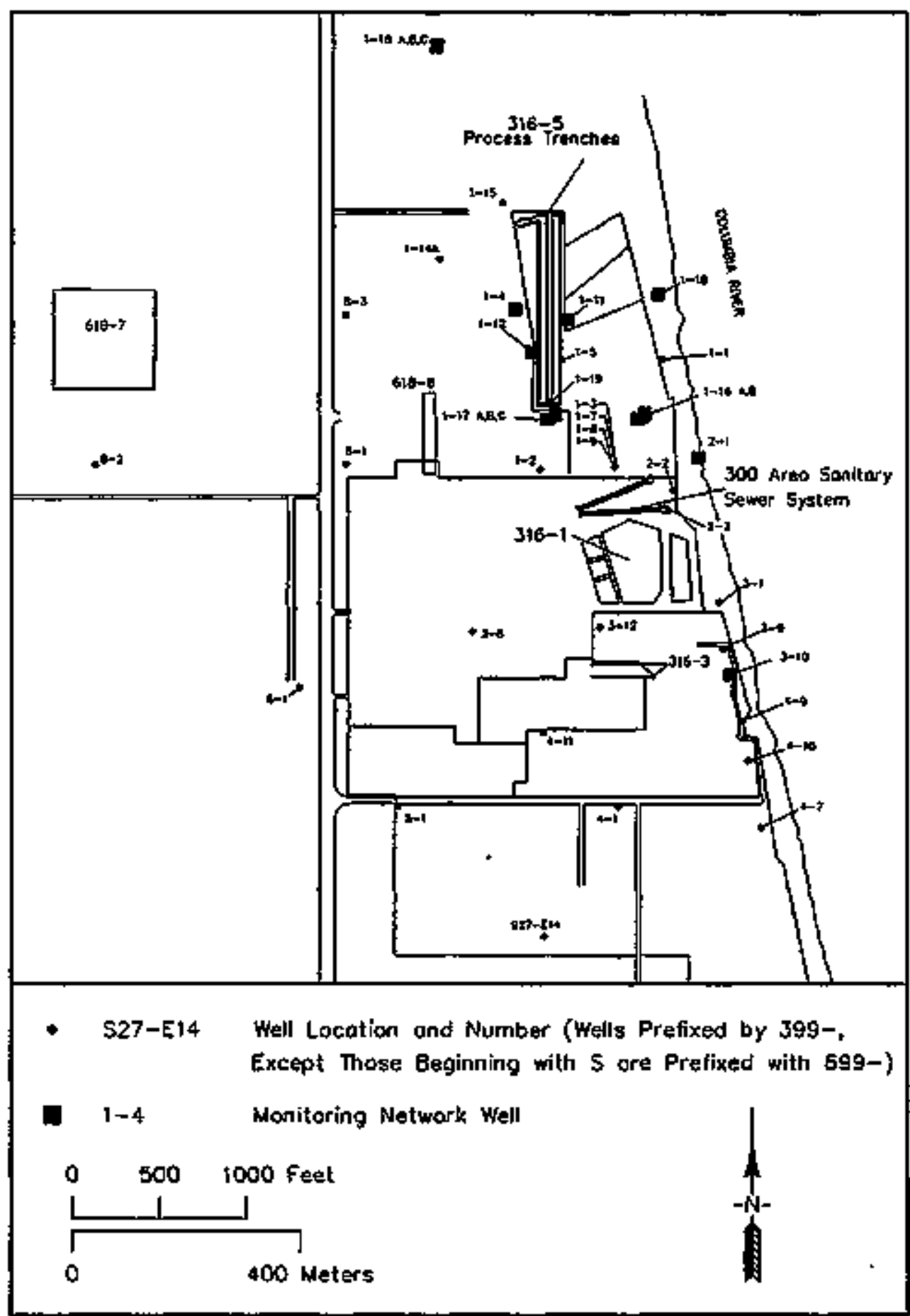

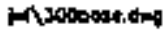


DOE/RL-96-01, REY. 0

figure 6.1-2. TCE in Well 399-1-168, 300 Area Process Trenches.

TCE In Woll 399-1-16B

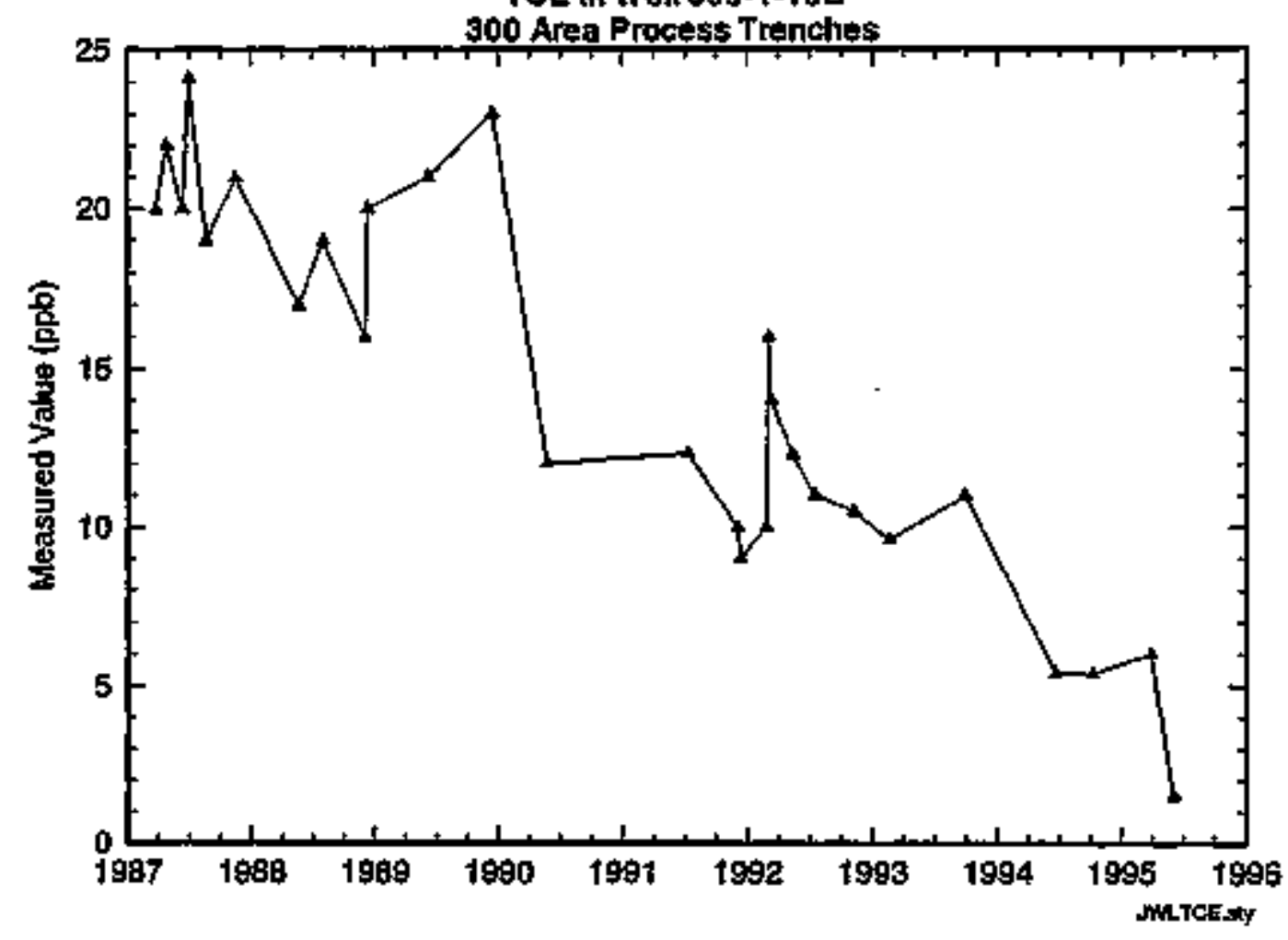


DOE/RL-96-01, REY. 0

Figure 6.1-3. CIS-DCE in Nell 399-1-16B, 300 Area Process Trenches.

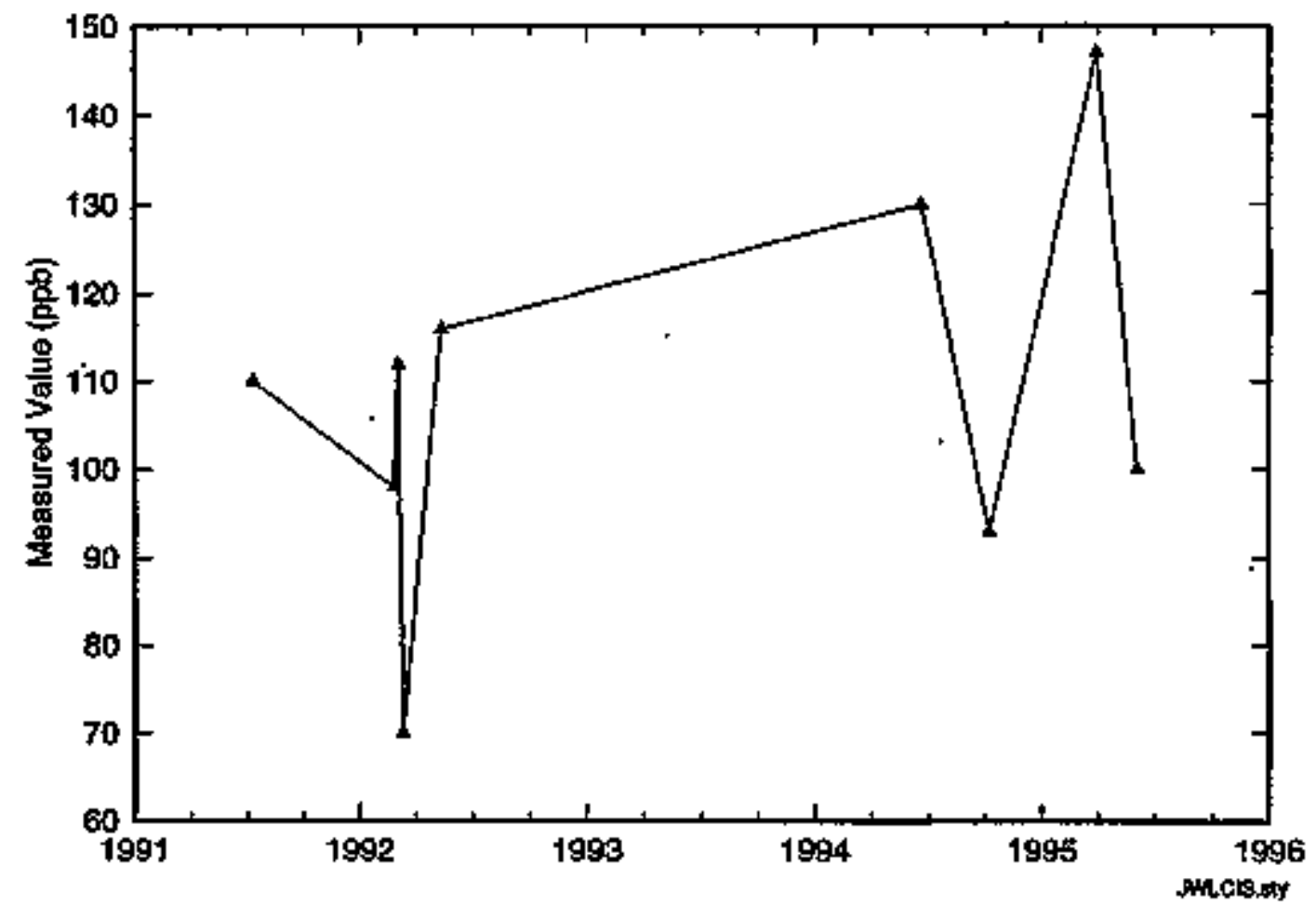

$6.1-10$ 
DOE/RL-96-01, REV. 0

Figure 6.1-4. Uranium in Well 399-1-17A, 300 Area Process Trenches.

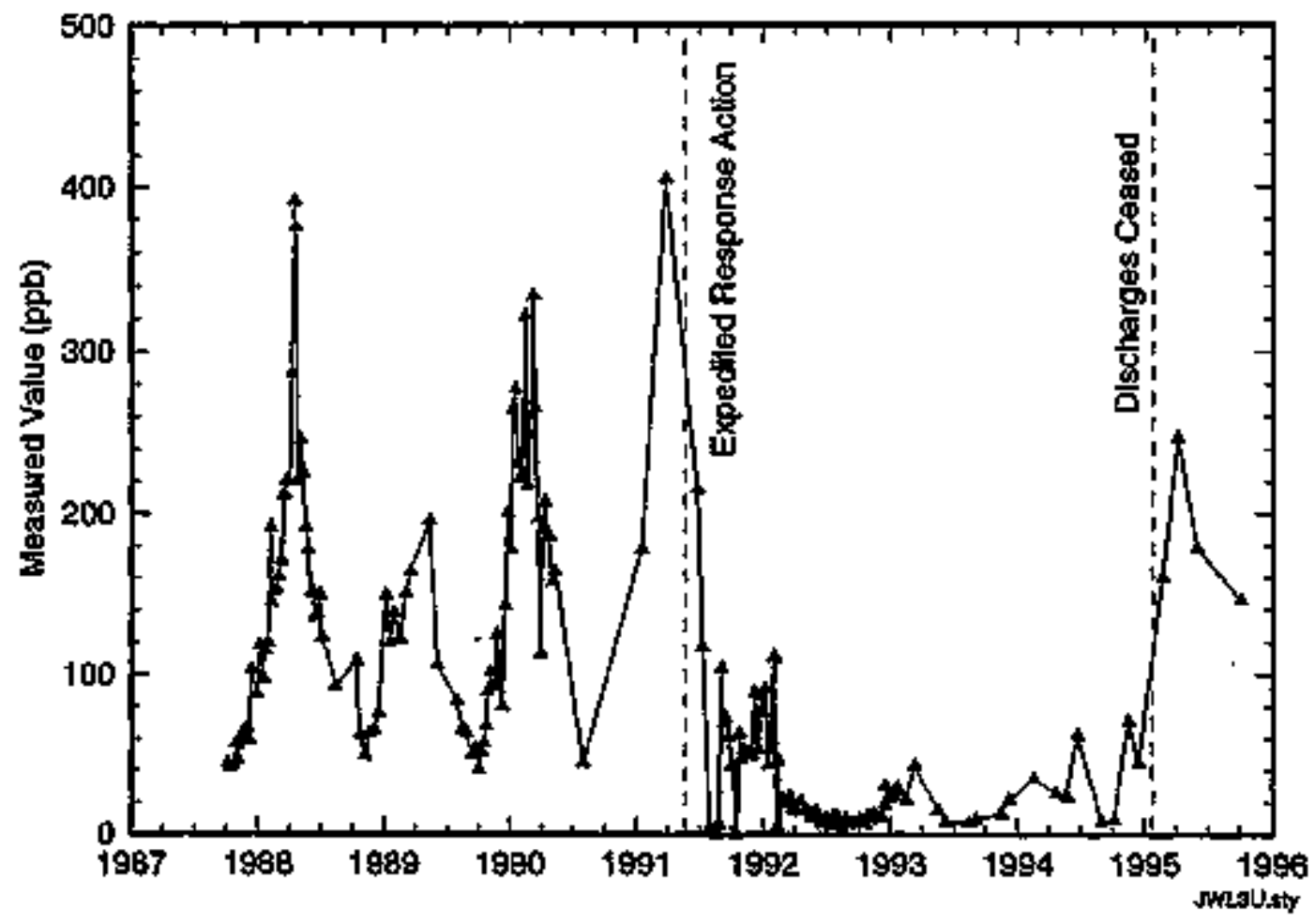


Figure 6.1-5. Uranium Plume, 300 ATP, June 1995.

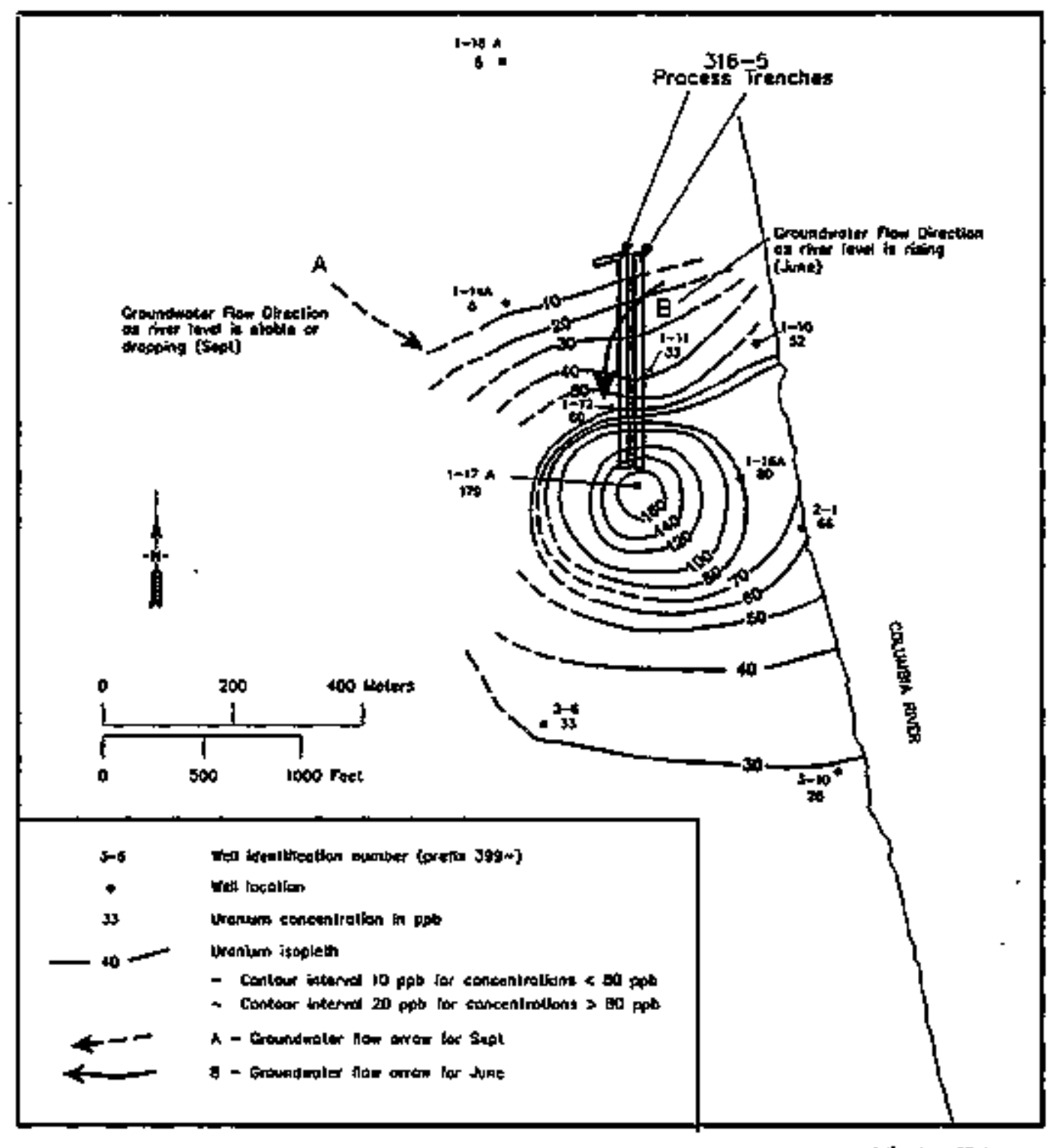

intupuenteg5.tum 
Figure 6.1-6. Water TabTe Elevation Map, June 26, 1995.

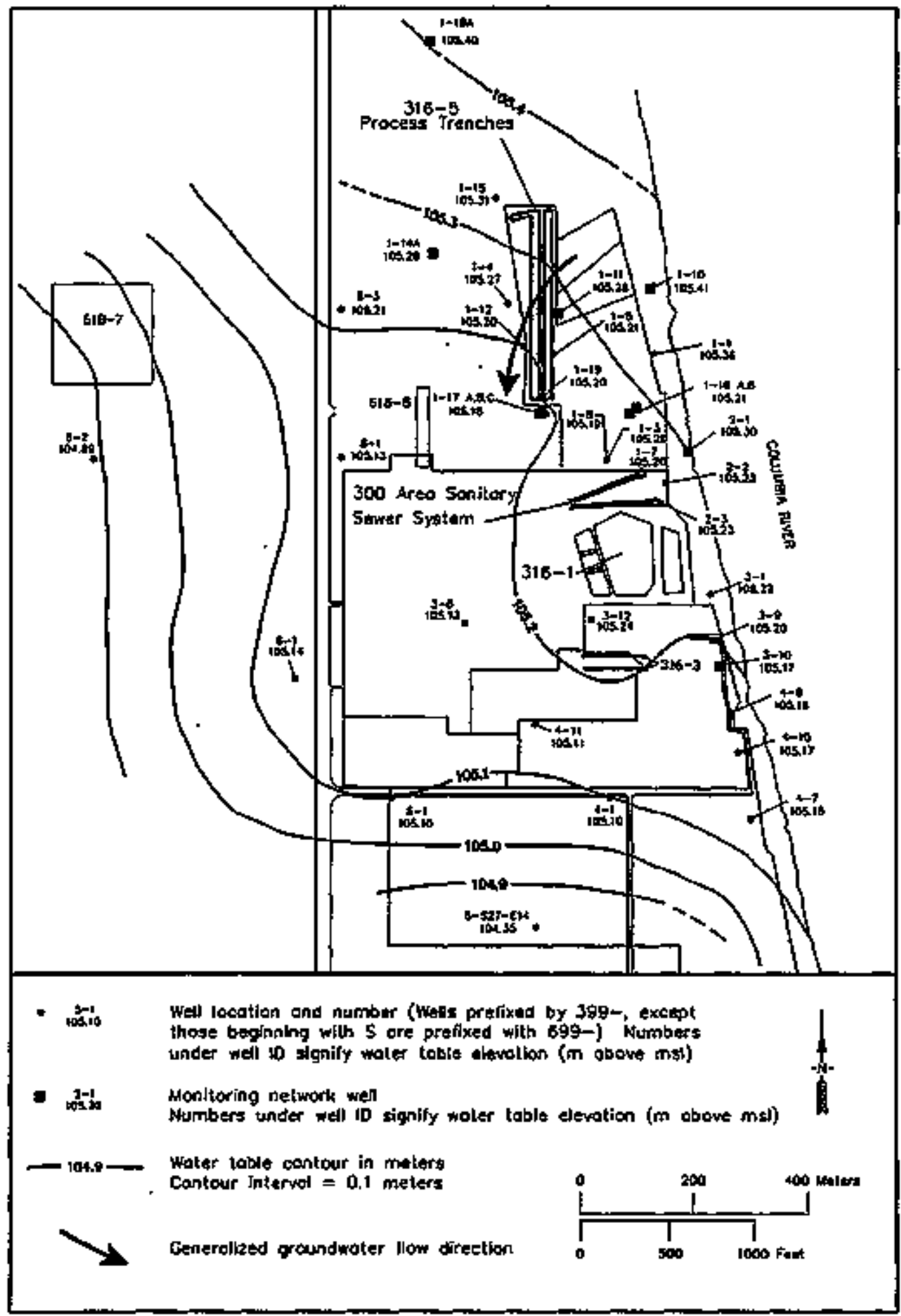

imsooghudang 
Figure 6.1-7. Water Table Elevation Nap, September 5, 1995.

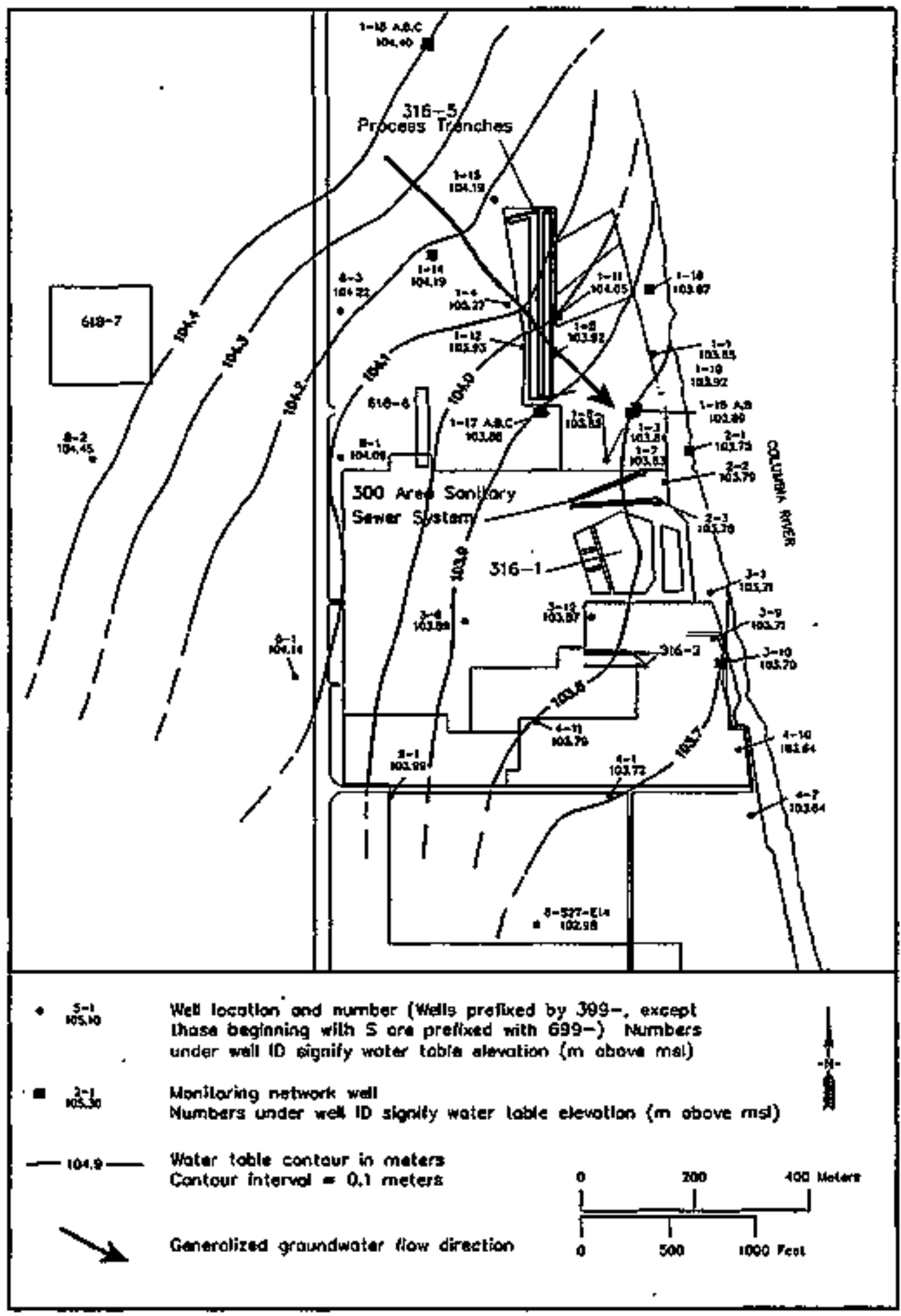

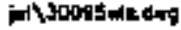


Table 6.1-1. Monitoring Kells Used for the 300 Area Process Trenches.

\begin{tabular}{|c|c|c|c|c|}
\hline Wel] & Aquifer & $\begin{array}{l}\text { Sampling } \\
\text { frequency }\end{array}$ & $\begin{array}{l}\text { Water } \\
\text { levels }\end{array}$ & $\begin{array}{c}\text { Well } \\
\text { standards }\end{array}$ \\
\hline $399-1-10 A^{85}$ & Top of unconfined & SA & Q & RCRA \\
\hline $399-1-11^{86}$ & Top of unconfined & $5 A$ & $\bar{q}$ & RCRA \\
\hline $399-1-12^{186}$ & Top of unconfined & SA & $\mathbf{Q}$ & RCRA \\
\hline $399-1-14 A^{86}$ & Top of unconfined & $\$ A$ & Q & RCRA \\
\hline $399-1-16 A^{86}$ & Top of unconfined & $\overline{S A}$ & Q & RCRA \\
\hline $399-1-168^{67}$ & Bottom unconfined & \$A & $\bar{Q}$ & RCRA \\
\hline $399-1-17 A^{86}$ & Top of unconfined & $\mathbf{Q}$ & 9 & RCRA \\
\hline $399-1-178^{86}$ & Botton unconfined & SA & $\vec{Q}$ & RCRA \\
\hline $399-1-18 A^{86}$ & Top of unconfined & SA & $Q$ & $\overline{R C R A}$ \\
\hline $399-2-1^{48}$ & Top of unconfined & $\mathrm{SA}^{\mathrm{B}}$ & Q & $\overline{\text { PRE }}$ \\
\hline $399-3-10^{76}$ & Top of unconfined & $\mathrm{SA}^{\mathrm{a}}$ & $Q$ & PRE \\
\hline
\end{tabular}

Notes: Shading denotes upgradient we11s. Superseript following well number denotes the year of installation.

- Well is sampled for supporting data.

PRE = we11 was constructed before RCRA-spec1fied standards.

$Q=$ frequency on a quarterly basis.

RCRA - well is in compliance with RCRA standards.

$S A=$ frequency on a seniannual bas 1 s. 
Table 6.1-2. Constituents Analyzed in the 300 Area Process Trenches.

\begin{tabular}{|c|c|c|}
\hline \multicolumn{3}{|c|}{ Contamination indicator parameters } \\
\hline $\begin{array}{l}\text { pH } \\
\text { Specific conductance }\end{array}$ & $\begin{array}{l}\text { Total organic carb } \\
\text { Total organic halo }\end{array}$ & \\
\hline \multicolumn{3}{|c|}{ Groundwater qualfty parameters } \\
\hline $\begin{array}{l}\text { Chloride } \\
\text { Iron }\end{array}$ & $\begin{array}{l}\text { Manganese } \\
\text { Sodjum }\end{array}$ & Sulfate \\
\hline \multicolumn{3}{|c|}{ Drinking water parameters } \\
\hline $\begin{array}{l}\text { Arsenic } \\
\text { Bariug } \\
\text { Beta-BHC } \\
\text { Cadalum } \\
\text { Chromium }\end{array}$ & $\begin{array}{l}\text { Coliform bacteria } \\
\text { Fluoride } \\
\text { Gross alpha } \\
\text { Gross beta } \\
\text { Lead }\end{array}$ & $\begin{array}{l}\text { Mercury } \\
\text { Mitrate } \\
\text { Radium } \\
\text { SeTenfum } \\
\text { Stlver }\end{array}$ \\
\hline \multicolumn{3}{|c|}{ Site-specific and other parameters } \\
\hline $\begin{array}{l}\text { Alkalinity } \\
\text { Aluninum } \\
\text { Antinony } \\
\text { Berylilum } \\
\text { Bronide } \\
\text { Caiciun } \\
\text { Cobalt } \\
\text { Copper }\end{array}$ & $\begin{array}{l}\text { Gamma scan } \\
\text { Isotoplc Uranfum } \\
\text { Magnestum } \\
\text { Nicke1 } \\
\text { N1tr1te } \\
\text { Phosphate } \\
\text { Potassium } \\
\text { Strontium }\end{array}$ & $\begin{array}{l}\text { Strontium } 90 \\
\text { Tin } \\
\text { Tritju: } \\
\text { Uranium } \\
\text { Vanadiug } \\
\text { Volatile organics } \\
\text { Zinc }\end{array}$ \\
\hline
\end{tabular}


DOE/RL-96-01, REV. O

\section{APPEADIX A}

QUALITY COATROL PROERAY

A- $\mathbf{i}$ 
DOE/RL-96-01; REV. O

This page intentionally left blank.

$t$ 


\title{
A.0 QUALITY CONTROL PROGRAY
}

\author{
H. Hampt/C. J. Chou/T. X. Mashington \\ West inghouse Hanford Company
}

\section{A.1 INTRODUCTION}

The Resource Conservation and Recovery Act of 1976 (RCRA) Qualjty Controt (QC) program is based on gutidance from the U.S. Environmental Protection Agency (EPA), the Resource Conservation and Recovery Act (RCRA) Groundwater Nonitoring Technical Enforcenent Guidance Document (EPA 1986a), and Chapter 1, "Quality Control," from Test Methods for Evaluating Solid Waste (EPA 1986b).

\section{A.1.1 Data Qual1ty object Ives}

The QC progran uses the five measures of data quality: precision, accuracy, representativeness, corpleteness, and corparability, along with appi Icable program-specific quality parameters to evaluate the quality of the data and the analytical laboratories analyzing the samples (WHC 1992a). Target values for precision and accuracy are specified in the Quality Assurance Project Pfan for RCRA Groundwater Monftoring Activities (NHC 1992b).

1. Precisfon is evaluated using data results from laboratory duplicates, matrix spike duplicates (see Section A.3), field duplicates, and blind samples (see Section A.2).

2. Accuracy is evaluated using data results from laboratory matrix spikes; laberatory control samples; EPA Water Pollution (NP). Water Supply (WS), and intercomparison studies (see Section A.3); and by biind samples (see Section A.2).

3. Representativeness expresses the degree to which RCRA facility groundwater samples represent the actual composition of the groundwater in the aquifer, coals for data representativeness for groundwater monitoring programs are addressed qualitatively by the specification of well construction, sampling locations, sampling Intervals, and sanpling and analysis techniques in the groundwazer monitoring plan for each RCRA faciTity.

4. Completeness is defined as the percentage of measurenents that are fudged to be valid. Completeness is determined by the number of data unflagged during the validation process, divided by the total number of data evaluated, and multiplied by 100 . The calcutated percentages used in reporting completeness are conservative because all values f1agged with $F, H, P, Q, R$, and $Y$ are used in calculating the percent complete. These flags point out potential problems related to data quality, but do not necessarily inval idate the data.

5. Conparability is the confidence with which one data set can be compared to another. Idealiy, it should be evaluated using 
replicates to ensure that samples analyzed by different laboratories or by the same laboratory over different time periods are comparable. The primary hazardous chemistry laboratory was requested to analyze samples and submit data for most of 1995; however, between March 15, 1995, and April 30, 1995, another hazardous chenistry laboratory analyzed samples and submitted data. Before using the second laboratory, laboratory procedures from both laboratories were compared to determine if the procedures were based on the same reference methods. The procedures for constituents of concern were examined individually to ensure comparability. A comparison of the method detection linits (MDL) was a] so conducted. Contractua] administrative controls were put in place with the second laboratory to make the contracts as simflar as possible. Ho split samples were sent to the two laboratories.

For 1995, two different Taboratories were used for total organic halogen (TOX) measurements. The methodology used by the two laboratories was similar; however, some differences have been noticed in the data (Section A.2).

On]y the primary radiochemistry laboratory was used for radiochenical analysis in 1995 .

Samples were analyzed in accordance with rest Nethods for Evaluating Solfd Waste (EPA 1986b) and other appl tcable approved methods. Comparabil ity of fjeld measurements is determined by following approved sampling procedures that ensure consistency among sampling events.

\section{A.2 EXTERUAL QUALITY CONTROL PROGRAM}

The external QC progran uses three ktnds of QC samp]es to evaluate quality in the field and laboratory. These are field duplicates, field blanks, and blind samples.

The analytical results of QC samples are judged to be acceptable if the following evaluation criteria are met.

- Field duplicates--Results of field duplicate pairs must have precision within 25\%, as measured by relative percent difference (RPD). Beginning with the April to June 1995 guarter, the criterion for RPD has been changed to $20 \%$ and only results that are quantifiable wil] be evaluated (WHC 1995).

- Blanks--Four kinds of blanks are used to check for contanination resulting from field activities and/or bottle preparation. These are full trip, daily trip, field transfer, and bottle blanks. Beginning with the July to September 1995 quarter, daily trip and transfer blanks were combined (WHC 1992d). The RCRA Groundwater Monjtoring program's primary regulatory and gutdance documents provide no requirement for daily trip blanks as they were previously collected. The new field trip blanks serve as trip 
blanks, but because they are collected at the well rather than in the Tab, more meaningful information is provided.

Except for common Taboratory contaminants, results above the 1 imit of two times the Nol are identified as suspected contamination. For common laboratory contaminants, such as acetone, methylene chloride, 2-butanone, toluene, and phthalate esters, sanple results greater than five times the HDL are identified as suspected contamination.

- Blind safiples--Blind samples are periodicaliy forwarded to the laboratories to eva]uate the laboratory performance (WHC 1992b).

Table A-l provides a sumpary of the field duplicate and field blank resutts evaluated for 1995 .

Tabies A-2 and A-3 summarize the total nember of field blanks and field duplicates outside of the OC ?init per method for 1995. The numbers listed in TabTes $A-2$ and A-3 were calculated from the tables used to prepare the first-, second-, and third-quarter-1995 quarteriy reports and regenerated QC tables from the fourth quarter 1994. The regenerated QC tables are not identical to those used for the fourth-quarter-1994 gearterly report. Wathods not 1 isted in Tabies A-2 or A-3 were 100\% acceptable for field blanks or field duplicates.

Throughout the year almost a]l the field blank constituents had Tow percentages of resuits exceeding QC 1 inits. One exception was turbidity. Winety-five percent of the turbidity results exceeded the QC 1 irits. Problems with turbidity have existed for several years. Midway through 1995, Iaboratory analysis of turbidity ceased. Turbidity measurenents are now taken in the fietd. Heasures have been taken to ensure reliability of data. For example, at certain problen wells, pusping rates have been slowed in order to acheive lower turbidity readings. In general, samplers now contact project scientists for guidance wen field turbidity measurements are outside the expected range.

Many field duplicate results for total organic carbon (TOC), turbidity, gross alpha, gross uranitum, and lead exceeded the QC 1 tutt. For TOC, turbidity, and lead, al1 of the exceedences were from the fourth quarter of 1994 and the first quarter of 1995 when nonquantifiable data were stiti used In the evaluation of QC results. For gross alpha, the percentage of flagged duplicates dropped from 35.7 to 11.8 between the first and second halves of the year. The percentage of flags for uranfum remained high. Expecting duplicate results near the detection limit to fall with in the former $\pm 25 \%$ RPD criterion was unrealistic and led to misleading data fiags. Results close to the MOL, or MDC are not quantifiable and precision in the region is poor. Durfing the first half of the year, before the change in the evaluation criteria, $8.7 \%$ of duplicate data were flagged. For the last two quarters of this year, $0.1 \%$ of duplicates have been fiagged.

Performance evaluation (PE) samples were sent out each quarter during the annual reporting perlod. Standards for ToX, ToC, inductively coupled p]asna metals (ICP), anions, and volatile organic analytes (VOA) were sent out during the reporting perlod. The ICP standards were spiked with iron, zinc, 
manganese, and chropium. The voA standards were spiked with carbon tetrachloride, carbon disulfide, benzene, and toluene. The anton standard contained nitrate. Fifteen of the 16 samples were sent to the primary hazardous chemistry laboratory. Only nine of the results recelved from the primary hazardous chentstry jaboratory were acceptable. The 1aboratory had unacceptable results twlce for TOX and once each for TOC, 1ron, zinc, and chromium. The TOX PE results were btased low. Results that seem to be btased low were reported for the NRONL and SWL projects. The impact of this bias is discussed in the sections for NRDWL and SWL in this report. WHC is evaiuating whether a new laboratory for TOX should be selected.

\section{A.3 IMTEBNAL QUALITY CONTROL PROERAM}

The internal QC program uses five types of QC data to establish and monitor performance in the laboratory. These data are laboratory blanks, matrix spikes, watrix duplicates, matrix spike duplicates, and EPA studies (WP, WS, and intercomparisons).

Every quarter the contracted Taboratories supply thetr own QC reports, in the fork of precision and accuracy, which include data quatity information on matrix spikes, matrix duplicates, matrix spike duplicates, and bianks. The contracted laboratorles also report their results for the EPA's WP, WS, and radiochemical intercomparison studies quarterly. The results of EPA studtes independentiy verify the level of laboratory performance and are expressed as the percentage of EPA-accepted results. Each ha7f-year the contracted laboratories also supply an $\mathrm{MDL} /$ minimum detectable concentration (MDC) report. In the future the hazardous chemistry laboratory wili only provide one MDL report per year. The MULs and MDCs are required to be below the contractualiy required quantitation $1 \mathrm{imit}$ (CRQL). The CRQL is not associated with a quantitation 7 imft as the name suggests; it is intended to be the lowest analyte concentration in a given matrix that a laboratory can be expected to detect consistently. The CRQL is agreed on under the contractual statement of work. A laboratory nonconformance report (HCR) is issued when the MDL is greater than the CRQLL. Westinghouse Hanford Company (WHC) QC team reviews each of these reports and summarizes the results in this section.

Results from the EPA water polfution, water supply, and Intercomparison studies are summarized in Table A-4. The EPA studies do not necessarily include an evaluation of laboratory performance for al1 constituents of concern to the RCRA program, but the EPA studtes do give an Idea of whether or not the laboratory is in control for those constituents that are included in the studies.

Radtochemistry precision and accuracy figures are provided in the radiochealstry laboratory's quarterly report, with percent acceptability calculated from duplicates and spikes, respectively. These results are summarized in Table A-4. The precision and accuracy results indicate the performance of all customers submitting water matrix samples. WHC samples represent on]y a part of the performance summary. 


\section{A.4 MOHCOMFORMANCE/IHCIDEMT REPORTS}

HCR and incident reports are methods of documentation by which contract laboratories can inform laboratory contractors and their customers of any probiems encountered with the analysis, data, and/or data deliverable. This methed of documentation is intended to jdentify occurrences, deficiencies, and/or issues that may potentially have an adverse effect on the data integrity. These may include, but are not $l$ inited to the following:

- Lost sample

- Broken bottles

- Instrument mal functions

- Calibration standards out of acceptable range

- Laboratory control standards out of acceptable range

- Matrix spike recovery out of acceptable range

- Blank contamination

- Procedural noncoripl iance

- Chain-of-custody discrepancies

- Shipping tenperatures out of acceptable range

- Hisreported data.

During the 1995 reporting year 43 NCR and inctdent reports were transmitted, affecting 246 data points. There were 40 reports transmitted by the hazardous chemisiry laboratory and 3 reports transmitted by the radiochemistry laboratory. The reports represent a $50 \%$ decrease in the number of incjdent reports transmitted during fiscal year 1995 as compared to ftscal year 1994. The reports describe incidents that affect either groundwater samples or externat QC samples (e.g., trfp blanks).

The reports transnitted by the hazardous chemistry laboratories affect 241 data points, 68 of which were rejected. The rejected data were primarily attributed to broken sample containers received at the laboratories. Additionaliy, 173 analytical results were evaluated as being suspect. These data points should be used for trending purposes only. The suspect data are primarily attributed to the development of air in the ToX sample bottles. Per SW-846 the JOX should have no head space at the time of collection, to prevent the potential loss of volatiles. The samples were noted as not having air at the tine of collection, but the samples had developed air bubbles by the time they arrived at the laboratory. The reason for this phenomenon is under investigation, however each sample that developed air was noted and flagged as bejing suspect.

The reports transmftted by the radiochemistry laboratory affect five data points, four of which were rejected. Three of the rejected radiochenlstry datz points were attributed to sample bottles being broken, the fourth data pofnt was caused by Taboratory contanination. The suspect data point is attributed to sample matrix effect that prevented the laboratory from achieving contractual detection limit. The incjient reports received from the laboratories during this reporting year have been instrumental in identifying potential issues for laboratory surveillances. 


\section{A.5 QuALITY ASSURANCE OCCURRENCES}

Quality assurance (QA) occurrences are situations that potentialiy affect the quality of the data. These situations are discussed through sumbartes of inspections of laboratory services and/or systen and performance audits/survetil lances. Inspection of laboratory services and/or system and performance audits/surveillances for the RCRA groundwater monitoring program are performed throughout the year by the laboratory contractor, the U.S. Department of Energy on varjous aspects of this program. QA requirements and data qualjty objectives are deftned in the Quality Assurance Project Plan for ACRA Groundwater Nonitoring Activities (WHC 1992b). Results of these oversight activities are docurented with the audit/ surveiltance and/or inspecting organization(s).

During the 1994 reporting period, WHC performed three inspections in conjunction with the contract administrator (i.e. PNil). Results of the jnspections were classified as findings and observations and were discussed in the 1994 RCRA Annua] Report. In February 1995 the contract administrator eva]uated the hazardous chemistry laboratories responses with respect to each of the findings and observations. As a result of this evaluation, three of the findings were reclassified as observations (see discussion for observations $\$ 3, * 4$, and $\$ 5$ below); two of the findings were withdrawn; and one of the findings was addressed by corrective action taken by the laboratories. The details of the report are provided below.

FINDING F Fllay94.121 The Contractor failed to track and verify implementation of corrective actions, as required by the contract

This Finding is withdrawn and changed to an observation.

Please refer to "Ohservation 3 " for discussion.

FINDIn6 * F2yay94.121 Noncomplitances were found with the hazardous chentstry laboratories procedures governing document controt. hu\}tiple instances were found of effective dates for procedures preceding approval dates

This Finding is withdrawn and changed to an observation.

Please refer to "Observation $4^{\text {* }}$ for discussion.

FINDILG * F3Hay94.121 Monconpliances were found with the impleantentation of the contractual requirenent for annua] review of procedures

Thts Finding is withdrawn.

Corrective actions were in process for 1994 procedure reviews; it appears that the hazardous chemistry laboratory is adequately addressing this issue and understands the need to continue its annual review of procedures. 
FIMOING \# F4hay94.121 Deficiencies exist in the traceability to specific procedures and standards used for the amalysis of samples

This Finding is withdrawn.

The contract administrator will require that al data be traceable to specific analytical procedures (including revision dates) in the forthcooing operations Year Statement of Work.

FINDINB * F5lay94.121 Moncompl lances mare found to procedural and contractual requirements of training

The corrective action provided for this finding is acceptable. Future inspections will evaluate implementation of the laboratory's corrective action in this area.

FINDIMG * F6Hay94.121 Deffciencies and inconsistencies exist in the controt charting and tracking for both analysis and reporting purposes

This finding is withdrawn and changed to an Observation.

Please refer to "Observation_5" below for discussion.

\section{OBSERVATIONS}

The Laboratory ts reminded that, in inspection, observation is a conclusion that presents the results of a generaily subjective evaluation of Implexentation practfces or management systems related to the area under review. An Observation may or may not relate to specific noncompliance(s) with contractual requirements but is based on the inspector's evaluation of factual evidence.

OBSERUATION NO, 1 The contract Taboratory was unable to clearly explain the responsibilities of its oh organization as applicable to MHC samples.

This Observation is withdrawn.

The contract administrator will reevaluate this issue during the next Inspection of Services. The evaluation will be based on the laboratory's internal procedures and Appendix B, Section I of the contract that required the organizational structure, functional responsibilities, level of authority, and lines of communfcation for the activities affecting quality that are to be documented. Such documentation must be consistent with the current practices within the laboratory.

OBSERVATION MO. 2 It was unclear whether the 1aboratory has an effective program in place to control contamination

This Observation is withdrawn. 
The contract administrator will make a contract change in fortheoming documentation that is expected to resolve the issues jnvolved. The "Contractual Required Quantitatton Limtt" (CRQL) will be changed to a "Contractual Required Detection Lim1t" (CRDL) and blank acceptance criteria will be tied to the CROL.

NOTE: The following observations did not appear in the original report and are the result of reclassifying three of the original findings as observations.

08SERVATION 15. 3 The Contractor falled to track and verify implomantation of corrective actions, as required by the contract

The laboratory acknowledges that the specific corrective action to the August 1993 Finding and observations taken was different from that committed to in its correspondence to the contract administrator dated March 24, 1994 . The contract administrator recognized that corrective actions cannot always be implemented as committed. However, the laboratory's changes to corrective action commitments could result in additional conditions that could adversely affect quality.

The contract administrator expects the hazardous chemistry laboratory to work toward improving its system for follow-up of corrective action commitments and notify the contract administrator in a more timely manner when changes to commitments are made (e.g., when it is determined the original/committed corrective action is not appropriate). The laboratory mast recognize that such changes are made at its ow risk and the possibility extsts that, on occasion, a change may be questioned and justification of the validity of the data may be requested.

A good example of how this could work is provided in the laboratory's May 12, 1994, correspondence to the contract administrator. If the changes addressed in this letter had been communicated to the contract adainistrator before the Hay 2-6 Inspection of Services, the inspection team would have had confidence in the laboratory's corrective action/follow-up system. Most of these changes were known by the laboratory before the inspection.

OBSERVATIOH NO. 4 Honcompliances were found with the hazardous chemistry laboratories procedures governing document controf. Multiple instances were found of effective dates for procedures preceding approval dates

In several instances, approval signatures' dates were later than the effective date of the procedure. These instances included administrative procedures, analytical procedures, and the laboratory's Enviromiontal Cheoristry Quality Assurance Program P1an, QA-2/83 revised 6/92. The discrepancy did not appear to affect the quality of the deliverable and implementation of the subject procedures was within a short time after the effective date. However, the laboratory should ensure in the future that indicated effective dates do not precede approval dates. 
DOE/RL-96-01, REV. 0

OASERVATION NO. 5 Inconsistencjes were noted in the control charting and tracking for both analysis and reporting purposes of the laboratory's QC. Progran.

Significant background Information has a7ready been addressed in the contract administrator's Septenber 6, 1994, Inspection of Services Report and in the laboratory's October 17, 1994, Response (Ref. 94p900) that addresses the complex and varied issues involved in this observation. The Jaboratory acknowledged that opportunity for inproventents existed in their QC Progran. Therefore, it is recommended that the technical parties invoived communicate directly on these issues to finalize the 1aboratory's control charting and tracking QC program. Any changes must be authorized through a formal contract modification.

The laboratory's committed corrective action to this issue is deemed acceptable as a response to this observation and is repeated below for follow up and verification.

"The laboratory will continue to develop and refine the existing computerized QC syston (with accompanying guideitines and documentation) such that specifications of the contract administrator are satisfied. Significant improvenents have been effected at the lab tn the last few neeks. As the program is finalized, the 1 ab will provide the contract adninistrator with documentation and details in an effort to provide a product that is considered acceptable."

The second inspection of services was performed July 6-8, 1994, at the radlochemistry laboratory. The third survet1lance was performed August 8-10, 1994, at the subcontracted laboratory responsible for analyses such as coljform, antons and biological oxygen demand. The official audit report has not been transmitted by the contract administrator. NHC has requested an official statement from the contract administrator to provide the status of these two surveillances.

Sampling and_Analysis

During the 1995 reporting period (October 1, 1994 to September 30, 1995), wh retajned the sampling activities and analytical services. RCRA sampling activities had previously been subcontracted to Pacific Horthwest Hational Laboratory (PMAL) by WHC. The analytica] services were also procured by WHC through PAHL analytical contracts.

In January, 1995, WHC began perforning al1 RCRA sampling activities. An internal survetiliance was performed in Jume to evaluate the WhC samplers on the preparation for a sampling event at RCRA we7]s. The surveiliance covered operator calibration of instruients for monitoring field paranteters, well purging, acquisition of field parameters, sample collection, chain of custody and welj securfty.

Initially there was a concern about the calibration (standardization) status of the E-tape used to deteraline the elevation of the groundwater. Note, there is a regulatory requirement to determine the elevation of grotindwater each time sampies are collected. The E-tape was 1ater determined 
to be in calibration. There were no findings or observations frow the survetiliance.

The analytical services were transitioned to WHC contracted laboratories in April, 1995. Per DOE direction the analytical services were transitioned back to PNNL contracted laboratories in May 1995.

\section{A.6 LIMIT OF DETECTION, LIMIT OF QUAMTITATION, AND WETHOD OETECTION LIMIT-C. J. Chou}

The concentration at which an analyte can be detected depends on the variability of the blank response. For purpose of this discussion, the 'blank' is taken to be a method blank. The liajt of detection (LOD) is defined as the lowest concentration level that is statistically different from a blank (Currie 1988). In general, it is calculated as the mean concentration in the biank plus three standard deviations of that concentration (EPA 1987). The blank corrected LOD is simply three times the blank standard deviation. At three standard deviations from the blank mean, the false posittve error rate and the false negative error rate are each about $7 \%$ (Mijler and Niller 1988). A false positive error is an instance when an analyte is declared to be present but is, in fact, absent. A false negative error is an instance when an analyte is declared to be absent but is, in fact, present.

The Timit of quantitation (LOQ) ts deftned as the level above which quantitative results may be obtained with a spectfied degree of confidence (Keith 199I). It is calculated as the blank mean plus 10 standard deviations of the blank (EPA 1987). The biank corrected LOQ is 10 times the blank standard deviation. The $L O Q$ is most useful for defining the lower limit of the usefui range of concentration measurement technology. When the analyte signal is 10 times larger than the standard deviation of the blank measurements, there is a 95\% probability that the true concentration of the analyte is $+25 \%$ of the measured concentratton. The LOD and LOQ are shown graphicaliy in Figure A-1. For purpose of illustration, the numbers appearing in this figure are the respective biank mean, LOO, and LOQ for TOC and TOX (see Tables $A-5$ and $A-6$ ).

The MDL is defined as the minimum concentration of a substance that can be measured and reported with a $99 \%$ confidence that the analyte concentration is greater than 0 . The $\mathrm{HDL}$ is determined from analysis of a sample in a given matrix containing the analyte (Currie 1988). The NDL is 3.14 times the standard deviation of the results of 7 repicates of a 10w-ievel standard. Hote that the MOL as deftned here is based on the variability of the response of low-level standards rather than on the variability of the blank response.

For this RCRA annua] report, TOC, TOX, and radionuclide field blank data are available for LOD and LOQ determinations. The field bianks are quality control samples that are introduced into a process to monjtor the performance of the system. The use of field blanks to calculate $L O D$ and $L O Q$ is preferred over the use of laboratory blanks because fie]d blanks provide a measure of the errors in the entire sampling and analysis system. Methods to calculate LOO and LOQ are described in detaj1 in DOE-RL' (1991, Appendix A). TOX samples have been anslyzed by Batachem Laboratories (DCL) of Salt lake City, Utah since June 1995. Only ToX blanks analyzed by OCL were used in the LOO/LOQ 
DOE/RL-96-01, REV. 0

determination. The results of the $L O O$ and $L O Q$ determinations for 1995 RCRA sampling at the Hanford Site are shown in Tables A-5 through A-17.

Because blanks data are lacking for other constituents of concern, MHC deemed it necessary to calculate approximated $\angle O D$ and $L O Q$ values using variabiltty information obtained from low-level standards. As shown in Flgure A-1, the values along the horizontal axis are measured in units of 'standard deviation' of the measurement process (1.e., based on well-known blank). If Tow-level standards are used, the variability of the difference between the sample and blank response is increased by a factor of $\sqrt{2}$ (Currte 1988, p. 84). The formutas are summarized below:

$$
\begin{aligned}
\text { HOL } & =3.14 * s \\
\text { LOD } & =3 *(\sqrt{2} * s) \\
& =4.24 * s \\
\text { LOQ } & =10 *(\sqrt{2} * s) \\
& =14.14 * s
\end{aligned}
$$

where $s$ denotes standard deviation from the seven repilcates of the low-level standard.

The results of $\mathrm{MDL}, \mathrm{LOD}$, and LOQ calculations, for other constituents of concern, are shown in Table A-18.

\section{A.7 QUALITY CONTROL DEFIMITIOAS}

Accuracy--The closeness of agreenent between an observed va]ue and a true value. Accuracy is assessed by means of reference samples and percent. recovertes.

Bi find sample--A sample that contains a concentration of analyte that is known to the suppiier but unknown to the anajyzing laboratory. The analyzing laboratory is informed that the sample is a QC sample and not a field sample. The blind, the double blind, and the natrlx-matched double blind samples are used to assess accuracy and monjtor the performance of the analytical 1 aboratory(tes) with prepared or purchased materials from EPA QC samples/ concentrates or primary materials.

Bottle blank-A sample that contains only Type II reagent water. The bottle blank contalns one sample for each bottle size, with at least enough bottles to include all constituents analyzed by a specific project, except radionuclides. Bottle blanks shall be submitted to the prifrary laboratory per lot of bottles. Bottle blanks are filled in the analyticaj 1aboratory under the sample preparation procedures. Bottle blanks do not go into the field. 
Contractually required quantitation 1 init--A value fntended to be the lowest analyte concentration in a given matrix that the laboratory can be expected to achieve consistently; agreed on under the contract statement of wark.

Daily trip blank--A sample that contains only Jype II reagent water. The dajly trip blank is used to check for sample contamination by volatile organic compounds arising from conditions encountered during the collection of samples. The daily trip blank is not opened in the field. One daity trip blank is collected for each day sampling occurs.

Double blind sample--A sample that contains a concentration of analyte that is known to the supplier but is unknown to the analyzing laboratory. The analyzing laboratory is not informed that the sample is a QC sample. AII attempts are made to make this sample appear like a field sample. For example, the double blind sapple should be submitted to the laboratory wfthin the same time period and with a sample ldentiffeation number similar to that of the field samples. The double blind sample does not include matrix utching.

External quality control samplo-Any QC sample prepared without the know]edge of the analytical laboratory.

Field duplicate sample--A sample used to determine repeatability of an analytical measurement on identfcal samples collected as close as posstble to the same time at the same location. These samples are stored in separate containers and are analyzed independently by the same laboratory.

Field transfor blank--A sample that contains only Type II reagent water. The blank fjeld transfer blank is used to check for sample contamination by volatile organic compounds arising from conditions encountered during the collection of sanples. The field transfer blank is taken during the collection of samples. The fleld transfer blank is filled at the sampling stte by pouring Type II reagent water from a cleaned container into a volatile organtc analysis vial. At least 1 field transfer biank is collected for each 20 samples, or 1 per sampling batch.

Field trip blank--A sample that contajns only Type II reagent water. At the time of sample collection, the field blank is filled at the sampling site by pouring Type II reagent water from a cleaned container into volatile organic analysis (VOA) vials. After collection, the field trip blank is treated in the same manner as the other samples collected durting the sampling event. Field trip blanks are collected only on days when samples are collected for VOA.

Full trip biank--A sample that contains only Type II reagent water and preservatjue, as required. A full trip biank is used to check for contamination in sample bottles and sample preparatjon. The fuli trip blank is analyzed for all constituents of interest on all types of sample bottles used during that sampling period. The frequency of collection for a full trip b] ank is 1 per 20 samples, or 1 per sampling batch. A full trip blank is filled in the analytical laboratory under the sample preparation procedures. The full trip blank is not opened in the field. 


$$
\text { DOE/RL-96-01, REV. } 0
$$

Internal quality control sarple- Any QC sample prepared by the anafytical laboratory and used to establish and monitor the qualjty of the analytical laboratory.

Limit of detection--The iowest concentration ievel that is statistically different from a blank. This is calculated by the average blank signal plus three standard deviations for the blank analyses (see Appendix B for more detail).

Hatrix-matched double blind sample--A matrix-matched double blind sample contains a concentration of analyte that is known to the supptier but unknown to the analyzing laboratory. The sampie matrix has been altered to closely. match that of the field samples.

Hethod detection 1 init--The minimun concentration of a substance that can be measured and reported with $99 \%$ confidence that the analyte concentration is greater than zero, and is deternined from analys is of a sample in a given matrix type containing the analyte.

Nininu detectable concentration--Required level of analytical detection for radiochenical samples.

Pracision--The agreentent anong a set of individual measurements of the same property, usually under prescribed stmilar conditions. Prectsion is calculated by using relative percent difference of the duplicate/replicate anaiyses. These samples should contain concentrattons of analyte above the NDL and may lnvolve the use of matrix spikes.

Reljable detection lovel--A detection limtt set at two times the concentration of the NOL, so the risk of both false positives and false negatives fails below $1 \%$.

Type II reagent water--Distilled or detonized water that is free of contaminants that may interfere with the analytical test in question.

\section{A.8 REFEREMCES}

ASTH, 1983, Specifications for Reagent Hater, Procedure 01193-77, American Society for Testing and Materials, Philadelphia, Pennsylvania.

Currie, L. A. (Editor), 1988, Detection in Analytical Chemistry: Importance, Theory, and Practice, American Chemical Society Symposium Sertes; 361, American Chemical Soctety, Hashington, D.C., pp. 17, 79-92.

DOE-RL, 1991, Annual Report for RCRA Groundwater Honitoring Projects at Hanford site Factlities for 1990, DOE/RL-91-03, U.5. Departiment of Energy, Richland Fleld office, Richland, Washington.

DOE-RL, 5994, Annual Report for RCRA Groundwater Konitoring Projects at Hanford Site Facilities for 1993, DOE/RL-93-88, Rev. 0, U.S. Department of Energy, Richland Operations Office, Richland, Nashington. 
EPA, 1986a, Resource Conservation and Recovery Act (RCRA) Groundivater Honitoring TechnicaJ Enforcenent Guidance Document, OWSER-9950.1, U.S. Environmental Protection Agency, Washington, D.C.

EPA, 1986b, Test Hethods for Evaluating Solid Waste, Volume 1A, SH-846, U.S. Environmental Protection Agency, Washington, D.C.

EPA, 1987, A Compendiun of Superfund Field Operations Hethods, EPA/540/P-87/001, OWSER 9355.0-14, U.5. Environmental Protection Agency, Washington, D.C., pp. 16-3 to 16-5.

Keith, L. H., 1991, Environmental Sampling and Analysis: A Practical Gulde, Lewis Publishers, CRC Press, Inc., Boca Raton, Florida, Pp. 93-115.

Miller, J. C., and J. N. Miller, 1989, Statistics for Analytical Chemistry, Second Edition, E111s Horwood Lfmited, Chichester, Eng]and, pp. 115-116.

Resource Conservation and Recovery Act of 1976, 42 USC 6901 et seq.

WHC, 1992a, "Evaluation for Requests for Analytical Data Review," Section 4.2, Environmental Activities, $\mathrm{KHC}-\mathrm{CH}-7-8$, Westinghouse Hanfard Company, Richland, Washington.

WHC, 1992b, "Evaluation of RCRA Groundwater Performance Evaluation Sample Data," Section 2.4, Environmental Activities, WHC-CH-7-8, Westinghouse Hanford Company, Richland, Washington.

WHC, 1992c, "Validation and Verification of RCRA Groundwater Data," Section 2.6, Environmenta? Activities, WHC-CH-7-8, Westinghouse Hanford Company, Richland, Washington.

WHC, 1992d, "Evaluation of RCRA Groundwater Field Duplicate and B1ank Sample Data," Section 2.1, Environmental Activities, MHC-CH-7-8, Westinghouse Hanford Company, Richland, Washington.

WhC, 1995, Quality Assurance Project Plan for RCRA Groundwater Monitoring Activities, WHC-SD-EH-QAPP-001, Rev. 3, Hestinghouse Hanford Company, Rich? and, Washington. 
Figure A-1. LeveTs of Detection and Quantitation.

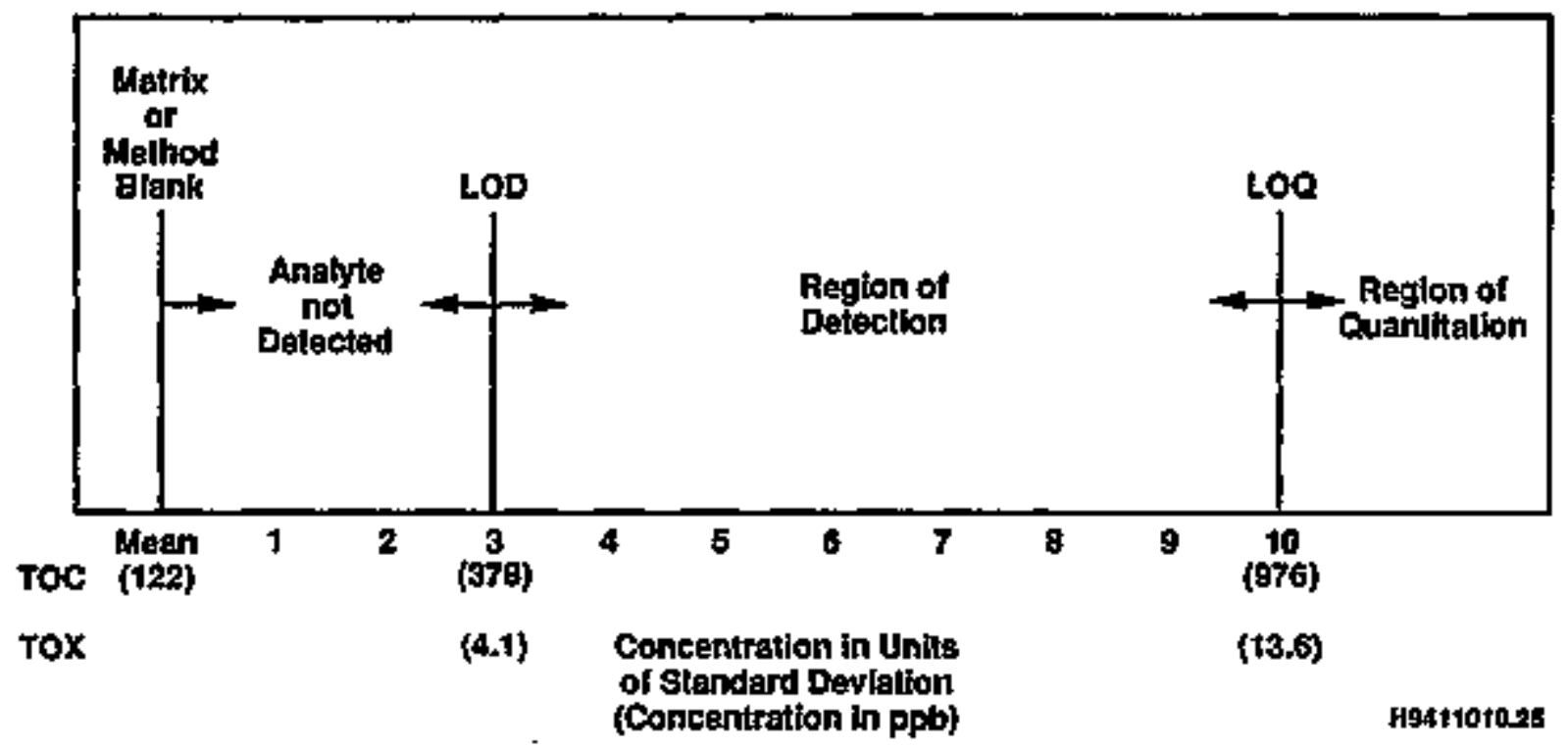


DOE/RL-96-01, REV. 0

Table A-1. Sumary of 1995 Quality Control

Quarterly Reports.

\begin{tabular}{|l|c|c|}
\hline \multicolumn{1}{|c|}{ Quarterly reports } & $\begin{array}{c}\text { Field } \\
\text { duplicates } \\
\text { (\% acceptable) }\end{array}$ & $\begin{array}{c}\text { Field blanks } \\
\text { (\% acceptable) }\end{array}$ \\
\hline October-Decenber 1994 & 94.1 & 95.1 \\
\hline January-Harch 1995 & 93.2 & 95.5 \\
\hline Apri\}-June 1995 & 98.1 & 98.2 \\
\hline July-September 1995 & 99.0 & 96.7 \\
\hline
\end{tabular}

Table A-2. 1995 Field Blanks Exceeding Qualtty Control Ltmits.

\begin{tabular}{|c|c|c|c|c|c|}
\hline Hethod & Nethod nams & crope & $\begin{array}{l}\text { Tokel } \\
\text { andelyses }\end{array}$ & $9 \mathrm{flog} s$ & $\begin{array}{l}\text { Xotut of } \\
\text { limits }\end{array}$ \\
\hline $12 y / 120$ & $54-8469060$ & TOS & 86 & 8 & 9.5 \\
\hline $124 / 10 \mathrm{des}$ & ASTM $0-4327-88 / E D h 300.0$ & Anions & 294 & 31 & 10,5 \\
\hline $126 / 1044$ & 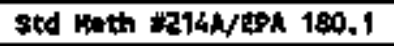 & Turbidity & 17 & 16 & 0.1 \\
\hline $127 / 113$ & ASTM $0.2579+n /$ Eed 415.1 & Total Cerbon & 2 & 2 & 100.0 \\
\hline $140 / 1269$ & JTas other Sean & Gamente & 21 & 2 & 9.5 \\
\hline $142 / 4255$ & ttas $\mathrm{H}-3$ & Tritiun & 35 & 1 & 2.9 \\
\hline 182/9300 & $s t-846$ d260 & von ect/1ns & 528 & 39 & 7.4 \\
\hline 16 & $944-8468240$ & Von $\mathrm{ct} / \mathrm{A} 5$ & 2,903 & 70 & 2.4 \\
\hline 25 & $94-846$ 8010/80201 & $\operatorname{son} \theta x$ & 187 & 10 & 5.3 \\
\hline $30 / 1197$ & str-gas bDGO & Phernals & 160 & 1 & 0.6 \\
\hline $34 / 1137$ & S4-846 6010 & JCP Metals & क्रs & 部 & 8.4 \\
\hline $40 / 1170$ & $54-846742 t$ & lead & 14 & 2 & 14.3 \\
\hline $41 / 1174$ & $94-8467470$ & Murcury & 15 & 5 & 33.3 \\
\hline $65 / 1039$ & Std Hith WZOSg/EPA 160.1 & IDS & 9 & 3 & $\mathbf{3 3 . 3}$ \\
\hline 67 & su-gub 9020 & Tox & 103 & 14 & 13.6 \\
\hline
\end{tabular}

Table A-3. 1995 Field Oupticates Exceeding Quality Control Limits. (2 sheets)

\begin{tabular}{|c|c|c|c|c|c|}
\hline lathod & Hethad nime & & $\begin{array}{l}\text { Toted } \\
\text { etalyoses }\end{array}$ & $\mathbf{a r}$ & $\begin{array}{l}\text { rout of } \\
\text { lifits }\end{array}$ \\
\hline $122 / 120$ & 9u-B46 \$060 & Foc & 5 & 12 & 22,6 \\
\hline $124 / 1043$ & ASTN D-4327-83/EPA 300.0 & Mions & 290 & 9 & 3.2 \\
\hline 12641044 & Sta heth stak/teph 180.1 & Turbidfty & ts & 6 & 37.5 \\
\hline 129 & AsTN D-1426-C & Almonivn ion & 3 & $z$ & 86.7 \\
\hline $135 / 1247$ & 8U-846 4510 , Alpha & Gross atphs & 35 & 7 & 20.0 \\
\hline $136 / 1252$ & su-846 9510 , Bets & Grose beck & 27 & 2 & 7.4 \\
\hline 237 & SH-B46 9315, Radiun & Radiun & 4 & 1 & $\mathbf{3 . 0}$ \\
\hline $943 / 1283$ & ITAS Te-\$9 & 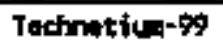 & 11 & 1 & 9.1 \\
\hline
\end{tabular}


Table A-3. 1995 Field Duplicates Exceeding Qual ity Control Limits. (2 sheets)

\begin{tabular}{|c|c|c|c|c|c|}
\hline wathed & Method nim: & & $\begin{array}{l}\text { Jotal } \\
\text { anditysas }\end{array}$ & $\theta$ Flags & $\begin{array}{l}\text { Wout of } \\
\text { linitis }\end{array}$ \\
\hline $145 / 1288$ & ITAS Groes U & Uranite & 17 & 5 & 29.4 \\
\hline 25 & $\$ 4-946$ 2010/8020 & voh st5 & 204 & $T$ & 3.4 \\
\hline $34 / 1139$ & $5+1-0.666010$ & ICP Mntsls & 25 & 57 & 6.7 \\
\hline $65 / 1035$ & Std Reth Hosa/erh 160.1 & TDS & 14 & 2 & 14.3 \\
\hline 67 & $51-8469020$ & $\tan x$ & 58 & 11 & 11.2 \\
\hline
\end{tabular}

Table A-4. Summary of 1995 Quality Control Semiannual and Quarterly Reports (in percent acceptable).

\begin{tabular}{|c|c|c|c|c|c|}
\hline $\begin{array}{c}1905 \text { durterly } \\
\text { reports }\end{array}$ & Prosiston' & Acaraty & $\begin{array}{l}\text { EPA woter } \\
\text { pol lut ion }\end{array}$ & EPA water suxply & $\begin{array}{l}\text { Rediochenical } \\
\text { interleb } \\
\text { comparisen }\end{array}$ \\
\hline oct-Des 1994 & 98.1 & 99.2 & $\begin{array}{l}\text { samples not sent } \\
\text { this querter }\end{array}$ & 94.8 & 100 \\
\hline Jer-Mar 1975 & 97.7 & 98.5 & 77.2 & $\begin{array}{c}\text { Samples not sent } \\
\text { this quarter }\end{array}$ & 100 \\
\hline Apr=dun 1995 & 100 & 99.2 & $\begin{array}{l}\text { senplea not gent } \\
\text { this guarter }\end{array}$ & 97.6 & 200 \\
\hline$w 1-50 \% 19 \%$ & 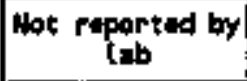 & $\underset{\substack{\text { Hot } \\
\text { lab }}}{ }$ & 76.5 & $\begin{array}{l}\text { Somples not stant } \\
\text { this qurter }\end{array}$ & Mot reported by \\
\hline
\end{tabular}

These figures repregent rudiochenistry duta.

ePh $x$ U.s. Emiromental Protection horky.

TabTe A-5. Groundwater Field Blanks Data from DataChem Laboratories. Constituent: Total Organic Carbon. (2 sheets)

\begin{tabular}{|c|c|c|c|c|c|c|}
\hline $\begin{array}{c}\text { Period } \\
\text { from }\end{array}$ & Period to & $\begin{array}{c}\text { Number } \\
\text { of } \\
\text { samples }\end{array}$ & $\begin{array}{c}\text { Mean } \\
(\mathrm{ppb})\end{array}$ & $\begin{array}{c}\text { Standard } \\
\text { deviation } \\
(\mathrm{ppb})\end{array}$ & $\begin{array}{c}\text { LOD }^{\circ} \\
(\mathrm{ppb})\end{array}$ & $\begin{array}{c}\text { LOQ }^{\circ} \\
\text { (ppb) }\end{array}$ \\
\hline $10 / 18 / 94$ & $12 / 30 / 94$ & $34^{\circ}$ & 119 & 88.0 & 383 & 999 \\
\hline $01 / 06 / 95$ & $03 / 24 / 95$ & 23 & 145 & 91.1 & 419 & 1,056 \\
\hline $06 / 09 / 95$ & $06 / 21 / 95$ & 6 & 94 & 65.4 & 290 & 748 \\
\hline $07 / 07 / 95$ & $08 / 14 / 95$ & 6 & 75 & 53.7 & 236 & 612 \\
\hline
\end{tabular}


Table A-5. Groundrater Field B1anks Data from DataChem Laboratories. Constituent: Total Organic Carbon. (2 sheets)

\begin{tabular}{|c|c|c|c|c|c|c|}
\hline $\begin{array}{c}\text { Period } \\
\text { frow }\end{array}$ & Period to & $\begin{array}{c}\text { Number } \\
\text { of } \\
\text { samples }\end{array}$ & $\begin{array}{c}\text { Mean } \\
(\mathbf{p p b})\end{array}$ & $\begin{array}{c}\text { Standard } \\
\text { devfation } \\
(\mathrm{ppb})\end{array}$ & $\begin{array}{c}\mathrm{LO0} \\
(\mathrm{ppb})\end{array}$ & $\begin{array}{c}\mathbf{L O Q} \\
(\mathbf{p p b})\end{array}$ \\
\hline Sumpary & 69 & 122 & 85.4 & 378 & 976 \\
\hline
\end{tabular}

'LOD equals the mean blank concestration plus 3 standard deviation and LOQ equals the mean blank concentration plus 10 standard deviation.

excluding contaminated blanks that were analyzed on $11 / 29 / 94$.

LOO = limit of detection.

LOQ = I imit of quantitation.

Table A-6, Groundwater Field Blanks Data from DataChen Laboratories. Constituent: Total Organic Halogen.

\begin{tabular}{|c|c|c|c|c|c|c|}
\hline $\begin{array}{l}\text { Period } \\
\text { from }\end{array}$ & Period to & $\begin{array}{l}\text { Nutuber } \\
\text { of } \\
\text { samples }\end{array}$ & $\begin{array}{l}\text { Mean } \\
(p p b)\end{array}$ & $\begin{array}{c}\text { Standard } \\
\text { deviation } \\
\text { (ppb) }\end{array}$ & $\underset{(\mathrm{ppb})}{\operatorname{LOD}{ }^{*}}$ & $\begin{array}{l}\mathrm{LOQ}^{*} \\
(\mathrm{ppb})\end{array}$ \\
\hline $06 / 07 / 95$ & $09 / 12 / 95$ & 25 & 0.191 & 1.356 & 4.1 & 13.6 \\
\hline
\end{tabular}

"LOD (blank corrected) equals 3 tines the blank standard deviation and

LOQ (blank corrected) equals 10 times the blank standard deviation.

LOO - limit of detection.

$L O Q=$ limit of quantitation.

Table A-7. Groundwater Field Blanks Data from IT Analytical Services. Constituent: Antinony-125.

\begin{tabular}{|c|c|c|c|c|c|c|}
\hline $\begin{array}{c}\text { Period } \\
\text { from }\end{array}$ & Period to & $\begin{array}{c}\text { Humber } \\
\text { of } \\
\text { samples }\end{array}$ & $\begin{array}{c}\text { Mean } \\
(\mathrm{pC} i / \mathrm{L})\end{array}$ & $\begin{array}{c}\text { Standard } \\
\text { deviation } \\
(\mathrm{pC} j / \mathrm{L})\end{array}$ & $\begin{array}{c}\mathrm{LO0^{ \circ }} \\
(\mathrm{pC} \mathrm{i} / \mathrm{L})\end{array}$ & $\begin{array}{c}\mathrm{LOQ}^{\mathrm{e}} \\
\langle\mathrm{pC} \mathrm{C} / \mathrm{L})\end{array}$ \\
\hline $10 / 28 / 94$ & $12 / 29 / 94$ & 3 & 2.733 & 10.478 & 31.43 & 104.78 \\
\hline
\end{tabular}

IOD (blank corrected) equals 3 times the blank standard deviation and LOQ (blank corrected) equals 10 times the blank standard deviation.

LOO - limit of detection.

LOQ = 1 jait of quantitation. 
TabJe A-8. Groundwater Field Blanks Data from IT Analytical Services. Constituent: Cesium-137.

\begin{tabular}{|c|c|c|c|c|c|c|}
\hline $\begin{array}{l}\text { Period } \\
\text { from }\end{array}$ & Period to & $\begin{array}{c}\text { Hunber } \\
\text { of } \\
\text { samples }\end{array}$ & $\begin{array}{c}\text { Mean } \\
\text { (pCi/L) }\end{array}$ & $\begin{array}{c}\text { Standard } \\
\text { deviation } \\
\text { (pCi/L) }\end{array}$ & $\underset{\langle\mathrm{pCj} / L)}{\operatorname{LoD}}$ & $\underset{\left(p^{2} i / L\right)}{\operatorname{LOO}}$ \\
\hline $10 / 28 / 94$ & $12 / 29 / 94$ & 3 & -0.400 & 4.623 & 13.87 & 46.23 \\
\hline
\end{tabular}

"LOD (blank corrected) equals 3 times the blank standard deviation and LOQ (b]ank corrected) equals 10 tiaes the blank standard deviation. LOD - jimtt of detection. LOQ $=1$ imit of quantitation.

Table A-9. Groundwater Field Blanks Data from IT Analytica] Services. Constituent: Cobalt-60.

\begin{tabular}{|c|c|c|c|c|c|c|}
\hline $\begin{array}{c}\text { Period } \\
\text { from }\end{array}$ & Period to & $\begin{array}{c}\text { Number } \\
\text { of } \\
\text { samples }\end{array}$ & $\begin{array}{c}\text { Meant } \\
(\mathrm{pCi} / \mathrm{L})\end{array}$ & $\begin{array}{c}\text { Standard } \\
\text { deviation } \\
(\mathrm{pCi} / \mathrm{L})\end{array}$ & $\begin{array}{c}\mathrm{LOD^{* }} \\
(\mathrm{pCi} / \mathrm{L})\end{array}$ & $\begin{array}{c}\mathrm{LQ}^{2} \\
(\mathrm{pC} \mathrm{C} i \mathrm{~L})\end{array}$ \\
\hline $10 / 28 / 94$ & $12 / 29 / 94$ & 3 & 1.357 & 2.149 & 6.45 & 21.49 \\
\hline
\end{tabular}

"LOD (blank corrected) equals 3 times the blank standard deviation and LOQ (blank corrected) equals 10 times the blank standard deviation. LOD - Iinit of detection. LOQ - 71mit of quantitation. 
Table A-10. Groundwater Field Blanks Data from IT Analytical Services. Constituent: Gross Alpha.

\begin{tabular}{|c|c|c|c|c|c|c|}
\hline $\begin{array}{l}\text { Period } \\
\text { frowa }\end{array}$ & Period to & $\begin{array}{l}\text { Number } \\
\text { of } \\
\text { samples }\end{array}$ & $\begin{array}{c}\text { Mean } \\
(\mathrm{pC} 1 / L)\end{array}$ & $\begin{array}{c}\text { Standard } \\
\text { deviation } \\
(\mathrm{pCj} / \mathrm{L})\end{array}$ & $\underset{(p C i / L)}{L C O A}$ & $\underset{(\mathrm{pCI} / \mathrm{LOQ})}{\mathrm{LO}}$ \\
\hline $10 / 14 / 94$ & $12 / 26 / 94$ & $\$ 1$ & 0.048 & 0.306 & 0.92 & 3.06 \\
\hline $01 / 10 / 95$ & $03 / 24 / 95$ & 8 & -0.041 & 0.150 & 0.45 & 1.50 \\
\hline $04 / 14 / 95$ & $06 / 29 / 95$ & 13 & 0.139 & 0.299 & 0.90 & 2.99 \\
\hline $08 / 07 / 95$ & $09 / 29 / 95$ & 8 & -0.045 & 0.133 & 0.40 & 1.33 \\
\hline \multicolumn{2}{|c|}{ Stumary } & 40 & 0.041 & 0.252 & 0.76 & 2.52 \\
\hline
\end{tabular}

"Lov (blank corrected) equals 3 times the blank standard deviation and LOQ (blank corrected) equals 10 times the blank standard deviation. LOD = limit of detection. LOQ $=1$ imit of quantitation.

Tabie A-11. Groundwater Field Blanks Data from IT Analytical Services. Constituent: Gross Beta.

\begin{tabular}{|c|c|c|c|c|c|c|}
\hline $\begin{array}{c}\text { Period } \\
\text { from }\end{array}$ & Period to & $\begin{array}{c}\text { Mumber } \\
\text { of } \\
\text { samples }\end{array}$ & $\begin{array}{c}\text { Mean } \\
(\mathrm{pCi} / \mathrm{L})\end{array}$ & $\begin{array}{c}\text { Standard } \\
\text { deviation } \\
(\mathrm{pCi} / \mathrm{L})\end{array}$ & $\begin{array}{c}\mathrm{LOD}^{\mathrm{a}} \\
\left(\mathrm{pCi}^{\mathrm{L}} / \mathrm{L}\right)\end{array}$ & $\begin{array}{c}\mathrm{LO}^{\mathrm{a}} \\
(\mathrm{pCi} / \mathrm{L})\end{array}$ \\
\hline $10 / 18 / 94$ & $12 / 23 / 94$ & 10 & 0.644 & 1.216 & 3.65 & 12.16 \\
\hline $01 / 10 / 95$ & $03 / 22 / 95$ & 8 & -0.796 & 1.695 & 5.08 & 16.95 \\
\hline $04 / 17 / 95$ & $06 / 27 / 95$ & 12 & -0.089 & 1.427 & 4.28 & 14.27 \\
\hline $07 / 04 / 95$ & $09 / 30 / 95$ & 9 & -0.438 & 1.291 & 3.87 & 12.91 \\
\hline \multicolumn{2}{|c|}{ Summary } & 39 & -0.126 & 1.406 & 4.22 & 14.06 \\
\hline
\end{tabular}

a LOD (blank corrected) equals 3 times the blank standard deviation and LOQ (blank corrected) equals 10 times the blank standard deviation. $L O D=1$ imit of detection. LOQ = 1 imit of quantitation. 
Table A-12. Groundwater Field Blanks Data from IT Analytical Services. Constituent: Iodine-129.

\begin{tabular}{|c|c|c|c|c|c|c|}
\hline $\begin{array}{c}\text { Period } \\
\text { from }\end{array}$ & Period to & $\begin{array}{c}\text { Number } \\
\text { of } \\
\text { samples }\end{array}$ & $\begin{array}{c}\text { Mean } \\
(\mathrm{pC} j / \mathrm{L})\end{array}$ & $\begin{array}{c}\text { Standard } \\
\text { deviation } \\
(\mathrm{pC} \mathrm{j} / \mathrm{L})\end{array}$ & $\begin{array}{c}\mathrm{LOO} \\
(\mathrm{pCi} / \mathrm{L})\end{array}$ & $\begin{array}{c}\mathrm{LOQ}^{*} \\
(\mathrm{pC} \mathrm{L} / \mathrm{L})\end{array}$ \\
\hline $11 / 21 / 94$ & $09 / 08 / 95$ & 9 & -0.079 & 0.315 & 0.94 & 3.15 \\
\hline
\end{tabular}

100 (b1ank corrected) equals 3 times the blank standard deviation and LOQ (blank corrected) equals 10 times the blank standard deviation. $L O D=$ Timit of detection. LOQ = limit of quantitation.

Table A-13. Groundwater Fteld 87 anks Data fron IT Analytical Services. Constituent: Radium.

\begin{tabular}{|c|c|c|c|c|c|c|}
\hline $\begin{array}{l}\text { Period } \\
\text { from }\end{array}$ & Period to & $\begin{array}{l}\text { Number } \\
\text { of } \\
\text { samples }\end{array}$ & 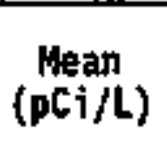 & $\begin{array}{l}\text { Standard } \\
\text { deviation } \\
\text { (pCi/L) }\end{array}$ & $\underset{(\mathrm{pC} C \mathrm{CO} / \mathrm{L})}{\mathrm{CO}^{\circ}}$ & $\underset{\left(\mathrm{pCi}^{2} / \mathrm{L}\right)}{\mathrm{LOQ}}$ \\
\hline $10 / 31 / 94$ & $06 / 22 / 95$ & 4 & 0.011 & 0.075 & 0.225 & 0.750 \\
\hline
\end{tabular}

"LOD (blank corrected) equals 3 times the blank standard deviation and LOQ (blank corrected) equals 10 times the blank standard deviation. LOD $=1$ imit of detection. LOQ $=$ limit of quantitation.

Table A-14. Groundwater Field 81 anks Data from IT Analytica] Services. Constituent: Strontium-90.

\begin{tabular}{|c|c|c|c|c|c|c|}
\hline $\begin{array}{c}\text { Period } \\
\text { from }\end{array}$ & Period to & $\begin{array}{c}\text { Nurber } \\
\text { of } \\
\text { samples }\end{array}$ & $\begin{array}{c}\text { Mean } \\
(\mathrm{pCi} / \mathrm{L})\end{array}$ & $\begin{array}{c}\text { Standard } \\
\text { deviation } \\
(\mathrm{pCi} / \mathrm{L})\end{array}$ & $\begin{array}{c}\mathrm{LQ0} \\
(\mathrm{pCi} / \mathrm{L})\end{array}$ & $\begin{array}{c}\mathrm{LOQ} \\
(\mathrm{pC} \mathrm{p} / \mathrm{L})\end{array}$ \\
\hline $12 / 21 / 94$ & $01 / 25 / 95$ & $\mathbf{2}$ & $\mathbf{0 . 0 2 7}$ & $\mathbf{0 . 1 5 5}$ & 0.464 & 1.548 \\
\hline
\end{tabular}

"Lop (blank corrected) equals 3 times the blank standard deviation and LOQ (blank corrected) equals 10 times the blank standard deviation. LOD = limit of detection. LOQ - liajt of quantitation. 
Table A-15. Groundwater Field Blanks Bata from IT Analytjca] Services. Const ituent: Technetiun-99.

\begin{tabular}{|c|c|c|c|c|c|c|}
\hline $\begin{array}{l}\text { Period } \\
\text { fron }\end{array}$ & Period to & $\begin{array}{l}\text { Number } \\
\text { of } \\
\text { samples }\end{array}$ & $\underset{(\mathrm{pC} 1 / \mathrm{L})}{\operatorname{Mean}}$ & $\begin{array}{c}\text { Standard } \\
\text { deviation } \\
(\mathrm{\rho C} \mathrm{C} / \mathrm{L})\end{array}$ & $\underset{(\mathrm{pC} i / L)}{\mathrm{LO})}$ & $\underset{\left(\mathrm{pC}^{2} 1 / 1\right)}{\operatorname{Lo)^{*}}}$ \\
\hline $12 / 23 / 94$ & $03 / 09 / 95$ & 4 & -0.465 & 0.460 & 1.381 & 4.603 \\
\hline $04 / 21 / 95$ & $06 / 30 / 95$ & 3 & -0.442 & 0.914 & 2.741 & 9.137 \\
\hline $07 / 16 / 95$ & $09 / 30 / 95$ & 4 & -0.517 & 0.629 & 2.741 & 6.288 \\
\hline \multicolumn{2}{|c|}{ Sunduary } & 11 & -0.478 & 0.706 & 2.119 & 7.063 \\
\hline
\end{tabular}

"LOO (bTank corrected) equaTs 3 times the blank standard deviation and LOa (blank corrected) equals 10 times the blank standard devlation.

excluding contaminated blank that was analyzed on $12 / 19 / 94$.

$\mathrm{LOO}=1$ imit of detection.

LOQ = limit of quantitation.

Table A-16. Groundwater Field Blanks Data from IT Analytical Services. Constituent: Tritiun.

\begin{tabular}{|c|c|c|c|c|c|c|}
\hline $\begin{array}{c}\text { Period } \\
\text { from }\end{array}$ & Period to & $\begin{array}{c}\text { Neqber } \\
\text { of } \\
\text { samples }\end{array}$ & $\begin{array}{c}\text { Mean } \\
(\mathrm{pCi} / \mathrm{L})\end{array}$ & $\begin{array}{c}\text { Standard } \\
\text { deviation } \\
(\mathrm{pC} \mathrm{i} / \mathrm{L})\end{array}$ & $\begin{array}{c}\mathrm{LO0^{ \circ }} \\
(\mathrm{pCi} / \mathrm{L})\end{array}$ & $\begin{array}{c}\mathrm{LOQ} \\
(\mathrm{pC} \mathrm{C} / \mathrm{L})\end{array}$ \\
\hline $10 / 20 / 94$ & $12 / 31 / 94$ & 11 & 95.20 & 148.361 & 445.08 & $1,483.6$ \\
\hline $02 / 23 / 95$ & $03 / 28 / 95$ & 5 & 138.88 & 109.422 & 328.27 & $1,094.2$ \\
\hline $04 / 21 / 95$ & $06 / 30 / 95$ & 12 & 68.69 & 73.866 & 221.60 & 738.7 \\
\hline $08 / 11 / 95$ & $09 / 30 / 95$ & 7 & 194.47 & 97.265 & 291.80 & 972.6 \\
\hline \multicolumn{2}{|c|}{ Summary } & 35 & 112.20 & 111.411 & 334.23 & $1,114.1$ \\
\hline
\end{tabular}

"LOO (blank corrected) equals 3 times the blank standard deviation and LOQ (bJank corrected) equals 10 times the bJank standard deviation.

LOD $=$ limit of detection.

LOQ $=1$ imit of quantitation. 
Table A-17. Groundwater Field Blanks Oata from IT Analytical Services. Constituent: Urantum.

\begin{tabular}{|c|c|c|c|c|c|c|}
\hline $\begin{array}{c}\text { Period } \\
\text { froa }\end{array}$ & Peried to & $\begin{array}{c}\text { Number } \\
\text { of } \\
\text { samples }\end{array}$ & $\begin{array}{c}\text { Mean } \\
(\mathrm{ppb})\end{array}$ & $\begin{array}{c}\text { Standard } \\
\text { deviation } \\
(\mathrm{ppb})\end{array}$ & $\begin{array}{c}\text { LOD' } \\
(\mathrm{ppb})\end{array}$ & $\begin{array}{c}\text { LOQ } \\
(\mathrm{ppb})\end{array}$ \\
\hline $10 / 21 / 94$ & $12 / 22 / 94$ & 4 & 0.029 & 0.0547 & 0.164 & 0.547 \\
\hline $01 / 12 / 95$ & $03 / 02 / 95$ & 2 & 0.047 & 0.1112 & 0.334 & 1.112 \\
\hline $04 / 23 / 95$ & $06 / 27 / 95$ & 4 & -0.010 & 0.0427 & 0.128 & 0.427 \\
\hline $07 / 14 / 95$ & $09 / 30 / 95$ & 3 & 0.012 & 0.0437 & 0.131 & 0.437 \\
\hline \multicolumn{2}{|c|}{ Summary } & 13 & 0.016 & 0.0584 & 0.175 & 0.584 \\
\hline
\end{tabular}

"LOD (blank corrected) equals 3 times the blank standard deviation and LOQ (blank corrected) equals 10 times the blank standard deviation. LOO = limit of detection.

LOQ - limit of quantitation. 
Table A-18. LOD and LOQ Calculations for Selected Constituents Based on MDL Report ${ }^{2, b}$ for Low Level standards. (11 sheets)

\begin{tabular}{|c|c|c|c|c|c|}
\hline Hinchod bar: & Constitunint lane & 201. & STD. WEY. & $1 \infty$ & Log \\
\hline $450110-1385$ & Hyxtezine & 2,8 & 0.892 & 3.78 & 12.61 \\
\hline Asth $0-1426-c$ & Anivin ton & 27 & 8.599 & 36,40 & 121,60 \\
\hline Nㅔㅅㅔ $0-1426-0$ & Anenican ion & 27 & 0.599 & 36.48 & 221.60 \\
\hline 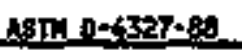 & Bromide & $\underline{x}$ & 로.830 & 97 요 & 326,74 \\
\hline 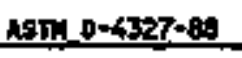 & chloride & 110 & 35,032 & 140.63 & 495,42 \\
\hline L8TH $0-43 \times 7-8$ & Fluoride & 52 & 16,561 & 70.26 & 236.20 \\
\hline ASTH 0-4737-88 & Hitrute & 120 & 3년,217 & 162.14 & 540.46 \\
\hline Asin $0-4677-89$ & Hitrita & 140 & 44. & 189.16 & 630.56 \\
\hline A8TI $0.4327+08$ & Phorghote & 340 & 100.280 & 459.59 & 1531.31 \\
\hline ASTH 0-4327-80 & sutfate & 130 & 41,, 401 & 175,65 & $5 \operatorname{sis} .50$ \\
\hline $\operatorname{Egh} 410.4$ & Chemical moxyen danend & 2000 & 923,567 & 3918.35 & 13051.18 \\
\hline Ep, $600,310.2$ & Mlkelinity & 3500 & $t \$ 14,650$ & 4729.05 & 15763.49 \\
\hline $\begin{array}{l}\text { Thouse Ion } \\
\text { ethres. }\end{array}$ & Perehlorote & 54 & 17.197 & 72.96 & 243.21 \\
\hline $540-3466010$ & Aluning & 31 & 9.873 & 41.97 & 139.62 \\
\hline sy-ges s010 & intimony & 24 & 7.643 & 32,43 & 100. 09 \\
\hline su-des $\Delta 010$ & Beriun & 1.4 & 0.448 & 1.20 & 6.31 \\
\hline $5 \%+8660010$ & Bamplitis & 0.63 & 0.201 & 0.85 & 2.84 \\
\hline $54-84660010$ & cormitn & 0.98 & 0.312 & 1.32 & 4.41 \\
\hline$S^{4}-8: 6,6010$ & calciun & 41 & 13.0s? & 55.40 & 184.06 \\
\hline str-246 0010 & Chronifun & 3.7 & 1,178 & 5.00 & 16.65 \\
\hline sir-8k 6010 & Cobolt & 5.3 & 1.688 & 7,16 & 23. \\
\hline sti-2/6 6010 & Coper & 2.1 & 0.669 & 2.84 & 9.46 \\
\hline sy-846_6010 & Iron & B. 9 & 2.8334 & 12.03 & 40.09 \\
\hline $5 N-8460010$ & 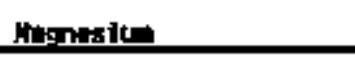 & 26 & s. & 55.13 & 197,10 \\
\hline sw-846 6010 & Nenzanese & 0.55 & 0.15 & 0.74 & 2.40 \\
\hline sus- 6010 & Nickel & 11 & 3,503 & 24,46 & 49,56 \\
\hline 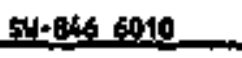 & Pestapaiy & 350 & 124.204 & 526.95 & $17 \times 6.50$ \\
\hline SU-846 6010 & silver & 5,5 & $1,7,72$ & 7,43 & 24,77 \\
\hline 토요우 6010 & socile & 46 & th.013 & 59.45 & 198.17 \\
\hline $51-8466010$ & Tin & 30 & 9,554 & 40,53 & 139.12 \\
\hline $85-84660110$ & VanedIIL & 1.9 & 0.605 & 2.57 & 8.56 \\
\hline$=54-8466010$ & zine & 3.7 & 1.178 & $5 . \infty$ & 16.66 \\
\hline $\begin{array}{l}\text { SN-846 } 6010, \\
\text { ICP Metats }\end{array}$ & strontilu & 0.31 & $0.00 \%$ & 0.42 & 1.40 \\
\hline su-846 7060 & Aranic & 2. & 0,637 & 2.70 & 9.01 \\
\hline
\end{tabular}


Table A-18. LOD and LOQ Calculations for Selected Constituents Based on MOL Report ${ }^{\text {is }}$ for Low Level Standards. (11 sheets)

\begin{tabular}{|c|c|c|c|c|c|}
\hline Method ㅂope & Conet 1tuent Nene & EN1. & sTh. OEv. & $\mathbf{L}$ & Los. \\
\hline $5+846$ 7421 & tesed & 0.8 & 0.280 & 1.19 & 3.96 \\
\hline 55N-86 7421 & Letes & 1.4 & 0.446 & 1.69 & 6.31 \\
\hline $51-8467470$ & mercury & 0.019 & 0.006 & 0.03 & 0.09 \\
\hline $548467 / 40$ & stleniug & 1.2. & 0.382 & 1.62 & 5.40 \\
\hline $54=467740$ & sntenie & 1.6 & 0.510 & 2.16. & 7.21 \\
\hline sy-846 7461 & Thatliun & 1.2 & $0.3 * 2$ & 1.02 & 3.40 \\
\hline $5 y-046$ 784 & Thallite & 2.44 & $0 . m$ & 3.30 & 10.98 \\
\hline $\begin{array}{l}51 \text {-846 } \\
\text { s010/8020 }\end{array}$ & $1,1,1$-Triealerothene & 0.061 & 0.019 & 0.98 & 0.27 \\
\hline $\begin{array}{l}51-846 \\
0010 / 8020\end{array}$ & 1,1,2-7richloroethens & 0.068 & 0.022 & 0.09 & 0.31 \\
\hline $\begin{array}{l}\text { sy-pus } \\
\text { sot0/8xpa }\end{array}$ & 1,1-0iehtarowthene & 0.047 & 0.015 & 0.06 & 0.21 \\
\hline $\begin{array}{l}\text { sy.646 } \\
\text { sio/s020 }\end{array}$ & 1,2-0ichloresthare & 0.049 & $0.0 t 6$ & 0.07 & 0.22 \\
\hline 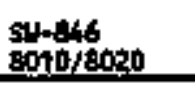 & 1,4-Dichlorobentene & 0.086 & 0.015 & 0.08 & 0.25 \\
\hline $\begin{array}{l}54-846 \\
0010 / 0020\end{array}$ & senzen & 0.059 & 0.019 & 0.08 & 0.27 \\
\hline $\begin{array}{l}\mathrm{N}+846 \\
8010 / 8020\end{array}$ & Earben tetractilortids & 0,042 & 0.013 & 0.66 & 0.19 \\
\hline $\begin{array}{l}5 \mathrm{~s}-846 \\
8010 / 8020\end{array}$ & chtoroform & 0.029 & 0.009 & 0.04 & 0.13 \\
\hline $\begin{array}{l}314-846 \\
3010 / 2020\end{array}$ & Etmplbenzene & 0.034 & 0.011 & 0.05 & 0.15 \\
\hline $\begin{array}{l}\text { sy-846 } \\
8010 / 2020\end{array}$ & inthylene ehtoride & 0.086 & 0.007 & 0.11 & 0.38 \\
\hline 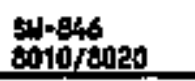 & Tetrechloreethene & 0.055 & 0.011 & 0.05 & 0.16 \\
\hline $90-846$ & Toluans & 0.048 & 0.015 & $0,0.5$ & 0.22 \\
\hline $\begin{array}{l}\text { sit-a4s } \\
8010 / 20020\end{array}$ & Trituloroethen & 0.075 & 0.024 & 0.10 & 0.34 \\
\hline $\begin{array}{l}511-846 \\
8010 / 0020\end{array}$ & Vingl thloeide & 0.25 & 0.930 & 0.36 & 1.13 \\
\hline $\begin{array}{l}51-246 \\
8010 / 2020 .\end{array}$ & xylenos (totst) & 0.085 & 0,027 & 0.11 & 0.38 \\
\hline $\begin{array}{l}5 r-646 \\
0010 / 20000\end{array}$ & eis-t,2-Dithleronthylene & 0.069 & 0.016 & 0.07 & 0.22 \\
\hline $\begin{array}{l}515-846 \\
8010 / 8020\end{array}$ & trens-1,2-otehlaroethylene & 0.045 & 0.0t6 & 0.06 & 0.20 \\
\hline $5:-0668021$ & 1.1, i-Tetehlorosthene & 0.061 & 0.019 & 0.08 & 0.27 \\
\hline $5 x-266$ anz1 & 1,1,2-7richlorosthere & 0.065 & 0.028 & 0.09 & 0.31 \\
\hline s.1. 8468001 & 1,t-oichlaraethane & 0.047 & 0.015 & 0.06 & 0.21 \\
\hline
\end{tabular}


Table A-18. LOD and LOQ CaTcuTations for SeJected Constituents Based on MDL Report ${ }^{0, b}$ for Lor Level Standards. (11 sheets)

\begin{tabular}{|c|c|c|c|c|c|}
\hline Hothod Mape & Cangtitument Mame & $\mathrm{N}$ & SID. 咮. & $L 00$ & 200 \\
\hline SW-ats a021 & 1.2-0idfiloxpothen & $0,0.09$ & 0.016 & 0.07 & 0.22 \\
\hline sW-846 8021 & 1.4-0ichloroborizint & 0.085 & 0.02:5 & 0.08 & 0.25 \\
\hline $54-0468021$ & Henzent & 0,059 & 0.019 & 0.08 & 0.27 \\
\hline sy-gas and & certon tetrsochloriste & $0,0<2$ & 0.013 & 0.06 & 0.19 \\
\hline SY-846 8021 & Chicrotorm & 0,009 & 0.000 & $0,0.04$ & 0.13 \\
\hline stit-846 s0021 & Ethydbentene & 0.036 & 0.011 & 0.05 & 0,15 \\
\hline $5 y-84680021$. & Nothylen chloride & 0.008 & 0.027. & 0.11 & 0.38 \\
\hline $14-846.8021$ & Tetrechlorosthene & 0.035 & 0.011: & 0.05 & 0.16 \\
\hline 5148580021 & Tolutene & 0.048. & 0,015 & 0.06 & $0.2 x$ \\
\hline$s y=84660021$ & Trichlorosshene & 0.05 & 0.024 & 0.10 & 0,34 \\
\hline s.5.84, 8021 & vincl ehloride & 0.25 & 0.000 & 0.34 & 1.13 \\
\hline 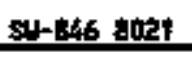 & Dyleter: (total) & $0.0 B_{5}$ & 0.037 & 0.11 & 0, 38 \\
\hline s4-846 g0021 & cin-1,2-0ichloronthylem & 0.069 & 0.016 & 0.07 & 0.22 \\
\hline s4-846 g023 & trene-1,2-0ichlornethylene & 0.045 & 0,004 & 0.06 & 0.20 \\
\hline $51+846$ enso & 2,4,6-Trichlorephemol & 0.8 & 0.255 & 1.09 & 3.60 \\
\hline 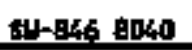 & 3,4eolichlareghinol & 0.43 & 0.137 & 0.5. 8 & 1.04 \\
\hline sy.846 so40 & z,a-pientinlpheml & $0,6 ?$ & 0.197 & a.84 & 2,78 \\
\hline str 846 8040 & 2,4-Dinterophenol & 6.8 & 2.266 & 9.19 & 30.63 \\
\hline 51284680010 & 2,6-Dichlorochenol & 0.52 & 0.166 & 0.70 & 2.34 \\
\hline $54+8460040$ & 2-chlorophenol & 0.6 & 0.194 & 0.81 & 2.70 \\
\hline $54.846,80040$ & $2=\| 3$ trophenol & 0.6 & 0.191 & 0.81 & 2.70 \\
\hline strets 8040 & 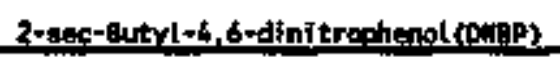 & 0.41 & 0.151 & 0.95 & 1.85 \\
\hline 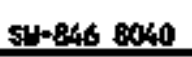 & 4.6-Dinitro-2-methytedinol & 0.86 & 0.268 & 1.13 & 3.78 \\
\hline $94-846$ 8060 & tothloro-3-athyl phenol & 0.52 & 0.166 & 0.70 & 2,36 \\
\hline $54+466$ & 4+Hitrophenol & 0.49 & 0.156 & 0.66 & 2.21 \\
\hline $5 \mathrm{w}-846 \mathrm{~s}, 8000$ & Crevols (netturlnengls) & $\therefore \quad 1.7$ & 0.51 & 2.30 & 7.66 \\
\hline $34-3468040$ & Pertachilorophenal & $\cdot 0.48$ & 0.153 & 0.65 & 2.16 \\
\hline Str-ens 8000 & Phenol & 0.59 & a-1:s & 0.78 & 2.69 \\
\hline $54-346$ 2040 & tetrechlorothenols & 0.52 & 0.166 & 0.70 & 2.34 \\
\hline $3 w-346 \operatorname{sos} 0$ & Ixichlorgphopola & 0.56 & 0.17: & 0.76 & 2.52 \\
\hline 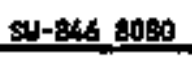 & $4,41-000$ & 0.0043 & 0.001 & $0.00 \mathrm{~s}$ & 0,019 \\
\hline su- 246 ango & $4,41-\operatorname{Dog} F$ & 0,0012 & 0.0001 & 0.002 & 0.005 \\
\hline$s 4-84660000$ & $4,4 \cdot-00 \mathrm{~T}$ & 0.00036 & 0.000 & 0.001 & 0.002 \\
\hline$s 4-240,0000$ & Aldrin & 0,000062 & 0.000 & 0.001 & 0,003 \\
\hline
\end{tabular}


Table A-18. LOD and LOQ CaTculations for Selected Constituents Based on MDL. Report ${ }^{0, b}$ for Lov Leve1 Standards. (11 sheets)

\begin{tabular}{|c|c|c|c|c|c|}
\hline Wethed Heos & const ituent Howe. & pol. & sic. $0 . x_{2}$ & 100 & 뇨 \\
\hline $8 \mathrm{sy}-846$ 8040 & Alohte-By:c & 0.0019 & 0.001 & 0.002 & 0.000 \\
\hline $54-3460000$ & Aroeloc:01016 & 0,006 & 0,008 & 0,055 & 0.112 \\
\hline $84-84650000$ & Aroctor-122: & 0.029 & 0,009 & 0.059 & 0.931 \\
\hline ș-84a 80010 & Arocklor-123: & 0.071 & 0.023 & 0.008 & 0.320 \\
\hline sytrext ang & Aroxlor-124tz & 0.018 & 0.006 & 0.026 & 0.081 \\
\hline sw-2ce & Areelor-12<s & 0.019 & 0.004 & 0,0106 & 0,086 \\
\hline 4.846 2090 & Aroelor-1254 & 0,0005 & 0.001 & 0,005 & 0.016 \\
\hline sy-846 soge & Aroeter-1260 & $0,0.11$ & 0.004 & 0.015 & 0.050 \\
\hline 84-0406 2000 & Beter-awc & 0.000066 & 0.000 & 0.001 & 0.004 \\
\hline $89-846$ a090 & Chlordine & 0.017 & 0.005 & 0.023 & $0.07 \pi$ \\
\hline $54-246$ and & Del ta-Buc. & $0,0,012$ & 0.000 & 0.002 & 0.005 \\
\hline $5 \mathrm{~W}-84680000$ & Dieldrin & 0.00053 & 0.000 & 0.001 & 0.002 \\
\hline 51-246 s080 & Entosulfen I & 0.00021 & 0.000 & 0.000 & 0.001 \\
\hline sty-846 90000 & Endosenttan $1 t$ & 0.0035 & 0.001 & 0.000 & 0.014 \\
\hline $34-646$ 8090 & Endosud fan aul fote & 0.00037 & 0.001 & 0.005 & 0.017 \\
\hline $5 y-466$ 80.00 & Endrin & 0.0005 & 0.009 & 0.006 & 0,016 \\
\hline str-bus asso & Endrin Aldthyte & 0.000055 & 0.000 & 0.001 & 0.004 \\
\hline $5 \pm-246$ 8090 & Heptamulor & 0.0012 & 0.000 & 0,002 & 0.005 \\
\hline $54-846-0000$ & Heptonter loroxide & 0.0012 & 0.000 & 0.002 & 0.005 \\
\hline su-846 ause. & Hethoxychlor & 0.0046 & 0.001 & 0.006 & O. 此1 \\
\hline s4-846 1000 & Toxuphene & 0.18 & 0.057 & 0.243 & 0.81t \\
\hline 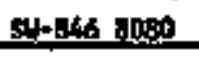 & 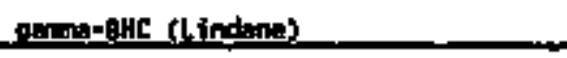 & 0.0013 & 0.000 & 0.000 & 0,106 \\
\hline $54=94601940$ & Ofaulfoton & 0.097 & 0.031 & 0.131 & 0.437 \\
\hline sy-246 $\$ 140$ & Wethyi parethion & 0.26 & $0,0.0 .3$ & 0.35 & 1,17 \\
\hline SU-246 :140 & Phornte & 0.12 & 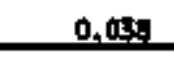 & 0.16 & 0,54 \\
\hline $54-246$ 8150 & $2,4.5 \cdot T$ & 0.029 & 0.009 & 0.05 & 0.13 \\
\hline Sw-ere a1so. & $2,4,5-7 P$ & $0,04 B$ & 0.015 & 0,06 & 0.22 \\
\hline s4-646 s150. & $2,4-0$ & 0.12 & 0.05 & o.t6 & 0.54 \\
\hline $34-8 * 6$ atso & $2+40 x-B u t y 1-4,6$-dinikrophenol (DileP) & 0 & 0.000 & 0.00 & 0.00 \\
\hline $54-8 \times 60800$ & 1,1,1,2-Tatrechlorotethane & 0.27 & 0.086 & 0.36 & t.2.2 \\
\hline sy-846, 82,40 & 1,1,3-Irfehloresthente & 0,4 & 0.127 & 0.54 & 1.80 \\
\hline $54-8<6$ 8240 & 1,1,2,2-Itetrechlortethare & 0,67 & 0.213 & 0.91 & 3.02 \\
\hline su-ex6 \$240 & 1,1,2-rfithloroethane & 0.65 & 0.207 & 0.84 & 2.9s \\
\hline
\end{tabular}


Table A-18. LOD and LOQ Calculations for Selected Constituents Based on MDL Report ${ }^{0,6}$ for Low Level Standards. (11 sheets)

\begin{tabular}{|c|c|c|c|c|c|}
\hline tethed Hom & Constitikent yus: & n.21. & SIth. Dey. & 10 & 109 \\
\hline$s 4846$ ando & 1.1-Dichlaroisheren & 0.19 & 0.061 & 0.26 & 0.06 \\
\hline $54-866090$ & 1,1-0iehloroethese & 0.14 & 0.045 & 0.19 & 0,6 \\
\hline $50-9469240$ & 1,2,3-Tripflorestopin & 0.77 & $0.24:$ & 1.05 & $3.5 t$ \\
\hline 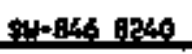 & 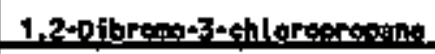 & 0.24 & 0.076 & 0.32 & 1.08 \\
\hline$s+6460240$ & 1,2-0ibronosthene & 0.63 & 0.201 & 0,85 & 2.84 \\
\hline 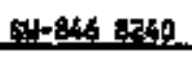 & 1.2. on ichlorathene & 0.12 & D_of & 0.16 & 0.54 \\
\hline $51-8668040$ & 1,2-01chloronthen & 0.35 & 0.111 & 0.47 & 1,58 \\
\hline s. & 1.2-0ienloregropen & 0.27 & 0_os6 & gn? & 1,22 \\
\hline 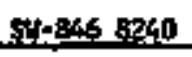 & 16-0tehlardsenzens & 0.38 & 0.171 & 0,51 & 1.71 \\
\hline $5 \mathrm{~s}-8460240$ & istopioxene & 79 & 25.159 & 106.74 & 355.00 \\
\hline $55-846$ o240 & i-Butenol & 170 & 54.140 & 239.70 & 765.66 \\
\hline $84-846.8240$ & 2-Hexpontex & 0.7 & 0.23 & 0.8 & 3.t5 \\
\hline $84-8<68240$ & 4-illethyl-2+pentinons & 8.3 & 2.643 & 14.21 & 37.38 \\
\hline sy-246 8240 & Actreone & 3.1 & 0.96 & 4.19 & 13,96 \\
\hline $84-8460240$ & ingtonitrile & 7 & 24.9k1 & 105.39 & 351,30 \\
\hline $51+2468240$ & Acrolsin & 8.4 & 2.66 & 1135 & I7, 83 \\
\hline $5+84080$ & Acrolonitertle & 3 & 0.955 & 4.05 & 13.51 \\
\hline $5 \mathrm{H}-8468260$ & Benzens: & 0.11 & 0.035 & 0.25 & 0.50 \\
\hline $94-2060$ & Brouodichleronthe & 0,38 & 0.108 & 0.45 & 1,49 \\
\hline$F 1+836$ BP?40 & Aronofora & 0.13 & 0.041 & 0.18 & 0,59 \\
\hline sti-846 8240 & carbon tisulfite & 0.7 & 0.232 & 0.99 & 3.29 \\
\hline $54-846$ sack & Caston tatrachloride & 0.094 & 0.050 & 0,13 & 0.42 \\
\hline st4846 9240 & Chlornbeng: & 0.18 & $0,0,7$ & 0.2 & 0.81 \\
\hline $54=84682240$ & Chloroethene & 0.98 & $0,3+2$ & 1.32 & 4,41 \\
\hline $84-8468240$ & Gillorofor: & 0.18 & 0,057 & 0.24 & 0.81 \\
\hline sul-8/6 2240 & chloroprens: & $0.2 t$ & 0.067 & 0.26 & 0.5 \\
\hline 돠요 846 9240 & Oibremoch Lorsmethene & $0.5 t$ & 0.162 & 0.69 & 2.30 \\
\hline sul- 6.6 .8240 & Dibroronthere & 0.ss & 0.207 & O. Be & 2. \\
\hline sy-ate 0260 & Ofichlarodtflugronther & 1.7 & 0,54 & 2,30 & 7.65 \\
\hline 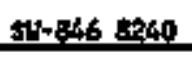 & Ethrol cranids & 3.5 & t.115: & 4.7 & 15.76 \\
\hline $511-846620240$ & Ithel nathesplate & 0.76 & 0.262 & 1.03 & 3.42 \\
\hline sit-846 octo & Ethrlbenzins: & 0.3 & 0.073 & 0.31 & 1.04 \\
\hline $54-84682000$ & 1spoutral slectiol & 52 & t6.\$\$1 & 70,26 & 25.20 \\
\hline . $31=846$ 8240 & methererylonitrite & 0,35 & 0.111 & 0.47 & 1.58 \\
\hline $51-8468040$ & Mathyl 1oitide & 0.76 & 0.262 & 1.05 & 3,42 \\
\hline
\end{tabular}


Table A-18. LOO and LOQ Calculations for Selected Constituents Based on MOL Report ${ }^{\mathrm{D}} \mathrm{b}$ for Low Level standards. (11 sheets)

\begin{tabular}{|c|c|c|c|c|c|}
\hline Hethed_mes: & conatituent y:-: & Lot & sip. nty. & Les & 나음 \\
\hline s11046 anco & Nethyl bropide & 0,8 & 0.204 & 1.12 & 3.74 \\
\hline$s u=8460240$ & Methry ehloride & 0.32 & 0.102 & 0.43 & 1.44 \\
\hline su- 46 a 3240 & Hethrd othyl keton & 2.5 & 0.796 & 3.38 & 11,26 \\
\hline $54 \times 8 \times 6 \quad 8240$ & Wethyl quthered att: & 0.83 & 0.265 & 1.12 & 3.74 \\
\hline SYI.846 8240 & Hethyl the chlorids & 0.11 & 0.175 & 0.15 & 0.50 \\
\hline $54-8468260$ & Pentechlorotethene & 3.5 & 1.210 & 5.13 & 17,11 \\
\hline $5+8060300$ & styrente & 0.25 & 0.075 & $0.3 t$ & 1,04 \\
\hline 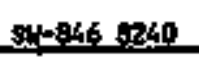 & Tetrethlesenthem & 0.6 & 0.204 & 0.86 & 2.68 \\
\hline $51+246060$ & Tetruhyofofuren & 3.7 & 1.178 & 5.00 & 16.86 \\
\hline 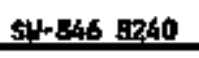 & Tolmen: & 0.16 & 0.051 & $0.2 ?$ & 0.72 \\
\hline sin-846 8240 & Irichlorenthene & 0.39 & 0,092 & 0.39 & 1.31 \\
\hline 540.8468040 & Trichloreconof twaromethere & 0.55 & 0.175 & 0.73 & 2,48 \\
\hline $503-346$ b240 & Yiml septate & 1.6 & 0.573 & 2.63 & B.11 \\
\hline 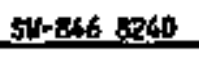 & Vilex enlorids & $0 . \pi$ & $0.25 z$ & 1.97 & 3,56 \\
\hline $\sin -80680$ & Xrlenge (total) & $\underline{0.65}$ & $0,2,17$ & 0.92 & 5.08 \\
\hline 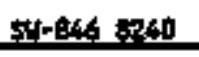 & Ellytchloride & 0.41 & 0.131 & 0.55 & 1,85 \\
\hline S5H-346 8240 & 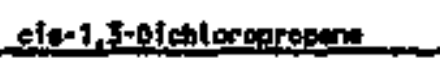 & 0,41 & 0,131 & 0.55 & 1.85 \\
\hline $54-846$ 19240 & trun:-1,3-0ichloropropeno & 0.67 & 0.150 & 0.64 & 2.12 \\
\hline sy-84s 0240 & trant-1,4-dichleco-2-butente & 0.26 & $0.08 \mathrm{~s}$ & 0.55 & 1.17 \\
\hline $51,-9460260$ & 1,t,1,2-Tetrectlorgethane & 0.11 & 0.035 & 0.15 & 0.50 \\
\hline sir-846 0260 & 1,1,1-triebloreathene & 0.28 & 0.009 & 0.13 & 1.26 \\
\hline $54+8468260$ & 1,1,2,2-tetrochloronthene & 0.54 & 0.172 & 0.7 & 2.45 \\
\hline $5 t-8460280$ & 1,1,2-Triethloroethene & 0.19 & 0.061 & 0.26 & 0.85 \\
\hline str-ek6 8260 & 1,1-0ichloraethan: & 0.22. & 0.070 & 0.70 & 0.98 \\
\hline ST-826 2000 & 1.1-0fectioroesthene & 0.26 & 0.083 & 0.35 & 1.17 \\
\hline 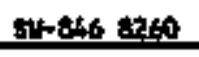 & 1,2,3etrichloroprogen & 0.52 & 0.189 & 0,0 & 3.66 \\
\hline $84-846000$ & 1,2-0llerouo-3-chtaropropare & 0.34 & 0.204 & 0.8 .8$. & 2. 盟 \\
\hline $\sin 4060$ & 1.3eplatronestine & 0.4 & $0.1<0$ & $0.5 \%$ & 1.98 \\
\hline $510=46060$ & 1,2-0ichlorothenthe & 0.34 & 0.076 & D..xP. & 1,ng. \\
\hline $54-0460260$ & 1,2-Dichloroechere & 0.26 & 0.093 & 0.35 & 1.17 \\
\hline $54-8460260$ & 1,2-0itchlorepropen & $0.05 t$ & 0.016 & 0.07 & 0.25 \\
\hline s14.846 明60 & 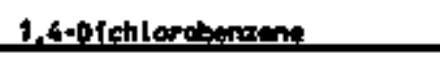 & 0.2 & 0.064 & 0.27 & 0.90 \\
\hline 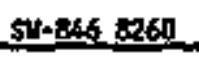 & 1, 6-aipxese & 62 & 19.75 & 8.7 & 23.24 \\
\hline $51-246 \operatorname{san} 6$ & t-ilutanol & 臮 & 26.752 & 193.50 & 372.32 \\
\hline$S^{2}+8 \times 60200$ & 2*Hexinane & D.51 & 0.162 & 0.69 & 2,30 \\
\hline
\end{tabular}


Table A-18. LOD and LOQ Calculations for Selected Constituents Based on KDL Report ${ }^{2}$ for Low Level standards. (11 sheets)

\begin{tabular}{|c|c|c|c|c|c|}
\hline method llane & Conatituent une & PL & swo. Dr. & 100 & 10 \\
\hline $84-846000$ & 4- Wethyl-2-onterane & 0.65 & 0.207 & $\mathbf{0 . 8 0}$ & 2.93 \\
\hline stre66 8260 & Acritone & $4,7$. & 1.47 & 6.35 & 2t.17 \\
\hline 50.8468260 & Acatonitrite & 69 & 21.975 & p.5.25 & 310.77 \\
\hline $8 y-8468: 260$ & Acroletein & 4.7 & 1.457 & 6.35 & 21.17 \\
\hline str-84s 8960 & Acrilonitrits. & 4.6 & 1.465 & 6.72 & $20, \pi$ \\
\hline $5 \mathrm{si}-866.8260$ & Benzente & 0.14 & 0.065 & 0.19 & 0.63 \\
\hline $511-846$ 8360 & Sronodich lerenethene & 0.053 & 0.011 & 0.06 & 0.15 \\
\hline S4-246 $=260$ & Oroteraforit & 0.41 & 0.13t & a.ss & 1.85 \\
\hline $34-260$ - 1260 & Earton diouf fide & 0.65 & 0.207 & O. Bs & 2.93 \\
\hline $8+-1<6$ t250 & Carbon tetrochlor ide & 0.22 & 0.070 & 0.30 & 0.98 \\
\hline sw-846 0260 & Gilorobenetre & 0.15 & 0.048 & 0.20 & 0.88 \\
\hline sw-846_2260 & Gilomenthith & 0.32 & 0.102. & 0.43 & 1.44 \\
\hline str.846 8260 & miteroform & 0.21 & 0.067 & 0.28 & 0.95 \\
\hline$s u-846 \Delta a 260$ & Chtoroprent & 0.2. & 0.073 & 0.31 & 1,04 \\
\hline $8 \mathrm{H}-8468200$ & Dibropochlorocetiane & 0.24 & $0.0 \%$ & 0.38 & 1.26 \\
\hline 포연 & odbrespathane & 0.36 & 0.115 & $0 ; 49$ & 1,62 \\
\hline $54-8468260$ & Dichlorodiftuorenethene. & 0.85 & $0.27 t$ & 1.15 & 3.93 \\
\hline $34+466$ Beso & Extyl grinfide & 2.7 & 0.0 .60 & 3,6 & 12.16 \\
\hline $34-846$ a260 & Ethrl nethosorytate & 0,56 & 0.178 & 0.76 & 2.52 \\
\hline 토스영 9760 & Ethrlbensens & 0.19 & n.061 & 0.26 & 0,06 \\
\hline S4-246 8260 & isoburtut sleshol & $\$$ & 29.535 & 127.01 & 42.36 \\
\hline $5+8468260$ & wethecrylonitefle & 0.46 & 0.246 & 0.62 & 2.07 \\
\hline $5+20658260$ & rettryl lodide & 0.23 & 0.073 & 0.31 & 1.04 \\
\hline $\operatorname{Sin}=465860$ & Nethyl bronide & 0.59 & 0.385 & 0.80 & $\underline{2.66}$ \\
\hline $51+8468260$ & Methyl chloride & 0.46 & 0.160 & 0.59 & 1.8s \\
\hline 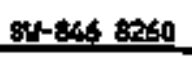 & 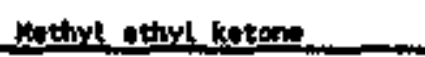 & 3.9 & 1.242 & 5.4 & 17.57 \\
\hline 545468960 & Dothyl nethecrylate & 0.41 & 0.131 & 0.55 & 1,35 \\
\hline 오묘영 82601 & 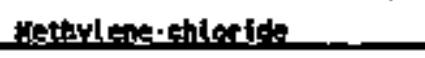 & p.s? & 0.197 & $0 . \%$ & 2.79 \\
\hline 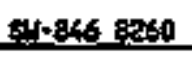 & Pentechloropthene & 0.1 & 0,052 & 0.16 & 0.45 \\
\hline $54-8462260$ & 8 rymente & 0.16 & 0.065 & 0.19 & 0.63 \\
\hline $84-466$ 2260 & Totrachloranthen: & 0.24 & 0.076 & 0,3 & 1.00 \\
\hline $15-9462830$ & Ietrehysereftren & 0.45 & 0.143 & 0.61 & 2.05 \\
\hline $54-2468260$ & Iolvenes & 0.13 & 0.031 & 0.18 & 0.59 \\
\hline $5+8468260$ & Ir fehloroethene & 0.26 & 0.076 & 0.32 & 1.08 \\
\hline $84-846$ 22500 & If tchloremonef tworomethane & 0.37 & 0.118 & 0.50 & 1.67 \\
\hline
\end{tabular}


Table A-18. LOD and LOQ Ca]culations for Selected Constituents Based on HDL Report ${ }^{0}$ for Lou Level Standards. (11 sheets)

\begin{tabular}{|c|c|c|c|c|c|}
\hline Nothod Hin & Coratituent Hones & . & STP. DE. & 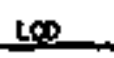 & 100 \\
\hline 510.468260 & Yimd metitass & 0.76 & 0.242 & 1.03 & 3.42 \\
\hline$s 1-8468260$ & vined chlocide & 0.33 & 0.105 & 0.45 & 1.49 \\
\hline $5 \mathrm{si}-84600200$ & xylenes (total) & 0.57 & 0.182 & 0.77 & 2.57 \\
\hline $5 \mathrm{sH}-846,8260$ & Allidehloridis. & 0.76 & 0.235 & 1.00 & 3.35 \\
\hline $5+24-2460$ & ait-1,3-Dithlorestepine & 0.43 & 0.137 & 0.59 & 1.96 \\
\hline 51.-846 apto & 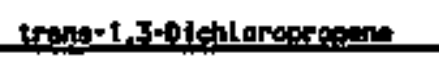 & 0.25 & 0,090 & 0.34 & 1.13 \\
\hline stre46 8260 & trings-1,6-dichlaro-2-butene & 0.66 & 0.206 & 0.86 & 2,8 \\
\hline sy-466 a270 & $1,2,6,5$-Tetruthlorobenzene & 0,42 & 0.134 & 0.57 & 1, \\
\hline$s y-946,9270$ & 1,2,4-Triehtorobenzene & 1.1 & 0.350 & 1.39 & 4.95 \\
\hline $54-840$ a & 1,2.0ichtelorabenzense & 1.3 & 0.352 & 1,62 & 5.60 \\
\hline $51-0468270$ & 1,3-0ichlorebenzene & 1.4 & 0.140 & 1.89 & 6.31 \\
\hline $5,1=8468979$ & 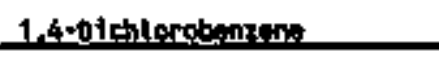 & 0.83 & 0.185 & 2.78 & 2.61 \\
\hline s5-346 2070 & 1,4+Haphtogutinem & 7,3 & 2.325 & 9.86 & 32.48 \\
\hline st-846 2070 & 1-techtoyleadm & 1.7 & 0.561 & 2.30 & 7.66 \\
\hline$s 1-846,970$ & $2,3,4,6$-Tetrechlorophenol & 1.3 & 0.414 & 1.76 & 5.06 \\
\hline sy-ecs 0270 & $2,4,5-$ Trienloroshenol & 0.48 & 0.158 & 0.65 & 2-ts \\
\hline $51-846 \quad 370$ & 2, 4,6 -Trichlorothenal & 4.2 & 1,358 & 5.67 & 18.97 \\
\hline 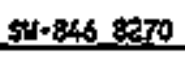 & $2,4+0$ lathlorophenol & 2.. a & 0.892 & 3.78 & 12.61 \\
\hline $57+3460270$ & 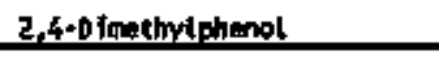 & 1.5 & 0.478 & 2.03 & 6.76 \\
\hline $9 y-2460270$ & 2,4-0 initrophenol & 4.7 & 1.007 & 0.35 & 21.17 \\
\hline $54-846$ scrm & 2,4-0, inferateluens & 0,8 & 0,2 , & 1.19 & 3.95 \\
\hline $52-8460070$ & 2,6-0ichlorophenol & 2.5 & 0.796 & 3.38 & 11.26 \\
\hline $5-246.2270$ & 2,6-0 intitratoluent & 0,7 & 0.232 & 0.99 & 3.29 \\
\hline $511+846 \quad 8270$ & 2-dietryleminofluorente & 3.2 & 1.019 & 4.32 & 14.41 \\
\hline 51-846 sam & 2-Ghloronshthalene & 2.3 & $0, \pi 2$ & 3.11 & 10,36 \\
\hline sy-846 8270 & 2-Chaloroghenat & 0.56 & 0.178 & 0.76 & 2.52 \\
\hline s11-346 ac7o & 2-Hethringhehalons & 0.19 & 0.061 & 0.26 & 0.86 \\
\hline su- 446 1870 & 2-kathylptienal & 0,29 & 0.0 然 & 0.39 & 1,31 \\
\hline $54=84602020$ & 2-Meghthydanins: & 2.1 & 0.669 & 2.84 & 9.46 \\
\hline $54-846,9270$ & 2-witrounitine & 2.4 & 0.766 & 3.24 & 10.81 \\
\hline $54-846 \quad 0270$ & 2-Uitrophinad & 4.2 & 1.338 & 5.67 & 18,62 \\
\hline $34-4601270$ & 2-picoling & 2.1 & 0.008 & 2.4 & 9.48 \\
\hline sw-246 :870 & 3.3'-Dichlarobensidine & 2.5 & 0.796 & 3.38 & 11.26 \\
\hline $51-8468270$ & 3.31-0 inethrolbenzidine & 3.3 & 1.051 & 4.46 & 14.85 \\
\hline $5 y-846.270$ & 3-Hethylehol anthreme. & 1.1 & 0,350 & 1.49 & 4.55 \\
\hline
\end{tabular}


Tab7e A-18. LOD and LOQ Calculations for Selected Const1tuents Based on MOL Report ${ }^{\mathrm{a}, \mathrm{b}}$ for Low Leve] Standards. (11 sheets)

\begin{tabular}{|c|c|c|c|c|c|}
\hline Muttrod Mane & Constitiment Hans: & $=1$ & STD. AEY. & Lim & LoO \\
\hline sit-84s $8 x+7$ & 3-Htitronitin & 4.3 & 1.368 & $5,8 t$ & 19.37 \\
\hline st-ess $0+20$ & 4.6-pinitro-2 zathrlethengl & 0.98 & 0.312 & $1,3 x$ & 4.41 \\
\hline $5+1-846$ : 8270 & A-l-inobiphenyl & 3 & 1,502 & 6.76 & 22,52 \\
\hline SSt-245 ar70 & 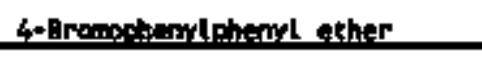 & 0.59 & 0.198 & 0.20 & 2,66 \\
\hline 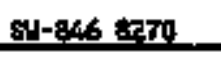 & 4-Chlorost-2nthylphnel & 0,5 & 0.159 & 0,6 & 2,25 \\
\hline $517+8468270$ & 4-chlofognilfine & 3.3 & $t .05 t$ & 4.46 & 16.8 \\
\hline g.t-846 8270 & 4-Chloroherodiphest other & 0.28 & 0.009 & 0.38 & 1.26 \\
\hline $514=846$ g270 & 4-llattyolenemol & 0.5 & 0.166 & 0.70 & 2,34 \\
\hline su-g4s 8270 & 4-mitrounilin: & 2..8 & 0.212 & 3.8 & 12,61 \\
\hline 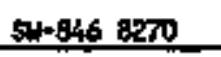 & 4-Hitroghenol & 2.7 & 0.860 & 3.65 & 12.16 \\
\hline $84-8468270$ & 4-witroctinoline-1-oxide & 19 & 6.051 & 25.67 & A5.57 \\
\hline su- 4068270 & s-uitro-o-tolutdine & 0.21. & 0.00 & 0.38: & 1.25 \\
\hline $54-8460270$ & 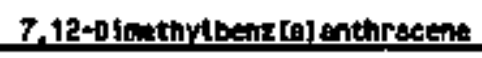 & 1.1 & 0.350 & 1.68 & 6.8 \\
\hline Str-846 3270 & Actruphthen & 0.48 & $0,156$. & 0.66 & 2.21 \\
\hline 표-846 82:0 & Acenuphthylene: & D. & 0.051 & 0.26 & 0,86 \\
\hline ste-846 2270 & Aeatophanone & 0.54 & 0.172 & 0.73 & 2,43 \\
\hline su-966 8270 & initine & 9.3 & 2.962 & 12.57 & 41.89 \\
\hline st4-846 9270 & Inthracene & 0.16 & 0.051 & 0.22 & 0.72 \\
\hline $54-8468270$ & Aratite & 1.3 & 0.414 & 1.76 & 3.86 \\
\hline s4-866 9270 & Entedolanthrecose & 0.19 & 0.057 & 0.24 & 0.81 \\
\hline $84-8468270$ & 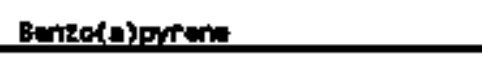 & 0.24 & 0.076 & 0,32 & 1.08 \\
\hline s14-846 9270 & Benzo(b) fluoreathene & 0.18 & 0.057 & 0.24 & 0.81 \\
\hline $84-8468270$ & Benzot phílyperylene & 2.6 & 0,028 & 3.51 & 11.71 \\
\hline $51+84658270$ & Bemeo(k)fluoremthene & 0.28 & 0.076 & 0,32 & 1.08 \\
\hline $8 x-8468270$ & Berpothtozole & 2,1 & 0.66 & 2.34 & $\$ .46$ \\
\hline S.51-846 8370 & Benzyl alcohol & 4 & 1.274 & 5.40 & 18.02 \\
\hline sir-846, 8:70 & Bis(2-Chorosthoxy)methare & 2.5 & 0.36 & 3.3 & 11.26 \\
\hline 5108460270 & B1:(2-chloroethyl) ettrer & 0,21 & 0.067 & 0.24 & 0.95 \\
\hline str-846 affo & Siesz-chleraligorgerl) etter & 0,24 & 0.076. & 0.5고. & 1.05 \\
\hline $915=846,8270$ & Bioca-ethrtheryl) ghelantete & 0.37 & 0.118 & 0.50 & 1.67 \\
\hline SIt-846 8270 & Butylbengyledthutate & 7.1 & 2.261 & 9.59 & 31.98 \\
\hline 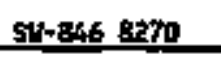 & Chlorobenzilate & 1.3 & 0.414 & 1.76 & 5.86 \\
\hline $85-846 \quad 8270$ & Chroverts. & 0.17 & 0,056 & 0.23 & 0.7 \\
\hline str-246 aero & Decene & 0.38 & 0.131 & 0.51 & 1.71 \\
\hline $512-8468270$ & of-n+butylehthe lote & 2.5 & $0.7 \times 4$ & 3.38 & 11.26 \\
\hline
\end{tabular}


Tabie A-18. LOD and LOQ Calculations for Selected Constituents Based on MDL Report"' for Lon Level standards, (11 sheets)

\begin{tabular}{|c|c|c|c|c|c|}
\hline Mathod Une: & Constituent Hase & 10 & sto. pyy. & 200 & 100 \\
\hline 34.846 a270 & Di-noectylonthelute & 0.055 & 0.018 & 0.07 & 0.25 \\
\hline $54-4460970$ & otalinte & 0.21 & 0.067 & 0.25 & 0.98 \\
\hline 51-468 8270 & 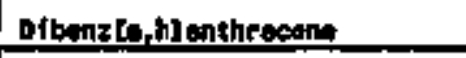 & 0.53 & 0.160 & 0.72 & 2.39 \\
\hline $81-8469270$ & Dtbenzofuren & 0.15 & 0.048 & 0.20 & 0.65 \\
\hline s14.846 8770 & Dietbrl phthalete & 0.12 & 0.058 & 0.16 & 0.54 \\
\hline $34+8468270$ & Dinothonte & 1.6 & 0.446 & 1. & 6.31 \\
\hline S15-2060270 & oinathyd phtholute & 0,13 & 0,041 & 0.18 & 0.59 \\
\hline $54+8460270$ & Difhemidemine & 0.44 & 0.140 & 0.59 & 1,8 \\
\hline 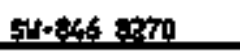 & Dodectnit & 0.26 & 0.005 & 0.35. & 1.17 \\
\hline sirte 846,0270 & Etthyl inthenesulforate & 3 & 0.951 & 4.05 & 13.51 \\
\hline $51=846,8270$ & talther & 5.4 & 1.720 & 7,30 & 24.32 \\
\hline 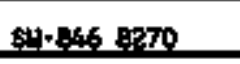 & Fluorentheri: & 0.12 & t, 0 , 55 . & 0,16 & 0.54 \\
\hline s4t- 84696270 & Plyorane & a.0.5 & 0.030 & 0.13 & 0.42 \\
\hline 8u- 846 : 0270 & Hexuchilorobertzense & 0.41 & 0.131 & 0.55 & 1.25 \\
\hline$s w=8468270$ & Exechlorobutsdien: & 0.55 & 0.175 & 0.76 & 2.48 \\
\hline sy+846 arto & Hexpechtorogyeloginteditene & 0.63 & 0.137 & a.s: & 1.24 \\
\hline 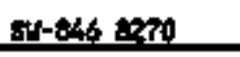 & Hexuchlaranthene & 0.58 & 0.17 & 0.24 & 2.40 \\
\hline $54=8468270$ & Hifexpechlarephers & 12 & $3,8 x 2$ & 16.21 & 54.05 \\
\hline 54.8468970 & Hexachloregrepene & 0.29 & 0.002 & 0.39 & 1.31 \\
\hline str-846 and & Indenol, 1, 2,3-edeprente & 0.5 & 0.115 & 0.78 & 2.61 \\
\hline sir- & Isodrin & 1. & 0.318 & 1.35 & 4.50 \\
\hline $5: 1-846 \quad 8270$ & Iserhorone & 0.092 & 0.029 & 0.12 & 0.41 \\
\hline swe.846 8270 & tagesuffole & 0,31 & 0.099 & 0.42 & 1.40 \\
\hline s!l-846 8270 & Kapene & 2 & 0,637 & 2.70 & 9.01 \\
\hline $5 H=8468270$ & Kerosene & 2.6 & 0.828 & 3.51 & 11.71 \\
\hline$S 1=846$ EZ70 & Methoprilene & 5 & 1.592 & 6.76 & 22.52 \\
\hline $54-646 \quad 8270$ & Methrl ofethenceulforete & 0.35 & 0.111 & 0.47 & 1.58 \\
\hline $81-86800$ & 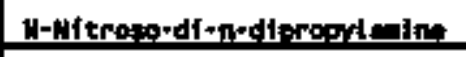 & 0.4ㄴ.? & 0.153 & 0.65 & 2.16 \\
\hline sin-24s 800 & 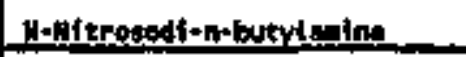 & 2.6 & O. & 3.51 & 11.71 \\
\hline sir-ats 8270 & 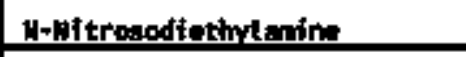 & 1.8 & 0,46 & $t .89$ & 6.31 \\
\hline 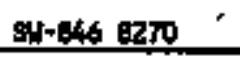 & $y$-nititrosodimathyleatins & 4 & 1.276 & $\$, 40$ & 18.02 \\
\hline s1. 846 .8270 & 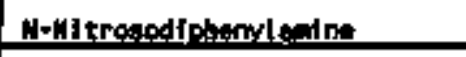 & 0.27 & $0,0.086$ & 0.35 & $1.7 ?$ \\
\hline Str-eas ats70 & W-Hitrorenthyletthyl wing & 1.2 & $0.3: 1.2$ & 1.62 & 5.40 \\
\hline S514846 8270 & H-Nl trosonorghal ine & 0.24 & 0.076 & 0.32 & 1.08 \\
\hline sit-2046 arza & n-Mitronopiparidine & 1.3 & 0.416 & 1.76 & 5.86 \\
\hline
\end{tabular}


Table A-18. LOD and LOQ Ca]culations for Selected Constituents Based on MDL Report" for Low Leve] Standards. (11 sheets)

\begin{tabular}{|c|c|c|c|c|c|}
\hline Nethod Lit:a & constitutent lan: & 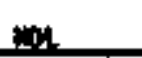 & 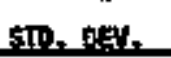 & top & 100 \\
\hline 91846 gero & Wephthalore & 0.16 & 0.051 & 0.2 & $0 . \pi$ \\
\hline 512846 agro & yerobongen: & 0.61 & 0.18 & O.的 & 2.75 \\
\hline uㅏ- & Witronorrolidin & 1.6 & 0.570 & 2.16 & 7.21 \\
\hline 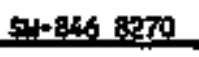 & 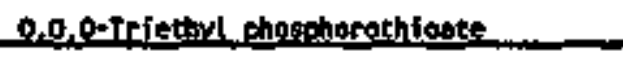 & 0,63 & Q.231 & 0.85 & 2.84 \\
\hline $54-8662270$ & 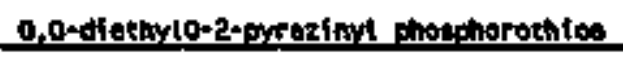 & 3.5 & 1.115 & 4.73 & 15.76 \\
\hline $84-846800$ & Purathilen & 0.54 & 0.172 & 0.7s & 2.43 \\
\hline $5 y-846 \div ; 0$ & Pentechlorebenzense & 0,3 & 0.009 & 0.42 & 1.40 \\
\hline$y-2469$ & Pentachilorenitrobinzeno (peries) & 4.7 & 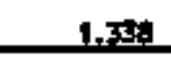 & 5.67 & th..92 \\
\hline sti-846 8270 & Pentuchloroghenol & 0.87 & $0 . \overline{2 \pi}$ & 1,15 & 3.92 \\
\hline $84-0.66270$ & Phenacesin & 1.3 & 0,114 & 1.76 & 5.06 \\
\hline s.t.846 0270 & Phenemthrene & 0.078 & O. & 0.10 & 0.33 \\
\hline s4-836 :270 & Phunol & 0.21 & 0.0 .67 & 0.28 & 0.85 \\
\hline s4t84t g270 & Pron:mide & 8.4 & 2.6位 & 11,5 & 37 . $9 x$ \\
\hline 돠요영 9270 & Pyrese & 0.16 & 0.051 & 0.22 & 0.72 \\
\hline$s+0468270$ & Prridine & 2,8 & 0.192 & $3.7 \mathrm{~s}$ & 12.61 \\
\hline su-246 2270 & Satrol & 0.77 & 0.0.8.6 & 0.,56 & $1.2 ?$ \\
\hline 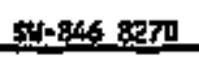 & Ietredecene & 0.20 & 0.009 & 0.38 & 1.26 \\
\hline s.1.846 8270 & 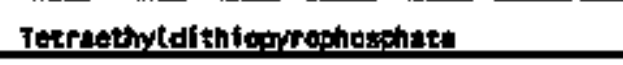 & 0.52 & 0.166 & 0.70 & 2,34 \\
\hline$s 1+8460270$ & Tributril Phosphace & 0.14 & 0,045 & 0.19 & $\underline{0.53}$ \\
\hline 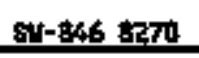 & Tris-2-chlorenthre phosphente & 6.6 & 7.0. & s.6s & 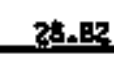 \\
\hline Sㄴㄴ 84698270 & 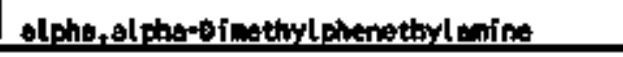 & 19 & 6.051 & 3.67 & 85.57 \\
\hline s4-846 a270 & morecresol & 0.7 & 0.245 & 1,09 & 3,47 \\
\hline sir-846 a270 & p-dinitetimain & 0.61 & 0.131 & 0.55 & 1.85 \\
\hline 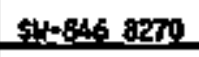 & Q-toluidine. & 2.1 & 0,669 & 2.8 & Q.46 \\
\hline sit-846 8270 & 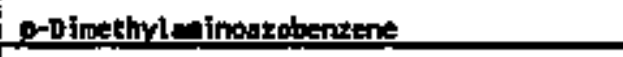 & 0.29 & $0.0 \mathrm{~m}$ & 0.39 & 1.31 \\
\hline $84+8468270$ & p-pherrolendidialne & B.s & 2.7207 & $11-48$ & 帮,25 \\
\hline $5 y-846 \quad 870$ & sue-Trinitrobangione & 0.87 & $0.7 \pi$ & 1,18 & 3.92 \\
\hline N5-846,9012 & Sxanits & 1.7 & 0.51 & 2,30 & 7.66 \\
\hline 5:4-866 9020 & Jotal arginic halogn & 6.9.2. & 2,197 & 9,38 & 31,000 \\
\hline $\mathrm{St}+8 \pm 6.9030$ & Sulfide & 40 & 60.510 & 15.2. & .555 .73 \\
\hline cent-ges 9060 & Tokel oroanie cerben & 140 & $44.5 \mathrm{ks}$ & $\mathrm{TH}, 16$ & 630.54 \\
\hline
\end{tabular}

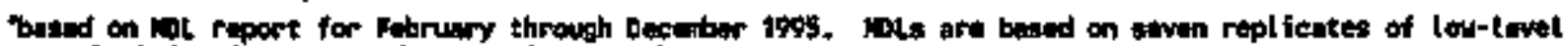

staxdarde by the ane analyst on the same dor.

inits art in parte par bitition (ppb).

$L O D=$ lfajt of detection.

$10 \mathrm{R}=[1 \mathrm{int}$ of quantitation.

DLL = nethod detection linjt. 
DOE/RL-96-01, REV. 0

APPEDIX 8

DATA EVALUATZOS

B-1 
DOE/RL-96-01, REV. 0

This page intentionally left blank. 


\section{B.0 DATA EVALUATION}

R. $Y$. Gray

Westinghouse Hanfort Company

Data evaluation is a process through whlch suspect data are identified and investigated. At present, the data evaluation process consists of the investigation of requests for data evaluation (RADE) and the statistical evaluation of contamination indicator parameter data.

The evaluation of RADEs is discussed in the following section. The statistical evaluation of contamination indicator parameters is discussed in the site-specific chapters and Appendix $C$.

\section{B.1 REqUEST FOR ANALYTICAL DATA EVALUATIOH PROCEDURE}

Suspect data called out in RADEs are evaluated in terms of the fojiowing (WHC-CH-7-8):

- A review of trends in historical data for the we1] in question

- An examination of contaminant distributions (e.g., plumes) that may affect concentrations in the well in question

- Results of quality control samples that may affect the data in question

- Laboratory data (e.g., chemist sheets) for the data in question

- Internal consistencles between replfcate analyses.

As a result of the RADEs, the data in question may be:

- Determined to be in error and corrected

- Viewed as acceptable, resulting in a $6 \mathrm{flag}$

- Viewed as suspect data, resulting tn a Y fTag

- Viewed as rejected data, resulting fn an $R$ flag.

\section{B.2 REQUESTS FOR ANALYICAL DATA EVALUATION}

A total of 178 RADEs were submitted from October 1994 through September 1995. The RADEs subuitted involved most of the major analytical groups; however, approximately $80 \%$ of the total was accounted for by the following five constituent groups: (1) $\mathrm{pH}$ and conductivity measurements performed in the field, (2) inductively coupled plasma metals,

(3) radionuclides, (4) total organlc halogen, and (5) anions (Figure B-1). 


\section{B.2.1 Field Measurements}

Forty-one RADEs involve measurements of $\mathrm{pH}$ and conductivity made by field samplers. These RADEs reflect values that are unusually higher or lower than historical trends and/or criticai means/ranges for a particular wall. This represents a long-term recurrent problen with field calibration and/or weasurement. The values are usually flagged as suspect data unless hard evidence is avajlabie to fTag the data as rejected, such as when laboratory measurenents made during the same sampling event or subsequent verffication sampling confirm that fjeld measuresients were in error.

\section{B.2.2 Inductively Coupled Plasna Metals}

Forty-two RADEs were submitted for inductively coupled plasma metals. There does not appear to be a systematic error, so evaluation for many of them will depend on jaboratory records and trending.

\section{B.2.3 Radionuclides}

Twenty-six RADEs were subnitted concerning radionuclide analysis. These RADEs seem to represent a randon collection of out-of-range data and do not indicate systenatic problens with the analyses.

\section{B.2.4 Total Organic Halogen}

This constituent group recelved seventeen RADEs. The RADEs for total organic halogen appear for the nost part to be the result of laboratory problems. Hany involve quadruplicate samples that do not agree. The others usually excoed historica? trends. The fliers are usually fiagged as suspect.

\section{B.2.5 Antons}

Seventeen RADEs were subnitted for anions. There does not appear to be a systematic error, so evaluation for many of then wil] depend on laboratory records and trending.

\section{B.2.6 others}

The remainder of the categories reflect a variety of random problems, of which none could be contrived as significant enough to warrant review of established sampling and analysis practices. Exarples in this category include total organic carbon, volatile and semi-volatile organics, turbidity, ancioniun, aTkaijinity, and water level measurements. 
DOE/RL-96-01, REV. 0

\section{B.3 REFEREKCES}

WHC-CM-7-8, "Evaluation of Requests for Analytical Data Review," Section 4.2, Environmental Engineering and Geotechnology Function Procedures, Westinghouse Hanford Company, Richland, Washington. 
Figure B-1. Histogran Showing Number of RADEs Submitted in Bifferent Analytical Categories.

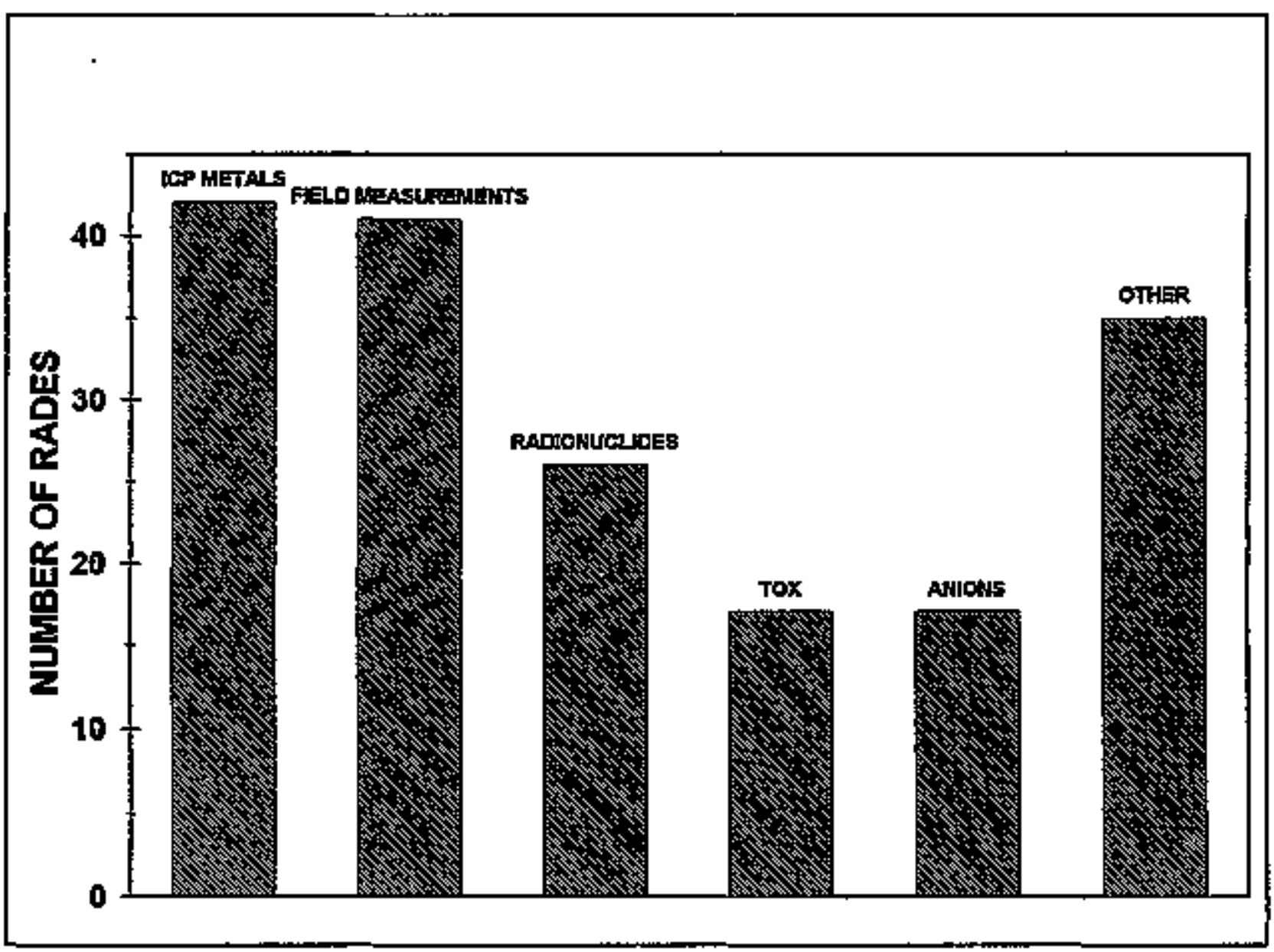


DOE/RL-96-01, REV. 0

APPENDIX C

STATISTICS

chi 
DOE/RL-96-01, REY. 0

This page intentionally left blank.

C-ij 
DOE/RL-96-0I, REV. 0

\section{C.0 IKTRODUCTION}

c. J. Chou

Nestinghouse Hanford Company

The Resource Conservation and Recovery Act of 1976 (RCRA) facilities include both 1 iquid and soild waste treatment, storage, and/or disposal (TSD) units. Those units with potentia] for contaminating groundwater require groundwater monitoring as prescribed in 40 Cade of Federa? Regulation (CFR) 265 and Washington Adkinistrative Code (WAC) 173-303-400 (interin status) and 40 CFR 264 and WAC 173-303-645 (final status). The primary objectives of RCRA groundwater monitoring are to: comply with the intent of applicabTe interin- and final-status state and federal RCRA regulations and assess potentia] impact on groundwater quality. Statistical evaluation at a TSD facility is required to detect changes in downgradient groundwater qual ity from conditions upgradient of the facility.

The final Hanford Facility RCRA Permit (RCRA Permit) was issued by the Washington State Department of Ecology (Ecology) and the U.S. Environmental Protection Agency (EPA) on August 29, 1994. The RCRA Permit became effective on Septenber 28,1994 . The perrit has two parts. The first part contains the requirements for operating the RCRA factlity and standards for managing it under the base RCRA program (Ecology 1994). The second part contains the requirements for corrective action conditions for the cleanup of hazardous waste under the Hazardous and Solid Waste Amendments to RCRA (EPA 1994). Groundwater monitoring activtties at most of the TSO units will continue to be governed under interim-status regulations except for the 183-H Solar Evaporation Basins (183-H Basins) and the 300 Area Process Trenches (300 APT), which are subject to final-status regulations. Statistical eva? uations under interim- and final-status regulations are discussed separately in the following sections.

\section{C.1 STATISTICAL EYALUATIONS-IMTERIM STATUS}

In accordance with interim-status regulations, RCRA projects are conducted under one of three levels of monitoring efforts: background monftoring, Indicator parameter evaluation, and groundwater qualfty assessment. Ail of the RCRA facilities at the Hanford Site have completed their initial background monitoring programs.

Statistical evaluations for interim-status facilities during the past year consisted of reestablishing background levels for several RCRA facilities to reflect changes in the monjtoring network, evaluating RCRA facilities' impact on the quality of groundwater, and performing required statistical evaluations for the Solid Waste Landfit? (SWL). The SWL is a solid waste disposal factilty. It is not a RCRA hazardous waste site. The current operations of the SWL fall under the regulations of MAC 173-304, and a permit appification for the factilty under this regulation has been prepared (DOE-RL 1993). Statistical method employed and results of statistical evaluations for the SWL are described in the SHL chapter of this report. The following sections provide a general description of the statistical mothods and results of statistical evaluations for the interim-status RCRA facilities. 
DOE/RL-96-01, REV. 0

\section{C.1.1 Statistical Method}

The statistical method used to summarize background data is the averaged replicate t-test method as described in Appendix $B$ of the Resource Conservation and Recovery Act (RCRA) Groundwater Nonftoring Technica] Enforcenent Guidance Document (TEGO) (EPA 1986) and Chou (i991). The averaged replicate t-test method, for each contanination indicator parameter, is calculated as:

$$
t=\left(\bar{x}_{i}-\bar{x}_{b}\right) / S_{b} * \sqrt{1+1 / n_{b}}
$$

where:

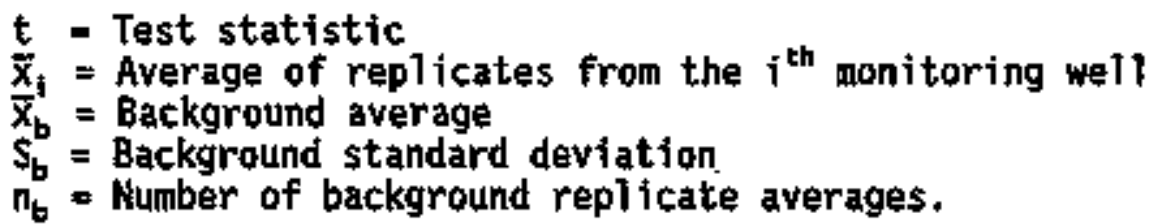

The Technical Enforcement Guidance Document states that a test statistic larger than the Bonferroni critical value $\left(t_{c}\right), i . e, t>t_{t}$, indicates a statistically significant probability of contamination. These Bonferroni critical values depend on the overall false-positjve rate required for each sampling period (i.e., $1 \%$ for interim status), the total number of wells in the wonitoring network, and the number of degrees of freedom $\left(n_{0}-1\right)$ associated with the background standard deviatjon. Because of the nature of the test statistic in Equation 2, results to be compared to background do not contribute to the estimate of the variance. The test can be reformulated, without prior knowledge of the results of the sample to be compared to background (1.e., $\bar{x}_{i}$ ), in such a way that a crittcal mean (CH) can be obtajned:

$$
\begin{aligned}
& C H=\bar{x}_{b}+t_{c} * S_{b} * \sqrt{\left(1+1 / n_{b}\right)} \quad \text { (one-tailed). } \\
& C H=\bar{x}_{b} \pm t_{c} * S_{b} * \sqrt{\left(1+1 / n_{b}\right)} \quad \text { (two-tailed). }
\end{aligned}
$$

For $\mathrm{pH}$, a two-tailed $\mathrm{CH}$ (or critical range) is calculated and a onetailed CN is calculated for specific conductance, total organic carbon (TOC), and total organic halogen (TOX). The $\mathrm{CH}$ (or range, for $\mathrm{pH}$ ) is the value above which (or above/velow in the case of $\mathrm{pH}$ ) a compared value is determined to be statistically different from background.

Most of the measured values for TOC from upgradient (background) we11s, were less than the contractuaily required quantitation limit (CRQL) of $1,000 \mathrm{ppb}$ for Datachem Laboratories. Estimates of the background standard 
deviations cannot be obtafned because of 1 aboratory reporting practices. Also, a new hazardous chenica] laboratory contract bocame effective during 1993. In the old contract (before April 26, 1993), these values were reported with the CRQL value followed by a ' $U$ ' qualffier. In the new contract (after April 26, 1993) results below CRQL but above the metnod detection linit (MDL) are reported with the measured value followed by an ' $L$ ' qualifier. Results below the VOL are reported with the WOL value followed by a ' $U$ ' qualifter. The lack of estimates of background variability precludes the determination of TOC crittcal means for various RCRA facjlities. In this case, a linit of quantitation (LOQ) will be used as the upgradient/downgradient comparison value. The LOQ for TOC was calculated to be $976 \mathrm{ppb}$ using 1995 field blanks data (see Appendix A).

Because of concerns over DataChem Laboratories' procedure for TOX, samples were analyzed by Roy F. Weston Laboratories from Noveniber 1993 to May 1995. The change of taboratories does not provide the needed background va]ues from which critical means are derived. However, the Tox data are evaluated using the following steps: (1) screening ToX values from upgradient we]ls; (2) if results fron upgradient wells indicate a history of non-detects, a LOQ will be used as the upgradient/downgradient conparison value; and (3) if TOX is historicaliy detected, a LOQ cannot be used as a surrogate background vaTue. In this case, the background va]ue nust be derived based on four quarters of monitoring data (e.g., 100-0 Pond) and used in the statistical evaluation. If four quarters of background data are not available, comparisons of upgradtent/downgradient TOX values will not be performed (e.g., Single-She11 Tanks Waste Hanagement Area U).

Finally, if the calculated critical range (for pH) was outside the chemicaliy posstble range $[0,14]$ or too large to be meaningfut because of the requirement to use four quarters of data to establish background

(e.g., 2101-H Pond, Liquid Effluent Retention Factility), the upgradient/ downgradient comparison value shall be the revised critical range using all available data. The expansion of the background data set to include wore than 1 year's data provides a better estimate of background mean and background standard deviation. More tmportantly, it increases the number of degrees of freedom associated with the background standard deviation. Other things being equal, a snaller $t_{c}$ value and a narrower critical range for ph would result. This approach is preferred becatse it compties with both the requirements and the spirit of the regulations.

\section{C.1.2 Results of Statistical Evaluations}

During the past year, no exceedances of critical means occurred for TOC, TOX, and specific conductance. However, several incidents of pH exceedance were noted. The wel1s (downgradient) were resampled. Yerification sampling results indicated that these exceedances were caused by erroneous pH measurements in the field. Detajied information can be obtained from each individuat chapter of this report. 


\section{C.2 STATISTICAL EVALUATIOHS-FIMAL STATUS}

Three levels of groundwater monitoring programs are required under final status regulations (40 CFR 264, Subpart $F$ and WAC 173-303-645): detection monitoring, complfance monitoring, and CL.rective action (Figure C-1). During most of the past year, however, g.'oundwater monitoring activities conducted at RCRA projects were monitored under interim-status requirements. Groundwater wonitoring plans reflecting requirements of final-status regulations were prepared for the 183-H Basins and $3^{n} 0$ APT.

\section{C.2.1 Detection-Level Groundwater Monitoring Progran}

In a detection-level groundwater monitoring program, groundwater parameter data (pH, specific conductance, TOC, TOX, or heavy metals, waste constftuents, or reaction products) from downgradient compliance-point we11s will be compared with data on area background wells semiannually to determine whether there is a statistically significant increase (or decrease for pH) over background concentrations. Statistical methods appropriate for a final status detection monitoring program will include analysis of variance, tolerance intervals, prediction intervals, control charts, test of proportions, or other statistical methods approved by ecology. The distribution(s) of monitoring parameters, the nature of the data, the proportions of nondetects, seasonal, temporal, and spatial variations are important factors to consider when selecting appropriate statistical methods. The statistical evaluation procedures chosen will be based on these EPA guidance documents: Statistical Analysis of Ground-Hater Nonitoring Data at RCRA Facilfties - Interim Final Guidance (EPA 1989) and Addendum to Interim Final Guidance (EPA 1992). Specifics will be addressed in the unit-specific permit applications and/or in the groundwater plans.

\section{C.2.2 Compliance-Level Monitoring Program}

A coupliance groundwater monitoring prograse will be established for a TSD unit if groundwater sampling during the detection-7evel monitoring progran reveals a statistically significant increase (or $\mathrm{pH}$ decrease) over area background concentrations for groundwater. In a compliance-level monitoring program, the monitoring objective is to determine whether groundwater protection standards have been exceeded. This is accomplished by comparing the concentration of a constituent of concern to groundwater protection standards such as a risk-based maximum concentration 1 init; aiternative concentration 1 imit; area or natural background; or applicable, relevant, and appropriate requirements.

Maximue concentration 1 imits will be identifted for each groundwater monitoring parameter 1 isted in Table 1 of WAC 173-303-645. Alternative concentration limits will be proposed after considering the observad concentrations of chemical constituents in the groundwater that might have originated from the regulated unit in question. The area background, natural background, and other standards that are applicable, relevant, and appropriate requirements will be evaluated when proposing an al ternative concentration 1 imit. 


\section{C.2.3 Corrective-Action Program}

If, during compliance-level monitoring at the point of compliance, dangerous constituents are measured in the groundwater at concentrations that. exceed acceptable greundwater protection standards, sufficient data, supporting information, and analyses will be provided to establish a corrective-action program. Detafis for the corrective action program will be specified in the unit-specific perrat applications. In addition, a groundwater monitoring plan that will be used to assess the effectiveness of the corrective-action measures will be submitted. This wonitoring plan wilt be similar in scope to the compliance-level groundwater monitoring program and will include all relevant infornation pertaining to the location and description of wonitoring wells, wonitoring network, well construction and development, sampling and analysis plans, statistical methods, and quality assurance and quality control procedures.

\section{C.2.4 183-H Solar Evaporation Basins (183-H Basins)}

As described earlier, the Hanford Facility RCRA Pemit became effective on 9/28/94. The 183-H Sol ar Evaporation Basins (183-H Basins) are one of five TSO units included in the RCRA Permit and are subject to final-status groundwater monjtoring regulations. This unit will be closed under finalstatus requirements (WAC 173-303-610).

Groundwater monitoring at 183-H Basins was mandated by a Consent Agreentent and Compliance Onder (Ecology and EPA 1986). It went directly into an interim-status assessument-level nonitoring program in response to the 1986 Consent Agreesent and compliance Order. The initial groundwater monitoring plan was prepared by Pacific Northwest National Laboratory based on interimstatus regulations using liaited data from then-existing 100-H Area wells (PILL 1986). In 1990 a closure plan was prepared (COE-RL 1991). However, groundwater monitoring described in these documents does not address whether 183-H Basins should be under compliance monitoring (equivalent to the interimstatus assessment monitoring) or corrective action (because some concentration limits have exen exceded). During 1995 a groundwater monitoring plan was prepared to reflect final-status compliance-level requirements, and to describe the updated well list, constituent list, and sampling frequency. Detailed statistical methods can be found in Hartman and Chou (1995).

\section{C.2.5 300 Area Process Trenches (300 APT)}

An extensive groundwater wonitoring program was carried out during the operational life (1975 to 1994) of the 300 APT. RCRA groundwater monitoring at the 300 APT was mandated by a Consent Agreenent and Compliance Order (Ecology and EPA 1986). It went directly into an interim-status assessmentievel monitoring program in response to the 1986 Consent Agreement and Cospoliance Order. The initial groundwater alonitoring $\mathrm{pI}$ an was prepared by Pacific Northmest Hational Laboratory based on interim-status regulations (Schalla et 21. 1986). In 1988 a revised groundwater monitoring compliance plan was implemented (Schalla et al. 1988). 
The 300 APT are scheduled to be included in the Pernit as a TSD unit undergoing closure tifrough the permit modification process. A groundwater monitoring plan was prepared for the 300 APT in 1995 (Lindberg et a1. 1995). This plan will be used to meet final-status compliance-level groundwater monitoring requirements from the time the 300 APT becomes part of the Permit and through the postelosure care period until certification of ftnat closure. This plan describes the updated monitoring network, constituent list, sampling schedule, statistical methods, and sampling and analysts protocols to be employed for the 300 APT in detai1.

\section{C.3 BACKGROUND taBLES}

This section contains revised background information for several RCRA facilities (e.g., 1301-N Liquid Waste Oisposal Facility, 216-A-36B Crib, etc.) because the change in the groundwater monitoring network warrants the reestablishment of background conditions. In addition, background levels have been revised for Low-Level Waste Managenent Area 3 to account for an upgradient source of contamination.

A set of three tables is provided for each facility (Table C-1 through [-9.b). Each set includes the table listing input data for background well( 5$)$, the table containing background replicate averages, and the table presenting the background sumnary statistics.

\section{C.4 REFERENCES}

Chou, C. J., 1991, Statistical Approach on RCRA Groundwater Monitoring Projects at the Hanford Site, WHC-SA-1124-FP, West inghouse Hanford Company, Ríchland, Washington.

DOE-RL, 1991, 183-H Solar Evaporation 8asins Closure/Postclosure Plan, DOE/RL E8-04, Rev. 3, U.S. Department of Energy, Richland Operations office, Richiand, Washington.

DOE-RL, 1993, Hanford Sfte Solid Waste Landfill Perait Application, DOE/RL-90-38, U.S. Department of Energy, RichTand Dperations Office, Richland, Washington.

Ecology and EPA, 1986, Consent Agreement and Corplfiance Order, Ecology Ho. OE 86-133, Hashington State Department of Ecology and the U.S. Environmental Protection Agency, Olympia, Washington.

Ecology, 1994, Oangerous Waste Portion of the Resource Conservation and Recovery Act Pernit for the Treatment, Storage, and Disposal of Dangerous Waste, Permit Number WA7890008967, Washington State Department of Ecology, OTympia, Washington.

EPA, 1986, Resource Conservation and Recovery Act (RCRA) Groundwater Monitoring Technical Enforcement Guidance Document (TEGD), OHSER-9950.1, U.S. Environmental Protection Agency, Washington, D.C. 
EPA, 1994, Hazardous and Solld Haste Arrendments Portion of the Resource Conservation and Recovery Act Pernit for the Treatment, Storage, and Disposal of Hazardous Waste, Permit Humber MA7890008967, U.S. Environmental Protection Agency, Washington, D.C.

ïartman, M. J. and C. J. Chot, 1995, Groumdwater Honitoring PIan for the 183-H Solar Evaporation Basins, WHC-SD-EN-AP-180, Rev. O., Westinghouse Hanford Company, Richland, Washington.

Lindberg, J. H., C. J. Chou, and V. G. Johnson, Groundwater Monitoring Plan for the 300 Ares Process Trenches, WHC-SD-EN-AP-185, Rev. 0. , Westinghouse Hanford Company, Rfch] and, Washington.

PAL, 1986, Revised Ground-Hater Monftoring Compliance PJan for the 183-H Solar Evaporation Basins, PHL-6470, Pactfic Northwest Laboratory, Richland, Washington.

Schalla, R., R. L. Aaberg, D. J. Bates, J. Y. M. Carlile, M. D. Freshley, T. L. Lijkala, P. J. Mitche11, K. B. 01sen, and J. T. Rieger, 1988, Revised Ground-Water Monitoring Compliance Plan for the 300 Area Process Trenches, PNL-6671, Pacific Northwest Laboratory, Richland, Washington.

Resource Conservation and Recovery Act of 1976, 42 USC 6901 et seq.

MAC 173-303, "Dangerous Waste Regulations," Hashington Adrinistrative Cade, as amended.

WAC 173-304, "Winimum Functional Standards for Soljd Waste Hand7ing," Washington Adotnistrative Code, as amended. 
Figure C-1. A Statistical Perspective of the Sequence of Groundwater Monitoring Requfrements Under RCRA.

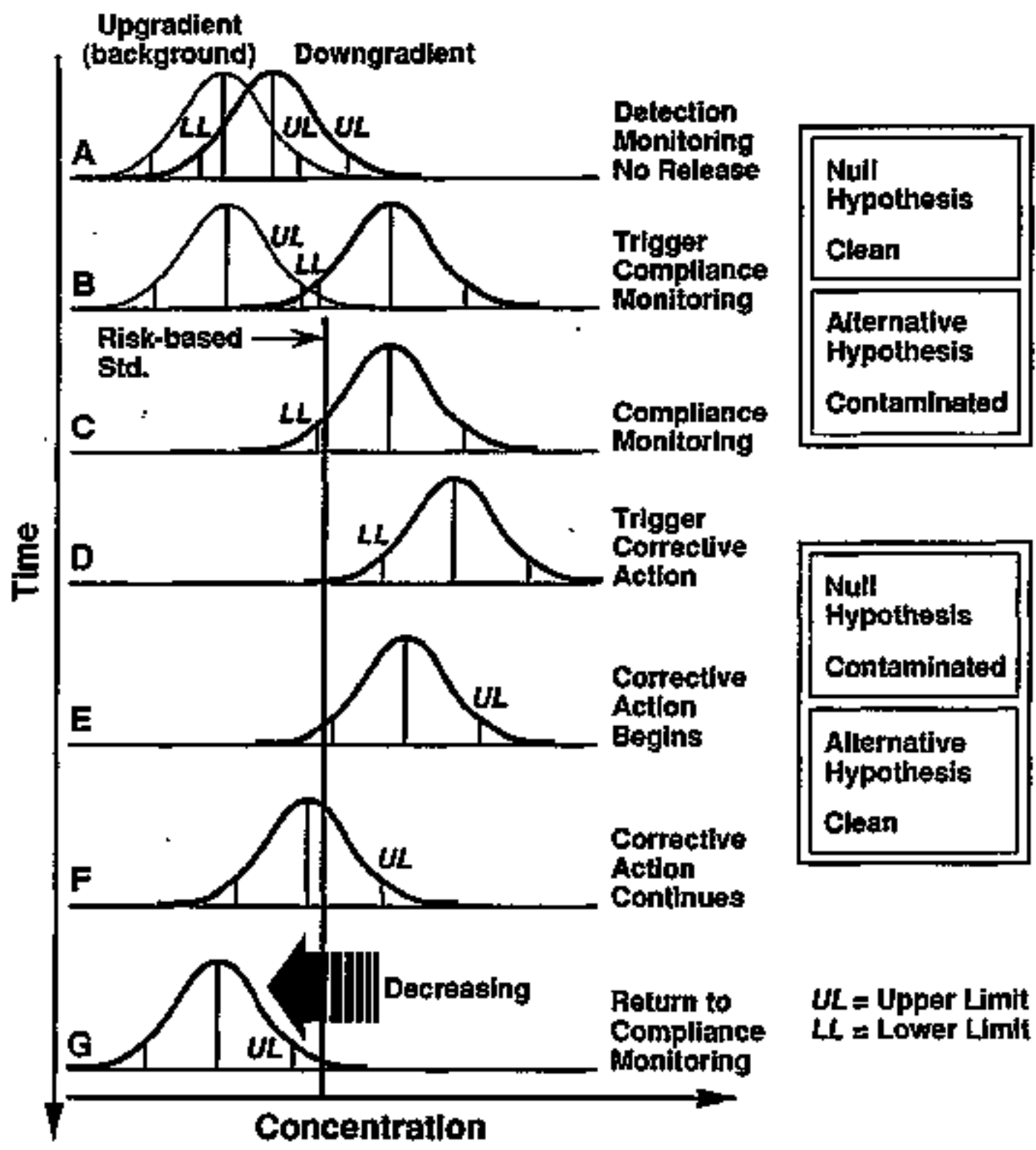

(Notice that until contamination above a risk standard is documented (D) the null hypothesis is that the tacility is ctean. Once the facility has been proven to be in exceedance of a health criteria then the null hypothesfs is that the facilfty is contaminated until proven otherwlse (G). 
Tabie C-I. Background Contamination Indicator Parameter Data for the 1301-N Liquid Waste Disposal Facility. (page 1 of 3)

\begin{tabular}{|c|c|c|c|c|c|c|}
\hline $\begin{array}{l}\text { Well } \\
\text { name }\end{array}$ & $\begin{array}{c}\text { Sarple } \\
\text { date }\end{array}$ & $\begin{array}{l}\text { Dupl. } \\
\text { sample } \\
\text { number }\end{array}$ & $\begin{array}{l}\text { Specific } \\
\text { conductance } \\
\text { pmolom } \\
1 / 700 \mathrm{~cm}\end{array}$ & $\begin{array}{c}\text { Fjeld } \\
\text { pH } \\
0.01 /[6.5, \\
8.5 s]\end{array}$ & $\begin{array}{c}\text { Toc } \\
\text { ppb } \\
1000 / .\end{array}$ & $\begin{array}{l}\text { Tox } \\
\mathrm{ppb} \\
10 / .\end{array}$ \\
\hline \multirow[t]{4}{*}{$1-N-34$} & $02 / 01 / 94$ & 1 & 317 & 8. 36 & $200^{\mathrm{L}}$ & 10.3 \\
\hline & & 2 & 317 & 8.34 & $200^{\circ}$ & $5.0^{\mathrm{V}}$ \\
\hline & & 3 & 318 & 8.37 & $200^{0}$ & 7.6 \\
\hline & & 4 & 314 & 8.36 & $200^{\circ}$ & 6.0 \\
\hline \multirow[t]{4}{*}{$1-N-34$} & $05 / 24 / 94$ & 1 & 333 & 7.87 & $320^{11}$ & 6.9 \\
\hline & & 2 & 333 & 7.87 & $320^{t}$ & 5.3 \\
\hline & & 3 & 333 & 7.89 & $320^{u}$ & 6.2 \\
\hline & & 4 & 333 & 7.89 & $320^{0}$ & $5.0^{\mathrm{U}}$ \\
\hline \multirow[t]{4}{*}{$1-N-34$} & $09 / 06 / 94$ & 1 & 338 & 7.75 & $400^{\circ}$ & $24.9^{* \star}$ \\
\hline & & 2 & 367 & 7.75 & $320^{\circ}$ & $5.8^{F}$ \\
\hline & & 3 & 366 & 7.75 & $320^{\mathrm{u}}$ & $5.4^{6}$ \\
\hline & & 4 & 367 & 7.74 & $320^{\circ}$ & $9.4^{\mathrm{F}}$ \\
\hline \multirow[t]{4}{*}{$1-x-34$} & $11 / 04 / 94$ & 1 & 340 & 7.89 & $200^{60}$ & 6.9 \\
\hline & & 2 & 340 & 7.88 & $300^{\mathrm{LB}}$ & 7.3 \\
\hline & & 3 & 340 & 7.89 & $200^{L B}$ & 6.8 \\
\hline & & 4 & 340 & 7.89 & $200^{\mathrm{LB}}$ & 9.9 \\
\hline
\end{tabular}

The column headers consist of: Constituent lame; Analysis Units; and Contractuatiy Required Quantitation Limit/Orinking Water Standard (suffix).

Suffix $s=\quad$ based on Secondary Maximum Contaminant Levels in 40 CFR Part 143, Hationa1 Secondary Orinking Hater Regulations

$w=$ based on additfonal Secondary Haximum Contamtnant Levels in WAC 248-54, Public Nator Supplies

Data flag:

Lenotes that concentration is below Contract Required Quantitation Liait (CRQL) but above the Hethod Detection Limit (MLL).

denotes that analyte concentration is not detected (CNDL).

Bdenotes blank associated with analyte is contaninated.

denotes suspect data currentiy under rovieu.

denotes reviewed data that have been rejected.

"denotes data value is inconsistent with the rest of analytical results and is not used fin the subsequent calculations. 
Table C-1. Background Contamination Indicator Paramater Data for the 1301-H Liquid Waste Disposa] Fact1tty. (page 2 of 3)

\begin{tabular}{|c|c|c|c|c|c|c|}
\hline $\begin{array}{l}\text { Well } \\
\text { name }\end{array}$ & $\begin{array}{c}\text { Sample } \\
\text { date }\end{array}$ & $\begin{array}{l}\text { Dupl. } \\
\text { sample } \\
\text { number }\end{array}$ & $\begin{array}{c}\text { Specifje } \\
\text { conductance } \\
\text { punho/cm } \\
1 / 700 \text { w }\end{array}$ & $\begin{array}{c}\text { Field } \\
\mathrm{pH} \\
0.01 /[6.5, \\
8.5 \mathrm{~s}] \\
\end{array}$ & $\begin{array}{c}\text { TOC } \\
\text { ppb } \\
1000 / .\end{array}$ & $\begin{array}{c}\mathrm{TOX} \\
\mathrm{ppb} \\
10 \% .\end{array}$ \\
\hline \multirow[t]{4}{*}{$1-N-34$} & $02 / 24 / 95$ & 1 & 327 & 8.03 & $200^{-}$ & 10.1 \\
\hline & & 2 & 328 & 8.05 & $200^{L}$ & 9.5 \\
\hline & & 3 & 329 & 8.07 & $200^{6}$ & 7.6 \\
\hline & & 4 & 329 & 8.06 & $200^{\mathrm{L}}$ & $5.0^{\circ}$ \\
\hline \multirow[t]{4}{*}{$1-N-57$} & $02 / 01 / 94$ & 1 & 892 & 7.58 & $500^{\mathrm{L}}$ & 13.4 \\
\hline & & 2 & $=$ & -- & $500^{L}$ & 9.6 \\
\hline & & 3 & -- & 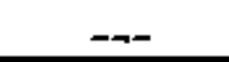 & $500^{2}$ & 7.4 \\
\hline & & 4 & -- & --- & $500^{2}$ & 8.7 \\
\hline \multirow[t]{4}{*}{$1-N-57$} & $06 / 14 / 94$ & 1 & 832 & 7.49 & $400^{2}$ & 14.6 \\
\hline & & 2 & 832 & 7.52 & $500^{\mathrm{L}}$ & 8.9 \\
\hline & & 3 & 833 & 7.53 & $500^{2}$ & 9.4 \\
\hline & & 4 & 828 & 7.54 & $400^{L}$ & 11.2 \\
\hline \multirow[t]{4}{*}{$1-4-57$} & $09 / 06 / 94$ & 1 & 795 & $6.80^{k}$ & $600^{\circ}$ & $27.5^{p}$ \\
\hline & & 2 & 792 & $6.80^{R}$ & $500^{\mathrm{L}}$ & $13.7^{\mathrm{F}}$ \\
\hline & & 3 & 790 & $6.81^{R}$ & $500^{2}$ & $16.0^{f}$ \\
\hline & & 4 & 798 & $6.83^{\mathrm{n}}$ & $600^{2}$ & $14.5^{F}$ \\
\hline
\end{tabular}

The column headers consist of: Constituent Hame; Analysis Units; and Contractually Required Quantitation Limit/Drinking Water Standard (suffix).

Suffix $s=$ based on Secondary Maxfmum Contaminant Levels in 40 CFR Part 143, Mationa7 Secondary Orinking Water Regutations $w \quad$ based on additional Secondary Maxinum Contaminant Levels in VAC 246-54, Pub7ic Water Supplies

Data flag:

Ldenotes that concentration is below Contract Required quantitation Limit (CRQL) but above the Method Detection Linit (MOL).

denotes that analyte concentration is net detected (<KOL).

denotes blank associated with analyte is contaminated.

denotes suspect data currently under review.

denotes reviewed data that have been rejected and were not used.

"n-" no data. 
Table C-1. Background Contamination Indicator Parameter Data for the 1301-N Liquid Waste Disposal Facility. (page 3 of 3)

\begin{tabular}{|c|c|c|c|c|c|c|}
\hline $\begin{array}{l}\text { Well } \\
\text { name }\end{array}$ & $\begin{array}{c}\text { Sample } \\
\text { date }\end{array}$ & $\begin{array}{l}\text { Dupl. } \\
\text { sanple } \\
\text { number }\end{array}$ & $\begin{array}{c}\text { Specific } \\
\text { conductance } \\
\nu \text { mho/cm } \\
1 / 700 w \\
\end{array}$ & $\begin{array}{c}\text { Field } \\
\text { pH } \\
0.01 /[6.5, \\
8.55]\end{array}$ & $\begin{array}{c}\text { Toc. } \\
\text { ppb } \\
1000 / .\end{array}$ & $\begin{array}{c}T 0 x^{p} \\
\mathrm{ppb} \\
10 \% .\end{array}$ \\
\hline \multirow[t]{4}{*}{$1-\mathrm{H}-57$} & $01 / 05 / 95$ & 1 & 923 & 7.83 & $700^{L}$ & 19.4 \\
\hline & & 2 & 923 & 7.83 & $700^{6}$ & 12.8 \\
\hline & & 3 & 923 & 7.83 & $700^{b}$ & 13.7 \\
\hline & & 4 & 924 & 7.84 & $700^{L}$ & 15.7 \\
\hline \multirow[t]{4}{*}{$1-N-57$} & $02 / 24 / 95$ & 1 & 803 & 7.84 & $600^{2}$ & 17.3 \\
\hline & & 2 & 802 & 7.84 & $600^{2}$ & 14.6 \\
\hline & & 3 & 802 & 7.84 & $6.00^{2}$ & 14.9 \\
\hline & & 4 & 801 & 7.84 & $600^{2}$ & $31.0^{\circ}$ \\
\hline
\end{tabular}

The colum headars consist of: Constituent Name; Analysis Units; and Contractually Required Quantitation Limit/Orinking Mater Standard (sufffx).

Suffix $s=$ based on Secondary Maximum Contaminant Levels in 40 CFR Part 143, National Secondary Drinking Water Regulations w = based on additional Secondary Maximum Contaminant Levels in WAC 248-54, Public Water Supplies

Data flag:

Ldenotes that concentration is below Contract Required Quantitation Limit (CRQL) but above the Hethod Detection Limit (MDL).

denotes that analyte concentration is not detected ( $\angle M O L)$.

denotes blank associated with analyte is contaminated.

denotes suspect data currentiy under review.

"denotes reviewed data that have been rejected. 
Table C-2. Average Replicate Statistics-Background Indicator Parameter Data for the 1301-H Liquid Vaste Djsposal Facility.

\begin{tabular}{|c|c|c|c|c|c|c|}
\hline $\begin{array}{c}\text { Constituent } \\
\text { (unit) }\end{array}$ & $\begin{array}{l}\text { Weit } \\
\text { namę }\end{array}$ & $\begin{array}{c}\text { Samplo } \\
\text { date }\end{array}$ & $\mathbf{n}$ & Average & $\begin{array}{l}\text { Standard } \\
\text { deviation }\end{array}$ & $\begin{array}{l}\text { c.y. } \\
(\mathscr{x})\end{array}$ \\
\hline \multirow{5}{*}{$\begin{array}{l}\text { Spectfic } \\
\text { conductance } \\
\text { (joho/cti) }\end{array}$} & $1-H-34$ & $02 / 01 / 94$ & 4 & 316.50 & 1.732 & 0.55 \\
\hline & $1-N-34$ & $05 / 24 / 94$ & 4 & 333.00 & 0 & 0 \\
\hline & $1-n-34$ & $09 / 06 / 94$ & 4 & 367.00 & 0.816 & 0.22 \\
\hline & $1-4-34$ & $11 / 04 / 94$ & 4 & 340.00 & 0 & 0 \\
\hline & $1-y-34$ & $02 / 24 / 95$ & 4 & 328.25 & 0.957 & 0.29 \\
\hline \multirow{5}{*}{$\begin{array}{c}\text { Ffe]d } \\
\text { pH }\end{array}$} & $1-H-34$. & $02 / 01 / 94$ & 4 & 8.358 & 0.012 & 0.15 \\
\hline & $1-N-34$ & $05 / 24 / 94$ & 4 & 7.880 & 0.012 & 0.15 \\
\hline & $1-H-34$ & $09 / 06 / 94$ & 4 & 7.748 & 0.005 & 0.06 \\
\hline & $1-11-34$ & $11 / 04 / 94$ & 4 & 7.888 & 0.005 & 0.06 \\
\hline & $1-N-34$ & $02 / 24 / 95$ & 4 & 8.052 & 0.017 & 0.21 \\
\hline \multirow{5}{*}{$\begin{array}{l}\text { TOC } \\
(p p b)\end{array}$} & $1-k-34$ & $02 / 01 / 94$ & 4 & $125^{\circ}$ & 50 & 40 \\
\hline & $1-11-34$ & $05 / 24 / 94$ & 4 & $200^{\circ}$ & 80 & 40 \\
\hline & $1-N-34$ & $09 / 06 / 94$ & 4 & $220^{t}$ & 120 & 54.55 \\
\hline & $1-N-34$ & $11 / 04 / 94$ & 4 & $225^{1 \mathrm{~B}}$ & 50 & 22.22 \\
\hline & $1-11-34$ & $02 / 24 / 95$ & 4 & $200^{t}$ & 0 & 0 \\
\hline \multirow{5}{*}{$\begin{array}{l}\text { Tox" } \\
(\mathrm{ppb})\end{array}$} & $1-N-34$ & $02 / 01 / 94$ & 4 & 6.600 & 3.259 & 49.38 \\
\hline & $1-H-34$ & $05 / 24 / 94$ & 4 & 5.225 & 1.931 & 36.96 \\
\hline & $1-H-34$ & $09 / 06 / 94$ & 3 & 6.867 & 2.203 & 32.08 \\
\hline & $1-14-34$ & $11 / 04 / 94$ & 4 & 7.725 & 1.466 & 18.98 \\
\hline & $1-N-34$ & $02 / 24 / 95$ & 4 & 7.425 & 3.452 & 46.49 \\
\hline
\end{tabular}

"statistics were calculated by replacfing not detected values with half of the method detection $] 1$ intt.

denotes that concentration is below Contract Required Quantitation Limit (CRQL) but above the lethod Detection Ljnit (MDL).

venotes that analyte concentration is not detected (<NDL).

Bdenotes blank associated with analyte is contaminated.

denotes suspect data currently under review.

denotes reviewed data that have been rejected and are not used in the subsequent calculations.

M.A. = not available. C.V. - coefficient of variation.

H.C. = not calculated. 
Table C-2. Average Replicate Statistics--Background Indicator Parameter Data for the 1301-N Liquid Waste Disposal Facility. (page 2 of 2)

\begin{tabular}{|c|c|c|c|c|c|c|}
\hline $\begin{array}{l}\text { Constituent } \\
\text { (unit) }\end{array}$ & $\begin{array}{l}\text { Well } \\
\text { name }\end{array}$ & $\begin{array}{c}\text { Sample } \\
\text { date }\end{array}$ & $\mathbf{n}$ & Average & $\begin{array}{l}\text { Standard } \\
\text { deviation }\end{array}$ & $\begin{array}{c}C . Y . \\
(x)\end{array}$ \\
\hline \multirow{5}{*}{$\begin{array}{c}\text { Specific } \\
\text { conductance } \\
(\mu m h o / c m)\end{array}$} & $1-1-57$ & $02 / 01 / 94$ & 1 & 892.00 & H.C. & N.C. \\
\hline & $1-H-57$ & $05 / 14 / 94$ & 4 & 831.25 & 2.217 & 0.27 \\
\hline & $1-N-57$ & $09 / 06 / 94$ & 4 & 793.75 & 3.500 & 0.44 \\
\hline & $1-N-57$ & $01 / 05 / 95$ & 4 & 923.25 & 0.500 & 0.05 \\
\hline & $1-\mathrm{N}-57$ & $02 / 24 / 95$ & 4 & 802.00 & 0.816 & 0.10 \\
\hline \multirow{5}{*}{$\underset{\text { pH }}{\text { Field }}$} & $1-4-57$ & $02 / 01 / 94$ & 1 & 7.580 & H.C. & N.C. \\
\hline & $1-\mathrm{N}-57$ & $06 / 14 / 94$ & 4 & 7.520 & 0.022 & 0.29 \\
\hline & $1-1-57$ & $09 / 06 / 94$ & 4 & $6.81^{R}$ & $0.014^{k}$ & $0.21^{k}$ \\
\hline & $1-4-57$ & $01 / 05 / 95$ & 4 & 7.832 & 0.005 & 0.06 \\
\hline & $1-N-57$ & $02 / 04 / 95$ & 4 & 7.840 & 0 & 0 \\
\hline \multirow{5}{*}{$\begin{array}{l}\text { TOC } \\
(\mathrm{ppb})\end{array}$} & $1-k-57$ & $02 / 01 / 94$ & 4 & $500^{6}$ & 0 & 0 \\
\hline & $1-N-57$ & $06 / 14 / 94$ & 4 & $450^{L}$ & 57.735 & 12.83 \\
\hline & $1-3-57$ & $09 / 06 / 94$ & 4 & $550^{2}$ & 57.735 & 10.50 \\
\hline & $1-H-57$ & $01 / 05 / 95$ & 4 & $700^{2}$ & 0 & 0 \\
\hline & $1-H-57$ & $02 / 04 / 95$ & 4 & $600^{2}$ & 0 & 0 \\
\hline \multirow{5}{*}{$\underset{(p p b)}{T o x}$} & $1-1,-57$ & $02 / 01 / 94$ & 4 & 9.775 & 2.580 & 26.39 \\
\hline & $1-N-57$ & $06 / 14 / 94$ & 4 & 11.025 & 2.580 & 23.40 \\
\hline & $1-N-57$ & $09 / 06 / 94$ & 4 & 17.925 & 6.454 & 36.01 \\
\hline & $1-4-57$ & $01 / 05 / 95$ & 4 & 15.400 & 2.929 & 19.02 \\
\hline & $1-k-57$ & $02 / 04 / 95$ & 4 & 19.450 & 7.794 & 40.07 \\
\hline
\end{tabular}

"statistjcs were calculated by replacing not detected values with half of the, method detection linit.

'denotes that concentration ts below Contract Required Quantitation linit (CRQL) but above the lethod Detection Limit (MDL).

denotes that analyte concentration is not detected (ANL).

denotes blank associated with analyte is contaninated.

Fenotes suspect data currently under review.

${ }^{2}$ denotes reviewed data that have been rejected and are not used in the subsequent calculations.

H.A. = not available. C.V. = coeffictent of variation.

M.C. = not calculated. 
DOE /RL-96-01, REV. 0

Table C-3. Background Statistics"-Contamination Indicator Parameter Data for the 130I-H Liquid Waste Disposal Facility.

\begin{tabular}{|l|c|c|c|c|c|}
\hline Constituent & Units & n & $\begin{array}{c}\text { Background } \\
\text { average }\end{array}$ & $\begin{array}{c}\text { Background } \\
\text { standard } \\
\text { deviation }\end{array}$ & $\begin{array}{c}\text { Background } \\
\text { C.V. }(\%)\end{array}$ \\
\hline $\begin{array}{l}\text { Specific } \\
\text { conductance }\end{array}$ & $\mu$ mho/ Ch & 10 & 592.700 & 272.527 & 45.98 \\
\hline Field pH & & $9^{*}$ & 7.855 & 0.248 & 3.16 \\
\hline TC & ppD & 10 & 377.000 & 205.037 & 54.39 \\
\hline TOX & ppD & 10 & 10.742 & 5.087 & 47.35 \\
\hline
\end{tabular}

background summary statistics for TOC and/or TOX were calculated using values below the method detection limits.

Excluding pH results from samples collected on 9/6/94 from well 1-N-57.

$-14$ 
Table C-4. Background Contamination Indicator Parameter Bata for the 216-A-368 Crib. (page 1 of 3)

\begin{tabular}{|c|c|c|c|c|c|c|}
\hline $\begin{array}{l}\text { Well } \\
\text { name }\end{array}$ & $\begin{array}{c}\text { Sample } \\
\text { date }\end{array}$ & $\begin{array}{l}\text { Dupl. } \\
\text { sapiple } \\
\text { ntuber }\end{array}$ & $\begin{array}{c}\text { Specific } \\
\text { conductance } \\
\text { phio/cw } \\
1 / 700 \mathrm{w}\end{array}$ & $\begin{array}{c}\text { Field } \\
\text { pH } \\
0.01 /[6.5 \\
8.5 s] \\
\end{array}$ & $\begin{array}{l}\text { Toc } \\
\mathrm{ppb} \\
\mathrm{a} /\end{array}$ & $\begin{array}{l}\text { Tox } \\
\mathrm{ppb} \\
\mathrm{b} /\end{array}$ \\
\hline \multirow[t]{4}{*}{ 2-E17-17 } & \multirow[t]{4}{*}{$09 / 13 / 88$} & 1 & 295 & 7.60 & $844^{*}$ & $10.5^{*}$ \\
\hline & & 2 & 296 & 7.60 & $747^{*}$ & $4.8^{*}$ \\
\hline & & 3 & 294 & 7.70 & $672^{\circ}$ & $8.9^{*}$ \\
\hline & & 4 & 294 & 7.50 & $775^{*}$ & $5.3^{*}$ \\
\hline \multirow[t]{4}{*}{ 2-E17-17 } & \multirow[t]{4}{*}{$12 / 21 / 88$} & 1 & 351 & 7.90 & $400^{*}$ & $-1.0^{*}$ \\
\hline & & 2 & 350 & 7.90 & $400^{*}$ & $-1.0^{*}$ \\
\hline & & 3 & 353 & 7,90 & $400^{*}$ & $0^{*}$ \\
\hline & & 4 & 354 & 7.90 & $400^{\circ}$ & $2.0^{*}$ \\
\hline \multirow[t]{4}{*}{$2-[17-17$} & \multirow[t]{4}{*}{$05 / 12 / 89$} & 1 & 230 & 7.90 & $600^{*}$ & $5.0^{2}$ \\
\hline & & $\underline{2}$ & 230 & 8.05 & $500^{*}$ & $2.1^{*}$ \\
\hline & & 3 & 230 & 8.04 & $500^{*}$ & $4.0^{2}$ \\
\hline & & 4 & 230 & 8.00 & $500^{*}$ & $6.0^{*}$ \\
\hline \multirow[t]{4}{*}{ 2-E17-17 } & \multirow[t]{4}{*}{$06 / 23 / 89$} & 1 & 316 & 7.71 & $500^{\circ}$ & $1.0^{*}$ \\
\hline & & 2 & 317 & 7.76 & $500^{*}$ & $1.0^{\circ}$ \\
\hline & & 3 & 317 & 7.75 & $500^{\circ}$ & $2.0^{*}$ \\
\hline & & 4 & 315 & 7.76 & $500^{*}$ & $2.0^{*}$ \\
\hline
\end{tabular}

The column headers consist of: Constituent Name; Analysis Units; and Contractually Required Quantitation Limit/Orinking Water Standard (suffix).

Suffix $s=$ based on Secondary Maximum Contaminant Level's in 40 CFR Part 143, Mational Secondary Drinking Water Regulations w - based on additional Secondary Maximum Contaminant Levels in WAC 248-54, Public Water Supplies

Data flag:

"denotes data analyzed by US Testing Inc. of Rjchland, Washington. Contractual detection limit before January $1989=1,000 \mathrm{ppb}$; after January $1989=2,000 \mathrm{ppb}$.

bdenotes data analyzed by US Testing Inc. of Richland, Washington. Contractual detection limat before January $1989=20 \mathrm{ppb}$; after January 1989 = $10 \mathrm{ppb}$.

* Jess than contractual detection linit value. 
Table C-4, Background Contamination Indicator Parameter Data for the 216-A-36B Crib. (page 2 of 3)

\begin{tabular}{|c|c|c|c|c|c|c|}
\hline $\begin{array}{l}\text { Well } \\
\text { name }\end{array}$ & $\begin{array}{l}\text { Sample } \\
\text { date }\end{array}$ & $\begin{array}{l}\text { Dupi, } \\
\text { sample } \\
\text { number }\end{array}$ & $\begin{array}{c}\text { Specific } \\
\text { conductance } \\
\mu \text { mho/cm } \\
1 / 700 \mathrm{w} \\
\end{array}$ & $\begin{array}{c}\text { Field } \\
\mathrm{pH} \\
0.01 /[6.5, \\
8.55] \\
\end{array}$ & $\begin{array}{c}\mathrm{TOC} \\
\mathrm{ppb} \\
\mathrm{a} / .\end{array}$ & $\begin{array}{l}\mathrm{TOX} \\
\mathrm{ppb} \\
\mathrm{b} / .\end{array}$ \\
\hline \multirow[t]{4}{*}{$2-E 24-18$} & \multirow[t]{4}{*}{$11 / 02 / 88$} & 1 & 407 & 8.00 & $400^{*}$ & $3.0^{*}$ \\
\hline & & 2 & 408 & 8.20 & $500^{*}$ & $6.0^{*}$ \\
\hline & & 3 & 408 & 8.10 & $500^{*}$ & $7.0^{\prime \prime}$ \\
\hline & & 4 & 408 & 8.20 & $500^{*}$ & $3.0^{\prime \prime}$ \\
\hline \multirow[t]{4}{*}{ 2-E24-18 } & \multirow[t]{4}{*}{$02 / 14 / 89$} & 1 & 323 & 8.50 & $500^{\circ}$ & $8.0^{*}$ \\
\hline & & 2 & 322 & 8.50 & $500^{*}$ & $9.0^{*}$ \\
\hline & & 3 & 323 & 8.50 & $600^{*}$ & $3.0^{2}$ \\
\hline & & 4 & 323 & 8.50 & $500^{*}$ & 1.00 \\
\hline \multirow[t]{4}{*}{ 2-E24-18 } & \multirow[t]{4}{*}{$06 / 19 / 89$} & 1 & 274 & 7.63 & $400^{\prime \prime}$ & $1.0^{*}$ \\
\hline & & $\underline{2}$ & 274 & 7.63 & $1,100^{*}$ & $1.0^{*}$ \\
\hline & & 3 & 274 & 7.63 & $1,100^{*}$ & $1.0^{*}$ \\
\hline & & 4 & 274 & 7.63 & $600^{*}$ & $5.0^{*}$ \\
\hline \multirow[t]{4}{*}{ 2-E24-18 } & \multirow[t]{4}{*}{$08 / 11 / 89$} & 1 & 338 & 7.96 & $500^{*}$ & $3.0^{*}$ \\
\hline & & 2 & 335 & 7.95 & $500^{*}$ & 10.0 \\
\hline & & 3 & 334 & 7.95 & $700^{*}$ & $4.0^{* \prime}$ \\
\hline & & 4 & 335 & 7.95 & $700^{*}$ & $8.0^{*}$ \\
\hline
\end{tabular}

The column headers consist of: Constituent Name; Analysis Units; and Contractually Required Quantitation Limit/Drinking Water Standard (suffix).

Suffix $s=$ based on Secondary Maximum Contaninant Levels in 40 CFR Part 143, National Secondary Drinking Water Regulations $w$ = based on additional Secondary Haximum Contaminant Levels in WAC 248-54, Pub1 ic Water Supplies

Data flag:

"denotes data analyzed by US Testing Inc. of Richland, Washington. Contractual detection limit before January $1989=1,000 \mathrm{ppb}$; after January $1989=2,000 \mathrm{ppb}$.

denotes data analyzed by US Testing Inc. of Richland, Washington. Contractual detection 1 ímit before January $1989=20 \mathrm{ppb}$; after January $1989=10 \mathrm{ppb}$.

"less than contractual detection 1 tmit value. 
Table C-4. Background Contamination Indicator Parameter Data for the 216-A-36B Crib. (page 3 of 3)

\begin{tabular}{|c|c|c|c|c|c|c|}
\hline $\begin{array}{l}\text { Wel1 } \\
\text { name }\end{array}$ & $\begin{array}{c}\text { Sample } \\
\text { date }\end{array}$ & $\begin{array}{l}\text { Dupl. } \\
\text { sample } \\
\text { number }\end{array}$ & $\begin{array}{c}\text { Spectfic } \\
\text { conductance } \\
\text { Hrho/cm } \\
1 / 700 w\end{array}$ & $\begin{array}{c}\text { Field } \\
\mathrm{pH} \\
0.01 / 6.5 \\
8.55] \\
\end{array}$ & $\begin{array}{l}\text { TOC } \\
\mathrm{ppb} \\
\mathrm{a} / .\end{array}$ & $\begin{array}{l}\mathrm{TOX} \\
\mathrm{ppb} \\
\mathrm{b} / .\end{array}$ \\
\hline \multirow[t]{4}{*}{ 2-E25-36 } & \multirow[t]{4}{*}{$11 / 04 / 88$} & 1 & 179 & 7.70 & $600^{*}$. & $10.0^{*}$ \\
\hline & & 2 & 180 & 8.00 & $600^{\circ}$ & $5.0^{\circ}$ \\
\hline & & 3 & 180 & 7.90 & $600^{\circ}$ & $7.0^{*}$ \\
\hline & & 4 & 179 & 8.00 & $700^{*}$ & $4.0^{*}$ \\
\hline \multirow[t]{4}{*}{ 2-E25-36 } & \multirow[t]{4}{*}{$02 / 14 / 89$} & 1 & 194 & 8.40 & $600^{\circ}$ & $4.0^{\circ}$ \\
\hline & & 2 & 194 & 8.40 & $700^{*}$ & $1.0^{*}$ \\
\hline & & 3 & 194 & 8.40 & $800^{*}$ & $4.0^{*}$ \\
\hline & & 4 & 194 & 8.40 & $600^{*}$ & $3.0^{*}$ \\
\hline \multirow[t]{4}{*}{$2-E 25-36$} & \multirow[t]{4}{*}{$06 / 19 / 89$} & 1 & 232 & 8.01 & $500^{*}$ & $5.0^{*}$ \\
\hline & & 2 & 236 & 8.06 & $500^{*}$ & $8.0^{*}$ \\
\hline & & 3 & 235 & 8.05 & $500^{*}$ & $.01^{*}$ \\
\hline & & 4 & 233 & 8.11 & $500^{*}$ & $3.0^{*}$ \\
\hline \multirow[t]{4}{*}{ 2-E25-36 } & \multirow[t]{4}{*}{$10 / 24 / 89$} & 1 & 239 & 7.63 & $600^{*}$ & $5.0^{*}$ \\
\hline & & 2 & $\ldots$ & -- & $900^{*}$ & $4.0^{*}$ \\
\hline & & 3 & $\rightarrow$ & $=$ & $600^{*}$ & $5.0^{*}$ \\
\hline & & 4 & $\ldots$ & $=$ & $900^{*}$ & $2.0^{*}$ \\
\hline
\end{tabular}

The colum headers consist of: Constituent Mame; Analysis Units; and Contractually Required Quantitation Limit/Drinking Water Standard (suffix).

Suffix $s=$ based on Secondary Maximun Contaminant Levels in 40 CFR Part 143, Mationa1 Secondary Drinking Nater Regulations - based on additional Secondary Maximum Contaminant Levels in Data flag: WAC 248-54, Public Water Supplies

"denotes data analyzed by US Testing Inc. of Richland, Washington. Contractua] detection 1 tmit before January $1989=1,000 \mathrm{ppb}$; after January $1989=2,000 \mathrm{ppb}$.

denotes data analyzed by US Testing Inc. of Rtchland, Washington. Contractual detection 7 imit before January 1989 - 20 ppb; after January $1989=10 \mathrm{ppb}$.

"less than contractual detection 1 iwit value.

" 
Table C-5. Average Replicate Statistics--Background Indicator Paraneter Data for the 216-A-36B Crib. (page 1 of 3 )

\begin{tabular}{|c|c|c|c|c|c|c|}
\hline $\begin{array}{c}\text { Const fituent } \\
\text { (unit) }\end{array}$ & $\begin{array}{l}\text { Well } \\
\text { name }\end{array}$ & $\begin{array}{c}\text { Satple } \\
\text { date }\end{array}$ & $n$ & Average & $\begin{array}{l}\text { Standard } \\
\text { devitation }\end{array}$ & $\begin{array}{l}\text { C.V. } \\
\text { (q) }\end{array}$ \\
\hline \multirow{4}{*}{$\begin{array}{c}\text { Specific. } \\
\text { conductance } \\
\text { (/mho/cas) }\end{array}$} & $2-E 17-17$ & $09 / 13 / 88$ & 4 & 294.75 & 0.957 & 0.32 \\
\hline & 2-E17-17 & $12 / 21 / 88$ & 4 & 352.00 & 1.826 & 0.52 \\
\hline & $2-[17-17$ & $05 / 12 / 89$ & 4 & 230.00 & 0 & 0 \\
\hline & $2-E 17-17$ & $06 / 23 / 89$ & 4 & 316.50 & 0.577 & 0.18 \\
\hline \multirow{4}{*}{$\begin{array}{c}\text { Field } \\
\text { pH }\end{array}$} & 2-E17-17 & $09 / 13 / 88$ & 4 & 7.600 & 0.082 & 1.07 \\
\hline & 2-E $17-17$ & $12 / 21 / 88$ & 4 & 7.900 & 0 & 0 \\
\hline & $2-E 17-17$ & $05 / 12 / 89$ & 4 & 7.998 & 0.068 & 0.86 \\
\hline & 2-E $17-17$ & $06 / 23 / 89$ & 4 & 7.745 & 0.024 & 0.31 \\
\hline \multirow{4}{*}{$\begin{array}{c}\text { TOC } \\
(\mathrm{ppb})\end{array}$} & 2-E.E17-17 & $09 / 13 / 88$ & 4 & $759.5^{*}$ & 71.164 & 9.37 \\
\hline & 2-E17-17 & $12 / 21 / 88$ & 4 & $400.0^{*}$ & 0 & 0 \\
\hline & 2-E17-17 & $05 / 12 / 89$ & 4 & $525.0^{*}$ & 50 & 9.52 \\
\hline & 2-E17-17 & $06 / 23 / 89$ & 4 & $550.0^{*}$ & 100 & 19.18 \\
\hline \multirow{4}{*}{$\begin{array}{c}\text { TOX } \\
\text { (ppb) }\end{array}$} & 2-E17-17 & $09 / 13 / 88$ & 4 & $7.375^{*}$ & 2.770 & 37.57 \\
\hline & 2-E17-17 & $12 / 21 / 88$ & 4 & $0^{*}$ & 1.414 & H.C. \\
\hline & $2-E 17-17$ & $05 / 12 / 89$ & 4 & $4.275^{*}$ & 1.664 & 38.93 \\
\hline & 2-E17-17 & $06 / 23 / 89$ & 4 & $1.500^{*}$ & 3.452 & 46.49 \\
\hline
\end{tabular}

"less than contractual detection 1 imit value.

H.C. - not calculated. C.V. = coefficient of variation. 
Table C-5. Average Replicate Statistics--Background Indicator Parameter Data for the 216-A-36B Crib. (page 2 of 3 )

\begin{tabular}{|c|c|c|c|c|c|c|}
\hline $\begin{array}{c}\text { Constituent } \\
\text { (unit) }\end{array}$ & $\begin{array}{c}\text { We11 } \\
\text { name }\end{array}$ & $\begin{array}{c}\text { Sample } \\
\text { date }\end{array}$ & $n$ & Average & $\begin{array}{c}\text { Standard } \\
\text { deviation }\end{array}$ & $\begin{array}{c}c . V . \\
\text { (\%) }\end{array}$ \\
\hline $\begin{array}{c}\text { Specific } \\
\text { conductance } \\
\text { ( } 2 \text { mho/cm) }\end{array}$ & $2-E 24-18$ & $11 / 02 / 88$ & 4 & 407.75 & 0.500 & 0.12 \\
\cline { 2 - 8 } & $2-E 24-18$ & $02 / 14 / 89$ & 4 & 322.75 & 0.500 & 0.15 \\
\cline { 2 - 8 } & $2-E 24-18$ & $06 / 19 / 89$ & 4 & 274.00 & 0 & 0 \\
\cline { 2 - 8 } & $2-E 24-18$ & $08 / 11 / 89$ & 4 & 335.50 & 1.732 & 0.52 \\
\hline \multirow{4}{*}{$\begin{array}{c}\text { Field } \\
\text { pH }\end{array}$} & $2-E 24-18$ & $11 / 02 / 88$ & 4 & 8.125 & 0.096 & 1.18 \\
\cline { 2 - 7 } & $2-E 24-18$ & $02 / 14 / 89$ & 4 & 8.500 & 0 & 0 \\
\cline { 2 - 7 } & $2-E 24-18$ & $06 / 19 / 89$ & 4 & 7.630 & 0 & 0 \\
\cline { 2 - 7 } & $2-E 24-18$ & $08 / 11 / 89$ & 4 & 7.952 & 0.005 & 0.06 \\
\hline \multirow{4}{*}{$\begin{array}{c}\text { TOC } \\
\text { (ppb) }\end{array}$} & $2-E 24-18$ & $11 / 02 / 88$ & 4 & $475.0^{*}$ & 50.000 & 10.53 \\
\cline { 2 - 7 } & $2-E 24-18$ & $02 / 14 / 89$ & 4 & $525.0^{*}$ & 50.000 & 9.52 \\
\cline { 2 - 7 } & $2-E 24-18$ & $06 / 19 / 89$ & 4 & $800.0^{*}$ & 355.903 & 44.49 \\
\cline { 2 - 7 } & $2-E 24-18$ & $08 / 11 / 89$ & 4 & $600.0^{*}$ & 115.470 & 19.24 \\
\hline \multirow{4}{*}{$\begin{array}{c}\text { TOX } \\
\text { (ppb) }\end{array}$} & $2-E 24-18$ & $11 / 02 / 88$ & 4 & $4.750^{*}$ & 2.062 & 43.40 \\
\cline { 2 - 7 } & $2-E 24-18$ & $02 / 14 / 89$ & 4 & $5.250^{*}$ & 3.862 & 73.57 \\
\cline { 2 - 7 } & $2-E 24-18$ & $06 / 19 / 89$ & 4 & $2.000^{*}$ & 2.000 & 100.0 \\
\cline { 2 - 7 } & $2-E 24-18$ & $08 / 11 / 89$ & 4 & $6.250^{*}$ & 3.304 & 52.86 \\
\hline
\end{tabular}

Tess than contractual detection linit value.

N.C. = not calculated. C.Y. = coeffictent of variation. 
Table C-5. Average Repl icate Statistics--Backgruund Indicator Parameter Data for the 216-A-36B Crib, (page 3 of 3 )

\begin{tabular}{|c|c|c|c|c|c|c|}
\hline $\begin{array}{c}\text { Constituent } \\
\text { (unit) }\end{array}$ & $\begin{array}{l}\text { Well } \\
\text { name } \\
\end{array}$ & $\begin{array}{c}\text { Sample } \\
\text { date }\end{array}$ & $n$ & Average & $\begin{array}{l}\text { Standard } \\
\text { deviation }\end{array}$ & $\begin{array}{l}\text { C. } y . \\
(\%)\end{array}$ \\
\hline \multirow{4}{*}{$\begin{array}{l}\text { Specific } \\
\text { conductance } \\
\text { (Umho/cm) }\end{array}$} & 2-E25-36 & $11 / 04 / 88$ & 4 & 179.50 & 0.577 & 0.32 \\
\hline & 2-E25-36 & $02 / 14 / 89$ & 4 & 194.00 & $\underline{0}$ & 0 \\
\hline & $2-E 25-36$ & $06 / 19 / 89$ & 4 & 234.00 & 1.826 & 0.78 \\
\hline & $2-E 25-36$ & $10 / 24 / 89$ & 1 & 239.00 & N.C. & N.C. \\
\hline \multirow{4}{*}{$\underset{\text { PH }}{\text { Ffeld }}$} & $2-E 25-36$ & 11/04/88 & 4 & 7.900 & 0.141 & 1.79 \\
\hline & 2-E25-36 & $02 / 14 / 89$ & 4 & 8.400 & 0 & 0 \\
\hline & 2-E25-36 & $06 / 19 / 89$ & 4 & 8.058 & 0.041 & 0.51 \\
\hline & 2-E25-36 & $10 / 24 / 89$ & 1 & 7.630 & H.C. & N.C. \\
\hline \multirow{4}{*}{$\begin{array}{c}\text { TOC } \\
(\mathrm{ppb})\end{array}$} & 2-E25-36 & $11 / 04 / 88$ & 4 & $625.0^{*}$ & 50.000 & 8.00 \\
\hline & $2-E 25-36$ & $02 / 14 / 89$ & 4 & $675.0^{*}$ & 95.743 & 14.18 \\
\hline & $2-\varepsilon 25-36$ & $06 / 19 / 89$ & 4 & $500.0^{*}$ & 0 & $\underline{0}$ \\
\hline & 2-E25-36 & $10 / 24 / 89$ & 4 & $750.0^{*}$ & 173.210 & 23.09 \\
\hline \multirow{4}{*}{$\begin{array}{c}\operatorname{Tox} \\
(\mathrm{ppb})\end{array}$} & $2-525-36$ & $11 / 04 / 88$ & 4 & $6.500^{*}$ & 2.646 & 40.70 \\
\hline & 2-E25-36 & $02 / 14 / 89$ & 4 & $3.000^{*}$ & 1.414 & 47.14 \\
\hline & $2-E 25-36$ & $06 / 19 / 89$ & 4 & $4.002^{*}$ & 3.362 & 84.01 \\
\hline & $2-E 25-36$ & $10 / 24 / 89$ & 4 & $4.000^{*}$ & 1.414 & 35.36 \\
\hline
\end{tabular}

Tess than contractual detection limit value.
H.C. = not calculated.
C.Y. = coefficient of variation. 
DOE/RL-95-01, REV. 0

Table C-6. Background Statistics"--Contamination Indicator Paranteter Data for the 216-A-36B Crib.

\begin{tabular}{|l|c|c|c|c|c|}
\hline Constituent & Units & $n$ & $\begin{array}{c}\text { Background } \\
\text { average }\end{array}$ & $\begin{array}{c}\text { Background } \\
\text { standard } \\
\text { devitation }\end{array}$ & $\begin{array}{c}\text { Background } \\
\text { C.V. (\%) }\end{array}$ \\
\hline $\begin{array}{l}\text { Specific } \\
\text { conductance }\end{array}$ & pmho/cm & 12 & 281.646 & 68.595 & 24.36 \\
\hline Fie]d pH & & 12 & 7.953 & 0.290 & 3.64 \\
\hline TOC & ppb & 12 & 598.708 & 125.606 & 20.98 \\
\hline TOX & ppb & 12 & 4.075 & 2.176 & 53.40 \\
\hline
\end{tabular}

"background summary statistics for TOC and/or TOX were calculated using values below the contractual detection limits. 
Table C-7.a. Background Contamination Indjcator Parameter Data for the Low-Level Waste Management Area $3^{2}$. (page 1 of 3 )

\begin{tabular}{|c|c|c|c|c|c|c|}
\hline $\begin{array}{l}\text { We11 } \\
\text { name }\end{array}$ & $\begin{array}{l}\text { Sazple } \\
\text { date }\end{array}$ & $\begin{array}{l}\text { Dupl. } \\
\text { sample } \\
\text { numiner }\end{array}$ & $\begin{array}{c}\text { Specific } \\
\text { conductance } \\
\text { Amho/cm } \\
1 / 700 \text { w }\end{array}$ & $\begin{array}{c}\text { Field } \\
\mathrm{pH} \\
0.01 /[6.5, \\
8.5 \mathrm{~s}]\end{array}$ & $\begin{array}{c}\text { Toc } \\
\text { ppb } \\
\text { 1000/. }\end{array}$ & $\begin{array}{l}\text { Tox } \\
\text { ppb } \\
10 / .\end{array}$ \\
\hline \multirow[t]{4}{*}{$2-410-13$} & \multirow[t]{4}{*}{$02 / 18 / 94$} & 1 & 385 & 8.21 & $300^{t}$ & 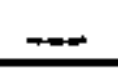 \\
\hline & & 2 & 390 & 8.20 & $300^{t}$ & --- \\
\hline & & 3 & 387 & 8.19 & $200^{t}$ & $=$ \\
\hline & & 4 & 387 & 8.18 & $200^{\mathrm{L}}$ & $=-$ \\
\hline \multirow[t]{4}{*}{$2-410-13$} & \multirow[t]{4}{*}{$05 / 25 / 94$} & 1 & 480 & 8.01 & $320^{\circ}$ & - \\
\hline & & 2 & 481 & 8.01 & $350^{\mathrm{L}}$ & $\rightarrow$ \\
\hline & & 3 & 479 & 8.01 & $320^{4}$ & $\rightarrow$ \\
\hline & & 4 & 477 & 8.02 & $330^{6}$ & --- \\
\hline \multirow[t]{4}{*}{$2-410-13$} & \multirow[t]{4}{*}{$07 / 14 / 94$} & 1 & 446 & 7.99 & $-\dot{-}$ & $\begin{array}{l}13.3 \\
14.5 \\
\end{array}$ \\
\hline & & 2 & 445 & 7.99 & --- & $\begin{array}{l}13.3 \\
14.1 \\
\end{array}$ \\
\hline & & 3 & 447 & 7.99 & --- & $\begin{array}{l}14.5 \\
12.1 \\
\end{array}$ \\
\hline & & 4 & 447 & 7.99 & -- & $\begin{array}{l}14.6 \\
14.3 \\
\end{array}$ \\
\hline \multirow[t]{4}{*}{$2-410-13$} & \multirow[t]{4}{*}{$08 / 31 / 94$} & 1 & 459 & 8.06 & $320^{\mathrm{U}}$ & $5.0^{\mathrm{t}}$ \\
\hline & & 2 & 458 & 8.06 & $320^{\mathrm{V}}$ & 5.5 \\
\hline & & 3 & 455 & 8.05 & $320^{\circ}$ & $5.0^{\circ}$ \\
\hline & & 4 & 455 & 8.05 & $320^{u}$ & $5.0^{0}$ \\
\hline
\end{tabular}

The column headers consist of: Constituent Name; Analysis Units; and Contractually Required Quantitation Limit/Orinking Water Standard (suffix).

Suffix s = based on Secondary Maximum Contaminant Levets in 40 CFR Part 143, Nationat Secondary Orinking Water Regulations

$w$ a based on additional Secondary Maximum Contaminant Levels in WAC 248-54, Publ ic Mater SLpplies

Notes and data flag:

area not impacted by upgradient source of contamination.

${ }^{2}$ denotes that concentration is below Contract Required Quantitation Limit (CRQL) but above the Method Detection Limit (MDL).

denotes that analyte concentration is not detected ( $\angle \mathrm{HOL})$.

n..." = no data. 
TabTe C-7.a. Background Contanination Indicator Parameter Data for the Low-Level Waste Management Area $3^{\text {. }}$ (page 2 of 3 )

\begin{tabular}{|c|c|c|c|c|c|c|}
\hline $\begin{array}{l}\text { We11 } \\
\text { name }\end{array}$ & $\begin{array}{l}\text { Sample } \\
\text { date }\end{array}$ & $\begin{array}{l}\text { Dupl. } \\
\text { sample } \\
\text { number }\end{array}$ & $\begin{array}{c}\text { Spectiflc } \\
\text { conductance } \\
\text { imho/cn } \\
1 / 700 \mathrm{w} \\
\end{array}$ & $\begin{array}{c}\text { Field } \\
\text { pH } \\
0.01 /[6.5, \\
8.5 s]\end{array}$ & $\begin{array}{c}\text { TOC } \\
\text { ppb } \\
1000 / .\end{array}$ & $\begin{array}{l}\text { Tox } \\
\text { ppb } \\
10 / .\end{array}$ \\
\hline \multirow[t]{4}{*}{$2-1110-13$} & \multirow[t]{4}{*}{$12 / 14 / 94$} & 1 & 452 & 8.51 & $110^{6}$ & 14.0 \\
\hline & & 2 & 453 & 8.58 & $200^{6}$ & 14.4 \\
\hline & & 3 & 450 & 8.61 & $140^{\prime}$ & 11.1 \\
\hline & & 4 & 451 & 8.61 & $120^{+}$ & 11.1 \\
\hline \multirow[t]{4}{*}{$2-410-13$} & \multirow[t]{4}{*}{$03 / 10 / 95$} & 1 & 407 & 8.17 & $200^{1}$ & 26.7 \\
\hline & & 2 & 405 & 8.17 & $300^{\circ}$ & 23.3 \\
\hline & & 3 & 404 & 8.16 & $200^{\mathrm{L}}$ & 22.6 \\
\hline & & 4 & 402 & 8.16 & $200^{\mathrm{L}}$ & 22.1 \\
\hline \multirow[t]{4}{*}{$2-49-1$} & \multirow[t]{4}{*}{$02 / 18 / 94$} & 1 & 418 & 8.05 & $300^{\circ}$ & $5.0^{\mathrm{U}}$ \\
\hline & & 2 & 413 & 8.03 & $200^{\mathrm{U}}$ & $5.0^{\mathrm{u}}$ \\
\hline & & 3 & 417 & 8.02 & $200^{\mathrm{J}}$ & $=$ \\
\hline & & 4 & 415 & 8.00 & $200^{ل}$ & $=$ \\
\hline \multirow[t]{4}{*}{ 2-Ng-1 } & \multirow[t]{4}{*}{$05 / 25 / 94$} & 1 & 441 & 7.66 & $320^{ل}$ & $=$ \\
\hline & & 2 & 445 & 7.67 & $320^{\mathrm{d}}$ & --- \\
\hline & & 3 & 442 & 7.68 & $320^{\mathrm{t}}$ & --- \\
\hline & & 4 & 444 & 7.68 & $320^{\circ}$ & - \\
\hline
\end{tabular}

The colum headers consist of: Constituent Kame; Analys is Units; and Contractual]y Required Quantitation Limit/Orinking Water Standard (suffix).

Suffix $s=$ based on Secondary Haximum Contanjinant levels in 40 CFR

$$
\begin{aligned}
& \text { Part 143, National Secondary Drinking Water Regulations } \\
& \text { based on additional Secondary Maximum Contaminant Levels in } \\
& \text { WAC 248-54, Public Water Supplies }
\end{aligned}
$$

Notes and data flag:

area not impacted by upgradient source of contamination.

denotes that concentration is below Contract Required Quantitation Limit (CRQL) but above the Method Detection Limit (MDL).

denotes that analyte concentration is not detected ( $\langle\mathrm{k} \cdot \mathrm{OL}$ ).

r_--" = no data. 
Table C-7.a. Background Contamination Indicator Parameter Data for the Low-Leve] Waste Management Area $3^{\circ}$. (page 3 of 3 )

\begin{tabular}{|c|c|c|c|c|c|c|}
\hline $\begin{array}{l}\text { Wel1 } \\
\text { name }\end{array}$ & $\begin{array}{c}\text { Sample } \\
\text { date }\end{array}$ & $\begin{array}{l}\text { Dupl. } \\
\text { sarple } \\
\text { number }\end{array}$ & $\begin{array}{c}\text { Specific } \\
\text { conductance } \\
\text { /mho/cm } \\
1 / 700 \mathrm{w}\end{array}$ & $\begin{array}{c}\text { Field } \\
\text { pH } \\
0.01 /[6.5 \\
8.5 s]\end{array}$ & $\begin{array}{c}\text { Toc } \\
\text { ppb } \\
1000 / .\end{array}$ & $\begin{array}{l}\text { Tox } \\
\mathrm{ppb} \\
10 /\end{array}$ \\
\hline \multirow[t]{4}{*}{ 2-wg-1 } & \multirow[t]{4}{*}{$07 / 14 / 94$} & 1 & 317 & 7.91 & $=$ & $5.0^{\mathrm{d}}$ \\
\hline & & 2 & 317 & 7.90 & $=$ & $5.0^{0}$ \\
\hline & & 3 & 318 & 7.89 & $=$ & $5.0^{6}$ \\
\hline & & 4 & 314 & 7.90 & $=$ & $5.0^{\mathrm{U}}$ \\
\hline \multirow[t]{4}{*}{$2-49-1$} & \multirow[t]{4}{*}{$08 / 12 / 94$} & 1 & 333 & 7.93 & $320^{0}$ & 12.6 \\
\hline & & 2 & 333 & 7.91 & $320^{4}$ & 13.4 \\
\hline & & 3 & 333 & 7.91 & $320^{1}$ & 9.6 \\
\hline & & 4 & 333 & 7.90 & $400^{2}$ & 6.1 \\
\hline \multirow[t]{4}{*}{$2-49-1$} & \multirow[t]{4}{*}{$12 / 14 / 94$} & 1 & $\mathbf{3 3 8}$ & 8.76 & $\begin{array}{l}110^{0} \\
110^{\circ} \\
\end{array}$ & $\begin{array}{l}5.0^{\mathrm{U}} \\
5.0^{\mathrm{U}} \\
\end{array}$ \\
\hline & & 2 & 367 & 8.75 & $\begin{array}{c}140^{L} \\
300^{1}\end{array}$ & $\begin{array}{l}5.0^{ل 1} \\
5.0^{\prime \prime}\end{array}$ \\
\hline & & 3 & 366 & 8.74 & $\begin{array}{c}150^{\mathrm{L}} \\
300^{2}\end{array}$ & $\begin{array}{l}5.0^{\mathrm{U}} \\
5.0^{\mathrm{U}}\end{array}$ \\
\hline & & 4 & 367 & 8.74 & $\begin{array}{l}200^{\circ} \\
200^{\circ} \\
\end{array}$ & $\begin{array}{r}5.3 \\
5.0^{N} \\
\end{array}$ \\
\hline \multirow[t]{4}{*}{$2-1 / 9-1$} & \multirow[t]{4}{*}{$03 / 10 / 95$} & 1 & 340 & 8.26 & $300^{2}$ & 10.5 \\
\hline & & $\underline{2}$ & 340 & 8.25 & $200^{L}$ & $5.0^{\mathrm{N}}$ \\
\hline & & 3 & 340 & 8.14 & $200^{\circ}$ & 9.6 \\
\hline & & 4 & 340 & 8.12 & $200^{L}$ & 5.1 \\
\hline
\end{tabular}

The column headers consist of: Constituent Name; Analysis Units; and

Contractually Required Quantftation Limit/Orinking Hater Standard (suffix).

Suffix $s$ - based on Secondary Maxinum Contaminant Levels in 40 CFR

Part 143, Hatjonal Secondary Ortnking Hater Regulations

$w$ - based on additional Secondary Maximum Contaminant Levels in

Notes and data flag:

WAC 248-54, Public Water Supplies

area not fmpacted by upgradjent source of contamination.

denotes that concentration is below Contract Required Quantitation Limit (CRQL) but above the Hethod Detection Limit (MDL).

denotes that analyte concentration is not detected.

"_-n" = no data. 
Table C-7,b. Background Contamination Indicator Parameter Data for the Low-Level Waste Hanageant Area $3^{2}$. (page 1 of 5 )

\begin{tabular}{|c|c|c|c|c|c|c|}
\hline $\begin{array}{l}\text { Well } \\
\text { name }\end{array}$ & $\begin{array}{c}\text { Sample } \\
\text { date }\end{array}$ & $\begin{array}{l}\text { Dupl. } \\
\text { sample } \\
\text { number }\end{array}$ & $\begin{array}{c}\text { Specific } \\
\text { conductance } \\
\text { tmho/cm } \\
1 / 700 \mathrm{w}\end{array}$ & $\begin{array}{c}\text { Field } \\
\text { phd } \\
0.01 /[6.5 \\
8.5 \mathrm{~s}]\end{array}$ & $\begin{array}{c}\mathrm{TOC} \\
\mathrm{ppb} \\
1000 / .\end{array}$ & $\begin{array}{l}\text { ToX } \\
\mathrm{ppb} \\
10 \% .\end{array}$ \\
\hline \multirow[t]{4}{*}{$2-110-19$} & \multirow[t]{4}{*}{$02 / 18 / 94$} & 1 & 567 & 7.97 & $300^{6}$ & - \\
\hline & & 2 & 562 & 7.93 & $300^{2}$ & $=-$ \\
\hline & & 3 & 559 & 7.91 & $300^{\mathrm{L}}$ & 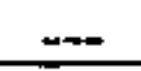 \\
\hline & & 4 & 560 & 7.90 & $300^{\mathrm{L}}$ & $=-\pi$ \\
\hline \multirow[t]{4}{*}{$2-410-19$} & \multirow[t]{4}{*}{$05 / 25 / 94$} & 1 & 570 & 8.19 & $340^{6}$ & $=-$ \\
\hline & & 2 & 568 & 8.18 & $320^{\mathrm{d}}$ & - \\
\hline & & 3 & 571 & 8.15 & $320^{\circ}$ & $=$ \\
\hline & & 4 & 571 & 8.14 & $340^{\mathrm{L}}$ & $=$ \\
\hline \multirow[t]{4}{*}{$2-1,10-19$} & \multirow[t]{4}{*}{$08 / 03 / 94$} & 1 & 518 & 7.99 & $=$ & 994 \\
\hline & & 2 & 515 & 7.99 & $=$ & 729 \\
\hline & & 3 & 513 & 7.99 & $=-$ & 939 \\
\hline & & 4 & 516 & 7.98 & $=$ & 1,030 \\
\hline \multirow[t]{4}{*}{$2-110-19$} & \multirow[t]{4}{*}{$08 / 15 / 94$} & 1 & 561 & 7.64 & $320^{\circ}$ & 833 \\
\hline & & 2 & 562 & 7.66 & $600^{4}$ & 870 \\
\hline & & 3 & 560 & 7.61 & $400^{L}$ & 955 \\
\hline & & 4 & 559 & 7.66 & $320^{4}$ & 685 \\
\hline
\end{tabular}

The column headers consist of: Constitient Name; Analysis units; and Contractually Required Quantitation Lfmit/Drinking Water standard (suffix).

Suffix $s=$ based on Secondary Maximum Contaminant Levels in 40 CFR Part 143, National Secondary Orinking Hater Regulations $w$ - based on additional Secondary Maximum Contaminant Levels in WAC 248-54, Public Water Suppi ies

Hotes and data flag:

area impacted by upgradient source of contanimation.

Lenotas that concentration is below Contract Requíred Quantitation livit (CRQL) but above the Method Detection Limit (BDL).

denotes that analyte concentration is not detected (CNDL).

"-.-" = no data. 
Table C-7.b. Background Contamination Indicator Parameter Data for the Low-Level Maste Management Area $3^{*}$. (page 2 of 5)

\begin{tabular}{|c|c|c|c|c|c|c|}
\hline $\begin{array}{l}\text { Well } \\
\text { natioe }\end{array}$ & $\begin{array}{c}\text { Sample } \\
\text { date }\end{array}$ & $\begin{array}{l}\text { Dupl. } \\
\text { sample } \\
\text { number }\end{array}$ & $\begin{array}{c}\text { Specific } \\
\text { conductance } \\
\text { prho/cw } \\
1 / 700 w\end{array}$ & $\begin{array}{c}\text { Field } \\
\mathrm{pH} \\
0.01 / 66.5, \\
8.5 \mathrm{~s}]\end{array}$ & $\begin{array}{c}\text { Toc } \\
\text { ppb } \\
1000 / .\end{array}$ & $\begin{array}{c}\text { Tox } \\
\text { ppb } \\
10 / .\end{array}$ \\
\hline \multirow[t]{4}{*}{$2-410-19$} & \multirow[t]{4}{*}{$12 / 14 / 94$} & 1 & 558 & 8.77 & $300^{2}$ & 1,000 \\
\hline & & 2 & $=$ & $=-$ & $m$ & -- \\
\hline & & 3 & - & $=$ & $=-$ & $=$ \\
\hline & & 4 & $=$ & $=-$ & $-\rightarrow$ & $-\rightarrow$ \\
\hline \multirow[t]{4}{*}{$2-1410-19$} & \multirow[t]{4}{*}{$03 / 09 / 95$} & 1 & 560 & 8.30 & $200^{6}$ & 1,060 \\
\hline & & 2 & 561 & 8.28 & $300^{4}$ & 1,060 \\
\hline & & 3 & 563 & 8.24 & $200^{\mathrm{L}}$ & 1,050 \\
\hline & & 4 & 565 & 8.21 & $200^{6}$ & 1,050 \\
\hline \multirow[t]{4}{*}{$2-410-20$} & \multirow[t]{4}{*}{$02 / 18 / 94$} & 1 & 593 & 7.76 & $600^{\mathrm{L}}$ & 717 \\
\hline & & 2 & 585 & 7.71 & $600^{\mathrm{J}}$ & 609 \\
\hline & & 3 & 587 & 7.71 & $700^{2}$ & 832 \\
\hline & & 4 & 587 & 7.69 & $600^{2}$ & 957 \\
\hline \multirow[t]{4}{*}{$2-110-20$} & \multirow[t]{4}{*}{$05 / 25 / 94$} & 1 & 613 & 7.70 & $500^{t}$ & -- \\
\hline & & 2 & 612 & 7.69 & $600^{\mathrm{L}}$ & $=$ \\
\hline & & 3 & 612 & 7.69 & $500^{\mathrm{L}}$ & $=$ \\
\hline & & 4 & 615 & 7.69 & $600^{\mathrm{L}}$ & - \\
\hline
\end{tabular}

The colum headers consist of: Constituent Name; Analysis Units; and Contractually Required Quantitation Limit/Orinking Water Standard (suffix).

Suffix $s=$ based on Secondary Maximum Contaminant Leve1s in 40 CFR Part 143, Hational Secondary Drinking Water Regulations $*$ - based on additional Secondary Haximup Contaminant Levels in WAC 248-54, PubTic Nater Supplies

Wotes and data flag:

area impacted by upgradient source of contamination.

'denotes that concentration is below Contract Required Quantitation Limit (CRQL) but above the Method Detection Limit (MDL).

denotes that analyte concentration is not detected ( $\angle M D L)$.

"n-n" = no data. 
Table C-7.b. Background Contamination Indicator Parameter Data for the Low-Leve1 Naste Management Area $3^{\circ}$. (page 3 of 5)

\begin{tabular}{|c|c|c|c|c|c|c|}
\hline $\begin{array}{l}\text { Well } \\
\text { name }\end{array}$ & $\begin{array}{l}\text { Sample } \\
\text { date }\end{array}$ & $\begin{array}{l}\text { Dupl. } \\
\text { sample } \\
\text { number }\end{array}$ & $\begin{array}{c}\text { Specifje } \\
\text { conductance } \\
\text { pdho/cm } \\
1 / 700 w \\
\end{array}$ & $\begin{array}{c}\text { Field } \\
\mathrm{pH} \\
0.01 /[6.5 \\
8.5 \mathrm{~s}] \\
\end{array}$ & $\begin{array}{c}\text { TOC } \\
\text { ppb } \\
1000 \%\end{array}$ & $\begin{array}{l}\mathrm{TOX} \\
\mathrm{ppb} \\
10 / .\end{array}$ \\
\hline \multirow[t]{4}{*}{$2-110-20$} & \multirow[t]{4}{*}{$07 / 14 / 94$} & $I$ & 618 & 7.60 & $=$ & 875 \\
\hline & & 2 & 618 & 7.59 & $=$ & 894 \\
\hline & & 3 & 618 & 7.59 & -- & 766 \\
\hline & & 4 & 616 & 7.59 & -- & - \\
\hline \multirow[t]{4}{*}{$2-W 10-20$} & \multirow[t]{4}{*}{$08 / 12 / 94$} & 1 & 628 & 7.67 & $400^{L}$ & 1,360 \\
\hline & & 2 & 629 & 7.65 & $400^{\mathrm{l}}$ & 930 \\
\hline & & 3 & 629 & 7.63 & $400^{4}$ & 848 \\
\hline & & 4 & 628 & 7.63 & $500^{2}$ & 1,400 \\
\hline \multirow[t]{4}{*}{ 2-410-20 } & \multirow[t]{4}{*}{$12 / 15 / 94$} & 1 & 623 & 6.87 & $400^{\mathrm{L}}$ & 1,280 \\
\hline & & 2 & 623 & 6.91 & $=$ & $=$ \\
\hline & & 3 & 625 & 6.95 & -- & +- \\
\hline & & 4 & 623 & 7.01 & -- & $\cdots$ \\
\hline \multirow[t]{4}{*}{$2-410-20$} & \multirow[t]{4}{*}{$03 / 09 / 95$} & 1 & 612 & 7.80 & $300^{\mathrm{L}}$ & 1,190 \\
\hline & & 2 & 611 & 7.81 & $300^{\mathrm{L}}$ & 1,310 \\
\hline & & 3 & 609 & 7.81 & $300^{2}$ & 1,180 \\
\hline & & 4 & 608 & 7.80 & $300^{\mathrm{L}}$ & $1, \mathrm{I} 10$ \\
\hline
\end{tabular}

The colum headers consist of: Constituent kante; Analysis Units; and Contractually Required Quantitation Limit/Orinking Nater Standard (suffix).

Suffix $s$ - based on Secondary Maximum Contaminant Levels in 40 CFR

$$
\begin{aligned}
& \text { Part 143, Hational Secondary Drinking Water Regulations } \\
& \text { based on additional Secondary Haximton Contaminant Leveis in } \\
& \text { WAC 248-54, Public Water Suppl ies }
\end{aligned}
$$

Hotes and data flag:

area impacted by upgradient source of contapination.

denotes that concentration is below contract Required Quantitation Limit (CRQL) but above the Hethod Detection Limit (MDL).

denotes that analyte concentration is not detected (CMDL).

"-." = no data. 
Tab]e C-7.b. Background Contanination Indicator Parameter Data for the Low-Leve1 Waste Management Area 3*. (page 4 of 5)

\begin{tabular}{|c|c|c|c|c|c|c|}
\hline $\begin{array}{l}\text { Well } \\
\text { name }\end{array}$ & $\underset{\text { date }}{\text { Sanple }}$ & $\begin{array}{l}\text { Dupl. } \\
\text { saumple } \\
\text { number }\end{array}$ & $\begin{array}{c}\text { Specific } \\
\text { conductance } \\
\text { imho/cm } \\
\mathrm{L} / 70 \mathrm{ow}\end{array}$ & $\begin{array}{c}\text { Field } \\
\text { ph } \\
0.01 /[6.5, \\
8.55] \\
\end{array}$ & $\begin{array}{c}\text { TOC } \\
\mathrm{ppb} \\
1000 / .\end{array}$ & $\begin{array}{l}\text { ToX } \\
\mathrm{ppb} \\
10 \% .\end{array}$ \\
\hline \multirow[t]{4}{*}{$2-w 10-21$} & \multirow[t]{4}{*}{$02 / 22 / 94$} & 1 & 529 & 7.59 & $400^{2}$ & 462 \\
\hline & & 2 & 525 & 7.59 & $400^{t}$ & 393 \\
\hline & & 3 & 530 & 7.61 & $400^{2}$ & 358 \\
\hline & & 4 & 530 & 7.62 & $400^{L}$ & 389 \\
\hline \multirow[t]{4}{*}{$2-110-21$} & \multirow[t]{4}{*}{$05 / 26 / 94$} & $I$ & 569 & 7.66 & $400^{6}$ & 446 \\
\hline & & 2 & 570 & 7.65 & $400^{\mathrm{L}}$ & 427 \\
\hline & & 3 & 571 & 7.65 & $320^{\prime \prime}$ & 466 \\
\hline & & .4 & 570 & 7.74 & $350^{L}$ & 461 \\
\hline \multirow[t]{4}{*}{$2-410-21$} & \multirow[t]{4}{*}{$08 / 12 / 94$} & 1 & 583 & 7.84 & $400^{-}$ & 300 \\
\hline & & 2 & 584 & 7.81 & $400^{t}$ & 385 \\
\hline & & 3 & 579 & 7.80 & $400^{t}$ & 371 \\
\hline & & 4 & 579 & 7.77 & $340^{2}$ & 408 \\
\hline \multirow[t]{4}{*}{ 2-W10-21 } & \multirow[t]{4}{*}{$12 / 14 / 94$} & 1 & 598 & 8.20 & $400^{\mathrm{L}}$ & 444 \\
\hline & & 2 & -- & --- & - & $-\rightarrow$ \\
\hline & & 3 & - & -- & -- & $\cdots$ \\
\hline & & 4 & -- & -- & $=$ & $=$ \\
\hline
\end{tabular}

The colum headers consist of: Constituent kame; Analys is Units; and Contractually Required Quantitation Limit/Drinking Water Standard (suffix).

Suffix $s=$ based on Secondary Maximu: Contaminant Levels in 40 CFR Part 143, Mational Secondary Drinking Water Regulations $w=$ based on additional Secondary Maximum Contaminant Leveis in WAC 248-54, Public Water Supplies

Notes and data flag:

area jupacted by upgradient source of contamination.

denotes that concentration is below Contract Required Quantitation Limit (CRQL) but above the Method Detection Limit (MDL).

denotes that analyte concentration is not detected (<MDL).

"---" = no data. 
Table C-7.b. Background Contanjnation Indicator Parameter Data for the Low-Level Waste Management Area $3^{9}$. (page 5 of 5 )

\begin{tabular}{|c|c|c|c|c|c|c|}
\hline $\begin{array}{l}\text { Well } \\
\text { nanee }\end{array}$ & $\begin{array}{l}\text { Sample } \\
\text { date }\end{array}$ & $\begin{array}{l}\text { Oupl, } \\
\text { sample } \\
\text { number }\end{array}$ & $\begin{array}{c}\text { Specific } \\
\text { conductance } \\
\text { umho/cm } \\
1 / 700 w\end{array}$ & $\begin{array}{c}\text { Field } \\
\mathrm{pH} \\
0.01 /[6.5, \\
8.5 \mathrm{~s}] \\
\end{array}$ & $\begin{array}{c}\text { TOC } \\
\mathrm{ppb} \\
1000 / .\end{array}$ & $\begin{array}{l}\text { TOX } \\
\text { ppb } \\
10 / .\end{array}$ \\
\hline \multirow[t]{4}{*}{$2-1110-21$} & \multirow[t]{4}{*}{$03 / 09 / 95$} & 1 & 589 & 7.35 & $300^{L}$ & 479 \\
\hline & & 2 & 589 & 7.85 & $300^{\mathrm{L}}$ & 470 \\
\hline & & 3 & 590 & 7.85 & $300^{4}$ & 476 \\
\hline & & 4 & 590 & 7.85 & $300^{2}$ & 452 \\
\hline
\end{tabular}

The column headers consist of: Constituent Name; Analysis Units; and Contractually Reguired Quantitation Ljatt/Drinking Water Standard (suffix).

Suffix $\mathbf{s}=\quad$ based on Secondary Maximum Contaminant Levels in 40 CFR Part 143, National Secondary Drinking Water Regulations $w$ based on additional Secondary Maximum Contamfnant Levels in NAC 248-54, PubTic Nater Supplies

Notes and data flag:

area impacted by upgradient source of contamination.

Lenotes that concentration is below Contract Required Quantitation Limit (CRQL) but above the Method Oetection Limit (MOL).

denotes that analyte concentration is not detected (CMDL). 
DOE/RL-96-01, REY. 0

Table C-8,a. Average Replicate Statistics--Background Indjcator Paraneter Bata for the Low-Level Waste Managenent Area 3*.

\begin{tabular}{|c|c|c|c|c|c|c|}
\hline $\begin{array}{l}\text { Constituent } \\
\text { (tunit) }\end{array}$ & $\begin{array}{l}\text { We11 } \\
\text { name }\end{array}$ & $\begin{array}{c}\text { Sapple } \\
\text { date }\end{array}$ & n & Average & $\begin{array}{l}\text { Standard } \\
\text { deviation }\end{array}$ & $\begin{array}{l}C . Y . \\
(\%)\end{array}$ \\
\hline \multirow{6}{*}{$\begin{array}{l}\text { Spectfic } \\
\text { conductance } \\
\text { ( } \mu \text { mho/cm) }\end{array}$} & $2-W 10-13$ & $02 / 18 / 94$ & 4 & 387.25 & 2.062 & 0.53 \\
\hline & $2-W 10-13$ & $05 / 25 / 94$ & 4 & 479.25 & 1.708 & 0.36 \\
\hline & $2-W 10-13$ & $07 / 14 / 94$ & 4 & 446.25 & 0.957 & 0.21 \\
\hline & $2-W 10-13$ & $08 / 31 / 94$ & 4 & 456.75 & 2.062 & 0.45 \\
\hline & $2-410-13$ & $12 / 14 / 94$ & 4 & 451.50 & 1.291 & 0.29 \\
\hline & $2-W 10-13$ & $03 / 10 / 95$ & 4 & 404.50 & 2.082 & 0.51 \\
\hline \multirow{6}{*}{$\begin{array}{c}\text { Field } \\
\text { pH }\end{array}$} & $2-410-13$ & $02 / 18 / 94$ & 4 & 8.195 & 0.013 & 0.16 \\
\hline & $2-410-13$ & $05 / 25 / 94$ & 4 & 8.012 & 0.005 & 0.06 \\
\hline & $2-410-13$ & $07 / 14 / 94$ & 4 & 7.990 & 0 & 0 \\
\hline & $2-410-13$ & $08 / 31 / 94$ & 4 & 8.055 & 0.006 & 0.07 \\
\hline & $2-410-13$ & $12 / 14 / 94$ & 4 & 8.578 & 0.047 & 0.55 \\
\hline & $2-W 10-13$ & $03 / 10 / 95$ & 4 & 8.165 & 0.005 & 0.07 \\
\hline \multirow{5}{*}{$\begin{array}{l}\text { Toc } \\
(p p b)\end{array}$} & $2-410-13$ & $02 / 18 / 94$ & 4 & $250^{6}$ & 57.735 & 23.09 \\
\hline & $2-410-13$ & $05 / 25 / 94$ & 4 & $250^{L}$ & 104.243 & 41.70 \\
\hline & $2-410-13$ & $08 / 31 / 94$ & 4 & $160^{\mathrm{U}}$ & 0 & 0 \\
\hline & $2-410-13$ & $12 / 14 / 94$ & 4 & $142.5^{\mathrm{L}}$ & 40.311 & 28.29 \\
\hline & $2-110-13$ & $03 / 10 / 95$ & 4 & $225^{\mathrm{L}}$ & 50 & 22.22 \\
\hline \multirow{4}{*}{$\begin{array}{l}\mathrm{TOX}^{\mathrm{b}} \\
(\mathrm{ppb})\end{array}$} & $2-410-13$ & $07 / 14 / 94$ & 8 & 13.80 & 0.906 & 6.56 \\
\hline & $2-110-13$ & $08 / 31 / 94$ & 4 & 3.25 & 1.500 & 46.15 \\
\hline & $2-410-13$ & $12 / 14 / 94$ & 4 & 12.65 & 1.797 & 14.21 \\
\hline & $2-410-13$ & $03 / 10 / 95$ & 4 & 23.675 & 2.076 & 8.77 \\
\hline
\end{tabular}

area not jmpacted by upgradient source of contamination.

statistics were calculated by replacing not detected values with half of the Method Detection Limtt (MDL).

denotes that concentration is below Contract Required Quantitation Limit (CRQL) but above the $\mathrm{MDL}$.

denotes that analyte concentration is not detected (《WiL).

N.C. = not calculated. C.V. = coefficient of variation. 
DOE/RL-96-01, REV. 0

Tabie C-a.a. Average Repljcate Statistics--Background Indicator Parameter Data for the Low-Level Waste Management Area $3^{3}$. (page 2 of 2)

\begin{tabular}{|c|c|c|c|c|c|c|}
\hline $\begin{array}{c}\text { Constiturent } \\
\text { (unit) }\end{array}$ & $\begin{array}{l}\text { Well } \\
\text { name }\end{array}$ & $\begin{array}{c}\text { Sample } \\
\text { date }\end{array}$ & $\mathbf{n}$ & Average & $\begin{array}{c}\text { Standard } \\
\text { deviation }\end{array}$ & $\begin{array}{l}\text { C.V. } \\
(\boldsymbol{\phi})\end{array}$ \\
\hline \multirow{6}{*}{$\begin{array}{l}\text { Specific } \\
\text { conductance } \\
\text { ( } \mu \text { mho/cm) }\end{array}$} & $2-49-1$ & $02 / 18 / 94$ & 4 & 415.75 & 2.217 & 0.53 \\
\hline & $2-49-1$ & $05 / 25 / 94$ & 4 & 443.00 & 1.826 & 0.41 \\
\hline & $2-49-1$ & $07 / 14 / 94$ & 4 & 421.00 & 2.160 & 0.51 \\
\hline & 2-49-1 & $08 / 31 / 94$ & 4 & 459.75 & 2.062 & 0.45 \\
\hline & 2-w9-1 & $12 / 14 / 94$ & 4 & 453.25 & 2.217 & 0.49 \\
\hline & 2-w9-1 & $03 / 10 / 95$ & 4 & 459.50 & 1.291 & 0.28 \\
\hline \multirow{6}{*}{$\underset{\text { pH }}{\text { Field }}$} & $2-1+9-1$ & $02 / 18 / 94$ & 4 & 8.025 & 0.021 & 0.26 \\
\hline & 2-W9-1 & $05 / 25 / 94$ & 4 & 7.673 & 0.010 & 0.12 \\
\hline & 2-N9-I & $07 / 14 / 94$ & 4 & 7.900 & 0.008 & 0.10 \\
\hline & 2-wg-1 & $08 / 31 / 94$ & 4 & 7.913 & 0.013 & 0.16 \\
\hline & $2-w 9-1$ & $12 / 14 / 94$ & 4 & 8.748 & 0.010 & 0.11 \\
\hline & $2-w 9-1$ & $03 / 10 / 95$ & 4 & 8.192 & 0.073 & 0.89 \\
\hline \multirow{5}{*}{$\begin{array}{c}T c^{b} \\
(\mathrm{ppb})\end{array}$} & $2-49-1$ & $02 / 18 / 94$ & 4 & $150^{\mathrm{L}}$ & 100 & 66.67 \\
\hline & $2-1 \times 9-1$ & $05 / 25 / 94$ & 4 & $160^{\mathrm{L}}$ & 0 & 0 \\
\hline & $2-1 \times 9-1$ & $08 / 12 / 94$ & 4 & $220^{\mathrm{U}}$ & 120 & 54.55 \\
\hline & $2-149-1$ & $12 / 14 / 94$ & 8 & $175^{6}$ & 94.981 & 54.27 \\
\hline & 2-w9-1 & $03 / 10 / 95$ & 4 & $225 \mathrm{~L}$ & 50 & 22.22 \\
\hline \multirow{5}{*}{$\begin{array}{c}\text { Tox } \\
\text { (ppb) }\end{array}$} & $2-w 9-1$ & $02 / 18 / 94$ & 2 & $2.5^{\mathrm{U}}$ & 0 & 0 \\
\hline & 2-w9-1 & $07 / 14 / 94$ & 4 & $2.5^{\mathrm{U}}$ & $\underline{0}$ & 0 \\
\hline & $2-w 9-1$ & $08 / 12 / 94$ & 4 & 10.425 & 3.315 & 31.80 \\
\hline & 2-W9-1 & $12 / 14 / 94$ & 8 & 2.85 & 1.000 & 34.74 \\
\hline & 2-W9-1 & $03 / 10 / 95$ & 4 & 6.925 & 3.779 & 54.57 \\
\hline
\end{tabular}

area not impacted by upgradient source of contamination.

statfstics were calculated by replacing not detected values with half of the Method Detection Limit (HDL).

denotes that concentration is below Contract Required Quantitation Limit (CRQL) but above the MDL.

denotes that anatyte concentration is not detected ( $\angle \mathrm{KDL}$ ).

N.C. = not calculated. C.Y. = coefficient of variation. 
Table C-8.b. Average Replicate Statistic5-Background Indicator Paraneter Data for the Low-Level Waste Managenent Area $3^{\circ}$.

\begin{tabular}{|c|c|c|c|c|c|c|}
\hline $\begin{array}{c}\text { Constituent } \\
\text { (unit) }\end{array}$ & $\begin{array}{l}\text { Wel } 1 \\
\text { name }\end{array}$ & $\begin{array}{c}\text { Sample } \\
\text { date }\end{array}$ & $\mathbf{n}$ & Average & $\begin{array}{l}\text { Standard } \\
\text { deviation }\end{array}$ & $\begin{array}{l}c . y . \\
(x)\end{array}$ \\
\hline \multirow{6}{*}{$\begin{array}{c}\text { Speciffe } \\
\text { conductance } \\
(\mu \mathrm{mho} / \mathrm{cn})\end{array}$} & $2-410-19$ & $02 / 18 / 94$ & 4 & 562.00 & 3.559 & 0.63 \\
\hline & $2-410-19$ & $05 / 25 / 94$ & 4 & 570.00 & 1.414 & 0.25 \\
\hline & $2-W 10-19$ & $08 / 03 / 94$ & 4 & 515.50 & 2.082 & 0.40 \\
\hline & $2-410-19$ & $08 / 15 / 94$ & 4 & 560.50 & 1.291 & 0.23 \\
\hline & $2+410-19$ & $12 / 14 / 94$ & 1 & 558.00 & N.C. & H.C. \\
\hline & $2-410-19$ & $03 / 09 / 95$ & 4 & 562.25 & 2.217 & 0.39 \\
\hline \multirow{6}{*}{$\begin{array}{c}\text { Fjeld } \\
\text { pH }\end{array}$} & $2-\$ 10-19$ & $02 / 18 / 94$ & 4 & 7.928 & 0.031 & 0.39 \\
\hline & $2-410-19$ & $05 / 25 / 94$ & 4 & 8.165 & 0.024 & 0.29 \\
\hline & $2-110-19$ & $08 / 03 / 94$ & 4 & 7.988 & 0.005 & 0.06 \\
\hline & $2-610-19$ & $08 / 15 / 94$ & 4 & 7.642 & 0.024 & 0.31 \\
\hline & $2-W 10-19$ & $12 / 14 / 94$ & 1 & 8.770 & N.C. & H.C. \\
\hline & $2-410-19$ & $03 / 09 / 95$ & 4 & 8.258 & 0.040 & 0.49 \\
\hline \multirow{5}{*}{$\begin{array}{l}\mathrm{TOC}^{\mathrm{b}} \\
(\mathrm{ppb})\end{array}$} & $2-w 10-19$ & $02 / 18 / 94$ & 4 & $300^{2}$ & 0 & 0 \\
\hline & $2-410-19$ & $05 / 25 / 94$ & 4 & $250^{\mathrm{L}}$ & 103.923 & 41.57 \\
\hline & $2-K 10-19$ & $08 / 15 / 94$ & 4 & $330^{\circ}$ & 212.603 & 64.43 \\
\hline & $2-\$ 10-19$ & $12 / 14 / 94$ & 1 & $300^{L}$ & N.C. & A.C. \\
\hline & $2-410-19$ & $03 / 09 / 95$ & 4 & $225^{\mathrm{L}}$ & 50 & 22.22 \\
\hline \multirow{4}{*}{$\begin{array}{c}\text { ToX } \\
(p p b)\end{array}$} & $2-410-19$ & $08 / 03 / 94$ & 4 & 923.00 & 134.638 & 14.59 \\
\hline & $2-410-19$ & $08 / 15 / 94$ & 4 & 835.75 & 112.734 & 13.49 \\
\hline & $2-410-19$ & $12 / 14 / 94$ & 1 & 1,000 & N.C. & H.C. \\
\hline & 2-번-19 & $03 / 09 / 95$ & 4 & 1,050 & 14.142 & 1.35 \\
\hline
\end{tabular}

area inpacted by upgradient source of contamination.

statistics were calculated by replacing not detected values with half of the Hethod Detection Limit (ML).

denotes that concentration is below Contract Required quantitation liait (CRQL) but above the FoL.

denotes that analyte concentration is not detected (CHOL).

N.C. = not calculated. C.V. a coefficient of variation. 
Table C-8.b. Average Repljcate Statjstics--Background Indicator Parameter Data for the Low-Level Waste Management Area $3^{*}$.

\begin{tabular}{|c|c|c|c|c|c|c|}
\hline $\begin{array}{c}\text { Constituent } \\
\text { (Injt) }\end{array}$ & $\begin{array}{l}\text { We]l } \\
\text { name }\end{array}$ & $\begin{array}{c}\text { Sample } \\
\text { date }\end{array}$ & n & Average & $\begin{array}{l}\text { Standard } \\
\text { deviation }\end{array}$ & $\begin{array}{l}C . V . \\
(\Phi)\end{array}$ \\
\hline \multirow{6}{*}{$\begin{array}{c}\text { Specific } \\
\text { conductance } \\
\left(\mu m h_{2} / \mathrm{cm}\right)\end{array}$} & $2-1110-20$ & $02 / 18 / 94$ & 4 & 588.00 & 3.464 & 0.59 \\
\hline & $2-410-20$ & $05 / 25 / 94$ & 4 & 613.00 & 1.414 & 0.23 \\
\hline & $2-410-20$ & $07 / 14 / 94$ & 4 & 617.50 & 1.000 & 0.16 \\
\hline & $2-H 10-20$ & $08 / 22 / 94$ & 4 & 528.50 & 0.577 & 0.09 \\
\hline & $2-410-20$ & $12 / 15 / 94$ & 4 & 623.50 & 1.000 & 0.16 \\
\hline & $2-410-20$ & $03 / 09 / 95$ & 4 & 610.00 & 1.826 & 0.30 \\
\hline \multirow{6}{*}{$\underset{\mathrm{pH}}{\mathrm{Field}}$} & $2-410-20$ & $02 / 18 / 94$ & 4 & 7.718 & 0.030 & 0.39 \\
\hline & $2-110-20$ & $05 / 25 / 94$ & 4 & 7.692 & 0.005 & 0.06 \\
\hline & $2-410-20$ & $07 / 14 / 94$ & 4 & 7.592 & 0.005 & 0.07 \\
\hline & $2-110-20$ & $08 / 12 / 94$ & 4 & 7.645 & 0.019 & 0.25 \\
\hline & $2-110-20$ & $12 / 15 / 94$ & 4 & 6.935 & 0.060 & 0.86 \\
\hline & $2-110-20$ & $03 / 09 / 95$ & 4 & 7.805 & 0.006 & 0.07 \\
\hline \multirow{5}{*}{$\begin{array}{l}70 c^{b} \\
(p p b)\end{array}$} & $2-410-20$ & $02 / 18 / 94$ & 4 & $625^{\circ}$ & 50.000 & 8.00 \\
\hline & $2-410-20$ & $05 / 25 / 94$ & 4 & $550^{L}$ & 57.735 & 10.50 \\
\hline & $2-W 10-20$ & $08 / 12 / 94$ & 4 & $425^{\mathrm{L}}$ & 50.000 & 11.76 \\
\hline & $2-W 10-20$ & $12 / 15 / 94$ & 1 & $400^{4}$ & N.C. & A.C. \\
\hline & $2-\$ 10-20$ & $03 / 09 / 95$ & 4 & $300^{\mathrm{L}}$ & 0 & 0 \\
\hline \multirow{4}{*}{$\begin{array}{c}\text { TOX } \\
(\mathrm{ppb})\end{array}$} & $2-110-20$ & $02 / 18 / 94$ & 4 & 778.75 & 149.707 & 19.22 \\
\hline & $2-W 10-20$ & $07 / 14 / 94$ & 3 & 841.667 & 65.684 & 7.80 \\
\hline & $2-W 10-20$ & $08 / 12 / 94$ & 4 & $1,134.5$ & 285.916 & 25.20 \\
\hline & $2-110-20$ & $12 / 15 / 94$ & 1 & $1,280,0$ & H.C. & N.C. \\
\hline
\end{tabular}

area impacted by upgradient source of contanination.

bstatistics were calcutated by replacing not detected values with half of the Method Detection Limjt (MDL).

denotes that concentration is below Contract Required Quantitation Limit (CRQL) but above the MDL.

denotes that analyte concentration is not detected (<MOL).
N.C. = not calculated.
C.V. = coefficient of variation . 
DOE/RL-96-01, REV. 0

Jable C-8.b. Average Replicate Statistics--Background Indicator Parameter Data for the Low-Level Waste Management Area 3*. (page 3 of 3)

\begin{tabular}{|c|c|c|c|c|c|c|}
\hline $\begin{array}{c}\text { ronstituent } \\
\text { (unit) }\end{array}$ & $\begin{array}{l}\text { We11 } \\
\text { name }\end{array}$ & $\begin{array}{l}\text { Sample } \\
\text { date }\end{array}$ & $n$ & Average & $\begin{array}{l}\text { Standard } \\
\text { devfation }\end{array}$ & $\begin{array}{l}\text { c.y. } \\
(\mathscr{*})\end{array}$ \\
\hline \multirow{5}{*}{$\begin{array}{c}\text { Specific } \\
\text { conductance } \\
\text { ( } \mu \text { mho/cm) }\end{array}$} & $2-410-21$ & $02 / 22 / 94$ & 4 & 528.50 & 2.380 & 0.45 \\
\hline & $2-1+10-21$ & $05 / 26 / 94$ & 4 & 570.00 & 0.816 & 0.14 \\
\hline & $2-N 10-21$ & $08 / 12 / 94$ & 4 & 581.25 & 2.630 & 0.45 \\
\hline & $2-410-21$ & $12 / 14 / 94$ & 1 & 598.00 & H.C. & N.C. \\
\hline & $2-\$ 10-21$ & $03 / 09 / 95$ & 4 & 589.50 & 0.577 & 0.10 \\
\hline \multirow{5}{*}{$\begin{array}{c}\text { Fleld } \\
\text { pH }\end{array}$} & $2-410-21$ & $02 / 22 / 94$ & 4 & 7.602 & 0.015 & 0.20 \\
\hline & $2-W 10-21$ & $05 / 26 / 94$ & 4 & 7.650 & 0.008 & 0.11 \\
\hline & $2-\mathrm{H} 10-21$ & $08 / 12 / 94$ & 4 & 7.805 & 0.029 & 0.37 \\
\hline & $2-W 10-21$ & $12 / 14 / 94$ & 1 & 8.200 & A.C. & N.C. \\
\hline & $2-W 10-21$ & $03 / 09 / 95$ & 4 & 7.850 & 0 & 0 \\
\hline \multirow{5}{*}{$\begin{array}{l}\text { TOC } \\
(\mathrm{pph})\end{array}$} & $2-W 10-21$ & $02 / 22 / 94$ & 4 & $400^{\mathrm{L}}$ & 0 & 0 \\
\hline & $2-410-21$ & $05 / 26 / 94$ & 4 & $327.5^{t}$ & 114.127 & 34.85 \\
\hline & $2-410-21$ & $08 / 12 / 94$ & 4 & $385^{6}$ & 30.000 & 7.79 \\
\hline & $2-\$ 10-21$ & $12 / 14 / 94$ & 1 & $400^{\mathrm{L}}$ & N.C. & N.C. \\
\hline & $2-410-21$ & $03 / 09 / 95$ & 4 & $300^{\circ}$ & 0 & 0 \\
\hline \multirow{5}{*}{$\begin{array}{c}\text { ToX } \\
(\mathrm{ppb})\end{array}$} & $2-W 10-21$ & $02 / 22 / 94$ & 4 & 400.50 & 49.882 & 10.96 \\
\hline & $2+W 10-21$ & $05 / 26 / 94$ & 4 & 450.00 & 17.531 & 3.90 \\
\hline & $2-410-21$ & $08 / 12 / 94$ & 4 & 366.00 & 46.569 & 12.72 \\
\hline & $2-W 10-2 I$ & $12 / 14 / 94$ & 1 & 444.00 & N.C. & H.C. \\
\hline & $2-410-21$ & $03 / 09 / 95$ & 4 & 469.25 & 12.093 & 2.58 \\
\hline
\end{tabular}

area impacted by upgradient source of contamination.

statjstics were calculated by repiacing not detected values with half of the Method Detection Limit (MDL).

denotes that concentration is below Contract Required Quantitation Limit (CRQL) but above the MDL.

denotes that analyte concentration is not detected (<MDL).

H.C. = not talculated. C.V. = coefficient of variation. 
DOE/RL-96-01, REY. 0

Table C-9.a. Background Statistics ${ }^{3}$--Contamination Indicator Parameter Data for the Low-Leve1 Waste Management Area $3^{6}$.

\begin{tabular}{|l|c|c|c|c|c|}
\hline Constituent & Units & $n$ & $\begin{array}{c}\text { Background } \\
\text { average }\end{array}$ & $\begin{array}{c}\text { Background } \\
\text { standard } \\
\text { deviation }\end{array}$ & $\begin{array}{c}\text { Background } \\
\text { C.V. }(\%)\end{array}$ \\
\hline $\begin{array}{l}\text { Spectfic } \\
\text { conductance }\end{array}$ & Mtho/ca & 12 & 439.812 & 26.865 & 6.11 \\
\hline F1eld pH & & 12 & 8.120 & 0.294 & 3.62 \\
\hline TOC & ppb & 10 & 195.75 & 42.296 & 21.61 \\
\hline TOX & ppb & 9 & 8.731 & 7.183 & 82.28 \\
\hline
\end{tabular}

obackground summary statistics for TOC and/or TOX were calculated using values below the method detection limits.

barea not impacted by upgradient source of contanination. 
DOE /RL-96-01, REV. 0

Table C-9.b. Background Statistics"--Contamination Indicator Parameter Data for the Low-Level Waste Management Area $3^{5}$.

\begin{tabular}{|l|c|c|c|c|c|}
\hline Constituent & Units & $\mathrm{n}$ & $\begin{array}{c}\text { Background } \\
\text { average }\end{array}$ & $\begin{array}{c}\text { Background } \\
\text { standard } \\
\text { deviation }\end{array}$ & $\begin{array}{c}\text { Background } \\
\text { C.V. (\%) }\end{array}$ \\
\hline $\begin{array}{l}\text { Specific } \\
\text { conductance }\end{array}$ & pmho/cm & 17 & 580.941 & 32.230 & 5.55 \\
\hline Field pH & & 17 & 7.838 & 0.3867 & 4.93 \\
\hline THC & ppD & 15 & 367.833 & 107.483 & 29.22 \\
\hline TOX & ppr & 14 & 797.923 & 319.605 & 40.05 \\
\hline
\end{tabular}

"background summary statistics for TOC were calculated using values below the method detection 1 limits.

area impacted by upgradient source of contamination.

C-36 
DOE/RL-96-Ol, REV. $O$

\section{DISTRIBUTION}

Number of copies

OFFSITE

3

1

9

9

ONSITE
Washinaton State Department of

Ecology - Kennewiek Branch

1315 W. 4th

Kennewick, Washington 99336-6018

ง. Wallace (2)

S. Leja

Westinghouse Savannah River Company

P. 0. Box A

Aiken, South Carolina 29801

R. C. Tuckfield

U.S. Department of.Eneray, Richland Operattons office

H. J. Furman (4)

H4-85

R. 6. McLead

년요

D. E. 01son

H4-83

K. M. Thompson

Public Readíng Room (2)

H4-83

$\mathrm{H} 2-53$

Bechtel Hanford, Inc.

J. v. Borghese

X0-37

K. R. Fecht

B. H. Ford

R. L. Jackson

HO-02

G. L. Kasza

HO- 02

A. J. Knepp

M. A. Mthal ic

$\times 0-37$

H9-11

H4-80

R. E. Peterson

$\times 5-53$

L. C. Swanson

H9-03

H9-1I 
DOE/RL-96-0I, REV. 0

DISTRIBUTIOA (cont.)

R. H. Bryce

K6-91

P. E. Dresel

K6-96

5. P. Luttrell

KG-96

B. E. Opitz

K6-75

D. L. Stewart

K6-96

Technical Files

X1-11

45

Uestinghouse Hanford Company

D. B. Barnett

H6-06

J. A. Caggiano

H6-06

C. J. Chou

J. D. Davis

H6-06

H5-61

- A. J. Diliberto

H6-10

J. J. Dorjan

H6-06

H. G. Gardner

$\$ 3-24$

R. D. Gustavson

W. H. Hawiliton

M. J. Hartioan (10)

F. N. Hodges

R1-51

T3-01

D. G. Horton

$146-06$

V. G. Johnson

H6-06

J. W. Lindberg

H6-06

H6-OG

R. B. Mercer

H6-OG

C. J. Perkins

$1+5-06$

$\mathrm{X} 0-21$

S. H. Price

J. S. Schmid

J. A. Serkowski

H6-23

M. D. Sweeney

H6-06

E. C. Thorntan

H6-06

W. E. Toebe

H6-06

H6-06

B. A. Williams

H6-22

H6-06

M. T. York

H6-32

Central Files

18-04

EPIC (7)

Information Release

H6-08

Adainistration

H4-17

OSTI (2)

Tank Farms Central Files

ᄂ8-07

Rl-20

01str-2 